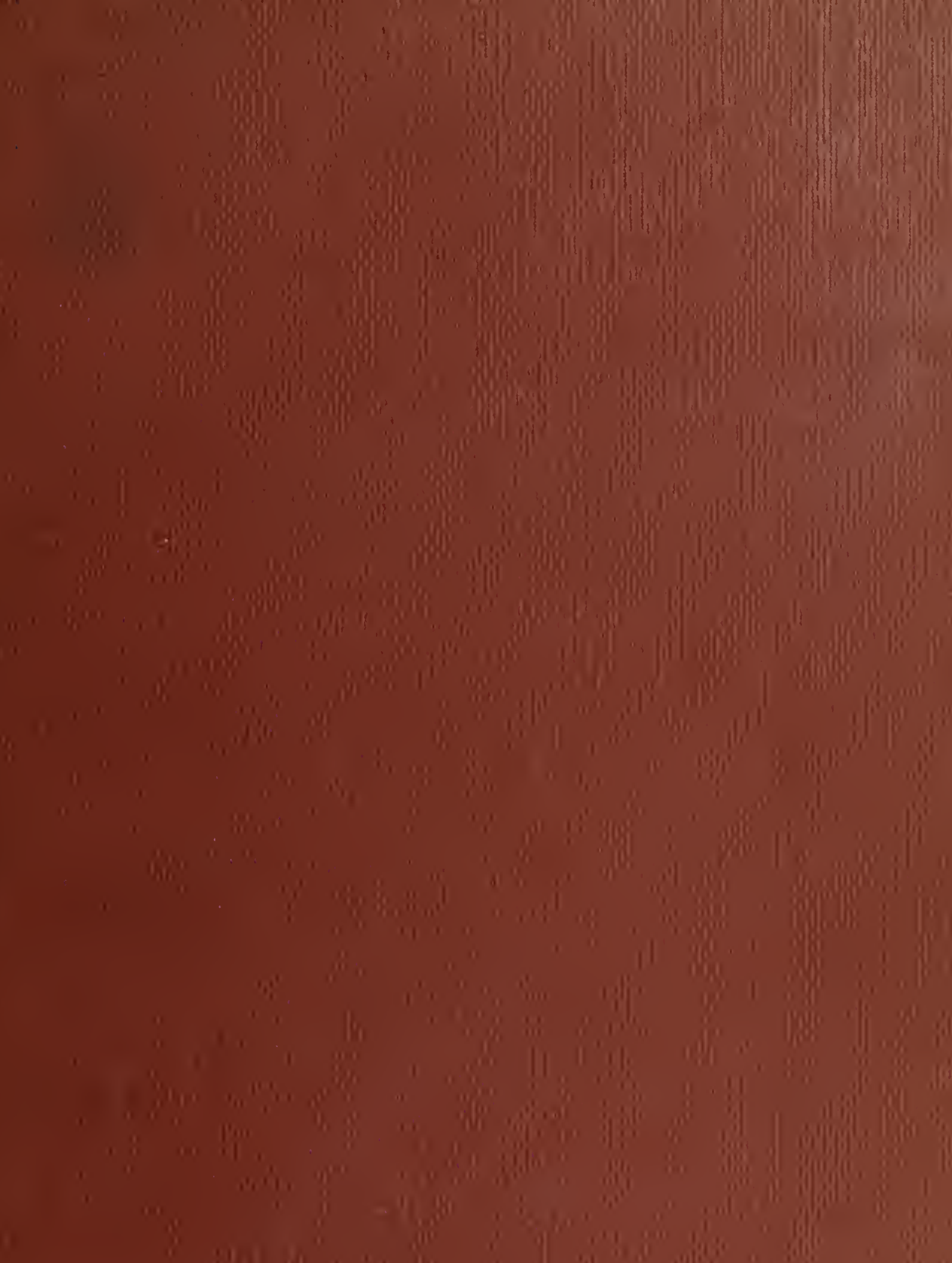

-

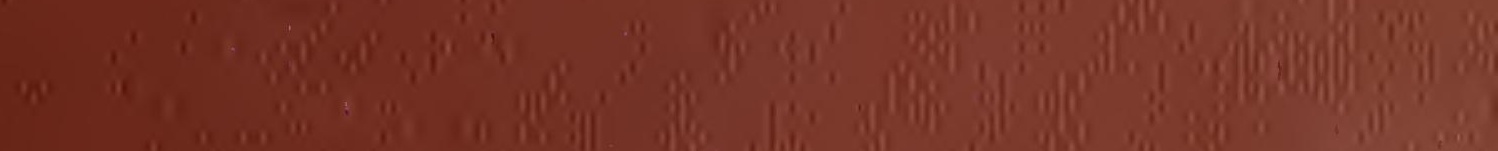

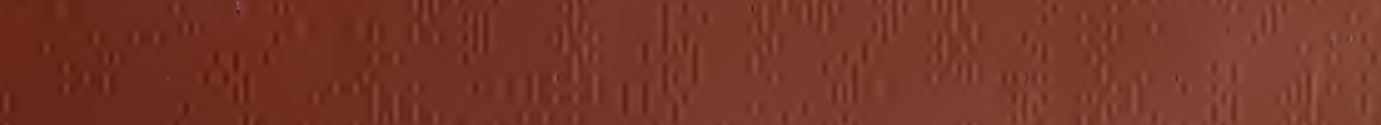
(n)

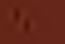




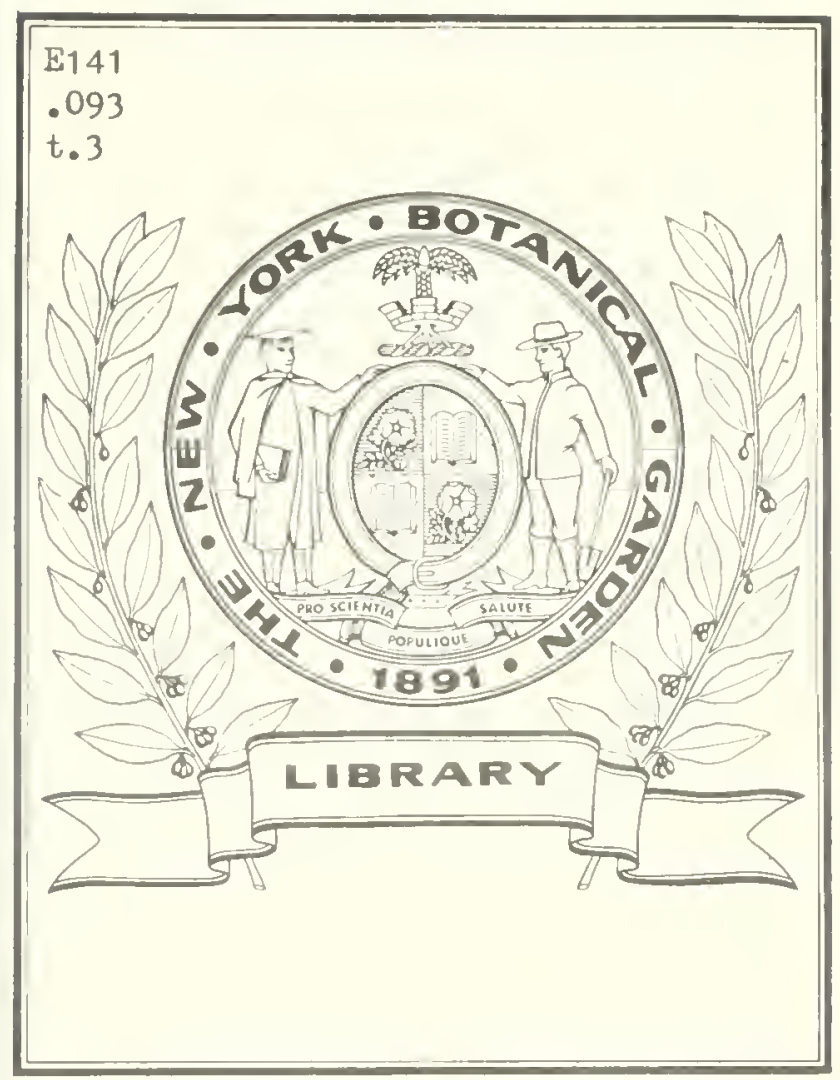








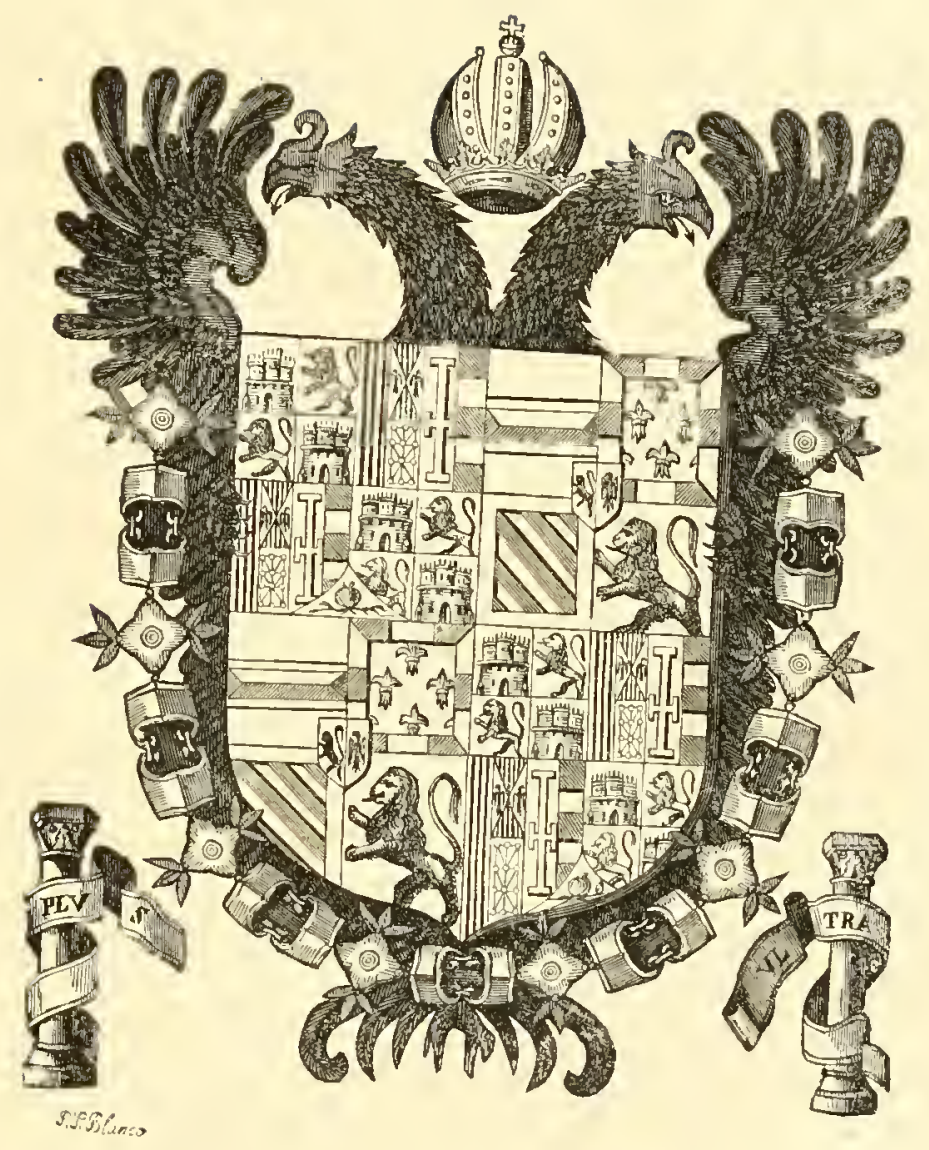

fal fjistorin Gomeral y ltatural De Indins. 



\title{
HISTORIA
}

\section{GENERAL Y NATURAL DE LAS INDIAS,}

ISLAS Y TIERRA-FIRME DEL MAR OCÉANO,

\author{
Por \\ DL CAPITAT GONZLLO PRRTANDER DE OVIEDO Y VALDES,
}

PRIMER CRONISTA DEL NUEYO MUNDO.

\section{PUBLICALA LA REAL ACADEMIA DE LA HISTORIA,}

COFEJDI COY EL CÓDICE ORIGINAL, ENRIQUECIDA CON LAS ENMIENDAS Y ADICIONES DEL AUTOR,

E. ILUSTRADA CON LA VIDA Y EL JUICIO DE LAS OBRAS DEL MISMO

POR

D. JOSE: AMADOR DE LOS RIOS,

Individuo de Nümero de dirho Cuerpo, Catedrático de Ampliacion de la Literatura Española en la Universidad de esta Córte, etc.

\section{TOMO SEGUNDO DE LA SEGUNDA PARTE,}

TERCERO DE LA OBRA.

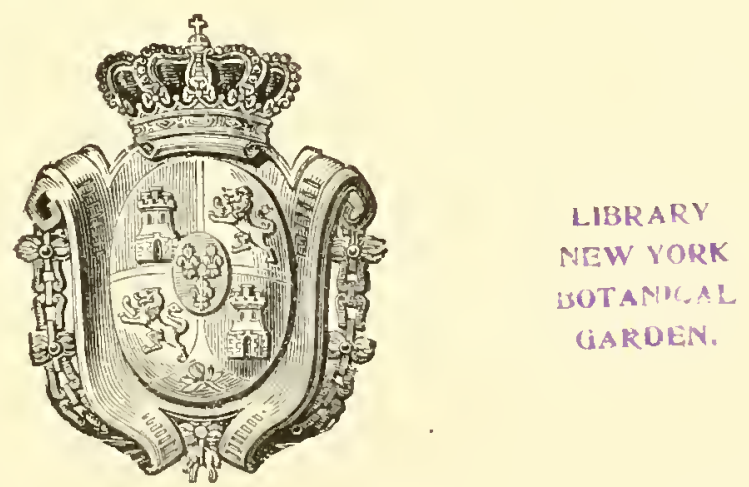

\section{MADRID.}

IMPRENTA DE LA REAL ACADEMII DE LA HISTORIA,

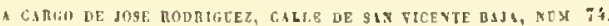





\section{ADVERTENCIA.}

C omo dejamos notado en el tomo anterior, compréndense en el presente los nueve últimos libros de la segunda parte de la Ilistoria general de Indias, euyo volúmen justifiea la formacion de uno y otro. Pero esta division no es hija solamente de la necesidad de sujetar á formas regulares la obra de 0viedo en está edicion, úniea completa de dielıa listoria : el mismo autor lubo de reconocer que era imposible enecral en un solo volímen toda la segunda parte, cualquiera que fuese la impresion de ella, y no vaciló en darle una division eonveniente, que es por cierto la alıora adoptada. Se lian cumplido en ennsecueneia los deseos del primer cronista de Indias, respecto de este punto, conforme al eódice autógrafo que la servido de texto, al eual debia extrietamente ajustarse la Academia.

En este segundo tomo se sigue el mismo orden que hemos reeonocido ya en el anterior sobre la manera de exponer los lechos. Mas si presentando los que eonstituyen la historia especial de eada gobernaeion, logra el cronista tener abierta siempre la narraeion, para acumular nuevos aconteeimientos, se vé forzado con frecuencia á reeorrer el mismo espacio, quitando á su obra la trabazon y enlaee propios de este linaje de tareas. Verdad es que ni hubiera podido Oviedo llevarlas á cabo de otra manera, con los medios que tenia á su alcance, ni á liaberlo pretendido, se ofreceria al estudio la Ilistoria general de Indias con la claridad que hoy presenta, abarcando tantos y tan varios sucesos, narrados por un actor y testigo, y careciendo por tanto de aquella eolıesion y unidad que solo pueden tener los trabajos listóricos, euando lia trascurrido ya el tiempo suficiente para juzgar los lıeelıos por sus naturales resultados y bajo un punto de vista verdaderamente sintélieo. La gran ventaja del método de Oviedo consiste á pesar de todo en que, si 110 puede esta parte de su obra ser considerada como una listoria que llene todas las condieiones del arte, eonserva todo el interés de unas memorias contemporáneas, donde hablan los mismos personajes y expliean por sí los aeonteeimientos en que intervienen, pues que solo en las eartas, rela- 
ciones a informes de Ins gohernadores, capilanes, religiosos y magistrados se funda esta peregrina narracion listórica.

Conlorme í este mélodo, almaza pues el libro XXIX, primero de este volímen, fodo lo ocurrido en la gobernacion de Castilla del Oro deste que Vasco Nunez de Balhoa se alzó con el dominio de Nuestra Señora de la Anligua del Darien liasta que pasó á aquellas regiones, para tomar residencia al licenciado Pero Vazyuez, cl doctor Robles. La parte mís principal de este libro es sin duda la concerniente al manlo de Pedrarias Dádvila, uno de los capilanes que más desaciertos é injusticias comelieron en el Nuevo Mundo, y único despoblador de Santa Maria de la Inligna. Con las de este desaleulado gobernador están estreclamente enlazadas las arenturas de Oviedo, durante la época en que aparece como actor en la conquista. De las penalidades y desgracias que le sobrevienen, como inevitable consecnencia de la enemistad del Pedrarias, queda ya liecha oporLuna mencion en la Vila y escritos del primer cronista de Indias, Irabajo que precede á la presente publicacion. Trás la narracion de los heclios relativos á la conquista, se dan curiosos é importantes pormenores, asi respecto de las minas de oro y pesquerias de perlas, como de las costumbres, funerales, ceremonias, supersliciones y creencias de aquellos indios, que lan de cerca estudió Oviedo. El libro termina con la noticia de los capitanes particulares, que siguieron las liuellas del Pedrarias, Pedro de los Rios y otros gobermadores, hallando desastroso fin en pago de sus liranias y crueldades.

El siguiente trata de la gobernacion de Cartagena desde la empresa malladada de Diego Gulierrez hasta la no más afortunada expedicion que en 1546 envió el almirante don Luis Colon a dicha provincia, bajo la conducla de Cristóhal de Peña. El cronista pensó continuar esta parte de su historia con la sucesiva relacion de los acaecimientos que fueran llegando á su nolicia, segun en su lugar vá advertido (pảg. 185).

La gobernacion de IJonduras es objeto del libro XXXI, más exlenso que el anterior y mucho más interesante por los peregrinos datos que en él recogió Oviedo respecto de los primeros pobladores de la ciudad de Trujillo, y sobre todo de las disensiones y sangrientos disturbios que en ella ocurrieron entre Vasco de IIerrera, Diego Mendez y Andrés de Cereceda. La descripcion de esta comarca, cuya gobernacion se reunió con la de Yucalan por mandado del Consejo Real de las Indias en 1559, la cnumeracion de sus minas de plata y oro, asi como de los animales, aves, plantas especiales y otros productos de la naturaleza forman los últimos capílulos, donde se narra lambien la arenencia lomada por los adelantados don Francisco de Montejo y Pedro de Alvarado, hlltimos capilanes que liasta el año en que Oviedo da fin á su libro, entendieron en aquella conquista.

La de Tucalan, unida como va dicho á la de Honduras, se refiere en el XXXII, ampliando lo dicho en el XVII de la primera parte, relativo al descubrimiento de aquella comarca, y recogiendo nuevas y más peregrinas noticias respecto de su riqueza y variedad grande de producciones. Las aventuras del adelantado don 
Franciseo Montejo, liasta poblar á Salamanea y Ciudad-Real, y el mal éxito de las expedieiones de Alonso Dávila, su teniente, son matcria de la mayor parte de este libro, donde, eomo en toda la Historia de Indias, apareee de relieve el heriosmo de los españoles, euyo sufrimiento raya en los limites de lo inverosímil.

El libro XXXIII está exelusivamente destinado á la Nueva España, formando la parte prineipal de este tereer volúmen. Válese 0viedo, para trazar la lisstoria de aquella extraordinaria eonquista, de diferentes documentos, euyo distinto orígen manifiesta el afan que tenia por deeir la verdad, á despecho de euantos interescs pugnáran por estorbarlo. Las eartas de IIernan Cortés, dirigidas al Emperador y publieadas hasta nuestros dias diferentes veees, son las primeras fuentes á que aeude Oviedo, llevado de aquel propósito; y ampliadas diclas relaeiones eon las de Alvarado, uno de los más distinguidos eapitanes de la Nueva España, Diego Godoy, no menos informado de lo que en su eonquista aeaeee, y otros eaballeros é hidalgos, aetores tambien en aquellos meinorables suecsos, rceurre el eronista á otro linaje de testigos, tales eomo fray Diego de Loaysa, de la Óden de Predieadores, don Antonio de Mendoza, primer virey de Méjieo (con quien sostienc euriosa correspondencia, de que ofrece en dos eartas intercsante muestra) y el hidalgo Juan Cano, marido de dona Isabel de Motezuma, y vecino de la eapital de Nueva España. De esta diversidad de informaeiones que amplia á otras partieulares, euyos autores no meneiona por sus nombres, pretende Oviedo saear la luz listórica que la menester para aeallar su coneieneia, siendo en verdad de suma importaneia, aun despues de los estudios hechos sobre el imperio mejieano, la multitud de noticias y los eontradietorios juieios sobre la conquista, que aeopió en esta partc de sus historias. No puede negarse que el libro XXXIII, por reproducirse una y otra vez la narraeion de unos mismos sueesos, earece de la unidad neeesaria á esta manera de trabajos; pero si bajo este punto de vista meramente literario es Oviedo digno de eensura, lo es asimismo de alabanza por la solieitud eon que atiende á inquirir la exaetitud listóriea, punto prineipal á donde eneaminaba todos sus pasos. Justo es por tanto dejar asentado que la eonquista de la Nueva Espana reeiloc nucvas y muy claras ilustraeiones con la publicacion de este libro.

El XXXIV habla de la gobernaeion de Nueva Galicia, llamada por los naturales Xaliseo. Fué esta eomarea conquistada por Nuño de Guzman, gobernador de Méjico, eélelore en la liistoria de Indias, no tanto por su valor eomo por sus erueldades. Sus expedieiones y las de sus tenientes oeupan los oeho primeros eapítulos de este libro, ofreciendo el IX, último de todo él, noticia de los lieenciados Lebron, Sepúlveda y Contrcras, que fueron á poner enmienda en los desaciertos de Nuño de Guzman, por mandado de la Audieneia de Santo Domingo.

báse en el libro XXXV conoeimiento de la gobernacion del rio de Panuco, cuyas lagunas fueron pobladas por disposicion é industria de Hernan Corlés; y sc refieren menudamente las desventuras de Panfilo de Narvaez y los que le siguieron en su malhadada expedicion al rio de las Palmas. Pcro esta relacion no pre- 
sentó en tiempo de Oviedo la novedad que las de otros sucesos, por haber sido publicalos ya, chando escribió este libro, los Naufragios de Alvar Nuñez Cabeza de Vaca, tesorero de la armada de Panfilo de Narvaez, y uno de los que más padecieron cutre los indios. Inserta en el tomo I de los IIistoriadores primitivos de las Inlias Occidentales formada por Bareia, no ofrece tampoco en nuestros dias mucho interés para los que conozean aquella coleccion; y sin embargo conviene observar que Ovicdo anadió algunos pormenores y circunstancias importantes, Irasmitidos por Alonso del Castillo y Andrés de Orantes, compañeros de Cabeza de Vaea en sus penalidaries é infortunios.

El libro XXXVI trata de la gobernacion de la Florida, cuyo descubrimiento narró ya Oviedo en el XVII, comprendiendo en el mismo las memorables expediciones de Ifernando de Sato, hasta su desastrosa muerte. Por esta causa se contrae el cronista á presentar en esta parte algunos pormenores, que si bien dan mayor esclarecimiento á la listoria, sirven más principalmente para la prosecucion del método por él establecido en la manera de exponerla. Este libro comprende solo dos capílulos.

Cuatro son los que encierra el XXXVII, que tiene por objeto la provincia de Chicora ó Gualdape, cuyas sonadas riquezas arrastraron al licenciado Lúcas Vazquez de Aillon á una perdicion segura. Solo el conocimiento de algunas produceiones naturales fué el fruto obtenido por los que siguieron al deslumbrado Aillon en su mal trazada empresa, cuya relacion trasmitieron á Oviedo fray Antonio Ifontesino, fray Antonio Cervantes, fray Pedro de Estrada, todos de la Orden de Predicadores, el capitan Franciseo Gomez, el piloto Pedro de Quexo y otros soldados que lograron escapar casi milagrosamente.

El libro XXXVIII es una disertacion geográfica, escrita con motivo de la reciente publicacion de Olao Gotho y Juan Magno, obispo Upsalense. Apoyado en sus tablas, apunta 0 viedo la hipótesi de que era posible la union de los continentes europeo, asiático, africano y americano, lipótesi racional, á que le llevaba la claridad de su investigador talento.

Tal es, pues, la extension de las materias contenidas en el presente volúmen. 
Este es el libro déçimo de la segunda parte, y es el vigéssimo nono de la General y natural Historia de las Indias, islas y Tierra-Firme del mar Oséano, el qual tracta de la provinçia y gobernaçion de Castilla del Oro, que comunmente se suele llamar Tierra-Firme.

\section{PROHEMIO.}

C terias de las que hasta aqui avrá leydo, si su lecion ha sido continuada, $y$ aun indinado con los que tractaron la muerte al general Diego de Nicuesa, segund se ha dicho en el libro preçedente; pero en este verá la justiçia de Dios, y la cuenta que tuvo para punir en esta vida á todos los que fueron en se la quitar; y assi se debe presumir que como justo y misericordioso se ovo Dios con los delinquientes, y con el que padesçió, sin lo merescer álos que tan cruda y desipiadadamente le echaron en un bergantin con otros trege homl,res por la mar, donde nunca mas paresçieron, ni se supo dél ni dellos cosa çicrta. Entiénlolo yo desta manera. I Diego de Nicuesa . como hombre, no le fallarian pecarlos TONO III. para sus trabaxos y muerte, y ya que la ovo de tal manera, es de pensar el que aquella penitencia y exilio mortal proçedió de la clemençia divina en parte satisfatoria de sus culpas para yr mas aparexado en la via de salvaçion; y téngolo por çierto, porque de personas que se hallaron pressentes supe que le oyeron deçir en su partida, con lágrimas, llamando á Dios: Ostende faciem tuam, et salvi erimus. Muéstranos, Señor, tu rostro, y seremos salvos.

Vasco Nuñez de Balboa, Nartin de Camudio, Lope de Olano, Diego Rilsero, el baclinller Diego de Corral, Diego Mllitez, Jolıan de Ezcaray, Luis dr. Mercado, Alonso Perez de la Rua. Hernando de Argiello, escribano, Luis Bo- 


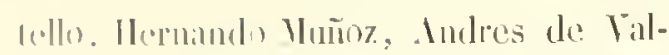

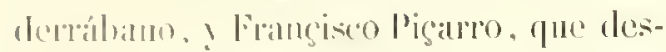

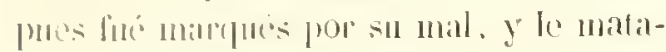

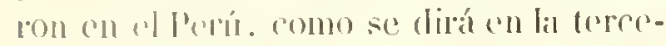

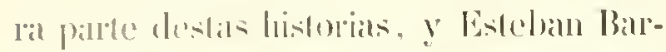

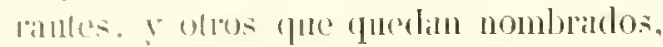
de puien jusia quededal podrár lener Diegro de Xichesal, y que fodos fineron en le deslruil. todos ovieron mal fin on este siglo falar fure asimosino tuviersen menos que purogar en la otra vida: cxegeplo sino fué, romo sinnel Gregrorio diçe en sus Morales,

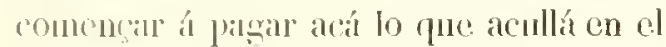
infierno nunca se acaba de padescer. Pelo como escél enmedio la sangre de JesuClupipso, á ál avrí plaçido que en esta vida hayan parado el mal que hicieron, porfue mediante la divina misericordia, pudicssen consegnir acullá la goria elerna. Eslo verá én su lugar apuntado quien conlinuare la lecion de los dos libros precedentes: y en aqueste llegare al calso.

Desta provinçia de Castilla del Oro fué (4) primero sallcador cl capitan Johan de la Cosa : y el segundo las refiruias del armilla y gente de Monso do Ojeda, entre los quales quedó por capilan primero y ulcalde en ápuclla tierra Vasco Nuñez de Ballsoa, al qual fué un hombre hidalgoo nalural de Jerez de Bislajoz. criado de don Pedro Puerto-Cirrero, scñor de Hoguér, (I Sordo. Dispues de Vaseo Nuñez, gohernador y capitan general, Pedrarias Dávila. matural de Segovia; al qual sul). cedió en la dicha golsernaçion un cavalleto de Cóndlova, Hamado Pedro de los liios. al rnal tomó residençia y quedó en a ofiçio el licenciado Intonio de la Gana: al liçnçado de la Gama subçedió un cavallero de Soria, Ilamado Franrisco de Birrionnevo, del qual se tractó un la primera parte, en el libro V, sotre la rebelion del caçique don Enrique. Despues de Francisco de Barrionuevo, fuć por juez de residençia el liçençiado Pedro Vizapuez, al qual subçedió el dotor Robles. Di todos estos zolomatores se tractará en este lilmo XXIX, y de otras parlicularidades desta provinģia de Castilla del Oro, y del primero descubrimiento de la mar del Sur, y de los rilos y çerimonias de los imlios, y de sus mantenimicntos, y otras muchas cosas convinientes al discurso destas historias: de las quales algunas con brevedad estín por mi escriptas en aquel Reportorio Sumario que se imprimió en Toledo, año de mill é quinientos é veynte y çinco años; pero mas largamente se repetirán aqui, y demás dellas se dirá todo lo que alí se dexó de escrebir, por no se aver salido al grunos en aquel ticmpo, como agora se saben, y la expiriencia lo la mostrado.

Tambien se hará mençion del prinçipio del descubrimiento del Perú, fecho por los capilanes Françisco Piçarro y Diego de Almagro; y mediante el divino favor se dirá todo lo que á esta gobernaçion fuere competente, porque en esta provinçia yo fuy veedor de las fundiciones del oro é ofiçial de Su Magestad alğunos años, y tengo noticia particular, como testigo de visla, de la mayor parte de quanto aqui se tractare. Tenga por aviso y verdad el leIor, questa poblaçion de Castilla del Oro es el principio y fundamento de torlo to (que en la Tierra-Firme, assi en la costa del Norte como en la del Sur, está descubierto y poblado de chripstianos: en el qual prinçipio pensó Vasco Nuñez, con sus cautelosas formas, quedar grand señor, viéndose capitan prinçipal de los primeros polyladores desta gobernacion, porque sin dulida él Irabaxó mucho en aquella tierra. Pero como dice Ciro ', rey de los Persas, sin dubda los hombres estiman que sea grande cosa adquirir el imperio: mas ciertamente muy mayor es conser.- 
varlo, despues ques adquirido, porque quauto mas los hombres poseen, tanto mayor envidia y envidias soportan, y mayor copia de enemigos han, máxime ayuellos que, como nos, por fuerça á los súbditos señorean. El que sube a algun señorio mas por acaso é favor de la fortuna que por prudençia y virtudes, ó por fraudes é mañas, sin méritos, no puede mucho permanesçer en tal estado. Viçio es de natıra que siempre avemos mucla confianca en las cosas no probadas. Assi lo diçe aquel grand Julio César en sus Comentarios ${ }^{1}$, y aun assi le acontesçió á él lo uno y lo otro, si quisiéredes oyr á los que su vida y obras notaron; pero en fin, toda la vida es trabaxo en tanto que en esta carne mortal estamos. No ignoraba esto aquel sancto Job, quando dixo : Militia est vito hominis super terram ${ }^{2}$. Astrubal Gripho, embajador de los Cartagineses, dixo á Cipion : "Son los pueblos naturalmente inclinados á lo peor, y aquello ques mas grato á la mollitud, há lugarar mas ayna ${ }^{3}$. Y assi suljçedió la mudança del estado de Vasco Nuñez de Ballboa, y aun de otros gobernadores que despues dél gobernaron esta provinçia; porque los liombres, por la felicilad nuevamente adquirida, mas soljerbios y menos cautos suelen ser las mas veges. El saber no viene de los hombres, mas de Dios, como se dice en el Ecclesístico primo: Omnis sapientia à Domino Deo est. Aristóteles no ignoraba esta verdad, pues dixo: Sapientia non est humana, sed divina possesio ${ }^{4}$. La sapiençia no es lumana, sino divina possesion. Assi que, pues de Dios el siber es y el poder, et sine ipso factum est nihil ${ }^{5}$, no sé yo cóuno los clripstianos, á quien Dios pone en lugar alto y con administraçion de otros lombres, sobre quien les da porler y jurisdiçion, se olvidan y desacuerdan de su

1 Lib. II.

2 Cap. $\%$

3 Apiano. superior celestial, al qual ni se puede mentir sin que lo entienda, ni lisongeando ganar su graçia, mostrando uno en la lengua y guardando en el ámimo lo contrario, que publican.

En el libro antes deste se dixo la forma que Vasco Nuñez ovo para salir desta cibdad de Sancto Domingo, escondido envuelto en la vela cogida en la entena de la nao en quel bachiller Martin Fernandez de Ençiso fué á buscar á Ilojeda; y cómo se les perdió aquella nao çerca de la punta de Caribana, y cómo estando en aquel trabaxo topó con ellos el capitan Françisco Piçarro, despues que oro desamparado el assiento de Urabí, que en dos bergantines, con la gente que quedaba de Hojeda lo venia á buscar á esta cibrlad; y cómo juntos los que llevaba Ençiso y los que traia Piçarro ganaron el Darien; y cómo Vasco Nuñez fué clegidlo alcalde, é prendió al bachiller Ençiso y lo envió á España; y cómo envió á llamar al capjitan Dicgo de Nicuesa para que gobernasse, y la manera y falsedarl, que contra él ovo para lo echar de la tierra donde se perdió con otros treçe hombres; y cóno fueron enviados por procuradores á España, de parte de Vasco Nuñez é de la commidad del Darien, el veedor Johan de Quicedo y el capitan Rodrigo de Colmenares; y cómo por otra parte le fué llevada una çédula del Rey Catlólico á Vasco Nuñez para que fuesse capitan y gobernasse aquella provinçia del Darien en tanto que su real vohuntad fiesse. Queda ahıra de deçir lo que despues subgedió, y deçirlo he, desde quandlo aquel pueblo del Darien se ganó á los indios, porque la historia vaya fundada desde su prinçipio, y subçesivamentese diga lo que proçedió de alí adelante lasta el tiempo pressenic; y es de aquesta manera.

4 Lib. 1, Meteor, c. 1.

5 San Juan, cap. 1. 


\section{CAPITULO I.}

L. onu lu provehido Pedrarias Dávila de la gobernacion de Castilla del Oro, que tenia Vasco Nuñez de Balboa, y otras cosas que convienen á la historia.

E II el libro preçedente se dixo cómo el bachiller Irartin Fernandez de Ençiso fué echarlo de la Tierra-Firme por Tasco Nunez de Ballooa y enviado presso á Castillit. donde llegó y se quexó de Tasco NuIic\% y de Bartolomé líntado, su companero. Isinnesmo se dixo cómo el veedor Johan de Quiçedo y el capitan Rodrigo de Cohnenares fueron por procuradores de la commindarl de la villa del Darien, que ia le llamaban Sancta Maria de la Antisurua; y cómo fué el alcalde Martin de Camudio por parte de Tasco Nunez á informar de lo que á su propóseito era. Pero como entre las otras culpas que le imponian á Vasco Kuñez se haçia memoria de la forma fure turo en cechar de la ticria á Diego de Vieuesa tan cruda y desapiaIadanente, no hastaron disculpas por prute de Vasco Nuñez: antes se enojó de mancra el Rey Cathólico, sabila la verdau, que turo nesçessidad el Camudio de huyr secretamente de la córte, y los senores del Consejo de las Indias le mandaron prender, y no pulo ser avido. Y el Rey acordó dé enviar gobernador á aquelli provinçia, y mandó que la llamassen astilliı del Oro, porque deçian que era mex rica tierra, y nombró por olrispo a tray dollan de Quevedo, do la Orden de since Françisco, predicador de su capilla ral. El objispo de Palencia, don Johan hodriguez de Fonseca, era presidente del Cunsejo de las Indias, y capellan mayor ? privalo del Rey, y á su suplicaçion y inr su respecto fué elegido por crobernador y capitan greneral un cavallero de Se-

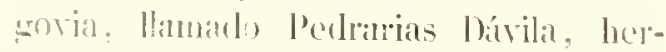
mano de Johan drias birila. que despues fué el primero conde de Puñoenrostro: por thessorero para la hacienda real Alonso de la Puente, natural de la Parra, çerca de Cafra; por contador Diego Marquez. natural de Toro, criado del obispo Fonseca; por factor Johan de Tabira, repostero de estrados del Rey, natural de Ocaña, y por veedor de las fundiçiones del oro aquel Johan de Quiçedo ques dicho que fuć procurador del Darien. Este, despues que volvia de la córte, allegado á Sevilla, murió hinchado, y tan amarillo como aquel oro que anduro á buscar : en el qual començó Dios á punir los que echaron á Nicuesa del mundo; y el Rey Cathólico me hiço merçed, á mí el clrronista, de aquel oficio de veedor, por fin de Johan de Quiçedo. Assi que, acordó el Rey que se hiçiesse una armata de tres mill hombres, y se provejesse muy cumplidamente, y que fuesse Pedrarias por su capitan general y gobernador, y inquiriesse las culpas y méritos de Yasco Nuniez de Balboa, $\mathrm{y}$ grobernasse y conquislasse y poblasse aquella tierra, señalálıdole por gobernaçion desde el Cabo de la Tela lasta Veragua, y desde estos límites, que son en la costa del Norte, colriendo la tierra adentro háçia la parte austral, todo aquello que oviesse de mar á mar, con las islas que en ello concurriessen. I' porque los reçinos del Darien eran unos mas antiguos que otros en la tierra, proveyó el Rey y su Consejo que en los repartimientos y caluallerias y mercerles y solares, despues de aver cumpliclo primeramente con sus ofiçiales, fuessen los primeros gratifieados los que fucron de la compañia del capitan Llonso 
de Ilojeda, porque estos ganaron aquella villa, y tras estos los que oviesse del capitan Diego de Nicuesa, y despnes á los demás, segund su antigiedad en la tierra.

Idos Pedrarias y el obispo y ofiçiales á Sevilla, se començó á juntar la grente, y por ser entrado el invierno y no ser tiempo de navegar . se tardó el viage todo lo restante de aquel año de mill é quinientos y treçe años, y aun parte del año siguienle; en cl qual tiempo se allegaron muchos cavalleros é hidalgos, y mucha gente de bien y muchos artesanos de diversos oficios; y assimesmo muctios labradores para la agricoltura y labor del campo, que para haçer este viage de unas partes é otlas siempre ocurrian á la fama deste oro. Y como el general Pedrarias era bien hablado, y decia muchas cosas de aquellas tierras, que aun ćl no sahia, é el obispo fray Jolıan de Quevedo en sus predicaçiones contaba cosas inauditas, y para mover á los cohdiçiosos prometia galardones y thessoros de que ninguna çertenidad ni verdadera informaçion avia, mas de la buena esperança; assi nunca çessahan de venir de toda España, y aun de fucra della, hombres que desscaban ver essas maravillas y grandíssimas riqueças quel olsispo y Pedrarias pregonaban, y jor su mandado otros capitanes inferiores. Deque se siguió que oro muchos que vendieron los patrimonios y rentas y haçiendas que tenian y heredaron de sus padres; y otros, algo menos locos, las empeñaron por algunos años, dexando lo çierto por lo dubdoso: otros dexaron á sus senores y perdicron el tiempo que los avian servido, no tenicudo en nada el galardon que esperaban, en comparaçion de lo que avian de addquirir y ganar en este camino.

Y porque dixe de susso de los predicadores ó capitanes inferiores, digo que solamente fueron nomblados por capitanes del Rey en esta armada los que ago- ra diré, porque ammque oro muchos tespues, cran hechos por Pedrarias: pero los del número real cran Luis Carrillo, Gonçalo Fernandez de Lago, Contreras, Francisco Vazquez Coronado, biego de Bustamante, Atiença, Johan de Lyora, hermano del chronista Gongalo de Lyora: este fué por teniente de capitan greneral. Otros muchos se llamaron capitanes, allende de aquestos seys, y tuvieron gente. y Pedrarias se la encomendó por los honrar y aprovechar, assi como Gaspar de Morales, primo del general: Pedrarias el Manceloo, sobrino del general; el capitan Françiseo Dávila; el capitan Meneses; el capitan Intonio Tellez de Guzman; el capitan Gamarra, y el capitan Rodriggo de Colnenares, que vino por procurador del Darien. Yotros lo fueron despues, andando el tiempo y durante la conquista ; porrue una de las prinçipales haçiendas ó aparejo para ganar es este nombre de capitan, como adelante se verá en el discurso destas historias. Por alcalde mayor de Pedrarias fué el liçençiado Gaspar de Espinosa; y despues, desde á mucho, se llamaron capitanes Gonçalo de Barlajoz, Diego Albitez, Johan de Ezcaray, Françiseo Hernandez, Hernando de Soto, Françisco Campañon, Hernand Ponçe de Leon. y Chripstóbal Serrano, antes que muchos de aquestos, porque fué desde aquesta cibdiat enviado con gente en socorro de Vasco Nuñez, y de los primeros pohladores del Darien. Assimesmo se llamaron capitanes y lo fueron Françisco Piçarro, Diego de Almagro, Galhriel de Roxas, Andres de Garavito, Johan de Cárdenas, Bartoloné Ilurtado, y otros que en su liempo y lugar serán nombrados. Y no paresca supérlluo arer nombrado aquestos capitanes, y tenga memoria y cucnta el letor con ellos, y sablái adclante grandes particularidades y cosas de sus personas.

Por manera que allegada la gente de la armada en Sevilla, esperando el via- 
gre, gastalian lo que teniam y buscalan mas paras se sostencer, á causa de la dilaçion de la partidar, Inagiendo cuenta

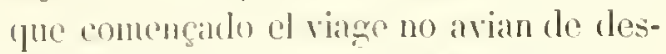
pender natal. porphe el liey liço merced á fodos de les dar pasiage franco y ef matalotige para d canino, y mandóles diar de conner mon mes despues que fuessen llerrados al Danien, y assi se hiço y cunplió. Mas pues ya se tractará de aqui adclante desta tierra, parésceme que es bien que se diga primero lo que interrino á Vaseo Nuñez de Ballooa, despues qućl y los primeros conpuistadores ganaron afuella villa (lel Darien; y adelante, en su lugara proprio, se dirá el riage que

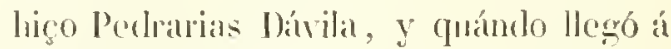
atpuclla tierra, y de lo que sulicedió de alli adclante en esta grobernaçion de Castilla del Oro.

\section{CAPITULO II.}

De lo que subecdici á Tasco Nuñez de Baboa despues que se ganó el Darien, y eúmo deseubrió el rio grande de Sanel Johan, que entra en el gulfho de Lrabá, y otras eosas nesçessarias al proẹesso de la historia.

\section{D} ixose en el lilıro XXTill cómo Taseo Nuñez de Ballioa, porque no le deturiessen sus acreedores en csla ciludad de Sancto Donningo . salió escondido envuelto en la vela de la nao en que yba cl bachiller Enciso á bnscar al gobernador Alonso de Ilojeda á L'rabí, y tambien se dixo pue esta nao se perdió en los baxos de la punta de Carilana, y rue se toparon alli con el capitan Françisco Piçarro, que despues fué golvernador del Perú, y entonges era teniente de Hojeda en Trabá: y la dexala desamparada y renia á esta cilidad de Sancto Dominẹo á buscar ¿ Hojeda; y con los bergantines en que Piçaro renia y con otros los quel Ençiso llevalı, se salró la crente; y juntados eslos espanioles, consirenidos de la nesgessidad y falta de bastimento, dieron en la provincia de Comaco y ganaron el pueblo del Dirien. lo qual mas largamente se di5o en cl capítulo Ill del libro XXIl. I luego estos chripstianos hiçieron alcaldes ordimarios. porefue no quisicron obcrlesçer al bachiller Ençiso ni á Piçarro; y uno destos alealdes fuć Tásco Nuñez, y el otro un vizayno, llamado Martin de Camudio: pero conis el Vaseo Nintez era muy manoso, y tenia mas persona, ćl cra cl todo.
En (l) qual tiempo se hiçieron algumas entradas la ticria adelante adentro, y se ovicron en reces mas de treynta mill pes. sos de oro, allende de otros treçe mill que sc lomaron, quando aquel assicnto se ganó. Nas porque seria cansançio deçirse los trabaxos y nescessidades y hambres que en aquellos prinçipios estos primeros conquistadores padesçieron, diré solitmente la entrada que Vaseo Nuñez hiço, quando descubrió el rio de Sanet Johan. en este capitulo: y en el sigruiente diré cómo descubrió la mar del Sur opuesta á la parte del Nediodia de la otra costa de la Ticra-Firme, que fué un serviçio muy se. nalado. Y sin ofensa de ningun capitan de quantos despues del almirante, don Chripstóbal Colom. primero descubridor destas Indias, han passado á estas partes, esta fué una de las mas importantes y señaladas cosas que acá se lan heclo. Y en la ver. dad Vaseo Nuñez turo valerosa persona. y cra para mucho mas que otros: ni tampoco le faltaban cautclas ni colodiçia: pero junto con esso era bien partido en los despojos y entratas que laçia. Tenia otra cosa. especialmente en el campo. que si IIn hombre se le cansaba y adolesgia en qualquier jornada quél se hallasse, no lo 
desamparaha: antes si era nesçessario, ylua con una ballesta á le buscar un páxaro ó are, y se la mataba y se la traia; y le curaba, como á hijo ó hermano suyo, y lo csforçaba y animaba. Lo qual ningun capitan de quantos hasta hoy, que estamos en el año de mill é quinientos é quarenta y oclı años, lıan venitlo á Indias, en las entradas y conquistas que se hallaron no lo la hecho mejor, ni aun tan bien como Vasco Nuĩez.

Yo me maravillo de la çeguedad de al. gunos capitanes secos y desapiadados con la gente, que aunque vean morir de liambre un clripstiano no le dan un jarro de agua, ni haçen mas chripstiandad con los enfermos que si fuessen piedras; pues ya que no tengan misericordia del próximo, debiéranlo laaçer por su proprio interes, pues que faltando la gente falta el ofiçio y la capitania, y ya cque totalmente no se les acabe, faltando algunos, a lo menos cnflaquésçese y desfallesçe en parte su poder del capitan quanto menos hombres ficne á quien mande. Assi que, en este caso ventaja liço á quantos yo por acá lie visto. Tornemos ál nuestra historia.

Despues que los procuradores del Darien partieron para España, quedando Vasco Nuñez por capitan y alcalde en el Darien, y ariéndole ya llevado una çédula del Rey, en que le líço su capitan y gobernador de aquella tierra en tanto que fuesse su real voluntad, acordó de yr la tierra adentro, porque se Lallaba ya con mas gente: que los primeros chripstianos que ganaron aquella villa, que serian lasta trescientos, cran muertos de lambre mas de la mitad, y despues avian ydo el capitan Rodrigo de Colmenares con una nao, é tocó en Gaira, debaxo de Sancta Narta, y matáronle los indios caribes mas de treynta hombies por su mal recabdo; y de allí se fué al Darien con los que le quedaron, que eran mas de ciento. Despues fué el capitan Chripstólıal Serrano, y llevó mas de dosçientas personas, en que. avia bien çiento é çinquienta hombres de pelea, y en otros navios avian ydo otros. Assi que ya aquella villa estaba mas poblada: con los quales primeros conquistadores, antes que Colmenares ni Serrano fuessen, se avian juntado los que quedaron del armada del capitan Diego de $\mathrm{Ni}$ cuesa, como se dixo en el libro preçedente. Y cn este camino descubrió Vasco Nuñez el rio Grande, que entra en la culati 6 ancon y golpho de Urabá: y es causa la mucha aģua y veloçidad de su curso, que con la jusente ó baxa mar se torna dulçe aquel golplio en doçe legruas ó mas de longitud, y seys ó siete de latitud. Yo he metido muchas veces in jarro de plata, colgado de una cuerda, allí estando en una nao surta en ocho braças de fondo, y saqué el ağua dulçe y potable; y arpuesto mesmo despues en bareas y canoas lo he probado muchas veçes en el mesmo golpho, y está de beher el agua en aquel golpho, quando la mar cstá menguante. Entra allí este rio por sicte ú ocho bocas, seggund alğmos diçen, y al mesmo Yasco Nunez oy deçir muchas veçes que son diez estos braços deste rio, quando llegan á la mar, y los seys dellos no menores quel rio de Guadalquevir. To no he visto destas bocas sino la questá mas reçina al Darien, y no me paresçió menos quel rio de Tajo ó Guadalquevir; pero es muy notoria su grandeça y muy scñalada en la cosmographia y pintura del mundo. Estas bocas están en siete grados y medio pocos minutos mas ó menos unas que otras, donde eutran en la mar, desta parte de la línia equinoçial: el Darien estí en Ios mismos grados. Corre este rio con tan grande ímpetu de la parte del Mediodia contra Septentrion, y es tan veloçe la fuga que trae, que fodo lo que una ligera caravela navegare á todas velas con próspero viento el rio arriba en diez dias, lo baxarái ó tornarí á andar hácia la mar 
donde entra. en un dia sin reda alcguna; por linto no es de malas villar de la velo-

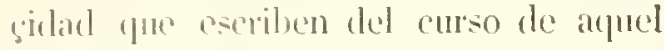
gramd roo Tigris.

Este rio Grande. de quien aqui se tracla . por stre aresciontes sale fuera de madro, é se exliende en muclias é gramdes reggats y cahanias. á calusa de lo gual en sus costas hay muchos ancogaliços: y chIran otros muchos rios por diversas partes yesteros 6 arroyos en rio prinçpal. y salcu dél muchas lagunnas 0 estanos, en "special láceia la parte del Oriente ¿ Laiçia la provinçia que llaman del Dabaibe. I este rio podroso puso nombre Visco Niñez rio de Sinct Johan, porque en tal dia le vido él, á reynte é quatro de junio de mill é quinientos y diez de la natividad de Chripsto, nuestro Redemptor.

En algunas partes de la costa deste rio lıa polblaçiones dentro del ağua, y están fumbladis las casas solore muchas palmas altas y juntas y gruessas: y lay buhío destos que tiene çinquienta y sessenta palmas: y ticnen sus eacalas licelas de bexuco, por donde suben y desçienden, y allá en lo alto está hecha la casa y labilaçion de los indios, y al pié de las palmas tienen sus canoas, con que salen á pescar y á labrar la tierra y sembrar sus mahiçales en lo que está enjuto y apartado del rio. Estas son muy fuertes y seguras casas ó moridas contra el fuego, y sin temor de sis enemigos y de los tigres y otras bestias fieras. y pocos hombres hastan á definder una casa destas contra muchos, aunfue sea uno en resistir á çiento.

Doste canino en que se descubrió este rio ggande de Sanct Johan, se ovo algurn oro que se halló en poder de caçiques de la comanea, éso ovieron algmos indios, sallédulolos segund coshmmbre de gentede gucria; pero despues de avidos, laçíalos tractar hien Vaseo Nuñez, y daba á los carcicues liakhas y otras cosas para los animar y traer á la anistad de los chripstianos. I los mismos caciques daban á los españoles al çunos indios que entre ellos tienen por csclaros. y se sirven dellos, que los han avido en la guerra, la qual nunca falta entre los indios umos con otros; y al ques esclavo lhímanle paco, y cada caçieue tiene sus esclayos lierrados con su señal diferençiada en el braço ó en la cara. y alğunos tienen por señal sacarle al esclavo un diente de los delanteros de la boca. Tambien los caçiques se pintan á sí y á sus indios y gente, $y$ tienen sus divisas é invençiones de pinturas para esto de otra manera, muy diferençiadas de las que usan poner ál los esclavos, y haçen aquellas labores con un çicrto carbon molido, que llaman thyle, que echan sobre lo que han cortado con mas navaxas sutiles de pedernal, ó punçándolo con unas espinas de tunas que sacan sangre, en la qual sc empapa aquel carbon, y quédales fija la pintura y señales para quanto vivan. que es negro y de aquella manera que en Berberia se acostumbran pintar entre los moros. Aquel polvo negro que assi se cchan en lo cortado, de que quedan pintados. que se llama lliyle, es muy presçiado entre los indios; $y$ es buen rescate para su tracto. 


\section{CAPITULO III.}

Cómo Vasco Nuñez de Balboa descubrió la mar del Sur y fué el primero hombre que la enseño ả los chripstianos, y de los eaẹiques que hiço de paz, é otras cosas conçernientes á la historia.

0 atro años avia que los chripstianos estaban en la Tierra-Firme: militaban debaso de la gobernacion del capilan Tasco Nunez de Balboa, y tenia hechos de paçes algunos caçiques, en espeçial al de Careta, questá en la costa del Poniente, veynte leguas del Darien, más al Oçidente, y el caçique de Comogre, que ya el uno $\mathrm{y}$ el otro se avian baptiçado. Y el caçique de Careta se deçia Chima y llamáronle don Fernando, y tenia hasta dos mill indios de guerra: el caçique de Comogre era mayor señor, y su proprio nombre era Ponquiaco, y en el baptismo le llamaron don Cárlos: tenia mas de tres mill hombres de guerra, y era señor de mas de diez mill personas. Estos caçiques estaban ya tán mansos, que enviaban sus mensageros y canoas, y yluan y venian al Darien muy (lomésticamente á ver los chripstianos, y como amigos se comunicaluan con ellos. Con esperança de los avisos que destos indios ya tenia Vasco Nuñez sabido y entendido en mucho secreto por sus lenguas, acortó de se partir un jueves primero dia del mes de septiembre, año de mill é quinientos y treçe años, y salió de la rilla de Sancta Maria de la Antigua con ochoçientos homlsres, y embarcóse en un galeon y nueve canoas con esta gente, só color de lusear minas y inquirir los secretos de la tierra. Y el domingo siguiente, í quatro dias de aquel mes, llegó de esta armada á Carela con las canoas la mitad de la grente porque el galeon quedó atrás con los restantes; y allí se desembarcó Vasco Nuñez, y el caçique don Fermando lo resçibió á él y á loda la gente muy bien, assi á los que fueron en las canoas como á los del galeon. Despues que lleTO.HO III. garon, como fueron todos juntos, aparti el capitan Vasco Nuñez los que le paresçió que debia de llevar, y dexó en aquel puerto los que avian de guardar el galeon y las canoas, y partióse la tierra adentro á los seys dias de aquel mes: y desde át dos dias adelante allegó al caçique de Ponca por camino muy áspero y de mucho trabaxo y sicrras, y hallaron al caçique y su gente que avian huydo al monte.

Antes que se proçeda adlelante, quiero quel que me escuchare sepa que la villa, que agora los clripsianos llaman Acla, es y está fundada en aquel puerto de Careta. Assimesmo quiero lacer memoria de un perro que tenia Vasco Nuñez que se llamaba Leonçico, y que era lijo del perro Beçerrico de la isla de Sanct Johan, y no fué menos famoso quel padre. Este perro ganó á Vasco Nuñez en esta y otras entradas mas de mill pessos de oro, porque se le daba tanta parte como á un compañero en el oro y en los esclavos. quando se repartian. Assi, yendo Vasco Nuñez, dábanle á él sueldo é parte, como á otros capitanes: y el perro era tal que la meresçia mejor que muchos compañeros soñolientos, que presumen de ganar holgando lo que otros con sus sudores y diligençias allegan. Era aqueste perro de un distinto maravilloso, y assi conosçia el indio bravo $y$ el manso como le conosçiera yo ú otro que en esta guerra anduviera, é tuviera raçon: é despues que se tomalsan é ranchealuan algunos indios é indias, si se soltaban de dia ó de noche, en diçiendo al perro: "ydo es, búscale, assi lo hagia; y era tan grand ventor, que por maravilla se le escapalsa ninguno que se les fucse á los chripstianos. Y cómo le al- 
cancilbat. si ol indio estalna puedo. atiale

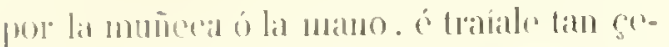

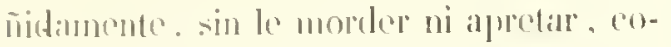

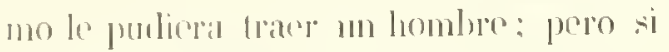
se ponia en defonsa, laçiale pelaços. Y rat tan temido ale los indios, gue si diem "lnipestianos yban con al perro, ylan mas

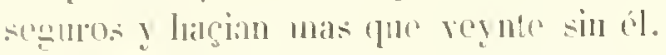
To vi este perro, porepue eframdo llegó Pedrarias á la terra. al ano signente de unill a puinientos y raltorese, cra vivo. y lo prestó Varco Nuney á al gumas entradas yne se hiçieron despues, y ganaba sus partes conko he dicho: y era un perro bere incjo, y el loceico negro ýmerliano, y" 110 alindido: pero cra reçio y doblado, y teuia muchas luericlas y señales de las que avia avido en la rontinuacion de la gucrela. peleando con los indios. Despues por anvidia. quien quiera que fuć, le dió al perro á comer, con qué murió.

Ilgunos perros quedillon hijos suyos, pero ninguno tal como él se ha visto despues en estas partes. Plinio, en su Natural historia', dice grandes cosas de algunos perros particulares y famosos: y entre las otras cosas de tal animal, dige queste animal solo conosce á su señor, y que enliende quál no es domóstico, y entiende sl nombre, y enticnde la roz doméstica. y atcuérdasele qualquicr camino ó senda que laỵa andado. aunque haya mucho tiem10 que no la vido, y diçe que no hay animal, excepto cl hombre, que tenga ma! or memoria. Estas cosis conosçidamente so vian en este perro Leonçico. y no hiço poca lalta con lit tierra, despues que le matavon maliçiosamente. Passemos adelante.

Despues de lo yues dieho, á los trege dreseptiomber vino d cacique de Ponca asconaralo por el capitan Vaseo Nuñez, y il le liço mucha lionra, y le dió camisas y harcluas, y le contentó en lo que pudo: el yual caçique, viéndose lien tractado, di- xo en secroto unthide cosis a Vaseo Nuñez, (pucl holgó de sillere, de los sereretos a riquegas de la tiorra: y cutre las otris le diso. fue cientas jornadas de alli avia otro pechry. pur en aquella lengua quicre deçir mar, a hiço presiente á Vaseo Nuño de altumams pieças de oro muy bien

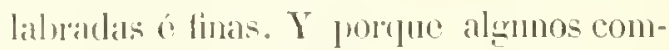
bañons avian adolesçilo, quediaron allí doce (hripstimos. para que se tornassen al puerto de Careta.

A los veynte de aquel mes se partió Vasco Nuñez de la tierra deste caçique con çiertas guias que Ponea le dió hasta que llegasse á tierra dol caçique Torecha, con el qual tenia grnerra Ponea; y á los vejute é quatro dias de aquel mes, dió de noche sobre el eacique Torecha y su gente. questá dicz leguas adelante de Ponca, de mal camino é de rios, que passaron loz españoles en balsas y á mucho peligro. Y allí se tomó alguna geute y algun oro y perlas, y se informó mas largamente Vasco Nuñez de las cosas de la tierra adentro é de la otra mardel Sur. É stlí en Torecha dexó parte de la gente, é partióse con hasta septenta hombres; é a los reynte é çinco de aquel mes, el mesmo dia que partió. llegó á los buhios é assiento del caçique, llamado Porque, y avíase absentado; Y no curó dél, sino passó adelante . siguiendo su viage, en busca de la otra mar. Y un mártes, vernte é cinco de septiembre de aquel año de mill é quinientos y treçe. a las dicz horas del dia, yendo el capilan Vaseo Nuñez en la delantera de todos los que llevaba por un monte raso arriba, vido deste ençima de la cumbre dél la mar del Sur, antes que ninguno de los chripstianos compañeros que allí yban, $\mathrm{y}$ volvióse incontinente la cara láçia la gente, muy alegre, alçando las manos y los ojos al çielo. ahabando á Jesu-Chripsto y á su gloriosa madre la Vírgen, Nuestra Señora; y luego 
Hincó ambas rodillas en ticrra y dió muchats graçias á Dios por la merced que le ar ia hecho, en le dexar descubrir ayuella mar, y haçer en ello tan grand serviçio á Dios y á los Cathólicos y Seleníssimos Reyes de Castilla, nuestros señores, que entonçes era el Cathólico Rey don Fernando, quinto de tal nombre, que granó á Grauada é gohernaba á Castilla por la Reyna doña Johana, su hija, madre de la Cessárea Magestad del Emperador don Cárlos, nuestro señor, é á todos los otros reyes sus sulycessores. Y mandó á todos los que eon él yluan que assimesmo se hineassen de rodillas y diessen las mésmas graçias á Dios por ello, y le suplicassen con mucha deroçion que les dexasse descubrir y rer los grandes secretos é riqueças que en aquella mar y eostas avia y se esperaban para ensalçe mayor é aumento de la fée chrijstiana, y de la conversion de los naturales indios de aquellas partes australes, é para mucha prosperidad é gloria de la silla Real de Castilla é de los prínçipes della, pressentes é por venir. Todos lo hiçieron assi muy de grado y goçosos, y en continente liico el capitan cortar un hermoso árlol, de que se hiço ma cruz alta, que se lincó é fijó en aquel mesmo lugar y monte alto, desde donde se vido primero aquella mar austral. Y porque lo primero que se vido fuć un golplıo ó ancon que entra en la tierra, mandóle Ilamar Vásco Nonez golpho de Sanet Migucl, porque era la fiesta de aquel arcángel desde á quatro dias; y mandó assimesmo que todas las personas que allí se liallaron con él, fuessen escriptos sus nombres, para que dél y dellos quedasse memoria, pues que fueron los primeros clnipstianos que vieron arjuella mar; los quales tolos cantaron aquel canto de los gloriosos sanctos dotores de la lglosia, Ambrosio y Augustin, assi como un devoto clérigo, llamado InArés de Vera, que en esto se laalló, lo cantaba con ellos con lágrimas de muy alegre devoçion, diciendo: Te Derm laudamus: Te Dominum confitemur, ete. Y porque yo conosçí y ví y hablé muchas reçes á todos los que allí se hallaron, porque, como tengo dicho, en el signiente año fuy á aquella villa del Darien, quando Pedrarias Dávila fué á tomar aquella gobernaçion, y á mi poder vinieron torlas las escripuras de Tasco Nuñez, y despues que murió tomé la cuenta de sus lienes por mandado alel Emperaldor, nuestro senor ; diré aqui quién fueron los que se lıallaron en este deseubrimiento con el capitan Vasco Nuñez, porque fué serviçio muy señalado, y es passo muy notable para estas historias, pues que fueron los chripstianos que primero vieron aquella mar, segund daba lée de ello Andrós de Talderráluano, que allí se halló, escribano real é natural de la villa de Sanct Martin de Talcleiglesias, el qual testimonio yo ví é leí, y el mismo escribano me lo enseñó. Y despues quando murió Vasco Nuñez. murió aqueste con él, y tambien vinieron sus escripturas á mi poder, y aquesta decia desta manera:

"Los cavalleros é hidalgos y hombres de bien que se laallaron en el descubrimiento de la mar del Sur, con el magnífico y muy noble señor el capitan Vasco Nuñez. de Balboa, gobernador por Sus Alteģas en la Tierra-Firme, son los siguientes:

"Primeramente el señor Tasco Nuñez, y él fué el que primero de todos vido aquilla mar é la ensenoó á los infrascriptos.

Andrés de Vera, clériģo.

Françisco Piçarro.

Dicgo Allitez.

Fabian Perez.

Bernardino de Morales.

Diego de Texerina.

Cluripstóbal de Valdebuso.

Bernardino de Cienfuegros.

Selastian de Grijalba.

Françisco de Ávila.

Jolian de Espinosa. 
Johan de Velaseo.

Benito Buran.

Andrés de Molina.

Antonio de Baracaldo.

porlio de Escohar.

Chripstólual Daça.

Francisco Pesalo.

Alonso de Guadalupe.

IIcrnando Jluñoz.

llemando Ilidalgo.

Jolian Rubio de Malpartida.

Ílvaro de Bolaños.

Alonso Ruiz.

Prançisco de Luçena.

Nartin Ruiz.

Pasqual Rubio de Malpartida.

Françiseo Gonçalez de Guadalcama.

Françisco Martin.

Padro Martin de Palos.

Hernando Diaz.

Andrés Garçia de Jaen.

Luis Gutierrez.

Alonso Sebastian.

Jolan Vegines.

Rodrigo Velazpuez.

Jolıan Camacho.

Diego de Jontehermoso.

Johan Matheos.

Maestre Alouso de Sanctiago.

Gregorio Ponce.

Francisco de la Tora.

Higuel Crespo.

Tiguel Sanchez.

lartin Garçia.

Chripstóbal de Robledo.

Chripstóbial de Leon, platero.

Johan silatinuz.

Villdenelono.

fohan de B as Loro.

Johim Ferrol.

Johan Ciutienrez de Toledo.

Johan de po:tillo.

Juhan Garcia de Jaen.

Hatheo Locano.

dohan de II ultin.

Alonso Minlin. coturiano.
Jolam Garcia Marinero.

Jolian Gillego.

Françiseo de Lentin, siçiliano.

Jolian del Puirlo.

Franciseo de Lrias.

Perlo de Orduña.

Nullo de Olano, de color negro.

Pedro Feruandez de Aroche.

-Andrés de Valderrálbano. escribano de

Sus Allegas en la sir córte y en todos

sus reynos é señorios, esture pressente é doy fée dello, é digo yne son por todos sessenta y sicte hombres estos primeros chripstianos que vieron la mar del Sur, con los quales yo me hallé é cuento por uno dellos: y este era de Sanct Martin de Valdeiglesias.o

Hecha la oraçion por Tasco Nuñez y los que con él yban, en la manera que se ha dicho, prosiguicron su camino hasta unos buhíos çerea de la mar del Sur, en tierri del caçique Clraje, de los quales se avian absentado los indios; y a posentáronse allí estos españoles. esperandoá los otros compañeros que avian quedado en los bulúos del caçique Torecha. I á los veynte é nueve de aquel mes, dia de Sanct Miguel, tomó Vasco Nuñez veynte é sers hombres con sus armas, los que le paresció que estaluan mas dispuestos, é dexó allí en Chape los restantes, é fuése derecho á lil costa del mar Austral al golpho (juél avia nombrado de Sanct Higuel, que podia estar media legua de alli. I en unos grandes ancones y llenos de arboledas, donde cl agua de la mar cresçia é menguaba en wrand cantidad, llegó á la ribera á hora le vísperas, é el agua era mengnante; y sentáronse él y los que con él fueron, y estuvieron esperando quel agna cresçiesse, poreque de baxa mar avia mucha lama é mala entrada: y estando assi, cresçió la mar á vista de todos mucho y con grande ímpetu. Y cómo el agua llecró, el capitan Vasco Nuñez, en nombre del Sereníssimo é muy Cáthólico Rey don Fernando, quin- 
to dè tal nombre, é de la Reyna Sereníssima é Cathólica doña Johana, su hija, é por la corona é çeptro real de Castilla, tomó en la mano una bandera y pendon real de Sus Dlteças, en que estaba pintada una imígen cle la Vírgen Sancta Maria, Nuestra Señora, con su presçioso Ilijo, Nuestro Redemptor Jesu-Chripsto, en braços, y al pié de la imágen estaban lás armas reales de Castilla é de Leon pintadas; y con una espada desnuda y una rodela en las manos entró en el agua de la unar salada, hasta que le dióá las rodillas, é començóse á passear, diçiendo: "Vivan los muy altos é muy porlerosos Reyes don Fernando é doña Johana, Reyes de Castilla é de Leon é de Aragon, ete. , en cuyo nombre é por la corona real de Castilla tomo é aprehendo la possesion real é corporal é actualmente destas mares é tierras é costas é puertos é islas australes, con todos sus ancxos é reynos é provinçias que les pertenescen, ó pertenesçer pueden en qualquier manera é por qualquier raçon é título que sea ó ser pueda, antigno ó moderno, é del ticmpo passado é pressente ó por venir, sin contradiçion alguna. É si alguno otro prínçipe ó capitan, chripstiano ó infiel, ó de qualquicr ley ó sceta ó condiçion que sea, pretende algun derecho á estas tierras é mares, yo estoy presto é aparexado de se lo contraducir é defender en nombre de los Reyes de Castilla, pressentes ó por venir, cuyo es aqueste imperio é señorio de aquestas Indias, islas é Tierra-Firme septentrional é austral con sus mares, assi en el polo ártico como en el antártico, en la una y en la otra parte de la línia equinoçial, dentro ó fuera de los trópicos de Cáncer é Capricornio. segund yue nas cumplidamente á Sus Maggestades é subcessores todo ello é cada cosal é pitrte dello compete é pertenesçe, é como luas largamente pror escripto protesto que se liná ó se pueda drecir é alegar on favor de su real patrimonio, é agora é en todo tienpo en tanto quel munto turare hasta al universal final juiçio de los mortales. assi hiço sus autos de possesion sin conträ diçion alguna y en forma de derecho; y como no ovo ni paresçió contradiçion alguna, lo pidió por testimonio, açeptando la possesion é señorio é jurisdiçion real é corporal é autoral con su mero é mixto imperio é absoluto poderío real, en nombri de Sus Magestarles, libremente, sin reconoscimiento alguno en lo temporal, de la mar austral é golpho de Sanct Miguel, c en aquella parte, por sí é por todo lo restante expresado ó por expresar de las dichas Indias, islas é Tierra-kirme é sus mares, assi en lo descubierto como en lo por descubrir. Y hechos sus autos é protestaçiones convinientes, obligándose á lo defender, en el dicho nombre, con la esparlit en la mano, assi en la mar como cn lal tierra, contra todas é qualesquier personas, pidiólo por testimonio. É todos los que allí se hallaron respondicron al capiLan Vasco Nuñez de Ballboa, quellos cran. como él, servidores de los Reyes de Ciastilla é de Leon, y eran sus naturales vassállos, y estaban prestos é aparexados para defender lo mismo que su capilan deçia, é molir si conviniesse solrcllo, contra todos los reves é prínçipes é personas del mundo, é pidiéronlo por testimonio. É los que allí se hallaron son los siguientes:

El capitan Vasco Nuñez de Ballooa.

Andrés de Vera, clérigo.

Franciseo Piçarro.

Bernardino de Morales.

Diego Albitez.

Rodirigro Velazquez.

Falian Perez.

Françiseo de Baldenebro.

Françisco Gonzalez de Guadalcama.

Sebastian de Grijalba.

Ilernando Huñoz.

Ilernando Ilidalgo.

Álvaro de Bolaños. 


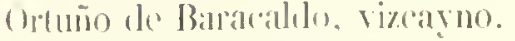

limurgison de Langemiar.

Bermardino de Cinnleugos, esturiamo.

Nartin Rui\%.

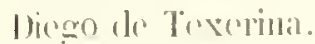

Cilupiokoblal Daça.

Jollain de Rispintosis.

Piscqual Ruloio dre Malparticla.

Franciseo Pesisdo de Malpartida.

Jollan de Portillo.

Jolan Gutierre\% de loledo.

Françiseno Martiu.

Jollan de Boils.

bstos veynté é sers, y a cescribano Andrés de Valulerríliano, fuerou los primeros clupiptianos que los piés pusicron en la mar del sur, y con sus manos todos ollos probaron el acua é la meticron en strs bocas, cono cosa nueva por ver si cra salada como la destotra mar del Norte: é viendo que era salatala é considerando é frniendo respecto á donde estabin, dieron intinitas gracias á Dios por cllo.

Aquel golpho de Sinct Miguel junto ä liema está en siete grados desta parte de la equinoçial, alounos minutos mas ó menos en parte del dicho golpho; é allí haçiendo Tasco Nuñez sus autos, hico con nin puñal que traia en la çinta una cruz en un ábol, en que batia el agua de la mar. por sonal de la possesion (pue assi se apreIn'ndió: é liço otras dos cruçes en otros dos inholes para que fuessen tres, en rererencia de la Santíssina Trinidad, Padre y llijo y Espónitu Simcto tres personas y III solo bios verdialdero, en cuyo nonulure. por Castilla é por los Reyes Sereníssimos presecules b por venir della, tomó la possesion. É lucego todos los que allí estaban hiçioron muchas cruçes en otros árboles. c cortaron algmons con las espatas. contimuando la posicsion. É lo pielió el capritan Yaseo Nunez por testimonio, é se volvió á los buhíos del cagigne Clape, donde avia desado la otra gente. y allí vinieron los otros copañoles que quedaron en la tierra é hulíos del caçique Torecha. I en tamto yne allí descansial)a procuró el capitan Vaseo Nunez de lacer de paces la ticral : e para esto enviaba sus mensagerosé lenguas á unas partes é ádras. para animar los indios é traerlos á su amistad. I assi vino alli un indio prinçipal, hermano de una inclia, que cra seĩora de aquella tierra porpue el caçigne Chape era muer10; y arpueste truxo çierto oro é algunas perlas é lo pressentó al capitan Vasco Nuñez. y él lo tractó con toda corlesia é le dió rescate é cosas de las de España. Altá oro el capitan informacion de unuchos secretos de la tierra: y este indio le dixo que cerca de allí se pescalıan las perlas. y ofresçióse quél daria siete ó ocho canoats jara que fuesse ó enviasse á donde se cogian muchas perlas, é divo quél yria á lo mostrar: y assi acordó Vasco Nuñez de yr á un caçique questá çerca de Cliape, para passar á donde las perlas se cogen.

\section{CAPITULO IV.}

Do la segunda possecion quel capitan Vaseo Nuñez de Balloa tomó de la mar del Sur, é quáles chripstianosfucron los primeros que con él navegaron en ella, é de las primeras perlas que vieron de aquella mar, é olras cosas nolables é nescessarias al discurso de la listoria.

\begin{abstract}
A los sicte dias de of ubre del mesmo año de mill é quinientos y treçe partió el cafilin Visen Niniez de Ballooa de la tierra del eaçique de Chape con lasta sessenta hombres de los que se han nombrado en
\end{abstract}

los capítulos precedentes, en ocho canoas pequeñas que dió aquel indio prinçipal, hormano del caçique de Chape: é la noche sigruiente se desembarcó cerea de la licrera de un caçique llamado Cuquera, é 
fucron por tierra tres leguas de camino trabaxoso hasta donde estaban los buhios del caçique; y estando á poco espaçio dellos, al quarto de las dos fueron sentidos te los indios, y apellidándose, luỵeron. Y quando fué de dia claro, despues quo ovieron puesto en salvo las mugeres é su ropa, se juntaron ciertos indios con sus armas y esperaron á los cln'ipstianos lasla que llegaron muy cerca mos de otros, pensando que eran los muestros otros indios sus comarcanos; y cómo vicron homJres vestidlos y con barbas cresçidas, $y$ con tanta voluntad y denuedo se les açercaban, espantados de cosa tan nueva á eltos, se pusicron en huyda. Pero siguiéronlos y tomaron algunos; y el capitan Vasco Nuñez liço sollar uno dellos, despues de le aver halagarlo é asegurádole, é dicho por medio de la lengua ó intérpetre que fuesse á llamar al caçique, é le diresse que no oviesse temor y viniesse á los cluipstianos é que seria muy lien tractado é avido por antigo: y el caçique vino aquel mesmo dia, é truso é pressentó á Kasco Nuñez algm oro é perlas, é decla. ró muy larganente dónde y cómo se pescaban, y quedó muy amigo de los chripslianos: y el capitan le dió cuchillos y mna lacha y otras cosas de Castilla.

$Y$ liecho esto, con sus compañeros se volvieron en las canoas a los buhíos de Chape, donde avia dexarlo la otra gente, y allí aderescó su viage para yr en demanda te la isla de las Perlas. y escogió entre los españoles que consigo tenia sussenta hombres que le paresció que estaban mas dispuestos para el camino. I á los dicz é siete de olulse, en las canoas ya dichas, fuć navegando por la mar del Sur dos dias a mucho peligro, porpue la mar andala alla y el tiempo no cra al propóssito; y el segundo dia en la noche desemharearon en la costa, çerca del assiento del caçirgue que se diçe Tumaca. I dexando guarda rn las cannas, fuése Tasco Tuñez con los otros chripstianos á buscar los lunhíos de los indios, y llegó á cllos á media noche: y aumque se pusieron en defensa tomaron mucha gente, sin que fucsse muerto ni lecrido peligrosamente algun cluripsimo: y el caçique liuyó. Allí se tomó alg̣um oro que se halló en los luulíos, y oviéronse? nuchas perlas gruessas y menudas y aljófar, y en el bulío del caçique se haliaron muchas conchas nácares de las ostias. en que se crian las perlas, y estas conchas eran grandes; y assimesmo hallaron ostias vivas en sus conchas frescas, cogidis y pescadas en la mar el dia antes: y dixeron los indios que las pescalban çerca de allí en unas isletas pequeñas, questán çerea de la Tierra-Firme, y las vian desde el bulio del caçique. É cómo Taseo Nuñez no era amigo de gastar el tiempo en ociosidad, y su solicilud era muchla. envió luego algunos indios. que soltó á llamar al caçique, ascgurámdole; é vino de paz desde á dos ó tres dias é fué muy bien tractarlo é asegentrado. Orose rlél informagion de las cosas de la ticrra, í dixo que en la provincia. en que estaluan era snya é se llamaba Clutarraga, é la qual tierra Yasco Nuñez nandó llamar la provincia de Sanct Lúcas, porque se tomó é ganó el dia de Sanct Lúcas en la noclıe. y el mesmo nombre se puso á un golplio que en la mesmacosta ó provincia está.

É para mas validaçion de la possesion queste capitan tomó de aquellas mares, y en continuaçion della, á los veynte é dos dias de aquel mes de otubre quiso salir á la costa brava de la ntar, é jiclió al caçique una canoa, porcque las otras en que los chripstianos avian salido de Chaje, estahai de la otra parte de acjuella cnsenada ó antcon en la costa. Lueggo el caçique hiço traer remos de los quellos usan para navegar canoas, é dió una çanoa grande : ý en las cabecis de los remos avia en algunos dellos algumos granos de aljófar y perlas perfuenias, congastadas y assentadas en la made- 
rá de los remos. Y maravillado dresto Vars(c) Nuñe\% y conjudmando do lis riepuega

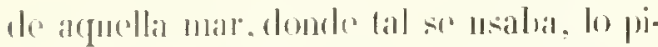
aio por testimonio, é liço testiggos dello a Nonso Vuñez do Mardrid y á Martin

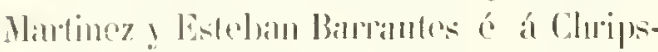
lóbal do Valdeluso. é a todos los demas

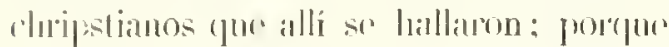
fodos vieron a tomaron en las mamos ostos remos, que los indios llaman nahes.

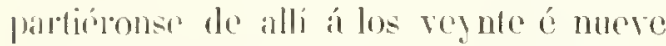
leofubre, en arpuella canoa, cosce capitan con alownos complanopos para salir á la nuar. Y fuŕ por unos anecrarliços ó estaños a esteros, guiarlo por los inclios: é salido ál la mar on la costa brava, salió en tierl’a el grobernator, é fué lasta mu playa llana á la punta del golphlo de Sanct Lủcas, junto á um isloo purestá allá cerca de la Tierra-Firme, al qual los indios llaman Crneraga, y Vásco Nuñez le puso nombre isleo de Samet Simon. Allí tomó la bandera ó pendon real de Castilla en la mino y una esparla desnuda. y con uma rodka cmbraçada sc entró en la mar. hasta que le dió el aqua a la rodilla; y estanlo assi, pidió en altas voçes que le diessen por testimonio cómo él, como capitan a vassallo de los muy altos é muy poderosos Prímçipes el Rey don Fernando y la Rryna doña Jolıana, su liija. Reyes de Castilla é de Leon. etc. é por sus subçessores, tomalna é tomó é aprehendió la possesion real é corporal é actualmente, é la jurisdiçion a señorio de la mar del Sur ó anstral , por la corona é egeptro real de Castilla é por el Rey ó Reynas, ya dichos, ć sus subcesonores. É hico todos los autos, que en tal riso se requicen, como los aria hecho en do golpho de Sinne Miguel, marliendo posscesion á possesion ć auto à auto: é aquella comtimuando sin contradiçon alowuma é para mas lirmera é fuerega dolderecho real de Castilla. señaló por roto o padron atpued istende Sanct Simon. que alli rstá en ol pasage ó frontero do la isla do las Porlas, que desde allí se paresce lákeia la parte del poniente, a la qual los imlios llaman The, y algumos Teramerpui. liv Vaseo Nuñez le puso por nomIre lsta lica; porque todos aquellos indios. fun laalló, le dixeron que allí avia graudissima rantidad de perlas, é muy ricas 6 muy grmessas; y porque la mar andalar loravar no entró Vasco Nuñez áa aquel isteo. Y hechos sus autos, lo pidió por testimonio á Andrés de Talderráliano (que era escrilano real y provector por absençia de Jolian de Quiçedo, y estuyo pressente á todo deste el dia que Tasco Niuñez y estos españoles salieron del Darien) Y él se lo dió assi por féc. E los testigos que purso en este testimonio, que estuvieron pressentes, fincron arpuestos:

Bartolomé IIurtado, alğtaçil mayor.

Françiseo Pirgarro.

Martin de los Reyes, piloto.

Esteban Barrantes.

Martin Ruiz.

Fermando Ilidalgo.

Andrés de Trra, preslílero.

Hermancio Mluñoz.

Diego Cavillero.

Alomson Martin. de Don Benito.

Flançisco de Luçena.

Françisco Gonçalez de Guadalcama.

Rodrigo Velazquez.

Dirgo Nlbitez.

Livaro de Bolaños.

Hornando Diaz.

Diego de Valdenchro.

Françisco Pesado.

Chripstóbal Daça.

Françisco de la Cossa.

Françisco de Miranda.

Chripstóbal de Robledo.

Andrés de Valderrábano, escribano real. ante quien passo todo lo que so ha dicho. como escriluno.

Estos reynte é tres liombres, con su canilan Vasco Nuñez, fueron los que mas chtraron en la mar por entonçes: y por- 
quél desscalá mucho ser informado de aquella Isla Rica y de otras cosas, mandó á arpuel escribano Andrés de Talderrál,ano, porque era hombre cuerdo y de mucha habilidad, que con reynte indios y seys chripstianos fuesse en una canoa, quel caçipue Tunaca dió, á uma isla questá cerca de la Tierra-Firme, en la mar ded Sur, pira que allí los indios sacassen ostias de las que crian las perlas, para que diesse fée dello. É assi parlieron postrero de otubre, y llegaron á la isleta; y los indios se ceharon á nado algunos dellos debaxo del agua, f sacaron hasta lies espuertas de ostias, é abrieron algrunas de. llas para ver si tenian perlas y no hillaron alguna. F dixeron los indios que en otra isla grande, questá quatro leguas de allí, dentro en la mar, se cogian las perlas grandes y en cantidad, y que las ostias, en que se laallaban, cran tres reges mayores que aquellas que sacaron en aquella isleta, donde cstaban. I apuella isla que los indios deçian es la quellos llaman Toe, á quien Vasco Nuñez puso lsla Rica, al ticupo que tomó la possesion del mar del Sur, y nombró al isleo Sunct Simon. como está dicho de susso. I poreque la mar andaba buava y no tenian contision para yr adelante, se tornaron d Valderráhano é todos los ques dicho, y con tanto peligro, que muchas veces peusiron sel anegados: é sacaron nuas de una espucra do aquellas ostias, para quel gुolemador é los chripstianos las viessen.

\section{CAPiTULO V.}

Cúmo el gobernador Vasco Nuñez de Balboa tornó al Darien deste la mar del Sur, y cómo cn ciertas pro vinçias hięo los eaęiques de paz.

更 quinicatos y trece años, el capitan Tasco Nuñez de Ballooa, con toda la grente que consigo tenia, se partió de la provinçia y golpho de Sunct Lúcas en las canoas en que aria allí llegado, y llevó consigo un hijo del caçique Tumaca (que de su voluntad se quiso je con él á demostrar otro caçique), por un braço de mar, muy gुercado de arboledas, nasçidas dentro del agrua en ambas costas; $Y$ en partes alogunas se juntaban las ramas y alcançaban de la una parte á la otra, y era nesçessalio cortarlas con las espadas é juñales para passal, y cn otras partes era muy ancho, hasta que entraron por una boca de un rio grande. Estos ánlyoles por la mayor parte son mangles, de los quales se liço relaçion en el libro IX, capítulo VI, en la primera parte destas listorias. Assi que, por este rio grande arriba sulieron con harto trabaxo, á causa de los granTOMO III. des raudales que en él hallaron; y otro dia siguiente por la mañana llegaron á la tierra del caçique llamado Thevaca, questá cerca de aquel rio, y fué salteado y tomado el caçique, sin que oviesse sentimiento ni sospccha que los chripstianos yban, hasla que dieron sobrél. Pero hiaçicndo virtud de la nescessidad, se aseguró é mostró que liolgaba con los espanöos, é dióles de comer de lo que tenia, é quedó de paçes, é liiço pressente de oro fino de muy liermosas picças, é tambicn dió algunas perlas; é quedó muy seguro é amnigo de los chripstianos, á lo que mostraba.

Y porene podria alguno pensar queste oro que aqui se llama fino, fuesse de ley de reynte é quatro quilates ó de onça, digo que no era assi; mas porque los indios acostumbran lalurar oro de muchas é diversas leyes, llamaban los chripstianos en esta sazon fino á lo que era de veynte 3 
quilites e do alli adelante y á lo que era de medio oro allaso, fue no le labllaban log por las puntis y el toque, Hamabin guanin.

Desde allí al gobornindor envió lis canoats, en yne avia mandado to que se la ¿licho en los capítulos de susso. é mandóles tornar á la provingega de Chape, donde costahan los olros chripstianos que allí atria dexado: lats pulales canoas llevaron diez españoles ? çiertos indios con aquel principal de chape, que con el gobernador avia andiulo. I assimesmo envió al hijo Iel casigue Tumaca, para que lo dexassen on el camino en la ticra de su padre; y envió á mandar á los chripstianos, que avian quedardo en Chiape. donde se avian tomado las canoas, yne se fuessen torlos por lierra lasta un caçique. á (londe el goobernador se yba por tierra á los esperar. Ýdespediclas las eonoas, se partió del casique de Theraca á los çinco de noviemhre; y aquel diat llegóó el gobernador á un eaçirne: que se llama Paera, al qual halló absentado, y enviólo á buscar, asegurándole y vino dle paçes, y dió çierto oro de pressente: porque todos los otros eaciques, en que arian estado los chuipstianos, avian dicho sertificadamente queste caçique Pacra cogia oro en su tierra, y que tenia minas ricas. I Vasco Nuñez le rogó mucho y le halágó porque se las mostrasse, y munca lo quiso hacer: solbre lo qual le hico atomentar hasta la muerte, y en fin nunca se lo hicgo deçir. I todos los indios é indias deste caçique confesaron que se celiaba con tres 6 quatro mugeres que tonia, é que usaba con ellas extra vas debitum, contra natura; y que quando fué moso, en la juventud usaba lo mismo con indios machos. Este pecado es muy usado en algunas partes de la Tierra-Firme, y á los indios pacientes en tal delicto llaman en aquella lengua de Cueva camayoa. A esta tierra mandó llamar el gobernador Vasco Nuñcz la provinçia de Todos Sanc- tos, porque en tal dia llegó á ella, y en la lengua de los imdios se llama Pacra; pero yo la llamíra la tierra de todos los males, pues que tan nefando pecallo allí se usaba por el señor della.

Allí llegóo la otra gente, que avia que. dado en Chape, y avian tomado en el camino un cagique que se deça Bonunimana, del qual ovicron çierto oro que truxeron, porque este era el principal intento questos pacificadores traian, y en lo que se exerçilaban, y en tomar indios é indias, de que se sirviessen. Algunos les daban los caçiques prinçipales, sin los que se tomalan los españoles; y con este gobierno, andaban hombres de los mas suel. tos é hálbiles que se pudieran hallar en el mundo, para el exerçiçio que traian ; puesto que en los menoriales y escripturas de Vasco Nuñez todo lo que lie dicho liallé escripto y signado, y lo que mas diré hasta queste viage se acale. Allí no estaban dichas crueldades; pero muchas ovo, y muchos indios hiço atormentar, y á otros aperrear en este camino, para que le diessen oro. Ya á unos se Iomaban las mugeres, ya á otros las hijas; y cómo Vasco Nuñez haçia lo mesmo, por su exemplo ó dechado sus mílites se ocupaban en la mesma labor, imitándole. $Y$ de aqui viene la culpa y delicto ser mayor en el que manda que en los inferiores; porque es la causa del mal que se haçe y la enseña á otros é consiente: ó por el opóssito, quando el capitan ó el prínçipe enseña buenas costumbres, siempre aquellas se continúan, y el señor es mas dino de gloria, y los ense. ñados no quedan sin galardon. Passemos á nuestra historia.

Estando Tasco Nuñez y los chripstianos, que con él estaban, en la provinçia de Todos los Sanctos, truxéronles pressentes de oro los caçiques Mahe y Tamao Othoque y un hermano del caçique Pacra, que se deçia Thenora; y primero dia del mes de diçiembre se partió de allí y se fué á los 
buhíos del caçique Bocheriboca, donde Ilegó á los çinco de diçiembre y lallòlo alçado. I tres dias despures llegó á los buhíos del caçique Pocorosa y hallólo alçado; pero á los treçe de aquel mes, que fué desde á çinco dias que allí llegóó, vino de paz este caçique Pocorosa y truxo consigo pressente de oro, y se le dieron algunas hachas y otras cosas de rescate, $y$ quedó de paçes. Otro dia siguiente llegaron dos indios, mensageros del caçique Chuyrica, y truxeron de pressente algum oro para el gobernador; y deste caçique ninguna notiçia tenian. los clıripstianos, y él de su grado se comidió á enviarles oro. Y á los diez é seys dias del mes llegó allí un caçique que se deçia Paruraca, y tambien truxo pressente de oro y se le dieron cosas de rescale, con que fué conlellto é quedó por anigo de los cliripstianos. Despues desto, un domingo dicz é ocho del mes, dos lioras antes del dia, el gobernador Vasco Nuñez, con ochenta hombres, tomó el luuhío del caçique Tubanama, y fué presso el caçique é muchos de su gente, y tomóse algun oro en esta trasnochada. I cómo fué de dia claro, vinicron ciertos indios del caçique asegurados y hablaron con él; y luego fueron á publicar por aquella provinçia que truxessen oro, para rescatar con los chripstianos y redimir al dicho eaçique de la prission. Y desde aquel dia diez é ocho hasta los veynte é uno, que fué dia de navidad, cada dia vinieron indios é pressentaban pieças de oro para comprar á su señor, unos con una patena, y otros á dos y á tres, otros cinco y otros oclıo, y otros á doce y mas, é indio oro que truxo quinçe patenas de oro: y oro en todo lo que truxeron treynta marcos de oro $y$ algunas perlas. Y hecho aquesto, aseguró el gobernador al caçique y laalagóle é híçole su amigo, é dióle cosas de rescates, cascabeles é qüentas de vidrio é cuchillos é cosas, que todo ello valia poco entre cas- tellanos en la feria de Medina del Campo. Y cómo el caçique mostraba micho contentamiento de aquello que le clió Vasco Nuñez, pensó que todo lo que quisiesse saber dél, se lo diria; y con esta confrança le preçuntó por las minas, y él no quiso confesar que las avia en su ticrra. Nas díxole grandes secretos é nuevas de oro é perlas que hallaria çerca de allí; y no se satisfaçiendo desto el gobernador, mandó secretamente, sin quel caçique lo supiesse, que catassen çicrlos arroyos é rios, y en todos ellos liallaron oro (sin tener espacio ni aparecos convinientes) en tres reces que lo fueron á luscar çiertos españoles á quien se connetió, y ál un quarto de legua ó menos del buhío, donde el gobernador estala con el caçique: é cogieron um pesso é çinco granos de olo menudo. Y en todas las bateas que lavalın, salia algun oro, aunque en poca cantidad; y aquesto era tentado en partes, que no mostraban aver manera de liallarse oro en ellas.

De allí se partió el gobernador Vasco Nuñez, contento con la esperança de las minas y catas que se avian dado, despues de passada la pascua, porque la gente andaba ya cansada y avia algunos enfermos, y atu el gobernador estaba flaco y no sano, y fatigado mucho de lo que en este camino trabaxó. Y fućsse desdo allí con los españoles á los buhíos del caçique Pocorosa, donde estaba toda la otra gente quél avia allí desado; y desde allí se fueron poco á poco á la villa de Sancta Maria del Darien ó Antigua, y en el camino llegó al buhío del caçique don Cárlos, liijo del caçique de Comogre, que era muerto. Y esturo allí deste el dia de año nuevo, primero dia de enero de mill é quinientos y catorçe años, descansando hasta quatro dias adelante; y allí le dió çierto oro de pressente este caçique don Cárlos, el qual caçique estaba ya de antes de paz y muy amigo de los chripstianos, porque 
(primdo pere allí avian passado, viviemto sir partre. se haptigaron ambos é puredialom de parges.

Drasle allí prissó Visteo Nuñez á l'onea,

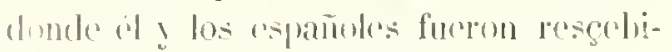

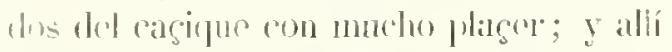

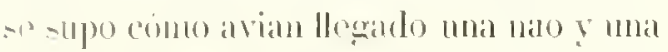

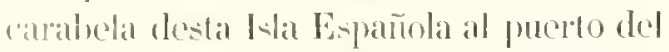
Marien eon algental grente I hatimentos, de pue todos ovieron mucho platerer. Desde alli se fué ol gobernator al prento de liaredal. de donde arvia salido á los serys the septicmbre del año antes de este. y llesó allí á los diez a sinte de enero de mill é quinientos y calorçe. Oro dia sisuiente en la noche so embaró en cl galeon que alli aria dexado (porene no haria tiempo para meterse en el mar con canoas), y fuesse al l arien con hasta veynte hombres de los españoles y hasta dosgientos naborias indios é indias. y con mas de dos mill pessos de oro, y dexó los utros chripstiamos con hasta otros seysgientos nahorias en cl caçique de Ponca. Y cómo el gobernador llegóo al Darien, fue fué á los diez é nueve do enero, envió el galeon y la carablua, questahan en (1) perto del Iarien, y avian ydo desta Lla Esinnola, al puerto de Careta por los cspañoles ques dicho; y los llevaron al barien ricos é bien servidos de muchos indios é indias. y con mucha ropa de mantas ! hamacas de algodon de lo que con othas pressas avian avido cn este viaye y descubrimiento de la mar del Sur. í despues do llegados. se hicgo el reparlimiento del oro é perlas que se arian avidu en este camino.

Pero porque es notable delicto é viçio Ilustos indios, y por donde es bien entpheada su perdiçion, digo que laallé escripto, y supe de muchos de los que fucron con Vaseo Nuñez en este viage ya dicho, que despues que llegó á Careta, cl qual eaçique ya cra amigo de los eluripatianos, luegro otro dia siguionte, despues do partido de alli Vasco Nuñer, llegéo á una provingia yme se dige Cance-

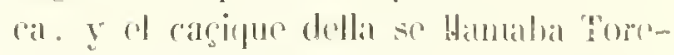
clar, y púsosede en defonsa y matítronle en la guaçálsala á él y algunos indios slryos; ýalli so halló un hermano smyo. veylido como muger, con niguas, y' usalua como muger, con los hombres, y ofros dos indios de la mesma mancri. que usahan romo mugeres y assi con naguas: y los renia el carifune por nangebas. I esto se haçia en aquellas partes prinçipalmente cutre los caçiques é otros indios, é se prescialoan de tencr tres é quatro, y aun reynte indios, para este suçio y aboumimable pecado. I en alqueste viage hiço Tasco Nuñez quemal é aperrear quassiçinquienta deslos, y los mismos caçiques se los traian sin se los perlir, desque vieren que los mandaha malar, to qual haciir poreque les daba á cutender que Dios en al ciclo cstaba muy enojato con cllos, portuc hasian tal cosa, y por esso caian tantos rayos é tan espantables trucnos; é por esso no les queria dar Dios el maliz y la yuca. Y deste temor, porque Dios aplacasse su ira, le llevaban aquellos camayoas paçientes en tal delicto. I ál la verdad era cosa temerosa y espantable los rayos y truenos que avia en aquella lierra. Y que yo oy aquel mesno año de catorge que llegó el armada. y los que fumos con el gobernador Pedrarias Dávila. porque quemaban Luhíos y mataban hombres; y a mí y ál otros acaesçió estar durmiendo en la cama, y del terrible sonido del rayo é trueno cacr de la cama abaso en ticra. I es rerdad que aquellos indios te la lengua de Curva, en la qual cae el Darien, tienen questá Dios en el çiclo. é ques al que cria é haçe todas las cosas : pero piensan ellos queste Dios es el sol, é ynes su mucrer la luma, é assi lo diçen é creen, é questos les dan los mantenimientos, é la vida e se la quitan. É otros errores muchos tiencn idolatrías, como se dirá addelante. 
Crevósn que en cale camino avia avido Vasco Nuñez mucho mins oro de lo que se repartió: de lo qual no es de maravillar, porque estos capitanes han tonido ojo á cumplir primero consigo que con los compañeros: pero en la verdad, como tengo dicho, uno de los mejor partidos capitanes que á estas Indias laan passado, fué Taseo Nuñez, en su licmpo, dexando aparte el Perú y la Nueva España, donde se ha hallado mas cantidlad de oro que no le vino á las manos á Vasco Nuñez: lo qual si él repartiera, se puede ereer que lo que hiço en esso que pudo, que mejor lo hiçiera en lo mucho. Pero este serviçio deste descubrimiento de la mar del Sur, y ser el primero de los clupipstianos que la vido, y con grandíssima diligençia que la buscó y halló, á solo Tasco Nuñez se: debe este tropheo; y él fué el primero que en ella navegó. y el que primero puso navios en ella de todos los chripstianos, como está dicho en los capílulos preçedentes. É grandes fueron los trabaxos quél y los olros españoles padesçieron en aquellos prinçipios: y de aquella escuela de Vasco Nuñez salicron señalados lımlres y eapitanes para lo que despues ha subgedido en la Tierra-Firme, como se dirá adelante en su lugar.

\section{CAPITULO VI.}

Del viage del gobernador Pedrarias Dávila á la Tierra.Firme, llamada Castilla del Cro, en la qual estaba por eapitan Vasco Nuñez de Balboa.

\section{$\mathbf{P}$} thólico Rey don Eermando arin dado el bachiller Ençiso contra Vasco Nuñez, entre las quales siempre haçia menoria de su injusta prission $\mathrm{y}$ destierro, $\mathrm{y}$ de la crueldad que avia usado contra Diego de Nicuesa; y por la relaçion que despues hiçicron los procuradores del Darien, el veedor Jolıan de Quiçedo y el capitan Rodrigo de Colmenares, y las cartas que contra él escriljieron el bachiller Dicgo del Corral é Gonçalo de Badajoz, teniente que fué de Diego de Nicuesa, é Luis de Mlercado é Alonso Perez de la Rua, á los quales tenia pressos Vaseo Nuñez, acordó el Rey de enviar á Pedrarias Dávila con una hermosa armada á conoseger de las culpas de Tasco Nuñez de Balboa, é á gobernar á Castilla del Oro en la Tierra-Firme. Y junláronse para esto tres mill hombres ó mas en Sevilla, y fueron allí los ofiçiales quel Rey envió prara su liaçienda, Alonso de la Puente por thessorero, Diego Marquez por contarlor, Johan de Tabira por factor, Jolan de Quiçedo por veedor de las fundi- çiones del oro íeste murió alli en Sevilia, ¿́ yo el chronista, Gonçalo Fernandez de Oviedo y Valdés, fuy provehydo por el Rey Cathólico de aquel ofiçio de reedor); por alcalde nayor de Pedrarias fué cl bachiller Gaspar de Espinosa, que despues se llamó liçençiado, natural de Medina de Rioseco; y por teniente de capilan general de Pedrarias fué un hidalgo de Córdoba, llamado Johan de Ayora, hermano del chronisla, Gonça de Lyora; y por capitanes de cada çien hombres Luis Carrillo, Françisco Dárila, Antonio Teilez de Guzman, Diego de Bustamante, Contreras, Françisco Vazquez Coronado de Taldés, Jolıan de Corita, Gamarra, Villafañe, Mtiença, Gaspar de Mlorales, primo del gobernador, Pedlarias, el mançelıo, que yba por capitan del artilleria, el qual cra sobrino del golvernador, Gonçalo Fernandez de Llago y el capilan Meneses. Los quales lie nombrado, porque de todos ó de los mas dellos, y de olros que en la tierra ya estaban, y de otros que despues se llamaron capilanes é lo fucron, resultaron ade- 
lante cosas, que convienen á la listoria y son notables.

En lo espiritual fué el obispo don fray Johan de Quevedo, de la Orelen de Sance Francisco, el primero prelado que passó at la Tierra-Firme, con titulo de obispo de Sancta Maria de la Antigna é de Castilla del Oro; y la cabega de aquel olispado fué atquella villa que le dicho Sancta Maria de la Antigua del Darien, que ganaron Vasco Nuñez y los que quedaron del armada del capitan Iloño de Ilojeda. La qual, despruesde la erecion deste olnispado, jor mandado del Papa é del Rey Cathólico se llamó ciludad, que fué metropolitana y calıça, como es dicho, del obispa(lo de Castilla del Oro, porque es gente noble, para lo que adclante se siguruió. Digo que entre las ordenanças y capítulos quel Rey Cathólico proveyó é mandó á Pedrarias, su gobernador, que tuviesse cspeçial cuidado, fueron estas quatro cosas: la primera, que con mucha atençion y vigilançia entendiesse en la conversion $\mathrm{y}$ buen tractamiento de los indios: la segunda, que no passassen letrados ni oviesse abogados ni procuradores en aquella tierra, porque se Ienia expiriençia desta Isla y otras partes que son perjudiçiales á la tierra, y como maestros de litigios y contiendas. inventan mas de las que suele aver sin ellos; sino que simpliciter y de plano, sin dar lugar á cabilaçiones maliçiosas, se determinassen los pleytos brevemente, haçiendo justiçia á las partes: la tercera, que se hiçiesse á los indios çierto requirimiento, antes que se les rompiesse la guerra, el qual adelante se dirá: la quarta, que en todas las cosas de importancia se diesse parte al obispo y ofiçiales, $\mathrm{y}$ se tomasse su parescer. En lodas estas cosas se verá la intençion del Prínçipe, que lo proveyó, santa y bnena, pensando quel gobernador y prelado siempre serian conformes en el servicio de Dios y del Rey, y en la buena gobernaçion y administracion del Estado y paçificaçion de los indios y poblaçion de la tierra. Pero salio al revés, porque desto que se proveyó para bien y provecho comun de todos, se formaron dos handos y parçialidades que fueron muy dañosas; y unos seguian al grobernador y otros al obispo aprasionadamente. Assi los ofiçiales que los avian de templar, y procurar que entrellos oviesse mucha conformidad, se mezclaron en las mesmas diferençias, como se dirá mas largamente en su lugar.

Aparcxada el armada, dilatóse la partida á causa de los ticmpos; y por nuevos avisos que de la Tierra-Fime fueron, el Rey mandó despedir la mitarl de la gente, $\mathrm{y}$ (que no fuessen sino mill é quinientos hombres; y assi despidieron á los demas, despues de aver hecho un hermoso alarde en Sevilla, y el grobernador, con los mill é quinientos, fué á Sanct Lúcar de Barrameda. Pero todavia cresçió el número de la gente y passaron bien dos mill hombres ó mas por las grandes nuevas, que se deçian de aquella tierra; y esta fué una de la mas hermosa gente y escogida que ha passado á estas Indias: y aunque no fueran sino quinientos hombres, se açertara cn ello para lo que subçedió. Y con veynte é dos naos é carabelas se hiço el armada á la vela, llevando por piloto mayor á Johan Serrano, el qual mataron despues con el capitan Fernando de dlagallanes en el desculırimiento del Estrecho grande é viage de la Especieria, como se dixo en el libro XX, capítulo I. I aquesta armada salió con muy buen tiempo del puerto de Sanct Lírcar de Barrameda, domingo de carnestolendas, año de mill é quinientos y catorge; y despres que la nao capitana estaba quatro ó çinco legruas en la mar, saltó el tiempo al contrario y ovo de darse la vuelta. La postrera nao. que salió del puerto era aquella en que yo yba, y aun quedaba otra surgida, en quel contador Diego Marquez estaha, que nunca se qui- 
so desamarrar, porque un piloto della, llamado Pedro Nliguel, tuvo mejor conosçimiento que torlos, y vido quel tiempo no era bueno y se estuvo quedo: el qual liempo saltó en vendabal, que otros llaman poniente maestro, é muy reçio. Y como los pilotos del rio avian dexado yr las naos fuera en la mar, $y$ se avian tornado á Sanct Lúcar en sus barcos, y la mar andaba lrava, forçosamente hiço tornar el tiempo el armada al rio; y la nao en que yo yba, assi como avia salido la postrera, ovo de entrar la primera; $\mathrm{y}$ al entrar por la barra dió çicrtos golpes en ticrra, y nos oviéramos de perder por falta del piloto, y quiso Dios ayudarnos por su misericordia, y que quassi pendiendo el un bordo por el agua surgimos dentro del rio de Guadalquevir, de donde avíamos salido. Y de una en una las otras naos é carabclas del armada hiçieron lo mesmo; y estuvimos en el puerto dos dias, que ni podiamos salir á tierra por el muclıo ticmpo, ni en el rio podian estar quedas las naos, garrando unas é travesándose otras, de manera que todavia corriamos tormenta ; pero en fin el tiempo abonançó, é porque no se gaslassen los bastimentos, se desembarcó el general é toda la gente, para esperar en la tierra el tiempo que fuesse al propóssito nuestro. Y cómo avia mucho que esperábamos esta navegaçion, estaban todos muy gastados y empeñados, y mucho mas lo estuvieron los que perseveraron hasta la segunda partida; y muchos mudaron de propóssito y dexaron el camino y se fueron á sus casas 6 donde les plugo, y no fueron essos los peor librados. Y assi estuvimos toda aquella quaresma, lıaciendo penitençia voluntaria, comiendo muchos las capas en el meson, y aun otros capas y sayos y lo demás, lasta que quiso Dios en la Semana Sancta traer el tiempo que esperábamos; y el martes santo, que se contaron once dias de abril de mill é quinientos y catorçe, se tornó á haçer á la vela esta arniada, é siguió su via con buen tiempo. I desde á ocho ó nueve dias tomó puerto en la isla de la Gomera, donde nos detuvimos veynte dias tomando refresco de carnes y de pescados, é quesos, y agua, é leña, é lo que convino para la jornada: é de allí se proçedió adelante con muy buenos tiempos. Y un sábado, tres dias del mes de junio, víspera de pasqua de Espíritu Sancto, surgió esta armada en la isla Dominica, en una aguada donde hay un buen rio, y saltó la grente en tierra y estuvo allí tres dias assentado real aparte de aquel rio; y el siguiente dia, despues que llegamos, fuć domingo de pasqua, é se dixo missa solemne y con mucha alegria de todos. Y mandó el capitan general Pedrarias que se llamasse aquella ensenada Bahia de Fonseca, como si él fuera el primero que lis descubria entonçes.

Esto es de lo que yo burlo y muchos se rien; y en algumos lugares en estas historias lo reprendo, y nunca alabaré á nadie que tal haga, si no fucre prínçipe, y aviendo justa causa para aniquilar el nombre primero. Aquella bahía, descubierta estaba algunos años antes, y muchos pilotos y marineros de los que allí estaban, la avian visto y saluido y entrado allí otras veçes. Mas parésceles á los gobernadores y capitanes que nuevamente vienen á estas partes ques bien mudar los nombres á los puertos é rios é montes é promontorios y á todo lo que se les antoja, porengrandescer sus licchos y poner en olvido to que hiçieron los primeros: lo qual no entiendo yo sufrir en mis liistorias, ni quilar á ninguno sus méritos. Bien sé yo quel obispo de Palençia, don Johan Rodriguez de Fonseca, Presidente del Consejo Real de Indias en aquella sacon, fué causa queste gobernador fuesse elegido para este ofiçio; y assi por se congraçiar con él, le paresçí á Pedrarias que era bien plantar el apellido de Fonseca en 
arpuella bahia: pero yo no desamé de derir la revedad. y desengantaré de dales

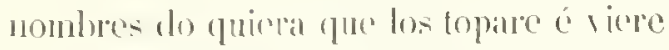
que injustamente los mula quien no debe, eomo fiel excriptor. Assi que este an-

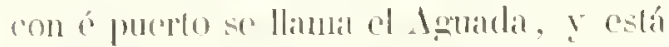

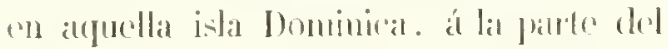
llueste, en ratoperesalos desta parte de

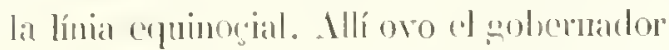
su acuerdo con el ohispo ? oficiales a pilutos, y ron al bachiller Enciso. qune fué

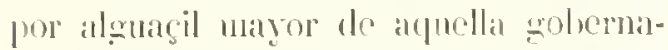
cion. I con cel eapitan Rod:igro de Culnenares. como hombres que degian gue sabian aquella costa de la Tierra-Firme . sobre la manera que se delia lager el viage le allí adclante. Porpue el Rey mandóa Pedrarias, que sin estorbo de su derota é "amino para el Darien, si se pudiesse hacer. toeasse en çirrtas islas ć puertos de caribes, assi como Sancta Cruz, y Gaira, y Cartagena, y Carunari, y Codego, y las islas de Barú y Sanct Bernardo, y Islas de Arenas y Isla Fuerte, questaban declarados por esclaros mucho antes, por raģon que comen carne humana en todas essas islas é puertos ques dicho. é por d daño que avian lechı á chripstianos é á los otros indios rassallos del Rey; y muchas reces passando los españoles á estas partes tocando, allí los avian mucrto. Y acordaron cunel armata fuesece á reconosçer el cabo del Iguja á Sancta Masta, ques en la costa de la Tierra-Firme, para saber si eran vivos onge chripstianos, que deçia el capitan Rodrigo de Colmenares que quedaron allí, quando le mataron mas de otros treynta, e para ver la dieposiçion de la lierra é hager en ella una forlalega : yne cra muy nescessuria para asegurar los navios, que despues riniessen; y que despues desde allí cl armada passasse á Cartagena é Codego, é á las islas de Barú ć isla Fuerte (pues questaban en el amino derecho quel armada debia hacer para el Darien), ć que se desasse la vila de Sancta Cruz, porque cestaba mury atrasmano apuella isla, y en desproporesion det viage.

Muchas reges despues, andando el timpo y platicando en este comsejo que allí se lonó, he visto ser mummurado y reydo con otros de los que allí nos halláhanos, y arordindonos de tan grande disparate, como cra dar créditoć que fuesse crejdo apued capitan Rodrigo de Colmenares, para lal acuerdo; pues fuél confesiba que en Gaira le avian muerto treynla hombres, quando por allí prassó. yendo desta ciludad de Sancto Domingo al Darien con mal nao, y no negaba que avial salido de allí, por no ser parte páa ofender á los indios: y mas que de passo se avia recogido á la nao y se avia ydo. Teamos con qué salvo conducto y debaxo de qué palabra avian quedado los otros onçe chripstianos, quél pensaba questaban viros!. Deslas y otras vanidades muchas se han predicado en Castilla por algumos de poco saber, porque ven que los que los escuchan, no los entienden. Finalmente, por acjuella consulta y acuerdo, d dia siguiente, por mandado del general, todos se enbarcaron en aquel puerto de la Dominica ó Aguada ques dicho; é porcue faltaban algunos de los compañcros, mandó que se tirassen alqunas lonluardas, poreque si algunos se avian entrado la lierra adentro se viniessen á recoger : é para este cfeto quedó aquella noche en tierra el Ieniente Johan de Ayora con cierta guarda de gente y con las trompetas, haçiéndolas tocar de quando en quando. Y assi algunos mancebos se recogieron, ú de los postreros vino uno. (pue avia muchos años que scrvia al gobernador, é se llamaba Sanet Martin, y porque venia tarde, tratóle nal de palabra el teniente; y enojado desto el Sanet Martin, diso que no se queria embarcar é que se queria quedar allí en aquella playa; pero no se debe creer que su intençion era de liaçerlo assi 
eomo lo respondió con enojo de verse maltractado con palabras injuriosas: y el Johan de Ayora, aviendo respecto que era del gobernador, fuéle á deçir lo que aquel su criado deçia. Por lo qual Pedrarias enojado, sin mas atender, envió allá al capitan Gaspar de Morales, su primo é criado, é mandóle que, sin oyr ni atender palabra, le liçiesse encontinente alıorcar de un árbol ; y assi salieron çiertos alabarderos de la guarda del gobernador con este capitan, é se ejecutó lo mandado é fué ahoreado aquel pecador. Verdad es que desde á çinco ó seys meses despues en el Darien se le hiço proçesso, culpándole de desobediente; mas lo que muchos sospeclaron y murmuraron desta açelerada jusliçia, é del galardon, quel gobernador dió á arpuel su criado, fué atribuirlo á algouna cuenta rieja ó desagrado que dél tenia de alğmn tiempo atrás.

Desde á una hora, estando yo con el mesno gobernador en su nao, vino allí de parte del obispo im honrado elérigo, llamado Cantado, su capellan, é dixo al general quel obispo, su señor, le pedia por mereged que diesse liçençia para que enterrassen á aquel hombre, pues era chripstiano, y que no quedasse colgaldo allí para que los indios lo comiessen; y el gobernador dixo que se liçiesse assi. É aquel mesmo clérigo é otros. acompañados de algunos soldados, salicron á lierra é lo enterraron al pié del mesmo árbol en la meșma playa de la bahía. Esta justiça cruel é açclerada dió á muchos temor; é sospecharon quel gobernador que llevábamos avia de ser muy rigoroso, é que avia de lagerer otras cosas de hecho, sin atender derecho ni processos, y que convenia cada uno mirar cómo assentabal del pié pues yue en sus criados comencalıa á mostrar cómo avia de castigar á otros.

Tornando á nuestro camino, partimos de la isla Dominica un dia despues de pas(yıa: á los doçe dias de junio, un lunes,

T0.110 III. llegí el armada al puerto de Sancta Marta, ques en la costa de Garra en la Castilla del Oro, y desde allí comenegaba la gobernaçion de Pedrarias. É á las diez horas del dia estaban todas las naos é carabelas surgidas ó echadas áncoras en aquel puerto; é por la playa andaban muchos indios flecheros en lierra, de unas partes á otras, con muchos penachos y cubixados, y sus arcos y carcaxes de flechas, mny orgullosos. I acordaron el gobernadior y al obispo y ofiçiales de arer su consejo con los otros capitanes, y determinóse quel teniente Johan de Ayora é otros capitanes saliessen con tres barcas, equipadas con toda la gente que en ellas cupiesse, muy bien armados, é á los indios se les requiricsse que viniessen á la obediençia de la Sancta Madre Iglesia, y en lo temporal reconosçiessen al Rey é Reyna, nuestros señores, é á la corona é çeptro real de Cástilla, como á sus Reyes é señores naturales. É que para este requiriniento Ilevassen consigo un indio que avia ydo á España, é cra de la provinçia de Cueva, en la Tierra-Firme, é al capilan Rodrigo de Colmenares por hombre plático en aquellas costas (pues que deçia él que entendia alggo de la lengna de aquellos caribes) por manera de intérpetres; é asegurassen á los indios é les dixessen que aquella armada no ylua á les haçer mal ni daño alguno, y que si quisiessen la paz, no les seria hecha guerıa , é que serian tractarlos como buenos vássallos de los Reyes, nuestros señores, é les serian hechas merçedes; y si lo contrario hiçiessen, yue se usaria con ellos, segund sus obras lo meresçiessen. É mandó el general á su teniente, é á los que con él yban, que no fuessen agresores ni les hiçiessen daño, y (fue sufriessen su grita todo lo que pudiessen, porque no oviesse rompimiento con cllos, hasta tanto que no fuesse racon de se dexar ofender ni maltractar á los cluripstianos, que con él yban. I mantó el golsernador que yo y 
otlas personds señaladas furssemos che alfuellas tres barras, que particron torlas Hes de la nao cupilana para tierra; y la fue Iha mas agerea de la costa llevaba 10 con hasta reynte houldees. Y la otha 'jue yla á par desta, mas en dagua, lleraba el leniente Jolian de Iyora con veynte é sineo hmulnes, y la tercera, mas desviala. llevaba el capitin Rodrigo de Colmenares con hasta quinçe hombres, ron aquel indio lengua: y todas tres bar"ats á lis par", con poco intervalo mo de otra. Luço vinieron láçia las bareas, corriendo al luengo de la playa por tierra a se poner enfrente, donde les paresçió que querianos desembincarnos, hasta çicn indios á nos rescelnir con mucha osadia, con licrmosos penachos en las cabegas, y las personas y caras cmbixadas, tan colorados como sangre todos cllos, y con sus arcos y fluchas, y con muy gentil denuclo. mostrando que nos avian de resistir la salida. E estando ya tan çerca unos de otros, que nos podiamos bien entender (si nos entendićramos con ellos), el indio é el Colmenares á altas voçes, les decrian muchas palabras, y los caribes estuvieron callando un poco. escuchando; pero en la verdad no los entendian más que se entendiera un vizcayno en su vascuençe con un tudeseo ó aráliggo, ó otro mas extremado lenguage. Estonge los indios 110 curaron mas de lo que les degian, ni le las scinas que en vano el Rodrigo de Colmenares y el indio haçian: antes pensando ofendernos, se llegaron con mucho impetu y mucha crita á la orilla del agua, tirando muchas flechas. que alcançaban á nuestras bareas, é alwrunas passaban idelante por alto: y algunos dellos se melian hasta la çinta dentro del aggua á lirar. Lo qual visto por Johan de Ayora, comensó á haçer protestaçiones é dlecia á los españoles que no les tirassen con ballesta ni arcabuz ni otra cosa, y que se cubriessen ron las rodelas é aguardassen:ć pedia tes- linonio cóno él ni los chripstiamos 110 eran los agresores, ó que convidalian á los indios con la paz y no lin puerian: antes ellos movian la gucra é procmahan de ofender é matar á los nuestros, non obstante los requirimientos yue se les haçian, en descargo de la real conçiençia de nuestros Prínçipes é sus capilanesé mílites, y que el claño que se siguiesse, fuesse á cargo de los indios, é no de los chripstianos.

É viendo ya el teniente que sus palabras é amonestaçiones eran descehadas ó no entendidas, é que las sactas allí son de ponçoñosíssima hierba é volaban entre nosotros, como lluvia muy espesa, y que estálamos á peligro, estando allí quedos. y volver atrás cra vergonçoso; envió un batel que se avia juntado con nosotros á haçer saber al gobernador lo que passaba. Pero como nos daban priesa é paresçia ya poquedad tanta paçiençia, se les tiraron dos tiros pequeños de pólvora, que yban en las barcas y passaron por alto; y mandó el teniente que las proas pusióssemos çabordando en tierra, é assi se hiço con mucha diligençia, é saltamos todos en tierra dentro del agua; pero tan presto ó mas fué la fuga de los indios á se poner en salvo. É ya el gobernador con otros batcles y gente yba la vuelta de la costa, donde le atendimos en tierra, porque nos av ian hecho señas, capeando, para que esperíssemos é no siguiéssemos los indios.

Despues quel general salió á tierra, llegamos á un buhío que allí çerca estaha, é luego, su espada desmuda en la mano, comencó á cortar ramas de aquellos árboles que ahí avia, lıaçiendo autos de possesion y continúndola en nombre de Sus Altegas y como su capitan general, y en nombre de la corona é ceptro real de Castilla. é corroborando el derecho é posse. sion real que los Reyes de Castilla tienen deslas Indias, islasé Tierra-Firme del nar Océano; é si nesçessario era, tomándola dr nuevo, é como tierras de su señorio é 
patrimonio real, protestando de tractar bien é gohernar é tener en justiçia, assi á los indios é gentes naturales de apuellas tierras que quisiessen obedesçer nuestra sancla fée catloólica, é viniessen á la obediençia de la corona real de Cástilla é de los Reyes, nuestros señores, é sus sulycessores, como á todos los demás de sus vassallos, en la mesma justiçia é su protecçion. É que arquellos que lo contrario hiçiessen, los castigaria como rebcldes é inobedientes, é como contumaçes proçederia contra ellos, segund hâllasse por fuero é por derecho, é como te era mandado por Sus Alteças. É hiço assentar por escripto todos sus autos, é pidiólo por testimonio.

É riendo la desobediençia de los indios, mandó al teniente que con tresçientos lıombres entrasse una ó dos leguas la tierra adentro, é procurasse de tomar alggmos indios viros é sin les haçer mal: é se tornasse luego, porque le queria esperar, como lo esperó, alli en la costa. É assi se liço: é en dos luğares pecpueños de hasta quinçe ó veynte buhíos, á donde llegaron çerca del mesmo puerto, á media legua ò poco mas, los hallaron despolılados: é tomáronse en la playa é arenales de arquel puerto quatro ó çinco chinchorros y redes. questahan tendidas á enxugar, muy gentiles de algrodon torcido (para pesear). E por la tierra adentro se hallaron algunas lıamacas, que son las camas en que duermon los indios: é las dexahan entre las malin é arboledas, por luyr mas sueltos é subirse á las montañas é sierras.

É desde á tres ó quatro horas quel gobernador esturo en tierra, mandó tocar las trompetas para recoger la gente á los navios, é hiço tirar algunos tiros de pólvora, para quel teniente y los que avian con él ydo se tornassen al puerto: é assi lo liçieron, y se embarcaron todos, é ningun chripstiano fué herido, ni algun indio muerto ni presso aquel dia.

\section{CAPITULO VII.}

Cóno estando con el armada en el puerto de Sanela Marla el general Pedrarias Dàvila, saltó la segunda vez nn tierra eon gente, y entrú la tierra adentro hasta tres leguas, è fueron pressos è muertos algunos indios è indias; y de lo que subçedió en aquel pucrlo, é qué se eontenia en el requirimiento que se mandó hacel á los indıos anles de romper guerra eon ellos; ́otras eosas que eonvienen al diseurso de la listoria.

D lo precelente, martes treçe le junio, avido el grobernador acuerdo con el obispo é ofiçiales, mandó que yo, el chronista, como veedor de minas é de las fundiçiones del oro, saliesse en tierra con los fundidores é algunos hombres diestros, é con forlo cl aparexo que era nescessario para rue cn los nascimientos é costas del rio que entra en aquel puerto, é donde paresciesse, se catassen las minas; é que fućsemos lı́́çia unas sierras que se parresçian la tierra adentro, tres ó quatro leguas de allí, donde se pensaba que nasçia aquel rio: i que para esto fuesse con nosotros
Pedrarias Dávila, sohrino del gobernador, capilan del artilleria, con hasta trescientos hombres; é que si se lallassen lıombres indios, se les notificasse el requirimiento que Sus Magestades mandaron laaçerles, é se procurassen de aver algunas lenguas indios, si posible fuesse, sin les laçer mal ui daño. É mandó el gobernador que ro llevasse el requirimiento in scriptis que se avia de haçer á los indios. é une lo dió de su nano, como si yo entendieráá los indios, para se lo leer, 6 fuviéranıos allí quien se lo diera á entender. queriéndolo ellos ojr; pues mostraples el papee, en rue cstaha escripto, poco laçia 
al caso: pero porpure, quando atclelante se lialde en cstos requindmientos, es bien que sis solo lo que so les requeria, quiero degirlo algui á la letris. Y es álquesto:

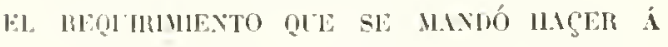
LOS IXDIOS.

-1. De parte del muy alto é muy porkroso é muy cathólico defonsor de la Igylesia, siempre vengedor y nunca rencido, M grand Rey don Fernando (quinto de tal numlne). Rey de las Españas, de las Dos Seciliats. ó de Itierusalem, é de las Indias, islis y Tierra-firme del mar Oçéano, etc., domalor de las gentes bárbaras; é de la muy alta é muly poderosa señora la Reyna doña Johana, su muy cara é muy almada hija, nuestros señores: Yo Pedralias Dívila, su criado, mensagero é capitan, ros notifico é hago saber, como mejor puedo, que Dios, Nuestro Señor, 1 mo ¿ trino crió el çiclo é la tierra, é un hombre é una muger, de quien rosotros é nozotros é todos los hombres del mundo fucron é son descendientes é procreados, é todos los que despues de nos han de venir. Mas por la muchedumbre que de la generacion destos ha subgedido desIe ginco mill años y mas que ha que el mundo fué criado, fué nesçessario que los unos hombres fuessen por una parte y otros por otras, é se dividiessen por muchos reynos é provinçias, que en una solat no se podian sostener ni conservar.

"Il. De todas estas gentes Dios, Nuestro Señor dió cargo á uno. que fuć llamado Sinct Pedro, para que de lodos los lombies del mundo fuesse príncipe, señor é superior, á quien todos obedesciessen é fuesse cabega de todo el linage humano, (londe quier que los hombres viviessen y ustuviessen, y en qualquier ley, secta ó creençia: é dióle fodo el mundo por su reyno é señorio é jurisdiçion.

"III. Y como quicer que le mandó que pussicsse su silla cn Roma, como en lugar mas aprarejado para resgir el mundo; mas tambion le permilió que purliesse estar é poner su silla en qualquicr otra parte del mundo, ó juzgar é grobernar á torlas las gentes, chripstianos, é moros, é judios, é gentiles, é de qualquier otra secta é creençia que fuessen.

"IV. L este llamaron Papa, que quicre deçir Idmirable, mayor padre é guardador; porque es padre é guardador de todos los hombres.

"V. I este Sanct Pedro obedesçieron é tuvieron por señor é rey é superior del universso los que en arpuel tiempo vivian: é assimesmo han tenido á todos los otros que despues dél fueron al pontificado elegridos; é assi se ha continuado hasta agora é se continuará hasta que el mundo se acaloe.

"VT. Lno de los Pontífiçes passados, que en lugar deste subçedió en aquella silla é dignidad que he dicho, como prínçipe é señor del mundo, hizo donaçion destas islas é Tierra-Firme del mar Océano á los dichos Rey é Reyna é á sus subgessores en estos reýnos, nuestros señores, con todo lo rue en ellas hay, segund que se contiene en çicrtas escripturas, que sobre ello passaron. que podeis ver, si quisićredes. Assi que, Sus Altegas son Reyes éseñores destas islas é Tierra-Firme, por virfud de la dicha donaçion. É como á tales Reyes é señores destas islas é Tierra-Firme, alğunas islas é quassi todas (á quien esto ha sido notificado) han resçebido á Sus Altegas, é los han obedesçido é obedescen é servido é sirven, como súbditos lo deben haçer; é con buena roluntad é sin ninguna ressistençia, huego sin dilaçion, cómo fueron informados de lo sussodicho, obedesçieron é resçibieron los varones é rcligiosos que Sus Alteças enviaron, para que les predieassen é enseñassen nuestra sancta fée cathólica á todos cllos de sil libre é agradable voluntad, sin premia ni condiçion alguma, é se tornaron ellos chrips- 
lianos é lo son, é Sus Altegas los resç. hicron alegre é benignamente, é assi los mandan tractar, como á los otros sus súbditos é vassallos, é vosotros sois tenielos é olıligarlos á haeer lo mesmo.

- V'H. Por ende, conio mejor puedo, vos ruego é requicro que entendais bien esto que ros he dicho, é tomés para entenderlo é deliberar sobre ello el tiempo que fuere jusı; é reconozcays á la Iglesia por señora é superiora del universso, é al Sumo Pontífice, llamado Papa, en su nombre; ¿ al Rey é la Reyna en su lugar, como á señores é superiores ó Reyes destas islas é Tierra-Firme. por virtud de la dieha donaçion; é consintays é deys lugar questos padres religiosos vos declaren é prediquen lo sussodielio.

- VIII. Si assi lo hiçiéredes, hareys bien é aquello que soys tenidos y obligados, é Sus Dlteģas é yo en su nombre, vos recilimán eon todo amor é caridad; é vos dexarán ruestras mugeres é hijos é haciendas libremente, sin servidumbre, para que dellos é de rosotros hagays libremente todo lo que quisiéredes é por bien toviéredes; é no vos compeicrán á que vos tornés elripstianos, salvo si vosotros, informados de la verdad, os quisiéredes convertir á nuestra sancta fée eathóliea, como lo han hecho quassi todos los recinos de las otras islas. É allende desto, Sus Nltegas os darán muchos previlegios y exençiones, é vos harán muehas merceceses.

"IX. Si no to liçiéredes y en ello maliçiosamente dilaçion pussiéredes, çertificóos que con el ayuda de Dios yo entraré poderosamente contra rosotros, é vos haré guerra por toulas las partes é maneras que yo pudiere, é ros suljectaré al yugo é obidiençia de la Iglesia é á Sus Alteças, é tomaré vuestras personas é dle vuestras mugeres é lijos, é los haré esclavos, é como tales los venderé, é disporné dellos como Sus Altecas mandaren; é ros toma- ré vuestros bienes, é vos haré todos los males é daños que pudiere, como á vassallos que no obelescen ni quieren rescebir su señor, é le resisten é contradiçen. E protesto que las nuertes é daños que dello se recresçieren, sean á vuestra eulpa é no á la de Sus Nlteças, ni mia, ni destos calualleros que commigo vinieron. E d como lo diggo é requiero pido al pressente eseribano me lo dé por testimonio signado.=Episcopus Palentinus, comes. $=\mathrm{I}^{\mathrm{a}}$. Bernardus, Trinopolitanus episcopus $=\mathrm{F}$. Thomas de Matienzo $=$ F. Al. Bustillo, magister $=$ Licenciatus de Sanctiago. $=\mathrm{lil}$ boctor Palacios Rubios.=Licenciatus de Sosa.=Gregorius, liceneiatus."

Esto es lo que contenia aquel requir:miento, eon el qual el uiéreoles siguiente catorçe de jumio de mill é quinientos y eatorge, poniendo en efeto lo que el general mandó, salimos en la playa mas di tresçientos hombres muy bien armados (en esclaresçiendo), y entramos por la ticra adentro con el eapitan Pedrarias, sobrine del gobernador, que yha por su teniente. é los capilanes Villafañe, é Gaspar de Ilo. rales, é yo é otros con la órden dada. É para efotuar lo que es dicho, si Dios lo permitiesse (puesto que los religiosos predicadores, quel requirimiento diçe, se quedaron en los navios hasta ver cómo subcedian las cosas), llegamos bien dos leguas apartados del puerto; y en el camino hallamos tres pueblos pequeños, é los indios avíenlos desamparado é huydo al monte é á las sierras: é por donde yban huyendo, dexaban algunas hamacas é mantas, é aun oro se halló en pieças labradas escondido entre las matas; y en $\mathbf{1 1}$ puchlo destos, el mas cercano al puerto, se hallaron muchos é muy hermosos penachos de plumas de papagayos é de diversas colores. É passados adelante, la gente nuestra yha muy desmandarla é sin órlen alguna, por culpa de los capitancs. é yban los chripstianos tendidos, como si 
andurieran í cazal de liveres, porque los indios que huyeron. devalban ayuellas cosals que he dielio apartaclase unas de ot ras, y assi los nuestros, por las topar, se derramaron. Yo ya por un laclo. y llevaba á callogo ciertos mineros á plateros e persohas, yue habian de dar las catas pala lowsall las minas: ć otros quinçe hombres de mis amiyos é crialos, fue por todos seriamos hissla tresuta personas. Subcedió que en çierto prasso, á la subicla de un monte ó çerro pelado. salieron alg̣mos indios con mucha groila é súbita; ć cómo la gente slua desparçida cada qual tiró por su parte. Es cetonces Pedrarias, el mançebo, como buen caballero, con mur procos hizoles rostro por la una parte del çerro, y juntóse con el rapitan Villafañe muy presto; y con los pocos que acudieI'on á estos capitanes començaron por arpuella parte á combatir. I yo con essos procos que tenia, halléme al otro ladlo del monte, é cómo ýamos mas juntos que los otros, cargaron mas indios solure nosotros, é cómo la cuesta era alta y masa, $\therefore$ los indios tenian lo alto, deste allí soltaban galyas muy grandes de piedras que con mucho ímpetu vinieron rodando, sin * poder tener ni nosotros amparar dellas, é al que topaban delante, lo maltracLaban. E çiento fué obra de Dios, segumd (ran muchos, no malar algunos chripstianos: pero oro hartos descalabratos deIlas. Todavia porfiando los que con Pedrarias y Villafañe se hallaron y los que conmig̣o estaban. los que de los nuestros se halian rediado, vicndo el ánimo de los delanteros, ovieron verouenga, y essos y los que atrís quedaban nos socorriejon á Luen tiempo; y suhimos el monte arriba, c cstando ya fuassi un la mitad del altula dél. donde ya nos podian alcançar los indios con sus flechas, no á mas lirar simo á tiro çicrto. nos tiraron muchas. é dexaron de tirar las piedras. porpue les fallaloan ya: y exercitaulo sus areos con una grita muy cerande, acomelieron á baxar algmos de los indios luáçía nosotros. Y allí me hirieron un hombre de los mios, que se deçia Hernando de Arrošo, montancos é valiente homulse, como lo dixe en cl libro XXIIL, cap. X, é le dieron con una flechá en la espinilla de una pierna estando á nui lado: é fué tan poca la herida. que en dándole la flecha, se casó ella en tierra: pero la hierha cra tal, que al momento desmaró é se vido que era morlal. É yo lo lieçe saear de allí á otros dos homlires mios. para que le llerassen á lá nao. donde le curaron. é se hiçieron con él todas las diligrencias que fué possible por remediarle: pero al terçero dia murió rabiando.

Finalmente, continuándose nuestra latalla, ganamos el monte por fuerga de armas. é quelaron mucrios tres indios de escopetaços, é fucron pressas dicz mugeres é una caçica ó muger prinçipal de cutrellas, E passamos adelante, en seguimiento de nnestro camino, élos indios apartados hacian rostro de quando en quando, assicomo yelan destiados; ć baxados de la otra parte de aquel çerro á unos llanos. secrúamos háçia un lıcrmoso rio. que de léxos nos convidaba la sed de lodos y el sol que era grande á no parar hasta llegara ác él : y am porque aquellos indios se retraian hácia aquella ribera, y por muy hermosos mahiçales que por aquella vega se mostraban. É ybamos ya en mejor órden de la que primero se avia traydo: porque quando subimos en la cumbre de aquel çerro ques dicho, paramos alli á descansar é comer parte de las mochilas, é haxamos con órden. É estando ya çerea del agua, nos aleanģaron dos mensagoros del general. con quien nos envió á deçir que él renia çerca é que le atendiéssemos, é assi se hizo: é quando lleçó á nosol ros, fuć á par de aquel rio, y éramos va assi de los primeros que aviamos salido por la mañana, como de los que cl gencral truxo á se juntar con no- 
solros, mas de mill é tresçientos hombres.

Passado aquel rio, entramos en un pueblo de lasta veynle huhios; y eslaba despoblado sin persona algura, y en ma casa de aquellas se entró el gencral con todos aquellos capitanes que allí se hallaron, é con el contador é factor é alcalde mayor, el licenciado Espinosa, y el teniente Jolran de Ayora, y en pressencia de todos yo le dise:- "Señor: parésçeme que estos indios no quieren escuchar la teologia deste requirimiento, ni vos tenés quien se la dé á entender: mande vuestra merçed guardalle, luasta que lengamos algyun indio destos en uma jaula, para que despacio lo aprenda é el señor obispo se lo dé á entender.» É dile el requiriniento, y él lo tomó con mucha risa dél é de todos los que me oyeron. Estando toda la gente repossando en aquellos buhios, esperando que el sol fuesse mas baxo, háçia las dos horas despues del medio dia, los nuestros dieron alarma, porque renian por un camino muy ancho y hermoso, orlaclo de muchos árboles á los lados, plantados por adornamiento suyo, mas de mill indios flecheros, con mucha grita y sonando unos caracoles gruessos que tambien se llaman cobos, é se oyen desde muy lexos: é venian en mucho conçierto hechos un esquadron, con sus perachos é pintados de aquella bixa que usan, que us miry mas fina color que un bermellon, é píntanse toda la persona é las caras, que paresce que están hechos un fino carmesi; y aquella tinta assiéntanla con çierta mixtura de gomas, é pégaseles para unuchos dias. Ha todos estos efelos: lo tmo aprieta las carnes é dá mas vigor á la persona; lo segumdo parésgeles á ellos que están muy gentiles hombres é fieros assi pinlados; é lo terçero, aunque sean heridos é les corra mucha sangre, no paresce tanta quanta es, por estar todo el indio (o)lorado.

El general salió presto del pueblo al campo á resçchir los indios en el mesmo camino é ordenó su grenle en otro bataIlon, estando á menos frecho de dosçientos passos los unos de los otros: é mandó que ningun escopetero ni ballestero tirasse. é que se pusiesse en lierra un tiro de pólvora de bronçe pequeño, de hasta dos quintales de pesso que allí teniamos, que doslebreles, que de sus dueños eran muy loados, á quicn por mucho correr no se escaparian los indios, se pusiessen en las alas ó liulos de nuestra hatalla, é quo quando el general diesse la señal que se tirasse el tiro, se hiçiesse; é en el instante, con una grita y todo junto, se soltassen los perros é cada mo arremetiesse á los enemigos é liciessen de valientes hombres.

Quisiera yo que aquel requirimiento so les hiçiera entender primero; pero como cosa excusadla ó por demás, no se tractó dello: y de la mesma manera, andando el tiempo, por este dechado y forma quel general ovo en esta entrada suya para haser essa diliggençia callólica con los indios, que se le mandó que lo hiçiesse antes de les romper la guerra á los indios; de cssa mesma manera y peor lo liçicron despues los particulares capilanes en muclias entradas, como se dirá adelante en la continuacion de la historia. Yo pregunté despues, el año de mill é quinientos é diez y seys, al dotor Palaçios Rubios, porque él avia ordenado aquel requirimiento, si quedaha satisfecha la conçiençia de los clupipstianos con atquel requirimiento; dixome que sí, si se hiçiesse como el requirimiento lo diçe. Mas parésgeme que se reia muchas veces, quando yo le contaha lo desta jormada y olras que algunos cipitanes despues avian hecho; y nucho mas me pulliera yo reỵr dél ja de sus letras ( que estaba reputado por gliand varon, y por tal tenia lugare en el Consejo lieal de Castilla), si pensaba que lo que dice aquel requirmiento lo avian de en- 
render los indios, sin discurso de años 6 tiempo. Épues en a rapitulo V"ll se les dá lugar ó se les promete en aquel requirimiento que tomen al tiempo que fuere justo. para entemder aquellos capílulos, é que puedan deliberar solve ello. qué tanto la tle ser este tixmpo quisiera yo que alli se expresána; pero si se les guardára ó no. no me delermino en esso. Adelante se dirá a tiempo (ue los capitanes les daJan, atando los indios despues de salteados, y en tanto leyéndoles toda aquella capitulacion del repuirmiento. Tornemos á la historia.

l)igo que de la manera que el general ordenó que esta batalla se diesse á aquellos indios que parescial que nos venian á cehar de aquel pueblo, assi se aparexó é pusso á punto todo: pero dada la señal é pegado fuegro al tiro, passó por alto y no mató ningúno. y en soltando los perros, arremetió el uno al otro é comengaron á se morder, sin curar de yr tras los indios. E cómo los enemiros estaban desviados de nosotros lo que he dicho, é sabian mejor los passos, pussiéronse en luyda, é salidos de arpuel camino ancho, como todo lo otro fuera dél cra boscajes cerrados, ningun indio fué tomado ni mmerto, sino encontinenti desaparesçieron de allí. Passamos Jien una legua adelante, é por donde ybamos salian de través muchos renados, y cómo en nuestro exérçito habia huenos kureles, conosgian mejor aquella monteria que la de los indios; y matúronse afuel dia çinco ó seys venados, yue se comicron essa noche en el real donde fuymos á parar , çerea de un rio. E estando allí se diso que estaba herido el piloto Pedro de Ledesma. y que lo avian herido aquel dia los indios de una flecha; y yo le fuy á rer y tenia un rómito. é víle un rascuño en una cadera, é parescyióne mas obrá de sus uñas que de la hierlas: é luego se sospredió que su mal cra avérsele acalado grierto vino que sacó de la nao aquel dia : pero porque era buen piloto é diestro de la costa, é el zeneral le ovo lástima. y era gruesso é pessado, á todos dió cuvidado de volverle al puerto otro dia. Passada la noche, seyendo hecla buena guarda, otro dia jueves, dia de Corpus-Chripsti, dixéronle al gohernador los hombres de la mar, y en especial apuel piloto Pedro de Ledesima, que ya la hierba se le yba passando, que el tiempo era bueno para proseguir nuestro viage y que se debia yr á cmbarear, é assi se hizo: é dió liconçia que la gente fuesse desparçila con sus capitanes, é que todos se fuessen á hallar temprano en el puerto á tal hora que se pudiessen embarear. En esta vuelta se hallaron en el. campo é por donde tornamos alguna ropa de mantas é hamacas é siete mill pussos de oro ó mas, en diversas piegas, labrado, escondido entre las matas en çinco ó seys partes, puesto en sus havas ó çestas. Aquel dia entré yo en un pueblo de quarenta buhios ó mas, é hafléle despoblado, é hiçe pegar fuego á una casa de aquellas que estaba llena de arcos é flechas é pelotas de hicrba, é debia ser casa de muniçion. En aquel pueblo se halló un çafir blanco y grande, é se oro una manta con ciertas plasmas de esmeraldas é otras piedras: lo qual todo, con otras particularidades de aquel puerto, se dixeron en el libro XXY1, hablando desta provinçia de Sancta Marta, y no es nescessario tornarlo aquii á repetir.

Assi que, este dia jueres quinģe de junio se embaré el general con toda su gente, é essa mesma noche, antes que fuesse de dia, nos lıeçimos á la rela. No se dexó de dar mucha culpa al general, por se aver ydo de Sancta Narta con tan poco fructo, como allí se hizo, y con muchat racon: porque despues por su defeto, é no arer él poblado atquel assiento, que lo pudiera fácilmente hager, pues sobraba grente, se le quitó aquello de su gro- 
bernaçion. Assi que, salida el armada de aquel puerto de noche, la nao capitana yba adclante é llevaba su farol, y trís ella, siguiendo, todas las otras naos y carabelas: y el viento se esforçó muchı, y la mar se ensoberbesçió tanto, que quando fué de dia, nos liallamos tan ensenados é metidos en tierra debaxo de Gayra, un puerto que assi se diçe, que pensamos dar todos al través. Sin dubda, si la claridad del dia se lardara dos horas mas, nos vićramos en tanto peligro, que no escapara hombre, si no fuera por miraglo. Y assi con mucho trabaxo, y prinçipalmente por la bondad y clemençia de Dios, podimos salir mas á la mar y seguir nuestro viage. É fué el armada á Isla Fuerte, que está dos leguas y media, poco mas ó menos del Cenú; ó allí salieron çiertos capitanes con grente, por mandado del gene- ral, é tomaron muchos çestos de sal del tamaño de ayucllos que se trien á Castilla con los besuggos de la mar cantábrica é septentrional de España, y se llevan á Burgos y por Castilla; pero estos çestos de sal eran muy mejor hechos, é la sal muy lıemosa é hlanca, $\dot{c}$ se laçe alli del agrua de la mar. É los indios cómo ricron desde léxos lantas naos, huyeron en sus canoas é se passaron á la Tierra-Firme. Aquesta isla es llana y baxa, é bojará ocho leguas ó menos, y está en algo menos de diez grados desta parte de la línia equinoçial: é estuvo allí el armada el diá que llegó y el siguiente, y el terçero se partió para el Darien, é llegóo al surgidero de aquella cibdarl, en el golpho de Urabá, á los veynte y nueve dias del mes de junio de mill é quinientos y catorce años.

\section{CAPITULO VIII.}

Cúmo el gobernador Pedrarias Dảvila llegó á la cibdad de Sancla Maria del Anligua del Darien, donde estaba por gobernador el capitan Vasco Luñez de Balboa, é tomó la possesion del officio, é se entendió en la residençia de Vasco Nañez, éfué enviado el teniente Johan de Ayora é otros capilanes con gente á poular á la otra costa de la mar del Sur.

A los treynta de junio de mill é quinientos y catorçe años de la natividad del Redemptor nuestro, saltó Pedrarias en tierra é entró en la cibdad de Sancta Naria del Antigua del Darien con todia la gente que llevalua del armada, que eran dos mill hombres ó mas, é muy bien aderescados é armados, é el obispo é offiçiales y capitanes, y en muy luena órden todos, que era cosa que en todas prattes paresçia bien. É Tasco Tuñez, que allí gol,ernaba, como es dicho, lo resçitró con quinientos é quinçe hombres que estaban allí aveçindados, é tenian fechas mas de çient casas ó bulíos: é estaba muy gentil poblaçion, é con un hermoso rio que passa pegado á las casas de la cibdad, de mnuy buena aggua é de muchos buenos pescados. Este es el TOHO III. rio del Darien, é no el que en el libro XXVII el liçençiado Vadillo llama rio del Darien, é este viene de la parte del Ilueste, y el quél diçe es un braço del rio de Sanct Johan, que entra en la culata del golpho de Lrabá, como la historia ya lo lia dicho. Tornemos a la historia.

Luego pressentó Pedrarias sus provisiones, y fué resçebido por gobernador, con mucho plaçer de los que alli estaban é de los que nuevamente yban, exçepto del Vasco Nuñez y sus amigos é los que esperaban dar cuenta, puesto que tambien Inostraban plaçer de nuestra yda. É el gobernador tomó las varas de la justiçia, $y$ caula uno començó á exerçer su ofliçio, segund yban proveydos dellos, é los que ovo de proveer el gobernador, los proveyó. 
Lia entre alpuchlos polladores primeros mas de mill o quinientos indios ó in-

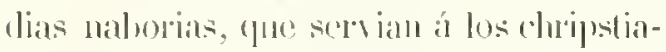
nos en sus hagientas é casalo; pero porque adelante so tocará algmats veges coste nombre de naborias. "s lien que aqui se declare. Naboria es el que láa de servir á un amo, ammque le pesse: é él no lo puede renter ni troear sin expesa liçencia del gobermador; pero ha de servir Lasta que la naboria ó sir amo se mucra. Si la naboria se muce, acabado es su captiverio; y is mucre su señor. es de provecr de tal naboria al gobernador, y dála á quien él quiere. É estos tales indios se llaman naborias de por fucrea é no esclavos; pero yo por esclavos los avria, quanto á estar sin libertad.

La gente que fué con Pedrarias, se reparticron é apossentaron con los pol,adores, que allí estaban on compañia de Vaseo Nuñez; é dióseles de comer é rasion á todos muy complidamente un mes despues de llegada el armada, é soJruron de la hacienda del Rey muchas pipas de vino é harina ó otras provisiones, que fuera mejor que tambien se eomieran, como se diráa alclante.

Lo primero quel gobernador hico otro dia despues que llegró. fué apartar á V'asco Nuñez en secreto, en mi pressencia (porque yo yba por escriluano general in nombre del secretario Lope Conchillos, é llevaba comision de proveer por el seeretario, en nombre del hey, todos los otros escribanos del audiencia del gohemador y del alcalde mayor y otros juzgados); y dixole quel Rey le avie mandado que lo tractasse muy bien, por lo que le aria sepvido en aquella tierra. é en todo lo que ovicsse lugar, le faroresçicsse é gratificassc; é se informasse dél del estado é cosas de la tierra, é qué indios avia de paz équáles de guerra, é en todo le divo que entendia tomar su prareserer. É á este propóssito le dixo muchas palabras dulges. de que d Vaseo Nuñez mostró rentenlamiento, y respondión quál bessalnal los reales piés al Roy, nuestro señon , por lorpue do parte de Su Altega le avia dicho, y á fo tenia en merged la roluntal que le of pescria; é que en torlo lo quél suppiesse ó purliesse avisalle é servir á Sus Iltegas. lo diria su pareseger con rerdad! volunfad entora de hagerle servicio: ć que para aquello era menester recoger su memoria, é daria sn respmesta con obra, dándole notiçia de lo quél supresse ecerca de lo quel general le mandaba é requeria, porque fuć por anto todo esto diclo y escriplo.

Fisi, despues del dia siguiente, que fueron dos dias de julio, le dió la respuesta por escripto, la qual contenia muchas cosas bien dichas y convinientes: y entre otras declaró los rios é quebradas é partes señaladas, donde se avia hallado oro é lo avian visto é cogiclo los cliripstianos hásta estonges. É dixo que de tres años antes hasta que Pedrarias llegó, avia hecho de paces aquestos caciques: Careta, Ponca, Careca. Clsape, Curuera, Juanaga, Bonanimana, Tecra, Comogre, Pocorosa, Pucheribuca, Chuyrica, Otoque, Cliorita, Pacra, Teaoca, Thenoca, Tamao, Tamaca, Tubanama é ofros; é avia descubierto la mar del Sur en el año de mill é quinientos y trege, é la Isla Rica de las perlas, é avia en persona atravessado la tierra de mar á mar, é en todo dico verdad.

Descle á pocos dias se pregonó la residençia contra Vasco Niñez é sus offiçiales, la qual le tomó el liçençiado Gaspar de Espinosa, alcalde mayor : ć por otra partc el gobernador con un largo interrogatorio, é secrelamente comencó á liaçer la pesquisa seerela contra Vaseo Nuñez, sim quel alcalde mayor lo supiesse. ó porque no se fiaba dél, ó porque no tenia expiriençia ni aria tenidlo eargo de justiçia (antes aquel era el primero que tuvo, y joco antes avia salido del estutio de Sa- 
lamanca) ó porque le paresçió que assi convenia, puesto que en la cédula quel alcalde mayor tenia del Rey Cathólico, mandaba á Pedrarias que no usasse con otro juez en las cosas de justiçia, sino con este liçençialo Espinosa. su alcalde mayor. Pero antes quél lo supiesse, se tomaron algumos testigos de aquellos primeros polbladores, que avian quedado de la gente é armadas de los gobernadores Alonso de Hojeda é Dicgo de Nicuesa, los cuales sabian muy bien la verdad de todo lo passado, é la vida del Taseo Nuñez; en el qual tiempo, en la residençia pública le pedian muchos, é se dieron contra él muchas sentengias de las cosas que avia tomado é delia á personas particulares; $\mathrm{y}$ con algumos se conçertó. É en estos principios parescia quel alcalde mayor tenia voluntad de haçer justiçia á todos; pero descle á pocos dias faroresçió claramente á Vasco Nunez, y crejóse que la causa era por contentar al obispo fray Jolian de Quevedo, que firoresçia á Vaseo Nuñez, y representaba muy á menulo sus servicios y el descubrimicnto de la mar austral, é que avia sido el primero chripstialno que la violo, é que laalló el estrecho que hay de la costa del Norte á la del Sur, e lo anduvo por su persona: é pulblicamente decia que era digno de grandes mercedes.

Al gobernador pessíbale destos loores. y cra de ofra opinion; mas como el obispo é offiçiales erán coadjutores en las cosas de la gobernaçion, é se oro noticía de la pesquisa secreta quel gobermador tomaba, sintiólo por injuria el alcalde nayor porque se avia fecho sin él; é sobre esto jasaron otras muchas cosas é palabras que no son para la historia. Pero redundó dello quel alcalde mayor se deternimó en le ayudar, por deshaçer lá pesquisa, en la cual se probaba la muerte de Diego de Nicuesa, ó aquel desapialado exilio, con que lo echó Tásco Nuñez de la tierra, é otras culpas. É en fin el gobernador le dió lo que estaba escripto, y no progeclió ui habló en cllo, mas de lo quel obispo y el licenciado Espinosa quisicron : é diéronle á entender que arjuellos testigos cran encmigos de Vaseo Nuñez. Mas el gobernador quisiérale enviar á España, y á una roz quassi todos esturicron conformes para que en grillos le llevassen, porque los testigos se rectifiearon en los dichos. É cómo el obispo cra sagaz, procuró de dar lugar al tiempo é que tal determinaçion se sobreseyesse; porque el obispoé Vasco Nuñez cran ya compañcros en las grangerias de las haciendas del campo é en las naborias é indios, é pensaba acpuel perlado ser muy rico por la industria de Vasco Nuñez. É dió á entender al gobernador, que si lo enviaba á Castilla, que en la hora que entuviesse en la córte, avia de saber el Rey que avia descubierto la otra mar, y avia hallado el passo ó estrecho que hay de tierra de mar á mar, é que avia hallado muchas minas de oro, é que avia andado la tierra por su persona, é hecho de paçes muchos eaçiques: é que en esta cibdad de Sancto Dontingo, ol thessorero Niguel de Pasamonte era á quien el Rey daba mas crédito que á lombre de quantos avia en estas partes, y hacia por Vaseo Nuñez, é seria causa que lo enviasse luego honrado é gratificado, é le darian la parte quel Vasco Nuñez quisicsse escoger de la gobernaçion de Castilla del Oro, lo qual él sabria nuy bien señalar, pues sabial la tierra: é que lo que le convenia á Peclraria era disimular é tener en palabras é plejtos á Vasco Nuñez. y en continua nesçessidarl, é que en tanto el tiempo le diria lo que se debia haçer. I lo mismo deçia al alcalde mayor.

i Pedrarias no le paresçió que se debria desechar este consejo: antes acordó de lo tomar, y desde á pocos dias se lo restituyeron á Vaseo Nuñez los hienes que 
por inventario fo estallan socuestrados, y poco liempo despres, por medio del oldispo, se le dialua prite en los negrogios de la golvernarion. É oro mas ligar esto, poryue el gobermator adolesció y esluro muy enfermo muchos dias, é dió poder al obispo é offiçales para golvernar en su lug̣ar, como él lo pudiera lacer.

Antes que Pedrariels llogasse al Darien, avia ydo allí un hidalgro, verino de Bilbao, Ilamado Pedro de Arliolancha, y era curial é conoscido en la córte y hombre de neggoçios: al qual Tasco Nuñez dió carlas é lestimonios de sas servicios, é que lriciesse saber al Rey Cálhólico cómo aria descubierto la otra mar é desculicrto minas é pacificado mucha parte de la tierra, y esperaba de dia en dia ser respondido.

En tanto que turó la residençia, é aun dias despues adolesció mucha gente del armada; é cómo no les daban ya de comer, morian muchos de lambre, é para excusar essas muertes é començar Pedrarias á poblar la lierra de la otra costa, temiendo que le aria de venir al Vasco Nunez algun despacho en su favor, é por ocupar la gente en algo, é començarse la destruycion de la lierra á que ellos llamaban paçificaçion é conquisıar), acordaron de enviar al teniente Johan de Ayora por capitan general, con los capitanes Hernando de Heneses é Françisco Dávila é Gamarra é otros, con quatroçientos lım-

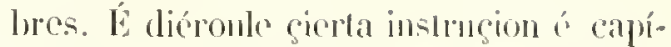
tnlos a c mandáronle que passasto a la ol ra mar del Sur y poblasise con apuedla gente en la olra costa, en la pardo della que mojor le paresciesse, è que tuviesse especial cuydado de laçer entender á los indios aquel requirimionto, que se dixo en cl capítulo antes deste para satisfacion de la real congiengia del Rey é Reyna é de los chripslianos; é mandóscle que en ninguna cosa los españoles fuessen agresores, ni consintiesse haçer mal ni agravio á los indios sin mucha causa, é dándoles término é placo para que respondiessen al requirimiento ques dicho: el qual fué ordenado é firmado por teólogos, é á los indios les era leydo en lengua. que no entienden, é seyendo gente salvage, é mandósele que no les liçiesse gucra, sin que los indios se determinassen y cscogiessen la paz ó la negassen. Mas hablando la verdad, el fin desto era, que aunque el Rey supiesse que Tasco Nuñez avia descubierto la otra mar, é enviasse algun faror para él, esluriesse polılada la costa por Pedrarias, é impedir á Vasco Nuñez el efetto de qualquier meresed que se le hiçiesse, é oponerse á clla Pedrarias, alegando que por su industria lo avia poblado, é que Vasco Kuñez no avia lıecho sino verlo, maltractando los indios, para lo lo qual tenia Pedrarias fechas algunas informaçiones contra él.

\section{CAPITULO IX.}

Cúmo el teuiente Johan de Ayora é otros eapilanes fueron enviados eon genle á poblar la eosta del mar del Sur; y eómo el Riey Callúlieo le envió é hizo merẹed á Vaseo Nuñez del lítulo de adelantado de la mar del Sur y de la gobernaçion de las provinçias de Coyba é Panamá : é eómo Pedrarias tuvo forma que no ussase de lales merçedes; é de las partes que el gobernador é offiçiales llevaron de las entradas, que fué una de las prinçipales eausas de aeabarse, $\dot{o}$ al menos disminuyrse los indios é asolarse la lierra, ele.

\section{D} rias al Darien, se informó de Vasco Nuñez del estado de la tierra, é supo dél quáles caçiques estaban de paz é quáles de guerra, é dióle por escriplo su parescer é dí- xole verlad, é aconsejóle muy bien, como muy mas largamente en el capílulo de susso queda dicho. Mas el gobernador no le dió crédito: antes pensó que le engañaba, é determinóse en enviar á su leniente 
Johan de fyora con ofros capitanes $y$ gente, que lıe dicho, ála otra mar: éfucron parte del camino la costa abixo al Oçillente hasta el puerto de Sancta Cruz, que es en ticrra del eaçique de Comogre. É hizo alli un puelılo, en que dexó lasta ochenta hombres, todos ó los mas dellos enfermos, y por capitan é alcalde desta gente á un mançebo, llamado IIurtado, homlse de ninguna expiriencia (é aun quassi no conosçilo), é de los que nuevamente fueron en el armada. Desde allí passó adelante, y dexó polblando en la provinçia de Tamao al capitan Fernand Perez de Meneses, é haçiendo un pueblo: é fué parte de la gente con el capitan Françisco Dávila á la costa de Panamá de la banda del Sur; pero muy poco vido de la mar austral, é por otros caçiques de aquellas comarcas se desparçió toda la gente.

En este camino Johan de Ayora, no solamente dexó de haçer los requirimientos é amonestaçiones, que se debian haçer á los indios, antes de les mover la guerra; pero salteálanlos de noche, é a los caçiques é indios prinçipales atormentáluanlos, pidiéndoles oro, é unos assalıan, é otros haçian comer vivos de perros, é otros colgaban, é en otros se hiçieron nuevas formas de tormentos, demas de les tomar las mugeres é las hijas, é hacerlos esclavos é prissioneros, é repartirlos entre sí, segund é de la manera que á Johan de Ayora le paresçió é á cada uno de los otros capitanes, por donde anduvieron.

É en esta caça ó monteria infernal se deturo esta gente algunos meses: en el qual tiempo é saçon en el Darien andaba tanta modorra y enfermedades por los chripstianos, y en espeçial por los que nuevonente avian yoloá la tierra en acpuella armatla, que cada dia murien quinese ó veỹnte, é algunos dias mas; y en poco tiempo murieron mas de quinientos homlores, é los mas dellos por filta de bastimentos, puesto quel Rey los tenia sobra- dos. Pero cómo los offiçales querian poner recal,do en la haçienda real, y á ellos no les faltaba de comer, tuvicron poca missericordia con los demás ; y para poner mejor custodia en la haçienda de Sus Mlagestades, hiçieron haçer un buluío grande en la costa á par de la mar, á la qual casa llamaron cl Toldo. É alli se descargó la laçienda, é meticron muchas pipas de vino é harina, é la mayor parte de los bastimentos: é desde allí llevaban poco á poeo á la ciludat lo que querian é lo ponian en la casa de la contractaçion, en que cstaha el factor Johan de Tavira.

Viendo Dios el poeo serviçio que él y el Rey rescelian de aquellos bastimentos, permitió que, pues con ellos no eran socorridos los pobres, é se caian los hombres muertos de hambre por las calles, que se pegasse fuego á aquella casa del Toldo, donde estahan los bastimentos; é assi se quemó quanto en ella avia, y se perdió todo lo que pudiera dar remedio y excusar muchas muertes de los que, por falta de comer, murieron: á los quales, si se diera aquella harina y vino, el Rey ganára muchos dineros, é pudiera ser que los que padesçieron, tuvieran vida. Pero no me aparto de la sospecha que muchos turicron, que quissieron deçir que los mayordomos que en la haçicnda entendian é la guardaban por el factor, fucron el mesmo tiçon que ençendió aquel fuego, para que, só color de aquellas llamas, so quemassen diez pipas é se lurtassen çiento, por dar la cuenta á carga çerrada, en nombre de caso fortuyto. Quédesse á Dios este juiçio, é pluguiérale á él que otıos mayores daños na ovicran acaeşido en aquella tierra. Pues cómo las muertes y enfermedades cran muchas, y la lambre intolerable, muclos de los que fueron en arpuella armada huyeron de la tierra, y algunos se volvieron á España, y otros se passaron á esta nuestra Isla Española, é Cuba, é Jamáyyca é Sanct Johan; y en 
ospacio de siete ú ocho nleses eran mas los mucrtos é yelos que los pure quedaron en la lierral y en aquellos que vivicron,

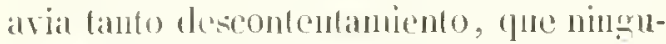
no estalua de su voluntal. Y am el gobernator, y obispo, y ofliçiales lesamparéran la ticrra, si con hucna color é sin verouienga lo pudieran laiger. É todos eserebieron (que era aquella cilstad é assien10 muy enfermo, é dieron á entender al Rey é á los de su Couscjo que era la mas mala tierra del mundo. é la infamaron por la peor cosa que avia en la Tiera-Firme, sicndo la rerdad en contrario; porque aquellas enfermedades futeron una açdental modorra, ć faltar los bastimentos de España, y tambien los de la ticra, á causa de tanta langosta que vino, é paresçia que cubric el aire, é destruyó los mahicgales. Pero passada aquella fortuna, esturo muy sana la tierra, é acudicron las labranças mucho abundantes: é las minas del oro liene á tres é á quatro leguas de la cibulad, é la ribera muy buena é de muchas pesquerias. é muy grandes monterias de pucreos. é renados é otras salraguinas, é no pueden dexar de conosçer los que persercraron quel Darien era la mejor cosa de la Tierra-Firme. Tolvamos á nuestra historia ó materia, de que de susso tractanos.

I es assi que, ustando las cosas del Darien tan alyorrescidas, como he dicho, comunmente de todos, el srobermador Pe. drarias tentó de se yr y rolver á España, é aquella ciblad de Sancta Maria del Intiqua del Darien no se le consintió, é le dixeron claramente que no se aria de yr, sin haçer residençia, é que lo mandasse el Rey primero: á causa de lo qual le quedó tanta enemistad con aquella cibdad, que no liolgó hasta pue despues la despobló, como se dirá adelante.

En esta sacon turalua la residencia de Bartolomé Hurtado, alguacil mayor é compañero que avia seydo de Vasco Nuñez: é para evadiu le de clla é disinular sus obras. que cran assaz dignas de castigyo, acordo la industria del obisjo, por lo pue le tocalba de la amistad de Viseo Nuñez, de dar á entender al goberuarlor é offiriales que ela bien que se enviasse á saber qué avia fecho Dios del teniente Johan de Irora é de la gente é eapitanes que con él avian ylo la tierra adentro é í la costa del mar del Sur (de los quales ninguno avia tomado ni se sabia cosi alguma). Y porclue este Bartoloné Hurtado era hombre suelto é plático un la tierra, assi se hico; é le coviiiron con veynte compañeros á buscar á Johan de Lyora, porque cste avia passado á la otra mar, quando la descubrió Tasco Niñiez, é saljia quáles cogiques avian quedado de paçes é quáles no. É es verdad que los indios que eu aquella saçon aria en aquella grober naçion, passaban de dos millones, ó eran incontables; ć avia de paçes nutuchos caçiques é otros neutrales y en dispusiçion ć aparejo grande de servir é ser amigos de los chrripstianos é renir á la obidiençia, é la tierra toda muy rica; é avia mucho oro labrado en poder de los indios, é los chripstianos que estaban con Tasco Nuñez viviun sin nesgessidad, é tenian aparejo para ser ricos presto, por la dispusiçion que avia en la Lierra para ello.

En fin, este Bartolomé Hurtado lıalló á Johan de Jyora, é le dió las cartas del gobernador é del obispo é officiales, é le dixo lo que le mandaron, é fornó con la respuesta . é dixo que deste á pocos dias vernia al Darien, y que la gente toda estaba luena. Mas puesto que se avic suspendido ó dilatado lá conclusion de la lesidençia deste Bartolomé liurtado, no por csso era acabada ni él dado por libre; é para ganar las voluntades al golernador é olsispo é offiçales, procuró de traer de camino algunos indios, que repartio entre cllos, no aviendo por inconvinicnte arerlos salteado y ser los $m$; indios de paz, 
aunque avia llevado el requirimiento quel Rey les mandaba hacer. I de vuclta, que venia con mas de çient pieças, llegó al caçique de Careta (prinçipal caçique é verdadero é primero amigo que los chripstianos turieron en aquella provinçia), é dixole que, porque aquellos indios qquél traia, renian cansados con las cargas, que le rogaba que le diesse algunos indios de los suyos que se las ayudassen á llevar hasta el Darien, que está veynte y quatro ó veynte y çinco leguas de allí, é que luego se tormarian. E demás de le hospedar al Ifurtado é darle de comer á él é su srente é indios, con mucho plaçer é buen acogimiento, mandó que fuessen con el IIurtado hasta dloçe ó quinçe indios de los suyos, para les ayudar á llevar las cargas, é que fuesse con ellos un prinçipal suyo, para que les mandasse lo que avian de haçer, é que se tornasse con ellos; é assi fueron al Darien. Con la llegada del qual Hurtado resçiljicron grandíssimo plaçer el gobernador é obispo é offiçiales é toclos generalmente, en saber que Jolıan de Ayora é los otros capitanes é gente estalaan buenos. é que presto vernían; é en presçio é gratificaçion destas nuevas, fáçilmente se concluyó la residençia de Bartolomé Hlurtado, é se olvidaron sus culpas, en tanta manera que á él le pessaba, porque no avid tenido mas, é á otros so dió exemplo para cometer otros delictos, con esperança que no serian castigados.

É un dia, juntados el gobernador é obispo é officiales é alcalde mayor, despues que estuvieron quintados los indios que este Hurtado avia robado é salteado por donde fué, lleró alli hasta treynta é tantas picças de indios, lombres é mugeres, de buenas dispusiçiones, é dió al gobernador é obispo cada seys, é al thessorero é contador é factor é alcalde mayor cada quatro pieças, que se llevaron á sus casas: é estas fueron las primeras partes quel golienador é oljispo é offiçiales é al- calde mayor llevaron, sin las ganar ni aver causa para que se les diessen. Y en tal hora lo començaron, que se quediron en costumbre de las llevar de allí adelante (ál lo menos el gobernator é offiçiales).

Quando este Bartolomé Hurtarlo pagó el quinto al Rey, entregó al thessorero de çinco indios uno, é assi al respecto de todos los que truxo (é dió por quinto el prinçipal é indios de Careta, que dixe de susso que le avia prestado el caçique de Careta, para le ayudar á traer las cargas, é que eran amigos é de paz): los quales luego fueron vendidos en almoneda é herrados, é los mas dellos se sacaron de la lierra por mar, é los llevaron á otras partes. É no faltó quien le diesse notiçia al gobernador deste fraude é maldad, é le fué dicho en la barba; pero ni lo castigó, ni curó dello. Pero esta ofensa é injustiçia no la olvidó el caçique de Careta, como se dirá adelante, pues pagaron otros chripstianos la culpa de Bartolomé Hurtado.

Assi como el gobernador é obispo é offiçiales é alcalde mayor ovieron resçclido aquel pressente ó parte de los indios, venido á dar cuenta particular del viage, é de cómo aria fecho las diligençias y el requirimiento quel Rey mandaba liaçer á los tristes indios, antes que fuessen pressos ni se les moviesse guerra; paresçió que avian seydo salteados, é que primero fueron atados que les dixessen ni supiessen que aria Papa, ni Iglesia, ni cosa de quantas el requirimiento deria : é despues de estar metidos en cadena, uno les leia aquel requirimiento, sin lengua ó intérprete, é sin entender el letor ni los indios; é ya que se lo dixeran con quien entendiera su lengua, estaban sin libertad para responder á lo que se les leia, y al momento tiraban con ellos aprisionados adelante, é no dexando de dar de palos á quien poco andaba, y haçiéndoles otros muchos ultrages, y fuerças y adulterios con mugeres extrañas y apartadas de la 
féc. I tampoco oro castigo ni reprehension en esto, sino tan larra disinulaçion, que fué prinģipio para tantos makes, que numea se acalarian de escrebir.

Desde á poeos dias llegó Jolann de Arorai, é dió cuenta de su viagre e de las diligençias que avia luccho con los indios, é dióla tan mala ó peor que la que avia dado Bartoloné Ilurtado, é lan dienna ó mas de castigro; pero cómo avia dado otros indios al obispo. fućle tam favorable que todo se disimuló, é por sentençia é paresçer del alcalde mayor fuć admitido, é aun loalas sus ohras, puesto que hiço exhemadas crucldades é muertes en los indios sin causa, aumpue se le venian á convidar con la jaz, é los atormentaba é robaba. É deçia que en Llamuz, donde tenia su casa, en tierra de Córdova, avia de vivir é lacer su vida, é no en Tierra-Firme, é que no avia de rer mas á csla gente, é que jurala á Dios quel oro que tenian 0 el coraçon le avian de dar. É assi hiço morir muchos con nucvas crucldades y tormentos, é comer perros vivos á olros; é dexó de guerra toda la tierra alçada, é dió prinçipio lan dialólico en el crédito de los indios contra los chripstianos, que nunca le salió del pecho la indignaçion, y una entrañable enemistad contra el nomhre chripstiano, y con muy justa quereIla. Y como quier que los ánimos culpados no tienen reposo, ni pueden vivir sin sospechoso temor los que han errado, conosciendo quel mas cirrto testigo de sus olsras se era el mesmo Johan de Ayora, é que essas no eran de calidad para confiar en aquella sentençia quel liçenciado Espinosa aria dado en su faror, y que llegaba á tiempo que estalıan divisos en dos parçialidades el gobernador y obispo y offiçiales en lo intrínseco, porque el obispo y el alcalcle mayor é Tasco Nuñez cstaban á una, é el gobernador é el tlicssorero é el contador é el factor al opqósito: é pues en discordia de los unos é de los ofros avia laallado lugar para no sel punido (á (ansial de los indios que les pressentó), simpleça é notorio pelig̣ro fiurra atronder á que los mas que atrás quediaban llegassen al barien, que bien sospechabla que entre tantos algunos arian de derir eosas, que diessen ocasion á que se tornasse á rever su cuenta. É assi procuró de arer liçençia é yrse presto de la tierra; é quiso su dicha que avia una caravela en el puerto del Darien, y fingiendo que estala enfermo y que se yla á cural í Espana, no atendió mas é vínose á esla çildad de Sancto Domingo de la Isla Espanola, é desde aqui se fué á Castilla, sin se detener.

Desde á pocos dias despues que Johan de Ayora partió del Darricn, llegaron los otros capitanes que con él avian ydo la tierra adentro, é liallálronle ydo; é luegoo se començaron á publicar las obras y culpas de Johan de Arora (en tiempo que no tenian remedio). É lúvose por çicrto que avia llevado una grand suma de oro robado y escondido, sin lo quintar é registrar; y por presto quel golsernator y offiçiales pudieron proveer $\mathrm{y}$ enviar á esta ciludad trús él, ya era yolo.

Essotros capitanes dieron su cuenta, y en lo del mal tractamiento de los indies, algunos lo liçieron menos mal que otros, y al que mejor lo hico se hallaba poco que agradescerle: antes hiçieron exçessos y crucklades muchas. Mas cómo avian sejudo absucltos llurtado y Lrora, paresçiera mal condenar á los que, en comparaçion dessos, 110 avian peccado, aunque no les faltaban culpas; y cómo daban partes é presentaban indios al gobernador é obispo é offiçiales, todos eran absuclıos; y cstaba ceto en tanta costumbre, que quassi por ley lo tenian todos los capitanes. É desta causa, é por el interesse destas partes, que se daban á los gobernadores é obispo é offiçiales en los indios, y al gobernador en los indios y en ol oro de cada entrada, y en llevarles sus mogos y negros y perros, y dirles 
has mejores partes en los repartimientos de los indios que se tomaban, continuaron á enviar capitanes á umas partes é á otras de la tierra. é dábanles el requirimiento quel Rey mandó que se liçiesse á los indios. y con él una instruçion bien ordenada. É yluan por tiempo limitado á la provinçia ó parte que los cnviaban; y quando tornaban, cargados de oro y de indios que avian tomado para esclavos, daban al gobernador dos partes en todo, é los offiçiales avian sendas en los indios. Écometíase el proçesso de las diligençias al alcalde mayor Espinosa, é aunque muchos crrores é faltas avia en los capitanes, y avian exçedido en las instrugiones, y no avian hecho el requirimiento, segund debian, cran dados por libres, y los indios por esclaros. Destas sentençias tambien dió hartas el bachiller Diego de Corral, al qual algumas veçes el gobernador é officiales cometian el conosçimiento de tales proçessos de entradas, por ausençia del alcalcle mayor, é todas estas sentençias eran aprobatas (por injustas que fuessen) del gobemador é officiales; porque de otra forma fucra nesçessario volver las partes que llevaban. Este hachiller fué uno de los mensageros que por parte del Darien fueron á llamar al gobernador Diego de Nicuesa, para que gobernasse aquella tierra, é despues no le quisieron resçebir, como se dixo en cl capítulo III, libro XXV'III.

Passando desta manera las cosas de Tierra-Firme, acordé de me yr á España, por dar notiça á mi Rey, é por vivir en tierra mas segura para mi conçiençia é vida; y d grobenador procuró de me estorbar la yda, diçiendo que vo aria de lager residençia primero. porfue en nomlire del secretario Lope Conchillos, que cra escribano general en aquella ticra, yo proveia los escrilınos del juzgado del grobernador y del alcalde mayor, y los que yban á arpuellas entradas: los quales, tomarlos dellas. ne entregaban los proTOM.IO III. çessos é diligençias que avian herdı los capilanes, y sabia lo que en sus viages avian hecho, por fée de los escrilanos. (ue yo avia enviado con cada capitan. I) como quier que yo no avia lle vado aquellas partes, se pregonó mi residencia por sessenta dias, en el qual tiempo ninguno me pielió cosa alģuna, ni cl gobernador uue dexó de prometer é ofrescrer que ne ayudaria, é temía manera cómo fuesse rico en breve tiempo; é que pues avia trabaxado é passado enfermedades y otraz nesçessidades, que no me fuesse en el tiempo que avia de ser aprovechado. Lo qual él deçia, porque sabie que yo avia visto todos los proressos de aquellos sus capilanes, y era testigo de las obras de todos, é avia de deçir verdad al Rey é á los señores de su Consejo; pero yo da ba á entender que la tierra me cra contraria, é que queria yr á curarme á España é volver con mi muger, é que sin ella no queria estar allí ni en otra parle, é por olras raçones á mi propóssito é lıonestas.

Quando el gobernador vido que no podia laçer otra cosa, ni dexar dle darme liçengia. él me la dió, mostrando que le pessaba de mi partida: porque diçie que perdia yo mucho en ello, y porque diçie que the tenia buena voluntad, é que quisicra que yo fucra con laçienda, y no aviendo perdido el tiempo é aviendo gaslado mas que otros. É dióme sus carlas é memoriales, en que deçia del obispo quánto estorbo era para la buena gobernaçion. é quám cobdiçioso ó roto de su lenģua, y sus clérigos quán exentos é deshonestos. É. cómo el olispo vido que yo estalua determinado de me yr, líçose mucho mi antigo, y encargóme la conçiençia para que diesse notiçia al Reỵ de los defetos de Pedrarias, é de su cobdiçia é inconstançia, é de las faltas é rolios de los offiçialesé del alcalde mayor. É rogóne muỵ afettuosamente que dixesse quán lábil y buen servidor del Rey cra Vasco Nuñez 
de liallonat a dlóne un errand nomorial destas y otras posias, como le paresció: cl yual yo loné, y le prometí de degir rendiul, si fuesse oydo; y la mesma respuesta di á l'erlrariats, quando ne dió el sliso.

Pocos dias antes de mi partida, andabian va muy clarias lits diferencias de contre ci gohernalor y el oblispo, é fialsan poeo el uno del otro; éassi carla mo dellos me cargó de memoriales, para que diresse al Rey Cathólico quán poco hacian en su servicio: é diçiondo lo mesmo quellos me encaraalsin, el Rey supicra (que era verdad todo usso y más, é que avia lien malcria é justas causas para removerlos, y echar al uno y al otro de lia ticrra. por muy limitado rue yo lo quisiera degir, épor aquellas sus memorias se podia mostrar firmado de sus nombres. É yo fuy a lispana é besé las manos del Rey Cathólico en Plasencia, que yba de camino para Sevilla: ć dióme liçençia para que fuesse á Madrid é visitasse mi casa í á mi muger, é mandóme que luego me fuesse a Sevilla, donde me oyria é se proveeria todo lo que conviniesse al bicn de atpuella tierra. Y desde á doge ó quince dias, continuando su camino, llevóle bios á su grloria ; é assi hico poco fructo mi trabaxo.

Estando yo para me embilucar en el Darien, ocho ó diez dias antes, llewaron unas provisiones del Rey Callófico para Tasco Tunez, las quales le enriaba despacha-

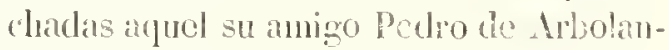
dha. de quien se higo mencion on el capitulo precedente: é la una cra el título we adelantado de la mar del Sur, y la otra cl título de gobernador y capitan general de las provinçias de Coyba é Panamá. É como Pedrarias turo siempre aviso en tomar las cartas que de España yluan, oro este despacho ál las manos; pero no fué tan secreto pue Vaseo Nuñez y el obispo dexassen de lo sentir, é comencaroró á lo publicar é quesarse del wolneronalor, diçiendo fue cla racon, fure pures fodos fram lilmes é vassallos del Roy, fue lilnomence puliesen escrebir á lispana é rescolor las cartas que les viniessen. Y aun púlulicamente ol obispo predicala que era grand captiverio harcese otra cosa contra la voluntad y servicio de Dios y del hing, y que se le daria noliçia desto, pues que assi al liey como á sus súlnlitos se le quitaIna la lilsertad. tomándole sus cartas. Por lo qual Pedrarias acordó de dar parte á los olliçiales é alcalde mayor, é que se viesse con consulta y dicssen sns votos si le delian dar las provisiones á Taseo Nuñez ó 110 .

Este consejo dió á Pedrarias el alcalde mayor q que ra avia dado la ruclta é dexado la parçialidad del obispo. é yo por ni mano escrebí los votos de cada uno dellos; é el thessorero Llonso de la Puente, y el contador Diego Marquez dixeron que no se le debian dar las provisiones, hasta que se diesse al Rey notiçia de la residençia de Tasco Nuñez, que nunca se acababa, annque avia diez meses (pue se començó, porque Pedrarias y el alcalde mayor querian que no turiesse fin (é am el obispo se lo avia dado por conscjo, quando una rez lo querian enviar presso á Espraña): el factor dixo que ni él era de parescer que se le diessen ni se le detoviessen, y que él se conformaria con lo que todos hiçiessen en conformidad. é no de otra manera; porque él no era letrado ni salia quál era lo mejor. El alcalde mayol dixo que era ragon quel hey supiesse primero los méritos é proçesso de la residencia, con el parescer del grobernador é de todos.

Despues quel obispo los oro oydo, quedó muy brario é divo que cra mey mal ponerse cllos en dispulits para lo quel Rey mandiaba, es que solo averlo pensido cra género de deslealtad é desobediencia, en espeçial expresándose en 
aquellas provisiones las causas é serviçios de Vasco Nuñez, é el desculnimiento de la mar del Sur", y lraçiéndole mercedes, y descargando su real consciençia, no querian cllos por sus passiones y envidias que se cumpliesse. É á este prepóssito dixo otras cosas é yo lo escrebí de mi mano, é cada uno firmó lo que avia dicho é rolado: y el gobernador quedó tan espantarlo del obispo, que dixo que le paresçia bien lo que el obispo deçia (aunque en la verdad quisicra lo contrario). I en fin, se acordó allí que se le diessen sus títulos el dia signiente, porque cota consulta duró hasta quassi media noche: y luegro se llamó Vasco Nuñez adelantado de la mar del Sur, del qual título ningum hien le vino. Porrue viendo el gobernadlor que desde el Darien á la parte del Lerante los indios son carilues é llecheros en aquella costa liasta el Cabo de la Velá. en la grobemagion quél tenia de Castilla del Oro, é áspera gente, é que á la parte del Poniente, á veynte y quatro ó veynte é çinco leguas, estaba Careta, y entraha de ahi adelante to que se le clahia al Vasco Níñez en Coylua é Panamá del Sir é parte del Mediodia, é le quedaria muy poca cosa entre aruello é Yeragua (que era de la jurisdiçion delahnirante); é que siendo Vaseo Nuñez adelantido de la mar del Sur é gobernador de las provincias de Coyba y Panamá, lo que restaba á Pedrarias é su golsernaçion era poca cosa, é que los interesses quél é los offiçiales esperaban de li ticrra cessaban, si Tasco Nuñez fuesse admitido, tomaron por medio, quando le dieron las provisiones é títulos que es dicho, de tomar seguridad dél que no usaria de la golsernaçion quel Rey le daba, sin liçençia é roluntad de Peclrarias: é demas desto propusicron de no le dar un hombre para ello, ni consentir que armasse. Al obispo é Yaseo Nunez, con la calor del título é nombre de adelantado, les paresçió que por estonçe hastaba csto, y aver sacado las provisiones de las uñas de l'edrarias é de los offçiales ćalcalde mayor é yure atlelante se haria lo demas con el tiempo. És a quedó en este término esta noğgoçiaçion, de la qual resultaron atdelante, con el ticmpo, muchas cosas é alteraçiones que se signieron sobre el falso fundamento é odioso que llevaban, como se dirá en su lugar.

\section{CAPITUlo X.}

Ln que sc relatan algumas cntradas que diversos capitanes hiçieron, por mandado del gobernador Pedrarias Dávila, en su gobernaçion.

\section{C} y lecrlo otros, y no luastaria pajel ni tiempo á expresar cnteramente lo que los capitanes liçieron para assolar los indios é robarlos é destruyr la tierra, si todo se dixesse tan puntualmente como se hico; pero, pues dixe de suso que en esta gohermaçion de Castilla del Oro avia dos millones de indios, ó cran incontables, es menester que se diẹa cómo se acaló lanta gente en tan poco tiempo. Y pues de algunos capitanes se lá dicho de sirsso, aģaviádolos avria, si callasse á otros que ovo tan culpados, ó podria ser mucho mas que no cllos: porque como se dixo en el capílulo de susso, essas partes quel robernador é offiçiales llevahan en las entradas, los tenian muy geharlos en cllas, y ol thessorero Alonso de la l'uente ordenalua las instruçiones é capítulos que Hevaba cada cajutan, é uma de las primeras clánsulas que ponia. era, que se le diessen il gohernador dos partes en el oro y en los indios que se tomassen, 6 sentats al con- 
lator é thessorcro é fattor, no en el oro, sino ch los indios; é assi se guardala y efetualba. Terdad es que en el oro los offiçiatles no llevaban partes, sino en los intios, como he dicho; pero cada uno dellos procuraba quel capitan, que avia de gr, fuesse su anmigo é quien le llevasse sus moços á galnar partes: é assi se proveian muchos cappitanes, que despues quando tornabau, aunque hubiessen fecho mill dessatimos é crueldades, eran defendidos con el favor de los mismos officiales.

Por manera que despues que fuć enviado el teniente Johan de Ayora á la mar del Sur, é los capitanes que tengro dicho que con él fucron la ticrra atentro, se proveyeron otros para otras partes, porque no (puedasse ninguna provinçia ni parte de la ticrra sin dolor. I fucron estos:

Fné por capitan Françisco Beçerra, con favor del thessorero, porque cra de su tierla ó su pariente; y este era uno de los soldados antignos ó primeros en la tierra y en ustas islas, é conosçia mejor la simpliçidad de los indios, é hiço mas crueldades que ninguno de los passados. His no fué reprehendido ni castigado, porque truxo seys ó siete mill pessos de oro é nals de tresçientos indios é indias en cuerda, en que Luvieron buenas partes el grobernador é obispo é officiales, y csto bastó para escusa de sus delictos y aun para ser loado y no reprehendido ni castigado, ariendo hecho machos insultos: antes, desde á poco que tornó, fué enviado con mas fausto é gente á otias partes, donde pagó lo que debia é otros muchos, que con él se peráicron. Mas en su primera entrada la tierra adentro corrió por el rio del caçique, que llaman del Suegro, é fué por él hista entrar en cl golpho de Sanct Miguel en li mar del Sur. En aqueste rio se juntan otros muchos, assi como el rio del casifue Tocagre, y el del caçigue Quentado: é ntas adtelante entra drio del caçique Queracha, que otros llanan de la Cia- noa Nueva; é mas adclante cntra cl rio del eaçique Tutibra, é mas adclante cntra el rio del caçique Toto, hijo del cargique Ocra. En la ticráa adentro, sobre la malno siniestra, cstán en la sierra el caciqure Tapicor, y el caçique l'enaca, y el caçque Porore: lo qual torlo es ticria alta y muy polbada de sierras é nontes, é hay en ella muchos rios é quebradas de oro.

Paresçerá al letor que llamarse caçique del Suerro nno, y decir á otro el caçique Quemado, questos nombres no son de indios (é assi es la verdad), y es lien que antesque í mas se proreda, aquesto se satisfaga. El Suegro so llamó aquel caçique, porque llegaldos alli los chripstianos le tomaron (ó él les dió de temor), lres ó quatro hijas que tenial á los eapitanes: é por este liospredage é adulterios de los yernos, quél no quisiera, le llamaron el Sucgro; mas su proprio nombre era Mahe. Al otro eaçique que llamaron Quemado, fué porque de hecho é sin causa le quemaron, porque no daha tanto oro como le pedian. Tornemos á la historia.

Oy deçir á este capitan é á otros que con él se hallaron en este su primero viage, que los animales que avian visto, fueron lcones rasos bermejos é muy anuados de uñas é dicntes, é de talle de galgos, pero mayores, de los quales lie yo visto algunos; é llámolos rasos, porque no tienen aquellas liablas, que los leones reales de Ifrica. Vicron muchos tigres, annque no afirmo si lo son, porque no tienen la reloçidal que del tigre se escribe: estos que cn aquella tierra lay, son hermosos y ficros animales, bermejos é pintados de manchas negras. Muchos çicrvos, puercos de aquellos que se llaman baquiras, raposas ó corras negras, dantlus, si lo son; los chrijstianos las llanan assi, porque el curro dellas es muy gruesso: á esle animal flaman los indios beori. Estos é otros animales son comunes en la licrraFirme. É porque el libro Xll labla parti- 
cularmente en ellos, volveré á lo que más vido este capitan en lo que anduvo.

Desde el caçique de Penaca, volviendo ú la mar del Sur, es tierra llana é de hermosas cabanas é rios ; é llegarlo este capitan é su grente al golpho de Sanct Miguel, signió la costa arriba al Oriente, y fué al caçique Jumeto, que está en la ribera de un hermoso rio, que entra en aquel golpho : é de allí passó al rio del caçique Chiriluca, é subió por él arriha liasta otro cacique que se deçia Topogre, é á otro que está mas arriba en la sierra, que se diçe el caçique Chucara. É deste allí fué al caçipue Canachine, donde se haçe una punta ó promontorio en aquel golpho, ques cosa muy señalada; y desde allí se via adelante una ticra alta, donde el cacique Jumeto dixo que vivia cierta gente que eran negros (pero la verdad desto no se supo, ni este capitan passó á la punta de Canachine); y desde allí vido la isla de las Perlas, que descubrió el adelantado Vasco Nuñez de Balboa, como en otra parte queda dicho. Desde Canachine tornó atrás este capitan hasta el caçique Toto, donde avia estado primero; é de allí atravesó á la otra costa del golpho de Sanct Migucl, y fué al rio del caçique de Chape; é de alli por la costa arriba del golpho fué al rio del caçique Tunaca; é de alli passó al caçique é costa de Thamao, é vido la costa de Panamá, pero no llegó á Panamá; y de allí de Thamao se tornó al Darien con el oro é indios que tengo dicho, to qual ovo como pudo y no como de raçon se avia de aver.

Despues de quintado é fundidlo este oro, é dadas las partes al gohernador é offiçiales, é repartido lo restante entre el capitin Françisco Becerra é la gente que avie llevado consigo, fuć proveydo para que fuesse al golpho de Urabá con dosçientos hombres ó mas é de la mejor gente que avia en la tierra. É como tiene Dios tanta cuenta con todo, é no le avian castigado de sus exçesos, él ni hounhre de quantos fueron con él en este otro segundo viage tornó, ni se supo dél ni dellos, y allá acabaton las vidas y sus malas ganançias.

En la mesma saçon fué enviado por capitan Françisco de Vallejo al mesmo golpho de Urabá, háçia la parte donde avia polslado el gobernador Alonso de Hojeda.

Y en el mesmo tiempo fué el capitan Gaspar de Norales á la mar del Sur; mandóle el gobernador que passasse á la isla de las Perlas, que descubrió el adelantado Tasco Nuñez.

En el mesmo tiempo fué el capitan Johan de Escudero á otra provinçia.

El capitan Gonçalo de Badajoz fué á otra parte.

El capitan Antonio Tellez de Guzman fué á otra provinçia. El adelantado Vasco Nunez de Balboa fué á la provinçia del Dabayde.

Por el rio grande, llamado el rio de Sanct Johan, fué el fattor Johan de Tavira con çiertos navios é armada, é poco antes fué á la provinçia de Abrayme el capitan Luis Carrillo.

Assimesmo fueron otros capilanes á otras partes é provinçias.

Vas porque esto seria grand laberinto é quassi infinito, ó á lo menos muy enojoso decirse tantas crueldades como usaron los mas destos capitanes cont"a los indios, diráse algo dello con brevedad; y porque no ignore alguno quán justo es Dios, si atento esturiere el letor en esta listoria, por ella verá cómo pagaron sus delictos los que los cometieron, por mostrar la justiçia divina a los ojos mortales quán verdadera es aquella sentençia del glorioso dotor de la iglesia Sanct Gregorio: "Ln vano presume de la esperança el que en sus obras nenospre- 


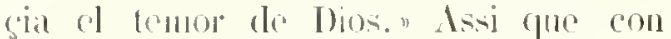
atençion se mire el discurso destos capilancs.

Dicho tengo que, fruando el teniente Jolian de Iyora prasó por el puerto de sancla Cruz, ques en la provinçia de $\mathrm{Co}$ mogre, dexó allí un pueblo con hasta ochenta hombers dubaxo de la capitania Ic un alcalde, llamado Hurtado, el qual y los demás en el tiempo que allí esturieron ractaron muy mal á los indios, tomámdoles quauto tenian, y las mugeres é lijos, $\therefore$ Iraçiéndoles otras muchas vecaçiones. E Ios indios sufrian todo, porque los cliripstianos que avian entrato con Johan de Ayora la ticrra adentro avian de rolver por alli al Ditrien. é no osaron aquelos indios de Comogre altorase para vengar sus injurias hasta que vieron que Johan de Ayora é los otros capilanes é gente cran tornados al Darien. Estonces los indios de Comogre no devaron á vida á homlite chico ni grande de torlos aquellos del assiento del pueto de Sincta Curuz para lo qual se juntó tambien el caçique de Poeorosa: en pena de lo qual el gobornador higo hacer grande castigo en los indios destos dos caçicues, i fueron pronunçiados por esclavos, sin aver respeto á que los indios no fueron agyesores, ni hiçieron muerte en chrijstiano que no se la turiesse aquel é otros primero muy bien merescida.

Otro capitan, Ilamado Lope de Olano, y era el mesmo que hiço la deslealtad que se dixo en el capítulo I del libro XXYilI al gobernator Diego de Nicnesa paresçiendo al gobernador Polrarias que estarian en erand sitio é muy buen puerto para la costa del Norte é para la contractaçion de la mar del Sur una fortaleça é pueblo en la provingia de Careta, é que ste cra hombre diligente, comelióle este olufiçio é fundaçion; é fué con çierta gente é liço la forlaleça é puchlo, é mandóle llamar Pedrarias la cibdad de Acla. Vanos alıora distinguiendo con estos capitanes con brevediad.

Porpue Luis Carrilio era mançebo ! hermano de doña Maria Niìn, numer del scerctario Lope Conchillos, mandó el grobernador que fuesse pol su coadjutor Françiseo I'içarro, teniente que avia seydo del gobmandor Nlonso de Ilojeda en Urabá. y es aquel que fué despues marqués ragobernador en el Perí: é estos fueron á las provincias de llorayme y Teruy, á donde los indios lienen sus moradas. como avés oydo, en los árboles, dentro en muy grandes ligunas y astaños de padules, é de alli salen á sus malhicales é conucos á ticrra enjuta con canoas. é están fuertes en estas moradas. y seguros del fuego é de sus enemigos. Desta tierra é otras partes truceron Luis Carrillo é Piçarro é los que con ellos fueron muchos indios y esclavos, é muy buen oro: é tambien usaron sus crucldades con los indios, porcuc ya esta mala costumbre cstaba muy usarla, é la sabia de coro el Piçarro, é la avia él usado de años atrás.

El capitan Esculero lo lice muy peor donde fué é truxo poco oro: pero él é los que con él fueron hiçion comer á perros dos caciques ó indios principales: é despues que volvió al Darien, como no truxo de qué pudiesse dar partes al gobernador y officiales, fué presso. Pro el jnez le alssolvió é dió por libre, porque al tiempo queste partió, para yóa arfuella entrada, avia dexado á guardar cierto oro al alcalde mayor que lo sentenció. É fueron tan públicos é feos los horrores deste y los favores de quien le juzgó q que se sospechó que se avia quedado con aquel oro, que le tenia en suarda; porfue meresciendo un púlhico castigo, fué absuelto é no penitençiado, sino lo fué en la pecunia. para quien no la avia de aver, sino el fiseo.

El capilan Françisco de Vallojo, despues que passó á estotra parte del grolpho de Crabá, oro tres mill pessos de buen 
oro fino rancheado; pero juntáronse los indios é fuéle forçado retraerse, pero no Lam descarada é vergonçosamente é con tan poco ticnto, como lo hiço, poreque é se pudicra salvar con toda su gente, si como lombre de huen ánimo é diestro lo hicicra. Mas fué tanto su miclo, que no cu10 de atender la compañia : é junto con su temor cresçieron los rios mucho, é con algunos chripstianos metióse en çicrtas balsas de canas y maderos por un rio, huýrudo, é dexóse allá mas de septenta hombres perdidos, yue lodos murieron por su porquedad, y los pudiera muy bicn salvar, si los atendicia: muchos de los quales quedaban colgados de las ramas de los áboles en la costa del rio, é passaba él con sus balsas, é pudiéndolos resçebir y recoger, ninguna picdad tuvo dellos, antes se passó de largo y los dexó. É con este buen recalydo se tornó al Darien, donde ningum capitan fué hasta estonçe punido de cosa que mal hiciesse, á causa de las partes quel gobernador é offiçiales llevaban destos viages, porque como ellos los elegrian y favoresçian para quel golsernador los eligiesse, quando yban á entrar, ellos nnesmos los defendian despues de sus errores é maldades. I porque lo queste capitan Francisco de Vallejo higgo fuć tan público é lan mal hecho, é por su causa é negligençia tan cobardemente perdió tantos chripstianos, la pena que se le dió fué que por sentençia se mandó é determinó que no pudiesse ser capitan en algun tiempo; é assi desde á poco se fué de la lierra con lo que avia robado. Despues, quando el Emperator, nuestro señor, hiço gobernador de Sancta LIarta al capitan hodrigo de Basliclas, fué por gobernador con él este Vallejo, é volvió á morir en la Tierra-Firme.

El capitan Antonio Tellez de Guzman fué la tierra adentro la vuelta del mar del Sur, é corrió mucha tierra, é lriço lo que los otros ó peor, é fué infamado de mass cruclelarles é mas púl,licas, é fué favoresçido del contador Diego Marquez. Ĺ lo que un official queria en este caso, los otros lo aprobahan por causa de las partes, que se les daban en los mejores indios é indias: é assi se quedó sin castigo ni puniçion, pordue á la rerdad el grobernador disimulaba en todo lo que via que los offiçiales querian muy claramente; y como él goçaba de aquellos despojos su parte. si reprehendicra lo quél haçia, pudiera ser respondido como prinçipal tirano.

El adelantado Yasco Nuñez de Ralboa fué á la provincia del Dabaybe con muy buena gente é armada, y en el camino los indios le desbarataron, y él volvió nal Lerido, y la gente maltractada; y el capitan Luis Carrillo, que con él yba, truxo un varazo por los pechos, de que murió desde á pocos dias que tornó al Darien, é pagó lo que avia liecho en el viage, que se dixo que fué á Terry é Alorayme.

El capitan Gonçalo de Badajoz fuć la ticrra adentro pror la costa del Sur, y este é los que con él fucron, vieron primero que otros chripstianos las islas de Taboga, é otras questán enfrente de la cilsdad de Panamá, á dos é tres é quatro é çinco leguas é seys dentro en la mar del Sur, é llegó Lasta Tata é ál Escoria. ís hasta este cacique de Escoria avia tomado á los intdios mas de veynte mill pessos de oro, é muchos indios é indias que traia en cuerda: é aunque con alguma templança se oro en las crucldades contra los indios, no quedó tan sin culpa que caresçiesse del crror de los otros capitanes en algunas cosas. E llegado al cácique de Iiscoria, ovo dél hasta nueve mill pessos de oro, quel caçique de su grado le quiso dar, en pago de lo qual le tomó una hija é sus mugeres, una de las quales era hermana del cacique de Paris, questaba adclante y era uno de los mas poderosos é ricos de gente é oro, que avia en todas aquellas provincias. É cómo vido el cacique Esco- 
ria que lo lievalua su hija á mugeres. salió trás él, rogándole que le diessen su hija é sus mugerers. é fuć mas de una legena. impottuándole por ellas; pero ol eapitan no lo quiron hilgel": antesejo amenaçó é diso rue si no se volvia á su casa, llevalia ál ó le maturia. É desque aruesto el raçique vido, algaha las manos ć los ojos al give. y quexúndose á Dios. dexóse caer en ticrra desesperado, é mordia la tierra é parescia que rabiaha : y el capitan y su gente, riéndlose de verle laregr vascas, se passaron de large é lo dexaron alli tendido. llorando su desarentura.

Este cargique dió luego notiça desto á su euñalo el caçique de Paris, y rogóle que le aỵulasse: el qual le envió á degir que á él no le avian hecho nual los chripstianos, ni les queria latger dano: antes proveyó en que sus mugeres del mesmo Paris le enviaron un pressente de seys mill pessos de oro, y envióle á decir que aquello le enviaban sus mugeres del mesmo Paris. ć quél queria ser amige suyo 6 de los chripstianos. É trás arnesto envió un principal suyo. para que viesse al capitan Badijoz é su grente, ol qual indio llevó consigo á su muger. que cra prima ó liermana det cacique Paris. y era moça y de gentil dispusiçion, ć liço pressente al eapitan de tres mill pessos dr olo, é resçilióle muy bien. Esta noche mesna Im devoto clérigo queste eapitan llevala consigo (porque era costumbre que con los mas de los eapilanes que salian á entrar yla un clérigo): é el que apueste cajitan llevalıa, aquella noche higo cehar dehaso de su hamaca al prinçipal á tomó en la hamaca á su muger é durmió con clla . ó mejor diçiendo no la dexó dormir ni estar sin entender en su adulterio. Por cicrto ezte tal clérigo mejor se pudiera llamar ono-centauro ${ }^{1}$; porque en griego onos quiere deçir asno, " por catr nonulue es figmarala la luxuria, segund da testimonio el propheta Eecentel diciendo: "Las carnes dellas serín assi como carnes de asnos. ${ }^{2}$ "Si este clériggo ovo algugna notiçia de Sanct Palslo, oydo avria que ni los fornicarios, ni los que sirven át los ydolos, ni los adúlteros, posscerán el reyno de Dios. ${ }^{3}$

El prudente indio disinuló su injuria, y otro dia por la mañma. con gentil semblante, mostlando muclio placere, se despidió del capitan con sus cuernos, llevando su nuger consigo: é con mucha diligençia fuesse á dondo el carique Paris estaba, é disole que aquetlos clutipstianos cran villanos y mala gente, é contóle su trabaro. É por esto quedó nuy indignado, é por lo que avia intervenido á su ennado el cacique Escoria. y juntó presto su gente é otros cariques de la comarea que eon él fueron á dar en los chripstianos: é aleancíronlos en un puchlo de su tierra del Paris, donde estalsan apossentados, y entráronle por fuerega de armas á los pocos chripstianos, que en él hallaron en guarda de nueve lrabas ó çestas srandes de oro que avian hasta estonce avido por donde arian andado, en que tenian quassi cinquienta mill pessos, é muchos indios pressos y encadenados yue traian de otras partes; é pegaron fuego en muchas casas é partes, é malaron é lirrieron algunos cluripstianos, é ninguno quedara con la vida. si un poco mas, durando la hatalla. se tardara el socorro. Én el qual tienjpo algumos españoles de buen ínimo salvaron del finegro sicte habas ó gestas de las nueve de oro, é sacáronlas del pueblo. que va ardia torlo, é pusiéroulas en un çerrillo serea de ahí. é las otras dos se quedaron en el fuegro é su quemaron allí.

Duranie la batalla, llegó el capitan Goncalo de Badajoz, eon la mayor parte de 
la gente, que por otra parte avia ydo á buscar al nnesmo caçique de Paris, é dió en los indios é mató muchos dellos. é çessando la barlalla, los puso en huyda. Pero en tanto avian ya llevádose las siete habas de oro, que estaban en el cerrillo que he dicho. luego se rehigo de gente el caçique de Paris para tornar con nayores fuerças y exérçito sol»re los chripstianos; pero ellos y su capitan Barlajoz quedaron tales, que acordaron de salirse de la tierra del eaçique de Parlis, perdido el oro é muchos indios prissioneros (que sin lástima no se puede oye, porque conno estaban encadenados no se pudieron huyr del fuego, ni los otros indios valellos, y se quemaron todos). El capilan se acogió á un rio, é de rentura halló çicrtas canoas en quél é su gonte se salvaron, é fueron huyendo; porque si atendieran, ningun chripstiano de todos ellos se escapari, porque el caçique Paris y Escoria yban trás cllos con mucha gente, é todas aquellas comareas estaban apellidadas é juntas y en conformidad contra los chripstianos.

Salido el capitan Gonçalo de Badajoz de la tierra de aquel caçique de Paris, dió la vuchta para el Darien, en la qual tomó en otras partes quassi veynte é dos mill pessos de oro, con las partes de los quales é de los indios que llevaron que les cupo al golsernador é offiçiales, se soldaron é perdonaron las culpas y errores do este capitan, é no sé labló en crueldad que ovicsse fecho, aunque fueron muchas é no faltó quien las dixo.

El capitan Gaspair de Morales, criado é primo de Pedrarias, que fue a la mar del Sur é á la Isla Rica de las Perlas, passó á clla é ovo muchas perlas allí, é mucho oro en las provinçias é caçiques, por donde anduvo. É por escurecer el descubrimiento, que aria fecho de aquella mar é islas Yaseo Nuñez de Balboa, començó á tomar possesiones por auto de escrilıano, assi en las islas como en otras partes, piTONO III. diendo testimonios en nombre de Sus Alteças é del gobernador Podrarias Dívila; é mudó el nombre a la isla, ć llamóle lsla de Flores, porque assi se lo avia mandado el golermator. É con mucho oro é perlas é esclavos. tornámdose rico. llegó á la proving ia del caçique di Chochama: é teniendo assentado su real en la ribera de un rio. vieron mucha gente de indios que venian de guera á colorar, si pudieran, sus nugeres é hijos é parientes, que este capitan les llevalua robados: y el capitan ovo su consejo con Andrés de Valderrábano é con un mançebo, que se deçia el capitan Peñalosa, pariente de la muger de Pedrarias, é acordaron de degollar en cuerda todos los indios que estaban pressos é atarlos, no perdonando unger ni nino chico ni grande de todos ellos, imitando la crueldarl herodiana, para que los indios que venian de guerra contra ellos se deduriessen allí, viendo é contemplando aquel crudo espectáculo : é assi se puso por la obra, é degollaron desta mancra sobre noventa ó çient personas. Pero en fin. este crudo ardid fué causa de quedar los chripstianos con las vidas; porque entre tanto que los inclios se detuvicron á mirar é llorar los muertos, é tan extraño caso, el eapitan Gaspar de Morales con su genle se puso en salvo, é se fué su camino á mas que andar. En fin, él llegó al Darien, donde fué tractado é dissimulado con él, por primo é criado del gobernador, sin castigo ni pena, ni otra reprehension, de cosa que mal oviesse fecho en su viage, en el qual oro muchas perlas, é cutre ellas una de hechura de pera, que pessó trejnta é un quilates; por la qual, puesta en almoneda, clió un mereader , llamado Pedro del Puerto, mill é doscientos pessos de oro, é fué suya. lí la tuvo una noche ó dlos, é con mucho tralaxo; é acordánclose que avia dado tanto por ella, no haçia sino sospirar. é sc tornó quassi loco. Fì coludiçiándola el go- 
Lemindor, tinvo forma de lo dar por ella los mesmos dineros, putesto yne algumos quisieron decil que todo avia seydo cantela. Esta perla es apuella mesma que se divo en el libro XIX, capítulo Ylll, yue la Enmperatriz. nuestra señora, de gloriosa unemoria, la compró despues a doña lsabel do Boratilla, muger del gobermador Pedrarrias Dávilat

Este Gaspar de Jlorales, sintiémdose 'nfermo é rico, se fué despues á Espraña á su casa, la que tenia en Mojados. donde vivió poco tiempo despues; é plegra á Dios que fuesse conosçicndo sus culpas.

El capitan leñalosa se passó á la isli de Cuba ó Furnandina, é en ella le mataron los indios.

El Andrés de Valderrálano, adelante se dirá la fin que ovo, que fué conforme al consejo, que dió para que fuessen degollados en prission los indios que es dicho, salvo que quando á él le degollaron, fué con pregon do la justiçia real por traydor, y á mi parescer sin culpa ó sin ser traydor; pero assi como los indios quél hiço degollar tampoco tenimu culpa para morir, ássi quiso Dios quél muricsse é phasciesse por las culpas deste ó otros conscjos.

El factor Johan de Tavira, estando ya rico é teniendo mas de quinçe mill pessos de oro, no se contentando con esso, ni se acordando que tres años atrís no tenia mas que una espada é una capa. é riendo quán presto los capitanes cres¿ion en laçienda. paresçióle que conforme á cierta noticia falsa que le arian dado del rio de Sanct Johan (que tambien te llamaban rio Grande, que entra en el solpho de Urabá), armando para allí, en breve tiempo lraria tanta haçienda que hiçiesse rentaja á los mas recinos de la rilla de Ocaña, de donde él cra natural. Puesto en este desseo, é teniendo licencia del gobernador para ello, armó é lisgo tres naos, que le costaron mas (aunque eran pequeñas caraveletas) que lo costáran tres naos en Vizraya, auncue freran de porte de cadar doscricnlos toncles. Con las quales é con gientas canoas, é con lasta dosçientos lrombres, fué al rio Grande que lıe dicho, é subieron por él septenta ó oclienta leguas, en lo pual estuvicron mas de otros tantos dias, í causa de la grandíssima corricnte : é en las costas del rio Lallaron muchas polbaciones en barlacoás ó casas muy allis, fechas é armadas sobre postes de palmas negras fortíssimas é quassi inexpugnables, á causa del sitio é riberas grandes donde estín fundadas, é por la forma y edeficio dellas son invençibles mucho mas de lo que sin verlas se puede considerar, é riéndolas, es cosa mucho para admirar.

Lna destas casas fuć combatida por los españoles en la provincia de Tatuma, y eran mas de dosçientos liombres á la combatir é no la pulieron tomar: é al cabo de dos dias que estuvieron trabasando en averla, fuć una noche desamparada de los indios, é se salieron por entre los chripsliamos, sin ser sentidos, é se fueron á otras barlracoas ó casas semejantes, donde se salvaroin: de que se colige que los que assi se fucron é la defendian, eran muy pocos, pues no fueron sentidos ni pressos; quando se yban. Otro dia los españoles tomaron la barbacoa, porque ninguno se lo resistió; é sulfidos en clla hallaron tres ó quatro indios muertos del artilleria y escopetas, con que les arian tirado lós nuestros: y en sola autuella barbacoa ó casa esturicron todos los cluripstianos apossentados y cabian muy lien, aunque eran mas de dosçientos hombres de pelea.

Salidos de allí, prosigniendo su viage el rio arrila, quanto mas subian, mas poderoso les paresçia é de mas agua; é quanto tenian nescessidad, saltaban en tierra á buscar de comer, é matúlbanlos los indios. De mancra que constriñidos de la nescessidad, se morian de lambre en los 
navios, é no ossaban salir í lierra muchas reçes.

Un dia, queriendo el fattor passarse á otro navio en una canoa, se trastornó, é abraçóse con él un hidalgo que se llamaba Johan Navarro de Virués, é estaha en esta armada por thessorero; é assi abragados se humdieron é ahogaron, é nunca mas parescieron. Í causa de lo qual el armada se tornó al Darien con mucha pérdida é muertes é enfermedades de muchos della; é cl fattor gastó en esto sus bienes ó la mayor parte dellos, y en los que le quedaban se entregó el Rey, por raçon del ofliçio é cuenta del fattorage. É assi pagó aquella harina é vino que se quemó en la casa del Toldo, donde estaban los bastimentos, sin los dar á los pobres chripstianos é nesgessitados, que se caian muertos por las calles, segund atrís se diso.

Pocos dias antes que yo saliesse de aquella ticrra, teniendo yo liçençia del gobernador para mi partida, vino Pedrarias Dávila, el mançebo (sobrino del gobernador) de la provinçia del Çenú, que es en la costa de Cartagena, donde el bachiller Ençiso deçia que avian de hallar grandíssimos thessoros de oro. Y él fué allá, y el capitan Diego de Bustamante é otros hirlalgos é compañeros, en número de dosçientos hombres; é diéronse tan buen recalsdo, que mataron al capitan Bustamante é á otros cluripstianos, é los demás tornaron perdidos y enfermos, é truxeron tan poco oro, que les cupo de parte á menos de un pesso de oro á calla honlhre, É al mesmo Pedrarias, despues que tornó á la ciludal de Ávila , de donde cra natural, le mataron allí, para que pagasse los (fuc por su mal recabdo murieron en el Cenú.

Assi que, este subçesso que he diclio en breves renglones, fué el de estos capitanes, á los quales pido de sraçia me hayan por excusado en lo que les parcsçiere agravia mi historia, é se acuerden que escribo en tiempo de testigos de vista, é que en ni pressençia se fundieron, como ante veedor, torlos essos thessoros que ovicron en sus entradas, é que de mi mano se ponian todos los escribanos que con ellos yban, en nombre del secretario Lope Conchillos, é que los proçcssos de sus obras é méritos venian á mi poder, é los ví, é ley é ví lo demás de sus residençias; é yo les ruego que me agradezcan lo que les quito é callo, é no me perdonen to que les levanto. Y si en esto tovicren consideraçion é respecto con mi pluma, verán que los lie tractarlo como amigos, é no con passion alguna: que en rerdid no la tengo en este caso. Antes quisicra hablar", hallando que loar en sus obras, porque fucra mas dulçe la leçion. y para mí mas aplaçible excrçiçio la oeupaçion destas materias; pero, como tengo dicho en otra parte, he de dar raçon por dónde esta licrra lia llegado á estar quassi yerma, sin indios: y el fundamento ć prinçipal causa es lo que tengo dicho. Y tambien escribiré adclante un capílulo en que se resuma to que se ha tocado destos capitanes, y de otros, de quicn adelante se ha de tractar. porque no se pucda deçir que excuso los unos y que desalabo los otros: sino que doy á cada uno el nonibre que meresce. 


\section{CIMTULO XI.}

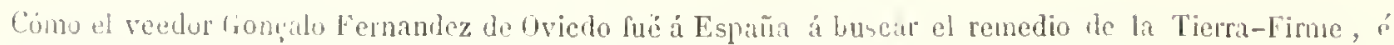
desdo á pocos dias que llegú á Castilla llevó Dios al Rey Callublico á su gloria; i eómo eonlinuỏ su eamino é fué á Flandes á dar nolịia al Rey don Cárlos, nuestro señor ; é cómo fué proveydo por gobernador de Tierra-Firme Lope de Sosa, un cavallero de Cordova, ¿ su muerte 1.

\section{D} rias para salir de la Tierra-Firme. comose dixo en el capítulo IX. me cmbirqué en una caravela del key a de que cra macstre é piloto Anulrés Niùo: é assinesmo en aquella renian el provincial de la órden de Sanet Francisco. Ilamado fray Diego de Torres. persona reverenda é muy buen religioso, é otro fray fra de su órden, su compañero. Ilamado fras Indrés de Valdés. que al presocente ostá en la cilodad de Sincto Domingogo: donde estoy. Lssimesmo venia affucl capitan Rodrigo de Colmonares, que avia valo por procurador del Daricn, quando Pedrarias fuć provey¿to por" gobernador de Castilla del Oro. É cómo reniamos en un navio. y el largo cannino i la mesa desculnen muchas veçes las roluntalesé propóssito de los hombres, alcancé á saber que el froy Dicgo de Torres yla por contrasono de mi cmbaxada, enviado por el obispo á España, só color de otros negocios de su órden; porejue cotos padres. á la sombra de su híthito, snclen darse lunena maña en otras muclas negociaciones. E! capitan Rodrigo de Colmenares yba envialo por Podrarias, tomiendo que yo avia de deçir. sin respeto de algruno, to que fuesse rerdad. E temian bien el uno y el otro. É aunque

1 Debe nolarse aqui que Oriedo modificó el epigrafe del presente capítulo, despues de puesta en limpio esta segunda parte, pareciendo dignas de ser conocidas làs cláusulas, que en él suprime. En la primera redaccion decia: "Cómo cl veedor Gonalo Fernandez de Oviedo, autor é historiador deslas materias, fué á España á buscar el remedio de la Ticra-Firme, como procurador é regidor de la cibdad de Sancta Maria del Antigua del Darien, go entendi a secreto de sus negogiagiones. no desé su commicacion é familiaridad, c latsta esta cilulad de Sancto Domingo de la lsla Española renimos en compañia é á una mesa é manteles.

Desde arpui el Colmenares se fuć primuro en ciertas naos que estaban á la colla, é llegó mucho antes que yo á Sevilla. El frayle, como cra mas entendido, no quiso salir del monesterio de su orden, que aqui hay, hista que yo me parIi, desde á mas de dos meses despues que el Colmenares, por no me perder de vista.

Tuyo nna astuçia é aviso Pedrarias, é con muclıo cuydado: é fué que nunca consintió que en aquella cildad del Darien ovicsse regidores sino puestos por su mano, de criados suros é personas dél afiçionados é parçiales, é no fechos al propóssito de la república sino para que en aruel conçejo no se tractasse ni hiçies. se ni se escriviesse cosa alguna sin que él lo supiesse; por lo qual d Rey ni su Real Conscjo nunca supieron mas de aquello que el gohernador queria que se supiesse por lengua de aquella cibdad. Pero por otras vias é cartas de personas particulares é principales, é arm de los mes. mos officiales (aunque commigo no estaban bien, porque yo deçia que lievaban

é desde á pocos dias que llegó á Castilla lleroó Dios al Rey Cathólico á su gloria, é cómo continuó su camino é fué á Flandes á dar notięia al Rey don Cárlos , su nieto é subcessor en los reynos; é cómo fuè proveydo por gobernador de Tierra-Firme Lope de Sosa, un cavallero de Córḋoba, el qual llegado al puerto del Darien murió en la nao, queriéndose desembarear, é otras cosas que pertenescen al discurso de la historia. 
injusiamente aquellas partes de las entradas), cadil uno dellos escrivió, é assi todos me daban crédito, é todos estalıan ya escandaliģados con el gobernadon ć olsispo: é con ellos nuesmos é otros se prolaba por sus cartas, muclro mas de lo que yo puelicra deçir.

Por manera que el frayle salió desta cibdad de Sancto Domingo en una nao, de que yo fuí por capilan, é llevé çicrlos millares de pessos de oro para Sus Magestades, que aqui me dieron el thessorero Migueldr. Passamonte é offiçiales. É demas de esso el thessorero, como ela antiguo criado del liey Cathólico, é arag̣onés, é tenia con él mucho crédito é con Johan Cabrero, el camarero, é con el sceretario Lope Conchillos (que todos eran aragoneses é privados é amigos de este thessolero), para todos me dió cartas é créclito, y envió seys indios é seys indias muy bien dispuestos (cllos y cllas carilıes), é muchos papagayos, é seys panes de açúcal é quinçe ó reynte cañutos de cañafistola: que fué el primer açícar é cañafístola que el Rey vido de aquestas partes, é lo primero qué España fué destas partes é isla.

É despues que llegué á Sevilla, fuy á buscar al Rey, é halléle muy enfermo en la ciludad de Plasençia, en el mes de diciembre, año de mill é quinientos é quince, é ylua de camino á Sevilla: é allí le besé las manos, é le dí las carlas é creençias de todos aquellos que le escrivieron de Tierra-Firme, é del tlessorero Mliguel de Passamonte. É holgó mucho de rer aquel pressente é indios; porque avia Su Alteça escrito al thessorero que desscaba ver qué genle cran estos caril)es, que comen carne limmana: los quales eran de las islas Dominiea, Matinino y Cilunqueyra, que los chripstianos Ilaman Sancta Cruz, é de otras islas próximas á estas que he dicho. É el Rey me oyó, é me pregauntó lo que fué servido saber de mí en cosas generales é del camino é de aquella lierra; pero las que haçian al propóssito de la gohernaçion é te su serviçio quiso entenderlas despaçio, é assi me dixo que en Sevilla, pará donde ylua, me oyria é despacharia. E yo le supliepré que ne diesse licençia para yo á Maidrid á visitar mi casa é muger, que avia quassi tres años que avia salido della : é Su Alteça lo ovo por bien. é me dixo que, pues le deçia queconvenia á sul servicio que me oyesse, que en llegando á Sevilla, se entenderia en cllo, é que entre tanto dexasse al secretario Conchillos una memoria de todo lo que fuesse nescessario proveerse, entre tanto que yo tornalia á la córte á entender en lo demás. É assi lo liçe, é me fuí á mi easa á Madriril.

É desde á poeos dias que allí llegué, luego el siguiente mes de cnero de mill é quinientos é diez y seyśa años, yendo el Rey Cathólieo á Sevilla, murió en Madrigalejos, aldea de la ciludad de Truxillo. Assi como yo supe que Dios avia llevado al Rey Cathólico á su gloria, me partí para Flandes á dar notiçia al nuevo Rey, don Cánlos, nuestro señor, de las cosas de la Tierra-Firme. sin me cansar, non obstante, el largo camino que desde la TierraFirme yo ladesia, ni el trabaxo é costa propria.

Aquel parlie fray Diego de Torres. quando yluamos á España, arribamos al Funchal, que es una villa de la isla de la .Madera del rey de Porlugal; é Lasta alli avíamos llevado muy trabaxosa navegaçion de tiempo é mar, é avíamos tardarlo septenta é çinco dias desde atpuesta cilydad de Sancto Domingo : é creyendo que la nao mestra se defuviera mas en aque! puerto, salió á tierra aquel reverendo padre con otro compañero, é çicrtos marineros, é dos ó tres passageros, para tomar algun refresco é dos ó tres pipas de agua: que ya no teníamos sino una por beber (y éramos mas de novenla personas). É de caso aquella noche, passada la 
primera guarta, saltó tanto riento al Sur (que es allí lavesía), que nuestra nao ni otras muclat naos é cararclas que allí estabin, no se pudieron sostener; é todos salimos del puerto luyendo, por no clar al través en aquella costa brava : é nos liigimos á la vola la noche siguiente al mesmo dia que allí llegamos, é todos los otros navios se fueron á guaresçer á una isla que se diçe Puerto Sancto, é nosotros seguimos nuestro viage para España, aunque con aquella poca agua que es dicho: pero essa nos bastó, é los frayles quedaron en la isla. Mas despues, desde á pocos dias. se fucron en otra nao, y en el camino adolesció al padre fray Diego de Torres, é llegó á morir dentro en la bahía de Cádiz . sin se desembarcar. Pienso yo que era tan luena persona. que no dexara de deçir rerdad. si llegara á la córte, é donde debiera deçirla.

Yido yo en Flandes, é llegado quassi á la costal de Bretaña, nos vino el tiempo contrario ; é cómo aviamos salido le Porlugalete, vinimos á tomar puerto en Laredo, é desde allí volvimos á la navegracion: é estando ya ruassi á mcrlio camino, é en el parage de la isla de U'xente, nos vino tanto tiempo é reçio Yordeste, que ovimos de dar la vuelta (alijando é pidiendo á Dios misericordia) á España, ó corrimos liasta el puerto de la Coruña. E desde allí fuymos en romeria algunos át visitar la caśa del Apóstol glorioso Sancliago o é dentro de terçero dia tornamos á la Coruña, é seguimos la via de la Canal de Flandes; y estando ya dentro della, nos dió tiempo contrario é nos sacó fucra, é con mucho trabaxo é mayor ventura podimos tomar las islas de Sorlinga. Y en una dellas estovimos oclo dias, haciendo vida peor que la de las Indias, porque no avia allí sino una fortaleça runada é yerma del rey de Inglaterra é quatro ó çineo choças pajiças, y no tales como los liuhios do acá con mucho: con todo avia vino, $\mathrm{g}$ tan caro é mas que aqui le helremos: tenian un poco de harina. de que laçiemos mas tortillas que cocíamos en (l) rescoldo ó seniça: olra cosa de comer no la teníamos; pero aria conejos, a algunos ballesteros de la nao mataron algunos. Y en esta penitençia, estovimos ocho diasó diez, esperando el liempo; é víamos deste allí la ysla de Inglaterra é seys ó siete lugares; e si por caso no puliéramos aferrar aque. llas ysletas, fircranos la ruelta de Islanda, é puliera ser que desde á un año no volviéramos á liandes.

Plugo á Dios que volvió tal tiempo, como le aríamos menester, é tornamos á la Canal, é fuymos á desembarcarnos á las Dumas, dos ó tres leguas debaxo de Dobra: é desde allí nos fuymos los passageros al puerto de la villa de Dobra, é la nao se furé á Lóndecs. Desde Dobra atravessamos aquella canal hasta Cales, é desde Cales fuy por tierra á Bruselas, donde. hallé al Rey. I es verulad que esture en este camino quassi quatro meses; é gasté é trabaxé mas que si dos veces viniera desde Sevilla á esta ciludad de Sancto Domingo. A la vuelta torné descle Gelanda á Portugalete en tres dias y medio.

Despues que ęn Bruselas besé las manos al Rey, nuestro señor, mandóme oýr á su grand chançiller de Borgoña i é assi se hiço. E rlespmes de ovilo, porque los mas de su Real Conscjo eran cxtrangeros. é los señores. que entre cllos avia españoles. tenian poco curso de semejantes negocios, fuy remitido por Su Alteça á España á sus grobernadores. que cran ol Cirdenal arecoluispo de Toledo, fray Francisco Ximenez de Cisneros, y el Cardenal de Tortosa, que despues fué Papa Adriano: á los quales mandó el Rey que, juntamente con las otras personas, que tenian á cargo las cosas de las Indias, me oyessen é viessen el memorial que yo avia dado á Si Ma. gestad, que yba señalado de su secretarie Ugo de Urries, scñor de Averve, é 
despues de visto lo despachassen, como conviniesse á su real serviçio é bien de la Tierra-linme; é que en lo que tocaha á mi persona, yo fuesse gratificado é pagado de inis gastos é serviçios, como criado de su real casa, teniéndosse por servido de mí.

Con esta remision volví á España, éal tiempo que me partí de la villa de Bruselas, ví acaso al Rodrigo de Colmenares enfermo é pohre, é rogóme que por amor de Dios le llevasse conmigo á Castilla; é assi lo hiçe, é aun le presté dineros que él me pagó mal: el quảl me dixo que lo quél avia dicho é negoçiado era en pró é utilidad de la Tierra-Firme, é tambien traia una remision para los Cardenales gohernadores.

Llegados á Hadrid, donde los gohernadores estaban, el capitan Colmenares, como no fué reșpondido á su propóssito, fuésse á Nápoles (aunque despues tornó á Tierra-Firme, mas de un año despues que yo allá estabạ, que fueron quatro años despues que partimos de Flandes ó que tornamos á España).

Yo les di á aquellos reverendíssimos Cardenales la remision é memorial que lıe dicho, é les supliqué que me oyessen, como el Rey, nuestro señor, lo mandaba; pero nunca fuy dellos respondido ni oydo ni despachado en cosa que tocasse á aquella tierra, ni á la paga de mis gastos é gratificaçion, que Su Mlagestad mantó haçerme; y assi la tierra se quedó con sus trabaxos é otros que se augrmentaron cada dia, é yo con los mios, é con más de dos mill castellanos menos, que gasté en aquellos viages. Sea Dios servido de todo.

La causa de no ser yo oydo ni aver efetto la remịion real, fué quel Cardenal de España estaba puesto en enviar, como envió, tres frayles del órden de Sanct Hierónimo á esta isla, y estos eran fray Luys de Figueroa, prior de la Mejorada, é fray Alonso de Sancto Do- mingo, prior de Sanct Johan de Ortega, é fray Bernaldino de Mançanedo; prior de Nontamarta (reverendas personas, y escogidos para remediar estas cosas de aquel Nuevo Mundo), para que estos padres tornassen á él é grobernassen esta cihdad é las fudias. É con muy grandes é largos poderes vinieron á esta cibdad de Sancto Domingo é residieron. en ella: é su venida en la verdad fué útil é provechosa á esta ysla, assi por su exemplo é dottrina, como en ser causa de algुunas grangerias, assi como en los átboles de la cañafístola , y en los ingenios del açúcar, é otras cosas, en que no me detengo, porque algo desto se tocó en la primera parte en el libro IV, capítulo 11. Mlas quanto al remedio de la Tierra-Firme poco ó ninguna cosa aprovecharon, ni la vieron. Quiero rolver á mi camino é trabaxos, que no pararon en lo que está dicho.

En aquella saçon estaba en la córte ef almirante don Diego Colom, pleyteando con el fiscal real sohre sus previlegios. Al qual el Rey, nuestro señor, despues que vino á reynar en España, le despachó para que se tomasse á su casa á esta cibdad, é mandó que se fuessen los Hierónimos religiosos á Castilla. Esto fué en el año de mill é quinientos é diez y siete: é aquel mesmo murió el Cardenal don fray Françisco Ximenez, é yo volví á mis negoçios, é me turaron hasta el año de mill é quinientos é diez y nueve, quel Rey fué á Barcelona, donde le vino la nueva de la elecion de Rey de Romanos é futuro Enperador. É allí fuy oydo de nuevo, puresto que avia ya çinco años que me luraba la porfia en los negoçios con muchos trabaxos é costas, é no llevando ya remedio muchas cosas de las que dehieran averse remediado en la Tierra-Firme: antes estahan algunos males é robos continuados, é puestos tan en la costumbre, que no tenian cura.

Allí en Barçelona proveyó Su Magestad 
de solvernador de Castilla del Oro á un cavallero de Córdova, Ilamado Lope de Sosa, que vivia en Grand Canaria (donde avia segrlo gobernador), persona tai qual courenia al bien de la Tierra-firme; é yo fuy despachado para rolver allá con él. É al liempo que me quise partir de Barçelona, supe que el obispo, don fray Johan de Quevelo, era llegado á España: cl qual me escribió que le alcndiesse en la córte, é assi lo hiçe. porque me holgara yo muclio de deçir en su pressençia lo que avia dicho en Flandes y en el Consejo ; é llegó á la córte, ó desde á muy pocos dias murió cerca de Barçelona. En el qual liempo llegó nueva cómo el gobernador Pedrarias avia degollado al adelantado Vasco Nuñez de Ballooa é otros por traydores, é confiseado sus lienes para la cámara é fiseo de Su Magestad. É el Emperador, nuestro señor, me mandó por sus cédulas reales que yo cobrasse sus bienes de aquellos sentençiados, que era fama que tenian mas de çient mill pessos de oro. É con este é otros despachos salí de Barçclona é fuy a Mladrid, donde 10mé mi muger é hijos, é fuy á Serilla, para desde allí yr á la Tierra-Firme: é assi al prinçipio del siguiente año te mill é quinientos y reynte, parti de España é fuy á la isla de Grant Canaria, é hallé quel gobernador Lope de Sosa ya yba adelante. É de aquella isla vine á costa, y estuve en esta cibdad de Sancto Domingo ocho dias con mi mugeer é dos hijos, é de aqui pas- sé á Tierra-linme; y un echando el áneora en el puerto det lorien, donde llegué de noclıe. supe de man nao que allí laallé, quel golvernador Lope de Sosa aria Tlegado á aquel puerto, é que estando para salir en tierra, le llevó Dios sin desembarcar. Lo qual fué quassi la tolal perdiçion de aquella lierra, porque era hombre que tenia buena consçiençia é larga expiriencia en las cosas de gobernaçion, y era yaron muy recto é con quien se remediáran mucho las cosas de aquellas partes: é yo me hallé confuso é arrepentido de mi diligençia, é sospeché luego que me avia de yr mal. porque el gobernador Pedrarias estaha mal conmigo. c la vola de lope de Sosa é removerle á él del cargo creyó que lo avia yo soliçitado, é túrome por cnemigo; ć paresciósene bien adelante en sus ohras y en mi persona y haçienda, puesto quél me mostró luen aeogimiento. é que holgaha de mi yola. Pero cómo yo lleval)a ni mugeré mis hijos, yue eran niños, no pude desar de atender é ponerme á lo que me viniesse. como se dirá adelante.

Jas es hien que se diga primero la causa de la muerte del adelantado Vasco Nimnez de Balboa, é otros pecadores que con él padesçieron con lítulỏ de traydores; pero aunque yo cobré sus bienes, cu nombre de Su llagesestad, para su cámara é fisco, no me determino si lo fueron ó no.

\section{CAPITULO XII.}

De la muerte del adelantado Vaseo Nuñez de Balboa, è Andrés de Valderríbano, é Fernando de Argiiello, ¿Luys Botello, a Fernan Muñoz, que fueron en una hora degollados en la villa de Acla, en TierraFirme.

E de lal nombre, aviendo resprecto á los servicios de Tasco Nunez de Ballhoa, le hiço adelantado de la mar del Sur é goberna- ror de las provinças de Coyba é Panamá, como mas largamente lo lıe dicho: y assinesmo dixe cóno Pedrarias le quiso detener las provisiones: é lambien se hi- 
ço mençion de lo quel olispo, fiay Jolıan de Quevedo, trabaxó é higo liasta que le fucron dadas. Resultó desto una enemistad é odio perpétuo en el gobernator, é offiçiales, é alcalde mayor, el liçençiado Espinosa, contra Vasco Nuñez, é nunca pudicron olvidar el odlio entrañable, que le tenian.

Cómo el obispo cra sagaz, é conosçia la dispusiçion destos ánimos, por yr conosçiendo maliçias é cautelas, é usando él de olras mayores, por salir con su desseo, que era ver scñor en todo á Vasco Nuñez; viendo quiel golocrnador cra hombre de mucha clad, é estaba enfermo, é tenia hijas, é era coldiçioso, movió este perlado á Pedrarias que casasse una de sus lijas con el adelantado Taseo Suñez, que era mançebo é de buena dispusiçion para trabaxar, porque seria á su propóssito: lo uno, porque Vasco Nuñez le serviria, como hijo: é lo otro, porrue era hombre hijorlalgo é tenia ya título de ade. lantado, y él casaha muy bien su hija, é scria su teniente, é descuydaria en las cosas de la guerra, é serviria muy bien al Rey, é acresçentaria su honra é haçienda, é demas desso çessarian las parçialidades é passiones de los offiçiales, y el grolsernador ternía mucho descanso. É deste tenor le dixo otras muchas palabras en el easo, é lo mesmo diso é persuadió á doña Isabel de Bovadilla, su muger, la qual estaba bien con el Vasco Nuñez, y él se avia dado mucho á la conlentar é servir. En lo qual el gobernador é su muger vinicron, é se hiçieron los capílulos matrimoniales, é le tomó por lijo é yerno (puesto que para la conclusion deste casamiento estaba la liija, que Perlrarias le ofresçió en España, é quedó que dentro de cierto tiempo la llevarian al Darien); é assi començó á llama liijo al adelantado, é á honrarle é favoresçerle, y en nombre de su hija, se desposó é dió la mano por ella, é passaron las escripłuras é firmeças TOMO III. que les paresçió. Y escrivió luego Pedrarias al Rey é á los señores del Consejo de Indlias, que este casamiento avia lıecho de su hija, porque todos sirviessen mejor é mas derechamente á Dios é Sus Mlagestades. Para mí tengo yo creydo é por muy averiguado que si el obispo estuvicra en la ticra, que el adclantado no muriera; pero él pensó que quedaba segurro, con aquel assiento del casamiento, de las cautelas del gobernador y de las del thessorero Alonso de la Puente, que era el que mayor odio le tenia, como lo mostró bien adelante.

Assi que, despues quel obispo dexó conçcrtado este debdo, é dadas las manos, como es dicho, é que el gobernador le fitrorescia, él se partió deste á poco para España, é se fué la córte á Barçclo. na ,é murió deste á muy pocos dias, como lo dixe en el capítulo de susso, entrante el año, ó diçiendo nıjor el postre. ro dia del año de mill é quinientos é diez y nueve, que fué víspera de la Natividad de Chripsto, veynte y quatro de diçiembre: é por su muerte fué clegido por perlado de Castilla del Oro fray Viçente Peraça, de la órden de Sancto Domingo, eI qual fué el segundo obispo de aquel obispado.

Tornando á la historia, estando el adelantado Tasco Nuñez muy en graçia de su sucgro, acordó de yr á la mar del Sur, con su liçençia, y en ella haçer çiertos navios, para descubrir aqucllas costas é mares, é saber los secretos é riqueças de la mar austral; de lo qual el gobernador fué muy contento, é aun turo mancra que de la hacienda del Rey se le prestassen dineros, para hacer el armada. Con los quales y con los que el adelantado tenia, é ayudándole con su haçicnda toda un su amigo, llamado Fernando de Argüello (natural de la Torre de Lobaton, que fué aquel escribano que en el capítulo IlI del libro XXY'll se diso que avia assentado el 
juramento que en al Darien hicieron los que con Vaseo Ximuez se conjuraron, para no rescebir ál Diegro (le Nicuesa), huego el arlelanlado comencó á dar órden en su despacho, para se yr á la otra costa del Sur.

En este liempo estaloa ya hecha la fortaleça é pueblo de Lela, é puesto en ella por alcayde el capitan Lope de Olano: é assi por el mal tractamiento que los chripstianos, que con él estahan, haçian á los indios é al caçique de Careta (en cuya lierra é puerto estaba apuella fuerca), como porque el cacique no tenia olvidada la maldad del capilan Bartolomé Ilurtado, que dió por quinto é hiço esclaros el prinçipal é inclios de paces, que le prestó este caçique para le llevar las carsas, quando volvia de huscar al teniente Johan de Ayora, como porque la muerte de Nicuesa é la maldad é traycion queste Lope de Olano le avia fecho, no estaban ante Dios en olvido; no pudiendo ya el caçique sufrir los adulterios è robos é sinraçones que se le hargian, acordó de matar á este Lope de Olano; é assi lo lirgo ron hasta otros doçe ó quinçe chripstianos, que con el estaban. En enmienda de lo qual se hicieron otras crueldades, é se dieron por esclavos los indios de Careta, sin aver consideraçion á la mucha raçon que este caçique tenia, para se vengar de sus enemigos, que lantas ofensas le avian fecho. En fin, que alli quedó aquel pueblo, el qual agora se llama la cibdad de Icla, y es pequeña poblaçion al pressente en la costa del Norte, en arquella gobernaçion de Castilla del $\mathrm{Or}^{\circ}$.

Assi que, el adelantarlo Vaseo Nuñez fuè allí por mar, é desde allí passó á la ofra costa é hiço çiertos navios con mucho trabaxo é grandes gastos; é á fuerça de braços con la gente que le siguió, y él por su persona, traia la madera á cuestas desde el monte hasta el astillero, donde se haçian, para seguir esta empressa; pero mató quinientos indios, haçiéndoles aca"rear cables é áncoras é jarchias é otros materiales é aparejos de una nar á otra, por sicras é montes é asperíssimos caminos, y passando muchos rios, para efeluar la olsa de los navios. É entre lanto que esta labor se haçia, envió capitanes por las conuareas, é tomaron muchos indios, como quier que los pudiessen aver, leyéndoles aquel requirimicnto rque es dicho, en tanto que los ataban, é no guardándoles cosa alguna que se les prometiesse; é parte de estos, assi pressos é captivos, ocupaban en el trabaxo de los navios, é los otros enviaban á vender al Darien por mano de aquel Hernando de Arçiiello ques dicho, sin que se declarasse si eran esclaros ó no. E lodo se disimulaha, só color de aquellas borlas quel gobernador con su hija avia ofrescido al adelantado, sin mirar ni tener respecto que se deservian Dios y el Rey, é que era todo aquello la total clesolacion de la tierra é de los naturales della, porque turó aquella labor é obras mucho tiempo.

Passóse aquel tiempo limitado é liçençia quel gobernador avia dado al adelantado para yr á aquel viage, que pensó haçer por la mar del Sur ; é diéronle á entender á Pedrarias, que pues el adelanlado no venia ni envialıa á dar raçon de sí é de su tardança, que delira estar alçado é se querria yr por la mar del Sur, con aquellos navios que aria hecho, á poblar en otras partes, donde fuesse señor è no obedesçiesse al Rey ni a gobernador. Lo qual Pedrarias crevó; é los émulos del adelantado, que eran los offiçiales y el bachiller Corral, riendo la dispusiçion quel tiempo les mostró en la voluntad del gobernador, para ençender mas su sospecha, é quitar el crédito á Vasco Nuñez, siempre le deçian palabras de mas indignacion. É estando las cosas en este estado é opinion, llegaron cartas del adelantado, dando sus excusas al gobernator de 
la tardança, á causa de la dilaçion é tien1) que se avia gastado en la labor de los navios laasta los echar al aggua, é suplicándole que le prorogasse el térnino para efetuar su viage. La qual peliçion le fué denegada, porque los offiçiales é aquel bachiller Corral decian que en ninguna manera el gohernador le debia dar tal prorogacion: é assi el gobernador no le respondió, é dilataba, sin conçeder ni negar", sino dando respuestas equívocas á los soliçitadores, entreteniendo los negocios.

De esto todo le avisó aquel Ilernando de Argüello por una carta, que le costó la cabeca, en la qual le escrivió que no le querian dar mas término ni prorogacion, é que le aconscjaba que no curasse dello, ni dexasse de hacer su viage; $e ́$ que hiçiesse lo que los padres lierónimos (que gobernaban desde aquesta ciludad de Sancto Domingo las Indias, conı superiores), en aquella saçon le avian escript) á Vasco Nuñez, que era que liçiesse el viage, pues tanto convenia al servicio de Dios é del Rey: é que esto le acordaba el IIernando de Argiello que hiçiesse, é no se curasse de lo quel gobernador é officiales hiçiessen ó dixessen, pues que avia grastado en la empressa é navios su laçienda, é la de sus amigos, con tanto tiempo é traxos.

Esta carta vino á manos de Pedrarias; y en esta saçon avia ya nuevas en la tierla que por mi soliçitud é las informaçiones quel Emperador, nuestro señor, tenia de la Tierra-Firme, se avia proveydo otro nuevo gobernador en lugar de Pedrarias; é con esta sospecha, el adelantado Vasco Nuñez se concertó con Andrés de Valderráluano é con cl capitan Andrés Garavito é Lnis Botello é Fernan Muñoz, que se enviasse ál saber en Acla qué nueva avia de la venida del nucvo gobernador, éque si oviesse venido gobernador, el mensagero tornasse diciendo: "Albricias! albriçias! quel adelantado Vasco Nuñez es goberna- dor de Tierra-Firmen; é le diessen ciertas cartas, en que paresciesse que le y ba el aviso dello. Lo qual él laçia é fingia, porque si la gente supiera que avia gobernador nuevo en la tierra, no la pudiera tener é se le tornarian al Darien, é tambien, porque si gohernador nuevo ovicra, sospechaba que le quitaria el cargo, por le dar áalgun pariente ó amigo suyo, ó le deternia, y él perderia su tiempo é trabaxo, é lo que avia gastado: é que si este mensagero que avia de yr ál Acla no hallasse nueva de la venida del nuevo gobernador, dixesse que no avia otro gobernador, ni nueva dél, sino Pedrarias Détvila, é que estaba muy bueno é alegre en avel sahido del adelantado Vasco Nuñez, é que le enviaba la prorogacion que le avia enviado á pedir.

Estas cartas y espias fueron tomadas por un Françisco Benitez, escribano que era allí en Acla, é dió aviso encontinenti á Pedrarias: el qual escrivió luego muy sabrosamente, como padre, al adelantado é lo envió á llamar deste Lcla, á donde se avia jdo; é luego, como hijo obediente, vino allí á ver al gobernador, é saber lo quél queria mandar, pensando que estaba en su graçia, como era raçon. Pero assi como llegó, te hiço prender, é assinesmo fueron pressos el capitan Andrés Garavito é Luis Botello é Fernan Muñoz é Andrés de Valderrábano é Hernando de Argaicllo, porque avia escripto la carta que se dixo de susso al adclantado. Estaudo assi pressos, fué aconscjado el Garavito que descubriesse lo que sabia deste negoçio, é pidiesse misericordia é merçed de la vida: é assi lo hiço, é dixo al gobernador é juró lo que es dicho; é por esla su confession ó declaraçion le fué remitida ó perdonada la culpa ó parte que le cabia en cl conçierto que es dicho, pues avia descubierto aquella trayçion, que se les imputaha al adelantado é sus consortes. É mandó el gobernador á su alcalde 
mayor, el liçençado Espinosa, que con nuch diligencia entendiesse luego en la residencia, é la hiciesse pregonar eontra Vasco Nuñez; é mandó que se le acumulasse la primera que se le avia començado á tomar, çinco años ó mas avia, é numca se avia acaloado; é todos los crímines y excessos (fu' del adelantado se pudiessen saber, con la muerte del capitan Diego de Nicuesa, é que todo se le truresse á consequencia : é que assimesmo que en el tiempo que Vasco Nuñez avia gobernado la tierra (antes que Pedrarias allá fuesse), avia tomado una marca real de marcar oro al veedor Silrestre Perez, é lo avia lıecho moril de hambre, é otros delictos.

En esta nescessidad puesto el adelantado Vasco Nunez, los officiales, el thessorero Alonso de la Puente y el contador Diego Marquez, é con ellos el bichiller Diego de Corral, vinieron muy de grado concertados, é pusiéronle una larga é criminal acusaçion, la qual, firmada de torlos tres, pressentó aquel bachiller, su antiguo encnigo; ć al alcalde mayor no le faltó voluntad para proseder en este progesso, é finalunente los sentençió á todos á ser degollados por traydores, é confiscalos sus bienes para la cámara é fisco de Sus Mlagestades.

Antes que esta sentencia se diesse, luvo forma el alcalde mayor con çiertos diputados de la compañia que avian hecho los navios, que hiçiessen un pedimento al gobernador, en que le suplicassen é pidiessen que mandasse abreviar la residencra de Vasco Nuñez, y enviasse al alcalde mayor, el liçençiado Lspinosa, por su teniente general é capitan, diçiendo que á él querian é no á otro: é aun decian que no avia otro que mejor lo hiçiesse, porque no se acabassen de perder tantos hombres, esperando ayuel viage é determinaçion; é í este propóssito otras palabras en faror del alcalcle mayor, segund quél mesmo las ordenó é las licgo firmar á acpuellos diputarlos de la comprañia.

Hecho esto, se dió la sentençia, de la (qual apeló cl adelantado Vasco Nuñez para el Emperador, nucstro señor, é su Real Consejo de Indias; y el alealde mayor envió á un Cluripstóbal Muñoz, que cra el escribano ante quien passiba la causa, á notificar al gobernador la apelaçion para que se hiçiesse lo que mandasse, é dixesse si se le otorginia la apelaçion por laçon del titulo de adelantado, ó si se le denegaria; y el goher'nador respondió por escripto que no lo remitiesse ni se la otorgasse, sino que hiçicsse justiçia. Aquel auto quel alcalde mayor mancló notificar á Pedrarias, é su respuesta, todo lo ordenó el liçençiado Espinosa, é lo escrevió Intonio Quadrado, su criado, é lo firmó Pedrarias, É assi fué execulada por pregon público la sentençia, é descabesados el adelantado é Fernando de Arguiello é Luis Botello é Hernan Muñoz é Andrés de Valderríbano en la plaça de Ac , é fué absuclto el-capitan Indrés Garavito, por descubridor de la trayçion. Y fué lincado un palo, en que estuvo la cabega del adelantado muchos dias puesta: é desde una casa, que estala diez ó doge passos de donde los degrollaban (cono carneros, uno á par de otro) estaba Pedrarias, mirándolos por entre las cañas de la pared de la casa ó buhío.

Desta manera acabó el adclantamiento de Vasco Nuñez, descubridor de la mar del Sur, é pagó la muerte del capitan Diego de Nicuesal por la qual é por otras culpas permitió Dios que oriesse tal muelte, é no por lo yuel pregon deçia, porque la que llamaban traycion, ninguno li tuvo por tal.

É assi pagó IIernando de Argüello aquel testimonio é juramento del Darien contra Nicuesa; é Andrés de Valderrábano pagó aquel consejo que dió para quel capitan Gaspar de Morales degollasse en 
cuerda tantos indios é indias é niños, quando venian de la isla de las Perlas.

El capitan Peñalosa, que fué en el mesmo consejo lıerodiano, despues lo mataron indios en la isla de Culba.

Luis Botello y IIernan Muñoz, pues cran daquellos primeros conquistadores é tan familiares amigos del adelautado, que se avian Irallado en aquellas entradas que he diclıo, no ternian tan linpias las manos de sangre liumana, que le faltassen méritos para la fin que ovicron.

El capitan Andrés de Garavito, despues de algunos años, en Leon de Nicarağua, para un juego de cañas, él é otros se disfraçaron é visticron como moros, y él é otro de caballo arremetieron láçia donde estaban çiertas mugeres españo- las, mirando la fiesta ; é como llegó çerca dellas, dixo: "Señolas, tornaos moras, " é otros desatinos. É loando la secta de Malroma, cayó súbitamente muerto, que no habló mas palabıa.

El Françisco Benitcz, escribano de Acla, que se dixo que avia descubierto las espias del adclantado, é que avisó al gobernador, despues mas de tres años, cstando en Panamá, murió súbito; é lo hallaron muerto echado en su hamaca, aviéndose acostado la noche antes muy sano,

Por manera que assi ovicron término las vidas destos pecadores. Plega á la misericordia de Dios que con sus ánimas se haya avido piadosamente, pues que á á los cuerpos no faltó su castigo.

\section{CAPITULO XIII.}

Cómo el lięenẹiado Gaspar de Espinosa, alealde mayor de Pedrarias, fué por su teniente general por la mar del Sur con los navios que avia hecho el adelantado Vaseo Nunez de Balboa, é de lo que hięo en el viage, é otras cosas antes deslo, en que este liẹençiado se avia hallado.

\section{A} ntes de la muerte del adelantado Vasco Nuñez de Ballıoa, el liçençiado Espinosa, alcalde mayor, estaba muy informado é instruydo é diestro en las crueldades que los otros capitanes acostumbraban liaçer contra los indios: é aun en aquellas avia él acresçentado otras cosas, porque avia liecho un viage, como teriente de capitan general, é avia ydo á la costa del mar del Sur, é de camino avia hecho muchas muertes en los indios de Comogre é Pocorosa é Chiman, só color de castigar á los que arian muerto á los cliripstianos del pueblo é puerto de Sancta Cruz. É passó á Nata, é llegó á la provinçia de Paris, en busca de aquel oro que aria perdido el capitan Gonçalo de Badajoz; é despues que algumos dias estuvo en tierra deste cacique, con dosçientos hombres oscogridos, laallóse en los llanos que diçen de Paris muy dentro de aquella tierra : é no Lallando allí rastro del caçique, acordó de enviar al capitan Diego de Albitez adelante con çient lombres, y él quedó cn la retoguarda con las yeguas é calıallos que llevaba, que serian quinçe ó diez y seys.

Pero no me puedo acordar de lo que agora diré, sin reyıme de las señas que los indios daban deste capitan, quando venian de donde andaba; porque cóno les preguntaban por el liçençiado, para dar á enteuder que le avian visto é dónde andalsa, reluznaban ó se esforçaban á deçir lo que sabian, roznando como asnos, porque nunca se avia visto tal animal en aquellas partes, y este liçençiado Espinosa traia uno en su compañia. E viendo que los indios tenian temor de oyrle, dábanles á entender que pedia oro para el Rey é sus capitanes, é no dexaban algunos de darlo. por amor del asno é por le contental. 
Tornando á nuestra historia, yendo Diego de Illitez adelante, halló al caçque en la costa de un lio, é peleó con él, é matóle çinquienta ó sessenta indios, é fueron heridos algunos chripstianos; y el alcalde mayor le socorrió, y el caçique é su gente se pussieron en luydla é se fueron á rohacer de mas gente, como lo hiçicron. En cssa sacon llegó el capitan Hierónimo de Valençuela con otros çient compañeros que Pedrarias envió en socorro del alcalde mayor; é cómo los chripstianos eran ya trescientos hombres, de hecho paresçiéndole al eaçique que no los podria ccliar de la tierra, sin daño della é de sus indios, usó de la cautela que diré. Enviódosindios, que se dexassen prender, háçia cl real de los chripstianos, é mandóles que les enseñassen el oro quel caçique avia tomado al capitan Gonçalo de Badajoz é á los españoles: Iomados estos dos indios, interrogólos Diego de Albitez para que dixessen dónde estaba el caçique de Paris, é no qnisieron dar notiça dél, é deçian que estaba en otra provincia : é preguntándoles por el oro, dixo el uno dellos quel oro él lo mostraria á los chripstianos dónde estaba, é quel caçique queria que lo tomassen é se fuessen en buen hora de sin tierra. Y cóms aver oro era el prinçipal intento que esta gente nucstra llevaba. mas que de hager al caçique su amigo ni le convertir á la féc, por aviso deste indio fué Diego Albitez donde el oro estaba, y en una arroyada le mostró un buhío, como pequeño ranchuelo, é allí laallaron diez habas ó çestas, en que avia hasta treynta mill pessos de oro. É no fallaba cosa alguna de quanto se le avia tomado al capilan Badajoz, si110 los seys mill pessos, que las mugeres (lel cagique de Paris le avian enviado al Badajoz, é los tres mill pessos que le aria rado aquel indio prinçipal, que tornó cornudo, por la bondad de aquel devoto clérigo. Estos nueve mill pessos de oro avia tomado el ciccique, ó lo demís todo estala allí quanto á Badajoz se le tomó.

Con este oro é olro que tomó el alcalde mayor en aqnel viage, volvió al Darien muy orgulloso é próspero; é descle estonçe quedó en repntaçion de hombre que sabia muy bien el arte de la guerra é de las sinraçones que se usaban hacer contra los indios, é aun fué inventor de una crucldad no vista en aqnellas partes hasta arpucl tiempo, é fué aquesta. Atado un indio de los de Chiman (qne él condenó á muerte por castigo de los chripstianos, que mataron en el pueblo é puerto de Sancta Cruz) arrimarlo á un árbol, hiço assentar un tiro de pólyora á diez ó doce passos dél, é mandúle tirar, é dióle por mitad ìle los pechos, é por donde entró la pelota, que seria tamaña como una nuez, hiço el ağujero de aquel tamaño, é por donde salió en las espaldas del indio hiço mayor abertura é llaga quel bulto de una grande botija de media arroba. Esto fué cosa de unucho espanto á los indios, é nolado por muclia crueldad entre los chripstianos, que lo vieron.

De esta expiriençia é ogtras tornó de ạuel riage con treynta é tantos mill pessos de oro é muchos indios en cuerda : é por tanto hallaban los diputados de la compañia que lo delian pelir por capitan de los navios del adelantado Vasco NuIrez, lo qual el gobernador les conçedió, con largos poderes que le dió para yr á tomar la gente é navios é proseguir el viage que avia de haçer el mal afortunado adelantado Yasco Nuñez.

Llegado á la mar del Sur, con título de teniente de capitan general, entró en los navios, é corrió la mar é tierra de la costa del Sur háçia el Oçidente; é ovo deste segundo riage del caçique de Paris quarenta mill pessos de buen oro, é los veynte mill pessos dellos hiço enterrar en Pananá, dentro de la ciludad, çerca de la costa, é dexó allí por teniente al capitan 
Gongalo de Badajoz. É los otros veynte mill pessos hícolos llevar á la ciblard del Darien, donde el goblyernador é offiçiales residian, para que se quintassen todos los quarenta mill pessos e fundiessen la resta, para proveer dellos á la gente de algुunas cosas, de que tenian nescessidad. I el liçençiado con los navios se tornó por la costa abaxo desde Panamá la via del Poniente en continuaçion del descubrimiento, é llegó á la punta de Cliame, que está veynte y çinco leguas la costa abaxo al Hueste, en la qual ya avia estado primero.

Esta punta ó promonterio está en siete grados y medio de la equinoçial, á la parte de nuestro polo. lí desde allí fué á reconosçer la punta de Guiera, que estí mas al Oçidente veynte leguas, y está en seys grados y medio desta parte de la equinocial: entre aquestas dos puntas de Chame é Güera está un golphete, que se llama golpho de Paris, porque todo aquello señorea el cacique de Paris. Dessle la punta de Güera fué mas al Poniente otras veynte leguas liasta la punta, que se llama de Buena Vista, la qual está en seys grados y un tercio desta parte de la equinoçial.

Desta punta de Buena Vista hasta la punta de Sancla Maria se corren al Hueste otras veynte leguas, y en este espacio se entra la mar á la vuelta del Norte mas de otras veynte leguas, $y$ en aquella ensenada hay muchas islas, y estín las islas de Cebaco, donde está enterrado el cosmógrapho Codro, veneciano, que por yerro en la impresion primera en la primera parte, en el libro $\mathbf{X}$, capítulo lli, se avia dicho que en las de Corobaro; pero no murió sino en estas de Cebaco '. Y en esta ensenada está otra isla mayor, que se diçe isla de Sancta Maria; y en lo mas puesto al Norte está el puerto de Ponuba.

1 Parece eonveniente manifestar aqui que no sc corrigió este error en el lugar eitado por Oviedo, sin duda por no haberse acordado de retocar aquella parle del mencionado capitulo, donde se expre-
Desde la punta de Sancla Maria hasta la punta de Burica se corren otras veynte leguas al Sudoeste; y estí aquella punta de Burica en seys grados y modio desta parte de la equinoçial. Esta es muy buenacomarca, fértil é abundante de los mantenimientos de los indios, de mucho mahiz é yuca é de las fructas de la tierra, é de mucha monteriá de puereos é venados, é de muchas pesquerias de buenos pescados, é buenas aguas, é muy hermosos é grandes mameys, é muchas palmas de los cocos grandes, y es una de las mayores provincias de aquella costa é de inejor gente. Entre estas dos puntas de Sancta Maria é Burica están las islas, que llaman de Benamatia.

Desde la punta de Burica al caloo de Sancta Maria se liaçe un golphete ó ensenada de diez ó doçe legguas, que llaman el golpho de 0sa, y está el diclıo cabo en seys grados y un terçio mas al Oçidente, é desta parte de la línia equinoçial. Corriendo desde dicho cabo de Santa Maria al Oçidente otras veynte leguas, está cerca de la costa la isla del Caño, la qual está en algo mas de seys grados y medio desta parte de la equinoçial. Llámase esta isla del Caño, porque allí está una fuente muy buena, é de una peña sale un caño que cac de lo alto, é dentro de las caravelas, é sin peligro dellas, las pueden acostar á quel agua del caño cayga, si quieren, dentro en los navios, tan gruesso como la muñeca del braço ó poco menos, é de muy buena agua.

Desde la isla del Ciño hay diez ó doçe leguas hasta las islas, que estín cerca de la punta de Sanct Láçaro, la qual punta está en siete grados y medio desta parte de la equinocial.

Desde estas islas de Sanct Láçaro fué

sa que Codro muriú "agerca de las islas de Corobaro (ó Cerebaro) é del puerto de Ponuba." La enmienda aqui introducidat no puede, portanto, ser inas oportuna. 
el liçençiado con los navios é gente que Ilevaba obra de otras quince ó veynte leguas mas al Oçidente, é llamó aquello golpho de Sanct Lúcar, é otros le dişen de Sanct Lúcas; pero no entró en la ensenada grande que está adelante, entre el cabo Blanco é la punta del puerto de la Herradura, ni lo vido. É todo lo quél vido é navegó é puclo testificar desta costa fueron hasta çiento y ochenta leguas, poco mas ó menos, porque de allí adelante del golplio de San Lícas liasla el puerto de la Posession, é mas adelante hasta la bahia de Fonseca, Gil Gonçalez de Ávila y el piloto Andrés Niño lo descubrieron, como se dirá en su lugar. Todo esto ques dicho, está en la costa de Panamá al Oçidente, en la mar del Sur.

Andando el liçençiado Espinosa con esta armada, que cran tres ó quatro navios, llegado el año de reynte, sobre mill é quinientos, en el mes de mayo, llegó al puerto del Darien el golsernador Lope de Sosa, de quien atrás se dixo que yba por mandado del Emperador á gobernar á Castilla del Oro, é Iomar residençia á Pedrarias é sus offiçales. É assi cómo fuć su nao surgida é se comencó á restir para salir en tierra, é acaló de dar órden en la manera de su salida á tierra, luego expiró é dió el ánima á Dios, dentro en la nao, sin salir á lierra. É cómo el gobernador Pedrarias le avia lıccho aparejar el resçibimiento, assi le liço sacar lionradamente, y enterrar en la yglesia mayor $\mathrm{y}$ episcopal, en el lugar mas preheminente della, delantedel altar mayor, al pié de las gradas, mostrando mucho dolor é sentimiento de su muerte; pero no sin mucha alegria de su coraçon, paresçićndlole que esto cra un miraglo é voluntad de Dios. en que mostraba quél queria que gober. nasse aquella ticra, é no otro, por estonçes. Pero pues con determinaçion de hablar verdad en todo se comencó esta historia, no se le dehe negar á Pedrarias su buen comedimiento é criança, que lo sabia muy bien haçer, como eortesano viejo, quando él queria: é assi á su liijo de Lope de Sosa, llamado Johan Alonso de Sosa, como á todos sus criados é á los que con él renian, los tractó muy bien, é les ayuló é ficroresçió. É entre todos los otros por quien él mas liço, é á quien él mejor gratificó, fué al liçençiado Jolıan Rodriguez de Alarconcillo (que Lope de Sosa traia para ser su alcalde mayor); pero no se dexó de sospechar que lo liço por el respecto é para el efetto, que adelante se dirá.

En este camino, que en la mar del Sur liço el liçençiado Espinosa, cstá é se des. cubrió aquel golpho que se llama de las Culebras; porque hay inumerables, que se andan sobreaguadas en la mar, de tres palmos é poco mas luengas, todas negras en los lomos, y en lo de abaxo de las barrigas todo amarillo, é de lo negro baxan unas puntas, é de lo amarillo suben otras que se abraçan unas con otras, como quien entretexiesse los dedos de las manos unos con otros, assi estas dos colores se juntan: las mas gruessas dellas son mas gordas quel dedo pulgar del pié 6 como dedos de la mano juntos, é de alí mas delgadas otras.

En este viage fué por piloto mayor Johan de Castañeda, buena persona é diestro en las cosas de la mar; y esto es lo que navegaron estos chripstianos en la mar del Sur hasta el año de mill é quinientos é diez y nueve años. 


\section{CAPITULO XIV.}

Cỏmo el capitan Gil Gonçalez de Avila fué á la Tierra-Firme con el piloto Andrés Niño, para yp deste Panamå a descubrir por la mar del Sur, por mandado del Céssar ; é cómo cl auclor destas historias volvíi á Castilla del Oro, é de lia forma que tuvo Pedrarias para despoblar el Darien.

\section{A} loto, llamado Andrés Niño; y este, cómo vido presso al adelantado Vaseo Nuñez, sintió que de su prission no podia resultar sino su perdicion, é que pudiendo aver aquellos navíos quél tenia hechos, se esperaba con ellos saber grandes cosas, é descubrir grandes riqueças en la mar del Sur. Essa invençion fué del thessorero Alonso de la Puente, el qual, con un criato suyo, llamado Andrés de Cereceda, que envió á España con este piloto, se puso entre ellos por movedor de la cosa. Llegados en España á la córte, el Andrés Niño intentó la negoçiaçion, é cómo no halló tanto crédito para que se le fiasse el cargo, puesto que era diestro piloto y experimentado en las cosas de la mar, jumtáronse él y el Cereçeda con Gil Goncalez de Ávila (contador del Céssar en esta cib. dad de: Sancto Domingo é Isla Española), que estaba en aquella saçon, el ano de mill é quinientos é diez y ocho, en la córte. El qual avia seydo criado del obispo de Palençia, don Jolnan Rodriguez de Fonseca, Presidente del Consejo destas Indias: é diéronle aviso de la prission de Vasco Nuñez, é conçertados con él, pidió el Gil Gonçalez el descubrimiento, é obtuvo la merçed, por causa del obispo, para quel Gil Gonçalez é Andrés Niño, con sus dineros é los de otros armáran, tomando Sus Magestades la parte que fuessen servidos de tener en esta armada. É fecha su capitulacion, diósele una çedula, en quel Rey mandó á su lugar leniente general é gobernador de Castilla del Oro, porque era informado que Vasco Nuñez de IBalboa, sin liçençia espeçial de Su MaTOMO III. gestad, fué á la parte de la mar del Sur á haser cierto descubrimiento con ciertos navios é grente, é que en él tomó é ovo algumas cosas, é que al pressente el Vis. co Nuñez estaloa presso, é porque Su Alteça enviaba á Gil Gonçalez de Ávila é Indrés Niño con çicrla armada al descubrimiento de la mar del Sur; por tanto mandó que en resçibiendo su çédula, proveyesse cómo se entregassen á Gil Gonçalez todos los navios é fustas quel Vaseo Nuñez llevaba é quedaron de su armada, para que con los demás, que de España Ilevaba, puliesse haçer el dicho descubrimiento é viage, por aute un veedor que para ello el gobernidlor de Castilla del Oro nombrasse, que le hiçiesse cargo de todo por inventario, é que lo proveyesse luego el goberuador, como cosa que mucho tocaba á su serviçio real.

Esta cédula yo la ví é se despachó en Barcelona á diez é ocho dias de junio de mill é quinientos é diez y nueve anos: é no habla con gobernador señalado, porque estonçes se tractaba de enviar á Castilla del Oro otro, é quitar el cargo á Pedrarias Dávilá. É assi en la mesma Barçelona fue proveydo de aquel offiçio é goberuaçion, desde á pocos dias, Lope de Sosa; pero quando el Gil Gonçalez llegó á la Tierra-Firme, ya avia passado lo que se ha dicho en el cápítulo preçedente del viage del licenciado Espinosa. É pocos dias antes que Lope de Sosa muriesse, llegaron al Darien el capitan Gil Gonçalez de Ávila y el piloto Andrés Niño, para entender en su deseubrimiento, en el año de mill é quinientos y veynte, poniendo Su Magestad çierta can- 


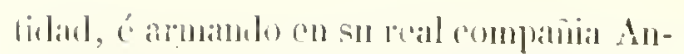

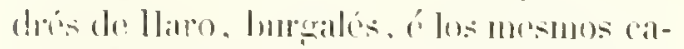
pilan Gil Comgale\% a piloto Andrés Nino,

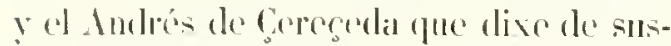
so pue yla proverydo pro thessorero, $a$ olros particulares que tambion ponian su palle en el armada. É luego Gil Gonçalez. deselr Acla comencó á entender on su despaclon, y en hager gictos navios en

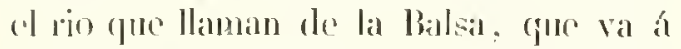
dare a la mar del Sur, en el zolpho de simet llignel porpue annque pressento la çédula que lie dicho, é requirió con ella á Peilrarias, aprovechó poco, porque á - arfuellos navios de Vasco Nuñc\% opusićronse muchos, diciendo que cran de compañia. É á tender á essto estaba Pedrarias muy puesto en estorbar á Gil Gonçale\%, Y esta coutencion no se acubara sin estar prinero podridos los navios, ý á esla causa fucra mas aparcjarlos que larer olros.

En esta armaçon entraron cl llessolero Alonso de la l'uente y el contador Dieso Marquez, offiçiales de Caslilla del Oro, por cuyo respecto Gil Gonģalez é sus consortes la pudicron sacar á luz; porque de ofra forma fuera imposible. porque al goJernador le pessaba desta amada ć le paresçia que demás de ser en verçiienga maya yr á su gobernaçion á armar otro. con liçençia del hey, le era grand cargo cofensa, é se apocalua su crédito. é no desacalua que por manos de olro se hiçiesse ni se supiesse cosa alguna de adguelli mar del Sur. É assi, en quanto él porlia, por diverzas formas. daba desvios á la expedicion y ariamiento de Gil Gongale\% con muclas cantelas.

Sentido csto por el capilan Gil Gonçale\% é entendidlo en parte la condiçion é cobdiçia del gohernador, é por aviso de los offiçiales el thessorero Alonso de la Juente y el contador Diego Marquez, que de mas dias é mejor le tenian conosegielo, se acordó de meterle en compañia en el armada. poregue por esta via seria fíçil

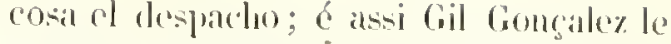
mos ió unn partide allogo donoso, é furé que le rendiesse Pedratrias un negrillo que tenia volfoulor, 6 yue le daria por él trescientos pressos, é que aquellos los laviosse

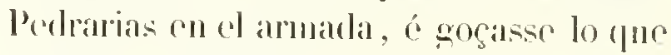
dolla progedicrse por rala lo fue fre cupiesse, por ragon de los tresçientos pessos. Con esto, lnegro antró é remlió al negro en el prossio que hro dieho. é se assentó aquella cantidad en al caudal por Pedrarias, romo armaulor é partiçipe de la compañia de afuella arualda, como si de otra cosa no tuviclä lanta nescessidad como de un muchacho que rolteasse, que amm para stumele no era: á con esto luego le començó á favoresçer d golucrnador . ć clió lugar á su despricho, puesto que á la rerdad. ammque lo disimulaba, todavía le pessaba en ol ánima deste descubrimionto, el qual se hicgo de la manera que se dirá en el signiente capílulo.

Desde a procos dias que murió Iope de? Sosa, é algumos meses antes que Gil Gonsulez se pariesse á descuhrir, llegué yo al Darien con mi muger é dos hijos, creyendo hatlar gobernando la lierra á Lope de Sosa ć llegrado al puerto de sanet Johaun. en la noclie regnte é qualro de junio del año de mill é quinientos é veynto, liablé allí otra nao. de la qual supe la muerte de Sosa. que yo sentí en ol ánima: prorgue luego me hallé é tuve por mas presso que si me vielia en tierra de moros. porfuce en la verdad yo avia proenradlo y hecho todo lo que en mí fué para que Pedrarias fuesso removiulo. É túreme. por perelielo, é no me engañé en ello, ni me desembarcara. si no fucra por mi mugrer é hijos : pero conto no pucle hacer otra cosa, atendí á me encomendar á Dios y esperir su socorto: que otro no le tenia. lu luego por la mañana. ol dia siguiente. envié nn hombre á licrra é dí notiça al gobernador de mi llegaida: el pual me envió á derir que lolgaba mucho de mi re- 
nirla, é que saliesse en hurn lorara: quél mo tenia por amigo é luren servidor de Sa Magrestad, é entendia aýdarme é honl'irme, cono si fursese su lijjo ó hermano, en torlo lo quíl pudiesse. Y en fin, aumpue yo creia otra cosa, salí con ni compania, ćalli luego á la costa vinieron á ne visitar é acompanar el bachiller Diego de Corral é Diego Maldonado: los quiales, de parte del gobernator, me dixeron lo que es dicho é otras muchas palabras rle amor. É llegado á la cibdad, firy á le lacer reverencia; é mostró holgarse mucho de mi venirla, segund de los attos exteriores se podia entender : é luego el gobernator fuć á visitar á mi muger á la posada é la labló con mucha cortesia.

En este camino yo avia tocarlo en cita ciludal re Sancto Domingo é supe aqui como doña Isabel de Bovadilla, muger de Perlıarias, avia licelio escala en la Yacruana, que es un puerto que está en esta Isla, al Oçidente, é la enviaba el golecmador á Castilla con mucl 10 oro é perlas (segund fama) por se hallar mas desocupirlo para la residençia, que esperaba que le avia de tomar Lope de Sosa, é por tener la haçienda puesta en cobro: fue es ma de las cosas que en estas partes nucho se usa entre golsermadores é jueçes, furando se les acaba el offiçio, que huyen con el dinero antes de la cuenta, ó la esperan, teniendo alçada la pecumia.

Desrle á dos meses despues que llegué al Darien, me llevó Dios uno de mis hijos, en edad de oclro años, é junto con este pessar lo que sentí de la muerte é filta del golsernador Lope de Sosa, muchas veges esture determinado de me tornar cn la mesma naro que fuy, si la nescessidad é la verguienca no me forçíran, porque yo yba cargado de casa é muger, é nuy de assiento. É lo que mas me obligóó a esperar lo queviniesse, fué porrque, por mandado del Emprerador, yo avia de colorar çient mill pessos de oro que avian darlo á cutender á Su Magresiad que valian los bienes, que le avian aplicarlo á su cámana é fiseo cn las condenargiones del adelantarlo Vasco Nuñez de Balboa é sus consortes; y volverne sin cumplir el mandamiento del Gúsar, pues que estalda ya en la tierra, fuera notable cror, y allende desso yo yla gristado. Todas estais causas me hicieron que me defuvirssu, puesto que so tenia por cierto quel gobernador avia de procurar de destruyrme. porque tenia aviso que en España no avia Lablado bien dél, é que avia procurards la yula de Lope de Sosa, é porque perli la gobernaçion de Sancta Marta para mí, como era verdad, é me fué concedida, é porque no se me otorgaron çient lábitos de Sanctiago para gient hombres hijosdalgaro, conno va lo dise en el libro XXTI, en el capútulo I y en el liI, dexé aquella empresa (lo qual se le quilalia a Pedrarias, é se le quiló de su jurisdiçion despues). E prinçipalnente yo temia quél me avia de hager malas obras, assi por lo que es dicho, como por las que ef me avia fecho; é á muchos avia diclio que me tenia por enemigno. Demás de lo yural, le pessaba en el ánina, porque yla por reseptor de Su Magestad para colorar los bienes del arlelantado é sus consortes é de todis las penas de la cámara real: é sin esso llevé á cargo la escrilumia gencral del secretario Lope Conchillos, y el oflicio de la fundicion, allende del que yo me tenia de verelor, y en todo avia de tener mano. lí lo cue mas daño me larcia en la opinion de Pedrarias, cra pensar el rue yo sentia algo é trina el reginniento propétuo de aquella ciblad del Darien para mi é sendos para los otros officiales, é otro para aquel bachiller Diego de Corral, los quales todos yo negrocié, aunene de fodos ellos ni ove las gracias, ni aun me pagraron los derechos del despacho de las prorisiones: lo qual yo hiçe é procuré, assi por los honrar, como pringripalnente por- 
que era serviçio de Dios é del Rey excusalr que cada año Pedranias haçia regidores át sus criados é anigos en aquella ciblarl, lo qual él sintió.

Demás de lo que está dicho, llevé una gédula para que el golıernador gobernasse solo sin los offiçiales; y desla manera, aunque cra en su favor, yo no la gané sino pensindo quel gobernador era Lope de Soza. Llevé otra para que los officiales no tractassen, y olra patra quel gobernador pusicsse las punlas' y el toque, con quo se quilataba d oro en quilatador, que diesse fimpgas: quel oro que quilatasse y en España paresçicsse de monos ley, quél é sus fiadores lo pagarian. Lleré las ordenanģas é fueros de la casa de la fundiçion; llevé merçed por quatro años para la tielra de la franqueça de los derechos del almoxarifazgo. Llevé más: quel primero año despues que yo llegasse, se pagasse al diczino del oro de minas al Rey, y el securullo año despues el noveno, y el otro siguiente el octaro; é assi rliscurriendo, lusta quedar en el quinto. E otras merce. des é franquegas llevé para la tictra é pobladores della, que grencralmente á torlos fucron úliles é provechosas, é á mí solo dañosas; porque demís de no me aver bado nadic, para gratificaçion de mi tratbaxo é gastos, un real ni valor dél, aunque, como en otras partes he dicho, fuy á Flandes, é gasté de mi laçienda la mayor parte, buscando el remedio de aquella tierra, como todo lo que yo liçe era á propússito de la comunidad y de todos, ningun particalar me lo agradesçió. Antes de alqunas cosas se resabiaron el gobernador 6 offiçiales, é todo el fructo que saqué, fue. ron muchos trabaxos é perder el tiempo é laçienda propria, como adelante se dirá, puesto quel gobernador é lodos mostraron mucho contenlamiento en aver yo tornarlo á la ticra é aver trayclo tan seTidadas merçedes para aquella cilodad é toda las provincia.
Mas cómo Pedrarias vido el tiempo dispuesto, é yo pressenté aquellas çédulas é provisiones que he dicho, él decia ntaravillas en mi favor, loando lo que avia hecho por aquella tierra: é por otra parte dixo á los offiçales que lo perdonassen, quél no quisiera gobernar sin ellos; pero que yo avia traydo aquella gédula que lo prohiloia, é la otra para que no tractassen. É lo uno é lo otro sinticron mucho: porque les era grand estorbo para sus cobdicias, é se les quilaba el mando é grandes interesses de haçienda; pero disimularon é tuvieron su cuenta conmigo, para dañarme en lo que pudiessen.

Desde á pocos dias el gobernador acordó de yrse á Panamá á esperar al liçenciado Espinosa. alcalde mayor, que aria dos años que andaba en la costa del Sur con los navios de Tasco Niunez, adquiriendo lo que podia, como lombre que se queria yó á España y no perseverar en la lierra.

Cómo yo ví quel gobernador se yba á la otra mar, híçe cierto requirimien1o, dlándole á entender que era despoblar aquella cibulad, dexándola él en tal tiempo; porque los officiales se yban con él, y él y ellos con delerminaçion de as. sentar en Panamá en la costa del Sur, é algrmos dellos en el Nombre de Dios en essotra costa: é expresé muchas raçones, por las quales el gobernador no debia yr; pero no lo dexó de haçer por esso é llevó consigo al thessorero Alonso de la Puente, é al contador Diego Marquez, é al fattor Miguel Johan de Rivas. É porque cl thessorero y el contador cran regidores del Darien, é no volviessen át aquella cilsdarl. dióles repartimientos de indios que los sirviessen en Pananá, ques ochenta leğuas del Darien: é aqui se vilo claramente quel gobernador queria despoblar el Daricn, assi porque la avia ganado é pohlado Vaseo Nuñez. su verno á quien 
aria degollado, como porque una vez que descle allí se avia querido yr Pedrarias á Espaĩa, sin hager residençia, el regimiento de aquella cilolad le detuvo. I tambien se quiso yr á Panamá, por hallarse pressente al recoger de los despojos, que esperaba que avia de traer el alcalde mayor de la costa del Sur, é porque en lo que su gobernaçion tenia en estotra costa del Norte todo estaba hollarlo en lo fune no avia flecheros (porque donde los avia, no le paresçió ser á su propóssito) : é junto con esto se deçia quel alcalde mayor y el capitan Badajoz avian ya vuelto á la otra costa con mucho oro. Assi que, por eslas causas aprovecharon poco mis palalras ni las de otros muchos que decian lo nesmo.

Determinado de se yr, liço una diligençia donosa, por manera de cumplimiento é abono suyo: é fué que aquel liçençiado Alarconcillo, que avia ydo con el gobernador Lope de Sosa, líçole Pedrarias su alcalde mayor é teniente, é hiço preggonar residençia contra sí mesmo por treynla dias en el Darien. La qual hiço á su plaçer, porque como se quedaba en el ofliçio é haçia su juez á su teniente, todo aquello era publicar conçiençia, de lo qual muchos se reian, é ninguno que tuviesse quexa dél no le osó pedir nada. .

Esta residençia fraudosa envió á la córte en tiempo que se aprovechó mucho deHa, porque en aquel tiempo el Rey, nuestro señor, no estaba en España, ni sus goheruadores en dispusiçion de entender en mas de paçificar las Comunidades: en lo qual el reverendissimo Cardenal de 'Tortosa, que despues fuć Papa Adriano, Vl de tal nombre, y el condestable de Castilla don linigro de Velaseo, y el almirante de Castilla don Fadrique Enriquez, que eran los que gobernaban, importunados de doña lsabel de Bovadilla, muger de Pedrarias, é de un Françisco de Liçaur, su procurador, le enviaron comi- sion al mesmo liçençiado Alarconçilio, para que tomasse residençia al gobernador, sı amo, é al liçençiado Espinosa, é á los que avian tenido cargo de justiçia por Pedrarias. En tanto que estas provisiones llegaban, estaban en Panamá el gobernador, y el thessorero, y el fattor; $y$ en el Darien estábamos el contador Diego Marqucz, é yo, que era veedor, con nuestras nutgeres, é por teniente Martin Estcte, que era casado con una criada de su nutger de Pedrarias, hombre de ninguna expiriençia en letras ni en armas.

Poco tiempo antes desto avia salido del Darien el bachiller Diego de Corral por capitan con çierta gente, por mandado del golvernador, á paçificar é visitar la comarca á la parte del Abrayme é Caranura é otras provinçias; é de lo que liço adelante se hará mençion.

Assi que, estando las cosas en este estado, vino á Panamá el liçençiado Espinosa con treynta y tres mill pessos de oro é más, que avia avido de indios salteados é despojados por la costa del Poniente. Estos demíts é allende de los otros veynte nill, que se ha dicho que tenian alli enterrados. Luego el gobernador envió á requerirnos al contador Diego Marquez é á mí, que estábamos en el Darien, que fuéssemos á Panamá ó enviásemos nues. tros tenientes, para que aquellos çinqüenta é tantos mill pessos, con otros que por rescates é otros de las minas se avian allegado, se fundiessen é quintassen, é Sus Magestades tomassen sus quintos é derechos, é lo restante se diesse á quien lo debia aver; y en espeçial fuy yo requerido (jorque á ni cargo estaba la fundicion, é tenia yo las marcas é cuños reales del oro, é á mi cargo era de cobrar los hienes del adclanlado Vasco Nuñez de Ballıoa é sus consortes por la cámara é fiseo) só çierlas protestaçiones, que contra mí protestó un procurador de Pedrarias. É viendo esto el contador Die- 
zo Marquez é yo, determinamos de yr á donde ol erolorernador estaloa: é Diegro Marefuez furosse de allancarla, é Heró su

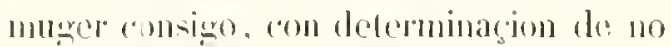
rolver al Dillien, é yo desé la mia allí. non olsstante fune canda dia los vecinos se yban, porepue el gohermador les pronedia é alalia indios de reparlimionto é ofros provechos á quantos dexahan arpolla ciblad. É assi cómo otros la desampraraban, comencé yo á labrar é dexé la traça é dincros á mi muger para que hiciesse mi casa: é hiçola lal, yue ninguna hasta aquel tiempo avia en la Tierra-Firme como ella.

Con esto la cibdad tenia alguma esperanga, porque aunque los otros ofticiales del Rey la avian desamparado, yo no lo avia hecho: é la cibdad me dió supoder, para que hiçiesse sus negrocios con ol gobermador.

Despues que llegué á Panamá, en mi pressengia se desenterraron los veynte mill pessos de oro de Paris, que el alcalde mayor avia traydo de su primero viage, quando dexó allí en rentarda de esse oro al capitan Gonçalo de Badajoz con poca gente, é de temor de los indios lo avian sepultado. Este oro, é lo quel liçençato traia, é lo que se avia salcado de las minas de Panamá é Capura ć Juanaga jor los veçinos del Nomlre de Dios á P'anamá, seria todo septenta mill pessos de oro.

En este tiempo llegró al Darien el Bartolomé Corral, perdido él é los que con él fucron. é aviendo hallado de paces la tierra por donde anduvo, dexóla de guerra en virtud de sus letras é poca maña. Patra lit emmienda desso fué luego á entrar el teniene Marlin Estete, e con ciertas canoas por aggua: é hícolo muy peor, é carla uno dellos fué hor ta parte para cl algamienor érebelion de los indios é dessolarion de apucolla cibdad, la qual en ađpuella saçon era la mayor é mejor poliaçion que chripstianos temian en la Tierra-Firme.
En este tiempo (puce batehiller Comal y

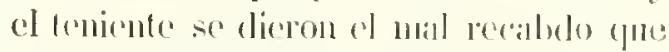
es dicho en a d Darion, so fundió (on l'ana-

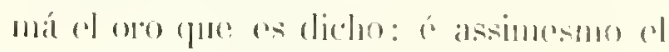

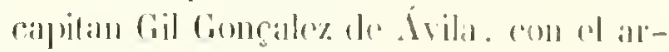

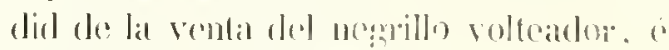

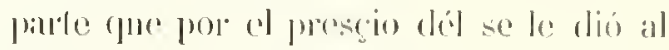

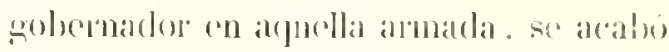

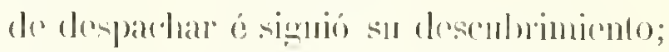

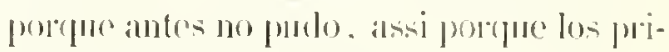

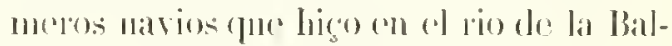
sil se le pudricron del sol re lluvia, é con

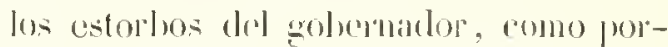
que si el ilegrrillo no lonára, numea de allí salicra.

En fir año de mill é quinientos é resnte y dos, partió é fué la via del Oçidente, é descubrió lo que adelante se dirá; é poeo anles yo me parti de Panamá para el Nombre de Dios. año de mill e quinientos é veynte y uno. é de allí para el Darien, por mar. en una caravela mia. É al tiempo de mi parlida requerí al gobernador, en nombre del Darien, todo lo yre me paresçió: é alli le dixe cómo á su causa aquella cibdad se perdia, ó tomé mis testimonios contra él. É cómo le pessibal que aquestas cosas anduviesen por eseripto, acordó de rogarme que quisiesse encargarme del Darien é su provincial, é tomasse la vara de su teniente; forcue deçia él que go me daria tan buen recalslo, que la cibdad é toda la tierra se sosternia, é daba raçones para ello porque él no podia quitarse al pressente de aquella mar del Sur. Yo no (pueria aceptar el cargo, assi porque me tenia por mas homado eon ser official del Rey, que no con sel teniente suyo, como porque no rueria yo tal cuydarlo: é díle por exeusa que siendo officiad del Rey, no avia de tener officio por él, é que cacria en alquna pena. pensando que servia mal en cllo. Finalmente. rogándomelo él ć ohos, acol-

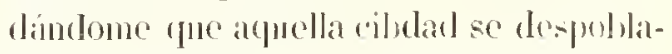
ria. a yo premia mi haricula si no avia 
quien della se doliesse, açepté el cargo, y el gohernador me lo mandó de parte de Sis Mingestades, sin em! hargo de mis officios de reedor de las fumdiciones do aquella gobernaçion é regidor de aquella ribdad é receptor general de la címara é fisco por Sus Margesalales, é porrue assi decia el golvemator que convenia al serviçio de Sus Magrestades. É assi me lo dió firmalo de su nombre, é yo lo açepté, porque tenia en el Darien mi muger é mi casa, é me avia allí heredarlo por mi mal, é porque assi lo tenia Dios ordenado.

En la lıora que se mé dió la provision, por la qual avia de gobernar acuella cil)dad é ser capitan de aquella provinçia, diso Pedrarias á algunos que por mi mal avia tomado aquel cargo (é assi fuć ello); porque mi condicion de hombre libre no pudo comportar cosas feas é lorpes, pues fuerer hagel justiçia entre gentes acoslumbrarlas á cesar sin ella é á mal vivir, no porlia ser sin nucho riesgo de mi pere sona, en especial estando tan aparojada en el superior en la licria la mala volumtad que contra mí tenia. Y aumene no igynoraba esso, por no ver perder la cibdard é mii casa é assiento, ahaxé la calregia, fiando en Dios, que es solme todo, i volví al Darien, de donde avia salido en el mes de agosto: é volví un sáluado nueve de noviembre del mesmo año de mill é quinientos é veynte y uno. É otro dia luego siguiente, que fué domingo, enterré á mii muger, que avia diez dias que estaba enferma: é con el dolor de pérdida lan triste para mi, transportado é fuera de sentido, viendo muerta á mi muger, que yo allaba mas que á mi, estuve para perder el sesso; porque demás de lan dulģe compaũiti, é ser mi dessen vivir en el estado matrimonial, como chripstiano, no cra acostumbrado á las mancebas que mis reginos tenian (é aun algunos duplicadas).

Este trabaxo mio plugo á los que me desamaluan, porque como luego me puse con la vara de justiçia en castigar los pecados públicos (en que muchos avia envejesçidos), presto fuy aborresçilo, porque no consentí que se pesasse came los sábados, como hasta estonçes lo haçian é la comian: lo segundo mandé pregonar que no tuviesse ninguno mangelua pública, é como sabian que lo avia de castigar, se apartaron los que las tenian públicamente á pan é cuchillo: Io terçero quité los juegos é hice quemar públicamente en la plaça todos los naypes que avia en el pueblo: lo quarto, castignć lás blasfemias: lo quinto, á un escribano tirano que robaba aquel pueblo, condenéle en çicitos quatıo tantos é suspendíle del offiçio por un año. En cada cosa de las que prohibí, fuy constante en casligar los transgresores, é defendí que no se cargassen las indias, que se servian dellas los chripstianos como de asnos. is assi hiçe otras cosas, en que yo pensaba que servia á Dios é al Rey, é que cran en pró é utilidad del comun: é lodo fuć para mis trabaxos la yesca que los encendió en las voluntades de los que me pusieron en la extremada nescessidad, en que me rí. 


\section{CAPITULO XV.}

Como el coronista quedú por capilan é teniente de gobernador en el Darien; é cómo los indios del caçique de Bea mataron al capitan Martin de Murga é i olros elıripslianos : é cómo por aviso a industria del dicho capitan, anctor destas historias, se paçificaron muchos caçiques $e^{2}$ indios caribes é fleclıcros de la cosla, é se meticron en el Darien muchos pessos de oro por rescales.

Q uando pressenté la provision de Pedrarias en el calbildo é regimiento de la cil-dad de Sancta Maria del Lutigua del Darien, fuy resçebirlo por su teniente con mucho plaçer de todos, porque vian quel gobernador miraba con enemistad las cosas de aquella cibdad, é que los otros officiales del Rey se avian desavegindado de allí, é passádose á Panamá el thessorero Alonso de la Puente y el contador Diegro Marquez, y el fattor Miguel Johan de Rivas al Nombre de Dios, é que yo avia querido perseverar é no haçer la mudança quellos. Antes compré las casás del contador é otras, y en lo mesmo que las pagala de contado las rendi fiadas á otros, é compré vacas é puercos, é di carne aluasto al pueblo, cl qual lıasta allí nunca la turo de propria criança ó cosecha.

En toda aquella jurisdiçion liçe una bucna quadrilla de esclavos è negros para sacar oro de Jas minas. Conçerté todas las diferençias gue pude entre los reçinos sobre sus debdas, y en algunas puse de mi casa mas que palabras por conçcrtar é arenir Jas partes. Hiçe muchas ordenancas y estatutos para pró é utilidad de la república. Pero, como dixe de susso, no todas estas cosas plaçian, sino las menos dellas, por la mala costumbre é soltura en que rivian. Hiçe en espeçial una cosa muy úlil é provechosa á la ciludad é á mí é á lodos en general, que fué aquesti. Provey una caravela mia de gente é viluallas, é Jien armada de paz é de guerra, y enviéla á la parte de Levante á los caribes de Cartagena é isla de Codego é otras partes; é sin me ayudar el Rry ni otras personas, sino á mi costa propria, dí prinçipio á los rescates con los indios hravos é á la pacificaçion dellos, no porque yo fuy el primero rescatador que aguesto comengó, poryue como en otras partes he dicho, el capitan Chripsólnal Guerra é Johan de la Cosa, Bastidas, Jolıan de Ledesma, Hojeda é otros muchos avian antes corrido todo aquello, é los mas de essos, só color de rescates, rol rando è alterando. Pero lo que yo liçe fué rescatar, pacificando é amansando lo alterado, é rescalé é ore en pocos meses mas de siete mill pessos de oro. I causa de lo qual, é por mi exemplo, los veginos del Darien compraron navios, é algunos Jos hiçicron de muero; é continuándose la mesma grangeria, se metieron en aquella cibdad en breve tiempo mas de çinquienta mill pessos de oro, de paz é sin riesgo, ni matar ni enojar á indio, como se dixo mas largamente en el capítulo III del Jibro XXVI, é en el caprítulo IV del mesmo libro. Lo qual fué causa de mucha reformaçion é remedio de aquella cibdad, é se faroresçió é ayudó mucho á causir de mi indıstria.

Junto con esto fuy temido juez, por no aver disimulado los pecados públicos, ni dexado de hacer justiçia (annque templada fuesse); ć cada uno sabia que no tenia nada en mí para se guedar sin pena ó moderada correccion, si culpado fuesse. De lo qual no poca indignacion contra mi folmaron algunos; porque al que yo casligaba, si apelaba, le alssolvia el gobernador é le daba dineros; è cómo estalan á su lado el thessorero y el contador è no tenian olvidadas aquellas rédulas que lle- 
vé para que no tuviessen voto en las cosas de la gobernaçion, ni tractassen como primero lo avian hecho, catos cran los que favoresçian los que yluan quesosos, aunque justamente yo los oriesse penado. Y desta forma on poco tiempo esture mal quisto de los tales é de sus parçiales; pero con los buenos é con los que estiban sin passion cstaba en su gracia. Mas estos $n$ o cran parte para me ayudar, quando me vicron en nescessidad. Antes fueron pocos los que osaron mostrarse por mis amigos, porque vian notoriamente quel gobernador me era contrario é que hablaba mal en mí, é muchas veces avie dicho estas palalnas: "Yo conozen que otro haria mejor lo que toca á la buena gobernaçion destas partes; é informato el Emperador, nuestro señor, desto, avia proveydo á Lope de Sosa, que haya gloria, que era buen cavallero é lo liiciera muy bien, é porque el veedor Goncalo Fernandez de Oviedo no faltó de lo acordar é soliçitar. Yo holgara de verme libre é retraerme ya, si Dios nofuera servido die me tener en estos trabaxos ć fatigas, que tengo en la substentacion destas partes . con tantos gastos de mi laçienda é con tan pocos interesses, é con tanlas enfermedades é con avérseme mucrto en esta tierra uno de mis hijos." É assi cntonado á este propóssito, deçia ofros muchos cargos que cchaba á bios é al Rey con su persona, los quales los que le escuchaban, açeptaban, é decian que sin dubla Dios queria quél gobernasse é no ot'o. É assi passaban tiempo con lagoterias 6 cosas que tenian en contrario bien clara lir respnesta, porque él é sus ministros é capilanes assolaron é destruyeron la tierra con robos é crucldades, sin los castigar, como en parte lo cuenta la listoria ; é lo quél y cllos llamahan pacificá, era yermar é assolar é matir é destruyr la tierra de muchas maneras, rolando é acalando los naturales dolla. E porcpre ro TO.10 III. lo decia alganas veges, me tomaroi en mala opinion los que quisicran que yo ovicra seguido el camino de los otros jueces.

Acercándose ni penitencia, signióse que un veçino del Darien, Ilamado el capitan Martin de Murga, rizcayno, cra visilador de los indios, por Pedrarias, de la provincia é repatimiento del Daricus: el yual me pidió liçençia para yr á risitar el cascique de Bea, que le estaba cncomendido á él, é vivia en las lagunes, çerea del rio Grande; é yo no se la quise dar, é le dice yae no fuesse allá, porque me avian dicho que aquel caçique e todos los de la tierra estaban alçados, desto quel bachiller Corral é Martin Estete, só color de visitar la comarea, la avian kevankalo; é quic en ninguna mancra le daria lisencia, porque yo no queria que to matassen á él é á los que con él fiessen. Desta respuesta se quexaba á muchos de mí, é no faltó quien me lo cỉxo é mandéd llamar, é dixele: "Martin de Alurga, dicho me han que os quexajs de mí, é no tenés raģon, porque si no os doy ligençid, es porque no os mate vinestro caricque, é querria yo que quando fuéssedes, fuesso de manera que tuviéssedes segura la vue:ta, é no quedássedes allí mıerto. Por vuestra vida que no murmurés de mí, ni digays que os ceho á perder é que no quicro que medrés, é por mi causa no vays por mil pessos. que deçis que os tia prometido vuestro caçique. Yo no lo hago sino por lo que os cumple; é si otra cosa á ros os paresce, tracel un escribano é requeridme lo que quisiérches: que yo duré mi respuesta, para que en todo tiempo parezea mi descargo con Dios é con el muri(d) todo."

Estonges el Martin de Mlurga dixo que me bessalua las manos. porpue te daba licençia que me requiriesse, é que me pedia por meresed yne no me pessasse del requirmiento. Yo lo rejilíqué que no nes pessaria, sino (fue loolgarlia dello. Lin fin, 


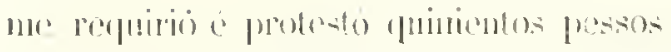
contra mi, si no le daba licencia pata yo á

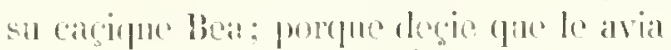

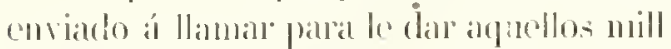

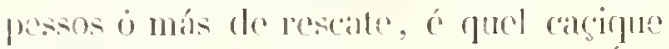
no cstaba alçido, sino mus pacifico. I lo fubil yo respondi que púlylicamente so sos-

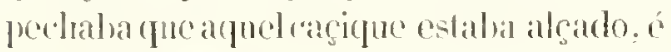
que mo paresçia é le aconsejala no fuesse allí, puesto que parra yr él no tenia nesecseidad de mi liçengia, pales que era visilador de los indios del Daricn. ó sin clla jodia yr donde quisiusse; pero que si todaria quiriesse mi consentimionto. qune go le daba licencia ron tanlo rue fuesse como era racon, ó de namera quélé los ane ron d fuessen no resçibiessen daño, nii fucssen á poligroro.

Pissado aynesto, el capitan Hurga se partió, sin le ver yo ni saber más en ello; "Hevó consigen en dos canoas á un Ruy Lopez de Talavera, é á un Jolan Lopez de Llerena, ó á un Jolran de Hedellin é diez ó dore indios mimsos. que bogaban. É llevó camisas é lachas é otras cosis. para dar al cacique é ál sus mugeres é indios.

Aquella gente de Bea está metida en mas lagunas, cerea del rio Grande, Hamado Sanct Johan. (fuc entra en el golpho de Lrabá; y es tal el assiento del cacique é de sus indios, que en algunos licmpos del año es muy peligrosa la cntrada, y en especial en el tiempo de las aguas; y es gerca del Darien.

Llegado este capitan Murga é los que lee dicho á Bea, fueron muy bion rescebidos, é abracólos á todos cl cacipile: y el capitan le dió gentiles camisas á él é á sus mugeres a alomos de sus indios principales, c les dió lachas vizeaynas é otras cosas: é para ver cómo cortaban, las pusieron luego en astiles. Á el cacique hico largo dar de conce al rapitan é chripslianos é a los indios manos, que con él rhan. de muchos é luenos pescados é

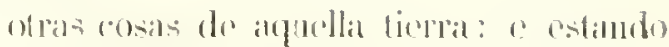

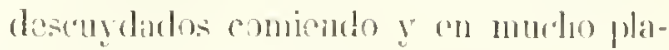
çrer. les direm sendos hachacos por detrís en las caluecas á todos quatro, quese las lendieron, fo no furiopon sentido para pelene ni se defender; poręure trás al prinuel wolpe heridos, acurdicron ron nlás 6 más golpes en el instante, é más indios, ć presto los acalaron de matar. Ĺ ataron á los mas de los indios mansos, para los licrlar por esclaros: é algumos dellos se cseiparon con (anto que mataban los chripslianos, 6 se tormaron al Darien.

Feclio aruesto, cl cariajue de Beas para solempniçar su traycion. púsose un çinto de oró un collar de lo mesmo, é junfados sus indios, ataron una cuerda á los piés al repilan Martin de Muroga, é tirando por ella, lo llevaron rastrando un quarto de milla apartado del bulnío, é lo dexaron allá para que las aves se lo comiessen. Por donde le llevaron rastrando, yban muchos indios é indlias é muchachos, con mucho placer é risa, cantando su areyto: ć el carifue. de quando en quanto. con mà macana guarnescida de oro, le daba un gonpe en la boca, é deçia: "Chica oro. chica oro, chica oro, "que quiere decir: "come oro, come oro."

Hechas csas obserquias á la macrle é imprudençia deste capitan. fomaron los cuerpos de los otros tres españoles, é assincsmo. arrastrándolos, los echaron en el canpo. De los indios mansos (que avian ido con essos peceadores cluripstianos. desde á tres ó quatro dias despues, tornaron algumos al Darien. ć dentro de oclio dias los más dellos, do los quales se supo lo que es dicho. F́ tomada la informaçion. deteminé de rá ó enviar í castigar afuel racique Bea, é aperçelí gente para cllo.

Y porque á ninguno de los mílites dostas partes que mal han acahado falla culpa para su casligo, por una ó por otra via, es de saber que este Mtmrga avia seydo alonaçil é ministro de las cruchades 
que an ia licelo el alealde mayor Espinosa en los viages, que aria licelio por la tierra desta provingsia de Cueva.

Teniendo yo aparejada la gente que avia de yr contra Bua (assi porque en la cibdad ayic poca gente, como porque cadia dia éramos menos, porepue el gobernador, á quantos yban á donde estaha, los halagalsa é daba repartimientos por allá, é los menos volvian al Darien), de temor de lo acaesçido á aquel Murgà, é porque se sospechaba que ofro eaçique, llamado Guaturo, se avia confederado con el de Bea é con otro, que era notorio enemigo de los cluripstianos (é muy varon) que se llamaba Corobari, é alçado andaba dias avia, é tenia dentro en la cibdad, en casa del bachiller Corral (al qual estaba encomendado por repartimiento) la madre é la mugrer é los hijos, é era cercano pariente de una india quel bachiller tenia por mançelsa, en la qual tenia lijos: y deste Corobari, como de ladron de casa, teniamos grand reçelo, porrque estaban dentro en el pueblo parte de sus indios, é cada dia le podian avisar de la poca gente é reçindad que ya éramos; con todas estas sospechas é indiçios, que cada cosa dellas cran de temer, lice armar é poner á punto tres canoas é una barca é bastimentos, é aun la mayor parte di de mi casa ó se pagaron con mis dineros. É acordé que fuesse con un mandamiento mio el capitan Johan de Ezearay. á prender el caçiyue Bea é los mas indios, que puliessen averse de los culparlos, è llevasse consiggo hasta quarenta lombres, é los diez dellos ballesteros, é que llevas. se por gruias dos ó tres indios de los nuesmos quel capitan Mrarga llevó, quando le malaron: é yo quedé á guardar la eibulad.

Estando on esla determinaçion, para yue otro dia siguiente el capitan Johan de lizuaray é lis grente que es dicho. oyendo prinero una misa do Meprírilu Sanceto, se partiessen, pessíndole mucho al bachilter
Diegry de Corral que arpuesta gente fuesse, porque se avia de saber enteramente la eulpa quél tenia de la rebulion é alçamiento de lia tierra, por donde el avia andarto. só color de la visitar; é porque aquel raçique Bea era pariente de la india Elvira, su mançcha, é de los hijos que en clla tenia, comencó á poncr grandes inconvinientes en la yda de arpuclla gente, é deça publicamente que yban á mucho pelisroo, y á esse propóssilo odras palabras escandalosas, atemoriçando los que cslaban nombrados é aperçeljidos para el viagre. E cómo regidor de aquella cibdad, the diso muchas cosas para removerne de mi buen propóssilo, diçiculo que ya yo via quán sola quedaria aquella cibdarl. si enviadi aquel capilan é hombres que tenia acordado, é si alguna nescessidarl sobreviniesse al pueblo en absencia de aquellos, no quediabin otros tantos yte defendiessen aquella república; ć si se crraba el viage, ó algun siniestro les ocurriesse, que yo era digno de mucha culpa, é que yo apociba las fuerças que nos fuclahan, rese can ya reducidas á tan poco múmero de hombres; que yda esta gente, olmos cariques de la comarca se atreverian á renir á pegar fuego á la cibdad, é que de todo cl daño que viniesse á los que yban é á los que querlálamos, yo cra el ministro, si no mulása ni voluntar é tomalua su conscjo. Y á este propóssito suyo dixo otras cosas, en que notoriamente para entre gente commn é basa é de poco entendimiento paresçia que su raconamiculo era lleno de buen selo, é que en lo que decia echalıa cargo á la ciblad, é que á los que yo mandaba y r los excusaba de un notorio y evidente peligro, é que yo me moria á esto enn rial consejo, é como hombre agelerado é no llegardo á racon.

I esta plálica estaba la mayor pallo del pubblo escuchando é untando, ć co100 yo estaba deleminado de curial di 
ras!igar á los delincpiucntes, por ser muy conviniente para excensarse otros alrevi-

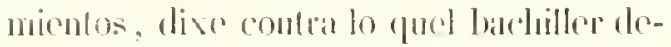
gial desta mancra: "Scuñor bachiller. pésame. porefne ruestras palabras me constrimen á que os resposula en públiea placa. pues que en ella arers querido dar á antender á estos señores vecinos é amigos nha rosia tan desviasla de lo çicrto é tan perjudiçal á lodos, é ype dedaso de restials caudelas ficlas y comleresgadas á ruestro interesse. hava otho entendimiento en li verkad, romo le hay, muy al revés de lo rue querriades que se os creyesse. Claro cád que si d atreviniento é lraysion, que bea ha cometido en la mucrle deleapitan hartin de Hurga y essotros peeradores, que con il mató, se disimulasse, que nascerian de esso otros daños mayores; y aun el mesno Bea ternía mucha causa para renir á quemar nuestras casas 6 aun nuestras personas con otros sus conferlerados, porque sabe que en vuestra casil colán los ligones, do liene sus espias c dehidos en ruesiro hijo Perico y en vuestra Elvira, de quien to ovistes, que es su prima de Bea. Ý á ros peor que di ningruno os está luablar en esto, y al que mas le conviene este castigo de bea soys vos, salvo si no pensays que lenés en él las espaldas seguras por los deludos que Ii dicho. Todos essos inconvinientes que ros poneys son excusados, y eslos hidalgos, (que yo envio con el rapitan Johan de Ezcaray son tan buenos, é lan leales, é ian experimentados. que bastan á mayor cosa que la que yo les eneomiendo; é a cadiano dellos le va en esto tanto, que aunciue el número de sus personas es poeo. (d rabo dellas es mucho para que todo se haga muy bien, é como Dios é Sus Mragestades se sirvan y esla cibdad se anegure. Y yo quedo aća para la velar é guardatia de las espias é debdos de Bea é de vuestro Corolari, que sabés é sabemos lodos que es un siand perro. que solme averle perdonado dos veres sus desleadtades, y averse lapticalo, y llat marse chripstiano, anda la lergera aluardo, y es al mas pujudicial enemigo que esla

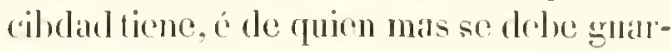
lar por vuestro respecto: pues yue en vuestra casa están su nudre, é mugrer, é lijos, é otros indios con quien se debe cntender: é tambion es debilo de vuestra Elsira é de vuestro hijo. El fin que yo tengo en esto mostrarí con la obra cómo tengo por principal fien el de todos, é fue otra cosa no me muere ni ofro interesse sino que se sirvan Dios é Sus Magestades y esta cilbdid se conserve, en la qual pues, yo tengro tanto que perder como el que más de los que en ella vivimos, é la pudiera dexar como la dexaron Ios otros offiçiales de Su Magestad, é con mucha ventaja de repartimiento é otros ofrescimientos ruel golsernador me daba, si yo ruisiera desampararla é mudar assiento. Por aqui rerés si mi deseo es sustentar esta cilulad é rivir é morir en ella.

"Cada dia nos faltan indios de los que nos sirven en nuesturs casas, é muerlos ni riros no parescen: si fuessen tigres los que noz los quitam, no poulria ser sin se arer entendido. Todos los que hay en esta cibdad sospechan, i yo con cllos, que estos traydores raçiques Corobari y Bea, parientes de ruestro hijo, nos los lumtan; é cómo el ladron y espia cstá en casa, sentimos el daño é no remos por do se remedie, aunque no del todo giegos, ni hay ninguno tan ignorante que dexe de entender quel remedio es cortar los troncos é çepas de essa mala simiente, que son estos caçiques de Bea é Corobari. Y tened por çicrto que en lanto que á mi cargo fiere el bien é procomun de todos, que amque me cueste lo que tengo é la vila con cllo. yo sacaré destos escrúpulos é sospechas á todos. El castigo. que convenga en este caso de Nlurga se ha de lasger, é no me hable ninguno en otra co- 
sa. É será mejor" que nos digays en qué pirte os dexastes dos ó tres cluipstianos riros de los compañeros, que llevastes, quando fuystes la lierra adentro, que de consialos y cufermos se quedaron, pudiéndolos vos traer, porque si por caso fuessen vivos, se cobrassen. "Oydo esto, d bachiller se tornó tan pálido é de color como muerto.

Es rerdad que yo tenia antes informaçion que, hincados de rodillas, con muclas lágrimas, pidiéudole socorro é misericordia al bachiller, le rogaron que los ayudasse é no los dexasse entre sus encunigos á morir ; é él les dixo que anduriessen, que de bellacos, porque los truxessen acuestas, se haçian malos. É uno lellos le dixo á él é á ofros: "Señor y señores, pues que assi os rays, rogad á l)ios por mi alma. " É ćl mancló passar adelante la gente, é siguió su camino, é los devaron, é tornó con dos ó lres compañeros á un buhío, donde quedaba un vizcayno (que era el último que no pudo segguir la (ompañia) é díxole: " G Vos por qué no aixlays?" Y el pobre compañero cstaba cchado en una hamaquilla é los piés muy hinchados, é dixo: "Señor capitan, ya reys que no puedo seguiros: acordaos que soy cluripstiano ", saliéndole las lígrimas de los ojos; pero ninguna piedidt turo dél ni de otros dos que dexaba mas atrás, é se fué. Y es rerlad que traia en lamacas sus indias, quando se le cansilban.

Finalmente, quando el bachiller me oyó lıblar en los que avia dexalo morir, por su culpa, en aquella su cntrada, muy turbarlo diso: "Señor, para que veays que no conviene que aquesta grente vaya á donde la enviays, yo os daré çient firmas de hombres los mas paincipales del pue1)lo, que dirán tgue no conviene haçerse lo que querés que se laga. Estonges yo mandé a un escriluano que assentasse lo frucl bachiller deçia, é assi se assentó: é assentalo, mandé que lo firmasse, y él lo firmó, é luego le manké por aucto que cntendiesse en buscar aquellas firmas, yue degia ante mí hasta otro dia á rísperas, so pena de çient mill maravedis para la cémara de Sus Magestades; porque si assi como deçia fucsse, yo me reprortaria á mejor consejo é paresçer, prara que so hiçiesse aquello que paresciesse ser mas provecloso é conviniente.

En esse punto el bachiller fué á buscar aquellas firmas entre los clérigos é frayles é personas que no avian de dar voto en la gnerra, é de aquellos que poco podian entender qué era aquello que fitmalsan; é no pudiendo juntar en todas diez, é aquellas de sus parçiales é de hombres de poco crédito é atherentes suyos; aquella mesma noclıe amotinó la mayor parte de todos los que avian de $\mathrm{yr}$. para que rehusussen el camino de Bea. É assi cómo fué de dia, vino á mí cl capilan Johan de Ezcaray, e me dixo: "Señor, espantado estoy de lanta mudanga é de lan poca vergiiença, como hay en esta cilulad; porpue ayer todos estahan de buen propóssito, y en esta noche passada lan mudado la voluntad, é paresçe que los llevan á la lıorca, é no veo lombre en dispusiçion de yr commigo. "Luego yo sentí la maldad del bachiller, é començé á aver informaçion contra él, é se ovo hien bastante del motin y estorbo quél daba en que no finesse la grente; y esto no pudo ser tan secreto quél no oriesse temor", é de su consçiençia ignorasse la culpa que tenia. É viémdose perdido, conçertóse con el dean Johan Percz Zalduendo (hombre sin letras, é que de largo ticmpo eran amigns) contra mí.

Nlgrmos meses antes yo aria tomado cuenta á un escribano, llamado Calripstóbal Ilnũoz, ante quien aria passado el proresso de la mucrte del adelantato Vasco Nuñez de liallon é sus consortes, cu cuyo poder estalı; é le peli aruel proresso para tassar los derechos dél por lo 
fue tocalaa al secretario Lope Conchillos, en cuyo nombre le tomalar la cuenta, (fue eral escribano mayor é geneneral, é alun para ver si fror alfuel progesso parescrerial terrer ol andelantarlo é sans consontes más bienes de los que yo sabia, para yue, co-

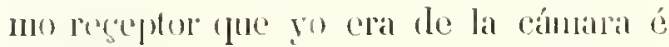
fisco, los colnatise. É venido este progesso ́́ mis manos, turele en mi poder algunos dias, é leyle rodo, é pússele cuento á todas las lojia por letras, é rubriqué- lats de la señal de mi firma, porene no se pudiesse humlar loja ni aucto, sin (pue se viesse la falla por al cuento que le prisse. Leste proçesso finć despues llevialo pror el escribano que he dielo á Pananní é como el gobernador y el alcalde mayor vieron apuel cuento é rúbricas mials, sospectaron que yo avia notado lis fillas é méritos del processo en ano dellos. E por esto sospecté que arian dado óden en mi muerte é lrabaxos.

\section{CAPITULO XVI.}

Cómo el auctor hiẹo jusliẹia de los eaciques de Corobari é Guaturo, que se avian rebelado del servirio de Sus Magestades, é cómo enviúpresso á España al baehiller Diego de Corral, é otras cosas, que eompelen a la historia.

\section{A} causa de las Comunidades é alteraciones que avia en España en aquel tiempo, muchos meses passaron que no yban narios al Darien, é quiso Dios que llegó al puerto te anclla cibdad una caravela. martes primero dia de julio de mill é quinientos é veyute y dos años, víspera de la Visilaçion de la Hadre de Dios á Sancla Isabel. En alguel navio fueron la justiçia celesiástica é seglar en dos personas: el uno fué el ligenciado Sancho de Salaya, que yla por alcalde mayor de la costa é mar del Sirr, en nombre de las Cessáreas é Cathólicas llagestades, y el otro cra el arcediano Rodrigo l'erez, al qual avia enviado prosso en grillos á España cl mesno dean, por partiçipe en la culpa é Irayçion del adelantado Tasco Nuñez é los que con él padescricron, persuadido el dean por Pedrarias Dívila y el liçençiado Gaspar de lispinosa, su alcalde mayor. İ rolvió alysucto, é trila mandamiento de Sus Hagestadesé del perlarlo, para que se le reslituyessen sus bienes.

Ved, letor, qué tal debiera ser la culpa é trayçion del infeliçe adelantado, pues que este arçediano cra uno de los mas parliçipes en ella, é renia absuelto, é volvió á la lierra.

Ei licenciado Salaya traia poderes del nuevo obispo, fray Viçente Peragsa, para tomar la possesion de la iglesia episcopal é remover los officiales é provisores, é proner los que les paresciesse : é lo primero que hico fuć tomar la possesion por el obispo, é luego removió de provisol al dean y eligió al arcediano Rodrigo Perez; é los dos secretamente inquiricron en los méritos de algunos vecinos, porque ya los hombres podian lablar libremente por descargo de sus consçiençias, é informaron de la verdad, é de quán perjudiscial era aquel bachiller Corral á aquella cibdad. É cómo vieron el bachiller y el dean que avia jụstiçia en la tierra, é me Ienian por reçio, é creian que avia de procurar de me satisfaçer dellos é del motin, rogaron al liçençiado Salaya é á çiertos religiosos de Sinct Francisco yue nos hiciessen annigos, é á su l’uego yo les liablé muy bien dende adelante, quando nos topábamos; pero no pronetí de olvidar mi enmienda: antes dixe que, non obstante que les hablases, no dexaria de seguir mi 
justiçia en el tiempo que me conviniesse, pucs avian seydo causa quel caçique de Bea no fuesse castigado; é con este adifamento se contentaron los terçeros. É cómo los culpados tarde ó nunea dexan de sospechar su castigo, é reçelarse de sus proprios méritos, aunque andaba la cortesia en los bonetes, no cra la comunicaçion ni habla tan soçiable como antes la oro, ni en mas de aquello que yo no podia recusar por mis olfiçios: é por esso no faltaban en el pecho passiones eseulpidas con letras diamantinas.

Estando ya mas informado el liçençiado Salaya de la persona, vida é parçialidades del bachiller Corral, consejóme que In echasse de la ticrra é lo enviasse á Castilla, donde tenia su muger, sin la qual estaba onçe ó doçe años avia, é público amançebado, é que con la informaçion de sus excesos se fuesse, por hombre perjudiçial é no conviniente á la república. lis yo le respondí qụe hiçiesse él del interrogatorio é se tomasse la informaçion: é que tomada, si le paresçiesse que era bastante é que convenia, que yo haria to quél me conscjasse é dixesse que era justiçial. É luego el liçençado tomó tinta é papel, é hiço de su mano un interroggatorio, é por las pregguntas dél se tomaron los testigos, los quales las hincheron, deçian abominaçiones dél. Tomada csta informaçion pol" consejo del liçençiado, le hise echar unos grillos é le mandé meter en una nao que cstaba de parlida para España, é con él un Liris de Córdova, espesiero é resino de Sevilla, al rual tenia presso por perjudiçial á la república, é porque aria mucho tiempo que estaba sin su mugere, é tenia allí en el Darien dos mançchas públicas. É por céchula de Su Magestad los officiales de la casa de ha Contractaçion de Serilla me enviaron una carta requisitoria, para que se lo cnviasse p’"csso á la casa de la Contractacion, para le hager que hirciesse vidla con su mugrer, é mandé llevar á ambos á aquella nao. En fin, lıcelıns á la vela, navegaron é vinieron á esta cibslad de Sancto Domingo, é desde aqui fueron á España.

Esta yda deste bachiller sintió mucho Pedrarias, porque ovo temor que cn España le seria contrario é diria mal clól.

Estando las cosas en este cstado, vino nueva al Darien, por aviso de un indlio que avia seydo de chripstianos é andiba en compañía del caçique Corobari, enemigo de nuestra ciblad, cómo aquel cacique estaba en una sierra, sicte ó ocho leguas del Darien, é ofresçíase á le dar en las manos de los cliripstianos. El qual indio fué presso é traydo ante mí, y examinado, dixo dónde el caçique estaba .é que la causa de su venida era porque avia dos dias quel caçicque le avia muerto á su muger, que cra chripstiana, é se llamiba Cathalina, porque ella avia dicho que los chripstianos eran buenos; é demás de csso avian hecho otras muchas muertes en indios mansos chripstianos ; é ofresçióse de llevar los chripstianos á donde estaba. Pucs cómo este caçique cra de quien más nos reçelábanos, é no sabiamos dónde andaba, despues que me ove hien informado del indio, prevey con treynta é çinco chripstianos de un capitan, hombre enerdo, é mandéle que Hevasse este indio por guia, é assi lo hiço; é fueron á dar en el caçique una noche, é prendiéronle con parte de su gente, é traydo al Darien, confessó espontíneamente ser verdad que avia muerto la india Cathalina é otros indios muchos chripstianos, é que cra enemigo de los chripstianos ; é que aviéndose alçado dos reçes, avia seydo perdonado anulas. é se avia rebelado la tercera, é apratádiose del serviçio de Sus Migestatdes, é hecho otras muchas maldarles. E enlre las otras cosas conlessó que sabia la muerte del eapitan Nartin de Hurga, é yne so lo avia dicho el bachiller Corral en una rstanca, que renia media legrua de la 
cibdad, é que alli se avian visto é c"minido juntos algumas veces el bachiller y este caçifue: lo qual era en tiempo que se veliba la cilydad, por temor del mesmo Corobari é del raçique do Bea, despues de la muecte del capitan Martin de Mnrga. Por lo qual dixo públicanente el licençiado Salaya, que si el hachiller Corral no fuera partido, que públicamente meresçia ser quemado con su caçicjue Corobari, por traydor enenigo de los chripstianos: é consejóme que mandasse quemar a este caçique, é assi se hiço: y cl liçençado, de su mano, ordenó y cseribió la sentençia, é yo la firmé. é fué quemado. Al qual yo mandé alıogar primero, porque quiso morir chripstiano y cra baptiçado. Esta muerte se le dió, porque los indios temen mucho el fuego, é todas las otras maneras de morir no las temen.

Fecho aquesto, cl liçençiado Salaya se fué á Panamá, donde el gुobernador Pedrarias estaba, y cn aquella saçon le cnvió doña Isabel de Bovadilla, sı muger, desde Castilla, aquella grangeada residencia que le mandaron tomar los gobernadores y el Papa Arriano, que estonces era Cardenal de Tortosa, ć asistia con ellos assimesmo en la golıcrnaçion de los reynos de España para que se la tomasse d mesmo liçençiado Alarconçillo que le avia tomado la otra, quél por su plaçeravialiecho; é que assimesmo tomasse residençia al licrongiado Espinosa é á todos los gune arian tenido carso de justiçia por Pedrarias. Esto fué negrogiado por la muger del sobrernedor é pror apuel Francisco de Lisao. que primero se diso.

En este tiempo tomé yo çierlas esplias del caçique de Guaturo que servia á 1 m veçino del Darien, el qual se avia alçalo é avia acordado de se juntar con el cacique de Bea, que aria muerto al capitan Murga é á otros chripstianos, para matar á todos los que estál)amos en el Jarien, é pegar fuego á aquelia cibdad. É cómo yo scuti lit cosa, viendo el peligio notorio ('n que la cildad cataba, acordé de y i en persona á buscar al caçique con latsta qualrenta hombes, dexando en la coiludad el mejor recalolo que pule: é porqur via re. saban las sospertas del bachiller Corral é de su caçique Corobari, de quien se avia hecho justiçia, é no osé fial este viag̣e de otro capitan alğuno, porqune aquel á quien este caçique Guaturo servia no me enganasse, porque él harto excusaba al caçique, diçiendo que no estaba alçado, é para satisfaçerme á mí é á él, llevéle conmigro, de lo qual le pessó nuıchı, é deçia que yo tomaba demasiado trabaso, é quél me traeria el caçieque á la ciludad. Pero yo, no fiando de palabras, partí del Darien; é llegado á las sienras de Guaturo, diez é ocho leguas del Darien, hallé alçado el caçique é ýdo al arcalunco ó montes, é desfecho su assiento; é plugo ál Nuestro Señor que me dí tal l'ccabdo que le prendí á él é á su mutrerer é dos hijos suyos, muy niños, éá un indio prinçipal, que se llamaba Gonçalo, que era su capitan, é por cuyo consejo se gobernaba. É tomáronse lasta quarcnta personas do su gente, é pressos confessaron su rebelion, é ser amigos ć naturales de Cemaleo, que fué un caçique señor del Darien (el qual é su gente é valedores è amigos eslaban dados por esclaros por el hiey Cathólico); é confessó que ylua á juntarse con el caçique de Bea para venir con el á dar una noche en nosotros. é pegar fuego á la cibdad é matiri los chripstianos. E conforme é sus coufinsiones á mal propóssito. se hiço justiria de cacigue é su canitan: é manelé que los indios que se ionaron algatos fuessen reparidus por los compañeros que comnigo furron. é lo mesmo hice con los de Colobari que primero le avia justiciado. Y en el menino, ro!viendo de Guaturo, ençima del gerro de Buenarista, ques á sicte leguas del Daricn, y ençima de las lasmas de Bea, don- 
de avian muerto al capitan Hurga, se ligo ma horca mas alta que mna lança de armas, ć allí fué álıorcarlo el capilan Gonçalo, para que los indios de Bea lo pudiessen ver desde las lagunas, que están debaso de atpuel çerro bien legua y media ó dos. É desde allí, ydo al Darien, assi como entré de camino como yloa, quedó alıorcado en la placa el cicsique de Guaturo: con lo qual é eon la justiçia que se avia hechon pocos dias antes del eaçique Corobari, quedó aquella cibdad é provinçia muy segura.

Pero quando torné de Guaturo, liallé en la cibdad çiertas cartas quel gobernador Pedrarias respondia á la cibdad, á lo que le avian escripto en tanto que yo estaba absente, é por las palabras de su respuesta se enlendia quel bachiller Corral, como regidor, con los alcaldes y un escribano del consejo, que no avian quedado mas del regimiento, y estos eran mis cnemigos, le avian escripto al grobernador lo que quisieron; y él, creyendo quel bachiller estaba alli, é no sabiendo que yo lo avia cnviado á España, é pensando que aun no era yo tornado, les daba graçias de muchas mentiras que le avian escripto contra mí. é deçia que se lo tenia en merced, é dábales á entender otras cosas á su benepláçito, é revocala el poder que yo tenia suyo, é dábale al bachiller Corral. É la primera vez que nos juntamos en el cabildo de la ciludad, despues que torné de Guaturo, me enseñaron estas cartas; pero como todo era falsedar é mentira aquello á quel gobernator respondia, yo dixe en el regimiento, que bien paresçia por aquellas cartas quel gobernador respondie á las fálssedades, que le avien escripto deste aquel cabildo el bachiller Corral, viéntose solo sin otro regirlor, é sus amigros: é que yo loolgára quel bachiller estuvicra pressente é tomala la vara en buen hora, porque tal juez. avia menester afuel puehlo como él, que TO.10 III. estándose velando la cibdial é velanelo el bachiller. quando le cabia la griardia, por reçelo de su carifue Corobari y el de Bea, se via él é se entendia con Corobari, como lo avia confessado el mesmo caçipue, quando dél mandé hacer justiça; é que yo conosgria que avia hecho falta á mi personid en avor seydo teniente de Pedrarias; perocpue no lo avia aceptado, sino portue $n$ o se despoblasse afjiella cibdad, como lo avia procurado. É dicho acjuesto, arrimé la vara en afuel consistorio, é púsecla ençima de la silla prinçipal, sobre que yo es. taba é presidia en su lugar del gohernidor, é passéme á otra silla mas baxa , é dixe: "Este es mi lugar, quel Cússar mo dió, é descle aquesle serviré yo á Sus Magestades, como su official, é no como teniente del señor gobernador; y en todo lo que yo le puliere contentar al señor gobernador con mi persona, é lo que yo alcançare que sea en serviçio de mi Rey y en pró é utilidad desta república, lo haré como lo tengo jurado é soy obligado.» Ẻ hiçe juramento de nunca lomar vara de justiçia por Pedrarias ni por otro, si no fuesse por Sus Hagestades, con su expreso mandado ó de su Real Consejo; é pedílo por teslimonio, é assi lo licce assentar por ancto.

Ved qué graçias é remunerariones pára quien acaluaba de librar la tierra de tan capitales é tan grandes enemigos, como tenia en los cacirpues de Guaturo é Corobari!

Junto con aquellas cartas de Pedrarias avia ydo un mandamicuto suyo, en que mandaba que la cibdad oligiesse procurador que fuesse á Panamá á la junta general quél deçia que queria hacer, para proveer cosas importantes á aquella goberuaçion, é para elegir procuradores de cóltes para enviar á España. Esta invençion era, porque el liçençado Espinosa se quelia yo á Castilla, é poroue llevasse salarios de lospeceadores ó de la commidad, 


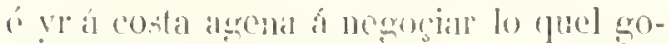
hernadory of guisiosento.

Jeydo este mamdinuiento. lodos quantor se labllaron de la ciblatel on alefued ayuntamiento, se levantaron en pić con los bonetes en lis manos, é discron que me pedian por merçed, que pues yo era recdor de Sus Magestades, é rogidor, $c^{\prime}$ veçino de atfuclla cilstied, é no avia otro yue assi lo hiciesse, ni la ciblad tenia dinoros para paczar á quien fuesse. que me suplicaban que por amor de bios, é por(pue arpuella cilulad y cllos no se acabassen de perder. quisicsse aceptar el poder forocuracion de aguella cibdad. alssi para yr á Panamá, como para cuviar á lispana; pues que me lenian por parlre, é yo avia sustentado aquella república, que no la quisiesse desamparar en lal saçon, é lo podia é sabria hacer. I en la verdad. ammpue en algumos de los que esto degian no avia méritos para que yo me movies. se á laicer lo que me rogahan, avia otros de sana intençion: é viendo con la nescessidad que estaban, las lígrimas de alymos, e porque yo cra uno de los que mas allí tenian, é mi laçienda se perdia como la de todos. Io açepté sin salario algumo, é me otorgaron luego el poder todos ellos en conformidad.

Aquella noclie el Darien anduvo tempestando, porque ol dean é sus parientes ćanigos ale bachiller Corral tuvieron mudra pena destal cleçion, paresçiéndoles que yo les podria lacer diño. ć no olvidindo la enenistad que me tenian; é porque desde la prission del hachiller estaban en sospecha é temor de mí. luego entendicron en convocar ć juntar algunos del pucblo, para que ofro dia en el regri- miento reselamissen ded porler que la ribdadl ne avia daulo; ćassi se juntó el caliklelo y el mocurador del concrejo, rue cra primo del deam, é dixo en nombre de la ciblat que muchos veçinos della pedian que se recogiosso ó quo no se me diesse

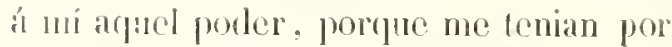
lombre apassionalo: é pidió é requirió á los alcaldes é reginiento quo se pusiesse en votos, é que eon mas deliberaçion é acuerdo " poder se diesso al que oviesse de yr á lo ques dichı, en nombre de ayuella cilsdad. E leyda esta peticion en regimiento y en mi pressencia, dixe que bien paresçia que todo açucllo cra fabricado por el dean: pero que non obstante que no avia por donde me desistir del poder. ni porque debiesse diar lugar á cllo, que por convencer maliçias, yo era contento que se tornasse á ver, ć que todo el pueblo rolatsse en el negoçio y eleçion, para quel poder se diesse í quien mas votos turiesse; é assi dixe que lo pedia é requeria , é assi se liço, é se votó por todo el pnchlo. É cómo aquestos questo haçian, eran pocos é de poca auçtoridad, ture yo muchos mas volos que ninguno, é assi de nesçessidad é contra roluntad de mis enemiggos é de aquella parçialidad del bachiller Corral é del dean, se me ovo de clar el podcr é instruçion para yr á Panamá a la junta, quel gohernador Pedrarias queria lıacer: é dióseme fícultad de sostiluye ó yr en persona ó nombrar á quien yo quisiosse ó me paresçicsse que se debia enviar ú España : é comencé á aderescar mi partida. é fleté un barco. para yr hasta el Nombre de Dios. porque lo demás avia de sel por lierra liasta Panamá, donde el gobernador Pedrarias cstalo. 


\section{- Capltulo XVII.}

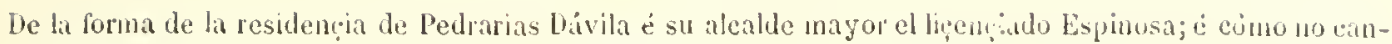

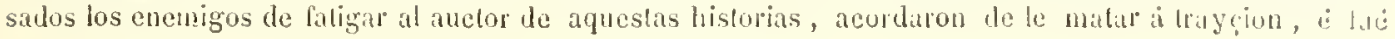
muy mal herido.

\section{I.} as fuergas de cadia uno no se manifiestan sino por las adversidades: assi lo dice Sanct Gregorio'. Yoconficssonpuestas firer'gas, con que se ressistieron mis trabaxos entre mis adversidades, no fueron mias, sino de quien me libró ẹlellos, que fué la ommipolengia de Dios.

Algunos amigos nios, ál quien lie comunicado lo que cscrivo, me han querido estorbar que no hiçiesse mençion en estas historias de mis llabaxos, e yo soy de olro parescer, por lodas estas raconcs: lo primero, porrue por hacer yo lo que debia é lager justiçia, se juntaron contra mí los que la tienen aborresgeida, é acordaron de me haçer matar á traycion: lo otro, porque Sanct Pablo fué sin comparacion mejor que yo, é no negaba sus açotes: A Judceis quinquies, quadragenas, unu minus accepi ${ }^{2}$ : lo tergero. porque Cluripsto, Nuestro Redemptor, es Dios, é no se despreçió de su passion, puesto questas comparaçiones son muy allas é desproporçionadas . porque Clnipsto no polia pecear, ni luvo culpa algma; pero enseñónos á sufrir, é Sanct P'iblo fué viso de eleçion é alumbrado por Dios é padescia por sn amor, é yo soy y he sido peccador; pero no permitió la bondad divina que mis enemigos saliessen con su intencion. Pero nunca se me desacordará lo quel glorioso dotor de la Iglesia, Sanct Gregorio, diçe por el Sincto Job en eslas palalnas: "Si alguna rez con silencio eonsintiera á los que laccian cosas injastas, ó no los contratixera con justicia, ciceta-

1 Moral., lib. XxIli, cap. 31 sohre los cals. 31 e $3 \pm$ de Jol. mente no tuvieral adrerssarios; mas polque duro los caminos de la vida, hatlo siempre desseadores de sn micrte. " " ha otra raçon es, porpue los rueste trabasu me dessearon, fueron los anugos de arpuel bachiller Corral, inventor de todo ello, e uno de los embaxadores de Viseo Nuícz á Diegro de Nicuesar, quando le truxeron á la desapiadada muerte que le dieron, é unı escribano á quien yo suspendí del ofliço de escribania, é le hiege pagrar gierios quatro tantos de derechos demassiados, porque públicamente robaba acquella cildad con su púnola; ćotro, que porepe yo no quise de officio proreder conlra su muger, que degia él que le ponia los cue:nos, se me tornó enenigo. pero en lin de quedar por los que eran, les vi harece mal fin á todos ellos; porque licne Dios cuy dado de suptir los defetlos de la justirial, ques administrada por los lombres, o deste el cielo custiga, yuando le plare á cala uno, segund él vé que conviene.

Tormando a nuestra materia de susono, cstando para prutime del Darien, llowg de aquella ciblad un Pedio de Barera, eseribino, fue pos manelado del liscuçiado Narconcillo, juez de residencia, venia de pregonar en la vilia de Acla lo que hiço pregonar assinesmo en el Darien, que toalos los que alggo quisiessen pedil al gobernador Pedrarias Dávila, e al liggencialdo Lspinosa, su alcalde mayor, paresciesscn en Pinaná dentro de diertio lipmino, à serian oydos é les guardarian su justicia. Pero cóno todos conosorian quers-

2 Al Curinl. II, cap. 11, vers. $2 \%$

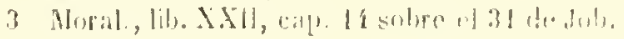


Lit residençia rra grangeada por Pedralias, é que passada, se avia de quedar en el mesmo ofliçio de golmernalor, començaron los cucrolos í lunlar é murmurar dr tal cuenta, porque les parescia que era uncjor disimular sus quexas é agravios fae no tralasar c abdar caminos ('n val(le. gastando dineros, si alli fuessen; pues no confiaban de tal mancra de juzgado. ni á ningumo convenia pedir ni cnojar al que so avie de quedar mandando la tierl'a, porque despurs no le destruyesse por tal causa : é assi ninguno oro tan falto de sesso que se pusiesse en tal jornada, pues avie de ser tiempo perdido. Pero cómo yo tenia que pedir al golecrnador é alcalde mayor muchas cosas, en nombre del Rey é de su haçicnda rual. é por aquella cibdad del Inarien, como regidor della, con la qual avia de cumplir, pues me avia encargado su poder. é por mi proprio interesse, acordé de ye á Panamá, ó un viernes diez y nueve de septicmbre de nill é quinientos 6 veynte y dos años, estando en mi casa aderesçando mi partida (taneron á missa de la confradia de Sanet Sebastian, de que todo el pucblo cran confrades é yo uno dellos), cntró un alcalde ordinario de los de la cibdad é dixome: "Scñor, iquiere vuestra nerced yr á missa do la confradia?. É yo le dixe: "Sí por cierto. "É assi él é yo é otros nos fuymos á la iglesia, rue era en calıo é fucra de la çibdad: á la puerta de la qual cstaban los mas del pucblo, esperanlo al clérigo, que aun no era venido á decir missa, é cóno vino, se entraron todos tras él.

Totad, letor, é ved lo que se me siguió rle venir este alcalde á me convirlar para yr á missa, cl rual cra amigo especial (lel i)achiller Corral, é le avia dicho que quando ol regimiento le nombró por alcakle, yo lo avia querido estonluar; é assi cra verdad, porque era liombre vil é avia seydoçapatero, é por cstać otrá rau- sas no me avia parescido que se debia laçer tal elecgion de alcalde semejante, puesto plue ora rico.

En fin, al tiempo que yo me quise entrar, como los otros, en la iglesia, me dixo: "Scñor, óggame vucstra merçed una palabra, cu tanto que se viste el clérigo. o E assi me detuve é nos quedamos ol alcalde é yo en la calle, passcándonos delanto de la iglesia, en la qual saçon llegó un mancelso, llamado Simon Bernal, boticario, liijo de aquel Luis de Córdoba, que tengo dicho (que envié presso á España en compañia del bachiller Corral: el yual Simon Bernal aria seydo criado del dean, é pocos dias antes se avia despedido dél, é con alğunas personas me avia enviado á rogar que lo resçibiesse por mio, diçiendo que me desseaba servir, porque via (que tractaba é ayudaba muy bien á mis criados, é á los que á mí se allegalıan. Mas cómo yo sahia (fue aquel mançebo avia seydo criado del daun, mi enemigo. é porque no quer'ia meter en mi casa hombre sospechoso, é porque denás desso avia cnviado presso á España á su padre, no le quise rescebir; y enviéle á deçir que yo le agradescria la volintad que deçia que me tenia, é que assi la temía yo muy buena para haçer por él lo que purdicsse, ofresçićndolo el ticmpo.

Guimulo este llegó donde cl alcalde é yo nos paseálhamos, delante de la iglesia, quitóse el boncte acatándome, é yo abaxé la cabega, como quien diçe: "Bien seays veniclo" sé arrimóse á una pared frontero de la iglesia. Y cl alcalde, en esta saçon, me rogaba que diesse la vara del alguaçiladgo de aquella cibdad á un hombre de bien (porche yo tenia poder para proveer de aquel officio, quando conviniesse, en nombre del alguacil mayor el bachiller Euçizo. por su absençia, que estaba en España, y era ni amigo); ć dise al alcaldir que me placia de hacer lo que me rogabal proue mr parescia que era buena 
per'sona afuel para quien me pedia la vara del alguaçiladgo. Y en este instante llegó por detríts el Simon Bernal con un punal luengo muy afilado (aunque traia of ra espada çeñida), é dióme una grand cuchillada en la cabeça, é desçendió cortando por debaxo de la oreja siniestra, é cortóne un pediego grande de la punta é huesso de la quijada, y entró hasta media mexilla; é fué lan grande é honda la herida. que me derribó é dió connigo en ticrua ,é al cacr, dióme otras dos cuchilladas sobre el hombro izquicrdo, é todo tan presto, que antes quel alcalde le viesse, ni yo me reconoscriesse, era fecho lo que es dicho. É el malhechor echó á luyer la calle adelante, no queriéndose acoger á aquella iglesia, á par de donde estábamos, porque si alli se entrara, fucra presso; sino fuésse á la iglesia mayor, donde el dean é otros clérigos, sus amigos é valedores, le atendian para le favorescer, como lo hiçieron.

Assi como cay en tierra alordido, dixe reçio: "Válgame la Nadre de Dios," é miré atrás é víle alçado el puñal ; é díndome priesa á levantarme, dixe: "Olı traydor, épor qué me has muerto?" é puse mano á la espada, que tenia coñida debaxo de una lola çerrada que lenia vestida, tomando el pomo por ençima de la ropa, medio sin sentido é tal, que no conosçí liren al que me hirió por la lurbaçion de la vista. E cómo ol traydor no se deluvo, aunque salieron muchos de la iglesia , é algumos comcnçaron á correr tras él, y el alealde assimesmo, como era mancelon é tenia buenos piés, fuésse á la iglesia mayor: é luego los alcaldes començaron á haçer requirimientos al dean é clérigos, para que les entregassen el malhechor: pero diéronse poco por sus auctos é pregones, con que le çilaban.

Estando desta mancra herido, me the- varon á mi casa, é peoli á mucha priessa un confessor, porque conosçi bien cl peligro en que estalaa; é venido un barbero çirujano, como me vido, no me queria curar, é diso que para qué avia de curar a un hombre muerto: é con importunaçion de los que ende allí cslaban, me curó, sin esperanca de todos los que me vieron, que pudiesse vivir tres horas. É yo no sentí la cura ni hablaba, é desde á mas de quatro lioras que estaba curado y cchado en la cama, volví á tener alým sentido, é lorné á pedir el confessor, é me confessé, é dixe por aucto ante un escribano que perdonaba é perdoné á quien me avia muerto, é á lodos los que en ello avian seydo, porque Dios me perdonasse á mí, pues se pusso en la cruz por mi redempçion é de todos los peceadores: lo qual yo liçe con entera voluntad, é lo guardára siempre, si me dexáran. É de allí adclantc entendí en mi salud, la qual, al parescer de los hombres, me dió Dios de poder absoluto, porque ninguno de quantos me vieron herido pensó que podia vivir ni salir de aquel dia; mas paresce ser que me tenia Dios gruardado para otros trabasos.

En fin, sanć en breve tiempo é quedé libre, puesto que con alguna poca de fualdad de la herida. É deste á ocho ó nueve dias que aquel mal aconscjado mancelso me acuchilló, le dicron de mano é le celharon de la iglesia los clérigos secretanente, por respecto del dean.

Yo no me desacordaba questos trabaxos me venian de la mano de Dios por nis méritos, pues que diçe Sanct Gregorio: "Quando en esta vida padesçemos lo que no queremos, nescessario es que inclinemos los estudios de nuestra roluntad á la de aquel que ninguna cosa injusta puede querer ". "Grand consolaçion es en lo que nos desplaçe pensar que lodo se haçe por la dispusiçion de Dios, al qual ninguma 
rosa sino lo justo aplage. Non olwante es-

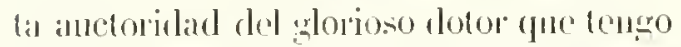

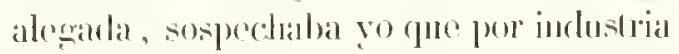

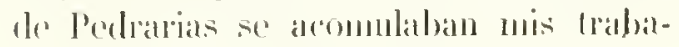
xos: a asi por esto como por cumplir con lo sue dehia, deste á dos ó tres dias que

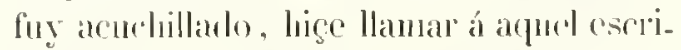
hano perloo de Bamedar, que ar ia yelo í pregonar la residençia de lodrarias, c pedíle por lestimonio quál estala, é protes-

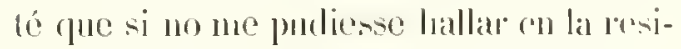
dençia, que no parasse perjuiçio á la laacienda de Su Magesead ni á la mial, para porler pedir despues al grobernador é su alcalde mayor diez mill pessos de oro en los cargos que yo tenia de Sus Hagestades é the mi propria laceienda. Desta prolestacion fueron luego avisallos el gobernador y el alcalde mayor, é se enconaron más contra mí. diçiendo que, aunfue estaba muerto, pensalda fatigitrlos.

En esle liempo que yo me curalat, ligicron su residençia nuty á su salıo , é prara que ningmo les pidiesse cosa alguna, usaron esta cautcla que agora diré, porque con tales mañas é con estar ol Rey tan lexos prassan catas cosas é otras semojanfes en lndiats. En el puerto que se progeronó la resirlençia, luegro otro diar, ó deste á dos ó lres, pregronaron el golscrinamelor y clalcalde mayor la reformacion de los inclios, pues como no avia ningumo (pue no quisiesse ser mejoralo á quo le dirssent

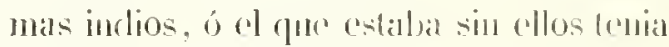
esperança de averlos a otros de lrocar los que tenian, é otros de los I raspasar ó venter, y esto avia de ser jur mano del gobernador é de su alealele major, por no los enojar é tenerlos contentos para li reformaçion de los indios, ninguno les pidió cosa que mal oviesse fecho ó se le debiesse, é assi se acaló la residengia; pero no dexaron de laçer un essá reformaçion lo que les paresçió.

Fecho esto, se fuć á España el liçençiado Espinosa con diez mill pessos de oro, segund fama; pero por(fue se ofresçe aqui un caso notalıle del pregon que se dió en Aclit para la residençia del golıernador Pedrarias é del liçençiado Rspinosa. su alcalde mayor, decirlo he en breves renglones.

\section{CAPITULO XVIII.}

bel preson que se dió en Acla para la residenẹia del gobernador Pedrarias è sus officiales; é cómo se fixó aquel pregon en un poste de la plaẹa, é lo rasgró un caballo que fué del adelantado Taseo Nuñez de Balboa*; é eomo el juez de residencia la tomó al auelor destas historias, é eondenó al que lo avia acuehillado a que fuesse ahoreado, y en olras penas.

E para que fuessen á perlir los que quisiessen al gobernador a alcalde mayor Espinosa á la cilulad de l'anamá, donde avian de larcer resiclenciar, fué fixado en um posle en li placa: y eslando allí puesto, acaesrió un domingo, que los del pueljlo que silian de missa se fucton muthos dellos, acompañando al capitan Andrós Garavito,

- En este epigrafo suprimió clautor la siguiente cláusula, que se lec en su prime MS.: "E lo rasgó un caballo, que lué del adclauliulo Vaseo Nuñez de que alli era teniente por Pedrarias; é llegado á la puerla de su posada, que tam. hien era en la plaça, paróse á hablar con los que allí estaban, en tanto que se haçia hora de comer. I cslando assi, entraron por la olra parte de la placa quincé veynle roçines ó yegruas, é començaron á pastar cicras licrbas que en la placa avia en harta cantidad ( jolofur como los pue-

Balboa, con mucha admirasion de todos los que lo vicron co supicron: lo qual dió causa á mucha murmuraston de la justicia tcmporal.n 
blos son nueros en suls fumdaçiones, hay hicrba en las calles é plaças, por ser tan Ińmeda la licrra, si no las limpian con mucha é contínua diligençia). E cstando aquellas bectias bien apartadas, se salió de contre ellas un caballo, que avia seydo del adclantado Vasco Nuñez de Balloa, é alta la cabeca, á passo lirado é sin pasçer ni entenderse á dónde yha, despues de aver andado mas de çient passos, desde donde dexaha las otras bestias, Ilegó al poste, donde estaha el pregon ó edicto afixado, é con los dientes assió del papel dos ó tres reçes é líçolo pedaços: é fecho aquesto, passo á passo, sin se detencr en pascer ni en otra cosa, se tornó á las bestias, de donde avia partido primero, é allí comencó con cllas á pascer.

El capitan Gararito é los otros que con él ricron atuesto, to notaron por misterio, é començaron á murmurar de la residençia, é deçir, que pues aquel roçin reclamaba della. que qué debrian haçer los hombres, é que de allí se dehia colegir y esperar en Dios que la verelatera residençia avia de venir del çielo. Í á la verdad paresçió cosa esta para dlar qué luablar á lodos, porque aquel caballo, como es dicho, era del adelantado Vasco Nuñez, al qual le fué corlada la cabeça á diez ó dose passos de donde el edicto fué rasgado. Esto ques dicho, fué notado por muchos, no solamente cn aquel pueJ)lo, donde cllo passó, pero donde quicla que se supo: é no lalló despues quien se ofresció á lo prohar en España ante los señores det Consejo de Intias conura el mesmo Pedrarias é su alcalde mayor.

Despues que fuy sano, tomé mas gente é púseme en mas costa, porque temia que no se avian de acabar las lrayciones contramí en la ques dicho. E aquel licençiado Alarconçillo, juez de residençia, envió al Darien, en tanto quél yba, por su teniente á un Johan Carballo, para que pusicsse co- bro en mi persona, porque no me fuesse de la tierıa, sin lascer residençia: é escribióme Pedrarias que ninguno se aria hallado tan mi amigo para aquello cono aquel, é que me rogaba que si me pidiesse framças ó me pusicsse alguna carçeleria, que oviesse paçiençia, que todo se Iraria hien. Todo aquello cra pensando espantarme é que avia de huyr (ó para inçilarme á que lunyesse) é grangeado pol él; porque sabia que aquel Carballo cslaha mal connigo, á causa que por çicrto delicto suyo le hiçe dar veynte pessos para comprar un indio ó esclavo, que fuesse vrrolugo en el Darien. E á este hiço dar Pedrarias la vara, para que fuesse á me nolestar con ella, como ho hiço: que lıego que llegó, me pidió diez mill pessos de fanças, ó los depositasse para la seguridad que no me huyria ni saldria de la cil)dad. é que haria residençia é pagaria lo que fuesse juzgado, é si no que avia de poner recaludo en mi persona. É cómo yo no tenia hecho por qué temiesse de la justiçia, ni Ienia tanto que deposilar, díxele que yo no tenia tanta laçienda ni fiadores, como me pedia, ni méritos para huyr: que hiçiesse lo que quisiesse. En fin. él me echó unos grillos á los piés en mi casa , é desde á dos ó tres dias dixo que me los queria quitar, porque estaha flaco $y$ enfermo, si deposilasse mill pessos de oro é hiçiesse una obligaçion que pagaria olros cinco mill para la cámara, si no guardisse la carçeleria de mi casa; ć todo se hico como lo quiso, é como era mi enenigo, ć lımbre de poca suerte é mal criado. me hiço otras descortesias, porque pensilua que servia en cllo á Pedrarias.

Estandlo en este trahaxo llegó el juez de residençia é la pregonó contra mí, para que dentro de treynta dias me pidiessen todos los que quisiessen civil ó crimiualmente, é yo no falté dia alguno de las audiençias, é de todo quanto se me pidió fuy absuclo por el juez de reșidencia, ex- 
gepto que en nombre del bachiller Diego de Corral, que yo envié presso á España, se me pidieron sessenta malleos de oro, porque avia negado dos apedaciones que de mí se avian interpusto para Pedrarias." lestos sessentá mareos de oro remilió el juez la causá á Sus Magestades. É assimesmo fuy acusado por parte de una muserer, que mandé agotar é sacarle giertos dientes, porque acusí á su marido de muerte é no le probó el delicto: y esto remitió assimesmo el juez al Consejo heal d. Indias. É condenóme en veynte pessos de oro de torlas é qualesquier culpas que contra mi resultassen . los diez para escrivir á mi costa la residençia en limpio (por(que la pagasse quien no tuviesse culpa) é los diez para la cámara, porque no paresciesse que yo estaba ó salia sin culpa desta cuenta. I en todo lo demás fuy absuctio, é me fué alçada la carçeleria é tornados los mill pessos de oro que aquel Carballo me avia becho depositar, non obstante quél no dexó de pedirme aquellos veynte pessos del verdugo; pero assi fuy dado en esso por libre como en to demás. Ted, letor, que tan amigo mio era este Carballo, que me avia escripto Pedrarias que se le avia encargado la vara, porque era el más mi amigo que se laalló.
Finalmente, di fiangas que pagaria to. do lo que en el Consejo lieal de Indiats se sentenciasse cu ragon de las remisiones que tengo dirho. é de la prission dea hachiller Corral; a luego pedi al jue\% (pue por quanto los alcaldes ordinarios del barien avian condenado al traydor, gue me lirió, en relseldia que le cortassen la mano derechar y el pié izquierdo, y en perdimiento de la milad de sus bienes para la cámara é fisco, y col las costas : é porque en essa sentencia avian seydo favorables al malhechor en no aver mirado la calidad de mi persona ć de la trayçion é asechança, é que era jue\% é offiçal de Sus Magestades, é otras calidades que concurrian en mi persona. que me mandasse desagraviar é hiçiesse justiçia. El juez resçilsió mi querella, é liego proçesso contra el traydor. é sentençiólo á que fuesse ahorcado, y en perdimiento de todos sus lienes, y en las costas en reheldia. É fecho arpuesto, el juez se fué á la villa de Acla á tomar residençia al teniente Andrés Garavito é al teniente Gabriel de Roxas, é yo me quedé en el Darien, curando de mi persona é alistando é poniendo en órden las cuentas de mis cargos, y en vela con mis enemigos del dean é sus parçiales.

\section{CAPITULO XIX.}

Cimo fuci presso el traydor de Simon Bernal é se hięo jusliẹia dal.

\begin{abstract}
Aunque estas cosas no son aplaçibles al que lee, como son competentes á curiosidad de litigios, no dexando de ser nescessarias jara entender á sentir lo que se padesce en estas partes con los que golier-

* En esta parle se lee en el MS. original, aunque borrado por el aulor: "La una [apelaeion] que mo quise olorgarle al baehiller, quando le prendi, "que pedia ser remilido á Pedrarias (é lo envié á "España al Consejo Real de Indlas); é la olra que, "quanelo mandí quemar al eaçique Corolsari, adnimbique por ecelaros sus indios que eon il se to-
\end{abstract}

nan, por absençia de los superiores é distamegia grande que hay liasta ellos, é por los grandes gaslos yne se lan de hacer luasta ser ovelo del prínçipe; pero porque esto es cosa que loca al auctor, no se di-

vmaron è los reparlí por la eompañia, gue los avian "tomado, é fué por parte del bachiller apelado para wante el gobernador.") Siendo eslas eláusulas de no poea imporlancia para la buena inteligencia de la hisloria, lia parecido oportuno ponerlas aqui, respelando no obstante, como es debido, la voluntad de oviedo, y eonservando la integridad del lexto. 
rán aqui tan particularmente alymas cosas, porque no parezca cue se jacta de la vitoria, con que pluggo á bios librarme de mis enemigos, y pror qué via é rodeo fué castigado aquel que á traycion me acuchilló, que ningun faror le aprovechó para huyr ni salvarse de la pena que la justiçia le dió ; é passó assi.

Despues que hiçe residençia, vendí parte de mi láçienda, é liçe cantidad de dineros, con pensamiento que teniendo tiempo, me yria ál España á pedir justicia contra Pedrarias é su alcalde mayor, el liçenciado Espinosa, que ya era ydo á Castilla, é para dar relaçion del estado de la ticra, y entender en el remedio de arquella cibdad, por no acabar de perder mi harienda. E un dia de fiesta, viniendo de missa (con çinco ó seys hombres nios que á la contínua me aguardiban con sus armas), se fueron conmigo algunos reçinos amigos é personas honradas del pueblo hasta mi casil é uno dellos dexó cacr una carta pequeña é cerrada, en el sobreescripto de la qual decoia: " $\mathrm{Al}$ señor veedor Goncalo Fernandez de Oviedo. "É uno de mis criados la tomó; pero 110 vido quién la echó: é cómo leyó el soloreescrijoto, diómela, é yo le pregunté que cuya era, y él replicó (que allí la avia hallido en tierra; é abríla, é deçia assi: "Señor, porque soy ruestro servidor, os consejo que mirés por vos é por vuestra persona: que andays en mucho peligro, é tenés mucha nescessidad dello.n

Esta carta no tenia frima ni se nombraba quien la escribió: la letra della era muy luenga, poryue no se conosçiesse cuya era: é cómo la ley é avia tan poco que me avian descalatsrado, cierto me escamdalicé; pero con alegre semblante disimulé é liçe sentar los que allí estaban, creyendo que entre ellos estaria el que avia cechado la carla, é dixe: "Senores, sentaos por no hacer mereged, é veleys lo (que me escribe qualquier ques aquel questa carta me ha TO.JO III. echado en casa." É lodos adınirados de lo que decial, se sentaron (é un poco anles avisé al que la carta avia hallado, é inandéle que se entrasse en olra cámara é pusiesse por escripto los nombres de los que allí estaban, é assi lo hiço). Suntarlos, ley la carta, é oydal. se movió altereaçion entre todos: é deçian umos quel que arpuello escribia no era cntero amigo, pues claramente no ne avisaba del peligro. en que la carta decia que estaba mi parsona: otros decian que era de pensar quel que tal aviso daba, lo haria pol me desvelar é dar mala vidat. é que siempre estuviesse en sospecha é cuydado puesto; é otros decian que creian quel que aquello escibia, no se osaba enemistar con mis adverssarios, é que por esso callaba su nombre; é otros deçian otras cosas. É assi á pró é á contra altercabain solre las palabras de la carta, lo qual todo oia muy. bien quien la escribió, aunque ninguna cosa cste deçia. É yo, despues rue todos dixeron sus paresceres, dixe assi : "Señores: yo creo quel que esta carla me escribe, es mi amigo, é le pessa de verme en trabaxo; porque sabe questa cilbdad se acabára de despollar, si yo la oviera dexado. como lo hicieron los otros regidores é officiales de Sus Magestarles, é conosege en quanto cargo me es esta república, assi cn lo de los rescates, como en otras cosas que yo he fecho por todos; y en pago desto ha visto las maldades que contra mí han passado hasta aqui, é debe tener notiçia de otras que de nuevo se deben fabricar ó se me ajarejan, é péssale dello, porque debe ser chripstiano é hombre de buena consçiençia : é junto con esto scrá amigo tambicu de algunos de mis enemigos, ó por no se encmistar con nadie, no osa hablar claro, ó por otros respectos: pero como quier que ello sea, yo se lo agradezco al que lo escribió, y en la rerdad vo le lengo por nuy amigo é conozco bien esta letra, y él ne dirá lo demas, é yo 
nuncal se lo deseonosceri ni le seré ingralto. "Pero la rerdad cra que yo no sabia cuya cra la lefra ni quićn la escribió, pero discolo atrifiçiosimente é á cantcla, é saliome á lien. É en esto çessó la plálica, é carla uno se fué á comer, é yo me qnede en mi casa con los mios, é en mucho cuydado é recelo pursto, é temia como hombe: pero acordíndome siempre de lo que dice aquel glorioso dotor de la Iglesia : Jesa-Chripsto se ha heeho tudo nuestro remedio; si tienes calenturas, él es fuente de refrigerio; si eres llagado, él os a médico; si temes la muerte, él es la vida; si te hallas desfavorosgido, él es la fortaleça; si quicres eomer, él es mantenimiento ó manjar, 4

De allí adclaute salia pocas reces de casa y mas acompañado. é velíbame, porque, amuque de la residençia (nuedaba ynasici lihre, buto mas quedahan mis ene. migos menos satisfechos, é se recelaban de 111 .

Signuióse que aqquel dia mesmo en la noche temprano enfró en mi casa un homlre de bien, ć apartóme en secreto, é dixo: "Señor, mas rerdad dixistes ros hoy que ninguno de los que deciam que no eral ruestro amigo el que claramente no os arisaba en aquella carta; porque quien la escribió yo fuy é si querés saluer si es assi, catad ofra tat como aquella, que os tenia eseripta, para que si aquella no viniesse á ruestras manos, riniesse esta otra; é yo me determino de deçiros lo que passil, para que ponqays recabdo en rnestra vida." A to qual yo le respondí assi: - Anigro, yo bien conoscí luego vuestra letra é cay en la verdad: y esperaba que fuesse mas de noche para enviaros á llamar, ó para yrme yo á luusearos; é lien sé que ros no the avés de deçir sino verdad, é sé que soys perfeto amigo é que soys

1 S. Ambrosio. Sus palabras son: Omnia nolis factus est Chris!us; st lebribus acstuas, fons est; si vuluus hubes, medicus est; si mortem times, ri- hijorlalgo, é no porleyss filtar á quien soys: i aregs risto muy bien que en todo lo que yo he podiclo hontaros é aprovecharos to le hecho de huena gima, y he desseado daros á entender que tenés en mí un buen amigro. is pues to ienés conoscido, decidme qué peligro íiene mi persona, é avisadmo de lo çierto; porque denás de serVir á ldios en cllo, me parays como amigo la buena voluntad, que sicmpre os he fenisto é tengo, y en csto arrí fodo el seereto que se repuice para vuestro honor é jersona. í desta mancra le dixe torlas las dukes palalmas, que yo supe decirle: $y$ este era un regino de aquella cibdad, a quien yo avia fecho buenas obras, é pessáluale de inis trahaxos.

É cómo yo acalué de hablar é le ove lie. cho mi exortaçion. él replicó assi: "Scñor, si yo no riesse tan enferma la justiçia, no ne penaria mata que se supiesse que yo os aviso; pero veo que anda el tiempo de otra manera, é areysme de tencr secreto, pues en lo que diré, vereys lo que os va cu cllo. Lo que yo sé en este caso es que ha tres noches que renian del campo á media noche apuel Simon Bernal que os acuchilló é Julian Guticrez, eriarlo ded lachiller Diego de Corral, é junto á la iglesia de Sanct Selbastian habló á Johan Rodrigncz Orfolano, el qual por la calor se estaba á la puerta de la cáreel, donde está presso; é cómo estos llegearon, le ha. blaron, y el Simon Bernal traia una ballesta armarla con un rallon puesto en ella, y el Julian una espada en la mano, que se venian á la cilndad; y el Johan Rodriguez le dixo: "Hirad cómo andays é que es. tays sentenciado á muerte, é mirad lo que avés fecho, é que tarlarín mas en tomaros que en poneros en la horea; é acordaos que no veynte passos de donde tenés los piés, heristes al reedor." A lo qual

tu est; si auxilio indiges, virlus est; si cibum quaeris, alinculum est. 
el Julian Gutierrez dixo: "Juro á Dios que assi se lo tengo yo dicho esso muclias veçes, y él lo debe mirar é apartarse de aqui." Estonçes el Simon Bernal dixo: - Ya yo sé que estoy sentençiado á muerte; pero juro á Dios queste harpon que traygo puesto en esta ballesta ú otro le tengo de echar al veedor por los pechos, estando parado á aquella ventana de su casa una noche." É diçiendo esto, señalaba con el dedo la ventana que se via desde allí, y era la cémara donde yo dolmia, é muchas veces de noche me paraba alli desnudo, por la calor. Y el Johan Rodriguez replicó: "Mal decis: mejor será enmendaros. Calad que cssa soberbia es lentar á Dios, y no veo que os arrepentis de lo mal fecho, é no sabés dónde os tracrán vuestros peccados: quanto mas que lo avés con liombre que liene que gastar é puede segruiros. Mirad lo que haçeýs é cómo andayss." El Simon replicó: "Venga lo que viniere: que si yo le mato, lodo se hará bien. . E ássi volvió las espaldas él y el Julian, é se entraten en la ciludad, y el Johan Rodriguez se quedó allí, é desrle á poco, como yo llegué, me contó lo que lıe dicho, é divo: Yo no os dixera cosa de lo que os diré que agora poco ha passado, hablando conmigo Simon Bernal, sino porque le veo mal determinado contra el vecdor, é con propóssito de perseverar en sus trayçiones: sabed que passa esto é aquesto: é contó lo cues dicho, é dixo mas. Si yo no esluviesse presso, yo le avisaria del caso, porque me paresce ques unucha consçiencia no lo laçer porfue desde aqui !e veo Inuchas noches paralo á aquelia su ventana, é fúçilmente aquel traychor le puede malä é dar una suciada, y es grand cargo de consçiencia no le avisar. Assi que, señor, ariendo yo salsitio esto, é viendio la parte que este traylor ticne en el dean y en vaestros enemigos, é conosçiendo ques pílblico quel gobernador os quiere mal, dissimulé é dixe al Jolıan Rodrigue\% que si aquel por alli andaba, por ventura sus peccados le traian al pagadero. Assi que, señor, este es el caso, de que tenés nesçessidad de ser avisado: proveed en no os parar á aquella ventana de noche, y en lo que más os paresçicre para vuestra salud."

Estonces yo le dixe: "Pucs arés fecho lo mas, é por los anigos se la de lager todo lo que los buenos son olsligados, haced por amor le mí una cosa, é sea esta: deçid á Johan Rodriguez que me distes notiçia desto que me arés dicho, é que ya él sabe que siempre le he tenido por anigo, é que yo he sabido que está presso por doscientos pessos de oro, que le pide Diego Rodriguez de Inuelva, que tambien es mi amigo: que yo quicio contender entre ellos é conçertarlos, é quiero pagar qualquiera quichra ó alcançe que se le haga é ponerlos en paz; é si quicere, luego prorné una barra de oro de minas en su poder, é se la daré graçiosa, que pesse doscientos castellanos, para lo que he dicho, con tanto que Johan Rodrigucz me a vise, quando viere á Simon Bernal, ó me lo enseñe cómo lo pudiesse rel desde qualquier parte que fuesse, $\hat{E}^{2}$ aquel mi amigo promelió de se lo deçir, é se lo dixo, é tomó con la respuesta: é dixo que Johan Rodriguez deçia quél haria todo lo que en él fuesse por amor mio, sin interesse algmo, portue le pessaba de mis Irabaxos é me lo delsia.

De allí adclante yo anduve mas solre aviso, é detcrminé con mayor diligencia de buscar á este que lan desseoso estaba de mi muerte; é para esto cada dia ó de tereger á tereger noclie salia de la cibdar, despues de sosegarla la grente, é y la una ó dos legrnas en derretior por las estancias é laçientias re mis contrarios, assi conto la dei hachiller Corral é del dean é de sus sccages, é huscaloa aquel mithechor: é otra noche salia cl capitan Johan de Rz- 
calray - ínlino aniggo mio, a le luscar con alerunos ficles criarlos ó amigos mios; pero $n$ o pulo cato ser secrecto. y al Simon algunas regeos no vido á ní é á los due le buscalium, por Io qual se rotruxo á la cibdiul. y en casa del dean é de sus amigros é parientes se lecogia é allegaba é assi estuvo algunos dias secreto.

En este tiempo. ma cararela de la isla de Jamíyca cstaba en ol puevto del baricn, é se apusstalua para se partir : é yo ture manera que al tiempo de la partida la fuesen á cakil mu alcalle y cl capitan Johan de Ezoray é otros nis amigos é algmos criados mios, llevando mn mandamiento que yo tenia del juez de residenciat, para prender á aquel trayelor: de rentura hilláronte metiłlo en una pipa arimarla con otras, ó solıre clla cables é otras cosas, é gotemnlo agna, para que paresciesec (jue cra de brevage, porque of escondido vertia agnua de quando en quando por çicrtos agugeros; é acaso un rriado mio dió un golpe en la pipa é sonó hueca, é diso: "Aqui podria estar aquel hellaco." Y cl capilan y el alcalde la hiçeron desfondar. ć hallaron dentro al malhechor é atado le truxeron á la cibdad, é le meieron on la cárrel, é aquel dia se cumplieron sicte meses é medio yue fuy herilo. No sintió menos que la muerte el dean esta prission.

La justiça mandó quel capi!an Johan de Lizearay tuviesse en guarda é á mi costa el presso. ó luego yo cnvié á avisar al juez de residençia, y él mandó que lo llevassen á Acla; ć para sacarle de alli ovo muchas contradiriones por parie del dean í sus secaçer, diçiondo que era contra los previlegios de la ciblad. pensantio de lo salvar ó poner la cosa cull haraxa. Pero aprorechóles poco; porrque con la voz de la juxiçia é con mis antigos no ovo parte que se alreviesse á lentar el remedio o lats armas. annque algmas reces se junlaron para cllo en casa del deam, é sin dubdla fincran bien

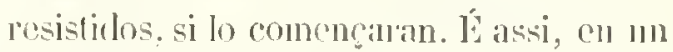
bergantin que yo lloté, le llevaron í Mela el alcaldo y el rapilan Johin de Exallay, con la gramola conviniente, é yo fuy on el mesmo bergantin á proseguir mi justicia. Finalunente, él conliussó su delicto, é ser liecho solre ascelanca é sobre pensado, é dixo que pliando avia procurado de vivir conmigo, era por me matar dumiendo ó como mejor le paresciesse, é condenó á un clérigo del salto, que diso que le aria puesto en ello, al qual, siento yo juez, le luve presso por ladron, é le casligara, si no luyera á la igclesia.

Coacluido el proçesso, el juez revocó la sentençia de muerte que en rebeldia avia darlo contra è é mantóle cortar la mano derecha y el pié izquierdo, é condenóle mas en destierro perpétuo de la licrra ó Indias, é confiscó sus licnes á la cámara l’cal, ¿ condcnóle en costas. La qual sentençia él consintió é yo assimesmo. é fué executada en la persona del malhechor, é le Iornaron á la cárecel por las costas; y ch un palo, que cslaba limcado en la placa, clavaron d pié é la mano, y era aquel mesmo palo donde avia cstado puesta la caliega del adclantado Tasco Nuñez de Balloa, como atrís se dixo. Y esta justiçia se hiço un sábado, é luego otro diil siguiente, domingo, saliendo de missa el juez é yo é otro con él passamos por la placa é á par de arpel palo llegados, llegó un mensigero de Pedrarias á grand priessa, é dico en alla roz: "Ca" valleros ó los que estays pressentes, sed testigos cómo pressento rste mandamiento rel senor golnernador Pedrarias Dívila, teniente general, al señor liçençiado Johan Rodriguez de Alareonçllo. juez de residençia, "é pieliúlo por testimonio á un escrilsano que allí se halló. El liçençiado, viculo aquella furia é aucto assi público, paróse en la plaça é leyó el mandamien10. é dixo al que le truxo: a heposaos, 
pues os aveys dormido en el camino é avés llegado larde; y el mensagero dixo: "Si me lie dormido ó no, mande vuestra merêed que se me dé por testimonio á qué lıra llego aqui, porque pueden sej tres ó quatro horas que amanesció, é despues de vísperas partí de Panamá." Assi que, por esta ragon paresçia que en menos de dos dias, ó en poeo mas de uno é medio, avia andlado quarenta leguas ó mas, é de mal eamino.

Estonçes volvió á mí el juez, é díxome: "Señor vecdor, aveys risto esto que diçe este mançebo é lo que trae en este mandamiento?.. "é cómo yo yoa á su latdo, ley en tanto quel juez leia, é dixe: - Señor, visto he lo que diçe; pero mirad dónde os toma este nuandanienlo, á quaIro ó çineo passos dessa picola ó pato, donde hicistes ayer poner aquella mano é pié del traydor de Simon Bernal, para que coitozcays é conozcamos la ventaxa que hay de aquel Juez Sobcrano á los de la tierra, é cómo no la sido en vucstra mano dexar de hager justiçia, ni en la de Pedrarias el procurar de la impedir, é dar á conosçer quáln nolorio enemigo mio es en quanto puede, é cómo quisicra sacaros de las manos este negocio, por escapar este traydor. Pero yo me partiré mañana ó essotro dia á Panamá, é le cntiendo decir delante de cavalleros é hidalgos, muy bien dicho, to que lı hecho é hace commigo، É lerego el liesnçiado dixo al cserihano que leyesse públieamente cl ruandamiento por el qual on cfetto deçia Pedrarias, que porque cra informado que Simon Bermal me avia acuchillado, y estaba presso, que mandaba al licençiado Alarconcilio, su teniente, é á otro jucz qualquicra que de la causa conosciesse, que visto aquel su mandamiento, no entendiesse mas ello, é se le remitiessen pa- l’a quél lo viesse é hiçicsse justiçia, y advoeaba á sí el conosçimiento desto, é suspendia al liçenciado é á olro qualquier juez para que no se proçediesse en la causa con çiertas penas. A lo qual el liçenciado dixo por aucto, quél se daba por ynlibido deste negocio, é que si no lo oviera sentençiado é antes llegara el mandamiento, quél se ynhibiera; y en lo demás, tocante al mallıcchor é á estos negoçios, lo renitia al gobernador. É yo pedí por testimonio aquella respuesta é remision, é dixe que yo no le avia pedido justiçia contra aquel trayulor é sus secaces, como á teniente del gobernador", sino como á juez de residença é juez de Sus Magestades, é que como lal atvia entendido él en esta causa, y cra muy agena del conosçimiento de Pedrarias. é que yo avia gastarlo é perdido de mi haçienda, á causa de apuel lraydor, mas de dos mill pessos de oro, é que protestilba de los colvar del goliernador é del licenciado Alareonçillo, si no le tuviesse presso é á luen recabulo hasta que yo colrasse mis gaslos é pérdirlas : é que claro le constaba que, si la justicia no fuera executada cn la persona de apued traydor, é oviera efetto el mandamiento de la suspension en este, yo fucra notoriamente agraviado co la diaçion. F́ pues quel juez se avia ynhibido, é al pressente no avia juez ni me convenia seguil mi justiçia eontra los eulpados é partíçipes en la traycion. que yo lo rescibia por agravio: é protesté que si se fuessen ó alssenlassen ó transportassen é vendiessen sus lienes, de manera que dellos é de sus personas yo no alcançasse justiçia, pue in pudiesse pedir é demandar al gobernador é liçençiarlo é á sus lienes, é á quien con derecho debiesse pedirlo en su tiempo, liggar é forma, é ante quien dello pudiesse conosçer : é pedílo por testimonio. 


\section{CAPITULO XX.}

Cumo el auctor se parlio de Aclit, fingiendo que se yta å Panamá, donde el gobernador estaba, á se quexar dél, é se fué í Espaūa á pedir jusliçia eonlra Pedrarias; é eumo el Emperarlor, nues!ro señor, le mandé oyr é fue proveydo por nuevo gobernador para Castilla del Oro Pedro de los Rios, un easia. llero de Córdora; é otras parlieularidades se traetan eonvinientes á la historia.

A veynte y tres, me embarqué en aquel bergantin en que avia llevado á Acla aquel traydor desde el Darien, é fingí que ylua á Panamá á quexarme del gobernador á él mesmo, de quán notoriamente por aquel su mandamiento se avia mostrado coutra mí en me impedir mi justiçia: é de hecho, despues que sali del puerto de Acla, el dia siguiente, conçetado secretamente con el maestre del navio, le hiçe mudar la derrota é renir la vuelta de las islas de Cuba é Jamáyea é de aquesta 1sla Española. Y en el camino adolesci de ficbres continuas é olrus passiones, é llegué á tauto peligrro é tan flaco, que no pensaba que podia salir vivo ni llegar á tierra: pero plugo á Dios que á los diez é siete dias de aquel mes aporté á la ciludad de Sanctiago, puerto de la isla de Cuba, i alli fuy muy festejalo del adelantado Diego Velazquez, é me çessaron las calenturas è me senti mejor" é deste allí torné á la mar é vine al puerto de la Yaguaua, en esta Isla Española, desde á oclo dias que partí de Cuba, è desde la Yaguana rine por tierra ochenta leguas luasta aquesta cibdad de Sancto Domingo, eu la qual repossé quinçe ó regnte dias, é laallé al señor almirante don Diego Colom, que tenia tres naos aparejadas é á punto para se partir á España, porque el Emperador, nuestro señor, le avia enviado á mandar que fuesse á su cólte. El qual almirante se lolgó mucho connigo é me hiço yren su nao: é salió deste puerto á los diez é seys de septiembre, é liegamos á Sanct Lúcar de Barrameda, en Eispaña, á los çinco de norienulıe del mesmo año.

Llegado en Sevilla, supe allí de cartas que hallé de la Tierra-Firme, sue apuel traydor de Simon B̉ernal, desde á tres ó quatro dias que yo sali de Acla, era muerto é se pasuó. Plegea á Dios que su muerte fuesse en estado cue su ámima se salvasse, pues que tanto mal liiço á sí é á mí! En Sevilla estuve pocos dias, é me fuy á la cólte é hallé en Burgeos el Consejo Real de Indias, que descle á poco se fué á la cibdad de Vitoria, donde el Céssar estala, á la sacon que tenia çercada su condestable, don linigo de relasco, la villa de Fuenterrabia, donde los françeses estaban desde el año de mill é quinientos é reynte y uno ó resnte y dos, quando las Comunidades se alteraron.

Allí informé á Su Magestad Cessírea, é á los scñores de su Real Consejo de lndias, de mis trabaxos, é me quexé de Pedrarias é hiege relaçion de las cosas de Tierla-Firme, é por virtud de los poderes que tenia de la cilulad del Darien, procuré que Su Magestad proreyesse de gobeinador prara aquella tierra. Y en esto me deture algun tiempo, porque aquel bachiller Corral que yo avia enviado presso, estaba ya de la parte de Pudrarias é se quexaba de mí, diçiendo que no le debicra enviar ni sacar de la tierra, é que no le avia querido remitir al gobernador. Finalmente, fuy condenado en çient mill mararedis de costas (que le pagué en España) y en que le pagạsse íos daños que por mi causa oriesse resçilido en su hacienda, para la qual averiguaçion finymos remitidos á la Tierra-Firme al juez nuevo 
que yha para la residençia, non obstante quel bachiller no fué absuctío de sus delictos, por dondle yo le envié presso. Y como en la córte andaba doña lsabel de Bovadilla, muger de Pedrarias, é otros sus procuradores con el bachiller Corral, estorbándome é procurando que Pedrarias no fuesse removido, duraron mis litigios mas de dos años con ellos: en el qual tiempo Pedrarias, enojado del poder que la cibdad del Darien me avia dado, fué allá é de licelıo la despolsló, como hasta agora está despolılada, siendo el mejor pueblo é assiento de chripstianos que avia en Tierra-Firma en aquel tiempo: la qual ciblad él la avia infamarlo é escripto que era enferma, é no siendo assi, sino por la destruyr, por el odio que le tenia, como la listoria to ha contaclo. Lo qual él hiço, assi porque la avia poblado el adelantado Vasco Nuñez, como por acahar de destruyrme; é assi perdí mi casa é muclıa parte de mi laçienda.

En fin, por mucha contracliçion que tuve, é por mucho farol que Pedrarias é su muger buscaron, no se pudo cxeusar quel Emperadol, nuestro señor, dexasse de proveer de golsernador de Tierra-Firme, en lugar de Pedrarias, á un cavallero de Córdova, llamado Pedro de los Rios; é mancló Su Magestad que fuesse por su alcalcle mayor é juez de residençia el liçençiado Jolian de Salmeron. É assi, en el año de mill é quinientos é reynte y seys años, se despachó en Sevilla este gobernador, llevando consigo á su muger doña Catlialina de Saavedla, para que le ayzudasse á allegar laçienda ; é con clos naos é una calavela, é hasta dosçientos hombres, fuć á Tierra-Firme, é yo con él, para pedir mi justiçia contra Pedrarias é los que me eran en cargo. E acaso fuymos en un navio aquel bachiller Corral ó yo: que ya nos avian liecho amigos, ó á lo menos nos habláhamos, é dlesde España hasta la Tierra-Firme comimos á una tabla, por- que yo pensé que eran acahados los pley" tos entre él é mí con aquellos çient mill maravedis que le pagué, sin se los deber, é porque desde la lora que yo le hablé, me determiné de no entendẹ en sus crímenes y exçessos, si él no innovasse las cosas passadas por atender á las de Pedrarias. Y el bachiller sintió, como yo, la pérdicla de su casa é haçienda del Darien; é sin dulula, si en conformidad pidiéranos á Pedrarias nuestros claños, él pagara lar’tos dineros al uno é al otro é á otros muchosé al Rey, tantos que no le bastara quanto tenia. Pero llevaba pensado el bachiller Corral cobrarlo de mí mas fáçilmente; é cómo saltamos en tierra en el Nombre dle Dios, luego desde á çinco ó seys dias me puso una demanda de ocho mill pessos ante el juez de resirlençia, diçiendo cue por le aver presso y enviado á España avia percliclo su haçicnda: é dlemás desso inçitaha é ayudaba á una muger (madre de la que yo mandé açotar é sacar los dientes porque acusó á su marido falsamente), la qual causa fué conclusa en España ante los señores del Consejo, é remitieron la deçision y sentençia al juez de residençia el liçençiado Johan de Salmeron. Y el bachiller, como he dicho, érame contrario tambien en lo ageno como en lo proprio; é cómo en este litigio no avia mas que altercar, yo fuy absuclto é dado por libre quanto á lo de aquella muger : é respondí al bachiller que pidiesse su laçienda á Pedrarias, que a via despoblado al Darien , é á él le perlí por reconvençion veynte mill pessos que yo avia perdido, por arer seydo él el fundamento, con el dean, de mis trabaxos, é por aver él amotinado la gente que yo enviaba contra el caçique de Bea, que avia muerto al capitan Martin de Murga é á otros chripstianos, é porque velándose la cibdad de los indios, é siendo el mayor enemigo de todos su caçique Corobari, que yo por tal mandé quemar, él se en- 
tendia con él, é se hablaban en su estançia fuera de la cibdad, conno el caçigue lo confessó antes de su muerte espontánea: mente, por lo qual él aria incurrislo en el mesmo armen é traycion, é delia ser punido como el dicho arcique lo fué : é por su causa se avia despoblado el Tarien, porque en ella estaba su manceba Elvira, en quien tenia un hijo, lá qual era muy cereana doudo del calcipue de Bea; é Corobari é su casa eslaba llena de espias contra los chripstianos en los indios que le servian de Corolari, que eran de quien frinģipalmente aquella cibdad se velaha, é con quien él tenia tracto é amistad é conversaçion: é reçelándose dellos se avian yolo nuchos reginos á vivir á otros pueblos é avian desamparado la cib)dad, por el notorio peligro é veçindad de su casa del hachiller, ¿a avian perdido sus haçiendas, é yo la mia, que era mucho mayor é mejor que la suya. E andando en estos litigios, por medio de algunas buenas personas que se metieron enmedio, venimos en conçierto, é de consentimiento de partes, assi to quel bachiller me pidió, como lo que yo le pedia por la reconvençion, to compromelimos en el mesmo juez de residença, pará que por juslicia ó arbitrariamente. como á quisiesse, lo determinasse. El qual lo dió todo por ninguno, para que en cllo mas no se hablasse, con grares penas: é assi lo pronunçió por su sentencia con la pena del compromiso, pues como el uno y d otro estábamos gastados. aunque cada qual pensalya ser agraviado, este fin luvo aqueste litigio; é con el silençio se acaló, 10 sin mucha pérdida de anubas partes. Pero la verdad es que ni en el bachiller Corral ni en mu no ovo la prudencia que escribe Sand Antonio, arcobispo de filorenria, que tuvicuon dos milites. Ilamarlos Guillermo de: Brindiz é Raýmundo Guasco, sevendo pressos por los tártaros, los quales querian que se matasse el uno al otro, por fiesta ú placer de los miradores crueles, diciéndoles quel vençedor quedaria vitorioso é lo loarian mucho despues. Pero como aquellos cavalleros cran buenos chripstianos, é salian que despues que oviessen peleado, avian de matar al veneedor (porrue nunca guardan verdad los tártaros), estos cavalleros cathólicos habláronse el uno al otro, é dixeron que mejor era que aquel combatimiento se convirliesse contra los lírtaros infieles; é assi unánimes dieron en los que allí avia, mirando la fiesta, é mataron quince é huricron muy nual otros treynta. Assi lo cuenta aquel sancto dotor que tengo diclio ${ }^{1}$.

Digo, pues, que si el bachiller Corral é yo nos junláramos contra Pedrarias é sus cautelas, quél no fucra parte para deshaçer el Darien en tanto que nuestros litigios pendian en la córte y estábamos alsentes; é si ćl supicra que estáluamos en conformidad, no lo tentélra, é ya que lo liçiera. nuestras haçiendis no se perdieran ni las de oúros. É assi pensalua yo que aquel bachiller . viendo perdida su casa, riniera en mi amistad enteramente por su interesse: pero figuróscle que mejor cobrára de mí lo que avia perdido que no del colsernarlor, é al cabo paró en que me quedó á mí solo la pendencia con Pedrarias. é de la del bachiller yo salí de la mancra gue tengo dicho.

1 El Antonio de Florencia, lit. XIX, cap. 8, \$. 14. 


\section{CAPITULO XXI.}

Q.e trach de alymas cosas motables que passaron en la Tiern-Firms entre el gobernador Pedraria, bivila y cl capitan Gil Gonp̧alez Dívila é otros capitanes, en tanto que yo esture en España negociando la yda del nuevo gobernador Pedro de los Rios, para que Pedrarias fuesse removido, a la relaeion de lo que descubrió el capitan Gil Goneqalez en la inar é costa alistral de la Tierra-Firme, é porque es larga la narraçion de lo uno i de lo otro, yrí este cupitulo diriso en ocho páralos.

A nuado la lecion, cómo de aver seyelo re. movido Pedrarias del officio de la gobernaçion de Castilla del Oro; ó á lo menos proveydo Lope de Sosa en su lugar, le quedó mucha indignaçion contra mí é tambien arrés visto por qué via ć rodeo se tractaron mis trabaxos, é fuy acuchillarlo á traycion, é cómo é con quánta ragon é cansa acordé de gastar quanto tenia, siguiendo mi justiçia en España, é pidiendo gobernador contra Pedrarias; ó cómo en fin Su Cessírea Ilagestad, como justíssimo Prónçipe, proveyó de aquel offçio é golvernaçion de Castilla del Oro á Pedro de los Rios. I pues está dicho quel año de mill é quinientos é reynte y seys fué ál Ticra-Firme, é yo con él á pedir mi justiçia, y en lo que paró parte dello, antes que á mas se proceda, conviene á la historia que se digan algunas cosas nolahles que passaroin en Tierra-Firme, desde el año de reynle y tres hasta el de veynte y seys, que esture absente, entre Perlarias y el capilan Gil Gonçalez Dívila é otros capitanes, porque son cosas notables é del mesmo jacz desta historia.

$\$$ I. En el capítulo XIV se dixo cómo Gil Gonçalez avia ydo á descubrir en la mar del Sur con una armada, de Ia q!al fiıé por piloto mayor Andrós Niño: el qual viage liço. é al tiempro gac yo me partí de Acla para ye á España, como se divo en el capítalo precedente, llegóá Pamaná de vuelta de su viage el capitan Gil Gonçalez con el oro é raçon de lo fue avia desculvicrto, é cómo avia hatlatlo una laTOIIO 115. guna muy grande, que se pensaba que era mar dulce. en la provinçia de Vicaragua, é avla convertido é baptiçado muchos millares de indios; é que tornedo á Panand se fundieron noventa é tantos mill pessos del oro que truxo é apartado el quinto de Su Magestat para criviarlo á España, quísoselo cmibaractu: Pedrarias, diçiendo que Gil Gongalez queria renil a csla cibdad de Sancto Domingo con el oro del Rey, é que si algund desastre ó caso siniestro le acaesçiesso, á él seria cargo, si no plisicse recabdo en ello, para que se enviassen seguros á Sa Magestad quinge mill pessos é más, que crin de aquel oro el quinto. Gil Gonçalez deçia quél lo avia sanado en el armada, que estaha á su cargo, é los que con él avian ydo con muclio trabaxo, é con la langa en la mano lo aria sacado de las manos de sus enemigos é inficles, que nenos seria llevarlo por tiorra é mares d: Sus Magestades ć de los amigos, é quél lo pornía cu rerabdo é daria euenta dello, é si nescessario fuesse, yría en persona á la cólte á lo llevar á Sus Magestarles é cí riaz racon de su viage é camino. Todo esto contradeçia Pedrarias é ponia inconvinientes para quel oro quedasse en su poder ó en la persona guél mandasse; pern en fun, Gil Gonçalez se partió con cl oro, é vino á la cibdad é puerto del Vombre de Dios; é despues de partiço, cayó est mayor arrepentimiento Permarias, por le arer dexado yr é éluego so puso en camino tras él para le prenter é lomar al oro.

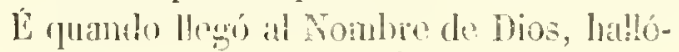




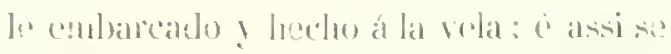

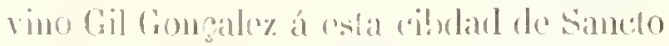

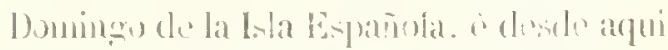

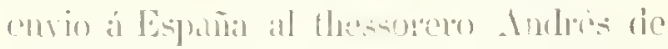

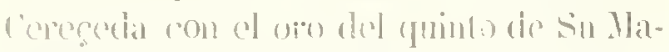
fertede e para que hiciesse relatgion del

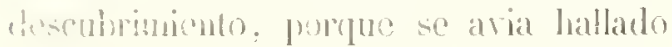

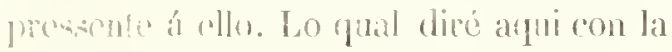
brevelat que supiere deciblo. propue es an parte que convicue á lat historia.

sil. IJichu tengo quel primero que des"ubrió la mar del sur á los chripstianos fué 1. adelanlado Vasco Xuñez de Balloaa : é ascimesmo he escrifo rómo con sus navio. fuc (despues gac le descollaron) enviado por cappilan á desconturir por la mar del Sar c) liencenculo Espinosa, alcalde mayor é teniente do Pedratias, ó lo que de aquelia ina?" co costas vido en el appilulo XIII lo live. conforne á las alturas é gados en yeu esta la costa ć islats. de que en su viage se turo noticia, seyendo priloto maror clu aquel eamino Johan the Castañeda. El terere gro de ló españoles navegó en la mar austra! fié el capitan Fernando de Magrallanes. quando descolbrio aquel menomble a garnde Estredho el año de mill é quinientos ? reynte. por el qual entro por la boca que tiene al Oriente, é fué mor lat mar dol sin é por aila mar álas islas de Malence es Espericria, lo qual tambien queda dicho en ol libro XX. El quar-

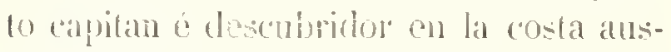
lual fuc el capian Gil Gonçalez Dívila s* (1) piloto Andrés Yino. é lo que se acrescenté pror an industia en la moderna cosmogiaphia, degilo he como lis carli emmendatal lo platira é yo la he visto d: la mano del cosmógrapho Alonso de Ciliaves. al qual no rulpo en arpuclio qiél no

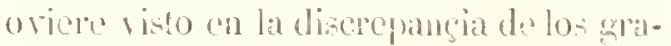

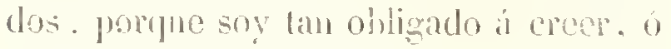
mejor dincindo, testificar" lo que mis ojos vicenen. como á lo que otros que no lo

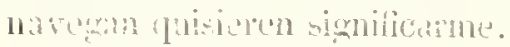

$Y$ ) dixe ife lo bllims qued liencia-

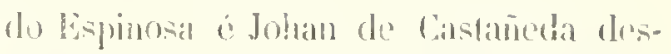
"olibricron fur hasta ver el rmbecamionto

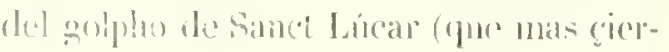

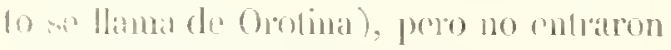

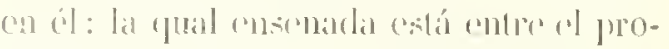
montorio o punta do la llerrudura y la

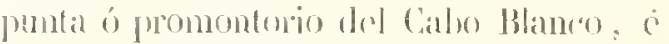

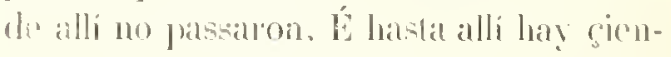
to y orhenta legrnas, pocas mas ó menos, anuque nuestros pilotos lis llaman dosétrintas. ć assi lo serian ó mas por la cosla, licrra á licrara ó de alli adelante se allribuyc á cistolra armatia, de gue fué por capitan Gil Gonçalez de f́rila. í todo lo que Andrés Yino anduro más quel liçenciado Espinosa fueron hasta çicnt leguas é quando mas ciento é reynte hasta la halua de Fonseca puesto que lierra á licra por la costa serian algunas mas; pero no las que Gil Gonçalez é Indrés Niño se jactaban. (que les daban nombere de segscientas y cincienta leguas desele Panamá á donde aria Andrés Niño llegado. É Gil Gonegalez eleçia que poi tirra avia él caminado trescientas y reynto leguas, desde donde tornó con çento y doge mill pessos que lo dieron eaciques. é mas de la milad dello Je oro muy baxo: éá mi me escrilió que se avian bapliçado treynla y dos nill ánimas ó mís de su volumlad é pieliéndolo los indios; pero parísceme que aquellos novamonte convertidos á la fée la entendieron de otra manera pues al cabo lo convino al Gil Conçale\% é su gente salir de la tierra mas que de passo. Hallaron grandes poblaciones, é descubrieron ma slandissima laquna. que pemsaron que ela mal dulce. en las costas de la qual viven grante multilul de pueblos é genentes de intios. Io qual yo ví desperes mir mejor, Guando fuy a aquella tizloa, é se sabe mas puntualmente. í quando se labile adelante en particular de aquellat gobernarion di Niearagul, se dirín muchas mas (osas. altende de las que estos armadores vicon. á los quales no se les delue negar 
el loor de su trabaxo. lero tornemos al canino, que en la verelaul fuć larto menos de lo que Auclés Niño é Gil Gongalez. le pintaron, é no fué menos de lo que yo aqui les alribuyré.

S III. Gil Gonçalez hiço quatro navios en el rio que llaman de la Balsa, que no estuvieron para navegar é se perdieron todos, y en esto gastó mucho tiempo é dineros, é turo nucho trahaso. Despues hice ofros quatro en la isla de las Perlas, que cstá en el golpho de Sanet Migued, é de allí se partió esta armarla á los veynle y un dias de encro de mill é quinientos é reynte y dos años, é despues que navegaron lasta çient legुuas al Oçidente, dixeron los marineros que toda la vasija del agua estaha perdida, é que no se detenia en ella ol agua ni se porlia remediar sin lacerze otra, é tambien hallaban ya los narios 10cados de mucha broma; é por esso les fué forgulo sacar en tierra todo lo que llevahan donde mejor dispusiçion hallaron. é poner á monte los navios para los ailohar. Lo qual lloró algunos años despues el carcique de Burica, porque este adobo se liço en su tierra é muy á su costa é de su gente, é les hico hartas fuergas é simraçones Indrés Niño é sus marineros; é assi đlespues lopagóconsu calıça, y le malaron indios, como se dirá en su luşar. Desde allí enviaron en hergantin á Panamá por pez para brear é por otras cosas, é cómo la gọinte no se podia sostener alli, donde los narios estaban, por falta de mantenimientos, ó porque se griardasse el bastimento. rfue cra para el camino de la navegacion, fuć nescessario quel capilan Gil fongalez, con çient lombres se entrassc la tierra adentro para se sostener, en lanio que la pez venia é la vasija se haçia é los navios se arlolaban, é lambion para comengar á erangear oro. que cra lo que prinçipalmente huseaban; porque de armarla liecha por muchas bolsas no se puede sospechar ynel desson do hendhirlas es poeo, ni que la eobdicia delos ministros della sea el mayor cuychdo, sino el ma yor intento de los amadores. Issi que, caminando Gil Gongalez la tierra adentro lágia el Ponicute, algumas reçon se hedló tam apartatlo de la costa. que so vido arrejentido: pero desó mandado á Ancirés Nino, que guedaloa con loa na: vios. que renida la pez, á ardobardos los navios, y liecha la vasija. se finesse la costa ahavo al Poniente, é que andinto ochenta o gient leguas, si llecrasse mavi presto, lo esperasse en el mejor puento que por la comarea hallasse, porque as-i lo haria él, si primero llegasse.

Yendo Gil Conçalez por la liera adentro, sosteniéndosse é baptigando muretres caciques é indios. Ie subegedió yne á canca de passar los rios muchas veges á pió á sulando, le solyevino un tullimiento dw una piernal. que no podla dar un parsen át pić, ni dormir de nocle ni de dia del du. lor, ni caminar á pié ni á caballo: ó por esto le llevaban en rma manta atuda en un palo, muchas reges on hombros de indios ó de chripranos, é de aquesta manera fué lartas jornadas. Was porque a caminar era assi mu! diliubloso, como por las mudhas aguas que entonçes havia. ovo de pararse en casa de me carcifun prinçipal, amene con harto cuylado de velarse (al qual caginuo tenia su pueblo en una isla yue tenia diez leguas de longitud é seys de latilui. la qual haçia dos lragos de un rio muy poderoso); (́ apossentóse Gil fonçalez en la casa cicl carique, que cra lan alla como una mediana tore, é de hechura de un pahellon, armada sobre nostes, é cubierta de paja, yen mediodcla le higgicron una cámana jor la lummetad, sobre postes. é lanlo allar eomo dos estarlos. Deste á quinge dias que alí astaban. lioviólanto ćnescioron los rios de

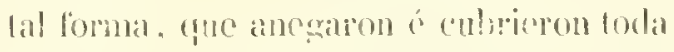
la isla, y en la casa domle ul capilan es-

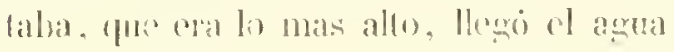

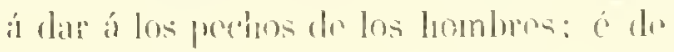


ver aquesto los españoles, pidicron ligencila al capitan, para yose á valer furcra del puchlo en los árboles, y ál se la dió a c se quetó alli en aquella grand casa con la srente mas de bien, esperando lo que Dios quisiesse hager é pensando que no hastaria cl agua á la derribur, é conjecturando en esta sospedta, é teucrosos de ver crescer el agua sin saber hasta quando. Con este cuydado tenian en lo alto de ha rasa presta una inágen de Nucstra Scñora é una lómpara de ageyto gae la alınJrabar é carla Jola se venian alli mas compañeros de los gie no se hallaban á su propussito de fuera y en ol ris partes: é á media nocde se quebraron todos los postes, é cayó la casa solme los que estahan dentro, é Jerribó la cámana donde estaba el capitan. é quedó sobre dos muletas de piés encima de la cémara, el agena á los muslos, c llegaron las varas de la techumbre al sucio, é quedaron los compañeros a agua á los pechos. Plugo á Dios que con quantos golpes dió la ciasa sobre el agua vino poen á poco al sucho, sin dar golpe en tierra é sin hared fuerega para que la límpara se muriesse: que fuć mey grand socono no quedite sin lumbre, para hallar mancra con que saliegren de alli é no se ahogassen, que estahan como Ins jáxaros que se toman (ó ratones) con li losilla, puestos todos (delaxo de una sobrecopa. E assi rompieron con una hacha la techumbre de la casal, é por allí salicron los compañeros que con el capjitan se avian yuclado, é á él le sacaron en los hombros. porque los denís se avian con firmpo acogido, con licencia de Gil Goncalez, á los áboles, é con cllos los indius mansos gree terian de servicio: é dosta mincha le lievaron, dando voges para que fo: compañoses y a capitan se pudiessen juntar, lo qual so hico con mucha fatiga. Despies rque lueron jumtos, colgaron ma hamaca ó manta de un álol á otro. en què capitan fuć puesto. é assi estuvieron liasta que fué de dia, no gessando en toda la noche de Hover mucho é con muchos truenos é relímpagos; é desta forma esturicron hasta quel agua cessó é menguaron los rios é tornaron á su curso. Fi temiendo que podria tornar á les acaescer lo mesno, hicieron solire los ámoles con varas é ramas giertos solrados é cámaras $\mathrm{cll}$. biertas con hojas, é de lal manera chie tenian fuego en cllos: en los quales sobrados se socorrieron otras dos veges por otras crescientes, huyendo de las ofras (asas baxas. Despues quedó la tierra tan Ilena de lama é çieno é de árboles quel rio truxo, que á gran pena podian andar por allí.

En este trabaxo se les perdieron algunas espadas é rodelas é restidos, é rescibieron mucho daño, á causa de lo gual highieroin daragas de algodon bastado, en lugatr de las rodelas que perdieron; y có10 el agua les llevó los mantenimientos, fućles forgatlo yr á buscar de comer hácia la costa, que era su intento, de la qual estaban desviados diez lequas ó mas, é por tierra no podian, é por esto Jicicron halsas de madera é árboles atados unos á otros: é assi pusicron ençima dellos su fardage é sus personas con Jos indios que traian é les servian, é fueron por el rio abaxo hasta llegar á la mar, aunque eran mas de quinientas ámimas los que en esta flota de balsas y han. É cómo algumos com. pañeros llegaron de noche, arrebatólos la corricute del rio é sacólos á la mar á media noche, motiéndolos la resaca muchas veges debaxo del agua; é otro dia, desde la costa, los vian cssotros dos leguas deníro en la mar, é como la meinguanto los avia apartado de la licrra, la crescicnte los rolvia despues. Pero el capitan, viéndolos en taí peligro, mandó cntrar en olras balsa perpmeña á algunos compañelos sueftos nadadores, é lueron allái é los traceron: á los quales hallaron tales, que ya se dexaban de ayndar, rendidos á la 
muerte é desanimados del cansançio é fatiga; pero plugo á Dios que ninguno se perdió. Mas es de creer que se acordaron muchas veçes con quánto menos peligro ganaban decomer, estíndose en su patria. En fin, estals cosas los hombres han de lacer, é no lodos, sino aquellos que son para mas que ofros.

Recogida esta gente é su capitan, caninaron por la costa de la mar al Poniente, é llegaron á un golphete, que se diçe Sanct Viçente, donde hallaron á Andrés Niño, que acaluaba de llegar con los navios aderescatlos, é con la rasija del agua liecha. É una vez pensó al capitan Gil Gonçalez le sé meter en la mar é haçer su descubrimiento con los marincros, poreque no tenia picmas para andar por tierra a pié ni á raballo, é quiso devar en lierlá um teriente con los hombres que llevaba. E cómo la gente oro conosçimiento dlesto, comengaron á nummurar é quexarse dél, porque dexaba su compañid, é porque ra avian comencado á topar mayores cacirunes, y el esperanesa de enriquescer se aumentalba, y en la tierra avia mas aparejo que en la mat para hallar oro: é assi por esto como por el contentamiento de los soldados, é porque con sul pressencia se larian nejor las cosas que tor caban á la paz é á la guerra, acordó de quedar en tierra, é con çient hombres é (quatro caballos proseguir adelante. É mandó que un teinicnte suyo. con Mndrés Niño é otros dos pilotos juramentados, nidiessen é assentassen las legrtas que se anduviessen en el descubrimiento de to que viessen, é assi por mar como por ticräa se continnasse el viage la via del Poniente, con iutençion de lacer paces é con buen tractamiento á todos los caçiques ó señores que hallassen, é á los que por bien no quidiessen lis par, se les hiçiesse la guerra. É quedaron alli dos navios é prarte de la gente en guarda de quarenta mill pessos de todos oros, que ya avian avido; é Andlés Niño fué ron los otros navios adchunte á desculnir , é Gil Gonçalez prosiguió por la ticrra : é acordóse que al mesmo puerto se tomassen á recoger.

Este grolpho de Sanct Viçente, si yo no lo tengo mal entendido, estí en la punta á promontorio que está próximo á la isla del Caño, la qual punta dista de la equinoçíl ocho grados é medio á la banda de nuestro polo: é de allí adentro es el ancon ó golpho, é lo que dél es mas septentrional en la.costa está en nueve grarlos de la línia del equinoçio, é dentro desta ensenada están algunas islas pequeñas.

$\$ \mathbb{I V}$. Dada la órden ques dicho, en el camino de la mar é de la tierra, por donde y ha el capitan Gil Gonçalez, se baptiçalıan muchos caçiques é indios de su voluntad: é llegó á un caçique llamado Nicoya, el qual le dió catorçe mill pessos de oro, y él con seys mill personas o mas se bilpticaron é tornaron chripstianos, é quedaron tan amigos de los chripstianos, nuestros españoles, que en diez dias que allí estuvieron, quando se quiso partir Gil Goncalez, le dixo el caçique, que pues que no avia de hablar ya con sus ydolos, que se los llevasse. É no le diera él tantos quantos el capitan tomara de buena voluntad, é assi le dió seys estátuas de oro tan grandes como un palmo, é algumas algo mayores; é rogóle que le dexasse algum chripstiano de los nuestros que le dixesse las cosas de Dios, lo qual no osó lager Gil Goncalez, por no le arenturar é porque llevaba poca gente.

Decíame Cil Gonçalez que desde aquel golpho de Sanct Viçente hasta Nicoya anduvo cinciienta leguas (pero liarto menos camino líy y), é no me maravillo, porque estonçes no se sabia la tierra.

Allí tuvo notiçia del caçique de Nicaragua, é muchos indios principales, que consigo llevaba, le consejaron que no fuesse allá, porcfuc era muy poderoso, c aun los españoles le decian lo mesmo: pero el ca- 
pitan no quiso temel sin ver de quición, é

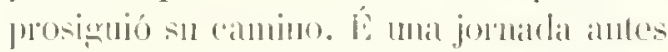

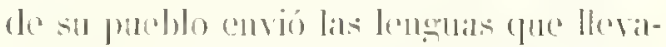
ba é seys indios promeipales do los foue con

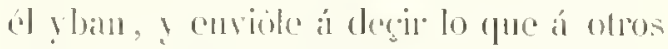

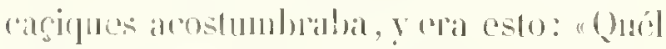

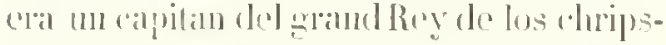
lianos, que por su mamlado y loa á arple-

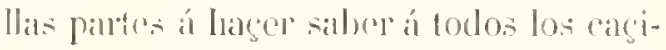
yues prin ipriles ó señores dollos, que en (d) riclo, murcho mas alto del sol, liay un sonor que licgo el sol é la luna é cicelos y estrellas, é á los lombies é amintales e ares é lia mar é los lios é los pescados é todas las otras cosas; ć los que estu credin é lo tenian por Sunor, son los chripstianos, é quando mueren, van arrilua donde él colá é gozan de su gloria; y los que no son chripstianos, van puando mueren, á $\mathbf{m}$ fuegro que cośá dehaxo de la licréa á penar para sientpre: é que todos los señones ó cacipues ó principales, á quien en aquella lengua llaman calacheimi, que atrás

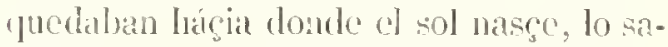
lian ya , y éle olros capitanes se lo arian dicho é lo creian assi, ‘ tenian por señor al Rey de Castilla. cuyos eran aquellos chripstianos y el capilan, é se arian hecho chripstianos é quedulan por rassallos del Rey de Castilla. E quél yba á to deril á los otros calarchunis é principes de lálcia donde el sol se pone, porrue lios assi lo mandal: á que le rogaba que le alendiesse ch su pueblo con sus indios é sente toda, é que no oriesse niedo; é quéd le diria otras coses muy grandes deste mesmo Dios, con rue avria mucho placer, sabićndolas; ć que si esto no quisiesse hager, ni ser vassallo del grand hey de los clripatianos, (pue se salicsse al campo de guerata que otro dia scria con col."

Arfiel mesmo dia, en la larde, siertos escopeteros, probindo la púlrona, pusicron fuego á su posada é á la del rapitan, é quemáloonso cllos mesnos, que fileron tres, lo qual dió mucha lurlarcion á los de-

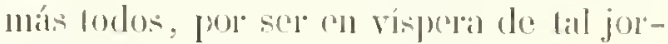
marla como la due esprealian olro dial. Y

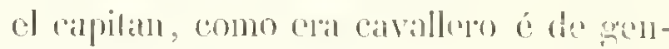

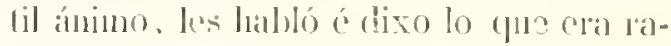
con paral qure no lemiessen ni oriesse fliqueca on ninguno, pues que cran españoles 6 de patria donde lan valemesos coritrones se crian. B) ríales que se alcordass'n que quardo ol romle Fernind Gongalez avia fucrido dar la latalla á los moros é í su rey Jlmancorer, que la tierra se abrió é tragó á un carallero chrínstiano, é por esso no dexó de ser vengedor el conde, é quedó mas viclorioso "; é que assi esperassen que lo serion ellos. si á las armas viniessen, é que aquello carla dia acaescia á los que tractalsan la pólvora (quanto mas que arpuellos vivirian). is assi á este propóssito les hico un gentil raçonamiento. con que quediron de voluntad é ánimo aparejados á todo lo que puliesse subederles.

Mlli deré el capilan los tres escopeteros á curarse é olro hombre eon cllos y el dia siguiente llegó á ma legua del pueblo é topó quatro indios prinçipales con los olros quél avia enviado: é aquellos quatıo diveron á Gil Gonçalez quel calachuni do esperaba en su pueblo de paz é como amigo. Y en Ilegando. apossentó al capitan é á los españoles en una plaça é casas de al rededor de colla, é lucgo le pressentó pirle de fuince mill pessos, que en torlo lo (lio) : Gill Goncalez le (lio una ropa do seda é una gorra de grina ó ma camisa

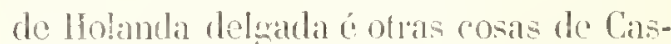
tillav É en dos ó tres dias que se le habló de las cosas de Dios. diso que queria sen chripstiano él a sus mugreres á indios. y (rn un tia se bapticaron mas de nueve mill personas. con lantal voluntad, á lo que mostraban, que de plaçer é derogion Ilo- 
raban algunos de nuestros soldados, dando graçias á Dios de lo que vian.

Allí estuvieron el capilan é su gente ocho dias, é se pusieron dos eruçes. como lo acostumbrahan lager en los otros pmeblos; ć puso ma muy grande en um monton de tierra grande de gradas, y en cada plaça lienen uno destos moniones de lierra, que paresce que los mesmos monlones pidei la cruz; ć dexó otra en su mezquita: quel mesmo calachuni la llevó en sus braços, é quiso que allí se pusicsse.

Esto destos montones no lo entendió Gil Goncalez ni los cilluipstianos estonces para qué cfetto los tienen; y es para sacrificar é matar hombres, como se dirá en su liempo adelante. quando so habke desta gobernaçion de Nicaragatua (la qual gente es de la mesma lengua de México é de la Nueva España).

Dusde á ocho dias que Gil Gonçalez allí estuvo, passó á ofra provinçia. seys leguas de alli, é halló seys puchlos á legua é á legua é media ó dos uno de otro, de cadia dos mill vecinos cada ino dellos; é despues que les oro enviado sus mensagreros, se apossentó en un pueblo destos, é los scũores le fueron á rer. é le pressentaron oro y esclaros, é dieron de comer á los chripstianos. É cómo sahian que Nicaragua é sus indios se avian baptiçado. dixeron que lambien querian ser ellos chripstianos; é vino cada scñor con su gente á lesçibir el baptismo, é cada dia le otros pucblos enviaban á pedir á Gil Goncialez que les enviasse el capellan que los haptiçasse é les dicesse las cosas de bios. É assi se laçian ó madiugahan los de un preblo é de otro para quál llevaria antes el clerigo.

Estandocn medio desta huena olra, paresce ser que otros eaçiques grandes, que cstaban adclante, ovicron notiçia destos nucstros cspañoles, é tambien salurian como les pressenlaban taguizle (que assi lla- man al oro en aquella lengua); é nno dellos. Ilamado Diriajen, vino á ver á Gil Gonçalez, é llevó consigo hasta quinienlos liombres, c cada uno con un paro i pava ó dos en las manos, é detrás dellos diez penflones ó landeras pequeñas sohte sus istas, é forlas blancas, é detrís destos pendones diez é siete mugeres, fortas quassi cubiertas de patenas de oro, é clos. cientas o lantas lachuelas de, oro baxo, que pessaba torlo mas de diez é ocho mill pessos. E mas atrás. cerea del calachuni c de sus prinçipales, venian çinco trompetas, ó mojor diçicndo pífaros, é çerca le la possada del capilan Gil Gonçalez tocaron un rato; ć acabado de tañer, entraron á verle con las mugeres y el oro. $\hat{k}$ mandóles preganular que á qué venian, é dixeron que á ver quién cran: que les avian dicho que era una gente con armas que andaban encima de unas animalias de quatro piés: que por ver quién cran é lo qué querian, los venian á ver. Estoneses el capitan Gil Gonçalez líçoles haçer aquel su sermon que se liço á Nicaragua, y él acostumbraba hacer á los indios con las lenguas á la soldadesca (despnes de arer puesto en recaludo el oro). é respondicron que querian ser chripstianos. Pregun!óseles que quándo se querian baptiçar, é dixeron que desde á tues dias vernian á cllo.

Es de pensar questos que nuestra catholica fie predicaban á estos indios, no publicaban ni les deçian lat polmecega que Chripsto é sus Ipóstoles obscrvaron, con Lanto menosprecgio del oro è de los hienes temporales, teniendo prinçipal inlento a li salvaçion de las ánimas, ni trian cuchillo, ni pólrora, ni caballos, ni cssotros aparejos de guema $y$ de sacar sangre. Mlirad lo quel Apóstol Sanct Bartoloné liso, quando le cupo en suerte la predicasion de Lycaonia y en la India Oriental, y por consiguiente los otros $\Lambda$ póstoles, dó (pricra que se Lallaron. que si solamente el 
(י)mer, ollacosit no Lomaluan '; pero nueslos conroplidores tomál,anles al oro. é

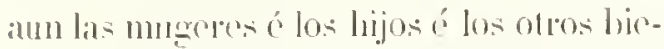

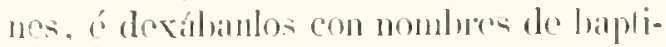
gados. 6 sin rntonder el bien de lan allo

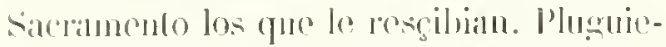
l'a í Jios que de cada millar dellos, ass bapticatos, guedaran die\% que bien lo supieran.

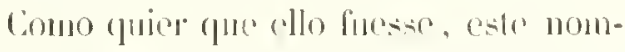

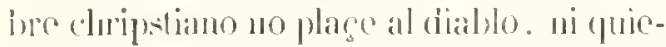
re la salvarcion de los lombers; y es de

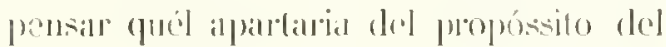
baptismo atfuellos indios, c lambica cllos vicron el poco número de nucstros espitîoles. y al teregero dia fue discron aviento ylo el clérigo en el mrjor caluallo de quatro que tenian, y dos ralientes homlires ron cl, á predicar á unos pacblos no líxos). estando los españoles descuvdindos de la wucra, súl ado diez é sicte de abril. á modio dia, é con orandlssima calor. dicron sobre el capilan fiil Goncalez és su genle lasta quatro mill indios amudos d su guisa, con unos jubones ó corncas sin mangas, de algorlon bastados. é arnaduras de cabecar, de lo mesmo. ć rodelas y espadis de palo regias, é muchos dellos con arcos é flechas puesto que no licnon licrla) é otros con varas palra tirar. li aniso Dios que á un tiro de ballesta antes que llegassen al lugar: un intio del pucblo dó estaban los chripstianos, los rido venir é dió aviso, é lo mas juresto yarc puclicron calabó el capitai en un caballo de los tres, c recogidos los compiñeros eu la plaga, delante de su possada. puso la tercia parte de su gente á las copaldas í al redudor, porpue como cran mucinos los contrarios, temieron fue los cereassen é les pusicssen fuego. F con orandlissimo impetu, llegados á la plaga, arlenneicron á los chripstianos, y cllos contra los indios, de manera de torneo pelcando los unos ć los otros con el mator esfuergo que jodia ser: Y ostmo ha halalla puassi medio yuarto dre loral on pesso, sin pue se conosciesse cuya avia de ser la rieloria. E despurs de aver herido derribalo en lierra seys ó sicte cspanoles, llevílnanse otro vivo en pesso, sin lo fuerer matar, á lo que mostraban : é cómo los de caballo arremeticron 6 anduricron un rato entre los cucmigos revucltos, tropellando é alauceando, cllos pusicironse on huyda : é sionuendo el alcange, amimando á los de pić. Ios coharon í langadas fucra del puehlo. I en el campo, cómo d capitan esliba on el mejor de los tros caballos, amque mal aderescrado de juez, ylua de los delanteros esforçaudo los nueslios. é laariendo, como buen capilan, su dleber: é desque se ovo cansado de alancear á los que á ma parle é á otra lopaba de los memigos, parrociéndole quo era error dexar tan atrós su genle. dió la ruella, en la qual fueron tanlas las varas é llechas é piedras que los indios le tiraron, que passó mayor peligro que quando de la plaga los celaron.

En fin . como llogó á los dulanteros de los compañcros que seguian ol aleange fue. Ja del puchlo, no consintió que procodiessen adclante, assi por su desavenlaja del poco número, conı porque los indios no le luviessen en poco é sospochassen que no eran más los que quedaban en el lugerer, é no se atreviessen á volrer solure ellosé renovassen la batalla, y aun porque on la possada se quedaba el oro solo é que los di.l puoblo no tenlassen otra ruindad, viondolos fucra é los robassen. Y assi lo nus presto que putieron, se recogicron con la vicioria, dando sracias á Dios, é se pusieron en órden, esperando la seemina batalla, si se la dicssen: lo qual no ligicron por rocoger los heridos é muerlos é no los dexar en cl campo. 
En esle tiempo aun el clérigo é los compañeros que con él fueron no eran tornados; é cómo el pueblo donde fueron, era háçia la parte de donde vinieron los indios que es dicho, pensóse que los avrian mucrto. É luego el capilan les escribió en breves renglones, con un indio del pueblo, que se viniessen luego, diçiendo lo que avia acacscido: é vino luego el capellan é los dos homlnes, sin aver topado quicn los enojasse. Nili se acordó que diessen la vuelta á buscar los navios, é se tornassen á la costa, assi porque liasta allí la gente a via ydo contra su roluntad, como porque todos se lo consejaron al capitan, y él conosçió é vido que no debia luager otra cosa contra el parescer de todos, é por poner en colro lo yue hasta cstonces avian ganado. Fassi se lo requirieron los officiales é alşunos otros de los principales espanoles, porque vieron quel capitan essa noche tenia en voluntad de dar en los contrarios por los respectos yá dichos; ćporque la gente estaba cansala, y alghinos compañeros heridos, é otros enfermos, é por no arenturar el oro que tenian allegado, é demas desso que de los de aquel pueble no tenian mucha seguridar, dieron la vuella con pensamiento que llegados á fierra de chripstianos, aunque estaban bien léxos della, porhian con mas gente é caballos é con mas propóssito volver á castigar é haçer de paz aquella gente, é á saber los secretos de la tierra, porque ella es tal, que ningmo la puede ver sin que le parezca muy lien.

$\$ V$. Como el caçique Nicaragua supo que Gil Gonçalez se tornaba, é que avia peleado con el caçique Diriajen é sus valedores, é supo que llevaban los españoles cantidad de oro, pensó de tomárselo é matarlos, como despues lo enseñó la expiriencia, é assi lo sospecharon los nucstros, al passar de su puchlo: con la qual sospecha el capitan Gil Gonçalez ordenó sul gente, que serian hasta sussenta TOMIO 11.
Lombres los que estaban sanos, y hecho un esquadron, metió dentro en él cl oro é lat gente flaca é las cargas de la cumida é haciendi que llevaban, é á los quatro cornisales ó esquinas yban los quatro de calsallo que tenian, é qualro esconeteros. Y desta mancra passaron por d pacblo á las onçe horas del dia, é ya que estaban fuera de la poblaçion, començaron indios de salir en su rustro, é deçian á los indios que les llevahan las cargas, que las doxas. sen ó se huyessen con ellas: ć assi camirando, los sufrian, por no quehrar con ellos; 6 algunos se atrevian á entrar entre los nuestros á sacar los indios, con las cargas, del esquadron. É viendo esta osadia el capitan, mandó á los ballesteros que les lirassen, é cómo hirieron algunos, súbitamente començaron á salir del pueblo muchos indios de guerra. Estonçes parescióle á Gil Goncalez que no se podia cxeusar de pelear, é mandó al thessorero Lndrés de Cueregeda é á los que Ilevalann la guarda del oro que caminassen todo to que pudiessen, é assimesmo los indios que llevaban las cargas del baslimento é ropa; y el capitan con los otros tres de caballo é algunos sueltos peones é ballesteros é rodeleros é quatro espingarderos, que todos serian liasta diez y sicie, se quedó en la recaga. É la gente que salia del pueblo, cra innumerable, é inuchos dellos flecheros: é començaron á se allegar con mitclı denuedo é grita mny grande, lirando fleclias, é los de caballo haçian algunas vucltas sohre los enemigos, é olras reges los cscopeteros é baliesteros, hiniendo á los que se acercaban. Pero quando los de calnallo volvian, era lanta la priessa dol luuyr dellos los indios, como la que suelen lıceer los peones en mi ticura de aquellos bravíssimos toros de la ribera de Xarana; é alançeaban aigunos, con mucha risa de rer ol temor que avian á los caballos. Á los indios les parescia grand novedad los hombres á caballo, porque nunca tales 14 
animales avian visto, é no cra para cilos menor espanto r fue ol de los rentauros en las boulas do l'erithoo, en arpurella batalla fue llácoles ovo con cllos": peronon obsfante a micdo que los indios a vian de los caballos, cra lim grande la muchedumbre dellos como enxambres de abejas.

El cansancio que los nucstros ovieron en esta jornata, fue muy exçesivo; pero mezclado su temor con su esfucrego é con la prutente diligençia de su capitan, no cessaron de trabaxar valerosamente lasta quel sol se quiso poner por una hermosa rega: é lo que mayor fatiga les fué cra el passar de alqunos arroyos, por no desamparar los dolientes y passar los de la reçaga ardelante. y cn cobrar los indios que les dexaban las cargas.

Finalmente, cómo vicron los contrarios que pervian gente, é no ganaban nada en seguic á los chripstianos, quando el sol se puso, dixeron que querian paz, y el capitan Gil Gonçalez se la otorgó : é dexarlas las armas, tres indios prinçipales mandaron que se quedasse atrús toda la otra gente, é rinieron á lablar con los nuestros, desculpando á Nicaragua é los suyos: édeçian que aquello avian fecho la gente de otro caçique, que estaba aquel dia en su pueblo, que se llamaba Zoatega, que los españoles no le avian visto. quando la primera vez por allí avian passado. i lo qual Gil Gonçalez respondio quél avid visto é conosçido algunos indios prinçipales aquel dia en la batalla, é que assi lo dixessen ál su teyle (que quicre deçir lo mesmo que calachuni ó señor) é que le haçia saber que los chripstianos todos quél traia cran tapaligues (que assi llaman en aquella tierra al hombre experimentado, é al que ha muerto á otro de cuerpo á cuerpo diçenle tapaligue ): pero quél era contento de la paz, é que si ellos otra cosa quisiessen, quél les haria la sulerrat de otra mancra, porrune los chripstimos no se cansan, ni lan menester yaat, ques rierta hicrba yne los indios traen en la bocia, ron la gual dicen cllos que no se cansan tanto cono no teriéndola, sin comparaçion. í lo qual no supicron los indlios responder ni replicaron mús en dlo, sino volvicndo las espaldas ylan diciendo: teba, teba, teba, xuya; quiere derir teba lueno, é xuya rete, como quien diçe: bien lo diçes é bueno eres; vete en buen hora. É halilando á los otros indios, yban diciendo estos prinçipales: toya, toya muchas veces, que quire decir anda ó aguija; é assi lo haçian todos, tornándose lıáçia su pucblo. Plıgo á Dios que ningund honbre ni oro perdieron los nuestros, ni ovo algruno herido dellos, excepto un caballo de una flecha, pero no peligró.

Essa noche repossaron en un cerro, que avia en su derecho eamino, haciendo buena guarda: pero perdióscles mucha ropa ál los compañeros, porque los indios que les llevaban las cargas, eran los mas de los de Nicaragua, que se los avian prestado á lí passada primero, é cómo vian que á la vuelta los llevaban de su lierra. dexaron las cargas unos, é otros se las llevaron. Ĺ desta causa quedaron algunos de los compañeros sin vestido, é otros sin comida, por atender a guardar el oro é no dexar á los dolientes, é por no salir de su ordenanga: é los indios que les querlaron, eran mas orientales (é hartos de la lengua rle Cueva), é como volvian hácia su tierra é no entendian á los de Ponicnte. essos no liçicron mudança: antes algunos dellos pelearon muy bieu, ayudando ál los clnipstianos. Despues que ovieron repossado cinco ó sejs horas, passada la media noclic é salida la lima, tornaron á caminár, por passar antes del dia un mal passo, al qual por otro camino 
podian yr á él deste el luggar, é tomándole los indios primero, les pullicran läcer mucho daño á los chripstianos; pero no hallaron imperlimento en lo passar, é assi caminaron el resto de apuella noche é los dias siguientes laista que llegaron al golpho de Sanct Vicente, donde se avian departido, quando Andrés Niño fué ádlescubrir desde alli, el qual era tornado ocho dias avia, é decia que avia descubierto trescrientas é çinquienta leguas al Poniente deste allí pero él se engañó nucho en la cuenta dessas leguas. Por la falta de los navios, é aun del agua, no passaron adelante.

I mí me escrilió una carta Gil Gonçalez, que diçe que de aquel pucblo deste caçique de Nicaragua la licrra adentro tres leguas de la costa de la mar del Sur, junto á las casas de la olra parte, está ofia mar dulçe, que eresege é mengua, é quél entró á caballo en clla, ć tomó la possesion en nombre del Emperador, é que se via una isla dos leguas dentro ó apartada desta costa desta ağma dulçe polnada, é quel tiempo no le dió lıgar á salıer mas en esto; pero que mandó entrar á algunos chripstianos en una canoa media lesua dentro, para ver si el agua corria háçia alguna parte, pensando que fuesse rio, aunque no vian la otra costa de háçia el Norte; é los que entraron no conosçieron que oviesse corriente. E sus pilotos porfiaban rue salia aquel agua á la nar del Norte; pero él y ellos hablaban por conjecturas é á tiento.

Bien se me acuerda que hablando Plinio en la gente de Scythia, diçe que Alexandio Hagno dixo que ałpel mar es dulce, é que Marco Varron escribe que lo mesmo fuć mostrado á Pompeo, quándo en la guerra de Mitridate era allí verino ó estaba cerea desta mar dulçe; é que aquesto procode por la grand co- pia de rioş que alli entran, que vengen á la salobre agua de la mar '. Torlo esto es deste auctor; pero ya tengo dieho cómo en el golpho de Urabát con baxa mar está dulçe el ağuat, é assi podria ser eseo que vido Alexandro é vió Pompeo, y menos es ser dulce la laguna de Nicaragua, porque su assiento é sitio es baso, é acuden á ella infinitos rios.

Ya lie diclıo en otra parte que, despues que Gil Gongalez estuvo en Nicaragua, yo fuy a aquella tierra, é ví esta é otras grandes lagnnas, é muchas cosas otras que dexo para las deçir adelante en su lugar.

Tornando al propóssito de Gil Goncalez, digo que despues que llegó al golpho de Sanct Viçente, halló quel mayor de los navios no estaba para navegar ni tenerse solbre el agua, y en los ofros y en canous se embarcó con su gente para l'anamáx: Pero quiero yo agora deçir la forma de la costa, é lo que navegó Andrés Niño hasta la postrera parte que llegó, é tambien diré aquella ensenada del golpho de Sanct Lúcar, que otros llanran golpho de Nicaragua (c otros le dicen golpho de Orotiп̃a, é otros golplıo de Guetares), é (qualquiera destos dos nombres postreros es su nombre proprio. E pintarle hé como yo le ví, é no como le hallo en las cartas de nuestros cosmógraphos puesto, liasta el presscnte año de mill é quinientos é quarenta y ocho; é dirć las principales islas que hay en esta ensenada, la qual, aurque está en el camino queste piloto navegó, no la vido ni entró en este- gołpho de Orotiña ó de los Giuctares, quel ligençiado Espinosa y el piloto Jolan de Castánedal Ilamaron golphio de Sanct Lúcar (desde fucra), pero tampoco entraron en él. É súbese de pressente que se pobló despues de chripstianos alguna parte de aquella gobernaçion por el capitan Françisco Iler. 
nander, leniente de Podrarias. É diré assimesmo desde alli al l'oniente la costa é sus allumas, segund la rarta modlena é nueva correcsion della. Y porcue dixe que deste las islas de Sunct Járaro navegró otras reynte legulis al Poniente dicenciaclo Espinosa y ('] piloto Johan de Cirstancela. digro que deste aquellas islas de Sanct Lágaro hasta el paerto de la Ilerraduris, la eosta aliaxo a! Ocidente, al Hheste quarial del Norucste, se ponen verunc loguas, é alli eomiengega la boca deste golpho de Guctares, (puel Espinosa llamó de Sinct Lícell, é se haçe una ensenada de diez y ocho ó vegnte leguas de longitud, que tiene en partes nuere de latilud. é mas é menos; dentro del qual hay gentiles islas é muy fértiles é pobladas. É de la otra parie duste golpho, frontero del pucito de la Herradura, está la punta del Cabo Blaneo (é llámase assi,

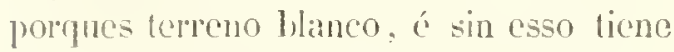
un furallon cerea dela punta muy blaneo); entre el qual é la Tierra-Firme ó punta puede entrar sin peligro una earavela de oehenta ó çient toneladas. Estát el puerto de la Herradura en ocho grados desta parte de la línia equinocial, y el dieho Caluo Blanco está cin sicte grados y medio, segund el cosmógraplıo Alonso de Chaves o los que le informaron; é porque mejor se entienda este golpho: pongo aqui la figrivia dél Lám. 1. $\left.{ }^{a}, f i g .1 .^{a}\right)$, si lo supe cntender todaria, só commienda de quien más parlicularmente lo oviere eompreliendido.

$\$$ TI. Pues he pintalo la figura del golpho de Orotiña ó de los Guichares. que eomumente suelen llamar de Nicaragua, y en las carlas de navegar, ó por no estar informados los cosmógraplios que las haçen, o pol no lo arer visto ellos, no lo ponen tan puntualmente, quicro passar á lo demás que desic golpho estos desculyrilores no dixeron, é que yo ví y es assi. La isla de Chira puede hojar sieic ó ocho leymas, y es muy pollarla é férlit: en la ynal avia, quando Gil Goncilez por allá anduro. mas de quinientos hombres de gucra, sin vicjos ni mugeres ni niños é de otras edades. É la isla que nnestros españoles llaman isla de Ciervos, es la que los indios llanan Cachoa; pero en crsa y en las otras hay innmmerables ciervos é puercos, y es menor: y estát entre la de Chira é la de Chara en la lianda del Norte, en la Tierra-Firme. En frente de la isla Cachoa estí la gente é provinçia de Oroliña, é mas al Leste está la gente é provinça de Chorotega, é á las espaldas, mas mas al Torte é al Kordeste, están las sierras é gentes llamados Güetares. Entre la isla de Cilchoa é la costa, háçia el Sur, está otra isleta que se dice Yrra; é mas al Leste está otra pequcũa que se dice Urrco; é mas al Oriente adelante ofra isleta que se alice Pocosi, cerea de ticra, á la parte austral del golpho. Estas tres pequenas islas están entre la Tierra-Firme é la isla de Cierros, dicha Cachoa. Deste golpho sube tres legtias la marea por el rio llamado Capandi, que está en la culata ó fin deste golpho; éallí hay un cacique, que tiene el nombre del rio, é se llama assimesmo Cápandi ; é á par dél, al Noroeste, está otro caçique que se llama Corobici. Los Guctares son mucha gente, é viven ençina de las sierras del puerto de la Herradura, é se extienden por la costa deste golphio al Poniente de la laanda del Norte hasta el confin de los Clorotegas. Al opóssito, en la otra costa del mesmo golpho. de la bandir del Sur, el mas çercano al rio de Capandi es Cange, y mas al Leste está otro que se dice Paro. En la ticrua deste caçiqne de Cange, y en la del eaçique Niquia, y en el de Nicoya (que todos son recinos deste golpho) hay mueho brasil, de lo qual halle yo algunos lenos en la isla de Clama, eon que las indias tiuen é dan eolor al algoolon é á lo que quieren teñir. Y los españoles que allí se hallaron connigo. por hrasil lo juzgamos; 
pero el cacique, señor de la isla, llamado Niari, me dixo que eran arboles de una braça ó poco mas de alto, é llamábanto nansi; de los quales árlooles hay muchos cu ticra de Nicoya y en Masaya y en Tecoatega y en muchas partes de Nicaragua. E deste árbol é su fructa se hallará nils particular mençion en el libro IX, capítulo XX.

Hay en la isla de Clina muy buena loça ó verlriado de cémtaros é jarros é todo lo que se suele hacer' de barro: 'la qual paresçe proprio açavache en la tez é color negro; y es muy hermosa cosa de ver las rasijas dello, é yo he traydo desde allí algunas pieças grentiles desta loça lasta esta ciludad de Sancto Domingo.

La isla de Chara es la que los chripstianos llaman Sanct Lúcar, é allí y en la de Chira y essotras deste golpho traen las indias mas bragas pintadas, que son un pedaco de tela de algodon de muchas laboresé colores, cogido en un hilo que se giñen: é esta tela es tan ancha como dos palmos, é por detrás baxa deste la çinta é métenla entre ambas piernas é passa delanie, é alcarica á cubrir el ombligo é ponerse deluaso del mesnio lilo ó çinta, é assi cubren todas sus partes vergonçosas: fodo lo denás de las personas traen descubierto é ilesnudo. Los cabellos pártculos las mugeres por mitad de la cabesa derechamente por la crencha, desile media frente al colodrillo, é de la una mitad lıaçen un trançado que viene á quedar ençima sobre la una orcja al un lado é de los otros medios cahellos liacen otro trancado al otro lado, é miny tiestos, é tan luengos como son los cabellos. Y es gente muy bien dispuesta, assi los hombres conı las mugeres. Algunas veces acaes-

1 Nec priús deeorem eapillorum redegit in ordinem quitum lantan urbem in suam polestatem restituil. (Chronicar. ab initio mundi als. Chronica touthonica.) çe que por algum incomviniente 0 nescessidad guardan aquel voto de Semíramis, que no se quiso acabar de coger los cabellos, quando se le rebeló Babilonia, hasta que la ovo sobjuzgado é vuclto í su obediençia: é assi estas indias, quando algुuna nescessidad ó servicio de su señor ó marido les ocurre, primero proveen á aquello que á la gála de sus trançados. É assi via yo algunas dellas con un trançado feclıo é otro suelto: é assi Semílanis no se quiso acabar primero de concertar sus cabcllos hasta restituyr su ciludad á su obediençia'. Con esta auctoridad de aquella corónica del inundo concuerda un terçeto de Francisco P'etrarchä en el Triumgho de la Fama, donde diçe: "Despues ví la magnánima reyna, que una parte de la crencha cogicla é la otra desparçida, corrió á la babilónica ruyna ${ }^{2}$. "E mas largamente toca esta historia de Semíramis Justino, el qual diçe que un dia, curando de sus cabellos é crencha, é aviendo cog̣ido la una parte é atáidola, le fué dicho que Babilonia se le avia rebelado, por lo qual tomó las armas súbito contra aquellos reheldes, é no se quiso coger la otra parte de los cabellos, hasta que ovo reduçido á su obediençia la cibdad ${ }^{3}$.

Tornando á nucstra historia , estas nulgreres que lie dicho deste grolpho de Nicoya é sus comareas, é los lıombres, son gente bien dispuesta. Ellos traen cogidos los cabellos con una çiuta de algodon, lıcchos todos los cabellos un trançado detrás, y es tan luengo como un palmo ó menos al colodrillo: otres los cogen para arriba, y el trancato sube derecho solse la coronilla de la cabeça. El micmbro ggenerativo traen atado por el capullo, haciéndole entrar tanto adentro, que á algou-

2 Poi vidi la magnanima reyna, Che una treeeia rivolta é l'altra sparsa Corse á la babiloniea rapina.

(Triumpho de le Fema, cap. II.)

3 Just, le bellocat., lit. !. 
nos 110 se les paresece de lal amil sino lia itadura: gue as mos hilos de algorlon allí revucltos. Pregundamblos yo la camsa

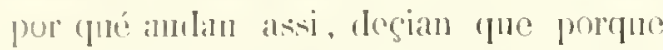
arjuello era su usanga, y rra mejor traterlo assi qua no sucllo, como los indios de la isla de Clara ó eomo mestros calballos.

En la isla de Chira ví una ninia de lassla dos años (pue mimalnal, é llorimdlo por su matre, que audaba cutendiendo en su casil degia mama muchats veress é preguntando yo al cascipue que quó deçia, ne dixo que llamalaa á su madre. Listos indios de Chara son de ollat lengua diversa, y entiéndense alyo con la do Cueva, porquecon la plática que tienen con los duripstianos, la han aprendido. Bojarál la isla de Chara en su çremferengia quatro leguats.

En cotas islas hay perlas, é yo lats ví cn las islas de Charia é Clima é Pocosi. é lis saqué de alqunas hostias que los inclios nos traian para comer. La isla de Pocosi es pequeña, é puede bojar lasta una legual, é go la he andiado por sur costa á la redondia. Es alta é muy singular puerio, y estí un tiro de escopeta de la TierritFirme, ó poco más, é tienc un pueblo pequeño de indios, y es abundantíssima de pespuerias. Hay en estas islas un pescado que Ilaman los chripstianos pié de burro, que son como unos hostiones muy grandes é muy gruessos, é tambien se lallan perlas en algmos dellos. Afirman los hombres de la mar que es el mas excelente pescado de todos: de las conchis dellos lracen los indios quientas para sus savtales é puinctes, quellos llaman chaquira. muy greniil é colorado, que parescen corales, é tambien morado é blanco; é cadi color es perfecta en las quientas que hacen destas conchas del pié de burro, é assiz duras; é son tan grandes estos piés de lunro como la cabega de un hombre, é de alí para abaxo algo menores.

IIay assimesmo de aquellos nacarones yue se dixo en el libro XIX, cap. IS, en los quales tammhien se hallan pertas; é de

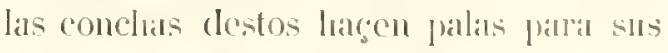
larores, é tambion lareen dellos niblues ó

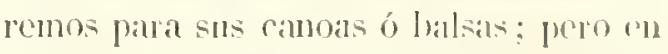
estas islas do Chara é focosi no ticuen canoas, sino halsas de quatro ó gineo 6 seys maderos atados ál los caloos y en medio á otros palos mas delgados atrayessirlos: é la ligradura es de bomigas de esparto de aynella licrear, ques como lo de Castilla é mas luchog, pero no tan recio; mas hasla para costo é para atar é liar la paja en la cobortura de lats casas ó lublíos. Ifay junto con restas yrandes pesquerias á perlas destas islas (en espreçial ren la de l'ocosi. en dur yo mo diduve algunos dias, á cansa de reparar allí ma caravela que se nos yla á fondo) olla manera de trabaxo, que para mí lué cosa nucva é muy enojosa, de muchas chinches en los luLíos, con alas: é no parescen de clia, ni avia poeas de noche, é son mas diligentes é prestas y enojosas que las de España, é piean mas é son mayores (jue aludis şrandes: é si se ensucian, lo qual hacen muy á menudo, ó las matays, rodéándoos en lia canı, se despachurran solre la hamaca ó sábana, é dexa ma mancha tan grande como la uña de un dedo. é tan negra como tinta de escribir é muy peor, porque nunca sale de la ropa con jabon ni lejia hasta que sale todo el pedaço de la tela, tan grande como fué la mançilla que hicgo; pero no hieden. I estas chinches en toda la provincia é islas de Nicaragua las hay. Comen los indios en estas islas muchos venados é puercos, que los hay en grrandíssima cantidad, é malriz, é fésoles muchos é de diversas maneras, é muchos é buenos pescalos. é tambien sapos: é yo les he hallado atados en las casas de los indios, é se los he visto comer assados; é ninguna cosa viva dexan de comer por suçia que sea. Tienen muchas fructas, en las yuales no me quicro aqui delener, porque quando se dé noticia de las otras 
cosas de Nicarag̨ua se dirá dellas, en especial de aquella que Ilaman paco, ques cosa mucho de notar'.

Los indios de Nicoya é de Oroçi son de la Iengua de los Chorotegas, é traen horadados los beços laxos, é puestos sendos luessos blancos redondos del tamaño de nuclio real ó nuas, como to traen los indios en la Kueva España. Son flecheros é valientes homlores, é llámanse chripslianos desde que Gil Gonçalez anduvo por alli; pero yo creo que hay pocos dellos que lo sean. Son viólatras é tienen muchos ydolos de barro é de palo en unas casillas pequeñas é haxas que les haçen dentro del puchlo, allènde de sus casas principales de oraçion, que llaman teyopa en lengua de Clrorotegas, y en la de Nicaragua archilobo. Es tierra Nicoya de mucha miel é cera, é las ahejas no pican, é son desarmarlas é tan pequeñas, como moscas de España, é negaras. Hay abispas muy malas. pequeñas. é que pican é dan muy yrand dolor. Todos los indios de Nicoya, en especial los principales é sus mugeres, traen pintados los braços de aquella pintura negra que se liaçe con la sangre propria é carbon, cortando é debuxando primero con navaxas de perlernal, é la devisa son tigres, que estos Chorotegas llaman nambue, y en iengua de Nicaragua se diçe teguam, y en lengua de Cueva ochi.

$\$$ YII. Desde cl Caho Blanco, baxando la costa al Poniente, çerca de tierra, está una isla que se llama Moya, y está mas al Orgidente de Cabo Blanco veynte leguas; pero antes está el puerto que llaman de las Velats. É destle el dicho Cabo Blanco adelante hasta el puerlo de la Possesion lay çient leguas, poeo mas ó menos, yendo en alta mar al Poniente: é todo aquello se Ilama golplıo del Papagayo, é no es improprio nombre, porque ateaesce que

1 Ya en el liłro Vill redicó Oviedo el capilulo XXXI í tralar de.la madera y de la fruta de este hablan allí los hombres llorando a orando. porque es mal passo de navegar. Está la isla de Mlova en siete grarlos é medio desla parte de la línia equinoçial: y está junto á la punta de Cathalina otra isleta. y esla punta está en ocho grados é un terçio diez é ocho ó veynte leguas de la isla de Noya. Destle la punta de Cathalina hasta lie punta de Nicaragua hay treynta legruas, y en la mitad deste camino se haçe cierta ensenada, que llaman golpho de Sanctiago. Esta punta de Nicaragua está en nueve grados é medio, é siempre desdo el Cabo Blanco, poco á poco la costa abaxo al Ocidente, se ra la costa cnareando ó metiéndose háçia nuestro polo ó Norte.

Destle la punta ó promontorio de Niearagua hasta el rio ó puerto de la Possesion hay diez leguas, el qual rio, segund las carlas modernas del cosmógrapho Alonso de Chaves, está en diez grados é medio. Este pucrto tiene en la entrada de la boca del rio una isla alta (é llana en lo alto della), que bojará un quarto ó alg̣o mas liasta media legua en redondo, assi que haçe el rio dlos bocas; é por la del Leste pueden entrar navios pequeños, y por la del Hueste entran las naos é mayores navios. To he estado dos dias surto en este embocamiento, é se mataron muchos peces de los que Ilaman roncadores, porque roncan, é son bien armados de dientes y es buen pescado: llámase este puerto é rio de la Possesion, porque allí hiço çiertos auctos de possesion el piloto Andrés Niño en este desenhrimiento. Pero midan él é Gil Gonçalez, como quisieren, essas sus seysçicntas é çinqüenta leguas, que dixeron que arian descubierto por la mar: que en muchas más de la mitad se engañaron, porpue deste aqueste puerto de la P’ossesion á P'anamá, no hay sino trescientas leguas, segund lo que se

írbol, como puede verse en la pág. 322 del tomo I de estas historias. 
platica al pressente, pocas mas ó monos; e yo bo he naregado dos veres ron pilotos diestros en aquella narreaçion.

Entre anpueste lio de la Posscsion é la punta de Niearagua que se dixo de susso. hay otro rio tpre se diege rio de Mesa. Vordad es que Andrés Niño baxó mas al ponionte reynte leguas (que: hay hasta la bahía de Fonscra a el qual nombre le pnso por celar cargo al presidente del Conscjo Rical de aquestas lndias, que á la saron cra don doltan Rodrigucz de Fonseca, obispo de laalengia (que despues lo fué de Búrgos), enyo eriatlo fué Gil Gonçalez. mávila : é á una isla rue está dentro de la lahía llanóla Petronila, por otra vaniclad que yo no digo. é que á aquel piloto latgotero se le antojó. Querria yo que ya yuestos descubridores no saben dar nomlires apropriados al puerto ó al rio ó golpho ó promontorio, que procurassen de saber de la grente natural de la tierra el nombre proprio que tieno la cosa. La boca desta bahía de Fonscea está en algo menos de onge grados desta parte de la equinocial, segund el cosmógraplio alecarlo: en lo qual, y en todo lo ques dicho desta costa deste Panamá, yo creo que le fué heela falsa relaçion. Y por tanto p para quel Chaves é los otros cosmógraphos de Céssar enmienden sus patrones ó pinturas de sus cantas de navogar, si me quisicren creer, diré lo que laallo en mis memoriales, que escribí. tomando por mi persona con el astrolabio las alturas on las partes que agora diré, en tierra é sosegadanente, é mnchas reçes. Está Panamá en ocho grados é medio: la isla de Chira, dentro del golplio de Orotiña ó de Nicaragna, está cn diez grados. Está la isla de Chara. que ofros llaman de Sanet Lícar, en nueve grados é treynta i ocho minatos, que son dos torçios de grado menos dos minutos. Está la isla de Porosi mas al Leste dos loguas, é mas metida al Sur en nueve grados é al- go mas de medio grado. Estí lia punta del Cabo Blanco, gues la boca del dicho gol. pho. í lis parte austral, mas al lonniente, en sicte grados é medio. Fstá la hoca ded dieho rio é puerto do la Posscsion, en lrege crados desta parte de la línia equinogial indubiladamente. Por nanera que to que Indrés Niño vido, ò desculurio mas adelante aquel piloto Johan de Ciatainda, fué descle el golpho de Orotiña é Cabo Blanco hasta la bahía de Fonseca, que purden ser diento é reynte leguas, poco mas ó menos. puesto due palra desculorir" las se navegarian mas; porcjar, como diçe aquel proverbio vulgar, "cl canino gue no se sabe, mas largo es al que nunea le vido."

Lntre agquel rio de la Possesion é la bahia de Fonseca está otro rio, fue se llama rio de Sance Pedro. La punta mos oçidental de la bahía de Fonseca se llama Cabo Hermoso, en ol qual quicro hacer punto por agora á la cosmogaraphia testa costa, lasta que tornemos á ella ; porefue me paresce ques tiempo que volvanos al discurso de Gil Gongalez é Perlmarias Dávila en lo que subecedió deste descubrimiento é oro, quando volvió á Panamá, que fué á los veynte é sinco de junio de mill é quinientos é veynte y tres años. donde se funclió aquel oro: é fuć muclio nomos el valor quel bulto dello, porque la mayor parte crá de muy baxos yuilates, é harto sin ley, puro colne. Pero cscaparlo Gil Gongalez de Custilla del Oro é de los impedimentos de Pedrarias, como está dicho, vímose á esta cilbdad de Sancto Domingo desta nnestra Isla Española, é tornó á armar aqui de nuevo é volvió con muy buena gente é navios á la TierraFirme, nas al Poniente, donde les paresció á él é al piloto Indrés Niño que podria responder el parage de la grand laguna dulce quellos pensaban que desaguala ó entraha on este mar del Norte. Í furon á descmbarear al cabo é pucito que se diçe de Higueras: í púsole nom- 
hre Gil Gonçalez Puertó de Caballos.

$\$$ VIII. Nlí se les murió un caballo (y esto no era causa sufiçiente para mudar su nombre al puerto; que olros avian mucho liempo antes descubierto), é líçolo enterar secrelamente, no por hacerle ofsequias ni honrarle con sepoltura, como Alerandio Magno á Buçéphalo', su cahallo (i otro caluallo liceo assimusno enterrar Octaviano Augusto, emperador, y el Cid Ruy Diaz mandó enterrar á Babieca, su cahallo); pero hiçolo Gil Gonçalez, porque los indios no lo viessen ni supiessen que los caballos eran mortales, á los quales mucho temen, porc[ue alli no los avian visto. É á otro puetto mas adelante llamó Puerto de Honduras, é lizo un assiento é puchlo, é Ilamóle Sanct Gil de Bnena-Vista, é dexó allí alģunos españoles, y entróse con la mayor parte de la gonie la tierra adentro, é pússose diez ó doce leguas de aruel puerto de Sanct Gil, en la parte que le paresció mas apropriala para su descubrimiento é concuista.

En el ticmpo que Gil Gonçalez vino á csta lisla, é lacía su segunda armada en esta cibelad de Sancto Domingo, sípolo Iternando Cortés, que estaha en la Nueva España, é proveyó de dos armadas contra Gil Gonçalez, porcfue no tomasse aquel puerto de Iligueras (que decian que era cosa rica); y envió la una por tierra con el capitan Pedro de Alvarado, y otra por mar con el capilan Chrijstóhal de Olit, lombres de guerra y experimentados capitanes. Y el Chripstóbal de Olit fuó con sus navios á la isla de Cuba, é cómo allí tocó, luego se alçó contra Coriés, é diso que no ylua por él, sino por si proprio, é queria tambien un perlaco de la Tierra-Firme, que le pertenesçia lan bien como á Cortés lo que tenia della. Fi desde aquella isla atravesó á la costa de la Tiepra-Firme, é salió en el puerto de lligue- ras, é púsose en la costa con si armada, eserea del otro pueblo de Sanct Gil, donde estaba Gil Goncalez, é polbio allí. É cómo tuvo notiça de Gil Gonçalez Dávilar y el Gil Gonçalez de Cluripstólaal de Olit, por-sus carlas é mensajeros se confederaron é quedaron muy amigos, para se ayudar é hacer el uno por el otro: é assi se visitaban por letras, é al parescer tenian mucha conformidad, porque su fin dellos era laçer sençillos sus enemigos é asegurarse de sus émulos; porque, como tengo dicho, Gil Gonçalez tenia por con. trario á Pedrarias á las espaldas, é avia enviado á pohlar á Nicaragua á su teniente Françisco Ilernandez con otros capitanes é gente. É Chripstónal de Olit temíase de Hermando Cortés: que les hastaban competidores porlerosos, sin que loz dos contendiessen entre sí. No es agora conviniente deçirse lo que Cortés liço en esto, porque quando se tracte desta gobernacion de Ilonduras, se dirá.

Tornemos á Peslrarias, que cómo fué yolo Gil Gonçalez de Panamá, en lanto quél estuvo armando en esta cibdad de Sancto Domirgo para volver á Tierra-Firme, colsdiçiando Pedrarias juntar lo que Gil Gonçalez avia descubiento al Poniente de Panamá en la provincia de Nicaragua con lo quél tenia, envió una armada á lo ocupar con su teniente general, el capitan Francisco Hernandez, é con él á los capilanes Gabriel de Roxas é Françisco Campañon, y Hernando de Soto, é otros. Y estos fueron é pohlaron en la provincia de Nagrando, á par de la grand laguna, donde agora está la cibdad que llaman Leon (la qual fundó por: su mal aquel teniente Françiseo Hernandez); é deste alli envió lia tierra adentro al capilan Gabriel de Roxas con gente, é topó acaso con Gil Goncolez, donde estaha pohlaudo, é Gil Gonçalez le dixo quél no tenia qué haçer 
en acpuella tierra ni Podramias; que se tomásse en huen hora á Franciseo llernandez, í que por su persona del eapilan Rosasallí temia toda la parte quel puisiesse; pero ane como capilan de Prellamias. ál ni átro avic de consentir yur anduriesse por aquella ticra. É con algunis buenas palaluas de cortesia el capitan liosas se fué, porreue no tenia tanta sente que fuese parte para liager otra cosa, é ann díxose que prometió de no lornar'. Cómo Roxas llecó al eapitan l'rançiseo llernandez, é le dió notiçia de Gill Gonçalez, envió luego con mas sente al capitan Ilernando de Soto en busea de Gil Gonçalez, el fual estaba en vela é sospechoso quel capitan Roxas é otros capitanes de Perlrarias lormarian solme él. É oro aviso de los indios de la tierra cómo el capitan llernando de Soto é muchos chripstianos Yban : é sabirlo esto. madrugó é salteólos. dando sobre ellos en un lugar donde eslaban, de noche; é pelcaron los unos eontra los otros. y en fin el capitan Soto é los ytıe con el yban. fucron pressos é desarmados é algunos muertos, é los despojó é quitó el oro baxo, que cra hapto lo que Yä tenian. É desdo á dos ó tres dias los solto solire cierto juramento é pleytesía e les lirgotornar su oro ó aluas, é setornaron á sll eapiatan ó tenicule loançiseo llernandez.

Trida esta ritoria Gil Gonçalez. contra el capilin Soto, se fuć á donde cstaba Chripstobal de olit, su amigo, el qual to prendió. E porque ra esto de aqui adelante seria fuera de la historia de Nicaragua, é no quicero tractar sino del gobernador Peclrarias, vuclvo á él. é digo que cómo llegéi al pucrto del Nombre de Ihios, é no pulo aleançar al Gil Gonçalez. para le detener é tomar el oro que truxo de Nicaragua, como rueda dicho de susso, supo alli quel nuero obispo de Ticru-Frme, llamarlo fray Viçente Peraça, de la Órden de Sancto Domingo, sulicessor al obispo fray lohan de Quevedo, avia desembarcado en la cibdad de Sancta Maria del Antigua del Darion; é assi para dar órden en que allí no parasse, como para acabar de destruyr é despohlar aquella cibdad, se embarcó é fué al Darien, á se ver con el obispo, de las quales vistas resultó to que se dirá en el capítulo siguiente.

\section{CAPITULO XXII.}

De is lotal despoblaçion de la cibdad del Darien, é de las diferencius que luvieron cl obispo, fray Vicente Pedraca, y el liçençiado Salaya, alcalde mayor, con Pedrarias; é del origen é prinẹipio del deseubrimiento del Peru por los capitanes Franẹisco Piçarro é lliego de Almagro, à su eosta, y en compañia del maestrescuela Feruando de Luque; $\dot{e}$ de lo que acaesció al sobernador Pedro de los Rios en la isla Dominiea, quando yba á tomar la gobernaçion de Castilla del Oro; cotras cosas.

直 cibdad del Daricn. despues pas se oro visto con el nuevo obispo, díxole muclio mal de aquella cilstad, é loóle mucho á Pananá é arsi le sacó de allí. y en público é secreto procuró con los reçinos rue se fuessen á Panamá é á Acla, diciendo que alli estaban perrliclos é que no aria allí indios que les puiliesse dar, é que en las ofras pololaçiones los avia, é todos es. laban ricos, é quél los emriquesceria más; é rohióse á Panamá él y el obispo.

Desle á dos ó tres meses adclante se despolıló el Durien por el mes de septiembre del año de mill é quinientos é reynte y quatro, é salidos los reginos de la cildad, quedaba de los postreros aquel Diegro Rivero, que se diso en el calpítulo II 
del libro XIV, que se le ar ia ydo ó alegado al gobernador Diego de Nicuesa con la barrea, é lo dexó perdido en la isla del Eseudo. E sus proprios indios deste Diegro de Rivero, é otros que con ellos se juntaron, le mataron; é á un hijo suyo, de edad de ocho ó diez años, le ahorcaron de la cumbrera de su proprio luhío, é mataron á la madre de aqued niño é otros tres ó quatro chripstianos cufermos, é quemaron la mayor parte de aquella cil)dad, y entre las otras casas la mia, que era lal como en otra parte he dicho: en la qual y en mis heredades é harcienda perdí mas de seys mill castẹllanos.

Todo lo que á mí me loca y lie dicho de mis trabasos é diferencias con Pedrarias, é con ayuel liçenciado Diego de Corral, fué la causa prinçipal por dó se despobló el Jarrien; porque en la verelad aquella cildad se sosturiera, si y'o no libera primero deslruvilo é perseguido por la forma que estí diclo. De mancra que apuella poblaçion turó deste el año de mill é (puinientos y nueve hasta ol de mill é quinientos é veyute y quatro; é no fuć menos deservicio á Dios é al Rey dexarla perder Pedrarias, de quanto fué muy senalado é grande averla ganado Énciso é los que con él se hallaron; ni seria menor bien restaurarla é recdificarla, por la fertilirlarl é riqueça de su assiento é comarcas. Tolvamos á la amistad del nuevo pellado é del grobermador.

Llegado ol goliernador y el obispo á láanamá, estuvieron un poco de tiempo conformes; pero despues, solre cierlo juego de naypes, rineron, y el obispo le tracló mal de palal)ra, pero poco vivió despues. Édisose que leavian dado con que muriesse, é olra lal opinion ovo de la muerte del licenciato Salaya, su alealde nayor de Pedrarias; porfue un dia públicamente le dixo algumas palaloras recias, á las quales te dixo el gobermator que se mesurasso, si no qur le cortaria li cabecia: y uliçnçiado replicó é dixo assi: "Quicn me oviere de cortar la cabera ha de siber más que yo, é poder más que yo, é ser mejor que yo; y este no soys ros, ni hay quicn esso haga en la tierra: é hartas cabecous aveys cortado sin causa ni justicili, é no aveys dado cuenla de ninguna. Por esso mirad lo que deris: que no me envió acá el Emperador sino á milaros á las manos, é no dexiaros ya hacer mas nuterles injustas de las que areys lecho, "E con estas pilabras é otris tales se despartieron; pero deste á pocos diats fueron muy amigzos, é le dió el golsernador indios é otras cosis, é le aseguró é desde á poco ardolescrió el licenciando é se murió, é se dixo que lo avian echado lainta cacamonía ch una purcoga, que le acaló. E aunque Pedrarias no fuesse en carro de su muerte, como avia poco que cral passada Ia rençilla ques dicho, quisicron algumos deçir que de las palabras quel liçençado aria dicho desacaladas al gobernador, suligedió su mutuerte.

Despues desto, estimdo en Nicinagua el teniente Francisco Ilermandez, fueron á se quexar dél çiertos capitanes, é dićronle á entender que estaha alçarlo contra él; é determinó de yr allá, é llevó toda la mas parte de la gente, é dexó muy poca en los pueblos de Acla y el Nombre de Dios, que estín en la rosta del Norte é aum en los de la costa del Sur, que son Panamáé Kata, á causa que en la mesma saçon avian yrlo con licençia de Pedrarias á descubrir por la mar del Sur con dosçientos hombres é cientos navios los capilanes Francisco Picarro é Diego de Almagro, compañeros del macstrescuela Fernando de Lupne, en la qual rompañia se dió mma parte al mesmo gobernador Pellarias, porcue viniesse en darles la licencia, sin poner nala de su casa, puesto que en la cappilulaçion avia de contribuir en los gastos. É apueste fué el orígen é principio del descubrimiento del Perí, de donde lan. 
tos lluesoros han resultado. Desta mafría so tractarí mas (anterannente en su lugar. Por manera que quassi devó l'edrarias solos é rlespoblados en parte anpellos quaro puchlos, auncue él los llama ciludatles, y a ch todos los quatro no avia ma mediocre aldea; é partio en (a) mes do enero de mill é quinientos é reynte y seys para Nicaragua desde Panamá. É aquel mesmo año partió de Espana cl postrero dia de alyil, deste Sevilla, el robornador Pedio de los Rios; a a los tresnla é uno de maso llegó á la Gomera, donde se tomo refreseo, í conlinuó su camino é fuć á hacer escala en la isla Dominica . y esturo allí tres dias é medio. tomando asua é leña é reparando una nao que se le avia descubierto un agua en el viage, é aun fué misterio poder llegar hasta alli, é vino á furrega de bombas. É en arfuel puerlo del Angla ded aguarla se reparó la nao; en cl qual tiempo que allí osturimos, alcunos compañeros se desmandaron á coger palmitos de muchas palmas que hay en la costa de aquella isla; é cómo allí lay indios caribes é flecheros, mataron á dos chripstianos: el uno se dregia Cogollos y el otro Valrogers.

É fecho aquesto, como gente viloriosa, se mostraron ca la plara muchos indios de zuerra, cmbixidos é con sus areos é flechas é roçinas de caracoles grandes, ó otro español cscapó con dos flechaços. Luego nuestra gente se puso en ónden, é se embarcaron las mugeres é muchachos é gente inúlil que avian saliclo en tierra aquel dia á lavar la ropa é refrescarse, $y$ el gobernador se cmbarcó con cllos, é quedamos en ticra haçiendo rostro á los enemigos el liçençiado Johan de Salmeron, alcalde mayor, é biego Guticrrez do los Rios, sohrino del gobernador é yo é un hermano bastardo del gobernador, Ilamado Eq̣as, é otros caralleros é hidalgos. Terdad es quel gobernador quisicra qur. dar allí: pero como era hombre pessado y grruesso, hiçimosle cmbarcar á dé al bachiller lliegro de Corral, é ane nos enriasse luego los bateles, para que los que quedábamos en ticra, nos embaré́ssemos.

Ia yo ylua proveydo de gobernador 6 capitan general de la provinçia é gobernacion de Cartagena é sus islas é ancxos, como se diso. tractando de aquella provinçia en el libro XXVt, capitulo Ill, é ylua á entregar los bienes del adelantado Taseo Nuñez de Balboa é sus consortes (que arian hecho degrollar Pedrarias é su alcalde mayor, el liçençiado Espinosa) para la cómara de Sus Magestades, é á pedir justiçia contra Pedrarias, para me yr á servir á Sus llagestades en la dicha gobernacion de Cartagena.

Assi que, puestos los que allí quedábamos á la resistençia de los indios, aunque eran inuchos más que nosotros, no osaron allegar tan çerca que pudiéssemos pelear con ellos. É cómo el sol se ylua ya á esconder, nos embarcamos é faltó el ticmpo para la batalla.

El dia siguiente tornamos á la navegaçion é llegamos al puerto del Nombre de Dios, lunes trernta de julio de mill é quinientos é reynte $y$ seys años. Otro dia luego signiente, el grobernador Pedro de los Rios y el liçençiado Johan de Salmeron, su alcalde mayor, tomaron en aquel pueblo las varas de la justiça é la possesion de sus offrios. Allí se supo quel gobernador Pedrariats avia sicte meses que era yodo á Nicaragna á castigar á su teniento Françisco llernandez, que deçian que se le ar ia alcado, é avíase llevado consigo Pedrarias la mayor parte de la sente, cono he dicho. de los chripstianos, é muchos indios mansos de servicio de la lengua de Cueva.

E desle á vernte é cinco dias quel nucvo gobernador Pedro de los Rios llegó al Nombre de Dios, se passó por tierra á Pa* 
naná, para esperar á Pedrarias que viniesse á haçer residençia, é á comengar a entender cn el esiado, en que hallaba lia tierra é cosas de la gohernaçion.

\section{CAPITULO XXIII.}

Cómo el nuevo gobernador, Pedro de los Rios, envió ęierla gente á pacifiear el eacique Trola; é eúmo fueron veneidos édesbaratados los elıripstianos; é eomo vino nueva que Pedrarias avia degollado en Xiearagua á su teniente Franęisco llermandez; é cỏmo vino el eapilan Diego de Almagro á Panamá, ṫuxo noticia del deseubrimiento del Perú *; é por que via el eapitan Iliego de Almagro, é por qué presẹjo echó fuera de su compañia en las cosas é interesses del l'erú à Pedrarias Livila.

D.

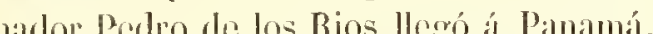
assi porque avia filta de bastimentos como por ocupar los nuevos soldados en algun buen exerçiçio, acordó de enviar parte dellos al puchlo de Nata, ques treynta leguas la costa abaxo de Panamá, assi portue allí avia mas aparejo de comida para se sostener, conto porque alyunos caçiques de la comarca andaban alterados, y en espeçial mo que se deçia Trota. É.despues que allí estuvieron, dióse órden rpue fuesse á entrar é paçificar arjuel caçifuc un hidalgo, llamado el capitan Alonso de Vargas: é llevó consigro lasta diez españoles de los reteranos soldados que allí estaban primero, é otros.treynta de los que con el grobernador avian venido de Castilla, que por todos scrían lasta quarenta lombres. Esto fuć en el mes de conero de mill é quinientos é vegnte y sicte años. É llevaban consigo un caçirue de paces, que estaba encomendado á un Pedro de Plasencia, veçino de Nata, paral que conno amigo de los cluripstianos, fucsse intervenidor émedianero, paraquel caçique lrota se asegurasse é viniesse á concordia con los españoles, sin rompimiento ni batalla.

Entrados en la tierra adentro una ó dos jormadas, vinieron dos indios espias para

\footnotetext{
* En el MS. original que nos sirve de texto, se lec aqui la signiente elảsula, si bien borrada por el misus Osiedo: "Ĺ丶 venia por gente para soeorrer a su compañoro, el capitan Francisco Picarro, i
}

considerar la forma é ser de los nuestros. é con qué órden proçedian; é fucron tomados é no bien gruardados, porque desde á dos dias se fueron por mala guarda. Despres vinieron algunos indios principales del caçique Trota é de otros eaçiques de las comarcas, digiendo que querian ser amiquos de los nuestros, é fingiendo una húmil é aplaçible paz, miraron bien las dispusigiones é poco número de los españoles. É fingiendo la amistad que publicaban, consideraron é vieron el mal aparejo de armas que llevalban los cluripstianos, é notaron que ylua enfermo el capitan Alonso de Vargas, del qual, aunque tenian notiça é sabian que cra valiente liombre, no les paresció quél estaba para pelcar: é assi con disimularion tractando de la paz. vino al real un indio prinçipal de aquel caçique que estaba en el campo enconendado á Pedro de Plasencia, el qual cacique se desia Pocoa, é eon acpuel indio venia otro del caçipue Trota. É parescióles al capitan é á los chripstianos que era bien que aquel caçique Pocoa fuesse intervenidor é movedor de la paz, é que para efétuarla por su mano. diesse assiento é conclusion en el negogio: Io qual el cacique Pocoa açeptó, mostrando tener muy buena voluntad en cllo. É diósele crédito,

volvió allà con alguna gente que le dió el gobernador Pedro de los Rios." l'areeiéndonos de algun interés, se la juzgado oportuno conserrarta. 


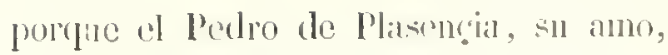
lo loaba mudedo de loneno é leal lombrer,

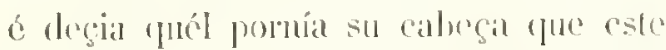
racique los sedeviria nuty bien é gue no

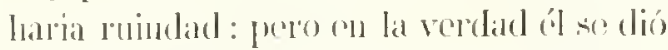
naturla á que no fuesse sola la rabera del Pedro de Plasenegia la que allí se prodediesse. Issi que, enviato por los chripstianos con arpuetlos dos indios á ladetir de las paçes con Trota ó olros caçiques de la comarea, el signicnte dia ó el tergero adelante que este caçifue salió del real, al fuarto del allat, de sobresalo llezaron sobie los chripstianos quinientos indios ó más de. guera, y el cagirgue Pocoa el delantero. con una graud patena de oro en los peclos, é slls raras para tirar cn las manos. Porque es costumbre en aquellas partes que los caçiques é hombres principales traygan en la batalla alguna joya de oro en los pechos ó en la cabega ó en los braços, para ser scunalados é conosgiclos entre los suyosé aun entre sus enculigos. Tambien renia allí el caçipue Trola: é con grande impetu é una grita que todos aquellos valles resonaban. dieron en los nuestros, tirándoles tanta mullitul de raras, que parescia una lluvia dellas. Los cspañoles, aunque no pensahan que tal respuesta les avia de tracr su amigo Pocoa, pelearon al principio animosamente contra los indios, é mataron lasta veynte y çineo ó treyula dellos; pero en conclusion. no bastando sus fuergas á lanta resistençia, fueron rotos é vencidos. é sn capitan Llonso de Varras muerto con otros quatro ó frinco de. los mas esforegados soldarlos ricjos ó pláticos compañoros, é de los otros que elan nucros en la licria e arian velo con el gobernador Pedro de los kios, doese ó treces de manera que por todos fuerón diez y nueve españoles los (fue muricron en csta guacúbara con su capilan, é los demas cseaparon. luny cudo por los moates, é dosde á algunos dias, ceparevilos rolvieron a tata. Entre
Ios otros que mataron lué uno aquel p'e-

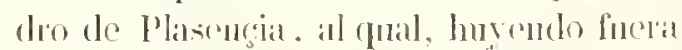
de la batalla gande espacio de lierrar, lo signió ol carcicfuc Pocoa a le matio, para le pagar ol benefigio ó nual tractamiento que le aria hecho en tanto que le turo de pages cul su cast.

Despues de passado esto bien avie tres mesces, vino á Pananá en un mario el cápitan Diego de Almigro, de donde en la costa austral él y el capilan francisco Pifirro, su compañero, estaban deseubriendo en la costa del Perí nueve meses avia, por mandado del gobernador Pedraria Dávila. De lo qual holgó mucho el gobernador Pedro de los Rios á todos, porque no se sabia cosa algema destos capitanes. É truxo hasta tres mill pessos de oro de diez y segs é diez y sicte quilates, é algyma plata en quientas menudas, é otras cosas; ć dixo que avia muclio oro en apuella tiera, é quél pudicra traer çient mill pessos dello, é que lo dexó, pensando que era muy baxo mats de ley de lo que en los tres inill pessos paresció que era, é que por esso lo aria deciado.

É despues que algunos dias el capitan Diegro de Almagro esturo en Panamí, descansando é visitando sus haçiendas é grangerias (que eran lunenas las quél é su compañero el capitan Francisco Piçarro tenian en aquella cilydad é su comarca), volvió á busear á Piçaro con quarenta ó ginguenta hombres quel gobernador Pedro de los Rios le dió: é llevó seys cabalos, á los quales los indios de aquellas partes donde avian andado los chripstianos con estos capitanes. tentan mucho, $\dot{y}$ en toda aquella costa del Perú. Dixo este capitim Nlnaggro que tenian notiçia de un cacique llamado Coco, muy lieo é pode: roso, é quel capilan P’içarro é los chripslianos que con él quedahan, eslaban en la costa de un rio muy hermoso é prande, que Ilaman rio de Sinct Johan, delante del Perí:- la costa y embocamicnto del 
qual está en dos grados desta parte de la linia equinoçial, á la banda de nuestro polo ártico. É otras muchas cosas é particularidades dixo de aquella lierra, que se diráu mas litrannente, quando se tracte della en la teresera parte destas historias; pero es muy gentil motable el que agora diré de Pedrarias é deste capitan Almagro, é por qué vial se salió de la compania, que con estos capilanes tenia en las cosas del desenbrimiento del Perí: en que tenia su terçia ó quarta parte en todo, é le ovicra cabido de su parte á Pedrarias é sus herederos mas de un.millon de pessos de oro, segund la opinion de muchos. Pero quiso Dios que, assi comoćl no avia metido en el caudal é gastos del desculrimiento sino palabras, que con cllas fuesse salisfecho, é tlo le quedasse mas de ló que Diego de Almagro le dió para sacarle del juego y cectarle fuera de tan grande negoçiaçion; é fué desta manera.

En el mes de diçiembre de aquel año de mill é quinientos é veynte y siete * vino á Panamá un navio de Nicaragua, é súpose que Pedrarias rernía presto, é que avia degollarlo al capilan Françisco Ilernandez, su teniente de la provinçia de Nicaragua, en que Pedrarias se avia intruso, alargando los línites de su gobernaçion por su interesse, á causa del oro (que de allí avia visto llevar al capilan Gil Gonçalez Dávila é por le haçer daño. Este navio venia sin pensaniento de lallar justiçia nueva en la tierra de otro goberinalor, sino ereyendo que Pedrarias no estaha removido del offrçio: é traia muchos indios de Nicaragria, para los vender é para se servir dellos los vecinos de Panamá, que los enviaban á quien los comprasse. É desde á pocos dias vino Pedrarias en otro navio, é salió en lierra çerca

* Asi está en el eódice original ; mas debe entenderse dieiembre de 1326 , pues que poeas líneas despues liabla del mes de febrero de 1527, lo cual no pue le ser en modo alguno, atendido el úrden de Nala, donde supo del nuevo gobernador, é lígole un mensagero con quien le escribió; y él vino despues á los lres de hebrero de mill é quinientos é reynte y sicte, é á los seys dias de aquel mes se preggonó su residençia, de la qual se dirá en el capítulo siguiente. En el qual tiempo yo tuve çicrtas cuentas con Pedrarias, é laçiendo la averiguaçien dellas en su casa, donde nos juntábamos á cuentas, chtró el capitan Diego de Almağo un dia , é le dixo: "Señol, ya vuestra señoría sabe que en esta armada é descubrimiento del Perú teneys parte con el capitan Françisco Piçarro é con el maestrescuela don Fernando de Luque, mis compañeros, é conmigo; é que no avés puesto en ella cosa alguma, é que nosotros estamos perdidos é aveunos gastado nuestras laçiendas ć las de otros nuestros amigos, é nos cuesta hasta el pressente sobre quince mill castellanos de oro: é agora el capitan Francisco Picarro é los clıripstianos que con él están, lienen mucha nescessidad de socorro, é grente, é calballos, é otras muclas cosas, para provecrlos; é porcue no no nos acabemos de perder ni se pierda tan buen prinçipio como el que tenemos en esta empresa, de que tanto hien se espera, suplico á ruestra señoría que nos socorrays con algunas vacas, para haçer carnes, é con algunos dincros para comprar caballos é otras cosas, de que hay nesçessidad, assi como jarçias é lonasé pè para los navios: que en todo se terná buena cuenta é la liay de lo que liasta aqui se la gastado, para que assi goge carla mo é contribuya por rata, segund la parte que luviere. É pues soys partiçipe en este doscalsrimiento, por la capitulacion que tenemos, no sears, señol, causa quel tiempo se liaya perdiclo é nosotros con él,

natural de los sueesos, que va Oviedo narrando; advirtiéndose por tanto que es solo error de pluma; no rectificado por involuntario desevido. 
ó si no queregs atemder al lin deste nergoçio, pagad lo que hasta aqui os calue por ralia, é dexcomosto todo." i lo qual Pedratrias, desque oro dicho Mlutagro, respondió muy cnoxado ć diso: "Bion palesegr que dero yo la gobernaçion: pues vos dlergís csso: que lo que yo pagríra, si no me ovieran quitado el officio, fucra yne me diérades may estrecha enenta de los curipstianos que son muertos por culpa de Piçarro é ruestla, ć que arés destruydo lia tierra al liey: é de todos essos \&lesórdenes é nuerles avés de diar raçon, romo presto lo reregs, antes qune silgays (le P'anamá." í lo tual replicó el capilan Amagro, é le diso: « Senor, desaos desso: que pues hay justiçia é juez que nos tenga en ella. muy bien es que todos den cuenta de los viros é de los mucrlos; é no fallará á vos, señor, de que deys 'cuenta. é yo la daré é Piçaro de manera quel Emperador, nuestro scñor, nos laga muchas é grandes merçedes por nuestros serviçios. Pagad, si quereys gocar desta empressa. pues que no sudays ni trabaxays en ella, ni avés puesto en cllo sino ma ternera quo nos distes al tiempo de la particla, que podia valer dos ó tres pessos de oro, ó alearl la mano del negroçio, é soltaros hemos la mitad de lo que nos debeys en lo que se ha gastado." Í esto replicó Pedrarias, riéndose de mala gana, é dixo: "No lo perderiedes todo é me dariédes quatro mill pessos." L Almagro dixo: "Tirlo lo que nos debeys os sollanos. 6 dejiulnos con bios acahar de perder ó de eranar." Cómo Pedranias vido que yal le sollaban lo quól debia en ol ammala, que á

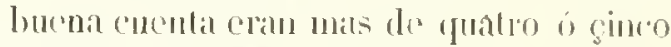
mill pessos, diso: "¿ ()uré nur darers de-

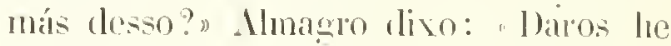
urescientos pessos" (muy conosalo, é jurraba á Dios (pue no los tenia: proro quél los buscaria, pol se apartar dél é no le pedir nada). Pealrarias replicó é dico: "E aum rlos mill me dareys. "Estonçes Almagro diso: "Daros he quinientos." "Mas de mill me dareys", dixo Pedrarias. É contimuando su enoxo Almagro, diso: "Mill pessos os doy, é no los tengo: pero yo daré seguridad de los pagrar en el término que me obligare."E Pedrarias dixo que era contento. E assi se hiço çierta escriptura de conçierto, en que quedó de le pagar mill jessos de oro, con que se saliesse, como se salió, de la compania de Pedrarias, é alçó la mano de todo aquello; é yo fuy uno de los testigos que firmamos el assiento é conviniençia, é Pedrarias se desistió é renunció torlo sin derecho en Nlmagro é su compañia. É desta forma salió del negrario, é por su poquedad dexó de atendel. para goçar de tan grand thessoro, como es notorio que se ha avido en aquellas partes. Tornenos á la residençia.

\section{CAPITULO XXIV.}

De la residenẹia que hiço Pedrarias ante el liẹenẹiado Johan de Salmeron, alcalde mayor de Pedro de los Rius, nuevo gobernador de Caslilla del oro; crimo Pedracias y el auclor destas historias se concertaron, icun qué condiçion.

\section{P} valo cl licenciado Espinosa dias avia ál Hspaña, envióse una çédula de Su Magestid para ytue no se les pidiesse ensia alguna de lo que oviesse passido antes de la residencia que les avia tomado el liçencia- do Johan Rodriguez de Mareonçillo: la qual no fué residençia, sino burla, porque aquel juez era su offiçial primero, é gratificado por Pedrarias, é pedido por su parte. Estas son las mañas é caulclas, con que la justiça es defraudada ý el Rey 
pierde sus vassatlos. Ilay otra cosa en estas residencias, por donde los gobernadores se quedan con sus culpas é los agraviados con sus daños é ofensas due delios hán resçehido; y es que, como los que pol acá en eslas parles andau son homlyres de passo é no arraygados, é vienen con intençion de dexar la ticrra é de no estar mas en ella de quanto lengan dineros, é avidos yrese á heredar á sis palrias, 110 sosiegan. Otros, por ser nuevos é no bien complexionados, ó por otras causas, se mueren: otros se van, é otros cehan sin causa los golyernadores é los desticran; é assi quando se les toma la cuenta, falla la mayor parte de los danificados, quanto másque los que dessean ó procuran arraygarse é perseverar en la ticra. á essos son los que les pessa quel gohernador no llaga lo que delie, y cssos son los quél tiene mas alıorresçidos. I demás desto. por la mayor parte, estos jueges que vicnen acé á desagraviar los ofendidos, vienen polres é adeudados é con desseo de no arer havegado tanlas leguas solamente por amor del alma, sino para sacar de nescessidad é polıreça su persona lo mas presto quellos puedan; y esto no puede ser sino por presçio del que ha gobernado antes: el qual no dá nada de lo suyo, sino de lo ques obligado á restituyr, no al que le tomó la cuenla, sino á quien él tomó la capa.

No diggo que Pelrarias hiçiesse nada desto, ni creo quel liçençado Salmeron tomára lal laçienda ; pero sé que usó uma muy sulil cautcla, é fué que, só color de poblar á Nicaragrua é castigar á aquel su teniente franciseo llernandez, desponló (fuassi á Castilla del Mro, é se llevó acullá la gente ó la mayor parte de todos appellos, que le avian de molestal en su residençia. Con todo, no fallaron algmos fue le pidicron nuchas cosas civil é criminalmente; pero los mas fueron excluydos ć perdicron su derceho, y el Rey ol TO.10) III. suyo, por cansa de apuclla célula fue so dixo de susso. Yo no la ví: pero el mesmo liçenciado Salmeron me diso que la avia, y en ricrlas cosas que yo le denuncié mo dixo quél no queria conosger de cosa algrunc, que oviesse passado hasla la residençia que le tomó á Pedrarias el liçençiado klarconcillo, ni me oyria sino en mis cosas proprias, é dexando aparte las que cumplian al Rey é á la república.

En este liempo de la residencia yo le puse catorge ó quinge demandas, en que tuve creydo que, giardándome justiçia, yo le condenára en mas de ocho mill pessos de oro. Y estando la mayor parte de los prosesos conclusos, y en tanto (jue laraban los liligios, fueron muchas personas las que se atravesaron á nos poner en paz é conçertarnos; é no pudieron, porque yo tenia creydo que me avian acuchillado con el faror é conscjo de Pedrarias, y estalsa sentido desto. Pero sospeché del juez yuc le cra favorable, é pensé que no me avia de guardar justiçia, é aunque me la hiciesse, acordábame que avia qualro años y más que la avia ydo á buscar á España, é con morirse un Rey é venir olro de tan léxos á heredar, é las mudanças de las Comunidades, é otras noredades de aquellos tiempos, me dieron grandes estorbos é dilaçiones, con muchos gastos, demás de olros trabaxos que padescí. É viendo quıc de las sentençias, queste juez diesse en favor de Pedrarias 6 mio, avian de ser apeladas por él ó por mí, para tornar á Espaи̃a desesperado del remedio; ove de conçertarme con Pedrarias, é dióme seplecientos pessos de oro é dos marcos de perlas, por racon que avia mas de tres años que me avia embargado dos mill pessos de oro, que me turo deteniclo hasla aquella residençia. Pero fué este concicrlo é amistad conlraydo con esia condiçion: que jurasse Pedrarias é hiçiesse pleyto homenage é lo firmasse de su nomIre; qie no avia seydo en dicho, ni hecho 


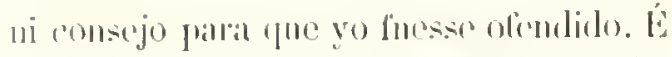

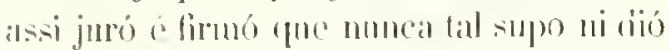
consenlimicnto ni paresçer on tal cosal antes dico furo lo avia pessatelo dello, é yo lo tengo assi firmado de su nonulure; jures como para entre huenos yo quelé satisferdo dél en cale caso. Qucdílbame mi recurso contra aquel dean, é yo llevala provision por que fuesse ron él oydo á justicia ", é quando en ella quise enten(lex. se murió : é quiso Dios que la cuenla tue yo pensibal perlirle, la diesso allá ante Sul Divina Jagestarl, á la quall plega averle perdonado: que en verdad él me hiço mucho daño é como cra lombre yiliota é sin letras, él se movió por 'onsejo de aquel bachiller Corral, para me laçer matar á traycion. como he dicho. De todos estos Irabaxos me quiso librar Dios de sll poter alsoluto, sin méritos mios, por su homdad e misericordia, e a fodos mis émules me ha dlevarlo ver, que son finera desta miseralbe vila. Ploega á él pue en la ofra haya piedad de sus áninas é los perilone.

Issi (fue, acabarla la residençia de PeMrariats, este bardeliller Corral se fué á España á çiertos negroçios, quél and wo cnliilaudo, é yo me fuy á la provinçia de $\mathrm{Ni}$ caragrua á ver al gobernalor Diego Lopez de Salcedo é ver atpuella tierra, como lo diré. quando della se tracte: á la qual fué despues por golsernador Pelrarias Dávila é le provejeron della (é aun antes que se supiesse ni se viesse en España sil resi(lençia), é quedó en Casstilla del Oro por gobernador Pedro de los Rios.

\section{CAPITULO XXV.}

Oue tracta de la gobernaçion de Pedro de los Pios en Castilla del Oro, è de otros gobernadores a jueçes que le subcedieron hasta el año de mill é quinienlos é quarenta y un años.

\section{l)} lias, por leformar mi consciencia é acalar de contender, é portuc desscaba venime á esta cibdad de Sancto Domingo é sosegar con mi muger é lijos, conosciendo la poca justicia (juc avia cn la Ticrra-Firme, ć vicndo las provisiones furorables fue se avian lluvado á Pedrarias, de consenso de amblos se lige una cscriptura de concordia , con pena de dos mill pessos de oro, qućl no fucsse contra mí ni yo contra él; é assi se assentó, é cada parte tomó signado esle assiento. É yo me fuy ál ver con el gobemador de Nicaragua, Diegro Lopez de Salgedo, domde estuve cierto tiempo, lasta que fué á grober-

* La siguiente clátusula, interesaute para la me. jor ilustrieion de estos hechos, annque horrada de inano de oviedo, nos parcee digna de ser conocida. Diec asi: "Yo llevabu provision det reverendis- nall aruclla licrra Pedrarias, donde no me fallaron trabaxos é pendençias nuevas con él, á causa del gobernador Diegro Lopez. de Salçedo, que era mi amigo, é su muger é la mia primas, hijas de dos hermanaz. Desto se dirá el suliçesso, fuando de Nicaragua se tracte, que hay mucho que deçir de las cosas notables de aquella provinçia. É de allí tornć á Panamá, donde esture mas de un año, en el qual tiempo hiço residençia Pedro de los Rios, porque se dieron dél é de su muger lanlas quexas en el Real Consejo de las Indias, fue no le turó el officio tres años. Y en la verdad ćl ra cavallero é de lnena casla; pero no para sobernar lierra tan nueranen-

simo Cardenal arçuhispo de Sevilla, don Alonso Manrique, inquisidol general, que ne dió Francisco Villegas, escribano del Consejo de la Sancha seneral Initusicion, cic.s 
te pobladis, porepue lo tenian por cobdiçioso, é la cobdiçáa de su muger insaçiable (por la qual el golsernador se gobermaba). Ved qué tales estarian los que debaxo de su parescer é ordenaçion viviessen.

Lo primero queste cavallero liço, on llegando á aquella ticra, fuć lomarse los depóssitos y embargos de dineros de particulares, é haçerse á si casa é posscedor de haçiendas ajenas: é pidió otros dineros prestados, é assi en lo uno y en lo otro, aquel primcro año que allá fué, recogió çicrlos millares de oro, para pagar sus fletes y enviar á España para lo que le cumplia. É sélo esto de vista, é porque de aquellos dos mill pessos que Pedrarias me avia tenido embargados thes años avia, como he dicho, destos me tomó pudro de los Rios mas de los mill é çiento y cinquienta: por manera que estas mudanças de gobernadores es saltar de la sáten en las brasas, ó cortar la cabega á la hidra prara que salgan dos, cono mas largo desta serpiente lo cuenta Oridio'.

Desde á pocos dias que Pedrarias hiço residençia, se fué Pedro de los Rios á Xicaragua (antes que yo allá fuesse); porque pensó que Pudrarias se avia entrado en aquella ticra que Lambien le pertenesçia á él, yne le avia subçedido en la goJer"laçion de Castilla del Oro.

Seyendo Su Magestad avisado que en el Cabo de Honduras aria contençiones de capitanes, é que Hernando Corlés avia ydo desde la Nireva España á buscar á Chripstóbal de Olit, que se le avia alçadlo y estaha on el puerto de IIondnras, é que Gil Conçalez pretendia tener aquello é lo de Nicaragua, é que Peclarar ías Dívila cutendia en lo mesmo; mandó á Diego Lopez de Salegelo, reçino desta cilidal de Sancto Domingo, sobrino ded comendador mayor de Aléntara, don
Frey Nicolís de Orando, que finesse á aquella lierra é la pusiesse en paz é quilasse arpuchlas behetrias é rontençiones de essos capitanes é otros. É quando fué á Ilonduras, halló que Cortés era ruelto á la Nueva España, é que á Cloripstóbal de Olit le avian muerto los capilanes Francisco de las Casas é Gil Gonçalez Dávila, é qué despues el Franciseo de las Casas avia presso al Gil Gongalez é llevídolo á Mléxico.

Desde Ifonduras se fuć Diego Lopez á Leon de Nicaragua, é llegaron á una saçon él é Pedro de los Rios, é pressentiron sus provisiones en el regimiento de acpuella cibdad, é resçibieron por grolernador á Diego Lopez, y excluyeron á Pedoro de los Rios ; é assi se tornó á Panamá muy mal contento, aviendo gastarlo el tienino é dincros sin provecho. Despues, (quando llegó su resilençia, se la tomó por mandado de Sus Magestades el liçençiar!o Antonio de la Cama; y en la verdad no dió lá cuenta como á él convinicra, é luesse á España en segumimicnto de su justiçia, é dexó allí á su miger. É por ruegro de aquella ciblad, como yo estaba para me venir á esta de Sancto Domingo ídespues (que rolví de Nicaragua á Pamanúi), fuy iupoltunado que fuesse á España: é açepté el poder é vine á esta cibdad, donde estuve pocos dias, é me partí en seguimiento de Pedro de los Rios. É llegados en Śvila, supliqué en el Conscjo Real de Indias que se viesse su residencia, é vídose é fué relatada en pressençia dél é mia. Lo (jue resultó della fué, que le quitaron ol officio é le mandaron que se fuesse á su casa, é no volvió mas á las luclias; é fué condenado en cierta suma de pessos de oro. É su muger nunca ruiso saiir de Panamá ni yrse á Córdova á su marido, diciento que si ál no yba jor ella, no avia de yr eon ofro; pero mas lo haçia. porque 
á causa delel Perú corria con l'anamá mucho oro, c con ciertas vatcals é ofrats ghange-

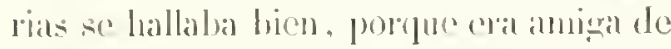
rescolour dineros: y entendiendo en los

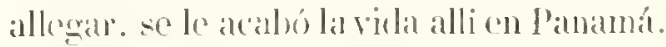
E el ligenchialo de la Gama, juez de resideméa, se quecló an algun tiempo en la gohernacion, hasta que diel enojados los de la tierra por su cohdicia, pidieron otro

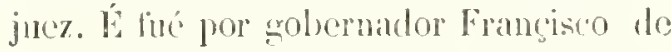
Barionurovo, del qual se llactó en el liIno $V$, capínto $Y$. de la primera parto destas historias: y deste tampoco lialtation an poco tiempo querellosos, por lo qual le fué á tomar residença col licençado Pero Tazquez, rue lo hico peor que los passados, é le luró poco el officio: liasta que fué el dotor Robles, que le tomó residençia. I no fuć menos colıdicioso ni mas justo en su olfiçio que los passados. é por esso le removieron del cargo, eslando ya carcado de oro.

D) todas estas mudangias de golsernadores é del remover indios é otras cosas no bien hechas, ha resuitido que en Castilla del Oro, doste el año de mill é quinientos y catoreg lasta de mill é quinientos é quarenta y dos, faltaron mas de dos millones de indios. Parte (y mucha para este daño) han seydo los golvernadores é los cobdiciosos é dezcongertados conquistadores: é mucha más causa, unerel Dios castigar las ydolatrías é sodomia é bestiales vicios é horrendos é crucles sacrificios é culpas de los mesmos indios, élas mezcladas nascionesque allá han passado de levantiscos é extrangeros.

Y pues se ha dicho de los golsernadores alguna parte de sus culpas. é no tanto quanto con verdad se podria decir é queda en mis memoriales, por no hacer aborrescible á los oydos humanos tal lerion, diré agrora ofras particuluridades.

1 Viase el acapilulo que tracta de las exeeten-

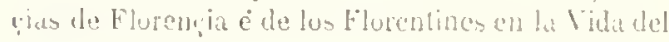
inatluc.) que serán de mejor systo oy dist que toda lo que costá dicho, desa grobremargion de Cisstillat del Oro. Pero no sé si se agertillá á conlorman ni pluma con el desseo que la mueve, en darlo á entender conto

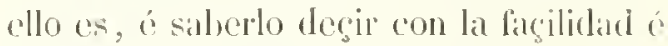
orramento é dulcedhumbre que suclen usat los que son diestros y (aloyiurules escrip)tores; porcque me acuerdo que dice Christophoro Landino, en apued comento que liço á la Comedia rlel Danthe, cotas palahras: "Cosa es entre los lombros miralsilíssima la elopgiençia: do manera que dos cosas son proprias al liomlure. de las quales ningun otro anminal partiçipa, que son sapiencia y cloqiiencia, é muchos mas ha avido salios que cloquentes. Haravilla ciertamente estupenda que siendo la oracion comun á lodos los hombres, raríssimos son aquellos que son en ella exçelentes; ć la eloquencia és reyno de los hombres, é quando es conjunla con la probitá é con la vertadera virtud, es utilissima solure todas las cosas '. "Todo es del auctor alegado, é á mi paresçer lien dicho, é todlo csso me falta. Has en confiança de Dios, é de la verdad que uso en estas materias, espero que to que he dicho é so dixere en cstas historias, es y seráa su loor é conforme á buen exergicio é provecho del que lo leyere, arrimándome á aquella anctoridad del palmista: "Aborrescriste á todos los que obran la iniquidad: desiruyrás todos los que hablan la mentira ${ }^{2}$."

No sé yo con qué sesso los que coslo salien se ocupan en estos tractados riçiosos é noveleros é agenos de torla rerdad que de pocos tiempos acá se componen é publican, é andan tan derramados é farnresgidos, que sin ninguna vergiença no falta quien los alegue é acote, como si fuessen histories veras; porque ni solo el com-

2 Odisii omnes qui operantur iniquilatem: ferdes omncs qui loquuntur mendacium. (Psilno I, vels, 7.j 
ponedor de lales novelas sea culpado, ni los que los alegan queden sin pena, pues cstá escripto: "ity de los que pensays cosas imúriles! " E Sinct Gregorio nos amonestal que tengamos por dinero prestado a entendimiculo que nos es concedirlo; pordue quanto mas se fia aquello dle nosolros por benignidad, tanto mas deblores somos obligados en la obra ${ }^{2}$. Pues arfuesto es assi, no se puerle pagar tal deluda con mentiras ${ }^{3}$; ć como el mesno dotor nos acuerda, Dios no ha menester al mentiroso, porque la rerdad no quiere ser guarnescirla del socorro de la falsedarl. Pero tambien me paresge á mí que en algruna manera es de tolerar ó se disimula con lales tractados, como con las malas mugeres, ó que convienen tales libros ra110s, no al que compone, porque ya aquel pecea, pues á sabicndas miente, ni al que los lee, porque pierde el riempo é linche sll cabega de viento, é aquella ocupaçion que alli gasla la podria mejor emplear; Ints satisfaçen al que los vende, é mucho más á la auctoridard y estimacion de las letras y escripturas, que contienen verdad, para que se tengan en lo que meresecen. E assi lo que dise de las mugeres no huenas, las sufren las repúblicas en alguna niancra por otras causas á (fue aprovechan, aunque seria mayor provecho que no peceassen.

Conviene, diçe este dotor saģrado, (fue haya Lereges, para que seyendo proba(los, sean manifiestos ${ }^{4}$. No quiero nombrar los libros ni los auctores que reprehendo, pues que dige Sanct Pablo: "Cada uno de nosolros dará á Dios raçon de sí ${ }^{5}$. " P'legga á él por su miscricordia que con la verdarl (fue sigue mi pluma estas listorias, scan acompañadas de su graçia, para (jue a su alabinça se influya é lenga tanto contentamiento el (jue las leyere, comóa mí me quelará, si le salisfago ${ }^{6}$. Y si no le satisficiere, ya yo sé que las hiervas que sulstentan á unos animales, matan á otros; y aun he muchas veces visto quel buen manjar no pierde su crédito, porcue el doliente lo aborrezea, y lic visto que la sentençia fue unos Ilaman injusta, otros la alaban: é sé que lodo esto avrá en mis renglones, porque los gustos no son uno nesmo, ni los juicios de los hombres siguen un parescer, ni son de igual ingenio ni inclinacion. Solo Dios es el justo y el que puede é sabe justamente juzgar á todos, porcine ninguna cosa le es oculta, $y$ es impassilule.

\section{CAPITULO XXVI.}

Te las costuntres é maneras de sirir rięiosas de los indios de la provinęia de Cueva é de sus ydolitrian; collas cosas particulares de la gobernaçion de Castilla del Oro é de sus provinçias.

苜B

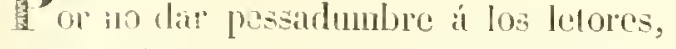
repiliendo algo de lo que está dicho, se tocarín en suma en este libro XXIX alganhias materias que en los libros precedenlesse ovicren memorado, declarmido las dili rencias fue oviere fle lo que está diclo cul la prineral parte, ál lo que se dige cu esla segunta on cosas semejautes. E

Nich., cap 11. Vers. I.

? Moril, lib. XXIl, eap. VI.

3 l)., lil. Xl, cip. Xll. assi diggo, que en quanto á la religiosidad ó costumbre de ydolatrar en la provincia de Cueva, es entre los indios en Castilla alel Oro muy ordinaria cosa arloriar al sol é la luna, é tener en mucho crédito é veneracion al diablo: é assi para sus yrlolaIrís é sacrificios tenian hombres deputados é reverengiados, los quales comun-

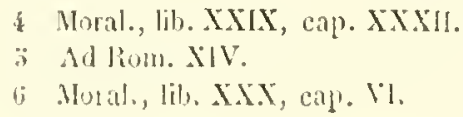


mente cran slls médicos, á conoscian mat-

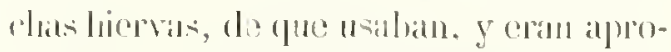

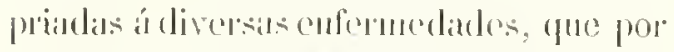

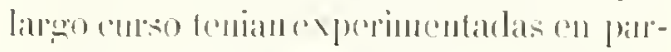
te, uo tan dignas de crédito botalmente al-

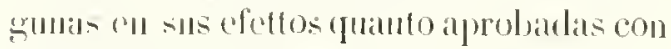
lit anceroridad que les (queria atribuye aquel sll médico ó maestro, Ilamado tequina, (juesto yue en algunas degian verdarl, é son (arolentes).

listos indios de Cueva. quanto í su dispusicginn de liss personas, son algo mayores que los destas nucstras islas por la mayor parte, é mas varones, é de la mesma color. Andan desinulos. y en su miemlro viril un caracol de pescado ó un cañuto de madera. é los testigos de fuera: é alfucl caracol ó cañuto con mu hilo asirlo é ceñido trabado de dos agujericos. I as mugeres tracn naguas, que soi mantas pequeñas de algodon, deste la cinta luasta la rodilla o mas alto, roduadas al cucrpo: é las señoras é mugeres principrilos (espaces) tracn cstas maguas haxas hasta los tobillos; é en las cabegas cllos ni cllis ninguna tosa, ni cu toda la persona, mas de lo ques dicho. Terrat us que algunos scuores, antrellos de los mas principales, traian en lugar de caricol un cañuto de oro torcido ó liso, de muy fmo oro, é las señoras espares, que son mugeres muy principales, por aloruamento é porque las letas (de que mucho se prescian), estoriessen altas ć mas tiestas. é no se les caygum. se ponian una baura de oro atraressiada en los pechos, debaso de las tetas, gue se las levanta, y en ella algrunos pácaros é ofras figuras de relieve, totlo de oro fino: qur jor lo menos pesalua çiento é sinctienta é aun dosçientos pessos una barreta destas.

Esta imvencion destas lyarras de oro, para levantar las telas, es primor ć usanca do las mugreres prinçipales del golpho de Crabá: las quales nugeres van th has halallas con sus maridos, é lambien quando

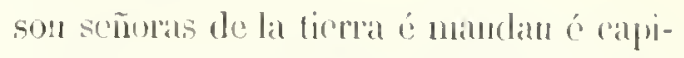
lanoan su gente. Mentís de las bantras yne

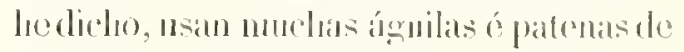
oro, assi lats mugeres como los lomminers,

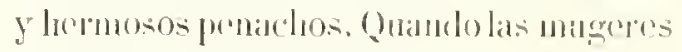

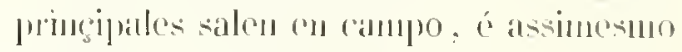
los scriores desta wente, como no tienen calsallos, ni bestias, ni camos yno los lleven acuestas. usan otra mancra do cabalIleria, que es desta manera (fue agrora diré. Sicmpre el señor, cacirfue ó saco, ó viuon principal, tiene una dogena ó dos de iudios de los mas recios, dipulados para sus andas, ch que van de camino echados en una hamaca, la yual va $\mathrm{cu}$ un palo largo puesta, que de su natura es muy liviano, é los extremos de aquel palo pueslos solne los hombros de aquellos indios, é van corricndo ó unclio trotando en galope con el señor acuestas. (2uando se cansan los dos que lo llevan, sin se parar, se ponen en el mesno lugar otros dos dellos que allí van jor respecto vaçios piara lo mosmo, é continúan su camino: é un dia, si es en ticra llana, andan desta manera quince ó veynte leguas. teniends postas puestas en paradas de tales indios para se remular. É los indios que para este olliçio tienen, por la mayor parte son esclavos ó nahorias, que son quassi esclavos é obligados á servil; y estos indios que en lo ques dicho sirven de las hamacas, búscanlos que scan carates. í para que se cnticnda qué cosid es carate, digo que carate se llama el indio (jue naturalmente ticne toda la persona ó la mayor parte della como descostrado, levantados los cueros á mancra de empegnes. Ellos parescen feos, mas comummente son regios é de mojores fuergas, é parescen frisados, é aquella frisa es dolencia que se acaba, quando la acibado de les andar todo el cuerpo toda aquella comeron ó enfermedad é han mudado fodo el cucro do la persona.

En algumal partes desta liema sou beli- 
cosos los indios, é en otras no tanto: no son flecheros, é pelean con macanas é con langas luengas y con varasque arrojan, como dardos con cstóricas (que son cjicra mancra de avientos) de unos bastones hien labrados, como aquí está pintado (Lámina $I^{\text {a }}$, figs. $I^{\text {a }}$ y $I I I^{\circ}$ ), , con los quales arrojan las varas, quedamlo sicmpre la estórica en la mano: é ponen la punta de la estórica en la punla de la vara, é sacúdenla muy reçia é derecha é léxos, ó serea, licn guiala, como luenos punteros. Algunas varas destas van silvando en el ayre, á causa que les laçen çerca del cxtremo çicrta oquedad ó ponna redonda é por la ofpuedad de aquella é agrugeros que tiene, assi como la celıan y cs locada del ayre, assi va lucgo por lo alto con ruydo silvando. Y estas tales que silvan, usan dellas en las fiestas, quando braçean por sentilecá, é no en la guerra, porque las tales, con arpucl sonido ó silvato avisan al enomigo, é quando en la guerra de m real á otro las tiran, ó de noche, es como en caso de menosprecio de los contrarios.

Los lombres que dise que tienen los indios en venelaçion, llamanlos para se conscjar con ellos para comencir sus guerras, é para todas las otras cosas que son de importangia. Deste nombre tequima se laçe mucha diferencia; porque á qualquiera ques mas lábil y experio en algun arte, assi como en sel mejor montero ó pescador, ó hager mejor una red ó una canoa í otra cosa, le llamas lequina, que quire decir lo mesmo qua macstro: por manera que al ques macstro de las responsiones é inteligenças con el diablo. Iámanle tepuina en aquel arte. porque arpuestc tal os el que administra sus ylolatrías é gerimonias é sacrificios, y cl pue habla con el diablo, segund cllos diçen, é á ćl dá sus respueslas; é le dice que diga ú los otros lo que lıan de laçer, é lo que serí mañana é doscle á mudios dias, poripue como silla- nás sea antiguo astrólogo, conosce los movinientos naturales del ticmpo á çiclos, ó planctas, é del zodiaco, ć inlluengias de arriba, é ré dónde van las cosas guiadas naturalmente; ć assi, por el chetto á que van referidas en su conclusion, dí él notiçia de lo que seríl adelante. E láceles cntender que por su deilat, é como scñor é movedor é disponcalor de fodo lo ques é será, sabe las cosas que estám por renir: é diçeles quél atruena é hace llover, é gria los tiempos é les dá ó quita los fructos en las plantas é hicrvas é arlonlos, y en todo lo que sulistenta las criaturas. l'ues como muchas reges ven que en cfotto assi acaesce, como se lo ha prenosticado algunos dias antes, dánle crédito en todo lo demás é sacrilicanle en muchas é diversas maneras, en mas partes con sangre é vidas humanas, y en otras con sahmmerios aromáticos é de buen olor é de malo tambien. É ruando Dios dispone lo contrario quel diablo ha dicho al terguina y el tequina á otros, é los micnte, dáles á cntender que ha mudado la sentensia por algun enojo ó achaque que ál co le paresce, conro aquel ques suliciente naestro de engaños con los mortales, en rspecial con geute que tan polme é desapercelida está de defensas contra tan grande adverssario, al qual cllos llaman tuyra. Y este mesno nombre en aquella lengua do Cueva dan los indios á los chripstinnos, porpuc los lienen por sagaces ó por lales romo al diablo, pensando que en degirlos tuyras, los lionran a loan mucho. Questas gentes se golbiernen, formando al gemna opinion de religiosidarl é crédito que dan á sus tequinas no me maravillo, pues tal feresero anda por malio como cl furla.

Mucha fuc la monelengia is golierno de los antiguos romanos é cartagineses cntro todas las nasciones; pero oyd a Tito livio é sabreys dél el erédito que daban á sus arúspices ó adevinos, á cuyos crores é ranidades é congecturas estaban subjetos 
‘́ sus locos sacrificios: é interviniondo en ellos el diablo, alqunas reges arertaban è degian algo de lo que despmes el liempo y rfetlo les mostraba, sin seaber dello cosa alguna ó gedtinidad más do lo yued comun adversintrio de natma lumbna les ensconaba, para los lraer á su perdiçion é muerte corporal y espiritual. É assi por consizuiente. quando el sacrifiço fallalua é salia defettroso, se exrusalan é ponian caulelosas y cquivocas respuestas, diçiendo que sus dioses que adolahan estaban indignados. como el tequina lo diçe á estos indios por el tuyra, á quien tienen por sul Dios:

Escuchad á Valerio llásimo. i verés con quánta prontilud de religion é euydado espeçial estos antignuos atendian on lodas las cosasque emprendian, que de importancia fuessen. por medio de sus agoreros ó arúspiçes. Grande es el pueblo quel universo contiene debaco do lim diabólicos errores, é grandes licmpos é millares de añoshan turado è nunca filtarín entre los que no fueren alumbrados é socorritos de Dios, Nuestro Señor : ¿ lanto mayor es la obligacion de los chripstianos para conoscer la miscricordia quel Redemptor usio an romunicarles su pelssion è reslimiolos. i muy justíssima la condenaçion de lo: insratos que tal desconosgen. y desin ánimas en el amor de Dins se desemydar.

En aquel sumario que escrilui el año do mill é quinientos é veynte y seys *. que fié impresso por mandado del Cóssall en la muy real cilubd de Toledo, yo tracte alli de diversas materias, no tam ordenamente ni lan apartado de otros cuyclatos romo quisicra, á causa de otras forgosas ocupaçiones, que en esta sacon tuve. firl-

* Asi se lee en el MS. original que tenemos telante; peroes equirocacion de pluma. Eil Sumario de la Natural historia de lus Indias, como vil nolado en la 111. Parle de la Vida y cserilos de Oxiedo (paig. Lll del 1. I), que se escribio en 1528 y se publicu el siguiente año de 1526 . Asi lo dijo rel mismo eronista en la introuluecion del lib. I de la i a palte: lámdono lal quictud que se recpucrial para la calidad de las cosas que alli dixo: é demás desso labléme desemydado dre mis lilros é memorias fanticulares, é am estonces no avia assi eomprelendido algunas particularidades e otras novedarles, quel liempo me las la inseñado. E acnerdome que me referíá esta General Ihistoria. que aunque no estaba copiada regladamente en las minulas a memorias que yo tenia de aquestas cosas, no caresçia en mi desseo la reperança de traerla á este estado que agora estát: y es bien que se cumpla lo que proneti. I assi yré discurriendo por lo que allí cacribí en alọunos passos, que estovieren por decire en lo que hasta aqui se ha dicho: los quales, si quisiere algumo espiar, para acrsar mi negligengia (si le paresciere que alguno olvido). le quiero avisar que no los toparả acqui á reo como allí los puse, pero estarán en sus lugares convinientos; porque á la rerdad aquel smmario lué mas breve que su litulo, porque le llamé: Orreno: De la Nalural historia de las Indias, è compro. hende mucho menos de lo que avia de lener deba co de tal nombre. Pero fué aquel tractado como mensagero o significador destos, que agora tracto en esta General Historia destas parles, ó como ma composta cue llaman los que haçen conserva del agícar i diversas fructas, quo en un vaso mezclan diferentes ééneros dellas: y por la mayor parte las unas ocupan ó impiden á los olras. é se embaraçan é no se dexan ni pueden gustar tan distinlamente, como si cada unil dellas, goçando de su almivar, cstoviesse sola en su bote ó vaso conficionarla; $y$ assi hiçe yo en aquel simario, que muchas cosas de las

"WL año que passó de la Nalisidlat de Chripsto de mill è quinientos $\dot{x}$ regne y eineo años yo escrimbi una relacion sumaria de parte de lo que aqui so neontiene; ¿do aquella fué su tilulo: Ovirno: De sla Valural historin de les Indias (prig. "̈, eol. 1." sdel t. i)." 
que allí se acumularon no se entiente puntualmente donde están.

Y pues de susso comencé en las armas con que pelean, é dixe de las varas que tiran con las cstóricas, láse de entender questa manera de armas se usan cn csta provinçia de Cueva, y en otras particulares provinçias, que son aquellas varas de palmas negras é de otrosárboles de muy Iuenas maderas, é las puntas delgadas é ağudas, que passan un lıombre de parte á parte, si lc aciertan por lo hueco. É algunas hacen de cañas de çicrtos carriços, que son muy derechasé sin ñudo alguno, tan gruessas como el menor dedo de la mano ó más delgadas, é ligeras é lisas: en las quales engastan al cabo en lugar de hierro un palmo é medio ó dos de otro palo de palma negra, muy bien labrado é con muchas lenguas; é á algunos ponen huesos de animales é de pescados por licrros, é son enconados. E las lanças luengas, que usan algunos destos indios, háçcnlas assimesmo de palmas é de xagua é de otras buenas maderas; é traen macanas de una é de dos manos, y en algunas provinçias, assi como en Esquegua, é Urraca, é Borica, é Paris, ticnen lanças tan lnengas ó mas que picas, de palnıs muy reçias é hermosas é negras como açabache.

Sus guaçábaras ó peleas son muchas veçessin propóssito; pero no sin darles el diablo causa, porque son gente que aunque tienen diferençias é passiones un señor con otro, las menos veces son movidos con raçon, é las mas son voluntarias é induçidos por el tuyra é su tequina, dándoles á entender ques divinamente intentada la guerra que les conseja. Pero entre la gente de un mesmo liba ó scñor pocas veces riñen ni vienen á las armas, ni es assi liviana la obediencia que tienen á sus mayores, como la de otras gentes; porque assi dispone el cacique ó señor ó tiba de las vidas de sus indios, como entre los chripstianos se dispone de las cosas que TUMO III. menos estiman; ni hay pleyto ni diferençia entrellos en que ture tergero dia la contencion, ni mas de quanto el señor la sepa é mande lo que en tal debate se debe hagere é justo ó injusto lo que manda, assi sc cumple immediate. Terlad es que como ol lurto entre aquesta gente le ticnen por el mayor delicto que se puede cometer, cada uno licne liçençia de cortar ambas manos y echársclas al cuclo colgadas al ladron que toman dentro en maliçal ó heredamiento, si solo un espiga hallan que lıa cortado sin liçençia de su dueño.

El principio de la guerra mejor fundado é sobre questas gentes riñen é vienen á batalla es sobre quál terná mas tierra ó señorio, é tambien sobre otras diferençias; é á los que pueden matar matan, é á los que prenten, los lierran é se sirven dellos por esclavos, é cada señor tiene su hierro conosçido, é alğunos los haçen sacar un diente de los delanteros al que toman por esclavo, é aquella es su señal, é le llaman paco al esclavo. El principal señor se llama quevi, y en algumas partes saco; é aqueste nombre caçique no es do la Tierra-Firme, sino propriamente desta Isla Española, é como fuć esto lo primero que polslaron é ganaron los clripstianos, ellos han dado este nombre caçique á los señores de otras partes por donde en estas Indias han discurrido. En la lengua do Cneva, de que aqui se tracta, el nombre del señor es queví, y cu algunas provinçias de Castilla del Oro se llama tiba, y en otras partes della se diçe jura, y en algunas guaxiro; pero este nombre guaxiro hínle tomado de los carilıes, que no es proprio de Cueva, sino allegado y extrangero. Assimesmo en Cueva, al ques hombre prinçipal, señor de vassallos, si es subjecto á otro mayor, llámanle á este tal prinçipal saco; é aqueste saco tiene otros indios á él subjectos, que tienen licras é lugares, é llámanlos cabras, que 
son como davilleros o liijos-dinlgros, scparados der la gente commu, í son mats prinçipales yno los olros del vulgogo, mandan á los otros. Proro el carcipur ó sat coća cabra cata mo liene su nomhre, a asimesmo las provingias é rios é valles r lugares é assientos donde viven, $\therefore$ los érboles é aves á anmales é peres lienen sus nombres proprios é particulares: $110 n$ olstante que assi como nosolros lecrimos en axeneral pescado, diçen ellos haboga.

La manera rómo $n$ indio rues de la gente baxa ó commó óplebea sulve á ser cabra, é alceanga coste nombre é hidalgnia para preceder á los olros commos, es quando quier que en una balalla de un señor contra otro se señala é sale herido, jeleanto animosamenic, aquella sangre son las lehas del previlegio é lílulo é principio de su nobleça: é el scñor cuyo es, le llama cabra, ó lo dá gente que mande, é le da lierra ó muger, ó le hage otra mercel señalada por lo que obró aquel dia en su pressençia, porque si el prínçipe no está frossente, no se gana tal honor. É dende "In adelante es mas lionrado que los otros é separado é apralado del vulgo é gente ‘onnun; é sns hijos varones deste subçeden en essa mesma lidalguia, é se llaman cabras, é son obligados á seguir la miliçia é arte militar de la guterra. Á la mmger del calıra, demáts de su nombre proprio, le llaman espace, que quiere deçir señora ó mas prinçipal muger (que las comunes ó plebeas mugeres: el qual tiIulo ella adpuicre immediate que su marido es cabra; é assimesmo á las mugeres de los querís ó sacos ó cabras llaman espares.

Quando van á la guerra, llevan sus caudillos ó capilanes: estos son sacos ó cabras, é son ya hombres de expiriençia cn las cosas de las armas quellos usan, é van con sus penachos 6 embixados o pinlados do sagua, é llevan insignias señaladas para so romoscoilos on las batallas, assi romo joyas de oro ó penarlo ú olva devisa. Ticmen ma particulanidad ó costmulıre entre si inviolalule, y es que annque prenclan á las espias é las hagan pediços, á tormentos que les din, ni por promosas que so les lagau, no confessirún mas verdad ni mentira de lo que les es ordenato por el capilan, lila ó señor, que los envia, ni en raño desu gente. Por la mayor parte sus cmpresis se fundan soIre una bebdera é areyto: é despres que estái acordiato lo que se la de haçer, lo cantan acpuel dia de la determinaçion ó el siguiente, é luegro se pone por obra todo to rute en el arejto se ha cantado. Esto es como para lestimonio ó consullaçion con (c) vilgo, despues quel señor ó los mas açeptos á él é su terfuina han consultado la cosa que quieren emprender; y esta órden tienen en las gnerras voluntarias los que son agresores, porque el que defiende, muévese acaso él, como le subçede la nesçessidad.

En las cosas de la justiçia lienen sus execulores, que son como algnaçiles, é aquestos prenden é malan á quien el principal señor manda que muera de los pleheos; pero si es lombre el que ha de padescer que sea saco ó calora, no ha de poner en él las manos ninguno de la coImunidal ó plebeo, sino el señor de tolos: é acpuel le mala por sus manos con una macana, ó le echa ma ó dos lanças ó varas primero, ćle hicre, é remílelo ál que lo acalse su execulor, si de aquellos primoros golpes no le mata: porque aquel prinçipio quel scñor dió á la execnçion re la justiça es como desgraduarle é quitarle de ser calora ó persona noble. 


\section{CAPITULO XXVII.}

El qual tracta de los pueblos prinçipales de los ehripstianos en esta gobernacion de Castilla del Oro, is de las casas ó moradar de los indios, é de sus malrimonios á algunas de sus çerimonias é costumbres.

D. las casas é moradas destas gentes se Ia dicho en of ras partes destas listorias. é de sus camas, que son las hamacas que se dixo en el libro $V$, caṕ́tulo II; pero aun en essas hay diferencias, porque las de Tierra-Firme en esta gobernacion de Castilla del Oro la manta de la hamaca no es hecha red, sino entera ć muy gentil tela delgada é anclia, é tan luenga como conviene. llay otras, que la manta es de paja texida é de colores é labores; é destas hay muchas en Nata y en otras partes: y csta paja está liccha como corrlon sobre hilos de algodon, é son cosas de ver é muy frescas é gentiles en la vista. Todo to demás que toca á estos fechos está dicho en el lugar alegado; pero no todos los indios las tienen, é los que no las alcancan, duemen en barbacoas, que son bancos hechos de cañas, ó en otro armadijo que esté dos ó tres palmos altos ó más de ticrra, por: la humedad: é los que mas no pueden, ćchanse en arquel comun colchon, ques el suelo, sobre paja ú hojas de palmas ó lo que hallan.

De los buhíos é casas tracté en la primera parte, en el capítulo I del libro VT, é dixe qué tales son en estas islas é otras: y tambien se dixo en el capítulo $X$ deste libro XIX de las barbacoas de las provinçias de Abrayme é Teruy, donde los indios viven é tienen sus moradas en los árboles, é assimesmo de las barluacoas sobre muchas palmas juntas, en que los indios viven en la costa del riogrande, que entrá en el gotplio de Crabá, la qual provincia se llama Tatuma, é son de mucha admiraçion, é allí tienen sus moradas: é sube una muger por el áliol arriba con el hijo en braços tan sueltamente como si fuesse por ticra llana, por çictos cscalones hochos de bexucos masçidos é peruceltosé atados al árbol, y el terreno de abaxo cubierto de agua é paludes basos $e^{\prime}$ partes hondos; é de alli salen en camois á la tierra enjuta, donde laçen sus labrangas é conucos. Esta mancra de puchlos lacen por estar seguros del fuego é de sus enemigos é de las bestias ficras, é porque están mas fuertes. En las ofras partes, donde los indios pucblan, por la mayor parte es desparidos en valles é laderas é costas de los rios é donde les paresce, é taubien en las sicras (á la manera de nuestras montañas de España y en Vizcaya é Galicia) puchlan como en harros, unas casas desviadis de otras; pero muchas dellas é grand territorio debaxo de la obediençia de un caçique ó tiba ó saco ó queví ó señor prinçipal, porcue estos nombres, eomo tengo dicho, usin los señores en diferentes provingias. Fste nombre queví en arálisigo quiere deçir grande; é assi al que en la lengual de Cueva llaman querí, es mas señor é de mas estato é gente quel tila ni el saco.

IIay otra manera de buhíos ó casas en Nata redondos, como unos rhapileles muy altos, é son de nucho apossento é seguros, porque el vienio de la lurisa, que allí corre mncha parte del año con mucho intpeto, no los puede assi coger como á los que son quadrados ó de otra forma. Son de reçia é buena madera, é mas licrmosos de dentro que lodas las mancras de casas que se ha dicho: é ponen cu la punta del chapitel una cosa de harro cosido á manera de candelero, y el cucllo alto, y en la forma questá aqui pintardo (Lám. II. . fig. I. '). Ial paja, con que se cu- 
bre es muy buena, é las cañas de las páa ledes eruesats, é por de fuera é de denfro fortadirs las paredes con cana delgale da muy bien puestar é con muchos apartamientos. Fl assiento deste pueblo es mu gentil é de lıermosas regas, ó muy llano é dispuesto para ganados é todas grrangerias; é hay muchas vacas é puercos é yeguas, y es licrra de nucha caça é monteria, porfuc serca hay montañas é boseages en ticrra alta.

Avia en este pueblo, quanto yo le ví el año te mill ć quinientos é veinte y siete lassia quarenta y ģinco ó çinqienta buhios, y cstá dos leguras de la mar un rio arriba, y ereo sin duda que mengua alli la mar en la costa dos leguas y más. En este rio hay tantos lagratos ó cocatrices grandes, que son innumerables los que cada dia se ven por lit costa echados on tierra al sol, de los quales en su lugar se dirá.

Panamá tiene mal assiento y es pecueTial poblacion é no sano; es estrecho é luengo el pueblo, é de la parte del Mediodia llega la marea hasta çerca de las casas, é de la parte del Norte á las espaldas está lleno de paluules é criénegasa, é á la parte del Este está el puerto, donde los navios é caravelas entran hasta fjerca de las casis, é con la monguante quedan en seco, é liaxa la ma más de legua y media. Por causa deste puerto é contractaçion del Perú, é por arer allí residido Pedrarias é los otros gobernadores, ha estado en mas repulacion, y cn el ticmpo que yo dexé aquella lierra, que fué el año de mill é quinientos é veỹnte y nueve, nunca hasta estonçes llegó hasta septenta huhíos. Es tienra seca y estéril; pero en las comareas es fértil é de buenos pastos é hartos granados.

El Tombre de Dios assimesmo por el puerto se sufie, á causa de la contractacion de la otra mar austral é del Perú é destas islas para las cosas de Tierra-Firme; y es de menos pollaçion é de peor dispusiçion para grangerias del cimpo, porque es lierrá íspera, montuosa é çercada de arboledas.

Acla cra mayor pueblo que ninguno de los ques dicho, é despues se ha diminuydo, y el puerto no es muy bueno; pero hay ancones é isletas de seguros puertos. É descle allí fué por tierra á descubrir la mar del Sur el adelantado Vasco Nuñez de Ballooa, quando la descubrió.

El mayor é mejor é mas fértil pueblo fué la cibdad de Sancta Maria del Antigrua del Darien, en la qual no es menester hablar, pues que está despoblada.

Otros pucblos ha avido, donde se han labrado minas; pero como essos se hacen é se dexan, segund anda el oro, no hay para qué memorarlos por poblaçiones, pues no permanescen é se passan los mineros de rio en rio, é donde les acude mejor la grangeria y exercicio de las minas; y assi se mudan, segund su propóssito al modo de los alárabes en Ífrica, que traen sus mugeres é hijos consigo, é todo lo que tienen, de provinçia en provinçia: é aun en la provinçia de Cueva suclen hacer lo mesmo los indios en algunas partes, que se mudan con todo el puchlo de un rio ó valle í lo alto é sierras, ó de las montañas á los llanos, é donde les plaçe; pero dentro de su señorio, porque tienen poco que hager en cllo. Sus casas son sin çimicntos é de madera é paja, y essos materiales á dó quiera que se van, los tienen. Sus bienes mucbles son pocos, é ligera cosa llevar la hamaca ó cl arco é sus personas: los heredamientos, tonde mejor acuden las simenteras del mahiz é de las otras cosas de su agricoltura, allí se hallan mejor ; é si en esta provincia se ra cansando la tierra, hallan otrá holgada, é assi se andan mudando.

Tienen una costumbre los indios desta provinçia de Cueva. ques muy soçialıle é obligatoria á los comunes con su señor cn ol comer; y es quel capitan ó señor prin- 
ripal, ora bea en el campo ó en su assiento é casa, todo lo fue lay de comer se le pone delante, y él lo reparte á todos, é nanda dirr á eada uno lo que le place. E tiene hombres deputados para que le siembren el maliz. é la yuca, é para sus lavores del campo, é otros para que le monteen é maten puereos é çiervos é otras salvaginas, é ołros que pesquen; é él por su persona allganas veçes en todas estas cosas por su placer se ocupa, en fanto que no tiene guerra. Al comer no le sirven lombres, sino mugeres: aquellas comidas que dise de susso, no son con todo el pucblo, quando el señor reparte la comida; pero con los prinçipales é mas señalados é aun algunos otros, estando en el campo, á la continua; y estando en paz, todas las fiestas, é algunos dias, aunque no sea fiesla.

En sus matrimonios lay cosa de notar, assi como que ningumo se casa con su madre ni con su hija ni con su hermana, ni han açeso carnal con ellas en estos grados, y en todos los olros sí; é si alguno lo lace en estos grados, no es teniclo por bueno, ni les paresce bien á los otros indios. El tiba ó señor principal tiene tantas quantas mugeres quiere; pero todos los otros sendas, é algunos de los ricos dos é tres, si les puede dar de comer. É estas mugeres no las toman de lengua é gente extraña, é los señores las procuran de las aver que sean hijas de otros señores, ó á lo menos de linage de hombres prinçipales ó sacos ó calras, é no plebeos, salvo si no es alguna tan bien dispuesta que, como señor, siendo su vassillla, la quicra. El primero hijo que han varon, aquel subcerle en el estado; é faltándole hijos, heredan las hijas mayores, é aquéllas casan sus parleres con los principales vassallos suyos. Pero si del lrijo mayor quelaron hijas é no hijos, no herełlan aquelas, sino los hijos varones de la segunda hija, porque arquelli ya se sa- be ques forcosamente de su generarion: assi quel hijo de mi hermana indulitadimente es mi sobrino é nieto de mi padre; pero el hrijo ó hija de mi hermano puédese poner en dubda.

Yá tengo dicho en el libro $V$, capítulo III, que esto assimesmo se usó en esta Isla Española; pero to mas comun en la subçession es quedar por señor el que mas puede de los que pretenden la herençia, al modo de Turquia, y al modo que la passado muchas veces entre chripstianos, donde han avido mas favor las armas que la justiçia, por culpa del tiempo é de las malas consçiençias de los hombres.

Algunas reçes dexan las mugeres que tienen, é toman otras, é aun las truecan umas por otras ó las dan en presçio de otras cosas: é siempre le paresçe que gana en el trueco al que la toma mas vieja, assi porque tiene mas assentado el juiçio é le sirve mejor, como porque de las tales tienen menos çelos. Esto haçen sin que mucha ocasion preçeda, sino la voluntad del uno ó de entrambos, en espeçial quando cllas no paren; porque cada uno acusa el defetto de la greneraçion ser del otro, é desta causa, si descle á dos años ó antes no se haçe preñada, presto se acuerdan en el divorcio. I esta separaçion se ha de haçer estando la muger con el mestruo ó camisa, porque no hava sospecha que yla preñada del que la repudia, ó él la dexa.

Comunmente en la lengua de Cueva son huenas mugeres de sus personas, aunque no faltan otras que de grado se conceden á quien las quiere, é son muy amigas de los ehripstianos las que con ellos han a vidlo alguna conversaçion; porque dicen que son anigas de lombres valientes, é cllas son máts inclinadas á hombres de esfurcro que á los cobardes, é conosren la ventaja que lagen á los indios. é quieren mas a los golsernadores é capitanes que á los otios inferiores, é se tiencen por 
mats hontadas, quamdo alguno de los lales las quiere lieu. É si conosoren á algmm chripstiano earnalmodele, suárdanlo leallad,

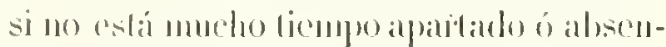
te, porfue dlass no lienen lin á sep riudas ni arials religgiosas.

Tambien hay en estan mageres de Cueval alemonas, que publicantente se dan á quien las quiere, á á las tales llaman yrachas, porque por degir numere diçn yra: é la ques de muchos ó amancebada dicenla vracha (como rocablo plumalitie que se exliende á muchos). Hay oflas litn amigas de ba libine, que si se hacen preñadas, toman ricrlal hicrvis, con que luego mucven é lançan la preñez; porogue diçen ellas que las vicjas han de parir, que ellas no quicen estar ocupadas para dexar sus placeres, ni cmpreñarse para que en pariendo, se les afloxen las ledas, de las quales se prescian en extremo, é las lienen buenas. Pero quando paren, se van al rio muchasdellasé se lavan la sangre é purgaçion é lucgo les çessa; é pocos dias dexim de hager exerçiçio en todo, por causa de aver parido: antes se cicran de manera, que segund lie oydo á los que á cllas se dan, son lan estrechas mugeres en esse caso, que con pena de los varones consuman sus apetitos; é las que no han parido, aunque hayan conosçido varon, están que parrescen quassi virgines. Dicho he cómo tracn sus partes menos honestas cubiertas, pero lambicu en algunas provincias ninguna cosa se cubren. Á la muger, como dixe, Haman yra, é al hombre chuy: pero en la provincia de Abrayme, ques desta gobernacion, le llaman ome al hombre.

IIay assimesmo en esta provinesia de Cueva sodomilas ahominables, é licnen muchaclios con quicn usim aduel nefando delicto, é tráenlos con naguas ó en hábito de mugeres: é sírvense de los lales en to- das las cosan y uxergigios pue haçen las mugeres, assi en hilar (omo on barrer la casia y en todo lo demás; y ostos no son desprectados ni maltraclados por cllo, a llámase el pargente camayou. Los tales ratmayoats 110 se aymulan á ofros hombros sim ligençia del que los tiene, é si lo lárenn, los mata: é por la mayor parte en este crror son los principales, no todos. pero algunos. Estos bellacos pacientes, assi como incuren cn esta culpa, se ponen sartales y puñotes de quientas cotras cosas que por arreo usan las mugeres, é no se ocmpan en cl uso de las ammas, ni hagen cosa que los hombes exergiten, sino como es dicho en las cosas feminiles de las mugeres. Dellas son muy abonescidos los camayoas; pero cono son las mugeres muy subjectas á sus maridos, 110 osan hablar sino pocas reces, ó con los chripstianos; porque saben que les desplace tan condenado é abominable vicio.

Bien he visto que algunas cosils de las que he dicho y estos indios usan, las escribe de los tártaros el Sanclo Antonio, arçobispo de Florençia, tan al proprrio, que paresce que los indios á los tártaros to enscinaron, ó que de Taplaria vinicron á la Ticrra-Fimme los tequinas ó macstros de sus viçios; porgue diçe este auctor que son ydólatras é sodonitas, é que tienen quantas mugeres pueden sostener, y en todos los grados de consanguinidad que sean, no guardan cosa alguma: é si se mucre la muger, no dexin de tomar su propria lija ó hermana en su lugar. Terdad es que tambien aige:

"Persone tres tantiom ab eorum excludunt matrimonio; scilicel mater, flia, soror; ct omnes alias personas, sibi vel uxoribus, quas habent vel habuerunt alitèr attinentes, accipiunt uxores '." No repudian la muger que tienen, si conçilse ó pare; mas si es estéril, déxanla si quieren. Son muy 
crucles, é no lienen reverença á los vicjos, ni lıan misericordia de los niños: hnélganse de verter sangre humana mucho, é de comer la carne de los hombres se deleylan, é de beher la sangre de los que matan. Son mas dolosos é llenos de fraude que de forlaleça, é ninguna verdad guardan: comen la carne humana assada ó cruda, como leones '. Diçe mas este auctor: que quando alguno muere, entierran con el una yegua con un potrico é un caballo con su silla é freno, é una lienda, porque en el otro mundo tenga todo aquello que con él entierran. é para que allá en la otra vida se pueda todo aquello muiltiplicar. É si es señor ó persona magnífica el lárlaro que mucre, con hábito preçiosíssimo le sepul!an, pero en remoto é ascóndito loco, porque no le despojen: é assi entierran con el tal prinçipal un caballo muy adornadó, é comen orro caballo por sit ánima. é lácen plauto solure el lal muerto treyuta dias, é quales más é quales menos, ó assimesmo tmo de sus esclavos vivo ponen en el sepulcro del tal prinçipal tártaro, é aquel él le eseoge antes que muera, é le señala para ello. Algruno destos tártaros, avicndo en fastidio á sus padres por su vejez, dánles de comer colas gruessas de carnero é cosas con que fácilmente se puedan ahogar; é muerto, le queman el cuerpo é guardan los polvos por cosa presçiosa, é cada dia despues, quando comen, chan en sus manjares de aquellos polvos ${ }^{2}$.

Todo lo susso dicho es deste sancto dotor en la tergia parte historial suya. Assi que, quiero deçir que quien leyere esta mi General historia de Indias, muchas cosas hallará conforme á las costumbres de los lártaros.

\section{CAPITULO XXVIII.}

De olras muchas particularidades de los indios de la gobernaçion de Castilla del oro en la provinçia de la lengua de Cueva è olras partes.

E son sin barbas ó lampiũos, puesto que algunos indios he visto, pero poeos, que las tienen, assi en las caras como en las otras parles que los nuestros hombres en nuestra España ó Europa. É queriendo yo mas particularmente entender arpuesto, averiguíé en esta provingia de Cueva (de quien aqui se tracta), que tambicn ternían barbas como los chripstianos; mas assi como les nazcen, se las pelan, é de labituarse á aquello é á untarse con algmas licrvas é otras cosas quellos saben, uingunas les nascen, ó si nasçen, no les turan; pero en sus vergiengas y en los solnacos, muchos inclios en muchas partes desta lierra tienen tantos pelos, como los chripstianos ó qualquiera otra nasçion, exçepto las mu- geres, que lienen mas diligençia é aviso para que en lales lugares no se les crie, ni lıàya polvo ni lana. Verdad es que çerca desta provincia, en la del Cenú, cllos con barbas, y cllas y cllos con todas las otras partes secretas que allí tracn públicas, no tienen diferençia ni menos que nosotros; y en este caso, quando en olras gentes destas Indias se hable, se dirá lo demás, ques nuy diferente de lo que está dicho.

Tienen por costumbre, assi los indios como las indias, de se lañar tres ó quatro veges al dia, por estar limpios é porque diçen que descansan en lavarse, é por de mañana que las indias vayan al rio ó fuente por agua, prinero que de allá vengan, se lavan é aum nadan un poco, en lo qual 
son muy diestros: y cate lavarse tornan á liaçer á medio dia é á la tarde, é pror lo menos una rez al dia ellos, é las indiats nurdo mas. Y es verdad fue estando un dia ó dos sin se lavar. como acaesce, ó jor andall camino ú of ras cansas, que maturalmonte liuelen á monte, ó un mal olor como el do los negrios de Guinea, que en algumos es insoportable.

Donde quiera que lay mar é rio hay pescados é pescadores; y estos indios de Cuevi son muy dados á este exerçicio de las pescurerias, de todas aquellas maneras que se dixo en el capítulo I del libro XIII; porque á la rerdad esta gente tiene en esta provinçia por prinçipal mantenimiento suyo el pescado, assi porque son muy inclinados á ello, como porque con mas façilidad lo pueden arer en abundançia é á menos trabaxo que lassalvaginas de puercos é venados, que tambien matan é comen. É assi en la pespuería como en la montería, se aprovechan mucho de las redes, que hacen de henequen é cabuya é assimesmo de algodon, que tienen muclio é bueno, de que natura los ha proverdo, é lay boscages é matas grandes como árboles dello. $\mathrm{Y}$ yo por árboles tengro alguna manera de algodon que hay en estas islas $\mathrm{y}$ en la Tierra-Firme, pues turan muchos años é son altos, puesto que la madera es feble ó floxa é vana assaz: é lo que los indios quicren haçer mas blanco é mejor, cúranlo é plántanlo en sus assientos y heredamientoséçerca de sus casas. Tambien sin redes matan é montean los animales que he dicho. é otros á lanģadas y en çepos que les arman, é á veçes en oxeo con rantilad de gente, é los atajan é redugen a lugares estrechos. Despues que los han muerto, como no tienen cuchillos para los desollar, quartéanlos, háçcnlos partes con piedras de pedernales é con hachuelas de piedra que tienen enhastadas; $\mathrm{e}$ assan la carne solne unos palos, que ponen á manera de trévedes 6 parrillas en hueco (yucllos llaman barbacoas) é la lumbre debaxo; porque, como la tierra está en clima que naturalmente es calurosa, presto se daña el pescalo ó la carne, fue se assa el inesmo dia que muere.

Allende de la carne é pescalos, tienen muclus é diversas fruclas: su pan, como tengo dicho, es mahiz é yuea. Todos por la mayor parte beben agua, pero á ninguno desplace el vino: antes son muy amigos dél, é aqueste laçen del maliz, segund la cantilat que quieren haçer de chicha, que assi llaman á su vino, é para haçerlo tienen esta forma. Ponen el mahiz en remojo, é assi eslá hasta que alli en el agua comiença á brotar por los peçones, é se hincha, é salen unos cogollicos por aquella parte quel grano esturo pegado en la magorca que se crió; ć desque está assi saçonado, cuéçenlo en buen agua, é despues que ba dado çiertos hervores é menguado la cantidad que ya ellos saben ques menester, apartan del fuego la olla ó tinajuela, en que lo cueçen, é repóssase é assiéntase aba so el grano. É aquel dia no está para beber; pero el segundo dia eslá mas assentado, é comiencan á beber dello, aunque está algo espesso: é al tercero dia está bueno é claro, porque estát de todo punto assentado. y el quarto dia muy mejor, é la color dello es como la del vino coçido blanco de España, y es gentil brevage. El quinto dia se comiença á acedar, y el sesto más, y el séptimo es vinagre é no para beberse: pero no lo desan Ilegar á esse término, é desta causa siempre haçen la canlidad que les paresçe, porque no se pierda ni tañe: é assi antes rque aquello no esté para beber, lienen otro. que se va haçiendo de la maneri ques dicho. I ini parescer es de mejor sabor é mas sulstancia que la sidra ó vino de mancanas que se haçe é behen en Vizcaya, ó que la serreça ó biara que behen los inğleses é en Flandes (que to- 
do lo uno é lo otro he probado é belsido). Este vino es sano é temiplado, é tiénenle los indios por presçiado é gentil mantenimiento, é tiénclos grordos. Tambien se lıąe muy buen vinagre del mahiz en esta manera. Tuestan los granos del mahiz al fuego, é despues muélenlos é háçenlos harina, la qual mezclan con aggua, é dánle egicrtos hervores, é apartan la olla como está, é pássanla donde esté repossada hasta otro dia, que la tornan á cocer assi como está: é despues del segundo coçimiento cuélanlo, é lo que lıa salido limpio, hecho åna ó vinagre, pónenlo al sol dos ó tres dias. É al tiempo que lo comienȩan á poner al sol, échanle un poco de agua limpia, para que se liaga mas fuerte; y en fée de aquellos tres dias que ha estado al sol, queda hecho buen vinagre é lura muclıos dias, que no se daña é corrompe ni afloxa de su ser que turo, quando mejor fué.

Dixe en el capítulo XXVl de susso que por la mayor parte los indios desta provinçia de Cueva fundan sus empresas sobre una bebdera ó areyto. Y uné cosa sea este areyto largamente se diso en el libro $\mathrm{V}$, capítulo 1 ; é de aquellas maneras que alli dise é otras muchas que dexé de deçir, por evilar prolixidad, se usan en esta provinçia de Cucva. I porque, cómo quedan horrachos, los menos se acuordan otro dia de lo que allí se tractó cantindo, siempre quedan algunos, como deputados é vicjos, que no andan en el bayle ó areyto: con los quales luego otro dia siguiente se comunica el cantar de la noclec ó dia de antes, é lo que allí se ordenó con los capitanes; é lo ponen por obra, como si quedassen obligadlos por un firme é bastante contracto ó juramento é pleytesia inviolable. I tambien liay algumos de tan buenas cabeças, que por mucho que beban, no se descuerdan ni caen embriagos. Estos areytos, como en ofra parte tengo dicho, son sus letras 6 memoriales. TOMIO III.
Una cosa de las que mas se lian espantado los indios de ytantas lian visto entre los cluripstianos son las letras, é que por ellas nos eutentamos con los ausentes. F́ assi, quando algum chripstiano escribe á otro que está algunas leguas de allí, é algun indio es el mensigero, quedan espantados que en la carta digan acullá lo cjue se ha fecho acá, que aquel indio ha visto laçerse, ó lo que se entiende haçer; é llévanla con tanto respecto é temor é guarda que les paresce que tambien sabrá deçir la carta lo quel indio piensa ó lage, como él mosmo, é aun alģunos piensan que liene ánima la carla, é ya se la platicado entre cllos para lo experimentar. É espeçialmente un caçique en aquella tierra de Cueva mandóa ú un indio suyo que á una carta de su amo, que avia de llevar á çierla parte á otros chripsitianos, le preguntasse en el camino á la carta cl que la llevalba algunas cosas que le mandó, é assi lo hiço: é clada la carta, volvió con otra en respuesta de aquel á quien yba, é despues aparte el caçique dixo á su indio si avia fecloo lo que le mandó, é dixo que sí pero que la carta no le avia querido responder á nada, ć que creia que maliçiosamente la carta no queria hablar sino con los chripsianos, é que clla a via dicho á su amo lo que le avia el indio preguntado; por lo qual el cacique, te temor desto, huyó é se alçó. Desde á pocos dias fué presso, é preguntándole la causa por que se avia huydo, pues que no se le avia feclo sinracon ni mal tractamicnto algmo, diso quél sabia que la carta le avia dicho lo que su indio le avia preguntado á la carta, é que aquel indio era bellaco, porque el caçique no se lo avia mandado, é quél lo avia muerto despues para lo castigar , é quél scria bueno: dando á cutender quél creia que la carta avia dicho por dónde á él le viniesse daño. El que esta expiriençia liço, fué el capitan Gonçalo de Badajoz, el qual le diso al cacjíue que la 18 


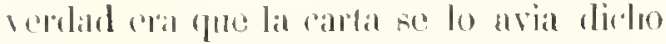

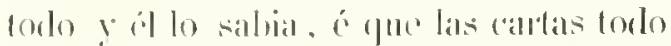

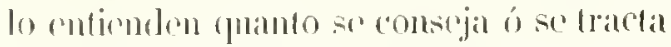

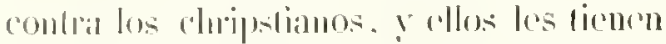

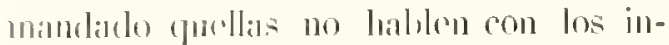
dios ni los desculban ningun secreto. É assise lo creyó esto racirume é de asta10 el rapitan quiso dexarle en esta sospeedial.

En las cosas de la gurma lie risto destal gente que se pressian mudio: é quando salen en campo, llevan caracoles crandes lochos loocinas, fue sucnan mucho, é tambien atambores é muy hermosos penachos, é algmmas amaduras de oro en los pechos, é patchas á lubsales é oflas piecas en las ealiegas é olras partes de la persona: é de nimguna mancia tanto como en la smerra se prescian de parescer genliles hombres é yr lo mas bien arlerescados fucllos pueden. Destos caracoles erandes se hacen unas conteçicas blancas de muchas mancras, ć otras coloradas, é otras negras, é otras moradas, é cañuticos de lo mesmo: é lategen liragaletes en fue con estas fiientas mezclan olras, é olivetas de oro que se ponen en las nutneeas y ençima de los tolbillos é debaxo de las rodillas por gentilega: en especial las mugeres, que se prescrian de sí é som p'mejipales, tracn todas estas cosas en las partes que ho dicho é a las gargantas, é lliman á estos sarlales cachira é á las cosas desta manera. Traen assimesmo çarȩillos de oro en las orejas, é horiddanse las nariges hecho un agugero cntre las vontanas, é cuelgan de alli solne el labio alto otro carrillo, ó se ponen alli un palillo de oro tan gruesso como ma pénola de cscribir. Algmos indios se lrespuilan, presto que commnmente ellos y cllas tienen buen cabello muy llano é negro é se proscian dello: é las indias lo biren fuengo hasta la mitad ho las espaldas, e bien cortado ienalmente é por ensima de las çejas, y en lugar de tisseras tienen navi- jas de prolernales, que cortan como lifenas lisseris.

I)iclio tengo ane los indios tienen los

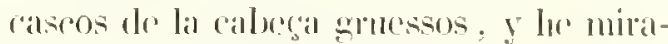
do on cllo murlats veces, y es assi verdaul, fues quatro tanto grmesso el raseo de un iudio quel de um chripstiano; é assi jor esto, quando peléan con ellos los chripstianos, tienen aviso en no darles cuchilladas en la cabega, porque so han visto rmoluar muchas epatas, porque demas de ser gruesso el casco, es muy regio en sí.

Assimesmo lie visto é notado destos indios de Cueva, que quando van á camino é se cansan, conoscen que les solma sangre: é para descansar, ellos mesmos se sajan las piernas é los braços con çicrtos pedernales delgados, que traen consigo para oste efelto; ć algumas reçes laçen cslas samgrias con colmillos de vílıorasmuy delgados, 6 con umas cañuclas.

Tambien he dicho de suspinturas de la bixa é de la xigua é de otras maneras. assi en guerra como cu paz ellos y cllas; pero en espeçial en la gucra se acostumhran á pintar mas á menudo los indios, é les paresce que no es homlne militar ol que no to hiçe. Algumos quieren deçir que no es solamente por la gala tal pinfura. sino porfue se hallan mas sanos, pinlíndose con tiles cosas; y por esso no dexam de usar de tales pinturas perpétuas, que no turan menos que sus vidas, ni se les acahan sino con purlrirse la carne pintada. I esta tal pintura ísanla de dos mareras: la ma es como marca en cierta forma. é con esta tal hierran al paco, que quiere degir esclaro: la otra es por gentilegar que siguifica gala é libutal, é cada uma destas se ponen en lugares deputirdos en la persona; porque en la cara de la boca abaxo, aunque alcançe á lis orejus. y en loz bracgos é pecho, es gala de lombres ó mugeres libres, é de la bocal arriba en la cara cos captirerio. É a luuella 
scũal. que traen tos libres vassallos é criados é ageptas personas al señor, son do una manera, tan justamente, sin tener uno mas que otro, que no paresce sino que por ustampa ustá hecho de molde: y en aquella pintura no menguan ni creseen, porque eomo he dieho es devisa ó como una librea conosçila del tiba ó queví, en cuyo señorio é olyediença viven los que assi estám piulados. Y ef mesmo saco ó tiba ó príncipe trae la mesma pintura; la qual pintura ó devisa escoge el señor, quando hereda la casi é estado, é la hace diferente de la que nsó su padre, prara que se conozea quáles sirvieron al uno ó quáles al otro. Otros hay que aumyue heredan la casa, no mudan la devisa que su padre tenia; é por esta cansa los que han de heredar no se pintan, porque tienen esperanga de mudar la devisa é tomar la que les paresçiere. É cstos tales son sicmpre odiosos á sus padres, poryue no se pintan de su devisa, é los que toman la marca ó devisa del padre, en sus dias, quiérelos mucho; é despres no la puede mudar ni menguar ni cresger en clla, porque lo ternían por malo é mentiroso á sil padre, é no le darian crédito en nada.

I estas gontes tampoco les falta p! biga ó coxisos que los molestan é produce la natura, para que entiendan quán pequeñas é viles cosas son haslantes para los ofender é inquietar é dar enojo: de lo qual el hombre de racon debe considerar si poco ser, para no descuydarse del officio prinçipal para que fué formado, yues conosçer á su llaģedor, dándole contínuas graçias de los henefiçios rescebilos, é andar por el camino derecho de su salvagion, pues tan abirrta é clara tienen la via los chripstianos torlos, que quicen abrir los ojos del entendimiento á conosecer si Iacedor. Émanc algumas cosas destas scan asquerosas ó no tan limpias para oyr como otras, no son nenos dignas de nolar para sentir las diferençias ć varias ope- raciones de lit natura por la dispensagion del Maestro dilla.

Ved la soberbia del leon, é la fortalera del elephante, é la crucklad del tiogre, é la pongoña de la víbora é del áspide, y cómo qualıuuier mosea ó mínimo mosquito los enoja é molesta. I assi entre los otros lähaxos que á los hombres en Tierra-Fin'me molestan é inquietan en muchas partes, por donde passan por los campros, hay mor inc vitable para dexarde incurrir enćl, y ess que, á causa de aver muchas agnas, 6 andau en piernas ó con garaluclles arremangados, é péganscles de las hiervas tantas garrapatas, que les culren las jicrnas, y lan chiquitas fue la sal molida es poco mas menuda: é despues que están llenos desta mala compañia é llegan donle han de parar á descansar aquella noche, en ninguna manera se las pueden quitar ni despegar de las carnes, sino untáirlose ron asegte: é despues que mu rato estín unlarlas las piernas ó prartes doinde las tienen, se mueren y engruesan algo, é ráienlas con un cnchillo, é assi las fuitan los chripstianos; pero los inclios, yue no ticnen aceyte, chamáscanlas con pajas ardiendo, é sufren mucho trabaso prara se las quitar. Y desto queda, en qualquier mancra que las quiten, tanto escoçimiento donde han estado que no se olvida ni dexil de dar pena esse dia é alg̣mos más; y en la jornata que las ha traydo el hombre á cuestas, no pudo ser sin grande enojo, sin lo poder recusil". Y cotas garrapatas no se laa de entender que las topan en todas partes; pero acacsice latias veres lo ques llicho.

Son los indios griandes mitestros te hitcer sal llel agaa de la mar, é tan diestros cae no pienso yo que les hacen ventaja los que en tal exergigio entienden (en ol Dinque de lelanda, serea le la villa de Mediolburque); poryue la de los indios es tan blanca quanto puede ser la nicve, y es mucho mas fucrte 6 no se ileshare tan 
presto, como la que le liclo. Yo he visto muy bien la ma é la otra, é la lie visto liarer á los unos é álos otros, y lie comido do ambas.

Quando los indios no lienen guerra, todo su exergicio co lractar ć trocall quanto tienen mos con otros; a assi fle unas partes á otras los que viven en las costas de la mar ó por los rios, van en canoas á vender do lo que lienen complimiento é abundaucia, é á eomprar de lo fue les falta. É assimesmo tractan por la tierra, é lleran sus caroas á cuestas de sus esclíros: unos llevan sal, otros malhiz, otros mantas, olros liamacas, ofros algodon hilado a pror hilar, olros pescados salados; otros llevan oro (al qual en la lengua de Cueva llaman yrabra). En fin, arpuello que les falla á los indios es lo que mas estiman, é aun algunos venden los proprios hijos. É todas cstas cosas é otras se dan mas a trueco de otras, porque no tienen moneda ni çierto presçio, é assi acaescen en esta mancra le cambiar muchos engaños, é que so dim cosas que valen poco, por las que valon mucho más.

En la provinçia é puerto del Cenú (que un timpo fué desta gobernaçion de Castilla del Oro, é agora es de la de Cartagruar), el año de mill é quinientos y quince, fucron allí cicrtos capilanes é gente por mandado del golsernador Pedrarias Dáivila. é lasllaron muchos costos (del lamaño de arpuellos que se llevan de la monlaña é de Vizcaya á Castilla con besugos): los fuales estal ian llenos de gigarras é grillos é langoslas de las que saltan : é deçian los indios que fueron allí pressos, que 10nian aquellos gestos para llevarlos á otras tierras é partes dentro de la tierra é léxos de la mar, donde no tienen pescado é se estima muctio arfuel manjar, para lo comer, é les dan por ollo oro é olras cosas, de que essotros tienen penuria é nescessidad, ron que vuelven cargagelos á sus casas.

Esta provincia de Cueva, on Indas las partes que se lablit su lengua, es tierra templada, y en sus liempos ordenarlos llueve, porque hay invierno é verano; pero al rontrario que en España, porque en Castilla lo mas reçio del invierno es dirientbre y enero, assi en yelos como en pluvias é frios, y el tiempo de mas calor es el de Sanct Jolıan é adelante en julio é agoslo; é por el opóssito en Cueva é Castilla del Oro ol relano é tiempo mas enjuto é sin aguas es por navidad é un mes antes é otro lespues, é aun parte de hebrero; y el liempo de las aguas es por Sanct Johan, é un mes antes é otro mes ó mes é medio despues. É aquello llaman los españoles invierno en aquella tierra, no porque estonges laya mas frio ni por diçiembre mas calor: antes el tiempo todo el año es quassi de una manera; pero porque en aquella saçon de las aguas no se vee el sol assi ordinariamente é la gente anda mas encogida, é sin que haya frio les paresçe tiempo frio, olssuro é menos aplaçible. Yerdad es que en las montañas ó sierras no dexa de aver frio, é sabe bicn la compañia del fuego; é los indios é aun los chripstianos ponen brassa debaxo de las hamacas de noche é se cubren con mantas de algodon para dormir.

Porque en otras cosas muchas desta gobernaçion se podria gastar tiempo en degir sus particularidades, no nos detengamos en ellas, pues que algmmas estín tocadas ó son commes á otras provinças (de quien se la escripto en los libros presedentes), assi como el sacar lumbre los indios con los palillos (segund se dixo en ol libro VI, capitulo V de la primera parte), porque lo nesmo se haçe en Tierra-Firme, en esta gollernacion, y en tollas las otras provincias que hasta agora se saben. Y assi con el ludir ó fletar de los tres palillos ençienden fuego; pero no traen aquel palo liso, para lorgerle sobre los dos que están en tierra, sino de lo mesno son todos tres, a so enriende mucho bien. ć de quales- 
quier maderas, con tanto que buscan las mas ligeras para ello, por penar menos en lo sical, é que essas no sean luecas.

De las nignuas y de la enfermedad de las bubas, de que se tractó en el libro $\mathrm{II}$, eapítulo XIV, digo que esta enformedad es muy comun en todas las partes de la Tierra-Firme, é en algunas hay el palo guayacan, con que se curan, é con hiervas é otras mancras de medeçinas, que aun no son bien entendidas por los chripstianos, y la passion de las niguas assi se cura, como se dixo en el lugar alegado. Pero hay otra, ques notable passion, eon los murçiélaggos, é desta yo tracté en el reportorio que se escribio en Toledo, lo qual aqui no repeliré porque lo dexo escripto en el libro XIV, capítulo VII.

Porque los capílulos prolixos cansan á los letores que son de arremetida, diré en el siguiente otras particularidades de otras cosas notables de aquesta gobernaçion de Castilla del Oro. Y dixe letores de arremetida, porque son como unos caballos que para ruar ó remeterlos en una calle ó corta carrera parescen bien é passan; pero para pelear é seguir el campo é la guerra no valen ni son sufiçientes. El que ha de leer no se ha de cansar ni clexar imperfeta la materia, ni puede entender cumplidanente el intento del auctor, ni la traça é órden del libro, ni ver cómo quadra eon el título que tiene, si lee un capítulo é falta adelante otros muchos; ni puede juzgar de alguna causa derēchamente el que alğ nos artículos ó partes dexasse de examinar en el volúmen del proçesso. Y los que leen de arremetida, como digo, no son los que saber dessean, ni á quien aproveelia el estudio, sino los que están cmbaraçados con otros cuydados, para olvidar aquel, ó para volver al mesmo, toman un libro en la mano, con que se duerman ó arrullen, buscando su sueño; é á los tales tambien se les passa la vida sonando. Y dessos querria yo que, quando topassen eon estas listorias, trocassen sus costumbres é me diessen un poco de atençion, si presumieren haçerse jueçes ó reprehensores dellas, para considerar questos tractados se fundan prinçipalmente en loor de Dios, que de tantas novedades é diversidad de eosas es el IIaçedor, é que se diçen para que le demos de todo graçias é mejor le conozcamos; y lo segundo, porque la elemençia de Céssar quiere que por su mandado se sepan é eomuniquen al mundo todo; y lo tercero, poreue es un grand contentamiento á los liombres, de qualquicr estado que sean, oyr cosas nuevas, seyendo, como son estas, verdaderas y escriptas y publicadas en tiempo de muchos millares de testigos.

\section{CAPITULO XXIX.}

De algunas parlicularidades de Castilla del Oro ésus provinẹias, allende de las que se han dicho en los capilulos preẹclentes.

W capílulo II tenoro dielıo qué cosa sou tabacos é alunnadis que los indios desta é otrus islas usin : pero en esta provinçia de Tierratrirme, en Castilla del Oro, usan cehar en el furgo ricrlas hiervas é gomas de cicros ámoles, que todo ello lierle $\mathrm{y}$ es incomportable sino á los indios, que lo han en costumbre, é diçen ellos ques sana cosa. Los quales sahumerios ellos usan, despues que laan çenado y están liartos, para se dormir por nedio de áquel huwo que desde el fuego resçibian é lo olian; con el qual, lucgo en poco espaçio, sobreviene un profundo é pessado sueño, é tanto mas grave é para mas tiempo quan- 
10 más el firego tura de consminir arfuellat maleria. É fonamelo tura un quarto de lora al lumo, diçen que les lura el streion (qualdro ó cinco horas despues á los indius, é assi á proporçion cllos cehan en el tuego lo pue les paresçe que les debe (le histar 6 (puieren estar sin despertar.

En lus areytos é cantares usin los mesmos atambores, fre dixe, de palo huecos en el V libro, é tambien otros que laçen encorados de cueros devenadosé de otros animales: é háçenlos sobre caxas de madera de un pedaço ó tronco cóncavo de un ámbol, tan gordo é fan šlande conno lo quieren. É haçen unos portátiles, que los puerle llevar un hombre como un tamborino ó atambor, ó otros tan grandes que son menester çinco ó seys hombres á llevar de una parte á ofra: é aquestos tales tiénenlos colgados cn la casa del tiba ó saco, é alli los tañen en una de dos maneras. Ó en los areytos é ficstas é borracheras que hagen, ó quando el caçigue quicre por su mano malar algun principal, tanen primero adgel grande atambor, pala que se junten todos los del puchlo á ver su justiçia, é sirven como de campana de conçejo; é primero que lo mate, dise alli sus culpas é delictos el señor, é la causa que tiene para le castigar, y el que padesçe las otorga, ques aquesto como uma satisfaçion ó cuenta que se dá al vulgo, como señor justo, paria que no le tengran por acelerado é malo. É despues de lreclo este complimiento, dale con una macana en la cabeça uno ú dos golpes; ć despues que ha caydo, mándale allí acabar de matar en su pressençia por mano de uno de aquellos que allí están pressentes, é háçelo echar en el campo á que lo coman aves, é no le dan sepoltura á este tal, aungue sea prinçipal. É aquesta tienen pror mayor pena que la mesma muerte;

Asi se lee en el MS. original; pero no habli el autor de las piinas sino en el cip. . II del libro porcpue paresce pue al tal muerto le privan de la dignidad é mayoria due teníd á los hombres plebeos, pues que en anduella provincia de Cueva, por la mayor parte, no se entierran sino los pringipales 6 señores; é toda la grente comun, furando se quiere morir alğno, él mesuro sé sale al campo é se mete en el arcabuco ó hosrue, á donde se acalıa de morir; y si él no se va, porque no pucde, lévanle su muger é liijos é otros indios á donde él diçe que se quiere yr á morir, é déxanle allí una calahaça con aģua é alggm hollo ó maçoreas de maliz, í ofra rosa de comer, é no curan mas dél ; é allí acaba, ó se lo come algun tigre ú otro animal, ó las aves.

Quanto á los mantenimientos de la provinça de Cueva, digo (pue lo prinçipal es mahiz é yuea; pero la yuca de allí no no ta, como la de aquestas islas: antes se come assada é coçida, como las luatatas é ajes, que tambien hay muchos. Timen mucho axí de muchas maneras: calabaças muchas de las mesmas de España, sin que las llevassen allá los (lnoipstianos, é son naturales de la Ticrra-Firme en muchas provincias: lihaos, assi como se dixo en la primera parte, los lay innumerables en Tiena-Firme, ó de las corteças dellos hacen muy lindas gestas y espuertas con sus tapradores, que los indios llaman habas, é otras cosas. Assimesmo lay muchas yracas que son diversas hiervas que comcu, é de que haçen potajes: piñas hay muchas, mayores é mejores que las destas islas nuestras, de que se tractó en el capuítulo XIII *, libro VII, y en alğunas partes se haçe vino dellas, y es bueno é de buen gusto. De los árholes que se han llevado de Espana, digo que hay naranjos é limas é limones é çielas. higueras, granados, palmas de dátiles alghinas,

que en esle lugar cita, como se puede ver en al to1110 J, pág. 280 
é algnnos cañafistolos, plátanos de los que aqui llaman plátanos é no lo son, sino musas: de los naturales de la tierra hay hobos, caymitos (como los desta isla quanto al árbol, pero la fructa es mayor ć redon(a). lig̣ueros muchos, xaģuas, gुuaçuma, guama, licacos yaruma, gुiabara, copey, gibucan, guanabano, anon, guayalo: todos estos son proprios árboles é fructas de la Tierra-Firme, ć mejores que los destas calidades en estas islas. Mamey: estos mameyes son mejores é mafores é de mas sucrtes en la Tierra-Firme, y en espegial en la provingia de Borica, ques desta gobernacion de Castilla del Oro, que son tamaños como Luenos melones de Castilla é de muy lunen gousto. Cargamoras, cardones, en que nasçen las pitahayas, cardones de los altos é derechos, mayores que lanças de armas, qua-. diados y espinosos, que los chripstianos llaman cirios, todas estas fructas é árboles lay en Cueva, é no hay para qué decirlos aqui, pues que en el filsro VIII de la primera parte se dixeron, é assimesmo de las parras é uvas. I demás de lo que se dixo en la primera impression, yo he despues añadido é acresçentado para la scgunda los que demás de aquellos hay en esta provincia de Castilla del Oro.

Quanto á los árboles salvages, digo que hay espinos, é de los nogales desta Isla Española, é de todas las maneras de palmas que se dixo en el libro IX, capítulo IV, é muchos árboles de los del xahon. É sin cssos, hay ficrtas rayces que tambien sirven de xabon, é alçan tanta espuma ó mas; pero la ropa que se usa lavar con estas rayces, por tiempo se torna amarilla, é se gasta é rompe antes que la que se lava con xabon. Hay gedros; pero yo no los tengo por sedros, aunque nuestros carpinteros assi los llaman, é son como los desta Isla Espanola. Ilay assimesmo de los robles que aqui hay, é de los terebinthos, que se tractó en el capítulo X del libro IX; pero en la rerdad yo no tengo por terebinthos los de aqui ni de TierraFirme. Ilay geybas, que son árboles grandíssimos; é lo que prometí en la primera impression, serea de la grandega deste árbol, en el libro IX, capítulo XI, ya lo tengo dicho, é allí lo verá el letor. llay muchos manganillos de aquellos, con que se liage la lierva rle los carilues flecheros. assi en el golpho de Urabá como en la costa del Darien é de Acla, y en muchas isletas de por allí é ya deste mal árbol (cn esta enmienda de la primera parte para la segunda impression, yo añadí lo que mas quedaba que déçir). Iay muchos árboles de los que llaman taray, alias cohaba, de los quales se tractó en el capítulo XIII, libro IX, é de los del helecho. En el brasil no hay mas que decir de lo dicho, porque es mury comun en muchas partes de la Tierra-Firme más que en las islas; pero lo cue se dixo de la lroma de las maderas desta Isla Española, el mesmo defetto tienen en la Tierra-Firme, é assimesmo en esto está dicho agora de nuevo, en el libro IX, lo que más se ha podiclo entender.

Otros árboles salvages, que hay en la Isla Española y en Tierra-Firme, demás de los que se pusieron en la primera imfression, son sin número y es menester alender el liempo para comprehender más su ser, é assi con el mesmo liempo yr aumentando la materia: lo cual yo haré en tanto que yo pueda hacerlo.

En lo que toca á los árboles éplantas medecinales, de que se tracta en el libro $\mathrm{X}$, allí se verá lo ques acrescentado despues de la primera impression, é allí lo busque quien lo quisiere ver. Pero en suma digo, que hay muchos árboles en la Tierra-Firme de aquellos que llaman de las soldaduras, é de aquellos que aqui llaman del bálsamo, de quien se tractó en el libro $\mathrm{X}$, capítulo $\mathrm{IV}$; ćassimesmo hay muchos de los que llevan las aredlamas ó matu- 
camillas para purgar. llay mucho algodon, liqueras do infrerno, cañas é carrigos, é de los juncos para báculos de los louldres viejos, é otras cosas que se lállarán acrescentadas despues de la primera im. pression.

Quanto á la lortaliça que en TierraFirme en esta provinçia de Cueva hay, la mayor parte es trayda la simiente de España, como leclugas, rílınos, açelgas, hiervabuena, peregil, berças, nalos, pepinos, melones, fésoles (y cstos fésoles tambien son naturales a TierraFirme, é los hay en mas cantidad é de mas maneras que en partes del mundo se pueden aver), ápio (le lo de España hay mucho, é llevada la simiente de Castilla. Hay culantro de la simiente que se llevó de Sevilla, é hay otro ques de la tierra, Ias hojas anchas; pero es el mesmo en el sabor. Hay mastuerço de muchas hojas é natural de la Tierra-Firme; canahorias é nabos se haçen, pero son de la simiente de Castilla. Pero de todas las hiervas que se haçe mençion en el capítulo II, libro XI, hay mas copia en Tierra-l"irme. Ilay de la hiceva Y mucha.

Si en la Tierra-Firme avic, ó hay aquellos animales que dixe en el libro XII que ovo en esta Isla Española, assi como hutia, quemi, molıuy é cori, yo no los lie visto en Tierra-Firme; pero en apuel mesmo libro Xil se han acresgentado los que en Castilla del Oro hay, de que hasta el pressente yo tengo noticia, porque el letor no ande á buscar en diversos libros de animales lo que oviere sabídose dellos. De los que de España se han llevado á Castilla del Oro, hay muchos caballos, é yeguas, é asnos, é vacas, é ovejas, é prereos, é perros: é los animales que lay naturales de la tierra, assimesmo se hallarín con el lilıro XII; é assimesmo de las sicrpes é lacartos é lagartijas. É assimesmo tigo que en el lilro XIII, que tracta de animales de agua, se hallarán cosas acresçentadlas y enmendadas sobre la primera impression, é con mas informacion de vista de ojos é çellificaçion bastante, añadiclo por mí. El libro XIV, que tracta de las aves se hallarám assimesmo acresçentadas en algunas cosas é otras enmendadas; y en la TierraFirme hay mas aves que las que se dixeron, quando se tractó desta Isla:é tambien hay de las que han llevado de España, assi como gallinas, palomas, pavos, únades é ánsares, y en lo que. se dixo en el IV capítulo de los papagayos, libro XIV, digo que hay tantos en la Tierra-Firme, é de tantas maneras é diferençias de plumages, é tan grandes é tan clicos, que sola esta manera de ares avria menester un grand volumen para se expressar ó deçir particularmente; é á mi paresçer digo que las diferencias de los papacayos deslas íslas é de la Tierra-Firme passan de ciento.

Quanto á lo que dixe en la primera parte de los animales insettos, en el libro XV se lıallará lo que toca á esta provinçia de Cueva; y assi en cada uno de los otros libros lo que se pudo saluer liasta el piessente tiempo, por no yr desparçiendo las materias, é que se halle junto el jaez de cada género de cosa, para mas descanso é satisfaçion del letor. 


\section{CAPITULO XXX.}

De las minas del oro éperlas é riqueças de la provinçia de Cueva é Castilla del Oro, e del viage de la Espeçieria desde Panamá á las islas de Malueo, ede la Puente Admirable, é otras cosas que pertenesçen á la consecuenuia hislorial.

$\mathbf{E}$ mera parte destas historias se dixo de los motales é minas de oro de la Isla Española ,é de la forma quel oro se coge; é por esso no hay nescessidad de repetir aqui la forma que se tiene en este exerçiçio ó grangeria. Pero puedo yo mejor que otro testificar en essa materia, conto reedor que fuy de las fundiciones del oro algunos años en esta gobernaçion de Castilla del Oro, que en muchas partes se sacaba oro, é lo ví sacar, é aun luve alğunas quadrillas de indios esclavos mios ocupados en esto, é sin duda alguna es rica tierra. Éá quatro leguas del Darien, é á tres é mas é menos desviados de la cibdad (infelice!) de Sancta Maria del Antigua del Darien, se cogia oro é muy bueno, de veynte y dos quilates é algo menos, é numca faltaLa á los que en esto se ocupaban. Pero pues venimos á hablar en las minas del Darien, como en parte que conviene, quiero desengañar á los que ovieren dado crédito al coronista Lucio Jlarineo en lo que dixo en aquella su olsra de las Cosas memorables de España, en el lilsro XIX, en el capítulo que quiso hablar en estas Indias, sin verlas, no se contentando de arer dicho tantas sosas en lo de España (mal informado), en especial quando quiso tractar de algrmas particulares gencalogias, en las quales se apartó de lo çicrto. Yino á las Indias entre sucños; y dixo entre sueños, porque aunque durmiendo halblára, no pudiera decir tan al revés de la verdad lo que dixo: é por esso es menester que el que escribe lo que no vé, mire bien de quién se informa. Él diço que los Reyes CallóTOIIO III. licos enviaron á Pedro Colom con treynta y çinco naos é con grand número de gentes á descubrir otras islas, mayores nucho que las de Cimaria; que tienen minas de oro, é se saca mucho en ellasé muy bueno; é que cómo navegó sessenta dias, llegó finalmente á ticrras nuuy apartadas de lispaña, en las quales todos los que de ací van, afirman que hay antipodas delsaxo de nuestro hemispherio. Y quanto á estos errores, diggo que no fué Pedro, sino Chrips. tóbal cl almirante Colom; é quanto á las caravelas fucron tres, é quanto al viage, yo le escribí en la primera parte desta General historia de Indias. Pero lo que yo mas le culpo es yue diçe que porque destas islas muchos lan escripto en latin é romançe, no hay nesçessidad quél esciriba; pero una cosa que no es dina de dexar por olvido la dirí, de la qual, segund él piensa, ofros que destas regiones eseribieron, no hiçieron mençion. E por çicrto tampoco él debiera hacerla de tan grand falsedal, y es que dige assi: "Assi es que en una region que vulgarmente se llama Tierra-Firme (de dinde cra obispo fray Johan de Quevedo, de la órden de Sanct Françisco) fuć hallada una moneda, con el nombre é ymágen de Céssar Lugusto, por los que andaban en las minas á sacar oro: la qual ovo don Jolan Ruplıo, arcobispo de Cosencia, y como cosa malavillosa, la cuvió á Roma al Summo lontifiçe: la qual cosa á los que en nuestros tiempos se jactaban de aver laallado las Indias é ser los primeros que á cllas avian naregado, quitó la gloria é fama, que avian alcançado. Por aquella unoneda consta que los roma- 
nos arian llegado grande liempo avia á los inelio: 4

Todo esto es de Luçio Marinco, é la mayor lalsedad del mundo; porejue on alquella mesnla lierra queste señala, no como cosmósrapho, sino como novelero, dice dónde al fray lohan de Quevedo fué obispo. Vod qué paralelo é sertifuagion de la altura é grados ó señas tan donosis de la lierra.

Pero essa que quiso decir es Sancta Maria del Darien, calseça de Castilla del Oro, de la qual aqui yo tracto; y yo fuy alli, quando esse obispo fuć, por veedor de las fumdiciones é de las minas del oro, é residí en la lierra hasla que el obispo se murió é despues alg̣nos años: é si essa medalla ó moneda paresçiera, yo era uno de afuellos á quien primero se avia de dar notiçia della, por mi offiço é porque ylua pena de la vida al que eneubriesse tal cosa. É si el arçolispo tal novedad é moneda envió al Papa, al arçobispo engañó quien se la dió y él al Papa; y este auctor á quantos tal desalino han oydo, si le crecn. Quanto mas quél cuenta este disparate calificado, en despreçio de los españoles é del almirante don Chripstóbal Colom, é quiere dar el premio á los romanos, ques olra menestra ó manera de lagoteria muy falsa. Ni los romanos nunca supieron destas partes, ni el Sículo tal ha visto escripto: los españoles sí, antes que oviesse romanos, porque como tengo dicho eslas islas son las Hespérides, assi llimadas de IIespero, que fué duodéçimo Rey de España, é subçedió á Ilércoles Egipçio en el año rejnte de Mameto, serscienlos é ginfiienla y ocho años despues del

1 Lueio Marineo Sieulo, lib. XIX, fól. 161.

* Oviedo se esfuerza en esle pasage por sostener una opinion, que no puede admitirse, segun dejamos ya nolado en su Vida y escritos (piar. XC del (. I); pero no por esto es menos reprensible el enpeño de Lneio Marineo Síeulo, que engeñado lorpemente por algun embaydor, no invo criterio bastunie para reehazar aquella patraña; yendo han diluvio, é quinientos diez y sers despues de fumblada España; é anles qune Troya se edificasse siento é septenta y un años, é antes que so lundasse la ciblad de lioma seysciculos y tres años, é mill é seysçicntos é cinguienta y ocho antes que JesuCliripsto encarnasse ". Todo esto está mas larganente dicho en el libro II, capítulo III de la primera parte desta Ilistoria General de Indias. I porque sepa Luçio Marinco Sículo quál es aquella tierra donde fié objispo friy Johan de Quevedo, digo ques la cibdad que lie dicho atrás que despobló Pedrarias Dávila, é se llama Sancla IIaria del Antigua del Darien; porque Darien se llama el rio que por allí passa, el qual entra en el golpho de Urabít, é estaba aquella cibdad en siete gradosé qua. renta minutos, que son dos terçios de unt grado desta parte de la línia equinoçial, á la parte de nuestro polo árlico. Tornemos a nuestra historia.

En esta provinçia de Cueva, en el rio que llaman del Pito, ovo bucnas minas, é anduvieron assaz quadrillas, é se sacó mucho oro en el tiempo que yo esluve en aquella tierra: y en otros muchos rios é arroyos é quebradas se lıa lıallado, demás de aquellos rios que está dicho que se ha cogido, é çcrca de Panamá, á tres é quatro leguas, en olros; pero porque assimesmo to hay é se halla en el rio de la Puente Admirable (que assi le disen porque el celafiçio della no es de lutmanos) é de aquella ya se dixo en la relaçion que escribí en Tolcdo, tornaré aqui á memorarla, porque no falıcé la hisloria general, de que tracto, una cosa tan senalarla.

lejos en su error que lasta llegó à equiroear cl nombre de Cristubal Colon, lo eual es por eierto nolable, pues lebió sin duda conocerle en la eórle de los. Ricyes Católieos. Verdad es que, despojándole de la inmarcesible gloria de deseubridor del Nuevo Nundo, no era ya importante el eonservar la exaetitud historiea de su nombre. 
Fué opinion del almirante primero don Chripstóbal Colom y de otros cosmógraphos modernos que hay estrecho de agua desde aquesta mar, que acá llamamos del Norte (én la costa de Tierra-Firme) á la del Sur austral, é aquel que hay ya le halló el capitan Hernando de Maggallanes, como se dixo en el libro I, capílulo II desta segunda parte, ques libro XX de la General historia de las Indias. Pero àcí en estas otras costas de la Tierra-Firme no se sabe que le haya, sino estrecho de lierra é no de agua; y este es el passo ó traviesa (que lay del Nombre de Dios á Panamí, ó desde Carcía á Acla, al golpho de. Sanct Wliguel, por donde el adeIantado Vasco Nuñez de Ballooa descubrió la niar del. Sur. E assimesmo se sabe que desde las sierras de Esquegua é Urraca (que están cntre la una é la otra mar) pucstos los hombres en las cumbres dellas, si miran á la parte septentrional, se vee el agua $e^{\prime}$ mar del Norte de la provin. çia é costa de Veragua, é mirando al opóssito, á la parte austral ó del Mediodia, se vee la mar é costa del Sur é provinçias que tocan en cllas de aquestos dos caçiques de Esquegua é Lrraca. É aquesto es lo mas estrecho que hasta el pressente se sabe desta costa de Tierra-Firme. Pero es tan doblada é íspera la ticrra por alli, que para lo andar los liombres, scria muy mas largo é trabaroso camino quel de Panamá al Nombre de Dios, puesto que este otro es asaz áspero é malo é de muchos montes é boscages é cumbres muy dolıladas, é muclıos valles é rios y espesissimas arboledas, é tan dificultoso dīe andar, que sin inucha fatiça no se puede hacer. E lo mejor deste camino es lo que se camina por dentro de los mesmos rios, é algunas reces con mucho peligro, por las súbitas cresçientes, porque lay parte en que sin salir del agua, han de yr una legua y media é aun dos cntre dos montañas altas; é si en aquel tiempo llueve. como es presto el crescimiento de los rios, á causa de las muchạs acogides é arroyos que se multiplican, en poeo espaçio de tiempo cresçen tanto, que se suclen aliogar algunos, en espcçial los que porfian á caminar é yr por el rio todavia, porque en cessando de llover, desde á poco desmenguan los rios; y el remedio desto es que assi como se viere quel agua cresçe ó llueve, se dexe de caminar, é se salgan del aggua, é se suban á lo enxuto en la una ó en la otra costa Jel rio, donde mejor dispusicion pudieren aver, Irasta quel ticmpo abonançe, para continuår cl viago.

En este camino se ponen de mar á mar diez y oclıo leguas, é yo las tengo por veynte cumplidas, porque aunque $\mathrm{cl} \mathrm{ca}$ mino no sea sino diez y oclıo, es mas malo de andar que si fuessen reynte y quatro en tierra llana, é más ticmpo se gasta en ello. Yo he eaminado dos veces á pié esta traviessa de mar á mar, en los prinçipios antes que lo pudiessen andar caballos, é despues lo he andado á caballo algunas reces; é liallo yo que desde el Nombre de Dios al caçique é assiento que llaman Joanaga, alias Capira, se ponen siete leguas é aun quassi ocho; desde Ca. pira al rio de Chagre se ponen otras ocho ó mús; assi que, son diez y seys leguas, é allí se acaba el mal camino; é desde alls á la Puente Admirable lay dos leguas, é deste la Puente otras dos á Panamá.

Verdad es queste fué el primero cani. no, que llaman el camino vicjo, é que al presente no curan de yr por aquella puente é la dexan á la mano dereclia, é so ataja camino, é pueden ser las diez y oclio ó dicz y nueve leguas que olros dicen; pero á mí me parescen veynte, é no chicas, las que puede aver en esta travicssa de mar á mar, poco mas ó menos. Eucs tantas leguas he andado peregrinando por el mundo, é tanto lıe visto dél, no es mucho que yo açierte en la tasaçion 
de tan corto camino, como el que lie diclio que poi alli liay de la una á la otra inar.

Si como se espera arlelante que con la roluntad de Dios lia de renir por allí la Espeçicria á Panamá, como es muy possible, digo ques muy grande el aparejo é dispusiçion que hay para la traer á estotra mar del Norte, non obstante las dificultades que de susso dixe deste camino, como lombre que muchas reçes lo he visto é andado; porque lay maravillosa dispusiçion é façilidad para andar é passar la dicha Espeçieria, como agora diré, despues que se ponga en Panamá. Porque deste allí liasta el rio de Claagre lıay quatro leguas de buen camino, é que muy a placer lo pueden andar carretas cargadas, porque aunque lay algunas subidas, son pequeñas, ć lierra desocupada de arboleda é llana, é todo lo más destas quatro leguas es raso. É llegadas al rio las carretas, allí se podria emluarar la especieria en barcas, porque el rio sale á usta mar del Norte doce leguas ahaxo ó mas al Oçidente del puerto del Nombre de Dios, é allí donde entra en la mar, le llaman rio de Lagartos, porque hay muchos dellos, como en otra parte lo tengo dicho.

El año de mill é quimientos é veynte $y$ siete de la natividad de Cliripsto, en el mes de abril, envió el gobernador l'edro de los Rios a catar este rio é rer qué navegaçion é curso tiene muy particularmente, é qué salida é dispusiçion de puerto en su embarcamiento á la mar, para lo que fucron elegidos un lidalgo, llamado Fernando de la Serna, y el piloto Pedro Corço. E la notiçia que truxeron desto, fué que hiçieron una canoa en la rosta del rio, en que entraron á los quatro de abril, y el sexto dia adelante, que se contaron diez de aquel mes, llegaron á la boea del rio, donde entra en esta mar, á la bancla del Norte, é lıallaron hondable é buena navegacion, pero con algunos raudales primero é segun. do dia; mas puédense passar al remo é á la sirga, é para lo que oviere de ser sir. gado, hay buenas márgenes é dispusiçion en la costa para lo passar. Estaha con mu. clias maderits é gruessas cunbaraçado el rio en alygunas partes; pero puédese limpiar.

Tentóse este descubrimiento en el tiem. po que menos aguas llevaban los rios en aquella provincia, y en año que la seca fué grande: de manera que en todo el otro tiempo del año suele llevar mucha mas agua. La boea del rio es de un tiro de piedra, que un hombre buen braçero la puede lançar de siete ú ocho onças de pesso, que al paresçer deste piloto debian de ser más de dosçientos passos el anchura. En lo más haxo del rio, ceerca de la boca, hay loraça é media, y esto á las orillas; pero á medio freo, ó por la canal de medio rio, hay tres braças de lıondo; é quanto mas va subiendo el rio arrilua contra su curso es tanto más hondable, has. ta cinco ó seys lıargas é más. Pueden su. bir caravelas de çient toneles de porte diez ó doçe leguas el rio arriba á la vela, y en la una é otra costa dél lay muy buena tierra é dispusiçion para polłar, é muclas é muy hermosas maderas, para hacer casas é navios, é muy fértil toda la co. marca para heredamientos de pan é otras grangerias. Y es tierra de muchas monterias de puercos é dantas é vacas de la tierra, que llaman los indios beori, é mu. chos çiervos é gamos é olros animales, é mucha caça de pavas é ánsares é de las otras aves que suele aver en la Tierra. Firme; é el rio es de muy buen pescado é bueno de manatíes é otras muchas maneras: é todo el fundamento del rio muy limpio é de buenos surgideros.

Assi que, en seys dias lo navegaron, é tornaron á andar lo mesmo el rio arriba en otros ocho, hasta el proprio ligar don. de avian entrado en él con aquella canoa, 
que fué í seys leguas de Panamá; é lo que fueron por agrua son veyute é çinco leguas, ques por todo treynta é una leguas, poeo mas 6 menos. De manera ques una pequeña jornada desde Panamá al rio de seys lequas é de buen eamino, é han de yr mas baxo de la Puente $\Lambda$ dmirable quassi dos leguas, por desechar el camino malo é algumos rios; pero desde donde se comencó á navegar el rio hasta la boca del, despues que esté limpio, que como es dicho se pnede bien limpiar, se tardará un dia é medio ó dos. en navegarle hasta la mal" é como lie dicho, hasta la mitad del camino pueden subir caravelas el rio arriba.

Los raudales que primero se dixo, no los lan de subir las caravelas el rio arriba, ni lıan de llegar tan allo liasta ellos; y el mas çereano al paradero de los navios, que por el rio entraren de la mar del Norte, está mas de ginco leguas de allí. Entran en este rio otros dos pequeños é de buena agua. Ia boca é puerto deste rio es muy conosgida cosa, porque hay dos farallones junto í la costa é un gentil ancon ó cusenarla, donde puede poner el navio el prohiz en ticra. É cada farallon es tamaño como un navio: el uno dellos lleno de arboleda, y el olro raso. É á la entrada está una punta de tierra como piedra blanca ó caliça, ó olras señales é mareas muy conoscidas. por donde no to puede crrar ni desconoseger el navio que fuere en demanda del rio, con tanto que lo haya visto una vez primero al piloto. Finera de la boca deste rio, á la cntrada de la mar, lay mas de Ires liragas de agua, y en rapaçio de una legua é á la parte del Nonibre de Dios é de Terasyar, de cada parte, hay muy buena dispusicion para poblar é para la agricollura é sementeras: é de fucra del rio, en la una parte y en la otra, hay gramde aparejo para hagerse dos pueblos, é hay senloz arrovos pequeños de muy singular agua. Desde la boca que tiene á la mar (que hasta el pressente se ha llamarlo rio de Lagartos) hay gineo leguas hasta Puertohelo, é deste allí una á la isla de Baslimentos, donde, amque es muy pequeĩa, hay muy buenos reparos de puertos; é desde allí al Nombre de Dios lay otras seys leguas. Es lodo muy buena tierra, como tengo dicho, de la una é de la otra banda del rio, é hay muy buena dispusiçion para se hager una torre ó fortalega en la boea del rio, donde entra en la mar, para guarda é defensa del puerto, é nucla piedra qual conviene para cllo: lo qual sin dubdi paresce ques todo assi aparejirlo por la Providençia Divina, para que con façilidad é menos tralıaxo de buscar los materiales se puedan edificar los puchlos 6 forlalegas, quando convenga. lis the notar que este rio Chagre nasce a dos leguas de la mar del Sur, é viene á meterse en la del Norte, puesto que corre mury reçio y es anchoé poderoso é hondirble, é tam apropriado para lo ques dieho, que no se puede deçir ni imaginar ni desscar cosa semcjante tan al propóssito para el efello que he dielıo.

Todo esto se ha traydo aqui á consecuençia del título deste capítulo, ques de las riquecas desta provinçia de Cueva; é no tengo este rio por la menor dellas, sino por una de las mayores. Pero porque de susso toqué en la Puente Admirable, digase qué cosa es, pues quel nombre lo pirle, y es assi.

Al tiempo que lombre llega á esla puente sin sospecha de tal edefigio, yendo de acá háçia Panamá, é sin la poder ver hasta tener los piés encima della, assi como comiença la puente, mirando soIre la mano derecha ó á la parte de loniente, se vee el hombre debaxo de sí un rio, que desde donde están los piés á pié ó á caballo hasta el agua, hay dos lanças de armas 6 mas espaçio en hondo 6 de altura desde el agua á ençima de la 
puente; y es pequeña iğua el rio que debaxo desta puente passa, no mas londa que hasta la rodilla en la mayor parte óa medio muslo: esto á lo ordinario. ó no aviendo aguas de plurias para que crezea. Y es muy boníssima agua, y es muy erraçiosa toda la ribera de aqueste rio ; é colre de la parte de Mediodia hasta la parte de Seplentrion, hasta que se va á meter y entra en el otro rio, ques dicho Chaere. Estando solre esta puente, mirandlo á la parte siniestra, está lleno de árboles, é no se ree el agna de la espesura de las ramas é hiervas; pero la puente está en lo que se passa ó atraviessan solıre clla tau ancha como quinçe passos, é tendrí de longitud septenta é çinco ú ochenta. Mirando á la parte por donde debaxo della passa el agua, está liecho un areo de piedra é peña viva, é tán natural ques cosa mucho de ver é para maravillar todos los hombres del mundo deste edeficio, fecho por la mano de arfucl Soberano Vlaestro del universo. De la mitad de la puente hasta lo mas alto del huceo del areo, hay mas de dos estados de maçiço en la peña; y es tanto mas hermosa puente que las otras todas que los hombres hasen, que ninguno la puede ver, sin se adnurar": y de aqui se le dió el nombre de Admirable, é assi es cosa para admirar. Paresçe ques toda la peña una piedra ó toda la puente assimesmo.

Tolmando al propóssito de la Espeçicria, digo, que quando á Nuestro Scñor le plega que por aquella via de Panamá se tlayga (ques muy posible) é desde allí despues en carros é por tierra hasta ario de Chagre, é despues por él se ponwa ch estotra mar del Norte, donde he dicho, é desde alli en España, mas de siete mill leguas de naregaçion se ganarán, é con mucho menos peliğro del que al pressente se navega pol los poltugueses que van á la Espericria. I de tres partes del tiempo se abreviarán las dos por este olro cannino, segund la raçon de la cosmographia; porque segund la notiçia de las cartas modernas é correctas, desde Pananá hasta Gilolo é Gatigará mill ¿ segrçientas leguas se ponen, pocas nas ó unenos, é Gilolo confina y es muy cerca de las islas é provinçia de Malueo. E pues esto es assi, yo pienso que no ne alargo, en lis tasaçion que digo.

Terdad es que no me laan faltado nobles amigos, que desele ltalia me lan avisado de alşnna poca de mormuraçion en cste caso, é de que personas dotas se pararon á pensar, despues que ovicron visto alpuel reportorio, que se imprimió en Toledo, donde liçe mençion deste grand atajo é abreviaçion, fue yo doy al camino é viage de la Espeçieria, pues que en todo lo quel mundo boja en su çircunferençia no se ponen sino seys mill leguas, reparlidas en tresçientos é sessental grados, dando á cada grado diez é seys lequas é dos tercios de legua. Otros ponen diez é sicte lexnas por grado: otros diez é siete y media; é si se ponen diez y sicte, avrá en la redondez seys mill é çiento y veynte leguas; é si fueren diez é siete y media, arria en el universo, en su mayor çireunferençia, seys mill étrescientas lecuas.

Yo no quiero reprobar ninguna opinion destas, sino remilir la deçision al muy enseñado é dolíssimo varon Ilicrónimo Fracastor, médico veronés, el (qual en nuestros ticmpos es famosíssimo astróloggo, é uno de los que mas alta é sotilnente han escripto del movimiento de los çiclos. Pero prarese ques cosa recia, aunque se tome la mayor parte. ser mayor el atajo que yo digro que toda la redondez; y no consintió el magnífico señor Johan Baptista Ramusio, secretario de la ilustrissima señoría de Teneçia, que se me diesse culpa de tal error, si le avia, sino cono noble é doto, atribuyendo la culpa al impressor, quiso responder por mí con mu- 
cha graçia é dotrina, fundando que yo avia dicho bien. Y junto con esta humanidad (é sin conoscerme) me escribió, dímdome notiçia de lo que en el estudio de Padıra, cntre varones de mucha çiençia é cavilleros é otras personas en este caso se avia altercado, y pidiendome que yo le escriljiesse assimesmo cómo sentia lo que he dicho, con muchas palabras de amiçiçia que desseaha aver con mi persona, en un su estilo no mediocre, sino de excelente orador. Y en este caso yo he satisfecho á aquel prudente varon éá otros scĩores, pues mis letras llegaron á sus manos; y porque será muy posible aver otros muchos dulxlosos en el mesmo caso, quicro satisfacer con la mesma raçon, que en esto tengo dada, y es esta.

Si desde España partiesse una nao de la isla de Cádiz, entrando por el estrecho de Gibraltar por el mar Mediterráneo, para yr á la cibdad de Veneçia, é andadas tresçientas leguas, pocas mas ó menos, hasta llegar á Liguria en Génova, é deste allí aquello que lay de traviessa derecha por ticrra lasta Venecia oriesse un grand rio navegable ó mar, por donde esta nao atravesasse por derecha via, sicto es que acabaria su camino lasta Veneçia con pocas mas leguas. Pero porque conviene desde Génova dar la vuelta á toda Italia (é por no aver tal passo ó atajo por la mar'), despucs ha de entrar por el faro de Ilesina é yr á buscar el mar Adriático, y en el fin dél ha de yr á Veneçia, se le dobla el viagge, é ha de navegar doblado camino. Assi, pues, desta manera, ó mi propóssilo trayendo el viage que los portugueses lacen al pressente para la Espeçicria, en la yda é ruelta hasta tornar á España, es mas luengo que toda la çircunferençia del universo; y el que yo digo, por la via de Pananıá, nucho más ó la mitad ó dos partes menos. É no digo yo en aquel sumario, donde este passo se me acoló, cosa que no sea notoria á los que tovieren notiçia é plática de la navegaçion deste ca. mino de acá ; pues que con mill é ochoçientas leguas, pocas mas ó menos de camino podıia ser conduçida la dicha especieria é navegada desde Maluco liasta esta cildad é puerto de Sancto Domingo desta Isla Española, si la pintura destas modernas cartas é la relaçion de los que navegan no nos engañan; é caso que se engañen, será en poca cantidad. Otra comparaçion en el mesmo propóssito (y esta es para los que por acá en estas Indias navegan). Digo, que si desde el Nombre de Dios partiesse una nao para yr á Panamá, é oviesse derecha traviessa de ın braço de mar para que la tierra que liay en medio fuesse agua, que aquellas diez é ocho ó veynte leguas que son del camino, no seria mucho que en un dia se anduviessen; pero aviéndose de yr por mar avia de subir desde el Nombre de Dios la via del Oriente á buscar el Cabo de Sanct Augustin, é de allí avia de yr en demanda de aquel grand rio de Paraná, alias de la Plata, é de allí al Cabo de las Vírgines, que está en el embocamiento del famoso é grande Estrecho de Magallanes, é passarle la via del Poniente hasta el Cabo Desseado. I hasta allí avria navegado dos mill é seysçicntas y quarenta leguas (segund lo tengo mas particularmente dicho en el I libro desta segundá parte, ques libro XX desta General historia destas Indias); pues entrando el Estrecho deste el Cabo Desscado hasta Panamá, mas de otras mill leğuas es nesgessario que luava en lo que está por apuntar é rlesculorir desde el dicho Estrecho en la mar Austral lasta Pananiá. Por manera que tres mill é seysçientas y quarenta leguas, por lo menos, se atajarian con aver el dicho passo por agua desde el Nombre de Dios á Panamá, para excusar lan grandíssimo rodeo como el que está dicho.

pero dexemos la comparaçion que lie 
dicho ques notoria, porque no satisfará issi á los antiguos cosmógraphos: jưinero la porné en el lavinte, que les es mas notorio y usido á cllos. Visto estí que quien particre de la punta, ó mojor diçiendo, de la ensenada del golpho de Patras, descle la Roxa ó Estira. para yr por mar á la isla que se llama Legina, que la de navegar muchos dias, é aun meses. porque ha de rodear la Acaya é la Horea y d Nésus, é otras muchas provinçias: la qual navregaçion, si se cortasse aquella poca tierra que hay en la ensenada de Eximilia, todo el camino seria viage de un dia ó menos desde la culata de Patras Lasta la dicha isla Legina.

Por manera quel assiento que tiene la tierra é las entradas é promontorios que laçe en la mar, esso es lo que acorta é resce la navegaçion. I no me maravillo que aquellos señores del estudío de Padua, ni del de París ó el de Boloña, ni aun de de Salamanca, que cstá mas á propóssito para hablar con los testigos que ran destas Inclias, se maravillen que les pareza noredad to que dixe en aquel reportorio; porque una cosa es medir el mundo por el esphera é su graduaçion, é otra cosa es navegarlo, porque los unos lo miden por el ayre ó el çiclo, é yo por el aģua é por el suelo é tierra, é la una é la otra cuenta es çierta é se puede saber è contar con mucha verdarl. Ya en este caso que se me avia acolado, é prinçipalmente por el literatissimo é reverendíssimo señor cardenal Bembo. su señoria reverendissima me liço saber por su carta que mi respuesta satisfiço á la dubda ques diclo: to qual yo ture en señalada mereed á la humanidad é henevolençia. con que su senorlia reverendíssima me escribió. Pássemos á las Perlas.

En aquel sumario que escrilí en Toledo dixe en el eapítulo LXXXIX é penúltimo que avia que colegir dos cosas muy de notar de arpueste imperio ogidental destas Inclias, deuás de las otras particularidadesexpresarlas, ó por deçir, que son de grandissima calidarl cada una dellas. La ma la hrevedarl del camino é aparejo que lay desde la mar del Sur para la contractaçion de la lispecicria, é de las inmumerables riqueças de los reynos é seinorios que con ella confinan de diversas lenguas é nasçones extraĩas : la otra considerar que immumerables thessoros han cntrado en España por carsa destas Indias, é qués lo que cada dia entra é lo que se espera que entrará, assi de oro é perlas y cincrildas, cono en otras cosas é mercancias que destas partes contínuamente se llevan, antes que de ninguna generasçion extraña sean vistasni tractadas, sino de los vassallos de Céssar españoles. Lo qual no solamente hace riquíssimos á los reynos de Castilla é de Leon, cuya es aquesta ladgienda, é cada dia lo serán mas; pero á toda España é á los circunstantes reynos extraños redunda tanto provecho é utilidad, que no se podria deçir sin muchos renglones é mas desocupaçion de la que tenia quando aquesto dixe; è dí por testiggo aquellos ducados ó doblones que la Cessárea Mlagestad por el mundo desparçia ó sembraba, é que salieron de España é munca á clla tornaron; porque como es la mejor moneda que por el mundo corre, assi como entra en poder de extrangeros. jamás dellos sale, é si á España torna, es en lábito disimulado, abaxados los quilites é mudadas las armas é cuños de Cúsar, é puestas otras insignias. La qual monera. si este peligro no tuviesse é no la deshiciessen en otros reynos (jor lo que en ella ganan) de ningun principe del mundo se lallaria tanta cantidad de oro en moneda con grandíssima parte é diferençia é ventaja de millones de oro, de lo qual todo son causa estas nuestras Inclias.

Esto toqué y escribí en el año de mill é quinientos é reynte ýseys; pero en es- 
tos veynte y dos años que laul passado despues hasta el pressente de mill é quinicntos é quarenta y ocho * se han llevado tantos millones de oro á España desta Tierra-Firme, é salido por el puerto del Tombre de Dios en cala provinçia de Cueva, á causa del l'erú é descubrimiento de los capitanes Françiseo Piçarro é Diego de Almagro, ques cosa incontable, é de tanta admiraçion que no luasta pluma ni ticmpo para expresar esto tan particularmente é al proprio como passa en efetlo. Pero adclante en la terçera parte destas historias se hablará en aquello nás particularmente, é aqui concluyamos este capítulo con las perlas, de las quales se habló en el libro NIX, en la primera parte, en el descubrimiento quel almiante primero, don Chripstólual Colon, hiço de la isla de las Perlas, llamada Cubagua, en esta mar é costa del Norte, çerea de la Tierra-Firme. É alli'se dixo mas particularmente lo que me paresció que bastaba, assi en la manera de sacar é pescar las perlas, como en ofras cosas ancxis á la materia; é por tanto no hay aqui qué se pueda repetir de lo dicho. Y assimesnı, en este libro XXIX, dixe cómo el adelantado Tasco Nuñez de Balboa descubrió es. la otra isla, que llamanos de Perlas en la mar del Sur, á quien los indios liaman Terarequi, que está á quinge legalis de l'anamá: en la qual digo que se han hallado muchas é luuenas perlas, é clesta isla fué arfuella gande perla que dise que oro Pedrarias Dávila, en el libro XiX, rapítulo Villl, de pesso de treynla é un quilates, que despues compró la Emperatriz, nuestra señora, de gloriosa memoria, y tambien la otra perla redonda, que yo tuve de vernte é seys quilates. F́ otras muclas é grandes perlas se avrian allí avido, sino que se sacan en mar mas profundo y entre peìas, é con mayor trabaxo mucho que en estotra isla del Norte ó Culagua. Y no dubde alquno que en esta isla que digo, y en las ofras próximas á clla, que son muchas é pequeñas islas, se halla cantidad de prerlis, é son mucho mayores que las desta ofra costa ó mar del Norle: é digo mas, que en la costa abaxo dicl P'onicnte é Panamá tambien las hay: pero como es grangeria mas dificultosa que el andar trás el oro é olras grangerias, no es exerecitadil por sus dificultades é lıoncluras del mar, ques mucha mas en la banda ó costa del Sur que desta otra parte del Norte. Y en su lugar se dirci, quando se lable de la golmernaçion de Nicaragua, dónde se hallan assimesmo perlas.

\section{CAPITULO XXXI.}

En el qual se traeta de las obsequias é cerimonias de los indios, quando se muere algun señor ques liba is quevió saco, es esrinçipal, en la provinçia de Cueva é en algunas partes de la gobernarion de Cactilla del Oro.

\section{P} das destos indios de la golsernaçion de Castilla del Oro, tráletese agora de sus muetes é fin, ques semejante é á la ma-

* Oviedo alteró sueesivamente estas fechas desde 1540 en adelante, viniéndose en conocimiento de que en el expresado año tenia ya puesta en limpio esta segunda parle de la llistoria General de Indias. En este pasage, que rulvia sin duda a TOMIO H. nera de su vivir bestial é de infieles. Y ante todas cosas es de notar, que si un indio ó india, por algun descontentamiento que tenga, ó sin causa, se determina

retocar en los últimos años de su vida, incurrió de nuevo en el descuido, nolado ya en ofro lugar, diciendo que eseribio en 1520 el Sumario de la hisloria natural, el cual se imprimió dicho aĩo $\mathrm{en}$ l.e ciurlad de Toledo. 
morir, é diçe morime quiero, es como verlo hedho, porque assi se muere determinadamente; é ahorresgen el comer é todo lo demás que les pueda dar vida, é se secan é desnayan; é ayudándoles á cllo el diablo. en breves dias se mueren, sin saber ni entender de su dolençia otra cosa, sino que fué su voluntad morirse.

En Panamá é Nala é Pacora, é otras provincias de la lengua de Cimeva, en la costa del mar del sur é por alli f̧erea, se acostumbra, en muriéndose el carique (ó señor principal), que fodos los fimiliares é domésticos criados é mugeres de su casa, que contiunamente le servian, se matan. Porque tienen por opinion, é assi se lo tiene dado á mintender ol diablo (alias tuyra) quel que se mata, quando el caçque muere, que va con él al riclo, é allá le sirve de darle de comer ó á beber, y está allá arriba para siempre exerçitando arquel mesmo offiçio que acá, viviendo, tenia en casa del tal caçique; é quel que aquesto no hace, que quando muere por otra causa ó de su mucrte natural, que tambien macre su ánima como su cuerpo; é que todos los otros indios é vassallos del señor muerto, quandlo se mueren, que tambien se mueren sus ámimas con el cucrpo; é assi se acaban ć convierten en ayre 6 en no ser cosa alguma (como el puerco ó el perro ó una ave ó el pescado ó otra qualquier cosa animada); é que aquestil prehentinencia tienen é gogan solamente los criados ó familiares que servian al señor ó queví ó tiba principal, en su casa ó en algum serviçio señalado. Lo qual persuade é induçe á tanta cohdiçia á los indios é indias de ser familiares é criados del señor, que les paresce, quando lo alcangan, que tienen adquirido todo el lien desta é de la ofra vida, quando el señor los rescibe é tiene por naborias (id est, criarlos de su casa). É de aquesta falsa opinion viene que tambien loz que entienden en el sembrar el pan é cogerlo, que por gocar de aquella prerogatival se matam é lacen enterrar consigo un poco de malizé una macana pequeña; é diegen los indios que aquello se lleva para que si en elçielo faltare simiente, no le falte aquella poca para principio de su exerciçio, hasta quel tuyra (que todas estas maldades les dá á entender) les provea de mas cantidad de sintiente.

Esto experimenté yo en las sierras de Gualuro, donde prendi al tiba ó caçigue de arpuella provingia . (que se avia revelado del serviçio de Sus Maggestades: é pregruntéle que çientas sepolturas que estaban lentro de un buhio cúas eran, é dixo que de unos indios que se avian muerto ellos mesmos, quando el cacique vicjo, padre deste Guaturo, murió. I porque muchas veges suelen enterrarse con mucha cantidad de oro labrado, hice abrir dos sepolturas, é liallóse dentro dellos el mahiz é macana, que de susso se dixo; é preguntada la causa, el caçique é otros de sus inclios dixeron que aquellos que allí avian seydo enterrados cran labradores, personas que sabian muy bien sembrar é coger el pan, y eran sus criados é de su padre; é porque no muriessen sus ánimas con los cuerpos, se avian muerto ellos, quando se murió su padre, el caşique viejo; é tenian aquel maliz é macanas para lo sembrar en el çielo. Á lo qual yo le repliqué que mirasse cómo el tuyra los engañaba, é todo lo rue les dala á entender era mentira, pues que aquellos muertos nunca arian llerado el mahiz ni la macana y eslaba allí podrido, é que ya no valia nada ni avian sembrado nada en el çiclo: á esto dixocl caçique, que si no lo avian llevado, seria por aver hallado mucho en el çielo, é assi no arria nesçessidad de aquello. $\dot{A}$ este error se le dixeron muchas cosas, las que aprovechan poco para sacarlos de sus errores, en especial quando ya son hombres de edad, segund el diablo los tiene ya enlaçados. En fin, ellos creen 
que muerto el carique, de los indios que se matan por su amor, al uno dá el ofiçio de pinçerna ó copero, como los poetas diçen de Júpiter é Ganimedes ', é otro á otro, é que en la otra vida larese los officios, rque aqui les dió su señor.

El auctor destos delictos, ques el fuyra, de la manera que les aparesce quando les habla por su tequina, de apuella mesma forma le pintan de colores é de muchas maneras, é tal le hacen de oro de relieve, ó entallado en madera, muy espantable é feo, é tan diverso como lo suelen acá pintar nuestros pintores á los piús de Sanct Mig̣uel Ardrángel ó del Apóstol Sanct Bartolomé, ó en otra parte, donde mas lemeroso le quicren figrurar. Assimesmo quando el fuyra los quicre espantar, promételes el huracan, que quiere decil tempestad ó tormenta de agua é viento, la qual hace tan grande que derrilua casas é arranca muchos é grandes úrboles, é les haçe mucho daño en sus heredades é fíuctos.

É assimesmo en esta gobernacion de Castilla del Oro, en algumas partes della, quando algun señor muere, toman su cucrpo é assiéntanle en una piedra ó leño; y en torno dél, muy cerea, sin que la lorasa ni la llama toque en la carne del defunto, tienen muy grạnd fuego é muy continuo, lanto que toda la grasa é hulmedad le sale por las uñas de los piés é do las manos é se ra en sudor é se enjuga, de manera quel cuero se junta con los luessos, é toda la pulpa ó carne se consume ó destila. Ra desque assi está enjuto, sin lo abrir, ni es menester, lo ponen en rierta parte que para aquello tienen en su casa depulada. junto al cuerpo de su padre del tal cacique, que de la mesma manera está puesto: é assi, viendo la cantidad é número de los muertos, se conosçe qué tantos señores ha avido en aquel lis- tado, é quál fué lijo del otro ó le sulygodió en el señorio, segund la órden subegesiva en que están puestos. Bucno es de creer quel que de los caciques murió en alguna loatalla de mar ó de tielra, é que quedó en parte que los suyos no pudieron tomar su cuerjoé llevarle á su lierra, paralo poner con los otros cacipues, que faltaron del número en fales assientos; é pàrá esto allí, dó avia de ser puesto, está vícuo, é largen pausa ó dexan tanto espacio, como el cuerjo avia de oeupar en aquella rengle. É para suplir la memoria é falta de letras (pues no las ticnen), luego haçen que sus hijos é la comunidad é vassallos que mandalad, aprendan é sejaru de coro la manera de la muerte de los que murieron. En fin, diegen que no pueden ser alli pueslos, é assi lo cantan en sus canlares, que los indios llaman areylos. Estos caçiques assi puestos se usa en las provinçias de Comogre é Climan, y en otras partes de la lengua de Cueva.

Tambien tiencen otra forma algunos; y es que quando se muere el caçique, despues que está enxuto por el fucro, segund es dicho, lo envuctren en çinco ó seys mantas ó mạs, é lo echan en una hamaca gue eslá colgada en el aỵe, é lo ponen en la cámara, donde les paresçe que esámejor ó donde él acostumbraba á dormir.

La manera de las muertes, que los eriados é servidores suyos se dan para matarse, es que juntos. y hecho su arey to, é cantaudo primero la vida é obras de arpuel su señor defunto, tienen assi puesta una grande toreba (que quiere dleçir olla) é una concha de ma ostia ó un calabarillo ó cuello de calabiça, de que se sirven do cuchara, é toman un trago de la ponçoña, o dos, que está en a(puclla olla ; y encontinenti caen muertos, segund es grande la potençia de aquel veneno ponçoñoso. É algunos llevan alli sus hijos pequeños é 
hargen primero behel aquello á los niños, ci desque los reen mucrtos, se matan á sí mesmos de la mesma matrera, sin que en ninguno haya lígrimas, sino muclo ronfontamionto dre tal fin. É assi se lleva el diablo con calla carcique quarenta ó rinquenla áminns, é mas é menos, de los criados é familianes que le servian.

Tambien en algunas partes se enticran de la forma que se dixo en el libro $\mathrm{Y}$, cafítulo 1!l, é sus mugeres con ellos, é ticnen esta formal. Muerto el pueríó señor principal, se juntan todos los señores sus anigos comareanos dentro de un dia, y el seguado que murió lo enticran; é anles que mucra, yuando veen que no puele vivir, se llegam los amigos para celebrä estas obsequias. Haçen un hoyo de loge ó quinge piés de luengo é otros tantos de ancho, quadrado, é un poyo á la redonda; y este hoyo es de loraça é média ó dos estados de hondo, é tienen allí apripjada madera é rama para lo cobrir. Sassientan el curifipte defunto en el poyo sobre una manta muy gentil, pintada, en lingre de tapete, é con sus joyas de oro puestas en su persona; y en ol espacio yaradrado de ennedio dleste hoyo ponen algunas calalogas con agua é maliz, é a dounas fructas é flores: é luego vienen las mugeres proprias del defunto gue tenaia, no todas, sino las que dellas lo quiereu laçù é segurrle, enterándose con ét viras, muy adereseadas de carcillos é axorcas de oro é de sus joyas, é siénlanse á los lados del muerto. E lura un dia é dos el cantar en torno de aquel hoyo á srand multitud de indios 6 indias, dicos e grandes, recontando las procegas y el esfuerco, la liberalidadé ouras virtudes del micrto, é loando nurho el amor de aquellas mugeres sujats, que con de se puicrea yr al çicto é morir allí dentro. $Y$ en cole tiempo fueste cautar tura, beben log que cantan, é baylan rontimmanente de rato cu rato, porine andan en forno dem llos otros hombres dándoles a beher: é lambien beden aquellas mugeres que eslám dentro del hoyo, é se cmbeodan, hasta quellas caed sin sentido rel poyo, $\dot{o}$ se quedan sentarlas, sin sentir, embriagadas. Estonçes, quando ellas están tales, itlariessan maderos por encima é fixina é tierra, y échanles mill cargas della acuestas, é assi acaban: é á los que cantaban no se les acala aquel dia el vino, é despiertan el siguiente, ó quando se les ha passado la bebdera. E assi se concluye la pompa funeral del diablo en essos sus mortuorios, é aqquel marsolco ó sepulero quedia como por in lugar sancto é acatarlo, é ponen en torno hermosis arboledas.

En tanto que lo ques dicho se haçe, el hijo que la de sulheder en el Estado está pressente hasta que fodo está hecho, é luego le dan la norabuena de la subçession ; é los viejos é mas ançianos que qne. dan cn su Estado, Itérante de los braços á una cámara, donde la de dormir, y échanle en una lamaea. É allí vienen á le dar la o!hidiençia todos sus súbditos, con cargas de pressentes de mahiz, é aves, é puercos, é renados, é pescado, é cosas de comer de las fructas é de todo lo que laxy en la licraa: é le laçen nuevos cantares de plaçer, é beben, como es dicho, otros dos ó tres dias. En apucllos cantares le digen qué cariques é señores, con sus parientes ć coila su genealogia, é quáles eran los anigos y cnemigos de su padre, é por qué causas, para lo retificar en la amistad ó enenistad, rne con su padre el caripue defunto tenian. É luego ruesto es fecho, envia sus mensajeros á los caciques é quevis é senores, hageiéndoles saber que su padre es umerto, é que como fuć su amigo, bl lo quicre ser assimesmo: é los otros lo hacen sus emhaxidas, ratificando la jaz é deblo é amor, é ofresciéndosele, como tales anigos. E la mesma diligencia hacen consus enemigos, calgunos so reconcilian é quadan por amigos: 
otros quedan por mas enemigos, é prenden ó matan tales mensageros, para que sea mas fija é perpélual la gnerra entrellos.

Son tamlas é tan diferençiadas las costumbres destit gentes, que no se pueden ann entender ni saberse, sin quel liempo dé lugar á collo é passen mas años. Ferdad es (fre en algumats partes desta gobemagion é otras partes, de lodo pento se han olvidado é perescido sus çerimonias por los peceados é vicios destos indios, para que haya en ellos el efelto de aquella sentençia de Job que diçe: "La morada de los malos no permaneceréc '. Sobre lo qual dice el glorioso dotor de la Iyglesia, Sanct Grogorio, en sus Morales, en li exposigion deste passo contra los malos: "Donde lunclgan con lis carne, allí entierran el ámima, lándole la muerte ${ }^{2}$ " Y assi estos malaventurados, apirtides de la verdidera morada, no solamente prata esta vida, pero para la clerna, siemprer serín muertos en tanto pue estén desviados del conosgimiento de bios verdadero.

To lengo hasta agora visto rrandissimo número destos indios en treyntil y cineo años que lia que tracto estas partes é veo esta generaçion, é ninguno perfotlo chrisptiano lie hallado culrellos de los que han avido plálica é conosçimiento con los chripstianos (seyendo de edad ; mas tengo creydo que de los niños que son dotrinados, se salvan murhos por la misericordia de Dios ć diliggençia de los calhólicos religrosos chripstianos, que en csto se ochpan en estat partes: de lo qual resulta grand lien para los méritos de nuestros prínçipes, por cuya voluntad inuchos mas se salvarian fó todos ellos, sin que ningino se perdiesse); pero no puede dexarse de complir en esto la providencia de Dios, que sabe ordenar lo que conviene.

Verdad es rue en esto tampoco quedan

1 Et tabernaculum impiorum non su'ssislet. (Job, cip. VIII, vers, 22.

2 Moral, lib. VIll. los chripstianos sin mucho cargo, en especial los perlados, si algun descuydo tavicren en poner la diligençia, que se requicre que latya on sus ministros y en él para reduçir estas ovejas al verdadero cubil. Y no deys, reverendos padres, coda li culpa á los soldados: que su castigo no les ha fillado á cosos en lo que mal han fecho, ni les faltatú á los que mal hiçieren; y por los fines de algunos podeys aver visto en estas historias cómo les ha yilo en la demanda deste oro, é quám particular cuenta lá lenido Dios con ellos. No crearys que la mitra ni el báculo pasto. ral se os dió prilla dormir á la sombra del mando, que Dios os permilió: acordaos que dice San Gregorio: "Qualquier perlado soberlio tantas veces cac en culpa do aposiasía quantas, deleylámdose en presidir solire los homlores, se alegra de la singularidad de su honra ${ }^{3}$." É mas adelante diese: "El Torlopoderoso Dios, por sola La calidad de los meresçimientos esamina la vida de los hombes; pero muchas veges dá por alli mayor pena por londe dió en ministerio de ofliçio estas cosas mayores, segund que la misma verdad dá testimonio diçiendo ${ }^{4}$ : Al que mucho es dado, mucho será demandado ${ }^{5}$. Por manera, seĩores perlados, que vineslaa carga no se descarga sino con trabaxo continuo é con la diligençia é obra, que para la salvaçion deslas gentes conviene.

Y este fué el intento de la Sanclidad del Papa é de la Cussárea Magestad, con que os cometicron tan sanclo cuydado ó las dignidades que os dieron, é descargadas estiul sus consciencias con las vucstras, y essa encomendays vosotros á vuestros vicarios, y cllos á los curas, y essos curan de la manera que remos el fructo. Assi que, va esto ensarlado de uno en otro á parar en un ydiota, que avria

3 Moral., lib. XXIT, sobre Job en el cap. 28.

4 lb., lib. XXV, cap. I, sobre el cap. 31 de Job.

5 Evang. de S. Lucis, cap. XII. 
menester quich al tal le ensentasso, Y sospecho que desta negligengia ha de subçeder á algrunos lo que á mo vieja diligente á sin prudencia intervino on mi ticra, que por poner mejor recalblo en unos pollos, que audiahan tras lá gallina pequeños, ató el nuno al óro, é otro al otro, é assi todos diez ó doce, y el postrero á la gallina, y la grallina á una silla, en que la vicja estaba assentada hilando; y el pollo que eslaba al calbo del hilo, como estaba mas destiado de la silla, é la cuerdi cra luenga arrebatóle el milano, é si no fué uno ó dos que eslaban mas ecrea de la srallina, por donde se quebró d lílo, todos los otios se llevó en su saria pendientes uno de otro.

Aplicando esto á nuestro caso, se ha de entender que la silla es de Sanct Pedro, y essa no puede crrar, porque su intencion es guardar sus pollos ú orejas; ni puede cl diablo, ques el milano, moverla de su lugar ni ofender á la gallina, ques cl liríncipe, cuyos son estos pollos ó vassallos; porque Sa Mageslad estí junto é conforme con la silla é no se aparla della: pero los otros que de alli abaso andan apartados, essos son los que tiencn el peligro ques dicho del milano, ques diablo é nunca duerme. Assique, auncue yo pague los cinco sucldos por dar conscjo donde no se me pide, y siendo yo tan falio prara esto, no es en verdad soberbia la mia, sino compasiljilidad de ver acá esios ministros, no lodos, sino algunos, no atidos en sarta como los pollos de la otra, porque los que están atarlos é midos tienen menos peligro, é aunque alguno se lleve el milano, los otros todos se colmrin i remedian: porque por aquella cuerda, que la vieja puso á sus pollos, el milino que los llevaba se assió en un olivo, ¿ comiendo el un pollo, la vicja é muchos muchachos que seguian por lo baxo al malfechor, Ilegaron donde estaba tan trabado é atado por los piés con el hilo. que lo tomaron é le mataron, sin se aver perdido mas de uno de los pollos.

bisa cuerda ares de ontendor ques la reglis, á que los rolieriosos andiun atados: ol írbol del olivo es la miscriendiat de Dios, donde somos todos socomidos é libralos del commu adverssario, é la vieja es la Iglesia, que siempre trabaxa en nos criar í dotrinar é librar dil demonio, ques nuestro milimo, é los mudradios ó niños, que con clla yhan en seguimiento de los pollos perdidos, son lás inorentes é puras conscriençias de los derotos religiosos é chripstianos, que la acompañan é aplacan la yra del Señor, para muestro socorro é amparo de su misericordia, para gue con la oliva llegue la buena nueva de la restauraçion é de ser passado el naufragio, como lo envió á significar é amunciar á Noé con un ramo de lal árbol, eslando en ol area metido, para que viessen quicl diluvio era passado, é que la paloma aria hallado ticra é paz en el Señor para sus criaturas.

Torno ál deçir, muy reverendos olispos é perlados, que examineys lien vuestros ministros, portque á veces os engañays en la elecion é os engañan. ¿Queréyslo ver? Mlirad las bolsas á algunos, é los negogios particulares, y el cautal con rue entratron en sus grangerias; é vereys quám aprartado anda el exerçicio del officio del saçerdoçio, é quím fuera de cuydado, de descuydaros, están é de quitaros de trabaxo, é cómo de passo en passo os llevan de la mano, é rosotros y cllos é otros en una cuerda ensartados al infierno, si no socorre Dios vucstras ámimas con otra oliva de miscricoldia, para que del mal sca lo menos, é lo pague solo aupuel que no guarda lo que debe é le teneys mandado. É para esto vuestro báculo cele sobre ellos é Indo el pucblo, que Dios os encomendó : é ved ruestra cuenta é la de todos á menudo.

No quiero señalar perlado ni saçerdo- 
te, aunque algunos me han robado á mí ć á olros, portue no parezea que hablo con passion en esto: pero yo he dicho verdal en todo, é assi, si no fuesse, ni meresçeria crérlito ni perdon. Las burlas de la pecunia é re los hienes agenos aun mas tolerables son (puesto ques mal que se hagan) que no las que se laçen á sí mesmos; portue si yo pierdo parte de la capa, quien me la quita pierde torla el ánima: y quanto mas honcsto é sancto es el lííbito, mas quedas é limpias lan de andar las personas y las manos, que han de Ilcgar al altar sin cnconarse ni buscar otra ocupaçion de seğlares, sino enseñando cstas gentes lúirbaras á salir de sus errores é rilos diabólicos, pues que para esto los envian acá , y no á heredar, ni encobrir ni transportar los bienes agenos, ni á enbosearse en grangeriasque impridan el sancto offiçio del saçerdocio. Junto con esto he paciençia con ver otros religiosos lan bendilos, lan sufiçicntes, tan lumuildes, é de lan perfelta vida y exemplo, ques para loar á Dios é alarle graçias, porque nos laaçe dignos de su compañia é comunicaçion.

Pásscmos á otras materias, ć desta de los religiosos é clérigos no se entienda lo ques dicho por los que están é residen en sus iglesias y monasterios, sino renítase la cuenta á los que tienen canónicamente el cargo dellas: que yo fiador que á los ta. les superiores les será acordarlo en su liempo lan por menudo y mas que lo sienten los lımanos; y ello passa conforme á la relitud de la divina justiçia.

\section{CAPITULO XXXI.}

The alıunas particularidades de los indios de Cueva, é tambien se hace mençion de algunas eosas en general de aquella provinçia, que se aũaden é ponen, acrescentando el género dellas en los libros de la prinera parte de aquestas historias.

Fin tori, en el lise VI, teactó de liversas toria, en el Tibro V, se tractó de diversas cosas, assi como de las moradas de los indios; $y$ en esta materia en cste libro XXIX se dixeron otras cosas diferenciadas.

En el juego del batcy y en los huracanes lrasta lo dicho $\mathrm{y}^{+}$escripto.

En lo de las canoas assi se usa lo mesmo en esla isla como en la Tierra-Firme, salvo que aunque tienen canoas pequeñas, lambien las usan grandes é nucho mayores questas islas; porque hay canoa que lleva cinquienta ó sessenta homlres é mas, é con sus árboles ć velas de algodon, é son muy diestros en ellas, en espeçial los caribes.

En lo que toca á la agricollura, todo lo que se dixo en el libro VII é otras cosas muchas mas de logumbres é fruclas so hallan en la provinçia de Cueva é gobernaçion de Castilla del Oro; y assi en csse mesmo libro, y en el VIII, $y$ en el IX, y en el X y XI y XII y XIII y XIV y en el XV, como en todos los demas de la primera parte destas liistorias, se ha puesto é acresçentado lo que rle lales materias hay é se sabe desla gobernaçion de Castilla del Oro, é se enmendaron algunas cosas rlespues de la primera impression: é por esso no hay para qué se repita en este libro, portjuc me paresce ques mejor que esté junto lo ques de un jacz ó gènero ó particular tílulo de carla libro.

Quétlame de deçir que en arpuesta lengua de Cueva hay muchos indios lıceliçerosce en especial un cierlo género de malos, que los cliripstianos en aquella tierra llaman chupadores, que á mi parescer deben ser lo mesmo que los que en España 
Haman bruxas y en lablia extrias. Ratos

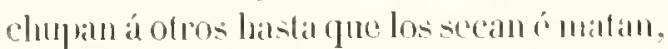
é sin ealent ura alguma de dia en dial poco á pocose enflatpuescoul lanto, que se les puce den contarlos huesos, que se les parrescen solanente cubiertos con el curro: y a vientre se les resulve do mimera tum omblig̣o traen pergado á los lomos y espinaço, é se tornam de arpuclla forma que pintan ä la mueve. sin pulpa ni callone. Festos chupadores, de noclor, sill ser sentidos, vin á hacer mal por las casis agerenas: é ponen la boca en el ombliggo de aquel que chupan. I cstín en arpel everçiçio una ó dos horas ó lo que les paresçe, teniendo en aquel trabaco al pacgiente, sin yue sea porleroso de se viler ni defender, no dexando de sufrir su daño con silençio. É conosege el assi ofendido. é vee al malliechor, y am les hahlan: lo qual, assi los que lategen este mal como los que lo parlesçen. han confessado alignnos dellos: é diren questos chupadores son criados é naborias del tuyra, y quél se los manda assi hacer, y el fuyra es, como está dicho, al dialsío.

Son muy grandes hervolarios algunos indios en aquella proving ia é ronosgen muchas hiervas para diversas enformedades, en especial los señores é hombres prinçipales, é aquellos tepuinas, ć aun atgunas mugeres, en las quales es mas peliggroso el officio; porque todas aquellas que se prescian de maestras de tal arte, son unas ricjas astulas é mal inclinadas, ć de mala proporçion é rista, que se cntremeten á adevinar vé laçen mas desconçiertos que los hembres de su officio. Y destas hay assimesmo chupadoras en mas cantidad que de hombres, que en esso entienden.

Un notable caso me ocurre, é quiérolo deçir, aunque es aparlado de las otras materias de que se ha tractado. pues quel pressente capítulo lie querido que sea de cosas mezcladas é diversas. Y es que en ol Dirtien. on Ache y ent el Nombre de Dios, y en lír costa de Tirmatrinture, que mina ál rsta isla é llamamos del Korlo, totodos los rientos, Nordeste, Nonte a Norueste son sanos, porpup rienen solne d agula de la mar, y el Yorte mas sano que rssotros ques dicho, porqur viene mas lilre, sin tierra, é los fue en donde lie dicho van del Surste á Sur é Suleste son enfermos, é mucho mas de de Modiodia ó austro, porpue vá mas sobre licra. I estosque allí son enfermos, son sanosen Panamí y en arjuella ofra costa austral: y lo mesmo acacsege en esta Isla Española y ciludad de sancto Donningo: que en la parte puesta costa mira al Austro, los vientos que rienen de Mediodia son sanos, y el Norte es malísimo é muy enfermo; é por el contrario en la costa questa isla ticne láçia el Septentrion, estos vientos que aquú son sanos son acullá dolientes y enfermos, é los que ayui son dañosos, en la olra custa son saníssimos.

Los indios de la provincia de Cueva son inclinados á juegos é oçiosidad é afiçionadíssimos á hurtar: é assi en esta gohernaçion de Castilla del Oro, como en las partes que he estado destas, he visto assimesmo y es notorio que los indios de poca clad, assi hombres como mugeres, hasta llegar á trege ó catorge años, é que se principie la clad de la adolescencia, y se comience en ellos el desseo é calor libidinoso, é se ayunten carnalmente hasta probar con cfelto la luxuria, son hasta allí (en lanto que no la han gustado con olora) los mejores servidores é mas buenos muchachos que se puede pensar ni arer visto en othas nasciones (si hasta llegrai á tal estado son corregidos é criados entre honestos chripstianos); pero quando son entrados en la edad adolescente, en conosçiendo muger, se tornam hestiales é diahólicos ellos y eilas con el curso venéreo. É con este vicio se les pegan é juntan otros, é olvidan lo que saben lueno é 
virtuoso, si assi lo han aprendiclo antes de buenas costumbres, é lis aborrescen por lit mayor parte; pero todavia (fuedim mejores que sus padres é prarientes. Éassi es de creer que con al liempo, mediante el faror dirino, siempre serán mas aprovechados é aparejados para ser chripstianos é merescer tal nombre é la sortoria del f̧ielo, interviniendo la sraçia de bios en ellos.

Y pres andamos al caho deste libro XXIX, será bien, pues en cada uno de los libros desta General historia de ln- dias se dicen las vidias de los soobrinadores (y aun de algunos dellos ó de les mas sus muerles), que se pongal aqui un capitulo particular é penúltimo, resuniendo la relacion de los capitames particulares é inferiores, para acordarnos contre tanto número dellos (con sola esta gobernacion do Custilla del Oro) quán pocos son aquellos que dexiron de morir mala muerte, aviendo su pago en cola vida conforme á sus obras y quín raros los que dellos han tornado á sus patrias.

\section{CAPITULO XXXII.}

En que sumariamente se tracla del subẹesso efin que hiẹieron los eapilines parliculares, que la avido en La gobernaçion de Castilla del Oro en tiempo del gobernador Pedrarias Divila, é antes é despues di! hatsla el liempo pressente.

P hres bien olvar, chue no mo saberlo hager. Bien creo yo que algunos capitanes de los que en esta grobemacion de Castilla del Oro lın andado, no supieron Lien olsrar, porque nunca lo aprendieron ni usaron; é la culpa é falta questos tales han obrado acá, tanto y más se deben atribuyr al gobernador que los admitióálal offiçio, como al que mal le usó. Otros alğunos destos capitanes, que supieron laçerlo bien é no lo hiçieron, essos tengo por diabólicos; puesto que algumos otros (que fueron los menos en número) son dinos de loor. Y assi con los mos é los otros ha tenido Dios tan particular cuenta é aviso, como sus fines é vidas lo han mostrado; pero porque este juiçio é casligo esté mas manifiesto prara correcion de los pressentes é por venir, digro assi.

I. El adelantado Vasco Nuñez de Balboa, que fuć causa de la mucre del gobermador Diego de Nicuesa, é de los que con él se conjuraron ante Ilernando de Arruicllo, escriluano (para no le rescebir en el Darien por gobermador', é cruelmenTOLIO III. te le echaron de la tierra por la mar en una barea, con otros trege hombres, y ol ni ellos munća mas parescicron), red como despues murió este adclantado degollado por Iraydor, é con el fueron descaberados aquel escribano Argüello, é Indrés de Valderrálbano, é Luis Botello, é Hernand Muñoz, que eran de los mesmos con jurados, é assi acabaron con el mesmo tjtulo de traydores.

II. El capitan Bartolomé Ifurlado, alguagil mayor de Vasco Nuñez, é uno de los conjurados contra Diego de Nicuesa, murió mala mucrete.

III. Françisco Pigarro, que despues fuć adelantado é marqués é gobermador é capilan general en la lierra austral, é que tan poderoso é rico se vió que ha sido sonado y estimado por el mundo quanto por estas historias se puede ver, uno fué de los conjurados de Vasco Nuñez contra Nicuesa. Y cstaudo en lit cumbre é mayor prosperidad que tuvo, murió mala mueve el año passido de mill e quinientos é quarenta y uno, é le mataron de una estocada por la garganta, é con 21 
di a un hermano suyo é olros ginco ó seys, porque no purelasse sin casligo ni renganga la mucrte injustar de sll compraticero el infeliere, a dino de infillible memoria, al arlelandarlo don Diego de Mnagrero, ni las de arpuollos precarlores. que malaron on

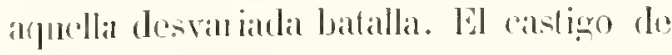
la qual is de tam grandes delictos, con lit mesma diliggion c ticmpo, ha mostrato la justicia de Ilos palpablemente, que ninsmono, que porfetlo juiçio langa, delse conliall de llessoros ni favor del mumblo.

IV. El capilan Johan de Exaray, uno le los conjurarlos eon Vasco Nunez conlara riego de Nicuesa, estando ya rico, é yendo deste Panmúá í lia villa de lela, le malaron sus indios é otros con quien se delictan contender; é nunea se pudo saber dónde tenia sus dineros, rue eran larlos, é se ereyó que los dexó ó los lenia enterrados. Otros hombres muchos que fueron capilanes, é que entraron en afquella conjuraçion contra Nicucsa, no los nombro: mas torlos ó los mas dellos acaLaron eon malas é diversas muertes.

V. El capitan Benito Ilurtarlo, estando con çicrta gente en un puedslo, rue se llama Villahermosa, quel gobernator Pedrarias Dávila hiço fundar en la gobernaçion de Nicaragna, lo mataron los indios, con otros muchos eluipstianos, por su descuydo dél é de los ofros españoles, porque sus ex. cessos no se pagassen todos en la olia vila.

VI. El capitan Lopo de Olano, que dexó á sugohemador Diego deNienesa en la mar, yendo aubos en sendos navios á Inscar el puerto de Veragna, é le dió cantonarla é se volvió donde el exérçito quedaba, é se hiço jurar por gobernador ó teniente de gobernador, despmes de algunos años le pagó Dios de su lraycrion. i le mató con ofros chripsianos el caçique de Carcela, donde agotal es la villa de Aela, trniento muy merescrida la fin, quél é otros hiçieron en su compañia.
Vll. Eil cappitan Fuancisco Becerra, con dosicientos respinoles que yovi yo (i numea volvicron) rleste dbarien partió, pror mandialo de Podrantists é só oppinion é tílulo ' fur cräl lombre soliçito é se rlaba maña á

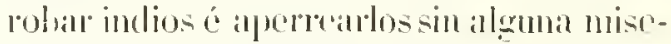
rienrdia, y porepurdesto se tenia expririençia de crienta entrada. de donde poco antes avia lolualo con seys ó siete mill pessosde oro é muclus inclios mal avidos, fué á la olra eosta de Camibana. Mas allíi le mataron á ci é á quantos españoles llevó consigro, sin que dèl ni de hombre de fodos cllos algumo escapasse, ni se supiesse nuevil alguna de cómo ni dónde muricron. Essle capilan é sente qurs dicho, partió del Darien año de mill é quinientos y quinre, y estamos en el de nill é quinientosé quarenta y ocho: assi que, pues han passado lrevila y dos años, bien los porlemos contar con los defuntos, é rogin á Dios que estén en gloria.

VIII. El capitan Francisco de Tallejo salió delDarien, despuesque partió el eapitan Becerra, jor mandado assimesmo del gobermador Pedrarias Dí vila, é passó á la costa. ques dieho, de Caribana, assi por saber nuevas del capitan Becerra é su gente, como por ayudarle ésaber de los secretos de la tierra; mas ol fructo que se sacó deste viag̣e, fué queste eapilan volvió huyendo, é se dexó allá quassi ochena hombres. E renicto al Darien, non obstante su mala deseulpa, la pena que se le dió fué inhabilitarle é que no fuesse eapilan en ningun caso ni liempo; é con este castigo piadoso se pagaron las vidas de los muerlos, y cl Vallejo se fué de la tierra é se passó al gobernador Rodrigo de Bastidas á Sancla Marla, donde murió pobre é infimado de cobarde.

IX. Johan Escudero fué enviado por capilan á çicrta provinçia, por mandado de Pedrarias, á ruego del alealde mayor el liçençiado Lispinosa: este era un hombre desordenado é de ninguna expiriençia, é 
ammene hirgo cosas por donde meresçia ser bien castigado, no lo fué, sino por(puce él tenia gana de yrse de la tierra, destreríronle della, porque tenia por amigo al que le avia de juzgar". El caso fué lal, que fuć muy murmurado el delicto feo, é acpuella entrada, é mucho mas la sentençia; por mancra que los indios queste nuevo capiLain mató é ofendió, se quedaron con sus daños, y a delinquiente sin pena, é los que lo vieron é supieron, çertificados de la poca justicia que avia, y ann çertificados que ningun malediçio a via de ser punido ni salisfeclıo, conloronc á las leyes ni ćla buena raçon.

X. El capitan ó alcalde lirtado, que residia en el puerto é pueblo de Sancta Cruz, cra un mancelso de poco sesso ć de ninguna expiriençia ni rergienega, ć mny desordenado é maltractador de indios é viçoso; pero como era antes crialo del conlador Diego Marrquez, por su respecto fue hecho capilan, sin tener expiriemeria, é alcalde sin letras, y tan mogo que no avia veynte y tres años; y conforme á esla edad é su maldad é deshonesto vivir, todo su intento era luxuriar y tomar á los indios sus mugeres é indias, é dar luggar que los otros españoles, yue delaxo desil juzgado estaban, liçicssen essas é otras torpecas é simraçones. Por lo qual, no pudiendo sufirir los naturales de la tierra las insolençias de tal juez é de los demis, quando les paresçió quel ticmpro era mas á propóssito para su vengança, mataron á cetc Ilurtado con mas do ochenta chripslianos, é juntáronse para cllos los cargiques de Comogre é Chiman é Pocorosa.

XI. El capitan Marlin de Hurga, que en diversas partes é liempo avia mucho laarlos indios, inclios le mataron á él é á olros tres españoles, esiando seguros é renando en casa del caçique de Bea, que le ser-

* En el capiluto XII de este mismo libro de. jû́ ya refenta Uviedo la peregrina muerte de cole via, como mas largannente la lisistoria lo ha conlado en este lino $\mathbf{X X I X ; ~ p o r q u e ~ d e ~}$ lit numerte deste subgedieron otros muchos males é triblaxos á nuí é á olros, é fué murcha causa de se relielar aquel cacirjue é otros, initando al de Bea, porefue este capilan cobdiçioso le fatigaba, porefue le diesse oro.

XII. El (appilan Andrés Galravito, uno) de los consortes de appella negogiagion,

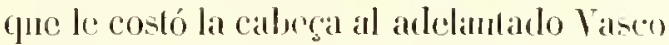
Nuñez, este fué el que lo descubrió, por las qual el golnernador Pedrarias le relevó del cuchillo. Pero como lenia cssa é otras mayores culpas ante Dios, en 11 juego di cañas se hiço máscara en un dia de fiesta cn Leon de Nicaragran, é arremetió con el caballo láricia donde estaban çicrtas mugeres españolas minando, é él les diso: "Señoras, tormanos molas", é otros desatinos, loando la secta de Malıoma * : é súbi. tamente se cayó del caballo abaxo nuerto, sin degir olra palabla alguna, sino trús las que en favor de Millonla diso se le acalbó la vida. Loada muerte fuera arpuesla en Turquia, é no entre chripstianos, simo muy expantable é aviso para quel cathólico esté aperçebido para morir, como debe; pres ninguno salue el dia ni la holá, en que será llamado para la ofra vida.

XIII y XIV. El 'appilan Gaspar Horales, primo é criado del goberualor Pediarias, y el cenpilan Peñalosa, pariente de su muger, doña Isaluel de Bovadilla, volviendo de lia isla de las Perlas de la mar del Sur, é trayendo crientos indios é indias, é muclos en cadenas é alados prissioneros, é no de Imena é jusla gunerra salieron, por los colirall sus padres é parientes é nutchos indios. Y por poder sal varse estos capilames, acordó Gispar de Morales de liarger degollir los pressos, é assi se lico por conscyo del Peñilosa é de Andrés de Valderríba-

capitan, casi con las mismas palabras. Viase, m efecto, la priger. 61. 
no. é huycron en tauto que los indios que assi venian á libertar los muertos, se pararon á los minrar con muchas lígrimats é dolor, considerando tanta cruckdid: é deteniéndose en casa trabarosal considerarion, el uno niriando el hijo, y el otro la muxer y el padre ó hermino, tuvicron ticmpo los malhechores de escapar con el oro é perlas que traian. É llegados al Dasien, no se Lalló culpa en el Horiles ni en el Peñalosa, por causa del debdo que tenian eon el gohomator é su muger: mas atumeque la tenian muy grande, no se castigó. Verdad es que, por muy carwado de perlas puel Giapar de Moriles desde á pocos dias, con licencia de Pedrarias, se fué para Bojados, donde era vesino en Espaina, le aleangó la muerte: é vivió poco ticmpo despues. Valderráhano, acordíndose Dios de ajuel consejo herodiano que dió para lo ques dicho, permilió que dél se hiciesse justriar, é fré degollado despues con el adclintado Vasco Niñez, cono es dicho. El Peñalosa, que marió mas farde, lo fue á pagar á la isla de Cuba, donde le malaron los intios.

AP. Pecilarias el nancelo, sobrino del gohernador, despaes que volvió al Dasien de arpuel viasce que hiço all cenú con el bachiller Enriso por cuyo consejo se hire aqquella mala jornadi, en la qual mataron de un tlechicro al capilan Diego de Buslamante ć á otros chripstianos que alí desaron lis vidas, é los demás tornaron pobres é con un poco de oro que no les cupo ni aun á pesso de oro, fuése á España, y en Civila, de donde él cra natural, le malliron *

SYT. El capitan Johan de Ayora, teniento de capitan gencral de Pedrarias, ensconó á pecear é mal olwar á otros muchos: y despues yne volvió al Darien con folo el aso que pudo arer, é ariendo nsado de

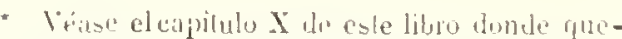

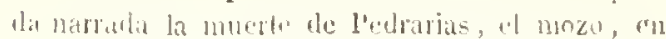

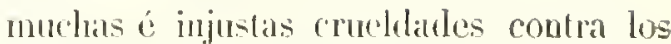
indios, diéronle liçonciat paran tue se fuesse, romo se fué: y cómo bil mejor que otro conoscia sus oluras, partióse con li mayor diligrencia quél pudo, é fuéso á España, donde murió deste á poco liempo que Hloyó, derando acuestas sus culpas sobre los hombros del obispo é del gobernidor é del alcalde may or: que le favorescieron, para que no le detuviessen ni diesse cuenta de lo yue avia fecho.

XVll. EI capitan Luys Carrillo fué con el adclantado V'asco Nuñez de Ballıoáá ma entradia de la provincia de Dabave, donde le desharataron e mataron algunos chripstianos, é hirieron al adclantado, é al Luys Cirrillo le dieron un varaço por los peclios, de que murió desde á pocos dias que tornaron al Darien, donde pagó las crucldades que le mostró á haçer Fránçisco Pigarro en una culrada. que primero arian fecho á la provinçia del Abrayme, llevando u Luys Carrillo como coadjutor é ayo al Piçarro, porque Iuyss Carrillo era muy moro é nuevo en el officio. é aun no cra dirstro en saltear é matar indios.

XYHI. El eapitan Antonio Tellez de Guzmai fué enviado á otra entreda, é truxo buen recalulo de indios. que repartió al raburnador é offriales é alizun otro, é mediante su diligeneia y el favor del contador Diego Marquz, aunque ovo quevas dél. todo se alapó é quedó sin pena; porque la costumbre bastabat para que no se le diesse ni se romengasse á usar con csle cavaHoro otro nuero estilo. Pero despues hiço penitengia en Sancta Marta, donde á la verdial sirvió lien á Su Magustad, puesto que le aprovechó poco por la tirania del wolremador Garçia de Lerma. Y despues de sus muchos tredhatsos, estando en esta cilulad, siguicudo su justiçia en la Audiencia Real contra Lerma, fuć por estos se.

lus minmos termbinas, piog. bit 
ñores enviado al Perí, é halló en lal dispusiçion trabada la discordia entre f'içarro é Almagro, que, mediance su Inena mana, purlo tanto hager, (pur los puso en paz (anmque turó poco entrellos): pero hastó para quél baralasse del camino tanto Oro, que se fuesse rico á la ciludad de Tofedo, donde nasció: é rasóse allí prara descansar a viril entre apuellos caralleros, sirs dobdoi en su palria, é aprartarlo destas Inchurias é peligros de luclias. É no tengays, letor, en poco esla paz, en que supo dar conclusion é alajar lás diferencias de los dos adclantados Picarro é NImagrro, Lasta yue lavays leyelo la terçera parte destas historias, donde hallarés ma mancra de letrados, que concurrieron despues entre los mesmos contendores, 6 ve. rés que ni bastaron á los poner en sosiego ni purlicron. ó no supicron, ó no quisicron efultur la concordia entre los que lie dicho: de que se siguieron las muertes dellos é de olros muchos. é lantas pérdidas al Rey é sus vassallos é reynos, que no se podria decir sin muchos renglones.

XIX. El capitan Diego Ilbilez fuc uno de los capilanes é vicjos pobladores de la Tierra-Firme, y en cslas historias calí escripta sur virla é mucrte, la qual pudiera ser més descansada é fuera del nauliagio que le acabó, si se contentína con lo que tenia, que era bastante á quél riviesse é muriesse honrarlo é sin nescessidad, é tenia aparejo para tener mucho mas: pero, desseanto mandar, procuró la gobernaçion rle Honduras, despues que murió el golsernador Diego Lopez de Salcedo, é Su Magrestad le lisgo merged della: é vendo á ejerece el oflicio é llegado á la costa, fué corriendo tal fortuna, que dió la nao al travér. "rerdió quanto llevalna é se ahograron tregnta prersonas, y á salio á nado, é tal, que deste á nueve dliats murió en apuella su golocruacion, quél lanto desseci, é sin la gobernar, ó por rentura fuó mejor para su ánima.
XX. El capitan Gonçalo de Badajoz, si se dicra recabdo, a via avido harto oro, é por su pora prudençia se to tomaron los indios del caçiqur de Paris. Y empleósele bien, por los adulterios que disimuló de un capellan (que consigo Ilevalsa, é por los quél no monos hacia con indias; é despunes murió en Pamaná polne éá Dios le haya plaçido que fuesse en verdadera penitencia.

XXI. El capitan Rodrigo de Colmenares fue drede aquesta cibdad de Sancto Domingo con una nao é gente al Darien, é cómollegó á la cosla deflicriatirme, saltó en Gayra, donde los indios le mataron parte de los españoles que llevalua, é olros su dexó vivosé perdidos entre arpuellos caribes, é con esta verguienza se fué con los restantes al Darien. É nunca açerló en cosa que entenliesse, puesto que era hiclalqo é buena persona, é soldado veterano; pero no diestro en mandar gente, por ser descuydado, é porque no lorlos los que tienen habilidad, para pelear debaxo do otros caudillos. son cllos para acaudillar ni gobernar la miliçia.

XXII. El capilan Françisco Ifernandez, teniente general der gobernador Pedrarias Dávila, y muy su aceplo y querido, fuć por su mandado á Nicaragua, donde se dió mny buena maña, y era gentil é taálsil poblador. Este fundó las cibdades de Leon é Giranada, con sendas forlalegas en la costa de la grand laguma, é repartió y encomendó los indios á los polbladores cluipslianos: é cslalo muy bien quisto comummente de todos los españoles, excepto de algumos capitanes particulares, que le enemistiron de tal manera con el goberniulor Pedrarias, que fué desde Panamá á le buscar, é le hiço un progesso á la soldadesca (que son olros términos apartarlos del estilo de los juristas), é le lrico cortar la ciblueca á no sin pessar á los mas de su muepte ć con plaçer de los particnlares sus enemigos. Pero la verdad es 
quél estaba tenido por erudo y de poca consçiençia; y assi me paresçe que se ovieron con ćl crudamente. puesto que los méritos que ante llos tenia para meresçer tal fur. no somos jueros dello. Mas en atpunlas poldiagiones, que le dicho, yo vi despues que muchos le suspiraluan ó loalan de buen polbador, é culpaban á sus émulos de maliçiosos y envidiosos dí Peclrarias de inconstante é açelerado é mal juez. Perdone lios á torlos.

XXIll. Ciripstóloal Serrano fuc assimesmo de los vicjos capitanes do atpuella tierra é buen polbador: el qual fué por capitan en una nao é gente que con él se enrió descle arpuesta cibdad de Sancto Momingo al Dimien, en socorro de Vaseo N'uñez é di los otros resañoles. y era buena persona. aunque algo eneogido: pero no hay dél cosa notable en su ofensa. Estaba ya rico é recogido é con buenos indios, aveçindarlo en la ciludarl de Granarla de Salteba, á donde se fué á vivir desde Panamá, despues que ar ia militado diez y sers ó diez y siete años en Castilla del (0ro, é llevóa Nicaragua su mugeré é murió sin hijos, è no sin lierediro: que su muger lo fué délé de otro marido que luso primero, é muerto el segundo, tomó por marido á un su criado, ques el terçero convugado que la poseyó. que ella heredúra como á los otros ha licclio, si no la venciera de dias el que tomó á la postre.

XXIT yXT. El capitan Johan de Cárdenas murió teniendo va de comer; pero no osíndolo gastar, y lan limitado, que no faltó á muchos que murumarar the su uncho gruardiar: de lo yual vo no leculpo á él ni á otro de que grardesu hacjenda, si es con buen propósilo, y en espegial á los que con muchos trabaros, como él padesçió, lo allegan. Él era lidialgo.é nunca oy deçir dél las crucldades que de otros, que para donde anduro, y con ser la conversarion entre muchos faltos de buena consegiençia, lo tengo por mejor é mas loa- he. Á esto dió larta causa la huena compaña y hermandad y estrorha amistal y

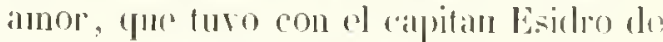
Robles, que despues so fur á visir en la tierra austral de la Nuera liastilla, é lué rien lombre, lomesto ó vidanso é prudente. é que vivió tenimelongras de justicia en tiempo de Pedrarias. é dió buena errenta dellos é de su persona.

XXV. E capilan Villafaño liuć uno do los primeros capitanes. que vinieron all)a. rien en Pedrarias: cra valiente lombre por su persona é lielalgo, é dél no se salbo que hirciesse apuellos cromes. que á ofros se les impuan por estas listorias. Vivió pocotiempo en estas partes, é dexó çiertos lijjos rirtuosos, que consigo truxo de España, muchachos, pero bien inclinarlos.

XXVIl. El capilan Ilierónimo de Valen. çucla fué de los pobladores que acá llaman de baquiu: que quiere derir viejos é veluranos, a militó con Podratrias. Este, aunque era hidalgo. cra de seca conversacion é poca piedad, como lo mostró muchas rie çes: y en especial con el filósopho Codro, el qual el dia que se murió, emplacó para ante bios á este capilan. diçiéndole quél cra causa de su muterte, é rivéndose de la cilaçion el Valençuela, é como por cscarnio. respondió é diso: "Poneos del lorlo é morios, quando quisierdes: que yo daró mi porler á mi parlecé alunclos, (jue os responderám por mi en el otro mundo." El caso es quel T'alençucla no dexó por esan de morirse al plaço puel codio le puso. Ein lo que paró el juicio de Dios entrellos no se salue; pero acá fué cosa notalble á los hombres, é passó como es dicho: aculla yo reeo que se le guardaria su justicia. Dios perelone al uno é al otro.

XXVIII. El capitan Martin Listete, criado muy açepto de Pedrarias Dévila, homlore no tam lát!il en la miliçia quanto desdicharlo é floxo en la capilania é cosas de la gruerra, pero despierto en otras ast ucias. reautelas, desde dDarien salió con gen- 
te á paçificar la tierra, é dexóla mas alterada que estala antes. Desde l.eon de Nicaragua hiço otras dos cultadas por mandado del Pedrarias, é ambas sin proveclıo, é volvió con menos honra é aun perdió parte de la gaente. II quohernador Diegro Lopez de Salgedo, que Ie homró é ayudó é favoresçió, é le liço su teniente, pagóle con tanta ingratilud, gue se le amotinó é le puso en pelig̣ro de perder la vida. Despues que murió l'edrarias, fuésse al Perí, donde fué muy rico: é al riempo que mas turo destos lienes de fortuna, fué á dar cuenta de sus obras á la otra vicla, dexando á su muger cargada de oro é plata é joyas. Y ella deste á poco se casó con $\mathrm{m}$ cavillero de lis opinion é amistad del minrqués don Francisco Pigarro, que se dió buen ticmpo con aquellos dineros de Astete, é le mataron, quando mataron al marqués, quedíndole ya pocos. Assi que, este fin hiço dstete é sus dineros: que segund he oydo afirmar á personas de crédito eran mas de quarenta mill pessos de valor en oro é plata lo que dexó sustete, quando dexó la vida é passó á la otra, donde castá. Plega í Dios que esté salyo de las penas infernales.

XXIX. El capitan é bachiller Diego de Corral no quicro repetir en su caso mas de lo que la historia ha dicho, sino que estando casado con una pobre é honesta é virtuosa dueña, llamada Johana de Gijon, liijadalgoo, la olvieló en Castilla por respecto de una indlia, en quien turo ciertos hijos, é assi como fueron avirlos con mal título, assi fué el groço que ovo dellos y de sus bienes. Y conforme á sus letras, rolvióá España, despues que sus diferençias é mias se acabaron, y buscando otras y su desasosicgo, murió en Sevilla, sin tenel allá un real que giastar; y un su criado, á quien encomendó en el Darien la haçien-

1 Las palabras con que Danthe eomicnca la Divira Comedia soa: da y casa y mançeba, se hiço rico á la sombra de Ios desatinosé inquicud de su ano: el qual fué émulo y cuchillo del adelintado Vasco Nuñez é sus consortes, con los quales tenia otras cuentas y litigios pala donde estan él y ellos. Y es de ereer que con mas leetilud son allá determinados de la queste letrado determinaba acá los proçessos, que de algunos eapitanes se le remitian, quando rolvian de las cntradas, en que los dala por libres, aunque muchos indios oriessen muerto y truxessen pressos contra raçon é justiçia.

XXX. Doscavalleros capitanesse ofiesçen á mi memoria, que en la verdad por ser cnamorados, alguna equidad piden sus errores; pues no fucron en cargo de sangre de indios macularlos, ni es de creer que la sacaron de sus amigas: é no quicro decir sus nombres, pues bastarán sus scĩas para los que son vivos é que nos Lallamos en aquella armada con Pedrarias, que fuć al Darien, para que por lo que agora diré, yo sea entendido y ellos sean conosçidos. Anbos fucron nombrados por el Rey Cathólico. I el uno cra muy mançebo, y para su recreaçion y no peecar con indias, vino peceando, y l'uxo consigo una amiga, muy desigual compañia, porque él cra carallero é de noble sangre, la qual faltaha en la señora: é empeñó ó rendió parte de su haçienda é patrimonio para venir acál, é mediante la industria de aquella muger, él se tornó á Castilla perdido y casado con ella, por navegar á la vuelta con menos peceado y sin dinero.

XXXI. El otro capilan assimesmo por sí é por sus parientes su casta es de nobles cavalleros, é puesto que llegaha en esta saçon í la mirad del camino de nuestra vida, como dixo el Di!ntle en el prinçipio de su Comedia ", truxo otra amigga é no conviniente á tal varon; porcque en la verdad cra

Nel mezzo del cammin di nostra vila Jii vitrovai, elc. 
homber de homar, si no la avenhurália en la annistad do mo monger semejaute de des-

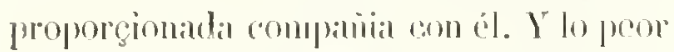
es yne ya que so deromimó de sere enatmoraldo, fuś de runa vicjal é muy lea hemma é de mala grargia. on la qual concon-

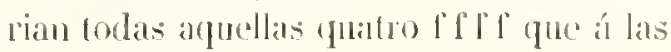

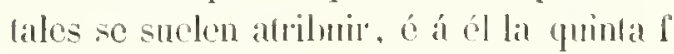
de falto de sesso, por al mesmo calso.

XXXII. Franciseo Vazpuez Coronado y de Valdés fué uno do los cappitanes, que vinieron con el gobcrualor Pedratias, hombre de buen linage, é dado de nollos a avalleros: el qual, como vido en aquellos pincipios que se moria mucha gornte en cl Darien, descontento de la licria, se pasoó á la isla de Cula, donde golsernaJa el adclantado Diego Telazquez, y él arpuella tierra se casó y herculó : é despues fué á la Nucva España, é anduro tempestando, buscando la vidia para si é su muger é los hijos que oro, é despues murió en aquelli isla, segund he sabido, no rico, sino polire, atenta la calidarl de su persona, el qual ni los dos enamorados que se dixo de susso no hicicron daño notable en los indios ni en li tierra, sino á si mesmos, é presto se salieron del Dirrien.

XXXII al XXXVII. El capitan Hernan Perez de Meneses, ol capilan Francisco Dávila, el capitin Gamarara, el capitan Aliença, d capitan Johan de Corita, todos estos cinco fineron con Puetriaras el año de mill é quinicntos y catolge al Darien, é se fueron de aquella ciludad el siguiente de mill é quinienlos y quince, é dexaron aquella liera; pero no sin aver padesçido muchos (rabaxas, porque fucron á poblar la ticria adentro é hácia la olra cosla del mar del Sur, quando fué el teniente Johan de Iyola. É por hablar mas al proprio, mas cicrto fuć su camino de todos cllos á despolular y espantar é allerar los naturales, como se lai dirlio en sus lugares apropriados á la listoria.

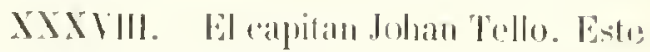
fue diestro en la equerra de los indios, é con daño dellos é de la conscrionria dial, puesto que en el mal tratimiento, que se les ha liecho, los más de los capitanes hain seydo culpaldos. Thapues que murió Pedrarian, se jaksó este capitan Johan Tello al Prón, donde le honró e aprovechó é hicorico el marpués don Franciseo Pigarro, ć le dió cargo de teniente suyo en un pushlo de arquellos de la Nueva Castilla, donde munió, alghm liempo antes que matassen al marofués.

XXXIX. El capitan Alonso de Targas fué raliente hombre de su persona, ó abonado por tal: é conliado de su sesso, filtíndole salud y enterno, fué por mandado del gobermador Pedro de los Rios, á patgificar al racique Trota, é matíronle los indios con otros diez y ocho ó reynte chripstianos, mediante líl nesçedad de un recino de Nata, Ilamado Pedro de Plasençia, que abonó lanto á un caçique que le servia, llamado l'ocoa, que aquel los vendió é llevó á la muerte, é mató de su mano al mesmo su amo Pedro de Plasençia, porque dió causa que dél se fiassen *.

XL. El capitan Gabriel de Roxas, conquistador é luren solktado, veterano en la 'J ierra-Firme, hombre de lromra y de expiriençia, é que ha dado buena cuenta de sí (el qual, si no se lallara en çierta entrada que hico Istete desde Leon de Nicaragua, no cscapara cluppstiano de quantos allí fucron, ó por el esfuerço deste calpitan Roxas se deturieron los enemigosé se silvaron los españoles), fué teniente de Pedratias en Acla, é de Diego Lopez de Salçedo en Giranada de Salteva, é del adelantado don Diego de Almagro en la cilsdad del Cuzco. El qual vive y es hombre para confiar dél todo to que de lunen ca- 
pitan se debe fiar; porque demás de ser valeroso por su persona é habilidid, es de buena casla, é grentil é conversable mílite, é buen compañero é muy bien partido é liberal. Cómo acabará, Dios lo sabe; porque assi él como los mas de lodos los susso dichos, é de los que adelante se dilán, son en cargro de hartas vidas de indios, é unos más que otros, y el officio de la guerra todo esso trae. Mas pućdese sospechar de sus obras que meresce todo buen fin, é ha muy bien servido á Sus Magestades é trabaxado mas que otros que antes quél han seydo ricos: é allí á donde él ha andado, assi por falta de su rentura, como por inadvertencia de la fortuna é de sus despenseros ó repartidores deste oro, quella ha puesto en poder de los que menos lo merescian. Y este error quella ha usado en la distribuçion ó dispensaçion de muchos millares de pessos de oro, si jo los oviera de gratificar conforme á sus méritos é buena consçiençia, muchos á quienes cargó ella de oro é plata, cargara yo de leña ó praja, ó los liçiera volver á los offiçios de sus padres, que tuvieron algunos muy apartados de la militar disçiplina.

XLI. El capitan Bartolomé de Ocon fué grande adalid é de muclıo conosçimiento en el campo, é valiente liombre de su persona; pero de áspera é grosera conversacion é de muy mala para los indios, é crudo. É con todo murió pobre é á la soldadesca, porque aunque no le mataron, ni él queria médico ni otro regalo, nollevó mas limpias las manos destas cosas de indios que sus vecinos, puesto que con toda su robustiçidad paresció muchas veces que pudiera lager mas daño del que hiço en algumas cosas de la guerra, en que á la verdad era mañoso.

XLH, XLIII y XLIV. El capitan Françisco Campañon fué un hombre muy hombre, é dehdo del susso dicho en sangre y en algunas cosas semejante en la miliçia, T0.110 III. puesto que de mejor conversacion a criansa. Este capitan y el capitan Ilernando de Soto y el capilan Iternan Ponce de Lcon fucron compañeros en las laçiendas, é todos tres hijosdalgo é bnenas personas: é mediante su compañia é buena maña en Nicaragua, é con darles el gobernador Diego Lopez de Salcedo muy buenos caciques é indios que los sirvieron, é con el faror deste gobernador, allegaron mucha haçienda. Ė Campañon murió en Lcon, en pocos dias, de una violenta dolencia: Hernando de Soto, seyendo capiian de la guardia de Diego Lopez de Sálçedo, que era gobernador de Niciragua, se juntó con el teniente Màtin Astete é otros sus secaçes, é amotinaron aquella república ó la mayor parte de la ciblad de Leon, é pusiéronle en tanta nescessidad que le oviera de costar la vida, en pago de las buenas obras que dél rescibieron. Las quales no há olvidado Dios; porque el Astete murió, como se la dicho de susso; é quedando Hernando de Soto en la compañia de Ileman Ponce, passaron despues á la tierra austral, donde mediante los thessoros de Alabaliba hincheron bien las manos, porque se hallaron al repartir de aquellas grandes riqueças y en su prission. Despues fué Hernando de Soto á España, é muy rico; é fué fama que metió en Sevilla solore cient mill pessos de oro, en oro y en plata, é gastólos: de manera que quando volvió á las Indias con la gobernacion de la isla de Cuba, é parte de la Tierra-lirme septentrional háçia el Norte, é provinçia de la Florida, traia algunos millires de pessos de oro de debdas, é muy empeñado, é volvió casado con una de las hijas de Pedrarias, llamada doña lsabel de Bovadilla, como su madre. Pues como este ca. pitan fuć buen hombre de su persona, é muy ocupado en estit monteria de matar indios, é tiene lartos envialos al infierno, no me maravillaria que le oviessen sus 


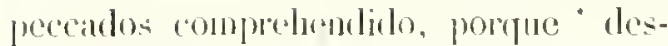
le Culna passó á la Tiurra-Firmo é so perdió é murió allá, ć ofros numchos se perdieron tras su sesso, y el perdic la vida é bo que lenia. É eonno su muger lo supo, se tornó á Castillir, desle á tres ó quatro anos que le atcondia.

XLY. El capitan Ilerman Ponce, que no llevó menos oro é plata á España (pue su compañero, me paresge pues el que mejor que otros ha cotendido estas cosas de Indias; porefue solo á Castilla, se casó con muger rica é de luena casta. é se heredó en Serilla, donde vire muy honado é á su plaçer, é donde porláa emplear muy lien el timpo é gosar de lo que tiene, sirviendo a Dios cono carallero honrado. E con su persona ha áleangado lo que Dios le ha dado, ques lo que he dicho, y en buena edad, para que con sus bienes temporales pucda grangear los de la vida ctema; pues no quiso, como otros, embelessirse s busar essos títulos de rana senoria, sino quorlarse con la nuered ques dicho, que le turarí mas á donde estíl é á sus snlyçessores, si por su culpa no fuere.

Porcque conoscri é ví é lancté á lodos los capitancs que lie dicho, é al grobernador Pedralrias, é al reverendo obispo fray Johan de Queverlo, é al liçençiado Gaspar de Espinosia, allealde mayor, é á los offiviales al thessolero Nlonso de la l'uente, é al contalor Dicogo Mlarequez, é al fattor Johan de Tiblura, tan congolphados en los interesses de afuellis partes, decirse lia con brevedad en al capilulo siguiente lo que compreliendí é vi de sus personas, para alyuma desculpa de los capitanes que parescen colpados por estas historias; aunque no será satisfaçion tan entera para la otra vida, como la ovieran menester.

\section{CAPITULO XXXIV.}

En quel historiador eulpa y desculpa á los gobernadores af officiales, y en deseargo de los eapitanes, y en reproche le los soldados á de los indios é naturales de la gobrmacion de Castilla del Oro.

\begin{abstract}
?
Sien creo que arré olvidado pocos del número de los capilanes inferiores ó particulares en el capitulo do susso: é puede ponerse con ellos el hachiller Gaspar de Espinosa, que fué á Ticra-Firme por alcalde mayor de Pecirarias. donde se hiço rico con los trabaxos é sudores del adelantado Vaseo Nunez de Balloa, quél hiço degollar; é con sus navios, segendo teniente de capitan general, allegó todo el oro quál pudo, con que se fué á Mledina de Rinseco, de donde era natural. É pu-
\end{abstract}

- En el eudice originalque tenemos a la visla, se leia en este pasage: "Porque ha mas de tres aĩos uque desile Cuba passó eon mas rle.... hombres a "la lierra ques dieho é hasta agora, questamos en sel año de mill é quinientos équarenla y oeho (anwea puso euarenta y sietr), ni se sabe dél ni de whomire algnino de quantos eon él fueron. Plega á diera ser muy posible que le fuera más seguro reposo que rolver á las Indias, perdiendo sus çanançias é los hijos é la vida: la rordarl es cfućl era hombre desseoso de homra, pero ni sé si le euente por capitan ó por letrado.

Deste el estudio de Salamanca salió con título de bachiller para yr con Pedrarias por alealde mayor, y en Tierra-Firme usó acpuel officio, é á temporadas el de capilan: é despues que rolvió á España fué corregidlor en Madrid, é cómo tal salario

"Wios quél y ellos vuelvan con prosprridad." La muerle del gobernador llernando de Soto la irjó ya narrada el uismo Oviodoen el eapilılo XXIX del libro XVH, añadido en su mayor parte á la primera y úniea impresion hecha por él, siendo verdaderamente sensible que no se haya encontrado dieho cafílulo como en lit pág. 577del lumo l queda noiado. 
no le paresció tan colnarlo como los interesses de acú, dió la vuclta á las Indias con título de ligenciarlo, é fué oydor en el Audiençia Real, que reside m esla nuestra ciblad de Sancto Domingo de la Isla Española, é fué quassi a bsoluto é solo presidente en ella. Despues volvió á Tierra-Firme, donde le mataron los indios su hijo mayor, é despues murió él en ol tiempo de las contenciones de Piggatro é Alınagro, aviendo ydo á ponerlos en paz (si pudicra) en compañia de otros letralos é personas, que en lo mesmo se quisicron ocupar en valde; pues paró todo en romjimiento é mucrte de ambos golıcrnadores éde otros muchos, que sc melieron en sus passiones é pargialidades.

Escrílese de un grand músico, que no sabiendo to que se largia, se dió á componer versos, é por cllos perdió el arte de la música, é no supo uno ni otro. Assi acacsge á los que no ropossan en su arte prinçipal ó primero. Parósceme á mí que los lenados, cuyo fin fué aprender derechos, para tener officios de justiçiá abogar é ganar de comer con los litigantes, que la paz les es aborresgible é no son amigos della, en la qual su voto se debe tener por sospechoso: antes los juristas en tales casos (no se entienda de todos) tienen alguna similitud de los elérigos cohdiçiosos, cuya ganancia está cu la mucrte de otros; é assi, quando unos se messan y lloran, cllos cantan é resciben ofiendis.

La verdad es que la paz de Pigarro é Almagro nunca esturo tan fija, viniendo por causa de los terçeros, como quando no conferian con letrados, por cuyo malio llegaron las cosas il termino en que estám, é antbos muricron malas mucrtes, sin los quales estuvieran seguras sus vidas é las de muchos.

Dexemos cato, é rolramos al liecençiado Espinosa, que tantos delictos de capitanes disimuló é decó de castigar, , pue se puede tal piedad atribuir á notoria cruel- daul; pues en lugar de se enmendar los culpados, lo hiçieron despues peor, é mostraron á pecear ámuchos que no peecáran, con que vicran que aria justiçia en más del nombre. É todo ó la natyor pa:te proçedió de aquellas partes que los capitanes diban á este juez, é al gobernador, é al obispo, é al thessorero, é contador, é fattor en apuelias inderidas ga nancias.

La muerte de Pedrarias fue seyendo de mucha cdad, porque le oy decir á él mesno que avia seydo page del Rey don Jolian el segundo, el qual murió año de mill é quatrocientos é çinqüenta y quatro, é Pedrarias murió en Leon de Nicaragua año de mill é quinientos y treynta; por mancra que passaron enmedio septenta y seys años. Pues pónganse solore essos los que al letor le paresciere que avria este page, quando el Rey murió, é poco mas ó nicnos llegarám á los noventa años, é assi lagiéndole decrépito arrám alguna excusa sus errores, si no fucran tan crucles. Pero yo creo quél se engañala é se haçia de mas cdad de la que tenia. E como es dicho, passó destavida en Leon de Nicaragua, porque él y Francisco Hernaudez, que al parresger de muchos hico injustanncute degollar, fuessen sepultados en una iglesia, é que desde aquel pucblo firessen á la otra vida, si allá le la de pedir cuenta de su cabega; pero verdad es que tan presto van deste Roma como deste Jerusalem é Sinctiago al cielo ó al purratol’ó ó infierno, los que allí han de y’’, como deste aquestas Indias, y assi no ternian mas camino que andar las ámimas del adelantado Vasco Nuñez é sus consortes, que Pedranias hico degollar en la villa de Lela en Ticra-Firuc, é le hico denegar la apelacion para ante el Enperador, nuestro señon; ni Johan de Cuenca, (pue por un jubon de brite pae lumpó de la hagcienda dol Rey. que entre ma pared de cañas cstaba la mua manga on lis callo. é pas- 
samelo el otro por alli acaso. assió della é se lo llevó, que podria raler un pesso de oro ó dicz reales, fué fecho quatro quartos ea el Darien; é por ensoñaça de los médicos é çirujanos é industria del liçençiado Barreda fectıo natomía, miráludolo tales lombres é mugeres, que yo lie rerợienca de su desvergiiença cruel, que viendo tal caso con atençion esturieron : é por esso no quiero nombrar lales miralores, por no arergongar los viros que con ellos tienea debdo. Mas he queste yue assi padesció. no andaria mas leguas lasta el mas alto tribinal yue los pues dicho, ni de las que andavo uno, llimado Sancl Martin, deste la isla Dominica, donde le hico alorear el gobernador Pedrarias, su amo, sin le oyr ni dar tiempo que se confessasse. Desde á seys meses le liço laçer un proçesso en el Darien. Ni han tenido más lareas jornadas que caminar dos millones de indios que desde el año de mill é quinientos y catorce que llegó Pedrarias á la Tierra-Firme lasta quél murió, en espario de diez y seys años é algunos meses, son miertos en aquellas lierras, sin que seles dirsse ál entender aquel requirimien10 quel Rey Calliólico les mandó liaçer añtes de les romper la guerra. É no creo Iue me alargo en la suma de los dos millones que he dicho, si se cuentan, sin los muertos, los indios que se sacaron de a ficella grobernaçion de Castilla del Oro é de la de Nicaragua en el tiempo que he dicho, para los llevar por esclavos á otras partes.

El caso es questas cosas son de lanto pesso, que quien se acordare dellas, si lo rido, no puede estar sin dolor, ni los que lo oyeren sin aver compasion , escuchando tales é tan grandes vertinientos de sangre lumana, ni el inficrno está sin mucho regocijo de rerse tan multiplieado, si algun género de plaçer alí siente aquella infernal universidad.

Pues huena pró os hagan ruestras par- tes, crobermador é obispo é offiçiales é alcalde mayor, é arpuellos indios que os pressentaron aquellos capilanes con quien disimulaste, pertonando sus culpas, hariéndolas ruestras: que ningun cuerdo avrá que os liaya envidia de tales partes ni de las que ganaron vuestros mocos y esclavos y perros, que enviábades á las entradas con essos capilanes, ć os las daban sin que las meresciéssedes, en pago de la disimulaçion que tuvistes con sus errores, matando indios, é assando á otros, é haçiendo comer á canes los unos, é alormentando á muchos, é usando de innumerables adulterios con mugeres inficles; pues lo supistes é no lo castigastes, allá estays todos, donde verés á cómo se vende el pan en la plaça, é deçiros laan: ¡Alu fray! quíntos dineros!.. I cotejarés las haçiendas que adquiristes, con el reposo que allá hallastes; pues ací no os alargaron la vidia ni allí os excusarán la mucrte eterna, si Dios por su misericordia no os pertona vucstros peccados é tales ganançias.

Verdad es quel gobernador murió res. çcluidos los sacramentos, como catluólico, éplega á Jesu-Chripsto que fuesse manducando diramente y en estado de graria; é lo mesmo digro del obispo fray Jolian de Quevedo, que como la historia lo la dicho, murió çerca de Barçelona, yendo á diar notiçia á Céssar de otras cosas de la Tierra-Firme. É tambien creo que por descargo de su consçiençia hablíra en las que aqui he diclıo, si no se lo estorhíra lo que le cupo de aquellas partes, el thessorero Alonso de la Puente, que ordenaha aquellas iustruciones á los capilanes, para que paresciessen bien escriptas ó mal guardadas, é á él no se le pudiesse inputar que echaba su firma sino en cosas bien dichas; encubriendo su sagacidad: que era de los seys el mas apercebido é astulo para quel juego se anduviesse entrellos. Ýl como un fiel é hábil on negociaciones lo oidenasse por todos. 
Puédame fijo en la mente, por to que mi flico juiçio alcança, que si se le pregunfasse agora si supo que de quantas instruçiones hiço, ninguma se guardó, é si sabido, defendió é faroresció á los transgressores, ó á lo menos los que de su parte é á su ruego yluan por capitanes, y el obispo los (puél encaxala, y el contador Dicgo Marejuez á sus amigos, y el alcalde mayor lodos los quél queria a yudar, y el fattor Johan de Tabira lo mesmo, é creo que todos seys dirian é confessarian que diggo mucha verdad, assi porqué están en parte que la mentira no les puede ser ya caudal para interessar con ella . como porque conmigo no ternian excusa, pues satben que lo pule saher muy lien é vivi entrellos. Eil thessorero con muchos dineros se fué á España, despues que Pedro de los Rios se fué á Tiera-Firme, é no rivió mucho despues que allá llegó; y era va muy vicjo.

El contador Diego Marquez, murió en el Nombre de Dios, é despues su muger, é con hartos dincros, é tambien cra muy ricjo.

El fallor Johan de Tavira, yendo pol el rio grande que entra en el golpho de Irabá, se alıogó, como la historia lo la diclio. Pleza á Dios que á todos ellos les liaya tomado la muerte con arrepentinuento de sus culpas, y en tal estado, que sus ánimas consigan la gloria del ciclo.

Bien conozeo quealgunos me culparán en lo que he escripto, en espeçial los (que de los muertos quisieran oye de otra color la historia viendo que por ella se acuerdan cosas que fuera mejor que nunca fueran; pero mirad, lefor, que tambien lie yo de morir, é que me hastan mis culpas sin que Jas haga mayores, si no escribiesse to gierto, y entended que hablo con mi Rey, é que le he de derir verdad. É lo aviso para que provea en lo pressente é por venir , para que Dios sea mejor servido é Su
Magestad que liasta aqui : é que no meresçiera perdon mi ánima si tales cosas caJlasse, é que están muchas provinçias asoladas é yermas en eslas partes, é que no puede arer disimulacion tan tertible y es pantoso daño. Ni penseys que lo que en este caso aqui he escripto, ó la mayor parte dello, no to he dicho en España, y en el Consejo Real de Indias lo dixe mas ha de reynte y quatro años, y lo que se ha enmendado en estas cosas no ha seydo poco, aurque no del todo; porque es menester en algunos subgessos dar lugar al tiempo, y el largo camino desde acá hasta nuestro Prímecipe es luengo é dificultoso.

Pero no quiero ni soy de parescer quo se cargue toda la culpa á los seys ques dicho: ni tampoco absuelvo á los particulares soldados, que cono verdaderos manigroldos ó buchimes ó verdugos ó sayones ó ministros de Satanís, mas enconadas es. padas é armas han usado, que son los dienles é ánimos de los tiggres é lobos, con diferençiadas é inmoneables é crueles muertes que han perpetrado, tan incontables como las estrellas (todavia sacando é dexando aparte los virtuosos é comedidos mílites á quien eslas exorbilançias nunca pluguicion, é que en parte templaron é repreliendieron á los culpados, en quanto en cllo fué, é les pessó de todo lo mal fecho). Ni se crea ni sospeche que los que males semejantes acometieron, lo fueron á pagar at otro mundo; pues por no tener allá tanto que jenar, ó porque su castigo la de permanescer para siempre sin fin, ó començaron aqui á padesçer, para que acullá como á tales carniçeros sean tractados deste la hora que acé mal acabaron, los nıas de los mallıchores, é muy pocos son los que á su patria volvieron, en comparaçion de los que por estas mares é rios é arenales é montes é cerros é valles peresçicron, Imos alogados, otros comidos de peges é cocatriçes é grandes lagartos é tiJurones, ć otros de tigres é bestias fieras, 
é olros de ares, é olros dro lanubre é otros de sedl, é omos dre firos y helatos é otros á manos de los indios é de otras ma-

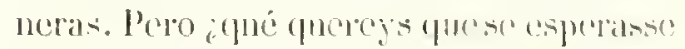
de tantas diforenciats é gentes a natromes mezcladas é de extrañas condigiones como á cotas ludias han renido é por cllas andan?. Tanto es arpuesto prejudicial, que los huchosé virhosos hiclalgos, é los perfellos españoles é gente de honra, que por estas partes estáu, viven é andan á mucho peligro.

Todo esto soñaba ó profetiçal a aquella muy Cathólica é Sereníssima Reyna dona Isabel, de imnortal memoria, quando ma!dó, é se guardó despurside mandidoen sus dias, que no passassen á estas partes de ninguna generagion, sino sus rassallos de la corona de Cistilla : cuyo es aqueste imperio ocidental, é aquessos dando primero informaçion cómo no eran sospechosos á la fée. ni hijos ni nictos de penitenciados por la Santa Inchisiçion, ni extrangeros. Despues, por culpa de los tiemposé negligencia de quien to pudiera excusar, muchas cosas se han hecho al revés de to que convenia hagerse; porefue agora peor está esta lierra quel area de Yoé. sin comlaraçion, porque allí aria solas ocho pelsonas, y essas sanclas, pues las escogió Dios para restaurar la humana gencrasçion, é todo lo restante era lleno de animales irracionales é bestias de diversos géneros, é acú hasla agera no reo otros sanctos sino aquellos mártires religiosos que los intios mataron en Tierra-Firme, como se dixo en el libro XIX, capítnto HI. Y tandien croo ane están con la gloria los que baptiçados lai llevado Lios en ealas partes en la colad de la inorencia é assi lo estarán los que en ella fucron. Mas e cqué diré de los que salsen perear, que no hay lengua en todo el mundo fue ací no haya passado, Hamámdose clripstianos? Mas queria yo mn buen fiador que me asegurasso si lo son todos, ó infreles algunos a pa- geanos, é delinciicutes, salvo que los mas dullos labtan castellano, para que blos y

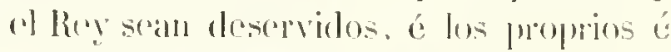

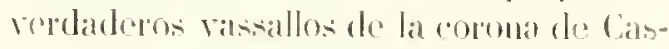

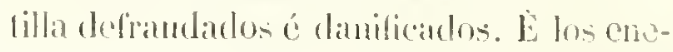
migngs de nuestra nascion emripnesecen é apoléranse con sus caulelas de nuestros interesses é fruclos desta tiema, con que despues hagan la gencra al señor della é á sus leates vassallos: é los (pue, por falta de habilidad, no pneden ó 110 saben contraharer nnestro romange, é trompegando en lo que diren se conosce, é claro, que son porlugucueses, Hámanse gallingos, é los franceses Ilimanse flamencos. 6 los suigos alemanes, é los italianos dífense siejlianos ó napolitanos. En lin. dando á entender á quien no los entiende que son de los scñorios de Céssar, passani como nosotros. Pues griegos é levantizcos é de olras nasciones son incontalles.

Scntiel é mirad entre estas generasgio. nes é diferentes calidades de hombres si arrá peccadores, éno de los comuncs assaz, sino de los mas perversos é desechados de sus proprias patrias, é de otras desterrados por sus nucritos. Ni tampoco es apriesto solo la causa de lia destruycion é assolacion de los indios, aunque harla parte para ello la causado esla mixlura: mas jumtos los materiales de los inconvinientes ya dichos con los mesmos delictos é suçias é bestiales culpas de los indios sodomitas, ylolátrias, é tan fatmiliares ć de tan antipuíssimos tiempos en la obidiencia é sepriço del diablo, é ohidados de nuestro Dios rino é uno, pensarse debe que sus méritos son capaces de sus daños, é que son al pringipal gimiento solure que se han fumblado é permitido bios las muetes é trabasos, que han padescido é padescerón lodos aduellos que sin baptismo salieron desta temporal vida. É am no dexo de sospechar que se perderám los mas de los que se bapticaren de la mancra questos nucsos 
negros se baptiçan, y como algunos capilanes han lıecho baptigar á muchos indios. Y no doy tanta culpa al capitan como al saçerdote que tan alto sacramento administra tan inconsideradamente, porcue los que tal haptisno lran de resceliir, seria justo que insitassen al cumuco que dico: "llé aqui cl aggua; dquien me prohibirá que no me haptiçe?" ' y (puel sacerdote se conformasse con lo quel Apóstol Sanct lelipe le diso á esso: "Si credis ex toto corde, licet.) ${ }^{2}$ Notorio esé infalible lo que dice la mesma verdard por la boca de su evangelista: "Qne quien creyere é fuere bapti. cado, se salrará, y cl que no creyere, scrá condenado." ${ }^{3}$ Jo me remito en todo á los sagrados theólogos.

Con todo, no purcde caber en mi cntendimicnto que sean chripstianos, conforme á cstas auctoridades, los negros ni los indios que son adultos é de edad, porque hay en cllos, allende de lo que estí dicho, que veo que allegan lioy muchos negros al puerto desta cibdad por la mar, y en desembarcándolos, esse dia ó el sisuiente lıcgo, sin quie entiendan cosa alsruna de la fée ni de lo que se les diçe, los baptiçan, sin quellos lo pidan ni conozcan el carícter que les invisten ó quisicron sus amos inrestirles; é non obstante la incredulidad é ignorançia de tales esclavos, envejesçidos en sus ritos é ydolatrias é çrcunçisos. É que para estos tales nuevos chripstianos é assi baptiçados ime constringan á sacar una çédula, para que puedan comer carne en la quaresma, sin saber ellos qué cosa es quaresma, ni arer entendido ni oydo qués la fée ni la Iglesia, é que por essa liçençia del provisor me lleven un pesso de oro, ó medio, segrund la cantidad de los negros que tengo,óin-

1 Las palabras del texto son: "Ecce aqua, quid prohibel me baplizari?.." (Actus apostolorum, capílulo VIII, vers. 36 ).

2 Id. id., vers. 37. lios, ó como los plaçe tasarlos. Yo no lo entiendo, é mas lo quiero pagar que disputarlo, pues veo que no hagen menos con mis verinos, puesto que los oygo quexarse desta limosna. Vurdad es quel consuelo que nos dan en csto es decir que tal monclis se allega para hacer una custodia para el Sanclíssimo Sacramento de la Eucarristia, é parésçeme sanctamente cmpleado; pero ni sé si plaçe á Dios dello, ni si los esclavos de los clérigos é de los monesterios ynte en esta cibdad tienen esclavos, pagan essas liçencias.

Dexemos csta materio é lagamos fin á este libro XXIX, é passemos á la provinçia é gobernacion del pucrto de Cartago é sus anexos, porque se continúc la órden que lrasta aqui se ha traydo en estas historias; pues lo que toca á la provinçia de Veragua queda cscripto, aunque mas açdental que Castilla del Oro; pero escribióse primero por las cuusas que la lristoria ha expresado, que fueron la propria nescessidad que lo causó para llevar regladas las materias, é aun prorque todo lo más de Cástilla del Oro entró In tiempo é antes cn la gobernaçion de Diego de $\mathrm{Ni}$ cuesa, con Veragua.

Todas estas cosas que están dichas, no os espanten, letor, porque si aveys leydo algunos tractados de guerras é conquistas de otras nasçiones, no os maravillareys de to que tengo dicho destos indios, donde grandes crucldades entro los orientales é diversas nasçiones lay escriptas; é la guera es la que camsa y causará, dó quicra fue la haya, grandes novedades é notables eventos, en especial, como he dicho, donde se juntan é concurren diversas é diferentes nraneras é costumbres de hombres á militar é segur la gucra.

3 San Nareos diee: "Qui eredideril el baptizatus fueril; salvus erit: qui verónon credideril, condemnabilur." (Cap. XVI, vers. 16.) 
Este es el líhro mndérimo de la segunda parte, y es el trigéssimo de la General y natural Iistoria de las Indas, islas y Tierra-Firme del mar Océano, de la corona é geptro real de Castilla é de los Reyes della, el qual tracta de la gobernaçion de Cartago é sus anexos.

\section{PROHENIO.}

E s tan copiosa é quassi infinita la abundançia de materias historiales, que cacla dia se nos aparejan é aumentiun para el colmo é definiçion destos tractados de Indias, que ni es posible poderse escribir todas en nuestra vida, ni se ha de perder esperança de hallar mas é mas diversidades que acresçentar é memorar en esta General historia, para dar loores á Diosé delectable ocupaçion ál los letores de aqueste tiempo é del que está por venir. É porque assi como la geographia é assiento de la tierra se vat mejor entendiendo, y ella mas palpalıle se nos manifiesta, assi va la Cessílea Magestad proveyendo de perlados é nuevos golsermadores é officiales en faror de la república cathólica é de su real serviçio, y exerçi- ten la ley evangélica por medio del çep. tro castellano en todas aquellas partes, que mas á este sancto propóssito convenga. Ofréscese una nueva gobernaçion para el puerto é provinçia que llaman Cartago en la costa interior de la Tierra-Firme, que mira al Norte é sus ancxos, con todo aquello que la voluntad real ha mandado juntar con la tierra ques dicho: de la qual mas difussa ó entcramente se tractarí en este libro XXX de la segunda parte deslás historias. I la dado cargo de esta adninistraçion é capitania general á Diego Gutierrez de Madrid, de quien Su Mlageslad quiso confiar la cmpressa, por su buen entendimiento é persona, puesto que de las cosas destas partes no liene expiriencia; mas como su buen natural é 
prudençia para esso é mas le abonen en el juiçio de los hombres, é de quien le fué favorable é interçesor alcançó crélito para ser proveydo de tal cargo en da voluntad real; y él se disipuso con la saya muy enteramente á ocupar su vida é liempo en lo yue le fué mandado, para que la gente natural de aquellas provinçias se conviertan á Dios, é la religion de los fieles clıripstianos sea mayor y en más partes é reynos aumentada. É con una hermosa é armada nao, é bien acompanado este golsernador le cavalleros é liidalgos é luçida gente, annque de poco número, llegó á esta cibdad de Sancto Domingo de la Isla Española á los çinco dias del mes de julio de la matividad de Nuestro Redemptor, de mill é quinientos é quarenta y un años, donde se hiço de mas gente é caballos é otras cosas á su empressa nesçessarias; é con hasta doscientos hombres muy hen aderesfados é proveydos, salió del puerto desta ciblad el siguiente mes, á los çinco dias de agosto del año ya dicho, en la mesma nao que vino, é con un bergantin, en continta çion de su viage para la Tierra-Firme. É despues, á los catorçe dias de otubre, salió otra caravela, que aqui dexó fletada, en su seguimiento con caballos é otros suplimentos para la empressa.

Bien creo que no fältarán fatigas á estos nuevos pobladores, porque las cosas destas partes, hasta estar los hombres diestros y hechos al ayre y exerçicio de la tierra, siempre los prueba alsuna enfermerlad, demás de haçerles probar otras nescessidades quel tiempo dispone; pero como diçe el Ipóstol: "El que no quisiere trabaxar, no coma '. "Pues los mas de los que acá vienen es porque no tienen en su patria lo (que avrian menester, tan copiosamente como sus lindos desseos é mérilos de sus personas lo piden, aparésense á sufrir, é pónganse en aquel cusclinlo é obra, con quel buen ballestero suele jugar la hallesta: que demảs de traerla tal qual debe ser para su exercicio é punteria, son los lançes é viras tan bien labradas, é las plumas assi ordenadas, y el luraço tan sosegado, é la vista tan viva é constante, que poniendo los ojos, no solamente en el blanco á que tiran, mas en el fiel, en que dessean açertar, no yerran el tiro ni pierden el tiempo é gaman el presçio. Y assi en estotro juego del mundo, en que estos otros vienen á emplearse, deben traer sns armas é almas tan á propóssito del camino que laçen, que por pensamiento no les passe, ni por obra jamás cometan, de se apartar ni quilar los ojos y el coraçon de aquel terrero glorificado é llaga del costado de nuestra redempçion é lumanidad é divinidad de Jesu-Chripsto, Nuestro Salvador, para que den en el fiel $y$ quede ficl el mílite conquistador, y convertido é seguro el indio conquistado, y el soldado ó poblador no se aparte, por memoria de aquella presçiosa sangre, de sacarla de ningmua otra criatura, en quanto posible le fnere. Porque yo os digo, que los que, sin este cathólico fundamen. to, acá derraman la sangre desta gente salvage, pero prógimos nuestros, siempre les da Dios el pagro que merescen, é los menos vnelven á España; é por uno que açierte á enriquesçerse destos bienes temporales, michos se pierden.

Testigo soy de lo que digo, é por estos tiactados lo podrés mejor entender los que desta leçion quisiéredes parte. Pienso yo, por lo que se me ligura de la persona deste gohernador, que dessea agerlar á servir á Dios é á su Prínçipe; é cómo este sea sı fin, assi será el cunél hará a propóssito de su salvaçion é honor de su persona, y el Espíritu-Sancto le darí garaçia para ello. I quando assi no fuesse, 
demlís de quedar obligado con su ímima 6 viela á la pagra que de lobos é á la jusliça rue dal Rey coperar. Lambien ladlará en unis renglones la medicla de sus olmas. Plega á arpecl, de quien todo lien progede, que-te gohernador las laga tales, que al que las oyrore. le dé alessco de imitarle é layga de qué avertr envidia los virtuosos. y $u$ dé que arer lístima de su subgresso é gobernacion.

\section{Capitulo I.}

Como lieno fultierrez, gobernador de la provinçia de Carlago i sus anexos, fué bien resçebido éobedes-

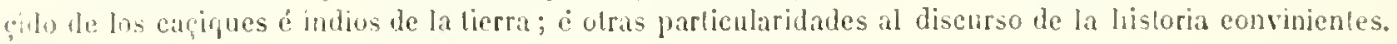

(Q) mando Diego Gutierecz estuvo en esta ribdad de Sincto Domingo, yo le comuniqué, conno amigo, é aun le dixe mi parescel, porque de años atrás nos conosciamos; é si yo supe entenderle, paresçióme que su intento era sancio, é no inclinado ni dispuesto á malas ganançias, ni á Inaltractar los naturales de aquella tierra donde yloa, sino aprovechar sus ánimas, é no ultrajar sus vielas ni robarlos. Y como era liombre bien hablado y de buena crianç, é mostraba ser çeloso al serviçio de Dios é del Rey, yo pensé que assi como lo reçia, assi lo pusicra por obra; aunque como en la introduçion ó prolıemio deste libro ya yo dise cuél no tenia pxpiriençia destas cosas de Indias, sé que nunca falta un cabestro de los desalmalos ó pláticos que por acá laan andado, que á los noviçios ó nuevamente venirlos a gobernar los enseñen á robar: y aque. llos, assi por la dispusiçion que hallan on el capitan pue viene y en su pobreca, como en la faita de providencia para se guardar de tales ennsejeros, dámles crédito é olvidan el lıuen propóssito é voluntad del Príncipe que los envia, y el temor de Dios. is por enriquesçer, presto ruelven la hoja, é trocado el intento con que particron de España, si bueno era, ó afirmado en el cauteloso que en su pecho eslaba callado, en poco ticmpo manificstan lis obras el contrario de las palabras, con yne se ofrescieron á servir al Rey en tal cmpressa. L como ya tengo dicho, los mas de los que acá vienen son hombres nesressitados, y este lo cra muclıo y cu muchos hijos. Nas pensalua que auncpue assi fucsse, podria mas la vergiiença é ronsciençia que los otros desseos de adquirir dineros; pero no me descuydé tanto en este cródito, que dexasse de sospechar lo contrario, acordándome cómo su padre, el thessorero Mlonso Gutierrez, allegó su hageienda muy desviadamente del arte militar, en que su hijo con esta empressa se queria ocupar. Pero tambien aremos leydo que muchos grandes varones acertaron á tener tales personas, que dieron, seyendo plebeos é baxos por sus predecessores, grand resplandor é fama á sus desçendientes, é ilustraron sus linages; é otros. por el contrario, que nascieron é se criaron con porterosos patrimonios y cncumbrados estados, hiçieron tales olvas que deshoniaron á si é á sus passados. De manera que á ninguno debemos juzgar por malo ni por bucno, lasta rer qué pintura é matiçes él dispone é compone en su vida é fin: é por csto dixe en el prohemio que mis renglones se couformarian eon la medida de sus obras ( con la simpliçidad é verdad que la listoria requiere).

$Y$ antes de renir á essos términos (pues el tiempo nos lo ha de enscĩar y (lisponer), digo que Cautago es una provinçia, assilla. mada á disparate por los primeros clırips. tianos que allí andovieron, eficne un ancon 
grande é lleno de isletas: el qual cstá en la costa de Tierra-Firme, entre las gobernaçiones de Veragua é llonduras, é puntualmente aquel embocamiento está en catorce grados é medio desta parte de la línia equinoçial. É dióscle por términos desle allí aluaxo al Oçilente hasta el rio Grande, é á la parte de Levante ifusde el diclio puerto de Cartago hasta los confines de Veragua, ques el ducado que se dió, con tílulo de Duque de Veragua, al ilustre almirante don Luis Colon, á quien el Emperador Rey, nuestro señor, lo la conçedido por mayorazgo para él é sus subcessores en esla gobernaçion, assi como es dicho, limilada á Diego Gutierrez. Es muy fértil en parte, é áspera en algुnas partes, pero de muy ricas minas é otros provechos, de queste gobernador é sus mílites podian ser aprovechados, si fireren para ello; é es lierra sana é de buen ayre é buenas aguas. I tambien hay gente belicosa en los naturales: es tierra de mucha monteria é de muchosé diverssos animales, é andau los hombres desnudos é las mugeres, é son ydólatras en diverssas maneras é ritos. Pero comunnente en todas las Indias conosçen que hay un Dios todopoderoso, é acjueste por diverssos nombres é diferentes maneras tractan dél, é sienten como ydólatras y envueltos en inmmerables errores, quel diablo les da á entender: el qual tiene mucha parte en ellos, como cu gente desapergebicla é apartada é sin defensa para su salvaçion, é sin conosçimiento de la fúe é verdad de la passion de Chripsto, Nuestro Redemptor; pero por su misericordia é con la conversaçion de los chripstianos se convertirám, é querrá Dios (que se salven é se te quile á Satanás la jurisoliçion que liene allí de tantos siglos usurpada, tragando tan incontables ánimas, si la coludicia de los que los han de enseñar la fée no se convierte en los malos usos, que en olvas partes de aquestas Indias han usado los conquistadores, qué nejor se pueden decir despolbladores é disipadores de las licras nucvas, en (fue sus peceados los han traydo á lagerer mal fin, la mayor parte de los tales mílites. Plega á Nuestro Señor queste goliernador se dé mejor recabdo del que en la dicha Veragua se dió Folipe Gutierrez, su hermano, de donde ss'ió con poco honor é con mucha vergiiença suya (como se dixo en el libro XXYlll desla segunda parte de la General historia de Indias), donde, demás de perder la mayor parte que llevó, á los que le quedaban dió cantonada é los dexó en poder de los enemigos, y él se luryó é se fué cautelosamente de la lierra, éá ella é á ellos desamparó: lo qual castigó Dios despues muy léxos de alli, en el Perí, donde fué á piarar, como se dirá en la tercera parte destas historias.

\section{Capitulo II.}

Del subesso del gobernador Diego Gutierrez, é de su cobdiçia é mal evento ; é cúmo le maltaron los indios á él é á quantos espanoles consigo tenia, excepto siete humfres.

\section{Y.} o tení siempre queste gohernador era mejor hablado que apercelbido para el cargo que llevalsa, é assi me paresçe que le sulgcedicron las cosas como él tirvo el saber é maña. Assi salve Dios mi ánima como yo holgúna quél açertitra á servir á
Jios é á su Rey é ál hager bien sus fiochos; mas fué por el contrario, é decirlo lie aqui con las menos palabras, que me sea posilsle, porque me paresçe (quél se dió tan mal recablolo, que quanto mas silençio yo turiere, tanto mejor él libra, é 
su mala maña menos se silhrí. Pero no callaré lo que en esta cilulatel de Sincto Domingo yo entendí de un liddalgo montamés, llamedo Johan de Espina, natural de la villa de Laredo en la montaña (que al pressente, que estamos en fin de otubre del año de mill é quinientos é (juarenta y çinco , está en esta cibdad de Saneto Domingo), el qual se halló á la muerte de Diego Gulierrez; y diese que desde fue salió Diego Gutierrez desta cibdad, liné á la isla de Janáyea, donde se le amolinó la gente é se le quitó el aprarojo para yo á su gobernaçion, á calusa de lo aual con muy pocos se fué deste Jamályca al Nombere de Dios, pensando deste alli contimuar mejor la cupressa, é adolesció y esturo muy gerea de partirse desta vida. En el yuil tiempo y enferme. dard se le fuć el resto de la grente al Perí ca cil otras partes. donde les paresció que tarian mejor stas lichos. ć lo devitron solo. Dispues que sanó, acordí de se gr leste el Nombre de Dios á Nicaragua, con solos quatro ó çinco lombres, é fuć al desaguadero de has ligunas de Nicarazha. que salen aquellats ayuas ál esta muestra mar, gerea dol puerto que llaman Cimtago, é deste desaundero se liné á

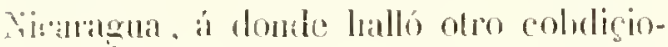
so, llamado Bacha, que renia del Perú rico: é aqueste le prestó al gobermador Dego Guticrez tres mill castellanos, con que higo sessenta hombres, con que fué á Nicaritgua. I el Diegro Gutierrez deçia que todo aquelio cra de su gobernacion, é liço pregronar que só pena de cient açotos. ninguno llamasce á aquella tierra Teraguar, sino Carbago é Costa Rica : é desprea flue allí celavo un año ó más, porye filtaron los bastimentos, se le amotin i la grente é se le fornaron á Nicaragua;

* Oriedo escribia en 1545 el presente eapílulo: sagunconsta por el siguiente, proseguia este libro in el de 1517, apareciendo, como se notari despues, que se proponia acrecentarlo con los sucesna é este gobernador se quedó con seys homlues solos an Vorigua, é aquellos que se le fireron, liallaron, llegados fror lierra al desaguatlero, riertos bergantines, que Ios Ilevaron al Nombre de Dios. P'ero aunque este gobernador estaba solo é con tan pocos chripstianos, como tengo dicho, no dexalan los indios naturales de les dar de comer é oro, sin haçer mal ni daño á ninguno de los nuestros. P'ues viendo el gohernador que le convenia busear mas gente ó dexar la licrra, acordó de enviar un pariente suyo al Nombre de Dios, el qual se llamalua Alonso do P'isa, con ochorientos pessos de nuy buen oro en águilas é otras piegas de oro que le arian dado los indios, porcue ya tenia dos caçfues de paz y heelos muy amigos. Con aquel dinero d Alonso de Pisa hiço çinquicnta hombres, que llevó á Yeragua, con loz quales, y en el número que tengo (lichı, fué este Johan de Espina. Con esta šcnte el gobernador se holgó mucho, é les dió harlas palabras é ofresçimientos; é desde algunos dias tornó el gobernador á enviar el mesmo Alonso de Pisa al Yombre de Dios con otros mill é quinientos castellinos, que se fundieron en Panamí, é llevó otros treyntạ hombres. Á essos ochenla diomhres ó pocos mas cliripslimos que ya eran, los indios les daban uny bien de comer maliz é carne de monterias é poseado é todo lo que avian menester . é cada dia traian oro al gobernator, el qual, como hombre de ninguna espiriencia, prendió á uno de aquellos caciques, que estaban de paz, que se decia el Cama (cl qual era muy rico), porque no le daha tanto oro como este gobernador le pedia: é sobre esto, é por le amedrentar, le laçia el gobernador fieros é le amonaçaha que le avia de matar, é

que fucran ocurriendo. Tal es en efecto el método seguido por él conslanlcmente, al escribir estas hisforias, como se habrí ya visto con la lectura de los fomos anleriores. 
para mas le atemoriçar, sacaloa la csparda desnula el gobernador, é dábale á entender que le avia de matar é cortar la caheca, si no le daba quanto oro tenia. É acabado este fiero, laçia llevar allí donde el caçique cstaha alquonos lobreles é perros denodados é hravíssinos, é haçíale deçir por la lengua ó intérpetre que aquellos perros le avian de comer é despedaçar al dicho caçique, si no daba quanto le pedian los chripstianos. El caçique, viéndose tan molestado, sollóse una noche é apellidó la tierra, é confederóse con otros caçiques é indios de las comarcas, é quemaron sus proprios puehlos é sus haçiendas é maliçales, é passaron de la otra parte de la lierra háçia el Sur, é dexaron en hlanco á los cliripstianos, sin quedarles de comer, y en tanta nesçessidad, que les fué ferçoso dexar su campo é assiento é yr tras los indios: é á çicrto passo, cómo el gobernador no cra diestro en las cosas de la guerra é dormia en su cama de reposo, sin tener las velas el cuydado que convenia, dieron solure los chripstianos, ć mataron ál ellos é ál su gobernador. É de oclienta hombres ó más no escaparon sino siete chripstianos, que fueron un clérigo, llamalo Diego Baxo, y este Johan de Espina é Luys Carrillo, é Tello Carrillo, ó Salaçar, é Françisco Hernandez Herrador, natural de Marlid, é otro hom. bre, (que no le supo el nombre el que dió csla relaçion.

Fuć lia luatalla en el mes de jullio deste pressente año de mill é quinientos é quarenta y çinco años, é de la otra parto de las cunbres, aguas rertientes á la otra mar del Sur; é lialláronse en ellas solno tres mill indios, é muchos dellos con pectos é braçales de oro é otras piecas, é con trompetas á manera de añafiles, de longura de tres palmos, assimesmo de oro, el qual en arjuella lierra liay mucío é muy fino. $\mathrm{Y}$ el golsernador en essa sucon mandala mal su persona por- que andaba tullido de gota é quatro negros le traian echado en una hamaca, lo qual le debiera bastar para ser mas paçiente con los indios; pero como ćl lo haçia, assi le dieron el pago ques dicho, é le tomaron á él é á los orros clripstianos, que allí murieron, sobre çient mill pessos de oro, que en paz é de su grado los indios les avian dado: é todo lo llevaluan consigo, porque como la tierra que dexaban atrás quedaba destruyda, tenian determinado de poblar donde mas aparejo hallassen é fuesse á su propóssilo; pero los indios, como gentes de guerras, llevaban espias sobre ellos, é no daban passo que no fuessen avisados por un indio que era ladino, é servia al golsernador é su gente de lengua ó intérpetre. Y este era el que los vendió á essos chripstianos é daba notiçia é aviso á los indios de todo, é por su industria los llevó á donde se perdieron, aunque fuć con muchas muertes de los indios. É los siete hombres que escaparon deste trançe, fué porque se metieron la tierra adentro; é otro dia des. pues de la hatalla vieron la otra mar ó costa del Sur, é porque no se pudieran salvar de otra manera, dieron la vuelta, tornando por mas háçia el Oriente á encumbrar la sierra, é volvieron á la otra costa desta parte háçia el Norte, éfucroa á parar al desaguadero de las lagunas de Nicaragua, que vaçia ó corre é entra en esta mar nuestra; pero hasta llegar allá, en tanto que continuaron su fuga, corricron mucho peligro, assi por temor de topar con indios, como por el exçesivo trabaxo de sus personas, é porque la hamlıe les aquexalıa, á la qual satisfaçian, comicndo liervas no conosçidas é lagartos é otras suçias viandas, é aun essas les faltahan. Pero encomendándose á Dios , é no cessando de caminar de dia é de che, llegaron, como es dicho, al desaguadero, é alli los tomó un bergantin que yha al Nombre de Dios, íl donde los lleró. 
Desde allí vino este Johan de lispina á esta nuestra cibdad de Sancto Domingo de la Isla Española, é cómo yo supe quél se llegallal á la casa del señor almirante duque de Vuragua, don luys Colon, pedile por merced que me hiçiesse ver con este lombre: el qual le mandó que me viesse, é hoy miéreoles, dia de Sanet Simon é Judas $\Lambda$ póstoles, veynte y ocho de otubre de mill é quinientos é quarenta $y$ çinco años, me dió la relaçion que tengo dicho. El qual paresce en su persona é manera que sus palabras son veras á la llana, é con la simplicidad é falta de ornamento retórico, como buen montañés hidalgo. lí porfue en esta sacon el señor almirante está aparcjado é armado para enviar un capitan con gente á poblar á Veragua, ques suya, como tengo dicho, y el Limperador, nuestro señor, con lítulo de duque della se la conçedió, pregumtéle á este Johan de Espina si entendia volver á aquella lierra, é me dixo que de muy buena gana yrá en esta armada del almirante, porque cree que no puede $\mathrm{yr}$ ningum capilan que no lo haga mejor quel Diego Gutierrez. El qual, segund este hombre dise, era mas çerimonioso (que mañoso, é ya le llamaban vuestra señoria, é assi tullido, estaba tan soberbio é mal acondiçionado, que era incomportable: todo lo qual pensaba yo dél al contrario, porque me paresçia hombre llano é sabio. Pero este oro y este mandar no se asienta de una manera en todas cabeças, la qual si él toviera como su padre Alonso Gutierrez, se diera mejor recalsdo; porque fué un liombre reposado é salio é allegó mucha hacienda por otra manera de exergiço léxos de la miliçia. É apuel arte debiera de seguir su hijo, a no muriera ni acabára de la manera queslá diclio; é assi acaesce las mas veces ál los que se introducen en oflicios agrenos. Dios le perdone á él é á loulos los demás que con él se perdieron, que en la rerdad mucha láslima es de aver de todos ellos; pero estos ánimos grandes é inquictos de los españoles, y esta inclinaçion natural, que tienen, á ser mas é á no se contentar con poco, causa lales empresas: y altévense at tomarlas hombres sin expiriençia, como era este, é sacan dellas mal nombre, con pérdida de sus proprias vidas, é háçenlas perder á otros muchos, que sin consideraçion ni entenderse, se allegan á ellos.

Todo esto ques dicho mas anexo era al libro XXVIII, ques el IX de la segunda parte destas historias; mas como este gobernador dió otro nombre ó título (ó mejor diçiendo Su Magestad) á la empresa quél llevaba de Cartago, é se entrometió en usurpar á Veragua, assi ha seydo nesgessario que la historia se relate. É assi hará fin aqui por agora, como el negoçio ha subçedido hasta quel tiempo muestre otras cosas, las quales, si fueren deste jaez y en mi tiempo, se pornán aqui segund subçedieren. Plega á nuestro Señor quel que agora vá á Veragua por el almirante, lo haga de manera que sea Dios mas servido que lo ha seydo de los que aquessa negoçiaçion é empresa han tomado. 


\section{CAPITULO III.}

Ln rue se haçe relaçion del mal subẹcsso del armada, quel almirante envió á poblar su dueado de Veragua.

1.

a dixe de susso que aquesto es para la gobernarcion de Veragui é no de Cartazo; pero quiso Diego Gutierrez laser á Teragha Cartago, é por esso quise aqui Irevemente poner lo que mas largo quedla richo en el libro XXVIII, capítulo VIII. Y es quel año de mill é qụinientos é quarenta y seys fué en nombre del almirante su teniente é gobernador á Veragua, llamado el capitan Cluripstóbal de Peña con hasta çiento y treynta hombres, é por sacar de verguiença á Diego Gutierrez, puesto que estotio era liombre que ha tiempo que anda por Indias, y estimado por diestro, 0 que ello fuesse por estar los inclios alçados, como se La dicho en el capítulo preçedente, ó por descuydo deste capitan, él é los que llevó libraron mal. É quando se supo por mí aqueste trabaxo dessa armada del almirante fué el año de mill é quinientos é quarenta y siete, es. tando yo en la córte del Prínçipe, nuestro señor, donde supe por carta de un cavaIlero, Ilamado Johan Mosquera, suegro del

- En cl MS. original, que sirve de texto, mostró Ovicdo tener ilea de continuar este libro con nucvas noticias, conforme manifiesta por las úllimas palabras de cste capítulo III, lerminado el cual

mosmo almirante, é de otros, fue me escribieron quel capitan Chripstólual de Peña, que avia ydo á Verąua, aportó al Nombre de Dios muy perdirlo, é que en Veragua le desbarataron los indios é le mataron la mayor parte de la gente que avia llevado; é entre los otros murió don Françisco Colom, hermano del almirante, y escaparon solamente quinge ó vernte hombres. Assi paresçe que queda algo desculpado Diego Gutierrez, pues que estotro capitan era diestro é saluia cómo le avian muerto al predeçesor en el offiçio.

Estas cosas destas Indias van por otros términos que las de Europa, porque en las Indias no pagan los thessoreros á los soldarlos, sino ellos mesmos se pagan, é aun ellos mesmos con su colddiçia se acaban.

Basta lo dicho hasta ver quién subçede en esta materia ó gobernaçion de Cartago: que no faltará otro cobdiçioso; pero qualquięra que sea, plegga á Nuestro Señor que açierte mejor" que los passados *

escribió: "Capilulo iV." Mas lıubo sin duda de sorprenderle la muerte antes de que pudiera ejecutar su propósito. 
Este es el libro duodéçimo de la segunda parte, y es el trigíssimo primo de la General y natural IIstoria de las Indias, islas y Tierra-Firme del mar Océano: el qual tracta de las provinçias a gobernaçiones del Caho de Itigueras é f'ucto de Honduras é de Yucatan; y despues torna á dexar á Yucatan é se junla con Guatinala é por tanto este libro es mas anexo é dedicado á la gobernaçion de Honduras.

\section{PROLIEMIO.}

- Olı fortunado, olı dichoso mançebo, que Lallaste á IIomero por pregonero de tus virtudes!" "

Conforme á esto, Françisco Petrarea, en uno de sus amorosos sonctos, diçe:

Gionto Alexandro á la famosa tomba Del fiero Achile, sospirando disse:

o fortunato, che si ehiara tromba

Trovasti, c chi di te si alto serisse?..

Quicren deçir sus verssos toscanos: "Llegado Alexandro á la famosa tumba del fiero Acliiles, dixo suspirando: joh afortunado, yue tan clara trompeta lallaste, é quien de tí assi altamente escribicsse! Plutareo diçe, en la vida que escribió de Alexandre Magno, que yendo contra Da-

- Las palabras de Ciceron, a quien se refiere Oviedo, son: "Fortunate, inquil, adolescens, qui rio, quando llegó á Troya, hecho el sacrificio á Hinerva, y heclas las obsequias á los semideys, despues corriendo en torno de la estálua de Achiles, juntamente con los compañeros, ungido de ungíento é desnudo, como era usança, coronó aquella estílua, Ilamando á Acliiles folice, porque en tanto que fué vivo ovo tan fiel amigo en Paltoclo, é despues de la muerte un trompeta tal como IIomero.

Estas palaluras de Alexandre muestran la envidia que ovo de aver tenido Achiles tau alto escriptor para su historia, é quél para la suya no tenia tal coronista; porque en la verdad el estilo y elocuençia del auctor de una famosa historia mucho 
la engraudesce é sublima por el ornamento ale su grargiosal pluma é sillo proseder, ó muelro le quita é disminuye del proprio valor, quandoen cl tal eseriptor no hay la habilidad que se requiere en cosas grandes.

Esto filta aqui por cierto, a yo confiesso que por tantas é lales é tan diverssas materias, como son de las que yo aqui tracto, fuera nescessutio otro ingenio quel mio; pero en confiança desta verdad á que roy arlimado, espero, si yo no hasto a tanto ilustrar nui obra (como lis que otros grandes varones escribicron) basta para mi consuclo é á la satisfargion de yuicm lee, que la anctoridad que acullí se da á Ilomero, era supliendo él la materia, é que aqui supla la materia al defetto de mii pluma é ingenio, para que no dexe de prareseger hien á los que vieren estas hislolias.

Junto con esto, me paresçen cosa ridícula las grandes peregrinaciones de la navegacion que de aquellos griegon se escriben por grand cosa, assi como yr de Greçia á Plırygia é Troya, é eomo venir lineas de Troya á llalia é como esso que de Ulixes se encaresce que anduvo vagando, en tanto qun la casta Penćlope con su tola le atendia, diez años texiendo de dia é deshaçiendo de noche, por no tomat otro marido, como la importunaban; y ella daba por su cxeusa, que acabada la tela le tomaria, é assi dilató las segundas bodis, é las excusó como buena, hasta que rino su marido.

Todo lo que Ulixes navegó en su vida, es mucho menos rue venir deste España á nuestras Indias; é por luengo é dificultoso é peligroso é eostoso ques cste camino, digo que en esta ciblad de Sancto Domingo vivió un mercadel lonrado, llamado Francisco IIcruandez. ć lan amigo de sus amigos, quél é su muger fueron convidalos, para ser par. drinos, á las bodas de otro sll anigo. que le escribió desde Sevilla que los cestaloa atendiendo para se velar é resceluir las bendigiones de la Iglesia con su muger; se particron de aqui en una nao, é llegados en Sevilla, se velaron sus ahijacios, é so tornaron luego sus padrinos á esta cibdad á su casa. E hoy dia vive ayui la muger de aqueste Francisco llemandez. que assimesmo era natural de Sevilli. Esto me parescia á mí muy mas camino que lo que los griegos ni los troyanos navegaron, porcue por muy luenos tiempos que se les liçiessen, en la yda y en la renida naregaron tres mill leguas, poco mas 6 monos, este muestro vecino é su muger en pocos meses.

Calle la nao de Argos, pues rimos poco liempo á la nao nomlerada la Victoria, que çirenyó el universo en el descubrimiento de la Espeçicria por aquel famoso Fstrectio quel capitan Fernando de Magallanes cnseñó. Aquel fué el mas luengo camino que hasta hoy se sabe rue lombres morlales hayan fecho (aunque se ponga á su comparaçion aquel viage de Nistro y Carabiso, enviados por Alexandro Magno por el rio Thanais, de quien Leonardo Aretino hace memoria en su suma de chrónieas, Ilamada el Aquila volante '. é diçe que llegaron al Parayso terrenal): que esso, é todo lo que está escrip10. é hombres liasta nuestro liempo lian visto, es mucho menos que lo que nuesros españoles han navegado, assi en aquel viage de Magallanes, como en ol que despres hico el comendador frey Gal-cia de Loaysa, por el mesmo Estrechn: pres algunos volvicron á España por la via del Levante. deste la Espeçieria, aviendo ydo allá pol el Oşilente, é dieron una vuclia al miverso, assi como el sol acostumbra á dal cu afuel paralelo, él por 
su superior curso, y cstos otros por al corporal elemento del axula. Quicro deçir on fin, que las cosas, de que aqui se traclá, sonu cll sí uny grandes é peregrinas, é que basta narrarlas llanamente é sin metíphoras, por ser tan singulares é nuevas é conformes á verdad, é tan sin olligaçion de afeyte ni corolarios de fálnnlas : é assi por su calidad como por mi condiçion, digo (jue antes estará derecha la tore Gatrisenda de Boloña, que mi pluma se tuerça é aparte de la verdad, puesto (que por mi colad va cansando la mano é cresciendo la volumad, para no desar de trabaxar ch sacar á luz estos tractados, auncue cono diçe Job): Quién une otorgará que yo sei, segund los nueses passados 4 . El questo puede lagcer es aquel de quien todo to lueno há sur prinçipio, el sine ipso factum est nihil ${ }^{2}$ : y por su medio é favor avráfin perfetto esta Natural historia de nuestras Indias, para que á su sancto serviçio goçen della los ausentes, é la estimen como cosa en que hallarán muclas vias é maneras para darle gracias: y los pressentes que acá en estas partes me oyeren, toparán en mis renglones assaz exemplos en que castigar é corregir sus vidas, mirando las de otros que por acál han seydo personas señaladas; é los por renir entenderán una historia vera, é tan grande, que de su calidad no se sabe otra tan copiosa por un solo auctor escripta, para lo qual conviene traerles á la memoria lo

1 Job, cap. XXIX.

2 Johan., cap. I. quel Proplucta dire: "Si no crevéredes, no entenderés."

Pues entended, letor, quel que prido hager el mundo, puede aver en él ordenado é criarlo todo lo que destas partes se puede expresar por roz limmana, é micho mas, sin comparacion, en lo que queda por deçir destas Indias.

Este libro tracta de la gobernacion del puerto de lligneras é Cáloo de Honduras, é de la provinçia de Yueatan, que la Gessúrea Magestad tuvo encomendado al arlelantado don Françiseo de Doniejo, su capilan general é gohernador: y deçirse ha con brevedad to que liçiere al propóssito de la lristoria, é sacar lie fuerças de mi Alaquega para ello, pues dice Sanct Gregorio, quel poderio del socorro divino nunca desampara nuestra buena intencion ${ }^{3}$. É si como ella es, yo lo açierto ádeçir, no me quedará de qué temer al que murmurare de mi trabaxo, si en él hallare algunos passos, en que le parezca que puede emplear su lança, juzgando mi obra no tan aplaçible como él la desseaba ó quisiera; porque este tal no será sino alguno que quisiera mi pluma á sabor de su paladar, é no al de la justicia é verdad.

Esta provinçia é puerto de Honduras ha seydo reyno é gobernaçion de contençiones é trabaxos para los capitanes é cliripstianos, que á aquella tisrra han ydo, como por sus muertes y vidas se puede colegir del pressente libro é capítulos siguientes.

3 Moral., lib. IIl, cap. XXIl sobre el It de Jut. 


\section{CAPITULO I.}

En que se tracla del descubrimiento del Cabo de Higueras é puerto de Houduras, è de los capitanes égobernadores que alli ha avido, ¿̇ otras cosas concernientes á la historia.

E n el libro XXI, capítnlo XXVIII, se dixo que la provinçia del Cabo é golpho de Honduras, lo avian descubierto con el Cabo de Iligueras los pilotos Viçente Yañez. é Johan de Solis é Pedro de Ludesma : é assimesmo dixe en el libro XXI que la punta ó Cabo de IIonduras está en diez y seys grados y medio desta parte de la línia equinoçial, y el Cabo de Iligueras está en onçe grados y medio de la Jínia, é lo que hay desde el un Cabo al otro queda particularmente dicho en el lugar alcgado. Destle allí se sube la costa al $\mathrm{Nol}^{\circ}$ te, çircuyendo la tierra é golıernaçion de Yucatan, que algun tiempo pensaron algunos que cra isla, no siéndolo, sino toda una costa. Pero porque estas provinçias han estado en diverssos gobernadores administradas, é cadia una por sí, diré primero de la de IIonduras, porcue la órden historial que he proseguido no se rompa. E assi digo, que despues quel capitan Gil Gonçalez descubrió á Nicaragua, vino á esta cibulad de Sancto Domingo de la Isla Española , é tornó á armar ; é desde aqui envió al contador Andrés de Cereçeda á España, á informar al Emperador Rey, nuestro señor, de lo (que avia hecho en su descubrimiento por la ma del Sur, é cómo por continuar su real serviçio estaba en esta cilsdad aderesçíndose para volver á continuar aquella ent-

- En el códice original, que sirve de texto, apareçen los elaros que aqui se dejan, no siendo posible llenarlos con exaclitud, por no luaber fijado Oviedo el número de la gente, quo llevó consigo Gil Gonzalez Dávila ni en este ni en el capítulo XXI del libro XXIX, en que refiere la parte de eslos sucesos tocantes á la gobernaçion de Caslilla del Oro.

* Debe notarse que Oviedo se refieve arai al pressa, y entrar por esta mar del Norte por el Cabo de Honduras, donde en aquella costa ó por allí çerca pensaba hallar el desaguadero de la laguna graude de $\mathrm{Ni}$ caragua. É fecha relaçion desso por el Cereçerla al Emperador, en Burgos, año de mill é quinientos é veynte y quatro, Cússar se tuvo por servido del capitan Gil Gonçalez, é le envió á mandar que prosiguiesse su empressa; é assi se partió du? aquesta cibdad aquel mesmo año con. . . . . . . . hombres é. . . . . caballos; é tomó puerto en la gobernacion del CaJo de Ilonduras, quarenta leguas mis al Oçidente, en un puerto, á quien él nombró pucrto de Caballos, porque despues quél ovo desembarcado los que llevaba, se murió uno dellos, é híçolo enterara con mucho secreto, porque los indios no to supiessen, ni viessen que los caluallos cran mortales.

En tanto que Gil Gonçalez esturo en esta cibdad de Sancto Domingo, aparejándose para este camino, envió Pedlarias Dávila, desde Panamá, á poblar é ocupar á Nicaragua, é lo que a via descubicrto Gil Gonçalez con Françisco IIernandez, su teniente, á otros capitanes, contra los quales ovo Gil Gonçalez çicrto reencuentro é diferençias, como se dixo cu el libro precedente, capítulo XXI * , quando echó de aquella tierra al capitan Ga-

libro XXIX y no al XXX, pareciendo digno de observarse que cuando escribia el presente libro XXXI aun no luabia peusado en añadir el anterior. Esto se halla confirmado, al repararse en que allero sucesivamente el número de los libros de esta segunda parte, hasla darles la colocacion con que ahota se inprimen. 


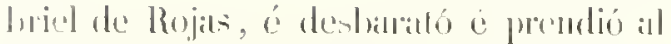
ranitan Ilemando de Soto. Hespues de lit

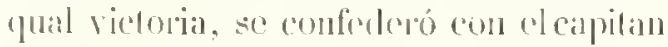
Chripstobal de Olis, que por mandado de Ifermand Cortés, deste la Nueva Lispaña, avia blo á poblar con gentre en llondurar,

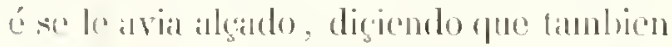
le pertenesçia á él un predicgo de la Tierrit-rilme. como á Coltés é los olros grobermaderes que mandialan en clla, é que-

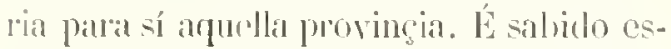
lo por Cortés, fué por tierra contra Cluripstúbal de Olit, y en tanto que llegalba á ltondlinas, temiondo Clupipsoblual de Olit de Cortés, r. Gil Gongalro regelátulose de Pedraliase de sus eaphanes, que se avian entrado en Nicaragna, parcesióles que estaindo conformes podian defenderse de sus emulos, \& que no era bicen contender al uno con el otro; é por esta callsal se hiricron amigos por sus cartas é mensajeros. Y en esta amistal assi contrayda, fiándose el Gil Goncalez, se fué á donde estaba Chripstólal de Olit, despues del destrarato de Lernando de Soto, portue tenia procar gente; é Gil Dárila, su solnino, y el piloto Indrés viño, con partede su exército, no paresciam ni parescioron con mas de septenta liombres que quedaron perdidos: a Ilegardo Gil Gonçalez á Chripistólal de Olit le rescibió con mucho placer. e descle á pocos dias le prendió. é con onta caulcla prondió assimesmo al cilpitan linnçisco de las Ciasas, cuñido de Hermand Cortés. fue avia allá ydo por su mandado: pero el uno y el otro cran bien lractados é comian con él á su mesa, aumfue cstahan pressos. Io qual es Jéxos de prudençia. E assi cómo turo en esso mal consajo, le sulıcedió despues. porque cl que estí presso ha de procurar su libertad, é no dahe estal tan á la mano del que le tiene privado della por fuerga. P'ues como cotos prossos clan cavalleros é de renti-

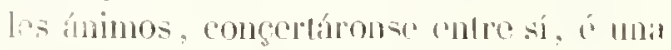
noche estindo conamio juntos los tres.

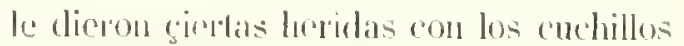
que cistabatn en lat mesal, ron nutulat açeleragion, an lo yual toregianon otros sus ronlederados; 6 vicudose lerido de murer-

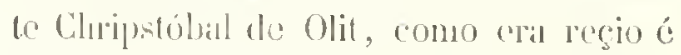
de grandes linergas é le tomaron descuydardo, púsose á huyr é descaluullóse de entre lis manos de adquellos capilanes, y escondióse en gierta prite, donde pensó salvill'se.

Eara Chripstobal de Olit un hidalgo nafural de la cibuladdle Bacga, valliente hombre de su persona, el fual en estas partes avia seydo vegino a concuistador en la isla de Cubar é passó con liernand Cortés ál Lu Tuva España, en la conquista de la fural se hiço rieo, é fué uno de los bien remumpratos por Corlés. Issi que. eslandu lecrido y escondido, luegro hicieron pregonal stls interlicetores, llamándose goburnirlores, que sú pena de muerte é prerlimiento de todos sus bienes, el que supiesse de Clupipsóblabl de Olit lo disesse, y en lin paresció; é assi herido romo estaba de inucrte, le liçicron degollar públicamoute por lirano é nsurpinlor de la jurisdicion real, con el pregron é título que á ellos los parescrió, é quedaron los dos en aquella gobernacion en conformidad. l'ero para pocos dias: porrue despues, como la mayor parte de aquella gente cra de la escuela de Cortís, a Franciseo de las Cisas cra casado con su liermana, acordó de prender á Gil Cionçalez, é púsolo por obra, é llevólo en grillos á la Nueva España. Y en tanto que allí J han, errólos llemand Corlés. que yba por tierra, (y ellos se fucron por mar), é llecơó á Honcluras é polbó en el puerto de Caballos lá villa de Truxillo. I estando allí fué avisalo rómo yloa el liçençiarlo Luis Ponce de Leon á la Nucva España á le tomar residencia, é supo assincsmo cómo los officolatus en illexico. por su ausençia, conIrudian y estaban en muchas diferençias ¿bandos sobre la gobernaçion: é dió lia 
rucla á la Nueva España, desde donde el Gil Goncalez fué remitido é llevardo presso á Castilla, donde murió deste á poco tiempo en Ívila en su casa, á causa de los trabasos que de ací llevaba impressos en su persona, é no sin arrepentimiento de sus culpas é de las muertes do Clnipstóbal de Olit é de otros, é aun de un clériggo de missa, que hicgo ahorcar de In árbol.

Cono el Emperador, nuestro señor, y el Audiencia Real que aqui reside supicron las diferencias que en Nicaragua é IIonduras andalian entre Pedrarias é sus ministros é capitanes, é Gil Gonȩalez Dárilal, c Chripstólual de Olit, é Francisco de las Casas. é Cortés, mandaron yr á Diego Lopez de Salçedo, rerino desta cibdad de Sanclo Domingo, por grobernador de llonduras é de apuella tierra, é á castigar y cvilar aquellas bchetrias, y cscándalos, ú revuclas, é contenciones de los gohernadores é capitanes ya dichos é de sus adlierentes: é quando llegó á puerto de Caballos, ya avia passado todo lo ques dicho, y cran ydos á la Nueva España Corlés é los demás. Ouedaron de mano de IIcrnando Cortés la justiça con los pobladores que avian alli areçindádose, é ydo con los capitanes que se ha dicho é desde á poco despues que Diego Lopez alli fuć rescebido por gobernarlor, supo que en Xicaragua andaban las mesmas revueltas, é Pedrarias é sus capitanes se avian entrado en aquella tiema, sin tener para rllo liçençia de Sus Jagestades, é acordó de yr alla: é dexú en aquella villa de Trusillo por su teniente á un Diego Mendez de llinestrosia, el qual ni se ovo bien con el ofliçio, ni fuć poco mal quisto de los recinos españoles. que querlaron en áfuella villa, como se diráa adelante.

En al canino por donde y la Diego Lopez lopó eon un capilau dre Pedrarias, Ilamarlo Dicgo Mllitez, é con un Selastian de Benaleaçar, a in escribano, llamado
Jolian de Espinosa, é otros, que yban í hager giertos requirimientos á Cortés, ó á su teniente que avia dexado en Truxillo, para que le dexassen la tierra, é altercar é reyterar las contenciones, conforme á ciertos capitulos é instruçion que Pedrarias le dió. É prendiólos Diego Lopez, en espeçial á los tres ques dicho, y enviólos con la informaçion ál la Real Ludiencia de Sancto Domingono, en la qual presidia ol licenciado Gaspar de Espinosa, exande amigo del Diego Albitez é de Selsastian de Benalcáçar, desde queste liesenejiado en Tierra-Firme avie seydo alcalde mayor de Pedrarias: é cómo hallaron al juez á su propóssito é amigo, lucgo fucron sucltos é absuchtos, é ovieron liçencia de se tornar á Tierra-Firme, Ilegado Diego Lopez á la cibulad de Leon de Nicaragua, la qual fundó é pobló Franciseo flernandez, teniente de Pedrarias, á par de la lagma graude que los indios llaman Ayagualo. I en la mesma cildad le avia despues degollado Pedrarias, porque le informaron que se avia carteado con Cortés, quando estuvo en Truxillo, é que le queria dar la tierra (puesto que aquesto otros nuchos lo negaron é deçian lo contrario, á los quales yo lo oy en la mesma cibdad de Leon desde á poco liempo, antes le atribuian é culpaban en la muerte de Françisco Lerman(lez ál los capitanes Françisco Campañon y liernando de Soto é otros sirs ćmulos, que con Pedrarias le avian enemistado); pero quédesse este juiçio para allí á donde cstán en la otra vida el que pradesçió y el que le juzgó.

Cómo Pedrarias le ovo fecho degollar, volvióse á Panamá, dexamdo á Lcon é aquella tierra de Nicaragua de su mano, é quandlo llegó acullá, laalló al nuevo gobernador de Castilla del Oro, su subesesor, Pedro de los Rios, é al ligençiedo Johan de Salueron, suatealde mayor, á quien por Sus Magestades se cometió la residen- 
ria; y estáudola lacsiendó Pedrarias en l'anamá, se fué cl prodro de los lios por la marr del Sur á Nicaragua, diggiendo que le perfenesçia tambion all su gobernaçion, pues Pedrarias la arvia tenidoé poblado, y cn un nesmo liempo llegaron á Lceon Pedro de los Rios por nar é Diego Lopez por tierra, porrque deste Truxillo á Leon no lay mas de septenta leguas, é de mar á mar doçe ó lrece mas que lay desde Leon de Nagrando al puerto de la Possesion.

Luego cada uno destos gobernadores pressentó sus poderes aute la justiçia é regimiento de aquella cilsdad de Leon, requiriendo que les entregassen las viltas é los admitiessen á la gobernacion, expresando, demás destos lítulos, carda uno deIlos sus raçones como mas á su propóssito podian, persuadiendo al cabildo á su opinion: en conclusion de lo qual adıutieron al Ineg̣o Lopez de Salçedo y excluyeron al Pedro de los Rios, é volvióse á Panamá, é quedó en Leon Diego Lopez algun poco de tiempo. En el qual, aunque cra carallero é amiggo de buenos, twro muchos enemigos despues, á causa que removió algunos indiosde repartimieutos, que avian cucomendado Pedrarias su teniente Françisco Ilemandez á algymas personas, é les dió á olros, reformando aquellos repartimientos de la provinçir, lo qual fué muy odioso, anunque lo liego con paresger de los capitanes é personas priuçipales. É aunque á otros gratiticó, aproscechóle poco para se librar de muclios trabaxos que por él passaron, é que mas laryamente se dirín, quando se tracte particularmente de la gobernaçion de Nicaragua en la terçera parte destas historias.

Lo que desto quadra aqui es, que en tanto que Pedrarias estaba en Panamá liaçiendo residençia de la gobemaçion de Castilla del Oro, procuró la de Nicaragua é la obtuvo, é despues se fué ál Leon de Nicaragrna, é prendió al gobernador Dicgo Lopez de Salcedo, é le tuvo en la forlaleca de aquella cildad sicte meses é mas en mucho trabaxo é nesçessidad puesto, de donde salió despues conforme á çierto assiento que entre él é Pedrarias se dió, á que yo esture pressente, é se fué á su gohernaçion de llonduras, como se dirá en el capitulo siguiente.

\section{CAPITULO II.}

De 10 que subęedio al gobernador Diego Lopez de Salęedo, pocos dias antes que de Leon de Nicaragua se partiesse para yr i Honduras, en la venida del eapitan Dierro Albitez, é el conçierlo que se dió entrellos, é la muerte de Diego Lopez, despues en su gobernacion, é las contiendas y escándalos que por su muerte ovo sobre quién avia de gobernar, é otras cosas que son anexas al discurso de la historia.

\section{G} el desseo de mandar á sus veçinos, olvidando aquella verdad erangélica que dice: "Quitó los potentes ó poderosos de la silla, $\mathrm{y}$ cusalcó los lumildes ' ". En el mesmo Evangelio está escrito: "Todos vucstros cabellos de la calueça son numerados ${ }^{2}$. Pues si tanta é çicrta cuenta

1 Deposuit potentes de sede, et exaltavit humiles. (Luc, cap. I.) se tiene con nuestros cabellos, red quámta se tiene y terná con nuestras obras. Volramos á la historia.

En el capítulo precedente se dixo cómo el gobernador Diego Lopez avia prendido al capitan Diego Nlbitez é Sebastian de Benalcáçar é Johan de Espinosa, é los envió remilidos á esta ciludad, é los absol-

2 Capilli capitis restri omnes numerati sum. (Luc. eap. XII.) 
vió el liçençiado Gaspar de Espinosa, e dióles liçençia que se tormassen á TierraFirme: é assi lo hicieron, é llegados á -Trusillo, supicron que en Leon de Nicaragua tenia Pedrarias presso al gobernador Diego Lopez, por lo qual estos é otros se juntaron de pié é de caballo, porque la ticrra estaba alcada é rebeldes los indios por donde avian de passar, é assi ovieron çierto recuentro, en que resçilsieron daño los chripstianos é muy mayor Diego Lopez, porque le llevaban mucha haçienda é todo lo perdió; pero passaron á dezpeclıo de los indios. E llegado Diego Albitez á Leon quiso fatigar al Diego Lopez con el favor de Pedrarias, non olsstante que aunque el liçençiado y el Audiençia Real alusolvió á Diego Mlbitez é sus consortes, no condenó en costas á Diego Lopez; mas cómo Pedrarias los avia enviado donde los prendicron, y era raçon quél los remunerasse é pagasse, quiso, pues tenia presso á Diego Lopez, quél los satisfiçiesse, é assi anduvieron en escriptos é libelos, molestando é pidiendo á Diego Lopez lo quél en verdad no les debia ni era á cargo. Tomóse por medio que Diego Lopez liçiesse cierta obligaçion í Diego Allitez para le dar é pagar mill pessos de oro á çierto tiempo, é tóvose manera de contentar al Sebastian de Benalcáçar é á Johan de Espinosa. Hecha esta obligaçion inválida, porque era otorgadla por hombre presso é sin libertar, Pedrarias le dió liçençia á Diego Lopez para que se fuesse a su gobernaçion de IIonduras: é assi lo hiço, é despues que estuvo allá un año, murió, porque yba latigarlo de una llaga vicja en una pierna, é mucho mas de los traluaxos é prission que avia tenido en Leon de Nicaragua.

Al liempo que se quiso morir Diegro Lopez de Salçelo, dió poder al contador Andrés de Cereceda para que gohernasse, en tanto cue Sus Magestades proveian de yobernador á quien fiesse su leal volun- lad. Nlas assi cómo murió Diego Lopez, eutraron en cabildo un alcakle, llamado Françisco Lopez, ć dos regidores vizcaynos, tmo yue se decia Jolıan Lopez de Gamboa, é otro llamado Sancho de $\Lambda$ nda, é sin él otro alcalde éregidores, é ante un escribano, Alonso Carrasco, liçieron justiçia mayor á un liidalgo, que se deçia Vasco de IIerrera, natural de la cibuad de Trusillo en Esiremadura: é nombráronse á sí mesmos con él por coadjutores é gobernadores juntamente, diçiendo quel poder dado por el gobernador Diego Lopez á Cereçeda era inválido é no bastante. $Y$ cómo estos cran amigos, querian quel jnego se anduviesse entrellos : é tambien porque estos mesmos algun tiempo antes con mano armada avian prendido á aquel Diego Mendez de Hinestrosa ques dicho, seyendo teniente de Diego Lopez, en tanto que cstaba en Nicaragua, por odio questos le tenian y el Diego Mendez á ellos (y quando el cabildo le prendió dió la vara al Vasco de Herrera, que en aquella saçon era regidor de aquella villa, y era capitan é maestro de campo del teniente Diego Mendez, é avie jurado de seguir é obedesçer é executar sus mandamientos), porque segund las obras del Diego Mendez, ó la costumbre de aquella tierra le paresció que assi convenia. De manera que presso ol Diego Nendez, é usando el Vaseo de IJerrera de la vara por el conçojo, le tuvieron en gratves prissiones maltractado lasta yue, como es dicho, tornó el grobernador Diego Lopez de Nicaragua, é le mandó soltar, é dixo públicamente que avian feclıo mal en le prender. Y porpue el Vaseo de IIerrera tenia dehdo con los parientes del Diego Lojez, no le quiso desfavoresçer, é porque é é los que cran contra Diego Mendez, unoscran de su tierra del gobernador é otros avian vdo con él á aquella gohernaçion, dexóle traer la vara todavia al Vaseo de IIcrrera, pero no le dió poder 
para cllo. Luego el Diego Mremler acusio ante el genobernador al Visco de lloprera ó sus consortes solore sul prission y ellos d

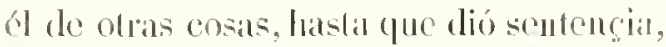
ch fule pronunciós ser injusta é mal fecha la prission del Diego Mendez, con juramento que liço quél no lo mancló jurender. Desla sentencia apeló Vaseo de Ilerrera é sus consortes para el Audiença Real de la Nuera España, y el Diego Hendez so arrimó á la ápelacion, y el gober-

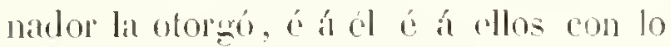
prosessado renitió á la Audienecia Real susto dicha.

Estando en este cstadlo este litigio, é travendo la rara el Vaseo de llerpera sin poder. fillesció el gobernador Diego Lopez, aviendo un año que cra venido allí le Nicaragua: por mancra que de no aver desarrimado de la vara al Yasco de Herrera, resultó no ser admitido á la gobernaçion el contador Cereceda, porepue no oviesse quien le pidiesse cuenta de lo que mal avian fecho este Tasco de Meprera é sus amigos á la sombra de su vara: y esla culpa la luvo Diego Lopez en se la consentir traer, pues que con clla avian fucho gnerra y escharos á los natudades de la tierra, $c$ otras sintacones é delictos. P'ero con alghuna astuçia celıaron tergeros al Cerecela para quél y el Vaseo de lYerrera gobernassen, é quel Vasco fornasse la vara al cabildo. é fuessci ambos resçebidos por virtud de los poderes suc cada uno de los dos tenian del go- bermator defento. Lis assi se lige por indestria de un aldenimistat de arpuellos, de

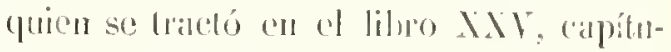

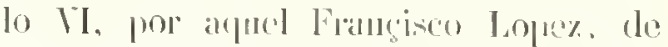
quien se ha dicho que avio seydo alcalede. quando so dió la varáa all Vaseo de llerrera; é cra escribano real é avia ydo í lir Tierra-Firme por secretario de bedro de los Rios, é con él fué á Leon de Nicarasua desde donde se avia passaddo á llonduras, y era un saco ó mina de cavilaciones; é cómo liactala con sente de poco saber, descle la prinola saltó en la valá, é con clla e sus astucias dió mucha caltsa á estas diforencias.

Finalnente, redncidos los negocios al estado ques dicho, exanninados los porleres, questos que prefendian gobernar tovieron, el de Cerecerla era bastante, otorgado por el gobernador ldicgo lıopez é doce tesligos, y el de Vaseo de Irerrera cra una minuta ó escriplura simple, sin firma del gobernador e sin dia ni mes ni año, fucil mostró é teriat en su poder, que á su importunidad é de otros amigos suyos icordadamente pensaron liager quel gobernador defunto to otorgasse dos ó ties meses anles fue muriesse: d qual, no solamente dexó de firnarlo, mas am mirar no lo quiso. quando se lo llevaron, por no lacer tom erande error; y csta eseriptura ó poder nuner otorgado se quedó assi en poder del Vaseo de Herrera, sin lager fée ni prueba.

\section{CAPiTULO III.}

De la eleçion de los nuevos guburnadores puestos por la republica de la villa de Truxillo, que fueron el contador Andres de Cereceda é Visco de Herrera, é cómo despues estorieron desconformes, r címo los indios mataron a algunos ehripstianos é se rebclaron en parle de la lierra, é cómo el Jiego Mendez de Hinestrosa mató alerosamente a Vasco hle llerrera, dios eschindalos é forma que en cello sc turo.

$\mathrm{N}$

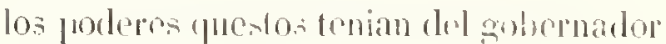
defunto bara rescribur la golsernarion, é quel uno era bastante y el otro no, cllo se lico de manera que Andrés de Cereceda, contador. é Vaseo do IIerrera: quedaron 
por gobermadores hasta que Sus Magestades otra cosa proveyessen. Pues como Diego Mendez de llinestrosa vido que Vasco de Herrera, su enemigo, qucdalaa por administrador de la justiçia, estaba temeroso, é con nuclıa raçon; porque aun en vida del gobernador le quisicron matar, é le aguardaron una noche á su puerta, é si no fuera socorrido, le matáran, é quedó mal herido: é nunca se pudo averiguar quićn lo hiço, mas de la clara sospecha, porque él les avia procurado é procuraba la muerte, é cobrar dellos los daños que avia resçebido. Y por tanto quiso haçer entender al cabildo, que pues essos poderes ques dicho del gobernador no eram bastantes, quel suyo, quél tenia del licmpo passado, era válido é no revocado, é quél era teniente é lo podia é delia scr: é con este intento fuésse á cahildo y cechó su haz de leña en las llamas de las discordias, quel diablo andaba aparejando, $y$ estaban va dispuestas á fodo escíndalo, é pidió que le diessen faror para usar del offiçio, con mandos é penas que les pouia. El cabildo le respondió que su poder era ninguno é revocado, é assi paresçió por escripto, y el golsernador Diego Lopez se lo avia quitado, é quél estala presso é remitido al Audiençia Real. É mandáronle, só pena de la vida é perdimiento de sus lienes para la cámara é fisco, que no hablasse en esto, é tomáronle el poder que mostraba del gobernador, é mandáronle tener al escrilıano de cabildo: é assi çessó esto, é se entendió en el conçierto del Vasco de Herrera é Cereceda, segund es dicho, para que juntanente goberllassen.

Luego enviaron çierta armada á pucrto de Caballos á la provinçia de Naco y á lo poblar, é acordaron de repartir los indios que Diego Lopez tenia, porque eran los mejores de la tierra : é á un lijo suyo, que dexó allí muchacho para sostener sus haciendas de vacas é gegura que T0110 IlI. tenia, se le dexaron algunos indios, y en pago de aver dexado su padre aqui muchit hacienda en esta isla, é perdérsele por su ausençia, ó aver ydo á servir á Sus Nagestades é perder la vida, no le faltó esse mal pago, por los coludiçiosos que quisicron tomar sus indios; pero esta es la costumbre de las Indias, que con ningum muerto se tiene cuenta ni respecto. I dieron por color aquellos escandalosos que se haçia porque la gente se sosegasse-, é los querellosos fuessen satisfechos con la capa de Diego Lopez, porque avia hien servido hasta la muerte: é aun essa tambicu lluvó desde á poco á su liijo, é se entraron en sus bienes é los goçaron essos liranos é otros.

La concordia destos gobernadores no fué furable, á causa del repartir é dar los dichos indios, porefue el Vasco de Herrera queria los mas é mejores para si é para un hermano suyo, llamado Diego Diaz de Herrera, é sus amigos é parçiales é otros nuevos en la ticra que se avian jumlado con él, y él se los avia prometirlo; é porque el Vasco de Herrera no dixesse quel Cereçeda no lo aprobaba por odio que les tenia, é le avian hecho jurar de no dar notiçia á Su Magestad de lo que passalsa, consintió contra su roluntad en el dicho repartimiento, y en el dar la vara de alguaçil mayor á Jolıan Cabrera, amigo del dicho Vasco: lo qual Cerecedia dixo despues quél no consintiera, si fuera solo, haçiendo lo que era raçon é justiçia, é que vino en ello porque no alterassen ni amotinassen la ticrra, y excusar mayores daños. Y porque el Vasco é su hermano eran hombres muy desasosegados, y cllos é sus parçiales nunca laçian sino deçir mal de la tierra, é que no desscaban cosa tanto como salir dlella, é porque el Diego Mendez esperaha tiempo para pedir su justicia, por estos é por otros respectos, acordó de temporiçar é disimular el coreçeda: y segumd la pora prumlençia é so25 
herbia destos hermanos, Vaaro de Hlerrerá ci Diergo Diaz de ILerrera, vinieron en descraciar de aprel alonaçil mayor é del Françisen Lopez, alcalde, y de otros sus amigros. porcjue no laçia en su provectio y honor lo (pue les parescia. Y como todos essos eran bulliçiosos.é desasosegados, acorlaron de salir de la ticrra é yrse á Gualimala el Diego Diaz y el alguaçil mayor é otros; é aunque el Ceregula lo supo. no osó hacer informacion dello; mas por excusar esse molin, acordó de casar dos doagelias con dos mançuhos delulos del Vasco de llerrera, é al uno dió parte de sus indios proprios. que le avia dado el gohernador Diego Lopez, é al otro dió otros mejores: é assi se liço con otros mancelos de aquella congregacion, é se rxrusó aquel escíndalo é partida que tenian pensada : porque el Ceregeda entendia en aplacar hasta que Sus Magestades provoyessen de jusliçia é les diessen gohernador. En estas tempestades estorieros quassi un año de deçir que se avian le yr, é á esta causa pocos se curaban del bien de la tierra, é los menos sosegahan: 6 publichbase que aquestos dos hermanos é otros dos, sus espuciales anigos, Ienian ocupalas quatro casas de mugeres casadas. y que de noche rompian los selos é paredis de las casas con infamia de sus maridos. Assi que, quando los ministros de la justicia son los adúlleros, ved qué remedio pueden tener los ofendidos.

Discubriéronse en essa sagon buenas ninas de oro é sacábanlo; pero trabaxando exçesivamente é maltractando los indios, porque los que avian de castigarlo, lo laçian peor, á causa de estar el pié en cl estribo, como ellos decian, para yrse dı: la tierra. É viéndose los indlios assi mojestados, acordíbanse cómo eran favoresçidos é bien tractados del gobernador Dicgo Lopez de Salgedo; é desesperados del remedio, subgediú que á ginco leguas de las mints. cu la provincia de un caçique cl mas priucipal de la licrra en quantos servian, que se llamaiba leycacura, mataron tres espaúoles en Ires puchlos (é los dos dellos eran sus amos, que los tenian encomendados), aviendo el Vasco de Herrera tenido aviso de crueldades é fuercas que les avian hecho aquellos sus amos, 6 ann en las personas de los mesmos carci(j!1es, é no lo castigó, estando ausente el Gereceda.

Trís lis muerte de los tres chripstianos, se alcaion la mayor parte de losindios (pue servian en loda la lierra, é con mucha raçon, é los que no lo hiçieron fué por ser enemigos de los que se alçaron: pero quedaron amenaçando, andando aviessos en el serviçio. I esto era un extremado trabaxo para los españoles, que no avian de dexar la lierra por ninguna adversidad; mas al Tasco de Herrera é sus secages no les pessára en que se acabríran de alçar todos los indios de demás, por dexar la lierra con justa color: é aun deģian claramente que avian de yr contra los alçados, é que los rancheassen é acabassen, é que los chripstianos saliessen ya de aquella lierra pobre (lo qual ella no es, sino muy rica). Y en fin se acordó que fuesse un capitan con gente á reconçiliar é pacificar los alçados: é solure la eleçion desse capitan ovo contencion entre los gobernadores, é al fin salió con su intençion el Vasco, con querer ỹrél en persona, é llevó consigo á su hermano é á Françisco Perez é Jolıan Lopez de Gamboa, regidor, é otros regidores de aquel año, é los mas é mejores de la tierra, y entrellos sus devotos ó parciales.

Bien conozeo que eslas contençiones no son aplaçibles á toda manera de lelores; pero son nesçessarias al aviso de los que han de gobernar, para escarmentar en cabegas agenas: son nescessarias, para rue se ronozea la diferengia (pue lay de ınos offiçiales é jueçes á otros: son nesces- 
sarias, para que nos acordemos de todos, cono al cabo tan particulamente se sabe, é descubrir coni el tiempo la malicia del lombre, cómo sus delictos se cometen: son nesçessarias, para yue con mis renglones sepan Céssar é su Real Consejo lo que otros no les escriben, ni osan por diversos respectos, ó por temor de los émulos con quien debaten, ó por amor de los afiçionados á sus desalinos, é aun algumos porque les paresçe prudençia ser neutrales entre su Rey y quicn lo ha de castigar, y los que deben ser punidos, pues que de deçir verdades á pocos alcança la remuneraçion, tan presto como se adquiere la enemistad. $\mathrm{Y}$ á essos que se entremeten en dar avisos de tales trahaxos y escíndalos al Prínçipe, é de otras cosas que requieren enmiendas, ó no los creen, ó no llegan sus cartas á poder de Céssar é de aquellos señores, que Su Hagestad tiene deputados para la golvernaçion destas partes, çerca de sí, ó se elicubren é paran en las manos de quien al revés de lo escripto informe lo que quiere. Porque por los peccados de los homlires nunca faltan á los malos alas para sostener sus culpas, en espeçial si las plumas son doradas, no se acordando de lo quel Apóstol escribió á los Thesaloniçenses: "Del tiempo é momentos de tiempo no teneys nescessidad que yo os escriba; porque vosolros mesmos sabeys quel dia del Señor assi ha de renir, como el ladion en la noche '."

Por çierto assi le vino de noche su fin á este peccador de Vasco de Herrera, é no como él arbitraba, sino como adelante se dirá. El qual, ydo con la grente é lo ques diclıo, dexó el camino que avia de llevar é tomó otro mas luengo por ver un caçique que le servia, por mostrarle su fausto é que viesse como mandaba á lodos: é estúvose allí tanto, que por su dilaçion

1 De temporibus autem ef inomentis, fratres, non indigelis ut seribamus vobis. Ipsi enim ditigen- los indios alcados se fueron á lás sierras é se pusieron en salvo, y en çinco meses que por allá andıvo, ni castigó mallıechor ni liço cosa que buena fuesse, ni tomaba consejo de nadie, sino de su hermano, que tenia lanta nescessidad ó mís de ser consejado. Y viendo esto sus mas espegiales anigros, que eran aquel Françiseo Perez é Johan Lopez de Gamboa, regridor $\mathrm{y}$ otros, se lo reprehendieron algunas reçes, é á la postrera resultaron entreilos y él paláluras feas, é tractólos de manera que la amistad se convirtió en odio. É le osó deçiı el Johan Lopez de Gamboa, á su usança vizcayna: "Yuro á Dios yo hiçe, yo deshaga; " ê luego estos dos se concertaron, para le descomponer. Por manera que tornados á la villa al cabo del tiempo ques dicho, rolvio el Vasco de llerrera malquisto, é tenido para menos de lo que antes se pensaba de su persona. De aquel Françisco Perez tenia mucha quexa el Diego Mendez de llinestrosa, en su prission, porque seyendo escribano de su juzgado, é su secretario, fué levadura de su prission, é avia descubierto á los del cabildo cosas quel Diego Mendez pensaba hacer contra algunos dellos, que con él avia comunicado; en pago de lo qual el Vasco de Ilerrera le liço haçer alcalde aquel año, é despues fué nombrado para lo ser el siguiente, to qual contradixo el Diego Mendez con ciertos requirimientos é protestaçiones, y en fill no le dieron la vara. Y este, enojado desto, con sus secaçes el Johan Lopez de Gamboa é Johan de la Puebla, regidores, creyendo quel Vasco de Ilerrera lo avia estorbado, é la vara que pensaba aver el Francisco l'erez se avia dado á un pariente del Visco, acordados en haçer mal al Vasco de Ilerrera, tomó la mano el Françisco Perez, como el mas mañoso, é fués-

fer scilis, quit dies Pomini, sicut fur in noete, ih. venief. (S. Paul ad Thesalon., cuist. i, cap. V.) 
r. al Diego Mendez é dióle parte del netongio, que no desseala cosa mas que verle sin vara al Vaseo de Ilerrera, é ven-

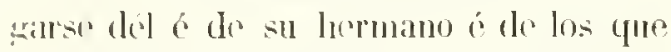
le prendieron, é dessónhales la muerte, y

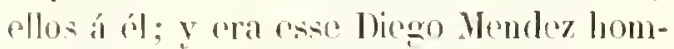
bre belicoso, e foniase por injuriado dellos. Y como el Françisco Perez le şertifi. ‘́ que en cl cabildo avia voluntad de privar del ofliçio al Vaseo de llerrera, amólo oyr á rogóle que entendiesse en ello: y twro forma como un regidor, en ausençia de ambos gobernadores, pidió en el cabildo que entendiessen en el remedio de aguella lierra, que estaba perdida por arver dos goloernadores, y essos discordes é mal avenidos. Y cómo tornaron á la villa el Ceregedla y el Vaseo, les dixeron en regimiento lo que se les avia pedido, y el Cereçeda calló, porque sabie que no se lecia por él: el otro, con mucha alteracrion y enojo, respondió que aquel tal por ‘pual de Diego Hendez lacia acpuello, ć imenaḉbalo; pero los gobernadores respondieron al cabildo que harian lo posible cómo en todo se hiçiesse bien, é cómo conviniesse á la buena gobernaçion. El Vasco de lierrera estaba muy léxos en esto de pensar que sus amigos Francisco Perez é Johan Lopez de Gamboa é Johan de la Puclila oricssen amasado esta cosa, porefuc ya se comunicalıan y entraban en su casa, y en todo ello celiaban la culpa al Diego Nentez, al qual tractó muy mal de palabra un dia el Diego Diaz de Herrera, é le diso muchas injurias. Y enojalo desta afrenta el Diego Mendez, dixo il Françisco Perez que le hastasse lo que avia hecho, seyendo su secretario, desrubriendo sus cosas, é aviendo dado órden cóno le preudicron; que por qué queria agora tractar como le matassen, ‘uél descuydado estaba de entrar en contiendas hasta que viesse que avia justicia; que le dexasse ya. Y él respondió que no lonia culpa. sino los regiflores fure le avian burlado, é (quel I)iego Mendez tambien se avia errado en lo que avia lrecho pedir al caldildo, yue no avia de pedir sino que le admilicssen al cargo de grohernador por tenicute, pues tenia poder del golnernador defunto, y que aquello se hiçicra antes que devir al contador solo en el cargro. É cómo el Diego Mendez vidlo movida la çisma, eneaxóle esta proposiçion, é rogó al Francisco Perez que trabaxasse en cl negocio: é porque el calildo le avia tounado el poder é pućstolo en las escripturas de su escribano Alonso Carrasco, quando otra rez el Diego Mendez pielió que le admitiessen, el Françisco Perez hiço quel escribano, que era su amigo, le volviesse el mesmo poder al Diego Mendez, porque aquel escribano estaba mal con el Vaseo de Ilerrera. Pues cómo tuvo su poder Diego Jlendez, fué al cabildo é pidió segruro, porque se reçelaba de algunas personas, é no osaba deçir algunas cosas que convenian al serviçio de Sus Magestades, ni las diria de otra manera; é dióscle el seguro, é assi como le tuvo, diso quél era teniente de gobernador, é pressentó el poder ques dicho, é pidió ser admitido, é aun mandó al cabildo que assi lo hiçiesse, poniéndoles penas á todos los del cabildo. Viendo este disparate, descuydado de lo encubierto, respondiéronle que su poder era condiçional, hasta quel gobernador Diego Lopez, ya defunto, proveyessc otra cosa; é quel Vasco de Herrera truxo la vara en su prission é pressençia, é quél esturo presso é avia hecho residençia, y cra revocado por el gobernador defunto; é assi lo excluyeron, mandándole, só pena de muerte, que no se llamasse teniente, é só pena de perdimiento de sus bienes para la cámara é fisco; é tornáronle á tomar el poder que pressentó.

I porque en el pueblo píblicamente se deçia que lo avien de resçelsir por teniente, mandó el cabildo pregonar que ningu- 
no le toviesse por teniente ni se lo llamasse, só çiertas penas. Y el Cereçeda é otros le dixeron al Vasco de IIerrera que sus proprios amigos le avian puesto il Jiego Mendez en aquello, é aun scĩalólo al Françisco Perez, que todavia se comunicaba con él, é respondió que no lo creia é que se lo decian por le poner mal con él. Luego mandó el Tasco de IIerrera que ninguno acompañasse al Diego Mendez, só pena de çient açotes é otras penas ( $\mathrm{y}$ envióselo á notificar con un escribano) ni él anduviesse acompañado: é la respuesta del Diegro IIendez fué recusarle, y expresando sus agrarios é qué avia fecho guerrá á los indios, é sin poder de Sus Macrestades, é avia fecho hierro para los herrar é haçer csclaros, sin to ser ni tener auctoridad para ello, é otras cosas bien feas é por escripto, é assi replicando el uno en contra del otro. É demás desso el Vasco de Herrera é su hermano amenaçaban de palabıa y en púlılico, y el Diego Mendez respondiendo, les deçie que por temor de Dios ni de Sus Magestades no avie de dexar de matalle. i todo esto el Cereçeda se estaba en su casa, é oya é callaba, porque el tiempo no le daba lugar á mas, y eran pocos los que en el pueblo no partiçipaban en estas passiones.

Pues excluydo Diego Iendez por el cabildo de su demanda, segund se dixo, por ariso del Francisco Perez, truxo á la memoria el Vaseo de IIerrera la pena (quel calsildo avia puesto al Diego Mendez, é dióle á entender que avia incurrido en ella , é paresçiéndole que cra causa para quitarle de sí, acordó una noche de to prender. É como el Diego Mendez traia sus velas con el enemigo, supo la intencion del Yasco de IIerrera, que era, despues de le prender, echarle en unas islas diez leguas de aquella villa: é temiendo que le harian cacdiço en la una ó le matarian, huyó á la iglesia con esso poco que tenia. Lo qual visto por el
Vasco de Ilerrera, procedió contra él é híçole çitar é llamar por preģones, diçiendo que lo haçia porque de sus bienes se colorasse la pena de la címara en que avia incurrido, sevendo público que en toda la tierra avia hombre mas pobre é adeudado: é hiço inventario de sus bienes, é halló que debia el sayo que traia restido é mas de tres mill é seysçientos pessos de oro, porque como hombre desordenalo, en onge meses que allí avia seydo teniente por el gobernador Diego Lopez de Salçedo, viviendo mal este Diego Mendez é desenterrando peceados é culpas agcuas é delictos viejos é olvidados, para se sostener só color de justiçia, lo que por una parte allegaba vertia por otras muchas, gastando mas de lo honesto é nesçessario é mucho mas de lo quel offiçio podia comportar.

Viendo el Vasco que era notorio enemigo é juez para el Diego IIendez, cometió la causa á Diego Nieto, alcalde ordinario, é procedió en el negoçio: é porque se avia retraydo á la iglesia antes de la acusaçion, porque le queria prender de hecho el Vasco de Herrera, el alcalde le oyó desde la iglesia, é como el negoçio era de calidad que requeria examinaçion sohre si era bien ó mal presso Diego Mendez, é si eran traydores ó no, dixéronse tales cosas en los escriptos Diego Mendez al fiscal contra Yasco de Herrera, y el fiscal en su favor contra el Diego Mendez, con cuyo paresçer en secreto los ordenaha, que sc ençendió el fuego de manera, que público é con juramento deçian Vas. co de Herrera y su hermano Diego Diaz de IIerrera avian de matar á Diego Men. dez dentro de la iglesia. ;Oh Indias! joh iufeliçes los que á ellas venis, para estar á la sombra de tales ministros de justicial l'ues en todo el mundo esta es uni virtud tan grande é tan exçelente é nesçessaria, que ninguna república ni estado se puede conservar sin clla, é no solamente liss 
cibdades é pueblos grandes ó clucos, mas aun las pequeñas ó partieulares casas, donde aquesta falta. so consmomen é disminuyen, é aum un solo hombre ó curpo que sea parte derlla se pierde!

Fo no sé cómo en estas partes anula esta justicia tan ofendida con los mesmos offiçiales della, ni puedo creer que á la Magestad Real ni á su Consejo llega la noticia destos é otros mesmos iusultos, pues fan olvidado está el castigo dello en la tierra, si no ricne del çiclo, como to hiço en este caso de que agora se tracta.

Oyd, letor, y verés lo que sabe é puede rodear el diablo, el qual en solo esto es bueno, como exccutor de Dios, pues to que hace no es mas de lo ques permitido por el mesmo Dios, á cyuien ninguma cosa puede impedir ni contrastar sus juicios é rectilud. Signióse que junto á las minas que llaman de Tayaco. donde se sacalua oro, se avian alçado dos caçiques, viendo que los otros que se avian alçado se quedaban sin castigo, y estos últimos alçados sacaban oro: é los qobernadores acordaron de enviar un capitan con gente para laçer que aquellos indios tornassen á servir, é si no se pudiesse lacer, castigarlos porque los otros se soscgasscn, é para castigar otros caçiques alçatos dias avie en un valle que se diçe $\mathbf{\Lambda}$ galta, que fueron en la muerte de los chripstianos de Vylancho, que nunca despues quisieron servir, é alteraban la ticrora é á los que sacaban el oro. É caso quel Cereçeda lo excusó lo que pudo, no bastó á acabar con el Vasco de Herrera que fuesse por capitan ofro sino su liermano Diego Diaz de Herrera, é porque aquel era yolo á ver su gente que traia en las minas, enviáronle allá los gohernadores la comision é instruçion, é no lo luro en nada ni lo (priso açeplar: antes escribió á su lıcrmano que no queria yr á cllo. y él le rescribió liñéndoselo, é assi lo açeptó é fué con' los que para lá jornada el Vaseo de llerrera le envió é con ofros mas españoles, pue on las minas estabans de forma que los que querlaron en la villa serian listat veynte lombres sanos y enfermos. Pues cómo todavia se continuaba cl pleyto criminal contra el Diegro Montez, é los escriptos é palahras caltin dia cran mas, deçia que lo avia de sacar de la igrlesia, y el biégo Hendez degia quel Vasen é los que le avian presso eran traydores 6 avia de podir justiça contua ellos é se avia de rengan dél y dellos; temió que allí en la iglesia le avian de prender ó matar sus encmigos, como le avian dicho muchas veçes. I paresçiéndole que la justiçia real, ante quien esperaba pedir suș injurias, tardaba, como era bulliçioso é determinado, lialló al diablo, que obraba parte é mucho cn el caso, que le dlió esperança de salir con sul desseo, é convocó á su opinion algumos quexosos de Tas. co de Herrera é de su hermano Diego Diaz, é con estos otros estancieros é marineros é liomlsres de poco saluer é desscosos de tener indios que mandar, á quien el lliego Mendez dió ál entender quel contador Cereçeda no queria ser gobernador, por las passiones gue via en la tierra entre el Vaseo de Herrera é Diego Hendez, y aum porque cadla dia el Tasco confendia con el Cereseda, por ser dos gohernatores: é que si el Cereçeda quisiesse quel Diego Mendez y él serian juntos al cargo, é quél era teniente de gobernador, é le ayudassen á prender al Visco de Herrera, porque en ello servirian á Dios éá Sus Mlagestades, quitando aquel tirano de la tierra, prometiendo de los gratificar por ello é los ayudar é favorescer en torlo lo quél pudiesse, porque el Vaseo le tenia tomada la vara y el cargo por fucrega. Y cómo á todos era notoria su prission é passiones de culrambos, fomaron sabor en las promesas de los indios é favores quel Diego Mendez les promedió por sí é por terecros; é assi un 
domingo, á dos lioras que fué de noche, ocho de otubre de mill é quinientos é trevnta y Im años, estando el Cereçeda en su casa lablando con un honrado clérigo, Ilamado Johan Arela, é otras personas, é platicando en algunos medios frara que las passiones destos se excnsassen, porque resultalan en daño de muchos otros, é no liallaban aparejo en sus condiçiones, assi porque eran muy soberbios é apartados de raçon, como porque ya algumas huenas personas lo avian tenLado, é no hallaban en el Vasco é su hermano ni en el Diego Mendez dispusiçion para apartarse de sus rencores y enemistad: y estando assi en su raçonamicnto, oyeron muchas voçes é ruýlo híçia la igrlesia, do possaha el Vaseo de Herrera, ć salieron á la puerta de Cereceda él é los que con él estahan, é oyeron vores diçiendo: "¡Viva el Rey!... é muchoestrépito é alboroto. É luego el Cereçeda se tornó á entrar en casa, é tomó la vara de la jus. tiçia é una espada é una darga, é mandóa los que alliestaban que fuessen con él é con lumbre de tea, delante corriendo. Assicomo llegaron á la plaça, salicron allí muchos otros á pié é á caluallo, é otros con ballestas é armas, é puisiéronse delante, haçiendo pavesada é unidos, encaminando sus armas háçia el Cereceda é los que con él ylıan, dirgiendo á grandes voces: "Viva el Rey! ", sin poder el Cerecerla conoscer sino dos ó tres de los que estaban delinte dél: y estalua como atónito, porque no salia si cran gente de fucra ó si le querian matar. Y estando assi un poco espario perplexo, pensó que dehian ser revueltas de Diego Jendez é de Vaseo de Herrera, é fuésse hária aquella grente, diriendo: "Viva el Rey é su justiçia que estíl aqui ", y entróse entrellos. Y llegó á un esquadroncillo de los armados, y entrellos vido al Vasco de llerrera en el suelo chsan. grentado : é como se llegó á él, dexáronsele todos, é assióle para le levantar, é no pudo ayudarse con la herida de muerte que tenia, y en esto vióse el Cereceda cercado de gente, y él é algunos de los que con él yban quisiéronle levantar: é llegaron é quitáronsele de las mauos aquella gente, tirándole de los bracos y de las piernas, y de una soga que le tenian echada á la garoganta, y en esto mené los ojoz el Vaseode llerrera, comohombre que estála al caho. Visto esto, é como otros deçian: "Muérese, muérese", començó Ceregeda á llamar al clérigo ya dicho, que estaba alli çerea, é díxole: "Padre, procurad por el ánima de esse hombre: quel cuerpo ya yo creo que no tiene lugar de curarse». É assi lo hiço llevar á la iglesia, entendiendo quel Diego Mendez avia urdido apunclla tela: é luego mandó pregonar yue torlos se fucssen á sus casas, só pena de muerte é perdiniento de sus bienes, é ninguno lo quiso haçer; antes algunos deçian á roges: "iVira el Rey é la comunidad!", con tanta alteraçion, que jensó que allí le arien de matar; é deçian que no avia alboroto, sino destiranicar é poner en libertad la tierra del Rey, que estaba en poder de tiranos. Á lo qual el Cereceda replicó: "Pucs sea, scñores, servicio del Rey, pues quereys que lo sea." É otros deçian: " ¡Viva el Rey é la commniclad! "É acordándose él de las cosas passadas de los comuncros de Castilla, turo por çierto que si de allí no se yba que le matarian, é salióse lo mejor que pudo de entrellos para yrse á su casa.

Ya ocurrian allí hasta las mugeres del pucblo, é alğmnos deçin: "Vamos á casa de Benito Pulido: que aquel es uno de los regidores que fueron en prender al teniente Mende\%,"E ya quel Coreceda salió de entrellos á mas priessa que de passo, salióle al encuentro Diego Nendez, armado é á calsallo, é con una lança é una adargà é con vara de justiçia, diçiéndole: "All señor gohernador, ah señor contador.» $\mathrm{Y}$ el Ceregeda disole, vicindole delante de 


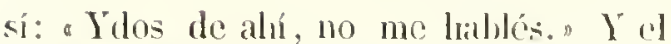

Diego Mlemelez replico: "Esencdadne. señor, lo que os quicro decir. a I l ol liereceda diso: "No hay que esenchatros." Mhatse de largor, y el bieno dlendez, vicndo que le desdeñaba, alravesó el caluallo delante, é dixole: "Escuchadme, si querés, que os está bien, si no calíl... " Esionces el Ceresceda, viendo que arincl calá cra amenaca, é que aquel andalsa determinalo ya en todo mal, esperó é dixo: - ¿Qué decís?" É él dixo: "Scñor, csto se la fecho por poner esta tierra en libertad é debaxo del servicio de Si Magestad, que ha tanto tiempo que está tiraniça: red to que mandays que se haga, que yo soy teniente de gobernador é lo quiero hager, como vuestro teniente. " lis Cureçeda estaba como hombre afronlado é como quassi fuera dé sí, é çereado de los malfechores, congecturando un caso lan iemerario é desacalado, é temia tambien de sí é de los que con él avian salido de su casa que los matassen, é calló; y el Diego Mendez replicó: "Án señor contador, alı señor gobernador, mandad lo que querés que haga: que como vuestro teniente lo haré, que lo quicro ser é lo soy.n Y cómo no respondia Cereçeda tan presto como en la saçon se requeria por su lurbaçion, Bernardino de Cabranes, eseribano leal é de aquella grohernaçion, é olros que con él avian saliclo de su posada al ruydo, y el reedor Francisco de Barrientos, que í la saçon allí avian llegado, díbanle grand priessa, tiríndole del sayo, é aun se lo rasgaron, diçićndole: "Conçeded con él, si queress que aqui no os maten á vos éá nosolros." I el Cabranes dixo recio, porque el Diego Nendez lo oyesse: "Decid que sí quereys, si es teniente Diego Nendez. „ E Ilegrósele al oydo é dixole: "Responded presto: que oygo á mis espaldas que os quieren matar. É assi el Cerecela. por se conformar con el tiempo, dixo al Dic- go Mendez: "L.o que manío es, scinor, que hagaras, o os pielo por merged que pongays torla ceslat cosa cu paz hasta manamade dia, fue se provea lo que eonvenga al servicio de Su Magestad. p lis assi hablanelo, se fué su camino el Geregerla; y el Diego Nendez dixo al Cabranes que se lo diesse assi por testimonio, é desviándose el Curegeda para su posada, so querló Diego Mendez con su genente, é liço pregonar, dicienelo: "Manda el señor Dicso Alendez, teniente de gobernador, ete. E oyéndolo Cueregerla, baxó sus orejas, é se fué á su posada con los que con él deIla avian salido é otros algunos, que se le avian allegado. É llegados á su posada, fué reprehendido, porque avia durlado lis primerar vez de responder á Diego Mendez, é le çertificaron que uno de aquellos sayones llegó en essa saçon al Diegro Mendez é le dixo: "Mirad, señor, malemos á cste, si no lodos somos muertos. "É respondió el Diego Mendez: "Esso no, porque el contador no la fecho por qué."

Tras esto le Ilegó nueva al Ceregeda como el Taseo de Herrora cra ya muerto en la iglesia, sin se poder confessar: el qual, estando en su postrera lrora, dixo mal pronungiando: "Mis peceados me han traydo á esto, "haciendo muestras é señales de chripstiano; é desnudándole para amorlajar, le lallaron una puñalada en el costado, debaxo del braco. É sabido por Diego Mendez que era muerto en la iglesia, reprehendió mucho á sus ayudadores, porque lo avian dexado llevar, diciéndole: "traydor, tirano;" é que si no le mandara Cereçeda meter en la igglesia, quél le hiçiera haçer quarlos, como á traydor, tirano é usurpador de la justiçia real.

Hablando, pues, Ceregeda aquella noche con los que estaban con él, dixo que no aria podido conosçer sino çinco ó seys, é fué informado que los más del escándalo eran marineros y estancieros, é otros amigos del Diego Mendez de quando era 
teniente de gobernador por Diegro Lopez de Salcedo, é algunos veçinos de aquella villa, que estaban mal con Vasco de Ilerrera. Diego Mendez llamaba capitan de su guarda á un Alonso Vazquez Raugel, é um marinero que se decia Pedro Vidal traia la vara como su alguaçil. É toda aquella quadrilla de Diego Nendez podriall ser hasta treynta y çinco ó quarenta liombres de pié é de caballo; ć los mas dessos avian venido la noche antes del campo, é se avian juntato en la iglesia con el Diegro Mendez, é descle allí salieron él y ellos á malar al Vasco de Ileirera. E para lo cfeturar dió un mandaninento, como teniente de gobernador, pará el Pedro vi- dal, alguaçil, mandándole que preudiesso al Tasco de Herrera, é que si se defendiesse, que lo matasse, é mandó en él que torlos le diessen favor é ayuda; é desta nnanera salieron él y ellos de la iglesia, donde Diego Mendez estaba relraydo, á hager lo que se ha dicho.

Sípose que dos ó tres veges, antes que esto acaescriesse, avia jurado solemnemente Vasco de Iterrera de matar al biegro Nendez, é que para ello avia de poner. otro dia el cargo de la vara en el caluildo, porfue viéndole sin vara el Diego Mendez, saliesse de la iglesia é lo pudiesse Ilacer.

\section{CAPITULO IV.}

De lo que Diego Mendez de Hinestrosa hiço con el favor de sus seeaçes, despues que oro muerto a Vasco de Ilerrera; é eómo, eontinuando sus desalinos, prendió despues al gobernador Andrès de Cereçeda; a cimo despues el Cereçeda le prendió al Diego Mendez é le biro haçer quarlos, é se dió fin á su tirania.

\section{E} stando én su posada el goberírador Cereçeda, platicando en lo que de susso se ha dicho, fuéronle á deçir que los malhechores é aquella gente alboroladora estaban dando saco á la casa de Vasco de Ilerrera. É luegro entró el alcalde Diego Nieto, quexándose de Diego Menrlez é su gente, que le avian querido tomar la vará, é aun se la avian quelsado, procurando de yuitar al Vasco Herrera de sus manos, é le dieron çiertos boles de lança, que mostró en la capa: é luego le cuvió á casa del Vasco de Herrera á ponérsela en colsro, é mandóle inventariar lo que hallasse, é que lo entregasse á un criado del Vasco de Herrera. É luego entró el otro alcalde, Ilernando Dalmao, pariente del defunto, asombrado, diçiendo que Diego Mendez é su ggente le avian quitado liı vara; é luego te dixeron al Coreçeda que Diego Mendez andaba por las casis á lomal las armas á todos. É vicndo esto el Gereçela , temió que le seria liecho lo mesno, T0110 111 . é despidió con buenas palaluras los que con él estaban, é aun porque tenia por sosjechosos algunos dellos, que mostraban tener mala voluntad al Vasco de Ilelrera é su hermano, pol malos tractamichtos, é aun tal avia alli que se deçia quel Vasco le rompia los setos para lablar con su muger; y estos tales hablaban en favor del Dicgo Nendez, paresciéndoles mal estas estorsiones, que los dichos hernanos le avian lıccho. Assi que, rogóles que todos se fuessen á sus casas á reposarl, (quedíndose solo el Ceregeda con sus criados é con el escribano Cabranes ques dicho, é temiéndose que si en su casa cotalıa gente, lo tomaria por achaque ol Jiegro Mendez, é por no le dar lugir que acabasse de perder la verguienga, los despidió.

É ydos, deste á nutry poco llegó Dregro Mrondez é su grente á él, á calatlo, ammado, é con una vara de justircia, que era del rasco de llemeria, é sus ammas 
del muerto puestas, que aria avido def silco, co con grand fitusto é ferogidiul, cono si en alguna lomrosil ballalla has oviera ganaldo contra iuffeles; c llaunó á voges al Geregoda, e disule ante Cimbranes ol escribano, que le requeria que luego quilasse los offiços que en el cabildo teniam los deservidores de Su Magestad, é los pusiesse en personas leales. I el Ceregeda le dixo que se fuesse con Dios. é pusiesse el pueblo en paz, como se lo avia rogado: que en acfuello el Ceregeda proveeria lo yue conviniesse al serviçio de sn Magestarl; é assi se fué, diçiendo que assi se avia de destiraniçar la justiçia de Su Magestad. Mas todavia el Cereçeda quedó sospechoso, poreque le fué dicho la mesna noche que los amigos del Diego Mendez se temilu, visto muerto al Vaseo de Iferrera, é conoscian que los aria burlado el Diego Mentez. porque creian quel Cerecela no avia de consentir que fuesse teniente, ni lo era: y el golseruador Dicgo Lopez á solo Cereçela dexó poder quando se quiso morir, é recelaban que avia de castigar los malhechores. Pero ni d Cereçeda osaba açeptar al Diego Mendez, ni llamar á Diego Diaz de Herrera, é á la gente que andaba fuera en la entrada, é una vez esturo movido para se yr á la iglesia; pero cómo valerle ó no, estaba en dubda, á causa del desatinado Diego Mendez. Assi, porque los malliechores no se fuessen é se llerassen los ca!allos é despoblassen la tierra, acordó de se estar en su casa, atendiendo el socorro de Dios, que en tales casos es licn menester, y en espeçial en estas partes. donde la diversidad de los hombres de la guerra todos ó la mayor parte acuclen, por falta de rergiiença, á la parte que conosçen próspera ó con aventaja.

Aquella noche escribió el Cereceda al Diegro Diaz de llerrera é al thessorero Jolıan Ruano, que estaba cn las minas de Taýaco, avisándoles del caso é lomiçidio;

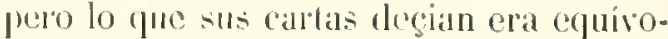
co, porrue ol que fuesse bueno se viesse dónde decelinal ara, diçiéndoles que la justigiat de Su Margestad rstaba retrayda en su casa é yue della no sildria liasta ver remedio para ello de Su Magestad (poryne si fuessen tomadals las cartas, ni pares. riesse quél tenia mala voluntat á ningrmo. ni aprobaba por cllas cosa mal lecha). Y como lo supo Diego Hendez, aseguróse algo, y pensó que todavia cl gobernador Ceregerla le convenceria, porque avia visto que no estaba bien con los dispárates del Vasco de llerrera: autes algunas veges quedaban en mucluas cosas discordes.

Otro dia siguiente se fué Cereçeda á la igglesia é hiço cnterrar al Vasco de Herrera, pressente el Diegro Mendez é su quadrilla con mucla desvergugiença, é allí pidió por Lustimonio el Diego Mendez al escrilsano Calranes, cómo por morirse lasco de Ilerrera, no le hiço quartos, é otras palalyras dixo desbarradas. I el Cereçeda á torlo esturo callando, é se fué á su posada quassi solo, quedándose alli el Dicgo Mendez con sus valedores, diçiendo quél é aquellos hidalgos compañeros avian lıccho á Su Magestad aquel serviçio lan grande é señalado, en le aver destiraniçado su justiçia é la ticrra, é que la rara quel Vasco de llerrera le aria tomado, él se la avia tornado á tomar. É luego se supo cóno el Diego Hendez avia enviado á llamar los caçiques de los hermanos Herreras, para que le sirviessen á él; é fué tal su denuedo é furia aquella noche é otro dia, que no esessalıa, dieciendo á todos que assentassen el pié llano, porque en sabiendo que alguno coxqueaba, le avia de cortar la calueça é hacer el proçesso en la uña, tanto que sus enemigos se fueron á reconciliar con él de lo passado, é deçian que sile crrassen, querian pagar con la vida. É assi unos por le contentar, é olros porrque no los matasse ó destrmyesse, é otros por no ser afrontados ó les quitasse 
Ios indios, de que se servian, algunos te mandalan é daban mucho maliz, é otros le prometian puercos, é otros. le pressentaban novillos é aves, é otros le enviaban mesas ć bancos é sillas, é paresçia que le assentaluan casa, porque de todo tenia nescessidad. Algunos lagoteros deçian que avia hecho un hecho romano, é otros loaban su prudençia é animosidad, é otros le daban á entender, (que sabido el caso por Su Magestad, no solamente le daria la gobernaçion perpétua de la tierra, donde estaban, mas que le aria de dar un condado é haçerle grand señọ, por ser su persona de tanto valor, é tan diestro y experimentado é para mucho. É assi él se lo creia y ensoberbesçia mas, é á cada canto sonaban pregones, diçiendo: "Manda el señor teniente, Diego Mendez de Ilinestrosa, capitan de Su Magestad é su justiçia mayor, etc.», relatando títulos quél no tenia ni meresçia, é amonestando é proreyendo lo que se le antojaba.

Otro dia despues de enterrado el Yasco de Herrera, acordó el gobernador Cereçeda de haçer juntar el cabildo en su casa, é pidió consejo de lo que delira haçerse en el caso; é dixo que ya sabian lo que passaha, é que Diego Mendez, só color de gohernador, é diçiendo que tenia poder, destiraniçaba la justiçia é avia mucr10 á Vasco de Iterrera, trayendo la vara, é se la avia el dicho Diego Mendez apropriado á sí por su propria auctoridad, é se alçaba con la justiçia é gobernaçion, y en lo demás haçia todo lo que le paresçia, á sabor suyo é de sus secaçes: por tanto que les rogaba, que como servidores de Sus Magestades é amigos suyos, le dixessen lo que se debia hager. É assi í este propóssito dixo otras palahras, é lo liço assentar por aucto á Bernarlino de Cabranes, escriluano de Sus Magestades. Respondiéronle que la lierra é Diego Mendez. estaban en tal estado quél dolia disimular lo mejor que pudiesse, é congertarie con Diego Mendez cómo no oviesse alteraciones en los chripstianos ni en los indios; é ovo regidor que dixo, ó temiendo al Diego Mendez, ó porque le paresçia ser conviniente á la república, que si no se pudiesse congertar en que fuesse su teniente Diego Mendez, que lo fuesse el Lerececla dél, porque esso era lo que conrenia al serviçio de Dios é de Sus Magestades, é al bien é sosiego de aquella universidad é de la tierra. É porque algumos se riyeron desto, replicó assi: "Reysos ó parésceos mal lo que he dicho? Pues asentadlo assi, escribano, que yo lo digo ạsi; y el tiempo os doy por testigo, para que os muestre que aquesto es la cosa del mundo mas nesçessaria á la quietud é ınena providencia é sosiego de las vidas é haçiendas de todos los que aqui vivimos, é aun para que la total destruycion nuestra se excuse."

Desde á muy poco espaçio el Diego Mendez, sospechando quel cabildo se avia juntado en la casa del Cereçerla en su ofensa, fué allá con su gente de pié é de caballo, creyendo que se tractaha mal dél ó que le querian prender, é apcóse con su vara y armado; y el escriluano no avia tenido tiempo de assentar lo ques diclıo. $\mathrm{Y}$ el regimiento, en tanto que se assentaban aquellos auctos, dixeron al tiereçeda que debia salir al Diego Mendez y entretenelle con buenas palabras: é assi lo hiço, é díxole que estaban en cabildo en su regimiento, para dar órden en algunas cosas de la villa; y el Diego Mendez, muy alterado, dixo: "í esso vengo yo tambien: que tengo que haçer en cabildo." Y el Cerececla replicó: "Pues luego entraremos." É poreue le paresçió que se lardaba ,é (jue le clebian ordenar algun jarabe para purgarle, se entró en el calildo, é dixn: "Yo soy servidor de Sul Magrestad, 6 no hre de rstorluar cosil que sea su servirio, sino ser en lo laaere el primern. $\mathrm{Y}$ c) Corveda ni le ozó yo á la mano, ni 
anm quisiera estar allt, porpue al rededor hal, y en lis puertal y en la calle. teria el biegro .ICndez gente, todos sus parriales. lí assi, drspues de assentados, dixo assi:

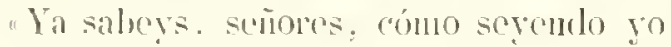
teniente de grobernadere, de lectro is sin "illsial ni temor de Dios ni de Sus Migersfades, me quitaron la rara é me prendicI'on el lirano Iraydor de Vasen de IIerrera y el cabildo desta villa, y el gohernador Diego Lopez de Salcedo despues declaró por sentencia que mi prission avia seyclo injusta é mal hecha, é aun ron juramen10: é que muerto el dicho Diego Lopez no te avian quitado la rala, é quél cra teniente, é les requeria que usassen con él en el dicho offiçio: é pues á ros, señor "ontador, Andrés de Ceregeda, dexó Diewo Lopez poder en su fin para gohernar, yo os requicro que, assi ros como estos señores é regimiento, useys al officio conmigo, é me hayays por tal teniente, en tanto que Sus Magestades proveen lo que lineren servidos."

Los del calsildo, no con poco temor de oyrle, respondieron que le daban por respuesta lo que á Cuereceda avian respondido; y el Cerecenla diso que veria la respuesta del cabildo é responderia. Todo eslo se assentó, é se fueron á sus posadas. El Diego Mendez dixo despues á sus aliados que ya el caliddo le avia resçebilo por teniente, é que no avia de mandar oro sino él; é assi lo haçii en todo é como lo queria.

El Cereçeda, visto to que Diego Mendez le requirió, é que muchos le decian yue hiçicsse lo que Diego Nondez le pelia, no estaba en cllo, porque Diego Mendez no tenia poder, y el que tuvo de Dicgo Lopez estaba revocalo. É viendo que cra malador y eslaba presso, é que si él un usso viniesse y ambos mandassen cra dino de macha rulpa. é amn la ticra se perdiria, por evilar cssos inconvinientes, acordo de dilitar la respuesta fono dobia dar al respuirimiento, esperando lo qued Alessorero Johian Ruano é Diego Diaz de Herrera respondritan á sus caulas. Pero decia Cerescela públicamente, yue lo que hisiesse Diego Mendez fuesse en buen hora hecho, é pluguiesse á Dios quél lo liiciesse de manera que todos le oviessen envidia, é que para la expriençia bastaban las cosas acaescidas por nandar dos; é rue pues biegro Mendez se melia en cllo, quél no prodia laçer sino callar é mirar y estarse en su casa, luasta que Sus Mageslades provegessen olra cosa: lo qual él deçia por no allerar á Diego Mendez, é descuydarite, porque si respondia al requirimiento. avia de deçir que cra nuatador, é castigrale, si pudiesse, con justiria; é pues aquesto no se podia assi hacer, acordó de temproriçar. Has el Diego Mendez, que conoscia sus proprias obras, é via quel Cerecenda dilataloa la respuesta, no le paresciendo bien acpuella dilaçion, curióle aquel reverendo padre Arela é otros, con quien le envió á rogar que fuviesse paz con él ; é que pues sabia lenia poder como él. y el Cereseda avia dicho muchas veces que desseaba dexar aquel cargo, que agrora tenia tiempo para se desocupar de las cosas de la justiçia, é questa se la dexasse al Diego Mendez, é quel Cereçeda entendiesse en lo demás de la gobernaçion y en el tar de los indios, é que del solo Diego Mendez tomasse su parescer, é no to viesse Cereçela mano en la jusliçia, é que assi lo aprobasse el cabildo y el Cereçeda lo jurasse é no truxesse vara. Ceregeda bien entendió questo pedia Diegro Hendez por temor de ser presso, é respondió al clérigo é á los demás, yue en desistirse de la justiçia que ni él poulia ni lo debia lraçer sin mandárselo Su Mlagestad: mas que en lodo lo demás quél queria que se hiçiesse como el Diego Nen(lez lo quisiesse, é que no desscaba sino fur lodos esturiessen en paz. É con esta bespuesta volvicron á Diego Mendez, é no 
le agradó mucho; pero al calso acordó de fiar del Cereçeda solore buena prenda. Y envió á llamar los alcaldes é regidores á su posada, sin quel uno supiesse del otro: é teniendo á la puerta de casa loda aquella gentecilla que le hacia espalias, quitó las raras á los alcaldes é diólas ál Alonso Vazquez Rangel, su capitan de su guarda, que fué uno de los prinçipales culparlos, é tan doto para el officio del juzgalo, que no sabia leer: la otra vara dió á inn Johian Copete, regidor de aquella villa aquel año, y el uno y el otro de rústico entendimiento; é dexó dos regidores de los yue yá lo cran, é puso con ellos otios dos de su-mano, é como teniente de gobernador, tomó de hecho los libros y cl area del cabildo, é liço á todos que lo jurassen por tal teniente.

Otro dia siguiente dió un mandamiento frara que aquel alculde, Nlonso Vazquez, fiuesse á casa de Diego Lopez, el gobernador, é sacassc una bandera real que allí cslaha del golsernador defunto, é la quitasse de poder de uno á quien tereceda, con otros bienes del golsemador Dicgo Lopez, la avia encargado: é porque acuel, á cuyo cargo estaba, no se la queria dar, lo maltractó hasta (pre se la dió,é la Ileró á Diego Mendez, ol qual, juntada sú quadrilla, lirgo jurar á la bandera que 110 la desampararian, y entrególa á un marinero é híçole alférez, é tomóle juramento como á los demás. Feclıo aquesto, salió á se pascar por la villa con la banlera é su gente delante, é fodos con sus armas, é la landera á par dél, amenàrando é diçiendo quel que se relulliesse le avia de poner colgado de un pino de aqquella villa, é que despues se haria el proçesso en la unìa.

Otro dia adelante jueves, teniendo ya á los alcaldes é regidores é fodo de su mano, é con su gente ò olros mas que se le allegaban, cabalgó por la villa, porque como pensabia diar de su mano los in- dios, seguianle sus amigos é aun los que no lo cran, é á otros enviaha í llamar é deçia que no aria otro teniente ni justiçia sino él solo: é liço pregonar, llamándose teniente de gobernador é capitan, que daloa por ninguno todo lo que avian fecho el traydor tirano Yaseo de Ilerrera é Andrés de Coreçeda, como su aliado, avia consentido, despues que fallesçió el gobernador Diego Lopez de Salgedo, é lo anulalıa por aquel pregon; é mandaba quel Cereçeda no usasse mas del cargo ni se llamasse gobernador, só pena de muerte, y envióselo á notificar con un escribano, é tambien envió á mandlar á Cabranes, escribano, que no usasse con el Cereçeda el offiçio, de lo qual él no curó, sino, haçiendo lo que debia, siempre contiunó su offiçio con el teniente Cereçeda cada é quando que convino.

Viendo ya Cereçeda lanta tirania é desverģiença en el Diegro Mendez, le envió la respuesta con el Cahranes, escribano, salisfiçiendo al requirimiento passado, quel Diego Mendez le aria fecho en el caLildo, en que le reçitó el delicto que avia fecho, é que era matador é persona privada para el cargo, é que estaba revocado por el grobernador Diego Lopez ya defunto, é que estala presso, é que cón su poder del Cereceda estaba revocado el suyo, é otras cosas á este propóssito, quel Caluranes le notificó en su posada, estando rodeado de aquellos sus adlierentes: de lo qual se alteró mucho é se afrentó, porque aquellos oyeron aquellas palabras ó respuesta, é laçia rascas é amenacas. li el escribano Calıranes era enerdo, é díxole: "Señor, no reçibays pena, porque esto no lo dice Cereçeda por enoxaros á ros ni á olro ni para daros passion; sino porduc la de responder al requirimiento que ruestrá merecel le hiço, é para dar cuenta, quando le fuere pedida, quiere tener sus auctos en su caxa, y él tiene poca a ninguna roluntad de se ocupar en la 
justiça : antes deszea estar desocmpado de la gohelnaçion en todo. Y Y con csto se asosegó Diego Mendez, y el Cabrantes se fué, aunque no dexáran de hidblar en lo prender ó matar; ‘ los clemás de aquella loca congregaçion le dexúran al Diego Mendez, é se fureran al Cereçeda, si no se halláran culpados en la muerte de Yasco de Ilerrera.

Pues viendo Diego Mendez que Cereceda tenia poder hastante para gobernar, quel golsernador Diegro Loprez al liempo de su muerte le dió, acordóse de yo á casa de Francisco Cepero, escribano de Su Magestad, ante (al qual Diegro Lopez aria otorgato el porler de Cerecerda, é tomóle los registros, diciendo quel proder era falso, é que quando se otorgó estaba ya Diego Lopez fuera de sentido: é prendió al escribano, é sin le dexar ver ni hablar á ninguno, le turo en su posada propria del Diego Mendez muy aprissionado: é hiço quel algoaçil Vidal, como fiscal de officio, le acusasse por falsario, é por otra parte le lialagaba en secreto, por le hacer vaçilar é que disesse lo quél queria; é otras reçes le deçia é jurala que lo aria de despedaçar á tormentos. si no confessaba quel gobernador Diego Lopez estiba sin sentido, quando avia otorgado el proder ál Cereçeda.

Johan Ruano, thessorero, avia resçelilo la carta de Cereçeda, y envió con indios la otra á Diego Diaz de Herrera; é tardó tanto en la resçchir, que llegó á donde estaba con la gente otro capitan criado por Diego Nendez, é requirióle que se la entregasse é a la gente que no le tuviessen por capitan al Diego Diaz. É assi se hiço, porque él era mal quisto. non obstante quél replicó que era capitan é criado por el contador Cereceda, que era gobernador é no otro. Pero no le aprovechó: antes la gente se acostó al ticmpo é al otro capitan fecho por Diego Ilendez. é luego se fué con ella á las minas para luager alli to que Diego Mendez le avia ordenalo. É Cuereceda avisó á Diegono Iniaz que se sguardatise, porque tenia peligro y cstalia en el campo, é acordó de renirse á la villa, é fuésse derecho á se apear á la ighlesia ; é cóno Diego Mendez lenia vela solire él é recablo en la igylesia, al apear ó dentro della le prendieron é llevaron á casi de Diego Mendez, é le pusieron en graves prissiones, sin le dexar yer á nadie: é de hora en hora se creia su murle, porfuc Diego Nendez, despues de se la desscar, estaba en su mano dársela; pero dilatábala, porque primero queria prender ó matar al Ceregecla, asoi porque no avia podido con el escribano Cepero haçer que dixesse quel poder de Cereceda era invílido, como por la respuesta que á su requirimiento le avia dado Cereceda con el escribano Calmanes, é porque sin essa, le envió á notificar á Diego Nlendez é su gente çiertos auctos é mandanientos, é mandóle llevar á mos. trar la provision que Su Magestad dió al gobernador Diego Lopez y el poler que le avia dado al Cereçeda, é leyóselo con otras eseripturas allí donde estaba aquel loco cabildo orendo con mucha saña lo que se les leia. Y enoxado Diego Mendez, se levantó con mucha yra é tomóle las escripturas al escribano Cabranes, é con dos pares de grillones que avia fecho hacer nueros para sus apetitos furiosos, dexó presso al escribano, é fuésse á casa del Ceregeda á prenderle con mucho escándalo é voces, alterando la tierra é diçiendo que para la paz della é sosiegro de todos assi convenia, para que viviessen seguros. F́ á ruego de algmos hombres de bien, que no desseahan que Cereceda reschlbiesse daño, é principalmente porque lo quiso Dios assi, no le echó grillos, é mandóle que tuvicsse la casa por cárçel é no salicsse della sin sn liçençia expresa, só pena de murete é perdimiento de sus lienes: lo qual él guardó, y esturo presso 
desta manera con sola la companiiia ded Bernardino de Cabranes. I no le osaban ylá ver sus amigos, por no enoxar al Diego Mendez; mas visilábanle de palabra, enviándoselo á deçir con el Cabranes, que ya le avian soltado.

Este detenimiento le luró al Cereçeda treynta y siete dias, y en las dos noches primeras y en las dos postreras se le pararon los mas de los cabellos é las barbas tan blancas, yue dió admiraçion á todos (porque hasta estonges cran raríssimas sus canas); porque congecturaba Diego Mendez, y aun lo dixo á algunos de sus anigos, que su vida estaloa segura con la muerte de Cereçeda, é tenia solore él siempre espias, y el Cereceda no lo ignoraba: antes pensaba que un clia avia de amanesçer muerto á puñaladas en la cama.

En esto llegó el thessorero Johan Ruano, é dixo al Cereceda lo que en las minas arian dañado los ministros de Diego Mendez, é como ya todos los de la villa avian jurado de le seguir é no ser contra él en pressençia de aquellos sus homiçidiarios, para quél y ellos pudiessen yrse quando les paresçiesse, sin que nadie fuesse tras ellos.

Nunca gessaba la voz de "Vira el Rey", como en el tiempo de las Comunidades; é viendo la perdiçion en que todos estaban con aquel tirano, acordó el Cereçeda de lo prender ó morir ó deshager acpuella tirania, é procurar quel Diego Hendez se tomasse viro.

Ia ninguno osalua entrar en casa del Ceregeda sino el thessorero Jolın Ruano y el vecdor Françiseo de Barrientos, é aquestos de tenor lo lagcian pocas reges, só color que se juntaban á entender en las cosas de la lageienda de S. M., como sus officiales. Fi en aquestas visitaçiones Cuerecedát rogó al thessorero Jolian Ruano que juntasse algunos de los annigos de entrambos, aunque avia pocos; é assi se lico, é una noche se juntaron trege de í pić ó calorçe, é quatro de á caballo en casa del Ceregeda, para que los de caluallo estorhassen los que acudiessen al ruydo. É puesto que tenian pocas armas, con las que lurieron le prendieron un martes en la noche, quinge de noviembre, año de mill é quinientos é treynta y uno, al fin del quarto de la primera guardia, é ya que le rendian sus velas, é fué presso vivo é sano el Diego Mendez por el Cereceda, defendiéndose con una espada é una adarga é la vara de la justiçia en la mano é dentro en su cámara, en la qual é de fuera tenia guardia: los quales todos huyeron, sin que otro alguno fuesse presso, poryne solamente se ovo ojo al Diego Mendez. Pero no se pudo esto laçer sin sangre, porque haçia muy escura la noche, é salieron heridos siete hombres, uno mucrto é un caballo, los quatro de la parte del Cereçeda, é los tres y el lombre é caballo de parte de Diggo Mendez: en el qual trançe el thessorero Jolian Ruano se ovo como valiente hombre é buen servidor de Su Magestad, é fué mucha parte de la vitoria é buen subgesso de todo. Assi que, presso el tirano, lo llevó el golbernador Cereçeda á su posada é lo aprissionó bien; é fecho esto, sosegó el preblo é cobró las armas que le avian tomado durante la tirania, que permanessió treynta y siete dias.

La noche mesma que fué presso Diego Mendez, se tomó su confession bien larga ante el alcalıle Diego Nieto, é dixo quién le avia dado favor é ayuda para lo fecho, y en esta ocupaçion se passó el ticmpo reslante de aquella noche. É otro dia miércoles siguicnte, diez y seys de noviembre de mill é quinientos é treynta y uno, fué llevado á la círçel pública ó real, é allí le sentençió como á traydor é lirano á que le cortassen la cabega é fuesse fuclo quartos. E assi fuć luego executada, ć su puso la cabeça en la plaça en un 
pato hasa que por tiemro se calyo seral, e los quartos se pusiconen en los canninos; c) fueron confiscalos sus hicmes para la cimara, pero todo lo que tenia no basta- ha a pragar lo que debia con dres mill pessos dee oro. I assi so libram de liss prissiones cor (que estaban Dicugo l)iaz de lferreläa y el escribuno l’ançisco Cepero.

\section{CaPITULO V.}

Cúno el gobernador Andrés de Cereẹeda, despues de la prission é eastigo del lirano Diego Nendez de Ilinestrosa, é eastigados los que mataron a Vaseo de Herrera, perdono á los demáts; é cómo lliego Diaz de Herrera tenia amotimala la gente para yrse de la tiera; "eomo, viniendo por gobernador Diego Albitez diú al través en la costa, é assi se alogarun veynte y cineo tombres é cineo mngeres, é salió el gobernalor á nạdo, édesde á nueve dias que fué resçebido por gobernador inurió, é dexúpor gobernador al mesmo Andris de Cereceda.

C omo en la prission de Diego Mendez, si se crrara, no le ylua mas á Cereceda é ¿ los que con él se juntaron, de perderse, aunque el tirano é sus valedores cran murhos é muy armados, y essotros con la voz del Rey é de su justiçia, diçiendo: "Dlueran los traydores é liranos», ¿ apellidando al Apóstol Sanct Ancliés por se conoscer, quiso bios que se acaló el negoçio assi como se ha dicho en el pregedente capitulo, teniendo cuydado los vençedores, los unos á sollar los pressos, y otros á cortar las cuerdas de las ballestas; é carla uno teniendo el caso por proprio, se determinó la vitoria por la justiçia cúya era en esla çivil batalla. É en el instante hiço pregonar el gobermador Cereceda que en nombre de Su Magestad perdonalua á los valedores de Diego Mendez, viniendo á la obodiençia de la jusligia de Su Magestad é de su goberuador dentro de un lreve término: é luego lo pusieron por olura muchos, por no perder las vidas é los bienes. É assi unos hincados de rodillas pidieron perdon, llamándosse engañalos, é otros huyeron á la iglesia; é desta manera quedó la casa de Diego Mendez desembaracada y él presso. É despues quel gobernador Cereceda lo llevó á su casa é lo dexó á recabdo, fućsse el gobernador á la iglesia á reyterar el perdon á los luaydos á clla, éc á quitarles las armas, por- que no se amotinassen con los buydos é se entrassen por la tierra é la alçassen: que fucra perilerla de todo punto, é á ellos matáran los indios; porque le paresçió que cra menos mal tolerar é clisimular. sufriendo alguas culparlos, que caresçer de gente, é que por colnarlos, si se fuessen, se perdiessen onros luenos é leales al servicio de Su Magestad. Y assi entendió en castigán los mas culpados, que cran aquel Pedro Vidal, alģuaçil, que dió la puñalada al Vasco de Herrera é le echó la soga al cuello, con la que fué despues ahorcado el malfechor'; y el otro Alonso Vazquez, alcalde é capitan de la guarda del lirano. Estos dos se juntaron acaso aquella noche con otros sus compañeros, é se fueron la costa abaxo á puerto de Caballos, pensando hallar alli al capitan Johan Farfan de Gaona, que avia enviado allí gente á poblar; é tomaron una canoa equipada de indios remeros, é fuéronse. El gobernador Cereceda proreyó de gente de pié é de caballo trás cllos por otras partes, pensando que yban la licrora adentro (y lanto mas por asegurar la tierra); pero luego se supo por dónde yluan, é mandó y á Diego Diaz de Ilerrera, Lermano del muerto Vaseo de Ilerrera, en otra canoa trus los malfechores: é tornóse, porque el tiempo de la mar fué reçio é contrario. 
Asegurados los demás por las palabras de Ceregeda, é viendo que á ningِuno haçia sacar de la iglesia, se acabillon de lecoger á ella los demás culpados, y entrellos uno que era de dos que turieron en palaluras al Visco de Ilerrera, entre tanto que llegó á echarle la soga el Pedro Vidal; y este era un marinero de Cartay, que se llamaba Jolıan Alonso, é se pressentó en la cárecel, é perdonóle Diego Diaz la muerte del heruano con liarta admiraçion du todos, é creyósc que fuć porque aquel Johan Alonso creuhria al Dicgुo Diaz algunas deshonestidades en ofensa de un reçino casado. 't́ cómo el gobernador vido que la parte mas ofendida perdonaba, aunque el caso era de manera quel castigo estaba meresçillo, ó assi por asegurar á los otros delinquicntes, como por usar de quietud é menos rigor, le condenó en çicrta pena pecuniaria para la cámara é fisco real, é á otros culpados hombles baxos condenó en açóes, é á otros en otras penas, menos assaz quellos las merescian padescer; pero por dar lugar al tiempo, quiso mas ser avido por piadoso que por açelerado ni rigoroso, siguiendo los méritos de los tales, é desta mancra aculó con los mas de aquel bando del tirano.

El Vidal y el Alonso Vazquez, desde á sessenla ó septenta dias despues que padesció Diego Mendez, tornaron á la costa é ovieron lengua como el golselnador Ceregeda se avia avido piadosamente con todos, é atrevićronse á confiar en su mansedumbre, y el Pedro Vidal, como mas suelto é de menos vergiença, dexando al Alonso Perez en las islas de los Guanaxes, y él é los que con él se avian yolo vinieron á Truxillo, é uná noche se metieron en la iglesia. É cómo Cerecgedia lo supo, fuce luego allá é sacó al Pedro Vidal é á uno de los otros, é lícolos llevar á casia de un alcalde, grand amigo del Yasco a Diego Iliaz de Ilerreri, y en pressencia TOIO III. de los que lo quisieron ver, le tomó Cereçeda su confession, porque se sospechaba queste sabia el fundimento de la cosia, aunque no queria confessar quél avia muerto al Vaseo de Ilerrera, sino el Diegro Mendez (aunque fué puesto á tormelito). En fin le mandó sentençial á hatser quartos, é mandó que sur cahega se pusiesse en un palo á par de la de Diego Mendez. É cómo se vido sentenciado, al extremo declaró delante del cscribano é firmó de su nombre quél avia clado la puñialada al Vaseo de Herrera; é al otro hombre mandólo el gobernador restituyr a la iglesia, de donde lo avia sacado. É fecho esto, envió ál la isla por el Alonso Vazquez, é traydo, fué sentençiado á que le cortassen la cabeça, é pusiéranla con la de Diego Nendez é Pedro Vidal: é no fué fecho quartos, como sus consortes, porque se supo que la noclic antes que muriesse Vaseo de Herrera matáran assimesmo al Andrés de Cerecgeda, si este no lo estorluára.

Los indios, viendo estas cosas, se alçaron los mas dellos, de manera que con mucho trabaxo volvicron á la ohediençia menos del terçio dellos: é platicábasse entrellos de se yr al monte é no trabaxar en las haçiendas de los chripstianos, pol"que desque no turiessen qué comer, no los segunirian, é que la hambre cchasse á los chripstianos de la ticrra, porque deçian que ya el Rey de Castilla tenia olvidados aquellos cluripstianos, pues que tanto tiempo a via que no yban allíotros chripstianos; é assi los pusieron en grand nescessidad.

Todavia aquel Dicgo Diaz de Ilerrera é sus devotos plílicaloan en yrse de la tierlaa, é deçian que avian de dexar al Cerescola con sı gol)ernaçion en seco, é. aunque él laçia informaciones desto secretas é públicars, éá veges le amenaçaba, ó otras le halagabar , é le hicgo muchas buenas olmas, nunca lo pudo sosegar. É descle á un año despues de lıccha la justiçia ques dicho, 
tenia concertalo con sus anigos que venido el verano requiriessen al Ceregeda gue fuessen á polblar donde oviessen mas indios, ¿ rue si no to higiesso, se fuessen é he devassen ó se fuessen ál la Nueva España ó donde les paresciesse; y el Cereçeda disimulaba con él, esperando tiempo de le castigar, si no se enmendasse. F ¿ los vernte y nueve de otubre del año de mill é quinientos é treynta y dos el capitan Diego Nlbitez, á quion Sus Mageslades enviaron por su gobernador á arpueIla tierra, llegó con dos navios é septenta hombres í arpuella costa, é con recgio liempo é tal tormenta, que dieron ambos navios al través á seys loguas de aquella villa de Truxillo, é se rompieron, y el gohernador é alğunos salieron á nado con harto trabaso, é la mar echó fuera alğnna ropa, é lo demás se perdió, é se ahogaron veynte y çinco homlses é çinco mugeres casadas. Éa la saçon estaban en un pucblo de indios, que servian, dos españoles que acudieron á la costa, que fueron mucho socorro para los que escaparon en les ayudar á salii de la mar é salvar to que pudieron con los indios. E lnego el Diego Albitez escribió al Cereçeda lo acaesçido, y él proveyó luego y envió allá al thessorero Johan Ruano é á un alcalde para le proveer de lo nescessario: é luego se fué á la villa de Truxillo, á donde llegó martes á çinco dias del mes de noviembre del año de mill é quinientos é treynta y dos. É juntado luego el cabildo, por las provisiones que llevaba de Sn Magestad fué resçebido por gobernador é capitan general de aquella gobernaçion con mucha roluntad é plaçer de lodos, porque era persona antigno en estas Indias é lionrada persona, é teníase esperança que seria tal como convenia al remedio de la tierra, por la mucha expiriençia que tenia é lo que avia visto en estas partes. lí con su llegarla del é dessos que llevó y escaparon de la marr, se exeusó cl motin que afprel Diơro Miaz de Ilerrera é sus consortes tenian acorelardo pol' estonges. P'iles cómo Diengo Mhitez se vido en tanta nescessidad, cono es dicho, prometió tener novenas en anjuellat iglesia de aguella villa de Truxillo, é de camino se entró en clla, donde le roscjbieron por goberuador a céllí se quedó para siempre, como bios quiso, porque era lomble de mas de: sessenta y sinco años é trahasado é pessado, é subcedióle su naufragio estando mal dispuesto é no sano: é al quinto lia que entró en la igglesia, le dió una fiebre morlal é hinchaçon de cabeça é ojos é toda la cara, é aumentósele de tal snerte, que al noveno dia de su gobernaçion mulió. Plega á Dios aver piedad de su ínima, porque como es dicho era buena persona é desseaba açertar á servir á Su Nagestad, á lo quél deçia é mostraba; mas este desseo de mandar le hiço dexar su casa é lıaçienda é indios que tenia en Castilla del Oro, donde avia ganado en muchos años to que tenia con assaz trabaxos, para lo perder en este camino suyo é jormada última en breves horas.

Aqueste es arpel capitan que se dixo en el capítulo 1, que con Sebastian de Benaicáçar é Johan de Espisosa le prendió Diego Lopez de Salçedo: el qual Diego Albitez al septeno dia de su enfermedal, temiendo la muerte, envió á llamar al contador Andrés de Cereçeda, é dióle poder para gobernar aquella tierra en tanto que Sus Magestades proveyessen otra cosa, y él de palahra le encomendó la tierra é los que con él allí avian ydo, é hiço hego allí juntar el cabilılo é que lo resçiliessen al carço; é assi se hiço, é no hiço testamen. to é dió poder a Cereçeda para que lo hiçiesse por él. 


\section{CAPITULO VI.}

Cúmo Andrés de Çereęa quedú por gobernador despues de la muerte del gobernador Diego Albitez, ẻ de algunas eosas que subçedieron despues, é lo quel Çereçeda escribió á esla Audiencia Real, que reside en esta eibdad de Sancto Domingo, del estado de aquella tierra é gobernaçion de Llonduras hasta el año de mill é quinientos é treynta y tres, mediado el mes de junio.

L a carta de Çereçeda deçia que si el gobernador Diego Lopez viviera mas diez dias, que aquella tierra se despoblara por estar mal quisto, é que assi por esto, é quererse yr todos, ha seydo grand cosa sostenerse la tierra, atriluyéudolo á su buena industria, é ser mas compadre de lodos que gobernador. Y esto habla él á su apetito, é como liombre que le sulhgedió bien el fin de aquellas contençiones; pero no ereo que en tiempo de Diego Lopez se le desacatíran sus mílites. Antes la mayor parte de aquellos escéntalos nasçicron de tener al Cucreseda en poco aqquellos Herreras ó errados contendores; é viéndose ya perdido é al cabo en ríspera de ser muerto ó presso, de manera que parara en lo que paró Vaseo de Herrera por la tirania de Diego Mendez, sacé fuersas de flaqueça, con el favor de Johan Ruano é por la virtud é fidelidad de Gabranes é aquellos pocos, que de desesperados é maltractados, y esperando de serlo peor cada dia, se juntaron con él á prender á Diego Hendez, no negánelele á Cereçeda, como otros, el poder é auctoridad que con derecho tenia para gobernar, en tanto que Sus Magestades otra cosa proveyessen. Sin dubda él sufrió mucho é sirvió bien, é Dios le ayudó con cl buen sulsçesso, é sus amigos lo hiçieron como leales; pero Diego Lopez era cavaIlero, é si estaba mal quisto, seria por lo que lo estuvo tambien en Nicaragua: que era amigo de verdad é de haçer bien su offiçio, y esto no agrada á toda manera de gente. Y la causa del trabaxo que los españoles alli padesçian, é de su polreça, se podia mejor atribuyr á que murclos indios, de ser maltractados eran muertos, é otros ydos; é porque en aquella tierra avia faltado el oro labrado de pieças; é porque haçiendo esclavos los indios á dies. tro é mas á siniestro los avian vendido é sacado de la tierra, é los que quchialan, luiian á los montes é se dexaban nırir, por salir de tan grande suljjeçion; é los chripstianos, por no tenellos, indaban por yrse de la tierra. Y todo esto confessaba el mesmo Cereçeda en sus letras: é tambien deçia que era grand causa de su daño no aver otro pucblo la tierra adentro, despues que los de Nicaragua celiaron del valle de Vlancho " Ios que desde Truxillo tenian alli poblada una villa, é despues los indios los mataron é hiçieron dexar la tierra, é los indios se entraron lia tierra adentro é assi los veçinos de Truxillo no se avian podido aprovechar dellos. Que la tierra nunca fué falta de minas de oro: antes en muchas partes de agquella gobernaçion se han descubierto muchas é buenas, sin se aprovechar dellas, á causa de las revueltas que se hau dicho en los capítulos preçedentes, é de los gobernadores á pares, é sus disensiones é diferençias é deslcaltades é tiranias, é aver falladio Diego Lopez de Sillcelo. Tornemos al subegesso del segundo poder de Cereseda que Diego Albitez le dexó.

Digo que fué admitido por el cabildo con mucha voluntad, y él lo açeptó cou 
menos, porque le avia licelo Inins merecel de navegar tres años entre tales contiendis é feligros, y en compania tan sospe-

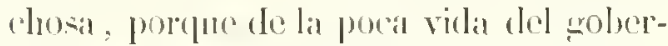
nator Mlliter se esperaban mas lubllicios on arfuclla licrra, é mas desasosiego en los eluriprotianos, á causa de las grambles nuevas yne se sonaban de las otras golnermaciones próximas; ése sospechaha clue se yrian muchos ó los mas dessos que avia á buscar la vida donde mas riquecas se predicaban. Y para evitar lodo esto, acordó el gobernador Cereçeda de hacer un pueblo la tierra mas adentro. donde oviesse minas é indios que sirviessen, é se pudiesse contractar con los de Nicaragua é Guatimala, para aver caballos é otras cosas que destle Panamá se llevan á aquellas gobernaçiones por la mar del Sur; é para este efefto, envió un capitan con sessenta hombres treynta é çinco ó quarenta leguas de Truxillo, é mandó que diez y seys leguas de allí le esperassen á él para que fuesse á los despachar, porque quedalua á hacer mas gente é á proveer de armas é ballestas é olras cosas.

É al tiempo que se quiso partir llegaron dos españoles con cartas del capitan Alonso Dávila, contador de Su Magestad en la gobernacion de Tucatan, que renia por la costa con ciertos españoles en temanra de navios para se yr á su gobernacion; y el Cereceda sospechó que podia ser gente amotinada ó fue yban á dar algun desasosiego en la lierra, é çessó la partida; y envió á sentir qué cosa era é á qué venian, y envióles alğun lastimento, porque M Monso Dáivila escribió la grand nesçessidad que con quarenta homlses traia muy trabaxados é muy desarmados. É supo Iél é dellos quel adclantado don Françisco de Montejo, si grolernador, le avia enviado con cinciucnta hombres la tierra adentro tresnta ó fuarenta leguas de donde él estaba á poblar, é que no halló dispusicion lasta sessenta 6 septenta legruas de su grobernaçion; é que avicudo assentarlo en buena parte, avisó á sul grobernador, é que los indios lo avian muerto dos veges los mensigeros, la ma dos lombres, é la secumbla seys chripslianos, é la mesma saçon se le alcó la lierra; y el Nonso Márila avia yolo allá con la mitad de la gente é caballos más que tenia, é no puclo passar con la mucha guerra que le avian darlo: é que creyendo que su adelantado é torla su gente eran muertos, pues estaba lodo alçalo, se avia procurado salir de la tierra por escapar lás vidas, é que mucla partè del camino avian venido en canoas, creyendo yue en Truxillo hallarian dispusiçion para ser socorridos, parra yr á saber la rerdal de su gobernador; é que avia dos años que andaban en esto, é que no sabian de su gobernador, é por grand ventura venian vivos, por les aver faltado los hombres yue los indios les avian muerto, é aver perdido las armas é quebrádoseles muchas dellas, é faltarles el comer y el vestir y el calçado, é con muy poca salud muchos dessos, que yban sin médico ni çirujano ni medeçinas. Assi (une, ydos allí, aria mal recaludo de refrigerio ó socorro de navios, porque aria tres años que no salbian en Truxillo de Castilla ni destas islas.

El Cereçeda aposentó en su casa al Llonso Dávila é otros, é los demás en casas de otros veçinos, y él se partió á despachar al capitan é los que yban á haçer el nuevo pueblo que enviabá á poblar. I estando allá, fué a visado que cran llegados dos navios pequeños de la isla de Cuba, é que te convenia venirse luego para despachar í Alonso Dávila, porque ya Diego Diaz de Ilerrera tractaba con él é otros de se yr do la ticrra con cllos á su gobernaçion é í otras partes; ́́ por esta nesçessidar dexó el campo é al capilan é gente que enviaha, é volvió á la villa para despachar á Alonso Dávila. Y estando el Monso Dávila de partida. Ileğbonle cartas al go- 
bernador Cereceda del capitan que enviaba á la nueva poblaçion, como entre los que allí tenia de la compañia del gobernador Diego Albitez estaba ordenado un motin, é dexarle solo é yrse, é que tenia pressos algunos dellos, de quien pensaba haser justiçia; por tanto que fuesse luego allá á poner recalsto en ello, ó le escribiesse lo que hiciesse. El grobernador Cereceda le escribió que hiçiesse justiçia de dos ó de tres dellos, los mas culpados; é quandó el mensagrero llegó, la noche antes se arian soltado los pressos que pensaba que mas dinos erain de castigo; é viendo que aquellos se àvian ydo, soltó los demás, dándoles á entender que á ellos no les avia prendido, sino para que guardassen á los culpados que liuyeron.

El Cereceda despaclió al capitan Alonso Dávila, é á los que de su compañia quisicron yr con él, en uno de los dos navios de Cuha, é fuésse á su gobernador , y él tornóse á despachar el capitan y entender en el motin conforme al tiempo; é despues que le ovo despachado, volvióse á Truxillo, é tríxose consigo algunos de los culpados del motin, é los huydos se quedaron por los montes, donde perdidos no les faltaria su castigo.

En aquella sacon sohrevino grand pestilencia en los indios, de sarampion é otras enfermedades, é numieron mas de la milarl dellos, assi de los que servian á los chripstianos en sus haciendas, como de las naborias de casa; é viendo esto, tornaban á platicar algounos en dexar la ticra. í causa de lo qual el gobernador Coreçeda y el cabildo é regimiento é officiales dle Sus Mlagestades, é otros vecinos, porque la tierra de Honduras é Naco es tierra rica the minas de oro, y en lo del puerto de Caballos, donde mataron í Chripstóbal de Olit, hay tierra para poblar é canticlad de indios, parescióles que quedando en Truxillo la gente que bastasse, era bien que Cereceda fuesse á po-
Whar á Naco con los demís é que quedassen en Truxillo cinquienta hombres, é que fuessen çicnto é ochenta con Cereçeda á Naco, é á los que quedassen cn Truxillo quedassen todos los indios de repartimiento, que á la sagon servian páa a coger oro en unas buenas minas que liay treçe leguas de aquella villa la costa arriba, á tres leguas de la mar. Pórque el Cereceda no dexaria la ticra, como lo hiço el capitan Johan Farfan de Gaona é la gente que con él envió una vez el Cereceda á poblar aquello, aunque se hallaba mucho estorbo para su camino por la falta de herrage é otras cosas que eran nesçessarias para haçer luego un reparo, donde se recogiessen al prinçipio é se guardasse la ropa, en tanto que otros yban á paçificar é castigar las muertes de los chripstianosque allí avian muerto, quando mataron septenta chripstianos que yban con Gil Dávila, sobrino de Gil Gonçalez Dárila, que yba en busca de su tio é otros que Hernand Cortés dexó pohlados en el puerto de Caballos.

Mas porque en otras partes destas historias se han apuntado las nescessidades que los hombres en estas tierras padesçen, no está malo de entender las que en tres años aquestos desta gobernaçion tovieron, allende de las tliscortias é motines ya dichos; é como suelen derir que con pan son buenos lodos los duelos, alli los tenian sin larina, ni vino, ni aceyte, ni vinagre, ni cosa de comer de las de España, sin herrage los caballos, é los cluripstianos sin vestido ni calcado ni liengo ni cosa de las nescessarias. I'n pliego de papel valia un castellano de oro, é una ağuja otro tanto; sin médico ni çirujano é sin medeçinas, pero no sin muchas enfermedades, lasta lá fecha de la carta de Cereceda, escrita á esta Real Mudiencia, en que da noticia de lo ques dicho. que fué á los catorece de junio de mill é quinientos é treynta y tres. 
En la villa de Truxillo del l'inar, puerto écalo de llonduras, con todas las tempestates á diferençiats de los pohladores ¿ falta de indios, é con quantas nescessidades ocurrieron, se sacaron tres mill é quinientos é treynta y dos pessos é quatro tomines é seys granos de oro de minas, que despues de fundidos quedaron en tres mill é tresçientos é çinqüenta y un pessos é un tomin é ocho granos de oro; pero andando las minas en este buen prinçipio, çessaron por los escámdilos que la historial lá dicho, e por el sarampion é falla do los indios. Y tiénese por çierto ques una de las provingias mas ricas de minas, yuo hay en todo lo que estí descubiento en las Indias destas partes.

\section{CAPITULO VII.}

Cómo el gobernador Andrés de Çereçeda fué á poblar el valle de Naco, é cómo eslando la tierra perdida enviaron á pedir socorro al adelantado don Pedro de Alvarado, gobemador de Guatimala, é fué en persona á paçificar la ticrra é poblú la villa de Sanct Pedro, é despues lué á España, é cómo Sus Magestades mandaron juntar esta gobernaçion de Honduras con la de Yucatan, que eslaba á cargo del adelantado don Françisco Montejo, é otras cosas.

\section{E} slando el gobernador Cereceda en la determinaçion ya dicha, é por la poca constançia de los pobladores y cxcusar sus alteraçiones, viendo que lodo se yba á perder, se acordó que firessen el thessorero Diego Garçia de Célis é Johan Ruano á huscar el remedio mas cercano que á la tierra se le pudiesse dar, é ninguno tenia tal ni tan á propóssito como el de Guatimala. É assi fueron los ques dicho el año de mill é quinientos é treynta y tres con hasta reynte hombres, deste el valle de Naco hasla la ciludad de Guatimala, abriendo é rompiendo el camino con mucha industria é trabaxo, é suplicaron al adelantado don Pedro de Alvarado, que por servir á Dios é á Sus Magestades, quisiesse socorrer á los pobladores chripstianos, que estabar en Honduras, en paçificar la tierra, é dar órden cómo no se acabassen de perder los españoles que allí estaban, despoblándose una provinçia tan rica de minas de oro é otros melales. El qual fué con gente de guerra é con muchosindios mansos é quadrillas de mineros diestros, é conquistó é paçificó la ticrra, é repartió los indios, é lo dexó todo muy llano y en paz, y exergitando las nimas ricas con las quadrillas é su gente, é con parte de la gente de los viejos ó primeros pobladores, sacando oro en mucha cantidad.

En tanto que aquesto se haçia por el adelantado don Pediro de Alvarado, se dió aquelli gobernaçion de Honduras al adelantado don Françisco de Ilontejo, é la mandaron Sus Mlagestades juntar con la de Yucatan, quél se tenia primero en administraçion. Esta provision se dió el año de mill é quinientos é treynta y çinco, é se la llevó un hermano snyo al dicho Montejo el año siguiente de mill é quinientos é Ireynta y seys, y se sacó mucho en aquel valle de Naco, quel gobernador Andrés de Cereçeda é los pobladores viejos avian paçificado, $y$ en otras partes de aquella gobernaçion, donde tambien se cree que hay ricas minas de plata. É segund el mesmo Cereçeda escribió, despues de aver pollado, édescubierto ricas minas de oro é topado con los indiçios de las de la plata, le sosluvo Dios con muchas contradiçiones y estorbos y peligros, hasta que en la mayor nesçessidar que eslaba la tierra y él puesto en estrecho de perder la vida, en el mesmo lugar donde fué 
inuerto á puñaladas Chripstóbal de Olit, le envió Dios el socorro eon la yula del adelantado don Pedro de Alvarado, al qual el clicho Cereçeda avia enviado á pedir socorro é ayuda eon los dichos thessorero Diego Garçia de Célis é Jolıan Ruano, sin la qual todo se perdiera. E con ella se paçíficó todo, como dicho es, é se pobló la tierra é se sosturo, á causa del adelantado don Pedro de Mvarado, é se fundó la villa de Sanct Pedro, cerca del puerto de Caballos: el qual adelantado se fué despues á España, donde assi por lo que en esto sirvió en la restauraçion de Honduras, como por otros serviçios é méritos, Sus Magestades le hiçieron mercedes. Y él se despachó para volver á su gobernaçion de Guatimala, con su muger segunda, doña Beatriz de la Cueva, é passó por esta cibdad de Sancto Domingo de la Isla Española, el año de mill é quinientos é treynta y nueve años, muy bien acompañado, con tres naos de armada, muy bien en órden, é con lasta quatrocientos hombres. É despues que aqui se rehiço de algun refresco é cosas que le eonvinieron, se partió á los doçe dias de março de aquel año; y en diez é siete dias que aqui esluvo, yo le eomuniqué é supe dél que tenia hechos sicte ú ocho navios en su grobernaçion, en la eosla é mar del Sur, para yr á la China é por aquellas partes láçia la Espeçieria é islas de los Halucos.

Algunos meses antes, en el año de mill é quinientos é treỹnta y ocloo, avian passado assimesmo por esta ciblad el nuevo electo del obispado de Honduras, el liçençiado Pedraça, clérigo, muy reverenda persona, é assimesmo el thessorero Diego Garçia de Célis, que avia icio á Castilla eon el adlelantado don Pedro de Alvarado; é los eomuniqué mucho, y el uno y el otro me han eseripto despues que llegaron á aquella gobernaçion de IIondıras, y entre otras cosas Diego Garçia, el thessorero, diçe en su earta quel adelantado don Françisco de Montejo, gobernador de aquella provinçia de Ionduras é la de Yucatan, está en aquella tierra en la conquista é ntieva poblaçion de Comoaxagoa, que está crmedio del eamino que hay desta mar cel Yorte á la del Sur, a veynte y çineo legnas de la una é de la otra; é que en la demora passada se avian fundido sessenta mill pessos de oro mıy bueno é rico, que se avia sacado con las quadrillas, que alli fueron de Guatimala: y porque estonçes estaba cl oro á pagar el quinto á Su ilagestad, se cree que se luurtó muclio oro en polvo (ó eomo se halla) en mas cantidad de otros quarenta mill pessos. I porque no lodos, fuera de Indias, saben qué cosa es demora, digo que acá se usa deçir demora aquel espaçio que hay de una fundiçion á otra, que en algunas partes es de seys á seys meses y en otras una vez al año. Andando muy buenas las minas, se ofresçieron çiertos debates é pusiéronse límites, para que no passassen ni cogiessen oro fitera de çiertos rios; é luego que esta tasa se hiço, se volvieron aquellas quadrillas á Guatimala, é çessó aquel exerçiçio: é no lo pudieron saear sino seys ó siete veçinos, y essos sacaban á sicte reales por batea ó mas, é otros á quatro é á çineo, é sin dubrla se eree que para muehos siglos avrá en aquella tierra minas ricas, sin que se aeaben ni se agoten, é se sacarí mucho oro, si lay gente diestra. Esto se ha sabido de aquella tierra por cartas feehas en la villa de Sanct Pedro de Puerto de Caballos á cinco de otubre de mill é quinientos é ireynta y ocho años. 


\section{CAPITULO VIII.}

Wo ta fertilidad de la licra é provinçia de IJonduras de aquella gobernaçion, é de algunas parlieularidades della é de los indios naturales de alli.

\section{Tis} dos acucellos animales é aves é pescidos é mantenimientos é fruclas é cosas, que hay en la provingia de Cueva é goluernagion de Castilla del Oro, porque como todo es Tiera-Firme, lo que hay en mat parte destas cosas, tales se halla y es comun en las otras generalmente. Y en pocas cosas difieren sus alimentos, ć la gente es de la nuesma mancra, é son assimesmo yclólatras, puesto que sus rilos é cerimonias son diferentes, y en la lengua muy apartados unos de olros. Son hombres de poca constançia, é amigos de novedades, é pronlissimos á mentir, é obedientíssimos á sus caciques é mayores. Ninguna cosa les agrada tanto como la ociosidad é la luxuria: lienen sendas mugeres commmmente ó por la mayor parte cada uno, é los principales quantas quicren ó pueden dar de comer" é fíçilmente las dexan por pequeña causa (é aun sin ella), sino porpue se le antoje al marido dexa la muger, é si ella quicre dexar á él, nunca él se congoxa mucho ni pena por esso, en especial si no tienen hijos; porque quando los hay, no hagen essas mudangas. Antes la falta de generacion paresce que los convida á sus dirorços, creyendo la muger quel defello está en el marido, y él piensa que clla es la impotente, é para csto ellos quicren probar otros vasos ó cllas otros maridos, é salir de su dubda.

En aquella tierra hay unos árboles que en ninguna olva destas Indias (excepto en la Nueva España) no se han hallado por nucstros cespañoles hasta el pressenteli(nnpo; de los quales nuis lancommente y en particnlar se tracla cu clib. X, ('al). XV, en la primera parte destas historias. Isos quales llovan aquella maleria que ací en estas partes los chripstianos llaman lipuidémbar, el fual licor es buena cosal, cn especial para sahumerios é para el mal do la madre puesto en el ombligro de la muger: y es muy gentilolor, ć paresec nn arrope muy espesso é viscoso, que se pega mucho é de color quassi negro. Y porque deste ambar liquido (ó lo quello cs) olros tienen mas expiriencia (puesto que yo lo lıe visto é teniclo larto dello), yo me remito á acpuellos médicos é poblarlores de la Nueva España, donde hay mucha cantidarl dello, é se lleva á Castilla por mercadcria para diverssos efullos.

Passcmos á hablar en la provingia é gobermagion de V́ucatan, de la qual yo pensaba lager un libro por sí é distinto; pero pues ya estas dos provingias andan debaxo de la administracion de 'un gobernador, para que mejor se sustenten la mua é la otra é mejor se lagá en ellas el servicio de Dios é del Céssar é mas útiles sean á los polbladores que en cllas viven, no es inconviniente que assi juntamente en este lilıo XXXIl " yo laacte é laaga relacion dellas.

* Asi se lee en el MS.; pero es equivocaeion de pluma. 


\section{CAPITULO IX.}

Cómo las provinçias de Yucatan ė de Honduras se juntaron por mandado de Céssar é de su Real Conscjo de Indias, \& se dió cargo dellas al adelantado don Franęiseo de Montejo, que primero era gobernador de Viueatan.

F

Trangisco de Montcjo fué uno de aqueIlos mílites que passaron á eslas partes con el gobernador Pedrarias Dávila, año de uill é quinientos y catorçe, é aquel mesmo año, quando los trabaxos é muertes que ovo en el Darien, fućsse de la TierratFirme, como lo hicieron otros muchos es. pantados de aquella provinçia, viendo moril á tantos, é passóse á la isla de Cuba, donde militó debaxo de la gohernacion del teniente Diegro Velazquez. Eepor su mandado fué desile alli é se lialló en el segundo descuhrimiento de Yucatan é de parte de la Nueva España, en la compañia é debaxo del capilan Johan de Grijalva; é despues volvió á aquella lierra con el capilan Hernando Cortés, donde sirvió muy bien é fué uno de los que en aquella ticrra medraron é fueron aprovecliados. Despues fuć á España en companiia de otro hidalğo, llamado Alonso Fernandez Portocarrero, é ambos por enbaxadores de Ilernando Cortés, é llevaron un rico pressente ál Géssar de oro é plata é muchas cosas nuevas, como se dixo en el libro XVII, capítulo XVIII. É con lo que este avia ganado en la Nueva España se heredó en la cibdad de Salamanca é su comalca, donde es nalural; pero assentó poco tiempo en cllo, porcfue sus desseos eran inclinados á mayor cosa que á contentarse con lo que avia adquirido en las Indias, é determinó de rolverse á ellas, é vendió lo que avia comprado, que ela tauto que bastálá á dar de comer á un cavallero. É con la voluntad de Céssar higo cierta armada, aviéndole darlo Su Magestad tílulo de adclantado de Yucatan, é hicole su gobernador é capiTO.110 111 . tan de aquella provingia de Yucatan é sus islas é ancsos, de la qual tierra hasta el pressente se ha fecho no tanto caso como de otras destas partes. É allí ydo con la gente que llevó, no ladn faltado nescessidades ni trabaros, como en Honduras é otras gobernaciones, puesto que no de aquella calidad de motines y escándalos ni alteragiones de los pobladores: antes ha bien gohernado é servido. É por tanto para el remedio de las diferengias é contengiones de Honduras, de lo gual se la tractado en los capítulos precodeutes, fué escogido este gobernador, assi por su expiriengla é buen concepto de su persona, como porque estabat en regindard ó mas cerca de la provinçia, puesto que quando llegaron las provisiones, que fuć, como tenğo dicho, el año de mill é quinientos é treynta y seys, ya el adelantado don Perdro de Alvarado avia pagificado é quitado las marañas é contiendas de IIonduras, é aria dado órden de lalırar é contimuar las ricas minas de aquella ticra, como en otra parte la historia lo ha dicho.

Por manera quel adelantado don Frannçisco de Montejo residió en aquella tierra de Ilonduras, é como provingia mas provechosa que Jucatan, se passó á clla; pero en lo (pue toca al descubrimiento de Yucatan, é qué tierra es, y en fué paralelo é clina estí, convienc al letor que se acuerde de lo yue se dixo en el libro XYII, capítulo Ill, y en el VIIl é dende en adelante en la primera parte destas historias, porque allí qureda relatado particularmente el descubrimicuto de Grijalva con el piloto Inton Alaminos, la qual ticroat este mesno piloto avia hallarlo antes en 2S 
compania del capilan Francioco Heman-

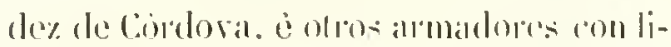

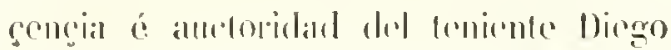

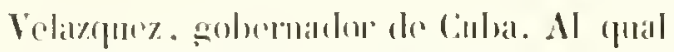

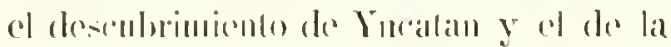
Nuera lisplana principalmonte se dibe

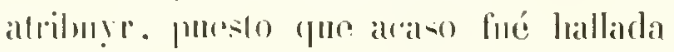

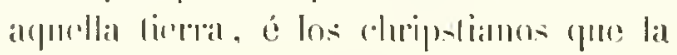

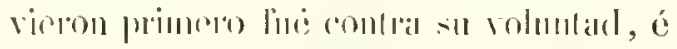

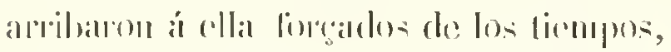

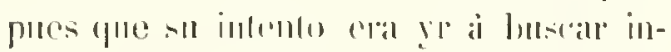

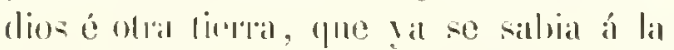

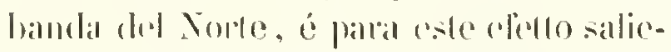
ron de Cuba ; é la lomluna los lleró á Yucalan, é de arpuel primero liaye pensaron rfue ela i.la, é por lal la luvicron es-
Ionces, è alli los malaron çientos chrips. lianus.

Todo esto queda dicho muy particular-

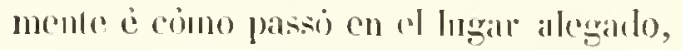
é pror r.so no hay nescessidad que atui se lorme a repelir", sino conlimar de ayni

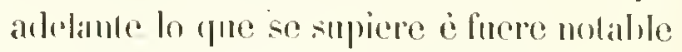
de Juralan é Ilonduras, demás de lo que e.la dicho, pues que ambats las pusioron

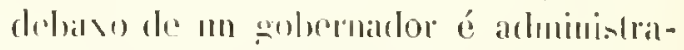
gion del arlelantarlo Hontejo, de donde de dia en elial esperamdo ricetos nasios que drala ciblad de sinncto bouningo de la lsla Espariola lineron, se supo despues to que la historia dirí.

\section{CAPITULO $\mathrm{X}$.}

Fn el qual se traela de cierlo trueeo é conviniençia entre los adelantados don Pedro de Alvarado é don Franciseo de Montejo, por donde e-la gobernaçion de Higueras ¿ Honduras se tomè a dividir é se aparló de la de Yuealan, ése junlú con la de Gualimala.

E año de mill é quinientos é treinta y nueve pissó por cista çibrlad de Sancto Domingo de la ka Épañola el idlelantado don Pedio de Mramalo con lies navios é muy buena grente que venia de Esjaña; é fiesse derecho á Honduras, porque desde alli fuesse por tierra con su muger doña Bealriz de la Cueva que consigo lleraba é con sll casa á Guatimalit. Y como se diso on el capílulo V́ll, avia ya esiado en aquella licrra, quando la fué á socorrer é sostener á ruegro de los espanoles, que allí estaban sin gohernator, por la muerte del gobernador Jiego Albitez; y en aquello avia gaslado nuclio é dexado en la lierra ganado é oflas ladciendas, é la avia resaurado con su buena industria é descubierlo minas ricas de oro. Y en tanto quel adelautado despues fué á España, melióse en todo el gobernador de Yucalan don Françisco de Iloulejo, porque Su Mageslad avia dídole ha gobernaçion de IIonduras, é mandỏ que se junlasse con Ýucalan, é que la una é la olral rohernase el dicho Montejo.

Sobre catas cosas ovo algunas conten. ciones entre ambos adelantados; y en cletto de inlumtad de los dos se concertaron en quel Francisco de Montejo dexó át Mliaradodicha golsernaçion de Honduras, para que se junlasso con la de Cualimala, con tamto quel Mrarado le diesse é desisse ol puchlo de Suchimilco en la Nueva Espana, con sus anevos é lierra, é mas la villa de Cibratal-Real de Chiapa, ques de la gohernaģion de Guatimala, para que se juntasse con Gilalimala, ques cerca de Yucalan, é mas de dos mill pessos de oro de minas. É assi se fué el adclantado Nontejo á Chiapa é Yucatan, y el adelantado Ararado quedò en la grobernaçion de IIonduras, é la juntó á la de Guatimala, y enviaron á smplicar á Su Mlagestad que lo admiliesse é fuesse sorvido deslo, como mas larģamente será dicho en el lilıro XL de la tercera parte, donde se tracta de la gober- 
naçion de Guatimala, en el capitulo I del liloro.

Assi que, quanto á esto no hay mas que decir, sino de aqui adelante proseguir la historia en lo que tocare á la grobernaçion de Ilonduras, cuyo propriamente aqueste libro es, atento á lo quel tiempo nos avisare é diere notiçia de las cosas de aquella provinçia ć gobernaçion.

\section{CAPITULO XI.}

We otras cosas é particularidades de la gobernaçion de Honduras, é de las minas ricas de oro éplata, que en aquella lieria liay.

E nl el año passado de mill é quinientos y quarenta, en el mes de noviembre, llegaron á esta cildad cinco ó seys hombres que merescieron crédito-en lo que aqui se dirá, y entrellos un clérigo sacerdote é buena persona, que se halló pressente á fodo lo mas que de aquella lierra aqui se la dicho, desde el tiempo del capitan Cluripstóbal de Olil: el qual reverendo padre es hombre sin passion é muy conoscido en estas partes y en esta ciblad. Y dige él, é los demás en conformidad, que tienen por muy rica lierra aquella é de nuclıo oro é plata, y encarésçenla é lóanla lanto que no se debe dubdar, porque del mo é del otro metal han traydo su parte, aunque no tanta como quisieran, no por falta ni dispusiçion de las minas, sino por culpa de los que laan goobernado la tierra é de las alteragiones é diferençias ya dichas en los capítulos preçedenles, é por faltar gente é por no aver reposado el adclantado Mvarado alli. Porque desde á pocos dias que fué con su mugrer, se passó á Guatimala, despues de los conçiertos de entre él y el adelantado Montejo, é dió priessa á su armada é se partió con ella por el mar del Sur; é segund estos diçen, él estaba en lan rica tierra, que tenia poea nescessidad de gor á buscar otra mas rica, ni creen quid la hallaria lan abundante de oro é de plata; é assi lo testifican ambos metales en lo que aqui han I raydo estos compañeros y este clérigo. Y alirman que si gente alli lay en cantidad, ó que si Alvarado sosegara con la que llevó y én la tierra estaba, que ninguna parie de las Indias lay donde tanto oro é plata se sacasse, assi en la provincia de Cala como en las minas de Tavaco. Pero yo no le doy tanta culpa al adelantado don Pedro de Alvarado como estos le dan. porque ellos labblan lo que quisieran, é yo sé que era cavallero, é que queria complir lo que lenia capilulado con Su Magestad, é prometido gerea del descubrimiento de la mar del Sur por aquella parte. Dios lo encamine en su sancto servicio, y el liempo dirá lo que sulgediere.

Tornando á IIonduras, todos estos diçen, é otros de crédilo escriben, ques lierra muy sana é fruclífera é de muy buenos ayres é agguas, é de mucha monteria é nutuchas aves, é de umuchas é grandes pesquerias, é de muy luenos pescados, de todas las maneras que en eslats partes los hay. Les mantenimienlos ordinarios de: la tierra son malliz, é caçabí, é balatas, é ajes, é muchos mameyes, y en tanlit cantidad que arpuestos son muy grande mantenimiento para los indios. Lal ynca es de la que no mala, é lambien de la obra; é de la ma é de la otra lagen cangabi é vino dellat, é lambien lacéen vimo del maliz. llovos muchos, é cirtuclas de muclas maneras, é grayabas, é lodas las olras fruclas que en essotras partes deslas fudias layy: muchos árboles del liquidámbar, los quales áboles son hrrmo- 
sos ć prandes é como blancos; é demás do lo pue dellos estít escripto on el libro $\mathrm{X}$, "apitulo $\mathrm{NT}$ ". diçen eslos lestiggos fue he dicho, quel fructo que llevan son como arbejones luengos, é que aquello que estí dentro de afucllas vaynats lamblien se forna licpuiclámlar, y es mas cxçelente en ol olor y en sus operaçiones quel otro, ques como negro, é que sale por las cuchilladas 0 golpes, que lesdan á los árboles; é questa fiucta se cae por la mayor parte, quando muy madura está, é á veces se queda en los úrboles, é que allí dentro de sus vaynas se haçe espesa, que siempre permanesce blanquíssima como un cristal; é que hay mucla cantidad de aquellos árboles, de que ningun caso se laçe para curarlos ni cullivarlos, sino assi como la natura se ha con ellos.

Los animales son çiervos é gamos é conejos y encubertados é osos hormigueros é dlantas ó vacas de la lierra é churchas, é fodlas las ofras salvaginas é animales foroces de ligres é leones é de quantas maneras se ha dicho quo los hay en Caslilla del Oro; é muchos gatos monillos é de muchas maneras, é de aquellos que llaman perico-ligero, é por consiguiente de lodas aquellas aves, questas hisiorias comummente lian traclado en la TierraFirme; y en especial hay otras de la manera que agora se clirá.

llay una are fues mayor ó tamaña co. mo un paro, quel pico é los piés tiene amarillos é de grandes pressas ó uñas, é desde la mitad de los pechos para arriba es el plumage muy negro, como un terçiopelo, é descle allí para alıaxo es á escamas , una negra é otra blanca, en tan lindo conçierto ques el mas lindo plumage

- Oviedo hubo de añadir al libro X de la primera parte este y otros eapítulos, á que alguna vez se refiere en esta segunda (Cap. VIII del presente libro) y en la tereera, y euyos tílulos eonstan ademas eu la tabla original de la expresada primera parle; pero desgraeiarlamente, ó no llegó á ingeir low citados enpitules oportunamente en los lu- que se puede aver visto: $e$ assi haxa hasta todas las mins calcrado, e los ojos muy hermosos, $y$ en la calecé un cuerno tan luengo como un dedo, é derecho, de plinmas, negrro é nuy lustroso; é si mira al suclo, lo declina é abaxa derecho hácicia el suclo, é alçando la cabeça, lo echa lı́́cia trás. La cola liene corla, de la mesma color necrra, é poco mayor que de una paloma, é las alas muy recogridas. Is avo de rapiña, é desque no halla olra cosa que caçar, ḉbase en algun gato monillo de las colas largas, que liay muchos dellos. Hay otras aves muy hermosas en el plumigge, é liene cada una dos cuernos levanlados para arriba, como el buho, pero mayores : é mandan aquellas plumas ó cuernos con mucha façilidad, é tríenlos muchas veces trastornados para atrés, ó quando miran abaxo á la tierra, a áxanlos hária el suclo, y es cosa mucho de ver: é tambien son aves de rapiña y de fieras uñas ó pressas. Hay unas águilas negras, como muy fino é muy pulido açabache, é grandes é de grandes pressas, é comen muchos de aquellos guabiquinajes, que hay muchos en aquella licrra.

Las minas de llonduras son en la villa que llaman Comayagua, héçia el valle de V'lancho, treynla y cinco leguas desta mar del Norte, y especialmente digo las minas le plata: é de un quintal de la vena so sacan seys marcos de plala é dos pessos de oro, y esto se ha visto ser assi por el ensayo.

Hay muy exçelente miel é mucha, é sera; y el lugar, donde se cria esla buena micl, se diçe Celimonga: y tambien la hay en Thepeaca.

gares á que los deslinaba, ó se han extraviado despues. Acaso pudiera haber sueedido to primero, de lo enal persuade hasta cierto punto el eneontrarse cn diferentes pasajes de toda la obra propuestas algunas enmiendas que no se hieieron por olvido, secgun habrán podido observar los leclores. 
Aqueste es el libro déçimo terçio de la segunda parte, y es el trigéssimo segundo de la Natural y general Historia de las Indias, islas y Tierra-Firme del mar Ogéano, de la corona é çeptro real de Castilla é de Leon: el qual tracta de la provinçia é gobernaçion de Yucatan.

\section{PROHEMIO.}

Wis

s de tanta violençia é tan poco permanoscriente el estado é señorios desta vida mortal, que amnque no quieran conosçerse los liombres, é ver quín flaco es su fundamento, el tiempo mesmo se lo enseña é acuerda, é dá á entender quán hreves son todas las cosas, en que los mundauos laaçen confiança (destas temporali(lades) para que no ignorando nuestras culpas, mejor conozcamos á Dios, é como lıcelura suya esté nuestra atençion dereclia é fixa en lo que lia de ser perdurable y $\sin$ fin. Y questo de ací sca, no para mas caso haçer dello de lo que haçemos de una prente para passar un rio, ó de una nao para haçer un viage é yr á Espaĩa ó á otral parte, pues que todo lo del suelo es para lo olvidar é dexar atrás, é lo ques para adelante é infinito es la gloria ó pena, que desde aqui meresçiéremos, é supiere cada qual chripstiano grangear é adquirir para la otra morada, donde el número de los dias, meses é años, lustros ó siglos, son sin número ui fin é sin mudança. Y aun en estos mis libros los trace el tiempo vaçilando para la órden, con que mi intento los ha traydo, quitando é poniendo diversos números en proçesso, liasta tener mucha parte de la terçera parte escripta á causa que quando passé del li. bro XXIX de la gobernaçion de Castilla del Oro, é quise proseguir en el de la gobernaçion de flfonduras, se juntaron las gobernaçiones de la mesma Ifonduras é 
Yncatan, é liçe de ambas un libro del número XXX * é de alli passé adelante y esrribí con minmero de XXXI d libro que fracta de la goloernaçion é concuistir de lal Nueva España, que aggora es núnero XXXIII, porque despues de arer mucha parte dè escripto, se tornaron á divillir las mesmas gobernaciones de lfonduras é Yucalan, quel adelantado don Françisco de Montejo tenia; porque liço çicrta promutaçion é truecos con el artelantado don Pedro de Mrarado, al quial dexó la gobernaçion de Honduras para que se junlasse con la de Guatimala, quel dicho Ararado primero tenia, porque él le dexasse á Mentejo la villa de CibulaulReal de Chiapa, que era de la gobernafion de Gualimala, é se juntasse con Yucatan, é dióle mas en la Nueva España la poblaçion de Suchimileo é su lierra é dos mill pessos de oro al dicho Hontejo.
Por manera que en este estado dexé yo la contimarécion ded dicho libro XXX, que crär como he dicho, promero dedicando á Ilonduras é Yucalan, ¿ por se ayer apar. lado de aquellas crobernaciones se continúa con sola la gobernaçion de llonduras aquel libro del numero XXX, el pual assicnto ó señorio estál á caṛo del diclıo adelantado don Pedro de $\Lambda$ rarado.

S çora conviene, para no se interrompir la orden prinçipal y estilo que estas materias llevan en esta cuental de los libros, quel pressente con nombre de XXXII, sea inlitularlo á Yucilan. É assi yré brevemente en el prinero capítulo apuntando lo que á esto loca (jorque eslá mas luengamente dicho en otras partes del origen é descubrimiento de Yucilan), é lo demás y rá escribiéndose como el liempo nos lo manifestare, é lo entendiere yo, en tanto queste excrgicio me turate.

\section{C.MPITULOO I.}

En que sumariamente se tracta lo que haẹe al propóssito de la hishoria é gobernaçion é deseubrinieuto de Yueatan hasla el año de mill é quinientos é quarenta y un aīos. "

$\mathbf{U}_{1}$ no de los mílites que passaron át Tierra-Firme con el gobernador Pedrarias líivila, el año de mill é. quinientos y calorçe, fuć Françisco de Nontejo; é aquel mesmo año, quando los I rabaxos é muertes que ovo en la cilsdad del Dirien subçedieron, se fué de aquella lierra, como lo liçicron olros muchos, é se passó á la isla de Cuba, donde militó debaxo de la gobernacion del adelantado Diego Velazquez, é por su mandado deste alli fué é se halló en el segundo viage del descubri-

* Ni aun esta numeraeion subsistió despues, eomo halján advertido los lectores: el libro que trati de la gobernacion de Honduras, y en el eual narra Oviedo su reunion con la de Yucatan, quedó sienlo el XXXIl, ingiriéndose por lanto el XXXl y eorriendo la numeracion del $\mathbf{X X X}$ dos libros.

* En ol MS. original que lenemos prownle se miento de Yueatan é de parte de la Nueva España, en compañia é dehayo del capilan Jolıan de Grijalva. É despues rolvió á acpuella tierra con el capitan Hernand Corlés, donde sirvió muy bien, é fuć uno de los que en aquella Nueva España fueron áprorechados, como mas lirgamenle esto é otras cosas que Locan á Montejo se tractaron en el libro precedente en el capítulo IX; y el deseubrimiento de V'ucalau puntuahmente está escripto en el libro XVII, que tracta de la gobernaçion

lee además, aunque borrado al parecer de mano del mismo Oviedo: “Conforme a lo que ha venido á notiçia del historiador destas materias; y porque ya aquello está dieho, referirlo ha este eapílulo, por que ni el letor se eanse con dobladas lreciones de un lefror, y porque su origen es en la historia donde qued priesto." 
de la isla de Cuba, en la primera parte destas historiass, y en el capilulo III, é dende en adelante. Despues de lo qual passó á confuistar é pacilicar á sul costa con una buena anmada Francisco de Montejo. ¿ por sussomiroios Su Mageslad lo hico moble, é le dió tílulo de arleliuntado, é le mancli llamar don Francisco. É como he dicho on el alewado é pregedente libro se diçe lo dromás, é rouno por la muerte del gobernador de llonturas, llicgo Nlbiter, al Einperador, numstro senor, mandó juntar la gobernaçion de Honduras con esta de Ýneatam, è dre la ma é de la otra fuesoe capilan groncral é gobernador el dicho adclantado don Prançisco de Montejo, é assi lo ha seydo alguglu linempo hasta el año passado de mill é quinientos é tregnla y nucre, quo fué allí el adelanlado don Pedio de Mrarado.

É entre los dos adclantados aria çiertos debates é diferençias, como se divo en el libro antes deste, en el capítulo $\mathrm{X}$. É: para bien de paz, é poreque á cada mo dellos les paresció que assi le conrenia, se conçertaron, como allí lo diçe, é le desó el adclantado Montejo la goberna- çion de Ilonduras, para quel adelantado Ararado la juntasse con la de Guatimala: é á el le quedó la que se tenia de Vueatan con mas la villa de Cibdad-Real de Chiapa, que era de la gobernaçion de Guatimala. pala que la tenga éjunte con Yucatan, de donde está vecina é anexo é á sı propóssito: é mas, le dió en la Nueva Esparia el dicho Alvarado el pueblo de Suchimileo é su tierra, ques muy buena cosí, é dos mill pessos de oro de minas. lí con este concicrto quedó Mlvarado en lis gobernaçiones é Montejo en la de Yucitan con el dicho. acrescentamiento de Chiapa, á la qual concordia é trueco diò buena conclusion la prudença del terçero que entrellos anduro é los conçertó, que fuc el licençiado Pedraça, electo del obispado de la mesma gobernaçion de IIonduras; é á ruogo de los dos adelantados, fué a España, para dar relaçion á su Cússárea magestad desta conveniença, é le suplicar la aprobasse, por ser para mas sor servido, é á le dar notiçia del estado de aquella tierra $\dot{e}$ de otras cosas convinientes á su real serviçio.

\section{Cap'TULO 11.}

El qual tracla del discurso desta historia de Yucalan ide muchas partieularidades é nuevos te mararillues

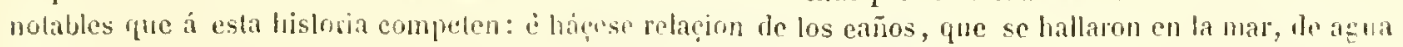
dultęe, riolas cosas muy dinas de oỵr.

C historias (y como se reepor la ceppiricnovia) que la mayor parte de los lombres que á las Indias vienen, es por ser movidos de su propria cobdiça, é no como los que son de órden sacra to atribuyen, al çelo que publican de servir á Dios, é otros por servir al Rey; lorno á degir que los unos é los otros con tolas las olras gentes, de qualquier calidad que sean, navegan é passan acá por sus proprios interesses, puesto que los inenos consignen tanta can- lidad de oro como dessean ó tomarian, si no estuviesse tan guadado por los inconvinientes é traharos, que son la llave é custodia de los thessoros, que vienen á buscar nuestros españoles ( $y$ en su compañia olros muchos de diversas nasçiones). Y de mill hombres (que de España sálen para eslas Indias, no como los noveleros y libros apocriplos é vanos, yne an estos ticmpos algunos componen, diçen que acaescia en linbulosas cuevas de mígriens, donte en algnmas, si diez entraban 
il aprender apuel condenado arte, quedalam los rinco, y en otras mas ó memos, é volvian los demás, segund á los desvariados anctores les paresece é quicren ordenir sul filsa é mentirosia novela, ni como en arpuel real del crodo é primero enperador de los tírtaros, Ilamado Cingiscaln. ene teniendo cereida una cildad de los quitaos, faltando los mantenimientos, laagia que de diez de sus soldados matassen el uno, é aquel comian, hasta que tomó la ciblad, etc.'; acá en estas nuestras Indias de los mill que vienen. no tornan çiento ni aun çinquienta á siss patrias, é á veses de treynta, no escopa alguno, como por estos nuestros rolúmenes se puede ver. Ni me paresçe que á estos nuestros milites quadra aquella auctoridad que diege: "El fiucto, que debe preçeder á los otros, es aquel que cuesta menos é con menos costa se coge.. 2

El oro que en cstas partes se ha visto é hallado, é lo que lay en sus nasçimientos y en la tierra, es tan grandissima suma, que no se puede comprender por su infinidad; ć para yro á buscar á las minas, no se pone estorlo á quien en ellas se quiere ocupar, ni los offiçiales del Rey dexan de dar liçençia para ello á quantos se la piden. Pues para aver lo que estí en poder de los indios que quieren la paz, nunca se le paga á sus dueños con igual equivalençia, sino dándoles por un marco ó dos de oro un cascavel ó una aguja ó un par de alfilcres, é assi á propóssito cosals de poquíssimo valor: é para sacar lo que estí en poder de los indios de grelral, es otra manera tan difieultosa, como desta leçion adelante oyreys. De manera que bien mirada esta cuenta é sacada en limpio, mas caro es el oro acá de lo yue los ynorantes é los salbios sabrán congecturar, ni los cobdiçiosos esti-

1 El Anth. de Florencia, tíl. XIX, cap. 8, \& 17 en su primera parte historial. mall, pues para que uno sea rico, pierden las vidats regnte hombres é aull á veçes giento. lí porque desta materia la mas clara relaccion que yo puedo dar en elliı, es remilir al letor a esta mi lristoria, oyga is note las cosas desta golscrnacrion de Yucatan é de los espanoles que en ella lian militado debaxo de la gobernaçion del adelantado don liancisco de Montejo é de su teniente, el capitan Alonso Dávilà.

Junto con esto desseo que no falte atençion á los que quisieren entenderme, é oyrán una luena suma de trabaxos exçesivos, é por ventura no probados con tanto esfucreo é ánimo por otros lombres; despues que bien informado quede el que lee, pálosse á pensar en cada cosa deslas. é verá quánto mas dulçe es la nononeda adquirida del merçenario, que con un açadon en el hombıro sale en mi tierra (ó castellana patria) por la mañana á la plisça á esperar quien le pagnue su fatiga é jornal, ó el del pastor que en el campo atiende la rigurosidad é jelos é tempestades del invierno en nuestra España, ó el sucldo del soldado en Italia é do quicra que por allá exerçitada sea la miliçia. Pues quel del açadon á la noche descansa en su cama ó domiçilio, y el pastor no está sin çamarro é bien sostenido, é si un dia liaçe frio, tampoco le falta limbre ni otros socorros, con que se comporte é alırigue, ni su cabana donde se acoja: ni el soldado en Italia, no pelea cada dia, sino los menos, é demás de ganar su sueldo é otras arenturas, con que se comportan é remedian los trabaxos de la guerra, que no son, como digo, en torlo tiempo ni de mna mancra, antes quando mas faliga é filla tienen comen á disereçion (ques una muy discreta cosa comer solre los villages é los polres labradores donde están apossentados). Todo lo qual ui es semejante ni

2 Plin., lib. XVII, cap. V. 
igual comparaçion con lo que cu estas partes é Indias nuestros españoles han expe. rimentado á costa de su disereçion é proprias vidas é sangre: é aun algunos que Lan-querido ser mas diligentes, tambien han perdido las ánimas como los cuerpos, si es líçito sospecharlo los que son catlólicos. É para que con mas órden se continúc esta historia, tomarla he algo mas atrás, aunque sumariamente haga mençion de lo que en ella se ha á pedaços tocado en los libros pregedentes.

En esta historia de Yucatan, como Ira costado muchas vidas, é de los muertos no podemos arer informaçion dellos, é de los quie quedaron vivos, aunque avemos visto algunos, $y$ essos aunque padesçieron su parte, no saben deçirlo, como acontesçe í la mayor parte de los lrombres, ni tienen habilidad para darlo á entender, como dicho es, para que la historia tenga su medida çierta, ni yo la he alcancado hasta ser llegado qaassi al fin del año de mill é quinientos é quarenta y uno, que permitió Dios que á esta cibdad viniesse un cavallero de la Orden militar de Sancliago, Ilamado don Alonso Luxan, persona de crédito é de buena memoria, que apuntadamente me satisfiço su relaçion como aquel que personalınente se laalló con el capitan é leniente Alonso Dávila á todo lo rue reglada é sulucesivamente dirá la historia, conlintándose los subçessos, de que tractián los capítulos, que con este serán dependientes: que en la verdad me paresce que es un nuevo modo de concuista é de padesçer. Juntamente con la qual relacion se dirán muchas cosas notilbles é de admiraçion para todo gentil é preregrino entendimiento; é aum algunas cosas de las que aqui se dirán, son muy diferentus é no oydas entre todas las que hasta cste libro en los preçedentes se han explicado, é para que nos acordemos de dir muchas graçias á Dios, sintiendo las diferençiıs destas provinçias é de las gentes dellas, ó para maravillar al que oyere la exçelenria de tan gentiles alientos é ́́nimos de aquestos conquistadores, aviendo respecto á su poco número de españoles, é á la grandíssima moltitud de los contrarios, contra quien delatian é pelearon, no faltándoles esfuereco para resistir inumerables adverssidades, sobrándoles é aumentándose cada hora muchas desaventuras é estorbos é desastres; con mucha sed é lambre, é con tantos é tales impedimentos, que será imposible deçirse todo, si no fuere con alguna parte dello, significando lo demás, de que no se hiçiere mencion. $\mathrm{Ni}$ se puede sospechar que lumanas fuercas pudiessen comportar lo questos sufrieron, sino por serles Dios favorable, puesto que Sanct Gregrorio en sus Morales dige, que el uso alivia todas las cosas '; y assies de creer que como varones tan habituados á mala vida é de lanta fatignan, con lil costumbre de su sufrintiento, meresçieron rer el fin que la historia aqui expresarí, aunque no lan bien escripto como yo quisiera que mi pluma lo supicra encaresçer, ó mejor diçiendo, dar á entender álos que fuera destas Indias lo leerán; y cómo les acontesçió desde el mes de mayo de mill é quinientos é reynte y ocho, que partió el adlelantado don Françisco de Montyjo del puerto de Sanct Lúcal de Barrameda, con dos naos grandes é tresçientos y ochenta hombres, é vino á esta cibdad nuestra de Sancto Domingo, donde tomaron refrescos é çingienta y tres caballos é yeguas: é desde á pocos dias que aqui esturo esta armada prosigruió sul camino, é llegó á Cosumel quassi á fin del mes de septiembre del mesmo año.

Aquella isla de Coçumel estí enfren- 


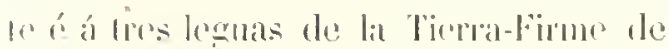

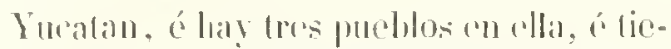
ne dre cirmuferencia hatsal veynte leguas, poeo mas ó monos. Ealli furron rescribidos de paze repossinon ahi quatro dias, i clúllimo dellos so passaron á Yueatan, ci tomaron purroro á media legrara de um pueblo ale indios: que se diçe Xalas: é por no salurer la ticrata pararon allí en un palmar junto í una ciŕnequil, en lopeor de loda

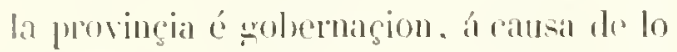
yual se murió muchia parte de lis garente de hs rinanoles. É conosciendo el golornat-

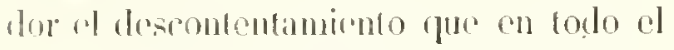
cércilo avia . lieco echar los navios al través, por aprovecharse de la grente é marincros col ha conpuista ci que no se le fuessen á la Nueva España, que confma con arpuella grobemaçion de Yucalan.

Muchas veces sospecho que se dehia acordar Hontcjo. que seyendo un pobre. lidalgo passó á buscar la vida á cstas Inlias, é que cómo se laalló en la conquista de la Nueva España, medró en ella, ce fué con tantos dineros despues á España que se heredó unuy hien en su patria, en Salamanca, de donde es natmal, é que hico un mayorazgo de tresçientos mill maravedis de renta ó mas. que te dehiera baslar, si su ámimo infuicto le dexála sosegar, é no tornára á lo vender todo por se emplear en cosas mayores, é rolver á los trabaxos passides de las ludias é á otros mayores, quele cslaban esperanto. Por manera (jue estando en la nescessidad ques dicha, siguióse que no llerando ni tenien do lengua, quiso Dios que un cavaIfero de su compañia, Itamado Pedro de Anasco, natiral de Sevilla, aprendió la lengua en muy poco licmpo, é fuć desta manera: (pe platicando un dia con $\mathrm{m}$ in. dio, sin se cntender el mo al otro, el indio te aliso: machneava (que quicere deçir cómo se llama esto?); y el dñasio no le en- Tendió, e tornó por respuesta á deçir machucara, senialando una cosa, y el indio te diso el nombre de acpuella é de otras, dicicurlo ál macheara. É pror sola esta palialua alcancó é supo la lengua torla é ron la continuergon della se hiçogrentil interpetre: lo qual fue mucho remedio paral los eluripstianos, que quedahan.

En arpuel mal silio se descargaron los navios é se higgo una casa grande de palmas, donde se motió la ropa é se apossinto of rrobernator á su gente lo mojor que pulicon, en lanto que se luaçian otras casas. E se licgo ma villa, que se llamó Salaunanca: y harto manca, ó de todo filta de la sçiençia y molbleça é fertilidad de la otra, por cuya memoria se lo dici lat nombre: en la yual se murieron otros muchos españoles; $\dot{e}$ digo muchos, por el poco número que todos cran. Y entre las ofras cansas de sus muentes, assi como la falta de hastimentos é de lodo lo nesçessario, é de las malas agias é nuevos ayres, los murciélagros mataron mas de los quarenta, que son lales é tan ponçoñosos como se dixo cn el lilno XIT, caprítulo VII, de la primera parte destas historias.

Viendose perdido el adelantado, salió de aquel mal assiento, dexando allí lasta fuarenta personas enfermos é mancos y en extremada nescessidad. é signio pol la costa adlelante hácia la Nineva España, con intencion de luscar sitio, donde pudiesse mudar la vivienda y el pueblo ques diclı. É paró á quince leguas de allí, en un pueblo de inclios llamado Pole, en el qual se le murió quassi la mayor parte de la gente que le quedalsa, y él estuvo muy al calıo de la vida; á lo qual dió causa la lambro é otras muchas nescessidades, é si no fuera por los calballos, que andaban suelios e relinchaban é servian de velas, é de su temor é relincho los indios se aparlaban, no escapíra hombre de los chripslianos restantes en aquella tierra. É cómo luvieron algguna mejoria, salió de allí el gobernador con noventa hombres, que es- 
laban para trahasar, annque flacos é no torlos sanos, é quedaron veynte enfernos que no pudieron salir por su mala dispusiçion, é quredó allí toda la ropa de los unos é de los otros, á los quales que assi quedaron, mataron los indios.

El gobernador entró la tierra costa á costa, é los indios devaban los assientos é lıuian la tierra adentro, é desta manera fueron hasta ponerse en el paraje de la isla de Coçmel, de la qua! se hico mencion de susso; y acaso passaba el cacique, señor de aquella isla. que se decia Unopate; ála Tierra-Firme con mas de quatroçientos indios en canoas, que yba a las hodas de una hermana suya, que se casaba en la tierra de la mesma Yucatan, el qual atendió á los chripstianos de buena paz, é les dió de comer de lo que -llevaba; é por este socorro, mediante Dios, que fué quien lo preveyó, no se acabaron de perder. É dixo este caçique al gobernador que le esperassen allí él é los chripstianos: quél yria á haçer de paz los indios de adelante, donde los esperaria. É assi lo cumplió, é hiço de paz un pueblo llamarlo Mlochi, de hasta çient casis buenas é muchos qües, que son sus templos ú oratorios de piedra muy bien lahrados; é allí allegaron los diripstianos é fueron en paz rescilidos, é les dieron muchas gallinas de las grandes, que son co110 pavas, é muchas lortillas é leche de mahiz; é les mostraron é aluicron el camino para yr adelante, of qual continuaron é fueron liasta una cabecera de mua provincia, junto á la mar, que se diçe Belma, é laallaron toda la costa muy poblada.

En arjuel pueblo, un hidaltwo que se decia Palomino, que era alguaçil mayor, dió un palo á un su criarlo, é fué tal el golpe, que lo mató; por lo qual el aclekantado le hicgo cortar la cabega. En aquel mesmo pueblo le liçieron un pressente de oro, en que avia dos joyas b palcuas hur- nas, é la una le pusieron al golumartor al cuello, é la otra á la lengua dñaseo, al cual Ilamaban los inclios Alquin, que quicre decir hijo ales sol, porque en aqquella lengua al quiere deçir hijo, é quin Ilaman al sol. Mlli vinieron de diverssas parles é provinçias muchos indios caçiques é señores de par, por ver qué gente eran los chripstianos, é para que les mostrassen los caballos que llevaloan, que era para aqueIlas gentes una cosa de mucha admiracion, é por toda la tierra volaba la fama de tales animales. Ý el adelantado hiego sacar un caballo, que a via llevado de Cistilla, ensillado y enfienado, é con un petral d? cascaveles, é teniéndole un clmipstiano del diestro, aunque no estaba grordo. era re. gocijado, é meneálbase de ma parte á otra logano é de huena gracias: é fué lanto el espanto en cllos, que algunos luyeron, en vióndole, ć olros mas pusilínimos se cayeron, é amorteridos en ticra é oyéndole relinchar, lates ovo que ni ovieron menester píldoras ni mejor purga para despedir por baxo, de tal manera quel hedor cäa incomportable, con que se acaluó acuella fiesta.

Desde á dos meses que alli descansaron d adclantado é su gente, passaron adelante por muchos puelilos de mill casas o de quinientas é mas é menos, é vieron muchos é luenos assientos donde pudieran poblar, si osáran, é dexáronlo de hècer por ser los españoles pocos é los indios muchos. En fin llegaron á un puehlo do cinco nuill casas, que se diege Conil, é allí salieron los indios á los rescelire é les truxeron canoas por tierra solme parales ó á firerga de bracos dos leconas: é puestas debaxo de ramiadas á la sombra, viçiaron en cllas mas de tres mill cántiros de agna, é pasiéronselas en paradas á tredros, é como es dicho, deliaxo de muthas ramas con mucho maliz é callinas de lis fue de susso se dixeron é lectle de maliz. De manera que asis los chriphtiancos eome 
sus caballos, lo tenian todo muy solorado, annque fucsen veynte tantos: é de media roll media legua, en férmino de quatro logras de despoblado, estabal el refrigerio repartido, y cra tanta la gente que concurria y en essa poblacion lallaron, quel grohemalor esturo algo suspenso é con temor de se apear; pero en lin lo hiso por no mostrar llaqueca, é lodos los espanoles se aposentaron to mas sociable é juntos que pudicron, haçicndo buena vela, e teniendo siempre aperegebidos seys de eahallo de noche é de dia. É ponian sus atalayas sobre árboles, de que toda la tierra es abundante é llana, é hay algunas manchas de savanas, é todo lo demás es arcaburos, ó tierra de muchas é divers. sals arboledas, é de tal dispusigion todo lo que andwrieron, que en mas de tresçienlas leguas ni hallaron ni vieron sierra alsuna ni rio. excepto que avia poços muy buenos de dos bracas de hondo, é algunas fuentes gentiles, al propóssito de las (juales se dirá aqui un notable de mucha admiracion, y es aqueste.

Yendo caminando por la costa, vian Ientro en el agua salada de la mar surşir solre la superfiçie de la aggua salada manantiales para arriba, de agua dulçe, ‘ue rompian é subian solsre la salada á horbollones: y entraban los chripstianos á caballo en la mar hasta darles en los ustrilıs, é bebian é tomaban aưua en aquellos surgideros ó fuentes, que se levantaban dulces solnre la dicha agua salada; y estos cran tantos, que no se podian eu alyunas partes contar por su murho número. É en parte avia que algu- inos cstiban mas en lo londo é lanto desviados de la costa, que acaescia entrar nadaudo el de á cáballo hasta ellos; é todos eran de muy excelente é clara agrai. É aquel surgir ó levantarse en alto no ela raño derecho é continuado, sino á ggolpes muy contínuos y espessos híccia arriba, saliendo un cobdo é mas é menos ençima del agua de la mar, como si hirvieran, segund su çcleridad ó presteça; pero no caliente el agua de tales manantiales, sino fria é suave é tal, que todos deçian que era la mejor que pudiesse averse visto, é sin que los rios mas famosos éfuentes mas loados les hiciessen ventaja.

Allí hiço ol adelantado hacer un jucgo de cañas por festejar los indios que decian ser sus amigos, é por el buen tractamiento que en ellos liallaron, é como suele acontesçer, cayeron algunos españoles, de que se rieron mucho los indios. É porque al gobernador le pessó dello, hiço que se les diesse á entender que los que avian caydo, avia seydo porque ellos lo quisieron haçer á drede, é assi hiço dar caluallos á otros que no eran diestros ginetes, é rayeron. En conclusion los indios creyeron que no caian los cluripstianos sino por su plaçer, é quándo é de manera que hacerlo quisiessen.

Assi para quel letor descanse, como por quedar la lecion en lugar scñalado, quando la quisiere dexar por su passatiempo é recreaçion, é porque con mas sabor ruelra á clla alentarlo, me paresce ques conviniente que los capítulos no sean muy prolixos, y que para este basta lo que está dicho. 


\section{CAPITULOO III.}

De lo que subęedio al adelantado don Franęisco de Montejo, desde que salió eon los españoles, que le quedaban del pucblo de Conil, é de la repúbliea éjusticia del pueblo llamado Cachi, é de los árboles del ençienso é su contraetaçion, é de la grandissima poblaçion llamada Chuaca * é de otras cosas que subẹedieron en aquella conquista.

C muando estas historias, viendo quán coxa é imperfelta quedaba entre todas, é por la mas abatida é olvidada aquesta de Yúucatan, porque sicmpre sospeché, ariendo respecto á su descubrimiento é al sitio é paralelos de su assiento, que era imposible ser menos fértil é poblada que las otras tierras de sus confines. E aunque de alğunos ó́a que la loaban, era por términos é palabras de personas de poea prudença é de baxo entendimiento, é que quando interrogándolos me detenia, me ayudaban á perder el tiempo mal satisfaçiéndome, hasta que topé este cavallero don Alonso de Luxan, que assi por su buen natural é habiliclad, como por la mucha parte que como testigo de vista le cupo destos trabaxos que aqui se memoran, lo sabia muy bien entender é deçir para que los que no lo vimos fíçilmente lo comprendamos, y en especial los que alguma notiçia écurso tenemos de las cosas destas partes. É una de las cosas que á mí me han dado mas fatiga; buscando informaçiones é inquiriendo estas materias, no ha seydo tanta la que siento en escribirlas lodas de mi mano, aunque passan de tres mill pliegos de papel los que he borrado y enmendado é reescripto una é clos é mas veces, quando me han fatigado algunos

- En el eodiee original se lee además en este epigrafe, bien que tachado al pareeer de mano del unismo Oviedo: "é la batalla que alli ovieron" eon mos inclios $\dot{e}$ de otra que mas adelante les dieron "los indios de Aqu é en ambas ovieron vittoria "los ehripslianos; é de los grandes pueblos por wonde pasaron hasla que volvieron i la villa de "Salamanea: é eumo el adclantado fué por la mar "hasta un pueblo que se dire Chilemal, é su te- torpes, é olros groseros, é otros apassionados, ć otros verdaderos. Entre los quales diverssos relatores he andado midiendo é areriguando é atendiendo al verdadero discurso que sigo en las cosas, donde soy ausente é constreñido á creer á otros ó á quitarles el crédito por mi estimativa: de los quales escrípulos en el pressente libro yo soy libre, por el conçepto, que á don Alonso de Lusan se le debe, é á la buena expresiva con qué! platica en esta armada del adelantado don Françisco Montejo, desde quella se prinçipió liasta que se acabó, cono adelante sedirá, continuando la historia, de la qual, liasta questa gente llegó al puelslo dicho Conil, contado se ha en el preçedente capítulo. Queda agora de decir en consecucncia cómo desde Conil guiaron los intdios á los chripstianos desde á dos meses que allí estaban, tres leguas adelante á otra poblaçion que se diçe Cachi, en el qual camino de media á media legua, como la historia lo ha dicho, les tenian otras ramadas, en que avia muclıs cántaros de agua é bastimentos é muy abundantes, aunque fueran muchos mas los hospedados.

En aqueste lugar avia una plaça bien grande, en medio de la qual estaba liucado un mástel derceho como un árbol de

„niente Alonso Dávila yba con çierta gente por "ticrra; é eúmo se volvieron á la dieha Salamanea "por la industria de un mal eliripstiano traydor que nestaba ¿ vivia entre los indios, llamado Gonęalo, "marinero: é eómo despues fué por mar en mua nearavela suya a la Nueva España é truxo genlı: "a un pueblo que se diçe Tabasco, al qual reegiu ná su teniente Alonso Dávila é a los pocos españo"les que de su genle le quedaban." 
tna nao, liso é puntiagudo, ol pual servia lo mesmo quel rollo doude se hace justigia entre clupipstianos, annene rou gränul diferengia en la forma de la execuciondeIla, porque deçian los indios que lineaban ó cmpalialan alli espectados vivos los mallechores, issi como ladrones, a los adúlteros, que tomaban las mugeres casadas é sin casar, sin liçença de cuyas cran, é por olros delietos.

Avia mucho congierto en esla república , é lenian muy grand lianguez ó placar. eon muchos tractaules é mereaderias assi de bastimentos é cosas de comer, como de todas las olras que culre los naturales allí se eompran é renden é fruccin.

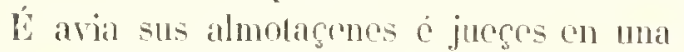
calsa junto é á un canto de la plaça á manera de consistorio. dome se deterninahan torlos sns letigios en poeas palablus, sin alcada ni apelaçion, sino del pié á la mano, sin quel sol se pilsasse ni hora entera sc cumpliesse, ni cusa se esclibiesse, ni dereclos ni hlertos se llevassen á ninguna de las partes, danto á cada uno lo que era suyo justamente.

Desde á dos dias frasaron nuestros españoles á otro pucblo pue estí dos leguas adelante, é muy mayor. el qual se diçe Cinçimato. En cate espacio du dos leguas están Lodos aquellos llanos é campos llenos de árboles de enciensso, muy curados é limpios, porque desta mereaderial lay alli muy grand tracto é cargacon para otras partes, assi para perfumar sus ques ú oratorios é gastarlo en sus sacrificios é mortuorios, como en otras cosas, le que se sirvendello. Estos árboles son muy genliles é frescos é grandes, y es para aquelia grente grande é útil mercadcria, poique no hay ençiensso en toda la provinçia sino alli: é para lo sicar, cortan en el árbol é hagen en él un vafuro tanto quanto es Im puño cecrado: é vaquado aquello, allí poco á poco se destila é corre allí ayued licor, é se espressa é laçe, quajúndose, ol engicusao; é dr allí lo toman, y es eono el mesmo onçionsso é ron el mesmo olor, y desto srandissima abmutancia. É cómo estal gente you ron tanto temor como lia cantilad clel encoiensso, $i$ appel salumerio no cra bistante para se le quitar, no se detuvieron allí mas que apuella noche : lnego, cono annuesció el signiente dia, se partieron. é á otras dos ó lies leguas adclante llegaron á otro puchlo tam grande. gate á melio dia que començaron a entrar en él. no desando de andir hasta que allegaron á la casa del caçique, donde d sobrmalor possó, era lora de vísperas sin salir de la poblaçion. É todas las mas casas cran de canleria, é sus oratorios ó quires muy extremados de buena la. vor: é aqueste purblo ó ciblad se llama Chanca, éfoda la mayor parte de la vecințal es de scñores é ciluladanos é mereaderes co gente muy polida en respecto de las publaçiones ques dicho; las quales son subjelas á esta república ó ciblad de Cliniea.

Despres que se ovieron apossentado los chripstianos, essa mesma noche se fueron los indios é lexaron vacio el pucblo con todo lo que tenian de mucha ropa é provisiones de ares é maliz, con pensamiento de dar olro dia solure los nuevos hućspedes, como lo liçicron. É quando fueron lis dicz del dia, rolvió mucla grente sin gritar ni hager las allaracas que sueien liacer (gritando é liũendo alambores c unos caracoles que sucnan como rocinas), sino muy sosegados é con tollo silengio dicron de solmesalto en los españoles con grande ímpeln. É quiso Dios quel adelantado, que tambien velaba sn quarto, se lialló ́́ caballo: é con tantóninimo, como si muchos cavalleros á par clél estovicran, solo dió en los indios, é puesto que hàn macho temor die los caballos, por su buen esfuerego, entrando é saliendo. se revolvió de lal manera con los cnemigros. que les hiço mucho daño é los detuvo tanto quan- 
to ovieron ticmpo los clnipstianos de salir a calıallo é á pié é juntirse para su defensa. Estos indios son flecheros é no tienen hicrva: peroson buenos punteros, é los lierros de sus sactas son de pedernal é muy malos, porque quando hieren, se desgranan, ques peor que la mesma herida. E tambien pelean nuchos dellos con rodelas é langas cortas de doge ó quince palmos, con hierros assimesmo de pedernal. En esta batalla muricroir este dia dicz ó doge chripstianos, que andibanderramados por el pucblo, en equivalencia de los quales murieron muchos indios, y entre ellos diez de los prinçipales.

Otro dia signiente vinieron de paz, é deste á dos dias despues de hechas las amistades, el goolnernador é los españoles se passiron delante á otro pueblo que se diçe Iqu, tan grande como el que se ha dicho, é todos aquellos pueblos están á una legua y media é á poco mas ó menos de la mar.

Esos indios que les llevaron las carcas, diseron á los españoles que los indios de Aqu tenian concertado de matarlos á la entrada del pueblo, lo fual no cra assi: antes quando allegaron, cran ydos del pueblo los veçinos dél, é huyeron porque estos de Clunaca les avian enviado á deçir que los eiripstianos yban con deteminaçion de matarlos é lagerles guerra é tomarles las mugeres. Por manera fite quando los nuestros entraron en cl pucblo, lualláronle solo é muy bien proverulo, ć los indios de Chuaca, que yben con los cluipstianos, saquearon las casas é cargaron de quanto bien les paresció é quisicron, é se tormaron á su pueblo é dexaron alli á los enripstianos. Otro dia vinieron los de Aru de guerra, é como el adelantado estala solsre el ariso, anticipóze á la defensa como luen capitan é diestro, é hiço grand destrogo en los contrarios, é murieron muchos de los prinepales é de la otra gente comun, sin que muriesse duripstiano, puesto que algunos ovo heridos é taunbien de los caballos; pero la viforia quedó con los españoles. El dia siguiente vinieron de paz, é pidieron perdon al adelanado, é les otorgó las amistades, é se hiçieron, é le dieron indios, que Ilevassen las carras arlelante.

Sabiendo por la comarea las batallas yues diclio ó la vitoria de los nuestros, enviaron muchos cacirjues sus embaxalores al adchntado, pidiéndole paz é sn amistad, y él se la otorgaha é les daba te lo que tenia, é deste en adelante no oro mas recuentro ni batalla.

Do allí passaron los españoles quatro leguas hasta Cicia, ques mayor pireblo de los quese han dicho, callí fueron hien resçelidos é scrvidos: é como no hallahan rio, ques la principil cosa que los hombres huscan en aquestas fartes, acordó el adelantado yr adclante, é passó á otro puchlo mayor que bicia, que está á quatro leguas, é llámase Loche. El cacip!ı de allí es grand scñor, é hico tan poco caso del adelantado é de los chripstianos, é mostróse tan grave con cllos, yue por despreçio se cstuvo (fuclo en su casa y cchado en su hamaca, é nunca habló tres palaluras: é sus principales que por torno dél estahan, hablaban por él, á causa de lo fual el adclantado Ilanó arguel!a poblasion el pueblo de la Gravedad. É quando algmal palabra el carcique deçia, cneontinente que començaba á lablar ponian luego dalante entre él y el adelantado una manta muy delgada, é tenianla tendida en el ayre, tontándola dos de aruellos indios, sus mas açeptos é çercanos á él, por las dos puntas alçadas, é las otras los caydas, assi que servia de cortina; é puesta de esla forma, deçia algunas pocas palabras.

Dusde alli atravessaron por la tierra alentro los españoles, é fucron con su capitan general á dar en el pueblo, fue se decia Silamanca, ć hallaron muy poblada 


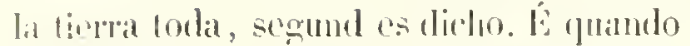
alli llewaron, no cram ya sino sessentar per. sonas, on los quales y en otros die\% ó dore (pue en aquella villa laallaron, cra reducirla torla su armada y exrirgilo; porepue fodos los demás cran muertos, é atpuellos doce avian eseapado porque dos puehlos pequeños los sostenian, que quiso Dios que no se alçassen, é aquellos les diban algun pescado é mahiz.

Parésçeos, letor, quesla manera de miliçia ques algo mas peligrrosa que la de los lárlaros, ni de sn emperador Cigiscan, de quien se liço memoria en el eaprílulo antegedente, que de diez de sus soldados malahan el uno, é ací en lo que deçimos desta armada, de tresçientos é ochenla hombres no quedaban sino septenta y dos liombres!.. Pues oyd, é sabreys que no se sabe que ningamo volviesse á España . sino solo el comendador don Alonso de Luxan, de quien de susso se ha hecho menfion, ni se eree que loy sean vivos diez dellos. ¡Oh inmenso Dios, quánto mas segruras están las vidas é las ánimas de aquellos que en tu serviçio se ocupan!... E quánto es diferençiado é mas complido é precioso el galardon, que consiguen los que te aman é temen, é que se apartan destos militares trabaxos mundanos, que los hombres (ólos unas dellos)á cseuras y embebescilos en estas malas é terronas ganançias, ó mejor diçiendo notorias pérdidas, con sus proprias manos é flacos entendimientos abraçan é toman sin entenderse, liasta que ni el daño tiene remedio ni el arepentimiento es en tiempo que les aproveche, ni excuse las muertes palpables, que por estar partes están cngastadas en este oro y esmeraldas que los más buscan é los menos goçan!

Despnes quel adelantado é los españoles alli estovicron, fuć una caravela desde aquesta nuestra çibdad de Sancto Domingo á buscar al adelantado, que cra suya, é apoltó á Cosumel, é desde allí passó á Tierratrirme é fué á arpuella viha do Silamanca, con col qual navio, issi ol adelantarlo como todos los demáts, se holgaron en extremo. Y al adclantado se metió en la caravela para yr á buscar por aquellas costas alguma sierra ó rio por donde mas á propóssito é mejor pudiesse láçer su assiento que en lo que avian visto; é llevó consigo ocho ó diez de sus eriados, é la otra gente quedó en Salamanca á deprender mas trabaxos; pero estos que allí quedaron, no fucron sino veynte ó veynte y dos hombres, con don Mlonso de Luxan, haçiendo un bergantin para seguir trásel aulelantado háçia donde él yoba, porque los restanles, que serian hasta quarenta españoles, mandó cl adelantado que fucsen por licra con su teniente el capitan Alonzo Dávila, cosla á costa y en la demanda quel adelantado yha. É assi lo hiçieron, sigruiendo çicrla instruçion del gobernador, é passaron por muchos pucblos no menores que los que la historia ha dicho.

El adclantado llegó bien ochenta leguas de aquella Salamanca á un pueblo de la costa cue se diçe Chitemal, é conforme á su última sílalıa mal suluçedió todo lo de allí.

El Alonso Dávila é los que con él yban llegaron á treynta leguas de alli, porque los indios les liçieron dar esla guiñada, ó apartarse esta distançia la ticrra adentro, por apartarlos del gobernador é poder con mas façilidad matar todos, á los mos é á los otros, lo qual se hiço por industria de un Gonçalo, marinero, que deçian los indios que estaha en la tierra desde que un Iguilar, Iengua que luvo Cortés en la conquista de la Nucva España, é olros clıpipstianos se avian perdido con una caravela en aquella costa. Y este Goncalo, marinero, era del condado de Nicbla, y cstaba ya conrertido en indio, é muy peor que en indio, é casado eon una india é sacrificadas las orejas é la lengua, 
é labrado la persona pintado como indio, é con muger é liijos, del qual se supo en esla manera.

En aquel pueblo de Chitemal, donde el gobernador llegó con la caravela, eclaron el batel fuera é saltaron en tierra, de noche, algumos españoles é tomaron tres ó quatro indios, é uno dellos dixo al gobernador que entrellos avia un cluripstiano como los de la caravela, é que estalua cassado é vivia entrellos, é avia seydo primero esclavo, é que ya era libre é su reçino, é sali muy lien la lengua de la tierra, é teni. tas orejas é la lengua, como los indiss, harpalas ó sajadas de quando ellos haçn sis sacrificios, como mas largamente tales ritos se Iractan adelante en el libro XXXIll, copítulo XLVI.

Informado de lo ques dicho el adelantado, ereyó que aquel cluripstiano que le deçian, seria grand socorro é ayula para paçificar é polslar la tierra é convertir los naturales della, é que ya que por sus peccados ó desdicha se avia allí aveçinclato; que todavia tenia memoria del baptismo é de nuestra religion chripstiana é dessearia salvarse, pues la misericordia divina tan buen aparejo le daba para se poler cobrar é servir á Dios en la conrersion de los indios, á causa de su interpretaçion; lo qual parescia cosa posible é muy aparejada ocasion. É assi el adelantalo encontinente le escribió una carta, en que le deçia assi: "Gonçalo, lıcrmano é amigo especial: á muy buena ventura tengo mi venida é aver sabidlo de ros del portador desta carta, la qual es para acordaros que soys chripstiano é comprado con la sangre de Jhesu-Chripsto, Nucstro Redemptor, á quien yo doy é vos deheys clar infinitas graçias, pues os da tan buen aparejo para servir á Dios y al Emperador, nuestro señor, en la paçificaçion é haptismo destas gentes, y en que demás lesso, saliendo de peceado, con la graçia de Dios, podreys honrar é aprovechar TOMO III. vuestra persona; é yo os seré para ello muy buen amigo, é sereys muy lien tractado. É assi os ruego que no ders lugar á quel diablo os clé estorbo, para hacer luego lo que digo, porque no os perdays para siempre con él. É de parte de Su Magestad os promelo de lo hager muy bien con vos é de cumplir todo lo que he dicho muy enteramente; i de mi parte, como hombre hijodalggo, os doy mi fóe é palabra de lo hacer complir sin falla a!guma, favoresçiendo é homrando ruestra persona, é de haçeros de los prinçipales hombres uno de los mas escogillos é amados que en eslas parles oviere. Issi que, sin dilaçion os venid á esla caravela ó á la costa á rerme é a eleltuar lo que he dicho, é lıęerse la con vtıestro consejo é paresger lo que más conviniere. .

Este mal arenturado, como se debiera descle su prinçipio aver criado entre baxa é vil gente, é no bien enseñado ni clollrinado en las cosas de nuestra sancla fée cathólica, ó por ventura (como se debe sospechar) él seria de ruin rasta é sospechosa á la unesma religion cliripstiana, 10mó la carł́a é leyóla, la qual le llevó aquel indio que al adelantado informó deste liombre. É digo que la leyó, porque otro dia siguiente el mesmo indio volvió con la respuesta é con la mesma carla que llevó, é venia escripto en las espaldas della, con carbon, estas palabras: "Señor, yo besso las manos dle vuestra merçed: é como soy esclavo, no tengo liberlad, atnque soy cassado é tengo muger é lijjos, é yo me acuerdo de Dios; é ros, señor, é los españoles, lerneys bucn amigo en mi..

Su amistad é olıra fué lal como quien él era, pues que induģidos los indios por él; barrearon é hiçieron cavas é forlalesçierou el pueblo, é dió guerra al adelantado é á los españoles; é los puso en eslato quo todos los chripstianos, que en aquella tierra estaban, se ovieran de perder, é dió á ententer á los españoles é al adelanlato 
quel capitan Alonso Dárila, con Lodos Ios

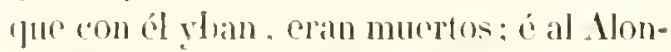
so Dhivila é sus compañeros les hiço entender (fuc los de la caravola y el adelantado fambien cran muertos. É para esto hiçieron los indios la paz con el golocmador, é dićronle sallinas é malıiz ć hastimentos é agua, con quese fuesse con su caravela é assi lo hirgo con mucha pena é dolor, prensando que arnella mala nueva era vepdad. E) Alonso Dívila, despues que le dieron tambien la mesma mala nuera, por su parte con su compañia, se tornó por donde avia ylo é rolvió primero á la villa ques dícho de Sialamanca. é mudó cl puelslo de alli é híçolo passar con el mesmo nombre á donde avian topado primero el cagique de Cocumel, quando sba á casar su hepmana: y en un lugarejo de pescadores, buen assiento, que por los indios se llamalsa Camanca, assentaron su recindad, doliéndose de la muerte del adelantado, pensando que era verdad lo que dél te avian diclıo, y esperando lo yue la voluntad de Dios quisiesse disponer dellos.

El adelantado avíase passado de largo descubriendo la costa; 6 acompañado de muchos tralaxos é tormentas llegó Iiasta treynta leguas de Honduras, á un rio que se diçe Liva. É desde allí dió la vuelta é fué á Coçumel, é supo de los indios de aquella isla adónde estaban los españoles con Alonso Dávila é fuésse á juntar con ellos con mucho placer, non obstante sus trabaxos de los unos é los otros: porrjuo por las nuevas que aquel mal chripstiano Gonçalo, marinero, avie publicado, todos pensalıan que cran muertos los que estaban viros, é se abraçalan con mezcladas lágrininas de goco.

Allí reposó esta grente pocos dias. porque el aparejo de su descanso estaba lé$\mathrm{x} o s, y$ el assiento de aquella villa no era á su propósito: é porcune el adchantado estaba muy desseoso y en determinacion de lusear un assiento é comarca. donde d liempo no se perdiesse, como hasta es. longes, y a estal callsal col la mesmal caravela fué á la Nueva España, é llegado á cla prosizuió su camino hasta Tenuxtilan, por se provecr allí de wente é volver á pohlar en arjuel puchlo é purerto de cilitemal, donde aquel traydor é renegaddo inarincro. Ilamado Gonçalo, liço la prueba quie la lisioria laa rontado. porefue allí aria visto (adelantado un buen rio é dispusiçion para lo (jucl gobermador desseaha. Vilo pres à lléxico, avia dexado oralenadoá Alonso Dávi ia con su poder, que, como su teniente, quelasse con la grente en aquella villa de Salamanca, en tanto quél yba á buscar remedio é gente, como es dicho, en Héxico ; é cómo era amiso de Hernand Cortés, qué poco antes avia venido con título de marqués del Valle, commnicóle sus trabaxos é lrançes passados, é cómo no avia hallado donde pudiesse poblar, é todo lo que por él avia passiulo. É díxole el marqués que, quando él avia yclo en busca del capilan Chripstóhal de Olit, yue se le avia alçarlo en Ilonduras, aria passado por una hermosa cildad que está en la gobernaçion del mesmo adelantado é tierra de Yucalan, que se diçe Acalan, rica é apropóssito snyo, é loúscla en tanta manera que le biço muJar de propóssito. É la Audiençia Real que en lléxico reside, mantóle y cneargó al arlelantado que fuesse á un puelilo que se dice Tavasco, que está en la costa del rio que llaman de Grijalra . é que tomasse residencia á un capitan que allí estaba para guarla de aquella tierra, é que la asegurasse, é pacificasse los indios de aquella provincia. É con este despacho se partió de la ciludad de México con hasla çinquienta ó sessenta hombres, é fué á la villa de Tavasco é emmplió muy bien lo que por el Audiençia Real le fué mandado; é deste alli envió dos navios á llamar alcapitan Alonso Dávila é á la otra gente, que con el avian quedado cn aquella villa 
de Salamanca é vinieron alli, porque le paresçió al adelantado que estaba en parte desde donde podria entender en la conquista é paçificaçion de Yucatan.

\section{CAPITULO IV.}

Del subçesso del adelantado don Françiseo de Montejo, despues que estovo en Tavaseo, ć eóno fuẻ en demanda de la eibdad de Aealan, é de las vistas de entre il y el eapitan don Johan Enriquez de Guzman *, de una nueva invençion é nunca antes oyda ni vista que los españoles inventaron para lleviar sus eaballos en eanoas **; é euénlanse olras cosas comernientes al diseurso de la liisloria.

D espues que en Tavasco el adelantado tovo pacífica la tierra é de paz toda su provinçia, pusoalli un teniente suyo porcapitan, y él entró por la tierra la via de AcaIan con hasta çient hombres, é Ios treynta dellos de á caballo: é despues que ovo caminado liasta sessenta leguas, adolesçió en un pucblo grande que estát en el nascrimiento del rio de Grijalva, que se diçe Teapa, en el qual passó muchos trabaxos, assi por lalta de mantenimientos como de otras nesçessidades quél é su gente padescieron. Siguióse que en el mesmo tiempo desele México avia ydo don Jolıan Enriquez de Guzman, por comision del presidente de la Nueva España, Nuño de Guzman, á la paçificaçion de la provinçia é cibdad de Chiapa: é despues que en ella estovo, salió á visitar la ticrra láçia el nasçimiento del rio ques diclıo de Grijalva, é por donde passaba é to laçia de paz, yba repartiendo la tierra, encomendando el serviçio de los indios á los mílites españoles, que en su compañia andaban. Lo mesmo avia Lecho el adelantado Montejo por donde avia passado liasta llegar al pueblo de Teapa: de manera que don Johan llegó á una pohlaçion, que se diçe Estapanguaxoa, ques á dos leguas de Teapa, é

- En esta parte se lee en el original : "é eómo el gobernador se volviú á Tavasco é envió á su leniente el eapitin Alonso Lávila eon gente, en demanda de Acalan, é cómo se tomó un pueblo que estaba dentro de un lago por muy gentil forma."

- Tambien aqui suprimió Oviedo las siguienles clíusulas, que se leen en el MS. original: ude dos en dos juntas é en cada par didlas los caballow llo cómo tuvieron notiçia los unos compañeros del un capitan de los del otro, acordaron de verse los capitanes; é con luena amistad se conçertaron, é don dohan socorrió con muchos puercos é otras cosas á Montejo, y él se los satisfico con otras, é quedaron de acuerdo, é sin que oviesse entre los unos é los otros contençion algrma, y en mucha conformidad: que era to que convenia al serviçio de Dios é de Stus Magestades. É comunicándose estos dos capitanes, dixo don Johan al adelantado que, pues tenia arordialode volver atrás por su enfermedad y enviar á su teniente Alonso Dávila en demanda de Acalan, que le paresçia que debia mandarle que se fuesse por Chiapa, donde don Johan tenia su assiento, é le ayndaria él con darle guias é con todo lo quél le pudiesse ayudar é favoresçer. pues que por alli era el mejor camino. E assi, teniéndoselo Montejo en merced, le respondió el adelantado que assi se haria, é don Johan con su gente se tornó á su assiento á Chiapa, é Montejo se volvió á Tavasco en canoas por el rio abaxo, y el teniente Aloisso Dávila fué con la gente en dentanda de Acalan.

Y en llegar desde Teapil liasta Clia-

Iravés, que en la una ambos eaballos llevaban las manos y en la olra los picis: é de lo que passaron estos españoles lıasta que llegaron á una laguna de dos leguas en anclio, donde se halló notięia de una forma extraĩa de una puente, quel marqués tel Valle, Ilernando Cortés, avia feelo algun tiempo atrís is inte, por donde passó aquella laguna." 
ja, que son lregula legulats, passo muchos lrabaxos con ochenlat hombres mililares que llovabal, é los mas dellos de caballo, porpue en canino es de los peores é mas frigoso que sí purde pensar: y assi se despontaron parte de los caluallos é parte dellos se aguraron, é los demís llegaron tales, que fueron de poco provecho. Ilas alli en Chiapa les hico mucha cortesia é bucn acoginniento el eapitan don Johan Enripuez, é si por aquel cavallero no fuera, mal pudicran passar aclelante; porfue assi é como los espanoles que con él cslaban, socorricron muy bien al Alonso Dívila ć sus companeros, éalli se repararon é rehicicron de caballos é armas, de algodon bastado é de lo yue le s convino para continuar su empressa, é les dieron guias, las quales mandó Ion Jolan que fuessen con Ilonso Dárila hasta le poner treynta lecruas apratado de los téminos de Chiapa. E assi se hiço, é fuando las guius ovicron servido hasta las treynla legruas, se tornaron, porque de allí adelante no sabian la tierra ni entendian las otras Ienguas que avia; é Alonso Dívila passó adclanto é siguió su camino, auncpue cra algo peor é mas áspero quel passarlo, llevando los caballos de dicstro, é rotas é desportilladas las lumbres de las whis, comur trabasados ć flacos. É desfa mancra liegaron á una laguma, que tiene diez ó doce leguas de çreunlerencia, y en la milad della un pucblo en una isleta con lasta sessenta casas de indios ricos é tractantes é de gucrra.

fi llegando allí, ó no aviendo forma ni aparejo para entrar dentro, salió del real el comendador don Alonso de Luxan con hasta ocho ó diez de caballo, para costear aquel lago é rer é considerar su dispusicion; é si hallarian entrada segura en él para aquella polslacion. E toparon en la costa quatro canoas peyuchas, y chtrados algrunos españoles ch ellas, atatas junlas. hiçieron una bal- sa, é lraydas á donde aria quedarlo el teniente Mlomso Dárila con la gente, netiéronse en esta nueva forma de halsal doge homber rodeleros é ballesturos; á los lados yban madando un caballo de cadla parle, é al saltar en lierra echíronles presto las sillats é cabalgaron en ellos dos ginetes veleranos é liestros, é hicieron rostro á los enemiggos, que no quedaron poeo espantados de ver láles animales é la osadia con que allí avian entrado cssos españoles. Y en tanto lis canoas ó balsa tornó á traer á la islela otros lantos chripslianos, porrace el trecho del agua por allí seria hasla un tiro de ballesta; é desia forma, entrados mas é maśmilites, ganaron el pueblo. É cóno los indios tenian canoas, fućronse por otro costado del pueblo con quanto pudieron llevar, puesto que (fuedaron bastimentos á los españoles, que lo avian bien menester , 6 no quedó persona ni se pudo aver sino una inclia sola, la qual dico que era esclava dol carique, é quella sabia dónde eslaha é que llevaria los cluripstianos allá, é quel cacique tenia doge cargas de oro.

Con esta simple informaçion se acordó que don Nonso de Luxan quedasse en la isla ó fué el teniente Alonso Dávila con la compañia que le paresció é con aquella gnia á bnscar el oro que avia dicho, é lleró í los chripstianos sers leguas de allí por arpuel lago, en bucnas canoas de algunas que los indios huydos avian dexado. E cómo Mlonso Dávila saltó en tierra, bien pensó que turiera alguna resistencia, porfue se vian muchos indios; pero no le osaron itender, ć dexílonse muchas cargas de plumas de las doradas, de que hacen los indios muy hermosos penachos, y es griande é riea mercaderia tales plumas entrellos.

É pues viene á propóssito, es de saher que en afuellas partes hay çicrlas aves no mayores que golondrinas, é assi la cola hendida eomo elliss ó como los mi- 
lanos; pero las dos plumas de los lados de la cola son luengas, é las ouras muy corlas, é aquestas dos plumas que digo es cada una dellas de dos ó tres palmos de longitud cada una, é mas é menos, segumd la edad del páxaro. Quindo le toman, vucla poco, porque si un poquito de viento hay, como tal are es cliequita, y es contrapesso aquellas dos plumas grandes para ella, luego la abate la manera de la pluma. Porque se han visto en España muchas dellas, y en ftilia é otras parles de Europa, donde las han Ilevado, no es nesçessario detenerme en esto. Es su color de muchas plumas ó hilos de aquellos que tienen las plumas de los pavos de España, doradas, é como unos tafelanes que haçen, que se diçen ggirasol, que junto con lo dorado, muestran otra color verde mixto: es muy hermosa é Ireçida pluma, é como he dicho, mucho estimada untre aquella gुente.

Tormando á la lisistoria, aquel oro que la india decia, no lo lallitron, é dieron la vuclia los españoles á su real, llevando algumos indios que tomaron desmandados, los quales dicron algouna notiçia del canino de Acalin, éfueron guias, con las quales el teniente Nonso Dávila é su ggente caminaron delante. É andadas treynta leguas desde aquella laguna é por muy mal camino é çiénegas é malos passos, allegaron á un rio que va á se juntar con el de Grijalva, é por la costa dél un pueblo de diez casis, los indios del qual esperaron de paz é los guiaron para adelante. Allí les dieron Iuenas canoas, con que abaxiron tres leguas por aquel rio, para tomar adelante el camino de Acalan, é para llevar los caballos en ellas, hacíanlo de la manera que aqui se dirá. Pero quiero primero traer ál la memoria del letor aquellas sicte maravillas 6 miraglos

1 Plin., lib. XXXVI, cap. 1 k.

2 la llist. de Rodas, lib. II, cap. 8.

3. I'linio, lib. XXXIV, cap. ?. particulares del mundo, que por exçelencia muchos escriptores antigtos memoran en sus tractados, é son apuestos.

El templo famoso de Diana Efesia, del qual el muy doto varon Erasmo laçe mençion en aquel su libro de la lengua, é mas lirgamente Plinio en su Nalural historia', el pual dige quos la verdadera admiraçion de la manifiçençia greea, é ytue toda la Assia le edificó en doscientos y veynte años, ele.

El segundo miraglo ó maravillir de las sicte, fue otros diçen ser el primero, fucé acpuella grandíssima é famosa estítua del sol, por otro nombre llamida el Coloso, que estuvo en Roulas; de la qual hagge memoria la historia de la perdicion de aqueIla isla, de fuando el grand Tureo procos años la la conquistó ${ }^{2}$. Aquesta cstátua, segund escribe Plinio ${ }^{3}$, la hiço Cares, escultor natural de Lidia, la (fual cra de septenta cobdos de altura, é diçe que sus dedos eran mayores que lo son muchas estátuas, é que pocos hombres abraçarian el dedo gruesso, etc.

El sepulcro del rey Yauseolo es uno destos miraculosos edefiçios, é llímase assimesmo mauscolo esta sepoltura, por respecto de aquel rey que en ella se puso, 6 por cuya memoria Irtemisia, su muger, la hirgo laçer; del qual elcficio largamente escribe Plinio en su Naluralhistoria ${ }^{\$}$ é da raçon de su grandeça é de la exçelençia de quatro eseultores, que labratron en este memoralsle sepulcro, é acabóle otro quinto macsiro, elc.

Diodoro hage mençion de una de lats tres pirámides entre los siete miraglos del mundo, en su libro II.

El mesmo auctor assimesmo lace mencion del obelisco de Semíramis por (tuo de los sicte miraglos ${ }^{5}$.

Él templo de Júpiter llamóse assimes-

4 Ib., lib. XXXVI, eap. ̋̈.

5 Iliodoro Siculo, lib. Ill. 
no uno de los siete miraglos del mundo. Segind el poeta Marreial, Lemnos es una isla en ol mar Griego, é los moradores della fueron autignamente dryotos de Vulcano, é le adoraban; por to qual la pringipal cibelad do apuella isla se llama Ephestial, é otra se llama Mlirrina, en cuya plaça se acala la sombra del monte Atlos de Macedonia, el qual de aquel lugar está apartado ochenta y seys mill passos, por lo qual se cuenta esto por una de las cosas maravillosas deste mundo, segumd afirma Solino 1 : Iráctaloassimesmo el Abulense ${ }^{2}$. Estos passos entienden los historiales assi, que dosçientos é veỹnte y cinco es un estadio, ques la octara parte de una milla: assi que dos mill passos serán á cste respecto una milla , ć ocho mill passos una legua; pormanera que ochenta y seys mill passos son onçe legruas, menos un quarto de legua. Esta medirla essegund lo tassa Leonardo Arretino en su tractado del Aquila volante, lilsro I, capílulo VIII.

Estos siete miraglos que aqui se han memorado, segund reo, los sers dellos se atriluyen al arte y edeficios de los hombres humanos, y el séptimo es edeficio natural del Macstro de la natura, que puso aquel monte lan léxos de donde alcança su sombra por la exgelsa cumbre suya. I este me paresce á mí ques muy menor que otros muchos que hiço el mesmo Macstro, ques Dios, si comengamos á contemplar los ciclos é sus morimienios, estrellas é planclas, é las mares é sns diferentes menguantes é cresçientes. "é la compusicion de la lierra é greographia de su assiento; é las diverssidades de los animales, é de las planlas é hicrvas é sus propriclades, é sobre todas las cosas la excelençia del hombre é sus partes. Pero como en estas cosas de las obras de la Divina Magestad

1 Solino en el Polihislor, cap. $13 \mathrm{y}$ en el d" Memorabuli'ts mundi, cap. 20. es un mare mağno, é que no se pucde acabar de considerar, ni mortal lengua lo puede exprimir, passemos las otras seys particularidades primeras ó miraglos que de susso se locaron, que lodos cllos se alribuyen al ingrenio de los liombres, é hallaremos que lodos é cada uno dellos es en sí de mucla admiraçion, aviendo respecto á la breverlad de la vida é pocas fuerças desta humanidad para tan suntuosas labores. Mlas á mi parescerer, no trayendo estas comparaciones para disminuyr su artificio é grandeca, sino para loar el mesmo ingenio humano, me paresçe que me puedo mucho mas maravillar sin comparaçion de aquellos caños de fuentes dulces que se levantan sobre el agua de la mar salada, segund se diso en el capílulo II, porque al monte Nhos podemos comparar el Olimpo é ofros que lay altíssimos en el mundo; porque como digo estas olras de natura son mayores é incontables, é todas compuestas por aquel Summo Macstro.

i las seys otras volviendo, digo que no tengo en menos que cada una dellas aquella muy alta torre de la iglesia mayor é arcobispal de Sevilla, é no tanto por su mucha altura é latitud, ques edefiçio morisco é del tiempo de los moros, quanto porque çerrada la puerta de la torre, é puesto un hombre que sordo no sea, sino de mucho oyr, aunque muchas voges le den de abaxo no las oyrá dentro de una cámara de las de aquella torre en ninguna manera, é aun con grand pena sentirá una campana ó trompeta ó roçina ; é parado á las ventanas de las cámaras superiores, lampoco oyrá ni podrá entender lo que otro le dixere desde abaxo(aunque sea á voges), assi por la grand distancia, romo por el tráfago é frequentaçion ó estruendo de las gentes del pueblo,

2 Abul. sobre el Eusebio De los tiempos, cn 1. terepera parte, cop. 211. 
ó de sus labores é diverssos exerçicgios. Para el remedio de lo qual está una argooIla de hierro al pić de la torre, alta del suelo siete ú ócho palmos, que á mi parescer no pessará dos libras ó veynte oncas, y está fixada con una armella ó estaca de hierro emplomada (Lám. II. a , fig. $\left.11 .^{a}\right)$; é assi como suelen llamar á una prerta con semejantes aldabas, Ilaman con essa é bate en la mesma pared de la torre, é al paresger (como es verlad) suena poeo aun alli çerea; pero como quier quello sea ó en que se consisla (que no lo sé comprehender), el caso es que aquel poeo sonido diçen que se oye muy bien dentro en qualquier parte de la torre, para quel alcayde della laga abrir al que llama ó con él quiere negoçiar. Esto aunque se vee, paresce imposible, sin lo experimentar, é con efetto dicen ques assi, como lo diggo. Io la he visto é tocado con la mano muchas veces esta argolla , é lo que he dicho me han dicho personas que lo tienen por cierto: yo no lo he probado ni ann lo ereo, si no lo experimentasse. Mas despues que por mis peceados he perdido mucha parte del ovr, é conosçido en qué consiste el primor de aquella aldavilla, é ques la causa de sı sufiçiençia para ser oyda en las interiores partes de aqquel grand edefiçio é bóvedas de aquella torre, é hallo por mí incapaz oyr que si estoy en pressencia de algumo que esté tañendo una vigüela ó. un clave çimbano, no lo oygo ni entiendo quassi, é si pongo los dientes en la cabeca de la viguicla ó de la caxa del clave çímbano, gusto y goco enteramente de la melodia é música que allí se executa, assi me paresce á mí ques mury á propóssito el afixamiento de aquella pequeña aldavilla en tan porleroso é magnánimo edefiçio, como el de aquella tore, la qual armella está puesta á la parte que la torre mira al $\mathrm{Nol}$ te. E no os maravilleys, letor, de lo que he dicho, si leyéredes una Summa que poco tiempo ha escribió el doto raron Johan Baptista Iænacio, veneçiano, delas "Vidas de los Emperadores Romanos n en lengui toscena, el qual en el II libro, en la descripcion que hace de Constantinopla, toea una cosa que me paresçe admirable é al propóssito de lo ques dicho, alegando á Dion, escriptor stavíssimo é dino de crédito: el qual diçe que en aquella cibdad avia sicte torres, hechas con tal artificio, que gritando alguno en una, 6 que se oviesse echado una piedra, que en todas sicte se oya igualmente el rumor ó soniclo.

Pero no cansando al letor con esto ni otras cosas, quiero volver á las canoas, que en aquel rio que dixe de susso se dieron á los españoles, en las quales, constreñidos de la mesma nesçessidad para llevar los caballos, hicieron una invençion, que lasta agora nunca creo que se escribió la semejante, ni hombres la liçieron de tanta admiracion; porque en fin una canoa no es otra cosa que una barca de un solo leño, y en él cavada é feclia á manera de ma artesa, ó como aquellos dornajos, que se usan en las sierras de Segovia é por aquella tierra. É hiçieron estos mílites de aquesta manera: juntaron las canoas de dos en dos, costado con cosfado, é ligadas muy bien, de manera que muy juntas é cosidas con bexucos yban atadas. Y ponian el costado de la una hácia la tierra y entraba mu caluallo metia los braços en ellas: luego al tiempo que metia el pié, passala la mano á la otra canoa, de mancra que quedaba assi puesto de través, las manos é braços en la una canoa é los piés en la otra. É á par de aquel caballo ponian y entraba otro en la mesna forma (Lam. II. a, fig. III. ${ }^{a}$ ); y el $n 110 \mathrm{y}$ el otro juntos llevaban las manos en una canoa, é ambos llevaloan los piés en la otra. É yloan assi de piés ó en pié atraressados, porque las canoas son luengas é angostas, á causa que, como es dicho, cada una es 
fecla de un solo árbol é masola piefar é si los ruisicran poner carla nono en tha canoa. no se pudicra lagere á a ransa que son navios de poco sosten é lérihmente se trastornan, y estando juntas, como es dicho, yhan sururos los caballos é la gonte.

lista mancra de navegacion é pasage de semejantes animales, munca antes fué rista ni hecha por otmos Iombres, antes destos, en nuestra naçion ni en otra, é no sin quodar los mesmos inrentores moly admirados, quando lo hicieron la primera vez, é á los indios fué mucho mayor maravilla, quando lo vicmon. E deste antificio se ayudaron despues los chripstianos en otras partes mas peligrosas y en la mar, como la historia lo dirá en su tiempo é largall; porryue la nescossidad no les daba otro aparejo ni industria para ello, sino la que está dicho, la qual fué muy grand novedad. Desta manera fueron aquellos cspañoles estas tres teguas el rio abaxo, é salieron á mna lierra llana; mas todas las tres leguas en ambas costas del lio están allí de peña naturalmente tajada, que para los que la andovicron ć aun para los que lo oyen, segund su altura de la una prarte é de la ofra, no es menos de admirarse.los hombres que de la sombra del monte thos de la isla de Lemnos.

Salidos de aquella canal é rio, hallaron un pueblo, que se diçe Tanoche, de hasta çient casas, cl qual estala solo é alçado, a causa que los del rio de Grijalva en canoas sulian liasta allí de contínuo á saltear, que son sessenta legruas del uno al otro é más. Allí entraron los españoles por la tierra á ranchear de noche, é tomaron algumos indios, de quien se informaron del camino se Acalan, é les dixeron que los pornian en el ammo de Malinde. (Este nombre Malindere llamalaan aquetlos indios á Corlés, é decínnle assi pol lespocto de ma india fure trilia ImI licmplo reomsigo, que (era lengara é se decia Manina.) Émostraron el camino, el prat sirniendo, a calso do quince logruas de despollarlo, llegaron á mola laguna muy gramcle, que tenia de través dos lecknas en ancho, de la qual longitud ni sabian ni se podian rer los extremos. Y co la ribera della sentaron su real, y enviaron por la costa á la diestra é sinicstra nano á buscill passagre, é autuque en esto se ocuparon tres dias, no le liallaron: antes descubrian muchas ciénegas é pantanos, é tal dispusicion de tierra, fue era imposilble poder entrar ni passal por allí gente de pié ni á caballo. É preguntando á los indios qué remedio se ternia, ó por donde avia passado Malinche, dixeron que por alli avia hecho una puente, é que aquel era camino derecho, é no avia otro sino atravesando la laguna. Estonçes Alonso Dávila, informado muy bien de la verdad, liço que los indios huscassen si aria rastro de la prente, que deçian de Malinche, é halláronse alģunos horcones lincados en el aggua, que cran é avian quedado de aquella puente que hiço haçer Coltés, quando con suexérçito atravesó aquella laguna, de la forma que en el capítulo siguiente se dirá, cuya fué primero aquesta invençion de nueva puente: la qual, volviendo á los edefiçios miraculosos que de susso se contaron, é que lombres hiçicron, no los tengo por tan trabaxosos para los edeficadores que en cllo se ocuparon, ni de tanto peligro ni admiraçion. 


\section{GAPITULO V.}

De la exiraña é nueva puente que los indios Ilamaban de Malinche, que hiço el marqués don IIernando Corlés, por la qual passó eon mas de quinẹe mill liombres é muchos caballos; é de la que despues hipo haçer quassi por el mesmo lugar el eapilan Alonso Dávila, por donde avia de passar con los caballos é gente, que eon él ylua en demanda de la cibdad de Aealan; é de otros muehos trabaxos é trançes por que passaron hasta que Hlegaron á Chanpolon. *

\section{D} espues quel capilan Alonso Dávila se informó muy bien de aquella puente Malinclıe, é cómo la avia hecho haçer el marqués del Valle, supo que avia seydo desta manera. Poníanse dos horcones limcados en el agua, aporrados con macos é apartados unọ de otro una buena braçada, é sobraba ó quedaba descubierto dellos dos cohdos poco más ó menos, é igualmente tanto del uno como del otro: ençima destos horcones atravesaban un palo reçio é quedaha hecha una horca de los tres palos, ques dicho. En un passo mas adelante haçíase otra tal derechamente, una delante de otra, é mas atdelante en el mesmo compás ofra : é solnre estas horcas, yendo assi muchas á la fila procediendo, ponian sohre los travesaños altos varas de luengo á luengo juntas é reçias muy hien atadas con hexucos. é quedalıa liecha una barbacoa ó suelo de la manera que se ha dicho, é solse aquel echaban lierra é faxina. É quedaba lan fija é baslante la puente, que por ençima della siu jeligro ni riesgo podian yr cahallos é hom. Ines, para poner aquellos puntales ú horcones é todo lo demás: andahan indios é chripstianos ençima de balsas de madera, continuando la lahor de la puente hasta la perfeçionar é concluyr; é acabada, passó el marqués é su exérçilo, con quinçe mill lıonhres ó mas é muchos calaallos, de la otra parte de aquel laģo é pantanos.

Esla invençion fué muy grande é nota-

* En este epigrafe hizo tambien oviedo algunas supresiones, segun se advierte en el cúdice original; pero no siendo de graude iuteres para la inteligen10.110111 . ble edefiçio, é por el marqués del Valle hallado este primor; pero tenia fuerça de gente para ello é muy obediente. Nas al teniente Alonso Dávila faltábanle essas fuerças é aun el comer, y esso mesmo á los pocos que con él yban, demás de yo muy cansados, non obstante que començando otro tal edefiçio, fué forçado dexarle, porque el invierno é las aguas muchas del çielo se lo estorbaron. É fué nes. çessario que volviessen atrís quassi tres jornadas, é assentaron real en çicrtas labranças é malriçales de aquel pucblo, llamado Tanoche: é alli passaron quatro meses é mas de invierno, en el qual tiempo los indios nunca osaron volver al pueblo lasta que la nesçessidad los truxo de paçes por respecto de aquellas labrancas, en yue los chıipstianos estaban apossentalos, é por los echar de la tierra. É les truxeron canoas muy buenas por ciertos esteros é arroyos, é las metieron en aquella laguna: é los españoles, aviéndolo á buena ventura, se metieron en ellas con sus personas é veynte caballos, poniéndolos de dos en dos, pareadas é juntas las canoas, segund que ya se dixo en el capítulo antes deste, é muy bien cosidas é ligadas una con otra; y eran hermosas é grandes canoas.

É assi passaron de la otra parte de la laģına, é dieron luego en el camino de Acalan por donde Cortés avia ydo, é lalláronle muy cerrado, porque avia dies

cia de la historia el eonservarlos, nos limitamos í apuntar el hecho, á fin de que se tenga la mís eompleta nolieia del MS. que sirve de texto. 


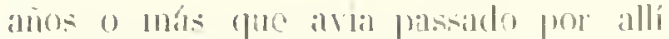

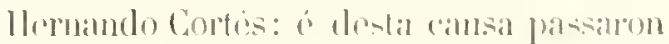
mncho lrabaso on alurirle, i como mejor

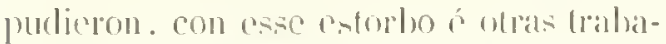

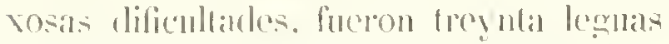
lasta rollar en la provinģia de doalan.

En aste ramino é jornatlats destas treyn-

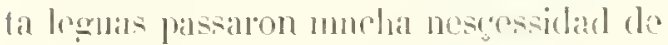
acrua, ć quiso llios proverolos desta matnera: que amucue hallisban la tierpa loda cerradia do arboledas é boscages muy routinmalos. avia (ontro los ofros) alsumos ápholes dellos. que tenian unos andos nasridos en ellos on lo alto, é hiriémulolos con la punta de mo langa, sellia nutucha agna dellos. con que remedialsan su sed. É assimesmo hallaron cañas de las muy gruessas ć huecas é los cañutos dellas llenos de grentil ageua: las quales horadahan é salia toda la que avian menester para toda la compania é á sus caballos, porque los cañutos grnessos cada uno tenia nna agumlre de agna é mís, é de los tales prira arriba, assi como la caña sencjante se va adelogacando para arriba, assi á proporcion avia menos agua en los cañutos superiores.

Poco antes de llegar á Acalan. deste unos puchlos perfucios de la jurisclicion, envió el teniente Alonso Dárila rejertos indios á larger saber á arpuella cibolan (que de alli cstaha tres leguas) cómo él ć aquellos españoles y ban. é a que divessen que se coturiessen fodos quedos en sus casas: que ungun enojo ni fuerga se les laria. Has arfuella embasada finé de poco provecho: porrfuc estaban escarmentados. é se llevó de allí llemando Cortés al señor de aquella lierra con más de seyscientos indios cargarlos, que munci éi ni cllos volvicron á la patria. Por lo cyal ni ereycrom á los mensageros de Alono Dá vila, ni osaron atcmerle: antes luyeron écleviron el pactso solo, bien lleno do roja é mantenimiontos.

Iliy en ayuella cibdad de . Lalan hasta

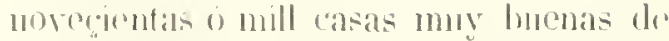

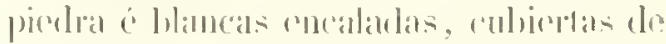
piljas, las mats dollak de lombres principalles. lí cómo el teniente fuéavisaldo por sue mensageros de la finera de los verinos dre Acalan. fućsoe luegro á la cibdad é apos-

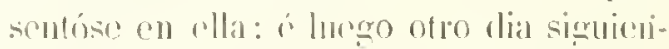
fo vinioron ciertos indios principales de

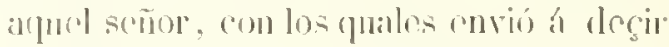

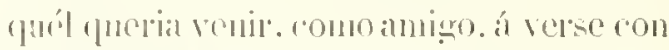
al truicnte . lonso bárila : e furberespondirlo que viniesto en buen hopa á su casa

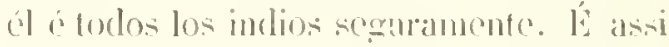
vina con hasta quatroxiontos lombres con muchas ares o batimento, é se lo pressento todo al teniente Nonso Dávila. cl qual le lice cohar luego una cadena al caçitue é á otros principales. que con ol vinieron, por se informar dél é dellos, é no con propóssito de les hager daño al. zuno: é aparlóse con ellos con la lengua, é diéronle noticia lucgo do la tierra é de lodos los pueblos de la comarea. É fundó allí cl teniente en la mesma lcalan ó caluegera una villa. é llimóla Sillamanca, é repartió la comarca é indios para que sirviessen, é dentro de seys dias todos vinicron de paz para servir aquellos amos chripstianos, á quien fueron encomendalos, é fué suelto el cagique é los demás é mu bien lactados de los españoles. Cúmo por alli corea no avia verindad de otras polulaciones, sino sola esta provinria. é los indios cran poeos para los espanoles, é no les daban oro ni otra cosa sino de comer, deste á quarenta dias despues que llegaron, se fueron édespoblaron li villa. e tomaron su camino para ofra provingia, questí treynta leguas de alli, y toda es de despoblado ćancegadicos. É fućronse allá. llevándose consiggo al taçique de Lcialan $i$ á sus indios, que de gratdo fueron á los acompañar, é dándoles de comer: é poreue al salir de Acalan avia un rio allí en la ribera dél. époco desviados del agna cstaban pollados los capa- 
noles, é convenia salio de alli pro apuot rio, é hasla llgar allá avia deste las casas al agua quassi dos tiros de ballesta. ć todo aquel espaçio lleno de lama é çiénarga, luego los indios hincheron todo aquello de tablones de madera, sobro los quales (que estaban tendidos en tierra) fueron los caluallos é los españoles hasta cl rio, donde les tenian canoas aparejadas. E passados de la otra parte, avia otra lanta lama s. inconviniente, é se hirgo otro tanto, como es dicho, por donde salieron hasla tierra enjula.

Atravesado esle mal passo ó signiendo sus jornadas Jasta Maçaclan, Ilevaron mucho trabaso de panlanos é çiéneģas, é por tal dispusiçion del terreno, que en todas treyna leguas no se halló donde pudiessen hacer lumbre. í una legua de Maçaclan hallaron un hermoso camino, ancho é llano é muy bien barrido á escoba, que yla á la cibdad, jor el qual entraron: é á um tiro de ballesta que por él yluan hallaron muchos hoyos é ramas, que los cubrian á manera de çepos, con estaças dentro lincadas é las puntas para arriba, en que cayessen los chripslianos. É conosçido este poligro. dexaron el cannino é hiçicron su via por defucra dél en el arcabuco, y cutraron en la poblaçion, en la qual no lablaron persona alguma, puesto (que eslaba muy bien çereada de riempo antiguo é de maderos gruessos é muy trabados, atados con bexucos, é con su barbacana é caras; é por una puente hien estrecha entrados los clripstianos dentro, se apossentaron como mejor les paresçió.

Desde alli salieron á correr lá lierra é romaron algmos indios, de los quales no se pudo saber cosa cicita de quanto se les pregumto: antes se dexaluan morir con formentos, por no revalar ni degir cosil de que en mingm tiempos so pudiessen arreprentir, ni we las que los aspañoles descaloan saber dellos. Pero an

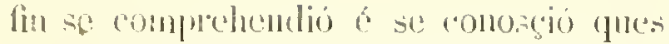
fierra mal poblada é pobre; é por esta causa sallieron della, sin llevar de allí gente de la natural, porofie en ninguma manera querian la compañia de los chripstianos ni peor ni mejor pallia que la suya, é assi los dexaron, malrartatos de vel siz teson é malicia. Solo un muchaclio ovo" que enseñó á los cajpanoles por dónde avian de yr báçia li mar, é los gruió hríçia clla, é aporlaron á Champolon, que está á par de la mar, é á lregnta le. gruas de aquel pueblo Maçaclan.

Llegados á Clumpoton por muchos looscagres é ciénegals, luasta una jomada del Jallándose, é no conozçiendo lá tierra, é aviendo perdido muchos companeros en estos viages, é sin sal)er á donde se estaban, salieron á unas limmosas savanas é vieron muchos é diverssos caninos, fure atravessaban de unas parles á otras, con que se alegraron mucho. É assentado su real donde les paresció ser más á su propossito, se pusicron arfuclla nocle algunos compañeros en salto, é prendieron rineo indios, que yban carados de sal la tierra adentro; y estos los llevaron é gutraron otro dia á Champoton, donde paresçió que estaban sobne aviso de su ycla, é salieron á r'esçeluir á los chripstianos més de quinçe mill hombres, con muchos hastimentos para cllos é sus caballos, mosrando mucho placer. Aqueste pueblo de Champoton es donde comienga la groluermarion de Yucalan por la parte que confina al Poniente enn la Nucra España. Los deste pucblo tienen contractacion con lo: de otra poblaçion, que se disc Xicalindo, ques toda de mereaderes. en lia costa del rio de Grijalva, a mueve legmas ol un problo del olro; é irenen mucha conversacrion é tracto é salnen sorvir á los chriphslímos, é lenian por señor al adelaulato don liamegisco de Montejo. con el pual ya ar ian avido indeligençia por sus mensajoros. Iny a (n Champoton hasta ocho mill 
Casas do piedra é cubierlas de pajas. e otras algumas con aggotats, y es puchlo cereado de un muro de piedra seca é con buenas cavas. E quando supieron que ylan estos españoles, aquella cibdad les lice en un solo dia é una noche un pueblo ó mejor diçiendo harrio, dentro de la dicha cerea, é aprartado de las casas de los veçinos: en el (jual avia su plaça é casas, y en cada casa su caballerica, y en aquella plaça puesto mucho mahiz é ınıchas aves é otros bastimentos, que bastáran para dar de comer un mes á mill hombres é más.

Allí los apossentaron con mucha fiesta é regoçijo é cantando unuchos areytosé contrapases en coros: é sin la provision ya dicha, cada dia dahan á cada español una gallina (ó mejor diçiendo) una pava de las de la ticra é mucho maliz, é para la noche mucho pescado é muy bueno de diverssos géneros. Y es cosa mucho de ver que carla dia ordinariamente salen de aquella cibdad mas de dos mill canoas á pescar á la mar por su costa, é vuclven cada noche. Dentro en la mar, tres tiros de ballesta ó un quarto de legua, está un isleo, hecho á mano, en que hay diez ó dore gradas en alto solsre la superficie del agua, é solore dias una torre lineu atla de piedra muy bien labrada, y estalua llema de yololos, é allí homralan é coelebraban á su dios de la pesqueria; é por apuedla iome teniam muchas eabeças de grandes pescados secals, colgadas. Mas cómo á los chripstianos no les placen acpuellas ydolatrias, echaron todos atpuellos yolobos á la mar, é pusieron una cruz ençima de la torre ; é luegro el caçirge dixo que queria ser chripstiano, é fué laptiçado, é pidió que le llamassen Alonso Dívila, como al teniente, y él fué su padrino. É assimesmo se baptiçaron otros indios prinçipales.

Feetra relaçion al adelantádo, que estaba en Clucialango, fuć muy espantado y goçóse en extremo, como cra raçon, de saber de su teniente é de los demás, que con él avian aportado á Champoton, porque los tenian á todos por muertos. É luego se puso en camino é vino á verlos en canoas con toda su grente: en las quales vistas los unos é los otros tomaron tanto placer é alegria quanto se puede considerar mejor que escribirse, é comunicaron e platicaban continuamente, recontando sus Irabaxosos subçessos, dando por todo infinitas gracias á Dios.

\section{Capitulo VI.}

Cómo el adelantado don Franęiseo de Montejo fué ả poblar al pueblo de Láęaro, que los indios llaman Campeche, é fundó una villa que se llamó Salamanea "; é del mal subẹesso de los españoles en esta jornada, é de muchos tranẹcs que se siguieron en ella.

\section{)} se juntaron, como la historia lo ha dicho, é reposaron algunos dias en Champoton, acordaron de yr á laçer su asiento en

- Aqui suprimió el autor lo siguiente : «E cómo desde alli envió á su teniente, Alonso Dávila, á Chitemal, por eastigar aquel Gonẹalo, marinero, renegado, que estaba heeho indio; é de las eosas que en esle viage acontesçieron, é de la mucha miel que lialliaron é muehos eoimenares della de abrjas otra parte, trece leguas adelante en la mesma costa, en el pueblo de Láçaro, que en la lengua de losindios se llama Campeele. É alli liçicron su assiento: é no es

blaneas é la çera negra a la miel muy buena, como la de Castilla; é fué fundada una poblaçion de chripstianos, que se llamó Cibdad Real; é cómo los de la provincia de Coehua mataron eiertos españoles, qual eapitan Alonso Dávila enviaba al adelantado; é cómo fur it eastigar á los malheehores, rte.n 
menor pucblo que Champoton, é tiene otro fal edefiçio en la mar, como el que se dixo de susso, é assi dedicado á la pesqueria. Allí fundó el adelantado una villa, é llamóla Salamanca, é para lan poca venlura é permanençia como las otras Salamaneas, que primero se fundaron, de que se lıa hecho mencion en los capítulos precedentes. É fecho apuel puelılo, descle á dos ó tres meses vinieron allí algunos navios é gente assimesmo de mas españoles por ticlara desde México, é llevaron cahallos é otras cosas para la nueva república : é á calso de este tiempo envió el adelantado á su teniente Alonso Dávila á la provinçia é pueblos de Chitemal, donde estaba aquel mal clrripstiano Gonegalo, marinero, hechı indio; ć llevó consigo hasta sessenta é çinco hombres é quinçe caballos. É poniendo en efetto su camino esla gente, passaron por una provinçia que se dice Tutuxio, que ticne de jurisdiçion treynta leguas mny pobladas: é mas adelante llegaron á otra provinçia, que se llaina Cochua, no menor que la primera, porque en las dos avia de longitud septenta leguas ó más. É destle allí fueron diez legnas adclante á la provinçia de Guaymill, é aposentáronse en un pueblo desta provinçia diclıo Maçanaho, en que hay hasta tres mill casas ó quassi : é despues que allí ovieron descansado veynte (lias, procedieron su camino en demanda de Clitemal. Y los de Maçanaho é otro puchlo no menor quél, que se llama Yiınpeten, quisieron los hombres prinçipales dellos acompañar á los chrijstianos lasta Clitemal.

Al calso de la provinçia de Guaymill, para chtrar en la de Chitemal, hay una laguna de doçe leguas de longitud, que alravesaron en canoas, que los indios les dieron, é passaron los caballos en la manera nuevamente usada, que la historia hal dicho: las quales dieron los indios de Baralal, rues á la orilla de aquella laquma.
É aqueste pueblo provee de canoas á todos los indios de aquella comarea por sus fletes, de que viven; pero á los españoles sirvićronlos con el passage fianco é de graçia. É assi entraron en Chitemal é hallát’onlo despoblado é sin hallar qué comer: cl qual es pueblo de dos mill casas, á dos leguas de la costa de la mar é quassi cercado de agua, porque la costa está de la una parte é la laguna de la otra, é tiene una entrada por tierra de dos tiros de ballesta.

Alli hallaron mucha é muy buena miel é colmenares grandes de á mill é dos mill colmenas en troneos de árholes, bien fechos, con sus celadicros y entradas; y es grande esta grangeria é contractaçion allí de la miel, é no es menos buena que la de Castilla en color é sabor; pero la çera es negra, como açabache. Y es cosa.para notar la forma destas colmenas, porque cada una es tan luenga como el braço tendido de un liombre, ó tan gruessa ó mas que por la çintura, y está en tierra tendida é tiene los extremos atapados con una piedra de cada parte, é inuy bien embarrada. Por encima é orillas de aquellas piedras entıan é salen lasabejas por un agujero, que está en la mitad del vaso de la colmena, en la mas alta parte della; ć hráçiala una piedra, desde la mitad ó descle el dicho agujero, haçen su labor é panales é sus çeldas é vasillos muy bien ordenados: é de aquellos sale é se destila la miel é va á la ofra milad del vaso é cae en unas bolsas de çera, é aquellas se linchen della, é la otra cantidird mayor de la çera toda queda á la otra parte de la colmena. É quando quieren sacar la micl é castrar las colnenas ó qualquier dellas, desatapan el vaso por ayuella parte derecha háçia donde están las bolsas, y en pungíndolas, hacićndoles un agujero lan gruesso ó delgado, cono quisieren que salga el chorro de la nucl, assi ella por alli hage su curso, é viene mucho lindia é 
salmosia é limpia sin coral alowna tan purrificuda, como si la ovicissen colado por un

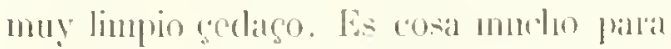

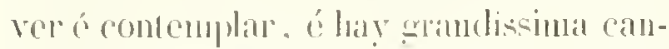
tidad e racto on arepuella lierra de acpuella miel. y esperialmonte alli.

Lals alyejas son en la forma é lamaño como las de Calstilla, excepto que en la color rotol rasson blancasé muỵ domésticas, porque ni huyen ni lagen nals á Lomando una ¿ mastrujúndola entre los dedos. hucle muy hien. El raso de la colinenla, como he dicho, es un troço ó pedaço de un árbol víquado de dentro, é dexíndlole entero como una caxa de un alambor, ć lan deloato, despues de labrado, como el dedo nienor de la mano. ó cono le quieren dexar, é por encima sin cortera é muy bien labralo, cutalladas lahores é follages de relicvo; é carla vaso é colmena liene esenpirda la señal é marea del señor, cuyo es el colmenar.

Ilay allí muy grandes a gentiles heredamientos de mameyes é de cacao. ques una firucla como almendras, é que corre por moneda, como mas largamente lo podrá ver el letor en el libro VIll, eapítulo XXX, é las casas mery proveydas de mucha cantidud deslas é otras fructas de bastimentos de la tierra.

Mandó el capilan, dando principio al castigno de arpel infiel marinero, é á la rebelion é alçamiento de los indios, quel español que algumd heredamiento destos ó colmenar hallasse, pue fucsse suyo é lo señalasse para si con una cruz.

Allí se fundó un pachlo é llamóse Cibdad Real, prorgue este capitan Alonso Dívila fué natural de Cibdad Real cn España.

Hay desde Chitemal á Campeche, donde quedaba el adelantado Nontejo, cient leguas de licrra, atravessando de costa á costa toda la provinçia de Tucatim: y costando en aquel assiento, acorló el capilan Alonson Dévila de yr la costa arrilua por- yue turo informaçion que tres leguas de allí estiba algado ol señol de Chitomal

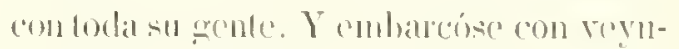

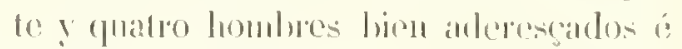

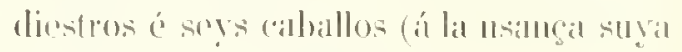
de las ramnas duplicarlas); co otro dia al quarto del alloa, ymanclo cesclanescia, dicron solpe los indios, sin ser sontidos, é mataron muchos dellos. éprondieron más de sessental personats, é perdioron me cathallo, que les malarnai de una lançada. Preguntamlo á los prososos pol apuol bre llaco mal chripstiano Gonçalo, mariticro, dixeron que rral muerto, é assi cral verdial.

Ilallíronse alli en este saltcamiento hasta mill pessos de oro lahrado, en diversas pieças é joyas que arfuclla gente nsan; é arpucste fué el primero oro que hasta estonces esios rhripustianos en toda la tierra avian tomado: é tambien se ovioron algunas plasmas de esmeraldas é turquesas é máscaras labradas de oro, é de tales pichras. É con esta pressa se tornaron a Chitemal, deste la qual el teniente Alonso Dávila envió aquel oro al gobernador Montejo con tres de á caballo é otros tres liombres á pié ballesteros: y en la provincia de Cochua, estando estos mensageros seguros é cenando una norhe, leg mataron los indios á todos seys é á los caballos, é les tomaron el oro é lo que llevahan: é assi esturo el teniente é los que los enviahan esperando la respuesta más de un año, sin saber el mal subcesso é muertes de los mensageros é del pressente. Pues cómo se les acaloó el mahiz ć otros bastimentos, y eran lan pocos los chripstianos, perdićronles el temor los indios, é començaron á darles guera, de tal manera, que constreñidos, comenȩaron dentro del pucblo, por su cxtremada nescessidad, á laçer sementeras con sus manos é sudores, con ayuda de algunos pocos indios, que ell sus casas mansos é domésiticos los servian. Fué tal 
la continuagion de la gucrai, que vinicron á se resmir estos poblarlores de la compañia del teniente Alonso Dávila en (puarenta hombres, 6 los diez dellos coros é mancos é inútiles, y en quatro caballos é mua yegua.

Llegados á esla nescessidad, é desseando Alonso Dávila saluer de sus mensageros, fuć con veynte y quatro compañeros é tres caballos, é tornó á passar aquella laguna, que aremos dicho, ć dexó los españoles otros en Chitenal. Entrando por Guaymill, fué resçebido de paz, ć alli supo que sus mensageros avian seydo muertos por los indios de Cochua : é assimesmo le informaron que á Montejo le arian dado guerra, é que le avian muerto parte de los cluipstianos, é quél se aria ydo á México, é que toda la lierra estaba algada; é assi cra la rerdad. É non obstante estas malas nuevas, se determinó el capitan Alonso Dávila de yr á castigar los indios de Cochua, é pidió para ello el favor é ayuda de los indios de Guaymill. y ellos lo respondieron que de muy buena voluntad se la clarian : ć assi fucron con los españoles hasta seyscientos amigos, é no quiso mas llevar, por la grand calor 6 aver poca agua en el camino.

Llegados á un quarto de legua del primero pucblo de Cocluna, estaban detrís de una allarmata muchos indios de suerra en celada, aparlados del camino un liro de flecha, tendidos en lierra: é cómo passaron los chripstianos adelante é los tuvieron enmedio, huycron los indios amigos, é dexaron las cargas é la compañia, é volvieron las espaldas. E se comencó la batalla, en que aria de los enemigos imnumerable gente: é cómo estaban entre anboledas, no se podian servir de los caballos: y los españoles yban cansados é muel'os de sed, demás de ser pocos en número, é avian lallado cegrados los poros, de que avian de beber, fure los desanimó mucho. Pero como la nescessi- dad suele muchas veces despertar los flacos é avivar los ánimos en los nuayores peligros, assi estoś nuestros españoles conosçieron que otro socorro no les quedaba ni le alendian sino el çelestial y el de sus proprias viritudes é manos, mostróse lo uno é lo ofro en esta jormada; porque cl capitan Alonso Dávila, viéndose en esla clansura y estrecho, arrenctió á pié é la albarrada, é con él don Alonso de Luxan, é con puñales largos de medias espadas (seyendo muy contrastados) á los enenigos cortaron un palo del palenque y las ataduras de los bexucos con que estaba trabado, é peleando como valerosos mílites, passaron adlelante. É por allí siguicron los de la compañia muy denoditdaniente, é les ganaron el albarrada, non obstante que les hirieron tres españoles. que despues murieron, é matáronles un caballo, é otros tres hombres se ahogararon de sed; y quedó la vitoria por los chripstianos cansados, é luycron sus enemígos, sin poder ser seguidos. Turó esti batalla un quarto de hora, é los vencedores, aviendo muerto assaz de los contrarios, passaron adclante á un lugar que liallaron quemado, é um pogo que allí avia halláronle gegado: é cómo no se pudo hacer otra cosa ni avia dia para mas camiuar, pararou allí é pusieron el mejor recabdo que pudieron en relarse ? é los que no velalıan, daban óden en limpiar el poço, que tenia siete ú ocho estados de hondo, é para le limpiar (que aunque del todo no estaba çicgo, estábalo el agua) metieron dos muchachos indios con los cabestros de los caballos, é con los çaragitclles, añidiendo como mejor podian, hiçieron sogas con que los baxaron, 6 con calabagas é arañando sacaron parte de cieno, é despues alguna agua tan buena, que no bebieron nenos tierra é loclo que ağla. E assi passaron arpuella nocho Lasta el signiente dia, que encomendímdose á bios. procediendo en su camino, 


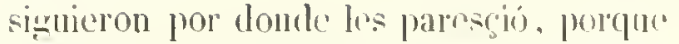
paral volver allís no cra ya tiempo, é los amigos de Guaymill. viendo sus pocats fucreas é poco número destos españoles. so alian converticlo on enemigos, is les tenian aparejada otra alliarrata ó celadal, é no estaban de propóssito de los acogere.

\section{CAPITULO VII.}

Lin que se traeta eúmo el teniente Alonso Dávila é sus eompañeros ovicron otro reeuentro è batalla con lus indios del pueblo de Cochua, que avian muerto los ehripstianos que llevalon el pressente del oro al adeIantado; é eónı los españoles fueron maltraetados en este feeho de armas ", é otras partieularidades notables que passaron estos militantes é trabaxados varones, hasta que tomaron el pueblo de Chitemal.

$\mathbf{L}_{\mathrm{a}}$ persona y esfuergo y vigilançia y buen atendimiento y gentil conversaçion, quel teniente Alonso Dávila turo. acompañada de una natural virlud, sin repelo ni altivez, é con una lileraliclad muy çierta de quanto él tenia para lo commicar é dar á sus amigos é á quantos con él andaban é le tractaban, fueron causas é partes para ser, como fué, muy lien quisto, é aun para que si ćl tuviera ventura de ser conosçido de un prínçipe poderoso, no pudiera dexar de hacerle grand senor. Viéndose este capitan en la fatiga é trabaxos quel precedente capítulo nos manifiesta , é teniendo muy espeçial cuydado de la salud é salvaçion de sus compañeros, como de sumesma é propria vida (pero siguiendo su viage), el segundo dia (pue escaparon de la hatalla que se diro de susso, é dos legruas adelante, hallaron otra allsarrada con muchos indios de guerra puestos en armas. los quales eran te aquel puchlo, donde a vian muerto los seys chripstianos, é tomádoles el oro, como es dicho. É como sabian que los españoles yban contra ellos, estaban aperçebidosé barrearlos con dos muros de madera é arboledas é muy fortificados: non olsstante lo qual se tentó la batalla por todas estas causas, puesto que con mucha desaren-

* Aqui se lee en el códice original, aunque bor. rado de manos del aulor, á lo que pareee: «É de los muelios trabasos, que en suma passitron é énu taja: lo uno, porque de nesçessidad los nuestros avian de ser acometidos, si ellos no acomelicran; lo segundo, porque no tenian ni podian seguir otro camino sino apucl que los enemigos les tenian ocmpado; é lo terçero, porque de nescessidad avian de buscar de comer, é no lo tenian, ni allí se lo avian de dar.

En fin, venidos á las manos, la batalla fué con muerte de muchos indios é con daño de los chripstianos: en lo qual heridos los mas ó quassi todos, se retiraron á fuera, quando vieron tiempo para ello, é fueron á haçer noche á un pucblo pequeño de diez casas. que estalıa al través del camino, donde los grió un indio, que solo les avia quedado de los de Guaymill. que les dió la vida; porque todos cstaban heridos, é los caballos assimesmo é muy cansados, exçepto el capitan Alonso Dávila, que no fué herido, porque le quiso Dios gnardar para que curasscé sirviesse á todos, cono lo haçia y muy bien, puesto que era el primero en los peligros y el que mas trabaxaba con el espíritu é con su persona. Antes del dia dos horas, començaron á caminar desde aquel pucblo, porque les paresció, y aun assi fuera, que si alli esperáran el sol, ningulno quedára con la vida: porque despues,

todos ereyeron que por la misericordia de Dios fue enviado en su ayuda el a püslol Sancliago, por cugu aviso escaparon.» 
en esclaresçiendo, llegó allí mucha gente de guerra de arpuellos con quien avian pe. leado, é de otros que de refresco con ellos se avian juntado, que yban sobre cllos é pensaban hallarlos alli durmiendo.

Sigurendo su honesta fuga, dixo Mlonso Dávila á aquel indio que les avia quedado de Guaymill, quél le haria grand señov en aquella tierra, si le guiaba á él é á los otros chripstianos, al cmbarcadero de Chitemal, donde avian quedado sus canoas, y los llevasse por otro camino; y el indio le dixo que assi lo haria. E afucl dia, aviendo andado tres leguas, los apartó del camino de Guaymill é los lleró por otro, aunque asperíssimo; é á medio dia llegaron á un pucblo, que no liçieron sino reposar en él media hora, é comicron algunas maçorcas de maliz verde, é passaron una laguna de dos tiros de ballesta á vado, y en partes á vuelapié, con larto peligro: que no parescia sino que como salsa, para comporla: el manjar de las faliggas passadas, se les ofresçian otras mas ágrias, para que las primeras tuviessen por livianas fatigas, seyendo carla una dellas quassi incomportables y extremadas.

Passados de la otra parte desta agua, avia un plaçel de otra lanta distançia, que ahondaban por él los caballos quassi haslil las cinchas: é salidos de allí entraron por un arcaluco ó boscage de arboledas é matas muy cerrado, y el capitan Alonso Dávila yha en la delantera con un machete ó puñal rizcayno, haçiendo el camino para todos: que no avia otro homlre sano. La retroguardia llevaba don Alonso de Luxan, y en los caballos no yluan sino aquellos que mas fallos de salud ó mas Lieridos estaban. Entrada la delantera desta gente nuestra por el arcabuco, ya muchos de los enemigos comencabau á passar fuera de la laguna tras los chripstianos con grande grila: é dieron al arma, é detírose el capilan que llevalua la delantera, como es dicho, é volvieron conT0MO III. tra los enemigos solos quatro 0 çinco españoles á detencrles el passo, los quales. como es diclıo, salian ya algunos de la laguma, grilando, al plaçel ques dicho. Lstonçes don Alonso de Luxan. que gha en la reçaga, liço apear de su caballo á uno de los heridos que (oll él yba, é cabalgó é dió la vuclta sobre los contrarios por aquel plaçel, ó mejor diçiendo pantano $o ́$ atolladero, que primero avian passado calıondando: é como començó á ballir las piernas con las espuelas, paresçió que yba corriendo, como si fucra por muy licsto á buen terreno, é haçiendo rostro á los enemigos no osaron atender, é se tornaron al agua é á rolver por donde reniam, Io qual notoriamente paresçió cosa miraglosa. É ya en esso se ponia el sol, (quando tornaron los nucstros á entrar por el arcabuco; $e ́$ visto que no paresçian indios. caminarou adelante. $\mathrm{Y}$ el camino estilsil tal de algun huracan, é tantos ć tan glandes árboles caydos é arrincados é alravosados é nuezclarlos unos con olros, qu" para andar un poco de distançia es tan grandíssimo trabaxo y estorbo, como de vuestro espaçio, señor letor, lo porlreys entender en el libro VI, ciúfítulo $\mathbf{~ I I , ~ p o r - ~}$ que aqui no se interrompa la listoria, dando á entender qué cosa son los lıuracanes. Assi que, volviendo á la jornada, á media noche llegaron á un pueblo de diez casas, donde les fuć harto consucolo liallar un poco de maliz, segund ybin nescessitarlos, cansados é muertos de hambre é sed; é allí se apossentaron, para reposar lasia quel dia viniesse. É lucgo otro dia, prosiguiendo en su camino tres jornadas, no les faltaba micl, por la abundançia que della lay en aquellas partes, de la qual se servian para su sustenlacion á vuellas de otros manjares é anargos sinsabores, é tambien para curar sus llagas: (que lampoco les faltahan.

Estanto ma noche Alonso Dávila pro. gumbando á arpuel indio ó lengrua que r puó 
Lanto estaban de pollado, dixo yue otro dia temprano llegarian al pueblo de Masanahao, desde el qual á la laguna lay dos leguas, donde avian dexidlo las canoas; pero que creia que avian de hallar resistençia, la qual nueva pronosticaçion ó sospecha puso en mucho cuydado á los españoles, porque yban todos heridos é cansados é flacos, é tenian mas nescessillar ile reposar é curar siss llaggas que de tomar otras.

Luego el capitan, como calhólico, les dixo: "Señores, ya aveys oydo lo que este indio diçe, é por lo que aveys experimentado hasta aqui, podemos arbitrar en lo porvenir, aunque no derechamente, Io que ha de ser alcançado; porque Dios solo es el que sabe perfeltamente el fin que todas las cosas han de lener. Pero á lo que la humana flaque. ça puede sentir notoriamente por nuestro cansançio y poco número, y por la multilud desla gente bírbara, y porque veen que aborresçemos sus ritos 'é ydolatrias é les quebramos y rompemos y derribamos sus ydolos, y condenamos y despreciamos las costumbres é manera de vivir, $\mathrm{y}$ en fin nos queremos haçer señores $y$ a ellos esclavos ó súbditos nuestros en su patria, en donde nasçieron con libertad; claramente está conosçido nuest ro peligro, é quán aborresçidos nos tienen estos indios, é quín aparejada tenemos la muer. te, si Dios con su poder absoluto no nos socorre. Y ya las cosas no están en salvarnos por nuestro esfuerço é virliosos ánimos, sino que ha de ser por misterio é quererlo Dios, al qual me encomiendo y os encomiendo, y os pido por merçed que en Jhesu Chripsto, Nuestro Salvador, y en su preciosa Madre pongays toda vuestra esperança, é que muy devolamente le supliqueys que sea su voluntad de llevarnos en salvamento al assiento de Chitemal; é que si de otra cosa es llios más servido, que aquello se laga, é que itcilbenos csta miserahle vila, como cathólicos. lu luogo haced vuestrat oraçion con la intençion que los huenos cluripstiatnos delıen ocurrir en sus nescessidades á su Dios, é vereys cómo soys socorridos é ayudados en vuestra triluulaçion. ”

Estas é otras palaluras devolas dixo este capilan, de manera que ningun religioso pudiera con mas graçia y efutto atraer aquella fatigada compañia á orar con tanto cuydado, encomendándose á Dios atentissimamente. Yassi paresció que sus sospiros y plegarias Ilegaron á Ia Divina Magestad; porque estando todos en mucho silençio, desde á pocas lıoras entró un soldado en su real dando voces, el qual estaba en la guarda puesto en el camino en vela, é lueggo los españoles se pusieron en armas, creyendo que aquella vela avia visto ó sentido los enemigos. E como llegó, preguntáronle que qué avia visto, é dixo assi: "Estando yo velando algo desviado al un lado del camino, lle. gó á mí un cavallero acompañado cọı otros seys ó siete cavalleros, é dixo:-No duermas; despierta, é vete é dí al capitan Alonso Dávila é á los chripstianos que vayan su camino é no teman, é quél venia assi á se lo deçir. $\mathrm{Y}$ en el mesmo tiempo que la vela deçia lo ques dicho, se sinlió una sancta fragançia é suavidad de un olor divino que paresçió que los avia alen. tado é confortado, é improviso fecho tan fuertes é sanos que ningun temor les quedó, é á muchos dellos, de goço, les saltaban las lágrimas, é deçian á una voz é de un crédito: "Sanctiago glorioso, nuestro patron de España, es este socorro que Dios por su miscricordia con su Apóstol. nos enviá. "É luego començaron á caminar, é bien paresçió ser miraglo; porque entre todos los españoles no yluan sino tres caballos, é la vela deçia que avia visto seys ó siete con aquel cavallero, ques dicho que le labló.

Como quiso amanesçer, llegaron á un 
pueblo, en que avia muchos indios, é no despertaron, é passaron por él sin haçer mal á ninguno ni ser sentidos: é de alli passados, llegaron adelante á las diez del dia al puchlo de Maçanahao. Y entrados en él hallaron que los indios estaban fuera en el campo, esperando en otro camino a los chripstianos para les dar la batalla, é no avian quedado en el pueblo sino las mugeres y los niños y con hartos bastimentos: é dieron notiçia á los indios de los huéspedes que les avian venido, é luego se recogieron mucha gente dellos, ¿ por la clemençia de Dios vinicron de jaz é nuy trocado su mal propóssito. Proveyeron luego de bastimentos é dieron canoas ál los españoles, en que se fuessen: que eran las mesmas de los chripstianos, que ya entre sí las tenian repartidas, pen- sando que todos eran muertos. Y estaban los indios alónitos espantarlos de vér cómo avian venido lasta allí , é mirábanlos, teniendo por maravilla é imposible cosa eslar allí, aunque los veian.

Eubarcados en sus canoas, Hegaron a su assiento de Clitemal, donde avian quedado un caballo é una yegua é lič y ocho 0 veynte españoles, los mas dellos cojos é mancos y enfermos, é hallíronlos vivos: que no fué međiocre, sino extremarlo é grandíssimo el goço de los unos é de los otros. É luego tuvieron novenas en la iglesia el teniente Alonso Dávila é los que con él volvieron, dando graçias á Nuestro Señor, porque assi lo avia fecho con ellos: é delos que assi tornaron, murió un español que venia mal herido, é todos los demás sanaron.

\section{CAPITULO VIII.}

Cúmo el capitan Alonso Dávila é los españoles que eon él estabah, desảmpararon d despohlaron aquella villa é assiento que avian fecho en Chitemal, é se fueron en eanoas duplicadas por poder llevar los cabaIlos de la forma é usanẹa nuevamente é por ellos inventada, é de los trabaxos extremados é trançes que les acaesẹieron *, eon que se da fin á esta relaẹion del comendador don Alonso de Luxan.

M e personas valerosas, que militaron en compañia del capitan Alonso Dávila, assi porque el galardon que sus haçañas ć proeças consiguieron fué morir al fin $\sin$ galardon ni premio de sus serviçios, demás de que la eterna vida se dá á cada uno, segund sus méritos; porque quisiera yo que pues en esta vida lan poco ó ningun deseanso tuvieron, que á lo menos sus deudos mas propínquos no quedáran sin algun premio para poder haçer algun bien por sus ámimas: lo qual la misericorliosa Iglesia cathólica liene bien proveydo con la comun é goneral é contínua oraçion é sacrifiçios, que por todos los fie-

* Tambien en csta parle se hallan borradas alsunas eláusulas, referentes i la historia, pero de po- les cada dia çelebra la sagrada Iglesia mililante en todos sus templos de los clurijistianos é fuera dellos. Y demás deste sancto socorro para la memoria de tan memorables mílites, ovieran menester sus meresçimientos é loables personas otra pluma mas á su propóssito que la mia, y que fuera tan hastante en su alabanģa é fama que para siempre quedasse puesta é fixada en el acuerdo de los vivos é de los que están por nascer. Resçiban mi volıntad todos essos vivos é defuntos, que jol estos trances ya dichos é por los que aggora diré passaron, é a vuelias de sus ilıfortunios é miserias, cuenten con ellas mi poca habilidad, si no he satisfecho al col- 


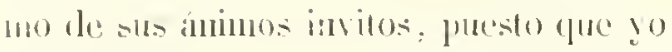
ne le colorgato de contar la rerdad llaHatmentl?

I contiunámdola, diggo, que viendo que calla dia cran menos las fuerças é companiia de Alonso Dálvila, é que por la mar en canoas é por la tierra los indios les haçian guerra, acordaron los clıripslianos (que era nescessario é aun forcoso dexar apuella tierra : é tomaron treynta é los canoas, é prareáronlas de dos en dos, muy bien liabadas é ligadas, é liçieron diez y seys yuntas, para poder llevar los calııllos é la gente de aquella sı forma é artifiçio, que la historia en algunos passos lo la contado: é quitaron las cruces, é deshicieron la iglesia, é despoblaron aquel pucblo, y embarcíronse para yr, como fueron, la via de la gobernaçion de Ilonduras.

En el punto que los indios ovieron sentimiento de su liuga, se apellidaron é dieron mandado á las comarcas, ć de muclias partes é con muchos fiuegos se llamaban de unos puelslos á otros, para que á toda diligençia armassen é fuessen tras los chripstianos, los quales, como la cos. ta $n o$ se podia caminar por tierra, tomaron por mejor partido yrse en aquellas canoas de la manera questá dicho. É començando su viage, salieron muchas canoas tras los esprañoles, é los siguieron un dia hasta la noche.

Ls un gentil notalle é cosa nunca oyda colra parte ni vista semejante dispusicion de costa porque toda es anegada de la mar en mucho espacio, é por esso no se puede caminar por lierra : é demés desso desle que partieron por la mañana ron el terral navegaluan engolphándose lasta perder yuassi de vista la tierra, é despnes de medio dia : quando tomaba la viracon $o$ marea, volvian a la costa. devaban sus velas en árboles ó mástel priesto sobre aquel borele. en que ambas canoas pareadas yban abrarjolas ó juntas a mancia de trévedes. porque quassi al pić de carla místel yha de camla partr lisaillo otro palo ó pié, y a mo se fixalya en la una camoa, y el otro en la otra, para y pucl mástel derecho é rescio estoviesse.

Llevilan indios pressos é con cormis, que logạahan quando era menester, é sabian la costa; é á liora de vísperas, é algunas veçes çerca de la nochı, llegahan á la tierra, aviendo andado ó ganado seys o siete leguas. I era cosa para maravillar que justamente poco antes.quel sol se jusiesse, hallahan un rio ó estero con un poco de arenal é playa cerea de la boca, donde sacaban los cabállos é lä gente, dexando en las canoas guarda, é descansaban allí en aquella estreclicra, que era tanta é tan medida, que si mas número de chripstianos é compaña fueran, no tuvieran lugar. Alli comian del mahiz que llevaban ellos é sus caballos, que era hien poco, é pescaban con redes que tenian, las quales entre dia navegando, haçan de calouýa y henequen: é aqueste era su exerciçio, porque sin las dichas redes no porlian vivir ni sostenerse. En carla dia las perdian ó parte dellas, é les convenia no cessar de tal labor, á causa que los pescados, que llamamos espadartes, hay muchos en aquella costa, y estos se las rompian ó llevaban muchas veçes. El dia siguiente volvian á navegar, y al fin dél luáçia la noclıe les daba Dios otro rio, donle repossassen é sacassen sus caballos é la gente é descansassen; é desta manera fueron por la mar más de dosçientas leguas, que hay hasta llonduras.

Es de saber que para se proveer de mahiz, quando se les acabaha é de algunos indios para el remo, porque algrumos se les escapaban é lunian de la compañia é se yluan á nado por no logar, tenian esta forma: que desataban algmas canoas, é los clurjestianos, que mas resçios gara trabaxar se tallaban, entraban en cllas a yban por aquellos rios arriba (por- 
que por las corrientes, estando juntos, no podian yr duplicadas); y entrados la ticrl’a adentro, salteaban en las costas de los rios (ó çerca dellos) algunos pucblos, é lomaban algunos indios é baslimentos, é de lo que llevaban. Lin tanto los que quedaban en el real en la costa, cortaban palmas é bexucos para reparar las faltas é renovarlas de calafateria é atarlas, religrándolas con nuevas cuerdas de bexucos é sogas de damalıagua, é corteças de tal árlool, que haçian porque las primeras vhan roçadas é maltractadas, é avia nescessidad de nueva ligacon, para las tornar á unir é atar en la continuaçion de su viage trabaxoso.

Siguióse que en una deslas entradas, questos fatigados españoles hiçieron por los rios, buscando de comer, fueron una vez seys canoas con algunos dellos para saltcar un pueblo: é quando á par dél llegaron; lloviendo muy resçiamente, hallaron que la barranca estaba mas de una lança de armas mas alta quel rio; é no pudiendo entrar en tierra al pucblo, llegó súbitamente la cresciente del rio, é tan grande, que no solamente emparejó con la tierra é barrancas altas, mas entró en el puello, donde se pensaron perder, é los indios de aquel lugar avian ya huydo la tierra adentro. Estando en esta nesçessidad, se siguió otra no menor, é fué que la cresçiente les llevó todas las canoas, é los cluripstianos se subieron por árboles para guarescerse, como mejor pudieron. E don Mlonso de Luxan, que avia salido en eśa compañia, latló por allí una pequeita canoa en quél solo é un muchacho indio se metieron, para volver al real, donde en la costa de la mar é boca del mesno rio estaba la otra gente, para que en il zunas canoas otras de las que allí tenian, volviessen á buscar las quel agua les llevó, é recogiessen los ol'os españoles que en ellas avian ydo. E haxando por el rio, se le trastoruó aquella pequcña vasijaóca- noa, é assido por una parte della, y el muchacho indio assimesmo, salieron al real, aviendo ydo desta mancra por aquella impetuosa corriente seys ó siete leguas: no faltando muchos lagartos ó cocatriçes en aquella ribera y en todas las de la costa, ques lo que laçe mayor el miraglo, é que se conozca que lo permitió Dios, é quiso guardar este cavallero por la salvaçion suya é de todos los demás. É llegado don Alonso donde fué socorrido, que ya la corriente lo llevaba á entrar en la mar, assi como fué recogido é reposó pocas horas, volvieron con él diez canoas é cargáronlas de maliz, é fésoles, é axes, é miel é de lo que hallaron en aquel pueblo, é recogricron sus canoas con harto trabaxo (porque como baxó el rio é volvió á su curso ordinario, avia puesto algumas en tierra é algunas ençima de los árboles); é recogidos á su real, continuaron su camino é navegaçion.

Cómo en aquella costa es grande la contractacion de aquella fructa cacao, que corre por moneda entre los indios, é les es muy útil é preçiosa é la mas rica y estimada mercaderia que tienen, van las canoas de Yucalan cargadas de ropa é otras mercaderias á Ulua, é de allí las vuelven cargadas de cacao; destas topahan muchas dellas, é los indios atendian, por no perder su mercaderia, y estotios clripstianos tomálbanles sus canoas, que eran mejores é mas sanas, é dáluanles las quellos traian, é passaban adtante.

Con esta trabaxada navegaçion, Ileg:iron á un embocamiento, que Ilaman Golpho Dulse, el qual es la boca de un poderoso rio; y era tanta la corriente, que los metió tanto adentro en la mar, que perdicron quassi de vista la lierra, é aun algunos la esperanca de morir en ellit, é se pensáron anegar lodos, é las canoas laçian ya mucha agua. En fin, yuiso Dios ayudarlos, é volvieron á una prnta, é allí hallarou buena la costa é ancha, é lm 
rio de dos legruas anclo, que se diçe el rio de la Lla : é atravesaron á la otra parrte, é laallaron muy huena é graçiosa ia tierra, é saltaron alli át descansar. F́ sobrevínoles tan grande viento del Norte, que les llevó las canoas todas é las perdieron, estando una noche en tierra la gente, é las canoas surtas con sus botalas, por falta de resones ó áncoras, é los tristes indios que en cormas estaban dentro dellas, como no pudieron nadar, se alıgaron todos. Otro dia por la costa caminó esta compañia con sus tres caballos é una yegua, en que llevaban los mas enfermos, é llegaron á puerto de Caballos, donde se les murió uno de los tres ques dicho, é porque la grente no lo comiesse, le hiço el capitan Alonso Dávila echar en la mar con una pessa; porque no fuesse achaque, si la grente le comiesse, que matassen los otros que les quebaban, si aquel les supiera bien: el qual sin dubda no les amargára, seģund su hambre é nesçessidad.

Tardaron desde Chitenal liasta puerto de Caballos siete meses, poco mas ó menos tiempo, cou la manera de vida que la historia ha dicho, ques á mi juicio una de las mas irabaxosas navegaçiones que nunca hombres han passado en estas partes ni en otras. Allí supieron é conosçieron ćl donde estaban, lo qual nunca avian $\mathrm{cn-}$ tendido en todo su viage.

Passados del puerto de Caballos quatro leguas, llegaron al rio de Ulua, que de mna parte é otra treynta leguas ambas sus costas va poblado todo de luertas de cacao (ques riquíssima cosa), é de inumerables indios aveçindados á harrios çercanos unos dle otros en la boca deste rio. En la costa de la mar hallaron una canoa grande empalagada, Ilena de arena que la mar dehiera aver"allí trayclo, é limpiáronla é hiçieron remos é subieron en ella reynte é quatro liombres por el rio arriba, dexando á la costa los enfermos é los caballos: é andadas tres leguas, queriendo saltar en tierra, les fué resistido jor nuuchos indios llecheros; é cómo los cliripstianos yban llacos é no tenian yaa armas de las suyas, que se les avian acabado é gastado, tenian issimesino arcos é pocas lleclas, é retiráronse por la nuucla moltitud de los indios contrarios, é volvieron atrás. É viniendo el rio ahaxo, cerca ya del real, laallaron un pueblo viejo con muclios maneyes, é cargaron lis canoa dellos é de cuescos dellos, que lállaban por tierra los cuescos. Y este luastimento llevarou para haçer maçamorras de los cuescos, é tambien la canoa por la costa para passar los rios que topassen, é la gente yha por tierra costa á costa: é assi llegaron hasta Honduras, que está trejnta leguas de aquel rio. $\dot{E}$ con esta comida é cangrejos, que no faltan por aquella costa, llegaron á Hlonduras, la qual gobernaçion en essa saçon administraba el contador Andrés de Cereçeda, por muerte del gobernador Diegro Allbitez: el qual Cereçeda, cómo supo la yda del capitan Alonso Dávila é los españoles, les hico proveer luego de bastimentos con to. da diligençia, bien quinçe leguas antes que llegassen, é llególes á tiempo este refresco que lo avian hien menester.

Allí en Honduras descansaron quinçe ó veynte dias, seyendo bien tractados del vice-gobernador é de los otros españoles, en el qual tiempo llegó una caravela de la Ilahana, en que se metió Alonso Dávila con los que le quisieron seguir, é algunos se quedaron allí, y él se fué á Campeclıe, donde estaba el adelantado Montejo; é quando se vieron, quedaron todos espantados, porque tenian por nuterto á Alonso Dávila é quantos con él avian ydo é lialládose en los trabaxos, que la liistoríi lia dicho.

Desde á pocos dias despues que Alonso Dávila llegó, subcedieron lan grandes nuevas del P'crú é riqueças de la mar Aus- 
tral, donde andahan los capitanes Françisco Piçarro é Diego de Almagro, que toda ó la mayor parte de la gente, quel arlelantado Montejo tenia, se le fué allá: é por no quedar solo é perderse allí, le fué forçado volverse á México, como lo hiço, donde desde á poco tiempo murió el capitan Alonso Dávila, del qual sin ofensa de nadie se puede tener é loar por uno de los valientes hidalgos é de los mas expertos é hábiles capitanes, que en estas partes é indias han militado.

Despues de lo ques dicho, informados Sus Magestades por parte ile Montejo, assi de las cosas que la história en suma ha referido, como de otras, é del estado en que estaba aquella gobernaçion de Yucatan, mandáronla juntar con la de Honduras: é proveyéronle de lo uno é de lo otro, é él volvió á la tierra é subçedió adelante el conçierto é truecos, que la historia di- xo en el I capítulo deste libro XXXII.

Y cl adelantado Alvarado se fué con su armada "por Ia maŕ del Sur, como lo cuenta cI libro XXXI, capítulo XI. É cómo los liempos é navegaçiones no subçedieron â su propóssito, la gente de la mar se salió de la armada é se fueron todos á Niéxico. Estaba allí el adelantado Montejo, que avia ydo á que le entregassen á Suchimilco, conforme al assiento que se avia dado entre él é Alvarado, el qual no se la quiso dar ni entregar. É litigando los dos sobre ello, recogió el Montejo mucha parte de aquella gente, é los que más pudo de otras, é volvióse á pohlar su gohernaçion en la tierra de Yucatan, ques muy buena é fértil é provechosa, donde al pressente reside, que estamos ya en el año de mill é quinientos é quarenta y dosaños de la Natividad de Jhesu Chripsto, Nuestro Reclemptor. 
Fiste es el libro déçimo quarto de la segunda parte, y es el trigéssimo terçio de la lieneral y Natural IIstoria de las Indias, islas y Tierra-Firme del mar Ogéano: el qual tracta de la provinģia e gobernaçion é conquista é pollaçion de la Nueva España, por el capitan Gonçalo Fernandez de Oviedo y Valdés, capitan de la fortaleca de Sancto Domingo y coronista del Emperador y Rey, nuestro señor.

\section{PROHEMIO.}

Y

o sé cierto que digo verdad en lo que escribo, y confiesso que en las cosas, en que no he seydo pressente, podrian averme cngañado los que me dieron relaçion dellas. Y sé que en estas historias se hallarám particulares materias, que contenten á unos y enojen á otros; y para que yo quede sin cargo y se deba creer que interesse ni passion no movió mi pluma á hablar en perjuiçio de nadic, háse de acordar el que lec (si mis palabras no le satisfacen) (que es general delicto reprehender los hombres unos á otros. Y por esto no me fallarín á mí murmuradores, menos que faltaron á los escriptores antiguos, y mas

1 Calumnia conturbal sapinntes el aufert robur cordis illius. (Lib. Sapient.) dotos; porque á estas partes han passado muchas diverssidades de hombres y lenguas, é por la mayor parte mas coludiciosos que continentes, é mas idiotas que sabios, é mas cuvidiosos que comedidos, mas personas de baxa sangre que hidalgos é ilustres. É quiero mas quedar abonado con uno de los virtuosos, diçiendo verdad, que contentar á todos los que no lo son, mintiendo '; quanto mas que á muchos de los exçelentes varones, que han escripto, no les faltaron acusaçiones, é pala el remedio dessas está escriplo: En ninguna manera contradigas la palabra verdadera $^{2}$. Aristóteles diçe que la verdad

2 Non contradicas verbo verilatis utho modo. (Eeless., eap. 1V, rers. 30.) 
se ha de preferir á la amistad.' Y por tanto delseys, letor', tener memoria que no lie seydo tan falto della, que en treyula é quatro años que ha que estoy en estas partes puediı aver entendido de un solo hombre (sino de muchos) lo que yo no oviere visto en las cosas que son notables $y$ de calidad, que requicren informaçion de bastantes testigos, para que no se sospeche que no he dado tolal crédito al laslimado ó afiçionado, ni le ąré quitado á los que deben sel creydos.

Esto, como he dicho, se ha de entender en aquello que pressencialmente no testificare; porque en lo ilemás yo quicro que me culpen, si me apartare de la retilud que debe aver en tan peregrinas y cxcelentes y nuevas listorias, como son aquestas, de quien tracto. Y si quisicre tener atencion el que me pensare reprehender, en las mesmas palahras é discurso que llevan, se conosçerá mi desseo; porque como dice el filósopho: Las palabras dản señal de lo que está en la voluntad 2 .

No consienta Dios que yo digga cosa que me dexe escrúpulo ni peceado por mi parte; ni tengo fin á ofender á ninguno, ni quiero quexas de amigos, ni de los vivos pido lisonjas, ni quiero ser de los muertos culpado. I todos gaic Dios y ampare, pues quantos viven pueden sel mejores de lo que son hasta que salgan desta vida $\mathrm{y}$ grocen de la gloria eterna.

Aqui se tractarí en este libro XXXIII la conquisla é paçificaçion é poblaçion de la Nueva España, con mas Jrevedad de la que podria arer en algumos passos, porque los mas hombres son ámigos de conclusion, é les enojan las cosas que se pueden decir en pocas palabras, quando son supérfluas; mas cómo se ha de clis-

1 Lib. I, Elhicar.

2 Voces sunt signa concepluum corum qุıx sunt in anima passionum nolx.

3 Omnes enim nos manifestari opporlel anle TO.XIO III. curril por los méritos de muclıos, é las obras, é condiciones son discrepantes entre los que unilitan, no es de maravillar que unos sean loados por sus virludes, ni que of ros sean aditados, conforme í sus culpas, pues que las buenas obras dan gloria y fama á quien las luace, y las lorpes y malas dan velogienca é infannia ál quien las obra. Í este propóssilo dice Sanct Pablo: a Conviene que lodos parezcamos delinte del tribunal de Clupipsto, pará que cala uno dé cuenta del bien ó mal que lıa lıecho ${ }^{3}$." Y mas adelante dice el mesmo Apóstol: "Cada uno por sí mesmo la de dar cuenta á Dios de lo que ha fecho ${ }^{4}$.

I assi haré yo, si contra mi consciençia disere de mas ó de menos de lo que debo, aunque como liombre no podré ser tan justo, que no tenga que enmendar é corregir en mis palabras; pero como re. loso de la mesma justicia, mi intencion é sentenchia dellas suplirín lal defetto, pues que go no hago esto para el ormamento de la oratoria, sino para la médula histolial é para el reidadero efelto, que contare. E ya.que en esto no satisfaga al que pellizcare mis renglones, daré cuenla a quicu la debo con aver fecho lo que en mí la seydo, sin negar á mi persona trabaxo ni diligencia, informáundome de lo mas cierto para dar á cada uno lo que es suyo é te compete de mis vigilias. Y prinçipalmente porrue no se pueda quitar ni añadir en ofenssa ó en loor de algun lercero, sin ofenderme á mí en lo mo y cu lo olro, si de la recla narracion me desviasse, porque nunca desseć, ni luusqué, ni pensé laallar el ĩudo en el junco. Como refiere aquel proverbio vulgar (y es bien diclıo), quando uno quiere lallar en la cosạ lo que no es, suélese deçille que busca el ñudo en el junco, cuya propriedal

Iribunal Clıristi ut referal unusquisque propria corcorporis proul gessil sive bonum, si malum. (Ad roman., cap. X(V).

4 Ilaque unusquisque prosse ralionem reddel Deo. 33 
natural es ser derecho é sin hudus. P'ues assi, seyendo igual á torlos los que tocare, ó convinicre en este tractado ser nuemorades sin adularion ni parcoialidad, será igual la pluma y ú ánimo tue la muere, é gloria é loor de Dios, en cuỹa confiança prosigo.

Demás desto digro que yo tengo cédulas reales, para que los gobernadores me envien relacion de lo fune tocare á la histo- ria eu sus gohernaciones para estas historias. I escribé a avisé al marqués dul Valle, don Mlernamdo Cortés, para que me enviase la suya. conforme á lo que subsesivamente mandalba, é remitióme á umas carlas misivas, que le cseribió á Su Max̣estad, de lo sulbecdido en aquella conquista, é no curó de mis; é dessas, é dè lo quo me informaron, de tolo liaré memoria en este libro XXXIll.

\section{CAPITLLO I.}

En que se Iracla del prinęipio de la conquisla de la Nueva España desle el tiempo del capilan llernando Corlés, é del rico pressenle, que envió al Emperador Pey, nuestro señor ; é cómo se aparló por esquisitas formas de la obidiençia a anislad del adelantado Diego Velazquez, su superior, por cuyo manrlado avia ydo á aquella tierra: é dẹirse han olras cosas, que conviene primero qque se declaren para la inteligençia del discurso de la historia.

A Gen é primero descubrimiento de la Vuce. va España, me paresce que seria cosa supérfua repetirlo aqui, pues alli se dixo garticularmente quel primero español é chropstiano que vido aquella tierra é la enseñó á los clưipstianos, fué acaso el piloto Anton de Alaminos, en compañia del capilan Françisco Fornandez de Córdova, que yendo á rescatar ó saltear indios á las islas de los Lucayos, para tracrlos á vender á lí isla de Cula, alias Fernandina, fueron transportados los que he dicho é otros con sus cararelas. por fuerça de los tiempos que se les opusicron, hasta tanto que la fortuna, contra su roluntad, los aportó á vista de Yucatan, dourle tomaron lierra, é aun les mataron parte de la gente. Estos tornaron á Cuba, é dieron noticia al teniente Diego Velazquez de lo que vieron, el qual armó luego çeı́tos navios, é con el mesmo piloto envió por capitan á Johan de Grijalva, en cuya compaña fueron los capitanes Pectro de Nlvaralo, que fué despues adelanlado é gobernador de Honduras é de Guatimala, é l'rançisco de Montejo, que agora es ade- lantado é gobernador de Yucatan. É despues que estos segumdos tornaron con grandes nuevas é muestras de la rípueça de la lierra, que vieron en la cosla de la Nueva España, tornó á armar el mesmo Diego Telazquez, é con aquel proprio piloto Nlaminos envió al capitan Ilernando Cortés á aquella ticrra, donde sus cosas subcedieron tan prósperamente, que que. dó grand señor.

Queda agora de degir de qué manera alcancó su estado, é hiço mayor d de Céssar, conquistando é pacificando aqueIla tierra; por lo qual Su Mlagestad le dió título de marqués del Valle eon muchos rassallos é renta para él é sus subrgessores. İ para que la órden de la historia vaya reglada, segund que se debe proçeder, digo que ydo el capian Hernando Cortés á aquella lierra eon diez navios é tres bergantines é quinientos lımbresé diez é seys caballos é siete capitanes de tierra, que se llamaban Alonso Fernandez Portocarrero, Pedro de Alrarado, Françisco de Montejo, Alonso Dávila, Johan Velazquez, Diego de Oldás é Clripstobal de Olit, se desemlarcó en el 
puerto de Claalchilmclea, que por otro nombre se llama Sanct Johan de Llua (porque assi le Ilamó el capitan Jolıan de Grijalva quando to desenbrió). É lo primero en que entendió, desde á pocos dias que esturo en tierra, fuć dar con los navios al través, como buẹn guerrero, porque no quedíudose los navios en su ser, excusarianse mucha parte de los motines, que se pudieran seguil entre los soldados; porque alli yban de diverssas condiçiones de gentes, unos afiçionados al mesmo Cortés, é otros al Diego Telazquez, de la qual amistad luego se mostró apartado Cortés, é tanto mas quanto sus cosas yban prosperando, y él entregándose é sojuzgándose pate de aquella tiera. En lo qual sirvió mucho una ó dos lenguas, que la fortuna é luena ventura suya le acarearon; porque quando llegó á Cosumel, Ilevaba relaçion en la instruçion que le dió Diego Velazquez, que aria siete chripstianos en poder de los indios, que avian escapado de un navio, que algun tiempo antes avia dado al través en la costa de Yucatan, uno de los quales se deçia Aguilar. É aqueste, cómo supo que avia cluripstianos en la lierra, se fué á Cortés, aviendo sicte años que estaba allá ; pero los otros seys, cómo estaban casados con indias, é con sus viçios, é tenian hijos en cllas, apartados de la féc cathólica, vivian ya como indios é no quisieron rednçirse á la fóe ni venir á la compaña de los españoles. Bien es de creer que los tales no podian ser sino de vil casta é viles heréticos.

Émas adelante, en otro puerto que se diçe Clampoton, se tomó nua india que se deçia Marina, la qual cra natural de la cilnlad de Mexico, é riertos mercatleres indios avíanla llevado á aquella ticrara, é aprendió muy lien é presto la longrua española. Assi que, estas dos lenguas dlarina y el chripstiano Iguilar fuecon mucho caudal é parte para el buen sulnesso de la empressa. Por manera que quando Cortés llegó con el armada al areual de Cempual, dió con los navios al través, é fuésse á la cilsdad de Cempual, la qual se le dió é vino á la amistad de los chripstianos: é a!li sc informó de la polençia, hermosura é grandeça de la cibilad de llésico, é luego entendió en la fundaçion de un pueblo, que llamó la Villa Rica.

Aquella cibdad de Cempual es muy viçiosa é abundaute de todo lo nescessario, segund la ticra, é de bucnos culeficios de piedra; y estos de C.empual fueron buenos anigos de los chripstiunos, porque los indios é ministros, que alli eslaban para mandarlos, eran ofiçiales é maỹordomos de la ciludad de México, y cran sus prinçipales, é residian allí, é tractaluan ayuellos vassallos de Cempual peor que á esclavos, é aun á la cara no los osaban mirar los veçinos.

Allí le dieron al capitan Ifermando Cortés é á los españoles mucho oro é joyas, en espeçial dos ruclas graudes, una de oro é otra de plata, á manera de planchas, é labradas de medio relieve; ć la de oro tenian en reverençia del sol, é la de plata en menoria de la luna. Pessaba la de oro quatro mill y ochoçientos pessos, ć la de plata quarenta é ocho é çingienla mareos: cada ma tenia nueve palnos y medio de anchura é treynla de sireunferençia. Las quales yo ví en Sevilla en la casa de la Contractaçion de lis ludias, con otras muchas joyas de oro é plata é muy liermosos penachos de plumas muy exllemados, gue lodo era mucho de ver, que á Cússar enviaron pressentido el capitan llemanalo Cortés é la grente española, qlie con él militiba, con sus procuradores Francisco de Montejo, del tual de sllsso se liço mencion, é Jloneo l'ormande\% l'ortocarrero, quassi en fin del ano mill e quinientos é diez y nueve. De los quales é del 
nesmo piloto Alaminos yo me informé, é smpe que quedaban eon Cortes hasta (pratroegientos hombers é que aquella tierra es muy fertil é ricat, é la gente della belirosa é gololítria, é de murbla familiaridial con el dialılo, al (qual hablan, é han sta respuestas ded, é le sacrifican lomhres, é aun los comen, cono mas largamente se dirí adelante.

Estos procuralores de Cortés yluan con "l pressente ques dicho, é á dar relarion de los serviços de Cortés, é procurar aniquilar los de quien á aquella tierra le rurió con esta armilda (jue cra Diego relazquez) como de la listoria se puede färgilmente colegir conforme ál rerdad.

Desde Compual fué Corlés la via de la srand ciludad de Véxico, é llegó á nun luwarr que se dice Jalapa, donde lablló mucha comida : el qual está á septenta leguas de Néxico, y en estas hay las treynta de camino despoblado. é uma sicrra muy alta, ftue tiene tres leguas de subida muy úspera, en la qual se liallaron entre los otros árboles salvages muchas parras con uras, é muchas colmenas de miel muy huena en los árboles. E despues que ron mucho trabaxo ovieron passado esta sicrra, llegaron á una laguna (que está enmedio de aquellos despoblados) satohre; " cómo no avia otra agua, assi por falla della, como por causa del trabaxo que ivian passado, enfermaron muchosehripstianos, é se vieron en mucha nescessidad.

Deste allífueron á un pueblo que llamaron Castillianco, en el qual estaba un señol que se deçia Olintecle, é por otro uombre Caltanmi, muy sulyjeto á Vontecuma, señor de lléxico, é aviale destruydo una vez que se le avia rebchado. Este tenia reynte mill vassallos, é para la seguridad de la tientra tenia alli Monteçnal ma cuarniçion de ginco mill hombres te guerra, é desde apuesta gente arvia postas de mensageros puestos en paradas. con que sabia IIontecmma do hora en hora todo lo que en la tierra se haggia.

Tenia este Olintecle treynta mugreres dentro en sil casa, con quien él domina, ális futales servian nas de cyicnto otras; é él cra muy servido de los suyos: é tenia ratorge mezquilas ú oratorios con muclos gdolos de piedra, é cada dia sacrificala alli muchachos, é mugeres, é aves codorniçes é palomas. Arompañaban su casa é palacio contínuamente mas de dos mill hombres. Preguntironle las lenguas, por mandado del capitan Iternando Cortés, si era rassallo de Honteguma, ć abaxados los ojos en tierra, dixo: "Grand rosa me areys pregumtado: ¿é (juién no es esclavo de Honteguma, quanto más su rassallo? Yo soy su csclaro y todos mis rassallos lo son, y este es el mas pequeño pueblo de quantos hay en su señorio.s l'reguntósele que quánta gente tenia Montecuma. Dixo: "Degidme rosotros quánta tiene vuestro Rey, é yo os diré luego la que tiene mi señor, Monteçma.» É dándole á entender con las lenguas la potença del Rey de Castilla, é sus grandes estados é reśnos, é la grand multitud de sus exérçitos é armadas de mar é de tierra, el indio respondió é dixo assi: "Mayor señor es Honterumat, é más liombres e rassallos ticne que lay pajas en todos essos buhios é cusas que reys: é tiene más de lregnta prinçipes á si suljetos, que cada uno dellos tiene çient mill hombres é más de pelea." En fin, quiso decir que eran sin número, é que cada año sacrificalı más de veynte mill personas, al tiempo quél les daba el agua é las otras cosas, significando la deidad de Honteçuma, é que dél prosedian todos sus bienes temporales, y él les daba el vivir é se lo quitalsa, quando le plaçia.

Pero porduc mas puntualmente se digga d diseurso de la historia de llemando Cortés. fuiero seguir en parto la relaçion de "sus mesuas cartas, escriptas á Cessar": lis (piales of prineramente envio con sus 
procuradores ya diclios, que fueron por él despachados á diez y seys de julio de mill é quinientos é diez y nueve, desde la villa de la Veracruz (quél fundó) en una nao, que avia ydo de mercaderia á aquella tierra, donde, assi lo ques dicho como otras cosas muchas escribió. É despues de aquellas primeras cartas dixo en las segundas lo que se sigue.

\section{CAPITULO II.}

Cómo el capitan Ilernando Corlés determinú de yr á México, é eómo primero dió al través con los navios, en que fué á la Nueva España, temiendo que la gente que dexaba en la villa de Veracruz, ú otros, se le amotinarian; é eóno en el eamino supo que ciertos navios dél capitan Franciseo de Garay andaban en la eosla, é del gentil ardid que turo para aver lengua dellos; é eómo tomó siete hombres, é la informaçion que dellos luvo; é cómo ovo notiçia del rio de Panuco é del señor dél; é cómo su amistad eon él fiẹo, etc.

\section{1} do Cortés á Su Marrestad Cessírea despues que ovo diclo las cibdades é pueblos que tenia conquistados, dió assimes. mo noticia de lo que los naturales le avian dicho en aquella tierra de la persona é grand estado de Honteçuma; é supo que estaba noventa ó çient leguas de donde Cortés é los españoles estalıan é de la costa é puerto donde se desembarcaron. lí aun se ofresció por su leha de aver á Montecuma muerto ó presso, ó sulyjetarlo á la corona de Su Hagestad Ceessárea, e yrle á buscar do quiera que esturiesse. Ė con este propóssito se partió de la cilsdad de Cempual, á la qual él puso nombre Sevilla, é á los diez y seys de agosto, con quinçe de calıallo é trescientos peones, siguió su camino, é dexó en la villa de la Veracruz çiento y çingüenta hombres de pié é dos de caballo, haçiendo una fortaleça. É dexó toda la provincia de Cempual con la tierra comarcana á la dicha villa, en que avia lasta cinquienta mill hombres de guerra, é çinquienta villas é fortaleças, muy seguras é paçíficas por vassallos de Céssar, como hasta estonces lo avian seydo de Montecuma desde pocos tiempos atrás, más por fuerça que de sil grarlo, segund ellos decian. É despues que Cortés los oro aninado é travdo a la obediençia é serviçio del Emperador le rogaron que pues ellos querian ser amigos de los chripstianos é vassallos de $\mathrm{Su}$ Magestad, que los defendiesse de la tirania de Montecuma, que los tenia por fuerca, é les tomaba sus hijos para se los sacrificar á sus ydolos. E Cortés les promctió que en él y en los españoles lallarian toda buena amistad é favor, é quel Einperador les haria mercedes si con lealtad sirviessen á Su Magestad. É para mas seguridad desta amicicia, por ser nuevamente contrayda, llevó consigo algunas personas de los prinçipales de aquella gente, que no le fueron poco provechosos en su camino. É porque algunos parciales á Diego Velazquez, pessándoles de cómo Hernando Cortés ya desconosçia la superioridad que le delsia, queriéndose yr de la ticrra, en espeçal quatro cepañoles, que se deçian Jolıan Escudero, Diego Cermeño, piloto, Gonçalo de Ungria, piloto, é Alonso Peñate, los quales fueron pressos é acusados que querian tomar un bergantin, que estaba en el puerto con cicrto pan é toçino, é malar al maestre dél, é yrse á la isla de Cuba, alias Fernandina, á haçer saber á Diego Yelazquez. cómo Córtes enviaba la nao ques dicha con aquellos procuradores é pressente que se dixo en el capítulo precedente, los quales fueron justiçiarlos. É cómo en eslas partes el Príncipe está lexos, éarues- 
to tocaba í las passiones del capilin llermando Cortés é del que le envió, lérgil es fle entender quán poeo achaque bastaria para que parlesçiessen todos atpuellos que le paresçiesse á Cortés que le cran contrarios é que no segruian su roluntad. l'assemos á lo demás.

Cómo Cortés vido que en su exérçio avia diverssas voluntades, y porque demís de los cue por ser criados ó amigros (l) Diego Velazquez tenian roluntad de salir de la ticrra, a via olros que, por verla lan grande é de tanta gente é lal, estabin del mesmo propíssilo, viendo el poco número de los chripstianos; é sospechando Corlés que si allí los navios dexasse, se le alçarian con ellos, é yéndose todos los que de aquella voluntarl estaban, él se quedaria solo ó quassi, é no scria parte para conseguirse sus desseos, só color (que los navios no estalban para navegar, hico dill con ellos al través en la costa. É con este ardid ó prudencia quitó la esperança á sus múlites de salir á la tierra por estonçes, é prosiguió su viage sin temer que, vuetas las espaldas, Je avia de faltar la gente que en la villa dexaba.

Desde á ocho dias que los navios celiaron á la costa, é salido ya de la Yeracruz lasta la cibdad de Cempral, que está quatro leguas della, le avisaron desde la di(ha villa cómo por la costa andaban uguatro navios, é quel capilan que Corlés dexó en aquella villa, avia salido á cllos en una barea, é le dixeron que eran del adelaulado Françiseo Garay, teniente de golernarlor en la isla de Jamáyca, é que andalsan á descubrir; é quel dicho capilan de aquella villa les avia diclıo cómo Hernando Cortés, en nombre de Su Magestad, tenia poblada aquella tierra, é que aria hecho aquella villa, que estaba á una legua de donde los navios andaban, donde se podian yr con el dicho capitan, é que Ir. Latrian saber su venida, é podrian lomar refresco é repararse, si alğuna nes- ressidal tenian; é quel dicho cipritan los gruiaria con su harca al puerto, é señalóselo con el dedo, domele estaba; é (fuellos le avian respondielo gue ya avian risto el pherlo é arian passado enfrente deel, é (que assi lo harian, como lo degia ; é que se avia tormado al pureto ol dicho capilan con la billeca, prero yue los navios no le signicron, antes se andilsan por la costa, é que no sabian su propóssito. Lo qual ogrlo por Corlés, se volvió á la villa, é supo que tres leguas de alli los dichos navios estaban surtos la costa abaso, é que niugun lom!re arin salido en licra. E Juego Hernando Cortés se lué por la costa alaxo con gente, por tomar lengui, si pudiesse, de aquellos navios; é ya que llegaba á una legua dellos, topó tres hombres que arian saltado en tierra, el uno de los quales deçia ser escribano, é los otros dos yluan para sej tesligos de çierto requirmiento ó notificaçion que su capitan les mandala haçer á Cortés, en que se contenia quél avia desculsierto afuella lierra é queria polsar en clla, é que le requeria que repartiesse con él los términos, porque su assiento lo queria hacer la costa aluaxo çinco leguas despues de passiada Nantecal, ques una ciludad á doge leguas de la villa, que agora se llama Lmeria. A lo qual respondió Cortés que viniesse su calpitan é se fuesse al pucro de la Veracruz con los navios, é que alli hablarian é sabrian de qué manera renian, é que si truxessen algwuna nes. cessidad, los socorreria con lo que pudiesse. Eque pues deçian que venian en serviço de Su Magestad, quél no desseala olra cosa sino que se ofreciesse en qué servir á Su Alteça, é que en le ayudar creia que lo haçia. i lo qual le replicaron quel capitan en ninguna mancra ni la gente saldrian en tierra ni donde Cortés estuviesse. De que se siguió que assi como fué de noche, se puso Corlés en çelada enfiente de donde los navios eslaban 
surtos, é allí estuyo secreto hasta otro dia quassi á medio dia, creyendo quel capitan ó piloto saldrian á tierıa : é visto que no salian, hiço quitar los vesticlos á arfuellos mensageros y cseribano que fueron á le haçer el requirimiento, é hiço vestir a otros tres de los suyos aquellos vesticlos, ć que se llegassen á la playa é llamassen a los de los navios. É luego salicron con una barea hasta dicz. ó doge hombres con ballestas y escopetas; é los españoles que llamaban deste licra, se apartaron de la playa á unas matas, que estaban gerca, cómo que se yhan á la sombra dellas, por causa del mucho sol que haçia. E assi salfaron quatro hombres en tierra, los dos ballesteros é los otros dos escopeteros, é como estaban ceceados de la gente que Cortés tenia en la playa escondida fueron tomados; y el uno era macstre de la una nao, é puso fuego á la escopeta, é matáa al capitan de la Yeracruz, sino que á la mecha le faltó cl fuego, é no prendió; é los de la barea se apartaron dentro en la mar, é antes que llegasse á los navios ya yban á la vela. De aquellos sicte hombres se informó Cortés como avian Ilegado á un rio, que estí treynta leguas de la costa abaxo, despues de passada N/meria, é que allí avian hallado buen acogimicnto en los naturales é les avian datlo de comer por rescate; é que avian visto alginn oro, que traian los indios, aunque poco; é que avian rescatado liasta tres mill pessos de oro, é no a vian saltado en tierra, mas de que avian visto rientos pueblos en lit lihera del rio, é que en ellos no avia edefiçios de piedra, sino de madera é paja, execpto que las casas tenian altos hechos á mano.

Esto supo Cortés más por entero de aruel grand scñor Monteçuma é de çichlas lengrias de aquella ticrra ruél tenial consigo, á los quales é á un indio que en los dichos navios trailun del dicho rio, due lambien Cortés Ies lomó, envió con cicrtos mensageros del dicho Monteguma para rue hablassen al señor de arfuel rio. que se diçe Panuco, para le trael á sa amistad é al serviçio de Céssar; y él le envió con ellos una persona prinçipal, que, deçian que cra señor de un pueblo, el qual dió á Cortés dle su parte çicrta ropa é piedras é plumages, é le dixo quél é toda su lierra cran muy contentos de ser vassallos del Emperador é amigos de Cortés é de los chripstianos. Y el capitan Hemando Cortés le envió otras cosas de las de España, con que aquel prinçipal se fué muy contento para su señor; y lanto contento, que quando los ofros navios de Françisco Garay allí aportaron, el dicho señor de Panuco envió á deçir á Cortés cómo los navios estaban en otro rio, lexos de allí çinco ó seys jornadas, é que les hiçiesse saber si eran sus amigos ó de su naturalega los que en ellos venian, porque les haria dar lo que oviessen menester, é quél les avia hecho llevar çiertas mugeres é gallinas é otras cosas de comer, é assi se haria, si eran sus amigos. 


\section{CAPITULO III.}

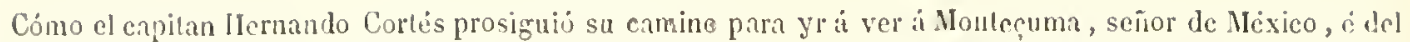
buen acogimiento que le fué hecho en las tierras de su señorio, a cúno se apartó deste camino por consrjo de los indios de Cempual, sus amigos, para yr a ver é contraer amislad con Tascaltcele, é cómo en fin se hiẹo cl amistad é confederaçion con cllos.

P artido Hernando Cortés con la gente, que de susso se dixo, para y' a verse con Monteçma, fué por la tierra é señorio de Cempual tres jornadas, donde de todos los naturales fué muy bien liospedado, é con mucho plaçer rescebido. É á la quarza jornada entró en una provinçia, que se llama Sienchimalen, en la qual liay una villa que por su sitio y assiento naturalmente es muy fucrte, porque está en una ladera de una sierra muy áspera, é para la entrada no hay sino un passo de escalera en una peña vira, ques imposible passar pol allí sino gente á pié (no resislida), y aun con harta dificultad; y en lo llano hay muchas aldeas é pueblos de á quinientos, é á trescrientos, é á doscientos veçinos labradores, que serán por toŁlos çinco ó seys mill hombres de guerra; y esto es del señorio de Monteguma. Alli resçihieron muy licn á los españoles, é les dieron muy bien los bastinentos nesçessarios para su camino; é lixeron al capitan Hernando Cortés que hien salian que yba ál ver á Monteçuma, su señor, é que fuesse çierto quél era su amigo, pues que les avia enviado á mandar que le hiçiessen Luen acogimiento á él é á los chripstianos, porque en ello le servirian mucho. É Cortés les respondió graçiosamente por su buen comedimiento, é les dixo quel Emperador, nuestro señor, tenia notiçia de Monteçma, é le aria mandado que le fuesse á ver , é que assi lo haçia é ponia por obra; é passó un puerto que estái al fin de aquella provinçia, é llamóle el puerto del Nombre de Dios, por ser el primero pisso áspero, que on arfuella tierra avian passado los españoles, el qual es tan aggrio é alto, que en España no se sabe otro tan dificultoso de passar (segund Cortés por su carta lo escribió).

Passado aquello sin contradicion alguna, halló en la baxada del puerto otras alquerias ó aldeas de una villa ó fortalega, que se dice Texnacan, que assimesmo era del nesmo Monteçuma, donde no menos bien que de los de Sienchemalen fueron los españoles rescebidos ; é les dixeron de la roluntad de Mlonteçuma lo que los testigos avian dicho, y Hernando Cortés les satisfiço de palaloras gratas é amorosamente, confortándolos á su amistad.

Desde allí fué este péqueño exérecito de los españoles é su capitan tres jornadas de despoblado de un páramo deslabitado, á causa de su esterilidad ć falta de agua é mucha frialdad que allí lay : por lo qual los españoles padesçieron mucho trabaxo de sed é hambre, é les tomó una tempestad de graniço é ağna en aquel despolnlado. que demás del peligro de la piedıa, que cayó unucha é gruessa, pensaron morir de frio, é de hecho murieron çiertos indios de los mansos, que tenian é avian lle. vado de la isla Fernandina.

En fin destas jornadaś ques diclıo, passaron otro puerto, aunque no tan áspero como el primero: en la cumbre del quad estaba una torre pequeña, que queria paresçer á los humilladeros que por derocion se usan entre los chripstianos en algunas partes, y assi eran oratorios de indios, porque estaban allí giertos ydolos, é al rededor de la torre avia mas de mill carretadas de leña cortadia é apilada muy 
compuesta ; é puso nombre Hernando Cortés á este paso el puerto de la Leña. Á la baxada deste puerto, entre unas sierras ásperas, llegaron á un valle inuy poblado de gente, que segund ella paresçia, debia ser gente polre. É despues de aver andado dos leguas por aquella poblaçion, llegaron át un assiento algo mas llano, donde vivia el señor de aquel valle, é tenia las mejores é mas bien labradlas casas, que Lasta estonçes los españoles avian visto en aquellas partes; porque cran todas de canteria labrada é muy nuevas, é avia en ellas muchas é muy grandes salas, é muchos émuy buenos apossentos, é muy bien obrados.

Este valle é poblaçion se llama Caltanmi, é al señor dél por su nombre proprio llaman Olintecle, como se dixo en el capítulo I. Allí fueron los españoles muy bien apossentados é servidos; é despues que IIernando Cortés ovo hablado á aquel señol muy amorosamente, é le dixo qué eran los chripstianos, é que ylon á aquella tierra por mandado del Emperador universal de todos los chripstianos, é le dixo, quan encaresçidamente supo, la grandeça é poder de Céssar; preguntóle por las lenguas si era rassallo de Monteçuna, 6 si era de otra parçialidad ú opinion: el qual muy admirado é como espantado de tal pregunta, le respondió é dixo assi: ¿Quién no es vassallo de Monteçuma? Queriendo deçir que Monteçuma era señor del mundo. $\bar{C}$ lo qual Hernando Cortés le replicó sonriéndose, como quien burlaba de su ignorançia, é le dió á entender que se engañaba, é manifestóle el poder grandíssimo del Emperador, diçiéndole que avia otros muchos en el mundo mas poderosos que Monteçuma, é ninguno ygual del Emperador: antes todos le son inferiores, le dixo, é que tenia innumerables prinçipes é scinores é capitanes vassallos suyos, é que assi lo avia de ser Monteçuma, é tener por muy grand TOMO IL. merçed ser suyo con todos los naturales de aquellas partes. É assi le requirió á este Olintecle que lo fuesse él, si queria ser honrado é favoresçido, é que si assi no lo hiçiesse, seria punido é libraria mal. É que para quel Emperador toviesse por bien de le rescelir por suyo, que debia dar algun oro, que á Su Magestad se enviasse. Á esto respondió que oro él lo tenia; pero que 110 se lo queria dar, si Nlonteçuma no se lo mandasse, pero que mandándolo él, quel oro é su persona é quanto tenia le daria. É por estorbar Hernando Cortés que no oviesse escándalo ni estor. bo en su propóssito é camino, disimuló, é replicó que presto le enviria á llamar Monteçuma, ó le mandaria que le diesse el oro é quanto toviesse.

Alli fueron á ver á Cortés otros dos se. ñores, que en aquel valle tenian su tierra, é le dieron çiertos collarejos de oro de poco pesso é valor, é sicte ú ocho esclavas, á los quales Cortés dió las mejores palabras que supo deçirles para su contentamiento. É desde á quatro ó çinco dias que allí estuvo, se partió é se fué al assiento de uno de aquellos dos señores, que estaban á dos leguas de allí, el valle arriba: el qual prinçipal se deçia tztaemistan, el señorio del qual era tres ó quatro leguas de poblaçion al luengo, sin salir casa de casa, por lo llano de un valle, ribera de un pequeño rio que va por él. $X$ en un çerro muy alto está la casa del señor con la mejor fortaleça que hay en la mitad de España, é mejor çercada de barbacanas é muros é cavas, y en lo alto deste çerro una poblaçion de hasta çinco ó seys mill veçinos de muy buenas casas é gente algo mas rica que la del valle abaxo. Allí fué muy bien resçebiclo Cortés é los que con él yban, é les dixo este señor que era vassallo de Mínteçuma.

Ailí estuvo Cortés tres dias, porque la gente descansasse de los trabaxos que en lo despoblado avian passado, é por espe. 
rar platro mensageros de los naturales de

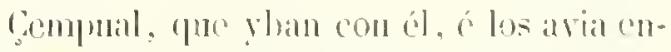
viarlo deste Caltammi á mat proving ia mur arande, fue so llama Tasealleca, rue le arian dicho que estaba secea de allí, los naturales de la yual poving ia cran anigos de los de benpual y enemiçíssimos de Monteruma. É diéronde á entender los de compunal que le querian confederar con arpucllos, porefue uran nuclos é muy belicosos é diestros en la guerra, é comfina su licrra por Iodas par. les con la de Montesuma, con quien continumente tenian grerra: y pensa-

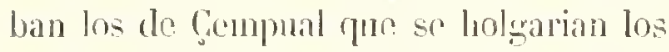
de Tasealteca con Contés é los chripstianos, é que los farorescerian, si el Monteruna se quisiesse poner en algo é se mostrasse contrurio á los cluripstianos.

Essos mensageros, en todo el tiempo que Cortés esturo en el valle ques dicho, que fué en folto ocho dias, no vinieron, é preguntó á aquellos principales de fempual que con él ýluan que cómo no tomaban, é dicéronle que debia de ser léxos é no porlrian rolver lan presto. É viendo que se dilatalıa su vuclia, é que aquellos principales de Cempual çertificalı́n é ascguraban mucho la amistad é seguridad de los de acquella provinçia, acordó Curtés de Ir allá é á la salida del valle lalló una grand gerea é muro de picdia seca, tan alto como estado é medio, fue altravesaba todo el valle de la mna sierra á la otra, é tan anclia csta muralla como veynte piés, é por toda ella un pretil de pié y medio de ancho, para pelear deste lo alto, é no tenia mas de mua cutrada tan ancha como dicz passos, y cn arpuclla cntrada traslapaba ó doblaba la una çerea sobre la otra, á manera de relollin. Lan estrecho como rinarenta passos, de forma que la entrada cra á vuclias é no derecha. Freguntala la canza de afuella crorea, dixeron á Cortés que la tenian assi, porque era frontera de arnella provin- cís de Titscaltera, la qual gente es de cnemigos de Monternma, é Ionian siom-

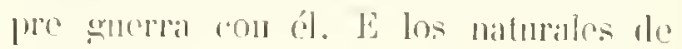
aquel ville le rogaron á Coplés que, pues

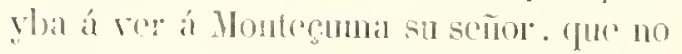
passasse por la ticrma de arpuellos sus unemigns, porfue ercian que serian malos ó le harian algun daño, ó quellos le llevarian siompre por tiena de Hontecuma, sin sulir della. á pror domle seria siempre bicn rescedido. Los de Compual degian yne no los crejesse, sino que fuesse por alli, é lo que aquellos le decion era pror le apartar de la amistad de aquella provinçia, é rue cran malos é traydores los de Montecuma, é le llevarian á meier donde no pudiesse salir. Pues cómo Corlés tenia mejor concepto de los de Gem. pual que de los otros, lomó su consejo y siguió el camino de Tascalteca, llovando su gonte lo mejor ordenada que pudo, y él y̧a delante bien media legua regelándose de lo que despues sulecelió por te. ner licmpo de descubrir el campo, é si algo se ofresçicsse, loviesse hugar de se recoger é conçertar éaperçebir los chripslianos para su defensa.

Despues que orieron caminado quatro legruas, encumbrando un gerro dos de á raballo, que yban delante del capitan Ilemando Cortés, vieron siertos indios con sus phmages, que acostumbran trace en la guerra. é con sus cspadar é rodelas: los quales assi como vieron los de caluallo, hrygeron, é como llegó el capitan, liçolos llamar é decir que no oviessen miclo, é fué mas atelante hácia donde estaban hasta quinge indios, los quales se juntaron ć començaron á lirar cuchilladis é dar roges á otra gente rene estaba en mu valle, é pelearon con cssos pocos españoles rorredores é con Cortés de tal mancra. que les maiaron dos caballos é hiricron otros tres é á dos de caballo. Y en esto salió la otra gente. que scrian hasta quatro ó çinco mill indios; é ya se avian 
juntado con Cortés hasta ocho de calballo sin los muertos, que pelearon con los contrarios, hagiendo algunas arremetidas y entradis en ellos, é lirricron los que podian, é teniéndolos hasta esperar los españoles, que con uno de caballo les a via enviado á degir Cortés que andoviessen.

En estas cscaramusas fueron alcancados émuertos çinquenta ó sessenta indios, sin que los chripstianos rescibiessen mas dano del ques dicho, puesto que los contrarios pelcaban con mucha osadia; mas como estos corredores ques dicho eran todos de caballo, cntraban é salian á su salvo, é con daño de los enenigos, los quales desde que vieron quel restante de los españoles se agcrcaban, se retruxeron porque eran pocos, é dexaron el campo á los chripstianos. E despues de se aver ydo, vinieron gientos mensageros é dixeron ser de la provingia ques dicha, é con ellos dos de los mensagcros que Cortés avia enviado, é dixeron que los señores no sabian nada de lo que aquellos avian hecho, que eran de commidarles, é que sin liçencia lo avian hecho, é que á ellos les pessaba, é que pagarian los caballos que avian muerto, é querian ser buenos amigos de los chripstianos, é que fuessen en buen hora veniclos á su tiurra, é que en toda ella serian muy bien rescebidos é tractados. El capitan Hernando Cortés les respondió que les agradesçia lo que deçín, é quél los tenia por anigos, é yria como ellos degian, adelanto.

Aquella noche se fué á apossentar é reprossar á par de un arroyo una legua delante de donde esta guagébara ó recuentro passó; é porque ya era tarle, é la gente ylua cansada, dinmieron donde es dicho; pero á buen recaludo de velas é centinelas de á pié é de á caballo. Éróno llegró la claridarl del dia signuiente, partieron de allí por su órlen é con sus corredores adclante, é llegaron á un pueblo pequeño, ya el sol salicudo: é illí viuionon
Ios otros dos mensageros llerando, í dixeron que los avian atado para los matar, e que aquella noche de antes se avian escaparlo; é á dos tiros de piedra dellos asomó mucha cantidaud de indios, é muy armarlos, segun su costunibre, é con un? grila que parescia que alrian los ciclos, conengaron á pelear con los chripstianos, tirándoles muclas varas é fleclııs. Estonces Hernando Cortés los comencó á hareer requirimientos con las lenguas que llevaba, é aun por ante un escribano, protes. tándose para satisfacion de la conscriencia real é suya é de los españoles, é para justificaçion de su dofensa é guenta pressente é porvenir; é quanto más en esso se ocupaba y entretenia á los cluripstianos que no peleassen, é peclia la paz con nucha instançia, tanto mayor priessa é atreviniento ponian en ofender á los nuestros. Por manera que viendo el generil capitan que sus palabras podian dañar á los españoles en los detener é impedir su delinsa, é que por cllis cresçia la soberbia de los adverssarios, dió senial á su gente frara que peleassen, y él delante dellos, como denodado capilan, pelcaron con tanto esfuergo entro más de gient mill hombres de pelea que por todas partes los tenian cercados, que cra cosa maravilosa rer lo que los chripstianos higicron lodo aquel dia en pesso, sin descansar hasta una hora antes quel sol se pusiesse é que los contrarios se relruxeroil.

Afirman los que en esta liatalla se hallaron que nunca tau poco número de españoles, ni de otros chripstianos pulicron ch ol mundo hacer en una jornadia tan liamosa expiriencia de su esfuerco conträ tanta moltitud de adverssarios. Los quales rotraidos, como es dicho, comenzaron i tirar media dogena de tiros peepueños de bronce, é çinco ó seys escopetas, é quirenta ballesteros, é con los trece de caballo que los quedaron, é liçieron numcho 
daĩo en los enemigos, sin le resçebir dellos más del eansançio é trabaxo de pelear, é la lianbre é sed, que no era poca: en lo qual paresçió que era Dios el que peleó por los nuestros, pues que entre tanta moltitud é tan animosa é diestra gente en el pelear, é con tauto género de armas para ofender á los chripstianos, salieron tan libres.

Aquella noehe el capitan general se hiço fuerte en una torreçilla de aquellas ydólatras, que estaba en un çerrillo, y en ella algunos ydolos que aquella gente honran y adoran; é como passó la noche, al punto del dia mandó el general que quedassen dosçientos hombres y el artilleria en el real, y él cabalgó con los de caballo é cient peones otros ehripstianos, é eon hasta quatroçientos indios de los de Cempual, que llevaba consigo, é otros tresçientos de lztaemistitan, y antes que los enemigos toviessen tiempo de juntarse, les quemó Hernando Cortés çinco ó seys lugares de hasta çient veçinos ó mas cada uno dellos, é prendió quatroçientas pereonas entre hombres é mugeres, é recogióse al real, peleando con los contrarios, sin resçebir daño alğnno. Luego otro dia signiente, en esclaresçiendo, dieron sobre los chripstianos más de çiento é quarenta mill hombres, que cubrian la tierra, que verse podia. (Pongo este número çiento é quarenta mill puntualmente, porque assi lo escribió Hernando Cortés á Su Mlagestad). Este acometimiento de los indios fué con tanta determinaçion, que alğınos, eon mas esfuerço que prudençia, se at revieron á entrar en el real, é andovieron á cuchilladas con los españoles; pero quiso Dios en tal manera favoresçer los chripstianos y diéronse ellos tan buen recabdo á su defenssa, que en esparçio de quatro horas avian fecho lugar, para que dentro de su real no los ofendiessen, puesto que no çcssaban en sus arremetidas, hasta que de cansados los infieles, é viendo con quanto ánimo de los nuestros cran resẹebidos, se retruxeron, é assi passó la hatalla este dia con mucho daño de los indios.

Otro dia siguiente, antes que amanesçiesse, tornó á salir Hernando Cortés sin ser sentido de los enemigos, por otra parte, é llevó consigo los caballos é çient peones é los indios amigos, é quemó mas de otros diez pucblos, en que ovo pueblo dellos de más de treynta é nueve easas; 6 allí pelearon con él los del pueblo, é dió Nuestro Señor la victoria ál los elripstianos, é mataron mucha gente de la contraria, é á loora de medio dia, ya que la gente de la tierra se juntaba de todas partes, estaban los nuestros en salvo retirados á su real con la victoria avida. Otro siguiente dia fueron mensageros de los señores de la tierra, diçiendo que querian ser vassallos del Rey de Castilla, é amigos de los chripstianos é de su eapitan general, é que le rogaban les perdonasse los yerros passados; é truxeron muy bien de comer ál los nuestros, é pressentaron ciertos penachos muy hermosos, que estiman é usan en aquella tierra. É Cortés les respondió por sus intérpetres que lo avian hecho mal; pero que era contento de ser su amigo é perdonar lo passado, eon tanto que de ahí adelante fuessen bue. nos é sirviessen á Su Magestad, eomo leales vassallos, pues deçian que lo querian ser.

Otro dia adelante vinieron al real has. ta quarenta hombres, que al paresçer eran personas de quien se haçia mucho easo entre aquellos bárbaros, é dixeron que yban á llevar de eomer á los chripstianos; é assi lo llevaron, é començaron á mirar las entradas é salidas del assiento del real, é las choçuelas ó ranchos, en que estaban apossentados los nuestros. É los indios anigos de Cempual llegaron á Cortés, é dixéronle que mirasse que aquellos eran malos, é venian á espiar é eonsiderar cómo podian dañar á los españoles, ó que 
toviesse por çierto que á otra cosa no avian venido, só color de pedir paz é perdon.

Estonçes Hernando Cortés hiço tomar uno dellos disimuladamente, que los otros no lo vieron (porque despues de los aver bien resçibido e respondido, andaban esparçidos inquiriendo la dispusiçion del exérçito chripstiano), é apartóse con él é con las lenguas, é púsole temor para que dixesse la verdad, é confessó que eran espias , é que Sicutengal, * capitan general de aquella provinçia, estaba detrás de unos çerros que avia enfrente del real con grand mollitud de gente, para dar aquella noclıe sobre los cliripstianos, porque deçian que ya se avian probado con ellos de dia é no les aprovechaba nada; que querian probar de noche cómo peleaban los españoles, é porque los indios no avrian temor á los caballos ni ál los tiros ni á las espadas, peleando á escuras:é que avia en viado á estos lombres, porque todos eran liombres de gucra, é á que viessen el real é las partes por donde podrian entrar á quemar aquellas chocas de paja ó ranchos que los cluripstianos tenian.

E luego hiço Cortés tomar otro espia de aquellos, y cxaminado, confessó lo mesmo quel primero, é otro é otro, hasta çinco ó seys de los espias, édixeron en conformidad lo mesmo separados é interrogados á parte, sin saber el uno del otro: lo qual visto por Cortés, los hiço prender á todos çinquienta, é mandóles cortar á todos las manos y enviólos á su capitan ó señor, é mandóles que le dixessen que de noche é de dia, é càla é quando él fuesse, veria quién eran los chripstianos, y en quán poco tenian á los indios. Y encontinenti hiço fortalescer su real lo mejor que pudo, é ordenó su gente é estançias donde convenia, é assi estovieron sobre aviso hasta quel sol se puso ; é assi cómo començó a anochescer, los contrarios baxaron por dos valles, pensando que venian muy secretos para cercar á los chripstianos, é ponerse tan çerca dellos que pudiessen execular su mal propóssito antes de ser entendidos; é cómo el general estaba prevenido, paresçióle que dexarlos allegar al real seria inconveniente, porque de noche, como no viessen el daño que se les hiçiesse, llegarian mas sin temor, é aun tambien porque los españoles no los viendo, algunos tenian flaqueça en el pelear, é temiendo que les ponian fuego (que si acaesçicra, todos los chripstianos se perdieran), determinó de salirles al encuentro con toda la gente de caballo, para los espantar é desbaratar de manera que no osassen llegar. É assi fué: que cómo sinticron los caballos que yban á dar en ellos, sin ninguna detenençia ni grita se metieron por los mahiçales, de que toda la campaña estaba quassi llena, é alibiaron algunos de los mantenimientos que tenian en sus mochilas ó talegas, para estar todo lo que pudieran sobre los chripstianos, por ver si los podrian matar e arrancar de la tierra. Pero como he dicho hiçieron, é aquella noclıe no ovo más de lo que está dicho, é quedaron los nuestros sin mas contraste algunos dias, descansando en aquel real, defendiendo la entrada de algunos indios, que venian á gritar é mover algunas escaramuças ligeras é de poca imporlançia.

Despues que estuvo el exérçito chripstiano algo descansado, salió una noche el general, rendida la primera guarda, con çient peones é con los indios sus amigosó con los de caballo, é á una legua del real se le cayeron çinco caballos é yeguas de los que llevaba, que en ninguna manera los pudo passar adclante, é líçolos volver al apossento de su real; é aunque todos los mas decian que se tornasse, por-

- El MS. original dice Sintogal; pero es error de pluma, reclifieado despues por el mismo 0viedo. 
que cra mal pronóslico é serial, todilvia el general prosignió sn camino, animando á los que eon él ýlon, é reprederuliendo a los que paraloan micntes en tales aģiieros. É aules que amancseriose. dirron soine dos pichlos, donde malaron assaz inrlios, é no quiso el general que se quemassen las casas, porque la rlarielad del fuego no diesse ariso é apelliclasse las otras polbaciones, que estaban juntas de allí é assi cómo fué de dia claro, dieron los españoles solore otro puedlo tan grande, yue tenia mas de reynte mill casas, 6. cóno Iomaron de solmresalto los indios, é salian desarnados, é las mugeres é ninos desmudos por las calles, hígose nucho daño en ellos. los quales, viendo que no se podian defender . vinicron çicrtos prinçipales del puchlo á rogar ảl greneral que no les hiciesse más mal; quellos querian ser vassallos del Rey de Castilla ó amigos de los cluipstianos: é decian quellos tenian la culpa en no aver querido creẹr al general Hernando Cortós; mas que de alí en adelante él veria cómo siempre larian lo quél les mandasse, en nombre del Emperador, nuestro señor, como verdaderos, leales é obudientes vassallos suyos. É luego vinieron al general mas do quarenta hombres de paz, é sacaron fuera muy bien de comer á par do una fuente, é alií el general les habló muy bien é los dexó muy sosegados, é se torinó á su real, donde halló la genteque avia quedado en él muy temoricada, pensandlo que avia subcedido algun peligro, porque la noche antes avian visto tornar los caluallos é yeguas ques dicho. Mas cómo supieron la vitoria é paz que se aria seguido, orieron mucho placer todos, é con mucha racon, porque estaban muy dentro en la tierra, melidos entre gente belicosa, é sin esperança de socorro de parte alguna; é aun en tal manera se murnuraba cutre los clrripstianos, que á los oydos do Cortés oyó él yue deçian ciertos compañeros:
- Mepueste muestro capilan es como Pedio Cialbonero, que no: ha medido en parto, que no nos salnói ni podrá sacar do donde estannos". Y costando Cortés an nna

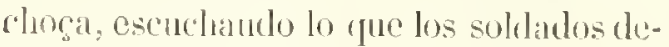
grian contrá él, sin que lo viessen ni sozpechassen quól los recuchabal, oyó que degian: "A eate nuestro capilan poco lo costó criamos, é si es loco é se mete donde no debe, no lo seanos nosotros, sino volvánonos á la mar : é si él quisiere volver con nosotros, bien; é si no dexemóslen. É muchas reges le requirieron públicamente que so bormassen á la costa, ó que no quisiesse morir á sabiendas, enprohendiendo con tan poca gente lo que no pensalon que era posible acabarse con tan pocas fuerçs. Á lo qual él respondia á sus mílites animándolos, é diçiéndoles que mirassen que eran vassallos del mas aito l'rincipe del mundo, é que en los españoles no se avia de hallar cohardia ni temor, é que estaban en parte, que demás de ganar muchos reynos á la Cessárea Magestad é á sn corona de Castilla, haçiendo lo que debian contra inficles é ydólatras apartados de la fée cathólica, ya que muriessen, ganalsan la gloria cterna, é viviendo, consonguirian perpélua fuma é la nayor honra, que de muchos tiempos acíavian lombres gamado; é que mirassen qiie lenian á Dios le su parte, á yuien ningruna cosa es imposible, como lo podrian ver por las vitorias que arian avido hasta estonges, é que tanla gente de los enemigos eran muertos ô de los duripstianos quassi ninguno; é que denás de quedar por tan lravañosos mílites, todos serian riquíssimos hombres. Con estas é otras muchas é muy bnenas palabras Hernando Contés los sosegó é truxo á su propóssito: que cra dar fin en la demanda comenrada.

Otro dia despues, á las diez loras del dia, vino al real de los españoles Sicutengal, capitan general de aquella provincia, 
con' hasta cinquienta lombres pringipales della, é rogóó á flemando Cortéz de su parte, é de la de Magiscaçin. que en aquella sacon cra la más prinçipal persona de toda la provinçia, é de otros muchos señores della. que los quisiesse admitir al serviçio rlel Emperador, é á la amistad de los chripstianos é suya, é les perdonasse los crrores passados, aviendo consideraçion que no conosçian quićn cran los chripstianos, ni por cuyo mandado é liçençia se avian entrado en su lierra con mano armata. Has ya que avian prohado todas sus fuereas con cilos, assi de dia como de noele, por su libertad é defensa, y exeusarse de subjeçion de extraños, pues en ningun tiempo su provingia avia seydo sojuzgada, ni tenian mi avian tenido scñor propictario, antes estaban en costumbre de vivir exentos por sí de tiempo inmemorial acá, é siempre sc arian defendido del poder de Montecuma é de su padre é aguielos, é toda la otra tierra tenian sojuzgada, é á ellos janás avian podido trace á suljeçion, teniéndolos como los tenian çereados por todas partes, sin tener lugar por donde salir de su ticrra, é que por esso no comian sal, porque en aquella provinçia no la hay, ni los dexahan salir á la comprar á otras partes, ni vestian ropas de algodon, porque én su tierra por la frialdad no se cria, é careçian de otras muchas cosas por cstar assi cncerrados, é que todo lo sufrian é a vian por bien, por ser exentos é libres de servidumbre, é no obligados ni subjetos í ninguno; é que lo mesmo quisieran haçe. con Cortés é los cluipstianos, é para ello avian probado sus fuerças, é que en cllas ni en sus mañas é cautelis no arian podido aprovecharse: pol tanto, quellos querian antes ser vassallos del ground Rey de Castilla, que no morir é ser del todo destruyulas sus casas é sus mugeres é lijjos, porque junto con esta nescessidad confialsan cque gente tan valerosa é de tan-
10 esfuerco, no podrian estar sin usar con cllos de elemençia para tencrlos favoresçidos é defendidos le sus enemigos, é porque pensaban que mediante la paz que perlian, alcançarian la quictud es reposo que nunca avian tenido con sus reçinos y enenigos.

Í esta peticion les respondió el general con mucho amor, é les satisfiço diçiéndo. les que ya cllos silbian que era propria culpa dellos é de su daño, convidándolos con la paz en los prinçipios, arerla menospreçiarlo; pues quél se a via venirlo á aquella licra, creyendo que yha á tierra de sus anigos, porque los de Cempual assi se lo avian certificarlo, que lo eran é lo querian ser. í que les avia enviado sus mensageros adelante para les lraçer saber cómo yba é la voluntal que de su amislad traia; é que sin responder, yendo segnro, le avian salido á saltcar on el camino é le avian muerto dos caballos y herido otros. E que denás desso, despues de aver peleado con él, le aria cnviado sus mensageros, diciendo que aquello se avia hecho sin ser su liçencia ni consentimiento, é que cierlas commidades se avian movido á cllo sin les dirr parte; pero quellos se lo a vian reprehıendido, é que querian su amistad; é quél, creyendo scr assi, les avia respondido que le plaçia, é que se yria otro dia seguramente á sus casas, como á casas de amigos. É que assimesmo le avian salido al camino é avian peleado con él todo un rlia, hasta que la noche vino, non obslante que por úl avian sejelo requeridos con la paz; y en fin les truxo á la memoria todo lo demás que contra él é los chripstianos avian hecho, ó les dixo otras cosas, justificándose á sí ća los españoles, y exhortando á los indios para que, pues decian que querian venir ¿l la obediençia de Cossar é ser sus vassallos, fuessen constantes é permanesçiessen en su servicio; é assi lo pronetieron, ofresçiendo sus vidas é personas é haçien- 
das con toda verdad é lealtad, é assi lo hicieron dende adelante.

E acabada de ajustar esta concordia, los indios se fueron muy alegres con la paz, y el general é su gente quedaron en su real seys ó siete dias, porque no se osaban fiar de los indios, puesto que le rogaban que se fuesse á una cilodad grande que tienen, donde los señores prinçipales de la provinçia viven é residen: los quales todos al cabo fueron á rogar á Iternando Cortés que se fuesse á la cibdad ques dicho, porque allí seria mejor resçelido é provejdo de las cosas nescessarias que no en el campo donde cstaba, diçiendo quellos tenian vergüença quél estuviesse tan mal apossensentado, pues le tenian por su amigo, y ellos é los chripstianos eran vassallos del Rey de Castilla. É á su ruego acordó de se yr á la cibdad, que estaba á seýs leguas del real, la qual es tan grande é de tanta admiraçion, que sin prolisa escriptura no se puede deçir ni dar á entender, porque segund Cortés escribió á Céssar, es muy mayor que Granada, é muy mas fuerte, é de tan buenos edefiçios é de mucha mas gente que Granada tenia al tiempo que los Catlólicos Reyes, de inmortal memoria, don Fernando é doña Isabel la ganaron, é muy basteçida de las cosas de la tierra, assi de pan é aves é caça, como de pescado de los rios, é de legumbres é cosas que los indios comen, é mas buenas fructas.

IIay en esta cibdad un mercado ordinario, en que cotidianamente concurren más de treynta mill ánimas, vendiendo é comprando, sin otros muchos mercadillos que hay en diverssas partes de la cilbdad. En este mercado prinçipal hay todas quantas cosas, assi de mantenimientos como de vestir é calçar, quellos tractan, puede aver. Ilay mugeres, que venden joyas é plumages, é todo tan bien conçertado como en la parada de Amberes, ó como pue- de ser en todas las plaças é mercados de la parte del mundo, donde con mas polideça é regla esté puesto. IIay mucha loca $\delta$ vedriado de barro de todas maneras, é muy bueno é tal como lo mejor de España. Venden mucha leña é carbon é hiervas de comer é mediçinales. IIay casas, donde lavan las cabeças è las rapan, como barberos, sin baños. Fillalmente, entre aquella gente hay toda buena manera de órden é poliçia, é son hombres de buena raçon é conçierto, é tal, que lo mejor de África no se le yguala, segun Cortés diçe.

Es esta provinçia de muchos valles llanos y hermosos, é todos labrados é sembrados, sin aver en ella cosa vacua. Tiene de gircunferençia esta provinçia noventa leguas é más, y en la relaçion que Cortés hiço al Emperador, nuestro señor, deçia que la órden que aquella gente tenia en su gobernaçion, era quassi como la de las señorias de Veneçia y Génova 6 Pisa, porque allí no hay señor general de todos; pero en esto yo me remito á él, porque no sé qué estatutos tienen ni cómo se goloiernan las señorias, que trae á comparaçion. Diçe que hay muchos señores, é que todos residen en aquella cibdad, ó los que viven en los pueblos de la tierra son labradores é rassallos de aquellos senores, é cada uno tiene su tierra por sí. Tienen unos más que otros; é para sus guerras júntanse todos, é todos juntos las ordenan é conçiertan. É créese que entre esta gente hay justiçia para castigar los delinquientes; porque uno de los naturales de aquella provinçia hurtó çierto oroá un español, é díxolo Hernando Cortés á aquel Magiscaçin, ques el mayor señor de todos, é hiçieron su pesquisa, é siguieron al ladron hasta una cibdad que está çerca de allí, que se diçe Churultecal, é de alli lo truxeron presso é se lo entregaron á Cortés con el oro, é le dixeron que le hiçiesse él castigar, y él les agradesçió la diligençia que en ello pusieron, é les di- 
xo que, pues estaba en su tierra, quellos lo castigassen, como lo acostumbraban, é quél no se queria entremeter en castigar á los suyos, estando en su tierra. De lo qual le dicron las graçias, y lo tomaron, é con pregon público, que manifestaba el delicto, lo hiçieron llevar por aquel grand mercado ques dicho; é le pusieron allí al pié de uno como teatro, que estíi enmedio del dicho mercarlo, y ençima del teatro subió el pregonero, é á altas voçes tornó á deçir el delicto de aquel, é viéndolo todos, le dieron con unas porras en la cabeça hasta que lo mataron. É muchos otros vieron los españoles estonçes, que los tenian en prissiones, é deçian que es- taban assi por hurtos é otros delictos, que a vian cometido.

Hay en aquella provingia, segund se vió por la visitaçion que despues hiço haçer Hernando Coltés, çiento é çinqüenta mill veçinos, con otra pequeña provinçia que está junto de la ques dicho, que se llama Guasineango, que viven á la manera de los ques dicho, sin señor natural: los quales assimesmo vinieron á la obediençia de Céssar é se incorporaron en el patrimonio real de Castilla, como los de Tascalteca, é quedaron otorgados é confederados por buenos amigos de los chripstianos.

\section{CAPITULO IV.}

De la embaxada quel prínęipe Monteçuma envió al general Hernando Cortés, ofresçiéndose por vassallo ć tributario del Emperador, con tanto que no fuessc á su tierra; é cómo los embaxadores procuraron desavenir al general con los de la provinçia de Tascalteca, ė cómo los de la provinçia avisaron á Cortés de la gente que tenia Monteçuma de guarniçion é de guerra csperándole *.

E stando Cortés é los españoles en aquel real, que tuvo continuando la guerra de la provinçia de Tascalteca, fueron á él por embaxadores seys señores muy prinçipales, vassallos de Monteçuma, con laasta dosçientos hombres que los servian, é dixéronle que yban de parte de Montecuma á deçirle cómo queria ser vassallo del Emperador é amigo de Cortés: é que viesse él qué era lo que queria quél diesse para Su Magestad de tributo en cada un año, assi de oro como de plata, épiedras, y esclavos, é ropas de algodon, é otras cosas de las quél tenia, é que todo lo daria, con tanto quél no fucsse á su tierra; é que lo lıacia porque era muy estéril é falta de todos mantenimientos, é porque le pessaria que Cortés é los que con él yban padesçiessen nesçessidad. É con essos sus

- En el códice original prosiguc en esta forma, si bien tachado por el mismo Oviedo: "Cerca de "Churultecal, la qual ganó Cortés é la puso debaxo TOMO III. embaxadores le envió hasta mill pessos de oro, y otras tantas pieças de ropa de algodon de la que en aquella tierra se usa; y estuvieron con él en mucha parte del tiempo que turó la guerra é hasta el fin della, é vieron bien lo que los espanoles hiçieron, é las paçes que con los de aquella provinçia se assentaron, y el ofiesçimiento que todos los señores de Tascalteca hiçieron al serviçio de Céssar: de lo qual mucho pessar ovieron los embaxadores, é trabaxaron por muchas vias é formas de revolver á Cortés con los de la provincia, é dixéronle que no era çierto lo que le deçian ni verdadera la amistad que le prometian los de Tascalteca, é que lo haçian por lo asegurar, para haçerle alguna trayçion á su salvo.

Los de la provinçia por consiguientede-

nde la obidiençia de Çéssar è en amistad de los vchripstianos.n 
çian a Cortés ô lo avtsaron quo no fiasso de aquellos vassallos de llonteguma, porque cran traydores é sus cosas siempre las haçian á trayçion é con mañas, é con cllas avian sojuzyado toda la tierra, é que le avisaban dello, como verdaderos amigosé como quien los conoscria do mucho liempo antes.

Vista la discordia é la desconformidad de los unos é los otros, no ovo poco plaçer Ilernando Cortés, porque le paresció que todo aquello era á su propóssito, é que se le ofresçia ocasion, para que mas ayna soljuzgasse aquellas gentes; $c$ que quadraba bien aquel proverbio comun que suelen deçir: "del monte sale quien el monte queman; é que aquella auctoridad evangélica se le aparejaba, la qual diçe que todo reyno diviso serí asoIarlo entre sí '. É assi, masando del tiempo con Ios unos é con los otros, mañeaba é á carla parte en secreto daba contentamiento, é les agradesçia sus avisos, é les ha. çia entender que cada qual dellos era creydo é no sus contrarios.

Despues de aver estado en aquella cibdad veynte dias é más, le diseron aque. llos embajadores de Monteçuma (que siempre estuvieron con Cortés) que se fuesse á otra cibdad que esiaba seys leguas de la de Tascalteca, que se llama Churultecal, porque los naturales della eran amigos de Hontecuma, su señor; é que allí sabrian la voluntad de Monteçuma, si era que Cortés é los chripslianos fuessen á su tierra, é que algunos dellos yrian á hablar con él, é á deçirle lo que Cortés avia dicho, é que le volverian con la respuesta; é aun deçian que sabian que alli estalan algunos nuensageros suyos, para le hablar á Cortés. Él les diso quél se yria é que partiria un dia çierto que les señaló.

Sabido esto por los de la provincia de Tascalteca, é que Cortés avia açeptado do yr con los dichos embinadores á ayuo lla cibdad, fueron á Cortés con mucha pe. na, é dixéronle que en uinguma namera fuesse, porque le tenian ordenada gierta traycion. para le matar en atyuclla cil)daul á él é torlos los de sil compañia; ć cue para ello avia enviado Nonteguma gente de sir tierra (porque algma parte della confinaba con aquella cilıdad) çinquienta mill hombres de guerra, é los lenia en guarniçion á dos leguas de la ciludad, segund señalaron, é que tenian cerralo el camino real, por donde solian yr, é fecho otro de nuevo, con muchos hoyos y estacas ó palos agudos hincados y encubiertos, para que los caballos cayessen é se maneassen é se matassen; é que tenian muchas do las calles tapiadas, é por las acoteas do las casas muchas piedras, para que despues que entrassen los chripstianos en la cildad, los tomassen seguramente é se aproveclassen dellos ái su voluntad. É quo si queria ver cómo cra verdad quanto le deçian, que mirasse cómo los señores do aquella cibdad nunca le avian reniclo á ver ni hablar, estando tan çerca, como avian venido los de Guasicango, que estaban mas léxos é que los enviasse államar é veria cómo no vernian. Cortés les agradesçió su aviso, é les rogó que les diessen ellos personas que de su parle los fuessen ál llamar, é assi se las dieron. Con los quales les envió á rogar que viniessen á verle, porque les queria hablar çiertas cosas de parte del grand Rey de España, su señor, éles querid degrir la causa de su venida en aquella tierra. Los mensageros fueron é dixeron lo que les fué mandado, é con (llos vimieron dos ó tres personas, no de mucha auctoridad, é dixeron á Cortés que yluan de prarte de aquellos señores, porque ellos no podian renir, por estar enfermos: que á cllos les dixesse lo que queria.

Los de Tascalteca dixeron ár Cortés que 
era burla, é que aquellos mensageros cran hombres de poca suerte, é que en ninguna manera se partiessen, sin que los scñores de Churultecal riniesscn allí. Estonçes Cortés habló á aquellos mensage. ros é díxoles que embaxada de tan alto Prínçipe, como el Rey de Castilla, no se avia de dar á tales personas como cllos, é que aun sus señores eran poco para la oyr; é que se fuessen, é que dentro de tres dias paresçiessen ante él á dar la obe. diençia al poderoso Rey de Castilla, é á of rescerse por sus vassallos, con aperçebimiento que aquel término passado, yria sobrellos élos destruyria, como á rebeldes é desleales. Y envióles con sus mesmos mensageros un mandamiento firmado de su nombre, é de un escribano, con relaçion larga de la Real persona del Rey, nuestro scñor, é de su venida de Cortés á estas partes, diçiéndoles cómo todas acrucllas provinçias ć otras muchas tierras é señorios son de la Corona real de Castilla; é que los que quisiessen obedesçer á Su Alteça, como sus vassallos, serian bien tractados é honrados é faroresçidos, é por el contrario haçiéndolo, scrian muy bien castigados, como desobedientes y enemigos. Pero aunque estas cosas in scriptis era como liablar con las paredes, é quellos ni saben qué cosa es letra, admirados, é no dexando de sospechar que fuessen protextaçiones para la futura guerra, temiendo della, otro dia vinieron algunos señores de aquella ciludad, ó quassi todos, é no tan bien informados de aquel mandamiento, pues no sabian leer ni lo entendian, como armados de su cautelosa é fingida cmbaxada ; é dixeron que si no avian venido antes, cra la causa porque los de aquella provinçia, donde Corlés estaba de Tascaltcca, eran sus cnemigos, é no osaban entrar por su lierra, porque no pensaban venir seguros; é que lien creian que le avrian dicho alguna cosa dellos en su perjuiçio, é que no les diesse crédito, que las deçian como enemigos, é no porque fuesse assi; é que se fuesse á su ciblad, donde conosçeria ser falsedad lo que le avian dicho sus adverssarios, e verdad lo quellos le deçian é çertificaban; é que desde estonçes se daban é ofrescian con su repúlslica por vassallos del Rey de Castilla, é lo serian paria siempre, ć lo servirian é contribuirian en todas las cosas, que de parte de Su Alteça se les mandasse. É assi lo hiço assentar Cortés á un escribano, por interpretaçion de las lenguas que tenia.

Fecha esla diligençia, deterninó todavia de yr con aquellos embaxadores á su ciblad, assi por no mostrar flaqueça, como porque desde allí pensaba lrager sus ncgocios con IIonteçuma, cuýa ticrra allí confinaba; ć allí usalsan venir los suyos é los de allí yr allá, porque en el camino no avia impedimento. Pues cómo los de Tascalteca vicron su determinaçion, pessóles mucho, é dixéronle muclıas veçcs á Cortés que crraba en lo que liaçia; pero que pues ellos se avian dado por vassallos del Rey de Castilla, é por amigos de los clıripstianos, que querian yr con él á aỹudarle en todo lo que se ofresçiesse, con la lealtad, la voluntad é obra quél veria, y el tiempo le enscñaria. É puesto que Cortés deçia que no trabaxassen en esto, é que loolgassen en sus casas, é les rogó quic no fuessen, diçićndoles que no avia nesçessidad, todavia le siguieron çient mill hombres ó más, bien aderesçados é á puntode gucira, é fueron con él liasta dos legiuas fuera de la cibdad; é desde allí, por mucla importunidad del general, se torna. ron, aunque todavia quedaron en su compañia hasta seys mill hombres dellos. É assi cómo los demás sc tornaron, ordenó el gencral sus esquadras de los españoles e por sí las de los amigos, y en mucho conçierto é órden caminó, é fuć aquel dia á sentar su real á par de un arroyo á las dos leguas, por despedir la gente, como 
es dicho, é que la cibdad á donde yba no se escandaliçasse, é porque no quiso entrar sobre larde en ella.

Otro dia por la mañana salicron de la cibdad al camino á le resçibir con muchas trompetas é atabales, é muclas personas de las que aquellas gentes tienen por religiosos en sus condenados templos é mezquitas, vestidos de las vestiduras que usan, é cantando á su manera, como lo acostumbran en sus casas de oraçion, con unas voçes desentonadas é mal avenidas e diferençiadas: é con esta solemnidad fueron hasla entrar en la ciludad, é metieron al general é á los españoles en un apossento muy bueno, donde muy largamente é á su contentamiento calian; é allí les llevaron de comer (aunque no muy complidamente). Y en el camino avian topado muchas señales de las que los de la provinçia de Tascalteca avian dicho, porque hallaron el camino çerrado é fecho olro, é algunos hoyos é algunas calles çerradas, é muchas piedras cn todas las açoteas, como gente que estaha aperçebida para mal haçer; ć á esta causa los chripstianos esturieron sobre aviso é á recabdo. É allí halló Cortés çiertos mensageros de Monteçuma, quic yban á hablar con los que con él estaban desde primero, é á él no le dixeron cosa alguna más de que yban á saber de aquellos lo que con Cortís estaba hecho é conçertado, para lo yr á deçir á su señor ; é assi se fueron, despues de los aver hablado ellos, y aun el unó de los que antes con Cortés estaba, y el mas prinçipal. Y en tres dias proveyeron los de la cibdad muy mal á los españoles de comer é de lo demás, é cada dia á peor, é muy pocas veçes le yban á ver ni hablar los señores é personas prinçipales. É estando assi sospechoso Cortés, una india de aquella tierra dixo á otra que llevaba Cortés por lengua (que era natural de allí é la avia avido en Champoton en el rio Grande, como se dixo en el capítulo I) (que muy cerquita de allí estaba mucha grente junta de Monteçuna, é que los de la cilulad tenian fucra sus mugeres é lijjos é toda su ropa, é que avian de dar solıre los chripstianos é matarlos á lodos; é que si clla se queria salvar é no morir, se fuesse con la que esto le deçia: quella la guaresçeria é pornia en salvo.

Esta india de Cortés dixo lo ques dicho á aquel Ilierónimo de Aguilar, lengua que se avia avido en Yucatan, como la historia lo ha contado; y el Aguilar dió notiçia desto á Cortés, el qual tomó á uno de los indios de la cilulad aparte é interrogóle, é aprobó é confessó ser verdad todo lo que la india avia diclıo, é aun lo que de Tascalteca avian avisado antes. E assi por esto como por las señales é indicios que para ello avia, acordó Cortés de baçer llimar á algunos de los señores de la cibdad, diçiendo que los queria hablar, é metiólos en una sala, é tuvo su gente aperçebida, é mandó que en soltando una escopeta, quél mandaria tirar quando tiempo fuesse, diessen en mucha cantidad de indios que avia junto á su apossento, y en muchos que avia dentro en él. É luego cahalgó é hiço soltar la escopeta, é dieron en los indios de tal manera, que en espaçio de dos horas mataron mas de tres mill dellos, aunque estaban tan aperçebidos que antes que Cortés saliesse de su apossento, le tenian todas las calles tomadas é toda la gente á punto, puesto que como los Iomaron de solpresalto fueron con façilidad desbaratados, mayormente que les faltaban los caudillos, porque estaluan pressos. É púsose fuego ál algunas torres é casas fuertes, destle donde los indios se defendian é ofendian; é assi anduro el general é su gente por la cilbdad peleando (dexindo luen recabdo en su apossento, que era bien fuerte) por espaçio de çinco horas, hasta que echó fuera della los reçinos por muchas partes, 
porque le ayudaban muy bien çinco ó seys inill indios de Tascalteca, é otros quatroçientos de Cempual, sus amigos.

Avida esta vitoria, volvió Cortés al apossento, é habló con aquellos señores que tenia pressos, é pleguntóles que por qué causa le querian matar á trayçion á él é á los clıripstianos; é respondieron quellos no tenian la culpa, que los de Culua (que son los vassallos de Monteçuma) los avian puesto en ello, é quel dicho Monteçuma tenia alli en tal parte (que segund despues paresçió seria legua y media) çinquienta mill hombres en guarniçiones para lo haçer; pero que ya conosçian cómo avian seydo engañados, é que soltasse uno ó dos dellos, é que harian recoger toda la cibdad, é traerian á ella todas las mugreres é sus hijos é ropa que tenian fuera, é que de ahi adelante nadie los engañaria, é serian muy çiertos é leales vassallos del Rey de Castilla, é muy verdaderos amigos de Cortés é de los españoles. Despues que Cortés los oyó, dixoles muchas cosas çerca de su yerro, animándolos y exhortándolos á la paz, é soltó dos dellos, como lo pidieron; é luego otro dia siguiente estaba toda la cilsdad poblada é llena de mugeres é niños, tan seguros como si cosa alguna de lo passado no oviera acaesçido. É luego el general soltó todos los prinçipales señores, que tenia pressos, é prometieron servir, como buenos é leales vassallos, al Emperador Rey de Castilla, nuestro señor, é á su corona real de Castilla é de Leon é sus suljçessores perpétua é inviolablemente. L encontinente apartaron é quitaron todos los cuerpos muertos donde no paresçiessen; y en quinçe ó veinte dias que allí se detuvo el general, quedó la cibdad é tierra tan pacífica é poblada, que paresçia que no faltaba nadie della, é sus mercados é tractos por la cibdad como antes los solian tener. É liço el general que los desta çibdad de Churultecal é los de Tas- calteca fuessen amigos, porque lo solian ser antes, é muy poco tiempo avia que Monteçuma con dádivas los avia traydo á su amistad é los avia fecho enemigos de essotros.

Esta cibdad de Churultecal está assentada en un llano, é tiene lasta veynte mill casas dentro del cuerpo de la cibdad, é tiene de arrabales otras tantas. Es señorio por si, é liene sus términos conosçidos, é no obedesçen á señor alguno: gobiérnanse por comunidad, como los de Tascalteca. Ios honrados cibdadanos della todos traen albornoces ençima de la otra ropa, aunque son diferençiados de los de Africa, porque tienen maneras; pero en la hechura é rapaçejos pendientes son muy semejantes.

Despues del trançe ques dicho, ẻ aver assentado la paz, fueron estos indios constantes en ella. Y es la tierra de aquella cibdad muy fértil é mucha, é riégase la mayor parte della. Deçia Hernando Cortés en sus cartas que es aquella cibdad por de fuera mas hermosa que todas las de España, porque es muy torreada é llana. Pero yo diria que la cibdad, que ha de parescer bien desde fuera, no la de ser llana, sino encumbrada é assentada en ladera, assi como Granada, Toledo, Cuenca é otras, que por no ser llanas, son muy hermosas, viéndolas desde fuera: é Burgos es assimesmo hermosa polblaçion por no ser llana, é de dia paresçen muy bien desde lexos, é de noche por consiguiente, porque como las casas están mas altas unas que otras, vense muchas lumbres á prima noche, y es muy hermosa la vista de tales poblaçiones. Las que están en llano se han de mirar, no desde fuera, como Cortés diçe, sino desde alğuna torre alta, para que lien parezcan, assi como Gante en Flandes, é Milan en Lombardia, é Sevilla en España, é otras que están assentadas en lo llano.

Toruando á nuestra historia, aquellas 
muchas torres de Churultecal son mezquitas, templos é casas de oraçion, que los indios tienen para sus ydolatrias é ritos, de las quales Cortés escribió que desde ençima de una dellas contó mas de quatroçientas torres: de mancra quél confiessa lo que he dicho, $y$ en la liermosura que diçe se ha de ver como yo dig̣o. É tambien diçe su carta que era pollaçion mas al propóssito para vivir españoles de las que hasta estonges aria visto en aquella tierra, á causa de los valdios é aguas para criar ganados, lo qual faltaba á lits que liasta estonȩes él avia visto en la Nueva España, por ser tanta la moltitud de la gente, que liabitaba en aquellas partes que no dexan palmo de tierra por labrar: é aun con torlo esso en muchas partes padesçen nesçessidad. por falta de paur, é hay mucha gente pobre, que piden limosna é vani mendigando entre los ricos por las calles, é por las casas, é mercados, é placias, como en España é otros reinos, donde hay gente de ragon, é se compadescen, é ayudan á los mendicantes. Por esso tal diçe el Florentino que torlo el mundo es hecho como nuestra casa: "Tuto il mondo é facto como la casa nostra. o Passemos á lo dennás.

\section{CAPITULO V.}

Cúmo el capitan general Hernando Cortés se partió de Churultccal con determilnaçion de ver ả Monteẹuma ¿ la gran eibdad de Temistitan; é lo que passó con los embaxadores de Nontecuma *; é de lo que en este camino le intervino; é eomo se vilo eon Nontecuma en aquella su gran ejbdad; é de la traycion, que contra los españoles se tracló por un prinẹipal señor, llamado Qualpopoea, vassallo de Monteçuma, é otras cosas anexas al discurso de la historia.

$\mathbf{P}$ cerlente, labló ol general a avellos emsetente, hablo el general a aquellos embaxadores de Monteçma, que con él estaban, é díxoles açerca de aquella traygion que se le avia querido hacer, cómo los señores de aquella ciludad de Churultecal afitmaban, que pol consejo de Monteçuma se avia hecho, é que no le paresçia era acto de tan grand señor enviarle sus mensageros é personas tan honradas, con quien le avia enviado á deçir que era su amigno, é por otra parte buscar maneras de le ofender con mano agena, para se excusar él de culpa, si el caso no subçediesse á su propóssito. $\dot{E}$ que pues assi cra que no guardaba su palabra é rerdad, que Cortés mudaria tambien su acuerdo, é assi como yba con voluntad de le ver é hablar é tener por

- Aqui suprimió Oviedo estas eláusulas : cédel pressente que le envió, é de la sierra de Guaxoçimgo, de la qual sale humo, assi eomo en el mon . amigo, é á tener con él mucha conversaçion é paz, de allí adelante queria entrar por su tierra de guerra, é hacerle todo el daño que pudiesse, comóa enemigo: é que á él le pessaba dello mucho, porque más lo quisiera conto amigo é tomar su parescer é consejo siempre en las cosas que en aquella tierra oviesse de laçer. Los emIaxadores respondicron quellos avian estado muchos dias en su compañia de Cortés, é que no salsian nada de aquel conçierto más de lo que allí en aquella cibdarl supieron despues que aquello se ofresçió; é que no podian creer que por consejo ni mandado de su señor Montecuma se hichiesse; y que le rogaban que antes que se delerminasse de perder su amistad é haçer la ğuerra, como deçia, se informasse bien de la verdad, é que dies-

te de la isla de Voleano, çerca de la isla de Seẹilia ó en el famoso monte Elna, que por ofro nombre Haman Mongibeln, ete. 
se liçença á uno dellos pará yr á lo hablar: yuel que fuesse, tornaria muy presto.

Hay desde Churultecal lasta dondo Honteçuma estaba é residia veynte leģuas.

El general le respondió que le plaçia, é dexó yr al uno de los cmbaxadores, é desde á seys dias tornó aquel mesno é otro que primero se avia ydo, é truxeron diez platos de oro é mill é quinientas pieças de ropa muy hermosa de camisetas, é mantas de diverssas colores é maneras, labradas, de algoodon é de pluma, é algunas dellas era cosa mucho de ver; é juntamente con esto muclıa provision de gallinas é panicacap, ques cierto brevage que los indios beben; é pressentáronlo al capitan general llernando Cortés. É dixéronle que á Nonteçuma le avia pessado mucho de aquel desconçicrto, que en Churultecal se quiso liaçer, porque Cortés no creeria ya sino que avia seyclo por consejo é mandado de Honteçuma, é quél le haria çicrto que no era assi. É que la gente que alli estaba en guarniçion, era verdad que era suya; pero quellos se avian movido sin los aver él mandado, por inducimiento de los de Cliurultecal, porque eran de dos provinçias suyas, que se llaman Acançisgo la unaé la otra Izçucan, que confinan con la ticrra de aquella cibdad de Churultecal, é que entrellos tienen çicrtas alianças de veçindad, para se ayudar los unos á los otros, é desta manera avian ydo allí, é no por su mandado. Pero que adelante Cortéz veria en sus obras si era verdad lo que Mlonteçuma le avia enviado á deçir ó no: é que todavia le rogaba que no curasse de jré su ticrra, porque era estéril é padesçeria nesçessidad; é que donde quiera que Cortés estuviesse, le enviasse á pedir lo que quisiesse é quél se lo enviaria complidamente. Á csto replicó Cortés que la yda á su tierra no se podia excusar, porque avia de enviar della y dél relaçion al Rey de lisdaña, su señor, é que Cortés creia lo que le enviaba á deçir: por tanto, que pues no avia de dexar de llegar á verle, quél lo oviesse por bien é no se pusiesse en otra cosa, porque seria muclıo daño suyo, é á Cortés le pessaria de qualquiera enojo que le viniesse.

Desque Mlontecuma vido quel general se pensaba de passar adelante, é que no se podia excusar, envióle á deçir que fuesse en lıora buena, quél le esperaba en aquella grand cibdad donde estaha. Y envióle muchos de los suyos para que fuessen con él, porque ya entraba Cortés por su ticra: los quales, llegados á él, é con muclia demostraçion de se holgar de su venida, le querian encaminar por çicrto camino, donde se sospechó que los indios dehian tener alğnn conçierto ó çelada para ofender á los chripstianos, como despues paresció por lo que se vidlo, pues muchos de los españoles que Cortés enviaba por la ticrra, hallaron en el camino tantos puentes é malos passos, que si por allí fucran, fáçilnente pudieran los indios cxecutar su mal propóssito. É quiso Dios mostrar otro camino, aunque algo áspero, pero no tan malo é peligroso como aquel, por donde los indios quisicran llevar á Cortés é su gente; é fué desta manera. $\Lambda$ ocho leguas de la cibdad de Clurultecal cstán dos sierras muy altas, que en fin de agosto tienen tanta nieve, que otra cosa de lo alto dellas no paresçe sino nieve: é de la una, ques mas alta, sale muchas veçes, assi de dia como de noche, tan grand bulto de humo como una grand casa, é sale sobre la cumbre de la sierra lasta las nubes, tan derecho como una sacta, é con tanta fuerça, que annque en lo alto de la sierra anda siempre muy reçio tiempo de viento, no puede torcer ni desparçir aquel lumno. É desseando Cortés entender nucjor la camsa de esto, mandó á diez liombres, los que le paresçió que serian mas lábiles de los españoles que llevalua, para que con mucha 
diligençia subiessen á la sierra, é con toda atençion supiessen aquel secreto de humo é de dónde proçedia: los quales fueron é trabaxaron quanto les fué posible por subir, é no llegaron á lo alto á causa de la mucha nieve que en aquella sierra lay, con muchos torbcllinos que, de la çeniça que de allí sale, andan por la sierra, é tambien porque no pudieron sufrir la grand frialdad que arriba haçia. Pero llegaron bien cerca de lo alto, tanto que estando arriba, comencó á salir aquel humo, é con tanto é poderoso ímpetu é roydo, que paresçia que toda la tierra é sicrra se caia, oydo.

$\dot{\mathrm{E}}$ assi, se ahaxaron é truxeron mucha nieve é carámbalos, para que los viesse el capitan general é todos los demás: á los quales paresçió cosa muy nueva, porque algunos pilotos que allí se hallaron, degian que aquella tierra está en veynte grados de la línia equinoçial á csta parte, é assi lo escrihió Cortés á Céssar. É á mi parescer Cortés é sus pilotos se engañaban en cssa medida ó graduacion, porque pues Churultecal está de Temistitan veynte leguas, á mí me escribió el muy reverendo scñor ohispo desta nuestra cibdad de Sancto Domingo, don Sebastian Ramirez de Fuenleal (que despues fué obispo de Leon, en el tiempo que fué Presidente de la Nueva España, é desde México, donde alğnos años residió) que aquella cibdad está en veynte grados: assi que no está en los mesmos la sierra de Guaxoçingo. Pero por no interrumpir la matcria, diré adelante á la letra lo que del assiento de México el perlado que he dicho alcançó: é volvamos á nuestra listoria.

Yendo aquellos compañeros que he dicho á ver aquella sicrra, toparon un camino, é preguntaron á los naturales de la ticra, que yban con ellos, que para dónde yha, é dixéronles que para Culua, é que aquel era buen camino, é quel otro por donde los querian llevar los de Culua, no era bueno. É aquellos españoles fueron por él lasta encumbrar y estar cntre la una é la otra sicrra, é descubricron los llanos de Culua é la grand cilidad de Temistitan, alias México, é las laģunas que hay en aquella provinçia, de que adelante será hecha mençion, é volvieron muy alegres por aver desculierto tan buen camino. É informado Cortés dellos é de los naturales de la tierra, habló á los cmbaxadores de Monteçuma, que con él yban para le guiar á su tierra, é dixoles que queria yr por aquel camino é no por el quellos le deçian, porque era mas corto; y ellos respondieron que assi era la verdad, que más lorere é llano camino cra; é que la causa por qué por allá no le encaminaban, era porque avian de passar una jornada por tierra de Guaxoçingo, que eran sus enemigos, é que por allá no tenian las cosas nesçessarias, como por la tierra de Montecuma; é que pues él que. ria yr por donde deçia, quellos proveerian cómo por la otra parte saliesse bastimento al camino. É assi se particon con harto temor de que aquellos quisiessen perseverar en querer haçer alguna burla á los españoles; mas como ya avian publicado ser allá su camino, ni paresçicra bien dexarlo, ni tornar atrás, porque no pensassen los indios que por falta de ánimo se dexaba.

El dia que Cortés se partió con su gente de la cibdad de Cluurultecal, fué quatro leguas con su exérçito hasta mas aldeas de la cibdad de Guaxoçingo, é de los naturales fué bien resçilido, é le dieron algunas csclavas é ropa é algunas pieças de oro, aunque era poco; porque no lo tenian, á causa que son de la liga é parçialidad de los de Tascalteca, é por tenerlos Monteçuma cercados con su tierra: de tal manera que con ningunas provinçias tienen contractaçion más de en su tierra, é por esto vivian pobremente. 
Otro dia siguiento subicron al puerto porentre las rlos sicmas ques dicho, é á la Laxada dél, ya que la tierra de Monteçnma descubrian por ma provincia della, que se dice Chateo, dos leguas antes que llegassen á las polılaciones, hallaron un muy buen apossento nuevamente hecho, tal é tan grande, que muy holgada é anclamente fodos los españoles se apossentaron en él, atunque ylan en sti compañia mas de quatro nill homlues de los naturales de las provinçias de Tascalteca. Guaxosingo, Cluturultecal é Cempual, ć para torlos muy complidamente de comer; y en todas las possadas muy grandes fucgos é mucha leña, porque lase allí mucho frio por la reçindad de aquellas dos sicras, y en ambas avia mucha nieve.

Allí fueron á laablar al general f̧icrtas personas que parescian pringipales, entre los quales aria uno que deçian ser hermano de Nonteçma, é pressentaron í Cortés hasta quatro mill pessos de oro; é dixéronle de su parte que Monteģma, su señor, le pressentaba aquello, éle rogaba que se tornasse é no curasse de gr a su cibdad, porque era ticra muy pobre de comida, é que para yr allá, avia mal camino, é que estaba todo en agrua, é que no podria entrar á ella sino en canoas; é otros muchos inconvinientes para la yda le pusicron. Juntamente con esto te dixeron rue viesse to que llonteçma, sı senor, podia haçer, que todo se le mandaria dar; é que demás desso se ordenaria de darle en cada un año çierta cantidar, é se lo llevarian hasta la mar é ronde él quisiesse. El general los resçibió muy bien, é les dió alggmas cosas de las de Espana, que los indios tenian en muclıo y en Castilla ralen pocos dinceros, y en especial al que deçian ser liemano de Nontecuma. É quanto í su emba vada respondió, que si cn su mano fucra volverse, quél to liçiera pror complaçer á Honteģuma: pero quél avia yelo á aquella tierra Tollo H. por mandialo del Rey de Castilla, su senor, é fur la prinçipal cosa que le avia mandado era que le hiçesse relaçion de Monteçuma é de arquella su gran cilvdad, de la qual é dél haçia mucho tiempo que la Cessárca Magestad lenia noticha é que le dixessen de parte de Cortés que le rogaha que toriesse por bien su yolá á verle, poryue della á su persona ni á su lierra ningrun diño se le seguiria: antes le seria muy provechosa su vista é amistad. E que despues que se riessen, si su voluntad fuesse todavia de no te tenel en su compañia, quél se volveria, é que mejor darian entrellos dos la órlen é manera que se debia tener en el servicio de la Cessírea Magestad que por tergeras personas (puesto que sus embaxadores eran tales (jue se les debia dar entero crédito). Con esta respuesta se tornaron los embaxadlores ques dicho.

En aquel apossento, segun las apariencias y el aparejo que en él avia, los indios tuvieron pensamiento que aquella noche potrian ofender á los chripstianos, y el general hico haçer tan buena vela é recalydo, que los adverssarios mudaron de conscjo, é muy secretamente liçieron yr aquella noche mucha gente, que en los montes estaba junto al apossento aparejada para laçer quanto mal pudiessen: Ia qual gente ricron muchas relas y escuclias de los chripstianos. Como fué de dia, se partió Cortés, caminaudo con buen concicilo, é á dos leguas llegó á un pucblo que se llama Amaqueruea, ques de la provinçia de Chalco, que terná en la prinçipal poblacion, con las aldeas que lay en torno délá dos İg̨uas, veynte mill reçinos; y en aguel puchlo prinçiral se apossentaron en unas casas del señor del lugar, é nutchas personas que parescian principales, fucron á hablar al general, é le dixeron que Montrecuma, su seior. los avia enviado para que le esperassen allí é le hiçiessen proveer de todas las cosis nescessarias. 
El señor de aquella provingela é paeJlo dió á Cortés lasita quarenta esclavas, é ties mill pessos de oro, é dos dias que allí se deturo, fué el exérçito bien proverdo de todo lo nesçessario. Otro dia, yendo con Cortés aquellos prinçipales que de parte de Mlontçuma dixeron que le esperaban alli, se partió é fué á dormir quatro leguas de allí á un pueblo pequeño, que está juuto ál una grand laguna, é quassi la mitail dél solsre el agua della, é por la parte de la tierra ma sierra muy áspera de piedras é peñas, é allí fueron muy bien apossentados, é aunque tambien (juisicran alli probar sus fucrgas los indios con los españoles, mas quisieran haçerlo á su silvo é de noche, é tomarlos descuydados. Mas cómo yban sobre aviso, y el general era tan apercebido que siempre se hallaba adelante de sus pensamientos, furó tal guarda, que las espias que renian por cl ağua é canoas, é tambien otras que baxaban por la sierra á ver si avia aparejo para executar su voluntad, amanesçieron aladas quassi reynte, que las espias de Cortés avian tomado é muerto, de forma que pocas volvieron á dar respuesta del aviso que renian á tomar. É con hallar siempre á los españoles tan aperegelidos, acordaron de mudar propóssito é lievarlos por bien.

Otro dia siguicnte, al tiempo quel general é su exérçilo querian partirse de aquel pueblo, lleraron hasta diez ó doçe señores muy principales, y entrellos otro mayor señor, mançcbo de hasta veynte $\mathrm{y}$ çinco años, al qual todos los olros mostraban tence mucho acatamiento, é cómo baxó de unas andas en que venia, todos los otros le venian limpiando é quitando las piedras é pajas del suelo delante dél. E llegado ante el general, le dixeron que venian de parte de Monteçuma, su señor, é que los enviaba para que fuessen con él, é que le rogaba que le perdonasse, porque no salia su persona a le rer é res- çebir por estar mal dispuesto; pero que ya su cibdad estaba cerca, 6 pues que 10davia determinalia de ye á clla, que allá se verian é conozgeria la luena voluntad que lenia al servicio del grand liey de Castilla. Mas que todavia le rogaba que allá no fuesse, si era possible, porrue padesceria mucho trabaro é nescessidarl; é quél tenia mucha verguiença, porque allá no le podria proveer tan complidaniente, como él desscaba. É en esto ahincaron é porfiaron inucho aquellos scĩores, tanto que no les quedaha por deçir sino que defenderian el camino, si todavia porfassen los españoles en yr adclante. El genoral los salisfiço é aplacó con las mejores palahras quél supo deçirles, dándoles á entender que de su yda no poclia seguirse daño, sino inucho provecho á Montecuma é á sus indios. É assi los despidió é les dió algunas cosas de las de Castilla, y encontinente se partió trás cllos muy acompañado de muchas personas, que paresçian de mucha auctoridad, como despues paresció serlo. L todaria seguia el camino por la costa de aguella grand laguna; ć á una legua adclante de donde partió el general vicron deniro en clla, quassi dos firos de ballesta, una cilıdad pequeña, en que podria aver hasta dos mill vecinos, todía ella armada é fundada cn el aģua, sin arei para clla cntrada alguna, é muy torreada, é de lindo paresçer: é otra legua adelante entraron por una calçada tan ancha como es una lança gineta complida, ó de veynte y çinco palmos, por la laguna adentro bien dos tiros de ballesta é é fueron por ella á dar á una cibdad, aunque pequeña, la mas hermosa que hasta estonçes los españoles allá avian visto, assi de muy licn labradas las casas é torres della, como de la buena órden é traça é novedad del assiento en el agua. E seria de hasta dos mill ve. çinos: de los quales nuestros españoles é su general fueron muy bien resçcbidos é 
servidos, é les dieron bien de comer, é rogaron al general el señor de la cibrlad é los mas prinçipales quẽ se quedasse allí á dormir, é aruellas personas prinçipales que yban alli de Montecuma le dixeron que no parasse alli, sino que fuesse á otra cibdad que está tres leguas de allí, que se diçe Iztapalapa, que era de un hermano de Ionteçuma, é assi lo hiço.

La salida de aquella cilsdad, donde comieron, fué por otra calçada, que tura una legua grande hasta salir á la tierral firme. Llegados á Iztapalapa, salieron á resçeljir al general é su gente el señor della é otro de otra grand cihdad, que está tres leguas de allí, é se llama Calnaalcan, é otros muchos señores que allí lo estaban esperando; é le pressentaron hasta tres ó quatro mill pessos de oro, é algunas esclaras, é ropa de la que allá usan, ques muy luena é sotilmente labrada, de algodon é de diverosas colores, é le hiçicron muy buen acogimiento. Podrá ser la poblaçion de iztapalapa de doçe ó quinçe mill vecinos, la qual estí en la costa de una lagmua salada é grande, é la mitad dentro del aggua, é la otra milad assentada en tierra firme.

Las casas del señor de la cibdad eran nuevas é no acabadas, é segund Cortés escribió á Cússar, eran tan buenas como las mejores de Essuaña de grandes é bien labradas de canteria é carpinteria, é suelos, é complimientos para todo género de serviçio de casa, excepto maconerias é olras cosas ricas que en España usan en las casas de los señores, que aquesto tal no se usa ni lo hay en estas Indias. Mlas avia muchos quartos altos é haxos, é jardines muy frescos é con muchos árboles é flores olorosas, é alloereas de agua dulce muy bien laloradas, con sus gradis lasti lo hondo é suelo de tales allereas. Hay otra muy grande luerta junta á la casa, é solre ella un mirador de muy hermosos corredores é salas, é dentro de la luerta un muy grande estanque ó allserca quadrado de agua dulçe, é las paredes desta allserca de gentil canteria, é al rededor della un anden de muy buen suclo ladrillaclo, tan ancho, que quatro personas pueden juntos passearse, é de esquina á esquina tiene quatrocientos passos, que son de çireunferençia mill é seysçientos. De la otra parte dei anden lúcia la pared de la lutuerta estaba todo labrado de cañas con unas verjas, é detrás dellas todo de arboledas puestas en mucha órden é de nuchas hierbas é flores olorosas. Dentro de la alberca avia mucho pescado é muchas aves, assi como lavancos, cerçetas é otros géneros de aresde agua, é lantas que muchas reces quassi cubrian el agua. En fin, es tal la alherea, que en Europa no se sabe, ó á lo menos no se liene noticia, de otra que se le iguale en to ques dicho.

Otro dia despues que á aquella ciludad llegó Cortés, se partió de alli, é media legua adelante se melió por una calçada que vá por medio de la lagguna ques dicho dos leguas, hasta llegar á la grand cibdad de Tomistitan, que está fundada en la mitad de aguella grand lağuna. Esta calcada es tan ancha como son luengas dos lanças ginetas, ó cinquienta pilmos, é muy bien obrada, é pueden yrú la par por ella ocho de á caballo. En estas dos leguas, de la ma parie é de la otra de la calcada, estín tres cihdades: la una se dice Mesicalringo, que está fundada la mayor parte della dentro de la mesma laguna; la otra cibdad se llama Niçiaca, é la otra IIuchilohuchico, que está en la costa de la layuna, é muchas casas de la uma é de la otra cihdad están dentro en el agua. Mesicalçingo terná tres mill veçinos, $\mathrm{Ni}$ çiaca mas de seys mill, é Iluchilohuchico quatio ó cinco mil veginos; y en lodas muy buenos edeliçios de casas é lorres, en especial las casas de los sciores é personas prinçipales, é las de sus templos é 
oratorios, donde aquella gente ticne sus ydolos. En estas ciludades lay mucho tracto de sal, que hacen del agrua de la mesma laguna é de la superfiçie yne está en la licra que haira la laguna en su costa, la qual cuecen en ricta manera. é laçen pancs de aquella sal, que venden cntre los naturales, é tambien para llevar fuera de la comarea.

Issi que, llernando Cortés é su exćrçito siguicron la rlicha calcata, é á media lewina antes do llegar al cuerpo de la cibdat de Temistilan, á la entrada de otra calçada fue viene á dar de la lierra firme á esta otra, estí un muy fucrte baluarte con dos torres, çercado de muro de dos estarlos, con su pretil de almenas poí 10da çerca. que topa con ambas calçadas, é no liene más de dos puertas; una por do entran é otra por do salen. Alli salieron á ver é hablar al general más de mill hombres, principales ciludadanos de la dirha Temistitan, torlos vestidos de una mancra é hábito, é segund su costımbre bien lico: é llegaron uno á mo hasla el capilan general, é assi cómo llegaban, hagian una cerimonia que entrellos se usil mucho (y es manera de salutaçion), ć ponia carla cfual la mano en lierra é la hessaba; é assi estuvo Cortés csperando fuassi ma hora hasta que carla uno hico lo ques dicho.

Junto á la cibdad estaba una puente de madera de diez passos de anchura, é por allí costí abierta la calçada porefue tenga lugar el ag̣ua de entrar é salir, porque cresçe é mengua, como lo sucle laçer la mar en sus costas, é tambien por fortaleça de la cibdad, porque quilim é ponen unas vigas muy luengas é anclas, de que la richa puente es fecha, lodas las veces que quicren; é dostas puentes lay muclats por toda la cibdad. Passada esta primera puente ques dicho, salió aquel graut principe Montecuma á resçibir á Jkrnando Cortés, acompañado de dos- ricntos scñores, sus vassallos, é todos descalços é vestidos de otra librea ó manera de ropa riea á uso suyo, már que la de los otros prineros: é venian en dos alas cu procession quassi arrintales á las paredes de la calle, ques muy anchil, miry hermosa é derecha, que desde el mm cabo della se paresçe el otro fin della, aunque tiene dos tercios de legrina de lon. gitud, é de la ma parte é de la otra muy buenas é quandes casas, asci de apossentamientos como de templos ó nezquitas. Montecuma venia por medio de aquellas dos alas é procession y de la calle con dos señores, el mo á la mano deredia suya y el otro á lá simestra. Destos cra uno aquel grand señor mamçebo, (que se dixo que avia salido primero á labblar á Cortés en las andas, y ol ofro era hermano de Honlecrmma, señor de lzlapalapa, ques aquella ciblat que se dixo de susso; é todos tres vestidos de una mancra, exgepto quel Hontecuma ylua calçado élos otros descalços. É cada uno llevaloa al señor assido de su braco; é cómo se juntaron, apeóse Ilernando Cortés é fué solo á abracall á Monteçuma, é aquellos dos señores que con él yban, lo detuvieron con las manos para que no le tocasse, y cllos y él hircieron la çerimonia ra dicha de Lessar la tierra: y hechoaquesto, mandó Hontceruma á aquel su hermano que se pusiesse al latlo de Cortés é lo llevasse por el hraço, y él con el otro yban delante de Cortés poen trecho. É despues que Monteguma en pocas palalmas ovo saludido al gencral, dichole que fuesse en Lmen liora su venidir. llegaron á le hablar todos los otros scñores de las dos proçessiones en órlen, uno en pos de otro. Fechá su salulaçion ya dicha, se tornaban con la mesma órden á sul progession.

Al liempo quel general llegó á hablar á Hontecuma, quitóse un collar que llevalua de margarilas é diamantes drevidro y rechósclo al cuello á Mlonteçuma. É 
despues de aver andado la cille adclanto, Ilegó un servidor é criado de Monteçuma con dos corales de camarones, envireltos en un paño, que eran hechos de huessos de caracoles colorados, que los indios tienen en mucho, é de carla collar colgaban ocho camarones de oro de mucla perfeçion, tan largos quassi como mu xeme; é cómo se los truseron, se volvió Monteçnura á Cortés é se los echó al cuello, é tornó á seguir por la calle adelante en la forma ya dicha, é Hegraron a una muy grande y hermosa casa que Montecuma tenia bien aderesceala para apossentar á Cortés. É allí lo tomó por la mano é lo llevóa una grand sala que estaba frontera de un patio por donde entraron, é alli lo hiço assentar en un estrado muy rico, é le diso que lo esperasse alli, é se fué : é desle á poco espaçio de tiempo, ya que toda la compañia de Cortés estaba apossentada, volvió con muchas é diverssas joyas de oro é de plata, é plumagges, é con lasta cinco ó seys mill piegas de ropa de algodon muy ricas é de diverssas maneras texidas é labradas, é lífgole pressente de todo ello.

É despues de se lo aver dado, assentóse en otro estrado, que lueggo le hiçieron allí junto con el otro en que Cortés estaba assentado, é con mucho silençio estando todos, començó Monteçuna á hablar, é dixo á Ilernando Cortés lo que se sigue: Muchos dias ha que por nuestras escripturas ó memorias tenemos aprendido de nuestros passados, é verdatlera notiça que yo é los que esta ticran habitanos, no somos naturales dellá, sino extrangeros, é venidos á clla de partes muy extrañas. É tenemos assimesmo que á estas partes truxo nuestra generacion un señor, cuyos vassallos todos eran, el qual se volvió á su naturalega é despues tornó á venir desde á mucho tiempo, é lanto que ya estaban casados los que avian quediulo con las mugrees nalurales de la tierra, é tenian mucha generaçion y lıechos puelolos, donde vivian; é queriéndolos llevar consigo, no quisieron yr, ni menos rescilirle por señor, é assi se rolvió. É siempre aremos tenido que los que dél desçendiessen avian de venir á soljuzgar esta lierra é á nosotros, como á sus vassallos ; é segund de la parte que vosotros deçis que venís, ques lárçia donde sale el sol, é las cosas que decís de esso grand señor ó Rey que acá os envió, creemos é tencmos por çierto ser él nuestro señor natural, en espeçial que nos deçís (fuél ha muchos dias que tenia notiçia de nosolros. É por tanto ros sed çierto (que os obedesçeremos, é ternemos por señor, en lugar de esse grand señor que deçís, é que en ello no avrá falta ni engaño alguno; ć bien podeys en toda la lierra, que yo en mi senorio posseo, mandar á vuestra voluntad, porque será obedesçido é feclıo; é todo lo que nosotros tenemos es para lo que ros quisiéredes disponer dello. É pues estays en vuestra naturaleça y en vuestra cisa, holgad é descansad del camino é guerras que aveys tenido: que muy bien sé todo lo que se os ha ofrescido deste Puntunchan acá , é lien sé que los de Cempual é los de Tascalteca os han dicho muchos males de mí. No creays más de lo que por vuestros ojos viéredes, en espeçial de aquellos que son mis enemigos, é algunos dellos eran mis vassallos é se me han relielado con vuestra venida, é por se faroresçer é congraciar eon vos, to diçen: los quales sé que tambien os laan dicho que yo tenia las casas con las praredes de oro, é que las esteras de mis estrados é otras cosas de mi servicio son assimesmo de oro, é que yo rue era é me haçia dios, é otras muclias cosas. Las casis ya las veys que son de piedra é cal é tierra." IDicho esto alçó las vesticluras, é mostrando las carnes, dixo: "I luí veysme aqui que soy de centure é linessos, como vos, é co- 
rno cada uno, é soy hombre mortal é palpable (é asíase él con sus manos de los braços é del cuerpo): red conı os lám mentido. Yerdad es que yo tengo algunas cosas de oro, que nue lan quedado de mis abuelos. Todo lo que yo loviere, teneys cada vez que ros lo quisiéredes. To me roy á otras casas donde vivo, é aqui sereys proveydo de todas las cosas nesgessarias para ros é ruestra gente, é no resçibays pena alguna, pues estays en vuestra casa y* en ruestra naturaleca. p

El capilan Hernando Cortéz, assi como acaló de hablar Monteçma, le respondió, satisfaçiendo á lo ques dicho, aquello due le paresció que convenia, en especial con le dar á entender quel Rey de Castilla era á quien Honteçuma é los indios esperaban. É con esto se despidió Honteruma é se fuć á la otra casa que diso, y llernando Contés é su gente fueron muy bien proveydos de muchas gallinas é pan é fructas é otras cosas nescessarias; ć desta manera esturo seys dias muy proveydo é visitado de muchos de aquellos señores é pringipales.

Al prinçipio se dixo que al tiempo que Cortés se partió de la villa de la Veraciuz, para yr á rer á IIontecuma, dexó ea aquella villa ciento é ginquienta hombres para haçer la fortaleça que quedó comencada, é lambien se dixo cómo aria dexado otras villas é fortaleras, de las comarcanas á aquella villa, de paz é por vassallos de la Corona real de Castilla. Les de saber, que estando Cortés en la ciljdad de Churnltecal, resçibió letras del teniente que dexó en la dicha rilla, por las quales le hiço saber cómo Qualpopoca, señor de aquella cibdad que se diçe Nantecal, é por otro nombre Ilmeria, le avia enviado á decir por sus mensağeros quél dessealna ser rassallo del Rey de Castilla; é que si lasta estonces no aria venido ni venia á dar la obidiencia que era obligado, é á se ofrescer por tal rassallo con todas sus tier'as é gente, cra la causa que avia de passar por ticra de sus enemigos, é que temiendo ser clellos ofendido, lo dexalua; pero que le enviasse quatro españoles que rimiessen con él, porque aquellos, por cuya tierra avia de passar, sabiendo á lo que venia, no le enojarian, é quél rernia luego. I el dicho capitan 6 teniente, ereyendo ser çierto lo que Qualpopoca le envió á deçir, é que assi lo avian lıecho olıos muchos, envióle los quatro españoles; é despues que los tuvo cn su casa, los mandó matar, de manera gue parescicese quél no lo haçia, E al ticmpo que se oro de execular su maliça, nuertos los dos chripstianos, los otros dos escaparon heridos, é por los arcabucos é boscages se volvieron á la villa, é fecha relaçion al teniente della, salió con su gentecéfué sobre la cibdad de Almeria con cincuienta españoles á pié é dos de á cahallo, é con dos tiros de pólrora é con ocho ó diez mill indios de los confederados é amigos de los españoles. É pelearon con los naturales de la cibdad, é la tomaron por fuerga de armas con muerte de muchos de los naturales della é é los demás echaron fucra, é la quemaron é destruyeron, porque los indios que fueron en compaña de los españoles pusicron en ello mucha diligençia: é fueron muertos en este trance ó batalla ó combate seys ó sicte españoles. Qualpopoca, señor de aquella cibdad, con ofros señores sus aliados, que alli avian ydo en su favor, se escaparon linyendo, é de algyunos prisioneros que se tomaron, se ovo notiçia é informacion de cúyos cran los que estaban en defensa de aquella cibdad, é por qué causa avian muerto á los dos españoles sobre seguro, é matáran ál los otros dos, si no luyyeran. É dixeron que Monteçuma avia mandado á Qualpopoca é á los otros que allí avian ydo, como á sus vassallos que cran, que salido Cortés de aquella villa de la Veracruz, fuessen sobre aquellos 
que se le avian alçado é ofresçílose í la amistad de los chripstianos, é que por todas las vias que pudiessen matassen los españoles, que cu aquella villa quedassen, porque Cortés no los pudiesse ayudar ni favorescer. É á esta causa confessaron algunos prissioneros que se avia hecho to que está dicho, por complir el mandamiento de su señor Monteçuma.

\section{CAPITULO VI.}

En el qual se traeta eómo el eapitan Hernando Cortés prendió al grand prínẹipe Monteçuma eautelosamente; é eómo fué heeha justiçia de Qualpopoca, señor de Nantecal, é olros scĩores prinçipales, que eon él fueron quemados, porque mataron sobre seguro cierlos elıripstianos.

\section{D} estaba en la cibdad de Temistitan, alias México, é a viendo visto alğ̉unas cosas de. lla, aunque pocas, segund las que avia quề ver é notar . por aquellas é por lo que avia visto de la tierra, le paresçió que convenia al serviçio del Emperador; que aquel grand rey Montecuma estoviesse en su poder, y no en toda su libertad, porque no mudasse el propóssito é voluntad que avia mostrado en la amistad contrayda é ofresçida al serviçio de Su Magestad é á la paz con los chripstianos. É porque importunándose dellos, les pudiera haçer tanto daño que no oviera memoria de aquellos, seģund su grand poder, é tambien porque teniéndole consigo, todas las otras lierras que le eran subjetas vernian más ayna al serviçio del Rey, como en efetto despues subçedió, determinó de lo prehender é poner en el apossento donde el mesino Cortés estaba, que era bien fuerte. É porque en su prission no oviesse algun escándalo ni allıoroto, pensando todas las maneras é formas que para lo haçer se debian tener, acordúsele de lo que el teniente de la Teracruz le avia escriplo cerca de lo acaesçidlo en la cibdad de Nantecal, 6 Almeria, como mas largamente se dixo en el capítulo preçedente, é cómo se avia sabido que aquello se avia hecho por mandado de Monteçuma.

É assi, dexando buen recabdo en las encruçijadas de las calles, se fué Cortés, con los que le paresçió que debia llevar, á las casas del dicho Honteçuma, como otras veçes avia ydo á lo ver. É despues que le ovo hablado en burlas é cosas de placer, Monteçuma le dió algunas joyas de oro, é una hija suya, é otras hijas de señores á algunos españoles; é muy conformes y en amistad departiendo, le dixo Cortés que ya sabia lo que en la cibclad de Nantecal avia acaesçido, é los españoles que alli le avian mucrto, é que Qualpopoca daba por desculpa que todo lo quél avia hecho, avia seyclo por su mandado, é como su vassallo, no a via podido hacer otra cosa; é que Cortés creia que no era assi, como Qualpopoca deçia, é que antes era por se excusar de culpa: que le paresçia quel Houteçuma debia enviar por él é por los otros prinçipales que en la muerte de aquellos españoles se avian hallado, porque la verdad se supiesse é aquellos fuessen castigados, y el Emperador, nuestro señor, supiesse la buena voluntad que Honteçuma tenia á su real serviçio claramente, y en lugar de las merçedes que Su Magestad le a via de mandar lıaçer, los hechos ni dichos de aquellos delinquientes malos no provocassen al Rey, nuestro scĩor, á yr contra él, por donde le mandasse lıaçer daño, pues la verdad era al contrario de lo que aqueIlos deçian, é que Cortés estaba muy satisfecho de Montecuma cn este caso.

Luego á la hora mandó llamar çiertas 
personas de los suyos, o dióles mal fignr ra pequeña de piedra de manera de sello, la qual él tenia attala en el hragen, cunandóles (pue fuessen á la dicha ciblad de Nantecil, alias Almeria, que cstá sessenta ó septenta leguas deste Temistitan, que truxessen al dicho Qualpopoea. é se informassen de los demás que arian seydo en la muerte de aquellos cepañoles, é alssimesmo los truxessen; é si por su rolunlad no quisicssen renir, los truxessen pressos, é si se pusiessen en resistir la prission, que requiriessen á çiertas romunulades comarcanis á aquella cibdad de Nantecal, que allí les señaló, para que con mano armada fuessen, para los prender, por manera que no viniessen sin cllos. Los Iuales luego se partieron, é assi ydos, Cortés dixo á Nonteçuma que le agradesçia la diligençia que ponia en la prission de aquellos, porque Cortés avia de dar cuenta al Rey de aqucllos españoles, - que para él poderla dar, convenia que Aontecuma estoviesse en la possada de Cortés hasta tanto que la verdad se declarasec, é se supiesse quél estaba sin culpa. É que le rogaba mucho quél no resçiliesse pena dello, porque él no avia de ustar, como presso, sino en toda su libertark; é que en servicio ni on el mando de su señorio no se le ponia impedimento alguno; é que escogiesse mu quarto de aquel apossento, donde él nlás quisiesse estar, que más á su plaçer fuesse, é que loviesse por çierto que ningun enojo ni pena se lt: avia de dar: antes, demás de su servicio, los españoles le servirian en todo lo que mandasse. É acerca desto passaron Cortés é Monteçuma muchas pláticas, en que dando conclusion, él diso que le plaça de se yr con Cortés, é mandó lueroo que fuessen á aderescar el apossentamien10, donde él quiso estar, é fué muy prestamenteaderesçado. É fecho esto, vinieron murhos señores, é (quitadas las restiduras é puestas por debaxo de los braços, é des- vilkos, truxeron mass andas no muy bicu arleresgadas, e llomando é solloçando, le tomaron en cllas con mucho silcncơo, é no menos lígrinas. é asci fucron hasta ol apossento, sim arer alloroto en la cibdad, aumque so coménçó á morer, lo yual sabido por Montecuma, envió á mandar que no lo oriesse. É assi estuvo fodo en quicelud, como antes la avia, ć la ovo todo al ticmpo que Cortés luro presso ál Monteçuma, porpure él estalba mucho á su plaçer é con todo el serviçio que acostumbraba á tener en su casa, que era bien grande é maravilloso. É Cortés é todos los españoles le haçian todo d plaçer, que les era posilsle.

Passados quince ó vernte dias de su prission, vinicron aquellos que avian ydo por Qualpopoca é por los que avian muerto los españoles, é truxeron á Qualpopoca é á un hijo suyo, é con cllos quinģe personas que decian que cran prinçipales é avian serdo en el dicho homiçidio: é traian á Qualpopoca en unas andas; mucho á manera de señor, como á la verdad lo era, é luegro Honteçuma lo hiço entrar y cutregar con los otros pressos á llepnando Cortés. É fueron puestos á buen recaludo con sus prissiones, é despues que confessaron aver muerto á los espanoles ques diclıo, fueron presuntados si eran vassallos de Monteçuma, é Qualpopoca respondió que si avia otro señor de quien pudiesse serlo (quassi diçiendo que no avia otro), é que sus vassallos cran. Timmljien se les preguntó que si lo que se aria fecho, si se avia fecho por si mandado, é dixcron que no, aunque despues al tiempo que en ellos se ere- cutó la sentençia que fuessen quemados, todos á una roz dixeron que era verdarl que Ilontecuma se lo aria enviado á mandar, é que por su mandado lo avian fecho. É assi fueron quemados estos indiosen mna plaça de Héxico 6 Temistitan, sin arer alboroto alsuno. lit apuel dia que 
los quemaron, porque confessaron que MLntesuma les avia mandado que matassen á aquellos españoles, le mandó cclar Hernando Cortés unos grillos, de que resçilsió no poco espanto, aunque despues delaberle hablado aquel dia se los mandó quitar, é quedó Jlontecuma muy contento. É de allí adelante el goneral trabaxaloa de darle placer é contentarle, é publicaloa é deçia á los naturales de la tierra, assi á los señores é priuçipales como á los plebeos, que la voluntad de Céssar era que Monteçuma se estoriesse en su señorio, reconosçiendo él la superioridad que Su Magestad solore él tenia, é sirviendo al Emperador, nuestro señor, como su vassallo: é que llaçiendo él esto, é permanesçiendo en buena lealtad, queria Su Magestad que Honteçma fuesse obedesçido é tenido por señor, como plimero é antes que los españoles é su general fuessen á aquella ticrra.

Deçia Cottés en su carta que fué tanto el buen tractamicnto que le hiço á Mlontecuma, y el contentamiento que Monteçuma tenia dél, que alğunas reçes é muchas lé çometió con su liberlad, rogándole que se fuesse á su casa, é que le dixo todas las veçes que se lo deçia quél estaba bien alli, é que no se queria yr, porque alli no le faltaba cosa de todo lo quél queria, como si en su casa cstoviesse; é que podria ser que yéndose é aviendo lugar los scñores de la lierra, sus vassallos, le importunassen ó induçiessen ál que hisicsse alguma cosa contra su voluntad, que no fuesse en sclvicio del Rey, nuestro señor : é quél tenia propuesto de servil á Su Hagestad en todo lo possible, é que lasta tanto que los toriesse informados de lo que queria haçer, quél estaba bien alli, porque aunque alguna cosa le quisiessen deçi", con responderles que no

* Asi lo eseribió Oviedo: debe decir sin duda Aben Hezra, cuya celebridad fué grande durante la edad media.

TOMIO III. estalsa en su libertad, se podria excusar y exiriur dellos. É muchas veçes pidió liçençia á Corlés para se yr á loolgar é passar liempro á çiertas casas de plaçer quél tonia, assi fuera de la cibdad como dentro della, é ninguna rez se lo negóo é fué muchas veçes á holgar con çinco ó seys españoles á una é á dos leguas fuera de la ciludad, é volvia siempre muy alegre é contento al apossento, donde Cortés le tenia. É cada vez que salia, lıacja muchas mẹrededes de joyas é ropas, assi á los españoles que con él yban, como á los naturales suyos, de los quales siempre yba tan acompañado, que quando menos con él yban, passaban de tres mill hombres, que los más dellos cran señores é personas principales. Á todos hacia continuos banquetes é fiestas: quantos con él yban tenian que contar de sus magnifiçençias.

Al coronista le paresce que, segund lo que se pucde colegir desta materia, que Montecuma era, ó muy falto de ánimo, 6 pusilánimo, ó muy prudente, aunque on muclıas cosas los que le vieron le loan de muy scñor é liberal, y en sus raçonamientos mostraba ser de huen juiçio. Dice Aloen Ruiz ": "Pues la muerte de nesçessidad ha de venir", nesçessario es quel bueno con esfuerco la haya de sofrir '." Á este propóssito ó intento, sintiendo Monteçuma que aquellos halagos de Cortés cran enforrados ó disinulaçion, para se enscĩorear con buena maña de lo que no pulicra con manifiesta fuersa, dilataba tambien Monteçuma su prission, pensando guiar su libertad por otra via, sin peligro de su persona, poryue ningun lıombre puede más de una rez morir, como diçe Sanet Pablo ${ }^{2}$. Pensaba Ilonteçuma que ninguna turbaçion le podia dar ni quitar la vida hasta que su ticmpo determinado llegasse; mas si este príncipe supic-

1 En el prólogo de la Phísica.

2 Sialutum esthomini semel mori. (Ad Hebraeos, cap. IX. 
la lo que escribe Xoenofonte cula vida ded rey Ciro, en si mesno pulierai ver rume

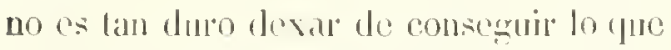

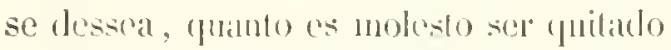
lo pue se prosece. Y assi me paresge á mí que auncule al fomor que aquellas sentes tenian á los caliallos era grandissimo, é demás de su cispanto, para cllos cra cosa de nutrela admiracion, in principe tan grande como Mloulecrmma no se avia de dexal incurrir en tales términos ni consentir ser detenido de lan poeo númeno de españoles ni de ona generaçion alguna. Mas como Dios liene ordenado lo que ha de ser, ninguno prode huyr de su juicio. Ni se podrá negar á la ventura de

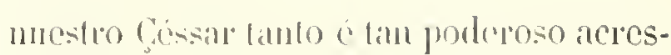

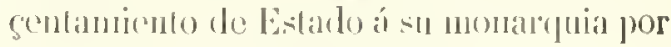

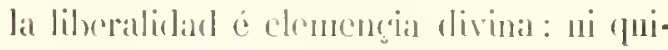
so permitir mustro liedemplon que afueIla tierra cstoviesse más en sus ydolat trias, ni dovasse de veniu á juntalse con la república de los felices chripstianos parra que su Sancto Evangelio se guarde ê

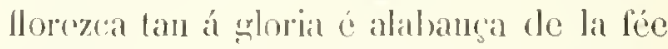
cathólica, como al pressente en la Nueva Expana se exerçia la roligion chripstiana, pol la diligencia de muclos religriosos de todas las órdenes celesiánticas, y en especial aquellos de la rogghlia é Ónden del se. ráphico é çlorioso Sunct Françisco. Pas. scmos á lo denús de muestra historia.

\section{CAPITULO VII.}

En que la historia traeta de las minas de oro de la Nueva España, é de otras parlieularidades de eiertas provinçias; écómo el prinejpe Tuchintecla vino á la objdiencia de Sus Magestades é a la amistad del capitan Hemando Corlés, é dió liẹeneia que los ehripslianos poblassen en su lierra.

\section{E} dor Rey, nuestro señor, que despues que conoscio de Honteguma el muy entero desseo que tenia al servicio de Su Hageslad, le rogó que porque más enteramente él pudiesse lacer relaçion á su Cessárea Magestad de las cosas de aquella licrm, le mostrasse las minas de donde se sacaba el oro, el qual con muy alegre semblante dixo que le plaria: é lneggo mandó llamar giertos servidores suyos, é dos en dos los repartió para quatro provinçias, donde divo que se sacaba, é dixo á Cortés que diusse españoles que fuessen con ellos, para que lo vicssen sacar. É assi Cortés proreyó de otros tantos cliripstianos, que fuessen assi de dos en dos con los indios: é los unos fueron á una provincia que se diçe Cuçula, ques ocho leğuas de la gran cibdad de Temistitan; ć los naturales de aquella provincia eran rassallos de Monteguma, é alli les mostraron tres rios, é de lodos tres truxeron muestra de oro é muy buena, aunque sacada con poco aparejo, porque no tenian ofros instrumentos más de aquellos con que los indios lo sacan. Y en el camino passaron tres provingias, segund aquellos mensa* geros despues diseron é como despues la paresciclo ser assi, de muy hermosa lierra é de muchas cihdades é villas, é otras poblaceiones en mucha cantidad, é de tales é tan buenos edefiçios, que deçian que en España no podian ser mejo res; en especial dixeron que avian visto una casa de apossentamiento é fortaleça mayor é mas fuerte é mejor edeficada quel castillo de Burgos. E la gente de una de aquellas provinçias, que se llama Tamarulapa, cra mas vestida que essotros ques dicho, é segund les paresçió á essos que Corlés envió, gente es de luena racon.

Los otros fueron á otra provinçia que se diçe Malinaltepeque, ques otras septenta leguas de la dicha gran ciludad, 
y es mas háçia la costa de la mar' ý eslos trixeron muostra de oro de un rio grande, que por allí passa. los otros fueron á otra tierra, que está este rio arriba poblada de una gente diforente de la lengua de Culua, á la qual llaman thenis, y el señor de a(quella tierra se llimalua Coathelicamal, y por toner su ticrra en unas sicras muy altas é ásperas, no era suljoto á Monteçuma é tambien porque lat gente de aquella provincia es muy belicosa é pelea con lanças de reynte y çinco ú treynta palmos. F́ por no ser aquellos do los rassillos de Montecuma, los mensajeros fque con los españoles yban, no osaron entrar en la tierra, sin lo haçer saher primero al señor della é pedirle liçençia para ello, diçiendo que iban con aquellos chripstianos á rer las minas del oro que tenia en su lierra, é que le rogaban de parte del capitan general de los españoles é de la de Ilonteçuma, su señor, que lo ovisse por bicn. El qual Coatclicamat respondió (que los españoles él cra muy contento que entrassen su tierra é viessen las minas é todo lo demás quellos quisiessen; pero que los de Culua, que son los de Monteçuna, no avian de entrar en su ticrra, porrue eran sus cnemigos.

Algo estovieron los españoles perplexos en sí, oydí la respuesta, é dubdosos si yrian solos ó no, porque los que con ellos yhan les dixcron que no fuessen, porque los matarian, é que por los matar, no consentian que los de Culua entrassen con cllos. É al.fin se determinaron de entrar solos, é fucron del dicho scñor é de los de su tierra hien resçehidos é traetados, é les mostraron siete ú ochı rios, de donde dixeron quellos sacalian el oro; y en su pressencia lo sacaron los indios, é truxeron í Cortés la muestra de todos. Con los quales mensageros é otros proprios suyos chvió arfucl scñor á ofres. cer st persona y Estado al serviçio del Rey Limperador, nuestro señor, y envió a Cortés çicrtas joyas de oro é muy hermosa ropa de la que en afuclla tierra se IIsa.

Los otros fucron á otra provinçia rue se dice Tuchitcheque, ques quassi en el mesmo derecho hícia la mar doce leguas de la provinçia de Malinalteleeque, donde ya es dicho que se halló el oro: é allí les mostraron otros dos rios, en donde assimesmo sacaron muestra de oro. É porque allí, segund los españoles que allá fucron hiçicron rolacion, lay mucho aparejo para haçer estançias é para sacar oro, rogó Cortés á Honteguma que en arpuella prorincia de Malinaltelseque, porfue era para ello mas aparejada, hiçiesse haçer una estancia c haçienda para el grand Rey de Castilla: é puso luegro en cllo tanta diligencia, que desde en dos meses que se le dixo, estaluan sembradas sessenta hanegas de mahiz é diez de fésoles, é dos mill piés de árboles de cacagruat, por otro nombre llamado cacao (ques una fructa como almendras, quellos beben molida, é la tienen en tanto, que se tracta por moneda en toda acpuella ticria, é con ella se compran todas las eosas nesçessarias en los liangiiez ó mercados é otras partes, donde algunas cosas se compran é venden, porque en fin essas almendras les son lo mesmo que á los chripstianos el dinero de contado). É a via fechas quatro casas muy buenas, en que en la una, demás de los buenos apossentos, hicieron un estanque de ağta é pusicron en ćl quinientos patos, que en acpella ticra tienen en mucho, porpure se aprovechan de la pluma dellos, é los pelan cada año, é laçen sus ropas con ella, é mantas de cama tan hermosas, yue de ningun brociado ni seda pueden sèr mas lindas, é línenlas de las cololes que quieren tan viras ó finds (prod nury rico earmesí ó púrpura no les laçe ventaia en la vista. Pusieron assimesmo hasta mill é quinientas wallinas, ó mejor diçiendo pavos (que en ol sabor son me- 
jores é mayores que los pavos de España) sin otros aderecos de grangeliats, que muchas reçes juzgahan los espanoles que lo vieron, que valia mas de veynte mill pessos de oro.

Assimesmo rogó IIernando Collés a Monteçma que le dixesse si en la costa de la mar avia algum rio ó puerto, donde los navios que viniessen de España, ó fuessen desta nuestra Isla Espanola é otros de otras partes pudiessen entrar y estar se. guros. El (pual respondió quećl no lo sabie, porque no sabia ni avia visto qué tales ni que tall grandes eran nuestras naos; pero quél haria pintar toda la costa é ancones é rios é puerlos della, é que enviasse él es. pañoles á lo ver, é que fuessen con los indios. quel Monteçuma daria para que los guiassen é fuessen con ellos; é assi se hico. É pintóse toda la costa en un paño, muy al natural, y en la pintura paresçia un rio, que salia á la mar, mas abierto que los otros, segund su figura, el qual paresçia estar entre las sierras que diçen de Sanct Martin; y son tanto en un ancon metidas, que los marineros é jilotos pensaron estonçes que se partia la ticrra en una provinçia que se diçe Maçanaleo, ó Guaçacalco. É dixo Monteguma á Cortés que viesse él á quién queria enviar, é quél provecria cómo viesse é supiesse todo. Cortés scñaló diez lıombres, y entrellos algunos pilotos é hombres expertos en las cosas de la mar; é con el recabdo que Monteçuna les dió, se particron é fucron por toda la costa desde el puerto de Chalchimeca, alias de Sanct Johan, donde Cortés se avia desembarcado, quando fué á aquella lierra: é anduvieron por ella sessenta é tautas leguas, sin ballar rio ni ancon donde pudiessen entrar navios, puesto que en la dicha costa avia muchos é muy grandes, é todos los sondearon con canoas. É assi llegaron á la provinçia de Guaçacalco, donde el dicho rio está y el scñor de aquella provinçia, que se deçia
Tuchintecla, los resçiljió muy bien é les hiço dir canoas para mitar a lóo, é haHaron en la entrala dél dos lracias é media larras en lo mas bixo de baxa már: é subieron por el rio arriba dos leguas, e lo mas haxo que en él lallaron fucron çinco ó seys bragas, é segund la dispusiçion que en el rio vicron, les paresció que subia mas de treynta legruas de aquedla hondura. En la ribera del qual rio hay muchas é grandes pollaçiones, é toda la provincia es muy llana é férlil é alsundosa de lodas las cosas de la lierra, é de mucha ó quassi inumerable gronte. Los de aquella provinçia no eran súbditos ni vas. sallos de Honteçuma: antes eran sus enenigros.

Este señor Tuchintecla assimesmo, al tiempro que los españoles llegaron, les envióá decir que los de Culua, que con cllos yban, no entrassen en su ticria, por. que eran sus enemigos. E quando se tornaron los españoles con la relaçion ques dicho, envió con ellos ciertos mensageros á Cortés con un pressente de algunas joyas de oro é cueros de tigres é muy hermosos phmages é piedras diverssas é ropas de algodon muy bien labradas; y envióle á deçir que avia muchos dias que tenia notiçia dél, porque los de Puntunchan (ques el rio que llaman de Grijalva, el qual está en diez y ocho grados desta parte de la línia equinoçial) que son sus amigos, le avian dicho cómo Cortés é los chripstianos avian passado por alli, é avia peleado con ellos, porque no le dexaban entrar en su pueblo, é que despues avian quedado amigos é se avian otorgado por vassallos de la Corona Real de Castilla. É que assimesmo el dicho Tuchintecla se ofrescia al serviçio del Rey, nuestro señor, é de sus subçessores en Castilla con su persona é tierra; ć quél rogaba á Corlés que lo toviesse por amigo, con tal condiçion que los de Culua no entrassen en su ticrra; é que viesse Cortés las co- 
sas que en ella avia, de que la Migestad Real se quisiesse servir: quél daria dellas las que Cortés señalasse cn cada un año, é serviria con toda fidelidad é verdadera amistad é obra, como lo veria con el tiempo.

Cómo los españoles ques dicho volvieron desta provingia á Cortés, informáronle que era aquella licrra aparejada para polslạr, é diéronle notiçia del puerto que avian visto, de lo qual él looggó mucho, porcjue era á propóssito, é nunca se avia hallado ni le hay en toda lia costa desde el rio de Sanct Anton, ques junto al de Grijalva, hasta el Panılco, ques la costa abaxo, adonde cieltos españoles, por mandado de Françisco de Garay, fueron á poblar, como se dirá adelante. Y para más se certificar Cortés de las cosas de aquella provinçia é puerto, é de la volun. tad de los natmales della, é de las otras cosas nescessarias á la pollaçion, tornó á enviar çicrtos españoles, lombres de expriençia, para qué inquiriessen con mucha atençion todo lo que les paresçió que se debia saluer. Y estos volvicron con los embaxadores que Tuchintecla le aria enviado; y en recompensa de su pressente envióle algunas cosas, conforme á la costumbre: que cra resçibir Cortés é los españoles oro, é dar en cambio de aquel algunas cosillas de vidro é cascabeles de laton é algun cuchillo ó espejo. Y envióle á deçir cómo él lo rescibia por vassallo de Su Nlagestad é de su Corona Real de Cas. tilla, é que como tal seria tractado é ayu. dado é favoresçido, ćle tomaba por amigo suyo é de los espatinoles, é le agradesçia su buena voluntad é olsıa, é á este pro. póssito otras palabras convinientes á la nueva amiçiçia contrayda.

Llegados estos segundos mensageros de Cortés, aquel señor los resçibió muy hien, y ellos con mas diligençia y atençion sondaron otras veçes el puerto é rio, é vieron muy particularmente la dispusiçion que avia para polslar. É de todo volvieron con entera é verdadera relaçion, é diseron que avia todo lo ques nescessario para la buena fundacion de un pue. blo bien assentado é proveydo; é quel señor de la provinçia era muy contento y estaba con mucho desseo de servil al Rey, nuestro señor, é de ser muy amigo de Cortés é de los españoles. Saluido esto por Cortés, proveyó de enviar un capitan con giento é çinquienta hombres, para que fuessen á traçar é formar una buena villa, é ordenóles que hiçiessen una fortaleça en la parte que más conviniesse é segura fuesse, porque el señor de la provinçia se avia of resçido de la haçer y edeficar assimesmo todas las casas que fuesse menester é le mandassen. É luego hiço seys en el assiento é parte que para el pucblo se señaló; é dixo que era muy contento que se fuessen allí á vivir é poblar en su tierra los chripstianos, porque tenia en mucho su amistad, é que en quanto él pudiesse los entendia contentar é haçerles buena veçindad. 


\section{CAPITULO VIII.}

Cimo fü presso el principe Cacamacin, señol do Aeulutean *, porque se rebeló despues de se aver ofres-

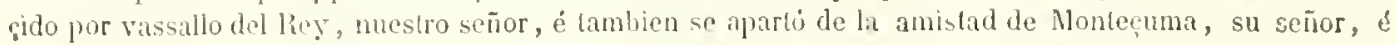
fué puesto un hijo suyo del dicho Cacimaçin por señor de su estado **.

A liempo quel capitan Hernando Cortés rba á la grand cibdad de Temistitan, como ya cueda dicho, salióle al canmo un grand señor á rescibirle de parte de Monteguma : cuyo pariente muy sercano era, é su señorio confinaba con el suyo. Este se llamalıa señor de Aculuacan, y la cabeca de su estado es una grand ciblad, que está junto á la ligguna salada: é desde ella lasta Temistitan hay seys leguas por el agzla, é por ticrra diez. Llámase Testuco, y es de treynta mill veçinos, en la qual el señor delta tiene unas casas uny excelentes. y está toda muy udeficada de torres muchas é muchos templos é oratorios muy grandes é muy bien labrados. Lay muy grandes mereados é contractacion en clla.

Demás desta cibdad tenia el señor deste estado ofras dos, la ma á tres leguas de Testuco, llamada Acuruman, é la otra á seys. que se diçe Otmmpa. I en cada una destas dos avia tres ó quatro mill verinos: é tiene la dicha provinçia ó señorio Aculuacan otras aldeas é alquerias en mucha cantidad, é muy buenas tierras élabranças; é confina todo este señorio por la una parte con la provinçia de Tascalteca, de la qual se ha tractado en los capitulos pregedentes. Este señor ó principe era mucha parte en aquclas fierras, é su proprio nombre era Cacamacin : el qual, despues de la prission de Monteçuma se re-

* Oviedo taehú en el MS. original la siguiente cláusula: Señor de Aculuacan, pariente muy sercano de llontesuma é grand señor en aquellas partes, ele.

* La última parle del epigrafe del presente capilulo estaba concebida en estos términos: "E beló é apartó de su obidiençia, é tambien de la fideliclad que avia prometido al Rey, nuestro señor, é de la amistad de Her. nando Cortés é de los españoles; porque le paresció que, pues Iternando Cortés avia detenido á IIonteçma, quel tiempo le daba oprortunidad á él para ser libre, é apartado de su vassallage, é del que los chripstianos començalam de nuevo á im. poner á los indios, é aun pensaba acres. çentar sus rentas é señorio, mediante la guerra comun. Y puesto que muchas ve. ces fué requerido que olbedesciesse los mandamientos que Cortés, de parte del Rey, nuestro señor, le enviaba, y el Mon. tecuma assimesmo por su parte, no solamente dexó de obedescer, pero respondia que si algo le querian, que fuessen á su tierra, é alli verian para quánto era y el serviçio que era obligado á haçer. É segrund la informacion que se ovo, tenia graud número de gente de guerra junta é muy á punto para se defender, é aun ofender ál quien quisiesse perturbar su tierra ó enojarle. Y cómo de las amonestaçiones ó requirimientos con él ningun fructo se conseguia, para lo atraer á lo que Cortés queria, habló á Jonteçuma el gencral é pidióle su parescer, para que aquel no quedasse sin castigo de su rebelion. El Monteçuma le respondió, como sabio, é dixo á Cortés que querer tomap por guerra á Cacamaçin cra cosa de mu-

tambien se apartó de la amistad de Montę̧uma, su señor, por cuya industria fué presso é entregado ¿t Hernando Cortés, é fué puesto un hijo suyo del dicho Cacamaçin por scñor de su estado, al qual llanahan Coeuzeacin.. 
cho peligro, porque era grand señor é tenia mucha gente é muchas é buenas fuerças, é no se podria aquello haçer, sin aventurarse mucha gente; pero quél tenia en su lierra del mesmo Cacamaçin muchos servidores é personas primçipales que rivian con él, é les daba salario: que lablaria con ellos para que atraxessen alguna gente de la del dicho Cacamaçin á sí; e que atrayda, y estando seguros que aquellos assi atraydos favorescerian el partido de Cortés, podrian prender seguramente a Cacamaçin.

É fuć assi, que Nonteçma hiço sus conçertos de manera que aquellas personas, á quien él to ordenó conduçicron al Cacamacin á que se junlasse con ellos en la cildad ya dicha de Testuco, para dar órden en las cosas que convenian á la conservaçion de su Estado, como personas prinçipales, é que les dolia quél hiçiesse cosas, por donde se perdiesse. É juntados en una muy gentil casa del mesmo Cacamaçin (que está junto á la laguna, y es de tal manera cdeficada que por debaso de loda ella navegan canoas é salen á la dicha laguua), alí secretamente tenian aparejadas çiertas canoas con mucha gente aperçebida, para que si el Cacamaçin quisiesse resistir la prission, pudiessen los otros salir con la empressa, ó matarle; y estando en su conoulta, le tomaron é prendieron todos aque- llos sus prinçipales, antes que fuessen sentidos de la gente de Cacannarin, é metiéronle en apuellas canoas, é salieron á la laguna, é lleváronle á la graund ciludal de Temistitan, que como es dicho, está seys leguas de allí. É llegados á Temistitan, le pusieron en unas andas, como sn estado lo requeria é aquel señor acostumbraba andar: el qual les dixo estonces: "No sé por qué me homrays agora, pues deslionrándome, me aveys traydo aqui contra mi voluntad, é como alerosos é malos rassallos é peores amigos, á donde padezea, por dessear mi libertad é la ruestra., En fin, sin responder lo llevaron, como es dicho, en pressente al capitan Hernando Cortés, el qual le hiço echar unos grillos, é mandóle poner á baen recabdo. É con parescer de Monteçuma puso en aqliel senorio, en nombre del liey de Castilla, nuestro señor, á an hijo de Cacamaçin, que se llamaba Cocuscasin; é proveyóse que todas las comunidades é señores prinçipales de la provinçia é scñorio de su padre, le obedesciessen por señor, hasta tanto que Su Magestad Cussárea fuesse servido. É assi se hiço: que de allí adelante todos los rassallos le tuvieron é obedesçieron por señor, como al mesmo Cacamaçin; é el nuero señor fué obediente ál Cortés en todo lo que de parte del Emperador Rey, nuestro señor, le mandaba.

\section{CAPITULO IX.}

Eh el qual se euenta la relaẹion quel grand prinẹipe Monteçuma dió de su origen á sus vassallos en una pública audiençia, en que les habló é mandó que obedesçiessen é sirviessen al Emperador don Cárlos, nuestro \&eñor, comóí Rey de Castilla é su natural señor, é despues dél perpetuanente á los Reyes de Castilla ćde Leon, sus subẹessores.

$\mathbf{P}$ assados algunos dias despues de la prission del príncipe Cacamaçin, mandó DIonteçuma juntar todos los señoles de las cibdades é ticrras comarcanas; é juntos, envióles á degir que subiessen adonde él estaba. É allegados en su pressençia, en manera que todos le podian muy bien oyr y entender, pressente estando é á par dèl sentado el general Hermando Cortés, é alli junto sus lenguas é intérpetres 
para le avisar de lo que se hablaba, Montecuma dixo assi:

- Amigos é hermanos mios, ya sabeys que de mucho liempo ać, rosotros é rucstros padres é abuelos é progenitores areys seydo é soys súluditos é vassallos mios é de nis anteçessores, é siempre dellos é de mi areys seydo muy lien tractados, honrados é favoresçidos; é rosotros assimesmo areys hecho lo que buenos é leales vassallos son ol,ligados á sus naturales señores: é creo que de nuestros padies é mayores teneys aviso é relaçion é memoria cómo nosotros no somos naturales desta tierra, é vinieron nuestros predeçessores á ella de muy lexana trerra: é los truxo un señor que en ella los dexó, cuyos vassallos todos eran. El qual rolvió desde á mucho tiempo, é halló que nuestros abuelos estaban ya poblados é assentados en esta lierra, é casados con las mugeres destas partes, é tenian mucha multiplicaçion de hijos: por mancra que no quisieron volver con él, ni menos le quisieron resçibir por señor de la tierra, y él se volvió é dexó dicho que tornaria ó enviaria con tal poder que los pudiesse constreñir é atraer á su serviçio por fuerga ó de grado. É bien sabeys que siempre lo aremos esperado; é segund las cosas quel capilan que pres. sente está, nos ha dicho de aquel grand Rey é señol que le cnvió acá, é segund la parte de donde él diçe que viene, tengo por cierto, é assi lo debeys rosotros tener, que aqueste es el señor que esperamos, en especial que nos dice que allá tenia noliçia de nosotros. Y pues nuestros predegesores no hicicron to que eran obligalos con su scĩor, liaǵímoslo nosotros, é demos graçias á nuestros dioses, porque en nuestros tiempos vino lo que tanto aquellos esperaban. I mucho os ruego, pues á todos os es notorio esto, que assi como hasta aqui á mí me aveys lenido é obedesçido por señor vuestro, que de aqui adelante tengays é olbelezcays á este grand Rey de Cistillia, pues él es vuestro natural señon, é despues de sus dias á sus subçessores en su silla real perpéluamente, é en su lugair tengrays á este su capitan grencral. I lodos los tributos que hasta aquí á mí me haccíades, los ha. cod é dad á é porque yo assimesmo tengo de contribuir á scrvir con todo lo quél mandare; é demás de lacer lo que debeys é soys obligados, á mí me hareys en ello inucho placer.

Lo qual lodo les dixo llorando, con las mayores lágrimas é sospiros que un hombre podia manifestar; é assimesmo todos aquellos señores que le estaban oyendo, lloraban linto que desde á grand espario no le pudieron responder. Era la cosa de tal manera, que ninguno de los españoles cslaba sin aver mucha compassion. Despues de algo ser sosegadas y menos las lágrimas, respondieron quellos lo tenian por su señor é avian pro. metido de hacel todo lo que les mandasse; é que assi por esto, como por la raçon que les daba para cllo, eran muy contentos de lo hacer; é que desde estonçes para siempre ellos se daluan por vassallos del muy alto é muy poderoso Rey de Castilla don Cárlos, primero de tal nombre en clla, é de sus sulogessores y licrederos en el real ceptro de Castilla é de Leon. É desile allí todos juntos é cada uno por sí dixeron que promelian é prometieron de hacer é cumplir todo aquello que en nombre de Su Hagestad real les fuesse mandado, como buenos é leales vassallos lo deben haçer, é de acudir con todos los tributos, serviçios é rentas que antes al dicho Nonteçuma haçian y eran obligados, é con todo lo demás que les fuesse ordenado, en nombre del Rey de Castilla, a quien por Su Magestad lo oviesse de aver é de resçebir é recaudar tan complidamente, como lo solian dar é acostumbraban servir á Monteçuma, é 
mojor, si mejor pudiessen hrucerlo, só las penas en que caen los desobedientes é desleales rassallos. E todo se asicentó assi é más copiosanente por aule un escribano é notario público, por auto y en forma, é Cortés lo piclió assi por testimonio en pressençia de nuchos espanoles; ć assi lo escrilsió él despues al Emperador, nuestro señor.

Y en la verdad, si como Cortés lo dice ó escribió, passó en efello, muy grand cosa me paresce la consciencia y liberalidad de Montecuma en esta su restituçion é obidiençia al Rey de Castilla, por la simple ó cautelosa informaçion de Cortes, yue le podia lascer para ello. Mas aquellas lágrimas, con que aliçe que Nonteçuna hiço su oraçion é amonestamiento, despojándose de su señorio, é lis de aquellos, con que le respondieron, acepplando lo que les mandaba y exhortaba, á mi parescer su llianto queria deçir 6 enseñar otra cosa de lo quél y ellos dixeron; porque las obediencias que se suelen dar á los príncipes, con risa é con cantares, é diverssidad de música é letiçia en señales de plaçer se sucle haçer, é no con lucto ni lágrimas é solloģos, ni estando presso quien obedesese: porque, como diçe Itarco Varron, "lo que por fuersa se dá, no es serviçio, sino robo."

I el mesmo Cortés dice en su carta en ilgunas partes, como se ha dicho en los capítulos precedentes, que IIontecuma siempro le rogó que no fuesse á verle, ni á Temistitan, ni lo gluisiera rer en ninguna mancra; é por lo que adclante se signio, se puede fáchimente considerar que esta novela ó restitucion no era de grato do Montecuma. Y no sin causa tengo ya dicho quél cra pusilánimo é lombre de poco ser, é que aquella su consçiençia, con que parescia quél daba lo suyo a su dueño, no resultó de su limpieça de ánima, sino de la roluntad de Dios, poi" los de. lietos é vicios desta gente. E por los sanos desseos é méritos de Céssar se encaminaron las cosas á otro mayor derecho é olígen del que Hontecuma deçia: porque si alli arian ydo sus progenitores, no se sabe ni está cscrito quién fueron essos, ni Cortés sabia en este cusolo que le deçia, mas de novelar é trace á su propóssito confalualaciones de mañoso é sagaz é diestro capitan, exçepto si, como se diso en la primera parte destas historias, en el libro Il ć capítulo HI, estas gentes tenian a!guma noliçia de lo que allí se tractó del rey XII de España, Hamado Ilespero. Pero no me quiero detener en estas congecturas, por passar á las otras cosas que hacen al discurso de la historia, siguiendo el tenor de lo que Hernando Cortés escribió al Emperador, nuestro señor.

\section{CAPITULO $\mathrm{X}$.}

En el qual se tracta cómo el capilan llernando Coltés persuadió á Monteçuma que enviasse por sus tierras a pedir á los prinçipales señores á vassallos que sirviessen con oro al Emperator Piey, nuestro señor, é lo hiçieron en cantidad de más decçiento é noventa y dos mill pessos, allende de otros çicnt mill pessos de valor éjoyas; é de algonas particularidades de la Nueva España ".

1. - assados pocos dias despues del aucto é ofreserimicnto que Montecuma é sus prin-

* Despues de estas palabras se leia en el Mis. original: “É del Estado é casa de Nontecuma é de los templos a ydolos de Temistitan é de los mereados 2 comereio de los indios; i del recuentro que passó entre el eapitain Heruando Corlús á el "eapilau lamphilo de Viarraez, éollas cosas mespessarina al $10.101 ! 1$. cipales vassallos hicieron al serviço é obidiencia del Picy, nuestro señor, como se,

discurso de la rerdad de la historia." Tero estas lineas fucron tachadas por el mismo aulor, porquo no llegó á lratar del rompimiento y choque eulre Coltés y Narracz linsla cl capílulo XII de este misuno libro, segun en su lígar puerde verse. 
la dicho en al capítulo de susso. acordó el capitan llemando Cortéa (porque

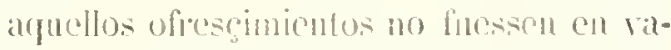
no, ó solamente palabrass) dle decorir á Jonteruna quel Emperador Liey, nuestro se. ñor, tenia nescessidad de oro para sierlas obras que mandialo haçer; que lo rogaba que enviasse algmas personas de los suyos, é que Corrós enviaria assimesmo algmos cepañoles con cllos. por las tioptas é casas de afuellos señores yue se avian ofpescido, á les rogar que de lo que ellos teniam sirviesson al hiey, matro señol, con alguna parte: porphe demás de. la nescessidad que Su Mage-tand Lenia, paresjeria que ellos comencaban á serrir, couformando con las oluras é palabras la roluntad que avian ofresçido.é que Su Alteca ternia más conçepto de las voluntades que á su serviço tenian: y quel mesmo Nontecuma diesse assimesmo de to que tenia, porque lo queria enviar con el oro, como las otras comas que antes se avian enviado á su Magrestad. í luego Honteruma divo yue le diesse los cspanoles que queria curiar, é de dos en tos é de ures en tres los envió con los indios, que le paresció que debian yr repartidos para muchas provincias é cibdades, porque algugnas estaban lexos, á ochenta í á çient leguas de la grand cibdad de Temislitan: é mandó á los suyos que fuessen con algnnos chriprianos á loz señores de aquellas provinçias é ciblades, é les dixesson cómo Cortes mandaba que cada uno dellos diesse ciertil cantidad de ono, que te les señaló. É assi liço: que todos aquellos señores á quien enviaron, dieron complidamente lo que se les pidió, assi ca joyas como en fujuelos é hojas de oro é plata, é otras cosas de las que cllos tenian, que fundido todo lo que era para fundir, cupo á Sa hagestad del guinto treysta é dos mill é qualroçientos é lantos pessos de oro, demás é allende de todas las joyas de oro é de plata, é pluma- jes e piedias, otras muchas cosas do valor (pue para léssal aparti Cortes é señaló. que poxilian valer ofros ciont mill

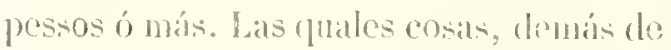
sul mucho valup, eran falos é tan matavillosas é nuevats. que consideradas por su lindeça y (x)aña forma, paresça que erai inextimables, é para creer que ninquan principe del mundo, de guien tengamos noticia. lis podrá tener tales ni tantas ni de tal calidad. Sin que paremea ser ento fabulowo; punes ques rerdad que todas las rosas crialatia naturalmente, assi en lis tierra ronno on la mar. de gne Monteruma pudiesse tener ronosgimicuto, las Ionia contrahechas tan al proprio assi de oro é plata como de perleria é de plumas, é con tal perficion, fine chassi parescrianser aquello mesmo gac (ynerian initar. De las quales todas dió llonteruma para el hey, nuestro señor. mucha parte, sin otras que Cortés le dió figuradas, para que las mandasse laçer de oro, issi como imágenes é crucifixos, melallas. joveles, collares é ouras muchas cosals de lis nuestras, que le hiço contrahacer. Cupicon assimesmo á Su Magestal, del quinto de la phata que se oro, çiento é tantos marcos, los quales hico Cortés labrar á los indios de plalos grandes é pequeños, y esculillas é tá cas é cucharas é otras piegue é raxilla, tan perfutto quanto se lo supieron dar á entender á los indios que lo higicron.

Demás desso dió Monteçuna mucha ropa de la suya, que era tal, de algodon é sin seda, fue daba admiraçion su valor é las muchas é diversasas labores: en que aria ropas de hombres a de muareses mucho de rel é parancntosé cortinajes de cama . que los de seda no se podian comparar á ellos. Aria otros paños. como de lapiceria, que podian servir en salas y en iglesias. Iria colchas é cobertores de camas. assi de pluma, como de algodon de diverssas é diferençadas maneras é vivas colores, é otras muchas cosas, que por 
ser tantas é tales seria dificultoso expresarlas. Tambien dió Monteçuma á Cortés

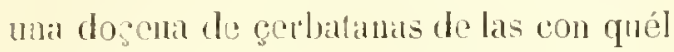
tiraba, muy hermosis, poryue cran fodas pintadas de muy exçelentes pinturas é perfeltos matices, en que avia figuradas muchas é diferençiadas maneras de avegicas é animales é árboles é flores é ỏras diverssas cosas é fantasias; é tenian los bocales é punteria tau zrandes como un xeme, de oro, y en el medio otro tanto, muy bien labrado. É dióle para con cllas un carnicl de red de oro, é otras muchas cosas, cuyo número fué. ruassi incontable.

E dá relaçion IIernando Cortés por su carta al Emperador, inestro scior, te otras muchas particularidades, cutre las quales reçita primero la forma de la provincia de México, ques donde está la grand ribdad de Temistitan, é algunas de las otras, de quien se ha hecho relaçion, é dondo estaba el prinçipal señorio é real silla de Nonteruma. La qual dicha provinfia es redonda é toda çereada de muy allas é ésperas montañas, é lo Itano delta terná de circunferençia septenta leguas, poco mas ó menos: y cll este llano hay dos lagunas, la una dulice é la otra sakada, é dirídelas por una parte una cordillera pequeña de cerros muy altos, que están en medio desta llanura, é al cabo se van á juntar las dichas lagunas en lun estrecho llano, que entre estos cerros é las sicras altas se hage. el qual catrecho terná de aberlura in tiro de luallesta. É por entre la una lagruma é la otra, é las cilutades é polılaciones que están en las dichas lağunas, contractan los indios por el agata unos con ofros en sus canoas, sin aver nescessidad de yr por la ticra. É portpic la laguma mayor é salada cresce é mengua por sus marcas (segund lo liace la mar), torlas las crescientes corre el agua della á la otra dulge tan reçio como to suele haçer un caudat é veloçe rio, é las menguantes con el mesmo ímpotu vacia, é va la corriente de la lagnna dulege á la salada: de lo qual se colige é consta claramente que la dicha laguma salada procele de la mar, y es clla mesma.

La grand cilodad de Temistitan está fundarla en esta laguna salada é deste la tierra fime al cuerpo de la dieha cildad, por qualruicera parte que quisicen entrar ál ella, Itay dos lequas ó puassi: liene quatro cntradas, todas de calcada fecha á mano, tan anclia como dos langas ginetas. Es tan grande la ciludad como SeviIla é Córlova: son las calles principales "della muy anchas é muy derechas. é atgunas destas é todas las demás son la mitad de lierra, é por la otra milad es acua, por la qual andin en sus canons; ć lodas las calles de trecho á trecho están abio:tas, por donde atraviessa of agua de las unas á las otras; y en fodas cstas aberturas, que algunas son muy anchas, hay sns puentes de muy anclias é muy grandes vigas juntas é regias é lien labradas, é tales que por muchas dellas pueten passar dicz de calıallo jumios á la par. É viendo que si los naturales desta cildedal quisiessen hacer alquna layçion, tenian para ello uuclto aparcjo por su assiento, é ser caleficada de la forma que está dicho; é que quitadas las puentes de las cntradas é salidas, podian dexar morir de liambre á los españoles, sin que pudiessen salir á la tierra, Inego que Cortés entró en la cibdad, mandió dar mucha priessa á hager quatro bergantines, é los hicieron muy presto, é lales que podian ectar trescientos hombres en la tierra, é ltevar los caballos carla vez que quisiessen.

Tiene esta cibdad muchas plaças, donde contimuancnte lay mercados é iracto de comprar é render; é sin essas plaças, que son como accesorias, tiene una tan grande cono dos veces la cibdad de Salamanca, torla sercadis de. provtates al rededor, donde hay cotidianamente más de sessenta mill personas comprando é ven- 
diondo todos los géneros demorcalderias. fue en lodas arpuellas partos se ladlan, assi de mantenimiculos a viluallas. como de joyas de oro é plata ci de plomo é laton

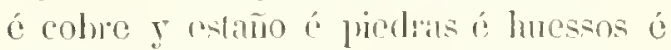
conchas de caracolés. é de plumas é penachos. Fi ríndense algunas piodras labradas é otras por labrar, é adobes é ladrillos, madua labracta ó por labrar de diverssas manpas. Hay calles de caca, donde renden todos los góneros re raleas de ares gre hay en aquella lierra é sus comarcas, assi como gallinas de las grandes, como paros, é tales como se dixo en el bilmo NT, capítulo XII * (los quales los chripatianos Ihaman paros de la papada). perdices, codorniçes, lavancos, dorales, çcrelas, tórtolas palomas, paxaritos de cañuch, papagayos, bularros, águilas, haleones, savilanes, cernicalos: é de alģtnas ares destas de rapiña renden los eueros con su pluma é cabeçs é pico é uñas. Tenden concjos, lichres, renalos, perros que erian castrados prara eomer: que no ladian.

IIay callos de herbolarios, donde hay todas las rayees é hierbas mederinales, assi potables como ungientos y emplastos. Hay casa como de bardreros, donde lavan é rapan lascalsecas. Ifay casas. donde dan de comer é de hober por presçio. liay houbres del arte de aquellos que en Catstilla llaman ganapanes, y con ofras partes bastages, para flaer é llevar cargas. llay mucha lina é rabbon. luascros de barpo, esteras de muchas maneras, assi para camas como otras más delgadas para ascicnto é para colcras de sabas é cámaras. Liay todas lis maneras de verduras qua se latlan, en ciperial gebollas, puerros, ajos, masiluerco, berros, horra-

- Debe nolarse en este silio que el libro XIV de la Ilistoria general y natural de Indias solo se conpone de diez capilulos, secun pucde verse desde la prigina 438 ś la 448 del tomo 1. Pero, como ya va advertido en olro lugar, seaso añadió oviedo al- jas, acceleras. cardos, Lagaminas. Esta

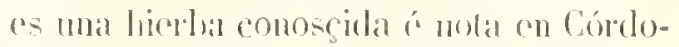
la y en Indaluroia é bmena para conmer. y as como explámegos ó cardillos. Hay fruclas de muchas mancras, en que hay gerecas, ginclas, gue son semejantes algo a las de lispaña: grayaras, ó muy lmenas. Tenden miol de aluejas é çera, é micl de cañas de maliz. gur son tan melosis é dulces como las de acúcill: é miel de umas plantas que Ilauan en esta Isla Española y ei otras maguey, ques muy mejor que arrope; c destas plamtas lakron acúcar é rino, que issimesmo renden.

Ilay á render muchas mancras de liblados de aitgodon de todas colores en sus madrajas, que paresce proprianente el consierto fue en esto hay al alcayeria de las sedas de Gramada, aunque estotro es en mucha mas cantidad. Tenden colores para pintores quantas se pueden hallar en España, é de tan excelentes matices é perifion. Trusten cueros de renados al pelo é sin él, teñidos, hlancosé de diverssas colores. Tenden muclia loça ó barro babrado en granil cantidad é muy buono. Tenden muchas varijas de linajas grandes é pequeñas. jarros. ollas. cúntaros. ladrillos, é innumerables é direrseas vasijas. todas de muy singular larro, é 10das ó las mas redriadas é pintadas.

Tenden mucho malize en grano y en pan cocidn: ronden pastelesdeares y empanadis de pescado: renden mucho pescado fresco r salado, crudo é guisado: renden luevos de gallinas é de ánsares é de otras muchas ares, y on mucha canlidad: venden torillas de luneros, fechas. Finalmente, que en los dichos mereados se venden todlas quantas cosas se luablan en toda la ticrra, que demás die las ques di-

stmos capilulos al cxpresado libro y cslos sc han perdido rlolorosamente, is lo que lambien pudo sueeder, fal vez pensó añdirlos y no lo hizo, por atender con preferencia á la terminacion de la obra. 
cho, son tantas é de tantas calidades, duo por la prolividad, dice Cortés en su relacion, é por no le ocurrir taulas á la memoria. é atun por no les saber los nombres á unchas, nis las expresa.

Cadar género de mereadleria se rende rn su calle, sin que entremetan otra mercateria algma, y en esto se liene mucha órken. Torlo se rend por cuenta é medida, exçpto que hasla en essa saçon ningma cosa se vidio render por pesso.

llay en aquella graund plaça una muy buena casa como de audicuçia. donde están siempre sentados dicz ó doese jueçes, que liluran lodos los casos é cosas que en el dicho liangiuez ó mereado acaesçen, é mantan castiqur los delinfjienles ó transgresoles de sus estatutos é ordenangas immediaté. Hay en aquella placa otras persoinas que andan continuo entre la gente, mirando to que se vende é las medidas con que miden lo que venden; é quicbran lo que está falso, é penan al que usaba dello.

Nunque es fuera de la rolaçion é historia que loca á Corlés, diré aqui un caso notable é ridieulo que en efello passó en esta grand cilsdad desde algunos años despues que se conquistó, el qual es á propóssito de los indios mereaderes. para deçir su astuçia é diligençia grande é ariso que lienen en las cosas de las mereaderias, y en lo que tractan é les paresçe ques útil á sus ganançias.

Noloria cosa es el castigo, que en España se dá á los herélicos, segund la calidad de sus delietos: que á unos açotan, á olros ponen en cércel perpétud, é á otros que se reconfilian, les ponen un Sanet Benito ó cosclete amarillo sin mangas é sin costuras por los lados, con una cruz grande colorada, vol sanguina, delante é otra detrís; á unos para que traygan esta insignia por timpo linitado, é á otros prara todos los dias de su vida é á otros queman por sus mérilos. Siguióse que un converso se penitención po: bus culpas en Temistitan, y el perlado ó jueces de la Sincta Inquisicion hiçiéronlo estar en el auto en pié, descalgo, sin çinto ó sin bonete é con un ririo ardiendo en la nano, é con el dicho Sanct Benito, en tanto que se divo una missa solempne un domingo: en la qual en su tiempo un notario del Sancto Officio leyó la sentencia é los méritos ó culpas de aquel delinquiente, por lo quali se le impuso aquella penitençia ó Sanet Benito. É ovo un sermon que predicó un deroto y esçiente predicador, conforme al auto é amonestando al penitente á la emuiconda de su vida, so pena del fuego, y extrortando á todos á bien rivir, como sc sucle haçer é predicar en casos semejantes, estando todas las personas prinçipales é offiçiales de Su Magestad pressentes, é mucha parte de la ciludad, é muchos indios de los convertidos é baptirados, para los instruyr en las cosas de nuestra sancta fóe catlúlica. Entre los quales indios un mercarler de los ricos, é soluradamente coludiçioso é diligente, no entendiendo bien la lıonra que á apuel recien conçiliado se le hico, parescióle que aquel grato de Since Benito debia ser una muy singular fiesta é lıonrosa para acpel penitençiaclo: é cómo ria cl indio que entre los clnipstianos españoles avia algunos cavalleros comendadores de las Órlenes de Santiago é Calatrava é Aleúntara, é de la Orden de Honlesa é de San Johan de Rodas, con eruçes cn los prehos de diferentes mancras é colores, é no traen urás de una cruz é pequeña, é á essotro diéronle dos é muy grandes, é una delante é olıa dedrás, assi persó el mereader queste nuevo lábito rra mas honrado é apresçialo á todos los olros, é que rra cosa que los chripstianos se presçiarian maś dél que de los otros ques dicho. assi como se acahó la missa, é se fué ol indio á su casa, arbitrando que le avia renido una grand ocasion pa- 
ra enricpuescerse piesto, hico hurgo haver tresçientos ó quatroçientos sanct licuilos ó mis, semejaules al de apuel reconçiliado, é púsose con ellos en el tiancier ó litcrealo, puestos en mo ó dos rimeros solire una mesa, y ch el canto drolla hincarla uma vara ó asta, y en ella puesto un Sanct Benito de arfuellos por muestra 6) señuelo, para que desile lévos se viesse la mercaderia que tractaba. P'nes cómo alžmos españoles Ilegaban á le progmuntar que para qué erau acuellos Sanct Benitos, y el indió los oyó nombrar, aprendió el nombre, é respondia que para hacerse (omendadores, como avian hecho al pues dicho. Los chripstianos réanse mucho dél e passahan adclante, porque era la mercarderia la ques dicho, y cl indio quedialsa dando roges, é diçiendo: "Sauct Benilo, Sanct Benito." En fin, cómo vido que no Ie quisicron comprar ninguno de sus Sanct Benitos, informóse de la casa donde vivia arruel reconciliarlo, é lieróselos torlos para ver si los queria comprar, é con mucho plaçer ofresçia de te haçer cortesia en el prescio. Wl olro peccarlor, cómo no esiaba tan contento de la nueva órden, como el indio pensaba , comencólo á amenaçar é á maltractar de palabra: de lo qual el indio muy espantado, se fué á quejur á la justiçia, donde le desenganaron de su mercaderia, é se fué, culpando ả su propria cobliçia, que le hico gastar su harcienda en lo que no le convenia, como siele acacscer á muchos, que se ocupan en las cosas que no entienden. Esto passó en efelto cono está dicho.

Tornemos á la historia é á las ofras particularidades de la grand cibdarl de Temistitan, en la qual hay muchas mezquitas ó templos é casas de oraçion, en que los indios tienen sus ylolos, é son de muy hermosos eleficios, repartidos ó puestos por collaciones ó harrios dellas. Y en los principales templos hay personas roligiosas de su solla, que residen alli continumente, para las quales hay sus apritados apossentos, allende do arpurdlas partes donde astán los vlolos: astos reli-

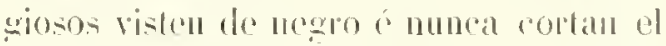
calbello ni le peynan, deste phe outran on aquella religion hasta que salen della. É torios los hijos de lis personas principales, azsi scenores como ciludidanos honiarlos, celán en aquellas roligniones é lálbitos descle chad le siele í ocho años hasta yue los sacan para los cassar : y esto más acaesece en los primogénitos, que han de heredar las casis, que en los ohros. To lienen acceso á muger. ni entra algmma en las lakes casas de religion : tionen alostinencia, é no comen de giertos namjares; y mís cll algun tiempo del año que en otios.

Entre arucllos templos hay uno funes el proincipal é mas magnifico, é tan grandle, que dentro dél (que está çereado do numro muy alto) se podria muy bien hacer cu otro tanto terteno ma villa de cuminicntos verinos: é dentro del dielıo çireuyto, todo á la redonda, hay muy gentiles apossentos de muchas salas é corretores, donde se apossentan los religiosos que allí cstán. Hay bien quarenta tores muy allas é bien libradas. quie la menor dellas liene cinquienta escalones para subir al cuerpo de la tore, é la mayor é mas principal es más alta que la torre de la iglesia mayor de Sevilla: é son todas de muy hermosa canteria é madera, ques mucha cosa de ver, porfuc toda la cantria de dentro de las capillas, donde tienen sus ydolos, es de ymagineria y caquicamies, y el marleramiento es todo de maconeria, é muy pintados de cosas de mónstruos é olras figuras é labores. É todas essas torres son enterramientos de scñores. é las capillas que en ellas tienen, son dedicadas cada una á su ydolo, á que tienen alguna particular deroçion. Hay tres salas priuçipales dentro deste grand templo, donde están los prinçipales ydo- 
los, de mucha grandeça é alinura é de diverssuls labores é figuras esculpidas, assi en la conteria como en el cumaderamicnto: é dentro destas salas estín otras capillas, que las puerlas por donde entran á ellos son muy pequeñas, y ellis no tienen claridad alg̣nia ; ć alli no estín sino aquellos religiosos, é no lodos. é dentro desLas casas están los bullos é figuras de los ydolos, aunque, como es dicho, de fuera hay tambien muchos.

Los mas principales destos ydolos, en quien cllos mas fúe é erecnçia tenian, derribó Ilernando Cortés de sus sillas, é los hiço echar por las éscalcras abaxo, é hiço limpiar aquellas capillas donde los tenian, yque todlas estaban Ilcnas de sangre de los liombres é muchachos que allí sacrificaban, é puso en ellas ymágenes de la sacratissima Vírgen Sancta Mlaria, Nuestra Scrĩora, é de otros sanctos gloriosos, é de apóstoles é mártires de Jesu-Clripsto. De to qual Monteçuna é los naturales sintieron mucha pena, é le diveron primero que no lo hiçiesse: (que si se supiesse por las comunidades, se levantarian contra el dicho Corlés, porque creian que aquel!os ydolos les daban todos los bienes temporales, é que dexíndolos maltractar, se enojarian é no les clarian mada, é les secarian los fruetos de la tierra, é moriria la gente de hambre.

El capilan Hernando Cortés les dixo é les dió á entender con las lenguas quín engeañados estaban en tener su esperança en aquellos ydolos, que eran licelios por manos de indios é de cosas no limpias. É que supiessen que lay un Dios solo, universal é Señor de lodos, que crió el çielo é la tierra é lodas las olras cosas, é liiço á ellos é á nosotros, é que este es sin prinçipio é immortal, é que á este ávian de adoràr é creer, é no á otra criatura ni cosa alguna. É assi á propóssito de la cathólica fée, les dixo todo lo quél supo de- çirles para desviarlos de sus ydolatrias é alractlos al conosçimiento de Dios, nuestro Scñor, é de su sagrada religion chripstiana. E Lodos, en espeçial Honteçuma, respondicron que ya cllos le avian dicho que no cran naturales de aquella tierra, é que avia muchos tiempos que sus predegessores fucron á clla. é que bien creian que podrian cestar criados en algo do aquello que tenian por costumbre de creer, por arer lanto tiempo que salicron de su naturaleça, é que Corlés, como mas nuevamente venido, sabria mejor las cosas que debian tener é creer que no ellos: que se las diresse é hiçiesse entender, quellos harian lo quèl les dixesse que cra lo mejor. I el mesmo Honteçuma é muclos de los prinçipales de la cibdad esiovicron allí con Cortés hasta quitar los ydolos, é limpiar las capillas, é poner las ymígenes, é todos con alegre semblante. E les defendió Corlés que no matassen criaturas delante de los ydolos, de niños é niñas é otras personas liumanas, como lo acostumbraban, ni en olra manera alguna; porque demás de ser cosa aborresçilule á Dios, el Rey de España, nuestro señor, por sus leyes lo prolibe, é manda quel que matare á olro, que lo maten; é de alí adelante se apartassen de incurrir en tan gran delieto é crímen. É assi en todo el tiempo que Cortés esturo en aquella grand cildedad, dende adelante no se rió malar ni sacrificar alguna criatura por entonces.

I insi todo esto que está dicho lo escribió Hernando Cortés al Emperador, nuestro señor. È bien pudo Dios dar lugar á ello; pero para mí yo tengo por mararj. lla, é grande, la mucha paçiençia de Montecuma é de los indios prinçipales, que assi vieron tractar sus templos é ydolos. Nlas su disimulaçion adelante se mostró ser otra cosia, riendo que una gente extrangera é de tan poco número les prendió su señor, é por qué formas los 
lacgia tributarios, é no castigaban é yurmahan los prinçipales, é se anifuilabsun disipalanu sus templos ó sofla, all que-

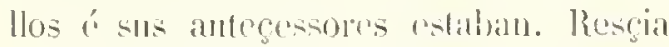
cosa me paresge comportarla con tanta quictur]; pero adelante, como lo diré la livisoria, mostró el lirmpo lo gue on el peche restaly ocmllo en torlos los indiog sencralnente.

\section{Capítulo XI.}

En el qual se tracla de la ydolatria édiabólicos saerificios de los indios de la Nueva España, y en espeecial en la grand cibdad de Temistitan; é de olras particulardades á la listoria pressente permitidas, en conlimagion de la relietion ruel capilan Hernamdo Cortis envióal Rey, nuestro señor. Los lullos é cuecros de los vidolos en quien aquellas gentes crevian é adoraban en la saçon quel capitan Ilernamdo Cortés passó á la Nueva España, (fuando la conquistó, eran hechos de mayores estátuas é grandega que la altura de un hombre alto. É la materia, de (ue eran compuestos, era ma cierta pasta ó masa de torlas las semillas é legumbres quellos comen, molidas é mezcladasé amasadas unas con otras con sangre de coraçones de enerpos é hombres humanos: los quales sacrificándolos é vivos. Los abrian por los pochos é les sacaban el coraçon, é de aquella sangre les amasaban acjuclla lrarina ó pasta, é hacian tanta cantidad quanta bastala para formar é lıacer aquellas cstíunas, tan grandes romo está dirho. Despues de liechas. les ofrescian más coraçones, (juc assimesmo sacrificabłum, ć untábantes las caras con aquella sangre fresca, con que digen los indios que aplacan á sus dioses. si están enojados, é los agradan é-haçen benignos. É á cada cosa tienen sn ydolo dedipado. al uso de los gentiles: por manera que para pedir firvor para la gnesra, tiencn mu ydolo. é para sus labraingas otro. é azi para cada cosa de las quellos quicren ó dessean que sc hagan. Tambien tienen sus ydolos, á quien honran é sirven.

Ilay en la grand cibdad de Temistitan muchas casas muy grandes é muy buenas, é la causa de aver tanlas que son principales. es porque todos los senores de la tirred que rrim rassillos de Nontecuma, tenian casa en la cil-dad é residian en cella cierto tiempro del aio. Demás desto lary muchos ciludarlanos rieos, que ticnen assimesmo muy buenas rasis con grandes é complidos apossentos, é muy gentiles vergeles de flores do diverssas maneras é nuy olorosas, assi en los apoasentos altos como en los baxos.

Por la ma calçada que í csta populosa ciblad cntra, vienen dos caños de arọamasa tan anchos como dos passos cada uno, é tan altos quassi como un estado, é por a uno dellos viene un golpe de agua dulçe muy buena. é tan gruesso como el curipo de mn hombre. que va á dar enmerlio de la ciludad, de que se sirven é belen torlos, y el otro caño está vacio: y quando quieren limpiar el que llova el agua, échanla por essotro en tauto rue se limpia. I porque el agua lad de passar por las puentes, á cansa de las quebradas, por donde traviesa el agua salada. echan la dulçe por unas canales tan gruessas como un buey; que son de la longura de las diclas pucntes. é assi sc sirve foda la ciludad. Hombres hay assimesmo, que en canoas traen ag̨ua á vender á la ciludad por todas lis ralles, é la manera de cómo la toman del caño es que llegan las canoas delaxo de las puentes, por donde estín las canales ques 
dicho, é alli hay hombres en lo alto que hinchen las canoas, é les pagan por ello su trabaxo.

En todas las entradas de la cibdad, y en las paltes donde descargan las canoas, ques donde vienen la mayor parte de los mantenimientos que entran en la cibdad, hay chocas licchas, donde están personas por guardas, que resçiben çierto derecloo de cada cosa que entra. Esto dice Cortés en su relaçion, (que no sabe si cra para Montecuma ó para proprios de la cilidad; pero que cree que era para Monteçuna, porqué en otros mereados de otras provincias se cogian semejantes de. rechos petra los señores dellas.

llay en todos los mercados é lugares públicos de la ciludad todos los dias muchas personas, trabaxadores é macstros de todos officios, esperando quién los alquile por sus jornales.

Lí gente desta cilydad es de mas maña é mas polida en su restir é serviçio que no la otra de las otras cilulades é provinçias, porque como allí residia y estaba siempre acpuel grand principe Monteçuma, é todos los señores prinçipales sus vassallos ocurrian siempre á su corte, en esta ciblad, avia en ella mas poliçia. X cra la casa é servicio deste señor con tanto conçierto, assi como lo podia arer en España, é aun para espantarse los que lo vian, considerando ser esta gente bárbara, é tan apartada del conosçimiento de Dios é de la comunicaçion de otras naçiones de raçon. Era cosa admirable ver la que tenian en todas las cosas tocantes á la repúlılica é á su señor, á quien tenian mucha obidiença é respecto: en cuya cámara tenia contrahcehas, como está clicho, de oro é plata é piedras é phumas, todas las cosas que debaxo del sielo hay en su señorio, fan al natural lo de oro é plata, que ningun platero en Europa lo pudiera laçer mejor; é lo de las piedras cra tal, que no bastalsa juiço á compreTUMO III. hender con qué instrumentos se podia haser tan perfetto; é lo de pluma no se pudiera hager tan al proprio de çcra, ni bordado, ni de otra forma. Y porque de muchas cosas destas se llevaron á Espaĩa, quellas mesmas lo testificaron, excusado es gastar ticmpo en r'elatar su forma é primor.

Yo ví algunas picdias jaspes, nicles, calçilonias, amatistas, jaçintos, connio. las é plasmas de esmeraldas, é otras de otras espeçies, labradas é fechas ca. begas de ares, é otras lıcchas animalesé otras figuras, que dubdo aver en España ni en Italia quien las supiera lacer con tanta perfiçion.

El señorio de Nontecuma cra muy grande, porque á dosçicntas leguas de un ca. bo é de otro de aquella ciblad, donde residia, enviaba mensageros é mandaba en todos, y era obedesçido é complido quan. to mandaha, puesto que avia algunas pro. vinçias en medio de aquellas tierras, con quien tenia geverra. Pero diçe Cortés en su relaçion, que ál lo quél alcançó, cra su señorio quassi tamaño como España, porque hasta sessenta leguas de la otra parte de Puntunchan, ques el rio de Grijalva, envió mensageros Montecuma, mandando que se diessen por vassallos del Rey de Castilla, nuestro señor, los naturales de una cibdad que se diçe Cumatan, que hay desle Temistitan á clla dosçicntas é rejnte leguas. Allende de re. sidir, como se ha dicho, los señores prinsipales en la cibdad é corte, donde este grand prínçipe Nonteçuma residia, todos los mas tenian sus hijos primogénitos en el servicio é casa deste señor. Y en todos los señorios dessos señores, sus súlıditos, tenia Montecuma fortaleças y en cllas sus alcaydes é gente, é sus goberuadores ó recaudadores del serviçio é renta que cada provinçia le dalsa : é avia cuenta é racon de lo que cada uno era obligado á contribuir, porque tiencn caractéres é fi39 
guras cscriptits en papel, yue haçen, por donde se entienden muy bien.

Cada provingeria servia con su género de scrviçio, scgund la calidad de la tierra: por manera que á poder del señor venia toda sucrte de cosas, que en las dichas provinsias avia. Era tan temido de todos, assi pressentes como ausentes, quanto lo pudo ser al más temido é acatado prínçipe del mundo. Tenia fuera é dentro de la cilsdad muchas casas de plaçer é cada una de su manera de passaticmpo, tan bien labradas quanto se puede deçir, é segund convenia á tan grand prínçipe.

Tenia dentro de la cildad surs casas de apossento, tales é tan grandes é tan maravillosas, que diçe Cortés en su relacion fucha á Céssar, que en España no hay otras semejantes. E tenia otra poco menos buena que esta, donde tenia un muy hermoso jardin con unos miradores que salian sobre él, é las columnas é losas dellos de muy preçioso jaspe, muy bien labradas. Avia en esta casa apossentos, para donde dos prínçipes muy grandes estoriessen con todo su servicio.

Hay en esta casa dicz estanques de agua, donde tenia todos los géneros de aves de agua que se hallan en aquellas partes, que son muchos é diverssos, 10das domésticas. E para las aves que se crian en la mar, eran los estanques de agua salada, é para las que cran de rios, avia lagunas de aggua dulçe, la qual agna vaçiaban de çierto tiempo á tiempo por la limpiça, é la tornaban á lienchir por sus caños. É á cada género de aves se daba afuel mantenimiento que cra proprio á su naturaleģa, é con que ellas, estando libres, se mantenian en el campo ó en el agua: de forma que las que comian pescado se lo daban; é las que gusanos, gusanos; é las que mahaiz, mahiz; é las que otras semillas mas menudas, por consiguiente se las daban; y cra la cosa con sí tan grancle, que á las aves que solamente comian pescadlo, se les daha cada dia diez arrobas del que se toma en la laguna salada. Aria trescientos hombres que tenian cargo destas aves, que ningma otra cosa entendian. Avia otros hombres que solanente entendian en curar las aves que adolesçian. Solse cada alverea y eslanque destas aves avia sus corredores é miradores, muy gentil é polidamente labrados, donde Monteguma se renia á recrear é las ver.

Tenia en esta casa un quarto, en que tenia hombres é mugreres é niños blancos de su nasçiniento en el rostro é cucrpo, é cabellos é ojos é pestañas é çcjas.

Tenia ofra casa muy hermosa, donde avia un grand palio solado de muy gentiles losas fecho á manera de bosques; é las casas eran hondas como estado é medio, é tan grandes carla una como seys passos en quadra; é la mitad de cada una destas casas cra cubicrta el soterrado de losas, é la milad que quedaba por colsrir tenia ençima una red de palo muy bien hecha; y en cada una destas casas avia una ave de rapiña, començando de cernícalo hasta águila, todas quantas se haHan en España, é muclas mas ralcas que allá no se han visto. É de cada una destas ralcas aria mucha cantidad, y en lo cuhierto de cada una destas casas avia un palo como alcándara, é otro fucra debaxo de la red, que en el umo estaban de noche é quando llovia, y en el otro se podian salir al sol é al ayre, é á curar sus plumas. I toulas cstas aves daban á comer gallinas todos los dias, é no otro mantenimiento. Ivia en esta casa çiertas salas baxas é grandes, fodas llenas de jaulas grandes de muy gruessos maderos, muy bien labrados y encaxados, y en todas ó en las mis dellas avia leones, tigres, lobos, corras é gatos de diverssas maneras, é todos en cantidad : á los quales daban de comer gallinas quantas les Lasta- 
han; é para estos animales é ares otros Iresçicntos hombres avia, que tenian cargo dellos.

Tenia otra casa Monteçuma, donde estaban muchos liombres é mugeres mónstrnos, en que avia chanos, corcobados, contraheclos é otros con otras disformidades; é cada una manera de mónstruos en su quarto por sí : é tambien avia para estos personas dedicadas para tener cargo dellos.

La manera del servicio deste grand prínçipe Monteçuma, era que todos los dias, en amanesçiendo, cullaban en su casa seysçientos señores é personas principales, las quales se scntaban é otros se passcalan por unas salas é corredores que avia en la dicha casa; é allí estaban liablando é passando tiempo, sin entrar donde la persona del señor cslaba. Los servidores destos é personas de quien se acompañaban, henchian dos ó tres patios, otros bien grandes é la calle, ques muy grande; y estos estaban sin salir de allí todo el dia liasta la noche, é al tiempo que traian de comer al rey Monteçuma, assimesmo lo traian á todos aquellos señores, tan complidamente quanto á su persona, é lambien á los servidores é gente destos les daban sus raçiones. Avia cotidianamente despensa é botilleria abierta para lodos aquellos que quisiessen comer é beher.

La manera de cómo le daban de comèr era esta: que renian tresçientos ó quatroçientos mançebos con el manjar, que era sin cuento, porque todas las veçes que este prínçipe comia é çenaba, le flaian de lodas las maneras de manjares, assi de carnes como de pescados é fructas é lierbas que en foda la tierra se podian a ver; é porque la tierra es fria, traian debaxo de cada plato y escudilla de manjar un braserico con lrasa, porque no se enfriasse. Poníanle todos los manjares en una grand sala en quél comia, que quas- si toda se licnehia, la gual cstaba muy bien esterada é limpia; y él cstaha sentado en una almohada de cuero pequeña é muy bien hecha.

Al tiempo que comia estalan allí, desviados dél, çinco ó seys señores ançianos, á los quales él daba de lo que comia, y estaba en pié uno de aquellos serviclores, que le ponia é alçaba los manjares, é pedia á los otros que estaban mas afuera lo que era nesçessario para el serviçio. Al prinçipio é al fiu de la comida siempre le daban agua á manos, é con la tolalla que una rez se limpialsa, nunca más se tornaba á limpiar, ni tampoco los platos y escullillas, en que le traian una rez el manjar, se los tornaban á traer, sino siempre nuevos, é assi laacian de los bra. sericos. Vestiase todos los dias quatio maneras de restiluras, fodas mucvas, é nunca más se las vestia otra re\%. Torlos los scĩores que entraban en su casa, no entraban calçados, é quando vban delanto dél algunos que enviaba á llamar̉, llevaban la cabeça é ojos inclinados y el cuerpo muy lıumillado: é labblando con él, no le mirahan á la cara, lo qual lıaçian por mucho acalamiento é reverençia. É súbese que lo liacian por este respecto, porque çiertos señores reprelıendian á los espaĩoles, é deçian que quando lıablaban con el capitan Ilernando Cortés, que por qué estaban esentos, mirándole á la cara, que paresçia desacatamiento é poca verguiença .

Quando salia fuera Nonteguma, queera pocas veçes, fodos los que yhan con él é los que topaba por las calles, volvian el rostro y en ninguna manera le miraban, é todos los demás se postraban hasla quél passaba. Llevalıa siempre delante de sí un señor de aqucllos con tres varas delgarlas altas, para que se viesse que yba allí su prersona; é quando lo desçendian de las andis, fomaba la una en la mano é llevábala hasta donde yba: Eran tantas las 
çerimonias que este principe tenia en su serviçio, que seria muy largo proçesso degirse, ni ann se sabrian assi expresar, porque ninguro de los Soldanes, ni otro infiel señor, de quien lasta d pressente tenemos notiçia, no se cree que tantas ni tales serimonias en su serviçio tengan ó hayan usado.

\section{CAPITULO XII.}

Cómo por mandado del adelantacio Diço Velazquez fué por capitan é teniente suyo á la Nueva España e capitan Pámphilo de Karvaez, con revocaçion de los poderes que dicho adelantado avia dado al capitan Ilernando Corlés; é del recuentro que cntre estos dos capitanes ovo; ć cómo fué presso Pámphilo de Narvacz *, ć quedó Hernando Cortés muy más apoderado é absoluto capilan despucs desta viloria.

\section{L} que la historia cuenta en este capítulo es assimesmo conforme á la relaçion, quel capilan IIcrmando Cortés escribió á Céssar, de la prission dei capilan Pámpliilo de Narvaez, al qual envió el adclantado Diego Telazquez con una armada é gente á su propria costa, á descomponer é remover á Hernando Corlés, é que lovicsse en su nombre del dicho adelantado la Nueva España, despues que supo que Cortés avia enviado al Emperador, nuestro señor, sus embaxadiores é un rico pressente, con la relaçion de lo que avia hecho en la Nueva España con la gente é armada, con que le envió el mesmo adelantado; é sin le responder, ni dar cuenta ni raçon, ni lasece el reconosçimiento que cra obligado, como á su sujerior. que le avia dado el cargo. É cuéntalo él dẹsta manera, aunque en menos palabras lo dise por la sentençia é relaçion de su mesma carla.

Estando Cortés en la grand cibdad de Temistitan, proverendo las cosas que te parescia que conveniam al serviçio del Emperador , paçificando é atrayendo á su devoçion é amistad muchas provinçias é lierras, pobladas de muchas é grandes cibdades é villas é forlalegas. é descubriendo minas, é sabiendo é inquiriendo muchos secretos de las ticrras é señorios del prínęipe Monteçuma, como de otros es- tados que con él confman, è de que Mlonteçuma procuraha tener notiçia; é lodo con tanta roluntad é contentamiento del dicho Honteçuma é de los naturales de aquellas lierras, como si de mucho tiempo ovieran conosçido á la Cessírea Mag̣estad por su Rey é señor natural, no con menos roIuntad haçian todas las cosas que en su real nombre ITernando Cortés les mandaba. I en este exerçiçio gastó de tiempo Ilernando Corlés, desde los ocho de no. riembre de mill é quinientos é diez y nuere anos hasta entrante d mes de mayo del signiente año de mill é quinientos é reynte, que estando en toda quietud é sosicgo en la grand ciludad de Temistitan, é teniendo repartidos muchos de los es. pañoles por muchas é diverssas partes, paçificando é poblando aquella tierra, ê con mucho desseo que fuessen navios con la respuesta de la rẹlaçion quél avia hecho de aquella tierra á Su Hagestad, para enviar con los narios que fuessen ${ }^{\circ}$ la que despues envió, é las cosas de oro é joyis, que avia despues resçibido para $\mathrm{Su}$ Magestad; fueron á Cortés giertos indios vassallos de Honteruma, de los que en ta costa del mar del Yorle viven, é dixéronle que junto á las sierras de Sanct Martin (que son en la dicha costa, antes del puerto ó Jalhia de Sanct Johan) avian Ilegado diez é ocho navios, é que no sabian quién

- Aqui se añadia en el original: “É le fué quebrado un ojo." Mas está borrado. 
eran, porque assi cómo los vieron en la mar, fueron á le avisar dello. É trás estos indios llegó otro, natural de la isla Fernandina, con una carta de un español que Hernando Cortés tenia puesto en la costa por espia, para que si navios vinics. sen, se le diesse raçon dellos; é de aquella villa que allí estaba çerca de aquel puerto, porque no se perdiessen, tenia mandarlo (jue los acogiessen.

En aquella carta se contenia que tal dia avia asomado un navio enfrente del dicho puerto de Sanct Johan, solo, ć avia mirado por toda la costa de la mar quanto su vista podia compreliender, é no avia visto otro, é que creia que era la nao que Cortés avia enviado á Su Magestad, porque ya era tiempo que rolviesse; é que para mas certificarse el ruesto escribia, qucdaba esperando que la dicha nao llegasse al puerto para se informar dclla, é que luego yria á le llevar relaçion.

Cómo Cortés vielo esta carta despachó dos españoles, uno por un camino é otro por ofro, porque no errasscn á algun mensagero, si de la nao viniesse: é mandóles que allegassen hasta el pucrtoé supiessen quántos navies cran llegados, é de dónde eran é lo que traian, é rolviessen con toda la diligencia que fuesse posible á decírselo. Assimesmo despachó otro que fues. se á la villa de la Teracruz á les leçir que de aquellos navios avia sabido, para que de allá assimesmo se informassen é le avisassen de lo quellos pudiessen saber. É otro mensagero envió al capitan que con los ciento é çinquienta hombres enviaba á haçer el pueblo de la provinçia é puerto de Guaçacalco: al qual escribió que dó quiera que su carta le alcançasse, se estoviesse, é no passasse adclante liasta que vicsse otra su segunda letra, porque tcnia nueva que cran llegados al puerto ciertos 'navios. El qual, segund despucs paresçió, ya quando llegó esta carta, sabia de los navios, que venian.
Enviados esios mensageros, se passaron quince dias que ninguna cosa supo, ni oro respuesta de ninguno dellos, de lo qual cstovo no poco espantado: é passados otros quince dias, fueron otros indios, vassallos assimesmo de Monteçuna, de.los quales supo Cortés que los navios estaban ya surtos en el puerto de Sanct Johan, é la gente desembarcada, é que traian ochenta caballos, é ochoçientos lıombres, é diez ó doçe tiros de fuego, lo qual todo llevaban figurado en un papel de la tierra, para lo mostrar é informar á Monteçuma. É dixeron á Cortés quel español, quél tenia puesto en la costa é los otros mensageros quél avia enviado, estaban con aquella gente, é que les avian dicho á cstos indios quel capitan de aquella gente no los dexaba venir con la respuestá, é que se lo dixesse assi á Cortés.

Sabido esto, el capitan Hernando Cortẹs envió á un religrioso quél traia consigo, con una carta suya é otra de los alcaldes é regidores de la villa de la Teracruz, que estaban con él en la dicha cibdad: las quales yban dirigidas al capitan é grente yue á aquel puerto avian llegado, haçićndoles saber muy por estenso lo que en aquella ticrra le avia subçedido; é cómo tenia muchas ciblades é villas é fortaleças conquistadas é paçíficas é subjetas al serviçio del Rey de España, nuestro señor, é de su corona real de Castilla, é presso al señor prinçipal de torlas aquellas partes; é cómo estaba en ayuella grand cibdad, ć la calidad della, y el oroć joyas que para Su Magestad tenia ; é cómo avia enviado reliçion de aquella tierra á Céssar. í que les pedia por merçed le hiçiessen saber quién cran, é si cran vassallos naturales de los reynos é señorios de Su Mageslad, le escribicssen si yban á aqueIla ticra por su real mandado, ó á poblar y estar cn clla; é si passahan adelante ó avian de volver atrás, ó si traian alguna nesçessidad, quél los laria pro- 
reer de todo lo que possilsle á él le fuesse, é que si eran de fuera de los reynos del Rey Emperador, nucstro señor, assimesmo le avisassen si traian algma nesçessidad, porque tambien la remediaria, pudiendo. Donde no, que les requeria de parte de Su Hagestad que luego se fuessen de sus tierras é no saltassen en ellas, eon aperçebimiento que si assi no lo hiciessen, yria contra ellos con todo el poder que toriesse, assi de españoles como de naturales de la tierra, é los prenteria $\delta$ mataria, como á extrangeros que se querian entremeter en los reynos é señorios de su Rey é scñor. Partido el dicho religioso con este despacho, desde á cinco dias llegaron á la cibdad de Temistitan veynte españoles de los que en la villa de la Veracruz estaban por Cortés, los quales le llevaloan un clérigo é otros dos legos, que avian tomado en la dicha villa: de los quales supo cómo el armada é gente, que en el dicho puerto estirba, cra del adelantado Diego Velazquez, é yba por su mandado; é que era capitan della Pámphilo de Narvaez, veçino de la isla Fernandina, é que llevaba ochenta de caballo, é muchos tiros de pólvora, é ochoçientos hombres, entre los quales avia ochienta escopetas é çiento y veyute ballesteros, é que se. nombraba capitan general é teniente gobernador de aquellas partes por el dicho adelantado Dicgo Velazquez, é que para ello llevaba provisiones de Sir Magestad; é que los mensageros que Cortés avia enviado y el hombre que en la costa tenia, estaban con el dicho Pámphilo de Narvaez, é no los dexaba volver. Eil qual se avia informado dellos cómo Cortés avia poblado alli aquella villa doçe leguas del dicho puerto, é de la gente que en clla estaba, é de la que Cortés enviaba á Guaçacalco, é cómo estaban en una provinçia que se diçe Tuchitebeque, treỹnta leguas del dicho puerto, é de todas las otras cosas quel dicho Cortés avia fecho en aquellas partes, las cibdades é villas que tenia conquistadas é pacificiers, é de la gran cibdad de Temistitan, é del oro é joyas que en la tierra se avian avilo; se avia informado dellos de todas las otrás cosas que le avian sulbceclido á Cortés. É que á estos avia cuviado el diclıo capitan Pámpliilo á la villa de la V'eracruz, á que si pudiessen lablassen de su parte á los que en ella estaban, é los atraxessen á sil propóssito, é levantassen contra Cortés. İ con estos pressos le llevaron más de ģient cartas quel dicho Narvacz é los que con él estaban, enviaban á los de la dicha villa, diçiendo yat diessen crédito á lo que aquel clérigo é los otros que yluan con él de su parte les dixessen, prometiéndoles, si assi lo liçiessen, de parte de Diego Velazquez é dél en su nombre, muchas meresedes, é çertificándoles que á los que lo contrario hiciessen, les seria fecho mal tractamiento.

Quassi junto con esto llegó á Cortés un español de los que yban á Guaçacalco con cartas del capitan dellos, que era Johan Velazquez de Leon, el qual le haçia saber cómo la gente que aria llegado al puerto era Pámphilo Narvaez, que ylua en nombre de Diego Velazquez con la gente que llevalsa. Y envióle una carta, quel diclıo Narvaez le avia enviado con un indio, como á pariente del Diego Velazquez é cuñado del dicho Narvaez, en que por ella le deçia cómo de aquellos mensageros de Cortés avia sabido que estaba alli con aquella ggente, é que luego se fuesse con ella á él, porque en ello haria lo que complia y era obligado á sus debdos, é que bien creia que Cortés le tenia por fucrça, é otras cosas quel dicho Narvacz le escribia. El qual capitan, no solanente dexó de açeptar lo quel dicho Narvaez por su carta le deçia, mas aun luego se partió, despues de arer enviado esta carta, para se juntar con Cortés, con toda la gente que tenia. 
Despues que llernando Cortés se informó de aquel elérigo é de los otros dos que eon él yban de muclas cosas, é de la intençion de Dieggo Velazquez é Narvaez, é cómo se avian movido con aquella armada é gente contra Cortés, porque avia enviado la relaçion é cosas de aquella tierra a Su Magestad é no al dieho adelantado Diego Velazquez; é cómo yban eon volınlad de matar á Cortés é á muchos de los de su compañia (que ya desde Culba traian señalados), é supo assimesmo quel liçenciado Figueroa, juez de residençia en esta lsla Española, é los jueses é officiales de Su Magestad que aqui residian, sabiendo qquel dicho Diego Velazquez haçia aquella armada, é la volıntad eon que la Laçia, constándoles el daño é deserviçio que dello podia resultar á Su Magestad, enviaron al liçençiado Lúcas Velazquez de Ayllon (uno de los dichos jueçes desta Audiençia Real) con su poder, á l'equerir é mandar á Diego Telazquez que no enviasse a(fuclla armada: el qual fué, é halló al dicho adelantado Diego Velazquez con toda la gente della en la punta de la isla Fernandina, ya que queria passar, é le requirió á él é á todos los que en la dicha armada yhan que no fuessen, porque dello Sus Magestades serian deservidos, é solyre ello les puso muchas penas, non obstante lo qual, todavia envió la dicha armada; é quel dicho liçençiado Ayllon estaba en el diclıo puerto, que avia ydo juntamente eon ella, pensando evitar el daño que de su yda se podia segnir : Io qual todo entendido rle Cortés, envió lıego al mesmo clériggo con una earta suya para Narvaez, diçiéndole cómo avia sabido de aquel padre reverendo é de los que con él aviun yolo, cómo él era eapitan de la grente que arjuella armada traia, é que holgalıa que fuesse él, porque tenia otro pensamiento, viendo yue sus mensageros no rolvian. Pero que pues él sabia que Cortés estaba en aquella tierra en ser- vicio de Sus Magestades, se maravillaba como no le escribia ó enviaba mensagero, haçiéndole saber su venida, pues avia de lolgar eon él, assi por ser su amigo mucho tiempo avia, como porque ereia quél yba á servir á Su Magestad, que era la eosa que Cortés más desseaba ; é que junto con esto no le paresçia bien enviar, eomo avia enviado, sohornadores é cartas de induçimiento, alterando á las personas, que Cortés tenia en su compañia sirviendo á Su Magestad, para que se levantassen é passassen á él, como si fireran los unos infieles é los otros elripstianos, ó los unos vassallos del Emperador, nuestro señor é los otros sus descrvidores, é que no lo dehia haçer; é le pedia por merçed que de allí adelante no toviesse aquellas formas: antes le hiçiesse saher la causa de su venida. É que le avian dicho que se intitulaba capitan general é teniente gobernador por Diego Velazquez, é que por tal se avia fecho pregonar é publiear en la tierra: é que avia fecho alealdes é regidores, y executado justicia, lo qual era en muelıo deserviçio de Su Magestad é contra todas sus leyes, porque seyendo aquella tierra de Su Magestad, y estando poblada de sus vassallos, é aviendo en ella justiçia é eabildo, no so dehia intitular de los diehos offiçios ni nsar dellos, sin ser prinero á ellos resçebido, puesto que para los exerger llevasse provisiones de Su Magestad. Las quales, si llevaba, le pedia por merçed é le reque. ria las presentasse ante él en el eabildo de la Veraeruz, é quel eabildo y él las obedescerian como eartas é provisiones de su Rey é señor natural, é eomplirian en quanto al real serviçio de Su Magestad conviniesse; porque él estaba en aquella eiblad, y en ella tenia presso á aquel señor, é tenia mucha suma de oro é joyas, assi de lo de Sul llagestad como de los do su compañia é suyo, lo qual no osaba dexar, con temor que salido él de la cibdad, 
la gente della se revolveria, é se perderia tanta cantidad de oro é joyas, é tal cibdad: mayormente que perdida aquella, seria perterse toda la ticra. E assinesmo escribió otra carta Cortes al licenciado Ayllon; pero ya Narvaez lo avia prendiclo y envíadole con dos navios.

El dia queste clériço se partió de Corlés. le llegó un mensagero de los que eslaban en la villa de la Veracruz, con el qual le hicieron saber que torla la gente de los naturales de la tierra estaban levantados e fechos con el dicho Narracz, en espeçial los de la villa de Compual é su partido, é que ningumo dellos queria ye á servir á la dicha villa, assi en la labor do la fortaleca como en las otras cosas que solian servir, diçiendo que les avia dicho Narvaez que Cortés era malo, é quél ylua á prenderle á él é á lodos los de su compañia, é los avia de llevar pressos é dexar la tierra. É que la gente quel dicho Narvacz llevala, era mucha é la de Contés poca; é que Narvaez lıaia muclıos cahallos é tiros, é Cortés tenia pocos; é que querian ser ál viva quien vençe. É que le haçian saher que eran informados de los indios que Narvaez se yba á apossentar á la cibdad de Compual, é que ya sabia quán çerca estaba de aquella villa ; ć que creian, segund el mal propóssito que Narvaez traia contra todos, que deste alli yria contra ellos; é teniendo de su parte los indios de la cibdad, que les paresçió que debian dexar la villa sola, por no pelear con ellos, por critar escándalo; é se subian á la sierra por causa de un indio grand señor, amigo de Cortés, donde pensaban estar hasta quél les enviasse á deçir Io que hiçiessen.

Diçe Cortés en su relaçion que cómo él vido el grand daño que se començaha á aparejar, le paresçió que con yr él adonde Narvaczestaba, se apraçguaria mucho; porque viéndole los indios, no se osarian levantar, é porque pensaba dar órden con Narvilez para que torlo rompimiento cesasse. É partióse àcuel dia, ilexando la fortalosa muy hic'n proveyda de malniz é agaua con quinientos lomberes dentro en ella é al memos tiros de pólvora; é con la otra gente que alli tenia, que serian lasta septenta hombres, siquió su camino con algunas personas prinçipales de Jlontecuma: al qual antes de su partila hico muchas exhortaçiones, diçiéndlole que mirasse el servicio del Rey, nuestro señor, é que ya se acerrabia dicmpo, en que a vian de resgelir muchas mercedes de Su Magestad por Ios serviçios que avia fecho; é que aquellos españoles le lexaha encomendados con torlas arfuellas joyas quél le aria dado é mandado dar para Su Magestad, porque él ỵba í aquella gente que nuevamente aria venido á la tierra á saber quién cran, porque hasta estonçes no lo aria sabirlo, é que creia que cra mala gente é no vassallos dei Rey, nuestro señor. Y él le prontetió haçer proveer á los que alli quedaron de todo lo nescessario, é de guardar nucho fodo lo que alli Cortés decaba para Su Magestad: é díxole que aquellos suyos que le dió, le guiarian por camino que no saliesse de su ficra, porque fuesse proveydo de todo lo nesçessario; é que le rogaba que le arisasse si aquella gente, nuevamente venida, si era mala, porque luego le enviaria mucha gente de guerra para pelear contra aquellos para los echar de la tierra. Lo qual todo le agradesçió Cortés , é le çertificó quel Rey le haria muchas mercedes, é dióle mucha ropa é joyas á él é á un hijo suyo é á otros scinores muchos, que con él á la saçon estaban.

Y en una cibdarl que se diçe Churultecal topó al capitan Johan Yelazquez (rue la historia la dicho que lo enviaba á Guaçacalco), que con toda la gente se venia; é sacarlos algunos que cstalsan mal dispuestos, que envió á la ciłsdad con él, con los demás aumentó 
su esquadron é siguió su camino. É quinçè legruas mas adelante de Cliurultecal topó ál aquel padre religcioso de su compañia, quél aria enviado al puerto á saber qué gente era la del armåda, que alli aria renido: el qual le truxo una carta de Narraez, en que le deçia quél traia çiertas provisiones para tener aquella tierra por Diego Yelazquez, é que lueggo fuesse á donde él estaba da las obedescer é complir ; é quél tenia fecla una rilla é alcaldes é regidores. E aquel padre le diso cómo avia prendido al liçençiado $\mathrm{A}$ Ilon é á su hermano el alçuacil, é los avia cnviado en dos navios; é cómo allá le arian acometido con partido para queste religioso atraxesse á algunos de la compañia é opinion de Cortés para que se passasen á la de Tarraez; é cómo arian fecho alarde delante dél é de çiertos indios que con él fueron de toda la gente, assi de pié como de caballo, é soltaron el artilleria que estaba en los narios é la que estaba en tierra, á fin de los atemoriçar: é que le dixeron al dicho religgioso: "Mirad cómo os poders defender de nosotros, si no hacers lo que quisiéremos. L tambien diso cómo avia lıallado con el dicho Narraez á un señor de la tierra, vassallo de Yonteçuma, é que le tenia por gobernador suyo en toda su tierra desde los puertos hasta la costa de la mar: é que supo que al dicho Narracz aria Iialslado de parte de Yonteçuma, é dádole çiertas joyas de oro, y el dicho Narraez le aria darlo á él otras cosas: é que supo que avia despacharlo de alli çiertos mensajeros para el dicho Monteruma, y envíadole á deçir quél le soltaria, é que ylua á prender át Corlés é á los de su compañia. é yrse luegogo é dexar la tierra é naturales della en su lilsertad. Finalmente, que segund lo que al Eimperador, nuestro señor, Cortés escribió, entendió quel Narvaez se queria apossesiorer de la tierra por su auctoridad, sin pedir que TOMIO III. fuesse resçelido de nimguna persona, é no queriendo Cortés ni los de su opinion tenerlo por capitan é justiçia en lugar de Diegro Velazquez, tomarlos por guerra: é para ello diz que estaba confederado con los naturales, en espeçial con Monteçuma por sus mensajeros. É cómo esto vido Cortés, aunque el exérçito de Narraez era maror, é porque segund Cortés dixo lleraba mandado Tarraez que á Cortés é ¿ otros sus consortes, si los pudiesse arer, los ahorcasse, no dexó de se açercar Cortés. creyendo por bien excusar el rompimiento que se esperalua. E quince leguas antes de llegar á Cempual, donde Narvaez estaba apossentado, llegó el clérigo que los de Teracruz avian enviado, que era el mesmo con quien Cortés aria escripto á Tarvaez é al liçençiado Irllon, é otro clérigo, é un Andrés de Duero, reçino de la isla Fernandina, que assimesmo fué con el dicho Tarraez: los quales, en respuesta de la carta de Cortés, le diseron que todaria fuesse á le obedescer é tener por capitan á Tarracz, é le entregasse la tierra, porque de otra manera le seria fecho mucho daño, porque demás de la gente muclıa é ventaja que le tenia, los de la tierra eran en su faror, é que si Cortés le quisiesse dar la tierra, le daria de los navios é mantenimientos que llevalba los que quisiesse, é le dexaria yr en ellos con los que quisiessen Ir con éi, con todo lo que quisiessen llevar, sin les poner impedimento alguno. I el uno de los clérigos le diso que assi renia capitulado é mandado de Dieģo Yelazquez que sc liçiesse con el dicho Cortés, é para ello traian poder el diclio Narraez juntamente con los dichos-dos clérig̣os: é que cerca desto le liarian todo el luuen partido quel Cortés quisiesse. El qual les r'espondió quél no via prorision de Su Magestad, por donde le aldeliesse entregrar la tierra, é que si alguna traia, que la pressentasse ante él é ante el cabildo de la villa de la 
Teraeruz, segund óndon de restumbre de lepana. é quél estala presto át la obedescrer é complie: é que liatsta tauto por ningmm inleresse ni partide laria lo gue derian: antos ó a los de su compania moririan on defension de la tierra: pues la arian granado é la tenian paçífea é segura en nombre de Sus Magestades, é por no sep traydores é droleales á su Rey.

oros muchos partidos escribió Cortés que le avian movido por tracrle śt su propóssito, rnél no cuiso açeptar sin ver provision de sut Magestad prara lo laeger, é que nunca se la quisieron mostrar. Alordaos. letor, de lo que á esto que Cortés dice, decia despues on Toledo al revós Pímplito de Narvac\%, como adclante se dirá. In conclusion, cstos clérigasos y el Indrés de Dacro é Cortís funedaron conreptados que Tarvaez é Cortés con cada diez personas (con seguridad de amlat partes) se viessen, é alli se mostrassen las provisiones, si Narvaez las llevaba é Cortés respondiesse.

É luego calla una de las partes envió á la otra el seguro firmado de su nombre, el qual dige Corlés que no tenia Narvaez pensamiento de guardar: antes dice que concertó que en aquellas vistaa se oviesse forma cómo de presto le malassen á Cortés, é que para ello fueron señalados dos de los diez que con él avian de yr, é que los demás peleassen con los que Corlés llevasse, porque decian que, muerto Cortés, cria su hecho acaliado. E assi dice Cortés (pre fuera cllo, si Dios no lo remediara con cierto ariso que oro de los mesmos que eran en la traycion (que le fué enviado juntamente con ol seguro que se le envió): fo cural sabido pror Cortés, escribió una carta al dicho Narvaez é otra á los terȩcros, diçéndoles quél avia sabido su mala intençion, é que no queria ye de aquella mancra quellos tenian concertado. É lucgio les envió çiertos requerimicnt os é man- damientos, repuiricudo al dicho Narracz que si alemmatrovisiones de Su Magestad llevalua, se las notificase. é que hasta tanto no se nombrasice capitan ni justicia, ni se entrometiesse on cosa algma de los dichos officios, so gientas penas que le puso. E mandí por arpuel su mandaniento que los que Narvatez lenia no le toviessen por capitan ni le olvedesciessen. é que dentro de çerto térnino paresciessen an1e Cortés, so crierta pena, para que les dixesse lo que delian lager en servicio de Su Margestad, so çiertia protestaçiones lo contrario laçiendo: é que prosederia contra ellos como contra tragdores é aleves ć malos vassallos, que se revelaban contra su key. ó querian usmpar sus ticras é señonios, ó darlas é apossesionar dellas a quien no pertenescian, ni tenia á cllas acçion ni derecho, é que grit contra ellos á los prender é cautivar, é otras palabras que se dexan por su prolividad. La respuesta de lo cjual fué prender al que fué á notificar cslo al Narvacz, é al escribano que con él ylua para dar fóe, é tomarles ciertos indios que llevaluan. I estovieron detenidos hasta que llegó otro mensagero que Cortés envió á saber dellos, ante los quales torniron á hirer alarde, amenaçímdolos á cllos é á Cortés, si la tierra no le entregitsse.

lí visto arpuesto Cortés, é que los naturales con estas noverlarles se alborotaban é levantaban á más andar, quiso prerenir ál lo que le pudiera acaesçer, é dexando las palabras, ponerlo en fucia de su industria é cautelas: É dió un mandamiento á Gonçalo de Sandoval, sı alguaçil mayor, para prender ál Tarraez é á los que se llamaban alcaldes é regridores, é mandóle que con ochenta hombres fuesse á haçer lo ques dicho; trás el qual Cortés siguió con otros çiento é septenta. sin tiro de pólvora ni calallo é á pić, para farorescer al dicho alguasil mayor, si se les pusiessen en resistençia el 
Narraez é los demás. Y el dia quel algaaçil Sandoval é Cortés llegaron á la ciludad de Cempual, donde Narraez estaba, supo su yda, é satió al campro con ochenta de caballo é quinientos peones, sin lo demás que dexó en su apossento, que era el templo prinçipal de aquella ciludad, assaz fuerte. É llegó quassi á una leggua de donde Cortés estaba, é cómo lo que salia Narvaez de la yda de Cortésera solo por lengua de indios, é no le lıalló, creyó que era burla, ć rolvióse á su apossento, 10niendo aperçebida toda su gente; é puso los espias quassi á una legura de la ciludad.

Cortés, como fuć de noche, siguió adelante con el mayor silencio quél pulo, é fuésse derecho al apossento del dicho Narraez (quél é los que llevaba muy bien sabiau) para to prender, creyendo que presso, los demás querrian obediscer á la justiçia, en esperial que nuchos dellos yban contra su roluntad, enviados por Diego Velazquez. I el dia de pasqua del Espíritu Sancto, á poco már de media noche, dió en el dicho apossentamiento; é antes topó las dichas esprias, é las que Cortés llevalua delante prendieron una dellas , é la otra se escapó, é de la pressa se informó de la mancra que estaba Narvacz. É porque la espia que escapó, no llegasse primero que Corlés, é dicsse mandado de su yda, dióse mucha priessa á caminar; pero no pudo ser lanta que la espia no diesse primero notiçia que Cortés yba, bien media hora antes. E quando llegóó á donde Narvacz estaba, todos los de su compania estaban armados, y ensillados los caballos é í punlo, é relaban cada yuarto sient hombres; é llegaron Lan sin ruidlo, fue quando fueron sentidos é los de Narvaez tocalıan al arma, entraba Cortés por el patio de su apossento, en el qual calaha toda la grente apossentarla é junta, é tenian fomadas tres ó quatro lorres, que en él avia, é lodos los demás apossentos fuertes. Y en la
Inad dearpuellas torres, donde el dleho Narraez eslaba apossentado, tenia á la escalelar della hasta diez é nueve tiros de fuslera: é dieron tanta priessa á subir á la dicha torre, que no tovicron lugar de poner fue. go á más de un liro, el qual no salió ni liço daño alguno. É assi se subió la torre hasta donde el dicho Narvaez lenia su cama, donte él é lasta çinquienta hombres, que con él estaban, pelearon con el dicho alguaril mayor é con los que con él subieron, puesto que muchas veres les repuirieron que se diessen á prission, é no lo quisicron hacer lasta que se les puso fuego, é con esto se dieron. I cn lanto quel dicho alguaçil mayor prendia al dicho Narvacz, quedó Cortés defendiendo lí sulida de la lorre á los que en socorro de Narvacz acudian, é hiço lomar toda la artilleria é fortalescióse con ella: por manera que sin muerles de lombres, más de clos que un tiro mató, en una hora estalan pressos todos los que Cortés quiso prender, é lomadas las armas á lodos los demás: é promelieron de ser oljidientes al rencerlor, é deçan que hasta allí a vian suydo engañados, porque Narvaez les desia que llevaloa provision de Su Magestat, é les avia fecho entender que Cortés estaba alçado con la lierra é que era traydor á Su Magestad, é otras muchas cosas.

Dicemás en su carta Corlés: que supo de los indios que si la rictoria fuera por Narvacz, $n$ puliera ser sin mucho dano de los chripstianos de ambas partes, é quellos malarian á los que avian quedado en la cibdad; é que despues se juntarian é darian solıre los que quedassen, de manera que la tierra quelasse libre, é no oviesse memoria de los españoles. Otras palabras muchas é á su propóssito diçe cn este caso Corlés, encaresçiendo su partido, que ni yo nicgo ni las apruebo tan puntuahnente, como su carta diça; porfue como he dicho estal relaçion se escribió por el. Mas porque dixe de susso que diria lo 
que al revés de todo esto decia l'álnphilo de Narvace, digo quel año de nill é quinientos é reynte y rinco estanto bóssar en la ciludad de Toledo, ví allí al dicho Narracz, é públicamente decia rue Coltés cra un lraydor, é que dándole Su Magestad liçencia, se lo haria conosçer de su persona á la suỹa ć (juc era liombre sin rerdad, $\dot{e}$ otrus untelas é feas palilras, Ilaméndole alevoso é tirano é ingrato á su señor é á quien le avia enviado á la Nueva España, que era el adclantado Diego Vulizfuez, á su propria costa, é se Ie avia algate con la lierra é con la gente é haçicnda, é otras muchas cosas que mal sonaban. I en la manera de su prission la contala muy al revés de. lo que está dicho.

Lo que yo noto desto es que con todo lo que oy á Narvaez (como yo se lo dixe) no puedo lablarle desculpa para su descuydo, porque ninguna nescessidad tenia de andar con Cortés en pláticas, sino estar en rela mejor que la que higo. É á esto decia él que le avian vendido aquellos de quicn se liaba, que Corlés le aria sobornado. E tambien me paresce donayre, ó 110 bastante la excusa que Cortús da para fundar é juslificar su negocio, ques decir quel Narracz pressentase las provisiones que llevalya de Su Magestad, y el mandamiento quél dió á Sandoral para prehender á Narraez, como si el dirho Cortés ovicra vo á aquella tierra por mandado de Su Magestad, ó con más ni hanta auctoridad como llevaba Narvacz, jues ques claro é notorio quel adclantado Diego Velazquez, que envió á Cortés, cra parte, segumd derecho, para le enviar á remover. y el Cortés obligendo á le obedescer.

No rquiero deçir más en cslo, por no ser odioso á ninguna de las partes; pero en uni juiçio yo no haillo qué loar á Cortés en su desobidiençia, ni á él le quedó nada por usar en sus caulelas, pari se puedar ell opinion y en officio ageno, contra la roluntad de cúyo cra á se lo dió y encomendó: ni á P’úmphilo de Narvilez le faltó la penitenegia de su deseryedo, ni á l)iego Telizepucz quiso la fortuma dexar de deslriyrle, ni á Corlés desfavorescerte para salir con su propóssito, como ha salido.

Yo veo questas mudanças é cosas de grand calidad semejantes, no todas reces anda con cllas la racon, que ál los liombres les paresce ques justa, sino orra definicion superion é juicio de Dios que no aleancamos; y eómo él es movedor de lodo (ó más servido de lo que sulpegele) é sin su voluntad ningma cosa se puede concluir, tengamos por mejor lo que remos efeluar, pues no se alcançan los fines para que se haçen las cosas; é de la providençia de I los no nos conviene plalicar ni pensar, sino que aquello conviene.

Has en la verdacl: quilado aparte este escrípulo de no acudir Cortés á Diego Velazquez. cuyo capilan é sostiluto fué enviado, en lo demás valerosa persona ha seydo é para mucho; y este degseo de mantar, juntamente con que fué muy bien partido é gralificador de los gue le sirvieron, fuć mucha causa (juntamente con ser mal (quisto Dicgo Telazquez) para que Cortés se saliesse con lo que emprehendió, é se quedasse en el offiçio é gobernaçion. ¿Quereyslo ver claro? Si aquel capitan, Johan Telazquez de Leon, no estoviera mal con su pariente Diego Telazquez, é se passara con los çiento é çinquienta lımbres, que avia llerado á Guacacalco, ála larte de Pámphilo de Narvacz. su cuñado, acabado oriera Cortés sil officio.

Visto he platicar sohre esto á cavalleros é personas mililares, solore si este Johan Velazpuez de Leon hico to que delia ó no, cn acudir al Diego Velazcuez, 6 al Púmphilo en su nombre; é convicnen los veteranos mílites, e a mi pares- 
ser determinan bien la quicstion, en que si Jolan Velazquez luvo conducha de capilan para que eon aquella gente quél le dió, ó toviesse en atprella tierra, como capilan particular le acudiesse á él, ó á quien él mandasse, Johan Velazquez faltó á lo que era obligado en no se passar á Pámphilo de Narvacz, seyendo requerido de Diegro Telazquez; más si le hiço capitan Ifernando Corlés é le dió él la gente, á él aria de acudir, como acu- dió, cxçepto si viera carta 6 mandauicnto expreso del Rey en contrario.

l'assemos á lo demás: que si bien ó mal hiçieron, aunque en el suclo no vean los hombres cómo se determinan estas cosas, ya sabemos ques cuenta corriente para adelante, é que ha de llegar todo á arpuel tribunal infalible, é donde no ha de faltar justiçia ni encolırirse delicto ni cosa mal hecha, ni quedar sin galardon to bien hecho, sin excepçion de personas.

\section{CAPITUULO XIII.}

En que se traeta eúmo despues de presso el eapitan Pímphilo de Narvaez, supo Cortés que lus de la eibdad de Méxieo se avian alçado eontra los españoles que alli avian quedado en guarda de Montecuma, é del oro é joyas; é fué allí, é despues de entrado, tovo mueha guerra eon los indios de la eibdad; é de la muerte desastrada de Monteruma * é euenta la historia algunas partieularidades notables en el easo.

\section{D.} vacz, polque en aquella cibdad no se podia sostener lanta grente jumla (mayormente que ya estalıa quassi destruyda, porque los que en ella estaban con el dicho Karvacz avian robado lo que pudicrou, é los veginos estaban ausentes é sus casas solas), despáchó Hernando Corlés rlos capilanes con cada doscientos lıomres, cl uno para que fuesse á hacer cl pueblo en el puerto de Guagacalco, rue antes avia enviado ál lager, segrund se lá dicho, y el otro á aquel rio que los navios de Françiseo Garay dixeron que avian visto. I envió ofros dosçientos hombres á la villa de la Veraeruz, donde hico que los navios quel dicho Narvaez traia viniessen; é con la genle reslante se quedó en la cibdad, é despachó un mensajero á la cibdad de Temistilan, con el qual hiço saber al capilan y españoles, que en ella avia desado, lo que le avia subçedido:

En el original proseguia: "É eúmo le eonvino á Cortés é á los españoles dexar la eibdad é peldieron el oro é artilleria é salieron eon mucho trabaxo pelcando lasta se poner en salro, pero eon pérdida de lo que tenian allegado é eou muerte de cl qual capian cra Pedro de Ararado. Este mensajero fornó desde á doçe dias con carlas del alcalde capilan que allí avia quedado, en que le haçian saber cómo los indios le avian combatido la fortaleça por todas las parles della, é puéstole fuego por nuchas partes é fecho çicrtas minas, é que se avian vislo con mucho peligro é trabaxo; é que lodavia los maturales le matáran, si el dicho Montecuma no mandáa cesar la gucro’a é que aun los tenian sereados, puesto que no Ios combalian, sin dexar salir ninguno dellos dos passos fucra de la forlalega; é que les avian tomalo en el combate mucha parte del bastimento que Cortés les avia desado, é que les avian quemado los quatro berganlines que tenian, é que estabau en muy cxtremada nescessidad; é que por amor de Dios los socorriesse con mucha priessa. Esle capilan é alcalde, que quedó en guarda del oro é de

muchos é valientes españoles.» Oviedo suprimió euerdanente estas eláusulas, porque parte de los heehos aqui meneionados se narran en el siguiente eapitulo. 
Monteguma, no le nombra Cortós en su relaçion, y era el comendador prullo de Avarado, ol qual se oro vilerosamente en este gereo.

Yista la nescescirlad que aguellos espa- noles tenian, é que si no fueseen socolrílos, demís de perderlos, se perderia forlo el olo é joyas que en la tierra se avia avido, assi para Su Magestarl como el de los particulares y el de Cortés. eon la mayor é nnejor cibularl de torlo lo descubierto en estas Indias lasta en essa sason, é perdida arpuella, se jerileria todo lo que estaba ganado, por ser la calbeca de todo aquel reyno, é á quien inumerables gentes obedescian; hego despachó Cortes mensajeros ál los capilanes que avia emviado con la gente que se dixo de sus8o, dándoles noticia de to que le arian escripto, para que deste do quicra que los alcançssen, se tormassen é pror el eamino mas gereano se fuessen á la provincia de Tasealteca donde Cortés con la gente que con él estaba, é con loda el artilleria que pudo llevar. é con septenta de á caballo, se fué á juntar con cllos. É allí juntos se hiço alarde, é se liellarón demás de aquellós septenta de caballo. quinientos peones; y encontinente se dió mucha pricssa caminamlo para la cilulad. Y cn torlo el camino ninguina persona le salió á rescibir del dicho Montcesuma, como antes lo solian hacere é toda la tierra estaba alborotada é quassi despoblerda, de lo qual se purlo concelir mala sospecha, cre. yendo que los españoles que avian quedado co la ciludad debian yii ser muertos, é que la gente de la tierra estaba junta, esperando en algun passo, donde pudiessen mejor aprovecharse de Corlés é de los que con él yban. Con este temor, fuć al mejor recalorlo que pudo hasta que llegó a la cibdad de Tesuacan, jue como se ha dicho, estí en la costa de aquella grand laguna ; é allí preguntó á algunos de los naturales della por los españoles que en la srand cibdasl avian quedado. los quálas discron que elan vivos: y a les diso

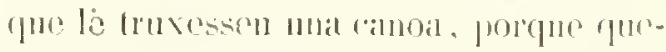

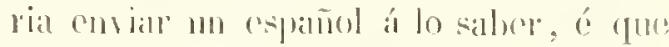

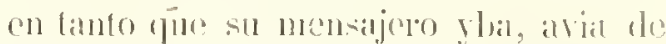

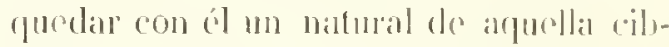

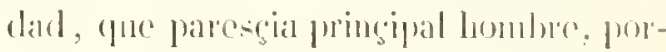
que los señones della. de quien Cortés tenia noticia, ninguno parescria. É mandirda traer la cimoa, covió cierto indios con el español, su mensajoro, y el indio ques dicho puedó con Cortís, como relien o prendia ó secomidad del plrip-tiano que rnvialsa. I estándoso embarrando el espanol parar ye á la cibdad de Temi-litan, vió veruir for la lagnna otra canoa, é cómo llegó al puerto, que renia en cllat mo de los espantoles que alvian quodado en la grand ciblad: é supnse líl que cran viros lodos los duripstianos, exsepto cinco ó seys ijue los indios avian marrlo, é que los restuntes estalman toutivia ecreados é no los decaban salir de lia fortaleça, ni les proveiam de lo pue avian menester sino por murlio reseatr, puesto que despues que supieron fue Cortés volvia, to hacian algo mejor con cllos: á Monterumal decia rue no esperaba sino que Corlés llegasson, para que luego tornisecen á andar por la riblad, como antes solian haçerlo. E con afuce español envió Honteruma un mensijero suyo. en que le en. vió á decir á Cortés que ra debia saber to acaescirlo en arpuella ciblad, í que tenia pensaniento que delia renir enojado por cllo, ó con roluntarl de le hareser alsmon daño: por tamlo, que le rogaba que perdiesse el ennjo, porgue ál le aria pessado tanto quanto á Cortés. é que ninsuna cosa se avia hecho con roluntarl de Ilnnteguma, i otras palabras semejantes prara aplacér la ina rue sospechó que Corfós lleralua; é que le rogilla que se fuesse á la cibdad á apossentar como antes cslaba: porque no menos se hirria en clla lo rue Corlés mandasse, que primero se 
haçia: el qual le respondió que ninģun enojo llevaba dél, porefue hien salbia su buena roluntad, é a tue assi como él lo deçia, lo lutria.

Oro dia siguiente, que fué rispera de Sanct Joḷan Baptistat, se partió é durmió en ol caunino á lres legruas de la grand cibdad: y cl dia de Sanct Johan, despues de arer oydo missa, se partió, é llegó á Temistitan quassi á meslio dia, é vidlo poca gente por la ciludad, í algumas puentes de las encruçijadas é traviesas de las calles quitarlas, de ques se ovo mal indiçio, auncur pensó Cortés que lo tracian de temor de lo que arian hechó los mexicanos, é que entrado él, los aseguraria.

Llegarlo á la fortaleça, en olla y en la mezpuita ó templo mayor a que está junto á ella, se apossentó loda la gente que con èl yba; é los que estaban en la fortaleça los resçibieron con tanla alegria, como redimidos ó que nuevamente les dieron las vidas, que ya ellos estimaban por perdidis: 6 con mucho plaçer se passó aquel dia é la noche, pensando que todo estalua pacífico.

Otro dia envió Corlés un mensajero á la villa de la Veracruz á darle las buenas nuevas de cómo los chripstianos que estovicron cercados, cran vivos, y ćl avia entrado en la cibdad y cstaba muy segura: el qual mensagero se tormó descle á media hora descalabrado y herido dando voses, diçiendo yue torlos los indios de la cilodad renian de guerra, é que tenian algadas todas las puentes. I encontinente solorevino tanta moltitud de indios sobre los espanoles é Cortés por lodas partes, que las calles é açoteas estaban llenas de los inficles, con alaridos é grita muy espantable, é para poner mucho terror á quien lo oia: y eran tantas las piedras que tiraban con hondas contra la fortalcega, que paresçia quel çiclo las llovia; é las flechas é tiraderas eran tantas, que las paredes é patios de la fortaliça estaban lan llenos dellas, que quassi los chripstimos no podian andar con ellas. Estonres Cortés salió á los enemigos jor dos ó tres partes, é pelearon con ellos muy reciamente, annque por la una parte salió un capitan con doscrientos lombres, é antes que se pudiesse recoger, le mataron quatro chripstianos, é hirieron á él é á otros muchos; é por la otra parte que Cortés andaba, le hirieron assimesmo á él é á muchos de los españoles: é de los indios muricron pocos, porque se acogian de la otra parte de las puentes, é deste las açotcas é terrados haçian mucho daño con piedras. Con todo se ganaron algunas dessas defensas, é las quemaron; jero eran tantas ć tan fuertes, é de tanta gente defendidas, é tan bastegidas de piedras é otras armas, que no bastahan Ios chripstianos para se las tomar todas, ni aun para defenderse á sí imesmos, sin ser muy ofendidos de los contrarios.

En la fortaleça daban tan reçio combate, que por muchas partes le pusieron fuego los indios é quemaron mucha parte della, sin que se pudiesse remediar, Iasta quel fuegro fuć alasado, cortando las paredes é derrocando un quarto que mató cl fuego; ó si no fuera por la mucha guarda que allí se puso de escopeteros é laallesteros é alğunos tiros de pólvora, les entriaran á escala vista sin que se pudieran resistir. É assi estuvicron todo aquel dia peleando, hasta que fuć de noche bien escuro: ni en toda clla gesaron las gritas é rebatos hasta que fué de dia.

Aquella noche se repararon los portillos de aquello quemado, é todo lo que á Cortés le paresçió llaco de la fortaleça, é concertó sus estancias é gente para la guarda, con la determinaçion de salir, como fucsse bien claro el dia, á pelear fuera; hiço curar los licridos, que eran más de ochenta. İ assi como el alba llegó, los enenigos començaron el combate muy más reçio é intenso quel dia passado; y 
cra tanta la moltitud de los indios, que los artilleros no tenian nesesesidad de punferia contra algun particular, sino assestar á los esquadroncs de los contrarios é derribar de rada tiro muchos: é assi se hiço mucho daño en ellos, porfue jugaban treçe tiros pequeños de hronçe, sin las escopetas ciallestas, é aunque derribaban assaz, paresçia que no fallaba ninguno, ó que no lo sentian: porrfue donde llevaha el tiro diez ó doce personas, se serraba encontinente de gente, é paresçia que no se laçia mella ni daño.

Dexando en la fortaleça recabdo conviniente, salió Cortés fuera con parte de sus mílites, é ganó algunas puentes, é quemó algunas cásas, é mataron muchos en ellas que las defendian; y como es diclo, la moltitud era tanta de los adrerssarios, que se haçia poca mella en cllos por muchos que malaban; é á los chripstianos convenia pelear torlo el dia cada uno dellos, é los indios peleaban por looras é se remudaban, ć descansando unos venian otros en lugar de aquellos de refresco, é aun les solıraba gente mucha, que miraba. por no aver tanto lugar para pelear, ni quien á cllo los forçasse.

Hirieron arfucl dia hasla sessenta espanoles; é despues de aver peleado hasta que fué de noclıe, se retruseron los nuestros á la forlalera, viendo el grand daño que los indios laçian, é que herian é maInban de los nuestros, é rue era más pérdida, segund el nímıero de los españoles, uno que fultasse dellos, que tresçicntos de los inficles. Toda arjuella noche é otro dia siguiente hico gastar el tiempo Hernando Cortés en hager tres ingenios de madera, é cada uno llevalsa veynte hombres, los quales ylyan dentro culliertos, porque con las piedras rue do las agoteas tiraban no los pudiessen ofender, porque yban aquellos ingenios cubiertos de la-

1 I.ib. X, caps. 19 y 20. hlas: é los que yban dentro eran ballesteros y escopeteros, é los demás lluvabin picos á açadones a harras de lierro para loradar las casas é derribar las allonrardats, que avia herhas en has ralles. Pistos arlefiçios suclen llamar los arquitectos lestugines ó tortugas, como largamente ritruvio las describe', é asimesmo Flavio Yrgeçio en su tractarlo del Arte militar 2. No sé yo si de tal p̧iençia Ilernando Cortós toviesse notiçia : poro su ingrenio é halilidad era á más que esso lastante.

Y en tanto rue tales arteficios se haçian, aunque no çessaba el combate de los contrarios ni la resistençia de tan bastante capitan é de los chripstianos, como los nuestros querian salie fuera de la fortaleca assi los inficles pugnaban por cont rar dentro en clla: é desta causa era el trabaxo de los defensores uspañoles muy exçesiro, fjue les ylua en ello las vidis, é í sus enemigos lo mesmo é su libertad. Honteçma, que todavia estaba presso. é un hijo suyo, con otros muchos señores que al prinçipio se avian tomado, dixo que le sacassen á las açoteas de la fortalera, quél luablaria á los capilanes de aquella gente, éles haria que çesassen en el combate y en la guerra: y el capitan Ilernando Cortés lo hiço sacar, y en llecrando á un prefil que salia fuera de la fortalega, queriendo hablar á los indios que por arpella parte combatian, le dicron una pedrada los suyos en la cabeça; é fué tal la herida que de allí á tres dias nurió. É Hernando Cortés lo hiço sacar mucrto, assi como estalba, á dos indios de los que estaban pressos, é á cuestas Jo llevaron á la gente, é no se supo lo rue dél hiçieron; mas por csso no çesó la gucra: antes cresçió la saña de todos é fué muy més reçia é crulla de cada dia.

Este dia mesmo llamaron por aquella parte por donde hirieron á Jlontecuma, é

2 Lib. IN, cap. 11. 
dixeron que se parasse alli Cortés, que le querian lablar ciertos capitanes de los contrarios; y él se paró alli, é passaron muclaas raçones, y él les rogó que no peleassen contra él, pues ninguna raçon tenian para ello, é que mirassen las buenas obras que dẻl arian resçilido, é cómo los a via nuy bien tractado. Lo que á esso respondicron, fué que les dexasse su tierra, pues que eran naturales della y èl no ; é que si assi lo liçiesse, ellos dexarian la guerra; é que no lo haçiendo, creyesse que hasta morir todos los indios, ó no dexar chripstiano vivo, no arian de çessar. Cortés entendió que este partido se to movian, porque saliesse de la forlaleça, é salido, le tomassen entre las puentes de la cibdad, é se pudiessen aprovechar con tal cautcla de aquellos españoles é dél. L esto les replicó Cortés que no pensassen que les rogalua con la paz por temor que les toviesse, sino de compassion de los indios; porque le pessaba del daño grande que les haçia, é del que esperalba más haçerles, que avia de ser muy mayor, é le dolia destruyrlos á ellos é á tan buena cilıdad, como aquella cra. Los indios replicaron que ya le avian dicho su voluntad, é que no avian de cessar sus armas hasta que los cluripstianos é Cortés saliessen de la cilodact.

Acalyados los ingenios é tortugas que se diso de susso, luego otro dia salió Cortés de la fortaleça con ellos, llevándolos delante de sí, é trús ellos quatro tiros de fuego é otra mucha gente de ballesteros, ó mas de tres mill indios de Tasealteca, que avian venido con él é servian a los españoles. É llevados á una puente, pusicron los ingenios arrimarlos á las paredes de unas açoteás, é çiertas escalas que llevaban para subirlas; y era tanta li gente que estaba en defensa de las açoteas é puente, é tantas é tan grandes las piedras que tiraban, que les desconcertaron los ingenios è mataron un español ó TO110 III. hirieron otros muchos, sin les poder ganar un passo, aungue la batalla fuć muy reñida é perseverante lassa medio dia, que los nuestros se volvieron á la fortaleça con mucho cansançio é dolor, por ser perdido su trabaxo é tornar con perrdida. Essto dió tanto ánimo ál los inficles, que quassi liasta las puertas Ilegaban: ć tomaron arguel templo ó mezquita grande, y cn li torre mas alta é mas primcipal so subicron hasta quinientos indios, que segund se supo despues eran personas prinçipales, é la bastecicron de pan é agua é otros bastimentos é de muchas piedras ; é lodos los demás tenian lanças luengas con unos lierros de pedernales mas anchos que los de las nuestras, é no menos agudos que los muy finos de Aspe. Desde alli haçian mucho daño á los españoles de la fortaleça, porque estaban muy çerca los unos de los otros. Aquella torre ques diclıo, combatieron los españoles dos ó tres reges, é la començaron á subir; é cómo cra muy alta é la subida muy agria é derecha de çient é mas escalones, é los te arriba pertrechados de muchas piedras ó otras armas, e favoresçidos con no les aver podido ganar las açotcas, ninguna vez los españoles tentaban subir que no volviessen rodando ó descalabrados. É los que de otra parte los vian de los indios cobraban tanto ánimo', que se yban lasta la fortaleca muy osadamente, sin que se conosciesse temor en ellos.

Viendo Cortés el notable daño que de la torre él é su gonte resçibian, salió fuera de la fortaleca, aunque manco de la mano izquierda, de mina herida quel primero dia le avian dato; e liada la rodela en cl braço fué a la torre con algunos veteranos soldados animosos que le siguieron, ¿ gercóla toda por haxo, porque se po(lii) muy bien hager, aunque no sin pelear por torlas partes con los contrarios, de los quales, por favoresçer á los suyos, se recrescieron muclios. Non obstante to 
qual Corfés comengó át subir la lore con los duripstimos, é annque so lo delendierom rigurosamente ó derribaron tres ó

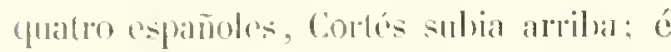
con timlo esfuergo il i los fue le seguian prolearon con los memigos. fue les fur forculdo sillar dre la torre albaxo á çiertas agoleas 6 andenes que tonia al rededor, tan anclios como tres i quatro pićs, cileslas tenia la lorre tres ó quatro gुiulas á trechos, mas ancha la ma que la otra lies estados; c cayeron alsumos abiso, c los que estabim de los nuestros al fić do la torre los mitaron con façilidad, aunque la caida les lastaba para morir. Los que quedaron en apuedlas cinters ó andenes pe. learon deste allí lan rosçiamente, que se tardaron mín do tres loras con los acaluar de ustar, de forma que ningumo escapó.

Fur ganar esta torre una cosa lan grande é lam seiralada, yue assi el capitan como los que en ello se liellaron son mur linos de todo loor, porque cra lal é lan furole que reynte hombres hatialsan á la defender de mill, si tan osidos mílites asudarlos de Dios no fueran; i los mesmos vencedores queditron espantidos de lo que avian hecho, dando graçias á Nuestro Redemptor é su gloriosa Madre. Encontinente. avida cola victoria, liço Ifernando Cortés poner fuegon á la torre é á las otras que en la mezquila ó templo estaluan, de las quales ya los indios arian quitarlo las ymágenes de los Sanctos, que avian alli puesto los chripsliunos.

Esta victoria de los nuestros fué macho quebrantamiento de la soberlia de aquella lárbara gente, é les hiço alloxar su ira por torlas partes. Lucgo fué Cortés á aquella açotea ques dicha, é haliló á los capitanes que primero avian hablado con ú, que estaban algo desmayados é mal contentos por lo que avian visto. é les dixo que mirassen el daño que los clrripstianos les hacian cada hora, é que malahan muchos dellos é quemalian é des. lulian su cibdat, é que no pararia hasta que dellar a dellos oviesse diuto fin. Respondieron que hien vian que rescilsian mucho daño é muerte de los suyos; pero que les cra tan dulec la libertad, gure les fuerian quilar los chripstianos. (pue hasta fur lodos los indios murirssen ó echassen de la lierra ál los respañoles no avian de cossar on la grucrat: é que pusiesse Cortés los ojos en arucllas acoleas é plaças é calles quán llenas de grente estahan, é que tenian lechas cuenta que con morir veynte Y cinco iudios por un solo chripstiano, so avian de acabar antes los espanoles ${ }^{2}$ Cortés. por su poco número á respecto de la incontable mollibul de la gonte, que los indios cran: é que le haegian saber que todas las catcalas de la ciblad avian des. hecho (y en la verelatl cra assi, que torkas las avian rompielo é (lrsbaratarlo, excepto una) é que ninguna parte tenian, por donde salir simo por el agra ó volando; é fue bicn salian quellos tenian ya poeo bastimento é poca agua dulge, é que no podian turar mucho, sin que de hambre se muriessen, aumpue los indios no los matasscun.

Otras muchas raçones passaron en esIr raçonamiento, favoresçiendo cada uno su partido. Y en la verdad auncue los españoles no fuvicran olra cuerra sino la hambre, era ya mucha su nesçessidad é falta de bastimento: é assi como fué lle noclre salió Cortés con algrunos es. pañoles, é halló algun descuydo en los enentgos é ganóles una calle é quemóles más de tresçicntas casas. é rolvióse por otra ya que alli acmlia la gente: é de la segunda calle quemó muchas casas assimesmo, en especial çicrtas açoteas que estaban cerea de la fortalega, porque desdo ellas resçibian mucho daño los espanoles. Deste fecho no pensado se acres. centó más el temor en los inclios; pero no tanto que les fallasse su perlinaçia para la continuacion de la guerra. 
Aquella noche se tormaron á aderesçar los ingenios quel dia antes se arian desbaralado, como se dixo de susso, é con mayor aviso se fortificaron y enmentaron; ć por seguir la victoria, salió Cortés ('n amanesciendo por la calle donde to avian desbaratado, é no la hallaron con menos defensa que primero. É cómo á los chripstianos les yban en ello las viclas é lonras, é por aquella calle estaba sana la calçada que salia á la lierra firme, aunque hasta llegar á ella avia oclıo puentes muy grandes é lıondas, é loda la calle de muchas acoteas é altas é torres, púsose tanta determinacion é ánĭmo por los nuestros, que con el favor de Dios ganaron aquel dia las quatro, é se quemaron 10das las açotcas é casas é torres que avia liasla la postrera dellas, aunque por el aviso de lo acaesçido en la noche passada tenian en todas las puentes fechas muchas é muy fuertes allarradas de adohes é barro, de tal manera que los tiros é batllestas no les podian lacec daño. Aipuellas quatro puentes se çegaron con los adobes é lierra de las neesmas albarratas, é con mucha piedra é madera de las casas quemadas; pero no fallando sangre de la una é de la olra parte, porque muclıos de los cluripstianos fucron heridos : é púsose recaludo aquella noche en la guarfla de las quatıo prientes, porefue no se lis tornassen á ganar.

Otro dia siguiente tornó á salil Cortés, é dióle Dios tan buena dicha ó victoria, ámque la competençia é los encurigos fincron muchos ó topala muchas alluarladas é lıoyos que aquella noche se avian liecho, que les ganó todas las otras puentes é las cegóó, é fueron alg̣unos de á caballo siguiendo el alcance lasta la lieria firme. Y estando Cortés reparando é fro gando lis dichas puentes, le vino nueva cómo los indios combalian la fortaleca 6 pedian paz, é le estaban esperando çicrtos señores, capitanes de los enemigos:é desando allí toda la gente é ciertos liros de fuego, se fué con solos dos de caba$1 l o$ á ver qué le querian aquellos prinçpales; é llezado, le dixeron que si los áseguraban que por lo liecho no serian j'uniclos ni maluactados, quellos harian alcar el çereo é tornar á poner las puentes é haçer las calçalis, é servirian á la Crossárea Magestad, conno primero to haçian. É rogaron á Cortés fue hiçiesse traer allí uno como relig̣ioso ruél tenia presso, que eral como general de afuella su religion é setla dañada; é venido afpuel, dió concierto entre las partes, é parescrió pue envialıa mensageros, segmmd los indios deçian, á deçir á los capilanes é gente que tenian en las estancias, para que eesassen en el combate que daban á la fortalega, é que toda la gucra de todas partes fuesse contredicha é çesasse; é con cate conçierto se despiclieron.

Corlés se entró en la fortaleça á comer; é assi cómo se assentó á la mesir, le vinicen á dereir que los indios avian cobradoé tenian ganadas laspuentes que acpuel dia les avian sanado, é avian muerto corlos espanoles; é caloalgó á caballo, é con la mayor pririssa quél pudo dar á las espuclas, corrio toda lis calle adelante con algunos de calvallo que le signicron, sin se detener en parte alguma, é rompió por los indios é tornóles á ganar las puentes, é signió el alcance hasta la tierra lirme. E cómo los prones cstaban cansados y heridos é temoriçados, ninguno dellos le sigruió á callsa de lo yual, passadas las puentes, quando Cortés quiso dar la ruella, las ladló tormadas á ahondar mucho de lo que se ar ia regando; é por la mara é otra parte de la calcalda loda celaba llena de indios, assi en la ticrar como en el agua ron canoas; é de mn larlo é de otro, como toros, eram garrocharlos é apedreados Cortés é los qune con él estaban, en lanta mancra, que si Dios por su acostumbrada miscricordia no los socorriera é 
diera taror de su poder alsoluto, era imposilule de otra mancla eseaprar de alli: am ya se deçia público entre los que que-

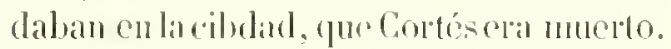

Quando llexgó de vuedta á la postrora

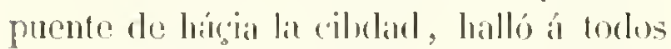
los de caballo que eon él yluan eaydos en clla , é un calnallo suelto: por manera quíl no pudo prassar, é le fué torģalo de ro. rolver solo contra los conemigos, donde halló no menos dellos que aquel que Petrarca digge que, solo contra Toscana, luyo o defendió lia puente en tanto que la cortaban por detrís dél, porque la gente del rey de Toscana noculrasse en homa'. Fsle se llamó lloracio Cocles, cono mas larxamente Tito Livio lo escribe ${ }^{2}$; é segund lo rue yo he entendido de algunos rue pressenter se labllaron, muy dino es Corlis que se compare este frelio suyo desta fornada al de Horaçio Cocles que se: tocó de susso, porque con su esfucré é lansa sola dió lanto lugar que los caballos judieran passar, é liço desembaraçar la puente. é passó á pesar de los enemigos, aumque con harto trabaso. Porque demís de la resistencia de aquellos, a via de la una parte á la otra puassi un eslado de saltar con el caluallo, sin le fallar muclas pedrarlas de diverssas partes é manos, é por yr él é su calıallo bien armados no los lirieron; pero no dexó de quedar atormentado de los golpes que le dieron, de la manera ques dieho.

Quedaron los nuestros aquella noche con la victoria é ganadas las quatro puentes, é prisose buen recaludo en las otras quatro: é Coltés se fué á la fortalega, é no cansado, ó á lo menos no cessando por el cansancio rescibido de proseguic é proveer en lo que convenia para conseguil lo que dessealsa é faltaba pala la total victoria de sn cmpressa, hiço haçer una puente de made- ril gue lin llevassen quarenta lionlures, comosciondoceland pelimo.en que costabat y el daño que los indios carda dia le hatcian. É tomiendo que tambien destarian

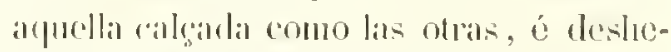
cha ningun iemedio (juredialsal, é fuera forcarlo morir lodos aquellos españoles, que con él se hallaban, é tambien poryue de fodos los de su contrania lué requerido que se saliesarm de la cilulad, porque todos los más estahan heridos é tales gue no podian pelear, óá lomenos largamente comportar acpel contímno resistir á los enculigos, acordaron de Io hacer aquella noche. É tomaron fodo el oro é joyas que tenian rue se pudiesse sacar, é puesto en una sala, luicolo entregar Cortés á los officiales de Su Magestad in çiertos lios, é rogó á los alcaldes é regidores, é á los demás españolos, que ayulassen á lo sacar é salvar, é aun se lo requirió é lió una yeggua, en que se cargó la parte yuel mesmo Corlés avia de llevar, é senaló çiertas personas que toviessen cargo de la yegua é de la carga del oro que le pusieron á cuestas; é todo lo demás se repartió para lo salvar é sacar solbe todos los restantes españoles. É desampararon la fortaleça con mucha riquega é tlıessoros, assi de lo que pertenescia al Emperador, como de lo de Cortés é particulares españoles; é con el mayor silençio é secrelimente que pudicron, llevando consigo un lijo é dos hijas de Monteçuma é á Cacamaçi, scñor de Aculuacan, é al otro su hermano, que Cortésaria puesto en su lugar , é otros señores de provinçias é cibdades que alli tenia presisos.

Llegados los chripstianos é su capitan á las puentes, que tenian quitadas los indios, á la primera dellas se cchó la puente que los nuestros Ilevaban fecha, é con poco trabaso, porque no ovo quien lo resistiesse, excepto ciertas velas que en ella 
estaban: las quales apellidaron tan reçio é con lanta perseverançia, que antes de llegar á la segunda, eslaban inumerables enemigos solne los españoles, combaliéndolos por todas partes, assi destle cl agua como desde la tierra. I el capilan IIernando Cortés passó luego (con ginco de caballo é gient peones á nado) todas las puentes é se las ganó hasta la tierra firme; é dexando aquella gente en la delantera volvió á la reçaga, donde peleaban muy osadamente los españoles é los indios, que eran sin comparaçion más, é assi hasian daño mucho en los chripstianos é sus anigos los indios de Tascalteca, que con cllos cstaban: los quales alli muricron todos los confederados que pressentes se hallaron, ó la mayor parte dellos, é nillchos españoles é caballos, é se perdió todo el oro é joyas é ropa é otras muchas cosas que sacaban, é toda la artilleria.

Recogidos los que quedaron vivos, Corlés con tres ó quatro de caballo é luasta veynte peones que osaron quedar con él, quedó é fué á la reçaga, pelcando con los indios, luasta llegar á mna cibdad que se diçe Tacuba, que está fucra de la calçada toda, con assaz trabaxo, poreque todas las reces quel capitan volvia solore los contrarios, assi él como los que le seguian, tornaban llenos de flechas é varas, é muy golpreados é tormentados de pedradas; porque como cra agna á cada lado de la calgada, herianlos á su salvo é sin temor, é los que salian á tierra, lnego que volvian sobrellos, saltaban al agua é rescibian poco daño, si no eran alģunos que por ser muchos tropecaban unos con otrosé caian, é aquellos morian. Assi que, con este trabaxo militar y extremado, peleando llegó Cortés á la cibdad de Tacuba sin le matar ningun español, sino uno de los de caballo que yba con él en la reçaga. É no cra menos ni más espaçiosocl pelear en la delantera que por loslados; pero el mayor impelu é trabaxo de la batalla fué en las cspaldas, por donde la gente de la cibdad venia en seguimiento de los chripstianos.

\section{CAPITULO XIV.}

En el qual se tracta cómo despues que Corlés é los españoles salicron de la eibdad de T'emistilan, llegado ¿l la eibdad de Tacuba, é prosiguiendo en su fuga, è los indios en su aleançe, haçiendo todo el daño que podian, le mataron los hijos de Monteẹuma i i los otros pressos prinẹipales que los chripstianos tenian *; é cúmo se recogieron Cortés é su gente à la provincia de Tascallecle; é otras cosas dinas de la historia.

Q nién dubda quel arte militar sohre 10dos los otros más potente sea, é sus efeltos mayores, por ol qual la libertad se mantiene é la malignidad se castiga, é la dignidad en las provinçias se ammenta, y cl imperio samamente ó en firmega se conserva?... Issi lo dice Flavio Vegegio", é másadelante, hablando en el caso de la hatalla campal, dige: "En semejante jornatda los capilanes tanto mas solicitos dehen ser quanto más ál diligente gloria é mayor

- Aqui decia en el original: "Se signio un gentil ardid que usó Corles para se salvar con los fuegos, aunque no sin pelear é mucho peligro de todos espera ser colocado é serle conçedida, é quanto más, aun de los peligros mayores, los no expertos las más reces snelen ser acompañados; en el qual breve espacio de liempo la dotrina del combatir, el uso de la verdadera arte y el buen consejo abielaunente scriorcan ${ }^{2}$.

Parésceme á mí que cste trabayo é vensimiento de los indios, excentado en la persona del capitan Ilernando Cortés y en los vençidos españoles, que con él se ha-

essos españoles que quedaban é sus confederados."

1 Vegec, lib. III, cap. 10.

2 lil., id., id. 
llaron, los latge mas gloriosos á loulos an goneral é á él en esprocial, eprél capritan ni mílites de todos quantos en estan parfos a Indias han menearlo las anmas, assi con ral r.suerco de todos los esprañoles. y!Ie de Temistitan salieron con tanta osadia é denucilo, romo eon la prudencia de su capitan 6 avivalo é invençible espiritu. i lo menos hasta el liempo pressente, en apuestas lndias esta perdida fan grande, é la inmmerable cantidadé moltitud de los adverssarios, é la vietoriosa venganca é victoriosal recuperagrion de la mesma Temistilan, é las otras particularilades é prósperos subçessos desta guerra é conquista de la Nineva España, á todas las demás preçede, como por estos volúmenes é verdaderas é particulares listorias se puede muy bien entender é colegir, sin ofensa de ninguno, si apartarlas las passiones é afiçion particular, algymo é tolos los que se quisieren ocupar en esto juicio lo quisieren entender, é saber lo que todos los gobernadores é capitanes han fecho é olsado con las armas deste el año de millé quatroçientos é noventa y dos años, fue fué el principio del descubrimionto del atmirante primero. don Cluripstólal Colom, hasta el pressente tiempo de aqueste año de mill é quinientos é fuarenta y ocho de la redempecion del linage lumano. E que esto sea assi la rerdad, é que merezea Cortés esta palma, verificase é pruébase con lo que está dicho, é con que llogando desl aratarloá la cildulad de Taculoa, halló toda la gente arremolinada en una plaça, que no salia lombre de los que quedaloan arlónde yr; y ćl, como luen capitan, dióles priessa para que saliessen al eampo antes que se recresciessen más enemigos é que tomassen las agoteas, porque no les hiçiessen mucho daño desle cllas, el qual estaba lien aparcjado, é díxoles: "Scñores, mirald que salimos de un cerco, de que Dios por su mi- sericordia nos hat librado, 8 no nos metamos en otro por muestra culpar ó inaldrer-

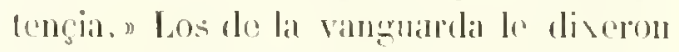
(jue no sabian por dónte arian de salir, é á essos hiço ruedar en la redrograrda; y é cono amimoso denque ó capilan gyeneral, tomó la delantera lissta los sacar fuera de la ribulad, y esperó en mas lalrangas á los postreros: é quando llegaron, supo que le avian muerto algunos españoles é indios, é (pue se quedabáa en el cimino muelıo oro perelido é que los enemiggos lo cogrian.

Allí cstoro Cortés liasta que passó toda la gente, pelearalo con los contrarios de tal manera, que los detuvo para que los peones chripstianos tomassen un cerro en que avia una torre é çierto apossento fuerte, é tomóse sin rescelir daño; pero ya no avia caballo de veynte y quatro que le avian quedado que purliesse correr, ni cavallero que pudiesse algar el lıaço, ni peon sano que pudiesse pelear, sino más que forçalo; porque aunque sus ánimos estaban enteros, las fuergas é prsonas estaban muy quelurantadas de la contínna fatiga del pelear.

Llegarlos á cste ilpossento, fortalescićronse los nuestros en él, é allí los çerearon liasta la noche, combatiéndolos de tolas partes, sin los dexar repossar ni una liora.

En este desharato é salida de Temislitan muricron çiento é cinquienta espanoles, é quarenta y çinco yeguas é caballos, é más de dos mill indios que servian á los cluripstianos, entre los quales mataron al hijo é hijas de llontecuma é á todos los otros señores, que traian pressos.

É aquella noche á media noche, creyendo no ser sentidos, salieron con todo el silencio que pudieron de aquel apossento, dexando en él licchos muchos fuegos, é sin saber camino alguno ni para donde yluan, mas de un indio de los de Tascaltecal, en cuya fidelidad se pusicron, é los 
gruiaba, diçicndo quél los sacaria á su tierra, si el camino no les impedian. I cómo estaban muy cerea algunas gruardas de los encmigos, assi como orieron conosçimiento de la fugga é partida de los chripslianos, apellidaron de muchas polulaciones çercanas que estaban á la redonda, é acudicron muchos indios en segnimiento de los españoles, como trás gente vencida, lasta que fué de dia; y en esclaresciendo, çinco de caballo que yban en la delantera por corredores, dieron en çiertos esquadrones de gente que estaban en el camino, é mataron algunos dellos, porque pensando que los de caballo eran más, se desharataron ellos mesmos. É cómo contínuo cresçia la mollitud adverssa, conçertó Cortés su gente lo mejor quél pudo, é de los que estaban sanos hizo esquadrones para la vanguarda é retroguarda é costados de su batalla, é puso en medio los heridos que no podian servir más de haçer cuerpo é muestra de mayor cantidad: é puso los de caballo en las partes mas convinientes, é prosiguió su camino, peleando todo el dia por todas partes. É fué tanto el embaraço é continuaçion en pelear, que en todo aquel dia y en la noche siguiente no pudicron caminar más de tres leguas, y essas é todo el tiempo ques dicho fué una continuada é trabada batalla, sin quedar passo sin sangre. E quiso Dios que quando el sol se entraba, vieron una lorre é un luen apossento en un çerro, al qual se recogieron é hiçicron alli fuertes: é aquella noche no lovieron contraste lasta el alba, que les dieron cierto rebate, en el qual no ovo más del temor, que ya los nuestros tenian concebido, por la contimuaçion de la mucha cantidad é incontable uńmero de los enemigos que yluan en su alcançe.

Seyendo ya una hora de dia, prosiguió Hernando Cortés su canino con la órden ques diclıo, como capilan cauto é aperçelido, é los contrarios assimesmo le si- gruieron de fodas partes, grilando é apellidando é aumentándose, porque aquella lierra es muy poblada, é todos venian de buena gana contra grente que pensalian rendir ó acabar presto en algun passo. É los de á caballo, aunque eran muy temidos, en ser ya pocos, puesto que á sus tiempos arremetian, Laçian poco daño, é tambien porque la liema cra algo fragosa, acogíanscles los indios a los cerros. Desta manera fueron aquel dia por çerea de unas lagunas, hasta que llegaron á una Juena poblaçion, donde pensaron hallat alguna resistençia con los del pueblo; mas como fueron á par dél, lo desampararon los reçinos, é se fucron á otras poblaçiones que estaban por allí çerea. de lo qual fueron muy alegres los españoles, por goçar de algun poco de tiempo sin batalla: é repossaron allí aquella noche y el signiente dia, porcue assi los lieridos como los sanos yban muy cansados é fíligados, é con inucha hambre é sed, y essos pocos caballos que tenian muy enflaquesçidos é trabaxados. Ilallaron allí algun mahiz, que comieron, é llevaron parte dél para adelante cogido é lostado; é otro dia se partieron de allí, pero con la contíma molestia é seguimiento de los adverssarios.

É assi fucron trás la guia ques dicho de aprel indio de Tascalteca, con tanta fatiga quanta el letor puede considerar ú colegir de lo que la historia ha contado, é porque muchas veges les conrenia lıacer el camino con las espadas. É ra que era tarde, llegaron á un llano donde cstaban unas pequeñas casas, é pararon allí aquella noche con mucha nesgessidad por falta de bastimento. Otro dia prosignticron su camino, assimesmo sevendo seguidos y escaramuçando á cada passo, é llegaron desde á dos leguas que andovieron á un pueblo sgrande, é á un lado dél estaban en un ferro alghmos indios: é pensindo tomalos, porfuc cisalian muy cer- 
car del camino, é por descobrir si ariat alsuma çelada de la otra prorte de arjuel serro, quiso Ilermando Cortes informarse por su persona, é con çinco de caluallo é hasta dose peones salió le culre su grente, fuć rodtundo el serro: é detrís dél estaba una grand cilsdad con mucha grente, la qual les salió al eneuentro. con quien pelearon tanto, que por la lierra áspera é pedregosa le convino retracrse al ofro pueblo que primero se diso, donde ya los otros españoles estahan.

De aqueste trançe salvó Corlés mal herido en la cabega de dos pedradas; é despues que se oro atado las lieridas, hiço salir los españoles del puchlo, porque no le paresçió seguro apossento para ellos, é caminaron seyendo todavia seguidos, é liriéronle quatro ó çinco es. pañoles é otros tantos caballos, é matáronles un caballo: el qual, aunque les liço mucha falla, porque despues de Dios, los caballos les eran mucha seguridad por el niedo que aquella ģente bárbara tenia dellos, con la carne dél 10vieron buen pasto, é se consolaron ó mitigaron en parte su hambre: é se lo comicron sin dexar cuero ni otra cosa dél, sino los luessos é las minas y el pelo, é aun las tripas no les paresçió de menos buen gusto que las sobreasadas de Nápoles, ó los gentiles calrritos de ivila, ó las sabrosas terneras de Sorrento é de Caragoca, segund la extrema nesçessidad que lleraban. Porque despues que de la grand cibdad de Temistitan avian salido, ninguna cosa comieron sino maliz tostado é coçido é lierbas del campo, é desto no tanto quanto quisicran ú ovieran menester.

;Oh faligas mumdanas buscadas por los hombres, más al propóssito (ó contra el propóssito) de sus cobdiçias, diriendo mejor, que por servir á Dios é por sacar en presçio de sus vidas de los hombres este oro, que lan caro ha costado á los más é tan pocos lo lan alcançado en estas par- les! lis aun dessos, que le han hallado, on presçio de lan amargos be peligrosos sudores para el cuerpo é para dánima, no ha segdo para que los mesmos le gororen, sino para otros, á quien descuydarlamente se fueron tales bienes sin los morescer ó esperar, sino para fundar torres de vic:sto é casas en el arena, é para que de lo mal adquirido se espere d fin que suclen hacer las olras cosas perescederas ó injustamente adluuiridas! Tornemos á: la listoria.

Viendo llernando Corlés que eada hora cresçian los perseguidores sus enemigos, y mas recios y descansados, y quél é su gente ylan siempre perdiendo y enfaquesçiéndose, liço que aquella noche que los herilos é dolientes (que llevaloan á cueslas ć ál las ancas de los cansarlos caballos, en los quales pendia mucha parte de su salvaçion, porque sin dubda acabados de perder los caballos, fueran perdidos los cspañoles, é para tener algzun aliento é poder con mas dilaçion excusar la muerte) hiçiessen muletas é bordones é olras maneras de ayudas para caminar poco á poco, porque los caballos é los españoles que eslaban sanos estoriessen lilmes para pelear. Y este aviso fué muy bueno, segund el sulygesso, porque cómo Corlés se parlió olro dia por la mañana de aquel apossento, desde á legua é media de alli hallaron al encuentro tanla cantidad de indios, que assi en la delantera como en las espaldas é costados ninguna cosa del campo quedó que se purlicsse ver vaçía ni desocupada dellos. F pelearon con los clripstianos con tanta osadiá é con lanta polvareda, que no se conosgian unos í otros: tan juntos y envueltos andaban é lan mezrlados, que sin dulyla creyeron los españoles que estaban en la úllima prueba, é que aquel era el postrero de sus dias! É assi lo escribio Corlés á Sn Magestad, por la grand moltitud de los adverssarios é por la poca resistençia que 
lallaban, por yr como yban cansados é acosados, é los más de los cluripstianos heridos, é todos quassi trasplassados é dehilitados de pura lambre, allende de los otros sus trabaxos; porque si esta no thvieran, fucran los dielos, como se dice, nuenos con pan. Fy que esse é toclo les faltalua, quiso Nuestro Señor socorrerlos de sn poder alssoluto, pues que con toda a fuella flaqueca de los nuestros, dió tanto ánimo é vigor á los quassi vençidos, que mataron muchos de los contrarios, y entrellos personas muy princiuales é señaladas, y en cantidad, porque eran tantos que los umos á los otros se estorbabin, de forma que ni podian pelear ni luygr. É con este asiduo trabaso se passó mucha parte del dia, hasta que quiso Dios que murió un capian, que debia ser lan prinsipal, que faltando aquel, con su muerte sessó aquella furia del pelear con tanta constançia, é llegóo el descanso de loz afligidos é cansados españoles, è fueron más sosergatos prosiguiendo su camino, aunque no del todo dexando de ser mordidos é salteados de quando en quando, hasta que llegaron á una pequeña casa que estaba en lo llano del campo, donde aqueIla noche se aposscutaron.

Ya desde alli se parescian ciertas sierras de la provinçia de Tascalteca, de que se sintieron tanta alegria los nuestros, que se acordaban bien de la que los liijos de Lrael porlian tener, despnes (pue Moysen subió deste el plano de lloals sobre ef monte de Kebó, ençina de Fasga contra Gericó, y el señor les mostró la lierra de Galaad lasta banı, é todo Neptalim, é les dixo: asta es la ticra que juré á Nhra- lam, Isace é Jacol, diçiendo: í tu simiente daré essa " ${ }^{4}$ ete.

Ya Ilernando Contés é su gente conosçieron deste adonde es dicho pror dóncle arian de yr, aunque no estalban muy satisfechos de hallar los naturales de la provingia de Tascalleca seguros ó por sus anigos: antes se sospechahan lo contrario, é temian que viendo á los chripstianos desbiratados, los acabarian, por vivir en la libertad que primero tenian sin su conoscimiento é amistad. Y esta sospecha les daba quassi tanto terror como el que llevaban hasta alli, peleando con los de Culua.

El dia siguiente, ya claro, començaron a andar por un canino muy llano que yba derecho at la provinçia de Tascalteca, por el qual los siguió poca grente de los contrarios, aunque avia cerca dél muchas é grandes poblaciones, puesto que deste algunos çerrillos y en la reçaga lodiavia los gritalian, como á rençidos é á maneäa de escarnio: é assi salieron arpel dia, que fué domingo ocho de julio, de toda la tierra de Culua, é comensaron ál entrar por tierra de la provinçia de Tascalieca, é fueron á un pucblo della que se llamaba Gualipa, de hasta tres ó quatro mill veçinos, é de los nalurales fueron bien rescibidos é reparados en parte de la grand hambre ć cansançio que llevaban. É resçibiéronlos con mucho amor, puesto que muchas de las provissiones que les lahan, eran por sus dineros é rescate, é no yuerian sino oro, y cran forcantos de dérselo por la mucha nescessidad en que se vian: ni les convenia dexar á los españoles de complatcer á afuella gente en esso y en más. 


\section{CiPITULO XV.}

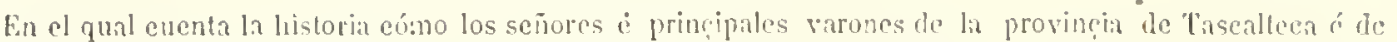

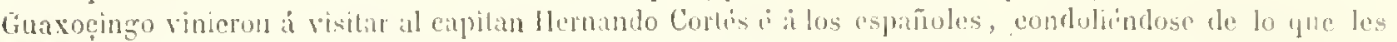

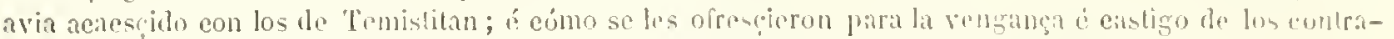

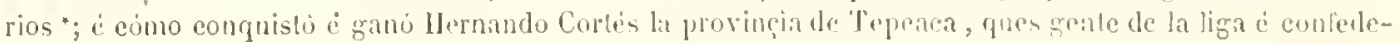
rarion de los de Culua; é cuentinse utras cosas notables **

\section{E} In ayuel pueblo de Gualipa esturieron Hernando Coltés é su ente tres dias; è alli le fueron á visilar Magriseaģin é Sicutengal, é todos Jos señores de la provinçia de Tascalteca, é algunos de los de Guaxocingo: los quales mostraron mucha pena de lo acuescito á los esprañoles, é consolando á Cortés é á ellos. Jes dixeron que se acordassen cómo muchas reges le avian ellos dicho que los de Culua eran traydores é sin verdad, é que se guardassen dellos , é no Jos avia querido creer Hlernando Cortés ni tomar sll consejo; pero que pues lo passado no podia dexar de ser, y él avia escapado vivo. que se alegrasse: que la fortuna é luena dicha que lasta allí avia fallado, vendria con tanta prosperidad como desseaban, é ynellos le ayudarian con toda lealtad Insta morir, por le vengar é satisfaçer del daño cue sus enemigos le arian hecho, assi por la voluntad que tenian de servir al Emperador, nuestro señor, por cuyos rassallos se avian ofresçilo, é complir con lo que eran obligados, como porque se dolian de los españoles, é tambien de muchos hijos y hermanos é parientes, sus naturales, que en compañia de Cortés á ellos les avian muerto, cuya sangre harian escotar é pagar muy lien á los adverssarios, é por otras michas injurias que los

- En este lugar se omitieron las cláusulas siguientes: "E del buen acoģimiento que hiçieron á él é à los chripstianos, é cúno alli supo Cortés del mal subresso é muerte de los españoles quél as ia dexado, quando fué à Temistitan, con ciertos millares rle pessos de oro é olras joyas é hapienda suya tiempos passados arian rescribido de los de Culua; é que toriesse por çierto que le serian muy verdirtoros amieros en todos sus hechos Inastat lit muerte. E que pues venia licrido él, é todos los dentís de su compañia muy trabaxalos, (pine se fuessen ál la cihdad, que está quatro lecuas do atuel pueblo, ć allí descansarian é se curarian é repararian de lo nescessario; é otras muchas palabras consolatorias é amorosas diseron á este propóssito. Las curales aceptó Cortés con otras raconcs sultisfatorias á su lunen comedimionto é ofertas, agradescićndosclo mucho; é les dió algunas pocas cosas de joyas que se avian escapato, de que fueron muy contentos los que las resçijicron, é juntos se fineron á la cildarl, en la qual Cortés fué muy bien a'escilido. E Magriscaçin le Jico luego traer una cama de madera encaxala. en cue durmiesse, con mur gentil ropa de algoton de la que en aquella ticral se usa : é á todos los españoles higo reparar de lo quél tuvo é pudo.

En arfuclla cibdad arian quedado sicrtos españoles, quando Cortés passó jor allí, rendo á la de Temistitan, é algunos de sus criados con plata é ropa é otras cosas de su lagienda é con alghtmas provissionos; é mandóles que allí le esperassen por yr más desocupado, si algun impedi-

\footnotetext{
¿ de los eapitanes.n

* Tambien arui suprimió lo signiente : E cúmo hiço una villa é la pobló de chripstianos é la llamó Segrura de le Frontera, para asegurar aquella tierra $e$ puerlos, por la oporlunidad del buen assiento."
} 
mento se le ofresciesse. É perdićronse todos los auctos y escripturas, que se arian fecho con los naturales de aquellas partes prara justificaçion de la gucrea, con lat ropa que quedó assimesmo de los esprañoles que con Cortés ylan. porque no quisieron llevar más de lo que tenian á cuestas vestilo, é sus armas é hamacas ó cama, ques cadal una sola mo manta, como en otra parte destas historias está dielı. É supo alli Cortés cómo uno de sus criados a via allí renido de la villa de la Yoracruz con mantenimientos é cosas para él, con cinco de caluallo é quarenta y cinco peones, el qual se llevó consigo á los olros que alli avian quedado, con toda la plata é ropa ć otras cosas que de Cortés é los compañeros quedaron, é con siete mill pessos de oro fundido que allí avia dexado Cortés en dos cofres, sin otras joyas, é más de otros catorge mill pessos de oro lalorado en pieças de direrssas maneras, que los indios de la provinçia de Tuchileleque avian dado á un capilan que Cortés enviaba á hacer el pueblo de Guaçacalco, é ouras muchas cosas, que valian más de treynta mill pessos de oro; é que los indios de Culua los avian muerto á lorlos en cl camino é tomáddoles fodo quanto llevahan. Assimesmo supo allí Corlés que arian muerto olros numchos españoles por los caminos, que yban á la dicla cilsdad de Temistilan, crevendo que estal)a pacéfico en ella é acquella lierra cslaba segura. Oydas tan malas nucras, sospechó Cortés que los contrarios avrian dado sobre los de la villa de la Veracruz, é que los que tenian por amigros, sabiendo su desharato, se arrian rebcelado; é á csla causa despachó lnego cicrtos mensajeros chripstianos con guias que les dieron los indios, é mandóles que fucsen fucra de camino hasta ser en la dieha villa, é que con toda brevedad le liscicssen saber to que allá passalıa : é quiso Dios que hallaron buenos á los españoles, ć í los nalu- rales de la lierla muy seguros. Desta nuera holgó nucho Corlés é todos los demás que con él cstabin, aunque para los de la villa fué mucha tristega saluer el desharalo é saliela de Temistilan ó México con tanla pérdida é mnertes como la historia lia conlado de susso.

En aquella provinçia de Tascalteca estoro IIernando Cortés veynte dias, curándose de las heridas que tenia, que por el camino é mali cura se le avian enconado, é hiço curar á los demás de su compañia; é algunos muricron, assi por causa de las heridas como por el excesivo trabaxo que avián padesçido. Orros quedaron mancos é coxos, porque demás de ser las lieridas malas, era peor cl aparejo de la cura é de poco socorro, é fallando todo lo nescessario, y el tienpo y el reposo; y el mesmo Hernando Cortés quedó manco de dos dedos de la mano izquicrda.

Viendo los españoles que cran muertos muchos dellos, ć que los que quedaban estaljan flacos y treridos, é temoriçados de los peligros é trabaros en que se avian visto, é tenicndo los por renir, considerahan en el pesso de la guerra futura que estaba toda sobrellos, é que Cortés entendia en la continuacion dẹlla; é por estos é olros respcetos acordaron entre sí unánimes, de le requerir que se fuesse á la villa de la Veracruz, é que allí se hiçiessen fuerles antes que los naturales de la tierra, que tenian por amigos, viendo su desharato é disfaror é pocas fuerças, se confederassen con los encmigos é tomassen los pucrtos que avian de passar, é diessen por una parte solıre Cortés é los yru con él estaban, é por otrá diessen sobre los de la villa de la Veracruz; é que estando juntos alli los navios, estarian las vidas de los unos é de los otros más se. grtras, ése podrian mcjor defender, pues10 que los acomclicssen, hasta tanto que enviassen por socorro á estas nuestras islas Española é Cuba é las demís. 
Parreseme que la respuesta gar á esto les dió Hermando Coptés, á Io yue hiģo en collo fuc una rosa de ámino invenciblo é de raron de mucha suete é valor, porque despues fue muy lien oro escuchado todo lo que lé quisienon derir é recpurir, l a respondió desta manera : "Cavalleros, señores, hermanos é amiges mios: yo he eatenelialo muy bien todo lo que me avers dicho i aun a!gunas vegea requerido nn publico y en secreto: y en la rerdat yo no reputo lo crue degis á flaquega ni falta de ámimo verestro. porgue vuestra virtud, vergiienea y esfocien fodo lo tongo muy bien experimontado, é sé que calda mo de rosolros rs digno de grandes merecdes, é assi capero que las areys de alcanfar del Emperador Rey, nuestro señor, cryos sops é á quien servis, despmes que Su Hagestad sepa lo mucho que ál Dios é al Rey areys servido en las cosas hasta arpui subcredidas. Junto con esto os conozc.) particularmente. çelosos cada mo é de sil honor proprio, que quiero deriros como anigo é compañero en vnestros subcossos é trabaxos lo que me paresce rue para colmat ruestros servicios se dobe lacer. Los que atienten al hecho de las ämas, no le exerrilan cou ámimo de estar sinmpe entre aquellas. sino que por medio suyo estiman conseguir riquecas é srandissimos y esquisilos honoros. é pomusia, é mayor folicidad para sí é para sil patria. Todos estos bienes é otros mayores, que Xenofonte no alcangó á sabure ni escribe' tencys rosotros aparejallos, pues que aquel como gentil no puto consulerar la gloria é premio cpue se nos aparoja y meresceremus con li conclasion de nuestra compressa, en ser contra infieles, alurgando é aumentando la féc chripstiana, é poniendo en sll obieliencia tantos millares de gentes hárharas como hay en nuestros adrerssarios, é cresciendo é au- montando la arcostumbrada é animosa forlalega de muestra nacion. ¿ alleșando é

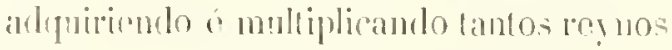
éseñorios, como pornemos dedaso do la virtud é pallimonio real dir Castilla ; ódomís de lo yues dicho, grandes intereses. que general ó particularmente conseguiremos continúndose la suerra. Deheys de mirar que mostrá á los maturales qualquicra flaquesa de ámo seria dan esfueré á los enemigos é perler ol crédito é reputacion con nuestros confederados, pala que con justa causa nos dleven, é scan contris nosotros. Demís desto es lo que drecis perder la confiança é promesa de los amigos, en cuya casa é lierra nos acogimos y estamos, é donde labllamos la anisad ć buen acogimicuto que en Espania nuestros debaros é propínumos nos liicieran. Fi sitos mal pensimiento toricran ó le avian de tencer, mejor lo pudicran exeregitar, quando aqui llecramos, que dexíndonos descansar é armámdonos, como In han hecho; quanto más que son cnemiéssimos antiguos é perpéluos adrerssarina de quien nos ha ofondido, é les capo parte é mucha de nuestro daño, é discean satisfocerse é rengar sus proprias iajurias en nuestio compañia. Acordios, scñores, que la fortuma liene por officio no estar on nuser, ć si lasta aqui avemos sido olvidados della, no de la fortuma nos quesmos, sino de nuestras culbaz: ć que no merescemos á Dios tanto liven como de cutre lis manos se nos saliú. y esperamos cobrarlo, si $n 05$ encomondíramos á él é mas quatos le fuéremos, pues que somos chripstianos é peleamos por su sancta fúc en nomlure de tan chripalianissimo Emperador: é no permilirá nuestro Señor que perezcamos ni se piorda tanta é tan noble é rica y hermosa ć Pertil tierra como está en punto de sc paçificar. Ni es bien ni honesto que tan 
grand bien é tan señalado servicio se dexe, é que por nuestra poquedad é falta de rosotros é mia rengan otros ál rengarnos é á goçar de lo que podemos lacer por nuestras personas. Antes me determino, en contianca de la buena ventura de Céssál, y en la esperança de Jesn-Chripsto, en cuya cemencia está cl buen fin que esta conquista ha de tenero, y en lá virlud de vuestros ámimos, de no haxiar los puertos háça la mar en ningma manera, sino morir sirviendo como buen hombre, é no vivir cometiendo tan notable cobardia como seria hacer otra cosa, desamparando esta ficra. E aun porque demís de ritestra verguienca é mia, y el notorio peligro que está aparejado en volver las cspaldas al enemigo, conteteramos mucha trayggion á nuestro Rey. Issi que, señores, yo he pensado mucho en esto, é os pirlo por merced que me sigays, pues conosegeys de mi persona que en las cosas donde hay peligro soy tan soggiable é aparejado á acompaũaros, como to avess experimentado; y en las cosas donde lay ganangia é interés tambien las parto con todos, como lo aveys visto; é si somos pocos los espanoles, no erears ques lo mejor la moltitud. Yo entiendo, con la ayuda de Jesu-Ci!nipsto, de volver solne los enemigos por quintas vias me fuere posible, $y$ espero con él en vuestra compaña é de nuestros confercrados alcancar vitoria é venganca de los que nos han ofendido. E no me lable ningrmo en otra cosa, y el que desta opinion no estoviere, váyase on buen hora: que mas holigaré de quedar con los pocos é osados que en compañia de muchos, ni de ningun cobarde ni desacordado de su propria lonra. Intes doy iufinitas graçias á Dios, porque nos ha traydo á tal liempo que conoserercmos é veremos quáles scrán a quellos de nosotros que beberín con la

1 "Qui lingua lambucint aquas sicut solent eanos lambere, separabis cos scorsum: qui aulem curratis genebus hilherint, in altera parte erunt.u Liber mano é con la lengua tomarán el agua; é quales de rodillas é de bruces para yue se aparte, como lo dixo Dios á Gedeon, é fué el número de aquellos que con la mano llevaron el agua ál la boca é bebieron assi treseicutos rarones. E con ayuel poco múmero prometió Diỏs á Gedeon de lo lacer vençedor contra los madianilas sus enenigos, é la otra mollitud toda le mandó que la dexasse, como mas largamente la Sagrada Escriptmanos lo acuerda ' Por manera, señores, que como de susso dixe, aquella anctoridad de Vegecio uque no creays ques mejor la moltifud ${ }^{2}$ ", por estotra de la Sagrada Escriptura os acuerdo que no dusconficys por ser pocos, porque si la vitoria consistiesse en el numero mucho de los hombres, no le dixera Dios á Gedeon que con pocos se quedasse. Ni aveys dexalo de ver vosotros palpablemeate tal maravilla, ni el mesmo Dios la dexado de commicárosla, pues os sacó de lan inmumerable cantidad de enemigos. Con soln uno de rosolros que me quede tengo de acalar en mi officio: é si esse me fillare, solo yo le haré, porclue nunca se dirá que yo, señores, os lälé é si vosotros me faltúredes, que no creo, liaced ruestra rohuntad é Dios haga la suỵa: que aparejudo estoy de darte graçias por todo, al qual plega dexaros acertar en lo que liviéredes, como el y el Eninerador, micstro scrior, más servidos sean he vosotros é de mí."

Ariendo acabado Cortés su exhortacion, como buen capitan, forlos los esparindes fuedaron nuy salisfeclos, é nutando su’primero propóssito, le diseron que larrian todo to que les mandasse de muy Inena roluntad, ć con essa é muy entera obra le segrumian en la paz y en la guerra.

Tornando á la listoria, aplacado el molin, que se comengaba á eugendrar, por la

Judiem, cap. Vil. vers. $\ddot{~}$

2 Vegecio, lib. III, cap. 1. 
pruslencia de Itemamdo Cortés, quediarom folos muy determinados, tales quales astoviessen, de ofreserer sus personits é vidas al compliniento de la conquista a a assi, passados los reynte dias que ristoricmon en la provinedia ques dicho, puesto yue Cortés no éstaba de torlo punto samo de sus licridas, é los españoles aun estaban flacos, partićronse para ofra provin(ia que se dice Tepeaca, que era de las ligya é consorçio de los de Culna ó mexicanos. Y cslos de Tepeaca avian muerto diez ó doge españoles que yluan de la Veracruz á la gran cibdad de Temistitan, porque por allí era el camino, é arpuella provingia de Tepeaca conlina é prarte términos con la de Tiscalteca é con la de Churntecal. y es muy grand provincia; y en entrando los españoles por áquella tierra, salicron muchos indios de los naturales della á se lo resistir é pelear contra ellos, evilíndoles la entrada é fuanto les fuesse posible, en especial en los passos fuertes é peligrosos. É cómo Cortés, por excusar la prolixidad de su carta, no dió cuenta particular á Céssar de muchas particularidades que en aquella guerra acaescieron, diré solamente dellia lo quél diçe: y es que despues de hechos los requirimientos que convenian, para que los enemigos viniessen á la paz é obodosçiessen los mandamientos qune de parte de Céssar se les hiciessen, no lo quisieron complir ni estimaron tal concordia, pues que era queriéndolos poner en servidumbre. É assi se les hico cruda guerra, é ovieron muchas escaråmnças é recuentros, en que siempre los contrarios perdieron el campo, é muchos dellos las ridas, sin muerte de ningon español, aunque la provinçia es muy grande.

En espacio de reynte dias se pacificaron muchas villas é polblaçiones della, los señores prinçipales vinieron á la olsidiençia á darse por vassallos de la corona real de Castilla, en la qual empressa é vi- mioso revento lueron mucha parto los confederados indios de Tascalteca.

Argesto assi aciabiallo, redó Contrós de aqualla tieréa á munchos do los dro Culata,

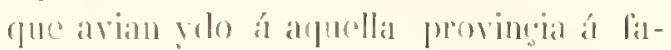
volesece los naturilás della contra los

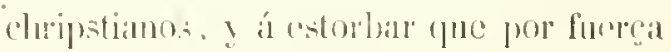

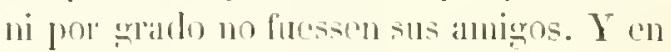
cierta parte desta provingial y en especial arlonde avian muerlo arpullos diry ó doce españolos fue so divo de susso. se mostraron los naburales do arpuella ticra mís rebchles é porfiarlos é fué nescressario scoñaldeto catiogo en eltos; y demás del que sa les dií. sojuzcríndolos con la fuerga de las amas, á fodos los que se tomaron á vida declaró Ilernando Cortés por esclaros, é fueron repartilos entre los conquistadores y licrados con fuctoro, en señal de su perpétuo cantiverio, é aun tambien porpue todos ellos comen carne lumana. Y este castigo puso mucho temor en los de la lengna de Culna, á rnien tan maldita costumbre es muy commo é usada.

Pero no dice Cortés en su relaçion una cosa, que no es de poco espanto entle aquella grente. y es para poner grima y terror á los que lo oyeren é aborresçible cosa miralo: la qual os que quando aquellas gentes polean en sus guerras, no hay nescessidial de pala ni hacadon, pues no enlicran los muntos ni quieren lal ocupaçion, sino ol que quedla vençedor del campo, lo primero que hacen los que permanegen vengedores es partir á podaços los cuerpos de los que lan muerto, é comérsclos cosidos ć assados, ć aun algunos hay que los comen en otros polages; pror manera que consigo llevan las sepulturas de los difuntos, que son los vientres de los vencedores, dentro de los rfuales sepultaron á los que vonçieron é matiron, remo es dicho.

En la defunicion de esta empresa é ritoria que se oro desta provincia de Tepeaca sinvieron nuy bien los indios de la 
provinçia de Tascalteca é Churultecal é Guaxoçingo, sin los quales fuera por demás tentarse lal empresa, segrund el poco número de los cepañoles á respecto de los contrarios; pero la buena maña de Cortés é sus buenas palabras pudieron adquirir el amistad de los confederados juntanente con la intigua encmistad, que ya ellos tenian contra los de Culua é Tepeaca.

Estando Cortés ocupado en esta guerra, le fueron carlas de la villa de la Veracruz, por las quales le hiçieron saber cómo arian llegado dos navios de los del capitan Françisco de Garay desharatados, que segund se supo él avia tornado á enviar con mas gente á aquel rio grande de Panuco: é pelearon con ellos los maturales é mataron diez y siete ó diez y ocho ehripstianos, é lirieron otros nuuchos, é les mataron sicte calbillos, é los españolos que escaparon fueron los que lovieron buenos piés para luugr é se acogrieron á nado á los navios; é que aquel capitan é los demás venian muy perdidos y lieridos, é quel teniente, que Cortés tenia en aquella villa de la Veracruz, los resçibió muy bien é los hiço eurar é proveer de lo nesçessario. Esto diçe Cortés que les acaesçió, por no aver ydo á él estos españoles, quando á la eosta de la Nieva Espaİa allegaron, porefue como experimentado en la tierra les avisára, de manera que se excusára su mal subcesso, en especial quel señor de aquel rio é lierra del Panuco se avia dado por vassallo del Emperador, $y$ en reconocimiento dello avia enriado á la cilubarl de Temistitan suš cmhaxadores ó mensajeros á Hernando Cortés con çicrtas joyjas é presseas. Assique, como Cortés supo lo rues dicho, envió á mantar a su teniente que si aquellos de Francisco de Garay se quisiessen yr, fuessen ayulados é favoresçidos para el buen despacho dellos é de sus mavios. Otros diçen en esto muy al revés, é (jue se les diba buenas palabras, é que por otra parr- te los impidieron é tovieron forma para que de nesçessidad se quedassen en la ticrira, é los navios al través. Pero dexemos estas conticndas, que usança es de los liombres de guerra usal de todas sus cautelas posibles para que se aumente su exérçito, en espeçial trás una nescessidad tan notoria cono la que en essa sacon te. nia Cortés de gente.

Tornemos á la provinçia de Tepeaca, que despues que fué paçifica, considerando Llernando Cortés, como prudente, lo que eonvenia larerse para que to eonquistado se conservasse y estoviesse la tierra en toda ruietud, é platicado en ello con los officiales de Cússar, viendo que los naturales de aquella provinçia, aviéndose dado por vassallos de Su Magestad, se avian despues rebclado é mucrto españoles, é que arpuellos indios están en el eamino é passo de la contractaçion toda de todos los puertos de la mar para la tierra aden. tro, é que si acuella provinçia se dexasse sola como de antes los naturales de la tierra é señorio de Culua, que son sus veçinos, los induçirian á que olra vez se alçassen, que seria muclio estorlso é impedimento para la paçificaçion de aquellos reynos, é cessaria la contractacion de la mayor parte de la tierra. poreque para el camino de la mar no hay más de dos pueríos muy fragosos é ásperos, que confinan eon aquelli provinçia, é los naturales della con poco traliaxo é gente los podian fácecilmente defender ; é para excusar estos é otros inconvinientes muclıos, paresçió que se delia lıaçer en dicha provincia de Tepeaca una villa en la parte que más á propóssito fuesse, é donde concurriessen las calidades nescessarias para los pohlarlores é reçinos della. É poniéndolo en efetto d capitin Ilernando Cortés, en nombre de la Cessírea Magestad, fundó la dichar villa, épúsole nombre Segura de la rrontera, é nombró alealiles é rescidores é otros officiales nescessarios á aque 
lla repiblica. E por mas seguridad ale los que allí pohbassen, hiso traciar mar torlale-

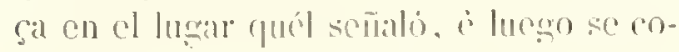
mençaron a lrace nateriales para la labor della con toda diligençia nesçessaria, siu cessill liasta la dexill defensible y en la perficion yme compenial.

\section{CNITULO XY.}

Cüno el scitur de la cibdad de Gigneachula envió sus mensajoros it Ilermando Corlés, ofrespiéndose al servi-

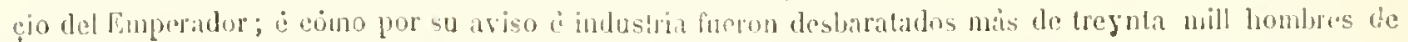

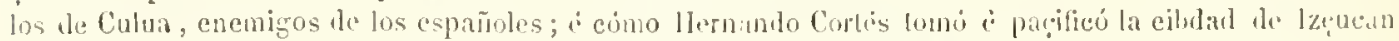
con olras polblaciones, a vinieron is se eonfederar con has chripstianos mucho número de indius contria

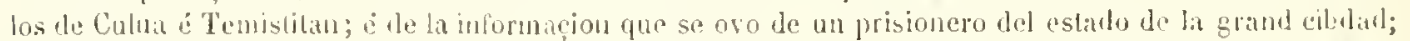

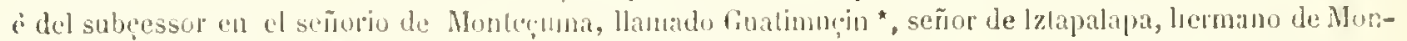
tecuma, é olras partieularitheles con que se darà lin a la relaçion de la earla que llemando Cortés cseribiỏ al Emperador, nuestro scũor, desde la villa de Segura de la Frontera, en la Nueva España, á los treynta de octubre de mill é quinientos y veynte años.

\section{C} ba lastimarlo i sentido de las cosas passadas con los de Hexico, è sus ánimos é desseos no le dahan lugar á olvidar sus trabaxos, é sus pensamientos eran de persona valerosa, pućdesele muy bien aplicar aquella sentençia de Platon que diege: * Tal es carla uno, qual es la cosa que ama é aquella de que se deleyta ". Assi que este capitan, que tan inclinado é amigo de la guerra fuć, é tan sufiçiente á tan alta empressa, no se puede comparar mejor su persona que ál la grandera della mesma; é aun assi se debe creer que yuien para ella le conservó contra muchos estorbos é contradiçiones, sabia mejor que los hombres quán nesçessario elar lal capilan, para que se sirviesse Dios dél en estas cosas é conquista de la Nueva España. É assi, estando eseribiendo á Cissar la relacion do las cosas que le arian acacscido, é que de susso se lan locado en los capútulos precedentes, llegaron á ál cierlos mensajeros de una ciludad, que está - cinco leguas de la provingia de Tepeaca. la qual se llama Guacachula, y es á la cntrada de un puerto que se passa para cntrar por alli en la provingia de Mexico: los

* En el original parcer deeia : Cuyllemasi; pero cs gerro de pluma. quales, de parte de aquel señor, le dixeron á Cortés que por que ellos pocos dias avia avian renido á dar la obidiencia al Emperador, i i su corona real de Caslilla, como vassallos suyos, ofresciendose de servir á Su Magestad, é porque Cortés no los eulpasse, ereyendo (que por su consentiutiento cra, le laçian saber cómo en la dicha cibrad estabin apossentados - ciertos capilanes de Culua, d que en ella é á una legua de allí cstaban treynta mill hombres en guaruicion, guardando aquel puerto é passo palra que los chripstianos no pudiessen entra por él, é tambien para defender que los naturales de dicha ciblad, ni de otras provinçias á ella comarcanas, sirviessen á Céssar ni fuessen amigos de los españoles; é que algunos ovicran venido á se ofresçer át su real serviçio, si aquellos no lo ovicran impedido. Por tanto que se lo haçian saber, para que con tiempo lo remcliasse, porque demás del impedimento que cra á los que buena voluntad tenian, los de la cilsdad é todos los comarcanos resçibian unclıo daño, poi'que como estaba mucha gente de gucrla junta, eran muy molestados é maltractados, é les tomaban sus mugeres é lıa-

1 Platon, De Republicâ, lib. V'l. 
giendas: assi que riesse lo que queria é mamdaba Cortés quellos liçiessen, porque díndoles favor, cllos to harian.

Cortés les agradesgió mucho quanto le dixeron, é st aviso é ofresçimiento; é les dió graçiosa respuesta conforme á la embaxada é á la voluntad, con que le infolmaron de lo ques dicho: é les dió trege de caballo é doscgientos peones para que con estos embaxadores fucssen, é treynta mill indios de los confederados, é fué concertado que los Ilevarian por parte que no fuessen sentidos; é despues que llegassen junto á aquella cibdad, el señor é los naturales della, é los restantes de todos sus vassallos é valcdores, estarian aperçelıidos é cercarian los apossentos, donde los capitanes estallan apossentados, é los prenderian é matarian antes que la gente los pndiesse socorrer, é que quando la gente llegasse, ya los españoles cslarian dentro en la cilulad, é pelearian con ellos é los desbaralarian.

Con este assiento é ardid se partieron estos indios é los españoles é confederados, é fueron por la ciludad de Clumrultecal é por alguna parte de la provingia de Guaxoçingo, que confina con lierra destal ciludad de Guicachula é con los de Culua, para fue debaxo de aquella cautcla llevassen á los españoles á la dicha ciludad, é que allá torlos juntos diessen en ellos é los matassen. É cómo aun no era de torlo punto olvidado el temor que los de Culua en su cihdad y en su tierra avian puesto á los chripstianos, púsoles muclıo espanto esta sospecha, $y$ el capitan que ylua con ellos hico sus pesquisas, como lo supo él hacer, pero no entendiéndolo como se debia cntender; é prendió á todos aquellos señores de Guaxocingo que yban con él é á los mensajoros de la cibdad de Guacachula, é con estos injustamente pressos se tornó á la cibdad de Clumbiltecal, qure está quatro leguas de allí, y envió todos los assi pressos con cierla grente de pié 6 TONO III. de caballo á Cortés, é con la inlormaçion que en el caso avia avido, y escribióles que los chripstianos estaban atemoriçados é que le paresçia que aquella jornarla cra unuy dificultosa é no conviniente.

Llegados los pressos á lleruando Coltés, hablóles con las lenguas, é sabirla la verdad, parescióle quel capitan no avia bien entendido el caso, é mandólos soltar luego é satisficolos con lucnas palabras, dándoles á entender que aquel capitan que los prendió, a via seydo engañado, é que no los avia presso de su voluntarl, sino pensando que le avian dicho verdad: é que creyessen que Cortés los tenia por verdaderos é leales amigos é buenos rassallos de Cússar. E determinóse Cortés, por quitarles escrúpulos, de yr en persona á pelear y echar fuera de la lierra á los de Culua; é assi lo puso por obra, porque con su persona se quitaban las sospechas y el atrenta hecha á los confederarlos, é se satisfarcia á los mesmos españoles. É assi se partió lucgo é fué á la cibdad de Churultecal, que está orho leguas de allí, é halló que los españoles Lorlavia pensaluan ser çierta la trayçion yal dicha; é otro dia fué á dormir al pueblo de Guaxoçingo, ques adonde aquellos señores avian seydo pressos. I d dia adelante, despues the aver concertado con los embaxadores de Guacachula por dónde é cómo avian de entrar on la cibdar, se partió Cortés para allá una hora antes del dia, é fué sobre ella quassi á las diez. horas del dia ; é á media legua le salie. ron al camino çiertos mensajeros de aquella cibflad, é le dixeron cómo todo eslalia á punto é muy lien proveydo; é que los de Culua no sabian cosa alguna de los chripstianos ni cómo yluan, porque ciertas espias quellos tenian en los caminos, los nalurales de la ciludarl los avian prendido, é lo mesno avian liecho á otros, que los capitanes de Culua cuvialuan á se asomar por las gercas é torles de la cib- 
dail á descolrir el campo, o a esta causa toda la gente de los eoutralios eslaba muy deseuydada, ereyendo que tenian recabdo en sus velas é rentinclas: por lanto, que seguramente llegasse, que no podia ser sentido. lí assi dió mucha priessa por Hlegare á la ciblad por mn llano, donde descle ella los podian bien rer, y en fin fueron vistos, é viendo que lan cerea estaban los chripstianos, luego çerearon los aposentos donde los dichos capitancs esfaban, é comengaron á peloar con los demás (juc por la cilulad estaban repartidos; é quando Cortés llegóó á un tiro de ballesta de la ribdad, ya le thaian hasta quarenta prissioneros, é sc dió priessa todavia á centrar dentro, é andaba mucha garita por las calles, peleando con los contrarios. F quiado Cortés por un natural de la cilubd al apossento, donde los capitanes estaban, hallólos cereados de más de tres mill hombres (que pugnaban por les entrar la pucrla, é les tenian tomados los terrados é altos todos; é los capitanes é los que con ellos estaban, pelcaban como hombres de mucho esfuerço, aunque eran pocos, é no los podian entrar por sus buenos ínimos é porque el apossento era assaz fuerte. Li como Corlés llegó é los combatió, luego los entró; é fuć tanta la ggente de los naturales que le siguió, que en ninguna manera Cortés los pudo socorrer, ni exeusar que brevemente no fuessen muertos, puesto quél quisicra tomar algunos á vida para sabel é informarse de las cosas de la tierra é cibdad de Temistitan, é de quién era señor della despues de la muerte de Nontecuma, é de otras partieularidades; pero no pudo tomar sino uno que estaha más muerto que vivo, é de aquel supo lo que adclante se dirá.

Por la cibdad mataron muchos de los que en clla estaban apossentados, é los que quedaban vivos, quando Cortés en la cibdad entró, sabiendo su venida, començaron á huyr híçia donde estaba la gente yne lenian en gruarnigfon, y en ol alcance assimesmo muricron muchos. F́ fuć lan presto oydo é sabido cate lumulto por la gente de guanticion, que estaba en un alto que soljuzgaha la cihdad é lo llano de al redulor, que quassi á una saron llezaron los que saliam luygendo é la grente que les yla en socorro, é á ver qué rosa rra aquallo: los quales cran más de treyuta mill hombres de muy buçila genle a muy bien armatos, segund sli coslumbre, é lleviluan muchas joyas de oro Cphatia solve sus personas é muy hermosos plumages. É como la cilulad es grande, comencaron á poner fucgo por muchas paldes en ella, é los nalurates con mucha diligoncia avisaron á Cortés, é salió con sola la gente de caballo, porque los peones estaban muy cansados, é rompió por los contrarios; é apretílos tanto, que los hiço retrace á çierto passo, el qual se les ganó. É siguicudo el aleançe por una cuesta arriba é bicn fragosa, quando fueron en la cumbre della, ni los enemigos ni los cspañoles podian yr atrás ni adclante de cansados, é assi cayeron de los contrarios muchos mucrtos de la calor é ahogados de sed, sin herida algruna; é dos caballos se aguaron, y el uno murió.

De lal manera se hiço esta jormada quel vençimiento fué muy copioso y el daño de los contrarios grandíssimo, porque coneurrieron en la vitoria muchos de los amigos confederados con los españoles; ć cómo yban descansados é los otros quassi ahogados de la calor, mataron muchos: de forma que deste á muy poco espaçio de hora eslaba el campo racío de los adverssarios vivos, puesto que de los muertos dessos mesmos bien ocupado. É continuándose este próspero alcançe, llegaron los chripstianos é sus amigos á los apossentos que tenian hechos en el campo los vençidos: é tenian aquel su exérçito en tres reales 0 partes repartido, é cada una dellas paresçia una villa, e no 
pequeña, porque demás de la gente de guerra, tenian mucho aparato écompaña de servicio, é bastimentos é fornesçiniento para sus reales. É avia entrellos muchos prinçipales hombres, segund despues se supo; é todo fué saqueado é quemado por los indios amigos, que ya eran más de çient mill los que en esto se haliaron.

Con esta victoria, aviendo echado todos los enemigos de la tierra, hasta los hacer passar de la otra parte de unas puentes é malos passos quellos tenian, se tornó Cortés á la cibdird, donde fué muy rescilido de los naturales, é aposseníado ¿̀ ésu gyente, é descansaron allí tres dias, porque tenian bien nescessidad de reposso. Estando allí goçando de la triunfante victoria ya dicha, para adornamiento.de aquella, vinieron á laçerla ma yor ć ofresçerse por vassallos del Rey, nuestro señor, é de su corona é çeptro real de Caslia, los indios de una pohlaçion grande que está ençima de aquellas sierras, á dos leguas del real, donde estaban los enemigos. Y estos están al pić de un monte muy alto de que continuanente sale humo, como lo haçe aquel del vilcan ó Mongibel, é llámase aquella poblaçion Ocupatuyo; é dixeron quel señor que allí tenian, se avia ydo con los de Culua al tiempo que Cortés los avia corrido é deslaratalo, creyendo que no parára hasta su pueblo; é que muchos dias avia que dusseaban estos la amistad de los clnipstianos, é ovieran venido á se ofrescer por vassallos de Céssar, sino que aquel su señol no los dexaba ni avia querido que lo hiciessen, puesto quellos muchas veces sc lo avian consejado é aun requerido; é quellos querian ya servir al Rey de Castilla, é que allí avia quedado un hermano de aquel señor, el qual siempre avia seydo de opinion que fuessen amigos de los chripstianos, é tenia propóssito de servir al Rey; é que le rogalsan al capitan
Heruando Cortés que oviesse por bien que aquel subcediesse en el señorio; é que aunque el otro tornasse, no consintiesse que por señor le resçiliessen, ni ellos le resçibirian. Cortés les respondió que por arer seydo hasta estonces de la liga é parçialidad de los de Culua, é averse rebelado contra el serviçio del Emperador Rey, nuestro señor, cran dinos de mucha pena, é que assi tenia pensado de dársela y execularla en sus personas é laçiendas; pero que por aver venido, como venian, é deçian que la causa de su rebclion é alçaniento no era ni fué de su voluntad, sino por culpa de aquel su señor, que Cortés, en nombre de Su Magestad Cessácea, les perdonaba sus yerros passados, é los rescibia é admitia al serviçio de Su Magrestad, con aperçibimiento (jue si otra vez cometiessen semejante delicto, serian punidos é castigados muy enteramente; $e$ que si leales é buenos vassallos fucssen al Rey, nuestro señor, é á su corona real de Castilla, serian muy faroresçidos é ayudados de Cortés é de los españoles como tales amigos é vassallos del hey, nuestro scñor. É assi lo prometieron que se haria inviolable é perpétuamente, é que por sus serviçios serian meresçedores de ser bien tractados é queridos.

Esta ciludad de Guacachula está assentada en un llano, arcimada por la una parte á unos muy ásperos é altos serros. é por la ofra todo es llano. La çercan dos rios, dos tiros de ballesta el uno del otro, que cada uno dellos tiene muy altas é grandes harrancas, de tal manera que para la cibdad hay muy pocas entradas, 6 las que hay, son ásperis de baxar ó subir cabalgado. Toda la cibdad está çercada de muy fuertes muros é anchos de cal é canto, é tan anchos como quatro estados por parte de fuera de la ciblad, é por de dentro está quassi igual con el suclo é passo de las calles, é por toda la muralla va 
('n pretil tan alto como un medio estado, para pelcar desde ól. Tiene quatro entradis tan anchas como uno puedir entratr á colballo, é lay cu cada entrada tres ó quatro vueltis de çerca, que encabalgan cl un lienço sobre el otro, é solne arpuellas vueltas lay engeima dellas sus pretiles para defender las diclas entradas peleando deste cllos, y en toda la çerea mucha cantidad de piedras sueltas, grandes é p'queñas, para pelear. Será la pohlagion desta cibdad cinco ó seys mill reçinos, é lis alcleas á cllas sulijetas otros tantos ó más. El tránsito ó sitio della es muy grande, porque tienen dentro dél muchas lmertas de diversas fructas, é jardines con muchas plantas é lierbas olorosas de unucha fragrançia é suavidad á su costumbre, de que acostumbran í laçer maçelas é guirnaldas é collares en sus fiestasé combites.

Passados Ires dias que Cortés estoro en aquella cibdad, fuć á otra que se diçe Izsucan. que está quatro leguas de la de Guacacluula, porque le informaron que avia en ella mucha gente de los de Culua ea guarniçion, é que assi aquella Izecucan como otras villas é lugares, sus sufragíneos, cran é se mostraban muy parçales a los de Culua, porque el señor della era su natural é aun pariente de Montecuma.

Llevaba Cortés en su compañia tanta rente de los naturales de la tierra confederados con los chripstianos é of vesçidos por vassallos del Emperador Rey, nuestro señor, que henchian los campos é sierras por donde yluan é quanto se podia alrançar á ver con los ojos, é passiban de ¿iento é vernte mill hombres; ó llegaron solıre la dicha cilodad de lzçuean á las diez horas del dia, y estaba despoblirda de mugeres é gente menuda. é deutro an "lla çinco ó seys mill hombres de guerra bien aderesçados. Pero como á los espa- noles é su exérçito avia Dios proverdo do capitan general, en quien concurrian las ralidades que Cillio, rey de Persia, decria, "quel officio del principe ha de ser sobrepujar á los otros de prudençia, consejo, industria é fattiga, no ogsiosidad é quietud e voluptad ", todas estas buenas partes calbian cu la persona de Ilernando Cortés: el qual, como buen soldado y experto cajilan, assi como los enemigos connencaron á defender su cibulad, ylua él informado é guiado para entrar por la parte que mejor entrada tenia; é ordenadas sus esquadras, cómo los nuestros comengaron á pelear con ferocíssimo ímpetu, los contrarios desampararon sus estançias é se pusieron en hayda. É siguiéronlos de tal manera é con tanta pricssa por toda la cilsdad, que á muchos hiçieron salir por encima de los adarres á mas que de passo é acogerse á un rio, que por otra parte la cerca toda, del qual tenian quebradas las puentes, é por esto se detuvieron algo en passar: pero con toda essa dificultad se siguió el alcançe bien legua y media: é ylua tan ensangrentada la vitoria, que escaparon muy pocos de aquellos del número ya dicho, que avian quedado en guarda de la ciludad. Í la qual tomando Hermando Cortés, envió dos indios naturales della, que estaban pressos, á que hablassen á las personas prinçipales lurydos de la ciludad (porque el señor della se avia ylo con los de Culua, que cstaban allí en guamiçion), para que los hiçiessen volver á su cibdad, prometiéndoles de parte del Rey, nuestro señor, que si leales fuessen, que demás de ser perdonados de su releelion, serian muy bien tractados é favorescidos. Aprovechó tanto esta amonestacion é seguro, que desde á tres dias vinieron personas prinçipales pidiendo perJon de su yerro é diçiendo que no avian podido hacer otra cosa ni su roluntad, 
porque su señor les mandó lo que avian lrecho, é que prometian de ahi adlelante, pues que su señor se avia ydo é los avia dexado, de dexar ellos á él é servir al Rey de Castilla, nuestro señor, muy bien é lealmente.

Las leyes pérsicas eran fundadas pringipalmente en dos $\operatorname{cosas}^{1}$ : la primera en enseñar á los hombres á obedescer, é la segrunda en mostrar á los prínçipes á mandar los súbditos: sin dubda Hernando Corlés tovo en esto especial graçia, porque como prinçipal capilan sabia mandar sus exérçitos, é á los que nuevamente venian á la obidiençia los enseñaba á obedeseger con halagos é palabras dulces, é con dádivas é gratificaçiones, quando convenia. É tan manso é henigno era eu la paz como áspero é resçio punirlor de los que con el cuchillo avian de ser corregridos. É assi en este fecho él se diótan buen recabulo, que asezuró los fugritivos de lal manera, que se vinieron á sus casas é truxeron sus mugeres é hijos, que estaban derramados en otros luogares é villas de sus parçiales, é nuandóles que lablisissen á los otros alterados é contrarios, para que se viniessen al servicio del Rey é amistad de los chripstianos, pertonándoles las cosis passadas, si assi lo hiçiessen, con apergebimiento que no lo haçiendo, se les haria cruda guerra. É assi desde á dos dias se tornó á polilar la ciblad de Izcucan; é los sufragéneos á ella é otros sus comarcanos vinieron á se ofrescer por vassallos del Rey de Castilla, é quedó toda aquella prorinçia segura é por confederados é amigos con los de Guacachula. É porque oro sierta diferençia solse á quien pertenescia el señorio de aquella provincia é cibdad de laçucan por ausençia del que se avia yelo á Véxico, non obstante los diverssos paresçeres é contradiciones é parçialidades entre un hijo bastardo del señor natural de la tierra, que avia seydo muerto por Nonteçuma é puesto el que á la saçon era, é cassádole con una solbrina suya, y entre un nieto del dicho señor natural, liijo de su hija legílima, que eslaba casada con el señor de Guacachula, é avian avido aquel lijo, nicto del dicho señor natural de lzçucau; se acordó entrellos que heredasse el dicho señorio aquel hijo del señor de Guacachula, que por legítima línia de los señores de allí le pertenesçia, puesto (puel otro fuesse hijo, que por ser bastardo no debia ser señor. É assi quedó esto, y en pressençia de Cortés obedesçicron á aquel muchacho, que era de edad de diez años : é mandó Corlés que pues no tenia edad para gobernar, que aquel su tio bastarlo é otros tres primçipales, el uno de la cibdad de Guacachula é los dos de la cibdad de laçucan, fuessen gobernadores de la tierra é toviessen ef muchacho en su poder hasta tanto que fuesse de edad para gobernar su Estado.

Aquella cibdad de Izçucan scrá de hasta quatro mill veginos: la qual es muy conçertada en sus calles é tracto, é hay en ella çient casas de oratorios ó templos muy fuertes, con sus torres, las quales todas se quemaron. Está assentada en un llano á la halda de un çerro mediano, doule tiene muy buena fortaleça; é por la otra parte de háçia el llano está çereada de un rio fondo, que passa junto al inuro, y eslá çircuyda de la barranca del rio, que es muy alta, é solne la bitranca fecho un pretil, toda la cibdarl en torno, tan alto como un cstado, y ençima de anjuclla cerea estaban muchas piedras suellas para su defensa. Tiene un ralle refondo muy fértil, de diverssas fructas é mucho algodon, y en ninguna parte de los puertos arriba se hacen, por la grand frialdaul, é alli es ticrra abrigada é calien- 
te, á causa que está amparada de las sierras çrcunstantes. Todo aquel valle se riega por muy buenas açequias, que lienen tan bien sacadas é conçertadas quanto en parte del mundo se puede haçer.

Allí estoro IIernando Cortés hasta dexar muy paçífica y en quietud é muy poblada aquella cibdad: en el qual tiempo vinieron allí á se ofresçer por vassallos del Rey, nuestro señor, los señores de dos cibdades, la una llamada Guaxoçingo, é la otra está diez leguas de la de Izçucan, é son fronteras de la tierra de México. E tambien fueron embaxadores de ocho pueblos de la provinçia Coastoaca, ques una de quien la historia ha fecho mençion, que la avian visto los españoles que Cortés envió á buscar oro á la provinçia de Culua, donde y en la de Tamacula, porque está junto á clla, se dixo que avia muy grandes pol,laciones é casas muy bien obradas, de mejor canteria que en ninguna de aquellas partes se avia visto. La qual provinçia de Coastoaca está quarenta leguas de allí de lzçucan ; é los natu. rales de los dichos ocho pueblos se ofiesçicron por vassallos de Céssar, como Rey de Castilla, é dixeron que otros quatro lugares que restaban en la dicha provinçia, vernian muy presto á haçer lo mesmo. É pidieron perdon á Cortćs, porque antes no avian renido, por temor de los de Culua; pero quellos nunca avian tomado armas contra los chripstianos ni avian seydo en muerte de ningun espanol, é que siempre, despues que se avian ofrescido al servicio de Su Magestad Cessálea, avian seydo buenos é leales vassallos suyos en sus voluntades; pero que no las avian osado mostrar, de temor de los de Culua. De manera que segund Cortés escribió en aquella saçon dixo que en breve tiempo pensaba colorar lo perdido, é formar á reIuçir la grand cilsdad de Temistitan á la obidiençia de Céssar, por fuerça de armas ó por su industria.
De aquellos que fueron pressos en la cilsdad de Guacachula, en especial de aqpuel herido, de quien se hiço mençion de susso, supo Hernando Cortés muy enteramente las cosas de la cibdad de Temistitan, é cómo despues de la mucite de Monteçuna, sulscelió en el señorio un hermano suyo, sonor de la cibdad de lztapalapa, que se llamaba Gualimuçin: é subgeclió en el señorio, porque murió en las prentes al hijo de Montecuma, que heredaba el señorio, é otros dos hijos suyos que quedaron vivos, el uno cra loco ó mentecapto, y el otro perlático, é inhábiles por sus enfermodades. Fi desta causa deria aquel indio, é fué vertad, que avia heredado a(puel hermano de Hontecuma, é tambien porque era buen capitan é de mucho esfierco, y él avia hecho la gaverra á los españoles, y era tenido por unury valiente hombre é de mucha prudençia. Supo assimesmo Corlés cómo se, forlalescia en la grand cibdad y en todas las otras de su señorio, é que se haçian muchas çercas é cavas é fosados é reparos, é muchos géneros de armas, en espeçal lancas luengas. como picas, para los caballos, 6 ya se avian visto alqunas dellas con que pelearon los indios en la provincia de Tepeaca, y en los ranchos é apossentos, que la grente de Culıra tovieron en Guacachula, se laallaron muchas dellas.

Despues que de todo lo que pudo firé bien informado Cortés, envió á esta Isla Española é á las otras que están en esta mar pobladas de chrijstianos, por caballos é gente para su socorro, é por pertrechos é armas, é otras cosas tocantes á la guer. ra, con pensimiento de pugnar en reducir á Temistilan al estado en que ya él tovo aquella cibdad por Su Magestad. É dió órden cómo se hiçiessen treçe bergantines para entrar por la laguna, é se llevassen por ticr'ra en piccas ó quadernas, é á la lengua del agua se ligassen, quando conviniesse: é hiço haçer clavaçon é to- 
do lo que fué nesçessitrio parà ellos.

En este tiempo supo Cortés cómo á la villa de la Veracruz aria ilegado una caravela pequeña con hasta lreynta hombres, la qual yha en busca de la gente que Françisco de Garay aria llevado ál aquellas partes; é llevaloa tanta nescessidad appuel navio, que si allí no fuera socorrido, murieran de sed é lambre: é súpose de aquellos cómo avian allegado al rio de Panuco, y estado en él treynta dias surgidos, é no vieron gente en el rio ni en la lierra, de que se crevó que á causa de lo subcedido, se avia despoblado aquella lierra. E tambien dixeron los de aquella caravela que trís ellos avian de yr otros dos navios del dicho Francisco de Garay con gente é caballos, é que creian que serian ya passalos la costa abaxo; é porque no les acaesçiesse otro semejante daño, como intervino á los primeros, proveyeron de enviar desde la villa de la Veracruz la mesma caravela á buscarlos, é que se viniessen á la Veraciuz, é que los esperasse allí aquel capitan, que envió Françisco de Garay primero.

En esta mesma saçon aquel Gualimuçin, que se dixo que subçedió en el señorio á Monteçuma, proveyó por todo su señorio é hiço saber á todos sus vassallos que les haçia graçia por un año de todos los serviçios é tributos que eran obligados á le haçer, con tanto que por todas las maneras é vias que pudiessen, fuesse hecha cruel gnerra á todos los chripstianos hasta los matar ó eclıar de toda la tierra ; é que assimesmo la liçiessen á todos los naturales que fuessen anigos é confederados suyos de los dichos chripstianos. Y estos confederados con los nuestros cada dia pedian socorro á Cortés de muchas partes contra los de Culua, porque les hacian guerra á causa de su aliança é amistad, y él no podia socorrer á lodas partes, como quisiera, por la falta de gente española: que eran pocos los nuestros.

En esta relaçion diçe Cortés que por la mucha similitud que aquella tierra tieno con España, assi en fertilidad como en su grandeça, y en la templança é frios que en ella hacen, y en otras muchas cosas le parescia, que se delja nombrar la Nueva España del mar Oçéano; é assi en nombre de Su Magestad le puso este nombre, é suplicó al Emperador lo oviesse por bien é lo aprobasse, é assí se hiço. Non obstante que lo uno de lo otro es muy diferente en sus climas é alturas, porque la parte más septentrional de la Nueva Es. paĩa en el rio Panuco, por cerca del qual passa ó junto á él la línia del trópico de cánçer, que está en veinte y tres grados y medio desta parte de la linia equinoçial, é la parte que España tiene mas meridional es el estrecho de Gilsraltar, y ese está en treynta y seys grados desta parte de la linia del Equinoçio; assi que es muy grande la diferencia, que son dose grados y merlio de Norte á Sur, allende de las muchas leguas é camino longuíssimo que hay del Leste al Hueste. Pero baste que la voluntad de Céssar fué que assi se llamasse la Nueva España, en los quales reynos se incluyen muchas é grandes provinçias, que la historia ha memorado é las que adelante se nombrarán. 


\section{CAPITULO XVII.}

Desde el qual tracla la hisloria ol subçesso de la conquista de la Nueva España, éla recuperaẹion r. la grand cibdad de lomistilan ", é olras cosas anexas al verdadero discurso de la relaçion é letçera carla que al Emperarlor Ricy, nuestro señor, Corlés le enviú, dindole cuenta é raçon de lo subecelido despues de todo lo ques dicho hasta fin del capitulo preçedente.

U no de aquellos navios que se esperahan del adelantado Françisco de Garay, de quien avia dado notiçia ol navio que se dixo en el capítulo de susso. llegó al puerto de la villa de la Veracruz, en el qual venia un capilan con lasta çiento é veyute hombres; é allí se informó como los del adelantado Françisco de Garay, que antes arian ydo, avian seydo desbaratados, é hablaron con el capitan que se halló en el desbarato, é les çertificó que sỉ yban al rio del Panuco, resçibirian mucho daño de los indios. I estando assi en el dicho puerto con determinaçion de yrse al rio, se levantó un temporal é viento tan resçio y súl lito, que hiço á la nao salirse de allí quebradas las amarras, é fué á tomar puerto doçe leguas la costa arriba, en un puerto que se diçe Sanct Johan, é saltó toda la gente en tierra, é sacaron siete ú ocho caballos é otras tantas yeguas que traian, é dieron con la nao al través en la costa, porque haçia mucha agua. É como esto fué fecho saber al capitan Ilernando Cortés, dió muchas graçias á Dios, porque paresçia que de su poder alssoluto le començaba á yr el socorro : é luego escribió al capitan de aqueIla gente, haçiéndole saber ó mostrando por su letra que le avia pessado de lo subçediclo, é quél enviaba á deçir á su teniente de la villa de la Veracruz que al dicho capitan é á la gente grue llevaba les hiçiesse buen acogimiento é les diesse todo lo que oviesse menester, é que le di-

* En esle sitio suprimió Oviedo algunas c'áususulas, que por no ser de grande interés para la his- xessen á él é á ellos que viessen lo que determinalan, é que si todos ó algumos dellos quisiessen volver á las islas con los narios que allí estaban, que se les diesse liçençia é fuessen despachados á su plafer: y el dicho capitan é los que con él vinieron determinaron de se quedar é yr adonde Cortés estaha, y él los acogió é resçibió muy bien. É del otro navio que con este esperaban no sabian cosa alguna, antes se temia que era perdido.

Y estando Hernando Cortés para se partir de aquella provinçia de Tepeaca, supo cómo los de las provinçias de Cecatamí é Xálaçingo, que son suljetas al señor de Temistitan, estaban rebelados; é como aquello es el camino de la villa de la Yeracruz para Tepeaca, avian muerto algunos españoles, é los naturales alçados estaban de mal propóssito: é por aseģurar este camino é castigar los malhechores, si no quisiessen la paz, envió Cortés un capitan con veynte de caballo é dosçientos peones é con conte de los amigos: y encargóle é mandóle de parte de Su Magestad que requiriesse á los naturales de aquellas provinçias que viniessen á la obidiencia é serviçio del Rey, como primero lo avian hecho, é que con toda templança so oriesse con ellos, si quisiessen la paz, é si no, que se les liçiesse la guerra; é que fecha é allanadas aquellas dos provinçias, se volviesse con todla la gente á la cibdad de Tascalteca, adonde Cortés les cstaria esperando. É assi se partió este capitan

Inria, no fracladamos i la proente nola. 
entrante el mes de diçiembre del año de mill é quinientos y veynte para atpuellas provinçias, que están veynte leguas de Tepreaca; é mediado aquel mes se parlió Cortés de la villa de Segura de la Frontera, ques en la dicha provinçia de Tepeaca, é dexó en ella un capitan con sessenta lombres, porque los naturales de alli se lo rogaron mucho, y enrió toda la gente de pié á la cibdad de Tascalteca, adonde se laçian los bergantines, que está de Tepeaca nueve ó diez leguas. É Cortés con veynte de caballo fué aquel dia á dormir á la cibdad de Chulula, porque los naturales della lo desseaban, porique á causa de la enfermedad de las viruelas (que tambien comprehendió á los de aquellas ticras, como á los de estas nuestras islas), eran muertos muchos señores de allí, é querian que por mano de Cortés é con su parescer se pusiessen otros en lugar de los defunctos. Ė llegado, fué muy bien rèscebielo, é dió conçlusion é contentamiento en este negoçio á plager de todos, é dlióles á entender cómo su camino era para yr á entrar, de guerra en las provinçias de México é Temistitan; é rogóles que pues eran vassallos de Céssar, é como tales arian de conservar el amistad con los chripstianos, é los chripstianos con ellos hasta la muerte, que para el tiempo conviniente ayudassen con gente, é que los esprainoles que Cortés enviasse á su tierra, fuessen é rolviessen por ella seguros, é fucsen bien tractados como amigos; $\mathrm{co-}$ mo lo eran obiigados á lo haçer ; é assi lo prometieron. É deste á dos ó tres dias se partió Cortés é tornó á Tascalteca, que está seys leguas de.allí, donde estaban juntos todos los españoles é los de la cil)dad, é se regoçijaron los imosé los otros con su venida. El siguiente dia que llegó, los señores de la ciludad é provinçia le fueron á hablar é decirle cómo Maxiseaçin, que era el señor prinçipal de todos ellos, avia fallesçido de aquella cuferme- . TO.110 III. laul de las viruelas; é que pues avia seydo grrande y especial amigo de llernando Cortés, é avia dexado un liijo de lasta doge ó treçe años, é que á aquel pertenesçia el estado é señorio de la casa rlel padre, que le rogalıan que como á tal heredero se lo diesse; é assi lo licgo, é lo aprobó por tal señor, en nombre de Su Magestad, de lo qual todos quedaron muy contentos é alegres.

Quando á ayuella cibdad llegó Cortès, halló que los maestros é carpinteros de los bergantines se daban mucha priessa en haçer la viggaçion é tablaçon para ellos. é tenian liceho harta parte; é luego se envió á la villa de la Veracruz por la clavacon é jarçia é velas é cosas nescessarias para ellos, é proveyóse cómo se hiçiesse pez un una sierra cerca de allí, para que ninguna cosa faltasse é todo estoriesse aparejado al tiempo que Cortés estoviesse en las provincias de México é Temistitan, enviando por ellos desde allá, que serán diez ó doçe leguas hasta la cibdad de Tascalteca. É dos dias antes de Navidad volvió con la gente de pié é de caballo aquel capitan que avia yolo á las provingias de Cacatamic Xilaçingo, é aunque algunos naturales dellas avian peleado con los españoles que allá fueron, al cabo por fuerça, é mejor aliçiendo por voluntad de Dios, vinieron de paz é truxeron algunos señores de aquellas provincias: los quales, no embargante su culpa é alcamiento é muertes de chripstianos, porque prometieron ser bucnos é leales de ahí adclante, fueron perdonados, é Cortés los envió á su tierra muy contentos. E desta manera se conchuró aquella guerra, en que Dios y el hey fueron muy servidos con la paçificacion de los naturales de alli, para seguridad de Ios españoles, que avian de yré venir é cursar por las diclas provincias, passando a la villa de la Veracruz.

El segmudo dia de pascua de Navidlad $+1$ 
hiço reseña o alarde Hernando Cortés en la cilodad de Tascalleca, é laallóse con quarenta de á caballo é quinientos é şinquienta peones, los ochenta dellos ballesleros y cecopeteros, é oclio ó nueve liros de campo pequeños, é cón menos pólrora que ovieran de menester; é hiço de los de caballo quallo quadrillas de diez caballos cadia una, y hecha la reseña, é uno pror uno visilados, con mucho placer é con buenas palabras, é gentil é alengre semblante, el capilan gencral les hiço un raconauicuto de apuesta maner"i : "Cavalleros é hirlalgos é amigos: exicusado es que gastemos liempo en palabras, pues que soys españoles, é lan amigos y experimentados de las olpas, assi naturalmente por la graria especial que Dios, Ninestro Señor, puso en nuestra saçion de España, como por la libertad y esfuerco parlicular de vuestras personas. Ya, senores, sabeys é os es manifiesto cómo vosotros c yo, por servir al Emperador Rey, nuestro señor, assentamos é pohlamos en esta tierra, é los naturales della se dieron por vassallos de Su Magestad, é como tales perseveraron en su real serviçio algun liempo, resçibiendo buenas obras de nosotros é nosotros dellos, hasta que sin causa los naturales de Culua (que son los de la grand cilodad de Temistitan, é los de todas las otras provinçias á ella sulvjetas) no solamente se rebelaron contra Su Magestad é se apartaron de la pleytesia é obidiençia que debian, mas aun mataron muchos cliripstianos, deudos é amigos nuestros é de nuestra naçion, que en sepriçio de Céssar en nuestra compañia, sírviéndole, militahan; é nos ccharon fuera de toda su tierra con mano armada, persiguiéndonos todo lo que pudieron por nos matar á todos los que de su trayçion é crueldad escapamos, con tanto Irabaxo como visteys é padescisteys vosotros é yo. É por tanto es raçon que os acordeys de tan grande é señalada in- jurial, é mireys quámto conviene al servi: çio de Dios é de Sa Hagrestad, é de la corona é ceptro real de Castilla, é ú nuestro proprio honor é vidas é repulaçion, yue por nuestra espada propria se torne á cobrar lo que pertimos, pues que para ello hay de nuestra parte muy justas é perentorias causas é racones: lo uno pelearemos en aumento de nuestra sagrada é sanclat fée callólica contra grente bálbara é infice, sirvicullo á I dios é á nuestro soberano Rey é señor; lo segundo asegurarse lan nuestras personas: é lo otro ternemos en nuestra ayuda muchos indios naturales destas partes, que son nuestros amigos é confederados, é que son enemigros de largo tiempo de nuestros adverssarios, ques mucha parte para el fundamento y esperança de la victoria. E para que nuestros amigos estén confiados della, luégoos, señores é amigos é compañeros mios, que os alegreys é useys de vucstro esfucrego natural é acostumbrado, para poner en cfello esta sancla guerra. É porque yo he fecho é ordenado çiertas ordenanças para la buena óden y exergiçio y execuçion desta empressa, oydlas é complidlas, pues todas cllas son justas é convinientes á fodos nosotros, é lan nescessarias quanto por ellas vereys."

Écon mucho silençio é atençion estando todos, un pregonero en alla voz las pregonó públicamente; é acabado el pregon, Helnando Cortés replicó, añadiendo á lo que se contenia en aquellos capílulos, que les rogaha que guardassen é compliessen todo lo que se les avia notificado en aquel pregon; é assi se lo mandó de parte del Em. perador, nuestro señor. só las penas en que incurren los inobidientes á la órlen militar. É lodos unánimes prometieron de lo guardar é complir de buena voluntad, é dè no se-apartar dello, poniendo las vi. das en serviçio de Dios é de Céssar hasla cohrar lo perdido é vengar tan grand tıayçion é injurias como avian rescebido de 
los de Temistitan é sus aliados. Y el capitan Ifermando Cortés se lo agrradesçió é tuvo en serviçio de parte del Emperador, nuestro señor, é de la suya les clió las graçias con mucho plaçer, como prulente caudillo; é con esto se passó aquel dia, que fué cosa mucho de ver, assi considerando la roluntad é olna que los españoles en esto mostraron, como en ver el exérçito lucirlo de los annigros confederados, que ya eran de mucho número, é muy dispuesta é luçida é ataviada gente á su costumbre, con hermosas rodelas, guarnescidas de oro muclıs dellas, é muy lindos é ricos penachos, é muchas joyas de oro é plata solore sus personas, y en lits astas é guarniriones de sus armas.

\section{CAPITULO XVIII.}

Ën que se Iracla lo que Hernando Corlés dexí proveydo para la difinicion de los berginlines, que se hacian para combatir por la laguna la grand cibdad de Temistilin; e émo se parlió eontra ella é los de Culua ; $a$ de la victoria que ovieron contra los de la eiludad de lztapalapa, que fué un fecho muy notable, é glorioso prinçipio para esperar el fin victorioso, que desta guerra adelante se eonsiguiú.

\section{D} te dia del glorioso Sanct Johan Evangelista, hiço el capitan IIernando Cortés Ilamar á todos los señores de la provincia de Tascalteca, é juntados, les dixo que ya sabian cómo él se avia de partir otro dia para entrar en la tierra de los enemigos, é que la cibdad de Temistitan no se podia ganar sin los hergantines que estaban laçiendo: por tanto les rogaba que á los maestros dellos é á los españoles que allí dexaba, les diessen lo que oviessen menester, é les hiçiessen el luuen tractamiento que siempre les avian lıcelı, é que estoviessen aparejados para quando él desde la cilddarl de Thesayco, si Dios le diesse victoria, enviasse por la ligaçon é talılaçon é otros aparejos de los dichos bergantines, pues que en ello servirian mucho á Céssar, y él les quedaria de su parte muy obligado en ello. I ellos le prometieron que assi lo harian, é que tambien querian que desde luego fuesse gente de guerra suya á acompañar á Cortés é servir al Emperador; 6 que para quando los

* En ell original se lee, aunque taelado de mano del autor: "E eómo passú el puerto de Thesmolnea con mucha dificullad, \& de lo que intervino it luergantines fuessen, tolos yrian con toda quanta gente oviesse en sn tierra, porque querian morir donde él muriesse, ó vengarse de los de Culua, sus capitales é antigruos enemigos. É otro dia siguiente, que se contaron veynte y ocho dias de diçiembre, dia de los Inoçentes, se partió de allí el exérçito de los chripstianos con toda la gente é mucla órden, é lueron á dormir seys leguas de Tascalteca, en una pollaçion qủe se aliçe Tesmoluca, ques en la provinçia de Guaxoçingo, los naturales de la qual tenian é tovieron siempre la mesma amistad é confederaçion é buena é leal amiçiçia que los de Tascalteca; é allí repossaron aquella noclıe. Pues como Ilernando Cortés ávia sahido que los de las provinçias de lléxíco é Temistitan aparejahan muchas armas é defensas de cavas é alloarradas é fuerças para la resistençia de la entrada de los españoles, é los contrarios salian que Ilemando Cortés é su gente tenian voluntarl de revolver solnellos, avia Cortés considerado todo esto, é no ynorando quán mañosos eran los adverssarios, e

los españoles é su capilan general en la cilulad de "Thesa yeo, que estí a seys leguas de Temislitan por lat laguna", cle. 
desvelíndose, congecturando por dóidle podria contrar para fomar con algun descuydo al enemigro, el qual tenial notiçia que los elıpjstianos sabian tres caminos ó entradas para poder dar en su lierra: por tanto acortós Cortés entrar por la via de Tesmoluca, porfue es el puerto más agrio y entrada más dificultosa que las otras, é creia que por allí no Lallaria mucha resistencia, ui los enemiggos estarian tan sol, are avo por la dispusiçion natural $\dot{c}$ áspera de la tierra en arquella parte.

Otro dial despues de los lnocentes. aviendo oydo missa uste calluólico exér¿ito, se encomendaron todos á Dios, é particron de la dicha poblacion de Tesmoluca, é Cortes tomó la delantera con diez de caballo é sessenta peones ligeros y escogidos hombres é diestros en la guerra, é començaron á segur el camino, el puerto arriba, con toda la órden é conçierto que les fuć posible; é fueron á dormir á quatro leguas de la dicha poblarion en las cumbers del pucrto, que era a término de los de Culua: é aunque Laçia grandissimo frio en él, como avia mucha leñi, se remediaron aquella noche.

Oro dia domingo por la mañana prosiguieron su camino por lo llano del puer10. é Cortés envió qualtro de á calballo é otros lantos peones suellos para descolnir la tierra; é signendo su viage començaron de basar el puerto, é los de á calarllo yban delante. é luego los ballesteros $\because$ escopeteros, é lrís cesos en si órden li otra sente. porrue sicmpre se sospechó que los contrarros arian de salir á los resçibir al camino en alghuna celatla ó mal frisso. É cómo los quatro de cilballo é yuatro peones siguicron su camino, haltáronle eqerado de árboles ć rama corlalos, é atraressados en él muy grandesé mruessos pinos é açipreses, que paresçia que estonces se acaluaban de cortar ; reyendo fuel camino adelante no estarial de aquella manera ocmpato, prosiguicon por ćl, ć quanto más yhan, més cerrado catilua de la mancra ques dicho. l's cóno por lodo el puerto avia espesas anboludas é matais gramdes, con mucho trabaxo é dificulad passaban aquel estorbo, é no sin grand temor, sospechando que trás cada árbol estaban los enemigos, porpue avia mucho aparejo para ser allí desharatarlos los nuestros, porrue la espesura de los gramdes áloles no diera lugar á se aprovechar de los caloallos. É assi ammentándoseles el temor ć multiplicíndose el imperlimento cues dicho, contrastando á todo la propria vergibenca y esfuerco matural de los españoles, é de su cxérçito é diestro capitan, passaron grand parte de afpucla maleça que los impedia, quando uno de los quatro de á caliallo delanteros dico á los otros: "Hermanos. no passemos más adclante, si os paresçe, é será bien dlecil al capitan el estorbo é peligro que hallamos tan grande, en que lodos eslamos, por no nos poder aprovecliar de Ws caballos: é si no os paresce que se debe lacerer como lo digo, vamos adelanw, que ofresçicla tengo mi vida á la muer10. lin bicn, como todos, hasta dar fin í esta jornarla. Les otros respondicon que Imen consejo era el suyo; pero que no les firresçia que debian volver al capilan hasla rer alguna gente de los memigos, ó salver qué tanto furaba aquel empacho y mubaraco del camino. É assi passaron adclante. ć cómo vieron que luraba mucho, dulnvióronse, é con uno de los peones liçiéronle salıer á Cortés la dispusicrion Imala, que hallaban para proçeder adelante. É cómo Cortés llevalıa la avan. smirda con la ggente de á caballo, dixo que no cla posible quel estorbo del camino ni apuel impelimento turasse mucho, é prosiguió por arfuellos malos passos, y envió á mandar á los de la retroguarda yuc se diessen mucha priessa é que no 10 viessen lemor, que presto sildrian at lo rasso. É cómo alcancó á los quatro de á 
caballo siguio adelante, aumejuc con mucho Irabaxo é inconviniente; é deste á merlia legua plugo á Dios que haxaron á lo raso, é delúvose alli Cortés, esperando la gente. E cómo alli se vieron, dieron muclas graçias á Nuestro Scñor por cllo; poreque en la verdad estaba tal el camino que avian passalo, que cra para espanlar é no se creer que hombres lo pudiessen andar sucltos, quanto inás con los caballos y en tan breve tiempo, lo que en mucho avian atavado inumerables indios para su seguridarl.

Desde alli se començaron á ver las provinçias de México é Temistitan, que están en las lagunas y en torno dellas; mas aumque holgaron mucho de las ver, era con mucha tristega mezclarla con esse goço, acordíndose del daño passado que avian en aquellas lagunas é provinçias resçebido: y entre estos extremos de plaçer é dolor se juntó una yra é desseo de la venganca, de tal manera, que destas tres ocasiones prometicron torlos de no volver atrás ni salir de aquellas provincias sin victoria, ó perder en ellas las vidas. É con esta determinaçion juntada la esperança lel premio é de ser ricos en breve liempo, yhan tan confiados é alegres, é tan denorlados é contentos, como si ya ovieran conseguido la victoria é no les quelá́ra más de laçer de gogarse con ella. Pero essa no se pudo alcançar sin sanģe é mucrles, é tantos trabaxos é tan exçesivos, como la lisstoria lo dirá; porque como los encmigros ovieron sentimicnto de los repañoles, comenearon en el instante á lager muchas é grandes alımmadas por toda lạ lierra, apellidándose, é uniendo sus amigos é parciales, 6 dando mucha grita á los chripstianos desde unas estangias é poblaçiones, que estaban, annque pequeThas, no muy lexos. para que se juntassen é defendiessen çiertas puentes é malos passos que por alli arial. Pero los españolos se dieron tanta priessa, que sin tue los enemigos toviessen tiempo de se juntar, baxaron en todo to llano: é sigruiendo su camino, se les pusieron delante çicrtos esquadrones de indios, contra los quales mandó Ilemando Cortés que se pusiessen quince de caballo é rompiessen por cllos, é assi lo hiçicron, porque el temor que avian á los caballos cra muy strande, é alançearon é malaron alı̧unos, é sin peligro se recogicron á su ordenança, é caminaron para la cilylad de Thesayeo, ques una de las mayores é más hermosa república de aquellas partes. É cómo la gente de á pié yba cansarla, acordaron de reposar en una poblaçion. que se dice Coantepeque, ques de la juriselicion de Thesayco é á tres leguas della: é laallároula despoblada, é sospechó Cortés é su gente que como arguella cibdad é su provinçia (llamada Aeuluacan) es muy grande, é se creia que en essa saçon avia en ella çiento é çinquienta mill lımbres, que quisicran dar sobre los nuestros: é por este temor el mesmo capitan IIcrnando Cortés con diez rle caballo comencó é tomó la vela é ronda de la prima, é mandó estar aperebebida toda la gente. É otro dia lunes último de diçiemlne prosiguió su camino con la órden acostumbrarla. é á un cuarto de legia de aquella polıaçion de Coantepeque salicron al cimino qualro lıombres iudios principales con una handera de oro en uma vara (la qual handera ura mo planclıa ó lámina de oro puro é fino, que pessaba quatro marcos de oro) é por elli claban á cntender que venian de paz, la qual era bien desseada de los chripstianos, porefue eran pocos é lint apartados de socorro é melinlos en las furreges de los encrumigos. Cómo Cortés vidlo á estos quatro indios, conoscrió al mo dellos é mandó (que se defuriessen los chripstianos. é Ilegó á labalar á los indios. y ellos le dixeron que rentan de parte del señor de arpuella cilsdal primesipal, que se alige Gua. nacaçin. é que de su parte le rogaba que 
"n su tierra no consintiesse haģer daño al:uno; poldque de los daños é cosas passirdas no tenian culpa sino los de Témistilan é no ellos, é que querian ser vassallos le Su Magestad é amigos de los chripstianos, é que guardarian é conservarian la amistad inviolablemente, é que se fuessen á la cilodad, é que en sus obras conosçerian su buen desseo é lo que tenian en cllos.

Cortés les respondió graçiosamente, dándoles graçias é ofresçiéndoles todo buen tractamiento, é les dixo que pues se excusaban de la guerra que le avian darlo en Temistilan, que bien sabian que şinco ó seys leguas de allí de la cibdad de Thesayco en çierlas polblaçiones á ella subjetas le avian. muerto la otra vez ejinco de caballo, é quarenta y çinco peones, é más de dosçientos indios de Tascalteca cargados, é les avian tomado nucha plata é oro é ropa é otras cosas; é por tanto, pues que esta culpa tenia mala respucsta ó no la avia por ellos que buena fuesse; que le tornassen lo que le avian tomado, é aungue cran dignos de muerte por ello, él avria por bien la paz, pues le convidaban con clla, é no de otra manera. Á esto respondieron que todo lo que alli se avia tomado lo avian Ilerado el señor é los más principales de Temistitan; pero quellos buscarian todo lo que pudiessen, é lo que hallassen, se lo darian. Fi preguntaron al capitan si aquel dia yria á la cibdad ó si se apossentaria en una de dos poblaçiones, que son como arrabales de la dicha cibdad, las quales se diçen Coantinclan é Guaxula, que están á legua y media della, é siempre vá todo aquel espaçio poblado, lo qual cllos desseaban por lo que adelante subcedió. Cortés les respondió que no se avia de detener hasta llegar í la cibdad de Tezenco, y ellos replicaron que fuesse en lıora buena, é que se querian yr adelante á le aderesçar el apossento para él ć los españoles: ć assi se fueron. É llegando á essas dos poblariones, salicron algunos principales á dar de comer á los nuestros, é á medio dia llegaron al enerpo de la cilsdad, donde los avian de apossentar en una casa gramde que aria seydo de su padre de Guanacacin, scñor de la ciludad. É antes que se apossentassen, estando los chripstianos juntos, hiço Cortés pregronar que só pena le muerte ninguna persona, sin expresa licencia suya, saliesse de la dicha casa, en la qual, aunque fuera doblato el número de los españoles, se podian biẻn apossentar. Esto se hiço, porque los naturales se asegurasaen y cstoviessen en sus casas, é porque le paresçió á Cortés que no se veia la décima parte de la gente que solia aver en aquella cibdad, ni lampoco parescian mugeres ni niños, que era señal de gente desasosergada é aperçelbida.

El dia que allí llegóo el exérçito nuestro fué víspera de año nuevo, é pensando que de temor los indios no paresçian, avia algun descuydo en los españoles, ć aquella larde dos compañeros se subieron á çicrtas açoteas altas, de donde vieron que los indios desamparaban la cibdad é con sus haciendas se vban á meter en la lascuna en sus canoas, que ellos llamaban acales, é otros se yluan á las sicrras; é aunque sc proveyó en les estorbar la yda, como ya era tarde é sobrevino la noche, no se pudo excusar su fuga, é assi el se. ñor de la ciludad é los señores della se fueron á Temistilan, que está de allí por la laguna seys leguas, é llevaron consigo quanto tenian. Assi que, por haçer á su sal ro lo ques dicho, avian salido primero con su falsa cmbaxada los quatro mensajeros de la bandera de oro, la qual quedó en poder de Cortés como en señal de rerdad.

De tales banderas creo yo que pocas historias haçen mençion, é aun allí fuć cosa nueva, sino que por ardid, é por dar á los chripstianos esperança de mucha riqueça í sosegarlos, tomaron esto 
medio para los contentar con su mentira.

lin esta ciblad repossó Cortés é su gente tres dias sin aver recuentro alguno, porfue ni los indios osaban venir ni acometer á los chripstianos, ni ellos curaban de salir lexos á los huscar, porque el fin de IIernando Cortés era laçer con la paz todo lo que se pudiesse para se excusal la guerra. É á calo de aquellos tres dias vinieron á le habblar el señor de Coanticlian é Guaxuta y el de Aulengo, que son tres poblaciones bien grandes, y están, como es dicho, incorporadas é juntas con la cibdad de Thesayco, é pidiéronle con lágrimas que los perdonasse, porque se. avian ausentado de su tierra, é que en lo demás ellos no a vian peleado con él, á lo menos por su volunlad, é prometian de haçer de alí adelante lo que en nombre de Su. Magestad les fuesse mandado. Cor'tés les resjondió con las lenguas que bien sabian el buen tractaniento que en él avian lallado, é que si su tierra avian dexado, que su desasosiego propria culpa dellos era é no dél ni de los españoles; é que pues promelian de ser sus amigos, que se asegurassen é se lormassen ál sus casas con sus mugeres é lijjos, é como ellos hiçiessen las obras, assi hallarian el buen tractamiento: é assi se fueron algo tristes.

Quando en estas historias se dixere Culua, liáse de entender que esta palalıra sola comprehende todas las tres provinçias subjetás á Temistitan.

Pues cómo el seĩor de Temistitan é México é todos los demás señores de Culua supieron que aquellos de las pohlaçiones ya dichas se avian yolo á ofres-

- Debe nolarsc aqui, para conocimicnto de los lectores, que Ovicdo escribio con suma variedad lo dos estos nombres de ciudades y provincias, prucba clara de que fiados solo á la memoria de los primeros conquistadores, no avian llegado i fijarse, como despucs sucede. Asi vemos que escribe con frecuencia rolua y Culua; Temixtilan y Temistitan; Tasealteca, Tuscallecle y Tascallo- çer por annigos de Cortés é por vassallos de la corona real de Castilla, enviá. ronles á deçir que lo avian hecho muy mal; porque si de temor era, que bien sabian quellos eran muchos é tenian tanto poder, que assi á los españoles como á los de Tascalteca *, los podian fáçilmente matar en breve liempo; é que si por no dexall sus tierras lo avian lıccho, que las dexassen é se fucssen á Temistitan, é allá les dàrian mejores casas é poblaçiones, donde viviessen.

Aquellos señores de Coantichan é Gráaxuta tomaron á los que les llevaron el mensaje ques dicho, é atáronlos é lleváronlos á Cortés: é luego confessaron que avian ydo de parte de los señores de Temistitan, pero que avia seydo para les deçir que fuessen allá para como terçeros, pues eran amigos de los chripstianos, entender en las paçes entre Cortés y ellos para que la guerra se excusasse; ć los de Guaxuta é Coantichan dixeron que no era assi, é que los de México é Temistilan no querian sino guerra. Cortés disimuló, mostrando que dalıa crédito á los mensajeros, porque desseaba con maña traer á su amistad á los de Temistitan, porque della pendia la paz é la guerra, é lo que aquella grand cilydad hiçiesse avian de querer é haçer todas las otras provinçias que estaban alçadas; é por esto mandó desatar aquellos mensajeros, é díxo. les que no teniessen, é quél los queria tornar á enviar á Temistilan, é rogóles que dixessen á los señores quél no queria gucrra con ellos, aunque tenia raçon de se la haçer, é que fuessen amigos como antes lo avian seydo, pues que los prin-

cal; Thesmoluca, Tezmoluca y Tesmoluca, ctc. Fsta misma incertidumbre sc advicrle en los nom. bres propios de personas. Al fijarlos en la prescnle cdicion, nos hemos atenido á la regla adoptada por nosotros respecto de la ortografia, respelando asi, cn cuanto es lícito, la indole especial de la del cronista. Ila flecidido por tanto el mayor número de egemplos. 
çipales movedores de la gruerra pissiala contra él eran ya muertos, é que lo passado fuesse passado, é no diessen causa á que les destruyesse la riema é sus cilbdades, que le pessaba mucho de su daño é lo queria excusar, si ellos lo quisiessen conoscer. É con esta embaxada se fueron los mensajeros, é prometicron de tornar con la respuesta, é los señores de Coantichan é Glaxuta y Ilernando Corlés, por esta buena obra, mas amigos é confeclerarlos; y él les perdonó, en nombre de Su Magestad, los yerros passados, del- qual perdon se siguió mucho contentamiento en ellos.

É despues que en Thesayco eslovo nuestro campo sicle ú ocho dias, fortalesçiéndose Cortés en su apossento, é viendo que los indios no yhan contra él, salió de la cildad con dosçientos españoles, en que avia diez y ocho de caballo é treynta ballesteros é diez escopeteros, é llevó consigo otros quatro mill indios de los amigos confederados, é fué por la cosla de la laguma hasta una cibdad que se diçe lztapalapa, que está por el agua á dos legruas de la grand cibdad de Temistitan é a seys de la de Thesayco: la qual cibdad us de liasta diez mill veçinos, é la mitad della é aun las dos terçias partes puestas en el aģua; y el señor della era hermano de Monteguma, al qual los indios despues de su muerte avian alçalo por señor, é aqueste fuć el prinçipal que avia fecho la guerra passada y cechato los españoles finera de Héxico. É assi por esto como porque Hernando Cortés supo que estalbaur de mal propóssito los de la cilodad de lztapalapa, determinó de yr á ellos: é como fué sentidlo de la grente della bien dos leguas antes que llegasse, paresçicron en el campo algunos indios de guerra é otros por la laguna en canoas, é todas aquellas dos leguas fueron los nuestros revueltos con ellos peleando con los de la tierra é coin los que salian del agua hasta que lle- graron á la dicha cibdad: é antes quasui dos terçios de lergua almrian una calçalit como pressa, que está entre la ligrunal durce é la salata , é rompida aquella calçada ó atajo, començó con mucho ímpetu á salir agua de la laguna salada é correr láiçia la clulçe, aunque están las aguas desviadas la ma de la otra más de media legua; é no mirando en aquel engaño cou la cobdiça de la victoria, passaron muy bien los españoles siguiendo el alcance liasta entrar dentro en la ciludad revueltos con los enemigos; é cómo estaban ya solore aviso, todas las casas de la tierra firme hallaron despobladas, é la gente é despojo dellas metido en las casas de la laguna. É allí se recogieron los que yban huyendo, é pelearon con los chupstianos muy reciamente; mas quiso Dios dar lanto esfucreco á los nuestros, que las entraron hasta los meter á los enemigos en el agua hasta los pechos é aun nadando, é les gamaron muclas casas de las que están en la laguna: é malaron más de seys mill indios é indias é niños, á cansa que los indios amigos de los españoles no perdonaban edad ni dexaron de malar todos los que pudieron, aunque fuessen mugeres é niños de poca elad ; é cómo solıevino la noche, çessó la batalla, é recogió Cortés su gente, é mandó poner fuego á algunas casas de aquellas, y eslando ardiendo, quiso Dios traer ál la memoria de Cortés la pressa de la calçarla que avian visto rota en el camino, é repressentósele el peligro en que cstaha metido: é con mucha diligencia se salió do la cihdad á mús que de passo, aunque lıacia muy escuro, é quando llegaron al agua, que seria á las nueve de la noche, avia tanta é corria con tanta velogilarl, que la passaron á vucla pié é ann se alo. garon algunos indios de los amigos, é se perdió el despojo que en la cilndad se avia tomado: é si se larláran dos ó tres horas más en passar aquclla ag̣ua, ning̣u- 
no de los nuestros escapálara, porque quedáran çercados de aggua, sin tener passo ni salida por parte alguna. É cómo fué de dia vieron como el agua de una laguma estaba ya en el pesso de la otra, é no corria más: é foda la laguna salada estaba Ilena de canoas con gente de guerra, rreyendo que avian ya dado conclusion en ello, é que tenian á Cortés é su gente en parte que ninguno quedára con la vida de los españoles.

Aquel dia se tornaron los nuestros á
Thesayco, peleando en algunas partes con los que salian del agua, aunque poco daño les podian luaçer, porque luego se acogian á las canoas. É llegados á Thesayco, hallaron que los españoles que allí avian quedado, no avian avido contradiçion ni molestia alguna, é assi goçaron de la soçable é comun victoria avida. É otro dia sigguiente murió un español que fué herido, é aun fué el primero que hasta estonces le mataron á Hernando Cortés en cl campo.

\section{CAPITULO XIX.}

Como li cibdad de Otumba é otras quatro vinieron á la amistad re los ebripstianos; é eómo hiçieron lo mes. mo los de Chalco é otras provincias *, é cómo Hernando Corles hiço traer á Tezcueo por tierra diez é, ocho leguas los treẹe bergantines o fustas, que avia mandado haçer para entrar por la laguna á Temistitan, é otras cosas dignas de la historia.

O tro dia siguiente vinieron çiertos entbaxadores de la cibdad de Otumba é de otras quatro cibdades que están junto é rercanas á clla é á quatro é ál çinco é á seys leguas de Thesayeo, é dixeron á Hernando Cortés que los perdonasse, si alğllna culpa tenian de la guerra passada (que se avia fecho (porcque alli en Otumlı fué donde se juntaron todo el poterio de Héxico é Temistilan, quando avian salido desbaratados los chripstianos, creyendo que los acabáran), puesto que bien conosçian é vian aquellos de Otumba que no se podian excusar de culpa, aunque dalsan sus excusas, diciendo que avian seydo mandados. É para aplacar á Cortés, diséronle que los señores de Temistilan les a vian enriado mensajeros para que fuessen de su parçialidad é que no hiçiessen amistad con los eluripstianos, si no que yrian sobre ellos é los destruyrian, é quellos querian ser vassallos de la corona real de Castilla é del Emperador, nuestro señor, é ha-

* Aqui suprimió Oviedo esta chínsula : "E de algunos reeuentros en eontinuacion de la guerra; como vino una nao con rierta sente española á la TOHO III. çer lo que en su nombre Corlés les mat1dasse; á lo qual les fué respondido que bien sabian ellos (quán culpados eran en Io passado, é que para meresçer perdon é ser creydos, convenia que primero truxessen atados aquellos mensajeros que deçian é á fodos los naturales de México é Temistitan que estoviessen en su tierra; é que de otra manera no avian de ser perdonados, é se tornassen á sus casas é las polılassen, é hiçiessen obras, por donde fuessen conosçidos por buenos vassallos de Céssar. Muchas patalıras se gastaron é fueron altercadas de ambas partes; pero no pudieron sacar de Cortés otra prenda ni seguridad, é assi se tornaron á su tierra, prometiendo quellos harian siempre lo que Corlés quisiesse, é atun assi lo cumplieron, siendo leales en su promesa por no faltar al serviçio de Su Magestad Cuessírea.

La historia ha recontado cómo al ticmpo que Cortés fué deslaratado y echado

villa é puerto de la Veraeruz.v Tambien quitó de este epigrafe otras frases de poea importaneia. 
de la ciludad de Temistitan, satcalsa consiggo un hijo é dos hijas de Monteguma, é al scñor de Thesayco, que se decia Cacamaçin, é á dos hermanos snyos. é á otros muclios scñores que tenia pressos, é cómo a torlos los avian muerlo los enemigos, puesto que fuessen de su propia nacion é sus señores algumos dellos, exçepto los dos hermanos del dicho Cacamaçin, que por grand ventura se pudieron cseapar. Y el uno destos dos licrmanos, yue se deçia Y pacsuchil, alias Quacuscacin, al qual de antes Corlés, con parescer de Monteçuna, le avia hecho señor (lesta vil)dacl de Thesalyco é provinçia de Lcuhacan, al tiempo que Cortés llegó á la provinçia de Tascalteca, leniendole en son de presso, se soltó é volvió á Thesayco, é cómo ya en clla avian alçado por señor á un su hermano Guanacaçin (de quien de susso se hiço mençion) diçen que hiço mafar al dicho Quacuscaçin, su hermano, desla forma. Que cómo llegó á la provinçia de Thesayco, las guardas lo lomaron é hiçiéronlo saber á Granacaçin, su scñor, el qual tambien lo hiço saber al scñor de Temislitan: é assi cómo supo que Quacuscaçin era venido, creyó que no se pudiera aver soltado, é que debia de yr por parte de los españoles para deste allá clarles algun aviso; ć por tanto envió luego á mandar al dicho Guanacaçin que malasse al Quacuscaçin su hermano, é assi se hiço, sin lo dilatar. Y el otro que era hermano menor quellos, se quedó con Cortés. é cómo era muchacho, imprimió más en él la conversacion de los españoles, é tornóse chripstiano, é llamảronle don Fermando: é al liempo que Cortés partió de la provinçia de Tascalteca para las de México é Temistitan, dexóle allí con çiertos españoles, é lo que con él sulıgedió se dirá adelante.

El dia siguiente que Corlés fué de lzIapalapa á la cibdad de Thesayco, envió á Gonçalo de Sandoral, alguaçil mayor de su cxérgito, por capitan con veynto dw caballo é doscientos hombres de pié, enure ballesteros y escopeteros ć rodeleros, para que eclassen fuera de aquella provinça á çicrtos mensijeros quél enviaba á la ciludad de Tascalleca í saber en rué fórminos cestaba la labor de los trece bergranlines que alli se hacian, é para prower ollas cosals nescessarias, assi para los vecinos de la villa de lá Veracruz, como para los de su compañia, é lambien para asogurar acpuella parte, para que pudiessen yr é tornar los españoles seguros: porque estonces ni ellos podian salir de la provincia de Aculnacan, sin passar por ticrra de los encmigros, ni los españoles que estaban en la villa ni en otras partes podian renir á Coltés sin mucho pelig̣ro. É mantó al dicho alguaçil mayor que despues que oviesse puesto en salvo los mensajeros ques dicho, llegasse á una provinçia que se diçe Galco, que confina con la de Aculuacan; porque tenia aviso que los nalurales de aquella provinçia, aunque cran de la liga de los de Culua, se querian dar por rassallos de Cistilla, é que no lo osaban liaģer, lemiendo de çierta guarda de gente de Culua, que Icnian puesta cerca dellos.

Ydo este capitan, é con él en compania todos los indios de Tascalteca, que avian traydo el fardage á los españoles é otros que avian ydo á ayudarlos, é avian avido algun despojo en la guerra, adelantáronse un poco.adelante; y el capilan, ereyendo que por yr en la reçaga los españoles no osarian salir los enemigos á ellos, cómo los vicron los contrarios, que estaban en los pueblos de la laguna y en la costa della, dieron en la reçaga de los de Tascalteca é quiláronles el despojo, é aun mataron algunos dellos. É cómo el capilan llegó con los de caballo é peones, dió nuy denodadamente en ellos é malaron muchos, é los que quedaron desbaralados, se acogicron al agua é 
á otras poblaçiones que estín çerea della; é los indios de Tascalteca se fueron á su tierra con lo que les quedó, é tambien los mensajeros que Cortés enviaba.

Puestos todos en salvo, el dicho capiIan Gonçalo de Sandoval siguió su camino para la provinçia ques dicha de Caleo, que está allí çerca ; é otro dia de mañana se juntó mucha gente de enemigos para los salir á resçibir, é pressentaron la batalla; la qual viendo los chripstianos aparejada, no la rehusando, arremeticron contra los enemigos, é rompieron é desharataron dos esquadrones dellos con los de cahallo, en tal manera que en poco espaçio de hora quedaron señores del campo; é prosiguieron matando é poniendo fuego en la tierra.

Fecho aquesto, é desembaraçarlo aquel camino, los de Calco salieron á resçibir los españoles de paz, é los unos é los otros se holgaron mucho. É los prinçiłales diseron que querian ver é hablar á Cortéz, é partiéronse luego é fueron á dormir a Thesayco, donde estaba; é llegados antes algunos prinçipales con dos hijos del señor de Calco, pressentaron hasta trescientos pessos de oro en pieças labradas, é dixéronle que su padre era muerto, é que al tiempo de su finamiento avia dicho que la mayor pena que deste mundo llevaba era no aver visto á Cortés primero que muriesse; é que muchos dias le avia cstado esperando; é que les avia mandado que luego quél á aquella provinçia viniesse, le fuessen á ver é le loviessen por padre; é que assi como supieron de su venidaá aquella cibdad de Tlıesayco, quisieran venir á verle; pero (jue por temor de los de Culua no avian osado, ni tampoco estonçes osíran venir, si ápuel capitan quél avia enviado no oviera llegado á su tierra; é que le rogaban que quando se oviessen de tornar á su tierra, les diesse otros tantos españoles para rolver en salvo á sus casas. É dixeron á Cortés que bien sabia él que en guenta ni fuera della ellos no avian seydo contra él, é que tanbien sabia cómo al tiempo que los de Culua conluatian la fortaleça de Temistitan é á los españoles que Cortés en ella avia dexado, quando se fué á rer á Compual con el capitan Narvaez, que estaban en su tierra dos españoles en guarda de cierto mahiz que alli avian recogido, é los avian sacado hasta la provinçia de Guaxoçingo, porque sabian que los de allí eran amigos de los chripstianos, porque los de Culua no los matassen, como haçian á todos los que hallaban fuera de la fortalega de Temistitan. Esto é otras muchas cosas dixeron con lágrrimas ante Gortés, y él les agradesçió mucho su voluntarl é buenas obras, é les prometió que haria siempre por ellos todo lo posible, é serian muy bien tractados, en tanto que por su parte dellos fuesse guardada la lealtad é obidiençia que of esçieron á Su Magestad é al ceptro real de Castilla.

Estos hijos del señor de Caleo, é los que con ellos vinieron, estovicron allí con Cortés un dia; é otro siguiente, porque dixeron que se querian tornar á su ticra, fué con ellos el mesmo capitan Gonçalo de Sandoval con çierta gente de caballo é de pié: al qual mandó Hernando Cortés que despues que oviesse puesto estos indios en su lierra, llegasse á la provinçia de Tascalteca é truxesse consigo çiertos españoles que allí estaban, é á aquel don Hernando, hermano de Cacamuçin, de quien de susso se hiço mençion; é deste á quatro ó çinco dias volvió con los espanoles, é truxo al don Hernando consigo. Desde á pocos dias supo Cortés cómo pol ser hermano de los señores de aquella cibdad, le pertenesçia á él el señorio, aunque avia otros lhermanos, é assi por esto como porque la provinçia estaba sin señor , á causa de Guanacaçin, señor della, que la aria dexado é yolose á la cibrlad de Temistitan; por cstas causas, é por- 
que era muy amigo de los chripstianos. le hiço Cortés resçibir por sceñor : como á vassallo de Su Magestad. É los maturales - de la cilulad, aunrue aria pocos en essa saçon en ella, lo hiçieron assi é lo obedesçieron; é connengaron á renirse otros muchos á la cilurlad é provincia de leulnacan, que cstaban ausentes é huydos. é servian muy de grado al dicho don Helnando; é de alli adelante se reformó í pobló muy bien aquella cilsdad.

Deste a dos dias que aquesto se liveo, vinieron ál Cortés los señores de Coantichan é Guaxula, é dixéronle que supiesse de çierto que todo el poder de Culua venia sobre él é con determinaçion de 110 dexar cluripstiano á vida, é que toda la tierra estaba llena de los enemigos, é que viesse si lracrian á sus mugeres é hijos á donde él estaba, ó si los llevarian á la sierra, porque tenian muy grand temor. Y él los animó é dixo que se estoviessen en sus casas é no hiçiessen mudança, é que no temiessen y creyessen que die cosa del mundo él holgaria más que de verse con los de Culua en el campo; é que estoviessen aperçebidos con huenas velas y espias por torla la lierra, é que en el instante que los contrarios viniessen, so Io liciessen saber; ú assi se fucron conçertados é apercebidos. É aquella noche Cortés, como buengucrero, puso su gente en órlen, é proveyó cn lodas las partes que le convino sus velas é çentinelas, sin dormir ni repossar con este curdado aquella noche $y$ of dia siguicnte, creyendo lo que avian dicho los de Guaxuta é Coantichan.

Otro dia despues se supo que por la costa de la laguna andaban algrunos de los enemigos salteando, y esperando tomar algunos indios de los de Tascalteca que yban é venian por cosas para el servicio del real de los chripstianos; é tambien se supo cómo se avian confederado con dos pueblos subjetos á Thesayco, que estal san alli junto al agua, para haçer deste all quanto daño pudiessen, é lag dau alharrá

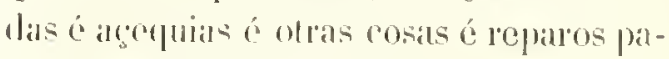
l'is su definsa dortalescerse.

Informado desto Cortes, tomó hasta duce de cabailo é doscrientos peones é dos tiros pedueños de bronce é fué allí adonde andalan los contrarios, que seria á leEna ó media de la cildand; y on saliento della, topó con ciertas spias de los enemigos é ron otros fue estaban cur utsa celada, é rompió por allos é alancéaron ó mataron algunos, é otros muchos se echaron al agua, é liço Contés quenar parto de aquellos puchlos, é lornóse al apossento victorioso.

Otro dia vinieron tres hombres prinçipales de aquellos pueblos á pedir perdon de lo passirlo, é a rogar á Ilernando Corlés que no los destruyesse, é promelieron de no rescibir en sus pueblos á ninguno de los de Temistitan. porque cslos no eran personas de mucho caso, y cran rassallos de don thernanto, se les concedió el perdon.

Orro dia despues ciertos indios de su poblacion vinicron á Cortés, ó alyunos dellos descalabuados, diriendo que los de México é Temistitan avian vucllo a su pueblo, é que cómo no les arian hecho el acogimiento que solian, los avian mallraclado é avian llevarlo pressos algunos dellos, é que si no se defendieran, llevíran á lodos los demás: por tanto, que rogaban á Cortés que estoriesse sobre aviso para los socorrer, si sus enemigos 101nassen, porque creian que con más gente avian de volver á los acabar de destruyr. É Cortés los esforego é dixo que estoviessen de buen ámimo, é que si tornassen los contrarios, le diessen aviso con tiempo para que los pudiesse socorrer ; é assi con este prometimiento se fueron á su puchlo.

La gente que avia quedado en Tasealteca haçiendo los bergantines, tenian nueva rómo al puerto de la villa de la Vera- 
cruz avia flegado una nato an que yban. sin los marineros, trejnta é quatro espatñoles é oclo caballos, é algunas lalleslas y escopelas é pólvora; é cómo no avian saloido cómo les yoa en la gaucra á los chripstianos que estaban en la ticrra, ni tenian seguridad para passar á se junlar con ellos, estaban perplexos é allí en Tascalteca delcnidos algunos españoles que no Osiban yr állevar á Corlés esala buena nueva. É un criado suyo, que en su nombre en aquella lierra estaba, hiço pregonar, só graves penas, que ninguno saliesse de allí hasta quel capilan general Hernando Cortés lo enviasse á mandar; pero uno se determinó, non obstante el pregon, conosciendo que de cosa del mundo Cortés no podia liolgar más que con saher de la venida de arfuclla nao é del socorro que llevaba; é aunque la licrra no estaba segura, salióse de noclee é fué á Thesayco, é no se espantó poco Hernando Cortés é los que con él estaban de aver llegado vivo aquel mensajero á perlir tales albriçias: é Corlés se las dió é lıolgó mucho, é lodos los demás, por la extrema nesçessidad en que estahan, esprerando que los socorricsse Dios.

Aquel mesmo dia llegaron á Thesayco çicrtos hombres de bien, mensajeros de los de Calco, é le dixeron que á causa de se le aver ydo á ofrescer por vassallos de Su Magestad, los de Temistilan é lléxico yluan sobrellos para los destruyr, é que para este efetto avian convocado é apercebido á torlos los çercanos á su lierra, é que le rogaban que los socorriesse é ayudasse en tan grand nescessidad, porrue pensaban verse en mucho trabaxo, si assi no lo hiçiesse. Pues cómo los chripstianos cran poeos é no porlian hager lo rule desscahan por su poco número, Cortés les diso quél queria enviar en essa siron por los hergantines, é que para ello tenia aprercebidos á todos los de la provinçia de Tascalteca, de donde se avian de traer on precas, e tenia nescessidad de emviar para ello gente de pié é de cahallo: que ya sabian que. los de las provincias de Guaxocingo, Churultecal é Guacachula cran vassallos de Céssar é amigos de los cluiptianos; que fuessen á ellos é de parte de Cortés les rogassen, pues vivian gerea de su tierra, que les fuessen á ayudar é socorter, y enviassen alli gente de guarnicion para que esloviessen seguros, en lanto que Cortés los socorrial, porque al pressente 110 se les portia dar otro remedio. E aunque no quedaron lan satisfechos los que pedian su ayuda, como lo estovieran, si les diera algunos cspañoles, agradescrićronsclo é rogánonle que porque fuessen creydos les diesse una carta, é tambien poirque con más seguridad se lo osassen rogar; porque entre estos de Calco é los de dos provinçias apuellas, como erăn de diverssils parcialidades, avia siempre diferencias. Y estando dando órden en esto, llegaron acaso sicrtos mensajeros de las dichas provinçias de Guaxoçingo é Guacachula, y en pressencia de los de Caleo diseron que los señores de aquellas p!rovinçias no avian vislo ni sabido rle Cortés, despues que a via parlido de la provinça de Tascalteca, como quicra que cllos sicmpre tenian puestas sus alalayas é velas por las sierras é gerros que confinan con su lierra é sojuzgan los de Héxico é Tenistian, para que viendo muchas ahumadas, que son las señales de la guerra, le viniessen á ayudar é socorrer con sis vassallos é gente; que porque avia poeos dias que ariatu visto alummadis más que numcá, venian á silber cúmo estaluan é si tenian nescessiclad al pressente, para que luego les proveyessen de gente de gunerra. Cortés les igradesció muchosu comedimiento, é les dixo que, loores á Dios, los esprañoles y él cslaban bucnos, é (que sicmple a rian arido victoria contra los animigasos ć que demás de se aver holgardo muchlo con su 
roluntad é pressençia, holgaba más por los confederar é liaçer amiggos con los do Calco, que estaban pressentes; é que assi les rogaba, pues los unos é los olios eran vassallos del Emprerador é de la corona real de Castilla, que fuessen buenos amigos é se ayudassen é socorriessen contra los de Culua, que eran malos é perrersos, y en especial que al pressente los de Calco Ienian nescessidal de socorro, porque los de Culua querian yr sobrellos; é assi lo concedieron como Corlés se lo pidió, é quedaron muy amigos é confederados. E assi en paz se fueron los unos é los otros muy alegres é contentos de la amistad contrayda: é se liçicron muy buena reçindad é se ayudaron los unos á los otros destle adelante.

Desde á tres dias, porcue ya se sabia que los hergantines estarian acabados de labrar, é la gente que los avia de traer aperçebida, envió Cortés al algguaçil mayor, Gonçalo de Sandoval, con dosçięntos peones é quinge de caballo á los lraer, é mandóle que deslruyesse é asolasse un puchlo grande subjeto á la cilulad de Thesayco, que confina con los términos de Tascalteca, porque los naturales dél avian muerto çinco de caballo é quarenta é çinco peones, que venian de la villa de la Te. racruz á la cibdad de Temistilan, quando estaba Corlés çercado en ella, no creyendo que tan grand traycion se les avia de hager : y como al tiempo que esta vez postrera entraron los nuestros en Thesayco hallaron en los oratorios é templos neplandos que aquella gente tienen, los cuerpos de los çinco caballos con sus piés é mamos y lierraduras, coçidos é lan bien adobados los cueros como en todo el mundo donde tal arte mejor se sepa se pudiera hacer, y enteros, y en señal de victoria ellos é mucha ropa é cosas de los españoles que matiron, ofresçidos á sus ydolos; é hallaron la sangre de sus compañeros y lier. manos derramada 6 sacrificada por Lodas acpuellas torres é templos; de lo qual redundó laula lístima é compassion, acoulpariada de yra, renovando las injurias é pérdiclas passadas, que ningun cluripsliano lo purlo ver sin lágrimas. E los indios de aquel pueblo é otros á él comareanos. al tiempo que aquellos chripstianos que padescieron, passaban por alli, les hicicron buen resçibimiento para los asegurar é hager en ellos todas las crueliades (jue quisieron, que fueron muchas: porque haxando por una cuesta é mal passo, todos á pié é los caballos del diestro, de forma que no se pudieron aprovechar deIlos ni de sus armas por la indispusiçion del termeno, do estaban puestos en çelada los enemigos de una parte é de otra del mal passo. los Iomaron en medio, é dellos mataron é se los comieron, é dellos prendicron é reservaron vivos para los trace á Thesayco á sacrificar, é sacarles los coraçones delante de sus ydolos. Y esto praresció ser assi, porque quando el dicho alguaçil mayor por allí prassó, riertos españoles que con él yhan, en una casa de un pueblo que está contre Thesayco é aquel, donde malaron é prendicron á los chripstianos ques dicho, hallaron en una pared blanca escriplas con carbon eslas palabras: Aqui estovo presso el sin rentura de Johan Yuste: el qual era un lidilalgo de los çinco de calıallo, que sin dubda fué cosa de muclio dolor é digna de notable casliyo.

Llegado el alguaçil mayor á este pueblo, conosciendo los naturales dél su grand culpa, començaron á ponerse en luycta, é los de á caballo é peones españoles é los indios sus anigos siguieron el alcançe é mataron muclos, é prendicron é capsivaron muggeres é niños muchos, que se dieron por esclavos, aunque movido á compasion, no quiso matar este capilan tantos ni destruyr tanto como se pudicra haser. É antes que de allí se parliesse, liien recoger la gente que quedaba. é que 
se fornassen á su pueblo, para que quando viessen aquellos pellejos de caballo ques dicho que tenian por memoria de su templo, se acordassen quán enteramente fueron castigados por ello. É assi se començó á reformar el daño que está dicho, que fué grande; é quedó el castigo fecho tan imprimido en los que quedaron é con tanto arrepentimiento, que sirvieron bien de ahí adelante. Y el alguacil mayor fué desde allí çinco logruas ó seys á una poblaçion de Tascalteca, que es la más junla á los términos de Culua, é alli laalló á los españoles é gente que traian los bergantines; é otro dia que llegó partieron de allí con la tablaçon é liģaçon dellos, lo qual traian con mucho conçierto más de ocho mill hombres, que era cosa mucho de ver é aun de maravillar é nueva cosa é memorable, porque fueron treçe fustas que Ilevaron diez y ocho leguas por tierra: é desde la vanguarda á la retroguarda avia dos leguas continuadas de indios carģados. E cómo començaron su camino, yhan en la delantera ocho de caballo é çient españoles á pié; y en ellas y en los lados por capitanes de más de diez mill hombres de guerra Yutecad é Teutipil, dos señores de los prinçipales de Tascalteca. En la reçaga yhan otios çient ó más espanoles con otros ocho de cahallo; y en esta retroguarda é á los lados yba por capitan con otros diez mill hombres de ginerra muy bien aderesçados Chichimecatecle, ques de los prinçipales señores de aquella provinçia, con otros capitanes inferiores que traia consigo. É cómo entraron en tierra de Culua, mandaron los maestros de los bergantines que fuesse en la delantera la ligacon dellos, é que la tablaçon se quedasse atrás, porque era cosa de mas embaraço, si alğuno acaesçiesse, lo qual si fuera avia de ser en la delantera; é Chichimecatecle, que traia la tablaçon, cómo siempre hasta allí con su gente de guerra avia traydo la delantera, tomólo por afien- la, é fué cosa reçia acabar con él que se quedasse en la retroguarda, porque él queria llevar el peligro que se pudiesse resçebil: é cómo ya lo conçedió, tampoco queria que en la reçaga quedassen en guarda españoles, porque era hombre de mucho esfuerço é queria él granar aquella honra.

Llevahan estos capitanes dos mill hombres cargados de vituallas, é con esla órden é concicrto fueron su camino, en el qual se detuvieron tres dias, é al quarto entraron en la cibdad de Thesáyco con mucho plaçer y estruendo de atabales é alambores é grilas que paresçia que abrian el çielo. Y Hernando Cortés los salió á resçebir, é cómo es dicho, extendíase tanto el hilo de la gente, que desde que los primeros començaron á entrar en Thesayco hasta que los postreros ovieron acaluadó de.llegar, passaron más de seys horas, sin quebrar el hilo de la gente. É despues que acaharon de llegar todos, Cortés les dió las graçias é se lo tuvo en mucho serviçio de parte del Emperador Rey, nuestro señol, é de la suya se lo agradesçió quanto era raçon. É los hiço apossentar é proveer lo mejor que se pudo haçer, y ellos le dixeron que traian mucho desseo de verse en el campo con los de Culua, é que viesse lo que mandaba, quellos é aquella gente venian con voluntad de servil á Su Jagestad é de se vengar de sus enemigos é morir en compañia de los españoles, como leales amigos suyos: de tal forma que tenian mucha esperança que de las cosas passadas se tomaria la enmienda muy complidamente. Ilernando Cortés con mucho plaçer les dió las graçias é les dixo que repossassen, que presto les diria las manos llenas, para que sirviendo á I)ios y al Emprerador, nuestro señor, quedassen satisfechos é rengados de sus enemigos, é ricos de sus despojos, o los adverssarios castigados de sus atrevimientos é delictos passados conforme á sus méritos. 


\section{CAPITULO XX.}

Cómo el eapilan Hernando Corlés salió en campo nuy poderosamente, i causa de la grand compañia de los amigos confederados, fiú sobre una poblaçion que se diçe Xaltoca, donde se hiço mucho daño en los encmigos, é lo mesmo hiço en la cibdad de Tacuba é otros pucblos *.

\section{S} co é prudencia de Hernando Cortés muy lignas son que entre los cavallerosé gento militar en nuestros tiempos se tengan en muclia estimaçion y en los venideros unnca se desacuerden. Por causa sury me acuerto muchas veces de aquellas cosas que se escriben del capitan Viriato, nuestro español y estremeño"; é por IIernando Cortés me ocurren al sentido las militares fatigas de aquel espejo de caballeria Julio Céssar, diclador, como paresçe por sus Comentarios, é por Suctonio é Plutarco é otros auctores que en conformidad escribieron los grandes liechos suyos ${ }^{2}$. Pero los de Hernando Cortés en un mundo nuevo ó tan apartadas provinçias de Europa, é con lantos trabacos é nesçessidades é pocas fuerças, é con gente tan iunumerable ó tan bárbara é belicosa é apaçentada en carne humana (é aum avida por exçente é sabroso manjar entre sus adverssarios), é faltándole á él é á sus mílites el pan é vino é los otros mantenimientos todos de España, y en tan diferençiadas regiones é ayres, é tan desviado ó lexos de socorro é de su prínçipe, cosas son de ạduriraçion. Céssar ovo sus batallas é victorias en provinças é partes pobladas é proveydas é de las mejores del mundo, en compañia de sus propriosé muclos romanos é naturales é otras gentes de raçon; é Viria10 dentro de España on sir palria; pero acá en colas tierras ol menor peligro es

* Este epigrafe terminaba asi en el códice autógrafo, bien que suprimidas ya las siguientes cláusulas: "E de los recuentros $\dot{E}$ cosas que subcedieron lasta que Corlés volvió a Thesayco, donde dió licencia á los scĩores é capitanes de Tascalteca, que el que de los hombres se puede recresçer, por grande que sea, á respecto de la contradiçion de los ayres é climas é regrones Lan dificultosas á la salud de los que nuevamente las conoscen, tan diferentes de las de España, en nuevo lıoriçonte é dehaxo de estrellas no vistas sino por acá: las aguas de muchas maneras é diferentes sabores, é assi de las otras cosas de que los cuerpos humanos han de ser alimentados, agenos de aquellos manjares que primero usaron nuestros estómagos, assi en el gusto como en la digistion, faltando el médico, y el cirujano, y el lecho é otras cosas tan nesçessarias como la vida las pide.

Dexemos agora esto, que hay mucho que deçir en ello, pues que en semejantes incomodidades todos le eran iguales á Cortés, é las padesçan sus mílites, é aun unás enteramente quél, porque es costumbre que de los mal librados, los capitanes tengan más oportunidad para las comportar: é no se pierda tiempo para la continuacion de la pressente historia, que á mi parescer es tal, que no está oyda ni escripta su semejante, ni yo sabria dar entero Ioor á Hernando Cortés é á sus cortesanos. Y assi los quicro llamar de aqui adelante, porque assi como en todas las partes é reynos la gente más valerosa é más de estimar son los que siguen la persona é casa del prínçipe é de su corte, é de aqui toman este nombre de cortesano,

avian traydo los bergantines, para se volver a $s u$ tierra."

1 Justino, lib, XLIV.

2 Comenl. de César; Suelonio; I'lutarco, en la rida de Cesar. 
d pues gentil é probado varon en sus cosats é huena criança y esfuerço, assi por consiguicnte dol nombre del capilan general es anligua costumbre nombrarse los soldados ć nuevos polyladores en aquollas provinçias quellos conquislan, segund mas largamente se diso en la primera parte destas listorias, en el libro II, capítilo III, nombrando á los españoles por llispan, é á los asirios de $A$ sur, é á los hebreos de Heher é á los persas de Perseo, los armenios de Armenio, los troyanos de Troo, los alesandrinos de Alesandro, é Ios romanos de Rómulo, etc. 'É assi méritamente conviene á estos milites de Cortés que se les pegue tal ditado del proprio nombre del linage de Ilernando Corlés, é yue pues con él militando, en tan señalada empressa se hallaron, é consiguieron glorioso evento, que su nombre sea cortesano, ques en la rerdad no poco, sino muy lıonoroso apellido para todos aquellos, que en esla guerra se hallaron é se prescien mucho della é del nombre.

Despues que toda la gente de guerra de Tascalteca ovo repossado en Thesageo tres ó quatro dias (y eran todos essos de muy luçidas é dispuestas jersonas é bicn armados át su usança), Hernanclo Cortés hiço aperçelsir veynte y çineo de caballo é tresçiontos infantes ú hombres á pié dè los cspañoles, é çinquienta ballesteros y escopeteros, é seys tiros de pólvora de hronçe, pequeños; é sin deçir á persona algruna adonde yba, salió de la cibdad de Thesayeo á las nueve horas del dia, é eon b́los capilances que se nombraron en ( ) eapítulo precèdente, con más de treynta mill hombres por sus esquadras muy biea ordenados, segund su costumbre. É á quatro leguas de la cibuad de Thesayeo, ya que era larde, vieron in batallon de gente de guerra de los enemigos, é atendieron muy osadamente, é nuestra geente

1 S Isidoro, Fthimal., lib. 1.K, cilp. 2. TON:O HI. de át cabilk rompieron por cllos é los desbarataron, é los de Tascalteca, que era gente ligera y expertos en el exercicio de la guerra, siguieron á los caballos, y en si compañia mataron muchos de lo: contrarios; é sobrevino la noche, é por su escuridad no ovo tiempo para más de assentar los nuestros su real con la guardia é aviso que se requeria. I ol dia siguiente procelicron en su camino. y el capitan general no avia dicho dónde era su intencion que fuessen, porque reçelabá de algunos de los de Tliesayeo, que yban en el exérçito, porque no diessen aviso de lo que pensaba hacer á los de Héxico é Temistilan, é porefue aum no tonia seguridad dellos, é porque es preçepto expresso del arie militar (y prudentemente proveydo) que aquella cosa que oviere el capitan de haçer, la diga á poquíssimos é fidelíssimos. Estoy yo may. bien con un dicho de Flavio Vegerio, que diçe: "El que la paz dessea, aparoje con ingenio la guerra, é aquellos que della querrian conseguir la victoria, á sus solclados enseñen con diligencia é con arte: é no á ventura combata quien dessea alegre fin de su obra ?." No dubdo yo que Ilernando Cortés ignorasse ál Vegeçio é á Caton é á otros excelentes auctores, que escribieron sobre el arte militar; ma; afirmo é ereo quel ingenio deste capitan cra lal en las cosas de la gruerra, que naturalmentenasçió para enseñar á otros muchos to yue en cila se debe hacer. Passo. mos á lo demás.

Caminando llernando Cortés con sil exérçito, llegaron á una poblaçion que so dice Xalloca, la cual está asentada en medio de la costa de la laguna, é al rededor della hallarou muchas é grandies aģequias llenas de agua, que hacgian aquel pueblo muy fuerte, porrue los de cabillo no podian entrar á á , é los contrarios á su sal.

2 Vergecio, the Re Militari, lib. III. 
vo tiraban muchas varas é llechas, é con tantas gritas, que sin dubda pornían mucho espanto en soldados nuevos y en quien no los la primero experimentado. Con todo esso, inuestra gente de á pié, ainque con mucho trabaxo, entraron dentro, y eeharon fuera los enemigos, é quemaron mucha parte del pucblo. É aquella noche fueron los ehripstianos é sus aliados á dormir una legua de allí ; é assi eomo paresçió la luz del siguiente dia, proçedicron en su camino, é hallaron los enemigos, é desde léxos eomençaron á gritar, eomo lo han de costumbre: é los nuestros signuićronlos hasta llegar á una hermosa é grand cibdad, que se llama Guantielan, é halláronla despolblada, é apossentáronse en ella aquella noehe. É otro dia bien de mañana prosiguieron adelante, é llegaron á otra cilsdad que se dice Tenayuca, ${ }^{\circ}$ en la qual no hallaron resistençia, é sin se detener passaron á otra que se diçe Acapuçaleo (todas estas pollaçiones están al rededor de la laguna ); é tampoco se detuvieron en esta otra, porque Hernando Cortés des. seaba mucho llegar á otra cibdad que estaba çerea de allí, que se llama Taeuba, ques muy cerea de Temistitan. É za que estaban juntoá ella, hallaron en su circunferençia muelıs açequias de agua, é los enemigos muy á punto; y encontinente los españoles arremetieron contra ellos, y entráronles la cibdad por fuerça de armas, é mataron muchos, é los restantes salicron luyendo: é cómo era ya tarde, aquella noche no se hiço más de apossentarse los nuestros en una casa, que era tan grande que cupieron en ella todos bien á plaçer. En amanesçiendo otro dia, los nuestros indios confederados amigos començaron á saquear é quemar toda la cibdad, salvo el apossento donde los chrips. tianos cstahan, é pusieron tanta diligençia en el inçendio, que tambien se quemó un quarto de la casa ques dicho. Esto se hiço assi, porque quando Corlés salió des- baratado de Temistilan, passando por aquella cilulad, los naturales della se juntaron eon los de Temistitan, é le hiçieron cruel guerra, é le mataron muehos españoles: assi que, muy bien tenian meresçido este castigo.

Allí estovo Hernando Cortés é sủ exérçito seys dias en Tacuba; pero ninguno passó sin alģun reneuentro ó escaramuça con los enemigos. Los eapitanes é gente confederada de Tasealteca é los eontrarios haçian unchos desafios particulares, é con los de Temistitan peleaban euerpo á enerpo unos contra otros, y en diverssos números, dos á dos é tres á tres ó más, como se conçertaban, diciéndose muchas injurias é ultrajes, meneando muy bien las manos; é sin dubda era cosa mucho de ver é de notar sus ánimos. É siempre morian muchos de los enemigos é rençian los nuestros, aunque como tenian tantas defensas resistian muy resçiamente defendiéndose, é muehas veces, fingian que daban lugar para que les entrassen dentro, é deçian: "Entrad, entrad á liolgaros." Otras veçes á manera de amenaças deçian: "Pensays que tenemos agora otro Montecuma, para que haga todo lo que quisiéredes?

Estando en aquestas pláticas, se allegó el general Hernando Corlés çerea de una puente que tenian quitada, é mandó á los nuestros que estoviessen quedos, é los enemigos que estaban de la otra parte, como entendian que les querian hablar, liçieron tener silençio á su gente: é Cortés les dixo que por qué eran locos é querian ser destruydos, é preguntóles si avia allí entre ellos algun señor principal de los de la eibdad, para que se llegasse allí, que le queria hablar é deçir cosas que les eonvenian mucho. Y ellos respondieron que toda aquella moltitud de gente de guerra quél por allí veia, lodos eran scñores; por tanto que dixesse lo que queria: é eómo Cortés vido que aquello era mentira, no 
respondió cosa algguna, é comenzáronle á deshonı'ar con palabras injuriosas, é uno de los nuestros dixoles: "Bien sabemos que os morís de hambre, é no os avemos de dexar salir de ahí á buscar de comer." I esto respondieron quellos no tenian nesçessidad ni falta de comer, é que quando la toviessen, que de los chripstianos é de los de Tascalteca comerian. É diçiendo esto, uno de ellos tomó unas tortas de mahiz, é arrojólas háçia los españoles, diçiéndoles: "Tomad, comed si teneys hambre, que nosotros ninguna tenemos." É luego començaron á gritar é á pelear con los nuestros.

Como la yda del general á esta cibdad de Tacuba fué prinçipalmente por haber plática con los de Temistitan é saber qué voluntad tenian, é su estada allí no aprorechalua á cosa alguna, á cabo de los seys dias acordó de se tornar á Thesayco, para dar priessa á ligar é cabar los bergantines, para poner cerco por la laguna é por la tierra á aquella grand cibdad: y el dia quel exérçito partió de vuelta, fueron á dormir á la cibdad de Goaoatan, de la qual la historia ha fecho mençion, é los enemigos no haçian sino venir siguiéndolos, por haçer el daño que pudieran al retirarse los chripstianos; mas los de caballo de quando en quando revolvian solse los contrarios é alançeaban algunos.

- Otro dia caminaron con su órden, é los adverssarios, pensando que de temor to haçian, junto grand número dellos siguieron á los nuestros, tan regoçijaclos é con tantas gritas, como si se vieran vençedores: y el general mandó á la gente de pié que se fuesse adelante sin detener, é que en la recaga fuessen cinco de caballo; y él se quedó con veynte cavalleros en çierta parte puesto en celada; é de aquessos mandó á los seys dellos que se pusiessen en otra parte, é otros seys en otra, é otros çinco en otra, y él con los otros restantes se puso en otra parte, porque la dispusicion de la tierra era aparejada para ello. É ordenó que cómo los enemigos passas. sen, pensando que todos yban juntos ackelante, que assi como le oyessen deçir: "Sanctiago, é ál ellos", saliessen é diessen en las espaldas de los adverssarios. É assi se puso por obra quando fué tiempo; é alançeando en ellos, les turó el alcançe çerca de dos leguas por un llano adelante, con mucha victoria de los cortesanos é muchas muertes de los contrarios, que allí pactesçieron á manos de los chripstianos é de los amigos confederados. É dende adelante los enemigos no siguieron, é los nuestros volvicron é alcançaron la gente que adelante yba de su exérçito; é aquella noche durmieron en una gentil poblaçion que se diçe $\Lambda$ culman, que está dos leguas de la cibdad de Thesayco, para donde otro dia se partieron, y entraron en ella á medio dia, é fueron muy bien resçebidos del alguaçil mayor, quel general avia dexado por capitan, é de toda la gente con mucho plaçer é regoçijo; porque desde que de allí avian salido no se supo dellos ni de lo que les avia subçedido, y estaban con mucho cuydado é pena hasta que con su pressençia salieron della.

Otro dia siguiente los señores é capilanes de la gente de Tascalteca pidieron liçençia al general, y él se la dió, para se tornar á su tierra, donde fueron muy contentos é con assaz despojo de los enemigos. 


\section{CAPITLO XXI.}

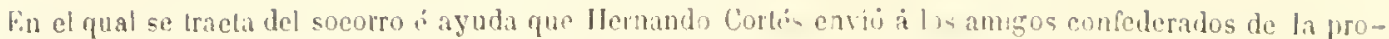

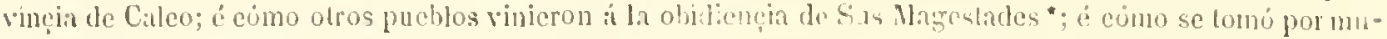
eha ventura la inexpugnable pohlaçion de Guamanaca, évo á la obiliencia de Sus Magestades el señor Hella ; cómo tomó a destruyú la cibdad de Suchimileo, ia ulras cosas notibles que Curtis é sus cortesanos milites hicieron, eon mucha ricloria a prisperos subessos.

) la ciblad de Tesayco, llegaron á él ģiertos mensajeros de los señores de Calco, e le hiçeron saber que los de México é Temistian yban solnellos á los destruyr, ¿ que le rogahan que los socorriesse, como otras veges se lo avian suplicado: $y$ el general proveyó luego y envió con el alguaçil mayor, Gonçalo de Sundoval, veynte calballos é tresçientos peones cortcsanos; é mandóle que con mucha diligençia diesse á los conferlerados é amigos todo el favor é ayuda que posible liresse. É llegado á Calco, lialló mucha gente junta, assi de la de aquella provincia como de las de Guaxogingo é Guacachula, fuc estaban esperando el socorro; é dada órden en lo que se delia hager, no esperaron que los acometiessen los contrarios, sino partiéronse para una pobliçion que se liçe Guastepeque, donde estaba la gente de Culua en guarnicion. é de alli hacian mucho daño á los de Calco. É á un pueblo que estél en el camino salió mucha gente de los contrarios, é cómo los confederados eran muchos é tenian por su parle á los españoles ques dicho, rompieron con mucho denuedo por los enemigos, los quales desampararon el campo, vertiendo mucla sangre é perdiendo las vidas yrand parte dellos.

Avida esta victoria, repossaron los españolesaquella noche en aguel pueblo, que estí antes de Guastepeque. Los de Culua,

* En esta parte suprimió Oviedo las sicaientes limeas: "E de los combates que arquel general oro cen dos peĩunes eon grant moltitud de indion, i le otro dia siguiente, ya tque los nuestros llegaban cerca de los adversarios, comenciaron á pelear con los cspanoles; pero en poco más de un quarto de liora fucron dicsharatados, é con muerte de muchos dellos los ceharon firia del puebo. É los de á caballo se apearon para dar de coner á sus caballos é apossentarse; y estando assi descuydados de to que subgedió, llegaron los enemigos hasla la plaça del apossonto con mucha grita, apcllidando y echando muchas piedras é varas é llechas: é los españoles dieron alarma, y cllos é sus amigos con nucha priessa salieron á la resistencia a é hiçiéronla tal que los ceharon fucra del pucblo otra vez, ć siguicron el alcanço más de una Jegrua, malando muchos dellos. E tornáronse con esta victoria los corteses é sus amigos bien cansados á dorriir á Guastepeque, é alli repossaron dos dias: en el qual tiempo ol alguacil mayor supo que en un pueblo mós adelante, que se dice Acapichila, avia mucha gente de gruerra de los enemigos: é determinó de yr allá, á ver si se darian de paz é les réquerir con ella, acordándose de aquellis auctoridad que diçe que paresce dulçe la batalla al que no ha prohado su amargura Aquel pueblo es muy fuerte é puesto en un monte alto, donde los de caballo no podian ofender ni hacer to que en lo llano acostumluraban ; ć cómo llegaron los españoles, comencaron los del pueblo í

Inna muy hermosa i grandissima hucrla del scñor de Cruaslepeque."

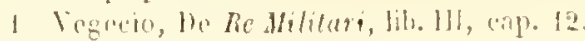


pelear con ellos, é desde lo alto celiaban í rodar galgas (ó picdras grandes) sin çessal": é auncue yha muclia gente de los amigos confederados con el alguaçil mayor, viendo el assiento fuerte de apuclla villa, no osaban acometer ni llegar á los contrarios: lo qualviendo los cluripstianos, determináronse de subir por fuerça á lo alto ó morir, ó llamando en su ayuda al glorioso patron de España Sanctiago, pusićronlo por obra: é plugo á Dios que les lió tanto esfucrȩo é ventura, que aunque cra mucha la resistençia que se les haçia, les subieron, puesto que oro muchos heridos; é como los indios confederados seguian la victoria, quedaron vençidos los contrarios, é muertos é despeñados muchos dellos. Oy deçir á personas de crédito que allí se hallaron, que un rio pequeño que çerea quassi aquel pucblo, por más de una hora fué teñido cn sangre, é les cetorbó de beber por cutonģes á los rençedores chripstianos, porqué como I açia mucha calor, Ienian nescessidad del agua: é assi todavia algunos de los nuestros luebian della, en espeçial los indios a migos, cue para ellos cra aquello un cxçelcnte brebage. De lo qual se puede loar á nucstros españoles ó cortesanos, ó atribuirles (aunque ellos no bebiessen tal igua) tan justamente como á Hario aguel versso del Pelrarea, que diçe en loor de Mario no bebió del rio más agua que sangre", quando venció los çimbros ó ludescos, lo qual mas largamente escribe Plutarco en la vida de Mario.

Dada conclusion en lo que está dicho, quedaron estas dos poblaçiones de paz, é ljien castigados los naturales dellas; y el

1 Franẹisco Petrarca, en aquella canẹion que comicnęa:

Italia mia, ben ehe'l parlar sia indarno *

* Esta cancion es la XXIX." de la primera parle del Cancionero de Pelrarca : el rerso á que Oricdo se reficie dice: alguaçil mayor, Gonçalo de Sandoval, se tornó á Thesayco con toda la gente é con scñalada victoria.

Cómo los de México é Temistitan supicron que los cspañoles é los de Calco avian fecho tanto daño cn su gente é amigos, acordaron de enviar çiertos capitanes con muclia gente á cnmendar su afrenta; é teniendo aviso desto los de Calco, enviaron á suplicar al general, que con toda diligençia los amparasse é socorriesse en tanta nesçessidad. Á causa de lo qual Hernando Cortés tornó Inego a despachar al mesno alguàcil mayor con çierta gente de pić é de caballo; pero quando este socorro llegó, ya los de Culua é los de Calco se avian visto en el campo ć avian avido batalla muy crucla, en la qual quiso Dios dar la ventura á los de Calco, é naataron muchos de los contrarios é prendicron luasta quarenta personas, cutre los quales avia un capitan de los de México é otros dos prinçipales, y cssos fueron luego entregados al alguaçil mayor, y él los envió á Hernando Cortés é dexó otros consigo. É por seguridad de los de Calco, estovo con toda la gente en un pueblo suyo, ques frontera de los de México; é quando le paresçió que no avia nesçessidad dersu estada, se volvió a Thesayco, é llevó consigo á los prissioneros restantes que le avian quedado.

Otros muchos reluatos é recuentros que oricron con los naturales de Culua, se dexan de escribir por evilar prolixidad, que bastaron para quel camino que hay deste la villa de la Veracruz á Thesayco estoricsse seguro. É assi cada dia sabian ya los chripstianos unos de otros, é con

Non piu bebe del fiume aqua che sangue.

E.sle pensamiento to lomí Petrarea del español Floro, que decia, en el cap. 3 del libro 111 de su Epítone: "Ul victor Romanus de eruento flumine non plus aquie biberil quam sulnguinis harbarorum." 
un mensajero enviaron al general giertas bállestas y escopetas é pólvora, que no fuć poco socorro en tal saçon; é con otro mensajero le liçieron saber que avian allegado á aquel puerto tres navios, que Iraian mucha grente é caballos, é que luego los despacharian para que se fuessen al general: é segund la nescessidad en ‘ue eslaba, paresçió que Dios por su misericordia quiso socorrer aquella gente nuestra.

Diçe Séneca que aquel es fuerte que esté aparejado á sufrir todas las cosas que son de temer '. Conforme á esto é á la prudençia que dehe tener quien ha de regir exérçito é dessea prósperamente concluyr la guerra, Hernando Cortés buscalua todas las formas é maneras que podia para traer á su devoçion é amistad los de Temistitan, assi por no los destruyr, como porque él é los chripstianos pudiessen descansar de tan continuos é largos trabacos passados é pressentes é por venir, é prinçipalmente porque Dios é Céssar fuessen servidos, é se excusassen las muchas muertes que de ambas partes estaban aparejadas. É cómo él podia aver á algunơ de la cibdad, enviábaselo con amonestaçiones é requirimientos para que quisiessen quictud é dexassen el peligroso é dañoso exerçiçio de la guerra, é goçassen de sus vidas é no se destruyessen á sí é á sus tierras. É un miércoles santo de tinieblas, que se contaron veynte y siete de março del año de mill é quinientos é veynte y uno, hiço traer ante sí aquellos prinçipales de Temistitan que los de Calco avian prendido, é preguntóles si queria alguno dellos yr á su cibdad á deçir de su parte á los señores della, que les rogaba que quisiessen tener paz con él é con los chripstianos, é que viniessen á la ohidiençia del ceptro real de Castilla é del Emperador Rey, nuestro señor, don Cár- los, como antes to avian heclio; porque su intencion é desseo era de tractarlos como amigos y liermanos, é no hacerles guerra, como á rebclados é desleales vassallos; é aunque essos prissioneros dixeron que creian que los avian de matar, llevando tal mensajeria, dos dellos se determinaron de yr, é pidicron una carta al general, porque aunque no avian de entender ni leer lo que en clla dixesse, sabian que se usaba assi entre los chripstianos, é que llevando aquella carta, se les daria créclito; pero con las lenguas se les dió á entender primero lo que la letra contenia, que era lo mesmo quel general les avia dicho á essos mensajeros, é assi se partieron con çinco de calıallo, que salieron con ellos liusta los poner en salvo.

El sábado signiente sancto, los indios de Calco é otros sus aliados amigos enviaron á deçir á Hernando Cortés que los de México yban sobrellos, é que le pedian por merced que muy presto los socorriesse; y él les respondió que desde á quatro ó çinco dias les enviaria el socorro que le demandaban, é que si entre tanto se viessen ell nescessidad, se lo hiçiessen saber, quél los socorreria; é que estoviessen $\sin$ temor y en vela con los cnemigos. I el tercero dia de pasqua de resurrecçion tornaron á enviar con más afincamiento, pidiendo socorro, é que breremente fuesse, porque los contrarios se acercalsan; y el general les respondió quél queria yr en persona, é luego mandó pregonar que para el viernes adelante estoviessen aparejados veynte y cinco de á caballo é trescientos infantes. Y el jueves antes llegaron de Thesayco ciertos mensajeros de las provinçias de Taçapan é Mascalçingo é Nautan é otras cibdades que están en su comarca, é dixeron que venian á se dar por vassallos de Su Magrestad é á ser amigos de los chripstianos 
é del general, porque ellos nunca avian muerto español alguno ni se avian alçado contra el serviçio de Cuéssar; é truxeron çierta ropa de algodon muy gentil, segund la costumbre de la tierra, y el general les dió las graçias, é les prometió de parte de Su Magestad é de sus subcessores en los reynos de Castilla, que si fuessen buenos é leales á su real serviçio, se les haria siempre muy buen tractamiento é compañia, como á tales vassallos.

Porque este nombre de Magestades es plural é compete á más personas de una, é me entiendạn los extraños de nuestra lengua en este passo é donde leyeren Nlagestades en estas historias, sepan que estas Indias, como en otras partes está dicho, son de la corona é ceptro real de Castilla, é no del imperio Cessariano; é la Reyna doña Johana, nuestra señora, madre del Emperador Rey, nuestro señor, vive; é della é de su real patrimonio de Castilla son estos estados é Indias. É assi en muchas partes la nombro por este título de Magestades juntamente con su hijo: el qual, como obedientíssimo, quiere é manda que assi se haga, é aun en las patentes é provissiones que se dan con el sello real juntamente lablan el hijo é la madre, âunque solo el Emperador las firme; porque la Reyna, nuestra señora, está retrayda é apartada de los negoçios é gobernacion de sus reynos, é assi lo quiere Su Magestad, é se descarga con tan poderoso é justo é buen gobernador como es su hijo, é tan acresçentador é buen administrador de sus reynos; y en esta forma no diçe ni pone Carolus, ni Emperador (digo en todo lo gue para Indias se provee), sino: To el Rey. É su madre ha seydo la más retrayda éhonestíssima viuda de quantas hasta el pressente tiempo se sabe, porque desde el año de mill é quinientos é seys, que su marido el sereníssimo Rey don Felipe, de grloriosa memoria, passó desta vida, siempre ha estado retrayda, y está en la villa de Tordesillas, acompañada de mugeres ançianas, generosas é devotas señoras é religriosos, é su palaçio é casa paresçe un templo de grand devocion, tan ordinario. (jue ha dado é dá exemplo á todas las viudas é honestas personas de maravillosa constançia é sanctidad; é allí residen en su palaçio é serviçio personas de grand auctoridad, donde es servida é tractada como quien es é como madre de Céssar.

Tolvamos á la listoria é mensajeros que á Cortés pedian el socorro de parte de los de la provinçia de Calco é sus valedores: los quales se tornaron muy contentos de ver quel general determinaba de yr en persona á los favorescer é se lallar con ellos contra sus enemigos; é assi lo puso por obra el viernes ques diclıo que salió de Thesayco, é se contaroi cinco dias del mes de abril del año de mill é quinientos é veynte y uno, é llevó consigo treynta de caballo é tresçientos peones españoles, é dexó en aquella cibdad otros veynte de caballo con otros tresçientos españoles en guarda della; Gonçalo de Sandoval, alguaçil mayor, por capitan. $\dot{\mathrm{E}}$ salieron con el general Ilernando Cortés más de veynte mill hombres de los de Thesayco, é con mucha órden fueron á dormir át una polslaçion de Calco, que se diçe Talmanalco, donde fueron bien resçebidos é apossentados; é alli, porque está una buena fuerça (despues que los de Calco fueron amigos de los chripstianos), siempre tenian gente de guarnicion, porque es frontera de lo de Culua.

Otro dia siguiente llegaron á Calco á las nueve horas del dia, é no se detuvieron más de á hablar el general á los señores de allí é deçirles su intençion, que era dar una vista é ver en torno lí costa de las lagunas, porque creia que hecho esto, que importaba mucho, hallaria acabados é aparejados los treçe bergantines para los 
cehar al ag̣a É cómo ovo liablado á los de Calco, partió aquel dia á vísperas é llegó á una poblaçion suya, donde se juntaron con el gencral nús de quarenta mill lombres de guerra te los amigos confederados. Aquella noclıe durmicron allí, é porque los naturales de aquella poblaçion dixeron al general que los de Culua le estaban esperando en el campo, mandó que al quarto del alha todo el cxérçilo estoriese en órden, é oyda missa, començaron á caminar ; y el gencral tomó la dlolautera con veynte de caballo, y cn la regaga mandó yr los otros diez con la gente de á pié, é assi passiron entre unas sierras muy ásperas. í á las dos horas despues de medio dia, llegaron á un peñon muy alto é áspero, ençima del qual estaba muclia gente de mugeres é niños, é todas las laderas de su circunferençia llenas de gente de guerra; é comengaron luego á dar muy grandes alharidlos é hacer muchas alumadas, é liraban con hondas é sin ellas muchas piedras, é langaban muchas varas é flechas, de tal forma, que en llegándose çerca los nuestros, resçclian mucho daño. E ya que avian visto que en el campo no avian ossado esperar los enemigos, paresçióle al general, puesto que su camino era ofro, ser poquedad passar adelante sin laçerles algun sinsabor, porque no sospechassen los adverssarios que por temor se dexaha de los acometer allí donde se avian liccho fuertes : é començó á dar una vista en torno del peñon, yue tenia quassi una legua de fircunferençia, y era tan fuerte en sí naturalmente, que paresçia temerario atrerimiento ponerse á ganarlo, puesto quese les pudiera poner cereo para que zastando tiempo, se diessen de nescessidad, siguiendo aquella amonestaçion de Flavio Vegecio, que dice en su militar disçiplina que es grandíssimo caso veneer antes con la hambre que con el fierro al enemigo '. Pero cómo el general tenia el intento á mayor cosa is no convenia delenerse en aquello, estabal algo perplexo, é al cabo se determinó por muclios respectos de tentar la subida por tres partes, que avia considerado en to que vido que tenian alguna dispusicion para se poder hacer. É mandó á Chripaslóhal Corral, alferez de sessenta liombres de á pié quel goneral traia siempre en su compañia, que con su bandera acometiesse é subiesse por la parte más dificultosa é éspera, é que giertos escopeleros é hallesteros le siguiessen; é mandó á los capitanes Jolan Rodriguez de Villafuerte é Francisco Verdugo que con su gente é otros ciertos escopeteros é hallesteros subiessen por olra parte; é mandó á los capitanes Pedro de Yresio é Audrés de Mucharaz que por otra parte con otros ballesteros y uscopeteros subiessen, é que los unos é los ofros lo començassen, en oyendo sonar una escopeta, é que carla Ino procurase de morir ó venger. É assi cómo se dió la señal de la batalla, assi se puso en el instante por la obra lo quel general les avia amonestado; é ganaron á los contrarios por fuerca do armas dos vueltas del peñon, é no pudieron subir más, porquc la dispusiçion áspera del terreno era lal, que con piés é manos no sa podian tener en pié, é la moltitud de las piedras que de lo alto venian rodando (é algunas se quebraban y cseupian los pedazos), haçian mucho daño: é fué tan reçia la resistencia de los contrarios, que mataron dos españoles é lirieron más de otros veynte, no desacordíndose los nirestros ni su general capitan de aquel preçepto del auctor alegado que diçe, que "donde por la propria salud se combate, no meresçe la negligençia perdon alg̣uno ${ }^{2}$. . El fin es que en ninguna manera los nuestros pudieron passar de allí; y el ge- 
neral viendo gue can imposible hacerse más de lo que avian hecho los cortesanos, é que se juntaban cada hora más de los contrarios en socorro del peñon, por mejor respecto mandó á los capitanes que se tornassen á baxar, é assi sehiço. É recogrida la gente de pié, los de caballo arremetieron á los que estaban en lo llano, y echíronlos de todo el campo, alanceando é matando en ellos espaçio de liora y media ; ć cómo eran mucha gente, derramáronse los de caballo á unas partes é otras, é quando fueron recogidos, supo dellos el greneral que algimos avian llegado hasta uma legua de alli, é avian visto otro peĩon con mucha gente, pero que no era tan fuerte; é que por lo llano serca dél avia mucha polslaçion, é que no faltarian dos cosas que avian faltado en el ques dicho: la una cra agua, é la otra que la resistençia seria menos é se podria sin peligro tomar la gente. É aunque con harto pessar de no aver conseguido la victoria del primero peñon, partieron de alli é fueron arpuclla noche á dormir serca del otro peñon, donde padesçieron mucha sed por no hallar agua, ni en todo aquel dia la avian bebido los nuestros ni los caballos; é assi se assentó el real con él recabdo de velas que convenia, é oian mucho estruendo de atabales é boçinas é gritos.

Cómo esclaresçió otro dia, movió el campo, y el general se adelantó con algunos de sus capitanes para ver é considerar el peñon, é no les paresçió menos fuerte quel otro, exçepto que tenia dos padrastos mas altos que no él, é no menos ásperos de subir, en los qualus estaba mucha gente de guerra para los defender. Y el general con algunos capitanes é milites veteranos é scñaladis personas, embracadas sendas rodelas é sus armas, fueron laćçia allá á pié, porcue los caloallos los avian llevado á beber una legua de allí esto no para más de ver la fuerça del peñon é por dónde se podria combaTO110 III. tir. É cómo llegraron al pié del peñon, laillaron gerea de si su gente, que sin les mandar cosa alguna se arian ydo trás cl general; é los de los padrastros, creyendo que los querian combatir por el medio, desamparáronlos por socorrer el peñon é á los snyos: é risto su desconçierto, mandó presto el general á un capitan de los suyos tomar el un patrastro, é assi se hico; y el general con la otra gente comengaron á subir el çerro arriba, donde estaba la mayor parte de los contrarios, é plıgo á Dios que les ganó una vuelta de la cuesta, é púsose en una allura que quassi igualaba con lo alto donde los contrarios peleaban, !o qual primero se pensaba que fucra imposible ganarse aquello, sin mucho peligro é daño de los chripstianos. É ya un capilan de los españoles avia puesto su bandera en lo más alto del çerro, é desde alli començaron á tirar escopetas é sactas á los enemigos; é cómo les laçian mucho daño, é consideraron el que se les esperaba seguir presto, hicieron scnal que se querian dar, é pusieron las armas en tierra; y el general muy alegre de verlos rendir (porque su intento siempre era dar á entender á aquella gente bárhara que tenia las puertas abiertas á la misericordia, pidiéndosela , y el cuchillo no menos pronto al castigo de los remisos, é que queriendo venir á la obidien. çia del Rey de Castilla, sus culpas avian de ser toleradas, si la enmienda permanesçiesse), é cómo era gente que se les cutendia lo uno é lo otro, mandó el general quel combate é armas çessassen é no les fuesse hecho más daño; é assi llegraron á le hablar los prinçipales de los adverssarios, pidiendo perdon, y el general los reşebió muy bien, é admilió su peticion; los quales, conosçiendo la templinça que se avia usado con ellos, hiçićronlo saber á los del peñon primero, é aunque la victoria avia quedaclo en ellos, rinicron assimesmo á la obidiençia como 17 
ustos otros, ofresciéndose por rassallos de Sus Magestades, é pidiendo perdon de lo passado.

Ein la poblaçion de á par de aquel peñon repossó el general é sus cortesanos milites dos tias, é deste alli envió á Thesayco los heridos, y él se partió, é á las diez horas del dia llegró con su cxérçitóa Guastepeque, de quien se hiço mençion de susso: y en la casa de una huerta del señor de allí se apossentaron todos, la qual huerta es la mayor é mas hermosa é fresca que los chripstianos avian visto en aquellas partes ni en España, porque tenia dos lequas de cireuyto; é por medio della passaba una gentil ribera de un rio. é de trecho á trecho cantidad de dos tiros de ballesta) hay apossentos é jardines muy freseos, é innumerables árboles de diverssas fructas, é muchas hicíhas, é flores olorosas, rues cosa de admiraçion ver la grentilega é crandega de toda aqueIla luerta é los estanquesé ares en ellos. é otras particularidades que se dexan de decrir.

A cuel dia repossaron en clla los chripslianos, é de los naturales fueron muy bien ć con mucho placer servidos. El dia signiente se partió el exérçilo, é á las ocho horas del dia llegaron á una buena poblaçion, que se diçe Yantepeque, donde mucha grente de guerra estaba de los enemigos, atendiendo la jornada ; é cómo se rieron los unos á los otros, paresçió que querian mostrar alğuna senal de paz, ó por el temor que toviessen ó por ençañar á los nuestros; pero sus cautelas turaron poco, porque sin más acuerdo desampararon su prieblo huyendo, y el general no curó de se detener en él, é signuió los enemigos con los treynta de caballo bien dos leguas hasta que los ençerró en otro pueblo que se llama Gilutepe, hasta el qual fueron muchos alançearlos é muertos. Én aquel pueblo hallaron la gente dél muy descuydada, porque antes que sus espias llegassen, databan cou ellos los nuestros, é mataron alguna gente, é prendieron muchas mugeres é muchachos, é los demás luyeron: é allí repossó (ol gee. neral dos dias, pensando quel señor de aquel pueblo viniera á dar la obidiencia, é no lo hiço: é por esto, quando se partió nuestro exérçito de allí, pusieron fuego á aquella villa, en la qual saçon lleçaron mensajeros del otro pucblo antes, que se diçe Tantepeque, pidiendo vénia con mucha lumildad. é ofresciéndose por vassallos de la corona real de Castilla; é fueron admitidos por el greneral: porque en cllos é sus casas é tierra se avia fecho notahle casligro.

Ficho aquesto, é progerliendo el general en su cmpressa, Ilegó aquel dia que de alli partió á un pueblo muy fuerte, que se diçe Caadnabaced, en el qual estaba mucha gente de guerra: y cra fuerte de sí, çereado de muclıs çerros é barrancas, que algunas aria de diez estados de hondura, é ninguna gente de caballo poulia entrar sino por dos partes, é aquessas los nuestros no lis sabian: é alun para entrar por ellas avian de rodear más de legua y media, non obstante que por puentes de madera bien pulieran entrar, si no estovieran quitaklas: de forma que estaban tan fuertes, que aunque fueran los españoles é sus amigos diez tantos de los que eran, no les temieran. Éassi como los nuestrosse açercaban, tirúlbaules muchas varas é flechas é piedras con grand osadia, porque pensaban que no podian ser ofendidos: y estando assi muy revueltos, los unos defendiendo é los otros procurando de ofender, siguióse que un indio de Tascalteca passó de tal manera por un passo mily peligroso, fue no le vieron; mas quando le reconoscieron, creyendo que los españoles entraban por aquella parte, é temoriçados é sin tiento, se començaron á poner cn luuvda. y el indio trás ellos. E tres ó quatro mançebos criados del gene- 
ral ó otros dos de una capjitania, cómo vicron passar al indio, siguiéronle é passaron de la otra parte; y el general con los de caballo comencó á guiar láçia la sierra para buscar entrada al pueblo, é los enemigos no haçian sino tirarle flechas é varas (porque entre los unos é los otros $n o$ avia más de una barranca como cava), é cómo eslaban embebesçidos en pelear contra los nuestros, no a vian visto los cinco españoles que estaban de la otra parte, como es dicho: é aquellos llegaron de soIresalto por las espaldas, é començaron á darles de cuchilladas, é cómo los saltearon sin sospecha que por las espaldas se les podia haçer daño alguno, ni creyeron que los suyos avian desamparado el passo por donde el indio é los españoles les avian entrado, espantados, quedaron como atónitos é no osaban pelear, é los españoles mataban muclsos dellos como gente abobada é que no tenian sentido; é despues que cayeron en lo que podia ser, huyeron. Ya nuestra gente de pié estaba dentro del pueblo, é le concnçaron á quemar é los enemigos todos á le desamparar, é assi continuando su fuğa, se acogrieron á la sierra; pero muchos quedaron muertos, porque los caballos los siguicron todo lo que fué posible.

Despues que nuestra gente halló por donde entrar al pueblo, era ya medio dia, é apossentáronse en unas casas de una hucrta, porque lo demás laallaron ya quassi quemado todo. En la tarde el señor de acpuel pueblo é otros principales, vicndo que cosa tan fuerte como era aqueIla villa no se avia podido defender, temiendo que acullá en la sicrra los avian de yr á matar, acordaron de se venir á ofrescer por vassallos de Sus Magestades, é fueron por el general resçebidos, prometiéndoles todo buen tractamiento, y ellos obligándose á guardar roda lealtad á servir, como dubian.

Listos indios é los otros que venian assi rendidos, despues de les aver quemado é destruydo sus casas é haçiendas, dixeron que la causa por qué venian tan tarde á dar la obidiencia era porque pensaban que satisfaçian á sus culpas en consentir que primero se les hiçiesse daño, que fuesse su penitencia : porque creian que despues de aver padesçilo, no ternian tanto enojo dellos los chripstianos, aviéndolos castigado é vengádose.

Iquella noche estovo el general é su gente en aquel pueblo, é por la mañana otro dia se partió por una lierra de muclos pinares, despoblada é sin agua alğnna, é passaron un puerto con mucho traluaso, é muchos de los indios amigos, que cn el exúrçito yban, peresçieron de sed: é a sicte leguas de aquel puerto pararon en unas estançias aquella noche, é otro dia en amanesciendo, prosiguieron su camino é llegaron á vista de una muy gentil cilsdad, que se diçe Suchimileo, que está edeficada en la laguna dulçe. É cómo los naturales della estaban avisados de la yda de nuestro exérçito, tenian fechas muchas albarradas é acequias é alçadas las puentes de las entradas de la cibdad, la qual está de, Temistitan tres ó quatro leguas, y estahi dentro mucha é muy luçida gente, con determinaçion de morir en la defensa ó quedar con vicloria. É llegado el campo nuestro é recogida la gente é puesta en órden, el general se apeó de su caballo é siguió con algumos infantes háçia una albarrada que tenian los contrarios, detrás de la qual estaban muchos deferisores, é començóse el combate con mucho denuedo de los chripstianos; porque no eran nuestros españoles de aquellos por quien Vegecio dicc, "que siempre es el soldado nuevo en aquellas armas quél y ellas largo tiempo vivieron 6 estovieron en reposso " 4 
antes if extos milites cortesintos muncal se les caian de acnestas, ni dexalban de ser exergitadis ellas y cllos, $y$ en su disciplina militar estaban tan dotrinatos y cxpertos, que valian por muchos mís. L: assi, continuándose la liatalla ó comlate, haçian mucho daño los escopeteros é billesteros, é ningum tiro era fecho sin malar ó herir á los encmigos; é assi forgados desampararon el allsarrada, é los españoles se echaron al agna é passaron adelante por donde hallaron tierra firme, y en espaçio de media lorá que pelearon, gamaron la prinçipal é nejor parte de la ciludad, é retraydos los contrarios por las calles del agua ensus canoas, pelearon hasta que fué de noche, que la escuridad los departió. É unos movian paz é otros en esse medio entre las pilabras no dexilban de pelear, é movieron lantas veçes esta plálica de la paz, sin la poner en obra, que se entendió que lo hacian para dos efeltos: el uno para alçar sus haçiendas en tanto que cssa paz fraudosa se tractaba, y el otro por dar lugar al tiempo é que les fuesse socorro de Temistilan.

Aquel dia mataron dos españoles, porque se desmandaron á rohar, é fué tanta la nesçessidad que no pudicron ser soeorridos. Dinamente díl la gruerra el pago que meresçe el que se desordena en ella, é sin tiempo ni auctoridal del eapitan se mete donde no puede salir: é ya que los enemigos no maten, los tales ni deben ser perdonados, ni quedar con la vida, porque muchas veçes da ocasion un des. mesurado é temerario á que por lo socorrer se vea en peligro lodo el exérçito.

En la tarde pensaron los enemigos cómo podrian otro dia alajar á los clripstia110s, para que no pudicssen salirde aquela ciludad eon las vidas; é juntíronse nuncha copia dellos determinados de venir por la parte que los nuestros arian entrado. E cómo los vieron renir lan de súbito, mallarilláronse de rel su ardid é agrlidarl ó prestega, é seys de cabillo qune con el gencral estaban más á punto (jue? los otros, arrenclieron contra ellos, é de temor de los cahallos volvieron las espaldas, é salicron de la cilulad trás ellos, matando muchos, aunque con assaz peligro; porfue no faltaluan algunos valientes imdios que osaban esperar à los dr á calallo con sus espadats é rodulas, ni era de tenerles en poco sus ínimos, por serles á ellos lam nueva cosa pelear los lombres á caballo, animales numea por collos en acquellas partes vistos. É cómo andaban revneltos grande espacio de hora aria, el caballo en quel general antalua, dexóse cacr en ticráa de cansado; é cómo los enemigos le vieron á pié, revolvieron sobre él, é como valiente varon començóse á defender con la lança; é un indio de los de Tascalteca, cómo le vido en tanta nesçessidarl, llegóse á le ayudar, é lo mesmo hiço un español criado suyo, é levantaron el caballo; é cúmo acudicron más españoles, desampararon todo el campo los contrarios, é los de caballo ques dicho y el general, como cstaban muy can-sados, se tornaron á la cibdad. É puesto que era ya quassi noche é debieran repossar, mandó Hernando Corlés que todas las puentes algatas, por donde yba cl agua se çegassen con picdra ć adobes que allí aria, porque los de caballo pudiessen entrar é salir en la cibdad sin estorbo alguno: é no se partió su persona de allí hasta que todos aquellos malos passos yuedaron bien aderesçados, é con mucho ariso en la guarda é velas se passó ayuella noche.

Bien me paresce áquello de Diodoro Síenlo ${ }^{1}$ que dice que si no oviesse escriptores, poro turarian los hechos señalados, 
porque qualquiera otro momuncuto es muy breve por los muchos acçidentes que estorban; mas el valor de las letras, que por todas partes strenar, hace.quel tiempo, que todas las otras cosas destruye, sea custodia é protector preçípuo, bien que la eloquiençia ayuda assaz, como virfud á ningruna inferior. Con la eloqüençia los griegos preçedieron á los bárbaros, los dottos á los yguorantes; causa que uno aunque sca de la mesma estirpe, sea superior á otro, porquie toda cosa es tanto quanto la virtud la hace del que habla. No hay dubda que aquellos que han fama de lonbres dignos, han abierto el camino ó via de la virtud, mas que para yr á ella lay direrssas sendas. Paresçe que la poesía mís se extiende á deleytar que á lo útil, é las leyes y estatulos más al punir que al cnseñar, é las otras artes todas no han con feliçidad consorçio, porque la utilidad que dellas nasce es mezclada con el daño: antes lay algunas que en cambio de la verdad enseñan á mentir. Por la qual la historia sola con palabras iguales á los liechos, trae consigo la verdadera utilidad, exaltando lo lonesto é conculcando é hollando el viçio, (ó lo que no es loable é sí deslionesto); é finalmente por la expiriencia que la historia pone de los tiempos passados, venimos á perfetto vivir. Nosotros, pues, considerada la alabança que los escriptores consiguen, avemos asmonto (ó tomado í cargo) esta olsra.

Todo esto es del auctor alegado, é traydo muy á propóssito é al de la materia, de que tracto; pero no con el intento de Diodoro en parte, porque yo escribo por mandado de mi prínçipe y él por su passatiempo. Yo sin la abundançia de letras que Diodoro tenia, y él con alto estilo y elegançia: la qual oviera aqui menester el valeroso y estrento y exçelente capitan Ilernando Cortés, de quien la pluma unia conosçe que solra la materia, ó que la lengua ni mi estilo no pueden tan adelante llegar, que le den el colmo que su loor é olsras merescen para la inmortalidad de su fama. Pero yrá arrinada á la simpliçidad é forma de lablar, que deben concurrir en la verdadera listoria : é llamo simpliçidad á lo quel gramático atribuye tal verbo, yues deçir sençillamente, sin lagoteria ni lisonjas to que laçe al caso.

Tornando á la listoria de los cortesanos, de yue se tracta, cómo los de México é Temistitan sabian que estaban en lia cilsdad de Suchimileo, acordaron otro dia siguiente al ques dicho de yr por la laguna con grand poder, é assimesmo con otro exérçito por la tierra á los cercar, creyendo que ya no podrian escaparse de sus manos. Y el general, avisado desto, subióse á una torre de un templo de aquellos ydólatras (donde liaçen aquellos infieles á sus ydolos é falsos dioses sus diabólicos é crueles sacrifiçios é ofrendas de cuerpos liumanos, segund su infernal é condenada costumbre), para ver é considerar desde alli cómo venian los enemigos, é para arbitrar por dónde podrian acometer, para proveer en ello lo que conviniesse. E luego puso por obra lodo lo que le paresçió que para la resistençia se debia aperçebir. É llegó por el agua una hermosa é grandíssima flota de canoas, que passaban de dos mill, é iraian más de doge nnill hombres de guerra; $\dot{\mathrm{e}}$ por la tierra llegaron tanta moltitud de indios que cubrian los campos:

Los capitanes que venian en la delantera, traian espadas de las nuestras en las manos, é cada esquadron apellidalıa su provinçia: unos decian "México, Mexico"; otros "Temistitan, Temistitan", 6 otros "Culua, Culua»; é junto con esto deçian muchos demuestos é injurias á los mestros, anenagúndolos que con aquellas espadas que les avian tomado la otra vez en la cibulad de Temistitan, avian de 
matar sh dexar á vida español ni amigo suyo quo lovicsen. Pues como el greneral tenia ordenado dóndle avia de estar é acudir cada capitan de los nucstros, é porque láiçia la lierra furme avia mucha copia de enemigros, salió ál cllos con reynte de caballo é quinientos indios de Tascalteca, repartidos en tres partes; é mandóles que desque los oviessen rompide, se recogiessen en çicrta parte al pic de un çerro que estaba media legua de allí , porque tambien avia allá muclia gente de los enemigos. É assi cóno fué tiempo, data la sciial, cada esquadion siguió por su parte contra los adverssarios, é desbaratảronlos é alancearon ć mataron muchos, é recogiéronse al pié del çerro ques diclio. I el general mandó á çierlos cortesanos é personas diestras é ligeros que subiessen por la parte mús úspera del monte, para quél con los de calsallo, rodeando por la parte más llana, los tomassen en medio, é fué assi: que como los enemigos vieron que los cortesanos subian el çerro, volvieron las espaldas, pensando que huian á su salvo, é toparon con los de caballo, que serian hasta catorçe caballos, de quien fieron resçchiclos en las lanças; é los amigos de Tasealteca meneaban tan bien las manos, que en breve espaçio mataron más de quinientos homlres, é los demás se salvaron, huyendo á las sierras.

Otros seys de caballo acertaron á y por un camino muy anclio é llano, alanceando en los enemigos: é á media legua de Suchimilco dieron en un esquadron de gente muy luçida que renia en socorro de los vençidos, é desharatíronlos é alancearon algunos; é á las diez horas del dia, fecho todo lo que se ha diclıo. estando ya juntos los de calyallo, se rolvieron victoriosos á Suchimilco, é á la cntrada estaban los otros españoles, que desseaban ver al gencral é los que con él avian salido, y entender lo sulicedido. li contánonle cómo se avian isto en mucho aprieto por echar fuera de la ciluad á los enemigos, de los quales avian muierto muchos; é dieron al general dos espirdars de las nuestras que les avian tomado, é di. xéronle que los luallesteros no teniam sae. tas, porque todas las a vian muy lien entpleado. I cstando en esta plítica, antes que se ayeassen, asomaron por una calçada muy ancha en un grand batallou muchos de los cnemigos, é cop tanta grita é alarielos que sonaban todos los montes é valies de la comatrea olorioso \póstol, assi como el capitan general dico "Sanctiago é á ellos", arrenetieron todos vesnte de caballo contra los indios; é cómo de la una parte é otra de la calçada era toda aggua, lançáronse en ella. é assi los desbarataron é se tornaron á la ciludad licn cansados: é mandóla luego el general quemar, excepto aqueIlo en quẹ́l é su genle cstaban apossentados; é quedó alli tres dias, que ninguno dexaron de pelear. É al cabo, dexándola quemada é asolada, partieron los chrips. tianos é sus amigos con el general, é aun con líslima de ver el daño que se avia fecho, porque tenia aquella cibdad muclas casas luenas, é muchos templos é torres de aquellos de sus ydolatrias, de canteria de cal muy bien labrados. É salićronse fincra á una placa que está en la fierra firme allí junto, donde los naturales largen su tianguez ó mercado, que quiere deçir lo mesmo: é dió órden que para su camino fuessen diez de calsallo en la avanguarda, é otros diez en medio de la gente de pié. y el general en la retroguarda con otros diez cavalleros: é assi como començaron á andar, pensando los te Suchilnilco que de temor se yban los nuestros, llegaron por las espaldas con mucha grita, y el general con los dicz de caluallo volvió contra ellos, é los siguió lasta los meter en el agua, en fal manera que no curaron más de tentar su atre- 
viniento. Y el exérçito nucstro continuó su camino, é a las diez lioras del dia llegaron á la cibdad de Guyoacan, que está de Suchinileo dos leguas, é de las cibdades de Temistitan é Culuacan é Lichiluluzco é Iztapalapa é Cuylaguaca, é Mizteque (que todas están en el agua) la más léxos de todas está legua é media ó dos, é hallálonla despoblata: é apossentáronse en la casa del señor, é allí estovieron aquel dia que llegaron y el siguiente. is porque en seyendo acahados los bersanlines, avia el general de poner gereo á Temistilan, quiso primero ver la dispusicion desta ciludad é las entradas é salidas, é por dónde los nuestros podian ofender é ser ofendidos. É otro dia que llegó, 10mó éinco de caballo é doscrientos peones é fuésse luasta la lağuna, que estaba muy serea, por una calçada que entra á la cil)dad de Temistitan, é viéronse tanto número de canoas por el agua, é con tanta gente de guerra, que no se podian contar por su moltitud; é llegaron á una alharrada, que tenian lıecla en la calçada, é los peones començáronla á combatir , é aunque fué muclıa la resistençia que hallaron é hirieron diez peones, al fin se la tomaron é mataron muchos de los enenigos, é los ballesteros y escopeteros despendicron hien sus sactas é pólyora.

Desde allí vieron los nuestros cómo yha la calçada derecha por el agua hasta dar en Temistitan bien legua é media, y ella é la otra que va á dar á Iztapalapa estaban llenas de gente sin cuento; é cómo el general ovo considerado bien lo que le convenia, porque en aquella cilsdad avia de estar una guarniçion ó real de gente de pié é de caluallo, recogoió su gente é rolvióse, quemando las casas é torres de aquellos templos de ydólatras. É otro dia siguiente se partió á aquella ciludar de Tacuba, que está dos loguas de alli, donde Ilegó á las nueve horas de la mañana, alanceando indios por unas partes é por otrass, porque los encmigos salian del agua por dar en los indios que Ilevaban el fardage de los chripstianos, é lrallábanse burlados : é assi la nesçessidad les hiiço que dexassen yr sin más requiesta á los nuestros. É porque, como está dicho, el intento del general en esta salida fué principalmente dar vuclta á las lagunas, é calar é ver é saher mejor la tierra, é tamlien por socorrer aquellos amigos, no curó de pararse en Tacuba; pues cómo los de Temistitan, (que está de allí muy çerca, é quassi se extiende su poblaçion tanto que llega cerca de la tierra firme de Tacula, vieron que los nuestros passaban adelante, cobraron tanta osadia vana, que con grand denuedo osaron dar en medio del fardage de los españoles; pero como los de caballo yhan bien repartidos, é todo cra por allí llano, aprorecháronse de los enemigos sin peligro de algun clupiptiano, excepto que corrian á unas partes é otras çiertos mancelıs, criados del general, que tenian cuydado de su persona, é desseaban mostrar para quánto cran, é halláronse en parte que los enemigos los preudieron : é créese que les dieron muy cruel muerte, como lo acostunbian, porque de generaçion que eome carne lumana, no se puede sospechar sino que harán della lo que suelen laçer los glotones con un buen capon ó faysan ó huenas perdiçes. Muclıo sintió el general la pérdida destos sus criados, assi por ser cluripstianos como porque eran valientes hombres é avian muy bien servido en ayuella guerra.

Salido el general desta cibdad, prosiguió su camiuo por entre otras poblaciones çercanas, é alcançó la gente; é cómo estaba lastimado de arerle los indios llevado aquellos mancebos, assi por vengar su muerte como porrue los chemigros con murcha osadia venian en seguimiento do nuestro exército, púsose con veynte do caljallo detrás de unas casas en çelada; é 
romo los indios reian a los otros diez de caluallo con toda la gonte é fardige y. adelante, seguian sin termor por un camino and nos, salió el general de través con los ginetes, é dió con los indios con tanto ínapetu, antes que puliessen acogrerse á las acequilas, que derriharon más de gient personas prinçipales é muy luçiclos, é con este cscarmiento no curaron de segnir más trás los nuestros. Este dia fué el eneneral ¿ dormir dos leguas adclante de lis cilulad de Coantinchan, bien cansados é mojados todos, porfue aquella tarde avia mucho Ilovido; é hallíronla despoblada.

El otro dia adelinte caminaron su viage, alanceando de quando en quando algunos indios atrevidos que los salian á gritar, é fueron á dormir á una villa que se dice Gilotepeque, é assimesmo la haIllaron despoblada.

Otro dia siguiente, á medio dia, llega- ron á la cibrand de Aculuacan, ques du señorio a juristicion de t'liesayen, dond" aquella noche durmicron, é fincron nuy hien resgebidos de los españoles, e se holgarou muclo con su renida á salviamento. porpue despmes yitel penorial se avia partido dellos, no avian saldido dét hasta aquel dia que lleganon, é avian trniclo muclos redatos en la ciludad, é los naturales della decian calla lora que los de México é de Temistitan avian de salir é venir solırellos, en tanto quel general por allá andaba. É assi se cumplió esla entrada, modiante el faror de Dios, é fué muy grand cosa, en la qual Sus Magestades rescibieron señalado é grand servicio; é la reputaçion de los chripstianos en el crédito de los infieles fué siempre aumenlándose, é poniendo más temor en aquella gente yobolatra para las cosas de irlelante.

\section{CAPITULO XXII.}

Fin el qual se traeta de una earta que un hidalgo llamado Barrientos escribió al general llernando Corlís desde la provincia que llaman Chimanta; $\dot{c}$ de como se aeabaron los bersanlines a se ceharon al agua para cerear á T'emistitan; ć como el general envio adelante çiertos eapitanes é gente á poner guarniçiones çerea de la grand eibdad de Temistitan;"é assimesmo se tratan olras cosas convinientes á la listoria.

A en Temistitan, viviendo Ilontecuma, quando primero fué Cortés á aquella famosa é srand cibdad, proveyó que en dos ó tres provinçias (aparejadas para ello) se hiçiessen çicrtas grangerias é haciendas para Sus Magestades. É ma de aquellas provinças se llama Chimanta (la qual es tierra muy fértil é buena), y envió para esto dos españoles: é la gente de aquella tierra no es subjeta á los de Culua: y en las otras que lo eran, al tiempo que le daban suerra en la cilslad de Temistilan, mataron á los que estaban entendiendo on aquellas grangerias, é tomaron lo que $\mathrm{ell}$ ellis avia, que era cosa de mucho valor, segund la manera de la tierra. Y de los españolesque estaban enClimanta, se passó quassi un año que no supo el general dellos, porque como todas las otras provingias de en medio estaban rebeladas, ni ellos podian salıe del exérçito chripstiano, ni los españoles tampoco podian entender si eran viros. É aquellos de Chiimanla, cómo se avian dado por vassallos de Sus Magestades, perseveraron en su fidelidat, é porque demís desso ran ene. migos de los de Culua ; é fueron tan lombres de lien que por ninguna mudanga del tiempo ni disfaror de los cortesanos no se quisicron partir de su amistad ni de la promesa de su lealtad: antes avisaron 
á aquellos chripstianos que en ninguna manera saliessen de su tierra, é les dieron notiça cómo los de Culua avian darto mucha guerra al general é á los que con él cstaban, é pensaban que ni los chripslianos que con él militaban eran vivos, sino que los avian muerto á todos. É assi se estovieron dos españoles solos en aquella tierra; y al uno dellos, que era mançcho animoso, higiéronle capitan, é salia con aquellos indios á dar gruerra á sus enenigos, é las más reges él é los de Chimanta eran rençulores. É cómo despues el general tornó á convalescer con rictorias contra los adverssarios, que primero le avian desharatado y echado de Temistitan, los de Chimanta dixeron á appellos dos chripstianos que avian sabido que en la provincia de Tepeaca avia elıripslianos, é que si querian saber la verdad que a venturarian dos indios, annque avian de passar por mucha tierra de sus enemigos, mas que andarian de noche é fuera de camino lasta llegar á Tepeaca, é los dos españoles se lo agradescieron; y escribió uno de afuellos eon estos mensajeros una earla, como Irombre de bien, dando notiçia de sí é del compañero ál los españoles, la qual era del tenor siguiente:

"Nobles señores: dos ó ties carlas he escripto á viestras mercedes é no sé si lıaı aportado allí, ó no; é pues de arpue. llas no he avido respuesta, tambien pongo en chulula averla desta. Ilágoos, señores, saber cómo todos los naturales desta tierra de Colua andan levintados y de gucrra, é muchas veces nos han acometido; pero siempre (loores sean dados á Dios) avemos seydo vençedores. I eoa Ios dle Tustebeque é su parçialidad dle Culua cada dia tenenos guerra. Los que están en servicio de Sus Alteças é por sus vassallos, son siete villas de los Tenez; é yo é Nicolás siempre estamos en Cluimanta, ques la cabecera. Mucho quisiera sabor dóncle está el capitan, para lo esTOMI0 III. cribir é hacer saber las eosas de acú. Í si por ventura me escribiéredes de dónde él está, y enviáredes vegute ó treynta cspañoles, yrme hía eon dos prinsipales naturales de aqui, que tienen desseo de ver y lablar al capitan; y será bien que viniessen, porque como es tiempo agora de eoger el eacio, estórbanlo los de Colua con las guerras. Nuestro Scnor quarde las nobles personas de vuestras mercerles como dessean. De Climanta á no sé quantos del mes de abril de mill é quinientosé veynte y un años. Í serviço de ruestras mergedes. = Hermando ole Barrientos. $\mathrm{p}$

Cómo los dos indios llegaron con esta carta á la provinçia de Tepeaca, el capilan que allí avia dexado el general con çiertos españoles, enviósela luego á Thesayco; é resçebida, assi él eomo todos los españoles lıolgaron muelıo é por muchos respectos, y en especial por saber de aquel hidalgo, que era buena persona é valiente lımbre, é del otro eompañero que con él estaba, é porque se temia hasta estonces que si se juntaban los de Chimanta con los de Culua, avrian muerto aquellos dos chripstianos, é los enemigos serian más poderosos. E paresçió que Dios lo liço mejor é que tovieron constancia é euydado de ser leales é de guardar la conferleracion é amistad que tenian con los españoles: é deste bien mucha parte fué la prudencia de aquel hidlalgo Barrientos, é la buena maña que eon aquella gente se dió en tanto tiempo como estovo en eompaniia de arpuellosindios, animándolos é consejánidolos para que no hiçiessen mudanea, é ruando convenia, haçia muy bien el ofliçio de esforçado é sabio capitin contra los inclios del bando contrario. Á lo menos estos dos españoles supiéronse nucjor conservar que olros dos que en el tiempo del capitan Ilojecla quedaron en la costa de Tierra-Firme perdiJos, á los quales los indios no les hiçie- 
ron mal, annque eran carilies: antes les daban de comer é los tractalaun bicn, porque ellos tomaron pror medio de darles á entender las cosis de muestra simcta fée cathólica é (pué cosa es Dios, é lolgaluan de oyrlos. E para saber los indios si les deçian rerdad, acordaron de tomarlos it parte, é preguntaron al uno si Dios tenia barluas y era liombre, é de qué mancra era aquel que decia que avia criado el mundo; y el chripstiano respondióles que no tenia harhas, ni ningrmo era dino de verle, é que cra Señor de lodos: é preguntaron lo mesmo al otro, é díxoles que Dios era hombre, é tenia barbas, é avia estado acá en la ticrra é nascido de la Vírgen Sancla Haria, que despues aria subido á los çiclos y cstaba allí. É viendo los indios tan diferentes respuestas, aunque cada uno pensaloa darla lmena. carcáronlos, é diséronles que por qué les mentian: quel uno degia que Dios era hombre é tenia larbas, y a otro que no. é que cran burladores é mentirosos. É ammque esans peceadores se quisieron conformar entre si é darles á entender cómo el uno y el ofro decian verdad, é aruello era tractar ya de la Triniclad, é añadian el Espíritu Sancto, demás de lo que primero avian dicho, y cllos sabíanlo mal deçir é los indios peor entender, no aprovechó su predicacion, ni los indios los escucharon más: é indignados los mesmos españoles, el uno al otro culpando to que avia dicho, vinieron á tan malas palabras, é dellas álas manos, que se mataron é acabaron comoneçios. I.o qual no haçia assiel dicho Barrientós é Nicolás, su compañero: antes quando los indios querian saber é le preguntaban las cosis de la fée, el Nicolás se remitia al Barrientos que lo dixesse, é deçia que aquel lo sabia mejor; é assi él les deçia lo que Dios le encaminaba, sin contender con el companero.
Dexemos esto, porrence el chripstiano que no es líbúlogro, siximpre se debe remitir a lo más sorgmro en lales casos, 6 aplicar sus respuentas á los religiosos é dotlas personas que la Iglesia admite para lo tal: é donde esto no ovicre. basta quel soldarto diga al infiel to quel chripstiano alcancra é cree, remitiéndose á los perlados. É ponicndo en esperanca de hacerle dar á entender lo que eonviene á su salvargion. con tanto tiento que no falte de la rerdad do la fée.

Cómo Hernando Cortés vido la carta ques dicho. escribió luegro al Barrientos, dímdole las graçias convinientes ó ofresçiéndole merçedes, é dándole cuenta á él é á su companero de las cosas passadas, 6 que tovicsen reperanca. que atmyur de todas partes estaban cereados de los encmigos, presto se verian libres é podrian entrar é salir secrmos.

Tornando á la listoria. siguióse despues que ariendo el general dado melta á las lacumas. ovo muchos avisos para poner el gerco á Temistitam por la tierra é fror el agua. y estovo en Thesayco forneçiéndose lo mejor que pudo de armas é pertrechos é gente, é dando priessa á que se acabassen los bergantines é una çanja ó trancliea ó acequia para los llevar hasta la laguna: la qual çanja se comencó á haçer luego que la liggaçon é tablaçon de los bergantines se truxo en una açequia de agira que ylua por cabe los apossentos liasta entrar en la laguna; é desde donde los bergantines se ligaron, é la canja se comencó á haçer hay bien medial leğma fiasta la laguma. En esta obra andovieron çinquienta dias, trabaxando més de ocho mill hombres de los naturales de la provinçia de Aculuacan é Thesayco; é tenia la çanja unís de dos eslados de hondura é ofro tanto de ancho, é yba toda chapada y estacada, de manera quel agua que por 
ella yha, la pusienon en el pesso que tenia la de la laguna, de forma que las fustas se podian llevar sin peligro é sin trabaro Lasta el agua con mucha façilidad. Esta fué mna olıra crandíssima é mucho de ver é no menos de admirar que las naves y olefiçios del grand rey de Egipto dicho Sesostri. Este rey diçe Diodoro Sículo que fué inventor de las naos luengas, é ganó muchos é grandes scũorios é reynos, é hiço poner en las partes, donde andovo conquistando, muchas columnas con letreros que deçian: "Esta provinçia grnerreando, vençió el rey de lodos los reyuantes Sesostri. "F. (londe hallal)a valerosos defensores, dexaba esculpidos los niembros genitales del varon, é donde no eran tales, los pudientes femeninos; dando á entender dónde avia frallarlo valientes liombres, é dónde vil gente é cobarde. Este rey hico una naveque tenia de lirengo doscientos é ochenta cobdos, de cedro, dorada de fuera, é por dentro toda plateada, é dedicúlil al Dios de Tébas. Levantó dos colunnuas ú obcliseos de piedra duríssina de dosçientos y rejnte colsdos, y en cada una eseulpidas lascibdades que avia vençido '.

Otras muclas é notables cosas cuenta el auctor que he dicho de aqueste rey Sesostri, en que no me quiero detener ni las tengo en tanto como esta tranchea ó çanja ques dicho é los bergantines de que tractamos, les quales dieron ocasion á que se oviessen mayores thessoros é provincias é reynos que no toro Sesostri, para la corona real de Castilla por la industria de Hernaudo Cortés. El qual, acabados los bergántines é puestos en aquella canja á los veynte y ocho de abril de mill é quinientos é veynte y dos años, hiço lagerer reseña ó alarde de toda la gente, é laalló que tenia ya oclıenta y sicte de calballo é ciento é diez y oclo ballesteros y escoperos, é septeçientos é mas infantes ó peo- nes de espada é rodela, é tres tiros de pólrora gruessos de hier.ro, è quinege tiros pequeños de bronçe ó nretal, é diez quinlales de pólrora. Hecho el alarde, hiço nna breve é substançial oraçion á todos los españoles, encargándoles y encomendáudoles mucho que guardassen é cunplicssen çiertas ordenanças militares quél avia liechoo, é que se alecrassen y esforcassen sin dublar de la victoria, pues que Dios por su clemencia parescia que lo yba prósperantente encaminando; porque avian visto que quando avian entrado en Thesayco, no eran más de quarenta de caballo, é avian venido navios é gente é armas como tenian, en que se mostraba claro que peleaban en favor é aumentaçion y en noulure de toda la religrion é república chripstiana, é por reducir á la corona real de Castilla é al serviçio de Sus Magestades Cathólica é Cessárea tanlase tan grandes provincias, como se avian rebelado, de que resultaria el descanso é galardon de todos para en esta vida y en la otra perdurable: é que pues á los espanoles no era cosa nueva el exerçicio de las armas ni la lealtad que siempre guardaron á sus prínçipes, ni les faltalua expiriencia para conseguir el triunfo de la militaré acostumlsrada miliçia, que no deJian sospechar ni temer algun siniestro caso, aunque en la guerra andan mezclados los desastres con las victorias, ó ál lo menos atravesíndose cosas que dan passion hasta conseguir el fin glorioso de la batalla, para que mejor sepan los tropheos c ganançias quanto mas sudadas é dificultosas fueren hasta ser adruiridas. "El valiente cavallero é Luen soldado en más suele tener su verguença que la propria vida. E assi espero de vosotros, señores y lıcrmanos, anigos é compañeros mios, que juntos venceremos ó juntos noriremos, sin que podamos ser dichos en nin- 


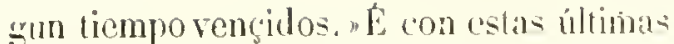
palaluras çessó, é todos respondicron sin discrepancia é á una roge diçentes: "Sílranse Dios y el Emperador, nuestro señor de tan bmen capitan é de nosotros: que assi lo haremos todos como quien somos, é como se dele esperar de bucnos españoles. "E eon lanta voluntad é desseo dicho, que paresça que eala hora les cra perter un año de tiempo. por estar ya á las manos con los enemigos, é porque la conclusion desta guerra, con sangre ó para alcancar la paz é sosiegro te aquellas partes, todo pendia de ser cereada é sojuzgada Temistitan.

Otro dia despues del alarde, el general envió mensajeros a las provincias de Tascalteca é Guaxoçingo é Churultecal, haçiéndoles saher que los bergantines eran acabarlos, é foda la gente estaba aperçebida é de camino para yo á çerear á la grand cibdad de Tomistitan: por tanto que les rogaba que con toda la mús genente é mejor armada que pudiessen, so partiesen luego para Thesayco, donde los esperaba diez dias. Pues cómo los de las provincias ques dicho eran enemigos naturales de los de Culua y cotaban apercebidos, fuéronse á Cáleo los de Guarocingo é Churultecal, porque assi se lo aria mandado el general, é porrue juntos por atli avian de entrar á poner el cereo; é los capitanes de Tascalteca con toda su gentellezaron á Thesayco cinco ó seys dias antes de pasqua del Espíritu Sancto, como lesestaba ordenado: y el general los satió á rescebir con mucho plaçer, y elloz yban con lanta alegria é buena ordenanga, que no a via mas que pedir : é segundl la cuenta (que los capitanes dieron, passaban decinquienta mill hombres de guerra, los quales fueron nuy bien rescebidos é apossentados. E aquesta gento de Tascalteca fré mu grand parte de los buenos subçessos de los chripstianos é de la próspera defmiçion questa empresara tovo, como adelante se dirá.
Il secrmolo dia de pasqua mándó cl general salir torla la çente dr pré é de ca-

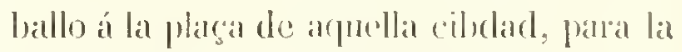
ordenar o dar a capilanes principales la senstrucionque arian de llevar a tres qualnirgones ó realles partirulares é distintos. que se avian de poner an tres ciludades que estin en torno de la de T'emistitan. De la mna gramiscion é campo hiço capitan al comentador Pedro de Alarado, cavallero de la Grden de Sanctiago ó disile ireynta de calballo, é liez y ocho hallesteros y escopeteros, é ciento y ringiienta peones de espada é rodlela, é mús de verute y cineo mill hontres de mirera de los de Tascalteca: y cotos arian de estar é poner su real en la ribdad de Tacula. E de olra guarniçion liço capitan á Chripstólsal de Olit, al cual to clió treynta y tres de caballo, é diez y ocho balléteros y escopeteros, é riento y sessenta hombies de espada é rodela, é más de veynte mill lombres de guerra de los indios annigos é confederados; é aquestos avian de assentir su real en la cilsdad de Cuyvacan. De la tercera guarniçion liço capitan a Gonçalo de Sandoral. alguaril mayor, é dióle reynte y cuatro de caballo, é quatro creopeteros, é trege ballesteros. é çiento y cinquienta peones de espadia é rodela, é los ciento dellos de mançehos escogidos, quel generat acostumbraba trace en su compañia, é lodia la gente de Guaxoçingo é Churultcal é Caleo, en que avia más de treynta mill hombres: é aquestos avian de yr por la cihdad de Izlapalapa, é passar adclante por ma calçada de la laguna con favor y espaldas de los bergantines, é juntarse con la guarnicion de Cuyoacan, para que despues quel general entrasse con loz bergantines por las lagunas, dicho alguacil moyor assentasse sus reales dontle le parescicsse que convenia. Para los trece bergantines. con quel general avia le cutrau por la laçuna, dexó trescrientos lrombres. é los mas dellos cran gente de la 
mar é diestros; y en cadal berountin youn veyute y çinco españoles, é cala fusta ó navio destos llevalıa su capitan é veedor é seys ballesteros y escopeteros.

Darla la órden que está dicha, los dos capitanes que avian te estar con la gento en las cibdades de Tiacuba éCnyoacan, se particron de Thesayeo á los diez dias de mayo, é fueron á dormir dos leguas y media de allí á una lucua pohlacion, que se dice Aculman. E otro dia se partieron de allí, é fueron í dormir á otra polblacion que se dice Gilotepeqne, é labláronla despoblada, porque era ya tierra de los ene. migos. Otro dia adelante en su ordenança prosedicron en su camino, é fueron á dormir á ofra ciblad que se diçe Guantican, é tambien la hallaron despoblada, é aquel dia passaron por otras dos cibdades é poblaçiones que estaban assimesmo despobladas. É li liora de vísperas entraron en Tacula, en la qual tampoco hallaron gente, é aprossentálonse en las casas del señor de allí, (que son muy hermosas é grandes; é aunque era ya tarde, dicron una vista los naturales de Tiscalteca por las entradas de dos calçadas de la cilodad de Temistitan, é peloaron dos ó tres horas valientemente con los de la cibrlad, é como la noche los departió, se tornaron á Tacuba sin peligro alguno.

Orro dia siguiente por la mañana, por: que el general en la instruçion que les avia dado les ordenó que quilassen el ağa, que por caños va á la ciblad de Temistitan. acordaron de poncrlo en obra; y al uno dellos con veynte de caballo é algunos ballesteros y escopeteros fné al nasçiniento de la fuente, que está un quarto de legua de alli, é rompió é corló los caños, que eran de madera é de eal è canto. é peleó valerosamente con los de la cildad, que se lo resistian por la tierra é por el aggua; mas al fin los desbarató é dió conclusion á lo que yba, que cra quitarles el agua duker que ontraba on la ciblad ; que ni fué pequeño ardid é provecho á los nuestros ni menor daño á los enenigos: antes fuć un grande é notable prinçipio de su notoria nesçessidad.

Aquel mesmo dia començaron los capilanes de aderesçar algumos passos malos é puentes é açequias que estaban por allí al derredor de la laguna, porque la gente de caballo pudiesse libremente correr á unas partés é otras. Y en esto se gastaron hasta lo acabar tres dias ó (quatro; pero interviniendo cn esse tiempo muchos rencuentros y escaramuças con los de la cibbad; é fueron heridos algunos españoles, é inuertos muchos de los contrarios, é se ganaron muchas allarradas ó puentes, $c$ ovo lablas é deșafios particulares entre los de la cibdad é los de Tasealteca, que cran cosas notables é para no se poder ver sin admiraçion, considerando la atençion é puntos de honor que de ambas parles guardahan, é capitulaban assi á la mente y enproviso, é tan diestra é reglada forma, que con acuerdo é por escripto entre otras gentes no se pudiera hacer mejor. É quando de cuerpo á cuerpo uno por uno avian batalla, las armas del venciclo tomaba el vençedor, sin que los contrarios lo impidiessen ni lo tentassen estorbar.

El capitan Cluripstóbal de Olit con la gente que aria de cslar en guarnicion en la cibdad de Cuyoacan, que está dos leguas de Tacuba, se partió, y el capilan Pedro de Mrarado se quedó en guarnision con su gente en Taculsa, donde cada dia tenia escaramugas é convenia pelear con los enenigos. E aquel dia quel capitau Clıripstóbal de Olit se partió para Cayoacan. llogó allá á las diez horas del dia, é apossentóse en las casas del señor de aquella cilstad, la qual cstaba despoblada, é otro dia fureron á dar vista á la calcada, que entra en T'emistitan, veynte de caballo é algunos hallesteros é lasta seýs ó sicte mill indios de los de Taseal- 
teci, è hallaron muy aperçebidos los contrarios, é rota la calcada, é fechas muchas albarradas, é pelearon con ellos, é los ballesteros mataron á alggumos é hiricron á muchos, y en seys ó siete dias contínuos no faltaron escaramuças. È una noché á media noche llegaron á gritar á los del real çiertas velas de los de la cilddad, é las velas de los españoles apellidaron al arma, é salió la gente é no hallaron ninguno de los enemigos, porque desde lexos del real avian dado la grita, de que se avia recrescido el temor. É cómo la wente nnestra estaba dividida en tantas partes. los de las dos gnaruiciones desseaban quel general llegasse con los hergantines; y entre tanto que yha en aquellos seys dias se juntaban los de un real é otro cada dia, í los de caballo corrian la tierra, porque estaban cecea los mos de los ofros, é alangeaban assaz de los cnemigos, é de la sierra recogian mucbo unaluz para sus reales, ques el prinçipal pan é mantenimiento destas partes: è aun afirmò en sn letra Hernando Cortés all Emperador que haçe mucha rentaja al mahiz de aquestas muestras islas. Lo qual ni apruebo ni lo contradigo, porque anqui en esta Isla Española hay muclsa simiente del malıiz de la Nueva España é de lo nafural de la Isla é segund la bondad de la tierra, donde ello se siembra, assi responden los fructos, é son buenos ò mejores unos que ofros. bexemos esto, ques para otro lugar, é tornemos al çereo de Temistitan.

\section{CAPITULO XXIII.}

Cómo el general Hernando Cortés entró cn la laguna con los berganlines, é combatió é lomú el peñon de lalapalapa; è eómo rompió è dembaraló la flota de las canous de los cnemigos con mucha victoria; ć cóno lué çercada la grand eibdad de Temislitan, é fué combilida mucha parle della è por muelias partes; è cómo fué en socorro de los españoles la grente de don Hernando, señor de Thesayeo, con más de çinqüienla mill hombres, con los quales cran ya màs de çienlo é treynta mill indios los amigos, que cn nuestro exèrcilo cstaban en favor é ayuda de los españoles eontra Temistitan.

\section{L}

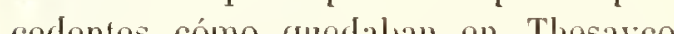
llernando Cortés é trescientos españoles ¿ los trege lrergantines, para que en sathiendo que las guanniciones é rente que mvió por tierra estaloan en los lugares ¿ partes que arian de assentar sus reales, el general se embarcasse é diesse ma vista á la grand cibdad de Temistitan, é hiçiesse algum daño en las canoas de la flota contraria. Y aunque el general desseaba mucho yrse portierra, por dar órdeu en los reales, cómo los capitanes ya dichos eran valerosos y experimentados cavalleros, de quien se podia muy bien confiar lo que tenian entre manos y era á su cargo, é lo de los hergantines cra de grandíssima importançia. é se requeria grand conçerto é cuydado, determinó al general de entrarse en ellos, porque el mayor riesgo é arentura se esperaba por el agna (presto que de personas pringipales de su compania fué requerido en forma que se fuesse con las guarniciones, porque cllos pensabau quellas llevalun lo mas peligroso), è conosçia el general que los marineros é gente de la mar que llevaba es gente que la menester rienda y espuelas para refrenar sus cosas, é para animarlos en su tiempo, escogió su compañia. É otro dia despues de la fiesta de Corpus Chripsti, viernes, al quarto del alba mandó el general salir de Thesayco á Gonçalo de Sandoval, alguaçil mayor, con su gente, é que se fuesse derecho á la cilsdad de Iztapalapa, que estaba de allí seýs leguas pequeñas; é á poco más de medio dia llegaron á ella é comenga- 
roú á la quenar, é pelearon con la gente della ; é cómo rieron el grand poder quel alg̣açil mayor llevalua, que eran más de treynta y cinco ó quarenta mill lıombres de los amigos confederados, acogiérouse al acua en sus canoas. Y el alcuacil mayol con el exérçito se aprossentó en aque. lla ciludad, y estovo en ella arjuel dia esperando lo quel general le enviase á mandar, é aquel mesmo dia se avia fecho á la vela é al remo con los bergantines; y en la saçon quel alguaçil mayor combatia á Izlapalapa, llegaron los bergantines á vista de un cerro grande é fuerte, que eslí cerca de la dicha cibdad é todo en el agrua, en el qual aria mucha gente, assi de los pueblos de al rededor de la laguma como de Temistitan, porque ya los enemiggos salian quel primero rencuentro avia de ser con los de lztapalapa, y estaban alli para defensa suya é para ofender, si pudiessen. É cómo rieron llegar nuestra flota, comencaron de apellidar é haçer grandes ahumadas, porque todas las cil)dades de la laguna lo supiessen y estoviessen aperçebidos; é aunque el intento del general era y á combatir la parte de la cibdad de Iztapalapa que está en el agua, revolvió sobre aquel serro ó peñon ques dicho, é saltó en él con çiento y cinquienta hombres, é non olstante su altura é que era áspero é con mucha dificultad se avia de subir, dióse tal recabdo, que por fuerça les ganó las albarradas que en la cumbre del gerro te. nian fechas para su defensa los contrarios, é ninguno dexaron á vida, ni escapó dellos sino las mugeres é niños.

En este combate quedaron heridos veynte y çinco españoles; pero la victoria é manera del fecho fué un trançe que méritamente debe ser muy loado, é á la vista muy dubdoso el fin que avia de tener, considerando el assiento é dispusiçion fuerte de aquel peñon, é la forma de cómo fué combatido é soljuzgado. Pues cómo los de Izlapalapa avian hecho las ahumadas desde las torres de sus templos de aquellos sus ydolos, que estaban en un cerro muy alto junto á su cibdad, los de Temistitan é de las otras cibdades que estat)an en el agua, conosçieron quel gaeneral entraba ya por la laguna con los bergantines, y encontinente se juntó tan grand flota de canoas para la resistencia, é yr á tentar qué cosa cran estos hergantines; $\dot{c}$ á lo que los nuestros pudieron considerar juzgaron que passaban de quinientas canoas, las quales se fueron derechamente háçia donde venia el greneral, el qual é la ggente que avian saltado en el peñon ques dicho, se embarcaron á mucha priessa. É mandó el general á los capitanes de los bergantines que en ningruna manera se moviessen, porque los de las canoas acometiessen la batalla, creyendo que por su moltitud los nuestros no osaban salip á ellos: é assi fué que los enemigos dieron prinçipio con mucho ímpetu á caminar, mostrando que querian embestir y encontrar los bergantines; mas se yendo á dos tiros de hallesta, repararon y estovieron quedos; é cómo el general desseaba mucho quel primero reneuentro fucsse fructuoso, é se hiçiesse de manera que cobrassen temor de los hergantines (porque la llave de toda la guerra estaba on ellos, y la cosa del mundo de quien podian rescribir más daño los contrarios, é aum tambien los muestros, era por el agua) quiso Dios que vino un viento de la tierra muy favorable para embestir con ellos, é mandó luego á los capitanes que rompiessen por la flota de las canoas é las siguiessen hasta las ençerrar en la cilsdad de Temistitan. É cómo el viento fuć muy al propóssito de los españoles, aunque huyeron los contrarios quanto pudieron, embistieron rompiendo por medio de la flota eneniga, é quebraron muclas canoas, é murieron á manos de los chripstianos muchos indios, é aho- 
gráronse muchos más, é fué ma cosa de mucla victoria é para dar nutuchísimo contentamiento é alegria á los venegedores, é á quantos lo miraban que cathólicos fuessen; ć de mucha lristega é casligo á los enemigos. Walcance se continuó hien Ires legras hasta encerrar las canoas en las casas de la cibdad ; é assi escribió Hernando Cortés al Emperador, nuestro señor, quel rençimiento fur muy mayor é mejor que lo pudicran aver pedielo hombres humanos.

Los de la guarniçion o rral de Curoacan porlian mejor que los de la ciludad de Tacuba ver esté rompiniento, é cómo vieron todas las treçe velas por el ag̨ua, é que les laçia tan buen tiempo é desharaliban las canoas, ovieron grandíssima alegria, porque ambas guarniçiones estaban entre inumerables encmigos, lanto que paresçia misterio nolos acometer, por ser los chripstianos lan pocos en número (non obstante sus valederos: que todo era poco á respecto de la inumerable canlidad (le los adverssarios), puesto que los chripstianos estaban determinados de morir 6 veneser, como hombres que ningun ol ro remedio ni socorro tenian sino es el de Dios (ques el mayor de todos) é sus armas. É cómo los de la guamicion de Cuyoacan vieron yr nuestra armada en segumiento de la contraria flota, tomaron su camino, assi los de pié cómo los de caballo que allí se hallaron, para la cibdad de Temistilan con su capitan Chripstólal de Olit, é pelearon muy reçiamente con los indios que estaban en la calcada, é ganálonles las albarradas que tenian fechas; é les 10maion é passaron a pié ć á caballo muchas puentes que tenian quiladas: é con el favor de los bergantines que yban cerca de la calçada, Ios indios de Tascalteca, nuestros confederados, seguian á los enemigos, é dellos mataban é dellos se cchaban al agua de la otra parte de la calçada por dó yhan los berganlines. E assi fueron más de mal lugua grande, sigruiendo la victoria por la ralcatla lasta llegar adonde a general aria parado con los bergantines.

Estos lergantines fueron bien tres tesuas, cómo es dicho, dando caça á las canoas, las quales se csciparon, llegándose entre las casas de la cibdad; é cómo era ya tarde, maudón d seneral recogrer á los bergantines. é llegóse con ellos á la calcada, é alli saltó én lierra con treynta lombros para ganal dos torres pequeñas de aquellos sitcrílegos oratorios ó templos, que estahan cercados de $1 m$ muro de cal é canto. donde no faltó resistencia de la parte contraria p pero al Gu las ganó, é hiço sacar en tierra tros lomhardas de hierro que llevaba. E porque de to que restaba de la calçada desde alli á la ciludad, que era media leguil, colaba lodo lleno de los enemigos, ó de la una parte é orra de la calçada, que era todo agua, lleno de canoas con grente de guelra, hico rargar et un liro de afucllos 6 pegáronle fuego. é fué la pelola por la calçada adelante haçiendo mucho daño en los enemigos. É por desenyelo del artillero, assi cómo liró, se encendió la pól. vora que le quedalia, lo qual si no intelviniera, se pudieran hacer otros liros semejantes; pero el general proveyó lnegon que un bergantin fuesse á Izlipalapa, do donde truxo más pólvora.

Ganadas las Iorres ques dicho, el geeneral assentó allí real, é ordenó que los hereantines estoviessen alli junto de lis torres, é que la mitad de la gente de Cuyoaran é otros çinqüenta españoles del alguagil mayor se viniessen allí olro dia; é proveydo aquesto, púsose aruella noche mucho recaldo en las velas, porfue eslaban co grand peligro, é toda la gente de la cibdad acudia allí por la calçada é por ol agua. É á media noche llegó grand moltilud de camoas é gente, é lambien por la calcada, á dar en el real del gene- 
ral, é pusieron á los nuestros en mucho temor é rebato por ser de noche, cosa muy apartada de la costumbre de los indios, é que en tal tiempo ni suclen acometer, ni se avia visto que de noche se moviessen ni osassen pelear, si no fuesse con sobrada victoria. Más cómo los españoles é su general estaban aperçebidos é prontos á la defensa, pelearon con los enemigos, é desde los bergantines, porque cada uno traia un tiro pequeño de pólvora, començaron á soltarlos, é los ballesteros y escopeteros haçian lo mesmo, é paresçia una música de diverssos tonos é general temor á los contrarios, é fué cosa tan nueva, ó no usada para ellos, que presto se retiraron á fuera, é no con pequeño daño suyo; é assi no se osaron llegar mas adelante, ni su rebato fué de manera que liçiesse daño sino á sí mesmos. É desta forma aquella noche no se tovo otra quietud hasta quel siguiente dia en esclaresçiendo llegaron al real de la calçada, donde el general eslaba, quince ballesteros y escopeteros, é hasta çinqüenta hombres otros de espada é rodela, é hasla ocho de caballo de la guarniçion de Cuyoacan. Y en el instante los de la cibdad por la calçada y en canoas ya peleaban con la gente del general inumerables enemigos, con tanla grila ć alliarido que paresçia que alapaban los sentidos de los hombres é los alemoriçaban: é por la calçada adelante el general, animando su gente, ganó una puente que estaba quilada é una albarrada que avian fecho á la entrada; é con los tiros é con los de caballo líçose tanto daño en los contrarios, que quassi los encerraron liasta las primeras casas de la ciludad. E porque de la otra parte de la calçada, cómo los bergantines no podian passar allá, andaban muchas canoas de flecheros é haçian mucho daño con llechas é varas que tiraban á la calçada, hiço el general romper un pedaço della junto á su real, é liiTo.110 111 . ço passar de la otra parte quatro de los bergantines, de los quales huyeron las canoas hasta se meter entre las casas do la cibdad, en tal manera que no osaban salir á lo largo. É por la olra parte de ia calçada los ocho bergantines peleaban con las canoas , ć las ençerraron assimesmo entre las casas, é aun entraron por entre ellas, puesto que liasta estonçes no lo avian osado hacer, porque avia muchos baxos y estacas que lo estorbaban; é hallaron canales, por donde entrar seguros, é pelealuan con los de las canoas, é tomaron algunas dellas é quemaron muchas casas del arrabal de Temislitan; é aquel dia todo fué batalla é se gastó en pelear continuamente.

Otro dia adclante el alguaçil mayor con la gente que tenia en Iztapalapa, assi de españoles como de amigos confederados, se partieron para Cuyoacan: é desde allí hasta la tierra firme hay una calçada, que tura logua é media; é cómo el alguaçil mayor comencó á caminar, á un quarto de legua llegó á una cibdad pequeña, que tambien está en el agua, é por muchas partes della se puede andar á cal)allo: é los naturales de alli començaron á pelear con él, é desbaratólos é maló muchos dellos é quemóles la ciludad.

Aria sabido el general que los indios avian rompido muclıa parte de la calçada é no podia la gente passar bien, é por esto envióles dos bergantines para que les ayudassen á passar, de los quales liçieron puente por donde los peones passaron : é desque ovicron passado, se fueron á apossenlar á Cuyoacan, yel alguaçil mayor con diez de caballo tomó el camiuo de la calçada, donde el general tenia puesto real, é quanto llegó, hallóle pelrando. Í el alggnaçil mayor é los que con él yban se apearon y entraron en la batalla, "que estaba muy trabalia, é con una vara hirieron al alguaçil mayor é le atravessiron un pié, é lirieron á olros españoles; 


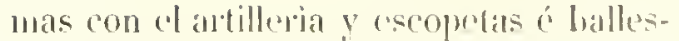
las se hicgo lanto daño en los inclios: fune ni los de las canoas ni los de la calcalda se osalan llegan lanto á los nuestros comosolian, é mostrabam algun lemor como escamentados é latimados. É assi estorieron seys dias, sin que fallassen nueros combates de la mua parte á la ofra: é los beroastines ylan quemando al reatedor de la cibdad todas las rasis que podian, ć descubrieron canal, por donde podian al rededor entrar por los arrabiles do la cibdad é llogar hasta lo crovesso de. lla, que fué cosa muy venturosa. Fis assi ressó la rejaçion de las canods, que va no osalua asomar alguna ni açercarse al real con un quarto de legua.

Extrano çereo, é para més que homhres tan alta é dificultosa empressa : porque era innosible á los humanos acabarla sin obrar Dios de su poder absoluto rn ello, por la manera é dispusiçion ded assienlo, en que esla la cibdad do Temistitan; ć otras están dentro de arfucllas lagunas que la historia ha dicho. ó quassi como la antigna é noble é poderosia é grande ciblad de Venecia: la cual despues que Troya fué destruyda por los sriegos, la pobló Antenor é sult gente. d qual capitan le dió prinçipio, é á Adrial, que está junto á la mar de Esclasonia, de la qual se llama aquel mar Adriático, segund escribe Justino en la abreviaçion de Trogo Pompego '. Maravilloso edefiçio, é opulenta é rica cibdad é república de las más nobles que en el mundo se sabe, é de las que mejor son gobernadas. É amnque en el mundo hay otros edeficios é poblaçiones fundadas en "l ağa, assi cómo la melropolitana é noWe cibdad de Ipsalense Real Stocolmensi, puesta en torno con arte é induslria, é con valientes é ricos ciluladanos, é muy forlísima (la qual está puesta en

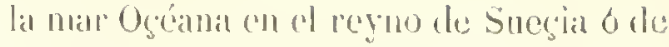
Godos, como mirs lalramente paresege por

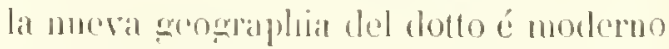
auchor Olao fiol ho, nalural de arpuellas parf(s). Pero nuestra Temistitan fienc munde similitud á la insigre ciblad renegiana. ó á lia cunes dicho yuanto al assirento, por cstaren el agua con tan soberbios ć grandes coleficios, que sin verlos seria dificultoso poderse loar tan enteramente como en si son magníficos é famosos. É puesto

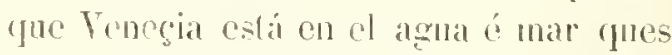
dicho: E lambien aquella su villa de Hurall, donde se hace apuel vidlio lan prerioso que á lodos execele, ó como estí dicho de la cilulad Lpsalense en Sueçiá Gordia, csotra mestra Temistitan está en aquella grand liguma salada o cotras cilydades sufragáneas á clla, que en los caprífulos precedentes se lan nombrado: las quales é cada una dellas no se pneden reo sin admiraçion; é carla calçada de apuellas, que assi sumariamente la historia ha memorado, es edeficio para ocuparse en él con mucho licmpo é gasto: y cll más se debe fener que aquellos tan famosos muros de Troya, de quien tantos renglones é auclores hablan. Dexemos viejas listorias, é lormemos á la nuestra moderna é mararillosa, peregrina é dina de mill escriptores.

Estando las cosas en el estado que está dicho, el comendador Pedro de Alrarado, que estaba por capilan de la guarniçion é gente que residia en la guarda de la cilodad de Tacuba, dió notiçia por una carta suya al gecueral, cómo por la otra parte de la cibdad de Temistilan, por una calçada que va á unas poblaçiones de tierra firme, é por otra perneña que estaba junto á clla. los de Temistitan entraban é saliam, quando querian: é que ercia que viéndose en aprielo, se avian de sillip todos por allí (pueslo quel general mís 
desseaba su satidal quellos mesmos, porque mejor se pudiera aprovechar dellos en el campo que no dentro de tan fortíssima cibdad, en el agua puesta como es diclı); pero para que estoviesse del lodo cercada, é los de dentro no se pudlies. sen aprovechar en cosa alg̣una de la tierra firme, puesto quel alguaçil mayor eslaba herido, mandóle que fuesse á sentar su real á un pueblo pequeño, adonde yba á salir una de aquellas dos calgadas. El qual, con reyute y tres de eaballo é cient peones é diez y ocho ó reynte ballesteros y escopeteros, fué atlá é assentó su real donde le fué ordenado; é assi quedó çercada la grand cibdad de Temistilan por todas partes, sin que por alguna calcada pudiessen entrar ni salir los enemigos.

En el real de la calcala tenia el general dosçientos infantes españoles, en que avia veynte y çinco ballesteros y cscopeleros, sin la gente de los luergantines, que eran más de dosçientos y cinquienta honlres; é cómo estalıan en algun aprieto los contrarios, é avia mucha gente de guerra de los amigos confederados, determinó de entrar por la calçada á la cibdad todo lo que pudiesse, é que los bergantines de la una parte é otra de la cibdarl estoviessen para laçer cspaldas : é nuandó que algunos de caballo é peones de fos que estaban en Cuyoacan se riniessen il real, é que diez de caballo se quedassen en la entrada de la calcala, hagiendo espaldas al general é á los que quediban en Cuyoacan, porque los naturiles de la cibdad de Suchimilco é Culuacan é Iztapalapa é Clitibuseo é Jlericalçingo é Cuilaguacad é Vlizquipue, que estan en el agua, estaban reluclados, y eran en favor de los de la cibdad de Temistitan; é fueriendo estos tomar las espaldas á los nuestros, eslaban seguros con los diez ó doço quel general mamdó andar á caballo por la calçada, é otros tantos gue sirm- pre colaltan en Cuyoacan, é más de riez. mill indios nuestros amigos. Assimesmo mandó el general al alguaçil mayor é á Pedro de Nrarado, que por sus eslancias acometiessen aquel dia á los de la cibdad, porque el general queria ganar por sir parte todo lo que más púdiesse.

É assi el general salió á pié del real por la mañana, é siguió por la calcada adelante, é luego hatló los enemigos en defensa de una ruebradura que tenian fecha en ella tan ancha como es luenga una lanca, é otro tanto era honda, y en clla fenian fecha una albarrada, é pelearon muy valientemente de ambas parles, é al fim se les ganó: é siguieron por la calçada adelante lassta llegar á la entrada de la cibdid, donde estaba una lorre te aquellos ydolos questal gente adoran, é ál pié della una puente muy grande levantada, é por ella atravessalba una calle de agua muy ancha, con ofra absarrada fuerte, donde se trabó la batalla de manos por amljas partes muy porfiada: mas como los luergantines peleaban por los lados, ganóse sin peligro, to qual fuera imposible sin ellos. É cómo los indios comengarọn í desamparar el albarrada, los de los bergantines saltaron en tierla, é los nuestros passaron el agua, e tambica los de Tascalteca é Guaxogingo é Calco é 'Thesayco, que eran más de ochenta nill liombres. Y entre tanto que se gegaba con piedia é adoves aquella puente, los españoles ganaron otra absarrada que estaba en la calle, que es la más prinçipal é más ancha de toda la cibdar; é cómo aquella no tenia agua, fué fáçil de ganar, é signióse el alcançe týá los cnemigos por la calle atlelante hasta llegar á otra puente que tenian alçada, salvo ma viga ancla por donde passaban, é puestos por ella é por el agna en salvo, quítáronla de presto, é de la otra parte de la pnente tenian fectua otra athariatit srande de adoves é harro. É cómo los 
nuestros llegaron á ella, no podiam passar sin echarse al agua, é aquesso era muy peligroso por la resistençia é buena roluntad con que los indios lo defendian: é le la una parte édde la otra de la calle avia infinitos dellos, peleando con mucha atençion y esfuerço deste las açoteas. Mas llegóse copia de ballesteros y escopeteros, é con dos tiros de pólvora por la calle adclante se hiço grand daño, é mataron indios á pares, é çierlos españoles se lançaron al agrua é passaron del otro caloo; mas todavia turó dos horas grandes en ganarse aquello. Pues cómo los enemigos vieron passar los chripstianos, desampararon el albarrada é las açoteas, é rolvieron las espaldas la calle adelante, é assi ovo lugar que passasse toda nuestra gente, y en la hora se començóa cegar aquella puente é deshaçer el alluărada. I en tanto los españoles é sus amigos confederados siguicron el alcançe la calle adelante, bien dos tiros de ballesta, hasta otra puente que está junto á la placa de ios prinçipales apossentos de la cibdad; y esta puente no la tenian quitada ni avia allsarrada en ella, porque no pensaron los de la ciludad que aquel dia ni en otros muchos se la avian de ganar ni llegar allí los chripstianos, ni aun los nuestros pensaban consegruir la mitad de lo que se hico aquel dia. í la entrada de la plaça se assestó un tiro, é con él resçebiån mucho daño los contrarios, porque eran tantos que no cabian en ella: é como los españoles vieron que allí no aria agua, determinaron de les entrar la plaça, é los de la cibdad, viendo su determinaçion é la moltitud de los confederados con los chripstianos (aunque de aquellos sin los españoles ningun temor tovieran), pusiéronse en lutuda, é fueron seguidos hasta los ençerrar en el çireuyto de sus ydolos, el qual es sercado de un fuerte muro de cal y canto, é no menor que una villa de quatrogientos veçinos; pero luego le des- ampararon, é los nuestros le ganaron ế se apoderaron dél é de las torres. Cómo los de la ciblial se reconoscrieron é vieron que no avia grente de caballo, volvieron sobre los españoles como leones feroçíssimos, é por fuerca de armas los echaron fucra de las torres é de todo el patio ó circuyto ya dicho: é viéronse en $\mathrm{mu}$ cho peligro los nuestros, é hiçicron rostro debaxo de cientos portales de arpuel patio, é de allí se retruseron á la plaça, é de allí los cecharon támbien liasta los meter por la calle adelante, de tal manera, quel liro que alli estalo fué desamparado, é aun perdieran con él las vidas muchos chripstianos, si no llegarán tres de caba1lo, que entraron por la plaça adelante. É cómo los enemigos los vieron, demás del temor grandíssimo que á los caluallos tenian, creyendo que eran muchos más, començaron á huyrr; é mataron algunos dellos, é ganáronles el patio é circuyto que se dixo de susso: y en la torre más prinçipal é alta dél, que liene más de çient escalones ó gradas hasta llegar á lo alto, hiçiéronse fucrtes allí diez ó doçe indios prinçipales de la cibdad, é quatro ó rinco españoles subicron por fuerca, aunque les era bien defendido, é mataron aquellos indios. En la qual saçon lleggaron otros çinco ó seýs cavalleros. los quales é los tres primeros se pusieron en una çelada, é quando fué tiempo salieron é mataron más de treynta de los enemigos; é cómo ya era tarde, mandó el general recoger la gente, é quando se retraian, cargalua tanta moltitud de los adverssarios, que si no fuera por los de caballo, rescelieran mucho daño los muestros. Mas cómo todos los malos passos de la calle é calçada, donde pudiera aver peliggro al tiempo de retrace, ya el general los avia hecho adtorar, podian muy bien entrar é salir por ellos los de caballo; é cómo los enenigos venian dando en la recaga de nuestra gente, revolvian los de calallo 
sobre ellos, é siempre alangeaban é mataban algunos. É porque la calle era muy luenga, ovo logar de hacer lo ques dicho quatro ó çinco reçes. é puesto que rian que se les lıacia mucho daño, é de cada vuclta los ginctes vertian mucha sangre de los de Temistitan, venian tan raliosos como cancs dañados, que paresria que ni estimaban la vida ni temian la muerte, é no dexaban de seguir á los españoles. É todo el dia se gastaba de la manera que está dicha, sino que ya cllos tenian tomadas muchas açoteas que salen á la calle, é los de caballo desta causa resçebian mucho peligro, é assi convino que sc retruxessen al real, é plugo á Dios que sin muerte de chripstiano alguno, pucsto que ovo heridos; mas quedó puesto fuego á las más é mejores casas de aquella calle, assi porque no les faltasse qué hacer aquella noche, como porque quando otra vez por allí entrassen los nuestros, no pudiessen los enenigos ofenderlos desde los terrados é açoteas.

Este mesmo dia el alguaçil mayor Gonçalo de Sandoval, y el comendador Pedro de Ạlvarado é su ggente pelearon muy reciamente cada uno dellos por la parte que guardaban contra los de la cibdad. É al tiempo del combate cstaban los unos de los otros é de donde el general estaha á una legua é legua y media, porque se extiende tanto la poblaçion de la ciblad, que segund Hernando Cortés cscribió á Céssar antes disminuia la distançia en to ques dicho: de lo qual se puede colegir la grandeça de Temistitan.

Pelearon este dia los amigos confederados que estaban en compañia de aquellos capitanes muy osadamente, é no resçbieron daño ni dexaron de laçerle grande en los contrarios.

En aquesta saçon don Ifernando, señor de Thesayco é de la provinçia de Culuacan, procuraba de atraer á todos los naturales de su señorio, en espeçial á los pringipales, á la devogion é amor á los españoles, porque aun no estaban confirmados en csto, como despues lo cstovicron. É cada dia venian al dicho don Hernando muchos señores y hermanos suyos, ofresçiendosele de ser en favor de los cluripstianos é pelear contra los de Temistilan é México é Culua; á cómo este don IJernando era muchacho é tenia mucho amor al general é á los españoles, é conosçia la grandíssima merçed, que en nombre del Emperador é de Sus Magestades se le avia fecho cn darle tan grand señorio, aviendo otros que le preçedian en of derecho de aquel estado, como grato senor, trabaxaba quanto le cra posible en que todos sus vassallos fuessen á pelear contra los de Temistitan, é que se pusiessen en los trabaxos é peligros en que entendia estaban ocupados los españoles, sirviendo á Dios é á Sus Mlagestades, para que con ellos gogassen juntamente de la victoria. É habló con sus hermanos, que cran seys ó sicte, todos mançebos é bien dispuestos, é díxoles que les rogaba que con toda la gente de su señorio fuessen á ayudar al general; é á uno dellos, llamado Ystrusichii, de elad de veynte y tres ó veynte y quatro años, muy esforçado é amado y estimado entre aquella su generaçion por su valerosa persona y expiriençia, híçole su capitan general, y envióle á nucstro campo: é llegó al real de la calçada con más de treynta mill hombres de guerra muy bien aderesça'los á su costumbre; é á los otros dos reales yrian otros veynte mill liombres, á los quales el general resçcbió graçiosamente, agratlescićndoles mucho su buena voluntál é obra, é quedaron sirviendo donde les fué ordenado.

En la continuacion clesta conquista parescerá al que lee, como es raçon que assi lo crea, que tan scñalado é grand socorro pol' un solo vassallo ó señor que era Estado de un grand rey, é no poco pode- 
roso, enviando çingibenta mill hombres fucra de su señorio, é lales; pues por esto exército se puede colegrir que quedabin en su fierra otros muchos, allende de la ofra gente inutil para las armas. El qual socorro fué de mucho pessar é dolor para los de Temistitan, en rer yr contra cllos á los que poco antes tenian por vassallos, é por amigos é parichtes y hermanos, y aun pardres é hijos, que de todos estos debdos avia cutrellos; pero ol tionpo es callead de talles mudangas, y el oflicio del mumdo no consicute que haya en la lierra cona pronenesoicnte muchos siglos, sin que semejantes diferencias é peroluciones de estados prochen los hombres, praral que mejor entiendan é conozcan á llios.

\section{GAPTULU MXIV.}

En que se tracta cúmo la segunda rez combaliu el generit llemando Cortís é los españoles a contideratios annigos suyos la grand cibdal de Temislitan, é se ticeo mucha matanca y estrago en los contrarios, i de

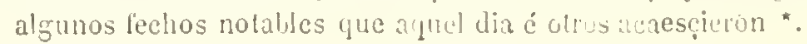

\section{D)} de la cilddad, segund que se dixo en el capítulo desusso, é llegada ya la gente y exérçito del prínsipe don Hernando, senor de Thesayco é Aculuacan, en socorro é ayuda de los españoles, vinicron á ofrescerse por vassallos de Sus Magestades é de su corona real de Castilla los naturales de la cibdad de Suchimileo, que está en el agoua ć laģuna grande, é çiertos puchlos utumies, que es gente serrana é de más copia que los de Suchimileo (y eran esclavos del señor de Temistitan). É suplicaron al general Hernando Cortés, que les perdonasse la tardança de haber venido tan tarde á hager lo que debian; y él los resçelsió muy bien é les dixo quio lıolgaba mucho con su venida, é que serian tractados é gratificados é tenidos en justiçia, como buenos vassallos del grand Rey de Castilla, nuestro señor; é que cn él hallarian su persona aparejada para los complaçer é dar todo fivor é ayuda, si ellos hiçiessen lo que debian haçer en serviçio de Sus Magestades: é assi lo pro-

* De esle cpigrafe quiló Oviedo las siguientes cliusulas : «É cómo Hemando Corlés hiẹo quemar çicrlas casas prinẹpales de las que Monterumat tr- uncticron ellos que lo cumplirian con toda fidelidad. Hucha raçon tenian nucstros espanoles de liolgar con esta nueva amistad; prorque si algun daño podian rescebir los del real de Cuyoucan aria de ser pol parte destos nuevos conferlerados, ó con tal aniçiçia cessó este inconvinieute.

De la parte del real de la calcada, por donde ol general colaba, ya se ha dicho que avian quemarlo los de los bergantines muchas casas en los arraluales de la (cibdad, é no osaba parescer canoa alguna por todo aquello. Purescióle al general que para su seguridad hastaba tener en torno de su real sicte bergantines, é de los otros seys restantes envió los tres al real del alduacil mayor, é los otros tres al del comendiulor Pedro de Alvarado; é mandó á los particulares capitanes de essos sers bergantines que por la parte de aquellos dos reales estoriessen avisados, porque Ins de la cibdad se aprovechaban inucho de la tierra en sus canoas, é metian agua é fructas é mahiz é otras riturallas é refrescos, é que se lo excusassen.

nia, de las quales en olra parte en los capilulos pricredentes desta historia se ha fecho mençion, en esperial en ol capitulo $\mathrm{X}$ del prescute librow 
X́ cuvió á mandar á los prinçipales capitancs de arpuellos dos exérçitos que $\mathrm{col}^{-}$ riessen de noche é de dia los unos é los otros del un real al otro, porque aprovecharia mucho esto para hacer espaldas í. la gente de los reales todas las veces que quisiessen entrar á combatir la cibdarl. Fué tal este proveymiento, que cada noclic haçian los bergantines muchos saltos é tomaluan canoas muclas é gente de los encmigos.

Luecro que esto se proveyó, hiço una lablsa pública é gencral Hernando Cortés á su exérçito ó campo particular, en que dixo que tenia determinado desde á dos dias de entrar á combatir la cibdad; por tanto que les rogalsa é amonestaba que todos viniessen para estonçes á punto de guerra, porque esperaha en -Nuestro Señor Dios de conseguil victoria é dar fin á los trahaxos de todos, ó poncr las cosas en tales téminos que con poca fatiga se acalyasse lo que les quedaria por hacer para la definiçion desta conquista; ć que en arquello eonosceria de los confederados si eran fictos ó verdaderos amigos, é qué intençion tenian al serviçio de Sus Hageslarles, como buenos é leales vassallos. É los unos é los otros prometicron de haçer su deber, remiliéndose á la obra. E luego liço meler en órden todo lo quie era nessessario para la jornada, y escribió á los otros reales é bergantines lo que tenia acordado é lo que cada uno avia de haçer. E llegado el plaço, assi como fué de dia se dixo una missi del Espíritu Sancto, que todos los chripstianos oyeron con mucha devoçion, é ann los indios, cono simples é no entendientes de tan alto misterio, con admiraçion estaban ateutos, notando el silençio de los catlólicos y el acatamiento que al altar $\mathrm{y}$ al sacerdote los chripstianos tovieron liasta resçeloir la bendiçion. La qual echada, luego el general informó á los capilancs de lo que ávian de laçer, ó mojor diçiendo, les acordó to que con cllos tenia ya consuitado; é salió del real con hasta reynte de caballo é trescientos españoles é con grandíssimo uúmero de los amigos confederados, é siguió la calcada adclante bien tres tiros de lia. llosta del real, donde ya los enemigos estalban esperando con mucha grita é voçinas é alambores. Ẃ cómo en los tres dias antes no se les aria dado combate, avian desiccho quanto los nuestros avian çegado del agau, é ienianlo muy más fucrié peligroso de ganar que de antes estabit. If loshergantines llegaron por la una parte é por la otra de la calçada, é cómo con ellos se podian llegar muy más serea de los enemigos, haçian mucho daño con las ballestas y escopetas: é assi saltaron cn lierra, é ganóse la albarrada é puentr. é passaron los nuestros de la otra parte siguicndo á los con!rarios, los quales se repararon é alendieron en las otras puentes ć albarradas, que tenian fechas adelante, las quales, auncque con mayor trabaxo é peligro que la otra vez, las ganaron los nucstros, y echaron á los enemigos de toda la calle é de la plaça de los apossentamientos grandes de la cihdad. Ĺ de alli mandó el general que no passassen los españoles, porque él con la gente de los amigos confederados andaba cegando con picdra é adoves loda el aģa de aquellos passos, en que ovo tanto que haçer, que aunque para ello ayudaban más de diez unill indios, quando se acabó de aderecar era liora de vísperas. Y cn todo este tiempo siempre los depañoles é sus amigos andaban peleando y cscaramuçando con los do la cibdad y echnindoles goladas, en que murieron muchos dullos; y el generil con los de caballo anduro un ralo por la ciludad, alamceamelo por las calles donde un avia agua los que alcançaban, de mancra que los tenian relaydos fue no osaban salir a lo firme.

É viendo el general que los de la cilsdad estaluan fan replieldes é mostraban 
tanta deterninaçion de morir ó defenterse, coligió dos cosas desto: la ima, que se avia de aver poca ó ninguna riqueça de la que á él é á los españoles avian quitado, quando los echaron de la cilulad: é la otra, que dahan ocasion é aun forçaban á los nuestros á que totalmente destruyessen la cilshad é los que della quedaban, lo qual mucho dolia al general, porque los queria más enmendados é por amigos, é que no se execulasse tanto rigor é muertes de humanos, como estaba aparejado. É pensaba qué forma podria tener para los temoriçar de manera que riniessen en conosçimiento de su yerro, é del daño que porlian resçebir de los nuestros: é no haçia sino quemarles é derribarles las torres de sus ahominables oratorios é ydolos é sus casas: é porque más lo sintiessen, aquel dia hiço poner fuego á aquellas casas grandes de la plaça (donde la otra vez que le echaron de la cil)dar él é los españoles čslovicron apossentados), que eran tan grandes é de tan magnificos apossentamientos, que un poderoso príncipe con mús de seysçientas personas de su casa é serviçio se podia apossentar en ellas, é olras que estaban junto á estas, que aunque algo menores cran muy más frescas é gentiles; é lenia en ellas Montecuma todos los linagesé géneros de aves, que en aquellas partes é otras muchas avia. $\dot{\mathrm{E}}$ aunque al general le pessaba mucho desto, porque á los contrarios les pessaba mucho más, determinó rể las haçer quemar, de lo qual los enemigos mostraron mueho pessar, é lo mesmo les dolió á los otros sus aliados de la cibdad de la laguna, porque essos ni otros nunca pensaron que la fuerça de los chripstianos pudiera bastar en ningun tiempo á les entrar tan adelante en su cibdad; y esto les puso mucho desmayo.

Puesto fuego h las casas ques dicho, porque ya era tarde, el greneral mandó haçer señil para recoged la gente á sil real; é cómo los do la ciludad vian que so retiraba, cargahan nuchos sobrellos, é venian con grand impetu dando en la retrogruarda. É cómo toda la calle estaha ya buena é aderesçada para porter correr los de caluallo, volvian solırellos é alangeaban de cada vuctia muchos, é por esso no escarmenlaban ni dexaban de venir dando grita á las espaldas. Sinticron unucha pena é afrenta este dia los contrarios, viendo entrar por su cibdar quemándola é destruyéndola é peleando con ellos los de Thesayco é Calco é Suchimilco é los ulumies, é nombrándose cada generassion de dónde eran, é por otra parte los de Tascalteca : quellos é los otros les mostraban sus ciludadanos hechos perlaços, diçiéndoles que los avian de çenar aquella noche é almorçar otro dia, comode hecho lo haçian assi.

Escriben que teniendo Sylla çercada á Athenas, tovieron los de dentro tanta nesçessidad, que despues de arer por la excesiva hambre comídose todas las hestias, comian los cueros é pellejos é que alğunos de los cercados arian comencado á comer de los euerpos humanos de aquellos que avian muerto los cnemigos; é al tiempo que se tomó aquella ciludad é se metió á saco, los romanos en muchas casas hallaron aparejado para comer el manjar de cuerpos humanos '. Acá en esta conquisla no se haçia por nesçessidad el coner de la carne humana, como lo dise Appiano é lo toqué de susso, en la gnerra de Nitridate é de los romanos. Más assi cómo mataban al hombre, ni le enterraban ni dexaban perder la carne, ni les negaban á los enemigos que assi mataban, si en su poder quedaban, sus cuerpos proprios por sepolturas, é lo tenian por manjar que muy bien les sa- 
lue. Ni podian ver los ojos de los chripstianos é cathólicos más espantable é aborresçida cosa, que rer en el real de los amigos confederados el continuo exerçiço de comer carne asada ó coçida de los indios enemigos; é aun de los que matahan en las canoas ó se ahogaban, é despues el agua los echalı en la superfiçic de la laguna ó en la costa, no los dexaban de pescar é apossentar en sus vientres.

Por manera que de la forma que eslá dicho, el general, volviendo á la listoria, trabaxó mucho por su persona y espíritu este dia, é los españoles pelearon como lo acostumbraban con mucho esfuerco é buen tiento, é los amigos confederados con grand osadia, é por complir su palabra, sacaron hartos de los enemigos que este dia murieron á cuestas; pe- ro repartidos entre sí á pedaços, prara les lacer las olsequias en los asadores é ollas é ponerlos en sus estómagos, segund su costumbre. É fecha ó dada la señal pror el general, se retrixicron á su real á descansar, porque la jornada fué de muclio cansançio. É los siete bergantines que allí andaban, entraron este dia por las calles del aģua de la cildad, é quemaron mucha parte della.

Los capitanes de los otros dos exércitos ó campos nuestros é los otros seys bergantines polearon muy bicn este dia, é se retiraron quando fué tiempo con victoria a sus reales: lo qual, por evilar prolixidad, se dexa de deçir, é aun porque el general Hernando Cortés en la relaçion que escribe á Céssar no lo diçe más particular ni largamente de lo ques dicho.

\section{CAPITULO XXV.}

En que se tracta de otros combales que Hernando Corlés é los españoles é confederados indios, sus amigos, dieron á la cibdad de Temistitan; ¿de algunas cosas señaladas que intervinieron en tanto que aquel çerco turo.

0 despues que se dixo missa al greneral é á los españoles de su real, volvió á la cibdatl con su gente é órden acostumbrada, porque los contrarios no toviessen lugar. de romper las puentes é hacer las alloarradas; é por bien que madrugaron los nuestros, de las tres partes é calles de aģua que atraviessan la calle ó calçadia que yba desde el real hasta las casas grandes de la plaça, las dos dellas estaban como los dos dias antes, que fueron mity reçias de ganar, é tanto que turó el combate desde las octo horas de la mañana liasta la una despues de medio dia, é se gastaron quassi todas las saelas é almaçen de pelotas que los ballesteros y escopeteros llevaloan. Era muy grande el peligro de los nuestros todas las veçes que aque10.160 Ill. llas puentes les ganaban á los contrarios, porque para ganarlas era forçado ccharse á nado tos españoles é passar de la olra parte; y esto ni podian ni osaban haçerlo muchos, porque á cuchilladas é á botes de lanças resistian los enemigos, defendiendo la salida de la otra parte; pero como ya por los lados no tenian açoteas, desde donde hiçiessen daño, é desta parte los asacteaban, porque estaban los unos de los otros á quarenta passos ó menos, en los españoles cada dia se acrescentaba sı ámimo é determinaçion de passar, conosçiendo que esta era la voluntad del general, é que cayendo ó levantando, un se avia tle hacer otra cosa, porque sabia muy bien reprehender al que mostraba flaqueça, é gratificaba é lıonraba al que era esforgado é se señalal en la gueria. 
Paresçerí al letor que pues tanto peligro resçebian los nucstros en ganar aquellas puentes é albarradas, que eran negligentes, ya que las ganahan, en no las sostener é guardar, por no volver cada dia de nuevo á fomar el mesmo trabaxo é peligro tan zrande é notorio. La desculpa quel general daba en esto, que á los absentes podria parescer negligencia, es que en ninguna manera se podia hacer otra cosa; porque para ponerse recabdo de guarla continua en esto, se refucrian dos cosas: ó quel real passára á la plaça é çircuyto de las torres de los ydolos, 6 que sufiçiente número de grente de guerra guardasse las puentes que sc ganassen, velando las noclies. É de lo uno é de lo otro porlia resultar grand daño, é no avia possibilidad para ello: porque teniendo el real dentro de la cildad, cra tan populosa é de tantos enemirgos: que cada liora é momento convenia pelear, é tovieran mil rebatos, é los nuestros eran pocos, digo los españoles, solore cuyos hombros cstaba la carcra é pesso é vela desta guerra; é si dellos se oviera de poner essa guarda, el trabaxo fuera incomportable, é por muchas partes avian de ser tentados con las armas sin tener algun reposo. Pues guardar las puentes gente de noche, quedaban los españoles lan cansados de pelear de dia, que no se compadesçia ni era posible sufrirse, ni convenia poner la guarda deilos para que les quedasse alguna hora die descanso: pues hager la guarda los anigos confederados, era sospechoso tal offiçio en ellos. É á esta causa era forgado é menos inconviniente ganar de nuevo cada dia las que entraban en la cibdad.

Este dia, de que tractamos, cúmo se lardó mucho en ganar las puentes y en las tornar á çegar, no ovo lugar de hacer más, salvo que por otra calle prinçipal que ra á dar á la cibdad de Tacuba se ganaron otras dos puentes é se çegaron, é se quemaron muchas ê buenas casas do aquella calle. lí con esto, llegada la tar. de é lora de rotraerse los nuestros, se puso por olua, é no con menos peligro fue en ganar las pucutes; porpue en viendo retirarse los cespañoles, colsrabau los de la cildat lanta osadia, como si ovicran avido loda la victoria del mundo, 6 coino si los chripstianos volvicran huyendo. lis para este retrace cla nescessario costar las puentes bien çicgas, é lo gegrado iğual al suclo de la ralle é calcarla, porque los de calballo pudiessen libremente correr á una parte éá otrá Éassi en el retraer, cómo los enemigos venian colodiçiosos trás los nuestros, algumas veces fingrian los cortesanos que huian, por sacarlos é que passassen más adelante; é revolvian los de caballo solure los alrevidos, é siempre alançeaban é malaban diez ó doge ó más do aquellos más esforçados; é con esto é algunas celadas que de parte de nuestro exérçito les armaban, llevaron los contrarios lo peor continuamente.

Cosa de admiraçion era, pues que les era notorio el daño (é muy continuo) que se les haçia al retracrse los chripstianos, no çessar por esso ni escarmentar de los seguir hasta los ver salidos de la cibdad: y desta manera se tornaban al real. Los capitanes de los otros reales hiçicron saber al general cómo en esse mesmo dia les avia subçedirlo muy bien é avian muerto mucha gente por la tierra y en el agua. Y el capitan Pedro de Alvarado, que estaba en Tacuba, escribió que avia ganado dos 6 tres puentes, porque como eran en la calçada que sale del mercado de Temistitan a Tacuba, é los tres bergantines quel general le avia enviado podian llegar por la una parte á tocar en la mesma calçada, no avia tenido tanto peligro como los ofros dias passados. $\dot{E}$ por aquella parte del dicho comendador Alvarado avia más puentes é más quebradas en la calçada, jues- 
to que avia menos açoteas que por las utras partes.

En todo este tiempo los naturales de Iztapalapa, Ochilobusco, Mexicaçingo, Coluacan, Mizquique é Cuytaguaca, que como es dicho, estin en la otra laguna dulce, nunca avian querido renir de paz, ni tampoco en todo esse tiempo avian fecho daño á los españoles; é cómo los de Calco cran leales vassallos, é veian que los chripstianos sus amigos lenian bien que laçer con los de la grand ciludad, juntáronse con otras poblaçiones que estaban al rededor de las lagunas, é haçian todo el daño que podian á aqurellos del agua dulçe. Y ellos, viendo cómo de cada dia los españoles avian victoria contra los de Temistitan, ć por el daño proprio que tamlien ellos resçebian é podrian resçelsir de los confederados é amigos de los chripstianos, acordaron de venir é llegaron al real, rogando al general que les perdonasse lo passado é mandasse á los de Calco ¿é los otros sus recinos que no les hiçies. sen guerra ni más daño. Y el general holgó mucho, é les dixo que le plaçia, é que no tenia enojo dellos, sino de los de Temistitan; mas para quél é los españoles creyessen que su amistad era verdadera, les rogaba, porque tenia determinado de no alçar el çerco hasta tomar por paz ó por guerra aquella cibdad, que pues querian la amistad suya é de los chripstianos, é que se ofresçian por vassallos de Sus Nagestades, é tenian muchas canoas con que podian servir é favorescer su particlo, que hiçiessen aperçelir todás quantas pudiessen con toda la más gente de guerra que en sus polblaçiones avia, para que. por el agua viniessen en ayuda de los españoles de ahí adelante. E tambien les rogó que porque los chripstianos tenian pocas é ruynes choças $y^{*}$ el tiempo era de muchas aguas, que hiçiessen en el real todas las más casas que pudiessen, é trıressen canoas para traer adoveś made- rá de las casas de la cilodad más çercanas al real. I esto respondieron que las canoas é gente de guerra estaban prestos para cada dia, y. en el hacer de las casas sirvieron tan bien, que de la una parte é da la otra de las dos torres de la calçada, donde el general estaba apossentado, hiçieron tantas que desde la primera casa Iasta la postrera avia quatro tiros de ballesta en luengo. De aqui se puede colegir el anchor de la calçada (que va por lo más hondo del agua) é de la una parte é de la otra yban essas casas juntas una á par de otra, é quedaba entre ambas açeras fecha una calle, por donde á plaçer á caballo é á pié yluan é venian por ella. É a via á la contínua en el real con españoles é indios que los servian más de dos mill personas; é toda la otra gente de los amigos confederados estaban apossentados en Cuyoacan, que está legoua y media del real. É tambien estos destas poblaçiones de la laguna dulçe proveian de algunos mantenimientos, de que avia assaz nescessidad, en espeçial de pescado é de cereças, que hay tanias en su tiempo, que pueden bastar çinco ó seys meses del año que turan á doblada gente de la que en aquella tierra hay, la qual es tantal como en otras partes destas listorias se lıa dicho.

Pues cómo dos ó tres dias á reo avian entrado los del real en la cibdad, sin otras tres ó quatro veçes que entraron primero, é siempre conseguian victoria contra los indios enemigos, é con los tiros de la artilleria y escopetas é ballestas mataban muchos, pensaba el general que esta nesçessidad é tralıaxo, en que los tenia, una hora ú otra les moveria á los çercados á aver compassion de sí mesmos, é á pedir la paz, la qual él desseaba como su salvaçion, por muchos buenos respetos; mas ninguna cosa aprovechaba para los traer á pedir ni mostrar quietud ni amistad. $\dot{\mathrm{E}}$ por ponerlos en mayor nescessidad 
é reduscinlos á la obidiençia, liço xénir todas las gentes de aquellas ciblades del agua en sus canoas: é acjuel dia por la mañana aviat en ol real más de çient mill lrombres de los amigos; é mandó que los quatro hergantines con la mitad de lis ranoas, que serian hasta mill é quinientas, finessen por la una parte, é que los otros con otras tantas fucsen por la otra, é corriessen toda la más de la cibdad en torno, é quemassen é hiçiessen quanto mal é dàno pudiessen. Y él entró por la calle principal adelante, é hallóla toda desembaracada hasta las casas grandes de la plaça, que ninguna de las puentes estaba abierta ; é passó adelante á otra calle que va á salir á Taculba, en que aria otras seysó sicte puentes, é proveyó desle allí que un capitan entrasse por otra calle con septenta hombres é seys de caballo, é fuessen á las espaldas para los ascgurar, é con cllos y lan más de diez ó dlosge mill indios de los annigos. L' mandó á otro capilin que por otral calle liciesse lo mesmo; $y$ ol generat con la gente que le suedalar siguió por la calle de Tacula iulelante, é suanáronte tres puentes, las quales se gegaron, é devaron para otro dia las otras. porgine ya era larde é se pudiessen mejor ganar. é porque el genoral desieala mucho que todia aquella calle se ganasse. poriue la gente del real de Pedro de Alvarado se comunicasse con la del real del general .é passasen del un exérçito é reat al otro, é quue los berọantines hiçiessen lo mesino. Fste fué un dia gglorioso é de mucha victoria, assi por el agua como por la ticria, é órose algun despojo de los de la cilplad. En los reales del illguaçil mayor é del comendador Pedro de Alrarado subçedió la jornada assimesmo prósperá é rictoriosamente.

\section{CAPITUlO XXVI.}

Cómo otro dia el general Hernando Corlés tornó á entrar en la cibdad de Temistilan ó ovo victoria; é cómo los encmigos desbarataron al capitan Alvarado; ć cómo despues por vengar aquello, se acordó de combatir la cibdad por diverssas parles, é fué desbaratado cl general Hernando Corlés é le hirieron á él en una pierna; é de otras cosas que acacsçieron en esta mala jornada. É tambien se tracta de otros trançes victoriosos y en favor de los chripstianos, en continuaçion del perco de Temistitan.

$\mathrm{C}$ te tornó el cencral Ilernando Cortés á cntrar en la cibdad por la órden que el dia antes avia entrado; é dióle Dios tanta rictoria, que por las partes que entraba con su gente parescia que no tenia resistençia su buena ventura; é los cnemigos se retraian tan reçiamente, que paresçia que les tenian tomadas las tres quartas partes de la cibdad. É tambien por el real del comendador Pedro de Alrarado daban mucha priessa á los çercados, é sin dubda el clia passado é apueste se creyó que vinieran de paz, de la qual sicmpre el general, con victoria é sin clla, lıacia todas las muestras quél podia, é nunca por esso se halló en los contrarios flaqueça de ánimo, ni menos constançia, ni señal de paz. É aquel dia se tornaron los nuestros al real con mucho plaçer, aunque al general le pessaba en el ánima ver tanta perseverançia é determinacion de morir defendiéndose los de la cibdad.

En los otros dias antes deste ques dicho, el capitan Pedro de Alvarado avia ganado muchas puentes, ć por las sustentar é guardar ponia relas en ellas de noclie, assi de hombres á caluallo como de pié, é la otra gente yluase al real, que estaba tres quartos de legua de allí: é porque este trabaxo cra excesivo é no 
comportable, acordó de passar el real al cabo de la calçada que va á dar al mercado de Temistitan, ques una plaça harto mayor que la de la ciblad de Salamanca, é toda cercada de portales á la redonda: é para llegar á ella, no le faltaban de ganar sino otras dos ó tres puentes; pero eran ınuy anchas é peligrosas de ganar, é assi estoro algunos dias, que siempre peleaba é avia victoria. É aquel dia que se dixo de susso, cómo él via que los enemigos mostraban flaqueça, é que por donde él estaba les daba muy contínuos é reçios combates, çebóse tanto en el sabor de la victoria é de las mhichas puentes é albarradas que les avia ganado, que determinó de les passar é ganar una puente que avia más de sessenta passos derechos de la calçada (lodo de agga) de liondura de estado y medio é dos; é cómo acometieron aquel mesmo dia é los bergantines ayudaron mucho, passaron el agua é ganaron la puente, é sigruieron trás los enemigos, que yluan puestos en huyda. Y el capitan Pedro de Alvarado daba mucha priessa en que se cegasse aquel passo, porque passassen los de caballo, é tambien porque cada dia por escrito é por palabra le enviaba el gencral á amonestar que no ganassen palmo de tierra, sin que quedasse muy seguro para entrar é salir los de caballo, porque estos eran el principal cabclal ó fuerça que los nuestros tenian para ofender á los contrarios. É cómo los de la cibdad vieron que no avia más de quarenta ó çinquienta españoles de la otra parte, é algunos amigos de los confederados nuestros, é que los de caballo no podian passar, revuelren sobrellos tan de súbito, que les hiçieron volver las espaldas y echar al agua, é tomaron viros tres ó quatro españoles, que luego los fueron á sacrificar, é mataron algunos amigos de los confederados de la parte de los chripstianos. Finalmente, el comendador Alvarado se retruxo á su real; é cómo aquel dia el general supo lo que le avia acaesçido á Alvarado, pessóle mucho, como era raçon que le pessasse, porque era ocasion de esforçarse los enemigos é que creyessen que en ninguna manera les osarian entrar. La causa porque el capitan Alvalado quiso tomar aquel mal passo fué confiar que, como avia garito unucha parte de la fuerça de los indios, é que mostraban ya ellos alguna flaqueça, é prinçipalmente porque la gente de su real le importunaban que ganasse el mercado, porque aquel ganado, cra toda la cibdad quassi ganada, é la fuerça toda y esperança de los indios tenian allí. E cóno los del real de Alvarado vian quel general Hernando Cortés continuaba mucho los combates de la cibdad, creian que avia de ganar primero quellos el dicho mercado, é cómo estaban más cerca dél que los del general, tenian por caso de lionra no le ganar primero, é por esto el comendador Alvarada cra muy importunado; é aun lo mesmo acaesçió al general en su real, porque todos los españoles le afincaban que por una de tres calles que yban á dar al mercado entrasse, porque no tenian resistençia, é ganado aquel, ternian menos trabaxo. Y el general disimulaba por no lo haçer, encubriendo con suprudençia la causa porque lo dexaba, y era por los inconvinientes é peligros que se le repressentaban, porque para entrar en el mercado avia innumerables açoteas é puentes é calçadas rompidas, y en tal manera, que cada casa, donde avian de $\mathrm{yl}^{*}$, estaba hecha comoisla enmedio del agua. É cómo aquella tarde quel general llegó á su real, supo el desbarato de Alvarado, otro dia de mañana fué donde eslaba para reprehenderle lo passado é para ver lo que avia ganado y en qué parte ávia passado el real, é para le dar su parescer é aviso de lo que debia laçer de alí adclante é fuesse nescessario para seguridad de los nuestros é ofensa de los 
contrarios. F́ cóno llegó al real ile Alvarato, se espantó mucho de lo que estaba metido en la cibdad é de los malos passos é puenteș, que aria ganado; é visto, no le halló con tanta culpa como pensaba primero que tenia, é platicaron entre ambos, é con acuerdo de otros liilalgos é personas de espiriençia en lo por venir. Aquel dia se tornó el general á su real.

Passado lo ques dicho, el general hiço algunas entradas en la ciludad por donde solia, é combatian los bergantines é canoas por dos partes, y él é la otra gente nuestra por la ciludad por otras quatro: de manera que un combate era de valor de seys combates, é siempre avian victoria, b mataban muchos de la parte contraria, assi por la asluça del general é continuaçion de las armas, como porque cada dia tha gen!e sin número en favor de los españoles. I el general cautelosamente dilataba de se meter más adentro en la cibdad: Io uno por esperar que los cercados podria ser que mudassen propóssito en su dureça, é aun porque la entrada no podia-ser sin mucho peligro; é lo otro porque ellos estaban muy juntos é fucrtes é determinados de morir. É cómo los chripstianos reian tanta dilaçion en esto, é que avia más de veynte dias que no dexaban de pelear, no çessaban de importunar á Hernando Cortés que entrasse á tomar el mercado; porque teniendo aquel, tes quedasse á los contrarios poco lugar en que se pudiessen defender, é que si no se quisiessen dar, moririan de hambre é de sed, porque no ternian que beber sino ağua salada de la lağuna: é cómo el general se excusaba, por los respetos ya dichos é otros inconvinientes, díxole el thessorero de Su Magestad que todos los del real afirmaban que cra nescessario é convenia mucho lo que le pedian, é que lo dehia liaçer. E assi al thessorero como á otros que en esta plática cstahan, respondió que su propóssito é desseo era muy hneno, é quél lo desscaba más que ninsumo; pero que lo dexaba de haçer por lo que importunado le haçian deçir, que cra que aunque el thessorero é otros lo hiçiessen como huenos, como en arfuello se ofresçia mucho peligro, avria otros que no to hiçiessen. Has en fin tanto se lo porfiaron, que conçedió que se laria en este caso todo lo quél pudiesse, concertúndose primero con la gente é capilanes de los otros reales.

Otro dia siguiente el general se juntóa consejo con algunas personas prinçipales de su real, é fué acordado que se hiçiesse saber al alguaril mayor é al comendador Pedro de Alvarado cómo olro dia siguiente avian de entrar á la cihlad é trahaxar de llegar al mercado, y escribióles Jo quellos arian de haçer por la parte de Tacuha; é aum, porque mejor se entendiessen viva roce, demás de las cartas envió dos criados suyos hien informados, para que arisassen á los capitanes ya dichos de la órlen que debian tener , é quel alguacil mayor se fuesse con diez de caballo é çient peones é quinçe ballesteros y escopcteros al real de Pedro de Alvarado, é que en el suyo quedassen diez de caballo otros, é que dexasse concertado con ellos que otro dia que aria de ser el combate, se pusicssen en çeladas trús unas casas, é que hiçiessen alçar todo su fardage como que le vantaban el real, porque los de la ciludad saliessen trás ellos é la cclada les diesse en las espaldas; é quel dicho alguaçil mayor con los tres bergantines que tenia é con los otros tres de Alvarado ganasse áquel passo malo, donde avian desbaratarlo al dicho capitan Alvarado, é diessen muclia priessa en lo çegar, é que passassen adelảnte, é que en ninguna manera se alexassen ni ganassen un passo, sin lo dexar primero giego é aderesçado; ć que si pudiessen sin mucho riesgo é peligro ganar hasta el mercado, que lo trabaxassen mucho, porque 
el genelal pensaba laçer lo mesmo. É que mirassen que auncjue esto los envialya á decir, no era para obligarlos á ganar un passo de tierra, en que les pudiesse sulyçader alğm siniestro caso ni peligro; y esto les avisaloa, porque conoscria que eran personas que avian de poner el rostro é las manos donde el general les dixesse, aunque supiessen que arian de perder las vidas.

Despachados estos mensajeros, fueron á los capitanes ya dichos é informáronles del caso é traça ó conçierto quel general tenia acordado; é porque ellos avian do combatir por sola una parie y el general por muchas, envióles ál deçir que le enviassen septenta ú ochenta hombres de á pié, para que otro dia entrassen con él, los quales con aquellos dos criados suyos vinieron aquella noche á dormir á su real.

Otro dia, despues que fuć dicla una missa del Espíritu Sancto, salieron del real del general los siete bergantines con más de tres mill canoas de los amigos por cl agua, y él con veynte y çinco de caballo é con la gente que tonia é los septenta hombres del real de Tacuba entró en la cibdad; y entrado, avia tres calles desde lo que tenia ganado que yban á dar al mercado (al qual los indios llaman tiangüez, é á todo aquel sitio donde está el tracto de lo que se vende é compra llámanle catebulco). La una destas tres calles era la prinçipal que yba al diclıo mercado, é por ella dixo el general al thessorero é al contador de Su Magestad que entrassen con septẻnta lombres é con veynte mill indios ó más de los amigos confederados, é que en la retroguarda llevassen siete ú ocho de caballo, é que cómo fuessen ganando las puentes é albarradas, las fucssen luego çegando, é llevassen para esso una doçena de liombres con sus haçadones, é más los amigos, que para aguello eran los que haçian al caso. Las otras dos calles ran desde la calle de Tacuba á dar en el mercado, é son mús anchas é de más calçadas é puentes é calles de agua; é mandó que por la más ancha dellas entrassen dos capitanes con ochenta lombres é hasta diez mill lom. Jyes ó más de los amigos. É al prinçivio de aquella calle de Tacúba mandó dexar dos tiros gruesos con ocho de calsallo cn guarda dellos, y el general con otros ocho de caballo é hasta çient peones, en que a via más de reynte y çinco ballesteros y escopoteros, é con gente innumcrable de los indios amigos siguió por la otra calle tercera angosta, é á la boca della hiço detener los de caballo, é mandóles que en ninguna manera passassen de allí, ni fuessen trás el general, si no se lo enviasse á mandar primero; y él se apeó é llegó á una albarrada que tenian los contrarios del otro cabo de la una puente, é con un tiro pequeño de campo é con los ballesteros y escopeteros se ganó, é passaron adelante por una calçada que tenian rota por dos ó tres partes.

Demás destos tres combates que se daban á la cibdad, era tanta la gente de los amigos que por las açoteas é por las otras partes les entraban, que no les paresçia que avia cosa que les pudiesse empecer; é cómo les ganassen aquellas dos puentes é albarradas é la calçada los españoles. nucsiros amiyos siguicron por la calle adelante, sin se les amparar cosa alguna, $\mathrm{y}$ el general se quedó con hasta veynte y cinco lombres en una isleta que alli se luaçia, porque veia que çiertos indios amigos andaban vueltos con los enemigos, é algunas reçes los retraian hasta los echar al agua, é con el favor de los españoles revolvieron sobre los contrarios; é demás desto guardaba que por las traviessas de las calles los de la cilodad no saliessen á tomar las espaldas a los españoles que avian seguido la calle adelante: los quales en essa saçon enviaron á deçir al general que avian ganado muclıo é que es. 
taban muy çerea de la plaça del mercado, é que en todo easo querian passar adclante, porque ya oian el combate quel alguaçil mayor y el capitan Pedro le Mrarado daban por su estançia. I el general les envió á doçir que en uinguna manera diessen passo adclante, sin que primero quedassen las puentes hien çiegas, de forma que si huviessen nesçessidad de se retirar al agua, no luriessen emlaraço ni estorbo alguno, pues en csto estalıa el mayor peligro; é replicaron que todo to que avian ganado quedaba bien reparado, é que fuesse allá é veria si era assi. $\mathrm{Y}$ el general, con reçelo que no se desmandassen ó dexassen mal reeabdo en el cegar de las puentes, fué allá, é halló que avian passado una quebrada de la ealle, que era de dicz ó doçe passos en ancho, y el agua que por ella passaba era de dos estados de hondo ó más; é al tiempo que la passaron avian echado en ella madera é eañas de earriço, é eómo passaron poeos á poeos é eon tiento, no se hundió la madera é eañas, é con el plaçer de la vietoria yhan tan ufanos embebesçidos, que pensaban quedaha aquel passo fixo. Mas al tiempo quel general allí llegó é lo vido, los españoles é muehos de sus eonfederados volvian á más que de passo en hıyda, é los enemigos como lobos hambrientos, dando en ellos: estonces Hernando Cortés á grandes voces eomençó á deçir: aTener, tener"; é ya quél estaba junto al aģua, hallóla toda llena de los elripslianos é indios, é de tal forma, que paresçia que en ella no avian cehado una paja; é los enemigos eargaron tanto, que mataban de los españoles é se eehaban al ağua tras ellos, é ya por las ealles del agua venian canoas de los enemigos é tomaban vivos los españoles. É cómo la cosa fué lan de súbito, é vido el gencral que le mataban la grente, determinó de se quedar allí é morir peleando; y en lo quél é los que eon él estaban mís aproveehaban cra en dar las manos ¿ algunos peccadores cspañoles que so alugaban para (pure saliessen fueral, é los unos sulian lıeridos, é los otros medio alıogados, é olros perdidas las armas; $y$ (b) enviábalos luego que se fuessen adelante.

En este instante cargaban tantos de los contrarios que al general é otros doce ó quinçe que con él estaban, los tenian por todas partes fercados; é eómo él estaba muy metido en socorrer ál los que se ahogaban, no miraba ni se acordalua del daño que podia rescehir su persona; é ya le venian á assir çiertos indios de los enemigos, é le llevaran, si no fuera por el eapitan de çinquenta hombres quel gencral acostumbraba traer eonsigo, é por.un mançebo de su eompañia, ol qual despues de Dios le dió la vida, é por dárze. la, eomo valiente liombre, perdió alli la suya.

En este medio los españoles que salian desbaralados, ybanse por aquella ealçada adelante, é cómo era pequeña ć angosta é igual al ag̣ua (que los eontrarios la avian assi hecho de industria ) é yluan por ella tambien los desbaratados indios eonfoderados, y cran muchos, yba el camino tan embaraçado é tardaban tanto en andar, que los enemigos tenian lugar de llegar por el aģua de la una parte é de la otıa é tomaban é mataban quantos querian. É aquel eapitan, que estaba eon el general, que se deçia Antonio de Quiñones, disole: "Vamos, señor, de aqui, é salvemos vuestra pêrsona, pues que ya esto está de manera, ques morir desesperado atender; é sin vos ninguno dẹ nosotros puede escapar: que no es esfucrco sino poquedad porfiar aqui otra cosa. o É no podia acabar con el general que se fuesse de alli : é cómo esto vido, assiólo de los braços para que diessen la v'uelta; é aunque el general holgára más con la muerte que con la vida, importunado del 
capitan é ofros compañeros que allí estaban, se començaron á retraer, peleando con sus espadas é rodelas con los encmigos, que venian hiriendo é vençiendo con tanta grita é osadia que era cosa de maravillar ver su denuedo.

En este punto llegó un criado del general á calsallo é liço un poquito de lugar por el temor que, como ha dicho la historia, avian los indios á los caballos; pero luego desde una agotea baxa le dieron una lançada por la garganta, que le hiçieron dar la vuelıa muy mal herido. Y estando en este grand conflicto é rompimiento, esperando que la gente passase por aquella calçadilla á ponerse en salvo, $y$ el general con aquellos pocos que con él atendian deteniendo á los enemigos, llegó un moşo suyo con un caballo para que calıalgasse, porque era tanto el lodo que avia en la calçadilla de los que enIraban é salian por el agua, que no avia quien se pudiesse tener en pié sin mucho trabaxo, por los empellones que unos á otros se daban por salvarse. Y el general calsalgó; pero no para pelear, porque allí era imposible estando á caballo, porque si pudiera ser antes de la calçadilla, en una islela se avian hallado los ocho de caballo quel general avia dexado, é no avian podido haçer menos de se volver por ella, é aun la vuelta fué tan peligrosa, que dos yeguas en que yban dos criados del general, cayeron de aquella calçadilla en el agua, é la una mataron los indios, é la otra salvaron unos peones; é otro mançebo del general, que se deçia Cluripstóbal de Guzman cabalgó en un caballo que allí en la islcta le dieron para se lo llevar, en que se pudiesse salvar; é antes que al general allegasse, mataron á él é al caballo: la mucrte del qual puso mucha Iristeça en lodos quantos le conoscrian, porque era muy valiente é virtuoso mílite.

Con todos estos trabaxos plugo á Dios T0110 111 . que los que escaparon, salieron á la calle de Tacuba, que era bien ancla; é recogirla la gente, el general, con nueve des caballo, se puso en la retroguarda; é los enemigos venian con tanta victoria que se les figuraba que no avian de dexar aquel dia chripstiano con la vida. É retrayéndose el general lo mejor quél pudo, envió á deçir al thessorero é al contador. offiçiales de la liaçienda real, que se retruxessen á la plaça con mucho conçierto, é lo mesmo envió á deçir á los otros dos capitaines, que avian entrado por la calle que yba al mercado: é los unos é los otros avian peleado valientemente, é ganalo muchas albarradas é puentes, que arian muy bien çegado; é assi aquellos no res. - çibieron daño, al relraerse.

Antes quel thessorero y el contador se retirassen, los de la ciludad, por ençima de una albarrada, donde pelcaban, les avian echado dos ó tres cabeças de clurips: tianos, aunque por estonçes no supieron si eran de los del real del connendador Pedro de Alvarado, ó del general. É recogidos todos á la plaça; cargaban por todas partes tantos de los enemigos, que avia bien qué haçer en los desviar, é por lugares é partes donde antes deste desbarato no osaron esperar á tres de caballo é diez peones; y encontinente, en una torre alta de sus ydolos, que está allí junto á la plaça, pusieron muchos perfumes é sahumerios de unas gomas que hay en aquella tierra, que paresçen mucho al anime, lo qual ellos ofrescen á sus yelolos en señal de victoria; é aunque se procuró de les estorbar su çerimonia, no se pudo lacer, porque ya la ggente nuestra á más que andar se yluan al real.

En este desharato mataron treynta y çinco ó quarenta españoles é más de mill indios amigos de los confederados, é hirieron más de otros veynte cluipstianos, y el general salió herido en ima pierua. Perdióse un tiro pequeño de campo que 
avia llevarlo, é muchas ballestas y escopetas é olras armas.

Los de la cilulad, luego que ovieron la victoria, por harer desmiyar al alguaril mayor 6 al comentador Pedro de $\Delta \mathrm{l}$ varado y cnflarpuesçer los áminos de los espanoles, fodos los chripstiamos que tomaron, viros ó mucros, llevaron al catelulco, ques el mercado; y en unas torres altas que alli hay los sacrificaron desnudos, é los abricron por los pechos é les sacaron lós coraçones, para los ofresçer á sus ydolos: lo qual los españoles del real del comendador Nivarado pudicron bien ver del real, donde pelealan, y en los cuerpos desnudos é blancos que vieron sacrificar, conosçicron que cran chripstianos: é aunque por tal espectácu lo, espantable é inusitado á la vista de los españoles, ovieron grand tristeça, se recogieron á su real, aviendo peleado aquel dia muy bien é ganado quassi hasta el dicho mercado: el qual aquel dia $s c$ acaluara de ganar, si lanta desdicha no oviera intervenido. Este dia fuć el gुeneral más temprano á su real que otras veces, assi por lo que está dicho, como porque decian que los bergantines eran perdidos, prorque los de la cibdad con las canoas les tomaluan las espaldas; pero plugo á Dios que no fuesse assi, puesto que los bergantines é las canoas de los amigos se vieron en mucho estrecho, é tanto que faltó poco de se perder un bergantin é hirieron al capitan é macslre dél; y el capilan murió desde á ocho dias.

Aquel dia é la siguiente noche, los de la cibdad hiçieron muchos regogijos de areylos, que son sus cantares é bayles, é sonaban é tañian nuchas ljoçinas é atabales, que paresçia que se lumdia aquella repúl,lica infiel, del estruendo é fiesta que consigo tenian de placer, solemniçando su trimplio é victoria. É abrieron todas las calles é puentes deal aguar, como de antes las teuian, é llegaron á ponel muchos fuegos é velas de noche á dos tiros de ballesta del real del general; é cómo los nuestros salieron tan desharáados é maluractados y lierilos, é muchos desarmados, tenian nesçessidad de reposar é rohagerse. En este comedio los de la cibdad tovieron lugas de enviar sus mensajeros á muclias provinçias á ellos suljjclas, haciéndoles saber cómo avian avido mucha victoria é muerto muchos chripstianos, é que muy presto acabarian con los que avian escapado ó quedaban, é que en ninguna manera tratassen.paz con ellos. La creençia que Ilevaban sus mensajeros, eran las dos cabeças de caballos que mataron, é otras de los cluripstianos que padescicion; las quales anduvieron mostrando por donde á ellos les paresçió que convenia.

Esta jornada fué ocasion de poner á los çercados é rebelados en mạs contumaçia y esperança de la que antes tenian; mas con todo esto, porque los de Temistitan no tomassen más soberluia, nj conosçiessen flaqueça en los nuestros, cada dia algunos espainoles de pié é de caballo, con muchos indios de sus amigos, yban á pe. lear á la cibdad, aunque no podian ganar más de algunas puentes de la primera calle antes de llegar á la plaça. 


\section{CAPITULO. XXVII.}

Cỏmo los amigos confederados de Guarnaguacar vinieron á pedir socorro al general Hernando Corlés, è se lo envió; é de la victoria quel capilan Andrés de Tapia é los españoles ovieron contra los indios de Marinalco; é de la victoria que eontra los de Temistitaı ovo un capitan, hombre prinçipal é señor de los de Tascalleca, que se llamaba Chichimecatcele, el qual cra uno de los amigos confederados de los chripstianos *; é otras cosas que compelen ả la historia.

D to, que ya se saljia por toda la comarca, los̉ naturales de una poblaçion que se diçe Guarnaguacar, que eran subjetos á la cibdad é se avian dado por vassallos de Su Magestad é amigos te los españoles, vinieron al real, é dixeron á Ilernando Cortés cómo los de la polılaçion de Marimaleo, que eran sus veçinos, les lıaçian muclı daño é destruian su tierra ,é que en essa saçon se juntaban con los de la provinçia de Cuỹscon (ques grande) é querian ýr sobrellos á los matar, porque se avian dado por vassallos de la corona é ceptro real de Castilla, é por amigos de los españoles. É annque lat rola, ques diclia en el capítulo preçedente, era fresca é los chripstianos tenian más nesçessidad de ser socorridos que de dar socorro, puesto quel general tuvo mucha contradiçion en sus mílites é se lo estorbaban, diçiéndole que se destruia, si sacasse gente del real, non obstante esso despachó con aquellos que pedian el socorro oclienta peones é diez de caballo con el capitan Andrés de Tapia, al qual le encomendó mucho que hiçiesse todo lo que le fuesse posible por los amigros; é que pues via la nesçessidad pressente, no se detoviesse allá en ỹr é venir más de diez dias. É nssi se partió luego, é llegado á ma poblaçion pequeña, que está entre Marinal-

- De esle silio quiló Ovicdo lo siguiente: "É cómo los olumies enviaron sus mensajeros à pedir socorro al general contra los de Matalçingo è les euvió con gente al alguaril mayor, Gonęalo de Sanloval, é de la victoria que ovo contra los contrarios; co é Coadnaocad, halló á los enemigos que le estaban esperando; y él, con la gente de Coadnaocad é con la que llevaba, començó su batalla en el campo, é pelearon los nuestros tan valientemente que desbarataion los contrarios, y en el alcance los siguieron hasta los meter en Narinalco, el qual pueblo esti assentado sobre un mionte muy alto, é de lal dispusicion de terreno que los de caballo no pudieron allá sulir. Viendo esto el capitan, destruyó todo lo que estaba en lo llano; é avida esta victorja, tornóse al real con su gente dentro del término que le avia seydo dado, en los diez dias. En lo alto de aquella poblaçion de Marinalco hay muchas fucutes de muy buena agrua, y es muy fresca cosa todo aquel assiento, é muy fuerte.

En tanto que este capitan fué é vino. algrunos españoles de pié é de caballo, en compañia de los indios amigos confederados, entraban en la cibdad de Temistian hasta çerca de las casas grandes, que están en la plaça, é de allí no podian passar, porque los de la cibdad tenian abierta la calle de agua que estí í la boca de la plaça, y cstaba muy honda é ancha, é de la otra parte tenian una muy grande é fuerte albarrada: é allí peleaban los unos con los otros hasta que la noche los despartia.

é como vinieron à la obidiençia é serviẹio de Sus Magestades à amislad de los españoles los indios de Marinalco é Nalalẹingo é de la provinçia de Cuyscon, elc." 
Un señor de la provinçia de Tascalte. ca, que se diçe Chichimecatecle (del qual se la fecho mençion que llevó la tablaron (que se hiço en aquella provinçia para los bergantines), desde el prinçipio de la guerra residia con toda su gente en el real del comendador Pedro de Alvarado; é paresçiéndole á él que por el desbaratọ passado los españoles no peleaban como solian, determinó de entrar, sin ellos, con su gente á combatír los de la cibdad, é pensó un gentil ardid; é fr̃̄e que dexó quatroçientos fleclıeros de los suyos á una puente quitada de agua, bien peligrosa, que ganó á los.de la ciludad, lo qual nunca acacscria hacerse sin ayuda de los españoles; é passó adlelante con los suyos, é con mucha grita, apellidandóé nombran(l) á su provinçia é señor. Pelearon aquel dia muy reçiamente, é ovo de una parte é de otra muchos heridos. Los de la ciblad bien pensaron que los tenian asidos; porque como es gente que al retracr, aunfue sea sin victoria, siguen con mucha leterminacion é roluntad más que con liento é prudençia á los que se recogen, pensaron que al passar de aquella agua, londe tenian por sicrto el peligro, se avian de vengar muy bien dellos é de su atrevimiento. Mas para este efetto, en su socorro avia dexado Clichimceatcele junto al passo del agua los quatrocientos llecheros suyos, que se dixo dle susso; é cómo ya se venian retrayendo, cargaron los le la cibdad sobrellos muy de golpe, é los de Tascalteca, echándose al agua é con el favor de los suyos flecheros, passaron: é.los enemigos, con la resistençia que hallaron opuesta delante se quedaron, é aun no poco espantados de la osadia que avia tenido Chichimecatecle.

Desde á dos dias que los españoles volvieron tle la victoria de Marinalco, llegaron al real diez indios de los ofumies (que eran esclavos de los de la cibdad, é como la historia lia contado, avíanse dado por vassillos de Sus Mlagestarles, é rada dia.yban á pelear en ayuda de los espatñoles); édiseronal general llemando Corlés cómo los señores de la provinçia de Matalçingo (que son sus enemiggos é vosinos) les laçian guerra é les destruian sus tierras, é les avian quemado un pueblo é llevádloles alguma gente, é que venian destruyendo fuanto podian, é con intençion de venir á los reales é dar sobre los chripstianos en socorro de los de la cibdad, é para que los gercarlos saliessen é acabassen á los españoles: por tanto que los socorriesse é proveyesse en cllo to que convenia. A estos mensajeros se les dió crédito, porque de pocos dias antes cada vez que entraban los nuestros a pelear con los de la ciblad, los amena. calan los de dentro con los indios de aquella provingia de Matilçingo, de la qual, aunque ol gencral no tenia mucha notiçia, bien se sabia que cra grande é que estaba á veynte y dos leguas de los reales; y en la queja que costos estonges formaban de aquellos sus veçinos, pedian con alrincamiento socorro. E aunque to demandaban en fuerte tiempo, el general, por quebrar las alas í los de la cibdad, que tan á menudlo amenaçaban con aquellos, é mostraban esperanca de ser socorridos dellos, é socorro de ninguna otra parte sino dessos les podia venir, maridó al algruaçil mayor Gongalo de Sandoval que fresse allá, é dióle diez y ocho de caballo é çient infantes, en que avia solo un ballestero; é con esta companira é otra gente de los otųmies confederados siguió su camino, puesto que yban con peligro, é los del real no quedaban sin él; pero por no mostrar flacpuega, se tenia disimulaçion con los amigos é con lós enemigos; pero muchas é muchas reces deçian los españoles que pluguiesse á Dios que con las violas los dexassen solamente, é si riessen vençedores contra los de la cibdad, annque en ella ni en tocla la tierra 
no toviessen otro interesse ni provecho; de que se colige la aventura é nesçessidad extremada que tenian sus personas é viulas. Como to he dicho, lo escribió Ilernando Cortés á Cússar: é no es de dubdar que algunos, cansados de tan largos é continuos trabaxos é peligros lo dixessen, viendo las cosas encaminadas á lan dubdosa salida ó fin de aquella guerra; pero no son palabras estas para aquella generalidad con quél las diçe, pues en aquellos mílites é hidalgos que alli se halaron, avia personas que antes supieran padescer mill muertes que deçir tales palabras, ni mostrar lanta flaqueça como cllas significan; pero como dixo Catluilina: "No han siempre los mortales un mesmo ánimo ". Tornemos á la listoria.

El alguaçil mayor fuć acuel dia á (lormir á un pueblo de los olumies, que está frontero de Matalçingo. E otro dia siguicnte por la manana se partió dle allí, é fuć á unas estançias tambien de olumies, las quales estaban sin gente é mucha parte dellas quemadas. É adelante en lo llano, junto á uma ribera, vido mucha gente de guerra de los enemigos, que avian acabado de quemar otro pueblo; é cómo le vieron, comencaron á dar la vuelta animosamente contra los chripstianos. E por el camino que llevaluan los nuestros háçia ellos, hallááonse muchas cargas ile nuahiz é quartos é tasajos de niños assados, que para su provision llevaban: Ios quales por sc desocupar ć liuyr más sueltos, a vian dexado tal bastimento, cómo sinticron yr á los españoles. Passado un rio, en lo llano los contrarios ordenaron sus esquadrones; y el alguaçil mayor con los de caballo rompió por ellos é los desharató é puso en huyda: é siguicron el alcançe derechamente al pueblo de Matalçingo, que estaba çerca de tres leguas de allí, y entrados los de caballo, lasta los ençerrar en sus moradas, malaron é alancearon muchos; é allí esperaron á los españoles e. á sus amigos confederados, que yhan matando á los que los de caballo atajaban é dexaban atrís. En este rompimiento é aleance murieron más de dos mill hombres de los enemigos.

Despues que los españoles de pié llegaron á donde éstabañ los de caballo é los amigos confederados, que passaban de sessenta mill hombres, ordenaron sus esquadras é movieron háçia el pucblo, donde los contrarios hiçicron rostro, en tanto que las mugeres é los niños é sus haçiendas ponian en salvo en una fuerça que estaba alli junto, en un çerro muy al10; mas como dieron de golpe en ellos, hiçiéronlos retraer á la fuerça ques dicho de aquel monte, que era muy áspero é fucte, y entraron los nuestros en el pueblo, é robáronle é pusićronle fueggo por muchas partes: é cómo cra ya tarde, el alguaçil ma yor no quiso combalir el çerro, ć lambien porque la gente de los amigos ć los españoles estaban muy cansados , é todo aquel dia avian peleado. Los enemigos toda aquella noche estuvieron dando allaridos é gritas é tañendo muclıos atabales é tambores é voçinas.

Luego por la mañana, assi cómo el siguiente dia llegó, movió el alguaçil mayor con mucha órden é conçierto para subur el monte contra los enenigos, é no sin esperança que avia de serle muy resistido por la dispusiçion é áspera subilla de aquel çerro; ć cómo llegaron al pié dél, loparon çiertos amigos de los confederados que descendian de lo alto, é dixeron que no avia arrilua gente alguna, porque al quarto del alba se avian luydo los contrarios; y estando assi, vieron por todos aquellos llanos á la redonda mucha gente, y eran los otumics; é los de caballo, pensando que eran de los enemigos, corrieron contra ellos é alan- 
cearon tres ó quatro, $\dot{c}$ cómo la leneruar de los otumies es otra diferente de lá de Culua, ho los entendian mas de como colıban las armas en tierra, é se renian parạ los españoles : aquellos fuedaron heridos, pero bien conosçieron essos é los lemás que avia seydo por no los conoscer. Pries cómo los enemigos no esperaron, los españoles acordaron de se rolver por otro pueblo de los contrarios, que tambicn estaba de guerra, é los veçinos dél, romo vieron tan grande exérçito sobre sí, salicron de paz: y el alguacil maror "habló con el señor de aquel puelslo, é disolo que ya debia de saber quel general II rnando Corlés resçebia é perdonaba con buena roluntad á todos los indios, que venian á la obidiencia é serviçio del grand Rey de Castilla, aunque fuessen muy culpados, cnmendándose: por tanto que le rogaba que fuesse á hablar con aquellos de Matalçingo, para que se viniessen al general, é quél seria muy buen tergero para que los perdonasse é hiçiesse buenas obras, si ellos no perseverassen en sus crrores é desobidiençia. É aquel señor se profirió de lo haçer assi é de traer de paz assimesmo á los de Marinalco. É con esta victoria ya dicha se tornó el alguacil mayor á su real.

Aquel dia algunos españoles cslaban peleando en la cilsdad, é los cibdadanos avian enviado á deçir que fuesse allá la lengua ó intérprete del general, porque queriain hablar cn la paz; y era fingida é cautelosa su embaxada, segrund paresçió, porque nunca dixeron sino que si la paz. concediessen, avia de ser con condiçion que los chripstianos se fuessen de toda la ticra: Esto harian cllos á nn de entretener con sus fielsos traclos é mensijes algunos dias suspensos los combales, y entre lauto proveerse de lo que oviessen menester; pero nunca dellos se conosció que les faltalua roluntad de pelear contra los nuestros:

Í estando en esta plática liablando con la lengua, é muy cerca los nuestros de los enemigos, que no avia sino una puente quitada en medio, min vicjo de los de la cilulad, á la vista de todos, sacó de su mochila ó lasca muy de su sipaçio çicrtas cosas, que comió con um descuydo grande á lo que mostraba, por dar á entender que no tenian nescessidal de comida, porque los españoles é la lengua decíanles que allí se arian de morir de ham. bre, si nose dicssen. Los amigos confederados deçian á los chripstianos que aquellas paçes é pláticas eran falsas, é que no las creyessen é peleassen con ellos; mas aquel dia no se peleó más, porque los principales dixeron á la lengua que hablasse al general é le dixesse lo quellos deçian de parte de aquella cilsdad.

Desde á quatro dias quel alçuacil mayor cra renido de la provincia de Matalçingo, los señores della é los de Marinalco é de la provinçia de Cuyscon (que es grande é mucho señorio y estabain rebelados) vinieron al real é pidieron perdon de lo passado al general, é se ofresçieron de servir muy bien á Sus Magestades con toda lealtad é amistad con los chripstianos; y Hernando Corlés los resciljió muy bien é los envió contentos, y ellos cumplieron lo prometido de allí adelante. 


\section{CAPITULO XXVIII.}

En el qual la historia cucnta cómo se dieron á la cibdad de Temistitan çiertos combatcs, é se le hiço mucho daño, en que escotaron bien los contrarios la vietoria que avian avido, de que se traetó en el eapitulo XXV, é cuéntanse assimesmo algunos trançes é cosas señaladas conęernientes í la historia.

$\mathbb{E}$ In lanto quel alguacil mayor Gonçalo de Sandoval fué con parte del exérçilo contra los de Matalçingo, segund se diso en el capítulo de susso, acordaron los de la cibdad de Temistilan de salir de noche á dar en el real del comendador Alvarado; $\dot{a}$ antes que esclaresçiesse el quarto del alba dieron de golpe, é cómo las velas de pié é de caballo lo sinticron, apellidaron llamando al arma, é los que allí estaban arremelieron á ellos, é cómo sintieron los de caballo, cháronse al agua. En tanto llegaron los nuestros é pelearon más de tres lioras, é oyóse en el real del general un liro pequeño de campo con que tiraban los de Nrarado, por lo qual. á mucha priessa mandó IIcrnando Corlés armar la gente para entrar por la cibdad, porque acullá afloxassen los que peleaban contra el comendador Alvarado ; pero $\mathrm{co}$. mo los indios hallaron por aquella parte, que avian madrugado, tan fuertes é avisados á los españoles del otro campo, tornáronse á su ciludad descontentos é aun con daño suyo, Y el general entró á pelear á la cibdad, porque ya él é los que del desbarato passado quedaron heridos eslaban sanos; ć á la villa Rica avia aportado un navio del adclantado Johan Ponse de Leon, que avian desbaratado en la Tierra-Firme é costa del Norte, en la provinçia que llaman la Florida (ques una lierra que está en veynte y çinco gralos y medio Norte Sur con la isla de Cuba, é más septentrional (que Cuba), y este navio llevó çicrta pólvora é ballestas é otras armas, de que avia extrema nescessidad, de lo qual IIernando Corlés dió muchas grracias á Dios. É ya por aquella comarca á la redonda todo estaba en su faror, ć viendo que los çercados estaban tan conslantes en su determinacion de morir, no sabia el general qué medio tomasse para quilar á los españoles de tan conlínuos trabaxos é peligros, ni cómo aquella cibdad se dexasse de destruyr, que era de las más hermosas poblaciones del mundo é más de ver. E no aprovechaba deçir á los f̧ereados que no se avian de levantar los reales, ni los bergantines avian de cessar un punto de darles guerra por el agua é por la licrra, ni que avian destruydo á los de Natalçingo è Marinalco, é que en toda la tierra ya no les quedaba quien socorrerles pudiesse, ni Ienian de donde aver mahiz, ni carne, ni fructas, ni agua, ni otro mantenimiento. É quanto más estas cosas se les deçian, menos colsardia é scĩal de flaqueca se veia en ellos: antes paresçia que peleaban con mayor ánimo cadla dia.

Pủes cómo el gencral vidlo quán poco fructo haçian sus amoneslaçiones é quo que por halagos ni temores no. mudaban propóssito los contrarios, é que avia ya más de quarenta dias quel çerco se avia puesto, acordó de seguir un medio para seguridad de su gente, é poner en más estrecho á los cercados; é fuć que assi cómo fuessen ganando por las calles de la cihdad, assi fuessen derrocando Lodas las casas é allanúndolas de un lado é açera é de la otra parte: de forma que un passo no se diesse adelante, sin lo dexar todo asolado, é lo que cra agua çegarlo é lıaserlo tierra firme, amnque oviesse toda la dilaçion que se pudiesse seguir. É para esto liço llamar á fodos loz señores é 
prinçipales amiggos confederados, é díxoles lo que tenia acordado, é rogóles que liçiessen renir grente de sus laluradores, é que truxessen coas (que son unos palos de que se aproveclan lanto como los cavadores en Espatia con las hagadals); y cllos respondieron que assi lo larian de lumena volumlad, é loaron mucho el acuerdo que tomalsa, de lo qual no holgaron poco, poreque les paresçió que era manera é buen camino para que la ciludad se asolase de todo punto : que de cosa del mundo no pudieran ser mas contentos.

Entre tanto que lo ques dicho se conçertalsa é los zapadores é gastadores, como diçen en Italia, venian, passíronse tres ó quatro dias; é los de la cibdad creyeron bien que esse descanso no se les daba pór complaçerlos con la dilaçion, sino que se debian ordenar algunos ardides contra ellos. É concertados los espanoles é sus amigos, para que por la lierra é por el agra combatiessen, otro dia de mañana, despues de aver oydo missa, tomaron el camino para la cibdad; y cn llegando al passo del aģua é albarrada, que estaba cabe las casas grandes de la plaça, queriendo dar obra al combate, los de dentro dixeron que querian paz, é assi el general mandó que no peleassen los nuestros, é mandóles á decir á los contrarios que viniesse alli el señor de la cilsdad á le lablar, é que se daria úrden en la paz. É con deçir que ya le avian ydo á llamar, passó más de una hora; pero en la verdad no avian gana de la paz. sino dilatar la guerra, amnque les ylua mal della. É assí lo mostraron, porque cstando quedos los nuestros, començaron los contrarios á tirar flechas é varas é picdras, é cómo este escarnio se vido, combalióse el albarrada cé ganóse: y entrando en la plaça, estaba toda sembrada de piedras grandes, é debiera fallar algo desta obra, para lo qual los enemigos avian dado arpuclla dilaçion ques dicho, so color de tractar la paz. Éa aquesto les paresció á ellos un grand ardid, é no les era inúlil, porque los caballos no podian correr í causa de arjuellas piedras, portue por lo firme é llano los calballos cran los que lárian cruda guerra. Li lallóse assimesmo una calle cerrada con piedıa seca, é otra tambien muy llena de piedras, porque los caluallos no pudiessen correr por cllas. Pero desde arpreste dia adelante se çegó de tal forma aquella calle del agma que salia á la plaça, que nunca despues los indios la abrieron : é destle allí comenģaron á asolar poco á poco las casas é çerrar é çegar muy bien lo que se ganaba dellas é del agrua. É cómo aquel dia avia más de çiento é çinquienla mill homlsres de guerra, híçose mucha labor, é tornáronse al real: é los berogantines é canoas de los amigos hicieron muy bien su offiçio en grand daño de la cibdad, é quando fué liempo, se recogieron á repossar.

Orro dia siguiente por la mañana, é con la mesma órden ya dicha, entraron 'Ios nuestros en la cildad, é llegados á aquel circuylo é palio grande, donde eslán las lorres de los vidolos, mandó el general á los capitanes que con su gente no liçiessen sino cegar las calles del agua é allanar los passos malos que estalan ganados: é á los amigos confederados mandó que parle dellos quemassen é allanason las casas, é otros fuessen á pelear por las partes que se solia hager, é que los de caluallo guardassen por las espaldas. Cosa cra de mucha lístima ver lo cdeficado allanar y henchir con cllo aquillas canales é calles de ag̣ua.

El general subióse en mna torre la más alla de aquellas, porque los indios le conosçian é les pessaba de verle allí en aquello quellos tenian por sagrato é sancto lugar todo aguello; y él via mejor to que cada uno haçia, é proveia é haçia socorrer donde era nescessario, porque como pelealıan á la contínua, é por la ocu- 
pacion de los que entendian en ruynar las casas y henchir las calles del agua con lo derribado, no por esso dexaban los otros de combatirse, é á veces los contratios se relraian, é á reges á los nuestros convenia hager lo mesmo: é luego eran socorridos con tres ó quatro de eaballo que ponian muclıo ámimo á los confederarlos para revolver solure los enemigos. Desta mancra é por esta úrden se hiço, y entraron los nuestros en la cibdad çinco ó seys dias á reo: é siempre al reticar echaban los amigos adclante, é poníanse algunos de los españoles en selada en unas casas, é los de caballo quedaban atrás é fingian que se relraian de golpe, por sacar á los contrarios á la plaça. Con esto, é con la celadia de los cavalleros alanseaban algunos: 6 un dia de aquellos ovo en la placa sicte ú ocho de caballo, esperando que los enemigos saliessen, é cómo vieron que no salian, hicieron que se volvian; ć los de la ciblad, con recelo que á la ruclta los alançearian, como solian, estaban puestos solure unas parcoles é agoteas inumerables dellos: é cómo los de caballo revolvicion, hallaron que avian tomado en lo alto una ruelta de una calle, é no pudieron seguir lrás los enemigos que yluan por ella, é oviéronse le retracr; é los enemigos favoresçidos, é ufanos de averlos lecho volver atrás, seguran lan encarnirados como tigres; mas con tanto aviso que se acogian dónde no rescelian daño, é los de calsallo, quando tomaban á cllos, lo rescebian de los que estaban solre las paredes: é assi se reliraron con dos caluallos licridos.

Aquel dia, recogidos todos en el real, de cando bien seguro é llano todo lo ganado, quediban los cercados ufinos, i creian que de su temor se arian retraydo los españoles é confelerados, en lo qual inucho se engañaron. É cómo el general estaba muy pronto é soliçito por ver la definicion de aquel rerco, aquella noche TOMIO III. hiço un mensajero al alğtaçil mayor para que antes del dia viniesse allí á su real con juinge de cáballo de los suyos é de los del comendador Pedro de Alvarado, é assi lo hiço; y el general tenia alli do los de Cuyoacan otros veynte y cinco, que eran quarenta: é á diez dellos mandó que luego por la maũana saliessen con toda la otra gente, é quellos é los lergantines fuessen por la acostumbradi órden á combatir é derrocar é ganar é allanar todo lo que pudiessen, porque quando fuesse tiempo de retraer, el general queria $\mathrm{y}^{\mathrm{N}}$ allí con los otros treyntit de caballo. Ba dixoles que, pues sabian que tenian ganada é allanada mucha parte de la cibdad, que quanto pudiessen siguiessen de tropel á los encmigos hasta los encerrar cu sus fuergas é calles de agua, é que allí se detoriessen con cllos hasta que fuesse hora de retracrse; é quél con los treynta de caballo, sin ser vistos, se podria meter en la cildad en unas casas grandes que estaban cerea de las otras casas grandes de la plaça. É los españoles lo liçieron como les fuć ordenado; é á la una hora despues de medio dia, el general fuć á la cibdad con los treynta de caballo, é dexólos melidos en aquellas casas, y él se fué y se subió en la torre, como lo solia hager: y estando allí, çicrtos españoles abrieron una sepoltura, é hallaron en clla en piecas é joyas de oro más de mill é quinientos pessos de oro.

Venicla la liora del retracr, mandó el general que con mucho conçierto se començassen á retirar, é que los de cabaIlo, desque estoviessen retraydos en la placa fingiessen que aconctian é que no osaban llegar, é questo se hiciesse quando viessen mucha copia de gente contritria al rededor de la plaça, y en ella. Ordenado todo esto, fucsse el general á meter con los treyuta cavalleros en la çeladi, porque desseala que se hicjiesse muy bien; é retrayéndoso los españoles de pié 
é de caballo é sus amigos confederados, que esperaban con muchá rolumtad ver efellualo lo ques dicho, venian los enemigos con tanla grila é allharidos como si truxeran consigo toda la vicloria, que desscaban : é los dicz de caballo hicieron que arremctian á ellos por la plaça adelaute, é retruxéronse de golpe, como atemoriçalos, los mesmos gineles. I esto fecho dos veçes, los contrarios, no bien entendiéndolo, venian tan osados que él las ancas de los caballos llegahan, díndoles hasta los meter por la boca de la calle, donde eslaba la celada: é cómo la celada vido passar adelante los españoles é oyó soltar una escopeta, que era la señal para salir, conosçido que era ya tiempo, salieron con el apellido del glorioso $\Lambda$ póslol Sancliago, é començaron á alançear é derrocar é atajar muchos de los contrarios por la plaça adelante, y eran tomados de los confederados que seguian á los de caballo: de forma que desta çelada, é por la mancra ques dicha, mataron unás de quinientos indios, fodos los más de los prinçipales y esforçados é valientes hombres. Aquella noche tovicron bien de cenar los amigos confederados, porque todos los que se mataron, tomaron é llevaron fechos piecas, é se los comicron, sin buscar otra salsa de más apetilo ó sabor que su cnemistad é diabólica coslumbre.

Fuć ranto espanto é admiraçion la que tomaron los çercados en verse tan de síbito assi desbaratados, é aver perdido tales é tantas personas, que los que escaparon é los que estaban çercados quedalron como mudos, que no lablaron ni gritaron en toda cesa tarde, ni osiron asomar en calle ni açotea, donde no estoviessen bien seguros é á su salvo. É ya que era quassi de noche, que los españoles se retraian, los de la cibdad mandaron á çicrtos esclavos suyos que mirassen si los nuestros se retraian ó qué haçian; é có- mo se asomaron por una calle, arremelieron diez ó dogse de caballo, é signuiéronlos de tal mancra que nimguno se les escapó que no matissen. Colmarron los enemigos desta jornada tanto temor, que nunca más osaron entrar en la plaça ninguna de las veres que los chripstianos se rotiraron, ammque solo uno de caballo viessen, ni osalan ya salir á indio ni á peon de los nuestros, creyendo que de entre los piés se les avia de levantar otra celarla.

Esta victoria fué muy prinçipal en calidad, é muy provechosa para que aquella cildad más ayna se ganasse; porque los naturales della rescibieron mucho desmayo, é los confederados acrescentaron su ánimo y esfuerço en mucha manera: porque demás de quedar la victoria por nuestra parte, ningun peligro ovo en los nuestros, exçepto que al liempo que salieron de la celada se encontraron dos de los de caballo é cayó un escudero de una yegua, y ella fuésse derechóa los enemigos é flecháronla, é bien lıcrida, cómo vido su mal rescelimiento que se le haçia, se volvió háçia los cluripstianos, é aquella noclıe se murió. F́ aunque pessó dello á los cespañoles, porque los calyallos é yeguas les era mucho favor é ayuda, no fué lanto al pessar como si muricra en poder de los enemigos, porque resçebicran más plaçer, con verla en su poder muerta, que no pessar por los que les mataban dellos mesmos. Los bergantines é las canoas de los anigos hiçicron grand estrago en la cibdad aqueste victorioso dia, sin resçebir peligro alguno.

Pues cómo ya se mostrala claro que los çercados estaluan ameárentados, súpose de unos dos dellos (hombres de poca manera, que de noche se avian salido de la ciblad é se avian renido al real nuestro) que se morian de ham. bre, é que salian de noche á pescar entre las casas de la cilsdad, é andaban 
por la parte que della se les avia tomado, buscando leña é rayges é hierbas que comer. E porque ya estaban muchas calles de ağua çegadas é aderesçados muchos malos passos, acortó el general de entrar otro dia al quarto del alba é haçer todo el daño que pudiesse : é los berganlines salieron antes de ser de dia, y el general, con diez 6 doçe de calsallo é çiertos peones españoles, é con parte de los amigos, entró de golpe é púsose en çelada; é las espias que tenia puestas, assi como fué de dia, hiçieron señal que saliesse de la çelada, é dieron sobre grand moltitud de gente. E cómo eran de aquellos más miserables é que salian á buscar de comer, estaban desarmados y eran mucha parte de mugeres é muchachos, ó la mayor cantidad, é líçose tanto daño en ellos por todo lo que se podia andar de la ciludad, que pressos é muertos passaron de más de ochoçientas personas: é los bergantines tomaron assimesmo mucha gente é canoas que andaban pescando, é hiçieron en ellos mucho estrago. É cómo los capilanes é prinçipales de la cilsdad vieron á los cliripstianos é confederados andar por ella á hora no acostumbrada, quedaron tan espantados como de la celada passada, é ningomo osó salir á pelear. E assi los nuestros se tornaron al real, con liarta pressa é manjar para los amigos de los cuerpos de aquellos tristes prissioneros é muertos contrarios, porque cada qual de los confederados lleva- ba brago ó pierna ú otra parte de aquellos que murieron; é los que llevaban vivos para sus diabólicos sacrifiçios, tambien se los comian, despues que padesçian la muerte que les querian dar.

Otro dia siguiente entraron los nuestros en la cibclad, é cómo ya los confederados amigos vian la buena fortuna que se tenia para la destruyçion della, cra tanta la moltilud que de cada dia venian al real como amigos, que no tenian cuento. Is aquel dia se acabó de ganar toda la calle de Tacuba, é de adobar los malos passos della, en tal manera que los del real del comendador Pedro de Alvarado se podian comunicar con el real del general por la ciblad; é por la calle prinçipal que yba al mercado se ganaron otras dos puentes é se çegó muy bien el agrua, é se quemaron las casas del señor de la cilbdad, que era mançebo de edad de diez y ocho años, cuyo nombre era Guatinuçin. Este fué el segundo señor despues de la muerte de Montecuma. En estas casas tenian los indios mucha fortaleça, porque eran muy grandes é fuertes é çercadas de agua.

Tambien se ganaron otras dos puentes de otras calles que van çerea desta del mercado, é se cegaron muchos passos: de manera que de quatro partes de la cibdad las tres estaban ya ganadas y en poder de los nuestros; é los indios no haçian sino retraerse háçia lo más seguro é fuerte, que era á las casas que estaban más metidas en el agna. 


\section{CAPITULO XXIX.}

Cimo el general Iternando Corlés acordó de prosegnir en los combates de la cibdad por su parte, é lo mesmo latia el comendador Peelro de Avarado por la suya i los otros eapilanes; é cumo se ganu el mercado, plaça prinçipal de Temistitan; c cómo en otro din, prosiguicudose el combatimiento, se ganó otro barrio; éde otras cosas notables é convinientes al discurso de la historiat.

\section{.} a mi, que assi como Matico Tullio Ciçeron deçia al pueblo romano, drespues del castigo de la conjuraçion de Cathilina: "Por estas cosas grandes ; oll romanos! yo no pido de rosotros algum premio de virtud, ni alçuma enseña de honor, 6 algum monumento de loor, excepto vuestra perpélua memoria de aques: la jornada. To cur vucstros ánimos quicro que scan mis triumphos pucstos: todos los ornamentos de honra, fodos los monuzuentos de gloria todas las insignias de alibança sean para mí en ruestros ánimos colocadas: porque ninguna cosa que mula sea, ninguna que calle, ni cosa de tal suerte que los indignos puedan conseguir, us Jemando. De Ia memoria ruestra joh lomanos! de la memoria ruestra sean mis cosas nodridas: crescerán por las palalbras, é lurarán por las listorias, tomando sicmpre una mayor fuerega. etc. ${ }^{4}$ sssi este invieto capitan lo debe pedir a ioda la nacion de Espana por sus grandes fechos en esta empressa olnados, é acabados é perfeçionados é concluy dos por muy coñaladas batallas é victorias que oro en fivor de la fée é república, é cresçimiento de la religion chripstiana, en serviçio de su Rey é corona é çeptro real de Castilla, (2) ampliamiento de la honra de su patria a memoria de su proprio linage de los Corteses, y en sublimaçion y ensalçamiento de su mesma persona, é ormamen10 destas historias. I assi deben estar escriplas, no tan solamente por muchos

1 Salustio, De bello Cathilinario.

2 Qui timebant futurum periculun diluvii el ignis, : 11 Tubalcain carlem artesin duabus columnis auclores é reros historiales. Ni solamente esculpidas en marmóleas columnas, como los antignos antes del dilurio escribieron los estudios y piencias de las antiguas artes, porque no se perdiesse la memoria dellas, como lo escribe Josepho 2; mas es muy justa cosa que en la memoria de los que viren estén escriptas las lacañas é fechos memorables de llernando Cortés, é quellos las enseñen á sus liijos, é aquellos á los que prosedieren deIlos, é dle una elad á otra é de tiempo en tiempo siempre estén acordadas é perpetuadas en la mente de los humanos, allende de lo que puede estur ó quedar escripto por mí ó por ofro más competente historiador; porcue son cosas raras é peregrinas, è no tienen semejança ni comparaçion con exérçito ni serco alguno de aquellos que por unu famosos cstín escriptos de los passados, considerando las calidades é assiento é gente- de Temistilail.

Ya se sabe que en Sagunto, quando la destruvó Aníbal, los que estaban cercados tomaron su oro é plata é joyas, é fecha ma loguera en la plaça: lo quemaron, ćalgunos se echaron con ello en el fuego, como más largamente lo escriben Tito Lir io é Plntarco ${ }^{3}$ é otros fanosos listoriales: ni aquel osado morir de los numanfinos. quando Sçipion Africano destruyó aquella cibdad, la qual debaso del yựo á muchos romanos avia fecho passar ${ }^{4}$ I en aquella suma de historias acumuladas

\footnotetext{
seulpsit, eic.

3 Tito Livio, lib. V, cap. 13, récada lil.

i Vrgecio, lib. I, cap. 15.
} 
por Leonardo Aretino, bistorioggrapho, el 'pual tractado se intitula el f́guila V'olante', diçe que la nescessidad é hambre de los sereados fué tal, quel padre comió el hiijo, é la madre la lija, y el marido la mugrer: pero en este sereo de Temistilan, an esso del comer arne liumana, otras cosas de más espanto aremos tractarto lussla aquil é cada dia y en muchas partos destas lndias se ha guartado essa feroçíssima, crucl é desapiadada costumbre, segund el letor puede colegir destas listorias. Tú rose por ahominable juramento é eonfederacion ó seguridad para la seereta conjuracion de Cathilina, mezclar en ol rino que dió á sus consortes á beber sangre liumana ${ }^{2}$; y entre los indios de la Nueva Esprina, y con muchas partes de la Tierra-Firme, no con vino ni otra cosa mezclada, sino por un suavíssimo cordial é goloso brevage, sola clla, la beben de sus enemigos, é aun de los amigos é naturales, en sus sacrificios execrables é malditos.

No curemos de hablar ni tener en tanto aquel sereo famoso troyano, quando dqamenon é los griegos destruyeron aquella polerosa cilsdad, porque fué un cerco grande é de mucho tiempo è años, é no toslos los que hablan en esa historia son de un acuerdo ${ }^{3}$. Josefo ó Josippo, sarerlote de los rle Ilierusalem, hijo de Mathatia, escribió en griego dos libros contra Ippion, sramático alexandrino, y en el prohemio de su tractado dire: "Sepan los griegos rue tarde y eseasamente pudicron conoserer la natura de las letias, ca el muy antiguo uso dellas se cree aver los griegos alcançado de los fénises, é han por gloria que las aprendicron de Carlmo; mas aum ninguno podria moslrar algo de atquel tiempo por escripto, ni en los templos ni en los públicos anathe-

1 Cap. 93.

2 Salustio, De bello Cathilinario.

3 De bello Graecorum contra Troyanos. Dares mas (quando ovieron de militar contra los troyanos, y en los negrocios de la guerra se detuvicron tantos años). Despues to vicron griand quistion é contienda si se aprovecharian de sus letras, é la verdad más pudo alcancar quel uso de las letras moderuas aum estonces no le fué conoscido. É aquesto consta, porque entro los griegos ninguna escriptura poélica absolutamente se lialla más vieja que la de Homero, y él es manifiesto arer serdo despues de las guerras de Troya. Ni aqueste dexó su poema en letras; mas fué la memoria dello guardada en cánticos, é despues fué compuesto. Y por aqueste he visto mucha disonançia en aquel pocma. * Todo esto es del auctor alegado.

$\mathrm{Ni}$ se delse creer que Pauphis, isla de Eggipto, que agora se llama Danmiala (y está en la hoca del Nilo) oviesse liallado la invencion del papel, pues que estonçes (digo quando lo ques dicho de Troya) no avia letras ${ }^{4}$. No es menester tampoeo Irace á comparaçion del çerco de Temistitan la destruyçion de Cartago é rençimiento de Aníbal; ni aquellas duras é serviles condiçiones en que puso Scripion Africano aquellas gentes, con mucho número de muerlos é prissioneros, pues que Plutarco é Tito Livio lo escriben ${ }^{5}$. Tornemos á nuestra labor é listoria pressente, que no es inferior de ninguna de laś que lıe tocado de susso, ni de todas las que se callan ó se podrian deciro que escriptas sean; pues que aqui, demás de la rerdadera relaçion é grandeça de lal empressa, no lay menos, sino mucho más de que se maravillen los hombres.

Otro dia siguiente, despues de la victoria, de que se tractó en el capílulo antes deste, fuć dia del apóstol Sanctiagro, y el general Hernando Cortés entró en la cili)-

\footnotetext{
frigio, d Dielis erelense.

4 El Aguila Volante, lił. I, cap. 33.

¿) Decada III, lib. X, cap. 3 é dende adclanlc.
} 
dad por la órden acostumbrada, é signió la calle grande, que ylua á dar al meleado: é ganóse una calle muy ancha do agua, en que los çercados pensaban que tenian mucha seguridad, amnque fuć licn defendida é se tardó en el combate, é fué peligrosa de ganar; é cómo cra-muy anclia, en todo lo restante de aquel dia 110 se pudo acabar de çegar, para que los de á caballo pudiessen passar de la otra parte. E cómo todos los nuestros estaban á pić, é los indios vian que los cahallos 110 avian passado, vinicron de refresco mucha cantidad dellos muy lucidos; é cónuo se les hico rostro é de nucstra parte ivia muchos hallesteros, dieron la vuclta á sus allarradas é fucresas; pero no sin lleval muchas sactis atravessadas por sus personas mal heridos. Demás de lo qual Ya todos los otros españoles de pié llevahan picas luengas, quel general avia fecho haşer, despues que le desharataron, y csto fué cosa muy prorcchosa é nueva á los indios cercados. Aquel dia por los lados de la una é de la otra parte de aquella calle prinçipal no se entendió sino en quemar é allanar casas, y era una grand lástima á los españoles verlo, de pura é humana compasibilidad, é mucho regoçijo é plaçer para los indios confederados; é cómo convenia que assi se hiçiesse, proçedióse en tal ruyna, arrasando é ponicndo por el suclo muy hermosos rdeficios: los de la cilodad, lastimados con tal vista é tanto estrago, decian á los indios confederados estas palabras: "Daos prissa, é no hagays sino quemar é destruyr nuestras casas: que nosotros os las laremos tornar á haçer de nuevo todas essas labores, é rosolros lo avés de pagar; porque si somos vençedores, ya sahés que ha de ser assi, é si vençen los chripstianos, las avés de haçer para cllos. " En esto postrero açertaban más en su adevinar, aunque los indios las oviessen de harer, pues que los mesmos rercados lis tornaron á rendeficar, ó los que dellos no murieron.

Otro dia adclante por la mañana entraron los nuestros, como lo acostumbraluan en su órden, éltegatos á la calle del agrua que avian comengado á ceran el dia antes, hallílronla como avia quedide; a passáton adclante dos liros de ballesta, é vanáronse dos açequias grambles de agua que tenian los contrarios rompidas en lo sano de la calle mesma: é llegaron á una torre pequeña de aquellos yilolos dessa gente, é hallaron allí, como trofeos, colqarlas çicetas cabeças de los chripstianos que les avian muerto, lo qual no fué poco dolor para los españoles verlo. Deste aquella torre yha la calle derecha (que era la mesma, en que los nuestros estaban) á dar á la calçada del real del alghuaçil mayor Gonçalo de Sandoval, é á la mano izquierda yba otra calle á dar en el mercado, en la qual ya no avia agua alguna, excepto una rue se les defendia; é aquel dia no passaron de allí, aunque pelearon mucho con los enemigos, é recogiéronse los españoles al real sin peliggro. é no con las requiestas que solian ser seguidos.

Adclante otro dia, estando aderesçando é armándosc los nuestros para entrar en la cibdad, á las nueve loras del.dia, vieron desde el real que salia mucho liumo de dos torres muy altas que estaban en el catebulco, alias tiangriez, ó mercado de la cibdad, é no podian pensar qué cosa fuessen: é cómo páresçia más que salumerios que acostumbran hacer los indios á sus ydolos, sospechóse que la gente del real del comendador Alvarado avrian allegadó allí; é aunque assi cra la verdad, no lo podia creer el general é los que en su real estaban. É çicrto aquel dia el comendador Alrarado hiço su offiçio de prudente capitan é de muy valiente cavallero, é á los que con él estahan no les quedó cosa por liaçer que á denodados mílites y esforçados.soldados se pueda loar: 
é avia muchas puentes por ganar é albarradas hácia la parte del general: jero cómo el capitan Alvarado vido que por la parte de Ilernando Cortés yluan estrechando á los eneurgos, trabaxó todo to que le fué posible por entrarles el mercado, poryue allí tenian puesto torlo el caudal de su esperança é fuerça é resistençia; pero no pudo más de llogar á vista dél, é ganarles algunas torres é otras muchas que están junto al mesmo mercado, ques tanto quassi como el çircuyto de las muchas torres de la cibdad: é los de caballo se vieron en liarto trabaxo, é les fué forcaclo retracrse; é al retraer, les hirieron tres calabllos. E assi se volvieron Pedro (le Mrarado é sn gente á su real. Los del campo del general no quisieron aquel dia ganar una puente é calle de agua, que quediba no mís para llegar al mercado, salvo allanar é regar torlos los malos passos; ć al retracrse, acometieron reçiamente los enemiggos, pero fué con daño é muerte de algunos dellos mesinos.

Otro dia, luego en amanesçiendo, entró el general con su gente é órlen, como lo acostumbraba, á combatir la ciblad, é cómo no ayia por ganar hasta llegar al mercado sino una traviessa de agua con su alharrada, que estaha junto á la torrecilla ques dicho, comencíroula á combatir; é un alferez é otros dos ó tres españoles echáronse al ağua, é los de la cibdad desampararon luegro el passo, é començóse á çegar é aderesçar para que los de caballo pudiessen passar. Y estándose aderesçando, llegó el comendador Pedro de Alvarado por la mesma calle con quatro rle caballo, é fuć sin comparacion el plaçer que ovicron la grente de su real $y$ el general é los suyos con verse allí, porque cra camino breve para darse conclusion en la guerra en que estaban: é Pedro de Avarado dexaba recabrio de gen- te á sus espaldas é lados, assi para con. servar lo que avia ganado, como para su defensa. É cómo luego se aderescó aquel passo, el general con algunos de caballo se fué á ver el mercado, é mandó á su gente que no passasse adelante de aquel passo; é despues que andovieron passcándose por la plaça lo que les plugo, mirando los portales tlella, los quales por las açoteas ó terrados estaban llenos de los enemigos, que cómo era muy grande la plaça é vian andar por ella los de cabaIlo, no osaban Ilegar. Y estonçes el general subió en aquella torre grande que está junto al mercado; y en ella tambien y en otras hallaron ofresçidas é puestas delante de los ydolos las caberas de los chripstianos que les avian muerto, é de los indios de Tascalteca, sus amigos, entre los quales siempre de mucho tiempo ać́ ha arido antigua é cruel enemistad. É desde aquella torre vido el general to que estaba ganado de la cibdad, que era de ocho partes las siete, é consideró que tanta gente de los enemigos no era posible sofrirse en tanta angostura, mayormente que las casas que les quedaban eran pequeñas, é cada una sobre sí en el agua. Demás desto la hambre cra grandíssina, é por las calles hallahan roydas las rayces é corteças de los árboles; é de compasion dicllos dexó de los combatir por algun dia, con pensamiento de moverles algun partido para que no muriesse tanta moltitud de gente, de quien avia mucha lástima; é aun porque le quadraba á su condiçion aquel dicho, que atribuye Salustio á Cathelina, en una oraçion que diçe "que vengarse de los viles hombres, no puede ser loor alguno á las personas ilustres ". É aunque allí en Temistitan estaban con el señor de la cilsdad particulares é prinçipales señores é animosos varones, cran ya muy pocos al 
respecto de otro número de gente quassi sin cuenta (pure quisicra el reneral que escapáran del cuchillo é de la rabiosa garganta de los amigos conferderados, que sabia (fue arian de comer quantos pudiessen aver de los cereados, (jue ál sus manos viniessen, mucrtos ó vivos, sin perdonar á hombre ni á mugerer ni edad algyma. La por excusar esto, siempre el treneral haçia sus diligençias, acometiendo con la paz á los contrarios: los quales respondian que on ninguna mancra se avian de dar, é que uno solo que dellos quedasse, avia de morir peleando: é que de torlo lo que tenian, no avian de aver dello los nuestros cosa alguna, é que lo avian de quemar y echar en el agua, donde unnea paresgiesse. Y el general. por no dar mal por mal, disimulaba todas acpuellas palablas é dilataba el combate: é cómo ya avia poca pólrora, aríase puesto en plática alswumos dias antes que se lirgiesse un trabuco, é aunque no eran suficientes maestros para tal obra, ricrtos carpinteros se ofrescieron de haçer uno pequeño: é lien pensaba el general é otros que no arian de salir con la obra: pero consintió que se hiciesse. I en aquellos dias que estaban tan arrinconados é apretados los enemigos, acalóze de luaçer aruel artifregio. lial qual era, é llevóse á la plaça del mereado para lo asentar en un edeficio, que como teatro estaba de cal é canto edcficado en medio della, quadrado, de dos estados y medio de altura, é de esquina á esquina aria treynta passos: el qual tenian los indios para quando algunas fiestas luaçian ó juegos, en que los repressentadores dellos se ponian, porque toda la gente del mercado é los que estaban cu baxo y enrima de los portales pudiessen ver lo que lraçian. Traydo alli, tardaron en lo asentar tres ó quatro dias; é los indios amigos amenaçaban con aquel instrumento ó artifiçio á los de la cilulad, del efelto del qual tan ignorantes eran los unos como los otros; mas decian á los de la cildadal ciue con aquel avian de matarlos á todos, sin que alguno quedasse vivo. Eitundue ofro fructo no hiricral, como no lo hicgo, sino c) temor fuc con esto se ponia á los rerre cados, pensala el general que cra hato é que se dieran: pero lo mo é lo otro çessó, porque ni los carpinteros salieron con su iutençion, ni los de la cildad, anrique tenian trmor, movieron algun partido ni aceptaron los que se les movicron, sino siempre se estovieron constantes parra no se dexar, captivos ni libres, sojuzgar ni rehusar la muerte. $\mathrm{E}$ assi se disimulo li falta de trabuco ó quarlago, dándoles í entender que de compasion no querian los nuestros españoles acaluarlos de matar.

Otro dia despues que fué assentido el trabuco ó disparate, tornó el greneral á cutrar en la ciludad, ć cómo avia tres ó quatro dias que no la combatia, hallaron lás calles por donde nuestra gente yba llenas de mugeres é niños é otra chusma plebea é miserable, que se morian de hambre, é salian traspassados é flacos, que era mucha lásima verlos. I el general mandó á los amigos confederados que no les hiçiessen mal; pero la gente de suerra no salia lomble dellos á donde pudiesse resçelvir daño, aunque los vian estar ençima de las acoleas, culbiertos con unas mantas que usan de algodon, é sin armas. Hiço el general este dia requerir á los conurarios con la paz, é las respuestas que daban cra dilatar é cautelas sin conclusion; é cómo lo más del dia se gastó en esto, envió á decirles que los queria comhatir, é que hiçiessen retraer toda su gente, si no que daria liçencia á los amigos para que los matassen. Ellos dixeron que querian paz, é fućles replicado quel general no via alli al señor de la ciblad, con quien se avia de tractar, é que viniesse, quél lo aseguraba, é lablarian on la paz: é cómo todo lo yue los contrarios deçian eran fiçiones é lurra, é todos esta- 
ban aperçebidos, despues de los aver muchas veçes amonestado, por los poner en mayor nesçessidad, mandó el general al comendador Alvarado que con toda su gente entrasse por la parte de un grand barrio de más de mill casas que los enemigos tenian, y él por otra parte á pié entró con la gonte de su real, porque á caballo no podian por allí aprovechar ; é fué tan reçio el combate, que se ganó todo aquel barrio con tanta sangre é mortandad de los enemigos, que passaron de dose mill personas los que allí perdieron las vidas: é usaban de tanta crueldad los confederados que no perdonaban criatura, aunque más reprendidos eran de los chripstianos, é decian quellos haçian lo que los vençidos hiçieran, si vençicran.

Otro dia siguiente, tornando el general á la cibdad, mandó que no peleassen ni fuesse fecho mal á los enemigos, los quales, como vian tanta moltitud de gente sobre sí, é conosçian que los yban á matar sus vassallos é los quellos solian mandar, é vian su extremada nescessidad é que no tenian donde estar, sino sobre los cuerpos muertos de los suyos, con desseo de verse ya fuera de tanta desventura é calamidad, deçian que por qué no los acababan de matar ; é á mucha pricssa dixeron que llamassen al general, que le querian hablar. É cómo los españoles dessealsan que esta guerra se concluyesse é avian lástima de los ençerrados é les pessaba de tanto mal como resçelsian, pensaron que querian paz, é hiçieron que Hernando Cortés se llegasse á una allarrada, donde çicrtos prinçipales estaban, que le querian hablar ; ć aunque él conosçia que aquel raçonamiento avia de ser tan sin provecho como los passados, fué allá, puesto que sabia quel no darse aquella gente consistia solamente en el señor dela y en otros tres ó quatro prinçipales de la cilddad, porque los demás muertos ó viros desseaban ya verse fuera de allí. ToNo 111 .
Llegado el general á la albarrada, dixéronle que pues ellos le tenian por hijo del sol, é que su padre, en tanta brevedad como es un dia é una noche, daba una vuclta á todo el mundo, que por qué él assi brevemente no los acababa de matar é los quitaba de penar tanto, pues que ya ellos tenian desseo de morir é yrse al çielo para su Ochilobus, que los estaba allá esperando para descansar. (Este ydolo assi llamado Ochilobo, es el que en más veneraçion aquella gente ticne.) El general les respondió por la lengua ó intér petre muchas cosas, para sosegarlos é atraerlos á que se diessen; é ninguna cosa aprovechó, aunque en los chripstianos vian muestras é señales de paz é buena amistad: ni jamás vençidos, llegados a tanta nesçessidad, mostraron á los vençedores !anta constançia de ánimoś cnduresçidos é obstinados ó remisos para morir de grado, pues que llegados á tal estado, no se conosçian flaqueça ni poquedad en ellos. Y el general, viendo aquesto, habló con un prinçipal dellos que estalsa presso dos 6 tres dias haçia, el qual avia prendido un indio de don Hernando, señor de Thesayco, peleando en la cibdad; ć aunque estaba muy herido, díxole si se queria volver á la ciludad, é respondióle que sí : é cómo otro dia volvió el general á la cibdad, envióle con çicrtos españoles que le entregaron á los enemigos çercados. É á este aviale IIernando Cortés hablado largamente, para que con el señor é los otros prinçipales tratasse la paz, y él prometió de haçer en ello todo lo que posible le fuesse; é los de la cibdad lo resçibicron con mucho acatamiento, conı á persona prinçipal que entrellos era, é lléváronle delante de Guatimuçin, su señor, y él le comenéó á laablar solre la paz; é á pocas palabras que ovo dicho en el caso, le mandó callar, é luego le hiço matar ć sacrificar, como á enemigo, aunque era hombre valeroso é de estimaçion, é de 53 
mucha cuenta é valor. De manera que la respuesta quel general esperaba fué de otra forma que la expiriençia é cruckdad obró en aquel señor, porđque en el instante que se hiço aquella crula injustiçia ques dicho, rinieron los contrarios con grandes allaridos, diegiendo que no querian sino morir é acaluar lilsres, tirando muchas varas é fleclas é piedras, é como Icones muy dañados é ficros, peleando: é mataron un caballo con un dale, que uno traia feclıo de una espada de las nuestras; pero al fin les costó caro, porque muricron muclıos dellos; é assi nuestra gente se tornó aquel clia á sur real.

El dia que á esto proģedió, tornó el ge. neral á cintrar en la cibdad, é ya cstaban los encmigos tales é tan castigados, ó mejor diçiendo tan ransados, que de noche nalsan quedar muchos de los confederados amigos de los nuestros. É llegados á vista de los contrarios, no quiso el general que peleassen, é andúvose passeando por la ciblad, porque tenia una poca de esperança que cada hora se avian de salir á poner en sus manos; é por los convidar á ello, llegóse cabalgando á par de una albarrada que tenian bien fuerte los contrarios, é llamó á çiertos prinçipales que estaban allf en guarda. los quales ef conosçia, é dixoles que pues se vian tan perdidos, é conoscian que si él quisiesse, dentro de uma liora no quedaria persona dellos, que por qué no le renia á liablar Guatimuçin, su señol"; quél le promelia te no laçerle ningum mal é que queriendlo él y ellos venir de paz, serian mıy Jien resçebillos é tractarlos: é passó con ellos otras raçones, con que los provocó á muclas lágrimas; é llorando, le respondieron que bien conosçian su yerro é perdiçion, é quellos querian yr á lablar á sur señor é que no se fuessen de allí, porque volverian á darle la respuesta. E assi se furon é tornaron desde á poco, é dixeron que, porque ya era tarde, su señor no avia venido; mas que otro dia á medio dia vernia en lodo caso á le hablar en la plaça del mercado. É con esto el general se tornóá su real, é mandó que pạara otro dia toviessen aderesçado allí en aquel edefiçio quadıado, que esı́a alto y en meclio de la plaça, para el señor é prinçipales de la cibdad, un estrado como entre aquella gente se acostumbra, é que tambien les toviessen aderesçado de comer; é assi se puso por obra é muy complidamente, seghind la oportunidad del tiempo.

\section{CAPITULO XXX.}

Fn que se tracla cómo el general llernando Corlés combatió la grand cibdad en la parle que estaban relraydos, é murieron en un dia más de quarenta mill personas de los enemigos; é cómo olro dia siguiente mataron otros muchos, é fué tomada é ganada la cibdad de lodo punto, é quedó Temistitan por de Sus

Magestades, éfué presso el señor della, llamado Guatimuçin, con otros capilanes é prinçipales.

\section{E} stando las cosas en el estado que se dixo en el capítulo de susso, otro dia sigruiente por la mañana, el general é sus cortesanos lá los quales, como en otro lugar lo tengo dicho, se les dá este nomlore derivado del que su capitan tiene de Cortés, por mucha gloria dél é dellos é desta cmpressa), juntados los más prinçipales del exérçito, ovo su acuerdo; éman- dó el general que la gente torla estoviesse aperçebida, porque si los de la cibrlad acometiessen alguna trayçion, como gento desesperada é que estaba çerca del extremado fin rle su vençimiento, hallassen la resistençia é castigo que conviniesse. $\mathrm{E}$ no descurydó que les dliesse lugar para sı defensa ni para ofender á los nuestros; y en espeçial con el romendador Pedro de 
Mlvarado, que alli estaba comunicado é avisado de lo mesmo, fueron al mercado, é luego el general envió á deçir á Guatimuçín cómo le estalsa esperando, y él no acordó de venir; mas envió çinco varones de aquellos más prinçipales señores de la cibdad, y estos dixeron que su señor los enviaba á rogarle con ellos que le perdonasse porque no venia, porque tenia mucho miedo de parescer ante él, é que demás desso estaba mal dispuesto, é quellos estaban allí, é que viesse lo que mandaba, quellos lo harian. E aunque el señor de la cibdad no vino, holgó mucho el general é los españoles que aquellos prinçipales oviessen venido, porque paresçia que era encaminarse los negocios á buena conclusion é paz: é fueron muy bien resçebidos, é mandóseles luego daır de comer é de beber, en lo qual mostraron bien el desseo é nesçessidad que deIlo tenian.

Despues que ovieron comido, díxoles el general que hablassen á su señor, é que no toviesse temor alğmo; é que le prometia é daba su fée é palabra que, aunque viniesse, no le seria hecho enojo ni ultrage en cosa del mundo, ni seria detenido: é que sin su pressençia, en ninguna cosa se podia dar buen assiento ni conçierto para la paz é para quél quedasse bien tractado; é que supiesse que entre los chripstianos eran mucho estimados é presçiados los cavalleros é prinçipales é capitanes, que se sabian defender é haçian su deber con las armas en defensa de sus personas é lierra; é quél avia fecho todo lo posible, como buen capitan, é no por su culpa, sino por su fortuna avian llegado las cosas de aquella guerra al punto en que estaban tan á su desaventaja. E que ya de alli adelante era tentar á Dios é querer morir como desesperado, é que debia de aver piedad de su gente é no dexarla destruyr totalmente, 6 que esto seria de más loor, pues via que las cosas estaban tan al cabo, é no tenian remedio mayor ni tan seguro como obedesçer é venir á la obidiençia del Emperador Rey, nuestro señor, é remitir su persona con todo lo demáts en sus reales manos é clemencia: é que fuesse çierto que por esta via él acertaria, y esto cra lo que le convenia para que con él se toviesse toda templança, é que fuesse bien resçebido é tractado; é que venido á le lıablar, se daria tal assiento quél quedasse contento é sus vassallos remediados. É dicho esto mandóles dar algunas cosas de refresco que llevassen para comer, é prometieron de haçer en el caso todo quanto pudiessen, é con esto se partieron. É desde á dos horas tornaron con la respuesta, é truxeron al general unas muy gentiles mantas de algodon de las quellos usan; y en pocas palabras se resolvieron, concluyendo que su señor Guatimuçin en ninguna manera vernia ni queria venir, é que era excusado hablar en ello: á lo qual el greneral les tornó á repetir quél no sabia por qué causa se reçelaba de paresçer ante él, pues via que á aquellos quél sabia que avian seydo los causadores principales de la guelra, é los que la avian sustentado, les laçian buen tractamiento é los dexaban yr é venir seguramente, sin que les fuesse hecho enojo ni descortesia alguna: que les rogaba que le tornassen á hablar é mirassen mucho en esto de su venida, pues que á él le convenia, é que por su provecho del mesmo Guatimucin el general lo hacia, porque oviesse lugar cómo él fuesse acogido é mirado como era raçon que tal señor lo fuesse. Y ellos respondieron que assi lo harian, é olro dia volverian con la respuesta ; é con tanto se fueron, é tambien los nuestros se recogieron á su real.

Otro dia, Isien de mañana, arfuellos prinçipales fueron al real é dixeron al general que se fuesse á la plaça del mercado de la ciludad, porque su señor le 
queria yr ál hablar allí é creyendo que luera assi, cubalgó con sus capitanes é hombres pringipales, é llevó la grente que le páresçió. É llegados á la plaça, estovieron más de tres horas esperando; pero nunca quiso renir ni paresçió el Guatimugin: é cómo el general vido la burla que dél se liaçia, é que ya crà tarde é no venian los mensajeros ni el señor, envió á llamar á los indios confederados amigos, que avian quedado á la entrada de la cilydad quassi una legua de donde el general estaba en -la plaça, porque les avia mandado que no passassen de alli, porque los de la ciludad le avian pedido que para hablar en la paz no estoviesse nirguno dellos dentro; y essos no se tarlaron más de lo que suelen tardar los buenos lebreles, despues que los suellan contra un buen javalí ú otra salvagina bestia. $\mathrm{Ni}$ tampoco los del real del comendador Alvarado mostraron pereça alguna ; é como llegaron, dióse el combate á unas albarradas é calles de ağua que tenian, que ya no les quedaba mayor fuerça á los contrarios, é ganúronselas asi los chripstianos como sus amigos.

$\Lambda$ via proveydo el general al tiempo que de su real salió quel alguaçil mayor Goncalo de Sandoval entrasse con los bergantines por la olra parte de las casas en que los indios estaban fuertes, por manera que los toviessen çercados, é que no los combatiesse lasta que viesse que la olra gente combatia; de forma que por estar assi aprelados ningum passo tenian, por donde andar sino por ençima de los muertos é por las açuteas que les queda. ban. É á esta causa ni tenian ni hallaban flechas ni varas ni piedraș, con que ofendiessen á los nuestros ni se defendiessen á sí ; é andaban los amigos mezclados con los españoles á espada é rodela; y era tanta la mortandad que en los contrarios se hiço en la cilsdad y en el agua ć lierra, que aquel dia fucron nucrtos é pres- sos más de quarenta mill personas. Era tanta la grrila é lloro de los niños é nuugreres, que no avia persona de los chripslianos que lo purliesse ver, sin mucho dolor é compassion; é ya los españoles tenian más que hiçer en estorbar á los amigos que no matassen ni liçiessen tanta crueldad, que no en pelear con los encmigos: la qial crueldad nunca en generasçion se pulo estimar tan reçia ni tan fuera de toda órden de naluralesa, como en los naturales de aquellas partes. J Los amigos confederados ovieron este dia muy grand despojo, el qual en ninguna manera se les podia resistir por los españoles, ni convenia tentarlo; porque los chripstianos eran hasta novecientos hombres é los confederados, que allí se hallaron, passaban de çiento é çinquienta mill, é ningun recabdo ni diligençia bastaba para les estorluar que no roluassen, aunque en esto se hacia lo posible.

Ina de las cosas, porque, los dias antes el general reusaba é dilataba, temporiçando é rogando con la paz á los cercados, era por no venir en tanta rolura con ellos, porque tomándolos por fuerça, temia que demás del daño de moril lanta gente, é acrescentar con ella la comunidad del infierno, avian los cercados de echar lo que toviessen al ağua; é ya que no lo hiçiessen assi, los amigos avian de robar todo quanto hallassen, de manera que para el Emperador a rria poca parte de la mucha riqueca que en aquella cilsdad aria, segund lo que antes allí lovo el general para Su Magestad. É porque ya era. larde y el mal olor de los otros muertos, que de los dias passados avia por aquellas calles, era cosa incomporlable, se fueron los nuestros ásus reales, é quedó conçerlado que luego otro dia siguicnte estoviessen aparejarlos tres tiros gruessos de arlillería é se llevassen á la ciludad, porque el general pensaba, como los indios retraydos estaban tan juntos, é que no tenian por donde se ro- 
dear, queriéudolos entrar por fuerga sin pelear, podrian entre sí alıgar los espanoles, ó que cra menos inconviniente haserles algun daño con los tiros deste fuera, porque se saliessen de allí se viniesse para los nuestros. Ved qué piadoso remedio, y en qué dispusiçion estaba la porfia é contumaçia de Tos cercados, que quassi por médicos se ponian aquellas pieças de artilleria, para sanar los que pudieran escapar, que serian assaz, aunque cada tiro llevaba de cada golpe muchos, por el estrecho lugar en que estaban reduçidos los enemigos, seyendo quassi inumerables é pucstos á terrero.

Avia el general ordenado al alguaçil mayor que estoviesse aperçclsido para enIrar con los bergantines por un lago grande, que se haçe entre unas casas adonde cstaban recogidas todas las canoas de la cilodad, é ya los çercados tenian pocas casas donde poder estar, y el señor de la cibdad andaba metido en una canoa con çiertos prinçipales, que no sabia qué lıacer de sí : é cómo amanesçió aquel dia, é la gente é capitanes estaban avisados del conçierto ya dicho, llevíronse los tilos gruessos. Y cl capitann Alvarado tenia ordenado por el general que le esperasse en la plaça del mercado, é que no peleasse hasta quél llegasse. Y estando ya juntos, é los bergantines apercebidos detrás de las casas del agrua, donde eslaban los enemigos, mandó el general que, en oyendo soltar una espingarda, entrassen por una poca parte que estaba por ganar, y cchassen los enemigos al aģua láçia donde los bergantines avian de estar á punto, é que lodos toviessen mucho aviso en mirar por Guatimuçin, é trabaxassen de lo tomar viro, porcue arida su persona, en aquella liora se esperalsa que çessaria la guerra. Y el general se subió ençima de inna acutea; pero antes del combate haluló con algumos de arpuellos prinçipales de la ciblad, quél conosçia, é les dixo que por qué causa su scinor no queria venirse á él, pues via el extremo en yue estaba, é que haça grand error en ser ocasion ó culpado en que todos peresȩiessen; é que le llamassen é viniesse seguro, que ningun desplaçer le seria fecho. É paresçió que dos de aquellos prinçipales lo yban á llamar, é desile á poco vino con ellos uno de los más prinçipales de todos ellos que se llamaba Ciguacoaçin, y era el capitan é goberuador de todos ellos, é por su consejo se guian en todas las cosas de la guerra: y el general le mostró buena voluntad, porque se asegurasse é no toviesse temor; mas como era muy varon, é conosçia la voluntad é obstinaçion de su señor, dlixo que en ninguna manera Guatimuçin, su señor, vernia ante el general é que antes queria por allá morir, é que á él le pessaba mucho desto: que hiçiesse Hernando Corlés lo que quisiesse. Ved si eran estas palahras en tal tiempo de hombre flaco ó inconstante. Estonges el general, cómo oyó esta determinaçion, díxole que se volviesse á los suyos, é quél y ellos se aparejassen, porque los queria combatir é acabar de matai; $\hat{e}$ assi se fué, sin mostrar'alteraçion ni temor alguno.

Cómo en estos parlamentos é tractos se passaron más de çinco horas, é los de la cibdad estaban todos ençina de los muertos é otros en el agua, otros andalıan nadando, é ofros ahogéndose en áquel lago donde estaban las canoas, que cra grande, era "mucha la congoja del capitan general, é intolerable la pena que los adverssarios padesçian; é no haçian sino salir inumeralıles hombres é mugeres é niños láçia los nuestros, é por se dar priessa á salir, unos á otıos se cchaban en el aggua, é se alıogaban entre aquella moltitud de muertos: que segund despues se supo; del agua salada que behian é de la hambre é mal olor, dió tanta mortandad en los cercados, que murieron des- 
la pestilengial ocasion más de ginquenta mill personas. Los cuerpos de los quales, porque los chripstianos no conoscriessen su nesçessidad, ni los echaban al agua porque los bergatutines no topassen con ellos, ni los echában fuera de su conversaçion, porque los españoles por la ciludad no los viessen, ni los confederados se los comiessen. É assi por aquellas calles en que estaban, aria tantos montones de cuerpos defuntos, que no se podian poner los piés sino en cllos.

Cómo la gente de la cibdad se salia á los nuestros, aria el general proreydo que por todas las calles estoviessen españoles para estorbar á los amigos que no matassen aquellos tristes, que eran sin número. É tambien dixo á todos los amigos capitanes que no consintiessen á su grente que matassen á ninguno de los que salian; é no se pudo tanto estorbar, como eran incontables, que aquel dia solo no matassen é sacrificassen más de quinçe mill personas.

Non obstante esto, todavia los puinçpales é gente de guerra de la cibdad se estalıan arrinconados y en algunas açuleas é casas y en el agua, donde ni les aprovechaba disimulacion ni otra cosa, jorque no se viesse su perdiçion é flaquesa muy a la clara. Pues cómo él general vido que la tarde cra llegada, é que no se querian dar, para usar del remedio que se dixo de susso del artilleria, hiço asestar los tiros gruessos contra los enemigos, por vel si se darian, "pues que mayor crueldad era dar liçencia á los amigos que les entrassen que no li de los tiros, que hiçieron harto daño: é cómo tampoco esto aprovechaba, mandó soltar la escopeta ó señal de la batalla, é incontinente fuć tomado aquel rincon que tenian y echados al agua los que en él estalyan: otros que quedaban, sin pelear, se rindieron, E los bergantincs entraron de golpe por aquel lago, é rompieron por medio de la flota de las canoas, é la gente de guerra que en ellas estaba ya no osalban pelear : é plugo á Dios que un capitan de un bergantin, que se llamaba Garçi Holgguin, fué en pós de una canoa, porque le paresçió que yban en clla lıombres de manera é prinçipales; é cómo yban en la proa dos ó tres ballesteros, encaralan á los de la canoa, quando la alcançaron, é liçiéronles señal que no tirassen, que estaba alli el señor; é saltaron presto en la canoa, é prendieron á Gualimuçin, señor de Temistitan, é al señor de Tacula é á otros prinçipales que allí yban. Y en esse punto el capitan Garçi Itolguin llevó á Guatimucin é los otros prissioneros al general ál la açutea, donde estalıa; é cómı Hernando Cortés vido á Guatimucin, liço que le diessen en que se sentasse, é no le mostró riguridad alģuna, sino semblante que se hoigalsa de verle. Mas cste señol, aunque presso, no mosllaba ser vençido, é llegóse al general é diso en su lengua assi: "Yo he hecho todo lo que de mi parte era obligado, para mi defensa é de los mios, hasıa verme en el estado, en que estoy: agora haz de mí lo que tú quisieres». Y estendió la mano é púsola en un puñal quel general tenia en li çinta, diçiéndole que le diesse de puñaladas é lo matasse, porque no cra ragon que viviesse en el mundo hombre que avia perdido lo quél avia perdido. El general te dixo que no temiesse de cosa alguna, é quél le tenia por buen capitan é lombre muy valeroso, é que estoviesse de buen ánimo, quél seria muy bien tractado.

Presso este señor, luego en esse punto çessó la guerra, á la qual por la divina graçia se dió conclusion martes, dia de Sanct Ípólito, treçe dias de agosto, año de la Natividad del Redemptor Ninestro Jesu-Cluripsto de mill é quinientos é veynte y un años. De manera que desde el dia que se puso çerco á la ciblad, que fué á 
treynta de mayo del mesmo año, hasta que se ganó passaron septenta y çinco dias, en los quales padescieron nuestros españoles muchos é grandes trahaxos, é mostraron tan señaladamente su esfuerço é militar disçiplina, quanto la obra y even. to de tan gloriosa victoria dieron testimonio perpétuo dello. I en todos aquellos dias que turó el çerco, ninguno se passó sin combate ó escaramuça con los de la cibdad, poco ó mucho, de los reales que les estaban puestos ó de alguno dellos. É aquel dia de la prission de la cibdad é de la persona de Guatimuçin, despues de aver recogido el despojo que se pudo aver, el general se recogió en su real, dando infinitas graçias á Nuestro Señor por tan señalada merçed é tan desseada victoria, como le avia dado.

Cuenta Josefo, De Bello Judaico, en la destruyçion de Ifierusalem que Annio, hijo de Eleaçar, testificó que çiento é quince mill y ochenta cuerpos se avian hallado que peresçieron en la cibdad, desde quel emperador Tito la çercó á treçe dias de abril liasta primero de julio, é queste no estaha por guarda de la puerta, mas que pagaba por la cibdad el jornal á los que sacaban los cuerpos muertos, é assi de nesçessidad los contaba; é otros muchos enterraban sus çercanos parientes. É era la sepoltura lançar firera de la cibdad los cuerpos muertos; pero sin este, otros liombres nobles que se passaron á los rounanos, decian que todos los cuerpos muertos echados por las puertas eran seysçientos mill, é quel número de los otros en ninguna manera se podia comprender; é porque no pudiendo bastar los pobres para llevar á tantos, juntaban muchos de los muertos y ençerrábanlos en grandes casas, como en sepoltura '. Todo lo dicho es de Josefo.

Diçe el auctor desta nuestra IIisloria de Indius que le paresçe mayor destruyçion é mortandad de lımmanos la de los indios de la cibdad de Temistitan que la de los judlios ques dicho en Hierusalem, porque dexando aparte los números de los muertos quel general IIernando Cortés en su relaçion dió al Emperador, nuestro señor (ques la que está dicha en esta listoria), no supo ni podia decir otro mayor número quel que vido en las calles de aquella cibdad, quando se vido vençedor della; porque faltaban los alıgados, que eran innumerables, é muchos más los sacrificados é comidos, cuyas sepolturas eran los cuerpos é vientres de los que quedaron vivos, é aun de aquellos mesmos muertos que hedian por las calles, é aun los estómagos de aquellos amigos confederados: que no les sahia peor la carne lumana, rençiendo é comiéndola por su plaçer y enconada gula, que á los otros çercados por su nesçessidad, satisfaçiendo su hambre.

Muchos hidalgos é personas he visto de los que con esto de Temistitan se hallaron, á quiven oí deçir queste número de los muertos más lo tienen por incontable y exçesivo al de Hierusalem, que no pol menos de la cuenta 6 relaçion de Josefo. É no es de olvidar un notable que supe del liçençiado Alonso Zuaço, oydor que fué por Sus Magestades en la Audiençia Real que reside en esta cibdad de Sancto Domingo, é antes desso avia en Temistitan seydo alcalde mayor de Hernando Cortés. Este cavallero me çertificó que se avia informado, é fué verdad, que los treçe bergantines que se hiçieron para cercar la cibdad y entrar á la combatir por la laguna, en lıgar de açeyte é sebo para los brear, se suplió é se hrearon con el unto de los indios enemigos que los chripstianos mataron, que fıé una grandíssima cantidad, demís de lo que está di- 
cho: lo qual oi negar á olros cavalleros diggnos de crédito, que diçen que es falso. Pero pues era público manjar á los indios comerse unos á otros, posible era aprovecharse del unto para una obra tan nescessaria como eran los bergantines; é no nos detengramos en lo menos: pues cutre chripstianos lic visto yo buscar tal unto para medecinas, no the maravillo si faltando lorea para lales navios, se aprovecharon de tal unçion é remedio para adquirir la victoria.

\section{CAPITULO XXXI.}

El qual tracta del valor del despojo que se ovo en la expugnacion é toma de la grand cibdad de Temistitan; é de cómo el señor de la grand provinẹia de licehuacan envió por sus embaxadores á se ofresçer por vassallo del Rey de España, nuestro señor; ė de la noliẹia que ovo el general Hernando Corlés de la mar del Sur ó austral en la costa de la Nueva España meridional, é olras vielorias é provincias que se conquistaron por capilanes de Iernando Cortés; é tráctansc assimesmo olras parlieularidades nolables.

U na de las mojor rengadas injurias é desleattades que gente alguna ha en el mundo comctido, fuć la que en Temistitan los indios contra Hernando Cortés é los españoles perpetraron; porque se rebelaron contra la corona real de Castilla, á quien tenian dada la obidiençia, cuyos vassallos ya eran, é como desleales echaron fuera de la cibdad á su capitan Hernando Cortés por fuerça de armas, é le mataron muchos chripstianos, é á él y ellos robaron, é passaron en esto las cosas que la listoria ha contado. En recompensa de lo qual él los castigó de la manera que en los preçedentes capítulos se ha dicho, é demás de vengar muy bien su particular injuria, los reduxo á la servidumbre é subjecion perpétua de la corona real de Castilla, é cobró parte del despojo ó cantidad de oro é joyas que allí perdió, quando le echaron de la ciludad. Pero para más particulariçar esto, es de saber que despues que la cibdad fué sojuzgada, estuvo el general en su real tres ó quatro dias, dando órden en muchas cosas que convenian, é despues se fué á la cilodad de Cuyoacan: é recogido el oro é otras cosas que se ovieron en el saco de Temistitan, se hiço fundiçion dello, é montó lo que se fundió más de ciento y treyinta mill pessos, de que se pagó el quinito al thessorero de Sus Magestades, sin el quin- to de otros derechos pertenesçientes á la Haçienda Real de esclaros é otras cosas; y el oro restante se partió entre el general é los españoles, segund la manera é servicio é calidad de cada uno. Demás del oro, se ovieron çicrtas joyas de oro, ${ }^{\circ}$ de las mejores dellas se dió assimesmo el quinto á Sus Magestades. Entre el despojo que se ovo tomaron muchas rodelas guarneçidas de oro, é penachos, é plumages, ć cosas mucho de ver é de estimar, é paresçióle al general que ni se debian quintar ni dividir, sino que de todas ellas se hiçiesse serviçio á Sus Magestades Cathólicas, é lo mesmo paresçió á todos los españoles de muy buena volmutad. É aunque Hernando Cortés no señala lo que los quintos é pressente ya dicho podia montar, ni lo diçe su relaçion, yo he querido informarme de algunos que lo vieron, é me çertificaron que á Sus Magestades les cupo en lo ques dicho más de çinqüenta mill pessos de oro.

Cómo la cibdad de Temistitan es tan prinçipal é nombrada en estas Indias, vino á notiçia de un señor de una muy grande provinçia, que está septenta leguas de Temistitan, que se diçe Nechuacan, cómo los españoles la avian destruydo é comado por fuerça de armas é quassi asolado. É considerada la grandeça é fortaleça de la cibdarl, á aquel señor de 
la provincia ya dicha, le paresçió rue pues Temistitan no se avia podido defender. que no avria cosa que se defendiesse á los españoles; é por temor ó por qualquiera otra causa que le moviesse, envió çiertos mensajeros á Cortés, que de su parte le dixeron, mediante los intérpetres de su lengua, que su señor avia sabido que los españoles y Hernando Cortés eran de un scĩor muy grande, é que si el general toviesse por bien, él é su grente lo querian tambien ser é tener nucha anistad con los chripstianos. Á esto respondió el general que era verdad quél é su gen. te é otros innumerables hombres é poderosos señores é prínçipes é reyes eran vassallos de su scñor, el Emperador Rey de Castilla, é que á todos los que no lo quisiessen ser, se les avia de hacer muy cruda guerra; é que aquel su señor, que deçian essos embaxadores, y ellos avian hecho bien é lo que les convenia, en se comedir á querer servir á Sus Magestades; porque á aquellos presçialıa él unís é favoresçia que de su voluntad se movian á ser suyos é renian á su obidiençia, que á los que con las armas eran sobjuzgados por sus capitanes.

Antes desto algunos dias, é no muchos, avia tenido Hernando Cortés un poco de notiçia de la mar del Sur, é preguntó á estos cmbaxadores si por su lierra podrian yr á clla, y ellos respondieron que sí é rogóles que porque pudiesse informar al Emperador de aquella mar é costa é de su provinçia é tierra, é de aquel su señor, que llevassen consigo dos españoles para que lo vicssen. É dixeron que de muy buena voluntad los llevarian; mas que para passar á la mar, avia de ser por tierra de un grand prínçipe, con quien ellos tenian gueria, é que á esta causa no podian en essa saçon llogar a la mar. Estos mensajeros de Mechuacan cstuvieron allí con el general quatro dias, é delante dellos escaramucaron los de caballo, para TON10 IH. que en su tierra lo eontassen, y estinan muy espantalos de ver los caballos é to que los españoles haçan en ellos: é dióles el general çiertas joyas para su señor é para ellos, y envió con cllos dos españoles á la provinçia de Mechuacin.

Avíanle dicho á Hernando Cortés que por dos ó tres partes estaba de allí la mar del Sur á doce é á treçe é á catorçe jornadas, é tenia mucho desseo de la ver é descubrir por aquellas partes; porque le paresçia que serviria mucho en clloá Sus lagestades, é pensaba que alli se avian de hallar muchas islas ricas de oro é perlas é piedras preçiosas, é la Espeçicria, é otros muchos é grandes secretos é novedarles, é aun assi se lo daban á entender algunas personas de letras é cosmógraphos. É á este fin despachó quatro españoles, de dos en dos, á diverssas provinçias, informados de las vias que avian de llevar, é dióles guias de los indios confeclerados que los guiassen, é mandóles que no parassen hasta llegar á la mar, é que en ella tomassen la posesion real é corporalmente por la corona é çeptro real de Castilla, é por Sus Magestades del Emperador ley, nucstro señor, é de la Cathólica é Sercníssima Reyna doña Johana, nuestra señora, su madre, é de sus sul)scssores é desçendientes en los reynos de. Cístilla é de Lcon.

Los unos mensajeros destos anduvieron cerca de çiento é treynta leguas por muclus é buenas provinçias, sin que les fuesse fecho daño ni estorbo alguno, é llegaron á la mar é tomaron la possesion della, y en señal desto lincaron cruçes en la costa della, é volvieron con la relaçion de su descubrimiento, é de lo que anduvieron é vieron particularmente: é truxeron consigo algunas personas de los naturales de aquella otra costa de la mar; é tambien truxeron muy buenas muestras de oro de minas, que liallaron en algunas provincias, por donde passaron. Los otros 


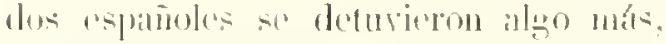

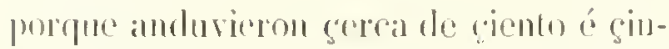
quenta leoguar por ofra parte lasta Ilegar á la mate, donde assimesmo tomanon la possesion por Sus Magrestades, é truveron langal redigion de la costa que vieron, ćtambien vinioron en sll compañia alșunos naturiales de aupullas eostas australes. É á los unos é á los otros resçilió el general staçiosamente é los informó de la grandeça é poder de Sus Magestades é dióles alqumis joyas, con que se partieron muy contentos y espantados de rer los (a)hallos é armas é artilleria é la manera le los españoles.

Al liempo que los indios desharataron y echaron fuera de Temistitan á Hernanto Cortés á los españoles, rebelíronse todas las prorincias subjetas á acpuella grand - illdad; é enmo paresce por los capítulos frecedentes, fodo aquello ó la mayor par11) fué reconquistado é soljuzgrado delios por industria y esfuerog é buena diligençia del general, sin verterse sangre, é lambien con catligo é euchillo flonde convenia usar de las armas. É porque rertas provingias, que están desta nuestra mar del Norte á diez é á quinge éá lreynta leğuas, desde que la cibdad se aria alçado estatban rebeladas, é los naturales dellas avion muerto á traygion é sobre seguro más de cient espanoles en reces, avíase divimulido su eastigo hasta averse dado conelurion en la guerra é cereo de la ciludad, é porfue antes no aria posibilidad nii aparejo para entender en esso. É assi cómo ovo el greneral despachado los mensajeros ques dicho que envió á la mar del Sur, luegro proveyó en enviar al alguaçil mayor Goncalo de Sandoval con treynta é çinco de cabillo é dosçientos espanioles é algguna gente de los amiggos é con aignnos principales é naturales de Temistitan á arpullas provincias, porque mejor entendiessen de testigns de vista lo que estaba hecho é eastigato. por dos efettos: el mno.

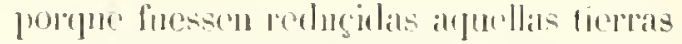

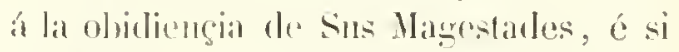
conviniesse é no fuessen oldidientres. se hicriesse con cllos por rigor un senalado casligo, é se les diesse la penitençia igurnal de sus uncritos; á lo otro, porque el mayor peligro que hay entre la gonte de gnerra es el ogrio é disenydo de las armas é de su exerricio, pordue demás de ponerse en condiçion é nesressidad el estado é auctoridad del prínsipe, tómanse inútiles los soldados é grente de guerra, porque como dice Tito Livio, el sucño y el rino é los manjares é meretrices é oçosidad continuada, de dia en dia consumen los cuerpos y entlapuescen los ámimos. É assi les ieacsçió al garand Anilal, eartaginés, é á su exćrçito, por se detener oçiosos en los campos é téruninos de Capua é sus estancias.

Este nuestro general Hernando Cortés, no incurriendo en semejante error ó desarylo, ni dexando passar el licmpo sin haçer alg̣m frueto, envió al capitan Sandoval a apuellas provincias, cuyos nomhres son Tatacteteleo, Tinstebeque, Guatuseo é Aulicaloa, é dióle la ynstruçion é órden que avia de tener en essa expedirion é gurerra donde le envió.

In la mesma saçon un teniente que avia devado Hernando Cortés en la villa de Sesura de la Frontera, ques en la provinçia de Tepeaca, vino á la cibdad de Cuyoaean. é di volecómo los naturales de aquella provinģia é otras con ella comarcanas, rassallos de Sus Magestades é amigros de los españoles, rescebian daño de los naturales de una provinçia que se diçe Guaxaca é les haçian guerra, porque essotros eran nuestros amiggos, é que demás de ser nesçessallio poner remedio en ello, conrenia mucho que se asegurasse aquella lierra é provincia de Glaxaca por muclios respetos. Assi, por la autoridad del servicio y estado real, como por la repuarion to los clıriptianos, é porrane adpue- 
lla tierra está en el camino de la mar del Sur ó austral, de que mucho provecho se esperaba conseguir para las cosas de arlelante, é tambien porque no quedissen sin pena los que la merescian, ni sin resçebir buenas obras los que erin leales é anigos de los españoles; é porque el general sabia gue aquel su teniente tenia en este caso más particularmente entendida aquella tierra, ó avia residido 6 estado cu ella, y cra hombre de bien é de conflanģa, y estando en el çerco de Temistitan le avia el general enviado alli porque los de Tepeaca pidicron socorro, é no llevó estonces sino reynté ó treynta españoles, é le hiçieron de allá volver los eontrarios más que de passo, quiso Ifernando Cortés quél mesmo tornasse con doçe de caballo é ochenta peones españoles. É á los treynta de octubre de aquel mesmo año de mill é quinientos é veynte y uno, estos dos capitanes se partieron de Cuyoacan, é llegados á la provinçia de Tepeaca, hiçieron allí sus alardes é cada uno se fué para su conquisla.

Lil alguaçil mayor, Ilegado á la provinsia de Guatusco, donde él pensaba aver menester las manos con los enemigos, porque aquella gente es exerçituda en la guerra y estaban muy fuertes en su tierra, salieron á él de paz é dieron la obidiençia á Sus Magestades; é dexando aquello muy seguro, passó adelante, é assimesmo no halló contradiçion, é todo se dió á Sus Magestades é se reconçiliaron cu la buena amistad con los espanoles. Y escribió este capilan al gencral la relaçion particular de su camino, é de todo lo que le avia paresçido, é demás desso le acordó que para lener segura loda aquella tierra, era bien haçer un pucblo de chripslianos en ella, donde más á propóssito fuesse el assiento, como ya antes desso se anda puesto cu plática al güluas veces; é que pues alquellos esplanoles y él cslaban allá, que viesse lo que en esto y en lo demás mandalo que se hiciesse. El general le respondió, agradescriéndole murcho lo que avia trabaxado en serviçio de? Sus Magestades en aquella su jornada , é loanclo su parescer é consejo en lo de lis poblaçion ; é conformándose con él, le mandó que fundasse ma villa de españoles en la provinçia de Tuxlebeque, é mandóla llamar Medellin, y envió nombrados los alealdes ordinarios é regridores é otros offiçiales para aquella nueva república. Y escribióles á todos muy graçiosamente, cneargándoles que mirassen mucho el servicio de Dios é de Sus Magestarles, y el buen tractamiento de los indios naturales de la tierra, la qual es muy buena é féltil é rica. Este nombre se puso á esta nueva polblacsion, porque Ilernando Ciortés es matural de la villa de Hedellin en Extremadura.

El olrocapitan de Segura de la Frontera, despues que esturo en la provinçia de Guaxaca eon mucha gente de guerra de los amigos de aquellas comarcas, aunepue los contrantios se le pusieron en resistençia é peleó con ellos dos ó tres veçes muy valerosamente é siempre llevó lo mejor, al fin se dieron é vinieron de paces siu daño de los cluripstianos, é fueron admitidos ć quedó la tierra en odidiençia é selviçio de Sus Magestades, para servir de alı́ adelante como leales vassallos lo deben haçer.

Aquesto assi aeabado, envió este capitan larga é particular relaçion al general, é informaçion de cómo aquella tierrá es muy fértil é de rieas minas de oro, y envióle muy buena muestra dello; é assi ovo próspero fiu esta gucria. 


\section{CAPITULO XXXII.}

Cómo el general Hernando Cortés é los españoles acordaron de reclefiear la grand cildad de Tenistilan ¿ haçer su asciento proprio é poblaçion para los chripstianos en ella; é de eómo el señor de la provinçia de Coantepeque, euyo señorio é jurisdiẹion es á la mar del Sur, dió por sus embaxadores la obidiençia á Sus Magestades; a de como Chripstóbal de Tapia, veedor que fué de las fundiçiones del oro en estat Isla

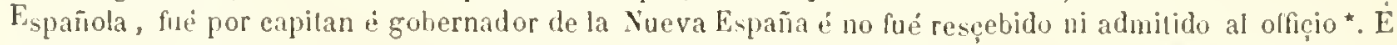
tambien se tractan en este capitulo otras cosas que al cstilo é continuacion de Ia historia son nesçessarias.

$\mathbf{E}$ capitan á quien tanto poder (del que puede) es conçedidlo en cuya fé é virtud los bienes de fortuna prestados á los ricos, la defension de las ciludades, la salud de los soldados é la gloria de la república es cometida, diligentíssimo é curiosíssimo, no tanto para todo el exérçito IJuanto para cada soldado, debe ser. Esla auctoridad de Flavio Vegeçio en su tractado del Arte militar ' escrita, es muy çierta é aprólsada, la qual aqui quadra en lo que se dirá adelante sobre lo que le intervino á llermando Cortés (queriéndole remover del cargo que tenia, la inulustria de sus émulos): el qual, aviendo dado la órden que en el capítulo de susso se dixo en el despacho de las dos conquistas ya relatadas, é avisado ya del buen subçesso dellas, é viendo cómo él tenia pobladas tres villas de españoles, é que con él estaban copia dellos en la cibdad de Cuyoacan, é avian platicado en qué parte se haria otra polblaçion al rededor de las lagunas, porque desta avia más nesçessidad para la seçruridad é sosiegro de aquellas partes: é assimesmo viendo que la cil)dad de Temistitan, que era cosa tan nombrada é de que tanto caso é memoria se ha hecho, paresçióles al general é á los españoles que en ella era bien que aveçindassen, porque estaba destruyda é se reparasse. É para esto, repar-

- De este epigrafe suprimió Oviedo lo siguiente: "Por la forma de eaulela que en ello se luro, ó porque les paresçió al generat Hernando Cortés é à los otros espanoles que con él militaban que asui con- tiéronse los solares á los que se assentaron por veçinos, é híçose nombramiento de alcaldes é regridores en nombre de Sus Magestades, para que esturiesse en justiçia é bien gobernada la república. Y entre tanto que se reparaba, hico su assiento el general en la ciludad de Cuyoacan, porque Temistitan se fortificasse é se reeleficasse para que los espanoles estoviesson en ella fuertes é seguros é muy señoreados de los naturales, é que dellos en ninguna forma pudiessen ser ofendidos los chripstianos. En la qual saçon el senor de la provinçia de Coantepeque, ques junto á la mar del Sur é por donde la descubrieron ó la vieron los dos españoles ques dicho de susso, envió sus embaxadores al general, ofresciéndose por vassallo del Emperador Rey, nucstro señor, con un rico pressente de joyas de oro é plumages mucho de ver; y el general los rescebió en nombre de Sus Magrestades con el agradesçimiento é buen acogimiento que se requeria, ababando á quien los envialua su leal comedimiento, é dióles otras cosas que le llevassen, con que se volvieron á su tierra alegres é contentos.

Assimesmo vinieron estonçes los dos españoles que avian ydo á la provinçia de Mechuacan, por donde los mensajeros, quel señor de aquella tierra avia enviado al gencral, le dixeron que se podia yr á

renia al servicio de Sus Magestades é á ellos mesnlos."

1 lic Re nilitari, lib. Ill. 
la mar del Sur, salvo que aria de ser por lierra de un grand prinçipe ó señor que era su enemigo: é con los dos españoles vino im hermano del señor de Mechuacan, acompañado de lombres prinçipales é servidores, que passaban de mill personas, á los quales el general resçelsió, mostrándoles mucho amor; é de parte del señor de la dicha provinçia, llamado Calcuçin ", truxeron para Sus Magestades un pressente de rodelas de plata, que pessaron muclios marcos, é otras cosas é joyas muchas de oro, é penachos de diverssas maneras. É por festejar á tan prinçipal embaxador é.á quien le envió, è que viessen la manera é arte de los españoles, é lo pudiessen degir en su tierra, salieron todos los de calsallo á una plaça, e delante de aquellos extranjeros corrieron y escaramuçaron, é la gente de pié salió en ordenança, é los escopeteros soltaron sus escopetas, é con el artilleria tiraron los lombarderos á una torre; é quedaron muy admirarlos de ver lo que della se derribó en un instante, é de ver los caballos é la agilidad é buena maña é prontitud con que los cavalleros chripstianos los exerçitaban. É liço el general questa nueva gente fuesse á ver la ruyna é destruycion é asolamiento de la cilsdad de Temistitan, é viendo su fuerça é assiento, quedaron muy espantados, maravillándose de todo. É á calo de quatro ó çinco dias que fueron muy festcjados, dióles el general muchas cosas para aquel señor de las quellos tienen en estimaçion mucha, é para ellos otras, con que se fueron muy contentos á su patria.

El rio que llaman de Panuco está la costa abaxo de la villa de la Veracruz

* En otras Crónicas inédilas de la Conquista de Meeluuaean, que deben formar partc de esta Coleeeion de llistoriadores primiticos de Indas, se lee constanlemente Cazonçi, nombre que sc la eunservido despues por la mayor parte de los eseritores de Indias y que en alguna ocasion cmplea el mismo Oviedo. Pero en esle Ingar le sueedió Jo que sinquienta ó sessenta legyuas, al qual los navios del adelantado Françisco de Garay avian ydo dos 6 tres veges é avian resçebido daño de los naturales de aquel rio, ó por falta del capitan general, ó de su ventura más cierto, en la contradiçion que alli tovieron la ggente de dicho Garay con los indios: despues de lo qual Hernando Cortés, viendo que en toda la costa de la mar del Norte de la Nueva España que mira estas islas nuestras liay falta de puertos, é ninguno hay tal como aquel de Panuco, é porque los naturales de alli avian ydo antes á ofres. cérsele por vassallos de Sus Magestades, é despues laçian guerra á los vassallos amigos é confederados de los españoles, acordó de enviar allá un çapitau con gente para que paçificassen aquella provinçia, é si la tierra fuesse buena, se hiçiesse en aquel rio é puerto una villa é se poblasse de españolcs, para que aquellas comarcas se asegurassen. $\dot{E}$ aunque los chripstianos eran pocos é desparçidos en tres ó quatro partes, é tenian entrellos contradicion para que no se sacasse gente de donde el general estaba, por socorrer á los amigos confederados, porque despues que se avia ganado la cibdad de Temistitan, avian ydo navios á la tierra, é llevado alguna gente é calıallos, hiço poner en órden veynte y çinco de caluallo é çiento y çinquienta infantes á pié, para que con el capitan que le paresçiesse fuesse en aquel rio á lo ques dicho. Lo qual no ovo efetto, porque en essá saçon le escribieron de la villa de la Veracruz cómo al puerto della avia llegado un navio, en que yba Chripstóbal de Tapia, veedor de las fundiçiones del oro desta Isla Espa-

olras muehas veces: no estando fija entre los españoles la pronunciaeion de los nombres amerieanos, y valiendose solo de relaeiones, en que lıabia esta misma raguedad, resulta de aqui la desavenencia que antes de alsora hemos nolado entre estos historiadores primilivos y los que les han sucedidu. 
nola, del gunal otro dia adelante rescebió Cortés mal renta, por la (pual le hiço saber cómo yla á acuella liema para tener la gobernaçion della por mandado de Sus Magestades, é que no aria querido pressentar las provisiones reales hasta que ambos se riessen, lo qual degia que quisiera que fuera luego; pero que cómo traia fatigadas sus bestias de la mar, no se avia metido en camino: é que le rogaba que se diesse órden cómo se viessen, ó viniendo el Cortés donde él estaba, ó yendo el Tapia donde Cortés estoviesse á la eosta de ba mar.

Aqui quiero yo, como buen historiador, para ser mejor en'endido, pedir al letor que se acuerde is dos cosas que agora diré: la una es que no desacuerde la anctoridad que al prinçipio deste capítulo se dixo de Vegecio, para lo que en esto se siguió é adelante oyreysó lecreys; é la otra que sepays que en el licmpo que esto passaba, el Emperador Rey, nuestro señor, estaba en Flandes é gobernaba en su real nombre los reynos de España el cardenal Tortosa, ‘ue fué despues Papa Urbano VI de tal nombre; é eon el dicho cardenal juntamente el condestable do Castilla, don lñigo de Velasco, é el almirante de Castilla, don Fadrique Enriquez: con los quales, durante la ausencia del Rey, nuestro scñor, se procuró que enriassen al dicho Tapia a la Nueva España. É sospechó Hernando Cortés questo era rodeado por el obispo de Burgos don Johan Rodriguez de Fonseca, á quien se daba prinçipal lugar é tenia la presidença en las cosas de las Indias, y era amigo é faroresçedor del adelantado Diego Velazquez, enemigo de Corlés; é aun se tractaba easamiento de una dama sobrina del obispo, llamada doña Mayor de Fonseca, con el dicho adelantado, y el Clnipstóbal de Tapia avia seydo criado del dicho obispo. Estas sospechas ó congecturas de Corlés no eran tan escuras ó inintelegilbles que dexassen de parescer lo mesmo á otros mittelos. Folvamos al suldresso, que esto luyo.

Cóno Cortés resçebió la carla de Tápia, respondióle quél loolgaba de su vonida, é que no podia yr persona proveyda por mandado de Su Magestad á tener la gobernacion de aquellas partes de quien más contentamiento él toviera, assi por el conosçimiento que entrellos avia, como por la crianca é vecindad que en rela l:la Española avian tenido; é porque la pacificaçion de aquellas partes no estatbi atur tan soldada como convenia, é de qualduieranovedad se daria ocasion de alterar á los naturales. É cómo el padre fray P'edro de Urrea, eomisario de la crucada, se avia hallado en todos los trabaxos passados, é sabia muy bien en qué estado estaban las cosas de la tierra, é de su yda Su Mlagestad avia seyclo muy bien servido, é los conquistadores aprovechados con su dothina é consejos, quél le avia rogado con mucha instançia que tomasse trabaxo de rerse con dicho Tapia, é viesse las provisiones de Su Magreslar: é pues el dicho religioso salia mejor que nadie lo que convenia á su real servicio é al hien de aquellas partes, quél diesse órden con el dicho Tapia en lo que márs conviniesse, pues tenia conçepto del dicho Cortés que no excederia un punto dello. Lo qual él le rogó á este padre en presencia del thessorero de Su Magestad é de otrus personas, que lo aceplasse, y él assimesmo se lo encargó mucho. É assi se pállió para la villa de la Veracruz, donde Clripstóbal de Tapia estabazé para que assi en aquella villa, como po: donde fuesse el dicho recdor se le hiciesse todo buen serviçio é acogimiento, despachó aquel padre ques dicho de lá órden de Sancl Françiseo de la Observançia, é con él dos ó lres hombres de bien de tos de su compañia: y él quedó esperando su respuesta en tanto que aderesgaba su par- 
tirla, dando órden en lo fuc le paresçia (que se debia provece para la pacificaçion é sosicgo de la tierra.

Desule á diez ó doçe dias la justiçia é regimiento de la villa de la Veracruz le escribieron quel dicho Tapia avia hecho pressentaçion de las provisiones que lleVaha de Su Magestad é de sus goloernadores eu su real nombre, é que las avian obedesçido ron la reverençia (que se dehia; é que quanto al cumplimiento, respondieron que porque los más del regimiento estalian con cl capitan Hernando Cortés, e sc avian lallarlo en el çereo de la cibdad de Temistitan, ellos se lo harian saber, é todos harian é cumplirian lo que fuesse más serviçio de Sus Magestades é bien de la tierra : é que desta su respuesta Clıripstólal de Tapia avia rescebido algunos desabrimientos y enojo, é aum aria

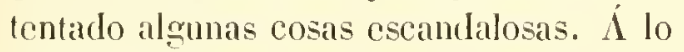
qual Hernando Cortés les respondió que les rogaha y cncargaba que, mirando muclıo é principalunente el servicio de Sus Magestades, trabaxassen de contentar al dicho Tapia ,é no se dicsse ocasion algnna á que oviesse bulliçio ni alteraçion, é yuél estaba de camino para se yr á ver con él é cumplir lo que Su Magestad mandaba é más su serviçio fuesse. Y estando ya de camino é impedida la vola del capitan é gente que avia de yl al rio de Pauruco, porque convenia que salido Cortés de donde estaba, quedasse muy buen recaludo, los procuradores de los conçejos le requirieron con muchas protestaçiones yıe no saliesse de allí, poryuc como toda la provincia de Néxico é de Temistitan aria poco que se avia pacificado, temian que con su alssencia se alborotarian, de que se podrian seguir nuevas alteraciones é desasosiegos en la tierra. E dieron en aquel su requerimiento otras muclas causas é raçones, por donde no convenia que al pressente saliesse de aquella cildad de Cuoacun, y quassi significando que la auc- toridarl y el nombre de Cortés sostenia la ticrra é yugo de los indios, é que faltando él, era todo perdido: é dixéronle quellos con poder de los concejos yrian í la villa de la Veracruz, donde el dicho Tapia estalıa, é verian las provisiones de Su Magestad, é harian todo lo cule fuesse su real serviçio. É assi se partieron luego, y Hlernando Cortés escriloió al Clıripstolsal de Tapia, laçiéndole saber lo que passaba ó lo que le paresçió, é quél enviaba con su poder al algुuaçil mayor Gonçalo de Sandoval é á Diego de Soto é á Diego de Valdenebro, que estaban allá en la villa de la Veracruz, para que en su nombre, junfamente con el cabildo della é con los procuradores de los otros cabildos viessen 6 hiçiessen lo que fuesse servicio de Sus Magnstades é bien de la ticrra.

Llegados á donde Chripstóbal de Tapia cstaba, que yloan ya de camino él é aquel padre fray Pedro Melgarejo, requirićronle que se volviesse : é todos juntos se volvicron á la ribdad de Compual, é allí el Chripstóbal de Tapia pressentó las provisiones é fueron rescebidas é obedesçidas con el acatamiento é reverenciá á Sus Magestades debida; é quanto al cumplimiento suplicaron dellas para ante Sus Magestades, diçiendo que assi conrenia á su real serviçio, por las causas que expressaron en su suplicacion, é las que más protestaron expresar en su real presençia. É passaron allí otros auctos é requirimientos entre el veedor Tapia é los procuradores de IIernando Cortés; y el dicho Tapia se embarcó en un navio suyo, porrque assi le fué requerido, porque de su entrada ć de laber publicado que yba por gobernador é capitan de aquellas partes, dise Cortés en su relaçion, se alborotarian los de México é Temistitan, é que tenian ordenado con los naturales de aquellas partes de se alçar é haçer una grand trayçion, que á salir con ella, oviera seydo 
peor que lo passado; é que çicrtos indios de México conçertaron con alqumos de los naturales de aquellas provinçias que avia paçificado el alguaçil mayor, que viniessen al general muy de priessa, é le dixessen cómo por la costa andaban reynte navios con mucha gente é que no salian á lierra, é que porque no debia ser buena gente, si él queria yr allá é ver lo que era, quellos se aderesçarian é yrian de guerra con él á le ayudar; é para que los creyesse lleváronle la figura de los navios en un papel: é cómo secrefamente le higieron saber lo ques dicho, luego conosçió su intençion, é que cra maldad é rodeado, para verle fuera de aquella provinçia, porque como algunos de los prinçipales della avian sabido que los dias antes el general estaba de partida, é vieron despues que se estaba quedo, a vian buscado esta otra manera para sacarle fuera. Y él disimuló con ellos, é despues prendió algumos que lo avian ordenado; de manera que refiere Hernando Cortés por su relaçion que la yda de Tapia é no tener expiriençia de la tierra é gente della causaron harto bulliçio, é que si allá quedára, fuera muy dañoso. É á este propóssito diçe otras cosas que tocan más á particulares passiones que á limpia historia ni á delectaçion de quien la leyesse, é por esso se dexan de escribir.

Á mi paresçer, por qualquiera manera que se rodeasse la vuelta del veedor Tapia é no consentir que quedasse en aquella tierra, Hernando Cortés fué para su propóssito bien consejado, assi por los indiçios é sospechas de la eleçion de su camino de Clnripstóbal de Tapia, como por no se ver despojado Iternando Cortés del pié á la mano de tanta gloria é triunfo como avia ganado en si empressa, é no aviendo aun conseguido la remmeraçion de sus grandes serviçios él ni los que con él se hallaron en aqquella conquista.

Parésceos, letor, que para la satisfa- cion é paga é gratificarion de merģedes que esperalan apueflos cavalleros é hidalgos rue tan señilardo é árduo é dificultoso cerco lovieron, é que con sus vidas é sangre le sostuvieron é acabaron, que con un gobernador que ylua de nuevo é que no lo avia hecho ni visto ni aun entendido, ni conosçia los méritos de cada uno, que los podia assi contentar ni galardonar, como aquel que en sil compaiiia é pressençia se halló con ellos, é con cuyó consejo é prudençia se consiguió la victoria? Demás desto, muchos dellos querian muy mal á Diego Velazquez, é otros avian seydo no bien tractados dél: Hernando Cortés estaba muy bien quisto y era liberal con todos eltos, é conosçíanle é conosçíalos á torlos, é salvia para lo que eran ellos; é tan bien tenian entendido el valor dél é la expiriençia de bnen capitan que tenia, y era tan importante, que en su compañia ni tenian peligro ni dexaban de cometer osadamente quanto el liempo é la ocasion determinassen. Y la auctoridad de Vegeçio, que al prinçipio deste capítulo se tocó, calia muy bien en IIernando Cortés, y su persona la henchia tan bastantemente como ella lo diçe, porque su diligencia era tan grande quanto en algun capitan se puede aver visto por su curiosidad inaudita, assi en general con todo su exérçito, como en particular con cada soldado, por mínimo que fuesse, como verdadero padre y exçelente capitan, á quien dignamente se puede aplicar uno de los más acabados é perfeltos loores que de la militar disçiplina puede resultar. É cómo en él cabia esto, é sabia que su Rey estaba fuera de España, no dió lugar á ser descompuesto del primero hote ó grita: é que lo rodeasse él por la forma qure está dicho y él en su relaçion dice, ó que lo ordenassen assi sus amigos, ninguno sin passion arrá tan des. acordado que le culpe á él ni á los demas, porẹte assi se hiçiesse. No parezca á nin- 
guno fealdad quel valeroso coraçon dessee señorio, con tanto que no se adquiera indebidamente.

Parésçeos que fué gentil cosa subçeder Dario como rey de los persas por la astucia que su caballeriço turo para que su caballo relinchasse primero que otro alguno, lo qual fué assaz mejor que no avia conquerido ó alcançado el reyno el antesesor desorejado, del qual fué interfector ó matador el mesmo Dario con otros cavalleros. Todo esto os dirá Justino "; pero no es menester acumular otras listorias á la nuestra. Quiero tleçir, que si buena asIuçia fué la de Dario para quedar señor, que no fué mala ni desconviniente la de Hernando Cortés, para quedarse por capitan general en aquella tierra hasta saber la voluntad de su Rey: el qual no solamente aprobó su persona é scrviçios, pero dióle estado é títulos de honor, como adelante la historia lo dirá.

Por çierto más es dessear el valor de su persona é ingenio, que de aver envi- dia de la fuerça de Cinegiro, cavallero ateniense, del qual escribe Justino que huyendo los enemigos á las naos por escapar de la muerte, tuvo una dellas tan firme con la mano derecha, aunque estaba cargada, que no la dexó liasta que le fué cortada la mano; é cómo aquella perdió asió la nao con la otra mano izquierda, é túvola firme hasta que assimesmo le fué cortada la otra mano; é tambien cortada aquella, tuvo la nao asida con los dientes hasta que lo mataron ${ }^{2}$. Pues digo yo que aunque no muriera ni perdiera sus manos, quisiera yo más para mí las fuerças de muchos buenos juiçios de discretos varones, que yo sabria nombrar, que la fuerca de Cinegiro, ni aun la de Samson con ella; y entre los tales que de prudençia y esfuerço é valor deben ser estimados en nuestros tiempos, es uno Hernando Cortés, méritamente numerado para que quede su memoria alabadit é acordada perpétuamente.

\section{CAPITULO XXXUI.}

Cómo el capitan general Hernando Cortés envió al comendador Pedro de Alvarado á conquislar la provinçia de Tcantepeque é la paçificó é llegó á la mar del Sur ć tomó la possesion della por Sus Mageslades, é de las grandes mucstras de oro é perlas que halló ; é cómo el general hiço haçer navios en la costa del Sur para deseobrir por aquellas mares, con lo qual, con otras particularidades, se dá fin á la relaẹion de la terçera carta, que escribió Hernando Cortés al Emperador de las cosas de la Nueva España.

\section{M} bien; pero muchas veces son do la amarga muerte ocupados. Yo que no mis años, sino mis victorias suelo numerar, si los dones de la natura cuento, luengo tiempo he vivido. Assi lo dixo Alexandro Nagno a Cratero en cierta respuesta que le dió ${ }^{3}$.

Por çierto si esta regla ó cuenta haçe Cortés, tenerse puede por de luenga edad, segund las victorias que le lıa dado
Dios; y tanto son de tener en más, quanto con más flaco prinçipio que Alexandro començó este capitan á buscar renombre entre los que son más ilustres é loables en el mundo. Prosigamos, pues, nuestra materia, é dése fin á la relaçion terçera que por sus letras hiço á la Cessárea Magestad.

Despues que estuvo paçífica la provinçia de Guaxaca, envió á mandar al capi- 
fan que alli tenta. que los ordental repate noles ó dieg de caballo que allí celiaban, los diesse al rapilan Podro de Mraralo, al dual emviaba á conquistate la prosincia de Toantrpecpue (ques qualental loguas arletante de Guavalea, junto á la mar del Sur), porfue acpedlos indios haçian muclo daño é gucrea á los que se avian ofresçillo por rassallos de sis Mlagrestades. é á los de la pros incia de Coanteprefue, porque avian desalo por su tirma crutrar a descobrir la mar del Sur, los animasse é refirmasso en la pazé obielioncia. I el capian Mrararlo se partió postrero dia del mes de enero de mill é quinientos é reynte y dos años, é con la grente quel general le dió é con la que estaba en Guaxaca juntó quarenta de caballo é doscientos peones, en que avia quarentâ ballesteros y escopeterośé dos tiros de campo pequeños. E prosiguiendo su cmpressa y entrando en la tierra que yba ¿ buscar, tomó çierlas espias naturales della, é informóse cómo el señor de Teantepeque con su gente le estaba esperando en el campo con su exŕrçito.

Llevaha este capitan, demás de los cspañoles ques dicho, mucha é buena gente de indios amigros, é continuando la gnerra, tres ó quatro poblaçiones se opusieron á la defonsa; pero no perseveraron, porque el capitan é su gente se dalan tal recaldo en los recuentros que avia, que siempre quedaban rencerlores: y en fin cutró en la ciludad de Teantepeque, é fué bien rescelbido del scĩor della é de los demás, é só color de cortesia dixo (que se apossentasse en mas casas suyas bien grandes, que tenian la cubertura de paja: é porque aquello no era proveclioso tanto como sospechoso para los de uaballo, no quiso el comendador Alvarado sino baxarse á apossentar d́ otra parte de la cibdad que era más llano, porque supo que se ordenaba de malarle á él é á los españoles desta manera: Que cómo todos los deripstianos estoriessen apossenlarlos en aprollats casas, que cran muy grandes, assi cómo de noclue durmiessen, les pusiessen fuegro o los quentasien todos; é cono fué el capilan avisado desto, levó consigo al otro apossonitaniento al señor de la provinģia é á Im hijo suyo, como on son de pressos. Los quales le dieron veynte y cinco mill pessos de oro en piegas labradas: é degianle al comendador los vassallos de aquel señor que tenia mucho thessoro. É torlo esto hícolo saluer Mlrarado por"su carta al general; é junto con esso, cómo tenia la provinçia muy parifica é los indios seguramente hacian sus merados é contractaçon como primero, é que la lierra era muy rica de oro de minas, é que en su pressençiale sacaron una muestra, quél le envió; é tambien to hiço salber cómo avia estado en la mar del Sur é avia tomado la posscsion della por Sus Magestades, é que en su pressencia sacaron los indios muestra de perlas, que tambien envió con la muestra de oro de minas. É demás desto le dió raçon de otras cosas particulares de fertilidad é bondad de aquella tierra: á causa de lo qual el general proveró con mucha diligencia, que en la una de tres partes, por donde avian descuhicrto la mar del Sur, se hiçiessen dos caravelas medianas é dos bergantines, las caravelas para descobrir é los bergantines para seguir la costa: é ál esto fueron con persona de recabdo quarenta españoles, en que avia macstros carpinteros de ribera é ascrradores y herreros é hombres de la mar ; é proveyó por clavacon é velas é otros aparejos nescessarios para los dichos navios.

Quando liernando Cortés estovo en la ciblad de Tlısayco, antes que de allí se partiesse á çercar á Temistitan, aderesçando é proveyendo lo que convenia, bien descuydado de to que ciertas personas ordenahan, vino á él uno de los que eran en el conçierto, é descubrióle que çicrtos 
amigos de Diego Velazquez, que estaban en su compañia, tenian ordenada trayçion para le matar, é que entrellos tenian elegielo capitan, el alcalde mayor, el algyuacil é otros ofiçiales; é que en todo caso lo remediasse, pues veia que demás del escándalo yue se seguiria por la falta de su persona, eslaba claro que ningun español escaparia de las manos de los indios viendo á los españoles revueltos entre sí, é que para esto, no solamente hallarian á los enemigros aperéchidos, pero á los que tenian por amigos que trabasarian de los acabar á lodos. Cómo el general vido que tan grand delicto se le avia descubierto, dió muchas graçias á Dios por ello, é hiso prender al que era el principal agresor, é aquel espontáneamente confessó quél avia ordenarlo é conçertado con muclas personas, que en su confession declaró, de prender ó malar al general, é tomar la gobernaçion de la lierra por Dicgo Velazquez; é que era verdad que lenia ordenado de haçer capitan é alcaldo mayor, é quél avia de ser alguaçil mayor, é le avia de prender ó malar; é que en esto eran muchas personas quél tenia puestas en una copia, la qual se lialló en su posada, aunque liceha pedacos, con algunas personas que declaró que avia platicado lo sussodicho. E que no solamente esto se avia ordenado alli en Thesayeo; pero que lambien lo avia comensardo é puesto en plálica, cstando en la sucra de la provinçia de Tepeaca. É vista su confession deste delintiiente, que se llamaba Antonio de Villafaña, natural de la cibdad de Zamora, é cómo se retificó en ella, un alcalele y el mesmo IIernando Cortés le condenaron á muerte, é firé execulatla en su persona. É puesto que en este crímen avia otros muy culpados, disimulóse con cllos, laçiéndoles obras le amigos (porque el caso era suyo proprio é aun más (que proprio), la qual clisimularion no fué de provecho por otrats cansas que Corlés dige en su malcion, enderescatasá las pasiones entre él é Diego Velazquez, que son más para los processos é libelos, enquellos anduvieron solıre la gobernacion de arpuella tierra, que no para nuestra listoria.

Despues que fué pressa la cibdad de Temistilan, ydo el general á la de Cuyoaican, falleció alli aquel don IIernando yne la historia ha dicho que era señor de Thesayco, cuya muerte pessó mucho á los españoles, porque era muy buen vassallo 6 servidor de Su Mageslad é grand amigro verdadero de los chripstianos; 6 con parescer de aquellos señores é prinesipales de afuella su cibelad é provinçia, se dió aquel señorio en nombre de Su Magestad á olro hermano menor suyo, el qual piclió el baulismo, é llamáronle don Cúllos, buen mansebo é de grentil converacion.

En algmas partes destas historias se ha hecho mençion de las provingias de Tascalleca é Guaxoçingo; é porque allí hay una montaña que quiere ymitar é parescer mucho al monte de Vulcan (isla ecrea de Cicilia), (ue tan discantado es de muchos historiadores é postas, será bien que aqueste no quede en olvido; pues dice el greneral Ilernando Cortés ques una sicrra redonda é muy alla, de la qual quassi á la continua sale mucho humo, que va derecho é violento como una sacta hácegia el ciclo. lí porque los indios daban á entender que cra cosa muy mala, é que morian los que allí subian, liço el general que ciertos españoles subiessen á ver de la manera que arpuella sicrra ó montaña está allá en lo allo, por donde aquel humo sale: é quando subicron, salió aquel humo con lanto estruendo é sonido, que no pudieron ni osaron subir hasta la boca. Despues hiço volver allá otros españoles, é sulicron dos veces lasta llegar á la boca de la sierra donde aquel humo sale, é dixeron que avia ele la ma parte de lia hoca it la ofra dos tiros de ballesta, porque la 
rircunferencia tiene quassi tres quartos de legrua, y es de tanta hondura que no pudicron ni bastó la vista á rer el cabo ó sinclo de aquella çima. E por allí al rededor hallaron algun açufre de lo quel humo expele; y estando una rez allá oyeron el ruydo que traia el lıumo, é diéronse priessa a baxarse; pero antes que desçendiessen á la mitad de la sierra, ya venian infinitas piedras rodando, é se laallaron bien arrepentidos, por aver allí subido, é ann en harto pelig̣o; é los indios tovieron á muy grand cosa arer osado yr á donde fueron aquellos españoles. (Lamina $I I$, fig. $1 \mathrm{I}^{\mathrm{a}}{ }^{\mathrm{a}}$ )

Escribió Cortés, en fin desta su relaçion ó carta terçera, quo los naturales de aquellas partes cran de mucha más capaçidad que los destas islas nuestras, é que le paresçian de tanto entendimiento é raçon quanto á.uno mediocremente basta para ser capaz; é que á esta causa le paresçia cosa grave por est onçes compelerlos á que sirviessen á los españoles de la manera que los de las islas; é que tambien şessando aquesto, los conquistadores é pobladores de aquellas partes no se podian sustentar, é que para no constreñir pol estonçes á los indios, é que los españoles se remediassen, le paresçia que Su Magestad Cathólica debia mandar que de sus rentas, que en la Nueva España le pertenescen, fuessen socorridos para su gasto é sustentaçion, é que sobrello Su Magestad mandasse proveer lo que más fuesse servido. É despues andando el tiempo", vistos los muclios é grandes gastos de Sn Nagestad, é que antes debia por todas las vias que posible fuesse acrescentar sus rentas reales que dar causa á se las gastar, é considerando assimesmo el mucho tiempo que aquellas guerras avian tura-

* En este pun'o está falto de algunas fojas el MS. original de Oviedo, que posee la Real Academia: no asi el de la Biblioleca Colombina, copiado por el docto académico D. Juan Baulista Muñoz, do, é las nesçessidades é dendas, en que á causa dellas estaban los españoles puestos en aquella ticrara, é la dilargion que avian en este caso hasta lo mandar proveer Su Magestad é de todos los españoles, é que en ninguna manera se podia excusar, le fué quassi forcado depositar los señores é naturales de aquellas partes en los conquistadores dellas, aviendo respecto á las personas é á los serviçios que avian fecho, para que en tanto que otra cosa se mandasse, ó questo se confirmasse, los señores é naturales sirviessen é diessen á cada español, en cuyo depósito estoviessen, lo que oviessen menester para su sustentacion. Y este medio se tomó con parescer de personas de buena inteligençia y expiriençia en la tierra, é les paresçió que era el mejor medio é lo que más convenia para que los españoles so manturiessen é los indios fuessen conservados é bien tractados, é se estoviessen en sus casas é assientos. E para las laçiendas é grangerias de la lieal Magestad se señalaron provinçias é cibdades de las mejores é más convinientes.

Esta relacion escribió Hernando Cortés más larga al Emperador, nuestro senor, desde la cibdad de Cuyoacan de la Nueva España, é fuć aprobada por los officiales de Su Hagestad, el thessorero Julian Alderete, y el contador Alonso de Gralo, y el factor Bernardino Vazquez de Tapia, fecha á los quinçe dias de mayo, año de la Natividad de Chripsto, nuestro Salvador, de mill é quinientos é veynte y dos años.

Passemos á la quarta relaçion de aquellas partes, la qual escribió el año de mill é quinientos é reỵnte y quatro, é assimesno envió otras relaçiones de otros sus inferiores capitanes, que por su man-

de donde tomanos el final de este y algunos de los siguienles eapitulos, para Ilenar la expresada laguna. 
dado andovicron por diverssas provinçias de aguellas partes, lo qual suçesivamen- te se contimuará en la fresente historia con la brevedad que se requicre.

\section{CAPITULO XXXIV.}

Continuảndose la historia de la Nueva España, eonforme à la quarla relacion que el gobernador Hernando Cortẻs envió al Emperador, utuestro señor, eon otras relaçiones que otros eapitanes parliculares le enviaron a Corlés despues de los subçessos que la historia ha eonlado; é Iráetase de olras provinçias que eonquistó é paeifieó, é otras eosas notables.

\section{N} te conquistados é venidos á servir, los que cstuvieron é goçaron la antigua costumbre de ser servidos é lilıres señores, viéndose siervos se alteren é muden paresçer, en especial uma gente quassi salvage é infiel é de tantas é diverssas lenyruas é costumbres, como la destas Indias. E aun porque, como diçe Ilerodiano, no taulo deleyta la libertad quanto ofende la servilud, é ninguno juzga ser obligado para usar de lo suyo, sino á su modo estimando ser asi la raçon; mas quien de sus lienes es despojado, nunca olvida la injuria. Todo esto es del auclor alegado.

Dexemos de buscar comparaciones en cosa que es tan usada en el mundo, como comportar impaçientemente el yugo ó nueva señoria los que largos ticmpos tovicron liçencia natural de no servir, ó que nasçicron sirviendo á su señor é aquel se le mudan. Llenas están las listorias desto tal desde remotos siglos: é continuemos mestra historia de la Nueva España, que assi hallaremos en ella cosas que parezcan á las passadas é se conformen con Herodiano. Para inteligencia de lo qual es de saber que por paçilicar las provinçias de Guatusco, Tuxteloeque é Guaxaca é otras á ella comarcanas, que son en la costa á la parte de la mar del Norte, desde que se rebeló Temistitan, que estaban assimesmo alçadas, envió el gobernador Hermando Cortés al alguaçil mayor Gonçalo de Sandoval con gente; é mandóle que poblasse allí é hiciesse una villa que se lla- masse Medellin, como ya la historia lo ha dicho. É assi se hiço é se paçificó todo aquello, y envióle más gente, para que fuesse la costa arriba lasta la provinçia de Guaçacalco, que está de la dicha Medellin çinquienta leguas é de Temistitan ciento y veynte: á la qual provinçia avia primero enviado el general al capitan Diego de Ordaz, é le avian resçelido nuy ljien en el tiempo que Montecuma vivia, é se arian ofresçido por vassallos de Su Hagrestad. É sabíase que allí avia un grand rio é buen puerto para los navios. E. como informado muy bien del dicho Ordaz, que le avia visto, mandó al alguaçil mayor que fuesse á visitar aquellas provinçias é á saber si cstaban en el propóssito primero de servir é ser vassallos de la corona de Castilla, é á deçirles que á causa de las guerras de Temistitan no les avia enviado á visitar tanto tiempo avia, é que aquella gente yba á ver si avian menester algo, para les ayudar ć favoresçer como amigos. I el alguaçil mayor lo dixo assi é hiço lo que le fué ordenado; pero no halló en la gentc la voluntad que primero avian publicado, sino á punto de guerra aparejados para no le dejar entrar en la tierra; y él turo lau buen aviso é tiento con cllos, que una noche salteó un pueblo, donde prendió una señora, á quien todos en aquella comarca obedesçian, la qual envió á llamar á todos los scĩores é prinçipales, é les mandó que obedesciessen al Emperador Rey, nuestro señor, é se liç̧iesse todo lo que en su 
leal nomlne fuesse mandalo, porque ella assi lo avia liecho. I cra lan querida é neatada de sus indios, que todo se cuntplió é hiço de la manera que ella lo dixo. De manera que en paz é sin ofro contras. te el algaçil mayor llegó al rio ques diclıo; é á quatro leguas de la mar, porque más çcrea de la costa no se lialló assiento, se pobló é fundó un pueblo, é púsosele nombe la villa del Espiritu Sancto. É allí residió el alguacil mayor con los españoles algunos dias, hasta que se paçificaron y rinieron á la olsidiençia de Su Magestad.

Otras muclas provinçias, que fueron Tabasco, que es en el rio de la Victoria, que otros llaman rio de Grijalva, Cunaclan, QQucchula é Quiçaltepecue é olras, é los naturales de aquellas provinçias, sc encomendaron é depositaron en los reçinos de la dicha villa del Espíritu Sancto; puesto que algunas tierras dessas se tornaron á alterar é se alçaron, contra los quales se enrió despues gente de pié é de caballo para los castigar é volver á la obidiençia. Tambien se avian ofresçido el señor é gente de la provingia de Hechuacan por súbditos de Su Magrestad; é porque la provincia é señorio del señor de Casulçi "es grande, é sc avian visto mues. tras en ella de mucha riqueza é por eslar çercana de la griand cibdad de Temislitan, despues quel general se rehizo de alguna más gente ć caballos, envió allá um capitan con septenta de cahallo é dosçientos peones bien aderesçados é con artilleria, para que viessen toda aquella tierra é secretos della; é si lal fuesse, polylas. sen en la prinçipal ciludad, Ilamada IIuyçiçila. É ydos, fucron muy l,ien resçebidos del scñor é naturales de la tierra ; é apossentados en aquella cibdad, los proveyeron muy bien de hastimentos é lo nescessal’io, é les dieron hasta tres nill marcos de plata é lata çinco mill pessos de oro nuezclaclo con plata é baxo, é muy guentil ropa de algrodon é otras cosas de lis que los imdios tienen. $\mathbf{A}$ los espanoles no les satistico mucho la ticrea para poblar en ella, é mostraron mala voluutard, é aum ovieron algmos bulliçios é alteraciones, por donde alghmos fucron casligados: é por estal causa mandó el general que volriessen los que volver se quisiessen, é á los denrás orklenó que fuessen con uu capitan á la mar del Sur, adonde estí pohlada la villa de Cacatula, de quien la listoria la hocho mençion, desde la qual lıasta la cibdad de Iluyçiçila lay çient leguas, donde di la sacon se liaçian por mandado del gobernador quatro navios para descobrir. Y en el camino luvo noliçia esta gente nuestra de una provinçia que se diçe Colimá, que está apartada del camino que arian de llerar solre la mano derecha, ques al Poniente sinquienta leguas; é con la gente que Ilevaha é con mucha más de los amigos de la provincia de Mechuacan fuć allá sin liçençia del gobernador: y enlró algumas jornadas, é ovo con los naturales algunos recuentros, é aunque tenia quarenta de cilsallo é más de cient peones ballesteros é rodcleros, los desharataron y echaron de la tierra, é les mataron tres españoles é mucha gente de los amigos. E desharalados, sc fueron á la ciblad de Cicalula, lo fual salido por el general, enrió á prender al capilan, é se lo lleraron, é lo casligó de su inobidiençia: lo que fuć muy justo, aunque fucra rençedor . como lo enseñó Torquato en el hijo proprio, que porque peleó de cuerpo á cuerpo con un francés é lo rençió é mató. sin tener liçençia para tal balalla, le hico corlar la cabeça.

Contado lí nuestra historia cómo el general Hernando Cortés envió al comendador Pedro de Alvarado í la provincia 
de Teantepeque, ques en la mar del Sur, ¿ de cómo tenia pressos al señor della é át un hijo suyo, é le pressentaron çierto oro é de çiertas muestras de oro de minas é perlas, que assimesmo se ovo. Queda de deçir agora que en la respuesta quel general le envió despues desso, le mandó buscasse un sitio convenible é poblasse en él; é que los reçinos de la villa de Sesura de la Frontera se passassen á apuel pueblo, porque ya del que estaba allí no avia nescessidad, por ser tan cerca de Teunislilan; é assi se liço, é llamóse al pueblo Segura de la Frontera, é como el que antes estaba fecho. E los naturales de apuella provincia é de las de Guaxaca, Coaclan, é Coasclahuaca, Tachquiaco é otras allí comarcanas, se reparticron entre los veçinos de aquella villa é los servian é aprovechaban con toda voluntad : é queló allí por justiçia el capitan, en lugar del general, digo el comendador Alvarado. E acaesçió que estando Hernando Cortés conquistando la provinçia de Panuco, como se dirá adelante, los alcaldes é regidores de aquella villa le rogaron al dicho Avarado, que con su poder fuesse á negociar con el general çiertas cosas que le encomendaron, y él lo açeptó é puso por obra ; é despues de partido, los alcaldes é regidores hiçicron çicrta liga é monipodio, convocando la comunidad, é hiçieron alcalile contra la voluntad de otro que avia dexado Mvarado por capilan, é despohlaron la villa é fuéronse á la provinçia de Guaxaca, lo qual puso mucho escéndalo é alboroto en aquellas partes. El que allí avia quedado por capitan hícolo saber al general, y él envió luego allá á Diego de Campo, alcalde mayor, para que avida su informacion, castigasse los culpados, los quales se ausentaron é andoricron algunos dias vagando de unas partes á otras. E al primero que prendió, sentensióle el alcalde mayor át mucrte, é apeló para ante el general, que tenia ya pres- sos á los demís, é los mandó culregar assimesmo al dicho alcalle mayor, é condenólos á muerte como al otro, é lambien apclaron. Y el gobernador, considerando la larga prission en que estovieron, é que avia mucho liempo que estaban en aquella é avian antes servido, aunque su delicto fué grande, se ovo piadosamente con cllos, é los desteró de la Nueva España en perpétuo exilio, para que nunca entrassen en clla sin expresa liçençia de Su Magestad, só pena de muerte.

En esse mesmo tiempo murió el señor de la provinçia de Tulepeque, y ella é las otras se rebelaron, á causa de lo qual envió el general al dicho capitan Alvarado con un hijo de aquel señor, que estaba en su po. der ; é aunque ovieron algunos recuentros é mataron alşunos españoles, tornó á sobjuzgar los rebeldes é las provincias, é las paçificó é puso en la obidiençia de Su Magestad, é tornaron á servir á los españoles seguramente. É aunque no se tornó í poblar aquella villa, por falta de gente, quedaron los indios dlomados, é tan humildes por el castigo que en ellos se liço, que hasta Temistitan vinieron de alú adelante á ver é lacer lo que les mandaban. E quedó en el señorio aquel hijo del señor defuncto.

Desde á pocos dias despues que se cobró la grand cibulad de Temistitan, é lo á ella subjeto, fucron reduçidas á la corona real de Castilla dos provinçias que están quarenta leguas della á la parte del Norte, que confinan con la provinçia de Panuco: la una se Ilama Tututepeque, é la otra Mezclitan, de lierra assaz fuerte é gente belicosa é acostumbracla à la guerra, por los contrarios enemigos que todas partes al rededor de sí tienen. Los quales, viendo las cosas passadas, é que á Sus Mlageslades ninguna cosa se les podia defender, enviaron sus mensajeros al general, é ofresçiéronse por vassallos de la corona real de Castilla: é fueron resçchidos con 
Inucha lumanidiud é placer, é se les liggo Iodo luen tractanicnto. Y esturicron muy seguras aquellas provincias hasta que despues de la yda del reedor, Chripstóbal de Tapia: que con la alteracion que della suliçedió, no solamente dexaron la ohidiencia que avian dado é se rehelaron, más allende desso licicron mucho daño á los comareanos en sus tierras, que cran de los amigos é vassallos de Su Jagestad, é quemaron muchos puchlos é mataron mucha grente; é aun en essa saçon el greneral tenia poca gente, y essa que avia estaha dividida en tres partes. Viendo que dexar de proveer en ello podria ser ocasion que los enemigos, que con aquellos rebelles coufinaban se podrian alçar é juntar con cllos por se excusar del daño é vejaçion que les haçian, é amn porque el general no estaba muy satisfecho de su voluntad dellos, envió un capitan con treynla de caballo é çient peones ballesteros y escopeteros é rodeleros, é mucha gente de los amigos confederados, é ovieron con los contrarios algunos recuentros; é mataron alguna gente de nuestros amigos é dos españoles. É plugo á Dios que non obstante esto, cllos de su voluntad se reduxeron á la paz, é fueron al general los scñores é prinçipales, y él los perdonó por su comedimiento é yrse á poner en sus manos, sin los aver prendido.

Despues, estando el general en la provinça de Panuco, començóse á rugir en Temistitan é sus comareas una nueva sorda, en que sonaba que Hernando Cortés se yha á Castilla: é no causó poco alborolo, é la provinça de Tutebeque se tornó á rebelar. El señor della baxó de las serranias con unucla gente é quemó más de veynte pueblos de los confederados é amigos de los españoles, é les mató á prendió mucha gente dellos: por lo qual, viniéndose de camino el general de la provinçia de Panuco, los tornó á conquistar, é aunque á la entrada malaron algu"na gente de los amigos que quedala recagada, é por la sierra reventaron diez o doce caballos, por ser tan áspera tierra, todavia é no sin mucho trabaxo, se conquistó la provincia é fué presso el señor della é un hermano sıyo, muchacho, é otro capitan general suyo, que tenia la frontera: al qual, é á su scinor con él, liiso luego alıorcar el general, é hiço esclavos todos los que en esta guerra fueron pressos, que scrian lıasta dosçientas personas, é los herraron é vendieron en almoneda. É pagado el quinto á Su Magestad de aquellos prissioneros, los demás fueron repartidos entre los que se hallaron en esta guerra, aunque no ovo para pagar la terçera parte del valor de los caballos que murieron. $\dot{E}$ por ser la tierra pobre no se ovo otro despojo. É fecho cste castigo, los denás que en aquclla provinçia avia, quedaron de paz, é por señor della aquel muchacho, hermano de aquel señor, de quien se hiço la justiçia ques dicho. Puesto que en aquella sacon no servian ni aprovechaban, por ser la tierra pobre, á lo menos bastó lo fecho para segu- ridad della, é para que no alborotassen ál los que servian; é aun para más seguridad, puso allí el general algunos natırales de los de Temistitan é de otras partes de la Nueva España. 


\section{CAPITULO XXXY.}

En que se eontiene un eapilulo á la letra que el eapitan Hernando Cortésentre olras eosas escrihio al Emperador, nuestio señor, en esta su euarta relaçion, quejándose del obispo de Burgos, é otras eosas; : más adelante se Iraela de la vietoria que ovo eontra los indios de la grand poblaçion llamada Ayuluscotaclan; é de la eonquista de las lagunas de Panueo, é vieloria que ovo con essos é otros pueblos, é otras eosas que convieilen al discurso de la historia.

A esta saçon, invictíssimo Céssar, llegó al puerto é villa del Espíritu Sancto, de que ya en los capítulos antes deste he hecho mençion, un bergantinejo harto pequeño, que venia de Cuba, y en él un Johan Bono de Quexo, que con el armada que Pamphilo de Narvaez truxo avia venido á esta tierra por maestre de un navio de los que en la dicha armada vinieron; y segund paresçió por despachos que traia, venia por mandado cte don Johan de Fonseca, obispo de Burgos, creyendo que Chripstóbal de Tapia, quél avia rodeado que viniesse por golsernador á esta tierra, estaba en ella. Y para que si en su resçibimiento oviesse contradiçion, como él temia, por la entera raçon que á te. merlo le inçitaba, envióle por la isla de Cuba para que lo comunicasse con Diego Velazquez, como lo liço, y él le dió el bergantin en que passasse. Traia el dicho Johan Bono hasta çient cartas de un tenor frmadas del dicho obispo, y aun creo que en blanco, para que viesse á las personas que acá estaban que al dicho Johan Bono le paresçiesse, diçiéndoles que servirian mucho á vuestra Cathólica Hagestad en que el dicho Tapia fuesse resçebido, y que por ello les prometia muy creçidas merçedes; é que supiessen que en mi compañia estaban contra la voluntad de Vuestra Magestad, é otras muclias cosas algo inçitatorias á bulliçio é desasosiego. É á mí me escribió otra carta, diçiéndome lo mesmo, é que si yo obedesçia al dicho Tapia, quél haria con Vuestra Alteça que me hiçiesse señaladas mer10:10 $\mathrm{ll1}$. çedes: donde no, que tuviesse por çerto que me avia de ser mortal enemigo. É la venida deste Johan Bono é las cartas que truxo pusieron tanta alteraçion en las gentes de mi compania, que çertifico á Vuestra Nagestad que si yo no los asegurara, diçiéndoles la causa porque el obispo aquello les escribia, é que no temiessen sus amenaças, y que el mayor serviçio que Vuestra Cathólica Magestad resçibiria, é por donde más merçedes les mandaria facer era por no consentir quel obispo ni cosa suya se entremeliesse en estas partes; porque era con intençion de esconder la verdad della á Vuestra Alteça é pedir merçedes en ella, sin que Vuestra Magestad supiesse lo que le daba: que hubiera Larto que haçer en los apaçiguar, en especial que fuy informado, aunque Io disimulé por el tiempo, que algunos avian puesto en púática que, pues en pago de sus serviçios se les ponian temores, que era bien, pues aria comunidad en Castilla, que la hiçiessen acá, hasta que Vuestra Alteça fuesse informado de la verdad, pues el obispo tenia tanta mano en esta negoçiaçion, que haçia que sus relaçiones no viniessen á notiça de Vuestra Altega: é que tenia los offeciales de la casa de la Contractaçion de Sevilia de su mano, é que allí eran maltractados sus mensajuros é Lomadas sus relaçiones é cartas é sus dineros, é se les defendia gue no les viniesse socorro de gente de armas ni bastimentos. Pero con liaçerles yo saber to que arriba digo, é que Vuestra Magestad de ninguna cosa era sabedor, é que tu- 
viessen por çicrto que sabilo por V'uestra Alteça, serian gratificalos sus servicios, é fechas por ellosaquellas merçedes, que los buenos é leales vassallos que á su liey é señor sirven, como ellos han servido, meresçen, se aseguraron. í con la merçed que Vuestra Alteça turo por bien de mandar hacer con sus reales provisiones, han estadio y están tan conteintos, é sirven con tan buena voluntad qual el fructo de sus servicios dá lestimonio, é por ellos meresçen que Vuestra Alteģa les mande haçer merçedes, pues tan bien lo han servido é sirven é lienen voluntad de servir. É yo por mi parte muy hamilde á Vuestra Magestarl lo stiplico, porque no en unenos merçed resgibiré la que á qualquiera dellos mandáre baçer, que si á mí se hiçiesse, pues yo sin ellos no pucliera aver servido a Tuestra Aiteça, como to he fecho. En espeçial suplico a Vuestra Alteça muy humildemente les mande escrebir, teniéndoles en serviçio los trabaxos que en su serviçio han puesto, é ofresçíndoles por ellos merçedes; porque demás de pagar la debda que en esto Vuestra Magestad (lebe, es a nimarlos para que de arqui adclante con muy mejor voluntad lo hagan.s

Diçe más el gobernador Hernando Corıés, que por una çédula, que Si Magestad mandó proveer en lo que toca al adelantado Françisco de Garay, paresçe que Su Hagestad fué informado rue Cortés estala para yr ó enviar al rio de Panuco á lo paçificar, á causa que se deçia que en aquel rio avia un puerto, é porque en él avian muerto muchos españoles. assi de los de un capitan que á él envió el dicho Françisco de Garay, como de otra nao ‘ne despues con licmpo dió en aquella costa, que no quedó alguno vivo: é polque algunos de los maturales de aquellas partes avian vonido al diclo general á se desculpar de aquellas muertes. diriendo que to avian hecho porque supicron gue no era de su compañia de Cortés, é porque arian seydo dellos maltractados; pero que si él quisiesse enviar allá gonte de su compaña, quellos la ternian en mucho é los servirian con todo lo quellos pudiessen, é le agradesçerian muclıo que los enviasse, porque temian que aquelia gente con quicn ellos avian peleado, volverian sobrellos á se rengar, é rambien porque tenian fiertos enemigos comarcanos, de quien resçibian daño, é que si él les dicsse cluripstianos, se favoresgerian. É porque quando estos vinicron a haçer estas desculpas é ofresçimiento, el general tenia poca gente, no pudo cumplir lo que le pedian; pero prometióles que lo haria lo más brevemente quél pudiesse: é con esto se fueron contentos, quedando ofresçidos por vassallos de Su Magesład diez ó doçe pueblos de los más comarcanos á la raya de los súbditos á la cibdad de Temistitan.

Desde á pocos dias tornaron á venir, ahincándole mucho que, pues que enviaba españoles á poblar á muchas partes, que enviasse assimesmo algunos á poblar allí coñ ellos, porque resçibian mucho dañode aquellos sus contrarios é de los del inesmo rio, que estan á la costa de la mar: que aunque eran todos unos, por averse. veniclo al general, les haçian mal tractamiento. Assi por complir con estos como por połlar aquella lierra, é tambien porque ya tenia alguna más gente, señaló un capilan con çiertos compañeros para que fuessen al dicho rio; y estando para partir, supo de un navio que fué de la isla de Cuba, cómo el almirante don Dicgo Colon, é los adelantados Diego Velazquez é Françisco de Garay quedaban juntos en la dicha isla, é unuy confederados para entrar por alli, como sus enemigos, á le haçer todo el daño que pudiessen. En esta sospecha ó imaginaçion Cortés se engañó mucho, porque el almirante numca le passó tal por el pensamiento ni orotal confoderacion: pero como él se 
tenia de los adclantados, dálbanle á entender aquello é otras cosas. É assi él por excusar que no le ofendiessen lo ques dicho, é porque pensaba que excusaria assimesmo por la yda de aquellos adelantados no se ofresçiesse otro semejante alboroto é desconçicrto, como el que sc ofresçió con la yda de Pamphilo de Narvaez, determinó, dexando en la cibdad de Temistitan el mojor recabdo quél pudo, de yr en persona; porque si los adelantados ó algunos dellos fuessen, se cncontrassen con él antes que con otro, porque podria él mejor excusar el daño. É assi sc partió con çicnto é veynte de caballo, é con tresçientos peones é alguna artillcria, é con hasta quarenta mill hombres de gucrra de los naturales de Temistitan é sus comarcas. É lleģado á la raya de su ticra, bien veynte é çinco leguas antes de llegar a! pucrto, en una grand poblaçion que se diçe Ayuluscoíaclan, le salieron al campo mucha grente de gucrra é pelcaron con ellos. É assi por tencr el general tanta gente de los amigos como ellos venian, como por ser el lugar llano é aparcjado para los cabalíos, no turó mucho la batalla; ć aunque algunos españoles fueron heridos, ć assinesmo algunos cahallos, é mataron algunos de los amigos, fueron los contrarios vençidos é desbaratados é muertos michos dellos. En aquel pucblo se detuvo el general tres dias, porque se curassen los licridos, é porque vinicron allí á él los ques dicho que á Temistitan avian ydo á se ofreseger por vassallos de Su llagestad; ć desde allí le acompañaron hasta llegar al puer10, é de allí adclante, sirviendo en todo lo que podian. É continuándose cl camino hasta el pucrto, en ninguna parte se ovo otro recuentro con aquella gente: antes los del camino, por donde el general é su exérçito passaba, salicron á pedir perdon de su yerro é á ofresgerse por vassallos é buenos servidores de Su Migestad.
Llegadus el general é sus mulites al puerlo é rio, se apossentó en un pueblo, cinco leģuas de la mar, que se diçe Chila, el qual estaba despohlarlo é quemado, porque allí fué donde disbarataron al arlelantado Françisco de Garay : é desde allí envió Hernando Cortés sus mensajeros de la otra partè del l’io é por aquellas lagunas (que todas están pobladas de grandes pucblos de indios) á deçirles que no tomiessen que por lo passado se les hiçiesse algun daño; porque bien sabia que por el mal tractamiento que avian resçcbido de aquella gente se avian alçado contra los nuestros, é que no tenian culpa, É nunca quisicron venir: antes maltractaron los mensajeros, é aun mataron algunos dellos; é porque de la otra parte del rio estaba el agua dulge, de donde nuestro cxérçito se proveia, poníansc allí é saltaaban á los que yban por clla.

Assi cn esta ocupaçion csíuvo el general mús de quince dias, creycndo atracrlos por bien é que viendo que los que avian venido de paz cran bien tractados, lo larian ellos assimesmo: pero fenian tanta confianca cn la fortaleça de la dispusiçion é assiento de aquellas lagunas, donde estaban, que no aprovechó ninguna templança ni cortesia con cllos. É cómo el general vidh el poco provecho que haçia é quel tiempo se perdia, atendió al remedio, é con unas canoas que al prinçipio se avian allí tomkido, se iomaron más, é con cllas una noche passaron algunos caballos de la oira parte del rio é gente; é quando fué de dia claro, ya avia copia de chripstianos é caballos é amigos de la ofra parte sin ser scntidos, y él se passó assinnesmo con cllos, dexando en el real buen recabdo. cómo los enemigos los sintieron de la otra parte, vinicron mucha copia de gentc dellos é dieron con mucho ímpetu sobre los nuestros, fanto que escribió el ganeral, que despues quól cstalıa en aquellas partes no avia visto acometer en ol 
campo tan denodadamente los indios cowo le arometicron. É mataron dos caballos é hirieron otros diez malamente, que no padieron yr en aquella jormada; mas al fin los numigos fueron vençidos é desbaratados é puestos en huyda: se siguió el a!cançe quasi una leģua, matando muchos dellos, é con hasta treynta de caballo que le quedaron al gobernador é çient peones, siguió todavia su canino. É aquel dia desta rictoria durmió en un pueblo tres leguas del real, el qual estaba poblado ; y en las mezquitas é templos de aquelloz yclólalras se hallaron muchas cosas de los españoles, que le avian muerto al adelantado Françisco de Garay.

Otro dia siguió su viage por la costa de una lagina adelante, buscando passo para passar á la olra parte della, porque del otro cabo paresçian pueblos é gente: é anduvo todo el dia sin le hallar caio ni por donde passar. É ya que ela hora de visperas, vídose un pueblo que parescria hermosa poblaçion, é tomado el camino para él, loda via por la mesma costa de la laguna, llegados cerca, era ya tarde, é no paresçia gyente alguna: é para aseģ rar las sospechas de la guerra, mandó diez le caballo que entrassen en el pucblo por el camino derecho, y él con otros diez tomó la halda del pueblo háçia la laguna, porque los diez ginetes llevaban la retrosuardia é no eran llegados. I entrando por el pueblo, paresçió mucha gente que estaba escondida dentro de las casas en çelada para tomar á los españoles descuydados; é trabóse la pelea muy osadamente, é mataron un caballo é hirieron quassi todos los otros é muchos de los españoles. É turieron tanta constançia peleando, que turó bien un quarto de hora o más, é fueron rompidos tres ó quatro veçes, é otras tantas se tornaron á rehaçer é acaudillar, é juntos, hechos una muela redonda, hincaron las rodillas en tierra, c sin hablar gritahan, como lo suelen ha-
Ger. Los otros esperahan, é ninguna vez entraban por ellos que no empleassen muclias flechas, é tan espessas que si los cliripstianos no fueran tan hien armados, como yban, no escapára hombre de los nuestros. E quiso Dios, Nuestro Señor, que á un rio que passaba junto y entraba en aquelia laguna quel general avia seguido todo el diá, algunos de los que más cercanos estaban al rio se començaron á cchiar al agua, é trás aquellos començaron ál luyr los otros al mesmo rio; é assi se desbarataron, aunque no huyeron más de hasia passar el rio, y ellos de la una parte é los españoles destoira se estuvieron hasta que escureçió la noche, é por ser el rio hondo, no pudieron passar á elios, é aun no les pessó á los españoles, quando les vieron passar. É rolviéronse el general é los que con él estaban al pueWo. que estaba un tiro de honda de aquel rio; é con la mejor gुuarda que supieron laçer, passaron aquella noche los nues¿ros, é comieron el caballo que les mataron, porque no tenian otro bastimento ni les supo mal, porque esta salsa de la lambre, con no tener otros manjares, es el mejor cosinero de todos.

Otro dia siguiente salieron por un camino, porrue ya no paresçia gente de la del dia passacio, é fueron á dar en tres 6 quatro pueblos que esiaban desamparados sin gente ni otra cosa, exçepto algunas bodegas del vino que los indios haçn de mahiz, "é hallaron assaz tinajas dello. Aquel dia no orieron ninguna resistençia, é durmieron en el campo, porque hallaron unos mahiçales con que la gente é los caluallos tuvieron algum refresco. E desta manera anduvieron dos ó tres dias sin hallar gente, aunque passaron muchos pueblos, é porque la falta del bastimento los aquexaba (que en todo este tiempo entre todos no oro çinquienta libras de pan) se tornaron al real; é la gente que en avian dexado, estaba muy buena è 
sin aver avido recuentro ni contradicion. E porque los contrarios todos paresçia que quedaban de la otra parte de aquella laguna quel general no avia podido passar, hiço una noche echar gente é caballos de la otra parte della con las canoas, é que fuesse gente de ballesteros y escopeteros por la laguna arriba é la otra gente por la tierra. É yendo desta manera, dieron sobre un grand pueblo, é como tomaron los moraadores dél descuydados, mataron muchos. Deste salto cobraron tanto temor, viendo que estando çercados de agrua los avian salteado sin sentirlo, que luego començarón á venir de paz; y en término de veynte dias vino toda la tierra á dar la obidiencia á Su Magestad, como vassallos de la corona real de Castilla, é quedaron en mucha paz é amistad con los españoles. Cómo el general vido la tierra paçífica, envió por todas las partes della personas que la visitassen é le liçiessen relaçion de todos los pueblos é gente que aria; é trayda la informaçion, buscóse el mejor assiento que por allí se pudo aver, é fundóse una villa, á la qual el general le puso nombre de Santisteban del Puerto, é á los españoles que allí quisieron quedar por veçinos, depossitóles aquellos pueblos é indios que los sirviessen con que se sostuviessen, é nombróalcaldes é regidores, é dexó allí su lugar teniente de capitan ó gobernador, con treynta de caballo é çient peones, é dióles un barco é un chinchorro que le avian traydo de la villa de la Veracruz para baslimento; é assimesmo se le envió de aquella villa un nario cargado de bastimento de carne é pan é vino é açeyte é vinagre é otras cosas, el qual se perdió con todo ello é aun dexó en una isleta en la mar, çinco leguas apartada de la costa de la tierra, tres liombres, por los quales el general envió despues en un barco, é Ios hallaron vivos, aunque con harto tral:axo: el mantenimiento de los quales en todo lo que allí esturicron fué lobos marinos, que venian muchos á aquella isleta, é avia assimesmo una frucla que queria paresçer higos.

Esto se ha dicho é traydo á consequiençia de la historia, porque passó assi, é porque de aqui se puede bien colegir cómo era aperçebido é prudente poblador Hernando Cortés, el qual escribió á Su Hagestad Cathólica que solo á él le avia costado este viage más de treynta mill pessos de oro, é á los que con él fueron otros tantos de costas é caballos y armas y herrage : el qual fué tan costoso que la herradura é clavos para ella no se pagaba con oiro tanto menos de oro pesso por pesso del hierro, ó por doblada plata quel herrage pessaba. En conclusion, que por el serviçio, quel general é sus múlites hiçieron en aquesta jornada, quedaron aquellos indios é provinçia debaxo de la obidiençia é rassallage de la corona real de Castilla. F fué de tanto fructo aquesta guerra, quo despues, no mucho tiempo passado, allegó allí un navio con mucha gente é bastimentos, é dió allí al través, que no podia hacer otra cosa; é si la tierra no esturiera de paz, no escapára persona de quantos en él yban, como los del otro que antes avian muerto los indios é se hallaron los cuerpos de los españoles, digo los cueros dellos, enteros é curados de tal manera, que tenian sus caras proprias de forma que muchos dellos se podian muy bien conosçer é los conosçicrois, puestos en aquellos diahólicos oratorios de essos yclólatras por ornamento é tropheos y en señal de su victoria. É aun quando allí lle. gó el adelantado Françisco de Garay, des. pues de lo que está dicho, no quedára él ni ninguno de los que con él yban, porque con liempo forçoso fueron á dar treynta leguas abaxo del dicho rio del Pauuco, é perdieron algunos navios, é salió la gente en tierra destroçados, como está bueno do considerar, que salen los 
que pucden y I)ios quiere cscapar de semejantes naufragios. É cómo la tierra ya eslaba de paz é poblatla de los españoles de la villa de Santisteban, ellos los socorrieron é truxeron á cueslas, como mejor pudieron, é los sirvieron lásta ponerlos en aquel pueblo; é si este soconro alli no halláran, sin otra guerra, aunque indios no los matáran, se muricran é perdieran torlos.

Muchos son los trabaxos que en esla parte se laan padescido, é grandes los meresçimientos é servicios de tan experimentado capilan é tan diestros é animosos conquistadores, hasta la qual expiriencia no se puede alguno intitular ni tener por maestro de tal arte, sin que le cueste años é sangre é haya probado las miserias é desaventuras y sed y hambre, pobreza y desnudez y otros inumerables trabaxos, que andan debaso de la militar disçiplina, por lo qual diçe Tegeçio: «De aquellos años cn que al hombre los primeros pelos le salen á la cara, se deben elegir los nuevos soldados. E Salustio diçe que el mançebo que la guerra ha de exerçitar, en la adolescençia sc debe elegir. Quiero deçir que esta gente quel capitan Hernando Cortés traia, ya de tiempo atrís muchos dellos avian exerçitado las armas, quando á aquella tierra passaron, é las avian seguido en España ć otras partes; é aunque lo de estas nuestras In- diiss es meva forma de trabaxos, diéronse á cllos, y cntendiéronlos é comportáronlos, como españoles, puesto que piria quedar los unos sendrados é perfettos, muchos consunió la gruerra é las difereriçiadas regiones, por donde se latlaron. Pero no se les niegue á sus ámimos la perfiçion de su militar condiçion, que está desde muchos siglos jubilada é aprobada. Diçe Livio que peleando los romanos debaxo de la obidiencia de löabio contra los cartaginenses, cuyo capitan era Anilsal, que cómo los romanos cran más, sin clubla vençieran, si presto no fueran socorridos de una cohorte, esquadra ó capitania de españoles enviada por Anihal en socorro de aquellos, porque los españoles son más aptos é ligecos é acoslimbrados á combalir entre las piedras é montes é ripas é peñas que no cran los romanos, é que haçiendo burla del enemigo, se fueron los españoles sanos é salros. Assi que, no ha pocos años que esta nuestra masçion está heredada en la universal opinion en el mundo por una de las generasçiones más famosas en las cosas de la guerra. Passemos á nuestra historia: que hay tanto que deçir y escribir en ella, que no es menester que nos detengamos en estos ormamentos, que de otras historias se mezclan aqui, no para otro efetto sino para dar á entender lo que conviene al propóssito de lo que se tracta.

\section{CAPITULO XXXVI.}

En el qual se tracla la paçificaçion de la provinçia de Coliman é de otras á ella çereanas, é de çierla relaçion que le fué fceha al general de una isla poblada de mugeres, é de la yda del adelantado Françisco do Garay al rio ó provinẹia de Panuco, é cómo murió despues cn la grand cibdad de Tenistilan, é olras cosas concernientes à la hisloria.

I laçion cómo yendo de camino el general Ilernando Cortés, despues de aver paçificado la provincia de Panuco, se conquistó la provingia de Tulepeque, que es- taba rebelada, é teníase nueva que de una provingia que está çerea de la mar del Sur, que se diçe Impelçingo, la qual es áspera tierra y de gente belicosa, lraçian mucho daño á los ronfederados amignos 
de los cluripstimos é vassallos de Su Hagrestad, é avian enviado á pedir socorro. i. aunque la gente estaba cansada, é hay de una mar á otra dosçientas leguas por aquel eamino que avian de $\mathrm{yr}$, hiço luego juntar veynte y çinco de caballo é ochenta peones, y envió eu socorro de los amigos un capitan con esta gente: el qual yrlo allá, é aviendo primero requerido con la paz á los contrarios, y ellos no la queriendo, subçedieron gुiertos recuentros; é por ser la tierra tan áspera, no se pudo conquistar de todo punto, mas quedaron en parte bien castigados.

Á este capitan le avia mandado el general que heelıo aquello, fuesse á la cilodad de Zacatula con la gente que lleraba é que con la que más de allí pudiesse sacar, llegasse á la provinçia de Coliman, donde la historia lia dicho que avian desharalado un capilan é gente nuestra que yban á Mechuaean; é que si no quisiessen aquellos indios obedesçer, que se les hiçiesse la guerra. Este capitan fué donde es dicho, é ya llevaba çinquienta de cahallo é çiento y çinquienta peones, é fuésse á aquella provincia, que está de la cibdad de Zacatula en la costa de la unar del Sur abaxo sessenta loguas; é por el eamino paçificó alģunos pueblos. É cómo llegó adonde al otro eapitan avian desbaratado, halló mucha gente de guerra que le estaba atendiendo, é como gente de luen ánimo, venidos á las manos, se trabó la batalla, é fué muy reñida; pero quedó la victoria por los españolés, sin que malassen á chripstiano alguno, aunque hirieron á muchos é algunos caballos; mas los enemigos pagaron hien el daño que avian hecho. Este eastigo fué de manera é con tanta sangre vertida de los eontrarios, que sin más guerra se dió toda la tierra; é no tan solamente aruella provinçia, mas otras muchas que con ella eonfinan se otorgaton por vassallos de los Reyes de Castilla, pressentes é por renir, perpétuamente: é fucron las más prinçipales Aliman, Colimante, Ciguatan. F́ deste allí hiço este capitan mensajeros al general, dándole cuenta de todo lo aeaescido: el qual le envió á mandar que buscasse un assiento que fuesse bueno, en que se fundasse una villa de espanoles, é se llamasse Coliman, como la mesma provinçia, y envió nombramiento de alcaldes é regidores para ella; é mandó que risitasse arjuellos pueblos é gente de aquellos puclılos é de aquellas provinçias, é le llevasse toda la más relaçion é secretos que pudiesse aver de la tierra: é assi lo hiço. é aun le llevó çierta muestra de perlas que allá halló. É el gobobnador repartió los puehlos de aquella provincia en los veçinos que allá quuedaron, que fueron veynte é çinco de eaballo é çiento é veynte peones.

Entre otras cosas, que se contenian en la relaçion que aquel eapitan llevó al general, era mna que avia nueva de un muy buen puerto en aquella costa, é assimesmo llevó relaçion de los señores de Çiguatan, que se afirmaban mucho aver una isla toda pohlada de mugeres, sin varon alguno, é que en çiertos tiempos passan de la tierra firme lionibres, con los quales ellas se juntan, é las quedan prenadas. Si paren mugeres, las guardan; é si lombres, los echan fuera de su compañia, É deçian questa isla está diez leguas de aquella provinȩia, é que muchos dellos han ydo allá é la laan visto, é ques muy riea de perlas é oro; pero destas mugeres no dá fée algun cliripstiano, salvo aquellos indios de Ciguatan lo testificaban de la manera ya dicha.

En nuestras cartas modernas de aquella navegraçion del Sur, está assentada una bahía ó ensenada grande, que se llama Coliman, ques en lá provinģia de que aqui se tracta: la boea de la qual está en eatorce grados desta parte de la línia equinoçial, á lì banda de nuestro polo ártico, 
segand la pintura del cosmographo Alonso de Chaves; pero segund mi opinion, yo creo que está en diez é siete grados, pocos más ó menos, como se dirú más largamente en la tergera parte desta General historia de Indias, quando se tracte en particular de los puertosé costas de la mar austral, donde se dirá el error de las cartas, desde el puerto de la Possesion la vuelta dei Oçidente é del Norte adelante. Assi que, esto se quede para allí, pues digo donde se dirá, que será en el capítulo II del libro XXXIX.

Digo pues assi, tornando á la historia: que yendo Cortés de la provinçia de $\mathrm{Pa}$ nuco en una cibdad que se dice Tuçapan, llegaron dos españoles, quél avia enviado con algunos de los naturales de Temistitan, é con otros de la prorinçia de Soconusco, ques en la mar del Sur, la costa arriba, háçia donde el gobernador de Castilla del Oro, Pedrarias Dárila andaba, dosçientas leguas ó más de Temistitan, a unas cibdades de quel general tenia notiçia muchos dias avia, que se llaman Volaclan é Guatimala, que están de la provinçia de Soconusco sessenta leguas: con los quales españoles vinieron hasta çient personas de los naturales de aquellas cibdades, por mandado de los scñores dellas, ofresçiéndose por vassallos é súbultos de Su Míagestad é de su corona real de Castilla. El general los resçibió con mucho amor é buen tractamiento, é los prometió todo favor, como á buenos é leales vassallos, si ellos no lo desmeresciessen; é les dió para ellos é sus señores algunas joyas é cosas de las quél tenia é quellos estiman ; é tornó á enviar con ellos otros dos españoles, para que los hiçiessen proveer á essos indios por camino de las cosas nescessarias. Pero no desde mucho tiempo fué avisado el general de los españoles, que estaban en la provinçia de Soconusco, cómo aquestas cibdades é sus provincias é otra que se diçe Chiapan. que está cercá dellirs, 10 grnardaban aqueIla voluntad que prinero mostraban: antes hacian daño á los pueblos de Soconuseo, porque eran anigos le los clıripstianos, é por otra parte enviaban mensajeros á los die Soconusco á desculparse, diçiendo quellos no lo hagian, sino otros indios. E para salser la verdad desto tenia el gobernador despachado al comendador Pedro de Alvarado con ochenta é tantos de caballo é dosçientos peones, en que avia algunos ballesteros y cscopeteros, é quatro tiros de artilleria é conviniente muniçion é pólvora: é assimesmo tenia fecla cierta armada de navios, de que enviaba por capitan á Chripstóbal de Olit, para que fuesse á la mar del Norte á poblar á la punta del Cabo de Higuerass, que está sessenta leguas de la ljalía de laz Isçension, ques arriba la costa oriental, ençima de la tierra que liaman Yucatan; porque tenia informacion que aquella tierra es rica, é aun porque le avian dado á entender algunos pilotos que por aquella bahía sale estrecho á la otra mar, lo qual e! general mucho desseaba saber. I esfando estos dos capitanes á punto para començar sus viajes con todo lo nesçessurio, llegó un mensajero de la villa de Sañtiestelyan del Puerto (que se pobló, como la historia to ha contado, en el rio de Panuco), por el qual los alcaldes de aquelia república le haçian saber cómo el adelantàdo Françisco de Garay avia Ilegado á aquel rio con çiento é veynte de caballo é quatroçientos peones é mucha artilleria, é que se intitulaba de gobernador de aquella tierra; é que assi lo avia dicho á los naturales de aquella provinçia con una lengua que consigo traia, é les daba á entender que los vengaria de los daños, que en la guerra passada avian resçebido de Hernando Cortés; é que fuessen con él, para eclıar de allí aquellos españoles quél avia allí dexado, é á los que más enviasse, é que los aỹudaria pa- 
ra ello, é que los naturaies estaban alterados. É para más gertificarse Cortés de la sospecha quél tenia de la confederaçion del adelantado Garay con el almirante don Diego Colom é con el adelantado Diego Velazquez, desde á pocos dias llegó al mesmo rio una caravela de la isla de Cuba, y en ella ciertos amigos é criados de Diego Velazquez, é un criado del obispo de Burgos, que deçian que yba proveido por factor de Tucatan; é toda la más compañia eran criados é parientes de Diego Velazquez é criados del almirante. Sabida esla nueva, Hernando Cortés, aunque estaba manco de un braço de una caycla de un caballo y en la cama, deterıninó de yr allá para excusar aquellos bulliçios, y envió adelante al comendador Alvarado con la gente ques dicho que tenia para su camino, y el gobernador se avia de partir desde á dos dias. Y estando las cosas en este estado, llegó un mensajero de la villa de la Veracruz quassi á media noche, é llevó cartas de un navio que avia llegado de España, é con ellas le enviaron una cédula del Emperador, nuestro señor, por la qual mandó al dicho adelantado Françisco de Garay que no se entrometiesse en el dicho rio ni en cosa alguna quel gobernador Hernando Cortés tuviesse poblado, porque era servido quél lo tuviesse en su real nombre. Con esta çédula çessó su partida, é no le fué poco bien, sino demás del mucho favor, notorio provecho para su salud, porque avia sessenta dias que no dormia del dolor del braço, y estalua con harto trabaxo. É assi despachó luego á Diego de Ocampo, su alcalde mayor, con aquella cédula de Su Magestad para que fuesse trás el capitan Pedro de Alvarado, al (qual envió el golsernador su carta, mandándole que en ninguna manera se acercasse adonde la gente del adelantado estaba, porque no se revolviessen: é mandó al alcalde mayor que notificasse aquella TON10 III. redula al ardelantado, é que le escribiesse luegro lo que á ella respondiesse. Con este despacho fué el alcalde nuayor á toda diligençia, é llegó á la provinçia de los guatescas, donde ya avia llegado el capitan Avarado, é yoba entrando por aquella provinçia adelante: é cómo supo quel alcalde mayor yba é que Hernando Cortés se quedalıa, hiçole saber luegon como el dicho $\Lambda$ varado avia sabido que un capitan de Françisco de Garay, Ilamado Gonçalo de Ovalle, andaba con veynte y dos de caballo, haçiendo daño por algunos pucblos de aquella provinçia é alterando la gente della, é que avia seydo avisado el dicho Alvarado que Gonçalo de Oralle tenia puestas cicrtas atalayas en el camino, por donde avian de passar. de lo qual se alteró Alvarado, pensando que Gonçalo de Ovalle le queria ofender. E por este temor Ilevó conçertada su gente hasta que llegó á un pueblo que se diçe de las Lajas, donde halló al Gonçalo de Ovalle con su gente, é allí ovieron habla, é le dixo lo que avian dicho que andaba haçiendo, é que se maravillaba dél, porque la intençion del gobernador Hernando Cortés é de sus capitanes no era ni avia seydo de los ofender ni hacer daño algguno: antes avia mandado que los favoresciessen é proveyessen de todo lo que tuviessen nesçessidad. É que pues aquello assi passaba, que para quellos estovicssen seguros é no oviesse escándalo ni daño entre la gente de una parte ni de otra, que le pedia por merced no tuviesse á mal que las armas é caballos de aquella gente que consigo traia, estoriessen en depóssito hasta tanto que se diesse assiento en aquellas cosas. Y el Gonçalo de Ovalle se disculpaba, diçiendo que no passaba assi como le avian informado, pero quél tenia por bien de laçer lo que le rogalua ; é assi estovieron juntos los unos é los otros, comiendo é holgando ambos capitanes é toda la más gente, sin que entre ellos 
oriesse enojo ni question alyma. Alumanos juzgaron desto, quel Gonfilo de OvaHe In hiço, como mal amigo de Fanciseo de Garay, cuyo teniente ó capitan era, é como peor pariente, pues que cra cassado con hermana de Frinçisco de Garay; ́́ que si, romo esta relacion lo dice, ello passó, no puede quedar sin culpa é nota de flaquera. Otros, disculpándole, diçen que ó por ventura no pudo ni le convino hacer ofla cosa. E aquesto es lo que los más sozpechan de aquellos á quien he visto tractar desta materia, por la. ventajosa gente que Alrarado Ileralaa assi de españoles como de indios aniggos, é principalmente por el descontento qua en los mesmos de Garay avia. Como quier quello sca, no parescicra mal alguna escaraimura í otro medio, sin que desarmáran los unos á los otros por la forma ya dicha.

Como el alcalde mayor supo lo ques dicho, proveyó con un secretario del gohernador que consigo llevaba, llamado Françisco de Orduña, que fuesse adonde estaban aquellos capitanes con un mandamiento para que se alçasse el depóssilo é les volviessen sus armas é caballos á carla uno, é les hiciesse saber que la intencion del gobernador era que fuessen favoresçidos é ayudados en lodo lo que luviessen nescessidad, no se desconçertando ellos en escandaliçar la tierra; é llevó otro mandamiento al dicho capitan Alvarado para que los favoresciesse é no se entrometiesse en tocar en cosa alguna dellos ni darles enojo, y él lo cumplió assi.

En el mesmo tiempo acaesçió qụe estando los más del adelantado Garay dentro en la mar, a la boca del rio de Panuco, como en ofensa de los recinos de aquuella villa de Santistelban (que está lasta tres leguas el rio arriba, donde suclen surgir todos los navios que á aquel puerto arribun), á esta causa un hidalgo, dicho Perlro de Vallejo, teniente de Her- nando Cortés en aquella villa, hicgo çicrtos requimimientos á los capitanes é maestres rlesta armada para que suljiessen al prerto é surgiessen en él do par, sin que la tierra resçilsiesse agravio nì alteraçion, e que si algunas provisiones traian rle Su Nagestad para entril á poblar en aquella tierra, ó en qualquicra manera que fuesse, que las mostrassen, con protextacion fue mostradas, se cumplirian en todo é por todo, como Su Hagestad lo enviasse á mandar. Al qual requiriniento los capilanes y maestres respondicron en efefto. concluyendo que no querian hacer cosa de to quel teniente les requeria é mandaba: é visla su respuesta, dió ofro mandamiento, más agravado con gierta pena, para que todavia cumpliessen lo que les mandalua, é tornaron á responder como primero. É fué assi que riendo los maestres é capitanes cómo de su ostada con los navios en la boca del rio por espacio rle dos meses ó más tiempo resultaria escándalo, assi entre los españoles que allí residian como entre ios naturales de aquella provinçia, un Castromocho, maestre de un mavio de arpullos, é otro Martin de San Johan, gnipuzcoano, maestre de otro navio, secretamente enviaron á aquel teniente sus mensajeros, haçiéndoles saber quellos querian paz y estar obidientes á los mandamientos de la justiçia: por tanto que le requirian que fuesse el teniente á sus navios, é que le resçcbirian é cumplirian todo lo que les mandasse, añadiendo que ternian forma para que los otros navios restantes assimesmo se le cntrogaran de paz, é cumplirian sus mandamientos. Ordópsio por dericute, él se deicrminó de yl con solos çinco hrombres á los dichos navios, é llegado á ellos fué resçebido de aquellos maestres que la historia ha contado, los quales meresçen las graçios ó tíulo de tan bnenos amotinadores como Gonçalo de Ovalle insuficiente capilan. 
Desde aquellos dos navios envió aquel teniente á deçir al capitan Johan de Grijalva, que era general de aquella amada por el adelantado Francisco de Garay y estaba en la nao capitana á la saçon, que assimesmo que él cumpliesse en todo aquellos requirimientos é mandanientos que ya es dicho: el qual, no solamente no quiso olsedescer, pero mandó á las otras naos que estaban pressentes que se juntassen con la suya en quél estaba, ć todas juntas, exçepto las dos de que se ha hecho mençion, se pusieron en torno de la capitana, é mandó á los capitanes dellas que tirassen con el artilleria á las dos naos é las echassen á fondo. Fste mandamiento fué público é tal que todos lo oyeron, é assi el teniente en su defensa mandó aprestar el artilleria de los dos navios que le avian obedesçido. Las naos que estaban al rededor de la capilana é los maestres é capilanes dellas no quisicron obedesçer lo mandado por el capitan ó teniente Johan de Grijalva, el qual entretanto envió un escribano, llamado Vicente Lopez, para que halılasse al teniente; é a viendo fecho su mensaje, el teniente le respondió justificando su causa, que su venida era álli solamente por bien de paz é por evitar escándalos é otros bulliçios que se seguian de estar las naos fuera del puerto, adonde avian de surgir, é como cosarios puestos en lugar sospechoso para haçer algun salto en tierra de Su Mageslad, é que paresçia cosa fea é sonaba muy mal. É á este propóssito suyo lixo otras raçones, que obraron tanto en aquel escribano, que tornando con la respuesta al capitan Grijalva, le informó de lo quel teniente deçia, é sobre esso le aconsejó, atrayendo al dicho Grijalva para que olsedesçiesse, diçiendo que estaba claro que el teniente era justiçia en aquella provinçia por Su llagestad, é quel capitan Grijalva sabia que hasta estonçes por parto del adelantado Francisco Garay ni por la suya se avian pressentado provisiones reales algunas, que el teniente con los otros veçinos de aquella villa de Santesteban debiessen obelesçer, é que era cosa muy fea estar de la manera que estaban con los navios como cosarios en tierra de Su Magestad. El qual Johan de Grijalva, movido por el parescer del escribano é por las raçones ya dichas, con los maestres é capitanes de los otros návios obebesçieron al teniente, é se subieron el rio arriba, donde suclen surgir los otros navios; é llegados al puerto, por la desolsidiençia quel Johan de Grijalva avia mostrado á los mandamientos del teniente, le mandó prender. Sabida esta prission por el alcalde mayor Diego de Ocampo, luego otro dia envió su mandamiento para que lo soltassen é fuesse favorescrido è é los demás que con él yban en los dichos navios, sin que les tocassen en cosa alguna. Tambien digo que aquel escribano Viçente Lopez es licen de colocarle en la reputaçion que á los maestres é á Gonçalo de Ovalle é al Johan de Grijalva por ignorante capitan, cuya poca prudençia é inhabilidad era ya nuy notoria á los españoles de aquellas partes deste aquel camino é descubrimiento quél avia hecho por el adelantado Diego Velazquez, como la historia lo cuenta en el libro XV'll de lis primera parte.

Assimesmo escriljió este alcalde mayor, como hombre sabido, al adclantado Francisco de Garay, que estaba en otro puerto diez ó doçe legguas de allí, haçiéndole saber como el gobcrnador Hernando Cortés no podia por estonçes yr á verse con él por su indispusiçion, é que le enviaba á él con su poder para que entre ellos se diesse assiento en lo que se debia lagerer, é para que vistas las provisiones de la una parte é de la otra, se concluyese aquello que más serviçio fuesse te Su Magestad. E cómo esta carta vido of adelantado, lacgo se fiué adonde el alcal. 
de mayor estaba, el qual fué muy bien resçchido é proreydo él é toda su gente de lo nesçessario. E assi juntos, despues que ovicron platicado é visto las provisiones é leydo la çédula, de que nuevamente se fico merçed al gobernador IIernando Cortés, é aviendo con ella requerido el alcalde mayor al adelantado, é obedesçila por él, respondió que estaba presto de la cumplir, y en complimiento della dixo que se queria yr á reeoger á sus navios con su gente para yo á poblar ofra tierra fuera de la contenida en la çédula real. E fue pues la voluntad de Hernando Cortés wa de le favorescer, que rogaba al alcalde mayor que le hiçiesse recoger toda sir gente, porque muchos de los que eonsigo avia traido se le querian quedar, é otros se le avian ausentado, é que le liiyesse proveer de bastimentos para los navios ć gente, de que tenia mucha nessessidal. E luego el alcalde mayor lo proveyó todo, como lo pidió, é se pregonó luego en el dicho pucrto (adonde estaba la más gente de la una é de la otra parte), que todas las personas que avian yo en acuella armada del adelantado Françiseo de Garay le siguiessen é se juniassen con él, só pena que el que assi no lo liçicsse, si fuere hombre de caballo, perdiesse las armas é eaballoé su persona le fuesse entregada en prission al dicho adelantado; é que si fuesse peon, se le diesse çient açotes, é assimesmo se le entregassoll. Pena cra esta que para exceutalla se perdieran primero muchas vidas, porque los açotes no los eomportan sino liombres viles; é aun para darse tal pena, deben ser muy comedidos los jucces para pregonar essa generalidad, pues remos á caballo algunas veçes personas que usan más dellos para huyr que no para esperar, é andar otros á pié que sabrian manlar á los tales de caballo. Assi que, bueno será quel hombre de bien que fuesse peon, tenga un caluallo é un arnés en de- póssito para tales pregones é tiempos. Pero estarl átento, letor, é sabreys de qué manera se guardó esse pregon, ó qué firucto salió dél, pues que todo lo que parescia cortesia é cumplimiento con el pobre adelantado, se le convirtió en trabaxos é total perdiçion suya.

Piuió assimesmo l'rançiseo de Garay al alcalde mayor, que porque algunos de los de su armada avian vendido las armas é los całallos en el pueto de Santisteban, y en aquel puerto doncle estaban y en otras partes de aquella comarca, que se les hiciesse volver, porque sin las armas é caballos, no se podria servir dellos. Y el alcalde mayor proveyó en ello, é lirco volver las dichas armas é eaballos á los que las avian eomprado, é darlas al adelantado é á quien lo ordenó; é hiço el alcalde mayor poner alguaçiles é prender á quantos se yluan huyendo, é se los entregó assi pressos muchos que se tomaron. Assimesmo envió el alcalde mayor á la villa de Santisteban (ques el puerto donde se hiçieron las más diligençias é pregonaron lo ques dicho), para que reeogiessen la gente que se le ausentaba é se la entregassen, é se tomasse todo el bastimento que se pudiesse àver, é se proveyesser las naos del dicho adelantado; é que se eobrassen todas las armas é eaballos que assimesmo se oviessen rendido, é se le entregassen al adclantado: lo qual se hiço todo eon mucha diligençia. Y el adclantado se partió al puerto para se yr á embarcar, y el alealde mayor se quedó con su gente, por no poner en más nesçessidad el puerto de la en que estalıa, é porque mejor se pudiessen proveer. I estuvo allí seys ó siete dias para saber cómo se eumplia todo lo que se avia proveydo y el gohernador mandó. É fecho assi, escribió al adelantado, porque avia falta de bastimentos, si mandaba alguna rosa, porque él se volvia á la cibdad de Temistitan. donde el gobernador avia 
quedado. Y el adclantado le liço luego un mensajero, haçiéndole saber cómo él no hallaba aparejo para se yr por aver hallado sus navios perdidos, que se le avian perdido seys dellos, é los que quedaban no estaban para navegar; é quél quedaba haçiendo una informaçion para que al gobernador le conslasse ser assi, cómo él no tenia aparejo para salir de la tierra; é que assimesmo le luacia saber al alcalde mayor, que su gente se ponia con él en debates é pleytos, diçiendo que no eran obligados á le seguir; ć que avian apelado de los mandamientos quel dicho alcalde mayor avia dado, diciendo que no eran obligados á los cumplir por diez é seys ó diez é siete causas, é una dellas era que sc avian muerto çiertas personas de bambre de los que en su compañia veuian, con otras no muy honeslas que se enderesçaban á su persona. É assimesmo le hiço saber que no bastaban todas las diligençias que se haçian para retener la gente, que anochesçian é no amanesçian; porque los que un dia le entregaban pressos, otro dia se yban en poniéndolos en libertad, é que acontesçió de la noche á la mañana faltarle dosçientos lombres: por tanto, que le rogaba é pedia por merced muy afettuosamente que no se partiesse liasta quél llegasse, porque él queria yr á verse con el gobernador Hernanclo Cortés á Temistilan, porque si allí lo dexaban, pensaria ahogarso de enojo.

El alcalde mayor, vista la carta del adelantado, acordó de agruardarle, é fué desde á dos dias que le escribió ; é desde allí hiçieron mensajero al gobernador, por el qual el alcalde mayor le hiço saber cómo el adelantado yba á verse con él á aquella cibdad: é porque ellos se yban poco á poco hasta un pueblo que se llama Cicoaque, ques á la raya de aquellas provincias, que alli aguardaria su respuesta. El adelantado le escribió, liaçiéndole relacion del mal aparejo que tenia de navios, é de la mala roluntad que su gente le avia mostrado; é porque creia quel golsernador ternia aparejo para le poder remediar, assi proveyéndole de la gente quo toviesse, como de lo demás que oviesse menester, é porque conosçia que por mano de otro no podria ser remediado ni ayudado, avia acordado de se yr á ver con él, é que le ofresçia á su hijo el mayor, con todo lo quél tenia y esperabit dexalle, para se le dar por yerno, é que se casasse con una hija suya pequeña do tiempo. En la qual saçon, constándole al alcalde mayor, al tiempo que se parlia para Temistitan, que avian ydo cu aqquella armada de Françisco de Garay algunas personas sospechosas, amigos é criados de Dicgo Velazquez, é que se avian mostrado muy contrarios á las cosas del gohernador Hernando Cortés; viendo que no era bien que quedassen ell aquella provinçia, porque de su conversacion nasçerian algunos luulliçios é desasosiegos en la tierra, conforme á çierta provision real que Su Magestad avia mandado enviar, para que quando fuesse nescressario é oviesse lás tales personas escandalosas, saliessur de la tierra, les mandó salir della. E los que avia sospechosos eran estos: Gonçalo de Figueroa, Alonso de Mendoga, Antonio de la Cerda, Johan Dávila, Iorenço de Ulloa Taborda, Johan de Grijalva, é Johan de Medina, é otros. É fecho aquesto, se vinieron al dicho pueblo de Cicoaque, donde les llegó la respuesta del gobernador á sus cartas, mostrando por sus letras que holgaba muclio de la vista é yda del adelantado, é que llegado á aquella cilsdad, se entenderia con mucha voluntad en todo lo que le avia escrijpto, y en cómo, conforme á su desseo, fuesse niuy bien despachado é proveydo. É mandó por su persona, por el camino á lodos los señores de los pueblos, que le diesson muy complickmente todo lo nosges- 
sario, é á lodos los que con él yluan.

Llegando cl adelantado á la grand cibdad de 'Temistitan, le rescilió el general Hermando Cortés con toda la cortesia é luenas obras que se regincria, é como mejor él supo laçerlo, ó lo liçicra con un verdadero hermano; porque dice en su relaçion, que en la rerdad le pessó mucho de la pérdida de sus navios é desvio de su grente, é le ofresçió su voluntad para hacer por él todo lo que posible fnesse. É cómo cl adelantado tenia muclio desseo que oviesse efetlo lo que le avia eseripto cerca de aquel matrimonio, fornó con nuclua instancia á le importunar que lo concluyesse: y el general, por lo haşer placer, acordó de Laçer en todo lo que le rogaba, y el adelantado tanto desseaba: solre lo qual se hiçieron de consentimicnto de ambas partes, con mucha gertinidad é jurameutos, siertos capítulos que concluian el dicho casamiento, é lo que cada parte avia de complir para se cfelluar, con tanto que, ante todas cosas, fuesse Su Mlagestad çcrtificado de lo capitulado, é lo oviesse por bien, é se 10viesse por bion servido dello. De mancra que demás de su amistad antigua, quedaron con lo tractado é assentado entro ellos, juntamente con el debdo que avian tomado por medio de sus hijos, tan conformes é de una voluntad é querer, que no entendian de más que en lo que á cada uno estaba bien en el despacho, prin. ripalmente del dicho adelantado.

Nucho trabaxó cl alcalde mayor en que la gente del adelantado, que andaba derramada por la tierra, se juntassen con é!, ¿ no bastó diligençia alguna para cxeusar ó apartar el descontentamiento que toda aquella gente tenia del dicho adelantado: antes sospechando que avian de ser compelidos á que todavia fuessen con él, eonforme á lo mandado é pregonado, se metieron la tierra adentro por lugares é parles, divisos de tres en tres é de seysen seys, y en usta manera escondidos, sin que pudiessen ser avidos ni recoggidos: (jue fué cansa prinçipal que los indios naturales de aquella provinçia se alterassen, assi por ver ál los españoles derramados por muchas partes, como por los muchos desórdenes quellos cometian entre los naturales, tomándoles las muggeres é la comida jor fuerça, con otros desasosiegros é bulliçios, que dieron causa á que toda la tierra se levantasse, ereyendo que entre los españoles, segrumt el adelantado Françiseo Garay avia publicarlo, avia division en dichos señoríos, como to dió á entender con una lengua suya, quando entró en la tierra. I lo que dello redundó fué, que tuvieron tal astuçia los indios, que informados primero dónte é cómo y en qué parte es. taban los españoles de dia, é de noche die. ron en ellos en todos los pueblos é partes que estaban derramados; é cómo andahan desapercebidos é desarmados, mataron mucho número dellos, en especial chapetones. (En estas partes llaman á los chripstianos nuevamente venidos chapetones, como en ftalia dicen á los nuevos soldados visoños, ó como quien diçe hombres que ignoran su officio y el arte de la guerra.) De cuyas mueries crescrió tanto la osadia de los interfutores que Ilegaron á aquelia vilia de Santisteban del Puerto, é la combatieron de lal manera, que pusieron á los reçinos della en tanta nescessidad, que pensaron ser perdidos; é se perdieran, si no se hallaran muy aperçebidos é juntos donde se pudieron hacer fucrtes é resistir á los contrarios, hasta que de cansados se retiraron afuera. Pero no alçaron la mano de pensar destruyr aquella villa: más como los que en clla se aveçindaron, cran soldados reteranos, salieron al campo contra cllos muchas veçes, é los desbarataron.

Extando las cosas en esta contençion, supo el gohernador Hermando Cortés lo sulycedido, por aviso que le dió un hom- 
bre de pié, que se escapo por habilidad de sus piés, de aquellos desbaratos; é le dixo é sertificó al greneral que toda la provincia de Panuco é naturales della se avian rebclado, é que ariau muerto muclıa gente de los españoles que en ella avian quedado de la compañia del adelantado, con algunos otros vecinos de la villa de Santisteban; é sospechóse, por la iuformaçion del que esta nueva llevó, que no quedaba allá algun español viro. Esta nueva dió mucho pessar al general Ilernando Cortés, porque tenia ya expiriençia que quando semejantes novedades é alteraçiones se ofresçian en aquellas partes, costaban muclıas vidas é haçiendas, é aun á veces ponian la tierta á punto de se perder. El adelantado infelice sintió tanto esta nneva é disfavor, que assi por le paresçer que avia él serdo causa dello, como porque tenia en aquella provinçia un hijo suyo con todo lo que avia llevado, de! grande pessar que ovo ado. lesçió é de aquella enfermedad murió, e passo desta pressente vida en espacio de tres dias. Assi lo dixo y escribió flernando Cortés en la relaçion que hiço al Emperador, nuestro señor, destas cosas.
Otros terceros juzgaron esta súbita mucrte ó tan açelerada del dicho adelantiudo en diferentes maneras é sentidos, en que yo no me entremeto, porque tengo por tan natural muerte al hombre la que es súbita ć arrebatada, como las que son dilatadús, pues muchas veçes las vemos. Verdad es que segund los naturales, más ayna mueren de extremado plaser, que no de extremado dolor ó enojo; pero lo uno é to otro es muy posible é acaescido muchas veces, como lo pone más largamente Plinio, é diçe solamente de dos que murieron, uno de plaçer é otro de congoja, segund diçe en su Natural Historia. Una mager avia entendido que su hijo avia muerto en la batalla de Canas, é despues tornando sano é salvo, de súlito por letiçia murió: Marco Lépido, de nobilíssima estirpe, el qual por angustia ó congoja de aquello que avia de ser, murió. A nuestro propóssito ó al deste adelantado. mucrte es esto postrero de Lépido; é paresçe apocada ó de hombres de flacos ánimos. Quien quisiere saber otras cosas acaesçitas de mucrte sílbiti ó açelerada, vea el auctor alcgatlo.

\section{CAPITULO XXXVII.}

El qual tracta cómo el general Hernando Corlés, eerlifieado de la rebelion de la provincia é indios del rio Panuco, envió á socorrer à los veçinos de la villa de Santisteban del Puerto, é del señalado é grand castign que se hiẹo en los prinçipales indius rebelados en aquella provinẹia é culpados cn la muerte del adelantado Françiseo de Garay.

D supo la primera nueva del alçaniento é rebelion de los indios de Panuco, como la historia en el capítulo preçedente lo ha contado, desseaba certificarse más del hecho, porque el que llevó la primera nueva no dabal otra raçon, sino que en un pueblo que se diçe Taçetuco, viniendlo él á pié é otros tres españoles á calıallo, les salicron al encuentro los de aquel pueblo é pelearon con ellos; é cómo los indios eran nuchos, mataron los dos caljallos é al otro peon y el caballo al otro: é que los dos que quedaron se escaparon huryondo, porque vino la noche; é que avian visto un apossento del mesmo pucislo, donde los ayia de esperar el teniente ron quinge de caballo é quarenta peones, queméndose el dicho apossento; é que creian, por las muestras que alii avian visto, rue los aviun muerto á todos.

Despres que esto se supo, é dió mucha 
alteraçion é pessar tal mensajero á quantos cliripstianos lo oyeron, llegó otro hombre del dicho teniente, que dixo que quelaba en mu pueblo que se llama Tenextequepar, ques de los subjetos á la eiludad le Temistitan é parte términos eon aquella provinçia. Kor su earta haçia saber al general, cómo estando en el pueblo de Tacelueo eon quince de caballo é quarenta peones, esperando más gente que se avia de juntar eon él, porque yba de la otra parte del rio a paçifiear çiertos pueblos que aun no estaban pacíficos, una noche, al quarto del alva, les avian çercado el apossento mueha copia de gente, é puéstoles fuego. É por presto que eahalçaron, eomo estaban deseuydados por pensar que aquellos indios estaban tan seśrmos é paçíficos, como hasta allí avian rstado, les avian dado tania priessa, que los avian muerto á lodos, salvo á él ć á otros dos de caballo. que huyendo se es(aparon, aunque á él le avian muerto su "aluallo é otro le sacó a las aneas; é que se avian escapado porque dos leguas de allí hallaron a un alcalde de la villa de Santisteban con cierta gente que los amparó; pero que no se deturieron muelıo, quellos y él salieron Iuyendo de la provinçia, é que de la gente que en la villa avia quedado, ni de la otra del adelantado Françiseo de Garay, que estaba en ciertas partes repartida, no tenian nueva ni sabian dellos; que más ereian que ninguno era viro. Porque despues quel dicho adelantado allí avia venido eon aquella gente, é avia hablado á los naturales de aquella provinçia, diçiéndoles que Hernando Cortés no avia de tener que haçer con ellos, porque él era el gobernador é á quien avian de obedesçer, é que juntándose ellos con él, echariau todos aqueIlos españoles quél tenia, aquel pueblo é los demás se avian alborotado, que nunca más quisieron servir bien á ningun español: antes bien mataban los que topa- ban solos por los camimss; é que creiun que lodos los indios se avian conçertado para liaçer lo que liçicron. É que eómo avian dado en él é la gente que con él eslaba, assi se debia pensar que avian dado en la gente que estaba en el pueblo, y en todos los demás que andaban derramados por los pueblos, porque estaban muy sin sospecha de tal alçamiento, viendo que sin ningun resabio liasta estonçes los avian servido.

Bien paresçe quel questas nuevas daba, confiessa su deseuydo y el de los otros españoles, é que no miraban que eran los que solojuzgaban á quien quitaban de la libertad que siempre tuvieron, y embebeçidos enseñoreándose, no se acordaban de la fatiga é cuydado en que viven aquellos que al nuevo yuggo é servidumbre ponen. Porque no solamente quieren é acostumbran enseũarles á lacerer rieos de sus proprios bienes á los enemigos y extraños, é assimesmo tributarios, pero á ereer é vivir de otra manera quellos viven é sus anteçessores vivieron: que son eosas que cada una dellas basta para quel nuevo señor ó conquistador, si prudente es, nunca esté sin sospecha de novedades, aurque fuessen los unos é los otros de una mesma ley ó setta, quanto més seyendo los unos gente polítiea é fundada sobre mandar, é la otra sobre salvajes é viciosos é oçiosidad; los unos chripstianos, los otros infieles ydólatras é de abomiuables viçios. Las eosas que son usadas é aprendidas en largos tiempos y clades envejesçidas, 10 se pueden desarraigar ni quitar lan sumaria é fáçilmente que se les olv:de á los viejos; y en tanto que aquellos viven, han de vivir sus heredados viçios.

Chripstianos los françeses, chripstianos los seçilianos, oyd á Sanet Antonio, arçobispo de Florençia, é vereys qué tales los pararon en Palermo y en otras cibdades é villas de aquella isła, por deseargar- 
sé de la solserluia señoria é subjeçion en que los gálicos los tenian, los quales por pequeñas causas crudamente castigaban; y eran las ciludades llenas de llanto é do cuchillo, como lo refiere el Aretino, llorando, en su Historia Florentina. Pues no creo yo que eran más comedidos nuestros españoles que los françeses, en espeçial aquellos desacaudillados é suctos é sin capitan que se apartaron del adelantado Francisco de Garay, é dieron ocasion á esta gente salvaje, 'con 'sus desórdenes, al daño que les vino.

Aviéndose el general llernando Cortés certificado de las muertes de aquellos pecadores españoles, á la mayor priessa quél pudo, despachó lueg̨o çinquenta de calballo é çient peones baliesteros y escopeteros, é quatro piegas de artilleria, con mucha pólvora é muniçion, con un capitan español, llamado Gonesalo de Sancloval, é con otros dos capilanes de los naturales de aquella giand cibdad de Temistitan con cada quinçe mill indios. É mandóles que con la mayor diligencia que pudiessen fuessen á aquella provinçia, sin se detener en otra parte, hasta llegar á la villa de Santistchan del Puerto á saber nuevas de los veçinos españoles que alli avian queclado, sospechando el grencral que podria ser estar çcreados, é que pudiessen ser socorridos. É fué assi, quel dicho capitan se dió toda la priessa quél pudo en su camino, y entró cn la provingia en dos partes, é queriéndole resiotir, pelcaron los contrarios con él, é le dió Jios victoria contra cllos; é passó adelante, continuando su camino, lasta que llegó a la villa, donde halló veynte é dos de caballo é çicnt peones. É avíanlos lenido cercados é combatidolos sey's ó siete reçes, é con çicrtos liros de artilleria que tenian se avian defendiclo, a unque no bastara su poder para poderse defender de ahi adclante, si el socorto se tardara dos ó tres dias más; é ninguno ruedara TONIO IIt. con la vida de los cercados, porque sn hambre cra ya insoportable é les faltaba todo lo que avian menester. Favian envialo un beryantin de los navios, quel adelatudado l'ancisco dic Garay alli avia tray do, á la villa de la Veracruz, para dar noliçia por aquella via al general del estado é trabaso en que cstaban, é para que les llevassen algm bastimento, cono dispues se les llevó, aunque quíndo esse Jlegó, ya avian seydlo socorridos de la gente ques dicho quel general les envió. Y el capitan Gonçalo de Sandoval estaba ya gogando de la corona obsidional, álias gramina, que ganaban aquellos que desçercaban á los que estaban çercados: de la qual dice Plinio. "Ninguna corona ó gruilnalida fué más noble en la mayestad del pucblo romano, vençedor de las lierras, en el premio de la gloria, que aquella de la gramina: la de piedras presçiosus, la de oro, la vallarí, la mural, la rostrata, la cívica ć las triumpháles lodas, eran despues desta, é todas son muy diferentes; las quales, hombres privados ó capitanes las dalian á soldados, é alguna vez á sus colegas. Concedió el triumpho el Senado despues que era libre del cuydado de la guerra y el pueblo estaba fuera de peligro; mas la corona de gramina se conçedia quando la cosa era en suma desesperaçion. $\mathrm{Ni}$ numca alguno ovo esta corona de otro que de todo el exérçito, ni jamás la ovo sino quando avia librado del cerco al exérçito cercado en el castro, de manera que los librados la daban al libertador. Las otras cran dadas por los capilanes; mas sola aquesta daban los soldados al capilan. Esla mesma es llamada obsidional, porque se daba al que avia librado el exérçito de la olssidion ó cereo, "Todo lo dicho es del anctor alcgado, el qual dice que esta hiceba gramina es verbena, la qual llevaban los legados quando eran cnviados á requerir los enemigos que volviessen las cosas tomadas á aqurellos, á quién las to- 
maron: y of umo de los laks legates crat llamado veit)enario.

Tornando á mestra licsoria, alli supieron estos descerardores cómo la gente quel adelantaulo Craray avia dexado en el puchlo que so dice Tamiquel, que serian hasla çient hombres de pić é de caballo. los avian muerlo á todos, sin escaparse ningmo dellos. sino m indio de la isla de Jamiryea que se melió por los montes: del qual se informaron cómo los tomaron de noche. É lablóse por copia que de la gente del dicho adelantado eran muerlos doscientos é septenta hombres, é de los veçinos que Corlés avia dexado en aquella villa quarenta ó tres, que andalian por sus pueblos que tenian encomendados, é aun se cree que eran mís de los dé la gente del adelantado, porpue no se acorlaban de lodlos; pero es claro que Garay llevó onçe caravelas é septecientos homlres, é que se perdicron más de los quatrocientos dellos.

Con la gente quel capitan Goncalo de Sandoval llevó, é con la quel teniente é alcalde Ienian, é con la que se lıalló en la villa, se llegraron ochenta de caballo: é partiéronse en lies parles. é diéronles guerra á los enenigos por ellas en aquella provinçia, de tal manera, que de senores é personas prinçipales fueron pressos laskia quatrocientos hombres, sin olra gence liaxa : á los quales lodos, digo á los principales, quemaron jor justigia, avienro confessirlo ser ellos los agresores é moverlores de foda aquella gruerra, é cada uno dellos aver seydo en muerte 6 arer muerto los españoles. Y execulada esta sentençia ó castiggo, soltaron los otros fuc tenian pressos, é con ellos recogieron loda la otra gente contraria en los preblos. Y cl apuilan ques dicho, en nomlre de Su Hagestad, proveyó de nuevos señores, en lugar de los que fueron quematulos, en torlos los pucblos, é de aquellas personas á quien perfenescia tal sncesion, segund las costumlures de siss lierencias.

Con esto se aseg̣mó é paçificó la lierra, é los indios de alí adelante sirvieron muy bien, con buena ó mala voluntad, porque aquella gente ì natura es belicosa é amiga de novedades, é de largo liempo avian heredalo lal costumbre, rehelándose é alçándose contra sus naturales scñores; 6 assi lo harán cada vez quel tiempo les diere ocision para ello, ó se rayan enmendando sus sucesores. Assi que, entonçes muy mejor é más cruelmente se ovieron con los españoles que tomaron descuydados, é aun con los que velaban que pudieron aver; é couforme a eslo méritamente les vino el galardon é pena del fuego, como es dicho.

\section{CAPITULO XXXVII.}

Cómo ol general Hernando Corlés tornó ả continnar el propossito que primero luvo de enviar ả poblar el puerto de Hligneras é calo de Honduras con el capilan Chripstóbal de Olit, segund se tocó en el capitulo XXXY, é le despachó é proveyó de navios é gente é todo lo nesçessario. É cómo despachó assimesmo al capitan Pedio de Alvarado por lierra con muy gentil gente de pié é de caballo ả las cibdades de Iclachan é Guatimala, como anles lo tenia propuesto.

Cuntado ha la historia que al tiempo
'fuel general Hernando Cortés supo la yda
del adelantado Francisco de Garay al rio
de Panuco, tenia á punto cierla armada
de navios de gente para cnviar al caboó
punta de llonduras, é las cansas que pa- ra ello le movian; y entonçes çessó por la yda del dicho adelantado, creyendo el gobernador que se quisiera poner en apossesionarse en la tierra por su aucloridad, é para se lo resislir, si nesçessario fuera, turo nesgessidad de toda la gente é de 
suspender aquel camino. Pero despues que se ovo dado fin en las cosas del ade. lantado, aunque se le siguió assaz costa de sucldos de marincros é bastimentos de los navios é gente que ovo de yr en ellos, paresçiéndole que servia mucho cn cllo á Su Magestad, signió todavia el propóssito començado, é compró más navios de los que antes lenia, que fueron por lodos çinco navios gruessos ó caravelas é bergantin; é liço junlar quatroçicntos lombres, hastecidos de artilleria é muniçion é armas, é de buenos bastimentos é vituallas. É demás de lo que allí se les proveyó, envió con dos criados suyos ocho mill pessos de oro á la isla de Cuba para que se comprassen caballos é bastimentos, assi para llevar en aquel primero viaje, como para que tuviessen á punto, en tocnando allí los navios, aparejo para cargarlos, porque de nesçessidad de cosa alguna no desassen de hacer aquello para quél los envió, é tambien porque al prinçipio, por falta de hastimentos, no faligassen á los naturales de la lierìa é que antes les diessen los españoles de lo que llevassen que tomarles de lo suyo. E eon este conçierto se partieron del puerto de Sanct Johan de Chalchiqqueca, á oncec dias del mes de cnero de mill é quinientos é veynte y quatro, con ordenaçion que fuessen a la Bahama, ques quassi en la punta de la isla de Cúba, para que allí se basteçiessen de lo que les faltasse, en espeçial de caballos; é recogidos allí los navios siguiesse su viaje para la diclaa lierra, y en el primero puerto della cehasse toda la gente é caballos é bastimentus é todo lo demás que en el navio llevaba, é que en el mejor assiento que te paresriesse se forlalesciesse con su artilleria, que llevaha mucha é buena, é fundasse un puchlo; é luego los tres de los navios mayores los despachasse para la dicha is- la de Cuba, al puerto de la villa de la Trinidad, porque está cn mejor parage è derrota, é allí avia de quedar el uno de aquellos criados del golernador para tener aparejada la carga de las cosas qu" fuessen menester. é quel capitan le enriasse á pedir. É que los otros navios menores y el bergantin, con el piloto mayol é un primo del general, Ilamado Diego Ilurtado, por capitan dellos, fucsse á colrer toda la costa de la bahía de la Asçension en demanda de ayuel estrecho que se creia que por allí avia; é que estuviessen allá hasta que ninguna cosa dexáss(n de ver, é visto, tornassen adonde el cliclıo capitan Chripstólual de Olit estuvicsse; is de allí, con el uno de los navios, le liiçiessen relaçion al general de lo que hatllassen, é de lo que Chripstobal de Olit tuviesse sabido de la lierra é le oviesse sub)coclido, para que de torlo se pudiesse enviar relaçion á Su Magestad. Todo lo ques dicho escribió Hernando Cortés al Emperador, nuestro señor: "pero el sulzesesso de lo demás, romo entonçes no se sabia, no to diçe, é aquello-en parte é con li muerte que turo este capitan Chripstoblyal de Olit, como ya lo la breventente tocado la historia en el libro XXY'TI, capítulo 1.

Passemos á to demís quel gobernarlor Heruando Cortés en su relaçion diçe, en la qual dió noliçia á céssar que la grente que tuvo aperegebida para enviar con (l capitan Pedro de Itrarado á aquellas cib)ciades de I'claclan *é Guatimala, como ya la historia dixo, é a otras provinçias de que tenia notiçia, tambien aria çessado por la yda del adelantado riancisco de Garay; é porque tenia ya hecha muchia costa de caluallos é armas é artilleria bastimentos, é se arian dado dineros de socorro á la grente. é porque pensaban que desto serian Sus Magestades muy servidos, é aum porque en aquella parte, sc- 
!rmol los avisos que lenia, pensalla des.obrir por alli muchas ó muy ricas y extrañas ticros, é de muchas é diferentes lenguas é gente, tornó todavia á insistil an su primero propóssito. É demás de lo que antes avia proveylo para este camino, fornó á rehagere al dicho comendador _llvarado, é despachole deste la cibrlad de Temistitan á seys dias del mes de diciembre de mill é quinientos é reynte y tres años: é llevó çiento é regunte de caluallo, en que con las dobladuras llogaban á çicnto é sessenla caluallos é trescientos peones, en que avia los çento é treynta ballesteros y escopeteros: é llevó assimesmo quatro tiros de arfilleria con mucha pótvora é mumicion; ćfucron en este exérçito alwunas personas prinçipales, assi de los te la grand cibdad de Temistitan, comode utras cibdades de aquella comarca, écon dlos atguna gente. aunque no mucha. por ser el camino largo. Y cneomendó el goneral al capitan Alvarado que tuiviesse espeçal cuydado de le laser larga é particular relacion de las cosas que por allá le acontesciessen, para que de lodo se dies. se cuenta á la Cescátrea Mlaggestạd; porque prisaba que se avia de juntar el dicho Pedro de Alrarado por donde yba, con el dicho Chripstóbal de Olit. si estreclio no le exensase. E diece que muchos caminos tales se ovicran liecho en arfuclla tirora, 6 muchos secretos della luviera sabilos, si estorloos de las armadas que aviam ylo no lo ovicran impedido: de que Sus Mlagestatles avian rescrobido mucho deservicio con allas, assi en no tener descubierlas muchas licras, como en averse dexado de adquirir para su real cómara mucha suma de oro é perlas, como de allí atlelante, si otros armaldores no shan, of pensilua aver para reslaurar lo perelido, sin exeusar sn persona de lrabaso ni gasto. É que demás de aver gasladio quanto él tenia, dige que ha tomado del oro que tenia de las rentas de Su Mageslad para los gaslos que avian hecho, sessenta é lantos mill pessos de oro, con más otros doçe mill que le avian prestado algunas personas para los gastos de su casa. Io qual se puede bien ereer por las armadas de mar é de lierra é olros gastos que con facilidad se pueden colegir de la pressente listoria.

En quanto al sulyegesso desta armada é camino del capitan Pedro de Alvarado no se tracta aqui más de lo dicho, porque lo que subçedió en clla, la lisistoria lo cuenta adelante en dos cartas é relíçiones, quél cscribió al gobenador ilernando Cortés.

\section{CAPITULO XXXIX.}

En que se lracla cumo el golyesnador Ilernando Corlés envió al capilan Rudrigo Ranjel á conquistar las prorincias de los çapotecas é de los mixes, ques gente belicosa di puesta en lierra muy áspera e fragosa e lal que la gente de caballo no puede servir ni aprovechar para la gucra de tales provincias é conquista.

1). del Espirilu Sancto é de las que servian á los vecinos dellas, se dixo en los rapítulos precelentes que algunas se avian rebelado é aun muclo çiertos españoles; ¿́ assi para redugir á la obidiençia, como para lrael al mesmo efefto otras ticras sus comareanas, porque la sente que en acquella villa estaban no cra bastante para sostener lo ganado, quanto más conquislar de nuevo, envió el general á un capitan con treynla de caluallo é çient peones. algumos dellos ballesteros y escopeleros, é dos liros de artilleria con el reralıdo de muniçion é pólvora que era nesçessario. É partiéronse á ocho de diçiem- 
hre del año de mill é quinientos é vešnte y tres años, con esperanca que se haria mucho provecho en esta conquista, porque aquello es un pedaço de lierra que está entre la conquista donde fué enviado el capitan Alvarado, é el otro donde fué el capitan Chripstóbal de Olit, é lo que cn esta saçon estaba paçífico háçia la mar del Norte ó parte septentrional. E conquistado aquello poco, hay por aquella parte del Norte más de quatrogientas legrras de ticrra subjeta á la corona real de Castilla, sin arer otra cosa ni estorbo enmedio; é por la costa de la nur del Sur más de quinientas leguas, é todo lo de la tierra adentro de mna mar á otra, que servian sin ninguna contradicion, excep10 dos provinçias que están cntre la provinçia de Tegoantepeque é la de Chimanta é Guaxaljalca, é la de Guaçacalco enmedio de lodas quatro, que se llaman la sente de ha ma sapotecas é de la otra mixes. Las quales por ser tan áspcras que aun á pié no se pueden andar, puesto glue avia el gobernador enviado dos veçes ál las conquistar, no se avia podirio lager, porque tienen muy reçia é.aspera ticrra é buenas armas: que pelean con langas de reynte y cinco é treynta pal1110s. muy gruessas é lien heclıas, y en las puntas dellas, en lugar de lierros, pedernales, é con esto se avian defendiJo é muerto algunos españoles de los que antes allá avian ydo, y liceho mucho daño á los veginos vassallos de Su Magestad, salteándoles de noche; é quemándoles los pueblos á cllos çcreanos, se avian apartado de la amistad de los españoles é confederados, é conexos. É porque no llegasse á peor estado, aunque avia poca gente de chripstianos por los aver enviado á lantas partes, hiço juntar el ģeneral liasta siento y sinquenta infantes at pié (porque los de raballo en aquella tierra no pueden ajurovechar), todos los más hallesteros y escopeteros, é quatro tiros de artilleria con nunircion é jólvora rescessaria; é con esta grente proveyó de capitan á un hidalgo llamado Rodrigo Rangel, alcalde de Temistitan, que un año antes avia ydo con sente sobre los mismos, é por ser en ticmpo de muchas aguas no pudo hacerles daño, é se Lornó con aver estado allá dos meses. El qual dicho capitan é gente parlieron esta íllima rez de Temistitan á çinco dias de febrero de mill é quinientos é regnte y quatro años; é por yr con buena gente y en luren tiempo, se huvo esperança que el subresso, mediante Dios, seria con victoria; é porque demás de los españoles youn tambien de los nalurales de Héxico é sus comarcas muchas gentes de guerra é diestra para dar fin en esla demanda. E fué muy nesçessario, porque no solamente aquellos indios de las prorinçias ya dichas de los capotecas ó miaxes no queniantservir, pero causarian á otros que hiçiessen como ellos.

Aquella lierra es muy rica de minas de oro, y cstando pacíficos aquellos indios, Ienian buena voluntad otros que lo ylsan ¿́ sacar allí, E porque estos sapotecas é sus consortes avian seydo tan rulyeldes é malos, é aviendo ya una rez ofresçídose de servir, como vassallos de Su Magestad, se quitaron de la obidiençia, é mataron cspañoles, é alteraron la lierra, fueron prommciados por esclavos; é mandó el general que los que se pudiessen tomar á rida que los herrassen como d tales caplivos, é sacando la parte é quinto de los derechos reales, se repartiessen entre aquellos que los fircron á conquistar.

Cada cutrada destas le costiba al general de su haçienda, segund en su relaçion escribió, más de çinco mill pesses de oro, é las dos que se dixo de susso de los capitanes Pedro de Alvarado é Chripstólal de Olit le costaron más de cinqüenfa mill pessos de oro, sin otros muchos fastos de sus haçiendas é grangerias. Do 
aqui se colige, demírs de su mucha liberalidarl, la mucha prontilud é diligenrobat que tenia á su proprial costil en lo que tocaba al servigio de sin Magestad é á dar conclusion é funal efetto á la conquista de aquellats partes; é porque conosçio, junln con lo que es dicho, de su buen gelo bo que dice Tito hivio: a El rico exéregito so, convierte an premio ded polse venesdor. .

\section{CAPITULO XL.}

En que el grobernador Ilernando Cortés flí su desenpa en la dilnẹion de ciertos navios que hiço haẹer on la eosta de la mar del Sur; é assinesmo euenta la listoria la forma de la reedifieacion de la gran cibiarl de Temislitan por la indushia del dicho gobernador.

C Cortio aria dado órlen cómo se hicios sen quatro navios en la costa de la mar ale Sur: es de saber. que por haber mucho licmpo que se avia comencado la lahor dellos é tan lésos dessotra mar del Norte, de donde se aria de llevar todo lo que convenia para perfece ionarlos (que hay de la una parte á la otra doscgientas leguas ò más por licrra, de fragosos pucrtos, de sierras é con muy grandes è caudalosos rios en el viage), no pulo ser menos de tardarse la olra, pues que no aria de donde se proveyessen sino de España é con mucha dificultad. É otro impedimento grande ovo demás de to que está dicho, é fué que el gobernador tenia en una casa en el puerto, donde los navios se haçian, todo el adereço que para cllos cra menester, assi como velas, claros, xarçia, clavaçon, áncoras, pez, sebo, açeyte, estopa, estoperoles, botímen é otras cosas. é una noche se puso fuego sin saber cómo, i se quemó todo cllo, sin quedar cosa de que se pudiesse aver provecho sino de las áncoras, que no se pudieron quemar, é aun de aquellas se quemaron los çepos: é despues fué menester que de nucro se tornasse torlo á provece con mayores gastos é más dilacion de tiempo. Terdad es que despltes lué ma nao de Castilla, en que se llevaron tolas las cosas nescesearias para los dichos navios, porfue el goherna- dor como prudente, temiendo atgun desastre ó lo que subcedió, avia prevenido en que llevassen todas aquellas cosas ó las más de las que se quemaron, assi porfunc no faltassen para la obra comencacla, como para haçcr más navios, si nescessario fuessc.

Decia el golernador en sul relaçion, quando esto escribió, que hasta estonçes le costaban los navios, sin averlos cchado al ağua, ocho mill pessos de oro é más, sin otras costas extraordinarias, é que pensaba que en la pasqua de Espíritu Sancto, o para el dia de Sanct Johan de aquel año podrian naregar; é que tenia en lanto aquellos navios, que no to sabia encarescer, porque con cllos pensaba ser catusa de acrescentar en aquellas mares muchos más reynos é señorios pará Su Magestad de los que hasta estonçes se te. nia motiçia. Dirge más aquella relaçion del gencral hecha á Cessar: que despues que la gran cibdad de Temistitan se cobró, le paresció que era bien residir en ella por muchos inconvinientes, é que se passó con toda la gente á un pueblo que se diçe Cnyoacan en la costa de la laguna, poryue desscaba que la cibdad se recdeficase por la grandeça é mararilloso assiento suro. Etrabaxó por recoger los naturales que por muchas parics ritaban absentados deste la gucra, é aunque al scñor della lo tenia jresso, hico á un eapitan general que on la suerra lenia, que 
(I evoberuador conosçia deste el liempo de ilonteguma, que tomisse cargo de lo tornar á poblar; é para que con más auctoridad lo pudiesse lagerer, se tornó í dar cl mesmo cargo que en tiempo de sn senor lenia, que era siguacoal, que quiere lanto deçir como lugarteniente del scñor, é á ollas personas prinçipales que assimesmo el gobernador conosçia de antes, les encargó otros cargos de gobernaçion de aquella cibdad que entre ellos solian lager. É á aquel çiguacoal é á los demás les dió señorío de tierra é gente en rque se mantuviessen, aunque no tanto como ellos tenian antes, ni que pudiessen ofenaler con ellos en algun tiempo. E honrábanlos é favorescíalos: y cllos trabaxaron de manera é tan bien, que quando IJernando Cortés cscriluió esta relaçion, avia en la cibdad poblados treynta mill veçinos, é se tenia en clla la órden que solian en sus mercados é contractaçiones. E dióles el gobernador tantas libertades y 'xençiones, que de cada dia se fué poblando más la ciludad; y cstaban los vecinos muy a su placer, porque los offeciales de artes mecánicas, que lay muchos, trabaxaban por sus jornales, assi como carpinteros, alibaniles, canteros, plateros é de otros officios, é los mercaderes muy seguramente exerçilaban su tracto é merraderias. É las otras gentes unos viven de pescadores, que es grand tracto en aqueIla cibdad, ó otros de agricoltura, porque muchos dellos tienen sus luertas é siembran en ellas las lıortaliças de España, de que allá se lleva siniente porque es gente muy inclinada á la labor del campo. É amnque Cortés en su relaçion no lo diçe, porque Lampoco en essa sacon no lo podia él aver comprendido, pues quadra arpui la maleria, digo que todo lo que se quiere sembrar en aquella lierra se lasge muy bien; é despues que se han dado d́ sembrar trigo, se ha fecho é liay tanto, que ha Ilegrado á valer la lianega de trigo un real de plata o i real y medio, y en tanta alumelançia, que la campiña de Córdova ni la fertilidad de la isla de Sieqlia no se le igrtalan. É lay mucho pastel é inumorable grana, de que se dír tal color á los paños é á las sedas é lerciopelo é rasos é damascos é tafelanes, que los muy ricos carmesies de Teneria no les hacen ventaja en la color; pero en olra parte se dirá más en este caso qut el ticmpo ha mostrado.

Despues que por fuerga de armas coJró el general la gran ciludad de Temislitan, como está dicho, puso luego por obra de haçer en ella una fuerega en el agua á una parte de la ciblad, en que pudiesse tener los bergantines seguros ó dusde ella ofender á loda la cibdad, si cn algo se pusiesse, é que esluviesse en su mano la salida é la entrada cada vez quél lo quisiesse. É lícose tal, que dice su relacion que aunque él avia visto algunas casas de ataracanas é fucrças, no eran iguales ni tales como estas, é que assi lo deçian olros muclies. E la manera que tiene aquella casa es esta: que á la parte de la laguna tiene dos lorres muy fuertes con sus troneras é defensas en las partes nesçessarials, é la una destas torres sale fuera del lienço híçia la una parte, con troneras que barren lodo el lienço; é li otra lorréa la otra parte de la mesma manera: é desde estas dos torres va un cuerpo de casa de tres naves, donde estan los bergantines, é tienen la puerła para salir y entrar entre las los torres láçia el agua. Todo este cucpo tiene assimesmo sus tloneras, é al caho dél háçia la cibhad está otra muy grand torre é de muclios apossentos baxos é altos con sus defensas á ofensas prara la cibdad. En conclusion, diçe que es tal que con tenerla, cstaba en su mano la paz é li guera. quando la guiriesse, teniendo como liemen cn clla los navios é muy buena arti lleria. 
Hechar arquella cara, porque le pares¿ió que tenia ya seguridad para complin to que desseaba, que era poblar dentro en la cibdad, se passó á clla con toula la gente de su compiñia, é repartió los solares por los veçinos, é á cada uno de los que fueron conquistadores, en nombre de Su Magestad, dió cada sendos solares por lo que en ella avian trabaxado, demás de otros cada sendos, como veçinos qua avian de servir, segund la órden de aquellas partes, ques que para adquirir entera possesion é poder testar ó disponer da los tales solares, que avian de servir é los avian de merescer, morando en la tierra en cllos tres ó quatro años. Diéronse lan. la priessa en haçer las casas de los veçinos, que al tiempo que esto eseribió el seneral al Emperador, nuestro señor, aria inuchas fechas, é otras en buenos prinçipios se continuaba la labor dellas, porque hay mucho aparejo de materiales, assi como piedra, é cal é ladrillo que los naiurales liaçen, é mucha é buena madera é todo es muy bueno. é las casas muy grandes é de lindos edefiçios. É dice la relaçion de Hernando Cortés, que desde cinco años seria la más populosa cibdad que oviesse en nucla parte del numdo, ó en torlo él, é de mejores edeficios.

Es la poblacion de los espanoles distinta de la de los naturales, porque los parte un braço de agua, aunque en todas las callesque porella la atraviessan, lay puentes de madera, por donde se contracta de la una parte á la otra. F́ lay dos grandes mercados ó plaças, el uno. en la parte que habitan los inclios, y el otro en la que moran los españoles, y en estos liay todos los bastimentos que en la tierra se pueden hallar, porque de todas las comarcas los vienen á vender, y en esto no avia falta de lo que antes solia, en el tiempo de su prosperidad. Terdad es que jojas de oro ni de plata ni plumages ni cosat rica no se tractaba entonces, como de antes lo acostumbraban, aunque algunas peguelas de oro é plata salian, pero no como primero.

Agora ya, despues que se escribió lo que esta dicho, es otro tiempo y es otro el tracto é de muchas cosas, que sin larza escriptura no se podia deçir. É viven los indios en muchó conçierto é sosiego, é como chripstianos, de lo qual se tractará adelante en su lugar.

\section{CAPITULO XLI.}

Rn el qual se tracta eúmo el general Hernando Cotlés hiẹo haẹer ẹierlas pieças de artilliria, é eómo buscando los materiales para ello, se hallaron minas de eslaño é vena de hierro, é mueho salilre para haçer pólvora, é assimesmo aęufre ; é como envió una media entebrina de metal rico de oro é plata á Su Magestad Calhóliea, que eseribio que le avia costado veynte y siete mill pessos de oru el metal é la hechura; $\dot{e}$ deçirse han olras cosas que escribió en su relaẹion, con que se darả fin á ella, sin que se dexe cosa de lo substancial, puesto que se dirá con menos palabras.

\section{D} escripta por el general Hernando Cortés al Eimperador, nuestro señor, que por las riferençias que Diego Telazquez avia querido tener con ẻl, é por la mala voluntad que á su causa é por su interçesion don Johan Fonseca, obispo de Burgos, le tenia, é por él é por su mandado los offiçiales de la casa de la Contractacion de las Indias, -que residen en Sevilla, en espeçial el contador Johan Lopez de Recalde, no avia seydo proveydo de artilleria ni armas, de que tenia nesçessidad, aunque muchas reçes avia enviado dineros para ella: é que cómo estaba en nesçessidad é sin esperança de remedio, Irabaxó de buscarle, porque no se perdiesse to que con tanto peligro se aria ganado por 
exeusar el deserviçio que en ello se pudiera seguir á Dios é á Su Magestad, y evitar el peligro de los chripstianos que allá estaban: é hiço buscar por todas aquellas partes cobre, é dió para cllo mucho rescate. É assi como tuvo cantidad dello, puso en obra con un maestro, que acaso allí avia ydo, de haçer alguna artilleria, é hiço dos piecas medias culebrinas, é salieron tan buenas, que de su medida no podian ser mejores. É porque para haçerlas, aunque tenia cobre, faltaha estaño, é para aquellos dos tiros lo avia avido con mucha dificultad (é le avia costado mucho) de algunos que tenian platos é ofras vasijas dello, é caro ni barato no hallaha más, inquiriondo é buscando por tolas partes, topáronse entre los indios naturales de una provinçia que se diçe Tacheo, çiertas peçuelas dello á manera de moneda muy delgadas, é proçediendo por su pesquisa, halló que en aquella provinçia é otras se tractaba por moneda. É Ilegando su informaçion más al cabo, supo que lo sacaban en aquella provinçia de Tachco, que está reynte $y$ seys leguas de Temistitan; é sabidas las minas, envió herramientas y españoles, é truxéronle muestra dello, é dió órden cómo se sacasse todo lo que fuera menester, puesto que con trabaxo.

Andando en busca destos metales, se topó vena de hierro en mucha cantidad, segund le informarou los que deçian que lo conosçian. Assi que, hallado el estaño, tenia hechas, quando esta relaçion envió á Su Magestar, çinco pieças, las dos medias culebrinas é las dos poco menos en medida, y él se tenia un cañon serpentino de dos sacres, que llevó quando fué á aquellas partes. Otra media culebrima compró de los bienes del adelantado Juan Ponçe de Leon; é de los navios que allá avian ydo, tenia entre todas treynta y çinco pieças de hronçe entre chicas é grandes é otras tantas de hicrro colado. TOMO III.
E para la muniçion diçe que proveyó Dios de tanto salitre é tan bueno, que podian proveer á otras partes dello; para el açufre se luvo esta forma en lo buscar. Fecho se ha mencion en esta historia de una sicrra que en aquellas partes de Guaxoçingo hay, de que sale mucho humo por la cumbre de un monte alto, como arquel que llaman volcan en una isla junto á otra, que se diçe Lipari, çerca de Seçilia; é creyendo que aquello proçerlia de algun venero de açufre, entró un español con cuerdas en aquella boca septenta í ochenta braças en hondo atado, é topó allá eu aquella profundidad el dicho açufre, é sacó, con que por estonçes se hico pólvora; pero porque la manera de lo sacar era traluaxosa é peligrosa, proveyóse en lo llevar de España.

Despues de aver el general poblado é assentado la villa de Santisteban en el rio de Pannco, é aviendo darlo fin a la conquista de Tutepeque, é aviendo despachado al capilan que fuć á los Impilçingos é á Coliman, como la historia lo la dicho, antes que se fuesse á Tenistitan, fué á la villa de la V'eracruz é á la de Medellin para las visitar. É porque halló que á causa de no aver poblaçion de esprañoles más çerca del puerto de San Johan de Chalchiqueca que la villa de Veracruz, yban los navios á descargar, é por no ser aquel puerto tan seguro, í causa de los muchos nortes é tiempos septentrioles que allí son muy ordinarios, se perdian muchos navios de los que de España é destas islas allá yban, fué á lusscar cerea del dicho puerto de Sanct Johan algun assiento para polblar, amme primero, al tiempo que allí saltó el gencral llernando Cortés, se buscó con laarta diligençia, é por ser todo sierras de arena. que se mulan á meuudo, no se halló. Ė aquesta última vez, como alli se detuvo algumos dias buscándolo, quiso Dios que a dos leguas del dicho puerto se halló 59 
muy buen assiento, con todas las callidades buenas que se requicren, porque tiene mucha leña é agna é pastos, salvo que la madera ni piedra no hay para edeficar si no se trae de léxos. É hallósc un estero ó arroyo junto al dicho assiento, por el qual mandó el general (puc subiessen con una canoa para ver si salia á la mar ó si por aquella agua podrian entrar larcas liasta el pueblo; é tentando, hallóse que yba á dar á un rio que sale á la mar, y en la boca del rio se halló una braça de agua ó más de fondo: por manera que limpiándose, conıo se limpió aquel estero que estaba ocupado de mucha madera de árboles, pueden subir las hareas hasta descargarlas dentro en las casas del pueblo.

Visto este aparejo ć la nescessidad que labia de remedio para los navios, mand6 el general que la villa de Medellin, que estaba veynte leguas la tierra adentro en la provinçia de Tuxtebeque se passasse allí é assi se hiço, é se passó allí la casa de la contractacion, porque aunque los navios se tarden de descargar, porque han de subir dos leguas con las harcas aquel estero arriba, estén seguros de perderse.

Nórase de lo que cstá diclio, para su antigiedad é origen 6 fundaçion de la villa, la causa de su mudança é adonde. Item el cuydado é diligençia grande é la astuçia de buen poblador, quel gobernador Hernando Cortés tuvo en todo lo que convenia á ennobleçinicnto é poblaçion de aquellas partes, é cómo sin perder tiempo, inquirió todo lo que á esto convenia, desseando saber el secreto de la costa, que estaba por descobrir entre el rio de Panuco é la Florida, ques lo que descubrió el adelautado Johan Ponģe de Leon: é de alii la costa de la Florida por la parte del Norte hasta los Bacallaos, creyendo que en aquella costa hay estrecloo que passe á la mar del Sar. É si se lalla, segumd çicrta figrnma que Cortés dige quél tiene del parage, adonde está aquel arcipiélaggo que descubrió el capitan Magallanes, paresce que saldrá muy çerca de allí: é dábanle á entender que se acortaria el viage de la Especicria, más corto las dos tercias partes que por donde al pressente sc navega; é que se seguirian grandes provechos é interesses á las rentas reales é al serviģio de Su Magestad. Yo le tengo á IIcrnando Cortés por mejor capitan é más diestro en las cosas de la guerra, de que avemos traclado, que no por esperto cosmógrapho al que lal le dixo; porque el estrecho de Magallanes está muy alieno de lo ques dicho é muy fuera de propóssito que por donde Cortés, segund lo dicho ó su pintura, que diçe que tiene, le han querilo signilicar, é por esso no hay que disputar agora en esto. Yo creo muy bien que al pressente lo siente muy mejor que estonģes lo escribió: porţue el tiempo ha mostrado otra cosa; pero basta con su bnen çelo de servir, pues diçe su relaçion que aunque está muy gastado y empeñado, por lo nucho que debia é avia gastado cu las otras armadas que avia hecho por tierra é por mar y en otros gastos, determinaba de enviar tres caravelas é dos bergantinesencsta demanda: aunque pensaba que le avia de costar más de quarenta mill pessos de oro, juntarse avia este serviçio con los otros que avia hecho, porqie le tenia por mayor si aquel estrecho hallasse, é ya que no se hallasse, no se dexaban de descubrir muy grandes é ricas tierras. La rerdad es que segund to que despues que essa su relaçion se escribió se ha andado en essas costas, léxos de lo çierto estaba informado el gobernador IErnando Cortés para haliar aquel estrecho (ques tan predicado é buscado y esto sin averle alguno visto ni hallado) para passar desta mar del Norte á la del Sur por el agua, exçepto que des- 
de Nicaragua para passar las lagunas clulçes el año passado de mill é quinientos é quarenta salieron navios á esta mar, ques una grandissima nuera, como se dirá adelante, porque aquel serviçio se lia de atribuyr á quien lo biço, que es muy senalado, de que se espera grandíssimo efetto, como en su lugar más puntualmente se lará mençion.

Tornemos á lo que contiene más la relaçion deste famoso gobernador, el qual diçe que entendia de enviar los navios, que tenia hechos en la mar del Sur en fin del mes de julio de aquel año de mill é quinientos é veynte y quatro por la mesma costa abaxo en demanda del dicho estrecho: digo deI quél pensaba que laallaria, porque si le oviesse, creia que no se podria esconder á los unos por la mar del Sur é á los otros por la del Norte; porque los del Sur avian de llevar la costa hasta hallar el dicho estrecho ó juntar la tierra con lo que descubrió Magallanes, é los otros del Norte, como ha dicho, hasta la juntar con los Bacallaos. É á este propóssito diçe otras cosas, en que la verdad paresçe que el que se las dió á entender se engañó, porque ni los unos ni los otros podian hallar el dicho estrecho, que pensaba hallar, ni el que han liallado los de Nicaragua, que se tocó de susso, aunque llegaron las armadas que dice a aquellas partes, quél señaló. Porque el esIrecho nuevo, aunque el agua, por clonde lıan salido de las dichas lagnnas, viene á responder por donde, poco lıa, lan salido navios á esta nuestra mar debaxo de la provinçia de Veragua, é subieron la costa arriba al Nombre de Dios, no sale á la otra mar del Sur, porque las lagunas desaguan en csta é no en la otra mar. Pero hay muy poco camino de tierra é muy llana deste lo más austral de las lagunas que digo hasta la mar del Sur, lo qual yo he visto, é como he dicho, en su lugar se tractará deste estrecho nuevo.
En la sagon que Hernando Cortes escribió su carta, estalsan los officiales que se avian proveydo para entender en las rentas reales, tomando las cuentas á los otros que antes avian tenido cargo de la laçienda; é los nuevamente proveydos fueron Alonso de Estrada, natural de Cibdad Real, por thessorero, é Diego Albornoz, natural de Nadrigal, por contador, y el factor Gonçalo de Salaçar, natural é veyntiquatro de la cibdad de Granada, y el veedor Pedro Mirezcherino, natural de Ubeda. É diçe Cortés quél avia gastado de las rentas de Su Mlagestad en la paçificaçion de aquellas partes algo inás de sessenta y dos mill pessos de oro; pero despues quél avia grastado quanto él tenia, é aun quedando empeñado en más de treynta mill pessos que tomó prestatdos de algunas personas: é porque los offiçiales no se lo passaban en cuenta, sin que pagasse á Su Mageslad lo que assi le alcançaban, suplicó á Céssar que paresciendo arer seydo bien gastados, se le resçiljiessen en cuenta é se le pagassen á él otros çinqiienta y tantos mill pessos de oro, quél avia gastado de su liaçienda é que aria tomado prestados de sus amigos, para quél pudiesse complir con los acreedores; pues sus serviçios no lo desmeresçan, ni el fructo que hiçieron no dexaba de dar testimonio dello. El caso es que, como la historia adelante dirá, el Emperador, nuestro señor, como gratíssino Prínçipe, le satisfiço de tal manera, que le hiço scñor de mucha renta é vassallos é le puso en el número de los grandes de su reyno.

Diçe más la relaçion, de que aqui se tracta, que un señalado pressente de muchas pieças de oro é plata, é plumages, é perlas é piedras preçiosas, é diverssos géneros de joyas é presseas, que el general envió autes desto al Emperador con dos caballeros, llamado el uno Antonio de Quiñones y el otro Alonso Dávila, que 
Cacron por procuradores de la Nueva España, fueron tomidos en la mar do cosarios françeses, é muchos á quien te oydo yo hablar en esto, é que vieron aquellas cosis, estimaban el valor dellas en más de ciento $y$ çinquienta mill ducados de oro, y en el dinero que demás desso Iomaron, ó mejor diçiendo en oro é plata, valia otros tantos. É á esto dice llerrando Cortés que por ser lats cosis que enviaba tan ricas y extrañas, desseaba mucho que Su Magestad Calluólica las viesse, porque demás del servigio que con ellas haçia, sus servicios le fucran más manificstos. É aunque se duele de to acaesciclo, diçe que por otra parte le plugo porque las llevassen, porque á Su Magrestad harian poca falta, é quél Irabaxaria de enviar otras muy más ricas y extraĩas, segund las nuevas tenia de algunas provinçias, que en essa saçon avia enviado á conquistar. E que assimesmo loolgó de tal pérdida, porque los franceses é otras nasçiones, á quien aquellas cosas fuessen notorias, conozcan que demás de los muchos é grandes reynos é señorios que en España é fuera della Sus Vageslades tienen, desde tan apartadas regiones destas Indias, seyendo él uno de los menores de sus rassallos, tantos é tales serviçios le pudo haçer en ellas, ganando tantos reyuos para el acrescentamiento del real septro de Castilla. E para prinçpio de su ofresçimiento, junto con esta carta envió con un caballero criado suyo, llamado Diego de Solo, cierlas joyas é cosas que diçe quedaron por desceho, como indignas de acompañar á las otras, ¿ algunas que despues él avia fecho; pero que aunque, como hemos dicho, quedaron por desechadas, tenian muy luen paresrer y eran ricas. É con ellas envió assimesmo una media culcurina de melal rico de oro é plata, que entraron en la fundicion della veynte y quatro quintales é dos arrobas é algo más, porque se fico dos ve- ces, é demás de lo que co-ló el melal, que fucron veyute y quitlo mill pessos de oro á raçon de çinco pessos de oro el marco; eon las olras costas de fundigiones é graLadores ó llevar la pieca hasta el puerto, le costó más otros tres mill pessos do oro; pero por ser lan rica é tanto de ver é digna de tan alto Prínçipe, se puso en este trabaxo é costa, aunque no le faltaban lis deudas que de susso se lán dicho. Esla piega vi jo dentro en el palaçio de Sn Calhólica Magestad el año de mill é quinientos é regnte y cinco, quando aqueste calballero Diego de Soto la llevó con más de sessenta mill pessos de oro de las rentas de su Magrestad quel gobernador é offirciales enviaron. É diçe la carta de Cortés que se atrevicron á enviar lanta suma junta, assi por la nescessidad (que se les repressentó que Su Magestad debia lener con las guerras é otras cosas, como porque no turiesse en mucho la pérdida de lo passado, pues que cada vez que oviesse aparcjo se le cnviarian nás é más thessoros, segund se yban ensanchando los reyinos é señorios, si no se te ofrescian algunos embaracos de los que hasta estonces el dicho gohernator avia tenido. Éllama mucla suma lo ques dicho, no porque ella fuesse mucha ni más de to que está dicho, sino porque Su Mlagestad liasta estonces tenia mandido que no se llevasse en cada nao sino lo que estaba ordenado; porque como ya se dixo en el libro III, capítulo V'II de la primera parte destas historias, quando se perdió en la mar el comendador Bovadilla é la armada, se perdió mucho oro en una nao en que yla aquel grano gruesso que pessala tres mill y seysçiontos pessos; é mandaron los Reyus Cathólicos que no se llevassen en una nao sino tres ó quatro mill pessos quando más, é que si oriessen más naos, que aun essos se repartiessen en lodas, por el peligro é causa de los naufragios. Pero csta ordenança se ha des- 
pues quebrado, como el letor puede aver comprendido, é verá adclante por estas listorias cómo inumerables thessoros á España se han llevado é se llevan cada dia.

Tornando á la carta de Hemando Coltẻs, digo que assimesmo escribió con lo que está dicho algunas passiones cntre sı emulo Diego Velazquez y él ; é aun habló tan largoo cn ello, que osó deçir quel factor Gonçalo de Salaçar le dixo que en la isla de Cuba, por donde passó, le dixeron que Diego Velazquez avia tenido formas con el capitan Chripstóbal de Olit, quel Hernando Cortés avia enviado á polilar al cabo de lligueras é puerto de Honduras, que se algasse con aquella tierra

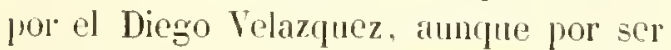
(1) caso tan feo é tan en deserviçio de Su Mlagestad él no lo podia creer, puesto que por otra parte lo creia, conosçiendo las maneras que Diego Velazquez avia querido tener para le dañar y estorluar que no sirviesse. É que quando otra cosa no podia haçer, trabaxaba en que no passasse gente á aquellas partes, é que cómo mandaba aquella isla de Cuba, prendia á los que venian de la Nueva España que por allí passaban, é les hacia muchas opresiones é agravios, é les tomaba mucho de lo que llevaban, é despues haça Irobanças en ello porque lo delibrassen, ¿ por verse libres dél, haçian é deçian todo lo quél queria. É que desto Cortés se informaria de la verdad, é que si hallasse ser assi, pensaba de enviar por el Diego Velazquez é prenderle, é presso enviarle á Su llagestad; porque cortando la liayz de todos aquellos males, que era arquel lombre y Diego Velazquez, todas lis otıas ramas se secarian, é quel dicho Cortés podria más libremente efottuar sus serviçios comencarlos, é los que peusaba començar.

No creo yo questats palaluras paresçicrou bien á Céssar porque yo oy murmsu- lail dellas à personas graves, é aum juzgarlas por desacatadas, en esperial escribiéndolas á Su Magestad, aviendo respecto quel I)iegro Velazquez estaba en la isla de Cuba, como la historia lo ha contado, donde Cortés no tenia qué haçer: antes le avia enviado por su capitan, y en su nombre passó á aquella tierra. Pero empleárascle bien tal prission, si Col-tés la pusiesse en efetto é con ella salicra, por la elecçion que dél hiço, para que por su industria fuesse, como fué, Dicgo Ve. lazquez descompuesto é perdido, é que le costasse la liurla como le costó, más de ochenta ó cient mill pessos de oro en aquella demanda, para haçer rico é señor á Hemando Cortés, de la persona del qual torno á deçir ques de mucho é grand mérito, é quel estado que tiene é otro muy mayor cabe en él. Pero junto con esto no le loo ni me parescen tolerables tales palabras in scriptis, porque sé yo muy bien cómo se tomaron, ć atti fueron por muchos reprochadas, porque como he dicho, me liallé en la corte de Céssar quando Diego de Soto llevó la carta de Cortés para Su Magestad, en que deçia lo ques dicho, é yo la ví é leí originalmente. É dende allí á pocos dias le enviaron á tomar residença, como adelante lo dirá la historia. É quiero primero poner un capítulo de aquesta carta del parescer que Hernando Cortés escribió çerca de la forma, que se debia tencr en la conversion de los indios, porque es de manera que no se deben mezclar mis palabras ni otras en cllo, ni quiero que en ningun tiempo él ni otro pueda deçir que quité ni añadí palabra ni letra, ni quiero voto ni parescer en lo que en este caso dixo, pues no soy juez para ello: el qual capítulo dice assi :

- Tordas las reçes que á Vuestra Sacra Magrstad lie escripto, he dicho á Vuestra Alteça el aprarejo que hay en algunos de los naturales destas partes para se con- 
verlir á nuestra sincta fée callólio é ser chripstianos, y le enviado á suplicar á Vuestra Cessáliea llagestal que para ello mandasse proveer de personas religiosas de buena vida y exèmplo. E porque hasta agora lan venido muy pocos ó quassi ningunos, y es cierto que harian grandissimo fiucto, la torno ál traer á la memoria de Y'uestra Magestad, y le suplico Io mande proveer con toda lrevedial, prorque dello Dios, Nuestro Señor, será muy servido, é se cmmplirá el desseo que Vurestra Altegatiene en este caso, como cathólico. E porque con los dichos procuradores Antonio de Quiñones é Alonso Dávila, los concejos de las villas lesta Nueva España é yo enviamos á suplicar á V'uestra Magestad mandasse proveer de obispos é otros perlados, para la administraçion de los officios é culto divino; y estonges paresçiónos que assi convenia, é agorar, mirándolo bien, háme paresçido que V'uesIra Sacra Magestad debe proveer de otra manera, para que los naturales destas partes más ayna se conviertan, é puedan ser instruidos en las cosas de la sancla fée cathólica. É la manerár que á mí en este caso me paresce que se debe tener, es que Tuestra Sacra Magestad mande que vengan á estas partes muchas personas religiosas, como ya he dicho, é muy çelosas deste fin de la conversion destas gentes; é que destos se lagan casas é monasterios por las provinçias que acá nos paresciere que convienen, é que á estos se les dé de los diezmos para haçer sus casas é sostener sus vidas; é lo demás que restare dellos, sea para las ighlesias é ornamentos de los purelılos, donde estuvieren los españoles, é para clérigos que las sirvan: é questos diezmos los cobren los offiçiales de Vuestra Nagestad é tengan cuenta é raçon dellos, é provean dellos á los dichos monasterios é igglesias, que bastare para fodo, é aun solırará har10, de que Vuestra Mlagestad se puede servir. E que Vuestra Altega suplipue á Su Santidaul concedá á Vuestra Magestad los diezmos destas partes para este efento. haciéndole entender el serviçio fure á Dios, Nuestro Señor, se hage en questa gente se convierta, é questo no se pollá facer sino por esta via; porque aviendo obispos é otros perlados, no dexarian de seguir la costumbre, que por nuestros pecados hoy tienen, en disponer de los bienes de la Iglesia, ques gastarlos en pompas y en othos vicios, y en dexar mayorazgos á sus hijos ó parientes. É aun-seria otro mayor mal: que cómo los naturales destas partes teniam én sus templos personas religiosas, que entendian en sus ritos é çerimonias, y estos eran tan recogidos, assi en honestidad como en castidad, que si alguna cosa fuera desto á alguno se le sentia, era pumiclo con pena de muerte, é si agora viessen las cosas de la Iglesia é serviçio de Dios en poder de canónigos é otras dignidades, é supiessen que aquellos eran ministros de Dios, é los viessen usar de los viçios é profanidades que agora en nuestros tiempos en essos reynos usan, seria menospreçiar nuestra fée é tenerla por cosa de burla, é seria d́ lan grand daño, que no creo aprovecharia ningma otra predicaçion que se les hiçiesse. É pues que tanto en esto vá, é la prinçipal intençion de Vuestra Magestad es y dehe ser questas geutes se conviertan, é los que acá en su real nombre residimos la delsemos seguir, é como chripstianos tener dello especial cuydado, lie querido en esto avisar á Tuestra Magestad Cessárea, é deçir en ello mi parescer, el qual suplico á Vuestra Alteça resçila como de persona súldita é vassallo suryo, que assi como cou las fuergas corporales trabavo é trabavaré que los reynos é señorios de V'uestra Magestad por estas partes se ensancheu, é su real fama é grand poder entre estis gentes se publique, que assi desseo é rra- 
lraxaré con el ánima para que Tuestra $\mathrm{Nl}$ teca en ellas mande sembrar nuestra sancta fée, porque en ello merezca la bienaventurança de la vida perpétua. É porque para laçer ordenes é bendeçir iglesias é ornamentos é olio é crisma é otras cosas, no avieudo obispo seria dificultoso y á buscar el remedio dellas á otras partes, assimesmo Vuestra Magestad debe suplicar á Su Sanctidad que conçeda su poder, é sean subdelegados en estas partes las dos personas prinçipales de religiosos que á estas partes vinieren, uno de la órden de Sanct Françisco é otro de la órden de Sancto Domingo : los quáles tengan los más largos poderes que Tuestra Magestad pudiere, porque por ser estas tierras tan apartadas de la Iglesia Romana, é los clripstianos que en ella residimos é residicren tan léxos de los remedios de nuestras consçiençias, é como lumanos tan subjetos á pecados, hay nescessidad que en esto Su Sanctidad con nosotros se extienda en dar á estus personas muy largos poderes, é que los tales poderes subcedan en las personas que siempre residan en estas partes, que sea en el general que fuere en estas ticrras, ó en el provinçial de carla una destas órdenes.

Pues como dixe de susso, he escripto el capítulo á la letra, quiero agora deçir otras cosas, salteando la relacion subcesice dexando lo supérfluo dello, para que se dé fin en este capítulo pressente á la relaçion, de que tractamos.

Diçe el general Hernaudo Cortés, que los diezmos de aquellas partes se avian arrendado aquel año de vesnte é quatro en alçunas villas, é que en otras anclaỉan en pregon; é que se entendia el arrendamiento desde el año reynte y tres á esíd parte, porque de los demas no le praresció que se debia facer, porque cllos en sí fueron poeos, é porque en aquel tiempo los que algunas crianças tenim, como era en tiempo de guerras, gastaban más en sostencrlo que valial el provecho que dello avian. E que los diezmos de la cibdarl de Temistitan de dicho año de veynte é tres, é de aquel de veyute é quatro, se avian rematado en çinco mill é quinientos é çinquienta pessos de oro por los dichos dos años, é los de la villa de Medellin é los de la villa de la reracruz andaban en presçio de mill pessos de oro, por el mesmo tiempo, é no estaban rematados, é subirian más: é los de las otras villas no avia sabido si estaban puestos en presçios, porque estaban léxos é no aviá avido respuesta. É de aquellos dineros deçia que gastaria en haçer las igglesias, é pagar los curas é sacristanes é ornamentos, é otros gastos que fueren menester para las dichas iglesias. Esto be querido tocar como lo escribió Cortés, porque aunque paresce que importa poco á la historia, no es sino conviniente é nesçessario para que se comprenda lo que los diezmos é clripstianos se han aumentado, pues que en tan poco tiempo hay tantos perlados é clero, é tanta moltitud de religiosos, como adelante se dirá, luasta este pressente año de mill é quinientos é quarenta $\mathrm{y}$ cinco.

Diçe más Ilernando Cortés, quexándose á Su Cessárea Magestad, que avia sey do informado de los navios que en aquella sacon avian ydo destas islas, que los jucçes é offiçales de Su Magestad, que en esta Isla Española residian, avian proveydlo é mandado pregonar, en estas y en todas las otras islas, que no sacassen yeguas, ni otras cosas que pudiessen mulliplicar, para la Nueva España, só pena de muerte. É que lo avian fecho á fin que siempre turiessen nescessidad de comprarles sus ganados é bestias, y cllos se los veudiessen por exresivos prescios: é que no lo debieran baçer assi, por estar $n$ otorio el macho aleserviçio que á Su Masestad se lacegia en excusar rue aquella lierra se polılasse é se parificasse, pues 
saldian qutrinta nescersidad avia de lo queIlos defendian para sostener lo zanado é ganar lo yue más hay, como por las lurenas obras é mucho ennoblescrimiento que aquestas islas han resçebido de la Nueva España. É porque dige que acá a via poca nescessidad de lo que se defendia, supliró á Su Mlagestad lo mandase proveer, para que las personas que lo quisiessen sacar, lo pudiessen hacger, porque allá no podrian conquistar cosa de nuevo, ni sostener lo conquistado: é quél se oviera bien pagado desto, de manera que los desta isla holgaran de reponer sus mandamientos é pregones, porque con dar él olro para que ninguna cosa de aquella ticra se truyesse ni descargasse en estas islas, si no fuessen las que aqui se les defendió, fue assi desarian Iraer lo uno porque se les resçibiesse lo olro, pues que aqui no tenian otro remedio, para lener algo, sino la contraclaçion de aquella lierra; ć que antes que la luviessen, no avia entre tolos Ins reçinos de las islas mill pessos de uro, é que por la Nueva España tenian más (quando él esto decia) que no avian lenido en algun liempo; ć que para no dar lugar á que los que han querido maldeçir. pnedan extender sus lenguas, lo avia disimulado hasta lo facer saber á Su Jageslad, para que lo mandasse proveer.

No es raçon que tan absolulamente s. disimule lo dicho, no se apruebe callando lo que hay en contrario, pues que lan rnganado estaba en este caso Hernando Cortés, aunque fué reçino desla isla, ó lam ilipados turo los ojos, como en pensar de hallar aquel esirecho que de susso se ha dicho que buscalıa, assi porque él nunca vido esta isla tan apocada como diçe, ni ron nesçessidad de la Nueva España, hasla hoy, ques el año de mill é quinientos i quarenta y şinco, como porque despues fue en ella se descohrieron las minas rel oro, é se començó á ỹr continuando el exercicio dollas, hasta el pressente liem- po, nunca lan poeo oro se saco en estir isla conto agora, á cansa de los açúcares é cranados é olras ricas gramererias, á que se han dado los verinos della, É por poco que se saca é por caydo que anda el exercicio de las minas de oro, en esta isla sola se cogen cada un año seplenta mill pessos de oro, poco más ó menos, é demás desto los derechos reales del almojarifazgo valen á Su Magestad un año con olro reynte mill pessos de las naos é caravelas, que en el puerto de aquesta cibdad de Sanclo Domingo entran: é ningum año hay que no se cargruen é salgan de sola csta isla para España, en oro é açúcar, en cueros de vacas é cañafísıla, é otras mercadurias de su propria cosccha, sobre çientoé çinquienta mill pessos de valor. No sé yo cómo puede deçir Hernando Corlés que entre lodos los veçinos deslas islas no se hallarín mill pessos: antes que la Nucva España se descoluriesse, í ann despues de descubierla, ovo muchos veçinos, quél conosçió, que uno á uno sacaban cada un año á millares los pessos de oro. Ni sé dónde tenia la memoria, quando lal dixo; é bien le sabria acordar sus nombres, é muchos testigos hallára hoy que contra lo quél diçe testifiquen de risla: é debiera acordarse siquiera de lo que le eostó á solo el adelantado Diego Velazfuez enviarle á él á la Nueva Espana , é primero al capilan Johan de Grijalva, é clespues de Corlés á Pamphilo de Narvacz, é de otras armadas en que gastó su hacienda. É acordándose desto, quél no pudo ignorar, entendicra que sin la Nieva Espana aria hombres, que Ienian en eslas islas muchos millares de pessos de oro.

Bien paresce en esto la passion que tenia, por averle redado aquellas cosas que diçe; y él quiere culpar á los questa isla gobernaban, é fuera bien que mirara que si en essa saçon se sacaran los ganados, que oviera llegado á tener: como lienen 
algunos reçinos desta isla á veynte é veynte é çinco mill cabeças de ganado vacuno é más, é de aqui abaxo hasta çinco mill cabecas, muchos hay que las tienen é más; $\dot{c}$ de mill cahegas hay tautos que no se Iaçe caso de los tales para deçirles señores de ganados. Pucs de bestias caballares, de tres ó quatro é çinco años á esta parte se lan sacado de sola csta isla para el Perí ó Ticrra-Firme ć otras gobernaçiones más de tres mill; é de Lestias mulares é açémilas, para la mesma Nueva España é olras partes de la Tierra-Firme, se han llevado en el dicho ticmpo más de otras mill destas islas, é siempre lleran. Lo quél culpa fué muy bien provelyydo: é mejor açertara él si dixera que por esta isla é las espalclas que la Nueva España é las otras partes de la Ticra-Firme han hallado aqui, como en madre é principio é sostenedora de todo lo destas Indias, se Iın podido sostener en acuellos prinçipios, é sin clla muy mal ć á costa de más vidas é haçiendas de clripstianos lo hiçieran él é otros capitanes, ó nunca, nejor diçiendo.

Esta isla é las otras antes lan empobresçido por la Nueva España que no medrado, porque como los hombres son mudables, é las predicaçiones de los gobernadores é capitancs apropóssito de sus cobdiçias, é para levantar la gente é desasosegarla no les dicen textos de los Evangelios, sino: haceros hé rico, é antes de un año tener en mucho, é daros hé esto ó aquello, con estas vulpinas ó enganosas artes é palabras sin veriad, cnganando simples pecadores que los siguen, han despollado estas islas; é alçándoles los piés del suclo, sirviéndose dellos como grangeria fropria para baçerse á sí mesmos ricos, é polres á quien los cree con peligino de los cuerpos, é á más de innumerables que movidos desta forma é debaxo de aquellas promesas vanas cstán

* Thebe lenerse presente que en el capúlulo XX T0.10 111. enterrados por essas playas, é alogados por essas mares é rios, é otros comidos de tilumones é dragones é cocatriçes é pescarlos, é de bestias fieras cono liğes ć lcones é otros animales é de aves, é aun de los proprios indios, é lo ques peor aun en partes ha avido tal nesçessidad, que chripstranos se comieron unos á otros.

Mejor açertara IIernando Cortés en dleçir que las islas de Cuba é Jamáyca é Sanct Johan estín destruydas é quassi despobladas, por causa de la Nueva España é de los descobrimientos de la Tierra-Firme, lo que no ha podido ni podrá cmpeçer á esta Isla Española, aunque no la ganado nada en cllo, porque eslá muy cdeficada; y en esta cilıdad sola hay muclos veçinos é lıombres ricos, que ninguna nescessidad tienen de la Nieva Espaüa ni de Tierra-Firme, antes rlesde aqui se han sostenirlo é sostienen lodos essos prinçipios é fundaçiones de fuera. É agora que está quassi despoblada la isla de Cubagha é sin el exerçiçio de las perlas. é se ha hecho otra poblaçion para cllas en cl cabo de la Vela, reamos de clónde se provec, é quién le envió gente é navios é todo lo demás, sino desde aquesta cibdad é isla. É los meses de noviembre é diçiembre del ano passado de mill é quinientos é quarenta, ¿ de dóude llevó el socorro para la gobernacion de Sancta Marta el capitan Johan Rodriguez de Monroy, sino dende esta ciludad? ¿De dónde llevó gient caballos é más, é otros çient hombres, solore los que truxo de Castilla, el adelantado Sebastian de Velalcáçar para poblar su gobernaçion de Popayan en la Tierra-Firme, sino desde aquesta cibdad? En el mesmo tiempo zde dónde sacaron el muy reverendo señor obispo de Veneçucla, don Rodrigo de Bastidas y el capitan Pedro de Limpias ciento é cinqiienta caballos é trescicntos hombres " para recdeficar 
aquella gobernacion é provingia de Veueçucla sino de aquesta cilshad? Y en el mesmo liempo yo estoy maravillado de Hernando Cortés cómo escribió lo dicho de susso, porque en aqueste caso tiene muy larga respuesta en estas lndias é fuera dellas, donde tales cosas se saben tau en contrario de su carta, como tengo dicho, é otros muchos que loy viven lo saben: antes me paresce que su relaçion en este caso es reduçida é no para parar en clla. Passemos á lo dentís.

Diçe assimesmo en su carta, que cómo le convenia buscar toda la buena órden que fuesse posible para que aquellas ticrras se polyassen, é los españoles que allá estaban é los naturales se conservassen, é nuestra sancta féc cathólica se arraygasse, pues Su Cessárea Magestad le hiço merçed de le dar esse cuydado, é Dios fué servido de le haçer medio por dó viniessen aquellas gentes en su conosçimiento é debaxo del yugo de Su Altega, que por todos estos respetos él hiço çiertas ordenanças é las mandó pregonar, é las envió á Su Magestad para que las mandasse aprobar, porque diçe que son muy convinientes. Pero que de algunas dellas los españoles no estaban muy satisfechos, en espeçal de aquellas que los obligan á arraygarse en la tierra, porque todos los nás tenian pensamiento de averse con aquellas tierras, como se avian avido con estas islas que antes se polblaron, ques esquilmar é destruyr, é despues dexarlas. É porque le paresçe que seria grand culpa á los que de lo passado tenian expiriençia, no remediar lo pressente é por venir é aquellas cosas por donde era notorio averse perdido las diclas islas, mayormente seyendo aquella ticrra de tanta grandeça en nobleça, é donde tanto podia Dios ser servido, é las rentas reales acresçentadas; por tanto perlia é supli-

gobernacion de Venezuela, dice que el obispo Baslidas llevó consigo solamente el número de "çien- caba que las diclas ordenancas se vies. sen, é si fuesse nesçessario, so añadiessen 6 mengِuassen, como Su Migrestad más servido fuesse. Porque como por la grandeca é diversidad de las tierras que cadia dia se manifestahian, é por muchos secretos que calla dia de lo descobierto resultahan é se conoscen, era nesçessario que á nucros acontescimientos, oriessen nucvos paresceres é conscjos: é si en algunos de los quél avia diclio ó divense de alí adelante paresçiesse á Su llagestad que contradiçen algunos passados, diçe quel nuevo caso le hace dar nuero paresçer; é con esto coucluye su carta fecha en la grand cibdad de Temistitan de la Nueva España á quinçe dias del mes de ottubre de mill é quinientos é vernte y quatro años.

Creerse debe que lo que flernando Cortés diçe gerca dessas ordenanças, é lo que en cllas ordenó, que todo se fundaria sobre buen çelo del serviçio de Dios é de Su Hagrestad é conservaçion de los españoles é de los indios; pero como esto es caso de tan grand importancia, y en que tanto vá á la poblaçion de la tierra é á la real consçiençia de Su Magestad, é á la aumentaçion de la república cliripstiana á loor de Dios guiado de mancra que por la diligença del Emperador, nuestro señor, é de su muy alto Conscjo de las Indias, están las cosas de la féc muy encumbradas, para lo qual han yclo allá tantas docenas de frayles, é cada dia ran de todas órdenes, é allá se han multiplicado, como se dixo del trigo. Y está la dottrina de Chripsto en otros términos, é lian cntendido en esso personas lan notables y sçientes. é de buena vida é sancto exemplo, que se sirve Dios, Nuestro Señor, mucho en aquellas partes, como más largamente se dirá adclante lo que hiçiere al caso en csto y en otras materias.

10 é cinquienla hombres é ciento é regnle caballos." 


\section{CAPITULO XILI.}

Fin el qual se tracta una relaçion quel eapitan Alvarado enviú al gobernador Hernando Corlés desde la eib. dad de Uclacan, ả once dias de abril del año de mill é quinientos é veynte y quatro, la qual envió el gobernador al Çessar juntamente con la otra, de que se ha tractado en los capitulos preçedentes.

Dis içe el comendador Pedro de Alvarado, que dende Soconuseo escrilsió á Hernando Cortés todo lo que lasta allí le avia subcedido: el qual despues que envió sus mensajeros á aquella gुente de la tierra, laçiéndoles saber cómo ylua á ella á conquistar é pacificar las provinçias, que só el dominio de la corona reat de Castilla, é de Su Magestad el Emperador Rey, nuestro señor, é de la Catlólica Maggestad de la Serenissinıa Reyna doña Jolıana, su madre, nuestros señores, no se quieren meter, é á cllos comı vassallos de Su Ilagestad, pues tales se avian ofresçido, piclió favor é ayuda para entrar por su ticeIa, porque haçiéndolo assi harian lo que debian, é como leales vassallos servirian ¿́ Dios en ello é á Su Magestad, y él é los españoles de su compañia los favoresçerian é ternian en toda justiçia. É lo contrario laçiendo, protextó que les haria la guerra, como á desobidientes é rebeldes contra el servicio de sus Reyes é señores naturales, é que por tales los declaraba desde estonçes, no viniendo en lo que eran obligados, çertificándoles que serian esclavos todos tos que en la gruerra se tomassen, si diessen lugar á que con ellos viniesse en rompiniento.

Despues que les envió sus mensajeros con estas amoneslaçiones, hiço alarde de toda su gente de pié é de caballo; é otro dia adclante por la mañama se partió en demanda de apuella tieria: anduvo tres dias por un inonte despoblado, y estando sentado su real, la gente de velas que lenia puestas tomaron tres espias de un pueblo de aquella tierra, Ilamado Zapotulan, las quales, seyendo iuterrogadas á qué venian, dixeron que á coger miel, de la qual lıay muclıa é muy buena é de muchas maneras por aquella tierra, aunque notorio fué que eran espias, segund adelante paresçió. É non obstante esso no las quiso apremiar : antes las halagó é les dió otro mandamiento é requirmiento, como el que se dixo de susso, é los envió á los señoles de aquel pucblo, é nunca á ello ni á olra cosa quisieron responder.

Despues que llegó este capitan con su gente á este pueblo, halló todos los caminos abiertos, é muy assi el real como los que atravessaban, é los caminos que yban á las calles prinçipales, atapados: de lo qual se pudo muy bien colegir el mal propóssito de los indios, é que aquello está fecho para pelearr. É allí salicron algunos indios á hablar, enviados por los de la poblaçion ques dicho, é deçian dende léxos al capitan Mvarado que se entrasse en el pueblo á se apossentar, to qual ellos quisieran, por poder más á sn plaçer dar en los cluripstianos, como lo tenian ordenado; pero el capitan hico assentar su grente é sur real junto al pueblo lıasta calar la tierra é sentir mejor la iıtençion de aquella ggente. E como donde falta prudençia, turan poco las cautelas, luego aquella tarde no pudieron ocultar su mala intençion ayucllos indios: antes mataron é hirrieron á algunos de los amigos que ylan en compañia de los espanoles; é como llegó el mandado, envió gonte de caballo á correr el campo, é dieron en una gelada de muclia gente de guerra, la quisl peleó con ellos, é hirieron algunos caballos aquella tarde.

Otro dia siguiente el capilan fuć á ver 
la dispusigion del camino por donde avia de yo, é vido tambien gente de guerra; e la lierra era lan montuosa é llena de racagualales, yue son apuellos árboles que la fructa se lracta é corre por moneda, como mís largamente se diso en el libro VIII, capútulo XXX de la primera parte. É tambien avia otras muy grandes y espesis arboledas, que haçian más fuerle cste pueblo é la lierra para los contrarios que no para los nuestros. E se volvió el capilan al real, é mandó adcrescar su sente; é puesta en óden, se partió otro dia por la mañana para entrar en el puehlo: y en el camino eslaba un rio de mal passo, é tenianlo los indios tomado, é fué nescrssillio pelear con cllos, é ganóse el passo por fuerga; é sobre una larranca lel rio, en un llano, esperó el capitan la reçaga, porque era peligeroso el vado, ó no le fucra hecho bien en los postreros, si él fuesse adclante. I cslando alli atendiendo á que todo su exérçito passasse, se juntaron por muchas partes los enemigos, e vinieron por los montes, é le tornaron á acometer, é fueron resistidos hasta quo passó todo su fardage: é despues de entrados en las casas, dicron en la gente con mucho ímpetu, é los desbarataron, i siguieron cl alcance hasta passar el mercado, é aun media legua adelante, vertiendo sangre é malando muchos de los contrarios. É quando al capitan le paresció volvió alrás, recogiendo su gente vic. torioso, é assentó su real cn el mercado o liangiez de arpuel pueblo, y estuvo alli dos dias reposando con su grente, é con alguma della corriendo la licrra.

P'assadlos los dos dias, se partió el comendador para otro puchlo que se llama Quecaltenago, é aquel dia passó dos rios uny malos, é de peña lajada en partes las costas del uno dellos, é aun ovo de laçer el passo con mucho trabaso. E comencó á subir su exérọilo un puerto yue liene seys leguas de luengo, y en la mi- lad del camino assentó real apuella noche, porque por ser tan ápero el puerto no purlicron andar már, ni aun lo podian subir los cahallos.

Otro dia de mañana siguruó su camino, y ençima de un reventon se halló una muger sacrificada é un perro, é segund dixo la lengua cra desafio ó protextaçion conla los chupstianos. Passando adelante, se halló en un pásso muy estrecho una alTarrata de paligada fuerte, y en clla no avia wente algrma yue la defendiesse. Acalado de subir el puerto, ylan delante todos los ballesteros é peones, porque los caiballos no se podian mandar, por ser tan fiagoso ol camino é todo acjucllo: $\dot{c}$ salieron hasta quatro mill hombres sobre una barranca, é dieron en la gente de los amiggos con tal refriega de piedras é varas é flechas, que los hicieron retraer abaxo; pero luego se ganó aquello. I estando arriba el capitan, recogiendo la gente para rehagerse, vido más de treynta mill hombres que renian solore los españoles: é quiso Dios que laallaron alli unos llanos, é aunque los caballos yban bicn cansados del puerto, esperaron hasta que los enemigos llegaron á cchar flechas. É quando al capitan le paresción, dió la señal á su gente é rompió por los contranios, los quales, como nunca avian visto caballos, cobraron tanto temor dellos que se pusieron en huycla; é fué el alcange muy sansriento, ć mataron muchos dellos. É allí aguardó á que acabasse de llegar toda la gente de los nuestros, que aun quedaban muchos atrás; é recogidos, fucron á se apossentar una legua de allí á unas fuentes de agua, porque acullá no la tenian é la sed los aquexaba mucho, é segund yban cansados, adonde quicra lomaban por huen assiento. É cómo ya aquello era ticrra llana, el capitan tomó la delantera con treynta de caballo, é muchos dellos lleraban caballos de refresco, é toda la gente demís yban hechos un cuer- 
po: é luego baxó á lomar el aģua el capilan, el qual é los de caballo, estando apeados bebiendo, vieron venir á ellos nuclıa gente de guerra, é dexáronla llegar, que venian por unos llanos muy grandes : é quando fueron çerea, los de caballo rompieron los ginctes por ellos, é allí se hiço otro alcançe é matança muy grande, annque ovo indios que uno dellos esperaba dos de á caballo. Es siguióse el alcançe bien una legua, é llegálsanse ya á mma sierra, donde hiçieron rostro; y el capitan Alvarado fingió que huia con siertos de caballo para sacar los enemigos al “ampo, é salicron hasta llegar á las colas le los caballos. É despues que se rehico ron los de caballo, dió la vuclta sobre los enemigos, lan presto é con tanto denuelo, (jue volvieron las espaldas, é se hiço un alcançe é castigo muy grande, en el qual murió uno de los quatro señores de aquella cibdad de Uclacan, que yba allí por capitan general de toda la lierra. É ivida esta victoria, el capitan Alvarado se retruxo á ayuellas fuentes, donde assentó su real arfuella noche, harto fatigados é cansados los españoles, é algunos dellos é caballos heridos.

Otro dia de mañana se partió nuestro exérçito para el pueblo que llaman de Quccaltenago, que estaba una legua de allí , é con lo acaescido del eastigo de antes to hallaron despoblado, sin hallar persona alguna en èl. É allí se apossentó el eapitan é su gente, y estuvieron reformándose é corriendo la tierra, que no es menos polslada que la de Tascaltecle, y en las labranças muy semejantes é de la mesma mancra, é tierra muy fria en demasia. É deste á seys dias que allí estaban, un jueves á medio dia paresçió mucla gente, y eu muclios cabos: de los quales supo que eran de la mesma ribdad los doge mill dellos é de los puelílos comareanos, é los demás cran incontables. $\dot{E}$ como el capitan Mlvaiado los vido, or- denó luego su gente, é salió á les dar la batalla en la mitad de un llano que tenia bien tres leguas de luengo, con noventa de caballo, é dexó gente en el real que le guardassen : é á un tiro de ballesta del real é no más se començó el rompimiento por los enenigos, é los desharataron por muchas partes. E siguióse el alcance dos leguas é media hasta tanto que toda la gente avian rompiclo, que no llevaban ya contradicion por delante, é despues revolvieron sobrellos, é los nuestros de pie en los enemigos haçian tanto estraggo, que no se podia haçer mayor: é çercaron un monte ó çerro raso, donde se acogieron los vençidos, é subiéronle arriba, é tomaron todos los que allí arian subido. Este dia murieron muchos de los contrarios, é fueron pressos grand número de los que eran cipilanes é señores é personas prillripales é scñaladas. É desque los señores de aquella cibdad supieron rue su gente era desbaratada, acordaron ellos é toda la lierra de convocar otras provincias para ello, é aun á sus encmigos dieron parias é los atruxeron, para que lodos se juntassen é matassen á los chripstianos: é para efeftuar su mala intençion, enviaron á deçir que querian ser buenos, é que de nuevo daban la obidiençia al Emperador, nuestro señor, é que el eapitan Ilvarado se viniesse dentro de aquella cibdad de Uclacan, como despues te Iruxcron, con pensar ellos que le apossentarian dentro, é que despues de apossentado, una noche darian fuego á su mesma cibdad, é que alli quemarian á los españoles é sus anigos, sin que les pudiessen resistir. É de hecho ovicra efello su mal propóssito, sino que Dios no consintió en ello ni que aquellos inficles oricssen victoria contra los nuestros; porgue la ribulad es inuy fuerte en demasia é no tiene sino dos entradas, la mal de treynta y tantos escalones de picela muy alta, é por la otra farte mir calcada fecha de mano: é te- 
nian mucha parte della ya corlada para acabar de la cortar aruclla noche, é ninğun caballo pudiera salir á la licra, é como la cibdad es muy junta, é las calles muy angostas, en ninguna manera los nuesfros se pudicran sufrir sin ahogarse, ó por huyr del fuego, lespeñarse. É cómo los españoles subieron seguros y el eapiran se vido dentro é vido la fortalegá lan grande, é que dentro della no se podian aprovechar de los caballos, por see las calles tan angostas y encilgadas, determinó de salirse luegro á lo llano, é dexó la ciludad, aunque los señores della le contradeçian é rograban que se sentasse á comer é que luego se yria, por tener lurar de concluyr su mal pensamiento. Mas él, conosciendo el peligro en que estaba, curió luegro gente delante á tomar la calcada é puente para salir á la tierra llama: y eslaba ya la calçadil en tales términos, que apenas podia subir un caballo. I al rededor de la ciludad avia mucha gente de guerra, é cómo le vicron passado á lo llano se apartaron. pero no tanto que se dexasse de rescebir daño de los enemigos, y el capitan lo disimulaba todo por prender á los señores que ya andaban ausentados, é por maneras que tuvo con cllos é por dádivas que les dió, para más asegurarlos los prendió, é pressos los tenia consigo. E 110 por esso los suyos dexaban de dar gnerra á los nuestros por los alrededores, é le herian é malaban inuchos al capitan de los indios que yban por hierba para los caballos: é un espanol cogiendo hierLa á un tiro de ballesta del real, desde encima de una barranea 1. echaron una galga ó grand piedra, con que le mataron. Es la tierra tan fuerte de quebradas, que liay quebrada que entra dosçientos estados de hondo, é por estas quelsradas no los podian castigar ni harertes la gucra, como ellos lo merescian. E viendo al capitan que con correr la tiena é quemarla. los potria atraer al ser- vicio de Su Magestad, determinó de (quemar aquellos señores que estalyan pressos, los quales dixeron, al liempo que los querian quemar, quellos eran los que avian mandado hager aquella guerra é los que la laçian, é la manera que se avia de tener para quemar al capitan é á los españoles con los demás en la cibdad, é con esse pensamiento le avian traydo al capitan á clla; é quellos avian mandado á sus rassallos que no vimiessen á dar la obidiençia al Emperador, nueśtro señor, ni sirviessen ni hiciessen olra buena obra. E cómo conosçió dellos su mala voluntad al servicio de Su Magestad, é para el bien é sosiego de afuella tierra, el capitan Alvarado los hiço quemar é assimes. mo hiço pegar fuego á la cibdad é derriLarla por los cimientos, porque estaba lan peligrosa é tan fucte, que más parescia reçeptáculo ó espelunca de ladrones que no de pobladores. É para buscarlos, envió á la cibuad de Guatimala, que está diez leguas de alli, á deçirles é lequerirles de parle de Su Magestad que le enviassen greule de guerra, assi para saber dellos la voluntad que tenian, como para temoriça la tierra; y ella fué buena é dixo que le plaçia, é para esto le envió quatro mill hombres, con los quales é con los demás quél tenia hiço una entrada é los corrió y echó de toda su tierra. Viendo el daño que se les hacia, le enviaron á decir al capitan con sus mensajeros que ruerian ser buenos, é que si a vian crrado, avia seydo por mandado de sus señores, é que estando aquellos viros, no osaban á hacer otra cosa é que pues ya ellos eran muertos é quemados, que le rogaban que los perdonasse. Y el comendador Alvarado les asegruró las vidas é les mandó que se viniessen á sus casas é poblassen la tierra como antes, los quales lo hiçieron assi como primero solian estar en la obidiençia é servirio de Su Vhagestad. E para más ascegu- 
rar la tierra, hiço soltar dos hijos de los señores, á los quales puso en la possesion de los estados de sus padres, porque se tuvo por çierto que harian bien todo to que conviniesse al serviçio de Su Maģastad è al bien de la tierra. Y en quanto toca á aquella tierra no hay más que deçir al pressente, sino que lodos los indios que se tomaron, se herraron é liricieron esclavos, de los quales se dió el quinto á Su Magestad y en su nombre at thessorero de la hacienda real Baltasar de Mendoça: el qual quinto se vendió en almoneda para que más segura estuviesse la lıaçienda de Su Magestad.

Yo lie ydo acortando palabras, sin dexar de deçir cosa de lo substançial de la carta del comendador Pedro de Alvarado: é agora quiero deçir el fin della á la letra . como lo diçe su relaçion al gobernador Hernando Cortés; y es desta manera:

«De la tierra hago saber á vuestra merçed que es templada é sana é muy poblada de pueblos muy reçios, y esta cibdad es muy bien obrada é fuerte a maravilla, é liene muy grandes tierras de pan é mueha gente subjeta á ella, lo qual con todos los pucblos subjetos á ella comareanos dexo só yugo y en serviçio de la corona real de Su Magestad. En esta tierra hay una sierra de alumbre é otra de açije, é otra de açufre, el mejor que hasta hoy se ha visto: que con un pedaço que me truxeron sin lo afinar ni sin otra cosa, hice media arroba de pólvora muy buena, é por enviar á Argucta é no fuerer esperar, no envio á vuestra merçed çinquienta cargas dello; pero su tienpo se ticne para cada ć quando fuere mensajero. Yo me parto para la cibdad de Guatimala lunes onçe de abril, donde pienso detrnerme poco, á eausa que un pueblo que está assentado en el agua, que se diçe Atielan. está de guerra é me ha muerto quatro mensaje- ros: é pienso, con el ayuda de Niestro Señor, que presto le atraeremos al serviçio de Su Magestad, porque segund estoy informado, tengo mucho que hacer adelante, é á esta causa me daré priessa por invernar çinquienta ó çient. Ieguas adelante de Guatimala, donde me dicen (é tenóo nueva de los naturales desta ticrma) do maravillosos é grandes edeficios. é de grandeca de cilıdades que adelante hay: a tambien me han dicho que çinco jornadas adelante de una cibdad muy grande, que está veynte jornadas de aqui, seacaba esta ticra, é afirmanse en ello. É si assi es. certíssimo tengo que es el estrecho. Pleza á Nuestro Señor me dé vietoria contra estos inficles, para que yo los trayga á su serviçio é al de Su Mlagrestad. No quisiera haçer en pedaços esta relaçion sino destle el cabo de todo, porque más oriera que deçir. Ia gente de españoles de mi compañia de pić é de caballo lo han lecho tan bien en la guerra que se ha ofresçido, que son dignos de muchas mercyedes. Al pressente no tengo más que decir que de substancia sea, sino que estamos metidos en la más recia tierra de gente que se ha visto; á para que Nuestro Señor nos dé victoria, suplico á vuestra merçed mande haçer una proçession en essa cibdad de todos los clérigos á frayles para que Nuestra Señora nos ayude, pues estamos tan apartados de soeorro, si de ella no nos viene. Tambien tenga vuestra merced euydado de haçer saber á Su Magestad cómo le servimos eon nuestras personas é haçiendas á nuestra costa: lo uno para deseargo de la consçiençia de ruestra nerçed, é lo otro para que Su Magestad nos haga mercedes. Nuestro Señor guarde el muy magnífieo estado de ruestra merced por largos tiempos, como dessea. Desta ciludad de F claran "á onçe de abril de mill é quinien- 
Ios r veynte y quatro anos. - E segund llevo el viage largo, pienso me filtará lıerrage: si para este verano que viene vuestra mereged me pudiere proveer de herragere será grand bien, é Su Hagestad seríl bien servido en cllo, que agrora ville cutce nosotros çiento y noventa pessos la doçena, é assi la mercamos é paganos á oro. = Bessa las manos de vuestra merced.=Pedro de Alvarado.

\section{CAPITULO XLIII.}

Lin que se tracta de otra relaçion Secha por el mesmo capitan Pedro de Alvarado al gobernador Hernando Cortís desde la ciblad de Sancliago de Guatimala, a ocho de julio de mill é quinientos é veynle y quatro años: la qual relaçion, por evitar prolixidad, se dirả conforme á lo substan iqal é sentenęia de lo que eontiene.

E. li relaçion de susso dió notiçia el capitan Pedro de Alvarado de las cosas que lasta Uclatan se le avian sulbcedido, y en esta cuenta lo que desile allí adelante le sulogedió hasta los ocho de julio de aquel año de mill é quinientos é veynte y quatro. É diçe que partió de la cilsdad dic Velatan, y en dos dias llegó á la de Guatimala, donde fué muy bien resçelido de los señores della, que no pudiera ser más en casa de sus padres dél é de los (jue con él yluan, sin aver falla alg̣una en lo nescessario. Desde á ocho dias que staba en aquella cibdad supo de los senores della que á sicte leguas de alli eslaba otra cilodad solsre una laguna muy grande, é que aquella laçia guerra á Guatimala é Iclatan é á todas las demás á ella comarcanas por fuerça del agua é canoas que tenian, é que de alli salian á saltear de noche en la tierra de los otros. É los de Guatimala dixéronle al capitan Alvarado ciuellos eran buenos y estaban en la obidiençia é serviçio del Rey Emperador, nuestro señor, é que sin su liçençia ni querian ni darla ni aun tomarla; pero que viesse el daño que de aquellos resçebian é lo remediasse: el quill les respondió que lo deçian muy bien, é quél los enviaria á llamar de parte de Su Mla-

Cinas vees se lec Iclacun, olras Vlatan y otras traclan, prucba evidente de las observaeiones que gestarl, é que si viniessen, él les manda. ria que çessassen en la guerra é fuessen vassallos de su ceptro real de Castilla, é luviessen é guardassen entera amistad con cllos é los que estaviessen en su olidiençia; é que si otra cosa hiçiessen, él yria con ellos á laçerles la guerra é castigarlos. É para este efetto les envió dos mensajeros de aquella cibdad, á los quales mataron, sin temor alguno: é sabido por el capitan, se partió contra los mallechores con sessenta de calallo é çiento y çinquienta peones, é con los señores é naturales de Guatimala; é anduvo tanto, que aquel dia entró por la tierra de los contrarios, é no salió gente alguna de paz ni de guerra á lo resçelsir: lo qual viendo Alvarado, metióse con treynta de calnallo por la tierra á la costa de la laguna, é ya que llegalan çerea de un peñon pollado que estalıa en el agua, vieron cerea de sí un esquadron de gente, é Alvarado les aconctió con los de cahallo que con él estaban, é siguiendo el alcanşe dellos, se metieron por una calçada angosta que entraba al dicho peñon, por donde no podian andar los calallos. E alli se apeó con sus compañeros, é á pié juntamente é á la vuelta, mezclado con los indios que huian, se entró en el peñon

en diferentes pasajos lievamos hochas. 
de tal manera, que no dieron lugar los nuestros á que los enentigos rompiessen las puentes, que á las quitar, no podian entraı allá. En este medio tiempo llegó mucha gente de la nuestra, que venian atrás, é ganóse el dicho peñon, que estaba muy pollado, é toda la gente dél se fué á nado á una isla, é se escaparon allá, á causa que no llegaron á ella tresçientas canoas, que venian por el agua, de amigos. Cosa fué de mucha ventura, segund la fuerte dispusiçion del peñon, ganarle de aquella manera sin peligro alguno.

Aquella tarde el capitan con su gente se salió del peñon, é assentó real en un llano de malhiçales, donde durmieron aquella noche. Luego otro dia de mañana, encomendándose á Dios, fueron por la poblaçion adelante, que estaba muy fucrte á causa de muchas peñas, arcal)ucos é boscages que avia, é halláronla despoblada, porque como vieron que avian perdido aquella fuerça tan grande que tenian en el agua, no osaron atender en la tierra, sino alguna poca de gente allá al cabo del pueblo, confiando en la aspereça de la tierra. É tomáronse çiertos indios de los naturales della, é á tres dellos envió el capitan por mensajeros á los señores, amonestándoles que viniessen á dar la obidiençia á Su Magestad é á ponerse debaxo de su real corona, donde no, que se les haria la guerra, é los buscarian por los montes é donde pudiessen ser avidos: los quales respondieron que hasta estonçes en su tierra alguno se la avia rompido ni entrado contra su voluntad por fuerça de armas; é que pues él avia entrado, quellos holgaban de servir á Su Magestad assi como se lo mandaba. É luego vinieron é se pusieron en su poder, y el capitan Avaradio por las lenguas les dió á entender la grand potenesia del Emperador Rey, nuestro señor, é les perdonó en su real nombre lo passato, é les amonestó que dende en adelante no hiTO.10 III. ciessen guerra á ningumo de los comareanos, é que tuviessen paz é amistad, pues que todos eran vassallos de la corona real de Castilla; é assi prometicron de lo hacer, é los envió muy contentos é seguros. I cl capitan é la gente se tornaron á Guatimala, é desde á tres dias fueron en ella todos los señores prinçipales é capitanes de la dicha laguna, con pressentes para el capilan, é le dixeron que ya ellos eran amigos de los chripstianos, é que se haIlaban muy dichosos en ser vassallos de Su Magestad, assi por tener tan poderoso señor é Rey, como por se quilar de trabaxos é guerras é diferençias, que hasta estonçes entrellos avia. Y el capitan los resçibió graçiosaménte, é les dió sus joyas, é despues que les ovo hecho muy largo raçonamiento é animádoles á ser fieles é perseverar en la paz contrayda, los envió á su tierra contentos; é son de la más pacífica gente que hay por aquellas partes.

Estando en aquella cibdad, fueron otros muchos senores de otras provincias de la costa del Sur á dar assimesmo la obidiençia á Su Magestad, diçiendlo quellos querian ser sus vassallos, é que no querian guerra con nadic, é que para esto el capitan Alvarado los resçiljiesse por tales. é los favoresçiesse é tuviesse en justiçia. Y él los resçibió, como era raçon, é les dixo que en nombre de Su Magestad los tractaria muy bien é los faroresçeria é ayudaria; é aquellos le dieron notiçia de otra provinçia que se llama Izeuytepeqie, que está algo más la lierra adentro; é dixeron que aquellos no los dexaban venir á dar la obidiençia á Si Magestad, é aun no tan solamente esso, pero que á orras provinçias que están de la otra parte de aquella, que estaban con buen propóssito é querian venir de paz, no los dexaban passar, é les deccian que á dónde yluan, que eran locos, si no que le dexassen yr al capitan é á los clnipstianos ailá. 
que todos les dàrian guerra. É cómo fué rertificado que era assi, se partió para allá con toda su gente de pié é de caballo, é durmió tres dias en un páramo ó despoblado, é otro dia de mañana, ya que ovo entrado en los términos del jueblo, halló todo aquello lleno de arboledas espesas; y estaban todos los caminos çerrados é muy angostos, que no eran sino sendas, porque con nadie tenian contractaçion ni camino abierto. Y el capitan echó los ballesteros delante, porque los de caballo allí no podian pelear por las muchas çiénegas é arboledas, é llovia tanto, que con la muclia agua las velas y espias de los contrarios se retruxeron al pueblo, porque no pensaron que aquel dia llegaran los nuestros hasta ellos, é descuydáronse é no supicron de su yda liasta que el capitan é su gente estaba dentro del pueblo. É cómo toda la gente de guerra estaba en los caes ó casas, por amor del agua metidos, quando se quisicron juntar, no luvieron lugar, aunque todavia esperaron algunos dellos, é lirieron algunos españoles é á muchos de los amigos que con ellos yban; é por la mucha agua que llovia, se escondieron por los arcabucos é bosques, que no ovo lugar de hiegerles daño alguno más de quemarles el pucblo. É lıego les envió el capitan mensajeros á los señores, diçiéndoles que no oviessen temor é viniessen á dar la obidiençia á Su Magestad, si no que les haria mucho daño en la tierra é les talaria los mahiçales; y ellos acordaron de lo haçer, é vinieron de paz, é diéronse por vassallos de la corona real de Castilla; y el capitan los resçibió muy bien, é los amonestó que fuessen buenos de ahí adclante, é assi dixeron que to harian. En aquel pucblo esturo Alvarado ocho dias, é allí fueron otros de muchos pueblos é provinçias de paz, que assimesmo dieron la obidiençia é se otorgaron por vassallos de Su Magestad é de sus subçessores.

Desscando el capitan Alvarado calar la tierra é saber los secretos della, determinó de passar de allí, é fué á un pueblo que se diçe Aliepar, é fué resçelbido bien de los scriores é naturales dél, que son de otra lengua é gente por sí : é á puesta del sol, sin darles causa ni haģerles daño alguno, remanesçió despoblado é alçado, é no se halló hombre en todo él. É porque lo resçio del invierno no le tomasse á este capilan ni le impidiesse su camino, passó adelante, llevando muy conçertado su exérçito; porque su propóssito era de llegar çient leguas adelante, é de camino ponerse á lo que le viniesse lıasta andar las çient leguas, é despues dar la vuelta paçificando lo que atrás dexasse. É assi otro dia siguiente se partió, é fué á otro pueblo que se diçe Tacuylula, é allí hiçieron lo mesmo que los de Atiepar, que los resçibieron de paz é se alçaron desde á una hora. De allí se partió á otro pueblo que se llama Taxisco, que es muy reçio é de mucha gente, é fué resçebido como de los otros de atrús, é durmió en él aquella noche, pero con buena guarda. É de allí se partió otro dia para otro pueblo que se diçe Nauçedelan: esta es grand poblacion. É temiéndose de aquella grente, que no la entendian, dexó diez de caballo en la reçaga, é otros diez niando yr enmedio del fardage, é siguió su camino; é podria yr dos ó tres leguas del pueblo de Taxisco, quando supo que avia salido gente de guerra, é que avian dado en la reçaga, é que le mataron muclıos indios de los amigos, é le tomaron mucha parte del fardage é fodo el hilado que llevaba para las ballestas, y el herrage que llevaba para los caballos, que no se les pudo resistir. É luego envió á Jorge de Alvarado, su hermano, con quarenta ó çinqüienta de caballo, á buscar á aquellos que avian tomado lo ques dicho, é lıalló mucha gente armada en el campo 
é peleó con cllos é los desbarató: é ninguna cosa de lo perdido se pudo cobrar, porque las cosas é ropa ya lis avian lıecho pedaços, é della cada uno traia en la guerra su pampanilla delante de sus verguienças. Llegados á este pueblo de Nauçedelan, Jorge de Alvarado se volvió, porque todos los indios avian huydo á la sierra, é desde allí lornó á enviar al capitan Don Pedro con gente de pié que los fuesse ál buscar á las sierras, por ver si los pudiesse atraer á la paz, é no se pudo haçer nada por la grande espesura de los montes é boscages, é assi se tomó: y el capitan Alvarado les envió mensajeros indios de sus mesmos naturales con requirimientos é mandamientos, aperçibiéndoles que si no venian, los avia de laçer esclavos, é con todo esso no quisieron venir ellos ni los mensajeros. i cabo de ocho dias quel capilan Pedro de Alvarado é su exérçilo estaba en aquel pueblo de Nauçedelan, vino un pueblo de paz que se llama Pacoco, que estaba en el camino por donde los nuestros avian de yr, y el capilan los resçilió benignamente, é les dió de lo que tenia, é les encomendó é rogó que fuessen buenos. É otro dia de mañana se partió para este pueblo, é halló á la entrada dél los caminos cerrados é muchas flechas hincadas en tierra; é ya que entraba pór el pueblo, vido que çiertos indios estaban haçiendo. quartos un perro á manera de sacrifiçio, é dentro del pucblo dicron de súbito una muy grande grita, é vídose mucha moltitud de gente de guerra puesta en armas: é arremelieron los nuestros á cellos, é rompiéronlos en tal forma, que los echaron del pueblo, é siguruóse el alcançe, que se pudo seguil, con assaz daño de los enemigos.

De allí se partió nuestro exérçito á otro pucblo, que se diçe Mopicalco, donde fué rescebido ni más ni menos que de los otros, é quando llegó al pucblo no avia persona ninģuna en él : é desele alli se particron para otro pucblo, llamado Acatepeque, que assimesmo hallaron desantparado é sin gente; é de alii se partieron para otro que se diçe Acarval, en el qual bate la mar del Sur. É ya que llegaban á media leguadel pueblo, vicron los campos Ilenos de gente de guerra con sus plimnages é devissas, é con sus armas ofensivas é defensivas, segund su costumbre; y estaban enmedio de un llano aģuardando, é quando los españoles estuvicron á un tiro de ballesta de los contrarios, mandó el capitan Pedro de Alvarado que todos los españoles estuviessen quedos é puestos en órden hasta que acabó de llegar la retroguarda. É desque todos estuvieron juntos, movieron é allegálonse á los enemigos hasta estar á medio tiro de ballesta los unos de los otros; pero los indios ninguu movimiento liçieron ni mostraron alteraçion alguna, porque estaban algo çerca de un monte espeso, donde se podian acoger. Mandó el comendador retirar su gente, que cran çiento de caballo é çiento y cinquienta peones, é hasta çinco ó seys mill indios de los amigos, é assi como se yban retrayendo, quedaba en la recaga el comendador porque su gente no se le desordenasse. Este retirar fué tan grand plaçer para los contrarios, que assi como lo vieron, se pusieron en seguimiento hasta llegar junto á las colas de los caballos, con tanta grita; que era cosa que pusiera muchó temor á quien no oviera visto aquello ó su semejante otras veces; y cran las flechas que tiraban tantas, que parescian lluvia, é passaban hasta los delanteros: é lodo esto era en un llano que para los unos ni los otros no avia donde tropeçar. Quando el comendador se oro retraydo un quarto de legua, é se vido en tal dispusiçion que á carla nno le avian de valer las manos é no los piés huyendo, dió la vuella solne los enemigos con toda la gente, rompión. 
dolos, é fué lan grande el destroço é matauça que en los contrarios se liço, que en poeo tiempo no avia vivo lombre de todos los que salicron, puesto que venian muy armalos: y el que cail en el suelo no se podia levantar, assi porque sus armas son unos coseletes hastados, de tres dedos rle alggodon en gruesso, é hasta los piés, como porque los nuestros al momento los acababan, en viéndolos derribados, sin que les valiessen sus areos é flechats ni lanças luengas. En esta luatalla ó recuentro fueron heridos muchos españoles, é al comendador le dieron un flechaço que le passaron la picrna y entró la flecha por la silla del caballo: de la qual lurida diçe en su relaçion que quedó lisiado, de manera que la una pierna le quedó más corta que la otra quatro dudos. I en este pucblo les fué forgado estar çinco dias, porque se curassen él é los demás.

Descle allí se partió á otro pucblo llamado Tacusocalco, adonde envió por corredores del campo al capitan don Pedro é a otros compañeros, los quales prendieron dos espias, que dixeron que arlelante estaba mucha gente de guerra del dicho pueblo é de otros de aquelia comarca, esperando a los españoles; é para más certificarse desso, llegaron hasta ver aquella gente, y cra grand moltilud della. É á la saçon llegó Pedro de Alvarado con quarenta de á cahallo, que llevalua la delantera, porque el comendador yba malo de la herida ques dicho, é hiço rostro hasta que llegaron todos los uuestros; é cómo fureron juntos, calbalgó el comendador en un calsallo, como pudo, por ordenar su batalla é gente, é vido que estaban los enemigos fechos un cuerpo de una grand falange ó batalla, é mandó á Goniez de Alvarado que hiriesse en los contrarios por la parte siniestra con hasta veynte caballeros, é á Gonçalo de Alvarado mandó que fuesse por la parte derecha con Ireynta caballeros, é á Jorge de Alvararlo mandó que rompiesse con todos los demás en los contrarios (que verlos de léxos era cosa pará espantar su moltitud, é porque los más dellos tenian lanças de treynta palmos luengas é arbolarlas en alto). El capitan Pedro de Alvarado, que yba por general deste cathólico exérçito, cómo no podia pelear, púsose en un cerro que allí jụnto estalıa, por porler ver cómo se haçia, é vió que llegaron todos los españoles hasta un tiro de herron de los indios, é ni los indios Luian ni los españoles les acometian, de lo qual el comendador estaba muy maravillado cómo los indios atendian con tanto esfuerço, é cómo los españoles no les acometian por la órden que les avia dado. É la causa era que un prado, que estaba entre los unos é los otros, pensaban los de cahallo que era çiénega; é despues que vieron que era duro é fixo el terreno, arremetieron con el apellido del apóstol Sanctiago, é rompicron por los indios é desbaratáronlos, é fueron siguiendo el alcançe más de una leğua, derribando é matando en ellos de tal manera, que para ellos é sus clesçendientes fué bastante castigo para nunca ser olvidado. Como los pueblos de adelante vieron que en el campo los desbarataban, acordaron de alçarse é dexar solas las poblaçiones sin gente.

Avidla esta victoria, que fué muy grande é muy sangrienta, descansaron los esjañoles é su exérçito en aquel pucblo dos dlias, y cn fin dellos luego otro siguiente se partieron para otro pucblo que se diçe Niaguaclan, donde tambien la gente dél se fué al monte, como los otros: é particron de allí los españoles para otro pueblo nombrado Atheluan, é allí enviaron los señores de Cuxclacan sus mensajeros, diçiendo que querian ser buenos é dar la ohidiençia á Su Magestad, como sus vassallos, é assi la dieron. I el comendador los 
resçibio, pensando que mentirian, como los otros; é llegando que llegó á aquella cibad de Cuxclacan, halló muchos indios della que lo resçibieron é todo el pueblo alçado, y en tanto que los españoles se apossentaron no quedó hombre de los veçinos en el pueblo, que todos se fucron á las sierras. Visto esto, el comendador les envió á deçir que no fuessen malos, que mirassen que avian dado la obidiençia á Su Mlagestad é á él en su real nombre, é que sin causa alguma se ausentaban, é quél no ylya á les haçer daño ni gucrra ni á tomarles lo suyo, sino á traerlos al serviço de Dios, Nuestro Señor, é al de Su Magestad. E respondieron que no conosçian á nadie ni querian venir, é que si él algo los quisiesse, que allí estalıan esperando con sus armas. Como el comendador vido sti propóssito, envióles un mandamiento é requirimiento de parte del Empcrador, nuestro scñor, cn que les requeria é mandaba que no quebrantassen las paçes ni se rebelassen, pues se avian dado por sus rassallos, donde no, que proçederia contra ellos como contra tray dores que se rebelaban á su Rey é señor, é les haria la gnerra á fuego é á sangre, é los que tomasse vivos, scrian herrados y csclavos: é seyendo leales, les ayudaria é favoresceria. É á este propóssito díxoles otras muchas é luuenas palabras, cxhortándolos á la paz, que á mi paresçer se les avia de enviar de letra firmada, ó no cursiva ó de tirado, pues que no saben leer.

Dicho he otras veçes, que con más espaçio é con término para deliberar, é por otra via se avian de haçer estos requirimientos, é no tan lureves é á la soldadesca, como si fueran gente que entendieran unestra lengua; pero tambien como esta gente era reluelada á su Dios verladero, é siguen sns ydolatrias é al diablo, assi permite Dios su castigo. El caso es que los mensajeros no tornaron ni otra respruesta, por lo fual el comendador envió gente á buscar los indios por los montes e sierras, é halláronlos de gruerra é pelearon con ellos, é litricron algunos españoles é á indios de los amigos: despues de lo qual fué presso un prinçipal de aquella cibdad, é para más justificaçion lo mandó soltar el comendador, é se lo envió con otro mandamiento é requirimiento, queIlos cumplieron como el primero, respondiendo lo que antes avian dicho. Y el comendador hiço prosesso contra ellos é contra los otros que le avian dado guerra, é los llamó por pregones é tampoco quisicron venir, porque como no entien. den essos términos ni derechos, sino los de su acostumbrada libertad, ó se hiçicron sordos, ó no les paresçió que les aconscjaban á su propóssito. Assi que, el comendador, vista su rebeldia, y el proçesso çerrado, los sentençió por esclavos é los dió por traydores é á pena de muerte á los señores de aquellas provinçias, é á todos los demás que se oviessen tomaclo durante la guerra é se tomassen despues, é que liasta tanto que diessen la ohidiençia á Su Magcstad fuessen esclavos é los herrassen, é dellos ó de su valor se pagassen onçe caballos que en aquella conquista destos fucron muertos, é los quno de allí adelante matassen, é más las otras cosas de armas é nesçessarias a aquella conquista. Solsre aquellos indios desta cibdad de Cuxclacan, estuvo el exérçito chripstiano diez é siete dias: que nunca por entradas que se hiçieron, ni por mensajeros que les enviaron, se pudicron atraer á la paz, porque la espesura de los montes, é bravas montañas é sierras, é quebrada é mala dispusiçion é áspera tierra, en que está aquella gente, los hiço porflados é fuertes en su opinion.

Diçe esta relaçion de Alvarado que allí supo de muy graudes tierras, la tierra adentro, con ciludades con edefiçios de cal é canto, é supo de los naturales cómo aquella lierra no tenia cabo, é que para 
conquistarse, segund es grande é de muy grandíssimas polblaçioncs, es menester mucho espacio é tiempo. li por el reçio invierno que entraba, no passó más adclante á conquistar, é acordó de volver á aquella cibulad de Guatimala é pacificar de vuelta la tierra que atrás avia dexado; é por mucho que lo trabaxó, no los pudo atraer á la obidiençia, porque toda aquella costa del Sur, por clonde fué, es muy montuosa, é las sierras çerca, adonde se acogen. Assi que, por las muchas aguas, se tornó á Guatimala, donde para mejor conquistar é paçificar aquella tierra tan grande, é tan reçia é belicosa gente, hico y edeficó en nombre de Su Magestad una cilodad de españoles, é nombróla Sanctiago, para que desde allí, que está en la mejor parte de la tierra é con más aparejo, se conquistasse lo de adelante; y eligió alcaldes é regidores para la gobernaçion de aquella república.

Passados los dos meses que quedaban del invierno, diçe en su relaçion el $\mathrm{Co}^{-}$ mendador Alvarado, que pensaba salir de aquella cibdad en demanda de la provinçia de Tapalan, que está segund lo diçen, quinçe jornadas de allí la tierra adentro, que segund le avian informado es cil)dad tan grande como la de Temistitan, é de grandes edefiçios de cal é canto é açuteas. É sin ella diçen que hay otras muchas, é que de quatro ó çinco dellas avian venido alli á dar la obidiençia á Su Magestad; é le dieron á entender que la una dellas tenia treynta mill veçinos, é que no se maravillalsa, segund son grandes los pueblos de aquella costa que la tierra adentro hay, á lo que le deçian: é quel verano siguiente pensaba passar dosçientas leguas adelante, donde esperaba que Su Magestad seria muy serviclo, é su real cstado aumentado, é quel gobernador IIernando Cortés ternia notiçia de otras cosas nueras.

Diçe más: que desde la cibdad de Te- mistitan lasta lo quel comendador anduvo é conquistó layy quatrocientas leguas, é ques mús pollarla aquella tiera é de urás gente que Ioda la que Cortés liasta estonges avia gobcrnado.

Diçe más: que avian hallado una sierla donde está un volcan, la más espantable cosa que se la visto, que echa por la boca piedras tan grandes como una casa, ardicndo en vivas llamas, é quando caen se laçen pedaços é cubren toda la sierra de fucgo: é que sessenta leguas adelante vieron otro volcan que echa lumo muy espantable que sube al çielo, en anchor de compás de media legua, y envuelto del humo; é que todos los rios que de alli desçienden no hay quien beba el agua, porque sabe á açufre; é que en espeçial viene de alli un rio caudal é muy hermoso, tan ardiendo que no lo pudo passar cicrta gente de su compañia que yba á laçer una entrada, é que andando á buscar vado hallaron otro rio frio, que entraba en el ques dicho, é allí donde se juntaban hallaron un vado templado, que lo pudieron passar. $\dot{\mathrm{E}}$ con esto diçe, que de las cosas de aquellas partes no lay más que contar é haçer saber por estonçes al gobernador, sino que le deçian los indios que desde aquella mar del Sur á la del Norte hay un invierno é un verano de andadura: en lo qual él y ellos se engañaban mucho, porcue assi en essa distançia , como otras cosas de las que de susso se han dicho de la grandeça de aquellas cibdades (que no hay tan grandes) se engañaron, porque el tiempo lo ha mostrado. $\mathrm{Y}$ el engaño es, que demás de no aver aquellos edcfiçios de canteria, como diçe, quanto á la grandeça hay en ello una cosa que lo hace verisímil, porque estín poblados en barrios continuados de Iongitud, unos cn poṣ de otros, é más se pueden degir provinçias que no pueblos. Pero desde que Alrarado escrilbió aquello, ques el año ya dicho, hasta agora cstá mejor 
entendido é penetrado todo aquello, como se dirá quando de la mar del Sur en la tercera parte desta General historia de Indias se tracte: las quales es una la de Guatimala, en la qual fué el primero gobernador este cavallero. É porque para quando aquello se escriba adelante, hace al propóssito el fin desta relaçion quél hico á Cortés, diré el pié della á la letra, que dice desta mancra:

- Tuestra Merçed me hiço merçed de la tenençia dessa ciblad de Temistitan, é yo la ayudé á ganar é la defendi, quando estaba dentro en el peligro é trabaxo que Vuestra Merçed sabe; é si oviera ydo en España, por lo que yo á Su Magestad lie servido, me la confirmara é me hiçiera más merçedes. Hánme dicho que Su Magestad la ha proveydo: no me maravillo, pues que de mí no liene notiça; é desto no tiene nadie la culpa sino Vuestra Merçed, por no aver hecho relaçion á Su Magestad de lo que yo le he servido. Pues me envió acá, suplico á Vuestra Merçed le lagga relaçion de quién soy, é lo que á Su Mlagestad he servidlo en estas partes é lónde ando, é lo que nuevamente le he conquistado, é la voluntarl que tengo de le servir en lo de adelante, é cómo en su serviçio me han lisiado de una pierna, quán poco sueldo yo y estos lidalgos que en mi compañia andan, avemos ganarlo, $y$ el poco proveclio que hasta agora se nos ha seguidlo. Nuestro Señor prósperamente crezca la vida é muy magnífico estado de Vuestra Merced por muy largos tiempos. Desta cihdad de Sancliago á veynte é ocho de julio de mill é quinientos é veynte é quatro años. $=$ Pedro de Alvarado.

\section{CAPITULO XLIV.}

Donde se traeta otra relaẹion feeha por el eapitan Diego de Godoy al gohernador Hernando Cortés, la qual, con las relaçiones que la historia ha eonlado, envió al Emperador, nuestro señor ; é deçirse ha lo substançial por evilar prolixidad, sin que se dexe de expresar todo lo ques notable é eonviniente á la historia.

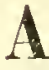
cosas que aquí se tocan, é pucblos é provinçias que aqui se nombran es supérfluo, é que la cosmographia anda escura por culpa de los questas relaçiones luacen, que ni distinguen los assientos é promontorios é costas de las mares é de los rios é lagos, ni dicen los grados ni alturas de cada provinça é pueblo, ni en qué clima ó paralelo están, sino assi á modo soldadesco, como si para ellos solamente fuesse; no creays, que aunque haya en ellos essos é otros defettos, que dexa de ser provechoso para adclante en alguna manera. Porque sin dubda todo lo que escribió Claudio Tolomeo Alexandıino en su Geographia, é lo que acumuló Plinio en su Natural Hisloria, 6 la mayor parte del!o, otros lo dixeron $y$ escribieron en pocas 6 menosé gruessas palabras, oydas á los que lo vieron antes, é los segundos lo apuntaron mejor. Ė de unos é otros vino la cosa perfiçionándose, hasta la medir é poner en sus grados é regiones por su cuen. la é reglas, confirmando las línias é climas çelestiales con los assientos, terrenos o sitios, para que la raçon de la tierra pudiesse estar assi bien entendida. É lo mesmo podeys entender que acaesçió en el arte de la pintura, (quel orígen tlella fué hallada de la forma del hombre çireuns. cripta con las línias: é assi fuć la primera pintura é la segunda fué de una color sola. é despues se hallaron las colores é matiçes, é vino de un tiempo en otro hasta allegar aquellos varones $\mathrm{y}$ exçelentes pin- 
lores, que son famosos en tal arle. I)esla manera, pues, nuestros soldados dicen los nombres de los puchlos é provincias como los oyen á los indios, é no distinguen en qué linir ó parte están, ques quassi como prinçipiar de la sombra estotra pintura del mundo. É los capitanes destas conquistas nudan algunas veces aquellos vocablos que hallan usados cntre los naturales, para que más borrado y escuro quede. É porque los que vinieren no me den á mí la culpa que á essotros, dígolo assi como de sus relagiones se colige; pero donde puedo acresçiento la claridad que alcanço, para darlo mejor á entender.

Diçe Alvarado en fin de su relaçion en el preçedente capítulo, que su carta es fecha en la cibdad de Sanctiago, é quien no mirare más, pensara ques la cibdad de Sanctiago en Galiçia; é por excusar esse error, añadí yo en el título del capítuIo XLIl é dixe desde la cibdad de Sanctiago de Guatimala, quiero deçir, que no soy adivino, ni nuestros soldados cosmógraphos; pero esforçarme hé, donde hallare lugar, para poner cada cosa en su debida cuenta; y esto no puede ser de un golpe tampoco, sino dilatándose el tiempo, como en la pintura, para que con él, con los mesnos nombres que aqui se dirán, otros perfiçionen é pongan al proprio los grados é alturas en cada provinçia destas.

Vengamos á lo que diçe este hidalgo Diego de Godoy en la relaçion ó carta que escribió á Hernando Cortés, é que fué enviada á Su Magestad con las que la historia de susso ha memorado: el qual hace mençion que desde el pueblo de Cenacantcan avia escripto y hecho saber al gobernador to de hasta cstonces. E prosiguiendo en las cosas de que lc avisa, diçe quel martes, tercero dia de pasqua de Resurregion, qlie fueron veyule é nueve dias de março (é no diçe qué año, y es el mesmo que essotras relaçiones de sus- so expresan de mill e quinientos é veynte é quatro) el teniente de Cortés se partio parar yé á nun pueblo, que se llama Quegreztean; fue de alli á Cenacantean avian renitlo de par los indios á un Francisco de Medina, antes quel tenicnte alli viniesse, que le avia enviado desde Chiapa; éque á este Diego de Gotloy, con otros seys de caballo é siete ballcsteros, envió por otro camino para visitar la provinçia llamada Chammla, que tambien ya avian ydo de paz los indios della, é les dixo que dende alli, cómo oriessen visitado á Chanula, se fuessen á donde el dicho teniente yba. É por el camino que á estos guiaron avia sinco pueblos pequeños de la dicha provincia, á vista unos de otros, cn espaçio de tres leçuas, de tan mal camino que muy poco dél pudieron yr cabalgando: é cómo llegaron al primero pueblo, halláronle despoblado, el qual estaba en un çerro alto. É baxaron á una cañada que se haçia para subir á los olros pueblos, que se vian desde el primero, puestos en una ladera muy alta, é cerca unos de otros, é avia una cuesta muy alta é áspera, que llevando los caballos de diestro con grand pena podian subir. É assi como començaron á subir por ella, vicron en lo alto, en el mesmo camino, un esquadron de gente de guerra, é las lancas enlicestas lan luengas ó más que lanças ginetas; é continuando assi por la cuesta arriba, vieron cómo por la loma de dicha ladera venian, á trechos unos de otros, muchos indios corriendo con sus armas á se juatar con los que estaban sobre el camino, é apellitlándose é llamándose unos á otros. Viendo aque-to cssos pocos españoles, é que la tierra que atrás dexaban para volver, pelcanclo, cra tan peligrosa, uque poniéndose con ellos en conlicnda corrian mucho riesgo, é corriéndolo ellos lo corrian lodos los otros espanoles que con el tenicute estiban, acordó el dicho Godoy que era mejor dexar ia 
subirla é tornarse al pueblo que atrás quedaba despoblado. É desde allí les envió á deçir que por qué lo hasgin tan mal, que no avian aderescado el canino, que los raballos no podian subir arrila, é que fuessen á aruel pueblo los señores ó algunos prinçipales, para que les dixessen lo quel teniente les avia mandado decir. Respondieron que no querian; que se rolviessen los españoles, si no que alli estaban con sus armas apergeljidos para los resçebir.

Viendo aquesto, que ninguno dessos españoles pudicra escapar, por no poder pelear á caballo, se tornaron, é la gnia los llevó por gierto alajo; é quando el sol se queria poner, fueron á salir adonde el teniente estaba apossentado, que era en el camino en una muy buena vega, muy grande é á par de un rio, é cercado de hermosos pinares, é á vista de tres pueblos de Cenacantean, que estaba en una sicrra que allí junto se haçia, é que avia hasta aquella vega de Cicnacantean dos leguas é media. É allí llegados, dixeron al teniente lo que avian risto, é que les páresçia que no era bien que aquellos inlios quedassen sin castigo, é assi le paresçió ál él; é otro dia por la mañana, treynta de marco, particron para yr sobre el dicho pueblo de Chamula, quedando en aquella vega todo el fardage é dolientes, é con ellos un hidalgo llamado Françisco de Ledesma, con diez de caballo, para guarda del real. E fueron gुuiados por otro camino que flua á la dicha cabeçera de la provinçia, é llegaron á ella á las dos horas del dia, é antes de llegar se hace una chesla abaxo peligrosa, en la qual algunos caballos cayeron co harti hondura, aunque no peligraron, por no ser lierra de piedras, é forque avia algunas matas é hierhas. É baxarlos de la caesta, é puestos al rededor de un pucblo que estaba en un cerro muy alto, hácese una cañada: é creyendo que presio se pudicTO.110 III. ra tomar, los de caballo se particron en tres quadrillas para çerear el pucblo é dar en la grente que huyesse, con parte de los anigos confederados; y el teniente con los peones é los más de los amigos (porque caballo en ninguna manera podia subir sino con mucho peligro é de diestro) començaron á subir por una ladera, jor donde el camino yba muy angosto, é á partes de peña tajada. É llegados ya arriba, antes de llegar al pueblo, á par de mas casas, resçibieron á los nuestros con muchas piedras é flechas, é con muchas langas, como las que se han dicho, que son las armas con que aquella gente pelea, é con unas pavesinas que les cubre todo el cuerpo, deste la cabeça hastil los piés: las quales, quando quieren lıuyr, ligeramente las arrollan é las toman delaxo del sobaco, é muy presto, quando quicren esperar, las tornan á extender. Alli pelearon un rato con ellos hasta los retraer é meter por una fucrte albarrada que tenian fecha, de dos estados al- ta, tan gruessa como quatro piés é más, toda de piedra é tierra entretexida con ârboles é fecha de mucho tiempo, é tan reçia, que los chripstianos no la supieran haçer mejor de aquella manera : é por la parte más íspera tenia una escalera de gradas, muy angosta, que subia arriba, por donde entraban adentro; y ençima de la dicha albarada, de luengo á luengo, puestas tablas muy gruessas, tan altas como otro estado, é muy fixamente atadas con muy buenos maderos, por fuera é por dentro, é muy fuerte ligaçon de vexucos en lugar de cuerdas.

Antes de llegar á esta albarrada, al pié della estaba fecha una paliçada de madera meticla en el suelo é cruçada una con otra, é atada de tal forma que los chrips. lianos estaban admirados del artifiçio é fortalega que en sí tenia: é dende la dicha albarrada de piedra, é por de dentro, deude un serrillo que se hacia todo llewo 
de arboledas é matas espesas, peleaban osadamente é tiralan tantas piedras, que no avia medio de poderlos entrar por ninguna parte. Estando assi, arremetieron ciertos españoles, hombres animosos, á la escalera que está dicho, pensando entrarles; é tan presto como llegaron arriba, los levantaron en pesso en las puntas de las lanças, é los hiçieron volver rodando por la mesma escalera. Esto mesmo se hico por dos ó tres veçes que se probó á entrarles, lo ymal era imposible, porque de dentro estaba hondo; é assi se defendian y lerian á muchos españoles é de sus confederados amigos, non obstante que con el artilleria é ballestas se les haçia harto daño, porque á veces se descobrian para pelear algunos atrevidos, é no podia ser menos: é andaban los combates de manera que pocos tiros se erraban, ni se dexaban de emplear en daño de los contrarios. E cómo los chripstianos vieron que con tanto ánimo peleaban los contrarios enemigos sin huyr, los de caballo que abaxo los estaban esperando, acordaron de dexar los caballos é subir á pié á lo alto: é pelearon todo aquel dia, hasta que fué de noche, procurando deshaçer la estacada de madera que estaba delante de la alliarrada de piedra. Y el teniente envió al real por hachas é haçadones é barretas de fierro para derribar el albarrada de piedra, porque de otra manera no avia medio para les poder entrar, que no se asomaba hombre sin que veynte lanças no le luviessen puestas en los ojos: é cómo la noche les tomó allí en aquellas casas, que eran dos ó tres, dende donde peleaban los nuestros, tuvieron la noche velando con buen recabdo, é no hiçieron menos los de dentro, porque toda la noche ligieron muy grandes areytos é gritas, é tañendo atabales é sonando voginas; é muchas veçes tiralıan flechas é algomas piedras, é se oia como arrancaban piedras para ti- rar, porque sonaban al ticmpo que las descargalsan é daluan on el suclo.

Luego otro dia siguiente, assi como fuć de dia, començaron los espanoles á combattir el allartrada; é ya quel sol salia, llegraron las hachas é haçadones é barretas por que avian enviado, é conencóse á deshaçer el albarrada. E cómo los enemigos se començaron á apartar, los amigros de los chripstianos truxrron luego haces de paja, é pusiéronla encima de la albarrada á las tablas para las quemar, é lan presto como començó el fuego á arder, en continente socorrieron los enentigos con muchas ollas de agua para lo matar. Antes desto avian fecho un ardid, y era que echaban mucha agua caliente envuelta con çeniça é cal, con que haçian daño á los que se allegaban. Y estando assi pelando, echaron un pedaço de oro desde dentro, diçiendo que dos pelacas ó cestas tenian de aquello, que entrassen adentro á las tomar, é como gente que mostraba tener los nuestros en poco. E ya que era hora de vísperas, quassi avian hecho los españoles dos portillos, por los quales se juntaban tanto con los conlrarios, que pié con pié peleaban, y ellos se defendian con tanta constançia, que los ballesteros, sin encarar, á manteniente, les ponian las ballestas en los pechos, é no hacian sino apretar las llaves é derribar dellos. Y estando en este estado el combate, vino una grandíssima agua, é una nicbla tan escura é çerrada, que apenas se vian unos ál otros, por gerca que estuviessen, é á csta causa los españoles se desviaron del absarrada á las casas. É turó el ağua una hora, en la qual passó aquella niebla é çessó de llover: é tornaron en continente los nuestros á continuar el combate, é halláronse burlados, porque segund paresçió, la noche antes cómo los enemigos vieron que los apretaban, no avian fecho sino alcar su ropa é mugeres é quanto tenian, é assi subida 
el albarrada no avia dentro ánima viva; é porque paresçiesse que estaban allí, dexaron las lanças arrimarlas al allarrada, que se parescian por de fuera las puntas de unas algo más de otras. Por manera que los uuestros entraron por el pueblo adelante, que era muy trabaxoso de andar porque cada cinco ó seys casas eran como una fortaleça, segund eran en si fuertes; é los arroyos de agua cran tan grandes de lo que avia llovido, que no podian andar los vencedores sino dando muchas caydas; é los amigos como eran más sueltos, siguieron á los que luian lasta abaxo, é tomaron muchas mugeres é muchachos, é aun alğunos hombres. Tenian assimesmo las lancas arrimadas las puertas de laś casas, porque se sospechasse que estaban dentro.

Arida la vietoria de la manera ques dicho, reposaron alli los españoles é sus amigos aquel dia é la noche, é hallaron harto de comer, que les era bien menester, porque avia dos dias que no avian comidlo, ni tenian qué comer ellos ni los caballos; é no hallaron otro despojo. Sípose de los pressos quel dia antes murieron de los enemigos dosçientos lıombres, é que aquel dia del vençimiento les mataron tantos que no los pudieron contar: Tambien dixeron que avian estado allí en la defensa assaz gente de la otra provinçia de Guegueztean. Y el viernes adelante, primero dia del mes de abril, se tornó nuestra gente á su real para descansar é curarse. que yluan los más de los españoles heridos, é para que se hiçiessen saetas é almaçen, que se avia gastado lo que teniun; y estuvieron allí el síbado siguiente. Y el domingo, tres de abril, despues que se rlixo misa, partieron para el pueblo é provincia de Guegueztean; y el camino hasta llegar í vista de arfuella cabecera de la provinçia es todo muy bueno é llano, de hermosos pinares é monte raso: é antes algo de en- trar en aquellia provinçia cstaba una grand cuesta que baxa láçia baxo, y el pueblo está sobre olra cuesta. E vieron cómo de otro pucblo yluan por una loma corriento mucha gente con sus armas á se meter en la dicla calyecera; ćllegados allá, luego vieron las albarradas, que tenian muy grandes, pero no tan fuertes como las de Cliamula. É cómo avian gustado é visto lo que en Chamula se avia fecho, desampararon el pueblo é alloarrarlas, é se pusieron en luyda por una ladera de unos cerros; pero la mayor parte de los fugitivos siguieron por un valle que abaxo se haçia te mahiçales, é por no aver buen conçierto en los muestros no se tomaron é prendieron mís de quinientas personas, todos hombres; porque el teniente no quiso aguardar que la gente fuesse toda juntaantes se adelantó con cinco ó seys de caballo trás los que yban por la ladera en lo alto, é como cra mal camino, no alcangaron sino muy pocos, que mataron, é tomaron algunas mugeres; y el valle en lo baxo yba todo lleno, que purdieron tomar muchos é malar los que quisieran, si la gente muestra fitera llegarla á liempo, ó el teniente no se açelerara. É assi quanđo los españoles llegaron, fué tarde, é los contrarios, como rençidos é por huyr más desocupados, dexaban en tierra las armas; y essos cinco ó seys de caballo, que yban con el teniente, llegaron hasta otro pueblo pequeño, que está media legua adelante, bien fuerte, é allí esperaron la gente, é se assentó allí el real.

Desde aquel lugar, principal cabeçera de Guegueztean, se parescen diez ó doçe pueblos á la redonda, todos en la sierrí, fue le son suljetos; y el ralle que passa por ahaxo es muy hermoso de labranças, é passa por él un loonico rio, aunque es pequeño.

Torlos los puchlos de aquella tierra tienen guerra unos cón otros: é deste allí liço el teniente yr mensajeros á los seño- 
res para que viniessen de paz: pero ó no to entendieron, ó mejor diçiendo, no to quisieron haçer, é nurguno vino. É de allí se partieron un mićrcoles, seys dias de abril, para Conacantean, é siçuicron por lis via que ra a Comatan: é cómo vieron Ins españoles que tan presto como se daban los pueblos de paz, tan presto é con poeo intervalo de dias se rebelaban, perdieron el esporança de se servir dollos: é como se descubrian muchos pueblos, pensaban ser rieos; más entendida é vista su mudança é poea constançia, no les paresçió que cra tierra para que ning̣uno osasse tomar indins alli do repartimiento. É: considerando aquesto, se fornaron, como es dicho, de eamino de Cenacantean; pero eon todo, un lidalgro llamado Nlonso de Grado fué á Chiapa é le rescilieron bien los indios, é a algunos españoles en otros pueblos, quel teniente les avia depositado.

Diçe más en esta carta este hidalgo Diego de Godloy que un miércoles, treçe del dieho mes de abril, vinieron indios naguatatos de una provinçia que se dice Anapanaselan, que ya otras veçes avian venido de paz, é con cllos otros indios de Michampa: é enn aquellos indios nagualatos avia enviado el teniente; é truxeron un poco de oro é una çestilla con casquillos para saetas, é dixeron que un español que estaba on Soeonusco, se los avia mandado haçer para Pedro de Nrarado. É aquestos dieron notiçia quel comendador Alvarado avia entrado en Lelacan é avia muerto mucha gente en la ğucrra, é dixeron que destle sn licria á Lulacan no avia sino sicte jornadas, é desde Chiapa á su tierra destos tres jornadas: de forma que por lo que aquellos indios decrian podria aver dende donde estaban nueslros españoles y al dicho teniente á Lclacan, cient leguas ó poeo más. Otros indios fueron allí á Cematan de paçes, en espesial de un pueblo que se dice Gueytumpan é de ofro que llanan Tesistolnque, étruxeron un poeo de orn: y al teniente envió con cllos dos españoles á ver estos puehlos. El jueves adclante se partio el tenionte é los mucstros, é á tres leguas do allí lıallaron fechos muchos ranchos é luenos, y el camino muy alicrto é desherberdo: é paresçió mna persona que dixo ser scñor de Clatipiluta, de buena presssençia, que lo avia mandado laşer, truxo muy abastadamente de comer, é dixo al teniente quél tenia abierto el camino hasta su ticrra, é que viesse lo que Io mandaba. E dioble el teniente las graças por ello, é disole que queria yr á ver su tierra, pues quel pueblo estalia tres le. cuas de allí. del peor eamino que hasta estonçes avian visto en la Nueva España, é tal. que si los indios no le tuvieran tan bien aderesçado, fuera imposible passar adelante, porque es de sierras muy úsperas, é legua é media de una basada muy peligrosa, porque de una parte es de una ladera de muelia londura, é á partes de una peña tosea, que no avia dónde los caballos pusiessen los piés. É teníanlo tan lien aderesçado de muchas estacas hineadas á la parte de la ladera, é maderos muy fuertes atados mur lien y rediada mucha tierra, é cavado todo lo que avian podiclo eavar, é aun en partes (quchradas las peñas é innumerables árboles cortados para alrir el camino, en que aria árbol (é se midió) de nuevo palmos, mealido por medio, que son en redondo ó de circunferençia veynte y seys, é otros muy grandes: de que se congeturaba que arfuclla labor ó eamino se avia fecloo de buena gana é con mucha gente, é aunque españoles en ello entendieran, no to pudieran aver fecho mejor. E passado aquel puclslo, los llevaron á apossentar fuera del pucblo á muchos ranchos que tenian fechos, donde vino el señor con pressentes de oro, aunque poco, é plumas de las muy lormosas, que paresen do color de 
oro é verdes, é unos páxaros muertos de los que las crian; ć truxeron larta aluundançia de comida é mucha grente, que andaban sirviendo é trayendo agua é hierla. Este pueblo, con otros que le son sul)jetos, estín en un lıermoso valle, á par de un rio, con sicrras de un caho é de otro. Allí fueron otros indios de paz é con comida é oro, poca cosa, é por esperar los españoles quel teniente avia enviado á Gueitcupan, esturo este exérçito quatro dias allí, lıasta que vinieron çiertos indios con un bonete dellos á (leçir que se yluan por otro camino á salir á otro pucblo, donde el teniente avia de yr á salir con su gente. Donde diçe en algunas partes deslas relaçiones que los indios que venian de paz traian poco oro, aveys, letor mio, de entender que diçe poco, porque no era tanto como tomaran los que lo resçiluian; pero no dexilba de ser buena cantidad dello. Allí vinieron ciertos indios de los gapotecas, que de Cliapa á Duichula se avian ydo á vivir, porque es çerça de aquel pucblo, é yban á traer de comer á un hidalgo llamado Grande, é á ver lo que les mandaba.

Miércoles adclante veynte de abril se partió esta gente, é desile á dos leguas llegaron á un puelslo que está junto á la ribera del mesmo rio de Chapitula, entro unas sierras, que es subjeto ál otro que se dice Silusinchiapa, otras dos leguas, donde fueron aquel mesmo dia. En estas dos leguas están otros pueblos pequeños que le son suljjelos, y en la mesma rilsera de aquel rio y contre sierras; y es el camino hasta llegar á Silusinchiapa el peor que se puede deçir, aunque los naturales lo avian aderescrado lo mejor que pudieron, segund la mala dispusiçion de la tierra. Allí fueron bien rescebidos é proveydos de mucha comida, aunque Ilovia mucho, é tanto, que cresçió aqquel rio de tal forma que no pudieron passar adelante, porque como es entre sierras ví el agua dél por el mesmo camino é muy furioso; y en lanto que descansaban Ios españoles y estahan assi detenidos por la lluvia, se fueron todos los indios, que ninguno dellos paresçió, sin averles dado causa, é ariendo, como es dicho, muy bien rescelsido á nuestra gente, é aviendo llabaxado tanto en aderescar el camino. Assi que, dos dias que estuvieron los nuestros detenidos por la lluvia, quando çessó se dieron algumas catas, porque paresçia que aquel rio tenia dispusiçion de iener oro, é halláronse unas puntas deIlo, puesto que aria mal aparejo é falta de bateas para lo sacar. Descle allí envió el teniente un mandamiente á los de Chiapa, que está mas adclante é subjetos á Sematan.

El lunes siguiente fueron dos leguas y media á otro pueblo tambien de la juris diçion de Cematan, que se llama Estapaguajoya, de lasta quinientas casas, é to(lo el camino es jor el rio ó lo más dél, é se passa muchas veços, que ni fué de poeo trabaxo ni menos peligro para los españoles, porque la tierra es toda riscos, y el rio muy lleno de piedras grandes é de muclia furia. lagion que en el mundo todo no pudieron calsallos aver andado peor camino, porque desdle que amanesçió hasta puesto el sol, sim parar, fuvieron bien que liaçer en andar acuellas dos leguas y media, 6 los caballos yluan los mís deshcrrados, é algumos cayeron de los riscos en el agua, que corrieron peligro. É mucho más el puelslo es apacilsle é muy bueno é de lucnas plaças é casas y lıcrmosos apossentos, y el valle muy graçioso á la vista é fértil de muchas labranças á par del rio de la una é la otra parte dél, é á los costados sicrras de un cabo é del otro, aurque no altas como las que dexaron atrís, é halláronle despoblado é sin sente.

Este Diego de Godor dise que despues 
de aquel pucblo de la cabegera de Compilco, él se fué adelante á visitar unos pueblos suljjetos á Compilco, que Iternanro Cortés le avia dado encomienda, e para que le sirviessen al Godloy é á un companero suyo, llamado Pedro de Castelar: é que los hallaron despoblados: y en los utros dos pueblos que tambien tenian en su encomienda hallaron en cada uno hasta treynta lombres, é les dieron hasa cient mill almendras é lrasta quarenta pessos de oro baxo, é les dixeron due toda la gente cra muerta. É no diçe ofra cosa que sea digna de la historia. sino relata passiones de entre sus veçinos é quexas á Hernando Cortés solıre los repartimientos:

Quechula é Anaclaxipila son Gabereras é jurisdiçiones, é tienen otros pueblos a si suljelos, assi como Quichula é otros. Calmesignata, Xávion, Anaçandan, Caltiva, Cltatepeque, Tilececoapa é otrosmuchos nombra: los quales todos servian en aquella saçon con darles de comer é oro é de aquellas almendras del cacao que se diso de susso. las quales entre aquellas gentes corren por moneda é sirven de moneda, é por cllas se compran todas las cosas en aquella tierra, de los árboles de las quales é dessa mesma fructa é de sus cfeftos largamente se tractó en el libro rill de la primera parte, capitulo XXX, donde el letor to hallarí. É con tanto se ha dide fin á las relaçiones, quel gobernador Hernando Cortés envió á Céssar en diverssos fiempos. Passemos adelante con nuestra historia de la Nueva España.

\section{CAPITULO XLV.}

En el qual se tracta olra informaẹion que de algunos cavalleros é milites que se hallaron en la conquista de la Nueva España se ha sabido por la diligencia del chronista, en que muchas cosas hay conformes con lo que queda dicho; é lambien se dirán otras particularidades que no son de preterir ni je dexar de memorarlas, porque todas ellas sơn muy dignas de la pressente historia, é suyas.

\section{1)} le ser rerdadera, sea assimesmo recolegida y entendida su traça é órden sul)cossivamente: tambien desseo que sea aplaçible é grata á los que la vieren, é sobre todo que resulten della infinitos loores á Dios, que tantas novedades nos enscĩa é descubre en nuestros tiempos; é para esta. continuaçion que desseo dar á entender, digo que quando aquel tiro de plata ó de metal rico llegó á España con el pres. sente de Hernando Cortés, el año de mill é quinientos é reynte y çinco, yo ví en aquella corte de Su Magestad tanta murmuraçion contra Cortés, que andaba ya público que su officio de gobernador se avia de proveer, é quel almirante don Diego Colom avia de yr á la Nueva España á le descomponer. É cómo llegaron al pres- sente é dincros que envió é las relaçiones presedentes del estado de la fierra, aunque no fallaban Pampliilo de Narvaez por su parte é ofros émulos de Cortés, que contra él hablassen, dióse por medio que fuesse enviado por juez de residençia á la Nueva España el liçençiado Luis Ponçe, que á la saçon era teniente en la cibdad de Toledo por don Martin Alonso de Montemayor, señor de Alcaudete: el qual liçenciado Luis Ponçe era persona de letras é prudenté, aunque mancebo, é de quien Su Magestad é su real Consejo tenian buen conçepto. I en lo de remudar a Cortés, sin le oyr é tomar residençia, fuéle buen terçero el duque de Béjar don Álvaro de Zúniga, porque se tractaba casamiento de su solorina doña Johana de Arellano. hermana del conde de Aguilar, 
con Hernando Cortés, que estaba viudo: y el duque le abonó é fió, è aplicó al Emperador, nuestro señor, é le dixo muchas cosas en faror de Cortés para que Su Magestad le oyesse, como despues le oyó, é aun le engrandesció, como se dirá adelante en la prosecuçion de la listoria.

Assi que, volviendo á nuestro propóssito, no olvidando lo que está dicho de aquel Olintecle, de quien se hiço memoria en el capítulo I, al tiempo que eslaba departiendo, como allí se diso, con Ilernando Cortés, é dándole á entender la grandega y estado de Monteçma, llegaron çiertos mensajeros del grand señor, en que le mandalaa que liçicsse muclaa cortesia á los chripslianos é se les diesse muy complidamente lo que oviessen menester, é los llevasse el Olintecle á Temistitan en hamacas. É luego este caudillo ó prinçipal señor dió órden cómo los cluripslianos fuessen muy festejados é proveydos de comida, é púsose en obra el camino. É porque á mejor evento fuessen encaminadas las cosas de Montecuma, é jor no faltar á sus ritos diabólicos, liço lucgo este Olintecle sacrificar cinquienta indios é indlias en aquellas mezquitas ú oratorios, en quellos lienen sus ydolos, porque en aquello pensaba que servia á su señor é cumplia con una forma de religiosidad, é perderia el enojo que tuviesse, si no avia llevado antes los chripstianos á la cibdad de Temistitan. Diçe esta relacion que los chripstianos é su capitan siguieron su camino con muchos indios que los servian, é á algunos llevalan á cuestas en hamacas, é guiaron para la cibdad de Tascaltecal,ó á los de Tascaltecle *, que está veynte leguas antes de México, donde envió mensajeros Cortés á requerir í

- Como advertirán los lectores, habia lado Oviedo eonstantemente el nombre de Tascaltecla á esta poblacion: sin duda ateniéndose á la relacion que aqui sigue y extraeta, y hallíndule eserilo en los indios de allí, yue diessen la obidiençii á Su Magestad. É respondieron quatro scñores los más prinçipales de Tascaltecle que qué genite era arquella de loz chripstianos que los yluan amenasando sin los conosçer, é que mañana vernian ellos á ver essos chripstianos é les responde. lian como verian. É assi fué, que luegoo otro dia siguiente párescieron lantos dellos que cubrian los campos, ordenadas sus csquadras, é con roçinas é atambores é penachos, é como gente de guerri muy luçida en su manera, é deçian entrr sí : "Qué gente loca é lan poca es aquesti que nos viene á amenaģar é que usa de lanto atrevimiento, que sin nuestra liçencia entra en nuestra tierra? Pero non obstante su error, démosles de comer primero que los matemos, porque no se pueda deçir que los matamos hambrientos 6 cansados." E assi lo hiçieron, que lueggo enviaron al real de los chripstianos tresçientas gallinas ó pavas, que lo son más çicrto é muy buenas, é septeçientas cargas de bollos de mahiz. (entiéndese, carcra de un indio, que son dos cestas, que por lo menos cada carga cabria más de una arroba) que fué grand refresco é socorro para los españoles, lo qual repartido entre sí (aunque con temor de rer lanta moltitud de gente aperçebida) comian é atendian, comiendo. E los indios se agercaron con sus esquadrones muy bien ordenados á una barranca grande que estaba entre ambos reales; é viendo cómo los cluripstianos no se movian, deçian los contrarios: "Vamos ya que avrán comido, é atarlos hemos, é pagádrnos han las gallinas é tortas é bollos que los enviamos, é sabremos quién los mandó entrar en nuestra tierra. É luego los quatro capitanes, debaxo de quien yba aquel exér-

la forma que va en el texto, lubbo de admitir esta variante, eosa por olra parle muy freeuente en la Iistoria de Indias, segun queda ya advertido. 
(cito, matularon a dosçientos lombres minripales fuc fuessen en lin delanteri, 6 yıe si los chripstianos tomassen armas é se defendiessen, los malassen á todos, é si no que los llevassen alados, sin les hafer mil; é passaron la barranca diçiendo: a Qué lionra podemos ganar con Lan civil gente, que tan queda se está? \# Pero viendo su intento é feroçidad é soberbia que llevaban, salieron los chripstianos de cahallo en tropel, é rompicron á los contrarios é alançearon muchos: é los peones españoles thás los de calballo mataban quantos se les paraban delante. De forma que los pusieron en huyda, é los pocos que acerlabau el passo de la barranca, escapaban; pero la mayor parte de los que avian passado, se quedaron muertos. En el qual tiempo toda la moltilud, para socorrer á los primeros, venian híçia la barranca, dando lales yritos que paresçia que se abria el çielo; pero viendo quín presto estaban degollados los primeros, pararon, é acordaron que por aquel dia no se hiçiesse más batalla hasta la siguiente jornada. É cómo los nuestros vieron retraer los contrarios, holgaron dello, é los unos é los otros se recogieron á sus reales é hiçieron buena guarda essa noche. Assi cómo otro dia amanesció, luego los enemigos cnviaron de courer á los chripstianos, como lo avian fecho el dia antes, é despues vinieron á pelear con ellos, é luró la batalla seys lıoras continuas, en que siempre los españoles quedaron con victoria é á ventaja. É passadas las seys horas, pararon é se quitaron afuera los contrarios. De la manera que está dicho se liego el terçero dia y el quarlo é quinto é lodos los demís hasta sel cumplidos quince dias contínuos; cosa que nunca en aquellas partes ni olrás semejante cosa ó combates assi sangrientos se usó ni vido ni he oydo que esté es-

- En la narracion comprendida en los primeros capilulos del presente libro eseribe iudistimtamente cripto. pror manera que el comer lo llevat ban seguro é abastadamente é con mur cha alegrial, é despues en lugar de fructa postrera, como lobos ó fieros leones procedian en las billallas, auncue siempre los indios llevaban lo peor. En fin de los quinge diats dixeron que querian ser amigos de los españoles, é se assentó la páz ć la guardaron muy bien.

Movido de allí el real se assentó en la cibdad grande de Taseallecle; pero hilgiendo bnena vela, sospechando que la paz era fingicla, é no fuć sino fixa é turable. É por quitar á los españoles de sospechas, é como les yban ya entendiendo la condiçion, por conservar la paz, les dicron muchas de sus hijas, é porque los querian por amigos, querian que oviesse delodo é casta de lan valientes hombres en su ticra; porque demás desso estos indios de Tascaltecle é otros de Guaxogingo tenian grand guerra con Monteçma é con otro pueblo que se diçe Chelula. * É aquestas son provincias grandes, é a quatro ó çinco leguas una de otra, y en cada una dellas avia çient mill hombres de guerra é más: é no las podia soljuzgar Monteçuma, porque cómo yba contra una provincia, acudian los confederados de las otras ques dicho en su socorro é favor, al modo de Italia. Allí les yban á los chripstianos mensajeros de Monteçuma, para que se fuessen á él, ofresçiéndoles todo lo quellos quisiessen; pero como cllos se avian informado de sus cantelas, no se determinaban assi presto, é como deçian que se querian yr , pessábales en el ánima á los de Tascaltecle, é desenojalban á los chripstianos, é consejaban é rogálsanles que por ninguna manera se fuessen ni creyessen á Monteçuma, porque assi á los españoles como á las hijas que les avian dado matarian, diçiéndoles que era un mentiroso é traydor MonteguCulua y Colua. 
ma; pero en fin, Hernando Cortés é los demás acordaron de yr adelante, por ver aquella cibdad tan nombrada. E vista su determinaçion, quiso el priuçipal señor de Tascaltecle, llamado Xicotenga *, que se fuessen veynte mill hombres de guerrá acompañar é servir á los chripstianos; pero los chripstianos no los quisieron llevar.

En essa saçon llegaron otros mensajeros de Monteçuma con un pressente de oro ,é rogando á llermando Cortés é á los chripstianos que fuessen á Mléxico; y estando en este acuerdo de yr, non obstante el buen tractamiento que se les avia liecho por Tascaltecle, siguióse que, como en aquella ciblad avia otro señor que se deçia Xicotenga, que tenia acordado de matar á los chripstianos, y era capitan general de toda aquella provinçia, é mançebo muy esforçado é crudo é muy temido, las mugeres que estaban allegadas, querianlos bien é avisálıanles de las trayciones secretas de los indios. É una hermana de aquel capitan general, como lo supo, avisó al comendador Pedro de Alvarado de la trayçion, y él á Iłernando Cortés, el qual, como sagaz é prudente capitan, sacando con palabras disimuladas fuera de la casa al dicho capitan, hícolo ahogar, que ninguno lo supo, porque no oviesse escándalo en la tierra, que no pudiera faltar.

Cada dia venian mensajeros é pressentes de oro de Monteçuma, rogando á Cortés é á los españoles que se fuessen allá, porque le pessaba de verlos en paz é amistad con los de Tascaltecle; y essotros se lo estorluaban con ruegos, é los desengañaban é deçian que no fuessen allá, porque Monteçuma era traydor é nunca guardaba verdad, é que algunas veçes avia hecho paçes con ellos é las avia rompido, é por esso estaban en determinaçion de nunca la tener con él, ni la querian, ni creerlo. É quo avia noventa años que tenian guerra con él é con su padre é abuclo de Monteçuma, é que en todo este tiempo no avian comido sal los de Tascaltecle, sino los señores prinçipales, porque les costaba muy cara, é aun la avian de aver encubiertamente; é si los que la traian cran tomados, luego Ios haçia Montecuma justiçiar. É que avian avido dos batallas campales, é que en la primera estuvo para se perder Tascaltecle, pero al cabo fué desbaratado Monteçuma, y escapó huyendo; y el capitan ques dicho que hiço ahogar Cortés, siguiendo el alcançe, le mató más de treynta mill hombres, é lo siguió hasta una provinçia que se diçe Tezcuco, é de allí se volvieron los vençedores con más de diez mill prissioneros, los quales todos sacrificaron en los quies por la victoria avida. (Estos quies se llaman por otro nombre oclrilobos, donde tienen sus dioses ó ydolos, é son sus casas de oraçion). Todo esto contaba Maxiscaçin, señor de Tascallecle, por excusar que los chripstianos no fuessen á Temistitan. En conclusion, que no creyendo los chripstianos é su capitan á tan buen amigo, pusieron en exccuçion su camino, é aquel señor lloraba porque se yban: é como vido que no le querian creer, hiço sacrificar treynta muchachos el dia que se partieron, é fueron en su compañia algunos mercaderes para rescalar sal é mantas de algodon; porque á causa de la guerra no comian sal ni vestian algodon, sino de un árbol que se diçe maguey, del qual está toda la tierra plantada por tal nescessidad. $\dot{E}$ no es árbol, sino hierba 0 planta, é da mucho fructo é utilidad, porque della haçen mantas é capatos é vino é arrope: é la rayz, despues que ha dado todos los provechos que se han dicho, la comen, como más larganente se dixo es- 
to é otras cosas en el libro $\mathrm{Xl}$, capitulo Xl.

Tornando á la historia, es de saber, que partidos los chripstianos de Tascaltecle para una cilidad que se diçe Chelula, de la qual, en su prosperidad, en el tiempo de la guerra salian en campo ochenta 6 noventa mill hombres de guerra, la qual estaba rebelada de Monteçuma; mas por esso no dexó de acoger á los chripestianos é darles mury bien de çenar aquella noche, á cada uno una gallina é tortillas de mahiz; é ofro dia dixeron que si se querian yr, les darian indios que llevassen las cargas, como lo hiçieron. Allí vinieron mensajeros de Nonteçuma, é truxeron un atambor de oro al señor de la cihdad, y envióle á mandar que atasse los chripstianos é se los llevasse. Y estaban de propóssito de lo poner allí por obra, porque avian venido para esse efetto treynta mill hombres, que estaban esperando á los clıripstianos dos leguas de allí, porque los indios desta cibdad no los dexaron entrar; mas ofresçicron de llevar atados á los chripstianos, y estonces Monteçuma pensaba de aver aquella cibdad, en achaque que yluan á rescebir los clrripstianos; pero essotros indios, avisados desta cautela, no los dexaron entrar.

Assi que, salido el sol, vinieron indios para llevar las cargas de los chripstianos, é los chripstianos decíanles que truxessen de comer; é los indios, sonriéndose, deçian entre sí: "Para qué quieren comer estos, pues que presto los lan de comer á ellos coçidos con axín. É deçian más: - Si Monteçuma no sc enojasse, aquí los matariamos nosotros, é nos los comeriamosn. En fin, este secreto se descubrió por la lengua $\Lambda$ guilar que los oya hablar, é lo dixo é avisó á Cortés, é le consejó que se tornasse á Tascaltecle, porque aquella gente era mucha é traydora, é los clıripslianos pocos. E cómo esto supo Cortés, se puso en órden, é aperçilió la gente para lo que subcediesse; é de los indios amigos que llevalsan de Tascaltecle, so fueron dos aquella noche, porque sintieron la trayçion, é avisaron á su señor; y él proveýo luego, é liço venir quarenta mill lombres de guerra á dos leguas de la cibdad, é tenian sus espias é sabian cómo passaba, é dieron assimesmo aviso á Cortés para que se guardasse. E Cortés dixo que seria muy bueno castigar aquella cilıdad, é mandó á los indios que truxessen hamacas para llevar á los chripstianos prinçipales, y ellos holgaron muclio desto, porque pensaban atallos en las hamacas y entregallos en ellas a Nonteçuma; é luego vinieron tantas é más hamacas que eran los españoles. En este comedio consultaron el caso con el diablo é sus ydolos, á su costumbre, é sacrificáronle çinco niños de edad de tres años cada uno, é çinco moças vírgines, porque es çerimonia que acostumbraban en prinçipio de la suerra. Y era ordinaria cosa en aquella cibdad, por aquello é otras causas de sus ritos é infernal costumbre, sacrificar cada año diez mill criaturas de muchachos é muchachas. Assi que, renidas las hamacas, pensando que los cliripstianos se metieran en ellas, hiçiéronse quatro esquadrones, é con quatro capitanes dellos se fueron á quatro puertas que tenia el apossento, que era un patio cercado de dos estados, disimulando el caso. Los de caballo estaban aperçebidos é dentro de una sala, para que quando se soltassc una escopeta, saliessen con mucho ímpetu, é los demás españoles é gente de pié, é meneassen las manos; é hiçiéronlo como lcones, é gentc puesta en tal estrecho: é fué mucho el daño que hiçieron en los contrarios, tanto que todos los nuestros estaban teñidos en sangre, é no podian pisar sino sangre il hombres muertos. En el instante llegó la gente de Tascaltecal en favor de los chripstianos, como si vinieran á valer é 
socorrer á sus padres: é como bucnos amigos encontráronse con los que venian á socorrer á los mal fechores, é trabóse de tal manera la batalla, que eran incontables los muertos de cada parte, é hiçiéronlo saber á los chripstianos, é subieron su bandera en un qü muy alto. É los clıripstianos acudieron, siguiendo el alcançe, é hiçieron muclıa matança.

Esta bandera de Tascaltecle es una grua que trae por divisa ó armas al natural, de oro, é tendidas las alas, é con esmaltes é argenteria, é puesta ençima de una vara alta assaz, á manera de un confalon de aquellos palermitanos, ó bandera. Aquesta enseña anda de continuo delante, al caminar, quando hay guerra: viene en la reçaga despues ques vençida la batalla é fecha la matança; pónenla en un çerro alto, é allí se recoge el campo; é toda la gente vençedora assienta su real, é buscan el camino é tierra mús fuerte, dó estén seguros de sus enemigos. Tiene aquel señor su gente de guarda, como la bandera que traen los españoles, é dan pena al que no se recoge.

En este fecho se ovo mucho despojo de oro é plata para los españoles, é los indios amigos ovieron mucha ropa é sal, que era lo que más desseaban; é llevaron sobre veynte mill criaturas, cliicas é grandes, las quales sacrificaron á sus dioses: otros dexaron por esclavos para sus haçiendas. É hasta veynte senores é personas muy prinçipales de aquella cibdad de Chelula se subieron en uno de aquellos sus templos ú oratorios, que tenia çiento é veynte gradas que subir hasta lo alto dél, é tenian allí recogidos é puestos encastillados muchos flecheros , é innumerables piedras, é haçian muclıo mal dende allí: écí un tiro de ballesta, el que se allegalıa, yba enclavado ó mal herido; é aunque fue. ron requeridos, nunca se quisieron dar. Pero con muy buen arte se les puso fue- go, é se quemaron allí todos quantos arriba estaban. Aquella gente desta cibdad de Chelula es dispuesta é cresçida, é sucltos é belicosos los hombres é las mugeres, é de gentiles dispusiçiones é gestos, é grandes maestros de liaçer joyas de oro é plata, é allí se haçe muy buena loça de torlas suertes, é son muy ingeniosos.

Alli reposaron los españoles pocos dias, y esturieron assimesmo los de Tascaltecle; y envióse államar la gente que estaba en çiertos pueblos de la jurisdicion de aquella cibdad, é todos los demas que se avian escapado, é otros señores de otros pueblos: é híçose un señor (porque los otros señores naturales todos murieron á manos de los nuestros), é aquel nuevo señor quedó muy amigo, al paresçer, con los chripstianos. É fecho esto, el capitan Hernando Cortés dió liçençia á los amiggos é gente de Tascaltecle para se tornar á sus casas, y él prosiguió con los españoles para Temistitan. Pues cómo los treynta mill hombres, que se dixo que esperaban dos leguas de allí, supieron lo que se avia hecho en Chelula, no osaron atender, é fuéronse más que de passo, pues. to que donde estaban hay una sierra de dos leguas de subida.

Cómo Montecuma ovo la nueva de lo ques dicho, ovo mucho temor, é dixo: "Aquesta es la gente, que nuestro Dios wo dixo que avia de venir, é se avia de enseñorear desta tierra, é tambien lo dixo á mi padre, porque mi padre me lo dixo á mín. É con mucha tristeça se fué á los qües, é aquel dia liço que se sacrificassen çinco mill personas para festejar é aplacar sus dioses, ó al diablo, con aquella sangre, é muchos areytos. Y estuvo ocho dias en ayuno en una selda, donde se dixo quel diablo le avia hablado y esforçado, diçiéndole que no temiesse, que los chripstianos eran pocos, é que los dexassen entrar, que despues haria dellos lo que quisiesse; é que no çessasse en 
los sacrifiçios; é quel dios de Clıclula no avia seydo contra los cluripstianos, porque allí sacrificaban pocos. É desta respuesta muy contento, liço llevar mucha comida al camino; y envió sus mensajeros á Cortés é á los clıripstianos, diçién. doles que holgaba de su yda mucho, é que los.estaba esperando.

La sierra ques dicho, es muy alta, é hace muclı frio en ella, é nieva alli muchas veces; é si la gente de Monteçuma que primero se dixo, esperara, segund la nieve mucha que tomó allí á los chripstianos, creyóse que todos se perdieran, porque no se podian valer, ni mandar las manos, ni regir las armas de frio (quan(lo allí se vicron). Dende la cumbre de aquella sierra se paresce la grand cibdad de Temistitan. é otras treynta ciludades é villas á la redonda della; y es una de las más licrmosas vistas que en el mundo se puede ver ó contemplar; pero á los españoles no les fué poco temerosa por su grandeça: antes se començaron í mover entrellos diverssos paresceres, que significalsan motines; pero con la prudencia, esfuerço é disimulaçion de Hernando Col'tés, é huenas palabras y esperanças que les daha, é con verle que era de los primeros en los trabaxos é peligros, sceguianle. De aquella cumbre de la sierra se baxaron á una provinçia que se llama Chalco é Atalmameco, en que avrá çinquienta mill hombres de toda gente. Allí hallaron los que enviaba Nontecuma con la comida; é andahan aquelloṣ indios con lanta prontitud en servir é contenlar á los españoles, que era cosa de maravilla. Assi como yba nuestra gente caminando, yban de una parte é otra, fechos dos alas é proçessiones. á la fila de gentes, como contratelas de justadores; de manera que los nuestros yhan çercados en espaçio de un grand tiro de ballesta. De torlas partes cra infinita la gente que de un cabo é de otro concurrian á mirar los españoles, é maravilláluanse mucho de los ver. Tenian graude espaçio é atencion en miar los caballos; decian: "Estos son teules", que quicre decir demonios.

Assi llegaron á una legua de Tenistitan, en la calçala de Iztapalapa, é salió Monteçuma át los resçebir debaxo de un palio, que to traian quatro indios en la cabeç, lacciéndole sombra: el qual era hecho de plumas verdes, muy rico, con mucha argenteria de oro é plata. iraia calçadas unas gutaras de oro, id est (çapatos de çierta forma, que son solamente las suelas é unas correas con que se alan) é delante yban dos indios que tendian una manta muy larga, por donde passaba. É otros ponian otras adclante, é otros cogíanlas, que quedaban atrás por, dó avia passado. É detrás dél ýban múchos señores de grado en grado, pero lien desviados dél, é tan acatados é comedidos, que ninguno le osaba mirar á la cara; é con este rescibimiento entraron en la cibdad.

Despues que ovo saludado á Cortés, é tomádolo á par de si, apossentó á él é á los cliripstianos en unas casas que avian seydo de su padre; y entrados en clla, le dixo Montecmma: "En vuestra casa estays: descansad é ared plaçer, é pedid todo to que quisiéredes». É luego le dió grand pressente de oro é plata é mantas, é indias á solo el capitan Cortés, é despues á cada esprañol por sí, con mucha gravedad é aspetto de señor: é dixo ál la lengua que preguntasse al capitan si aquellos cluripstianos que llevaba eran sus rassallos ó sus csclavos, porque á cada uno queria dar un pressente, segund la calidad ó cómo cada uno fuesse, é que le dixesse la verdad, porque assi se usaba en aquella tierra. quando venia un capitan extrangero. Cortés le respondió assi : "Yo os hablaré, señor Montecuma». É dixose que le dixo que eran todos sus hermanos é amigos, é otros cran sus criados. Pero el dicho Montrenma se informó de las lenguas quál era 
cavallero 6 ludalgo, o.quál villano, é secretamente (que nadic lo supo), les presscntaba y cnviaba á su casa un prinçipal mayordomo suyo, é miraba lo que faltaba á los españoles é los haçia provece luegro, assi de mugeres de serviçio, como de cama, é les daba á cada muo ma joya que pessalua lasla diez pessos de oro, é más ó menos pocas ó ningunas: é las que cran mejores é más ricas diba á los más prinçipales, seggund quél estaba informado.

\section{CAPITULO XLVI.}

En el qual se traeta de la manera del estado é serviçio é saerificios é rilos é ydolatria de Mlontecuma, é de la forma de su easa, é de los animales é aves que tenia en sus palacios; é la forma con que se lico seĩol de México é Temistitan, é destruyó é mató con engaño en un eonvite una de dos parcialidades que alli avia: é dáse relaçion de las mugeres é hijos que tenia; $\dot{c}$ otras eosas que eonciernen é son adherentes al discurso é veldad de la lıistoria.

( uando este grand prínçipe Montecuma comia, estaba en una grand sala encalala é muy pintada de pinturas diverssas; alli tenia cnanos é chocarreros que le derian graçias é donayres, é otros que jugaban con un palo puesto sobre los piés, grande, é le traian é meneaban con tanta façilidad é ligcreça, quc paresçia cosa imposible, é otros haçian otros juegos é cosas de mucho para se adınirar los hombres. Á la puerta de la sala cstaba un patio muy grande, en que avia cient apossentos de reynte é cinco 6 treynta piés de largo cada uno sobre sí en torno de dicho patio, é alli estaban los scñores prinsipales apossentados, como guardas del palaçio ordinarias; y estos tales apossentos se llaman galpones, los quales á la conlinua ocupaban más de seysçientos homlıres, que jamás se quitaban de alli, é cada uno de aquellos tenian más de treynta servidores: de manera que á lo menos nunca faltaban tres mill hombres de guerra en esta guardia cotidiana de palacio. Quando queria comer aquel prínçipe grande, dábanle aggua á manos sus muggeres, é salian allí hasta veynte dellas, las más queridas é más hermosas, y cstaban cn pié en tanto quél comia; ć traíale un ma yordomo ó macstresala tres mill platos ó más de diverssos manjares de gallinas, codorniçes, palomas, tórtolas é otras aves, é algunos platos de muchachos tiernos guisados á su modo, é todo muy lleno de axí y él comia de lo que las mugeres le traian ó queria. Despues que avia acabado de comer, se tornalia á lavar las manos; é las mugeres se yban á su apossento (lellas, donde cran muy bicn servidas; luego ante el scñor allegábanse á sus burlas é graçias aquellos chocarreros é donosos, é mandábales dar de comer sentados á un cabo de la sala; é todo lo restante de la comida mandaba dar á la otra gonto que se ha dicho que estaban en aquel grand patio. É luego venian tres mill xicalos (ć́ntaros ó ảnforas) de brevago; é despues quel señor a ria comido é bebido, é lavádose las manos, ybanse las mugeres, é acabadas de salir de la sala, entraban los negoçiantes de muchas partes, assi de la mesma cilulad como de sus senorios. É los que le avian de hablar, hincábanse de rodillas quatro varas de medir é más apartados dél é descalços é sin manta de algodon que algo valiesse; é sin mirarle á la cara, deçian su raçonamicnto, y él provehia lo que le parescia; é aquellos se levantaban é tornaluan atrís, retrayéndose, sin volver las espaldas, un buen liro de picdra (como to acostumbraban lader los moros de Granada delante de sus scriores é prínçijes).

Allí ar ia muchos jugadores de divers- 
$60 s$ juegos, en especial con unos fésoles, á manera de habas é apuntados como dados, ques cosa de ver; é juegan quanto tienen, los que son tahures, entrellos.

Yban los españoles á ver á Hontecuma, é mandábales dar dulıos, que son unos banquillos ó escabelos, en (que se sentassen (muy lindamente labrados é de gentil madera) é deçíanles qué querian, que lo pidiessen é dárselo hían. Su persona era de pocas carnes; pero de buena graçia é afabil, é tenia çinco ó seys polos en la barba, tan luengos como un xeme. Si le paresçia buena alguna ropa quel español toviesse, pedíasela, ć si se la daba liberalmente, sin le pedir nada por ella, luego se la cobria é la remiraba muy particularmente, é con plaçer la loaba; mas si le pedian presçio por ella, haçíalo dar luego, é tomaba la ropa é tornábasela á dar á los chripstianos, sin se la colorir; é como descontento de la mala criança del que pedía el presçio, dleçia: "Para mí no ha de aver prescio alguno, porque yo soy señor é no me laan de pedir nada desso: que yo lo daré, sin que me den alguna cosa, ques muy grand afrenta poner presço de ninguna cosa á los que son señores, ni ser ellos mercaderes".

Con esto concuerdan las palabras de Sçipion Africano, que de sí diçe en aquella contienda de prestançia, que escribe Luçiano, entre los tres capitanes más excelentes de los antiguos, que son Alexandro Magno, é Anibal y Sçipion: "Desde que nasçí, ni vendí ni compré cosa ninguna». Assi que, deçia Honteçuma, quando assi le pedian presçio: "Otro dia no te pediré cosa alguna, porque me has hecho mercader: vete con Dios á tu casa, é lo que oviesses menester, pídelo é dársele há; é no tornes acá, que no soy amigo dessos tractos, ni de los que en ellos entienden, para más de dexársclos usar con otros hombres en mi señorion.

Tenia Monteçuma más de tres mill se- ñores que le eran subjetos, é aquellos tenian muchos vassallos cada uno dellos, é carla qual tenia casa prinçipal en Temistitan, é avia de residir en clla çiertos̉ meses del año; é quando se avian de yr ú su ticra, con liçençia de Honteçuna, avia de quedar en la casa su lijo ó hermano liasta quel señor della tornasse. Esto haçia Nonteguma por tener su tierra segura, é que ninguno se le alçasse sin ser sentilo. Tenia una seña que traian sus almoxarifes é mensajeros, quando recogian los tributos, y el que criaba, lo mataban á él é á quantos dél venian. Dábanle sus vassallos en tributo ordinario de tres hijos uno, y el que no tenia hijos avia de dar un indio ó india para sacrificar á sus dioses, é si no lo daban, avian de sacrificarle á él. Dábanle de tres hanegas de mahiz una, é de todo lo que grangeaban ó comian ó bebian, y en fin, de todo se le daba el terçio; y el que desto faltaba, pagaba con la cabeça.

En cada pueblo tenia mayordomos con sus libros del número de la ģente é de todo lo demás, assentado con tales figuras é caractéres, quellos se entendian sin discrepançia, como entre nosotros con nuestras letras se entenderia una cuenta muy bien ordenada. É aquellos particulares mayordomos daban cuenta á aquellos que residian en Temistitan, é tenian sus allolies é magaçenes é depóssitos, donde se recogian los tributos, é officiales para ello; é ponian en cárçeles los que á su tiempo no pagaban, é dábanles término para la paga, é aquel passado é no pagado, justiçiaban al tal deludor, é le haçian esclavo.

Avia en Temistitan un patio de más do un tiro de ballesta, enlosado, é un betımen de cal muy bueno juntaba las piedras tan fuertemente como si assi juntas nasçieran, y estaba tan limpio é liso que no pudiera ser mejor. I en medio deste patio avia un qii, que tambien sc llamala 
ochilobo ó casa de oraçion, muy alto, quo avian feelı los señores todos que liasta estonçes avia avido, é tenia sessenta gradas para subir arriba; é lo que avian feelıo los seĩores passados en aquel altor que les tomó la muerte se haçian enterral en la más alta grada, é despues el subçessor subia otras dos gradas, é assi se acabó. É despues que los chripstianos lo deshiçieron para reforntar é ordenar mejor la eibdad, se hallaban aquellas sepolturas en unanera de loóvedas, y en ellas muelıo oro é plata é piedras de valor, que metian allí con aquellos señores, quando morian.

Avia otros sessenta quies á la redonda del que es dicho, á manera de jglesias ó templos comunes é perroelias, adonde yban los otros señores inferiores é gente más baxa é plebea; pero el mayor, con otros tres oratorios, tenia Monteçuma, en que sacrificaba al honor de quatro dioses quél tenia, ó ydolos, que á uno tenia por dios de la guerra, como los gentiles á Marte; é á otro lionraba é sacrificaba eomo á dios de las aģuas, segund los antiguos á Neptuno; otro adoraba por dios del viento, segund los perdidos gentiles á Eolo; ć otro acataba por su soberano dios, y este era el sol, en euyo nombre tenia otro ydolo en mucha veneraçion é acatamiento el seĩor, é todos sus vassallos. Tambien tenian otros dioses; é á uno haçian dios de los mahiçales, é le atribuian la potençia de la guarda é multiplicaçion dellos, eomo á Çerere los fabulosos poctas é antiguos gentiles. É á eada eosa tenian un dios, atribuyéndole lo que se les antojaba, é dándoles la deidad que no tienen, ni se debe dar sino solo á Dios verdadero. É á aquellos quatro ó çineo dioses prinçipales que se han dieho de susso, sacrificaba Monteçıma cada un año, en ciertos tiempos diferentes, más de çineo mill personas, por consejo de dos demonios, que deçian los indios que andalıan en aquellos quies, que hablaban eon ellos é los traian engañados, eomo lo estuvieron largos tiempos muchas gentes, é aun lo están hoy por el mundo. Si no, preguntadlo á essos brujos é brujas, é aun á essotros hereges de la peña de Amboto é sus seeaçes de la condenada setta de fray Alonso de Mella. ¿Y qué diremos de aquellos famosos romanos é de sus tcm. plos, que ni cran de más sanetidad ni de menos que los de aquestos indios, errores é desvarios fundados, pues que á cada eosa que se les antojaba haçian dios ó su templo, eomo hiço Rómulo, que ordenó al dios Júpiter un templo, é púsole nombre Jove ferretro, donde fuessen ofresçidas las armas y enseñas de los reyes é eapitanes que oviessen avido de los enemigos que oviessen muerto ${ }^{1}$ ? $\mathrm{E}$ assimesmo, como eseribió Livio ${ }^{2}$, Rómulo ordenó aquel templo llamado Estatorio, porque estuviessen quedos é no huyessen los romanos en aquella cruda batalla eon los sabinos, quando las piadosas mugeres sabinas despartieron á los padres é maridos de aquel notable combatimiento? El templo de la Dea de la Salud, constituyó Bubuleo Censor por la guerra de los samnites ${ }^{3}$. Pues demás de los dioses vanos, tambien tenian por diosas á Vénus, Palaš, Juno é otras muchas. Demás desso, qué subjetos á sus auríspiçes é adevinos fueron! é qué agoreros é obidientes á vanidades, fundadas sobre religiosidad é falsa sanetimonia! Quiero deçir, que si miramos las eosas de los gentiles en este caso, por tan profanas é diabólicas las tenemos como las de nuestras Indias.

Dexemos esta materia, é volvamos á este grand prínçipe Monteçuma, el qual, 
un una grand sula de çento é cinciuenta piés de luengo é de çinquienta de anchu, de grandes rigas é postes de madera que la sostenian, ençina de la qual cra folo un terrado ó açulea, tenia dentro desta sala muchos géneros de aves é de animales. Aria çinquenta águilas caudales en jaolas, tigres, lobos, culcbras, tan gruessals como la pierna, de mucho cspanto y (n sus jaolas assimesmo, é alli se les llevalua la sangre de los hombres é mugcres é niños que sacrificaban, é çchaban con ella aquellas bestias; é avia un suelo fecho de la mesma sangre humana en la dicha sala, é si se metia un palo ó vara, temblaba el suelo. En entrando por la sala, cl hedor era mucho é aborresçible é asqueroso: las culebras daban grandes é lıorribles silvos, é los gemidos é tonos do los otros animales allí pressos, era una melodia infernal é para poner espanto. Tcnian quinientas gallinas de racion cada dia para la sustentaçion dessos animales. En medio de aquella sala avia una capilla, á manera de un horno grande, é por ençima chapada de láminas de oro é plata é piedras de muchas maneras, como ágatas é cornerinas, nicles, topaçios, plasmas de esmeraldas é de otras sucrtes muchas é muy bien engastadas. Allí entraba Nontecuma é se retraia á hablar con el diabı, al qual nombraban Atezcatepoca (que âquella gente tienen por dios de la guerra) y él les daba á entender que era señor é criador de todo, é que en su mano era el vençer; é los indios en sus areytos é cantares é hablas le dan graçias, é lo invocan en sus nescessidides.

En aquel patio é sala avia continuamente cinco mill hombres, pintados de cierto betum ó tinta, los quales no llegan á mugeres, é son castos; llámanlos papas, é aquestos son religiosos; é creen los indios que si un papa de aquellos dice: "Quiero que te mucras", que ha de morirse, sin que tal suntençia falte. Entre estos papas hay gradlos de superioridad, como quien dixesse obispros é arcohispos, é dignidades de ahí abaxo, que inçenssan aquellos diabólicos é descomulgados templos: é aquel ençienso es blanco \& hay çierto monte en la Nueva España, donde se cria, é créese ques verdadero é perfelto encienso, como aquel de quien Plinio largamente escribe '; pero en la Nueva España se coge desta manera. Dan unas cuchilladas en los árboles questo produçen, é por aquellos golpes sale á manera de resina 6 goma, é ponen debaxo en que cayga este licor, é quáxase é tórnase espeso é de tan buena olor é de aquella forma que ençienso perfetto; é con esto sahuman aquellos sus dioses é ydolos aquella gente prieta, ques dicho tienen por sanctos religiosos. Están toda la noche inçenssando é reçando, diçiendo sus oraçiones en un tono baxo, en quellos mesmos se entienden; é traen los cabellos luengos hasta la çinta, muy ahetrados é de mala graçia, é con muchos piojos, que á tiento ellos se sacan por debaxo de la melena, é se los comen en tomándolos. Avia allí más de dos nill figuras de piedra de monstruosas cosas. Son las casas é salas todo de terrados. Tenian muy grandes acequias de agua, por donde se servian los indios.con canoas, porque las calles de agua atraviessan toda la cibdad.

Avia dos parçialidades ó bandos en aquella república: la una se deçia Mlexicanos, é la otra Tatebulcos, como se diçe en Castilla Oneçinos é Gamboinos, ó Giles é Negretes. Y estos dos apellidos turieron grandes difẹrençias: é Monteçuma, como era mañoso, fingió grande amistad con el señor prinçipal del bando Tatebulco, que se deçia por su nombre proprio Samalçe, é tomóle por yerno, é dióle una 
su hija, por le asegurar. Con este debdo, en çierta fiesta é convite que hiço á este Samalçe, é á tolos sus capitanes é parientes é hombres prinçipales, híçolos embeodar: é desque estuvieron bien tomados del vino, hícolos atar é sacrificarlos á todos, sacándoles los coraçones vivos, como lo tienen por costumbre. É los que padesçieron esta crueldad passaban de mill hombres, señores prinçipales: é tomóles las casas é quanto tenian, é poblólas de sus amigos é de los de la otra parçialidad mexicana. É á todos los que tuvo por sospechosos, desterrólos de lá cibdad, que fueron más de quatro mill hombres; y en los bienes é moradas destos hiço que viviessen los quél quiso enriquesçer con bienes agenos. É aquellos que desterró, hiço que poblassen quatro leguas de allí, en un pueblo que de aquella gente se liiço, que se llama Mlezquique, é que le sirviessen de perpétuos esclavos. É assi como la cibdad se deçia, y es su proprio nombre Temistitan, se llamó é llama por muclıos México dende aquella maldad cometicla por Nonteçuma. É los mexicanos y españoles hallaron un pariente de aquel señol de Tatevulco, al qual deçian quo de derecho venia aquel señorio de Samal. ce que Monteçma avia muerto, que era abuelo deste, é llamábanle á este señor ó nieto del muerto Tatatecle.

Tenia Monteçuma una casa muy grande, en que estaban sus mugeres, que eran más de quatro mill, hijas de señores, que se las daban para ser sus mugeres, y él lo mandaba hacer assi: é las tenia muy wuardadas é servidas, é algunas veçes él daba algunas dellas á quien queria favo- rescer é lıonrar de sus prinçipales: ellos las resçilian como un don grandíssimo.

Avia en su casa muchos jardines, é gient baños ó más, como los que usan los moros, que siempre estaban calientes, en que se bañaban aquellas sus mugeres, las quales tenian sus guardas é otras mugeres como prioras que las gobernaban; é á estas mayores, que eran ançianas, acataban como á madres, y ellas las tractaban como á hijas.

Tuvo su padre de Monteçuma çiento é çinquienta hijos é hijas, de los quales los más mató Monteçuma , é las hermanas casó muchas dellas con quien le paresçió; y él tuvo çinqiienta hijos é lijjas, ó más. F́ acaesçió algunas veçes tener çinqüienta migeres preñadas, é las más dellas mataban las criaturas en el cuerpo, porque assi diçen que se lo mandaba el diablo, que hablaba con ellas: é deçíales que se sacrificassen ellas las orejas é las lenguas é sus naturas, é se sacassen mucha sangre é se la ofresçiessen, é assi lo haçian en efetto.

Paresçia la casa de Monteçuma una cil)dad muy poblada: tenia sus porteros en cada puertid. Tenia veynte puertas de serviçio: entraban muchas calles de agua á ellas, por las quales entraban é salian las canoas con maliz é otros bastimentos é leña. Entraba en esta casa un caño de agua dulçe, que venia de dos leguas de allí por ençima de una calçada de piedra. que venia de una fuente que se diçe Chapietepeque, que nasge en un peñon que está en la laguna salada, de muy exçelente agrua. 


\section{CAPITULO XLVII.}

En que se traeta cómo Monteçuma dixo a Hernando Cortés que se fuesse él ć los rspañoles de su lierra, promelićndoles de les da. tanto oro que fuessen ricos, c de la prudente respuesta de Hernando Corlés *: $e^{\circ}$ eumo llegó á la tierra Pamphilo de Narvacz, é fué presso, é se tornó Corlés á Nléxieo, de donde los indios lo ceharon à él é á los españoles; $\dot{e}$ de. la mucrte de Monteçuma ** é otras eosas convinicntes al diseurso de la historia ó relaẹion assaz diferente en algunas eosas á lo que se eontó hasta el fin del eapitulo XLIIl.

\section{Otras veces tengo dicho que en las re-} laçiones feehas por el gobernador Hernando Cortes , quedan más ordenadamente expresadas muehas cosas de las que se diçen desde el capitulo XLIV hasta fin del preçedente, é de las que se dirán en este y en el siguiente despues dél, con que se dará conclusion á esta relaçion, que aunque vá salpicada, hace mençion de alģunas eosas que se han dicho en las relaçiones de Cortés, pero de otra manera. É tambien dice otras muchas, que no se han memorado en la historia, ni Cortés habló en ellas. Assi que, con estos dos eapítulos, é con los dos de susso, se acabará esta relaçion quel elironista acumuló y entendió de personas fidedignas, que se hallaron pressentes en esta conquista. É no le parezea al que lee ques contradecirse lo uno á lo otro, porque los hombres assi como son de diverssos juiçios é condiciones, assi miran y entienden las cosas diferenciadamente, é las cuentan; puesto que vengan los unos é los otros á una geeneral é mesma conclusion, é aun á las veçes se contradicen en muchas eosas puntualmente. Cada dia vemos que se ofresçen casos no pensados, é aun acordados; é queriendo un juez ó prínçipe informarse de la verdad, juran los testigos é deponen diferençiadamente, con más ó menos palabras, é diçiendo uno las partieularidades que ofro testigo calla, ó no entendió, 6 no las supo entender, aunque las

\footnotetext{
- De esta parte quitó Ovicdo la siguiente eláusula: "Diçiendo que no tenia navios, pero que ce daria forma de los hacer, é sc puso por obran.
}

vido: de forma que en an mesmo negoçio hay diverssas pruebas, é amnque sean eontestes en la sentençia ó sentido, son apartados en deponer unos mejor que otros. Assi con estas condiçiones aveys, lctor, de pensar lo que está dieho, é lo que demás se dirá desta conquista, aviendo por máxima que yo me he informado de personas que merescen ser creydos, é que en todo se hallaron. Destos tomé y examiné lo que conviene á la materia, aunque parezea, eomo he dieho, que vá salteada.

Quieren deçir, é aun es de sospechar, quel diablo, enojado de los sanctos sacrifiçios é sacramentos é çerimonias cathólicas del altar é culto divino é ministros de Jesu Chripsto, Nuestro Redemptor, que los ehripstianos, muestros españoles, comencaron á usar, celebrando misas é bapticando y exerçitando las cosas de nuestra saneta fée cathólica en aquella grrand eibdad de Temistitan, puso en coraçon á Monteçuma que eehasse los ehripstianos de México, si no quél se yria, si no los mataba; porque la misa y evangelio que predicaban é deçian los chripstianos le daban grand tormento. Ė débese pensar, si verdad es, quessas gentes tienen tanta eonversacion é commicaçion con nuestro adverssario, como se tiene por çierto en estas Indias, que no le podia á nuestro enemigo plaçer con los misterios é sacramentos de la sagrada religion chripstiana : é á esto de-

\footnotetext{
* Lo mismo esta : aE cómo fueron los chripstianos socorridos é acogidos de la gente é indios de Tascallccles.
} 
çan que le respondia Monteçuma, que no era bien que los matassen allí, pero quél les diria que se fuessen de aquella eibdad á su Castilla, é que los haria matar á todos en el eamino. Avida esta responsion ó consultaçion diabóliea, hiço Monteçuma aperçebir. çient mill hombres de pelea, para que hablando él al capitan Hernanlo Cortés, é diçiéndole que se fuesse de su tierra, si no lo quisiesse hacer, lo prendiessen ó matassen con todos los españoles.

Fecho aqueste aperçebimiento, salió Monteçuma al patio de su casa, que era la morada de su abuelo; donde él acostumbraba salir á holgarse; y en aquella easa estaban apossentados los chripstianos, y envió con la lengua á llamar á Hernando Cortés, el qual dixo luego: "No sé qué novedad es aquesta: plega á Dios que sea por bien; pero no me agrada esta em. baxada ". É tomó eonsiģo hasta doçe hombres; é llegado donde estaba Monteçuma, no le paresçió que le resçibia con la voluntad que antes, puesto quél se levantó é tomó de la mano á Cortés, é metióle en una sala, donde hiço traer en qué se assentassen los dos, é dixo á la lengrua assi: "Dí al capitan que yo le ruego que se vaya desla cibdad é de mi tierra, por. que mis dioses están enojados porque están aquí él é su gente, é que pida lo que quisiere, que yo se lo daré, é váyase a su tierra. É que no piense questo que se lo digo burlando, sino porque assi ha de ser fecho; é que diga lo que quiere ó ha menester para su eaminon.

Cómo Cortés entendió sus palabras, é adonde yhan enderesçadas, antes quel intérpetre acabasse su raçon, proveyó con uno de los españoles que allí estaban, y envió á deçir á los chripstianos que se tractaba de sus vidas, é que estuviessen aparejados é á recabdo para su defensa, aunque él conosçia que no eran parte para se defender, si Dios no los defendies. se; é avisóles de la voluntad é palabras de Honteçuma. (Estonçes se acordaron los españoles de Tascalteele, é de lo que les avian dieho, avisándoles de las cosas de Montecuma.) Los españoles respondieron á Cortés que á punto estaban para lo que Dios ordenasse, é para haçer lo que debian en favor de la fée elıripstiana y en serviçio de Su Magestad; é que ya sabian que Dios é sus manos avian de ser quien los librasse de tanta moltitud de adverssarios.

Cortés respondió á Monteçuma desta manera: "Yo lie entendido lo que me deçís, é os lo agcadezeo mucho. Determinad quándo quereys que nos vamos: que assi se hará. " Monteçuma, eomo prínçipe lien eomedido, replicó é dixo: "Señor capitan, no quiero que os vays sino quando quisiéredes: é tomad el término que os parezca, que yo os daré para vos los eargas de oro, é una para eada ehripstiano. Estonçes Cortés le replieó é dixo: "Ya sabeys que nuestros navios los echamos al través, é tenemos nescessidad de otros para volver á nuestras tierras. El oro que nos days, os tenemos en merced; pero queria que hiçiéssedes venir todos los earpinteros que teneys, para que labren la madera é la corten: que yo tengo maes. tros que hagan los navios; é fechos, nos yremos en ellos á nuestra tierra, é vos os quedareys en la vuestra: é darnos heys lo que nos mandays, é assi lo deçid á vuestros dioses é á vurestros vassallos». Monteçuma mostró contentaniento desta respuesta, é dixo: "Bien me paresçe lo quie deçís, é assi se larán. Y en continente mandó que viniesse eopia de carpinteros, é Cortés proveyó de maestros é personas que entendiessen en la labor de los navios, é dixo despues á los españoles des. ta manera: "Señores y hermanos: este señor Mlontecuma quiere que nos vamos de la tierra, é conviene que se hagan navios. Yd con essos indios, é córtese la madera, y entrelanto Dios nos proveer 
le gente é socorro: por tanto, poned tal (lilaçion que parezea que liageys alģo, é se haga con ella lo que nos conviene; siempre me escribid é avisad qué tales estays en la montaña, é que no sientan los indios nuestra dissimulaçionn. É assi se puso por obra: que con muchos indios fueron á cortar la madera los chripstianos que envió Corlés, é talaron grandes állboles, é se labraban para el efetto ques diclıo.

E dende á ocho dias que se ocupabàn en lo ques dicho, llegó Pampliilo de Narvaez á la costa con onçe navios é ochocicntos lomlres, entre los quales avia dosçientos de caballo, al qual enviaha el adelantado Diego Velizquez: y en continente que paresçieron en la mar, fué avisado Montecuma de sus indios, con tanta diligençia, que en quatro dias anduvieron sus espias ó avisos ochenta leguas; y él ovo temor desque lo supo, y envió á llamar á Cortés, el qual é todos los chripstianos estaban con mucho cuylado atemoriçados, pensando, que cómo les dixeron que salia al patio Monteçuna, que querian dar en los españoles; é Corlés les dixo: "Señores é amigos: yo quiero yr á ver qué quiere Honteçuma: por csso estad en lo que debeys estar, para que mediante Dios, si mal pensamiento tiene ó en algo se pusiere, os acordeys quién soys, é que si oviéremos de pelear, es contra inficles y en serviço de Dios é de Su Magestad, y en defension de nuestras personas; é que las manos de cada uno sean tales, que muestren con la obra é propria espada el valor de vuestros invençibles ánimos: que aunque muramos, quedamos vencedores, pues a vremos complido con el offiçio militar, é con lo que lebemos". Á lo qual todos le respondieron que barian su deber hasta morir, sin quel temor ni el peligro se lo pudiesse estorluar, porque tenian por nienor cosa sus vidas que su honor.
Ylo Cortés delante de Hontecuma, él le dixo por medio de la lengurua ó intérpetre: "Capilan, hágoos saber que teneys uavios fechos, en que os porleys yr de aqui adelante". É Cortés le replicó é dixo: "Senor, en teniéndolos fechos, yo me yré. E Llontecuma le replicó é le dixo: ance navios están en el puerto de Cempual, é presto verná nueva si laan saltado en tierra los que en ellos vienen, é sabrenos quién son é qué grente vienen. Cortés dió muclias gracias á Dios, é dixo: "Bendito sea Jesu Chripsto por las unergedles que me hace á mí é á todos los hidalgos é compañeros mios, porque se ha acordado de nosotros por su misericorlia*. É uno de los españoles que allí estaba, fuésse á lo deçir é dar nuevas á los españoles, con las quales cobraron mucho esfuerço, é se abracaron unos á otros de gogo, porque les paresçia que miraculosamente escapaban de la muerte (como en la verdad la tenian bien aparejada). Y estando todavia Cortés con Mlonteçuma, llegó otro mensajero, é dixo: "Dosçientos caballos é seysçientos hombres han salido en tierra, como estos que aquí están pintados». E mostró una figura, en que estaban debuxados assi los de pié como los de caha1 o, é las onçe naos ó navios que avian llegado al puerto ques diclıo.

Estonçes Monteçuma se levantó é abracó á Cortés, é le dixo quél se queria yl á comer con él, é Cortés le dió las graçias, é tomados por las manos se fueron al apossento de Cortés; é mandó Cortés á los españoles que no mostrassen alteracion alguna, sino que estuviessen juntos é solore aviso, é que pues Dios les avia librado de la muerte, le diessen continuas graçias. É comieron Monteçuma é Cortés juntos, é con mucho plaçer (en diferençiado goco), porque Monteçuma pensaba que los chripstianos se yluan de la fierra, é Cortés no desconfiaba de sobjuzgarla.

liahado de coner, Montesuma se furs 
á su apossento, é cada lıora venian nuevas de la venida de aquella armada; é aunque Monteçuma no mostraba altera. çion, bien se conosçia que le pessaba de la venida de los cliripstianos.

Un capitan de Monteçuma, que era de los de su consejo é más açepto, le dixo que debia matar los chripstianos que estaban en aquella çibdad, é á Cortés, su capitan, con ellos, porque oviesse menos que haçer en resistir á los que de nuevo venian; é que muerto Cortés é su gente, yrian luego á buscar á los de la nueva armada, é que no esperasse á que los unos é los otros se juntassen é fuessen más poderosos, porque el exérçito de los chripslianos dividido se pudiesse mejor abatir, que no se haria estando unido.

Monteçuma liço juntar su consejo, é allegados sus sátrapas é consejeros, é algunos capitanes expertos é favoresçidos suyos, tractaron é platicaron en el caso; é á algunos les paresçió bien que assi se hiçiesse, é á otros paresçia que de otra manera lo guiassen. Y en fin fué acordado que era mejor que los que venian llegassen, é que á todos juntos los malas. sen; porque si mataban los de la cilydad, los otros se tornarian á embarcar, é huyrian á su tierra é tracrian mucha más gente; é matando á todos, no quedaria persona que pudiesse llevar la nueva dellos. lin este acuerdo fué la determinaçion é consejo concluydo; é de ahí adelante los indios servian mucho mejor á Cortés é su gente, é cada dia le yba á ver Monteçuma con más de quinientos hombres, senores prinçipales, vassallos suyos.

Los chripstianos é Cortés pensaban que Diego Velazquez ylua en persona en aquella armada, ó quél la enviaba; 'é aunque por una parte se alegrahan de la venida le los que assi venian, por otra parte les pessaba; porque algunos lemian más á Diego Velazquez que á los indios, é no sin causa.
Narvaez llegó al puerto de la Villa Rica é desemlyarcó su gente, é fuésse dende allí a Cempual é assentó su real é ordenó su gente é capitanes : é preguntó por los chripstianos, é los indios le dixeron adónde estaban: el qual dió luego á entender á aquellos indios quél era el señor é capitan general, é que Hernando Cortés no era ya capitan, é que le avia de corlar la cabeça, é que los quél tenia eran criados suyos del Pamphilo Narvaez.

Aquestas palabras, é otras peores, fueron referidas á los que estaban con Corlés, é las repressentaban çiertos compañeros que se le amotinaron, ofresçiéndose á Cortés por sus cartas; é si fuesse assi óno, bien hay que deçir en cllo. Pero concluyen los más que Cortés leyó essos avisos, callando los nombres de los que se los enviaban; é dixo á los que con él estaban cómo Pamplilo deçia que eran sus moços, é que los amenaçalıa; é quél queria haçer un mensajero y enviar algunos collares é joyas de oro, é partirse trís el con la mitad de la gente que tenia, porque con Narvaez estaban dosçientos ó tresçientos hombres que se passarian á su parte, é quel primero seria el artillero: por tanto, que los que quisiessen yr con él, se aparejassen, haçiendoles muchos ofresçimientos, si Dios le diesse victoria. Y en la verdad afirman muclios, que en essa saçon estaba tan bien quisto Cortés, que si á todos los quisiera Uevar, todos se fueran trás él. É lueggo despachó, segund se dixo, un mensajero con cartas para particulares, $\dot{e}$ con una carga de collares de oro ricos é otras joyas, para que secretamente se diessen en el real de Narvacz. Y. Ilernando Cortés se partió con çiento é çinquienta hombres, é dexó al comendador l'edro de Alvarado en la cibdad de Temistitan con otros tantos, é á Montecuma en su poder, porque no fuesse adonde estaba Nillvace.

Asi que, siguiendo su cannino Cortés. 
llegró á un rio que cstaba çerea del real de Pampliilo, é toparon dos velas, é la uma se tomó, é la otra huyó y entró por el real, á roçes diçicndo: $₫ \mathrm{Al}$ arma, al arma: que ahí viene Cortés". El qual, quando se vido cerea, se apeó él é otros tres de caballo; é todos á pié, con sus picas, entraron por cl real, é fueron derechos á un apossento, donde estaba Pamphilo de Narvaez, y estábanle diciendo: - Señor, catad que viene alıí Cortés!" Y él respondia: "Dexadle venir: que es $\mathrm{mi}$ liijo ". Y estando vistiéndose unas coraças, sulbieron treynta hombres donde estaba, y él salia por la pucrta armado, é diéronle con una pica un golpe en el ojo, que se le quebraron, y en continente le echaron mano é le llevaron rastrando por las escaleras abaxo ; é finalmente él fué presso é su gente desharatada, é muchos de los suyos pressos, é otros muertos. Dixose que como Narvaez vido á Cortés, esfando assi presso, le dixo: "Señor Cortés, tened en mucho la ventura que aveys tenido, é lo mucho que aveys lıceho en tener mi persona (ó en tomar mi persona)". E que Cortés le respondió é dixo: "Lo menos que yo he hecho en esta tierra, donde estays, es averos prendido". É luego le hiço poner á buen recabdo, é le luvo mucho tiempo presso.

Otro dia por la mañana, despues de aver Cortés recogido su gente, é averse congraçiado é atrayclo á sí la mayor parte de la gente de Narvaez, se partió para Temistitan, donde el capitan Alvarado esfaba en mucho aprieto; porque cómo Cortés salió de la cibdad, intentaron é pussieron por obra los indios lo que tenian acordado, aunque no como Monteçuma lo avia pensado efelluar, segmud se dixo de susso; pero con su acuerdo ó sin él quisieron matar á aquellos chripstianos que allí quedaron, para dar despues por los restantes.

Quando Cortés salió de arquella cibdad. encargó muclıo al capitan $A$ rarado que velasse y estoviesse muy solne aviso para que Nonteçuma no se fucsse á Narvaez: é dióse tan gentil recabdo, que cono car vallero y experto capitan, assi como ovo sentimiento de la alteraçion de los indios é los vido con mano armada moverse por dar la lilıe'tad á su señor, assi él se puso al opóssito para se lo impedir con essos pocos españoles que alli quedaron en su compañia. É quando llegó Cortés, avia ocho ó diez dias que cada dia peleaban contra innumerables indios, é no avia clipipstiano que no estoviesse herido de los que estaban çercados, é aum con muchas heridas, é parte dellos avian muerto: é quando cslaban cansados de pelear, sacaban á Montecuma sobre una açutea para que mandasse á los indios que se aparlassen é dexassen de pelear, é assi lo haçian. Y estaban ya en tanta nesçessidad que les faltó el ağua, é cavaroi en el patio tanto como hasta la rodilla, é milagrosamcnte se hinchó el hoyo de agua dulce, non olsstante que aquella casa está en medio de la laguna salada. Intervino otro miraglo muy señalado, é fué este: pusieron la imágen de la Madre de Dios en un qui muy alıo que allí avia en la cibdad, é los indios començaron á echar mano della para la quilar, é pegábanseles las manos dó estaba la imágen, é dende ál buen rato se les despegaban, quedando allí señaladas, de manera que no osaban llegar allí más.

Otro miraglo subçedió en essa saçon ó tiempo, é fué muy notorio, é fué aqueste. Tenian los clıripstianos un tiro de pólvora gruesso, é cargáronle para tirar á los indios é haçerlos apartar afuera, é pcgáronle fuego é no quiso salir: lo qual viendo los indios, dende á mucho rato, perdida la sospecha é temor quel tiro avia de salir, arremetieron como leones, con un ímpctu leonino é con tanta grita é moltitud dellos, que no se puticran resistir 
por nianos de lumanos, si Dios no obralá de sus maravillas é poderio absolito. É combatiendo con mucho furor é perseverançia para redemir á su señor é sacarle donde estaba, é con palancas é otros instrumentos, determinados de morir é derribar la fuerça ó conseguir victoria, é no dexar chripstiano con la vida; é la verdad era que ya los españoles, cansados de su defension, y embaraçados é ofendidos por las innumerables varas é flechas $c$ piedras que los tiraban, estaban á tanto estrecho que ninguno dellos dexó de pensar que estaba en la última lıora de la vida. En aquel mayor trabaxo y lıervor del combate salió el tiro, sin le aver más celsado ni pegádole más fuego, con lorrible sonido; é como la pelota era tan grande quassi como la caleça de un lıomlıre, é tenia dentro perdigones que escupió pol muchas partes, hiço mucho daño en los indios, y espantólos de manera que quedaron atónitos é se retiraron más que de passo para atrás, quedando muclıos muertos, é otros muy mal heridos. Afirman que se vido el apóstol 'Sanctiago á caballo, pelcando solse un caballo blanco en favor de los chripstianos; é deçian los indios quel caballo con los piés é manos é con la boca mataba muchos dellos: de forma que en poco discurso de liempo no paresçió indio, é reposaron los chripstianos lo restante de aquel dia.

Ya sé que los incrédulos ó poco devotos dirán que mi ocupaçion en esto de miragrlos, pues no los ví, es supérflua ó perder tiempo, novelando; é yo hablo que esto é más se puede é debe creer, pues que los gentiles é sin fée é ydólatras escriben que ovo grandes misterios é miraglos en sus tiempos, é aquellos sabemos que eran causados é fechos por el diablo. Pues más fáçil cosa es á Dios é a la inmaculata Vírgen, Nuestra Señora, é al gुlo- rioso Apóstol Salnctiago é á los Sanctos é amigos de Jesu Chripsto laaçer essos iniraglos que de susso están dichos, é otros mayores.

Escribe Tito Livio que debatiendo Luf̧io Tarquino Prisco, quinto rey de los romanos, con Actio Navio; famoso en los augurios, diso al adevino como por cosa de burla: "¿Adevinarás lo que yo agora pienso ó deviso en mi colaçon?" Y el adevino, que estaba guardando en sus puntos é sçiençia, dixo que sí. Estonçes dixo el rey: "Yo devisaba que tú cortabas aquella piedra con una navaja: toma lia navaja é haz aquello que tus aves adevinan." 'El adevino deliberadamente tomó la navaja é cortó la piedra: assi que, ved lo quel diablo puede, que hico que la navaja cortasse la piedra.

El mesmo auctor, entre otros prodigrios, escribe que habló un buey, é dixo: "Roma, guárdate". E que los aurispiçes mandaron que aquel buey con suma diligençia fuesse guardado ${ }^{2}$. Ningun chripstiano cathólico hay que dubde que essos miraglos que escribe Livio son olsras det demonio; é pues quél las pudo haçer, pequeña é fáçil cosa cran para Chripsto é su gloriosa Madre, é para el Apóstol Sanetiago, cıyo caballero militar de su Órden del Espada fué este capitan Alvarado, aquellos quatro miraglos que de susso se tocaron. Quanto más, que nuestros espanoles eran chripstianos, y entrellos no podian faltar devolos é amigos de Dios. Volvamos á la historia.

Orro dia siguiente á lo que es dicho avia tantos indios como si no faltára ninguno de los muertos, é paresçia que siempre cresçia el número de los infieles ó la moltitud dellos, porque número era dificultoso saberse. E deçian: "Si no oviéssemos miedo de esse del caballo blanco, ya vosotios estarícdes cocidos, 
anncue no valeys madil paral comeros, porjue los clupipstianos que tomamos essotro dia, los cocimos, é amargaban unuclio; mas echaros hemos á las ácuilas é leones, que os coman por nosolros. Pero lıolgad: que de aqui á un poco lo vereys, si no soltays á Montecuma, nuestro señor, porque siendo él aquel Dios que cria todas las cosas, avés ossado pirendelle. „ Estonçes los españoles le hiçieron poner en un terrado, y él les dixo quél no estaláa presso, sino que aguardalıa á Hernando Cortés, capitan de los chripstianos. É los españoles les respondieron á las gentílicas y heréticas ranidades que los eneniggos decian, que Montecuma era hombre mortal como ellos, é que no avia otro Dios sino el de los chripstianos, que avia criado el çiclo é la tierra é todo lo del mundo; é que aquel del caballo blanco era un criado é cavallero suyo, que se llama Sanctiagro, que les avia enviado del cielo para que les ayudasse é faroresçiesse é matasse los indios, como lo podian bien entender, pues que seyendo tan pocos los españoles, se defendian de tantos indiosé los ofendian. É que pues deçian los indios que veian una muger que les echaba mucho polvo en los ojos, quando peleaban con los chripstianos porque no los viessen, que creyessen que era la gloriosa Virgen, Nuestra Señora, Sancta Maria, Madre de Chripsto, nuestro Redemptor.

Estando en este estado la cibdad é los clıripstianos que alli avian quedado, vino nueva cómo Corlés yba con la gente toda de Pampliilo de Narvaez é con la quél se avia llevado; é Montecuma mandó á los indios que dexassen de pelear é dexas. sen venil los otros clıripstianos, porque á lodos juntos malassen; é aquesto se cree que fué su intento. É assi çessaron estonçes en el combate; pero desde á poco, ó porque assi les fuesse ordenalo, ó por su voluntad propria, se tornó á refrescar la pugua, é peleaban como hombres de mucho esfuerro, é que mostraban bien que avian rima de concluyr é acabar su empressa. Estahain todos aquellos defensores cercados, heridos é con mucha fatigra, é aun no muy conformes por la diverssidad de sus opiniones de Diego Velazquez y Iternando Cortés, que los unos cran parciales al uno é los otros al otro; y entre ellos avia un hidalgo, que se deçia Botello, que echaba conjuros é presumia de pronosticar algunas cosas futuras, bien (que lo tal es reprobado é no segriro para la consçicnçia del člıipstiano: y este dixo que si los chripstianos no salian una noche señaladanente, que no quedaria hombre dellos á viula.

Ya Ilernando Cortés estaba dentro en la cibdad, é con su llegada é juntarse los chripstianos con los primeros cercados cresció el faror de los nuestros; pero no çessó la guerra por esso: antes paresçia que los enemigos é su perseverançia cresçian cada lıora en los combates, de lo que se coligió quel acuerdo primero é consejo de Montecuma, cue tomó quando se supo de la venida del capilan Narvacz, estaba fixo para que juntos los españoles que de nuevo yban con los que allá estaban, los matassen á todos. En fin, Coltés determinó de creer 'aquel adevino ó desvariado' parescer del Botello: é mús çierto debiera de ser que le paresçió (como á hombre que conosçia é via el estado en que estaba ) que le convenia la salida de la cibdad é dexarla, como varon experto é de grand conosçimiento, é aun porque la nesçessidad es la que enseña á los hombres en tales trances lo que conviene á su salvaçion. Via que los enemigos eran señores de los bastimentos é del campo, é que estando encerrados los chripstianos, era mayor su nescessidad cada hora é la hambre mayor, y essa sola sin las armas bastára á los acabar. E por todas estas causas se determinó, avido su consejo con los otros 
capitanes, sus inferiores, de salirse con Ia gente fuera de la cibdad, cayesse el que cayesse, é salvarse el que Dios ordenasse que salvo fuesse.

Muchas veçes me acuerdo, quando me ocurre oyr ó leer alguna vanidad destos sorteros ó adevinos que quieren entremeterse en deçir las cosas que están por venir, de un muy notable caso que está escripto en aquel tractado que escribió Josepho, saçerdote de los de Jerusalem, hijo de Matathia, en lengua griega, contra Apion Grammático Alexandrino, é dige assi: "Segund supe de un varon judio que militaba en aquella éxpediçion, cuyas palabras contenian aquestas cosas, dizic assi : Yendo yo al mar Bermejo, ylua allí de consuno con otros cavalleros judios uno que se llamaba Mesolano, varon de fecho, é de ánimo guerrero sobre todos los archeros. Aqueste, yendo assi muchos jantos é presurosos en el caminar, resçibió un adevino aguiero dél, é otrosí pidiógelo, é dixo que todos estoviessen quedos, y él preguntóle que por qué sè detenian: el adevino le mostró un ave quél miraba ante sí, é díxole ser complidero que todos se detuviessen, si aquella ave estoviesse queda; é que si se levantasse é volasse ante ellos, que estonçes caminassen; é que si volviesse las espaldas, convenia que todos se volviessen: y el cavallero, callando á esto, començó á tirar sactas con su arco, é hirió la ave é la mató. Ensañáronse contra él assi el adevino como otros algunos, diciéndole que lo avia fecho mal; y él dixo estonçes: "Malditos demonios, por qué os ensañays? É teniendo el ave en la mano, muerta, replicó: a Aquesta no supo de su salud, é podrá juzgar la salvaçion de nuestro camino? Si ella pudiera antedeçir lo advenidero, en ninguna nanera viniera á este lugar con temor que no la matasse con sacta Mesolano, judio». De lo que está dicho dá por auctor Joseplio á IOMO III.
Ifecatheo, listoriador antiguo. Assi que. estas cosas assi lis deben sentir los de sano entendimiento, como lo sintió Mesolano. É haçiéndolo assi el capitan Ifernando Cortés, aperçibió á los españoles é dixn que le siguiessen pror la calçada de Tacuba ; é mandó á Jolıan de Guzman, su camarero, que abriesse una sala donde estaba el thessoro de mucho oro é plata é piedras é joyas, para que cada mno tomasse lo que quisiesse, quél se lo daba. $\dot{E}$ dió la retroguarda al comendador $\mathrm{Pe}$ dro de Alvarado, é començó Cortés á caminar con hasta çient hombres de los veteranos de sus mílites; é los que avian ydo con Narvaez arrojáronse en la sala, é cargáronse de aquel oro é plata quanto pudieron; pero los menos lo goçaron, porque la carga no los dexaba pelear, é los indios los tomaban vivos cargados, é á otros llevaban arrastrando, é á otros mataban allí; é assi no se salvaron sino los desocupados é que yban en la delantera. Esto era despues de media noche, é muy llena de niebla. Oíanse muchos clamores é gritos é voçes, unos llamando á Dios é otros á Sancta Naria, Nuestra Señora, de los que prendian é mataban los indios. Bien pensaron los españoles que ninguno dellos quedára, é quiso Dios que de todos quedaron hasta tresçientos é quarenta y çinco de pié é de caballo; é si los indios no se detuvieran en buscar é lıurtar y esconder el oro que tomaban, tanpoco quedáran con las vidas essos, como los demás.

En esta relaçion se cuenta muy diferençiadamente de como atrás está dicho, en la relaçion de Cortés, la muerte de Montecuma; y yo tengo por más cierto que su fin fué cono Cortés lo escribió é la historia lo ha contado; é porque demás desso, viva roce, yo to he oydo al comendador Alvarado, que estuvo pressente á ello. Bien que nunque en esso discrepen los testigos, en estotra relaçion se 65 
diçen otras cosas veríssimas, que en las parsadas cartas ó relaçiones de Cortés no se laçe memoria dello. Assi que, tornando al disemrso desta relacion, diçe que dos mançebos avian lomado cargo. por mandado de Cortés, de sacar á Monteçma, é que llevíntolo, le dieron una pedrada en la cabeça, no lo conosciendo, que dieron con él en el suclo, é mataron á los dos españoles que lo llevaban, ć nunca lo conoscieron hasta que fué de clia: é que cómo le conosçieron, se deluvicron con él los inclios é dexaron de seguir á los chripstianos, haçiendo grandes llan10s, pero breves, porque reconosçidos del desastrado fin de su señor, fueron más de quarenta mill hombres eu seguimiento de los españoles. I el capitan general avia mandado al comendador Pedro de Alvarado que se quedasse en la relroguarda á recoger la gente, é desque vido tanta mortandad en los nuestros, é quél tampoco no podia escapar, atendiendo más, Ilevaba una lança en la mano, é siguió trás Hernando Cortés, passando sobre los muertos é caydos, oyendo muchas lástimas; ć llegó á una puente, que ya la a via passado Hernando Cortés é los que escaparon, y estaba alçada, é todo aquello lleno de muertos quassi lasta arriba. E como era mançebo é muy suelto, juntó la lança contra los enemigos, é assi como se deluvicron un breve espacio, en contincnte, sin perder tiempo arremetió, é sobre el quiento de la lança saltó tan ligeramente que travessó todlo aquello que la puente solia ocupar, é púsose del olro lado en salvo, quedando los indios espantados clello; porque fué tan extrenado de grande el salto, que á muchos hombres que han visto aquello he oydo deçir que paresçe cosa imposible averlo podido saltar ningun hombre humano. En fin, él to saltó é ganó por cllo la rida, é perdiéronlat muchos que atrús quedaloan ; é Hegó á lortés, yne estaha ençima de unas gra- das de un eju, sentado, diçiendo muchas lástimas, é á vuclta dellas otras palabras contra los que avian atrís quedado. É por no acalar de se perder, movió de allí con cssos pocos que le quedaban, é con mucho trabaso é poleando á cada passo, él y ellos llegaron á la cibdad de Tascaltecle, torlos heridos. Pero en este camino, desde á cinco dias despues que salieron de México, los cercaron más le dosçientos mill indios por mandado del señor de Temistitan, Hernando de Montecuma, 6 subcessor en su señorio; no porque él allí fuesse, sino un capitan é mayordomo suyo que se decia Xuquetenģa; é peleando con los chripstianos, le mataron á esse capitan é desmayaron los contrarios é dexaron de seguir á los ehripstianos. É assi con assaz peligro é cansançio é muclias heridas, los que quedaban llegaron á una fuente, donde se parte el término de Tascaltecle con el de México; é quiso Dios que vinieron los de Tascaltecle con mucha gente de guerra, en que avia más de çinquienta mill homìres, é detrás dessos más de otros vernte mill hombres é mugeres con bastinıento é comida é ağua á socorrer los chripstianos. É cómo toparon con ellos, lloraban é deçan: "Bicn os lo diximos, quando te nosotros os partisteys, é os avisanos que essos mexicanos son grandissimos traydores, é no nos quisisteys creer". É los lalcasteclanos é alguno de caballo dieron en los que todavia venian de umas partes é otras en busca de los chripstianos, para los acabar de matar é robar, é híçose grand matança en los tales; é recoggidos, se fucron á Tascaltecle, é fueron acogidos é tractados é procurados, como si fueran proprios hijos. É allí estovieron hasta que se allegaron de los españoles, que despues fueron á aquella ticra otros quinientos 6 más hombres, que con los veteranos, po$\cos$ á pocos, passaban de ochocientos hombes do guerra: la qual luego se co- 
mençó ó se prosiguió, continuándose ál guerra guerreada á fuego é á sangre muy crudamente, contra los mexicanos é sus valedores.

\section{CAPITULO XLVIII.}

En el qual se tracla cómo fué cobrada la grand cibdad de Temistitan, y el señor della fuć presso; é otras particularidades. É dảse fin con este capilulo á esta relaçion que, como es dicho, fue sacada de muchas informaçiones é testigos que en aquella conquista sc ballaron.

P rosiguiendo esta relaçion, es de saber que en ella se haçe memoria de los treçe hergantines que Hernando Cortés hiço hacer para la conquista é recuperaçion de Temistitan, é çercarla; é cuéntalo de la mesma manera que se ha dicho en esta historia. E dice assimesmo que Ilernando Cortés le puso tres reales á la cilsdad, uno en la calçada de lztapalapa, é otro en la de Tacuba, por donde avian los chripstianos salido huyendo, é otro en la calçada que llaman de Saltoca; é ordenó que aquellos bergantines anduviessen en aquella grand laguna, á par de aquellas calçadas, é por todas partes discurriendo, porque los indios no pudiessen meter hastimentos en la cibdad. É tambien se haçe mençion que se ordenó una grand trayçion en Tezcuco por los indios; pero que se puso recabdo en ello, segund la historia lo ha contado. É assimesmo diçe el motin, en que tenian ordenado de matar á Cortés, por industria de un Villafañe é un tal Escudero é otros que se hallaron, é fueron castigados, é pagaron su mal desseo con las vidas; porque essos é otros émulos de Cortés, por parte de Diego Velazquez, andaban amotinándole la gente; pero el castigo lo aseguró todo.

De manera, que quanto al çerco, se ordenó que IIernando Cortés fuesse en los hergantines, é tres capitanes otros por tres partes con el restante de la gente española é anigos confederados, por tierra; en que avia, sin los chripstianos, más de çinqüenta nill hombres. E sabido por Guatimuçin ", señor de Temistitan (subçessor en aquel grande estado á Monteçuma), hiço aprerçebir sus gentes para su defensa, é quitar las puentes de las calçadas; é hiço muchos sacrifiçios á sus dioses, y en espeçial á su dios de la guerra, quellos llaman Cuancual, é sacrificó aquel dia quatro mill muchachos ó más, é quatro españoles que tenia vivos en una jaola. É ovo su consultaçion con el demonio, é díxose que le avia dicho que no temiesse de los chripstianos, é que saliesse á ellos, é le ayudaria é los mataria á todos; é que le sacrificasse, como solia.

Escribe Livio, que haçiendo la guerra el cónsul Fabio á los tarquinienses, los Tarquinos sacrificaron tresçientos é siete. cavalleros romanos, quellos avian presso, en deshonra de los romanos; de manera que non menos que en Indias, en Italia entre aquellos antiguos gentiles tractalsa tambien el diablo esta condenada usança de sus sacrifiçios. Tomemos á nuestra historia.

Hiço Guatimuçin venir por la laguna muchas canoas é alğunas piraguas, é tan grande armada que quassi ocupaban las çinço leguas que tiene la laguna de longitud por aquella parte; é por su mucho número, con el estorbo que se daban las unas á las otras, no podian navegar á su placer. Los atambores é voçinas é gritas, era para espantar, mirando con quánta osadia é audaçia venian é amenaçahan á los chripstianos, é deçian: "Aqui avés 
de quedar todos, como los otros que primero matamos s. E porque su injusta petiçion fuesse oyda é açepta á sus dioses, sacrificalıan muehaehos que alli traian, 6 arrojábanlos en rl ayre, é deçian: " $\Lambda$ ssi avés de pagar vosotros». E diçiendo essas é otras semejantes locuras é fieras é solverbias palabras, quiso Dios que vino viento próspero en los bergautines y ambisticron con la llota de los enemigos, haçiendo grande estrago en ella, quebrando y rchando á fondo muclas canoas ó indios, en lanta manera, que en muchas partes paresçia al agua propria sangre, por la mucha que de los indios alli se vertia. li demás de los mucrtos fueron otros Imiclos pressos, é assaz señores é prinçipales dellos, de los quales se supo que todos los chripstianos que tomaron, quan(lo los echaron de Temistitan, Ins avian muerto é sacrificado é comido, á causa de la division de los señores, que unos deçian que era bien é nescessario para haçer la paz con los ehripstianos, é otros deçian lo contrario, diçiendo que pues Iontecuma, su señor, era muerto, que no era raçon que chripstiano viviesse. I en fin, con muchas é diverssas crueldades los mataron á todos.

En esta hatalla naval quedó la victoria por los nuestros, é se assentaron los reales en las calçadas é partes que está dicho, é se partieron los bergantines con cada real, y el capitan general por su parte. É cada dia peleaban los unos é los otros, por entrar en aquella grand cibdad, contra lo qual simpre se hallaba mucha resistençia é moltiful de enemiggos. É un dia el general se desmandó á passar uma açequia, que atravessaha la calçada, é á li vuelta le tomaron treynta españoles vivos, é los sacrificaron en un qui muy al10; é faltó poco de prenderle á él con cllos, si no fuera socorrido de ciertos milites é rriados sllyos: é de los otros rea. les se perdieron ayper dia olros quatro hombres. Esta guerra, sin çessar, turó dos mesez é más, é a cabo deste tiempo començaron á allanar é ruinar é poner por a suclo la ciludad por una parte é otra, juntamente con la ayuda de Tascaltecle: é los de la cilulad se retruxeron á una parte della, sin se querer rendir, aunque cn ellos se laçia mucho daño é mataban racla dia: $y$ el hedor era incomportable. É Im dia, juntamente los españoles é sus ronfederados, les dieron tan resçio combate le todas partes, que Guatimuçin se rntró en una canoa con reynte remeros. que paresçia tan veloçe por dó passába, como una saeta. E un capitan que se deçia Garcí Holguin estaha en uno de los bergantines, é tenia allí presso un señor indio muy prinçipal, el qual te dixo: "Capitan señor, dáte buena maña, que aquellos indios que van en aquellax canoa son esclavos de Guatimuçin, é podrá ser quél va alli huyendo, porque su bandera ya no paresçe". Estonçes el capitan Garçí llolguin, cómo oyó esto, dióse toda la priessa quél pudo é siguió á la canoa; é quando fué á par della, un poco antes, so subió en popa Guatimuçin; é porque vido que çiertos ballesteros encaraban con las hallestas contra él, dixo é liço señal que no tirassen, quél se rendia por presso. É assi lo fué por aquel capitan, é llevado luego al general Hernando Cortés; é lo pusieron en una açutea muy alta, é dixole Hernando Cortés que dixesse á los señores é capitanes suyos que viniessen luego á dà la obidiençia á Su Magestad, é al general en su real nombre, si no, que no quedaria hombre dellos ron la vida. E assi se hiço, é depusieron las armas más de septenta mill hombres.

Preguntáronle los chripstianos por el thessoro é Laçienda, que avia quedado en la cibdad, quando los desbarataron, é dixo que avia ocho dias que lo avian echaIo en la laguma, porque el diablo le avia dienı que arian de ser rençidos, é quo 
lo mesmo hiçieron del artilleria que avia quedado; pero dixo que lo daria todo, é no dió la terçia parte dello.

Preguntáronle por los chripstianos, é dixo: "No me preguntés esso; é si me quereys matar, matadme ya: que harto estoy de vivir". Y el capilan general le dió buenas palaliras, consolíndole é haciéndole entender que avia fecho su deber en su defensa, como buen prínçipe, é que por esso no seria maltractado, sino tenido en más: é líçole llevar de allí é ponerle en buena guarda, con buen tractamiento de su persona, é mandó hacer muchos fuegos en las calçadas por alegria de la vicloria conseguida. É recogióse mucho oro é joyas, é hiço herrar por esclaros con el hicro del Rey á muchos indios é indias, porque estaban dados por traydores. Ė despues que la cibdad fué subjeta, liço el general passar el real de los chripstianos á la cibdad de Cuyoacan, que está á dos leguas de Temistitan.

Muchas cosas acaescicron en este çerco, que entre otras generasçiones estuvicran discantadas é tenidas en mucho, en espeçial de las mugeres de Temistitan, de quien ninguna mençion se ha fecho. É soy çertificado que fué cosa maravillosa é para espantar ver la prontilud é conslancia que tuvieron en servir á sus marirlos, y en curar los heridos, y en el labrar de las piedras para los que tiralian con hondas, y en otros offiçios para más que mugeres.

Pues cómo Hernando Cortés acordó de passar á Cuyoacan, dexó en la ciludad de Temistian á un cavallero que se deçia Villafuerte, con ochenta liombres, para gtaarda de los hergantines, é varáronlos en tierra, porque los indios no los ruemassen. E cómo fué presso Guatinucin é sus prinçipales é capilanes é mayordomos suyos é de su liemano Alontecuma, deçian adónde avian echarlo el oro en la laguna, é hallóse parte dello; mas no la terçia par- te de lo que se avia perdido. É afirmaban muchos que de más de quinientas leguas venian emlyaxadores é indios te señores prinçipales á dal la obidiençia. É despues desta señalada vietoria, fuế á aquella tierra Chripstóbal de Tapia, vecdor de las fundiçiones del oro en esta cibdad de Sancto Domingo, con provissiones é poderes para gobernar aquellas partes por Su Magestad. E cómo el Emperador, nuestro señor, estaba en Flandes en aquella saçon, é aquellas emanaban de sus gobernadores, é á Cortés no le paresçió que sin ser entendidos sus serviçios debia ser descompuesto, tuvo sus formas para lo laçer volver á un puelslo que se dice Jalapa, é allí lo hiçieron embarcar é se tolnó por donde vino ó fuć allá. É tornados los mensajeros, que fueron Alvarado é Diego de Soto ć otros, hiçiéronse las partes del oro avido en el saco de TemistiIan; é demás de se pagar el quinto á Su Magestad, el capitan general é todos los demas del exérçito clripstiano dieron muclias joyas para el Emperador Rey, nuestro señor, que valian más de cient mill pessos de oro, en oro é plata é prescas. É lodo aquello se perdió é lo tomaion cosarios françeses, de lo qual querla fecha más cumplida relaçion en los capítulos passados.

É tambien se recolige desta relaçion, cómo Hernando Cortés envió á Cluripstóbal de Olit á poblar en la costa é puerto de IIonduras é Iligueras, é diçe que se alçó: por lo qual, avisado Hernando Cortés, envió á un cavallero, cuñado suyo, llamado Francisco de las Casas, contra él; é dió al través en parte que lo prendió Clıripstólal de Olit á él é á los que llevaba consigo, é muchos se ahogaron. É ya tenia el mesmo Chripstóbal de Olit presso al capitan Gil Gonçalez Dávila, el qual é Françisco de las Casas se conçertaron é mataron al Clıripstólıal de Olit, çenando con el, como la historia lo ha contado en 
(libro XXX; é cuedaron por gobernadores los interfectores allí en Ilonturas. Jespues Francisco de las Casas prendió al Gil Gonçalez é llevólo á Temistitan, é halló que era yolo Cortés en busca de Chripstóbal de Olit por tierra; é dexó por gobornador al thessorero Alonso de Estradla é al contador Rodrigo de Allıornoz; y en las cosas de la justiçia al liçençiado Alonso Cuaco. É cómo Hernando Cortés se fué su camino, sujo en el viage questos sus sostitutos se arian rigorosamente en la gobermaçion, ó no á su voluntad. É dió otro poder para gobernar la tierra al factor Gonçalo de Salaçar é al veedor Pedro Mirez Cherino: é assi redundó destos poderes una contençion é diferençia entre los offiçiales, que oviera de ser causa de se perder la tierra.

Dexemos esto, é volramos al riage de Cortés, que llegrado állonduras, llegó desle á poco tiempo un fraryre pariente suro, é dixole los movimientos é revuelias le México, é persuadióle á que se fucsse luego á poner la ticrra en paz; y entretanto envió el mesmo bergantin, proveyendo que gobernasse Françisco de las Casas, é otra provission para Alrarado; pero los menzajeros fueron pressos, é ya el factor Salaçar avia prendido á Françisco de las Casas é sentenciárlolo á muer1e, porque avia muerlo á Chropstólual de Olit; é apcló de su sentençia. Mas quanlo llegaron los mensajeros de Cortés, ya lo avia enviado presso á España. É vistas las cartas de Cortés, quel vulgo tenia por muerto, juntáronse el thessorero y el contador é otros de su parçialidad, que estaban retraydos en Sanct Francisco con otros amigos é servidores de Cortés, que á ellos se allegaron, é con mano armada fucron á prender al factor Gonçalo de SaIaçar, que estaba en la casa de Cortés, que la avia tomado por fucrȩa con toda el artilleria, é aun avia ahorcado á un primo de Cortés, llamado Rodrigo de Paz, su unayordomo, é alģıaçil nayor de Temistitan, é tenia doscientos hombres á la continua en su guarda é opinion. Pero al tiempo de la nesçessidad todos le fallaron, sino diez ó doge: é non obstante esso, como varon é lrombre de gentil ánimo, se puso en defensa, y él mesmo pegaba fuego á la artilleria é liros que tenia asestados a la puerta; mas cutráronle por muchas partes, é prendiéronle, é lo llevaron cuassi arristrando, é fuć puesto en una jaola, donde se le lirgieron assaz vituperios. En el qual tiempo avia yelo el veedor Pedro Mirez á paçificar una provinçia que se avia alçado, é arian muerto los indios á más de çinqüienta españoles é más de diez mill esclavos, que andaban en las minas sacando oro en la provincia que llaman Quatan: el qual, cómo supo la prission del factor Salaçar. é que Cortés era viro, liuyó escondidamente, é dexó la gente, é se acogió á un monesterio que está en la provinçia de Tascallecle, é de allí lo sacaron los indios é lo llevaron á México, é fué puesto en otra jaola. Y el thessorero y el contador se llamaron grobernadores en nombre de Su Magestad, é con esta roz liçieron prencler á muchos amigos é algुunos criaclos del factor é del veedor, que tenian conçertado de quelrar las jaolas é los poner en libertad: é á unos alıorcaban, é á otros açolaban, é a otros cortaban piés é manos; é andaba un fucgo y escándalo tan grande que los indios estaban atónitos y espantados de lo que vian. Parte desto passó antes quel liçcnçiado Cuaço fuesse presso, del qual é de su naufragio adelante haçe mençion la historia en el último libro de los Naufragios.

Passadas estas cosas, ó mejor diçiendo no todas, sino hirviendo é turando las diferençias de los offiçiales, sc desembarcó Cortés ochenta leguas de Temistitan, é fućronsele á quexar muchos indios de las cosis acarsciclas en su amsençia. É llega- 
Jo á la cilsdad, se le hiço grand resçelsimiento: é desde á diez ó doce dias, queriendo entender en las cosas del factor é del veedor, llegó la nueva de cómo yba el liçençiado Luis Ponçe por juez de residençia é gobernador, é que estaba desembarcado en la Villa Rica, al qual le fuć dicho que queria haçer justiçia del factor é del veedor, é tomó postas, y en çinco dias Ilegó á Temistitan. É la gente que llevaba, que serian hasta çient personas, los más se murieron por el camino ó dende á muy pocos dias despues que en la tierra estovieron: é con su llegada subcedieron otros escándalos é trabaxos; porque él se fué derecho a la iglesia, é fué resçelido en nombre de Su Magestad conforme á las provissiones, que llevó é pressentó; é salió de allí, é dende á ochı dias le dió el mal de la muerte, é con ella concluyó con sus offiçios. Pero dexó en su lugar por gobernador al liçençiado Márcos de Aguilar, el qual era hombre de letras é diestro en las Indias por la expiriencia que avia tenido en esta Isla Española y en esta cibdad de Sancto Domingo, donde fué alģunos años alcalde mayor por el almirante don Diego Colom. É dado aquel poder gobernó en virtud dél con mucho trabaso por los escándalos ya dichos, en que la tierra estaba, é diéronle por acompañado á Gonçalo de Sandoval, que era deblo de Cortes, para que sus cosas se mirassen; pero él no lo quiso resçebir. É dende á poco se murió este licençiado, del qual se esperaba que la justiçia fuera bien administrada, porque era hombre que la supiera haçer : cl qual dexó en su lugar al thessorero Alonso de Estrada, é diéronle por acompañado al dicho Gonçalo de Sandoval, porque el thessorero tractaba inal los criados é amigos de Cortés; y él lo rescilisió el dicho acompañado, aunque contra su voluntad. E Cortés estuvo muy desabrido con el thessolero por algunos desacata- unientos que usaba con él, ó que le paresçial ál Ifernando Cortés que lo eran, porque quisiera que tuviera más respelto á su persona. Destas cosquillas se pensó que resultáan nuevas puñadas é trabaxos; $y$ el thessorero era lombre hijodalgo é offiçial de Su Mlagestad, y en Cilsdad Real, de donde era natural, era uno de los regidores é principal hombre; é tenia sus pensamientos como de hombre de bien, é pensaba que teniendo cargo de la justiçia, la avia de preçeder é administrarla como era raçon, puesto quel ticmpo estuviesse enconado é los ánimos españoles alterados y en diverssas opiniones.

En essa saçon dende á poco tiempo salieron de las prissiones el factor y el veedor , porque les fueron çédulas de Su Mlagestad para ello; y Hernando Cortés se fué á España, é quedó el thessorero Alonso de Estrada gobernando. En la qual saçon fué nueva como Nuño de Guzman yba por gobernador. É assi fué, que llegó á lléxico con quatro oydores é nueva Chancilleria: é murieron los dos, é quedaron vivos los liçençiados Johan Ortiz de Matienço é Delgadillo, é prendieron al thessorero Estrada é al capitan Alvarado, que avia ydo de España. É líçose almoneda de los bienes de Hernando Cortés, é tan sumaria, que se daba todo por mucho menos de lo que valia; é llamáronle á pregones, é si estuviera en la tierra, se viera en trabaxo; é sus amigos con este disfavor no osaban paresçer.

Dende á poco liempo proveyó Su MIagestad que se quitasse el cargo á Nuño de Guzman, porque en poco tiempo ovo dél más quexas que de los passados. E cónı lo supo ó fué arisado que le quitaban el offiçio, acordó de haçer una entrada á las provincias de los Ulichichimecas de Xalisco, en demanda de Culuacan, que es de donde algunos diçen que vinieron todos los indios que estaban en Temistitan. 
L: donde Nuño de Guzmin fué, laclló gente belicosil vestidos de cueros de venados muy bien adolados, é ticnen liermosas mugeres, é grente de mayores estaturas que los indios de la Nueva Ispanir. Este cavallero llevó quinientos de á calballo, unos pressos é otros contra su voluntad, é los que con ella yban, cran los menos. É llegó á Mechuacan, é prendió al señor de aquella provinçia, llamado Caçonçi, estando de par, el qual servia á llernando Cortés: é fué fama que le sacó diez mill unarcos de plata ó más, é mucho oro, é tomóle diez mill indios que 'le llevó; é aun despues le quemó, porque no se pudiesse quexar, é á otros indios principales con él. En fin, él prosiguió su camino é fué donde es dicho, é allá estırvo en contínua guerra é le mataron assaz clıripstianos; pero conquistó á Xalisco, é fundó tres pueblos é polblólos de cluripstianos. É allí estuvo hasta quel visorey don Antonio de Mendoga fuć á la Nueva España, el qual lo mandó prender (ó la Audiençia Real que en Temistitan reside). é fué enviado á Castilla á dar cuenta de sus serviçios ó culpas al Emperador.

Aquella tierra é provinçia de Xalisco se llamaba el Nuero reyno de Galicia, porque es region áspera é montuosa é de gente resçia.

Despues que Nuño de Guzman fué á aquellas partes, antes que allá fuesse el señor visorey don Antonio de Mendoça, fué á Temistitan el obispo de esta cibdad de Sancto Domingo don Sebastian Ramirez Fuenleal, presidente de la Audiençia Real que aqui reside; é por mandado de Céssar fué á reformar á México é Temistitan é aquella Real Chancilleria que alli hay, é como presidente é persona de letras y expiriençia : é fueron con él los liçençiados Johan de Salmeron, que avia estado en la Tierra-Firme, é Quiroga, é Caynos, ó Maldonado.

Este perlado puso en libertad los in- dios, á cinsia de lo quat los conquistado. les dexilham la tierra é se yluan á luscar las vidas; mas cómo al Emperalor, nuestro señor, le yluit unás en que su tierra estuviesse bien gutrtrdalar, é su consciencia segura, dióse tal órden en el tractaniento de los indios é polliçón de la ticrat, que aria la raçon é justiçia que conviene, é convertidas innumeribles gentes á nuesllà sancta féc catlólica, é con muchos templos é iglesias, assi motropolitana como de muchos obispados é dignidades, é muchos monesterios de religiosos, como más particulamente lo dirá la historia adelante en el lugar que convenga. I estando aquel nuy reverendo obispo presidiendo en aquella Real Chançilleria é gobernando la Nueva España, volvió á la tierra IIernando Cortés con título de marqués del Valle, del qual estado le hiço mereged la Çessárea Magestad, como bien informado de sus señalados é grandes serviçios; é le dió mucha renta é vassallos, é le conçedió otras muchas merçedes. F́ cómo allegó á la Nueva España, le salieron á rescebir é á quexársele más de mill señores é indios; é deçian que los liçençiados Matienço é Delegadillo les avian robado á ellos é á él, é que viesse si queria que los matassen á ellos é á los demís. Y el marqués los consoló é aplacó con huenas é dulces palabras y esperancas futuras para su satisfaçion: al qual mandaron los oydores, só graves penas, que no entrasse en la grand cibdad de Temistitan, é á los conquistadores que se fuessen á vivir é residir en aquella cibdad, só pena de muerte, por quitarle la gente al marqués. É aun se tractaba de prenderle é tornarle á cnviar é España, porque deçian á voçes que yba á alborotar la tierra. Y él, con buen sufrimiento, lícose pregonar en la villa de la Veracruz por capitan general de Su Magestad, é assi lo era: é juntada mucha gente con él, é muy bien en órden, de pié é de caballo, 
fuésse á Teztuco, que está çinco leguas de Temistitan; é allí le envió á mandar el Aurliençia Real que no entrasse en la cildad, só pena de perdiniento de sus bienes, é la persona á merçed de Su Magestad: y él obedesçió lo que le mandaron. Y estaba allí tan acompañado é con tanta corte é más que la que avia en Temistitan.

En este medio tiempo acordaron los indios de matar á los chripstianos; y estando muchos é innumerables conçertados para ello, porque vian la divission é passiones que entre los españoles avia, ovieron mucho temor los oydores é todos los demás. É de nesçessidad, paresçiéndoles que no tenian mejor ni más çierta defensa que la persona é crédito é valor del marqués del Valle, enviáronle á llamar, porque cada dia los indios mataban chripstianos de los que andaban desmandados por la tierra, é faltaban ya más de dosçientos españoles. Y el marqués fué á Temistitan muy bien acompañado é con mucha gente de guerra, é cómo hombre que la entendia: é se juntó conaquellos senores de la Audiençia Real é fueron pressos é castigados muchos indios, é quemaron é aperrearon tantos dellos que quedaron bien escarmentados, é a visados que cada vez que se moviessen con qualquier alteraçion, se avia de haçer lo mesmo. Y en breves dias todo estuvo llano é pacífico.

Junto con sus títulos é prosperidad de marqués del Valle, llevó consigo á la Nueva España á la nrarquesa, su muger, con quien se casó en Castilla, ques áquella señora de quien se hiço memoria en el capitulo XLV, llamada doña Johana de Arellano, hermana del conde de Aguilar, que hoy tiene aquel estado, é solrrina del drrque de Béjar don Álvaro de Cúninga. La qual es una de las mugeres de lispaña ge- nerosas é ilustres por su sangre é de las unás virluosas, é valerosas por su propria persona: la qual sin mucha lefura no se puede cumplidamente loar conforme á sus méritos é prosípia.

É porque desla relaçion estamos quassi al cabo, digo que en ella supe que las minas de plata están en una provinçia que se llama Soliço, en la qual assimesmo hay muchas colmenas é abundançia de miel é çera de muchas maneras. En lo de la plata, digo que yo ví en Sevilla, en la casa de la moneda á montones por el suelo, muchas barras é quintales de plata, é barriles llenos de la llevada de la Nueva España; é me çertificaron los offiçiales reales que avia en la Nueva España en essa saçon dado de quinto a Sus Magestades un solo hombre çinco mill marcos de plata, porque aquel año avia sacado veynte $y$ çinco mill marcos; é cada marco es ocho oncas. É ví que por no se poder despachar de fundir tanta plata quanta se llevaha á Sevilla en aquella casa de la moneda, dieron liçençia á sus dueños que la fundiessen donde les pluguiesse: é assi estaban ocupadas muchas casas de herreros é otras, fundiendo plata en grandes cantidades.

En la provinçia de Mechuacan hay muchas minas de oro, é de plata assimesmo otras: la qual es tierra muy fria: y el señor della era señor de muchos thessoros, é llamálbase Caçonçi.

Hay al pressente en la Nueva Espana nueve iglesias cathedrales *, allende de la metropolitana de Temistitan, con sus olsispados é dignidades, etc. Hay muchos monesterios de las Órdenes de Sancto Domingo é Sanct Françisco é de la Mersed é de otras Órdenes.

Hay tanto trigo, é háçese tan bien, que
- Las eatedrales de que habla Oviedo parecen ser: Puebla de los Angeles, Tlascala, Durango, TO.110 111
Guatemala, Mechoacan, Guadalajara, Yucatan y Chiapa. 
un solo labrador la acaescido coger, de quatro fanegas que sembró, seysçientas; é porque es cosa notable, le nombran é se llama Françisco de Terraças.

É con esto se concluye é dí fin á esta relaçion, que en la verdad, si los que me informaron no luvieron passion en lo que está diclıo, á lo menos por mi parte cstá fielmente escripta, é á la llana é con menos palabras assaz de las que fuy infor- mado, en lo ques dicho en estos quatro capílulos que contiene.

$\Lambda$ gora se escribirá otra que de un reverendo padre de la sagradia Órden de Sinncto Domingo yo supe, y él me la dió en la provincia de Nicaragua, que ylua de la Nneva España. É aunque en ella se toque algo de lo que está dicho, tambien hay otras cosas, que no se deben preterir.

\section{CAPITULO XLIX.}

En el qual se contiene una relacion de diverssas cosas de la Nueva España; quel chronisla eseribe por informaçion del reverendo padre vicario fray Diego de Loaysa, de la sagrada ńrden de los Predicadores; é deçirse há eon más brevedad de la que esle religioso lo dio in scriptis, firmado de su nombre.

Y. he procurado por muchas vias de entender aquellas diferençias que en la Nucva España se tractaron entre los offiçiales quel Emperador, nuestro señor, allí tenia para su laçienda real; é supe de muclos que lo vieron lo que está diclıo en los quatro capítulos preçedentes, é despues más puntualmente algunas cosas deslas por un religrioso, persona reverenda é de crédito, que estando yo en la costa de la mar del Sur, en la provinçia de Nicaragua, fué á aquella tierra dende la Nueva España.

Este me dixo quel gobernador Hernando Cortés estalıa en el puerto é cabo de Honduras, descuydado de las cosas que en la Nueva lispaña passaban; porque despues que dende la provinça de Guaxaca avia cnviado al factor Gonçalo de Salacar é al veedor Pedro Almirez * Cherino, con poderes que revocaluan los que avia dado al thessorero Alonso de Estrada é al contador Rodrigo de Albornoz, é los haçia sus tenientes é capitanes en su nomlsre, ellos, assi comofueron resçelidos é admitidos en Temistitan, sabiendo que
Cortés estaba muy léxos la tierra adentro, é dubdando su vuelta (que ylua á buscar á Chripstóbal de Olit que se avia alçado), avido su acuerdo, propusicron en sus ánimosé obras de se enseñorear é gobernar absolutamente; é assi subçedieron grandes discordias é bulliçios entre todos quatro offiçiales y un Rodrigo de Paz, primo de Cortés, que era alguaçil mayor de Héxico é mayordomo mayor de la casa é haçienda de Cortés, que juntamente con ellos concurria, pero en la opinion de Cortés, é no en lo demás. Y fueron encendiéndose los enojos, é á proporçion dellos cl de su discordia, subcedicron las cosas de mal en peor, aumentándose; y essos officiales, factor é veedor, prendicron al Rodrigo de Paz, é todo el fin de la prission fué porque dixesse del thessoro de Hernando Cortés, quellos pensaban quel Rodrigo de Paz lo tenia enterrado, é que solo cste su primo, como debdo tan çercano é camarero suyo, é que era partícipe en sus secretos, lo sabia. É para que dixesse la verdad fué alormentado muy crudamente; é finalmente, no co- 
nosçiendo nada, to hiçieron alrorcar muy aviltadamente.

Desde á pocos dias prendieron á los capitanes Françisco de las Casas é comendador Gil Gonçaloz Dávila, é condenáronlos á muerte; é si no fuera por los padri. nos é religiosos que se atravessaron á interceder é rogar por ellos, los degolláran, porque avian muerto al capitan Cluripstóbal de Olit; y enviáronlos en una carave. la en porler del capitan é piloto Johan Bono de Quexo, é de Villarrocl é Tapia, que yban por procuradores á España (en nombre de las cibdades de la Nueva España, $y$ en favor destos dos officiales que gobernaban); y enviaban con ellos doce mill ducados de oro en barras é joyas de oro ricas (queste padre me dixo que las vido é tuvo en sus manos), lo qual llevaba un Johan de la Peña, criado del factor; y en el camino se perdió el navio en el puerto de la isla del Fayal, ques una de las islas de los Açores; pero salvóse el oro de Su Magestad y el de todos los que alli yban, é perdiéronse los proçessos destos pressos.

En aquella saçon fué á buscar á Cortés un frayle de la Órden de Sanct Françisco, Ilamado fray Diego Altamirano, primo suyo, é dióle notiçia de lo que en TemistiIan passaba, porque yba á buscarle é saber si era muerto ó vivo; é para este efetto fletó un navio en la villa de Medellin de la Nueva España, é fué al cabo de Higueras é puerto de Honduras, é halló á Cortés en la villa de Truxillo. É fecha su relaçion, quedó informado Cortés de la verdad de lo que passaba en la Nueva España; y este frayle fué el primero que le nombró señoria, y le consejó é liço que se pusiesse con sitialá oyr misa, é pusiesse estrado, é solempniçasse su estado, dándole á entender quel Emperador le avia lıccho duque é adelantado de la mar del Sur, lo qual no fué assi. É cómo pensaba volver a lléxico por tierra por la pro- vinçia de Guatimala é Nequepio, estando hrechos é aderesçados los caminos liasta el valle de Ulancho, para que las ásperas sierras de Chindon se pudiessen passar sin mucha dificultad, é para servir á Cortés todos los caçiques de la tierra estaban aparejados, porque tenian en mucho su reputaçion é fama por aver conquistado á Temistitan; é nombrábanle Malinche, á respeto de una lengua que traia consigo que llamaba Marina. É por importunaçion grande del frayle mudó consejo é se partió por la mar, para que con más brevedad remediasse la Nueva España : é con próspero viento en veynte é çinco dias fueron en la Habana, ques en la isla de Cuba; é dende allí en otros quinçe dias llegaron al puerto de Sanct Jolıan de Jua, en la Nueva España, é tomó la gente de sobresalto una mañana que aun los veçi nos estaban en las camas, é fué tanto el plaçer de todos, que de atónitos y espantados no creian que era él; é aun muchos le desconosçian, porque yba mal dispuesto y enfermo de calenturas, que en la mar le avian muy mal tractado.

Los indios de la costa, sabida su venida, saliéronle á rescebir á los caminos con pressentes de oro é comida é mantas. Esto liço la cibdad de Cempual, é le siguicron la mayor parte del camino de allí adelante; é de las comarcas por el semejante salian con comida é con cántaros de agua puestos en aquel desierto que tura quarenta leguas, sin poblaçion, exçepto las ventas feclas por los cliripstianos: é desta manera llegó hasta Tezcuco, é allí fué resçebido de los indios con mucha fiesta é solempnidad. É salió el contador Rodrigo de Albornoz una jornada antes que llegasse á Tezcuco con muchos espaũoles á resçebirle, é assi por el consigruiente por su parte el thessorero Alonso de Estrada, con todos los allegados á estos é á la parçialidad de Cortés. É assi con mucha alegria, é grandes areytos do 
indios de noche é de dia, é instrumentos de españoles de trompetas o atabales fué rescelidilo.

Tres meses antes que llegasse Cortés, grobernando el factor Gonçalo de Salaçar, se hiço pregonar por gobernador de la Nueva España é capitan general, en nomhre de Su Magestad, cono official suyo, porque la lierra estaba tiraniçada é alçala contra Su Mlagestad en poder de Cortés. E assi en la plaça de Temistitan deçia que cra tirano traydor Cortés é todos los que le siguiessen. Y en todas las cosas de la gobernaçion é capitania general entendia absolutamente, como si fuera grobernador; ć acompañálıale en golıcrnar ol veedor. É duspues que ahorcó á Rolrigo de Paz, se levantaron çiertas provinçias de indios en Guaxaca, é fuć allá el veedor con dosçientos hombres á sosegrarlos: é hiçićronse fuertes los indios en Inos peñones; é viéndlose aprefados, recogiéronse todos á uno muy fuerte, é los españoles, assi por sacarlos de allí, como por aver dellos una sierpe de oro é çiertas rodelas é moscadores é olras joyas de oro ricas, estuvieron quarenta dias sobrellos. É supieron los indios por sus espias que los chupiplianos los avian de combatir é subir, é una noche los hombres de guerra é viejos huyeron por las sierras sin ser sentidlos, de manera que desque los chripstianos les subieron el peîon, no hallaron sino mugeres vicjas é niños.

Estando en esta conquista cste veedor, é el factor on Temistitan con grand triunfo, llegó Martin de Orando, moço de espuelas del dicho Cortés, con cartas para a thessorero é contador, é con una provission para que gobernasse Françisco de las Casas en lugar de Hernando Cortés; y este salió en un navio que yba á Panuco, é fué por licrra dende la isla de los Sacrifiços, é de alli en Tierra-Firme hasta que llegó á México muy secrelamente, que no fué sentido del factor ni sus adherentes, porque si lo tomíran, le hiçieran quartos, llevando mueva que era vivo Heruando Cortés, é que revocalsa los poderes que les avia dado al factor é veedor: los quales publicaban que Cortés é los que con él avian ydo eran muertos por los indios, é que lo traian figurado en un paño de la manera que los avian muerto. É cómo no avian sabido nueva que çierta fuesse, túvolo el vulgo por çicrto, é aun los criados é amigos de Cortés le licicron las honras é obsequias por defuncto, é lo mesmo algunas mugeres por sus maridos que con él avian ydo. Despues de lo qual, venido aquel moço ó mensajero de Cortés que es dicho, entróse en Sanct Francisco secretamente, é dió las cartas al thessorero; é los criados é amigos de Cortés re. cogriéronse todos á Sanet Françisco, é juramentáronse los más de seguir al thessorero, é todos le eligieron por capitan é teniente de gobernador en nombre de Cortés; porque Françisco de las Casas, á quien yba el poder, ya era enviado á España presso é condenado á muerte, y el comendador Gil Gonçalez Dávila, por la mucrte del capitan Clıripstóbal de Olit.

El contador usó de una manera para acostarse á la parte que salicsse con su intençion, é secrelamente híçose con el thessorero; y el dia quel thessorero determinó de prender al factor, á medio dia, fué el contador dende Sanct Françisco á la possada del factor, é se le ofresçió que ni seria con él ni contra él, sino en poner paz. É despidióse dél con intençion de se yr á su casa, y en el camino topó con la gente que salia de Sanct Francisco con el thessorero, todos en ordenança é á cabaIlo, é hiço que públicamente le hiçiessen quitar de la mula é calualgar en un caballo que le dieron é armas, é assimesmo los suyos, con la cautela ques dicho, para que si la parte contraria vençiesse, pudiesse deçir que ylua forçado. Assi que. 
ydos derechamente á la casa de Hernando Cortés, donde el factor paralıa y estaha con gente armada de sus amigos é criados, é çiertos tiros de artilleria á la puerta prinçipal por la calle que sale á Sanct Françisco, vido que la gente que consigo tenia se le salian, pocos á pocos, por los corredores, y en especial don Luis de Guzman, que fué uno do los primeros que se echaron de los corredores abaxo donde estaba el thessorero con la gente, diciendo que si le resçibiria. Y el thessorero çercó la casa con la ggente, é viéndose el factor çercado, é que los que le avian de ayudar se le yban é se passahan á la parte contraria, con buen ánimo, é como valiente liombre, se abaxó á la puerta con un tiçon en la mano é pegó fuego a la artilleria; é quiso Dios quel un tiro que salió, abriéndose la gente, no hiço mal, é fué á parar la pelota en una pared de Sanct Françisco; y en continente arremetió el thessorero é su gente y entraron por la puerta, é retrayéndose el factor á una cámara le prendieron, é le echaron una cadena é le llevaron presso por la plaça, é despues le pusieron en una jaola en la casa de Cortés é con mucha gruarda. Y el thessorero y el contador se vinieron á la mesma casa.

Cómo el veedor supo la nueva del mensajero que avia enviado Cortés, partióse con la grente de guerra que tenia de donde estahan para meterse en Temistitan é ayudar al factor su compañero, é supo en cl camino su prission, é luésse á Tascala, é metióse en un monesterio de Sanct Françisco que allí lay: é sabido por el thessorero é contador, enviaron grente por él, é metiéronle en otra jaola junto con el factor. Y en esta saçon çiertos españoles secretamente determinaron de matar al thessorero é contador, é sacar al factor é veedor de las jarolas; é negociaron con las guardas que al tiempo que diessen en el thessorero é contartor. quando estoviessen comiendu, ellos soltassen al factor é reclor. É porque las llaves de sus prissiones tenian el thessorero y el contador, descubriéronse á un Guzman, que era grand maestro de hacer vergas de ballestas é cerragero, natural de Sevilla, hijo de un judio (que el nombre ó apellido de Guzman no le venia ni le tiene por linage, sino porque fué su padrino uno de los del ilustre linage de los Guzmanes); y este les prometió de les haçer llaves ó gançuas ó darles limas para abrir las prissiones del factor é del veedor, é descubriéronle lo que estaba conçertado contra el thessorero é contador. Este Guzman les prometió que dende çicrtos dias les daria liecho el recabdo que era menester para soltar los pressos, é por otra parte fuésse al thessorero ó contador é díxoles lo que passaba: Ios quales encontinente prendieron á un Escobar é á otros de los que hablaron al Guzman en lo que es dicho, é á otros que ovieron por sospechosos, é degollaron los que avian ydo al Guzman, é pusieron otras guardas de nuevo más fuertes é fieles para guardar al factor é veedor. Y estando assi pressos subçedió la llegada de Cortés de la manera dicha: el qual liço luego elegir alcaldes é regidores, é privó é quitó de los officios é liço prender á Gongalo de Ocampo é á otros muchos de lat parçialidad del factor, é secretamente se haçia pesquisa de los que se avian levantado con ellos contra él.

En esta ocupaçion passaron veynte y çinco dias, y eu fin dellos llegó el liçençiado Luis Ponçe, que fué de España proveydo por juez de residençia, é aun se deçia tambien que avia de quedar por gohernador, é lleró por su teniente al liçençiado Márcos de Agnilar, é fué por alguaçil mayor el comendador Proaño, é po: alcalde fué el capitan Salagar de la Pedrada : é fueron assimesmo otros cavalleros é hiulalgos, é algunos religinsos de la 
Orden de Sancto Donningo, para la fundaçion de las casas de su Órden sagrada en aquellas partes; entre los quales fueron fray Thomás Ortiz, grand predicador, é fray Viçente de Sancta Ana, muy buen letrado, é fray Domingo de Sotomayor, hermano del señor de Orellana, é otras notables personas. Luis Ponce, sin repossar del trabaxo de la mar, con la gente más resçia que purdo seguirle (ó le pensó seguir) se partió de la villa de Medellin para Temistitan, porque le diseron que Cortés no le avia de resçelsir, é le dieron á entender que avia de salir al camino á le prender; é por esto se fué por la via de los pueblos á grand pricssa. É cómo Cortés supo la nueva de los indios (que en tres dias despues que llegó al pucto Luis Ponçe lo supo Cortés; aunque el camino es de ochenta leguas ó más), proveyó luego á dos leguas de Temistitan en un pueblo que se diçe lztapalapa, que se aparejasse el resçebimiento para Luis Ponce é su gente, é que se les hiçiesse grand banquete é fiesta, é le sirviessen Ios criados del dicho Corlés; é allí se le dieron muchos é diferentes manjares, entre los quales dieron unas natas, é puestas á Luis Ponçe comió unas pocas, é * las demás dió en el mesmo plato al padre fray Tlromás Ortiz, que cabe él estaba, al qual dixo el maestre de sala Hernando de Tapia: "Otras tracián para vuestra reverençia". E dixo el frayle: "Dessas ni de otras». É luego encontinente se levantó de la mesa Luis Ponçe, é revesó, é los más que con él comieron. É de aqui se sospeclı́ que le avián dado ponçoña, $\mathrm{y}$ el frayle lo afirmaba que avia seydo $\mathrm{cm}$ las natas: lo qual diçe esta relaçion que fué falso; porque como Luis Ponce é su gente yban del camino trabaxados é con hambre, é alli hallaron mucha comida, naturalmente se les avia de ofresçer mala dispusiçion é aquellos vómitos ć cámaras; que no de ponçoña, porque si ponçoña fucra, el comendirdor Proaño comió de todo lo del plato de Luis Pouce, é no enfermó ni menos revesó, é siempre esturo bueno.

Saliéronle ál resçebil Cortés con el thessorero é contador, y el comendador Avarado con todos los cspañoles, é assi entró en México, é apossentáronle en la possada de Cortés. Otro dia siguiente en Sanct Francisco, despues te aver oydo misa, pressentó las provissiones de Su Magestarl, é tomó las varas á los alcaldes é justiçias, é luego se las tornó á dar, é diso quanto á la vara de Cortés: "Esta quiero yo para mí ". Ẻ con mucha cortesia se salieron é se fueron á comer. Dende á pocos dias, salientlo un dia del monesterio de Sanct Françisco Luis Ponçe con una grand calentura, que realmente fué modorra, se fuć á la possada, y ccliado en la cama estuvo tres dias muy fuera de sí, cresciendo cada dia más el calor é gana de dormir; é los médicos que lo curaron, fucron el doctor Hojeda y el licençiado Pedro Lopez, y essos llevaron los términos en su cura de hombre enfermo de modorra, é assi siguió sus términos de mal en peor lasta el septeno, é allí ordenó su ánima é resçibió los sacramentos. É una tarde antes que muriesse, mandó que le tañessen una baxa, y él estando en la cama, con los piés la anduvo, é señalaha los compases de la dança con los piés, é luego se le quitó la Labla, é otro dia antes del alba espiró. Cortés, sabida su muerte, hiço tan grand llanto sccreto como si fuera su hermano. Enterráronle con mucha solempnidad en Sanct Erançisco.

El liçençiado Márcos de Ağuilar, aunque mal dispnesto, con el poder que tenia de Luis Ponçe gobernaba é romalua residençia á Cortés, é dende á dos meses enfermó él é su liijo de flaquega é calenturas, allende del mal vicjo que Márcos de Iguilar se tenia de las buas; é ambos 
I1trieron, é el hijo dos dias antes que el padre.

Despues de la muerte de Luis Ponce, estando enfermo llárcos de Aguilar, se partió el contador Albornoz á España, é quedó poder al thessorero para gobernar; é los de la parcialidad de Cortés no consintieron, é tomóse por conçierto que gobernasse el thessorero é Gonçalo de Sandoval, é assi juntamente gobernaron, é Cortés tenia el eargo de lo que tocaba á los indios, é los que es dicho gobernaban la tierra de los españoles é la cilbdad. El contador, llegado á la.corte, hiço relacion del estado de la tierra, é proveyóse que la persona que Márcos de Aguilar en su testamento señalasse, gobernasse hasta tanto que Su Magestad otra cosa proveyesse; é por esto gobernó el thessorero solo en todo, de lo qual subçedieron cosquillas entre él y Hernando Corlés. Y el thessorero, viéndose solo, é temiendo que Cortés le atropellaria, se confederó eon el factor é con el veclor, que estaban pressos; é la gente de sus amigos é parçiales se llegaron al thessorero, é con este favor recliaçaba las cosas de Cortés, ó no las haçia tan á su favor, eomo él y uisiera.

Subçedió en essa saçon que unos eriados de Cortés acuchillaron á un capilan, é prendieron al uno dellos, é aquel dia le hiço el thessorero cortar la mano derecha, é lo hiço tornar á la cárçel, é desterró á Cortés cinco leguas de la ciludad de Temistitan; é fué cosa de tanto escándalo, que se pensó que aquel dia se dieran de lançadas todos los españoles.

Oro dia siguiente despues de esto feclıo é Cortés desterrado, lo supo este reverendo padre, cuya es aquesta relaçion, que yba del puerto de la Villa Rica con el muy reverendo obispo primero de Tascaltecle, fray Julian Garçés, de la mesma Órden de los Predicadores, la qual provincia é obispado por nuevo nombre se dice el Obispado Carolense. É llegados á Tezcuco, é sabido lo que es dicho, con mucha priessa entraron estos padres en una canoa por la laguna, y en quatro horas fueron á la cibdad, é los dos monesterios, assi el de Sancto Domingo como el de Sanct Francisco, con todos sus frayles, con las cruces é clériggos de la igglesia mayor, llevaron en procession al dicho obispo hasta la iğlesia mayor, é dada la bendiçion, se fué á apossentar al monesterio de Sanclo Domingo; é otro dia, interviniendo aqueste perlado entre Cortés y el thessorero, los hiço amigos. Despues llegaron ciertas provissiones de España para que fuessen sueltos el factor y el veedor é les restituyessen sus offiçios é haçiendas, de lo qual é de lo passado aflixido Cortés, determinó de yr en España, y envió delante á un hidalgo natural de Sevilla, llamado Pedro Ruiz de Esquivel: é á cabo de treynta dias en la laguna en una isleta le hallaron muerto eubierto de tierra é piedras, é la una mano de fuera, la qual tenia comida de perros, y él estaba en calças é jubon, sin las cartas é dos barras de olo que llevaba; é una herida tenia en la traviessa de la frente, sin tener en su cuerpo otra alguna, é un negro suyo que llevaba nunca se halló ni los indios ni la canoa, en que avia partido de la ciludad de Temistitan, ni se supo quién lo mató.

Cortés, aderescando su viage para España, dexó su haçienda é casa, é por mayordomos nayores al liçençiado Altamirano é á Diego de Ocampo é á Sancla Cruz; é deçíase que la Laçienda quedala avaliada en doscientos mill pessos de oro. Él se fué al puerto con sus criados é amigos que á España llevó, é fueron con él Gonçalo de Sindoval é otros lidalgos de su casa en dos navios. Llevó indios prinçipales señores de la tierra, un liijo de Monteçuma y el hijo de Magiscaçin don Lorenzo, é otros muehos prinçipales se- 
ñores de Talscala é de Temistitan é Cempual, é otros indios: entre los quales llevalua doge jugadores extrenados de la provingia de Tascaltucle del juego del la ley, que es de pelola gruessil hecha de leche de çiertos árboles é otras mixturas, que salta la pelota mucho. É llevalua otros indios á maravilla diestros en un juego de un palo de mancra nunca en España oyda ni vista lıasta estos, que haçian con muclıa ligereça vueltas muy sutiles, en tanto que uno dellos rolteaba en el palo al son del areyto ó cantar, é contrapás, que otros ocho indios al rededor andaban con sonajas é atabales pequeños: como acalıalıa aquel de voltear, entraba otro de los mesmos, hasta que de uno eu uno todos ocho ó nueve que eran, avian fecho sus vucltas unas diferentes de otras. Llevaba enanos y enanas; llevaba indios é indias más blancos que alemanes. El oro que llevaba consigo eran veynte mill pessos de oro de minas, é hasta diez mill de medio oro, é dos ó tres mill en joyas, é mill marcos de plata labrada é por labrar.

Cómo llegóo á la isla de Cuba, tocó en la Habana, dende donde continuando su viage, llegó á España; é aqueste reverendo padre fray Diego de Loaysa fué hasta allí con él (digo hasta la Habana) é dende alli atravessó é naregó á la TierraFirme, é fué á se desembarcar á puerto de Caballos en la gobernaçion de Honduras, é dende allí fué por tierra á Leon de Nicaragua, donde yo le ví é comunicó conmigo lo que es dicho: allende de lo qual, preguntándole más cosas, me dió en la relaçion suya noticia de lo que diré aggora, de quél deçia que estaba muy bien informado y de muchos indios çerca del origen de Monteçuma, en esta manera:

El padre é abuclo de Monteçuma se halla aver venido de muy léxos de Temistitan, é conquistaron la ticrra, é los indios que en elli hallaron, eran clionda- les en las siemas, é otros de diverssas lenguas en los llanos; y el puelolo en mitald de la lagruna, las casas fectas isletas, é dos calçalias en la cildad grande, y edefiçios é uchilobos ó quies, que son casas donde tienen sus dioses y exerçitan su ydolatria. Oclıenta años se cumplicron quando fueron los cliripstianos á aquella ticrra, quel abuelo é padre de Monteçuma avian yolo á clla. La polılacion de lis cilklad scria de çinquenta mill reçinos. Otros muchos pueblos de indios, que fueron con el aludelo é padre de Monteçuma, polslaron al rededor de la laguna: diçen que boja, ó tiene de gircunferençia la laguna sessenta leguas. Es de agua amarg̣a, ó mejor diçiendo salolsre, y el pescado della malo é doliente. Los chripslianos derribaron todos los uchilobos é los apossentos de los prinçipales, é allanaron la cilıdad, atapando las calles del agua é fundaron sus casas de cal é canto é madera de çedros tan buenas é mejores que las lıay en España. Hernando Cortés tiene dos casas prinçipales en los mesmos assientos de las casas de Monteçuma. El tianguiez es quassi dos tiros de ballesta, é allí se juntan grand moltilud de indios con sus mercaderias, é cada género de cosas está en su lug̣ar situado: é pagan á los señores de la tierra çiertos derechos por aquel suclo, donde haçen su tiangiez ó mercado, é los señores son obligados á no consentir haçer agravio ui hurto á los tales mercaderes; é los litigios que resnltan de comprar ó vender tambien los determinan. Los enterramientos del abuelo é padre de Nonteçuma no se hallaron, é muchos indios quieren deçir que Monteçuma los enterió en la laguma con grand suma de oro, en un edefiçio que hiço debaxo del ağua (no se ha sabido en qué parte), exçepto que una fuente medio quarto de legua de la cilsdad de Temistitan, que se llama Tapnstepeque, está al pié de un repecho de una sierra muy alta 
é áspera, que es quassi peña tajada, en aquel repecho están dos figuras fechas en la peña viva, é diçen los indios que son el padre é abuclo de Monteçuna (entrelalladas é como en fiesta de areytos, con una maçana en la mano é una rodela en el hraco, assi como ellos en sus fiestas solian estar). É luego allí á par hay una escaicra que sube á un uchilobo á manera de ermila, que está sobre la cumbre de la sierra.

Aquella gente é sus costumbres es mucho lo que se puede deçil dellos. Comen carne humana : haçen sacrifiçios maIando muchos indios; é abriéndolos por los pechos é sacándoles el coraçon, le arrojan al sol. Los que lienen cargo de los uchilobos se llaman papas (que quiere decil persona sancta). Muchos dellos no comian sino solamente la sangre de los que sacrificaban. Estos aborresçian el coyto é no conversaban con mugeres, é mucho más el pecado de la solomia: é antes que tengau cargo del uchilobo, han de tener su año de aproLacion sin salir del uclitobo, é al cabo del año, si quieren quedar en aquellos templos, les passaban unas varas por las lenguas, é quedaban alli en el templo para siempre: nunca se cortaban ni peyualaan los cabellos. Estos hath de ser hijos le caçiques é hombres prinçipales: é los que quieren salirse no entraban más en el templo para servir en él.

Los españoles, despuesde aver allegadoá Temistitan é polılados allí, envió Cortés á Panuco al comendador Pedıo de $\mathrm{Al}$ varado é Chripstólal de Olit, é despues de pacificado, poblaron un pueblo que se llamó Santistebau. Despues fué Françisco de Garay con quatroçientos hombres, é sabido por Ilemando Cortés, tornó á enviar á Alvarado con gente, é Cortés le siguió luegro; é la gente de Garay se per.

* En el MS. de Oviedo hay un claro, que no es Ti) $110 \mathrm{III}$. dió, é por lnenas palahras Garay en son de presso fué llevado á Temistilan, donde dende á poco murió de dolencia , é orros deçian que de enojo: dexó por su allagcea é lestamentario á Hernando Cortés. Poblóse la provinça de Guaçacalco: pohlóse en el puerto de Sanct Johan de Lilla la Villa Rica, la vieja que diçen, e çinco leguas de allí otro pucblo que se llamaha Medellin. La Villa Rica se despolıbó en el liempo que gobernaba el factor Gonçalo de Salaçar, é se pobló mnís abaxo á la vera de un rio á media legua de la mar é quatro del puerto; é por ser buen assiento é sano, é que las barcas entran cargadas dende los navios á las casas del pueblo, é Merlellin ser enfermo é grand trabaxo para llevar las mercaderias, se deshiço cn el tiempo que gobernó el thessorero Estrada, ć se passaron los veçinos á la Villa Rica, é se hiço una cibdad de doscientos veçinos, que se llauna la cibdad de la Veracruz. Orro puedilo en el tiempo que gobernó Alonso de Lstrada se fué á haçer en los llanos de Chia. pa, quarenta leguas de Tegoantepeque, dentro en la tierra que ticne las minas del oro, á quatro leguas del pueblo, el qual fué á polılar Maçariegos, primo del dicho thessorero. En Guaxaca hay minas le oro: pero moríanse los indios por ser la tierra caliente.

Los monesterios que primero se fundaron, fueron de la Órden de Sanct Françisco Ires, uno en Temistitan, otro en Tiscaltecle é otro en Cempual: olro está treçe leconas de Néxico, en. . . L Los religiosos señalados de aquella Órden y primeros en aquellas partes fucron el padre fray Pedro Meluarejo, fray Dicgo de Soto, fray Johan de Valencria Custodio, varon muy religioso, é otras personas de alta religion é buena vida de la mesma Orden. De Sancto Domingo eslá fundado en Temistitan un moncsterio 
muy sumptuoso, y en la cibdad de la leracruz otro, é otros en otras partes é provinçias. Hebispo pimero que fué á la Nuera Espana fué el de Tascallecle, llamado fray Julian Garcés, del que se ha hecho mencion de susso, de la mesma Orden de los Predicadores, luena persona por sí é do limpia sangre. é hijorlalgo 6 grand letrado. Hay fundadas muchas iglesias en la mesma ciludad de Temistilan, é hay iglesia cathedral é perlado, que es el obispo fray Johan de Carraba, de la Órden de Sinnel Françisco, en el rual obispado entrabi la cibdad de Guaçacalco é Tepeaca é la Villa Rica, la qual iglesia es muy bien servida con sus dignidades é canónigos é clero.

Dende el puerto de Sanct Johan de Ulua á la cibdad de Temistitan hay dos caminos, uno de poblaçiones de indios é otro despoblado; pero con muchas ventas é buenas, donde se halla todo lo nesçessario, é por este camino ran todas las recuas, que por el camino de lós pueblos, si no son españoles á caballo, pocos ran. Llímase aquella grand cibdad en lengua de los indios naturales della Temistitan, é assi la solian Hamar: é dentro della avia dos parçialidades é bandos de scñores; unos se deçian mexicanos é los otros tatelucos, e los españoles correspondiendo al proprio nombre, la llamaban México. Acuérdome por este nombre que en Plinio lıay otro que le paresçe; pero aquel tiene una $A$ más, é llámase Améxico, y es en Asia aquel pue. ho, que dice el auctor alegalo assi: a El primero lugar de Troade es . Iméxico, despues Crebenia y essal Troade llamada Antigonia, hoy Mlexandria, colonia romana, cte. '"

Tormando á la relaçion de nuestra materia, dige que la cilodad de Temistitan cita desta nuestra mar del Norte oclienta leguas, todo de muy buenas poljaciones c de muchos indios, é otro tanto poco más ó menos lay dende la dicha Temistilan á Tergoantepeque, que es grand cibdarl é puerto de mar en la costa de la mar del Sur, donde se hiçieron quatro navios que llevó á la Espeçieria Alvaro de Saave. dra ál bnscar al comendador frey Garçia de Loaysa, que avia ydo por capitan general de Su Magestad á la Especieria, como se dixo en el libro XX, capítulo III, ć dende adelante en la segunda parte pressente, y en el capítulo XIII é capítulo XXYI é dende adclante. Este capilan Salavedra fué á diez é ocho de otubre del año de mill é quinientos é veynte y seys proveydo de bastimentos para un año, é avia de dar la vuelta el un navio de los quatro el siguiente año por Sanct Johan de mill é quinientos é veynte y siée, para el qual tiempo avian de estar otros quatro navios aparejados á la lengua del agua para proveer de gente é bastimentos para passar adelante á descubrir la Especieria. Por manera que con lo que vá dicho se concluye la relaçion del dicho reverendo padre fray Diego de Loaysa. 


\section{CAPITULO L.}

En que el chronista escribe, ú mejor diçiendo, copia una breve relaẹion que le fué enviada desde la cił.dad de Veneçia *, adonde la avia enviado el señor visorey don Anlonio de Mlendoẹa á su hermano el señor don Diego de Nendoça, embaxador lé la Çessárea Niggestad en la dicha Vencẹia; é púncse í la leıra el capilulo que ell esto habla, é diçe despues el chronista su parescer en cl mesmo caso.

E en la Nueva España un minero de piedras muy negras é duras, que enmedio tienen çierta rena colorada muy viva, como rubí: envia dos aras á Su Magestad, é ha mandarlo cortar un suelo para una estançia . Cosa extraña! Envia en seys naos gran cantidad de dinero á Su Magestad é particulares. Escrilıe el dicho á don Diegro, su hermano, que la fundaçion de Temistitan fué desta manera: Que vino de la parte del Norte láçia la provinçia de Panuco un capitan que Ilamalsan Orchilobos; con quatrocicntos hombres bien ordenados á su modo, con armas de plata é de oro, estando los de México en guerra con los de Tascala, é que se metió á ayudar á los de Néxico en la guerra, los quales por su industria y esfuerço fueron vençedores; $c$ que viendo el lugar aparejado en una laģuna que allí era, la qual tenia una estrecha entrada de peñas, que yba á una isleta ó roca de peña que estaba quassi isla ennedio de la laģuna, conıençó á habitar con su gecnte, é liço una pequeña tore de piedra, que despues quedó por templo mayor de Orchilobos consagrado á su nombre: en la qual se recogia, é de allí poco á poco fué mandando é sojuzgando los reçinos

- De este punto suprimii cl antor las signientes cláusulas, que no eareeen de interís y contribuyen á ilustrar su vida: "Por el dolto é muy enseñado varon Hiẹer Johan Baptisla Ramussio, sceretario de aquella ilustrissima Señoria, aniẹissimo espeçial del auctor desta General historia de Indias, la qual relaçion diçe este secretario quel muy ilustre
Lasta haçerse señor de México; y en las provinçias comarcanas fué allegando assi pobladores hasta que la habitaçion cresçió en forma de cibdad. Hecho esto, dió las leyes: la prinçipal dellas fué quel más valiente é mayor capitan fuesse entre ellos su rey. Dióles gerimonias, órden de sacrifiçios é leyes de conubates é duelos. Despues, juntando la grente de la cibdad, dixoles una nuy larga labla, en que les liço saber quél era enviarlo de Dios é queria tornar a él; que le esperassen, que quando ellos más nesçessidad tuvies. sen volveria á ellos, é assi se despidió con los que quedaban de su gente, sin llevar otra cosa más de lo que avia traydo. É se fué ál la parte de Guatimala, dende donde creen que se partió para el Perú, porque hay relaçion que en aquella provinçia hallan çierta órden de sacrifiçios è vestigios de Orehilobos.

Los de México gutedaron sin señor muchos años; é porcutue donde Orchilobos hico la primera habitacion avia un árbol, porque el fructo dél se llamaba assi, é porque tenian por sol á Orchilobos, llamaron al árbol árbol del sol, é á la ciludad de Temistitan, que era deçir fructo del sol. Despues cligieron rey, é de nuo en otro vinicron a Guateguma, al qual eligicron

geñor don Antonio de Menrloẹ, visorey de la Nueva España, envio al Emperador Rey, nuestro seĩor, del origen ¿ fundaçion de Temistitan; y otra tal copia envió a su hermano, cle." Tambien del final del capítulo quitó algunas cláusulas, pero de menos sustançia. 
por rey por su vertul of valentia, o porfore filmulosamente degian ser hijo de Opchilolos.

bigen que en el templo die Orelilolos

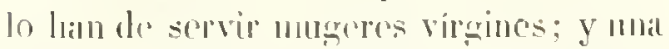
destas mu dia limpiamdo al velolo, se le eayó una plunua, ć tomándola é poniéndola en los pechos, se durmió é soñó que venia á clla Dreluilolos é que dormia con clla. En fin. gucoló preñalia, é dende á poco parió á Grateçuma, é por cxcusarse le la pena é por haçer mayor su hijo, rontó lo fute le avia acarescrido: los de Temistitau, no la ereyeudo, la desterriron de lá cilstarl, y ella se fué á gierta movinçia, diçióndoles cono en profeçia fue aquel niño seria su rer. Despues, venido Guatecuma en edad, fué tan valiente, que diçen que rençió veynte é siete campos por su persona, é cómo era lan estimalo é mas hermoso que los otros, dieron féc á la fábula de su madre, é liiciéronle capitan contra los de Tascala, los quales fueron siempre perpétuos enemigos suyos. Guatccuma vençió los de Tascala é mució allí. Que Monteguma era jóven, el qual de la edad de doçe años le tomaron por capitan contra las provinçias comarcanas, é salió tal, que con su valentia los sojuzgóo á todos é liço triluula. rios los de Tascala. Hícose elegir señor de la tierra. Era tan cuerdo é tan sabio que quassi lo adoraban, é tan valiente rue por su persona vençió diez y ocho campos.

Quando vino Cortés con los españoles, los de la lierra lo rescilieron, pensando que fuesse Orchilobos, el qual en su cuenta dellos avia quatroçientos años que era partido. É todo esto é otras historias tienen ellos en sus libros de sacrifiçios escriptos por figuras, los quales haçe el visorey interpretar para enviar á Su Mlasestad con un libro, que hace hacer de la rescripçion particular de las proviuçias. pueblos é fructos do la tirma, é leves. é costumbes é origenes de la gente.

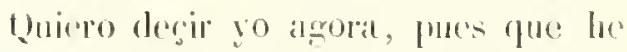
dicho lo gue de Penergia alfuel nui es-

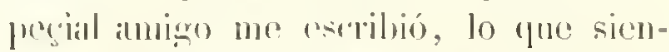
to destal relateion del siñor visorey hechal al Emprialor, mestro señor. is croo hien quál escribió verdad, segund firé informado, pues demás de ser personal ilustre, es silhio é hounhre de muchat prodonçia, é si en alogo sus intérpetres no ronsuenan con lo cirrto, el es descoulpado é amm yo en lo yne dixere, discantando ó apuntando la relaçion cue están dicha. É será bien que passo por passo la vaya satisficicndo en algunas cosas, que paresce que le compadusçe ó ha lugar el replicato; porepue son cosas notables é de pesso ó calidiad, é se han de ver é leer por hombres que son aurigos de especulaçion de estas cosas, é amo por los que han estado en la Nueva España, que si no en torlo, en parte sabrán apuntar lo que no podrán los que no lo han visto.

Quanto á las piedias muy negras é minero dellas, sin duluda creo que debe ser assi, porque en esta ciludad de Sancto Domingo lay algumas que se han traydo de la Nueva Espana, tales como es dicho, exçepto sin aquella vena colorada, viva como rubí, pero sin tal vena yo la he visto de allá lrayda: diggo no tan colorado cono rubí, pero como leonadas de forma de jazpes, é otras todas negras é muy hermosas, é lan prictas é lustrantes como açabache muy polido. E destas piedras se han llevado á España muchas é á esta cilsdad de Saucto Domingo, é se haçen muy hermosas aras: yo he tenido quatro dellas y tales como digo.

Quanto á la grand cantidad de dinero que á Su ulagestarl se envió en seys naos, muchas é muchals más van siempre te todas estas partes ó Indias que llevan á Su Magestad é á parliculares grandíssimos thessoros de oro é plata, é no me quicero 
detener en esso, porcute es cosa tan gran. de é tan notoria como todos los hombres saben en España é fucra della en la mayor parte del mundo.

Quanto á la fundaçion de Temistitan, que diçe que acquel capilan llamado $\mathrm{Or}$ chilobos fué de la parte del Norte háçia Panuco é de alí á Jéxico con quatroçientos hombres, armados de oro é plata, é cuenta la forma que turo para se haçer scñor, é les dió leyes é çerimonias é órden de sacrifiçios é leyes de combates, é que les hiço una hallak, quando se quiso yr, prometiéndoles de tormar cquando más nesçessirlad tuviesen; é que se fué láaçia Guatimala, é creen que de allí fuć al Perú, porque hay relaçion que allá hay vesligios de sacrifiçios é Orchilobos; é diço más, una manera de fábula de cómo fuć engendrado Guateçuma de la pluma del ydolo que su madre se metió en el pecho, é cómo fué lıerho señor por su esfuerço é grand ser de su persona, é despues fié su hijo Monteçuma. É diçe que á Cortés le resçibieron los indios de la tierra, pensando que era Orchilobos, que volvia á cabo de quatroçientos años que avia que era ydo, é que estas é otras historias tienen por figuras en sus libros, etc. í esto digro que es muy diferente la relaçion que Hernando Cortés escribió al Emperador, nuestro señor, segund el mesmo Hontecuma le dixo, como más larganente queda escripto"en el capítulo $V$; é allí no dice que de la parte del Norte viniesse Orchilohos, sino de la parte de Levante, háçia donde el sol sale; é tambien diçe que ya esse capitan volvió é no le quisieron resçehir, é otras cosas mucluas é apartadas de la relaçion que se hiço al visorey. $\mathrm{Y}$ es de creer que Monteçuma mejor estaria informado de su generasçion é orígen que no los nuevos ó modernos informadores de agora: quanto más que lo que dixo á Cortés Montesuma fué en pressunçia de los más prinçipales de su seño- rio, de los quales pocos 6 mingnnos lay al pressente de aquellos ançianos é sabios que estonçes avia. É más adrlante en el capítulo IX el mesmo Mlonteçma, reyterando la mesma relacion del orígen á sus vassallos en pública audiençia, en pressençia de Cortés é de los españoles, dí raçon de cómo vinieron á la tierra sus anteçeśsores. Demás desso, en la relacion que se tracta en el capítulo XLV, se cuenta la forma (jute Monteçuma turo -para se haçer señor de Temistitan, ayudando á la parçialidad de los mexicanos contra el bando de los que seguian la parte ó apellido Tatelulco, tomando cautelosamente por yerno al señor de diclıo bando, llamado Samalçe, y en una fiesta ó banquete le hiģo matar á él é sus capitanes, etc. Y en la relaçion antes desta del visorey, en el capítulo XLVIII, diçe quel parle y el abuclo de IIonteçuma vinieron de muy léxos de Temistitan, é conquistaron la ticra ochenta años antes que los chripstianos fuessen á cella.

Lo que á mí me paresce es, que no se debe creer fue, caso fuel orígren de Monteruma fuesse Orchilolıos, él oviesse venido de la parte del Norte ni de la del Perú, que está de la Nueva España puesta á la parte del viento Sueste: antes se debe sospechar que fuć de la parte de Nicaragua, ques provinçia más oriental que Guatimala, en la costa del Sur, de la mesma lengua que se liabla en la Nueva España, la qual Guatimala estít entre lo uno é lo otro. É los orchilobos é sacrifirios, é comer carne humana, é otros ritos, as. si como sacrificarse las orejas é lenguas é miembros generativos, é otras muchas cosas que acostumbran, todo es de una manera, ó muy conlorme. í assi pienso yo, é pensarín los que vieren aquella licrra é leyeren lo cues dicho, ques justo que se piense que no del Perú, sino de Nicaragua ovicron orígen essos indios e su capitan Orehilobos, li los mesmos 
orchibolos 6 quíes ó templos ó yololos tienen por aquella costa: é lo del Porí es muy extraño é apartado desso. assi cu la lengua como en lo demás. Ý este nombre Perí es improprio, porque no es de appuella ticra ande ol gobernator Pigarro ó Almagro lan andado, donde Atabaliba fué señor, sino muy más cerca del Darien é de Panamá, como se dirá en su luçar, quando se tracte de la tercera parte desta General historia.

Quanto á la clecesion de Guateçuna, padre de llonteguma, me paresge que pues diçe essa relaçion que avia quatroçientos años que Orchilolsos avia ydo, no consuena con lo que Cortés é otros diçen que entendieron de Monteçma é otras personas; pues Montecuma diçe que tambien su abuelo fué señor de arpuella tierra, é quel abuclo y el padre vinieron á clla.

Quanto á lo que diçe essa relaçion que viniendo Cortés con los españoles, los de la lierra los resçibieron, pensando que fuesse Orchilobos, tampoco se debe creer; porque como la historia la contado, an. tes que Cortés fuesse, avian ydo Johan de Grijalva é Alvarado é otros, é antes que essos Françisco IIernandez de Córdora, é les avian muerto chripstianos: é lo mesmo hiçieron á Cortés, é lo echaron de Temistitan más que de passo á lançadas, ó le mataron la mayor parte de la gente.

Aquel sueño que diçe de cómo fué conçebido sa padre de Nonteçuma, me paresce mucho al cuento de Rea, madre de Remo é Rómulo, virrgen vestal, que otros llaman Ilia é otros Silria. como más largamente lo escriben Plulareo é Tito Livio '; é la una fálbula é la otra se quicren parescer. Officio es de las malas buscar excusas para encubrir é dorar sus delictos é Iuxuria; é digo dorar, porque no solaunente los encubren, pero háçenlos mira- glo. La madre de aquellos fundadores do Roma, los quiso laçer hijos de Marte, dios de las hatallas cutre los antiguos gentiles. I esta otra que se durusió con arjuella pluma en el pecho, quiso hireser á su hijo divino, pues dliçe en essa relaçion (pue Orehilobos era enriado de Dios, é que dixo, quando se fué de Temislitan, que se tornaba para él. Por manera que, resolviendo mi opinion, los anteçesores de Montccuma son de la mesma costa del Sur de Nicaragna é de aquel golpho de Orotiña; é de allí alıso hrícia cl Ocidente é por ticra pudieron yr muchos á sn plaçer á la Tiueva España. É no es cosa nueva en el mundo á los capitanes transportarse de unas provincias é partes extrañas en otras, é adquirir nuevos estados é señorios.

Quanto a lo demás, en la forma de se enseñorear en la tierra Monteçuma é sus progenitores, dicho está lo que he podido entender, aunque direrssamente congecture: é lea el que quisicre ser bien informado é tome destas historias lo que viere ques más veriśmil pues que en la verdad, assi como un jucz no puede rectamente juzgar sin quel litigio se concluya, despues de aver las partes hedio sus probanças, é acuellas examinar é probar sin passion; assi tampoco no puede ningun sabio letor determinar ni desecedir la medula é rerdad de la historia con rectilud, ni de algun libro sentençiar semejantes dubdas, si no lo passare todo é llevare continuada su leçion.

Por manera, que tornando al diseurso de la gobenacion de la Nucva España, digo que á los gobernadores ques dicho, subredió nuestro obispo desta ciludad de Sancto Domingo de la Isla Española, don Scloastian Ramirez de Fuenleal, presidente de la Real Audiençia ó Cluancilleria que aquí reside; é por ser 
tin experimentado en las cosas de la justiça, le mandó la Cessúrea Magestad yr á resillir por presilente de la Chançilleria de la Nueva España á Temistitan, donde fué é la reformó é tuvo muy bien gobernada, é dexó en mejor estilo que hasta alli avia estado. É de allí le mandó Su Magestad gr át Castilla, é le hiço obispo de Leon é presidente de la Real Chancilleria que reside en Valladolid; é mandó yr á gobernar la Nueva España al dicho señor visorey don Antonio de Mendoca, el qual es el primero que tal título de visorey ha tenido en aquella tierra.

Despues de todo lo que está dicho hay grandes nuevas de la nueva tierra, que se la desculierto dende acpucllas partes híçia el Norte, solsre la qual el marqués del Talle y el dicho visorey debaten: $y$ esto se dirá en el libro II de la teregera parte que será el XL de la Natmal historia destas Indias, porque me paresce que alli quadrará mejor; pues assimesmo aquel libro, como este, compele á la Nueva Espaĩa, é tracta de las cosas della.

Passemos á lo que nos queda por deçir para la conclusion deste libro XXXIli, hasta quel tiempo nos muestre otras cosas que se puedan acomular en él.

\section{CAPITULO LI.}

En el qual se tracta una sumaria relacion, en que se relata la forma que en la Nuera España tenian los indios en pagar los tribulos ả Monteçuma é á sus señores, untes que allá fuessen los chripstianos, porque agora ya assi en lo que se dirá como en otras cosas, hay olras costumbres é novedades: é demás de lo que toea ả los tributos é agrieoltura, se dirán otras cosas en que la historia hasla aqui no ha feelo mencion, que son notables é dignas de se oyr.

I lo que yo he porlido inquirir é saber de personas de crédito, é que dende los primeros españoles que con Hermando Cortés militaron en aquella conquista ellos Supieron comprender, es la gente más pobre que lay entre muchas naçiones que liasta el pressente se saben en estas Indias. No tienen en sus casas numchle ni restuario más quel que traen sobre sus personas, ques muy pobre, é una ó dos piedras de moler maliz, é unas ollas para lo cocer, é ina estera, en que duermen. Su comida, por la mayor parte, es lierbas coçidas con axí, é pan; é comen poco, no porque no comerian, si más alcançassen, puesto que la tierra es muy fértil ú de grandes mantenimientos é cosecha; pero la grente comun é plelocos son tan tiraniçados de sus señores indios, que a la inayor parte les tasan los mantenimientos en esta manera. Solos los seño- res, é algunos sus parientes é algunos principales é mereaderes, tienen heredades é tierras proprias, é las venden é juegan, quando les paresce; $y$ estos las siembran é cogene ó no tributan ellos ni ningunos officiales, como son albañiles, carpinteros, cotros (ue hacen plumages. plateros, cantores é atabaleros, porque ningun sẽ̃or indio lay que no tenģa músiea, ć cada uno segund su estado. Todos estos no tribulan con más de tributo servil cada uno con su persona, quando le han menester, é no se les dá paga alguma í ningruno dellos.

Toda la gente plebea, cada señor indio en su tierra, quando á ella se vienen de otras partes á pololar (é á los que estín poblados) les dan ticrras en que siemlren, señiladas que cada uno conozca las tierras que la de sembrar. I la mayor parte dellos tienen su casa en la heredad que ticnea por suya; y entre reynte é 
treynta é quarenta é çincpienta catsas ticnen un indio prinçipal que se diçe tiquitlato, que en leigua castellana quicre deçir tributo halla ó tributo pide, ques quassi como en Castilla jurado de collaçiones. Al tiempo de coger al mahir, este tiquitlato mira la sementera é lo que cadia uno coge, é cogidlo se lo manifiestan, é cuentan las magorcas del mahiz que cada uno coge, é cuenta las mugeres que cara un vassallo tiene de los queste tiene á cargo, é los hijos. Y estando delante la cosecha ó pan que cogió, haçe cucnta quántas macoreas ha menester cada persona de aquella casa lasta otra cosccha, é aquellas dá al indio dueño de aquella casa, é las de sus mugeres é hijos; é lo mesmo latce en las otras semillas, que son frésoles, qualssi á la manera de haluas pequeñas; é axí, ques su pimienta; é chia, ques tan menuda como mosiaça, que la tienen para beber, molida, hecha un brerage en agua, que beben en tiempo de calor, é por medecina tostada é molila; é cacao, ques unas almendras que corren por moneda, é las beben molidas hechas brevage; é algodon, donde se coge, que se dá en lierras calientes é no en las frias, é pulque, ques su vino: é todo lo que de aqueIla planta del maguey se coge, que dél se lıaçe para comer é beber é calçar é restir, y este se dá en tierras frias, y es á manera de canila las hojas, pero mucho mayores. De todas estas í otras cosechas no le queda al vassallo más de lo que ha menester para sustentaçion de un año; é demás desto ha de grangear el vassallo para pagar el tributo de mantas, oro, plata, cacao, miel, cera, cal, madera, ó de lo que en aquella ticra se coge, ó lienen costumbre de tributar; y este dan de sessenta, ó septenta, ó quarenta, ó norenta dias, ó como se conçicrtan. I este tributo coge assimesmo aquel tiquitlato é lo lleva á su señor indio: é desto dá á su amo el chripstiano, yue le tiene encomen- dado, el tributo que le licne tasado que: dé al amo, ó al corregridor del pueblo ó pueblos que al pressente están en corregimiento. Ĺ assimesno le lleva gallimas las que cria, que no las osa comer ni se aprovecha de más que de los limevos, é anin no de todos.

Al tiempo de los sessenta ó çient dias, ó los que han de ser, quando lia de dar el tributo, dicz dias antes recoge en casal del señor indio lo trasido por los tiquitla10s; é si algun pobre indio no puede cumplir lo que calve de trilsuto, ó por enfermedad ó polsreça, ó que no lialla dónde trabaxar, diçe el liquitlato al señor que fulano no quiso cumplir la parte del tributo que le avian echado: é manda el senor al tiquitlato que al tal vassallo que no quiso cumplir, le lleve á vender por esclavo á un liangüéz, que quiere deçir mercado, que se laçe de çinco en çinco dias en todos los pueblos de la tierra, é del presçio quel tal indio es rendido se paga el trilsuto. I porque alguna vez acaesçe que la justiçia real del Emperador, ques administrada por los chripstianos, si por caso salve que los tales indios por tal causa son vendidos, lo estorba é los pone en libertad; pero los tales no osan volver á la lierra de aquel señor, porque no los sacrifiquen, é vámse á vivir á otra parte.

Ninguna misericordia ni caridad.alguna hay en los señores indios, ni cosa alguna hagen por virtud, sino por temor: ni aun al diablo no le haçen fiesta por bien que le quieran, sino por miedo que le tienen; que diçen que si no le sacrifican ó hacen fiestas, les apedrea los panes y lieredades, é los destruye. Son aquellos indios muy laraganes é oçiosos, é vínse ellos á emborrachar y envian las mugeres í cavar é sembiar é coger, é a los otros trabaxos: esto por la mayor parte, puesto que todos trabaxan algunas reçes (non olsstante que las vean muy preñadas, las la- 
çen trabaxar é huelgan ellos); mas comunmente se acostumbra lo ques dicho.

Todos los pueblos tienen tierras proprias, señaladas de mucho tiempo lá, para la fábrica de los orchilobos ó quies ó templos, en que tenian sus ydolos; y estas tales tierras eran é son de las mejores. É tienen esta costumbre: que al tiempo de sembrar salian todos á voz de conçejo á sembrar estas tierras de las fábricas, é á escardarlas á su tiempo, é á benefiçiar los panes é cogerlos y encerrarlos en una easa, donde residian en cada templo mayor el papa é los teupisques, pioehes, exputhles é piltoutles (comó quien dixesse obispos, dignidarles, é eanónigos é raçioneros, ć hasta moços de coro: que eada templo tenia estos çinco géneros). É desta eosecha se mantenian, é les eriaban gallinas que eomiessen.

En todos los pueblos tenia Monteçuma sus tierras señaladas, que le sembraban por la órden que á los templos, é lo que se eogia, se lo llevaban á cuestas á la grand cibdad de Temistitan, de donde no tenia gente de guarniçion, y en los pueblos donde la tenia, eomian deste pan su gente de guerra; é si no lo sembrahan, el pueblo les avia de dar de comer, é demás desso les avia de dar gallinas é todos los otros mantenimientos nescessarios.

Porque cumplamos lo quel título deste capítulo LI promete, ques dar relaçion de cosas en que la historia hasta aqui no ha fecho mençion, que son notables é dignas de se oyr é de mueha ealidad, digo que la sagrada religion chripstiana está muy adelante, é se sirve Dios, Nuestro Señor, en la conversion de aquellas gentes. É aunque los religiosos dominicos é de las otras Órdenes laan bien trabaxado en reduçir aquella tierra é naturales della á la union de la Iglesia chripstiana, prinçipalmente es aqueste mérito é más lıan hecho en ello los religiosos de la Órden del glorioso Sanet Françisco, predicando y TOMO III. enseñando eon mucha atençion é vigilançia contigua los indios de aquellas partes cómo se salven, é mostrándolos á leer y escribir é grammática, é todas las otras buenas costumbres que para su salvaçion son menester. É ha llegado este saneto é loable excrçiçio tan adelante, ques para dar muchas graçias á Dios ver los muchos monesterios de todas Órdenes, é los habilíssimos indios muchachos é mançebos que hay buenos latinos, é grandes é diestros eantores é músieos en diverssos instrumentos, assi de saeabuches é cheremias é eomo biguielas de arco é de mano é flautas é órganos, que en España é Italia, é donde quiera que la música bien se entienda, serian estimados los tales indios, eaća uno en su espeçie. É porque es justo que de tan buen varon haya memoria, digo ques notorio que entre los otros predicadores de la verdad evangéliea, fray Pedro de Angulo, de la Órden de Sanct Françisco, ha fecho tanto fructo en aque. lla tierra, que son muchos los millares de indios que ha eonvertido é quitado de la eondenaçion infernal, é traydolos á la earrera de su salvaçion. $\mathbf{E}$ porque es cosa notable é maravillosa é notoria é apropóssito de la eonversion de aquellas gentes, se eseribió á esta cibdad por personas de mucha auctoridad é crédito é religiosos quel año passado de mill é quinientos é quarenta, en México, paresçió una cometa sobre la cibdad muchos dias, é pas. sados, començáronse á morir todas las gallinas de Castilla en toda la ciludad: é mandó el visorey pregonar, só çiertas penas, que nadie comiesse gallinas: é dende á pocos dias començáronse á morir las ovejas é yeguas, é un hombre que eomió de una oveja se murió (digo de las que assi se morian).

Despues desto començaron á derriharse é salir de las sierras é montañas de treynta é quarenta leguas léxos de Temistitan infinidad de indios, que nun- 
ca avian oydo nueva de Dios alguna; é vinieron á la cibdad, pidiendo que los baptiçassen: y eran tantos que no se podian quantos frayles avia en toda la tierra dar manos á los dottrinar, é otros á haptiçar. Y era tanta su constançia de los indios en esto, que sufrian caerse de hambre é de sed muertos; é deçian que antes querian morir assi que volver á sus tierras, sin se baptiçar. Fué cosa de grrandíssima admiraçion su perseverançia, é juiçio çierto divino.

Pocos dias há que supe de un religioso, hablando en aquella tierra, que avia visto é halládose pressente á este miraculoso aucto é conversion; é aun deçia quél avia ayudado á tan sancta obra. Tambien le oy deçir que ver las repressentaçiones é farsas de devoçion que los niños é muchachos repressentan é reçitan en lengua castellana é latina, en versos é prosa, que en Italia ni en Castilla no se podria haçer mejor por los naturales españoles ó italianos.

Acuérdome de mi descuydo en aver dexado de deçir en otra parte desta historia, que en la Nueva España hay é se haçe innumerable seda, é bay infinita grana, que tambien se puede deçir exçelente púrpura ó carmesí: hay mucho é muy buen alumbre, é assimesmo mucha orchilla, que son cosas de rico tracto é mercaderia; é aunque no sea cosa de tracto, ni de las que buscan los hombres para enriquesçer, hay clavellinas de mucha suavidad de olor é de extremada manera, á lo menos para mí es cosa nueva, é que no menos, sino mucho más me holgaria con ellas que con essotras mercaderias los mercaderes, porque son amarillas é de çient hojas cada clavellina. Al propóssito de las quales clavellinas é de los muchos jardines que hay de otras rosas é flores de muy suave olor é fragançia, é aun para sacar de la dubda en quel letor puede aver quedado de lo ques dicho çerca de los tributos é pechos que los indios scñores ponen, estrechando á sus inferiores con tan grave é cruel pena, como vender é sacrificar al que bien no paga el tributo; é para que se entienda cómo lo pueden cumplir, me queda de deçir una grand particularidad para satisfaçion de todo esto. Y es, que assi por ser la tierra muy abundante de caça é monteria de diverssos é innumerables animales é aves, como de muchas é zrandes pesquerias en las lagunas é rios, como en aver siempre en qué trabaxar é ganar los merçenarios jornaleros en diverssos exerçiçios, como demás desso en la hortaliça é jardines de las flores, é haçer maçetas é ramilletes é collares é guirnaldas dellas para vender ( $y$ en otras muclias é diverssas maneras); siempre ballan é tienen en qué entender y en qué ganar (por la mucha confrecuençia é moltitud de gente, é por la grand fertilidad de la tierra, é por sacar oro é plata y en otros muchos exerçiçios) los que quieren trabaxar é darse á grangerias con que paguen los dichos tributos que son allende de la agricoltura, ó que pueden haçerse en tanto quella se cria y en todo tiempo. É pocas veçes acaesçe que se execute la riģurosa pena ques dicho, sino por ser notorio é bellaco haragan el que en ella incurre. Pero de aquella grand subjeçion é tirania é cruel castigo, é de andar el diablo tan soçiable y exerçitado entre los indios con sus abominables ritos é sacrifiçios, agora ya dexando essos errores é convirtiéndose á la fée cathólica, é con la equidad é buena justiçia é honestas é sanctas é virtuosas costumbres, en que los chripstianos ponen estąs gentes; é sobre todo obrando Dios, Nuestro Señor, en ello, expeliendo á Satanás é su conversaçion, sin dubda Jesu Chripsto, Nuestro Redemptor, es servido mucho, é la sagrada religion de la repiblica clıripstiana muy aumentada on arrullas partes. 


\section{CAPITULO LII.}

En que se tracla una çierta ẻ notable relaçion quel visorey don Antonio de Mendoça por su carta mesiva escribió al historiador destas materias, en respuesta de otra quel auctor le avia escripto para su informaçion; é por ser nesçessaria é al propóssito del discurso destas historias, se pone aqui á la letra.

Al muy noble señor Gongalo Hernandez de Oviedo, alcayde de la fortalega de Sancto Domingo en la Isla Española y chronista de $\mathrm{Su}$ Magestad.

\section{Muy noble señor:}

"Resçebí una carta vuestra con el arçediano desta iglesia; y es verdad que el no responder á la que me truxo el padre fray Antonio de Leon, fuć la causa estar fuera desta cibdad; é segund lo muclı que avia que deçia que se partia, yo pensé de ser vuelto antes quél se embarcara : que por lo demás bastaba ser vos, señor, quien soys y el exercicio de letras que teneys para dessear yo vuestra amistad, quanto más pudiéndola heredar de mi padre, é acordándome de veros, scĩor, en Madrid conversar muy familiarmente con él muchas veçes. É por mi parte no qucbrará esta amistad: antes la renovaré; é si alguna cosa se ofresçiere en estas partes que os toque, lo haré con muy entera voluntad.

¿Quanto á lo que, señor, deçis que os enviaron de Veneçia una relaçion, que yo enviẻ á Su Magestad de algunas cosas de las desta tierra, é que entrcllas deçia venir los mexicanos de la parte del Perú, es verdad que yo he escripto algunas cosas que me paresçian de notar; mas no esta, porque tengo la opinion contraria, porque para mí ellos vinieron de la parte del Norte, é assi lo diçen é se muestra en edefiçios antiguos, y en nombres de lugares por donde vinieron. É pues allegaron hasta Guaçacalco con un señor que se llamaba Queçalcoat, no tengo á mucho que passassen otros á Leon. Lo que se me acuerda aver escripto en cste caso es, que á mí me truxeron çiertos huessos é mue- las de hombre tan grandes que á la proporçion seria de diez é ocho ó diez é nueve piés de alto; y esto diçen los naturales que fueron hasta çinquienta lombres, los quales repartieron por diverssos lugares é los mataron. No tenemos notiçia que haya gigantes sino es al Estrecho de Magallanes: sospecho yo que aquellos vendrian de allí, porque de la parte del Norte yo no tengo notiçia de gente tan grande, aunque la hay harto bien dispuesta.

"La relaçion de las cosas desta tierra yo he procurado de sabello muy particularmcnte, é hallo diverssas opiniones ; porque como avia muchos señores en cada provinçia, cuentan las cosas de su manera. Yo las ando recogiendo é verificando, y hecho, os lo enviaré; porque me paresçe que seria cosa muy vergonçosa que os enviasse yo relaçion y que me alegásedes por auctor dello, no sicndo muy verdadera. Y lo de aqui no es tan poco que no podays haçer libro dello, é no será pequeño; porque aunque Monteçuma é México es lo que entre nosotros ha sonado, no era menor señor el Caçonçi de Mechuacan, $y$ otros que no reconosçian al uno ni al otro.

"En lo que toca á los descubrimientos que yo tengo començados, como todos son prinçipios, paresce que hay poco que deçir. Solamente quiero, señor, que sepays, pues tocays en las desórdenes destas partes, que mi gente ni juega, ni reniega, ni toman á los indios nada contra su voluntad, ni haçcn exçesos de los que gente de guerra suelen haçer. Es verdad que algunos dirán que no se les ha ofresçido en qué lo puedan mostrar: confessarlo hé en lo que toca al oro é á la pla- 
ta) mas mugeres blancas y hermosas ec comida lıasta agora lian hallado en abundançia, é no han tomado cosa contra voluntad de sus dueños, si no ha sido dada 6 rescatada. I con esto cstán en el dia de loy passadas de nueveçientas leguas desta cibdad, con notiçia de aver adelante ınuchas vassijas de oro, é perlas, é grandes cibdades é casas, é tierra muy abundante de comida, en especial vacas (que diçen aver más que en España). La relacion particular de todo esto espero para este mes de noviembre, con ayuda de Nuestro Señor. Cómo sca venida, yo terné cuydado de enviárosla, porque aquella será de vista, y lo de aora es de oydas.

"Su Magestad fué servido en un assiento que se tomó con el adelantado don Pedro de Alvarado para los descubrimientos desta mar del Sur, que yo tuviesse parte; é aunque entre mí y él ovo alguna discordia sobre el conçcrtarnos, á causa que Su Magestad me hiço la merçed, sin yo pedillo ni sabello, á la fin, teniendo delante los ojos lo sulycedido en el Perú, yo me convine con él, é acordamos despachar dos armadas; una para descubrir la costa desta Nucva España, é otra que fuesse al Poniente en demanda de los Lequios y Catayo. Y yendo el adelantado á entender en esto, subçedió que en la Nucva Galiçia unos indios, por descuydo de un capitan, le desbarataron: cómo se halló cerca con la gente de las armadas, quiso yr á servir á Su Magestad en paçificar aquello; é allegando á un peñol, donde $\mathrm{l}_{\mathrm{O}}$ indios estaban fuertes, en tanto quél daba vuelta para ver por cónde le combatiria, se le desmandó la gente é matáronle çinco españoles, antes que pudiesse recogerlos. Subçedió tanta agua é tan resçio tiempo, que le fué forçado retirarse á Guadalaxara: è laçiéndolo, en un mal passo ylua un criado suyo por una ladera más alto quél yba, el qual rodó é vino à topar con el adclantado, é llevóle tres ó quatro vucltas la ladera abaxo, sin que se pudiesse apartar: quedó tan quebrantado que dende á tres dias murió. Yo be determinado de yr á paçificar aquello, no tanto por la nesçessidad en que nos ponen los indios, quanto por la discordia que quedó entre los capitanes que tenia allí. Ha sido causa de no poder despachar las armadas en tan breve tiempo cono se hiçicra, si esto no oviera subçedido. De lo demás desta tierra, á Dios graçias, cada dia vá en aumento, assi en lo que toca á las cosas de la fée, como en las de poliçia.

"Deçís, scñor, que os envic las alturas é sitios en questas tierras que agora nuevamente sc descubren, están. No lo hago, porque por dos eclypsis te luna que ha avido, despues que yo estoy en estas partes, he verificado la longitud que hay hasta Toledo, é son ocho horas é dos minutos é treynta é quatro scgundos: é teniendo respecto á esto, hallo que todo lo desta mar del Sur está falso, por causa de los regimientos ser hechos en Es* paña, é procuro de haçcllo corregiri ; é por esto no hago calidad de lo de antes de agora. Bien ereo que en essa cibdad, vos, señor, é otras personas terníades cuenta con el celypsi. Holgaria que me pagássedes en la mesma moneda, en escri. lirme á la hora que allí començó, para saber lo questa tierra dista dessa.

"Quereys, scĩor, saber quién fué mi madre é no es raçon de negároslo, pues que esclaresçicndo vos á mi padre entre essotros señores de España, no me puede dexar de caber mi parte; é siendo ella tal en virlud y en bondad, mal liaria de callar su nombre, el qual fué doña Françisca Pacheco, lija del macstre don Jolian Pacheco. Nuestro Scñor vuestra muy noble persona é casa guarde. De México á seys de otubre de mill é quinientos é quarenta y un años $=\hat{\Lambda}$ lo que, señor, mandáredes. = Don Antonio de Nendoça. 


\section{CAPITULO LIII.}

En que se contiene una carta quel historiador envió al visorey de la Nueva España, respondiendo á la letra del capitulo preçedente, en que se tocan algunas cosas conçcrnientes á estas historias.

Al muy illustre señor don Antonio de Men. dosa, visorey de la Nueva España é otros muchos reynos por Sus Magestades.

"Muy illustre señor:

"Una carta de Vuestra Señoria resçebí en esta cibdad á los onçe de hebrero de mill é quinientos é quarenta y dos años, y con todo lo que diçe tan largas merçedes, que no se pueden servir ni meresçer en tan poca vida, sino lomándoseme en cuenta el desseo, con que yo me emplearé en su serviçio todas las veçes quel tiem. po lo permita. Porque cómo Vuestra Señoria diçe, que hereda la amistad de la buena memoria del marqués, su padre, que en gloria está, heredó Vuestra Señoria en esse caso un muy çierto criado en mí, é como tal, me presçiaré yo de tenerle (como lo tengo) por mi señor, é como á tal, quando se ofresçiesse en qué, acudiria á pedirle las merçedes de lo que me tocasse en essas partes, como Vuestra Señoria manda que lo haga.

„Quanto á lo que Vuestra Scñoria diçe de la relaçion que me enviaron de Veneçia del orígen dessa gente ser venida del Perú, é que tiene la opinion contraria é cree que vino de la parte del Norte, yo assi lo pienso como lo diçe Vuestra Señoria, é quessos de Nicaragua serian la mesma gente, porque tambien son modernos, é los de la lengua chorotega son los naturales, si no lo son los chondales; porque aunque lay otras muclias lenguas estas dos paresçe que son más generales; y desde ellos al Levante, ni de los unos ni de los otros no hay tales lenguas á lo que yo he podido alcancar.

"La mesma opinion tengo assimesmo que Vuestra Señoria tiene en la gente de los gigantes, cuyos huessos signilicaron ser su estatura de diez y ocho ó diez y nueve piés de alto; porque sin dubda son de la parte del Estreclıo de Magallanes é de alli adelante: é assi fué la informaçion que se Iruxo á la Cessárea Mlagestad por algunos de los que se hallarou en el viage, que por el dicho Estrecho hiço el comendador frey Garcia de Loaysa. La gente del Norte, que diçe Vuestra Señoria que es bien dispuesta, assi lo mostraban aquellos indios que á Toledo llevó el piloto Estéban Gomez el año de mill é quinientos é veynte y çinco: los quales eran de la costa del Norte, donde aquel estuvo en quarenta y dos grados; é seys ó siete dellos que yo ví, todos eran mayores comunmente que todos los indios que yo he visto, é tan altos que exçedian la conun estatura de los hombres que en España deçimos medianos.

"Diçe Vuestra Señoria que anda recogiendo é verificando la relaçion de las cosas de essa tierra, é la dificultad que ha. lla en las diverssas opiniones, é que me lo enviará presto. Yo besso á Vuestra Señoria las manos por ello, porque será con su auctoridad colmar estas mis vigilias desta General y natural Ilistoria de Indias, é haçer el nombre de Vuestra Señoria inmortal, como es raçon que lo sca: é assi le torno á suplicar que no se descuyde de cumplir su palabra por todos estos respectos; prinçipalmente porque será Dios servido que se sepa lo que su república chripstiana tiene debaxo de la gobernaçion de su vireynado; y lo otro porque como he dicho á Vuestra Señoria es mucha gloria; y lo otro porque holgaré yo, 
como salvar mi ánima, de emplearme en la acomular en su nombre con lo que tengo escripto, que es hasta loy quassi dos mill liojas, en tres volímeues ó partes, en çinquienta libros, é serí el de Vuestra Señoria el que cumpla el jubileo, é perfeçionará el númeró de los çinquienta. Creo que impressos no serán tantas hojas; pero sospecho que passarán de mill é tresçicntas, aunque en esto de las hojas la marca del papel, el tamaño de la letra ó forma della lo liaçe crescer ó menguar. Pero yo hablo al respecto de aquella letra, en que se imprimió la primera parte destas mis historias en Sevilla, año de mill é quinientos é treynta y çinco, la qual está agora enmendada é muy acresçentada un terçio más de lo que estonçes tenia. Y lo otro, porque yo tengo liçençia del Emperador, nuestro señor, para llevar á Su Cessárea Magestad lo escripto, y es muy desseado en España é fuera della, é ando alistando mi parlida, y espero, con ayuda de Nuestro Señor, scríl en todo el mes de mayo, é no pienso volver acá hasta dexarlo todo impresso. Por tanto, vuelvo á mi suplicaçion, pues que estaré aqui tres meses ó quatro, quando más, y Vuestra Señoria diçe en su letra que esperaba la relaçion por todo el mes de noviembre passado de ${ }^{\prime}$ los otros sus descubrimientos, è que como fuesse venida, me hará merçed della é de la enviar: é caso que yo fuesse ydo á España, se me puede enviar allá, dirigida al banco de Françisco Liardo, porque es muclıo mi amigo, é teniéndola él, me la cnviará á recabdo á do quiera que yo estoviere.

"Diçe Vuestra Señoria que en sus descubrimientos hay poco que deçir por ser prinçipios; pero que quiere que yo sepa, pues toco en las desórdenes destas partes, que su gente ni juegan, ni reniegan,

1 S. Mallico, cap. VII. ni toman á los indios nada contra su voluntad, ni haçen los exçesos que suelen haçer la gente de guuerra, etc. Muy sabido y entendido está que los que militan, siempre siguen los passos de su cabeça, ó que del prínçipe se toman, ó él enseña á los de su señorio, las virtudes ó los viçios. Yo no me maravillo, señor, de las desórdenes que en estas Indias ha avido; ni Vuestra Señoria se maraville que yo vista á los que las han causado de sus mesmas obras, porque los que han hecho desatinos, no podian açertar á haçer otra cosa, sino acaso. Pero maravillaríame yo, si viesse que Vuestra Señoria dexala de usar su acostumbrada vida é generosidad, ni que açertasse á errar en lo que otros han errado; porque ni soy como ellos ni ellos como Vuestra Señoria, pues diçe la mesma verdad: Non potest arbor bona malos fructus facere, neque arbor mala bonos fruchus facere ${ }^{4}$ Ni me espanto porque uno de mala calidad é sangre açierte algुuna vez á liacer grandes cosas, pues lecmos que lo han hecho algunos que de baxos sulbieron á ser illustres; pero tan grande ó mayor novedad es que illustres hagan otra cosa, sino su officio; é caso que, conforme á esta verdad, á algunos que verán mis listorias les causaren escándalo, dico vobis quòd si hi tacuerint, lapides clamabunt ${ }^{2}$.

"Nuchas cosas avia oydo, é cartas han venido de diverssas personas, é aun diferentes en sí, sobre la diferençia que Vuestra Scñoria é Alvarado tovieron en lo del descubrimiento, é mucha merçed me ha hecho con su a viso en esto. É cómo Vuestra Señoria diçe que tuvo delante los ojos lo subçedido en el Perú, é que se convinieron en despachar las dos armadas, una para la costa de la Nueva España, é otra en demanda de los Lequios é Catayo, é que despues subçedió la muer- 
te del adelantado tan desastradamente, plega á Dios de le perdonar á él é á su muger, que me paresçe que fué más desdichada quél. Y en verdad yo les he avido tanta lástima, que no me paresçe que oy en toda mi vida cosa de más dolor quel fin de aquella señora é sus criadlas é de otras personas, que con ellas padesçieron.

"Crea Vuestra Señoria que de la veçindad dessos montes, donde hay veneros de açufre ó de alumbre, é sin mirar lo que los antiguos é aun modernos diçen de Mongibel é de Vulcan, lıe visto yo mucho desso en la cilodad de Puçol, ques çerca de Nápoles, y en Nicaragua de tantos temblores é dias de temor, que no lo pudiera creer sin verlo; porque en un solo dia é una noche en la cibdad de Leon de Nicaragua tembló tantas veçes la tierra que no se pudo tener cuenta en ellas; é saltó un perlaço de un monte que está allí çerca con tanta tierra é peñas, que bastarán á cubrir á Leon (ó á esta cibdad), é hiço mucho daño. Quanto más que en España en nuestros dias ya Vuestra Señoria sabe é avrá oydo las desaventuras de Almeria é Moxacar é de Vera é de otros pueblos ruynados por tales tempestades. Tenga Dios en gloria por su misericordia á los unos los otros, que assi murieron.

¿Diçe Vuestra Señoria que ha determinado de yr á paçificar aquello de la Nueva Galiçia é la discordia de çiertos capitanes. Yo espero en Dios que ya á la hora de agora estará todo en quietud y hecho, como de mano de Vuestra Señoria, é que las armadas serán ydas en buena hora á servir á Dios é á Su Mlagestad, é assi en lo que está paçífico como en lo que so paçificare, avrá el aumento que diçe que hay en essa tierra en lo que toca á las cosas de la fée, y en todo lo demás que tocare á la poliçia é buenas repúblicas, mediante la prudençia é buen gobierno de Vuestra Señoria.
„Estoy maravillado de lo que Vuestra Señoria diçe que lıa verificado de la longitud que lay liasta Toledo desde essa cibdad de México, é que son ocho horas é dos minutos é treynta y quatro segrundos; é diçe que teniendo respecto á esso, halla que todo lo dessa mar del Sur está falso, á causa que los regimientos de la declinaçion del sol son hechos en España , é que procura de lıaçerlo corregir ; é que por tãnto no laaçe caudal de lo de antes de agora, é que cree que en esta cibdad yo é otros terniamos cuenta con el eclypsi, é que lıolgaria que le pagasse en la mesma moneda, en escribirle á la lıora que acá començó para saber lo que esta tierra dista dessa.

"Yo confiesso a Vuestra Señoria que demás de no saberlo baçer yo, como querria, los eclypsis que Vuestra Señoria diçe yo no los vi. Verdad es quel uno, estando yo enfermo en la cama, me dixeron otro dia que le avia avido; é demás desto desde Veneçia me es. cribió el magrnifico Hiçer Johan Baptista Ramusio, secretario digníssimo de aquella illustríssima Señoria, que estuviesse sobre aviso para notar un eclypsi de sol que avia de aver en el año de mill é quinientos é quarenta: é quando resçebí la carta, avia diez ó doçe dias que aquello era passado, digo el término en que avia de aver el eclypsi. Pero acá no le ovo, para le avisar de la hora en que passó. Y porque estos Reportorios, questos nuestros astrólogos de España lıaçen, diçen que en el mes de agosto del año de mill é quinientos é quarenta y uno avia de aver otro eclypsi, para que aquel grand varon allá lo mirasse é yo acá, le avisé con tiempo, é tampoco le ví aquí, ni le ovo, aunque estuve sobre aviso con otros. Pero en esta sçiençia celestial yo, señor, sé mucho menos que otro, é como hombre falto de tal estudio, quedóme del desseo de entenderlo una voluntad de tomar 
estas alturas con estos estrolabios é regimientos questos nuestros marinos usan; $y$ assi como uno de los que peor lo haçen, voy mendicando estas alturas, puesto que con mi poca expiriençia ha muchos dias que yo he entendido muchos errores palpables destas cartas del Gaboto é dessotros cosmógraphos. Y esto causar lo há lo que Vuestra Señoria diçe, é no aver navegado los que pintan estas cartas en España : á lo menos en lo que yo he visto en Nicaragua ponen estos cosmógraphos el puerto de la Possesion en diez grados, y cstuve yo en él quinçe dias ó más esperando tiempo para yr á Panamá, é tenia conmigo dos pilotos, y cllos é yo cada dia tomábamos allí cl altura muchas veçes, é siempre en conformidad hallamos aquel puerto en treçe grados. Y estos tres de diferençia creo yo que está toda la cosla criada en las cartas de alii abaxo, yendo la vuclta del Norte; porque coino Vuestra Señoria mejor sabe, dende aquel pucrto se va enarcando la tierra háçia Seplentrion, y en estos grados tres ó más de menos pienso que lo pintado hasta agora es falso. Harto bien será que Vuestra Scñoria dé luz á todos en este caso é lo haga ver muy puntualmente. El señor obispo don Scbastian Ramirez, que agora lo es de Leon, en el tiempo que pressidió en essa tierra me acuerdo que me escribió una vez desde México que aquessa cibdad está como esta en diez y ocho grados.

- Diçe Vuestra Señoria que la señora marquesa su madre (que en gloria está) se llamaba doña Françisca Pacheco: ya yo sabia que cra hija del maestre de Santiago don Johan Pacheco; pero hasta aqui yo pensaba que se deçia Maria. Mucha merced me ha hecho en avisarme de la verdad; é tengo yo este linage de Pacheco por de Córdova de su orígen é por el más antiguo de los linages de los nobles de España, pues que Céssar en sus
Comcntarios diçe quél envió en favor de Córdova contra Sexto Pompeo, porque en todo tiempo aquella cilsdad avia seyda ficl al pueblo romano, seys cohortes con otros tantos cavalleros debaxo de la guia de Junio Pacheco, hombre noble de aquella provinçia é muy sabio cavallero en la guerra. Y en la Vila de Marco Craso diçe Plutarco que Julio Pacheco, que vivia çerca de la mar en España, le sostuvo ál Craso, haçiéndole dar de comer secrelamente á él é á los que con él estaban escondidos en una espelunca, de temor de Mlario é Cina, ocho meses; y esto fué antes de lo ques dicho. É Céssar ya sabe Vuestra Scñoria que estonces no era Emperador, é que despues lo fué quatro años é sicte meses, é Chripsto, Nuestro Redemptor, nasçió á los quarenta y siete años del imperio de Octaviano Céssar Augusto, que serian quarenta y çinco años é siete meses; é mill é quinicntos é quarenta y dos juntados con los que he dicho, podemos tener seguramente de más de mill é quinientos é ochenla y ocho años lı́i quel Pacheco é Pachecos que he dicho eran nobles. É si dixere que ha mill é seysçientos é diez, no pienso que me engaño en ello, porque Casar Lusilaniam et quasdam insulas in Oceano capil, segund Eusebio, y en essos tiempos andaba Céssar por España, ć ya cran aquellos Pachecos antiguos nobles en ella. Esto se quede para en su lugar: que si Dios fuesse servido, algun dia lo verá Vuestra Scñoria con otras estirpes de sus linages é predeçessores, é de otros nobles de Castilla, si Dios me dexasse vivir dos ó tres años, é tener salud é un poco de espaçio para sacar lo escripto en limpio.

"Nuestro Señor la muy noble persona y estado de Vuestra Señoria largos tiempos prospere, como él é sus servidores desscamos. Desta fortaleça de la cibdad é puerto de Sancto Domingo de la Isla Es- 
pañola á primero de março de mill é quinientos é quarenta y dos años, donde queda á serviçio de Vuestra Señoria.= Gonçalo Fernandez».

\section{CAPITULO LIV.}

En el qual el auelor dá raçon por qué çessó su eamino é yda á España; é haçe relaẹion de olras eosas ć subçessos de la Nucva Espraña: é diçe algunas particularidades que á su notiçia han venido, las quales son del jacz de las que la historia ha contado, é para más verifieaçion é verdad de algunos passos que que dan escriplos de otra forma, no le aviendo tan puntualmente informado, como agora se dirá. E euéntanse otras eosas del jaez destas malcrias, assi cnmendando algunas cosas hasta aqui apuntadas, eomo deelarando é perfiçionando otras de que hay nescessidad que los letores sean adverlidos *.

D ice un famoso listoriador de nuestros tiempos, llamado Joannis Carionis, de nasçion aleman, que en aquella su lengua ha escripto con mirable artifiçio, de la qual en latino sermon fué trasladada é con mucha diligençia corregicla su olora, en que se comprende la abreviaçion de muchas é notables listorias; é aplicando á su propóssito la ntilidad de la historia, é amonestando á los lelores, acuerda que es la listoria ministro de la prudençia, é no menos es maestra de la vida. É por causa de la leçion, diçe que se puede estimar que lanto a vemos vivido quanto es antigua la historia que lecmos, criyo conosçimiento conviene á todos los que gobiernan la república, porque de las cosas passadas que de la leçion se coligen, se imprime en la mente del que lee un aviso seguro, por cuyo exemplo nos apliquemos á la raçon de la bien considerada dispensacion de las cosas, que nos ocurren é son de importançia. IIallamos en la historia de los gentiles é sabios antiguos la origen de los reynos, é por qué causa subşedieron sus mudanģas, é hallamos los preçeptos de los offiçios é virtudes que hacen á la república firme é la conservan feliçemente; é diçe quel mundo es assi. mesmo semejante en todo liempo: Mundus idem et sui similis manet. Deçia un peritis.

- De cste resúmen quitó Oviedo algunas eláusulas, á fin de haeerlo más breve, pareeirndonos TOMO III. simo hombre en la miliçia (auctor de varias materias en griego), nombrado Tuçidides, que la historia es un thessoro que nunca le deberiamos quitar de la mano por ayudarnos della, por la semejança que los heclıos passados é sus acontesçimientos han é son conformes á los que traclamos é quassi semejantes las causas; é tanto es más verdadero thessoro quanto de más varias cosas avisa á los que rigen la república. Todo lo dicho me paresçe ques al propóssito de las muchas é diferentes materias destos tractados de nuestras Indias; é de las cosas que en ellas hasta aqui están escriplas se pueden congeclurar parte de los eventos fucturos, para que supliquemos á aquel que puede haçerlo, que lodo subçeda mejor de lo que los méritos destos conquistadores é pobladores de Indias lo tenemos meresçido é se nos apareja. Yo me declararé más en la prosecuçion de la historia. Agora sutisfacer quiero á lo que propuse en ol tílulo deste capítulo pressente.

Yo luve liçençia del Emperador, nuestro señor, para yr á España (como lo significué en la carta preçedente que escribí en respuesta de otra al illustre visorey de la Nueva España, don Antonio de Mendoça); y estando para partirme resçebí tres letras de un tenor (ó duplicadas) do

oportuno el indiearlo, para dar la idea más eabal del MS. original, que sirve de texio. 
la Cessúrea Magestad, forlats en Monson de Aragon á los treguta de agosto del año que passó de nill é quinientos é quarenta y dos años, en las crinales me mandó que turiesse el euydarlo é vigilançia que Su Magestad de mi persona confia, é cómo soy obligado en la guarda é fortilicaçion desta su forla leça de la cibdadé puerto de Sancto Domingago que á mi cargo estí, cu que yo resido en sil real servicio, porque la guerra está rompida é fué prinçipiada for el rey de Frangia contra la Cossúrea Magestud é sus rernos é señorios. Y desta causa, como olvidiente ó liel alcayde é criarlo, cossé en mi camino: é poniendo en efello lo quel Emperador, nuestro señor, me mandó, he estado quedo, atendiendo el tiempo é á su real serviçio: y assi estas materias se han suspendido quanto á la impression dellas; pero hánse aumentado, é cada dia cresçen en su discurso historial.

Despues que de Monçon partió Céssar, passó en Alemania, y cn aquellos sus Estados, que por alli tiene, le dió Dios los buenos sulygessos que en la segunda parte que escribí del Catálogo Real de Castilla, dende el capítulo IV adelante, podrá ver, entender é conosçer quien sano juicio toviere: y conosçerí la soberbia del rey Françisco de Françia, é la demasiada diligençia, que con todas sus fuereas ha usado para fatigar al mundo é á los chripstianos en compañia é confiança del grand tureo é sus infieles exérçitos por mar é por tierra. Diçe Homero: "En la guerra pone Dios su escudo delante de los prínçipes para los defender". Pueden muy bien testificar todo esto todos los que hoy viven é tovicren alençion é conosçimiento é verdatera notiçia de los subecssos é acciones del Emperador, nuestro scñor; é cómo Dios es su escu-

1 "Sacre litteræ enim consolantur nos el docenta pertẻ post labefactum germanicum postre- do, de muchas mancras lo aremos visto. Dexemos esto paril olros auclores que están mús cerea de la persona dos Ma Magestad, fue lo discantarín mejor; pues

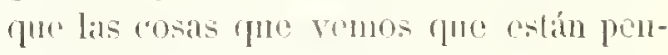
dientes deste Sigraralo l'ríncipe son tales é tantas é lan grandes é tan notorias, que no solamente las lenguas é plumas que á cllo estín dedicadis, mas todos los humanos, pues á torlos tora é importa la vida deste Mlonarea, lo deben pregonar: las paredes lan oydos, los campos é selvas tienen ojos, é lodas las aguas é mares no la ignoran, y cntienden é deben publicar é lamentarse de los trabaxos de Fiandes, é Julies, é Güeldres, é Cleves, ó Clambrise, é Lucemburg, é Alemania y España, é más que todos la infelice Lngria á toda la universal república clupipstiana; é no sin lágrimas de los proprios françeses, que tal rey ó tiçon les avia dado lios como cllos lo merescen é sus culpas é solberbia.

Pienso que se va açercando lo quel auctor alegado alcman nos acuerda: el qual diese que las letras sagradas son en nuestro consuclo, pues que diçe que ruynada la monarquia de los germanos, será el fin del mundo'. De lo qual se colige que hat do turar esta monarquia hasta el últino dia é fin del mundo, é todos los demás reyes é reynos le han de ser inferiores é suljetos. Dexemos esta materia de Asia, Lfriea y Europa, que tan enconadas están en nuestro tiempo y en mucho peligro, pues tan léxos estamos en las Indias de donde al pressente aquestas cosas hierven: relátenlas los que allá se hailan, phesto que á nuestras personas é bienes alcança grand parte de tal calamidad.

Volvimos á la narraçion deste imperio occidental de nuestras Indias, entretanto 
que Nuestro Señor permite algun aliento á mi vista é pluma: que en rerdad pares. se que Nuestro Señor permite que mis ojos no se çierren é que alcarigen más claridad en la historia que entre manos tengo, pues se me rienen á ellas avisos é inteligençias para polir é perfiçionar al-. gunos passos notalyles que atrís quedan escriptos, segrund fú informado, é que lasta aqui no eran bien entendidos en parte, por aver seydo no perfeltos ni atentos considerantes los que me dieron nolicia dellos. E yo continuando la historia, los puse en este volúnen con buena fée, creyendo que deçian lo çierto, é aun assi lo afirmaban aquellos; pero como el entendiniento de los hombres sea mucho mejor en unos que en otros, no es de maravillar que discrepen en sus dichos é aun en sus hechos, en esprecial en cosas semejantes, en quel intento é afiçion é interesse particular cansa cssas direrssidades en la informaçion, que algunos me han dado en lo cfue no he visto. E cómo solo Dios es el que salue é puede entender á todos, yo como homlire podria ser engañado ó no tan al proprio informado, como conviene; pero oyendo á muchos, roy conosçiendlo en parte algunos errores, é assi voy é yré emmendando donde convenga mejor distinguir to que estoviere dubdoso ó desviado del camino derecho.

Permitió Dios que llegó á esta cibdad de Sancto Domingo á ocho dias de septiembre de mill é quinientos é quarenta y quatro un gentil hombre hijodalgo, Ilamado Johan Cano, que vive en la cilstad de México y es natural de la cilddad de Cúceres, el qual venia de España, adonde avia ydo sobre sus negocios proprios. Y es casado con una hija legítima de Monteçuma, é passó á la Nueva España con el capitan Pamphilo de Narvacz, é se halló pressente é con él peleando, quando le prendieron, puesto que este liidalgo cra mançeho de diez y seys ó dicz y siete años, é se lialló (lespues en todos los subcessos de la Nicra España: al qual yo comuniqué aqui, é no tanto quanto yo quisicra quél aqui estoviera, porefue como hombre de buen entendimiento é testigo de vista, me satisfacia á mis preguntas lo que esturo alinunas reces en esta fortaleça laasta su partidla que se partió: que fué jueves veynte y cinco del mes ya diclıo con dos naos que ylan á la Nueva España. É porque, como en otras partes he dicho, yo he tenido por estilo el dar los contextes é nombrar los testigos de lo que escribí donde me lie hallado, será el capítulo pressente continuado á manera de diálogo, é satisfaciendo en parte al título deste capítulo LIT, y porefue no canse al letor con el nombre de los interlocutores, donde oviere tales letras ALc., quicre deçir Aleayde, é donde estovieren arquestas C.., quiere deçir Johan Cano, é assi yo preguntando é Johan Cano respondiendo, diré aquellas cosas en que platicamos, porque no ovo tiempo para más, á causa que poco antes de su partidla vinimos en conosçiniento é á contraer nuestra amiçicia. I digo assi:

Drílogo del Alcayee de la fortaleca de la CImdad é puerto de Sixcto Donivgo de la Isla Espiñola, AUCTOR É CHronista destas IISTORMS, DE LA UXA PARTE, É DE LA OTRA UX CAYALLERO NEÇYÓ DE LA GRAYD CUEDAD DE México, llamado Johlan Cajo.

Alc. Señol, ayer supe que Vuestra Merced vive en la grand cibdad de México, é que os llamays Johan Cáno; é poleque yo tuve amistad con un cavallero, Hamado Diego Cano, que fué criado del Sereníssimo Prínçipe don Jolıan, mi señor, de gloriosa memoria, desseo saber si es vivo, é de dónde soys, señor, natural, é cómo (fuedistes aveçindado en estas partes. É resçebiré meresed que no resçibars pessadumbre de mis preguntas, porque 
tengo nesçessidad de saber al grunas cosas de la Nueva España, y es raçon que para mi satisfaçion yo procure entender lo quo alesseo de lales personas é lálbito que merezcan crélito. Y assi, señor, rescebiré mucha merçed de la vucstra en lo que digo.

Ca. Señor Aleayde, yo soy el que gano mucho en conosecros, é tiempo há que desseaba ver vuestra persona, porque os soy afiçionado, é querria que muy de veras me loviéssedes por tan anligo y servidor, como yo os lo seré. I satisfaciendo á lo que Vuestra Hereged quicre saber de mí, digo que Diegro Cano, escribano de cámara del prínçipe don Johan é eamarcro de la tapiçeria de Su Alteça, fué mi lio, é lái poco tiempo que murió en la cibdad de Cáçeres, donde vivia é yo soy natural. É quanto á lo demas, yo, señor, passé desde la isla de Culsa á la Nueva España con el capitan l'amphilo de Narvaez, é aunque moço é le poca cdad, yo me liallé çerea dél, yuando fué presso por Hernando Cortés é sus maneras. Y en esse trance le queloraron un ojo, peleando él eomo muy valiente hombre; pero como no le acudió su gente, é con él sc hallaron muy pocos, quedó presso y herido é se hiço Cortés señor del campo, é truxo á su derocion la gente que con Pamphilo avia ydo; y en recuentros y en batallas de manos en México é todo lo que ha subçedido despues yo me he hallado en ello. Mandays que diga cómo quedé areçindado en estas partes, é que no resçiba pessadumbre de vuestras preguntas. Satisfaçicndo á mi assiento, digo, senior, que yo me casć con una hija legúlima de Monteçuma, llamada doña Isabel, tal persona, que aunque se oviera criado en nuestra España no estovicra nús cnscĩada é bien dottrinada é eathólica, é de tal conversaçion é arte, que os satisfaria su manera é buena graçia: é no es poco úlil é provechosa al sosiegro é contentamien- to de los naturales de la ticrra, porque como es señora en lodas sus cosis é amiga de los chripstianos, por su respecto y exemplo más quictud é reproso se imprime en los ánimos de los nexicanos. En lo demás que se me preguntare, é de que yo lenga memoria, yo, señor, diré lo que supiere conforme á la verdad.

A.c. Yo açepto la meresed que en esso rescibiré, é quiero comencar á deçir lo que me ocurre, porque me acuerdo que fuí informado que su padre de Montecuma tuvo çiento é çinqiienta lijos é hijas, é quél turo çinquienta lijos é más, é que le acaescrió tener çinquienta mugreres preñadas; y assi cscribí esto é otras cosas á este propóssito en el capítulo XLVI. Lo qual, si assi fué, queria saber cómo podés ros tener por legritima Irija de Montecuma á la señora doña lsabel, vuestra mıcer á qué forma tenia vucstro suegro para que se conoscicssen los hijos bastardos cntre los legítimos ó espúrios, é quáles eran mugeres legílimas ó concubinas.

CA. Fuć costurubre usada é guardada entre los mexicanos, que las mugeres legílimas que tomaban, era lé la manera que agora se dirá. Conçertados el hombre é muger que avian de contraer el matrimonio, para le efettuar se juntaban los parientes de ambas partes, é haçian un areyto despues que avian comido ó çenado; é al tiempo que los novios se avian de acostar é dormir en uno, tomaban la halda delantera de la camisa de la novia, é atábanla á la manta de algodon que tenia cubicrla el novio: é assi ligados, tomábánlos de las manos los prinçipales parientes de ambos, é molíanlos en una cámara, donde los dexaban solos é á eserras por tres dias continuos. sin que de allí saliessen él ni ella, ni allá entraha más de una india á los proveer de comer é lo que avian menester. En el qual tiempo deste encerramiento siempre a via bayles ó areylos, quellos llaman milote, y en fin de los 
tres dias no hay más fiesta; y los que sin esta çerimonia secasan, no son a vidos por matrimonios, ni los hijes que proçeden por legítimos, ni heredan. Assi, cómo murió Monteçuma, quedáronle solamente por hijos legítimos mi muger é un hermano suyo, é muchachos ambos; á causa de lo qual fué elegido por señor un liermano de Montecuma que se deçia Cuytlavaçi, señor de lzlapalapa, el qual vivió despues de su cleccion solos sessenta dias, é murió de viruelas: á causa de lo qual un sobrino de Monteçuma, que crá papa ó sacerdote mayor entre los indios, que se llamaba Guatimuçin, mató al primo, hijo legítimo de Nontecuma, que se deçia Asupacaçi, hermano de padre é madre de doña Isabel; é híçose señor, é fué muy valeroso. Este fuć el que perdió á México, é fué presso é despues injustamente muerto con otros prinçipales señores é indios; pues cómo Cortés é los clıripstianos fueron enseñoreados de México, ningun hijo quedó legítimo, sino bastarcios, de Montecuma, excepto mi muger, que quedaba viuda; porque Guatimuçin, señor de México, su primo, por fixar mejor su estado, sicndo ella muy muchacha la tuvo por muger, con la cerimonia ya dicha del atar la camisa con la manta, é no ovieron hijos ni tiempo para procreallos. Y ella se convirtió á nuestra sancta fée cathólica, é casóse con un hombre de bien de los conquistadores primeros, que se llamaba Pedro Gallego, é ovo un lijo en ella que se Ilama Johan Gallego Monteçuma; é murió el dicho Pedro Gallego, é yo casé con la dicha doña lsabel, en la qual me ha dado Dios tres hijos é dos hijas, que se llaman Pedro Cano, Goncalo Cano de Saavedra, Johan Cinno, doña lsabel é doña Cathalina.

Alc. Señor Jolıan Cano, suplícoos que me digays por qué mató IIernando Cortés á Guatimucin? Reluclóse despues, ó qué hiço para que muriesse?
C.. Aveys de saber, que assi á Guatimuçin cono al rey de Tacuba, que se deçia Tetepanquecal, é al scñor de Tezcuco, el capitan Ilernando Cortés les hiço dar muchos tormentosé crudos, quemándoles los piés é untándoles las plantas con açeyte é poniéndolas cerca de las brasas, y en otras diverssas maneras, porque les diessen sus thicssoros; é teniéndolos en continuas fatigas, supo cómo el capitan Chripstóbal de Olit se le avia alçado en Pucrto de Caballos é Ilonduras, la qual provincia los indios Ilaman Guaymura ; é determinó de yr á buscar é castigar al dicho Chripstóbal de Olit, é partió de México por ticrra con mucha gente de españoles é de los naturales de la tierra, é llevóse consigo aquellos tres prinçipales ya dichos, é despues los ahorcó en el camino. É assi enviudó doña Isabel, é despues ella se casó de la manera que he dicho con Pedro Gallego, é despues conmigo.

Alc. Pues en çicrta informacion que se envió al Emperador, nuestro señor, dice Ilernando Cortés que avia subcedido Guatimuçin en el señorio de México trás Monteçuma, porque en las puentes nıurió el hijo y lıeredero de Monteçuma; é que otros dos lijos que quedaron vivos, el uno era loco ó mentecapto, y el otro paralítico, é inhábiles por sus enfermedades. E yo lo he escripto assi en el capítulo XVI, pensando quello seria assi.

C.1. Pues escriba Vuestra Merced 10 que mandare, y el marqués IIernando Cortés lo que quisiere: que yo digo en Dios y en mi consçiençia la verdad, y esto es muy notorio.

Alg. Señor Johan Cano, digame Vuestra Herçed: ¿de qué procedió el alçamiento de los indios de México, en tanto que Ilermaudo Cortés salió de aquella cibdad é fuć á buscar á Pamphilo de Narvaez é dexó presso á Montecuma en poder de Pedro de Alvarado? Porque he oydo so- 
1) ce csto muchas cosas, é muy diferentes las unas de las otrats, é yo querria escrilir rerdad, assi l)ios salve nui china.

C.. Señol alcaryde, esso que presunlays es un passo, ch que pocos de los que lay en la tierra salorán dar raçon, aunyue ello fué nuly notorio, é muy naniliesta la sinnaçon que á los indios se les hiço; é de alli tomaron tanto odio ron los chripstianos, que no fiaron más dellos, é se siguieron quantos males ovo despues, é la rebelion de México, y passó desa manera. Essos mexicanos tenian entre lis otras sus ydolallias cicrtas fiestas del año, en que se juntaban á sus ritos é çerimonias; é llegado el tiempo de una de aquellas, estaba Mrarado en guarda de Monlecuma, é Cortés cra ylo donde areys dicho; é muchos indios pringipales juntáronse é pidieron liçençia al capitan Alrarado para yo á çelelurar sus fiestas en los patios de sus mezquitas ó quies mayores, junto al aprossento de los españoles, porque no pensassen que arguel ayuntamiento se haçia á otro fin; y el dicho capitan les dió la liçencia. É assi los indios, todos señores, más de sersçientos, desnudos, é con muchas joyas de oro $y$ hermosos penachos é muchas piedras presçiosas, é como más aderesçados é gentiles hombres se pulieron é supieron aderesçar, é sin arma alguna defensiva ni ofensiva, baylaban é cantaban é haçian su areyto é fiestas, segund su costumbre: é al mejor tiempo quellos estahan embebescidos en su regocijo, movido de cobdiçia el Ararado, hiço poner en cinco puertas del patio carla quince hombres, y él entró con la ggente reslante de los españoles, é començaron á acuchillar é matar los indios, sin perdonar á uno ni á ninguno, hasta que á todos los acabaron en poco espaçio de hora. I esta fué la causa por qué los de Mléxico, viendo muertos é robados aquellos solpre seguro, é sin aver merescido rue tal cruedar an ollos se oviesso lecho, se algaron é hivieron la gruerra al diclo Alvaralo, é á los chripstionos que con él estaban en gouarda de lonteroma. y con mucha raçon que tenian para dlo.

Alc. Monteçuma, cómo murió? Porque diverssamente lo he entendido, é assi lo he vo eseripto diferenciadamente.

C.. Monteçma murió de mna pediada que los de fucra tiraron, lo qual no se liçiora si delante dél no se pusiora un rodelero, porque cómo le vierar ninguno tirara; a assi por le cubrir con la loodela é no creer que alli estaba Nontecuma, le dieron mima pedrada, de que murió. Pero quiero que sepays, señor alcayde, que dende la primera l'obelion de los indios, hasta quel maroués volvió á la cilidad despues de presso Jaurvaez, non obstante la pelea ordinaria que con los chripstianos tenian, siempre IJontecuma les haccia dar de comer: é despues quel marqués tornó, se le hiço grand resçebimiento, é les dieron á todos los españoles mucha comida. Mas areys de saber quel capilan Mrarado, cómo le acusabá la consçicnçia, é no arrepentido de su culpa; mas queriéndole dar color, é por aplacar el ánimo de Monteçuma, dixo á IIernando Cortés que fingiesse que le quelia prender é castigar, porque Jonteçnma le rogasse por él é que se fuessen muertos por mucrtos. Lo qual IIernando Cortés no quiso laçer: antes muy enojado dixo que eran unos perros, é que no avia nesçessidad de aquel cumplimiento: y envió á un prinçijal á que hiçiessen el tianguicz ó mercado: el qual principal, enojado de ver la yra de Cortés é la poea estimaçion que laçia de los indios vivos, ć lo poco que se le daba de los muertos, descleñado el prinçijal é determinado en la rengança, fué el primero que renovó la guerra contra los españoles dentro de una hora.

Alc. Siempre of deçir ques buena la 
templança é sancta la pieclad, é alıominable la solserlia. Diçen que fué grandíssimo el thessoro que llernando Cortés reparlió entre sus inílites todos, quando determinó de dexar la cibdad é yrse fuera della por consejo de un Botello, que se presçiaba de pronosticar lo que estaba por venir.

C. Bien sé quién era esse, y es verdad quél fué de paresçer que Cortés é los chripstianos se saliessen; é al tiempo de efettuarlo no lo hiço saber á todos: antes no lo supieron sino los que con él se liallaron á essa plática, é los demás que estaban en sus apossentos é quarteles se quedaron, que eran dosçientos é septenta hombres, los quales se defendieron çiertos dias peleando, hasta que de lambre se dieron á los indios; é guardáronles la palabra de la manera (que $\Lambda$ lvarado la guardó á los ques dicho. É assi los dosçientos é septenta clripstianos, é los que dellos no avian seydo muertos peleando, todos quando se rindieron, fueron cruelmente sacrificalos. Pero aveys, señor, de saber, que dessa liberalidad que Hernando Cortés usó, como deçís, entre sus mílites, los que más parte alcançaron della é más se cargaron de oro é joyas, más presto los malaron; porque por salvar el albarda, murió cl asno que más pessada la lomó. é los que no las quisieron, sino sus espadas é armas, passaron con menos ocupaçion, laciéndose el camino con el espada.

Alc. Grand lístima fué perderse tanto thessoro é çiento é çinquienta é quatro españoles é quarenta é cinco yeguas é más de dos mill indios, y entrellos el hijo é liijas de Montecuma, é todos los otros señores, que traian pressos. Yo assi lo tengo escripto en el capítulo XIV desta listoria.

C... Scñor alcayde, en rerdad quien tal os dixo, ó no lo vido ni supo, ó quiso callar la rerdad. Yo os certifico que fueron los españoles muertos en csso (con los que como dixe de susso quedaron en la ciludad, y en los que se perdieron en el camino, siguiendo á Cortés é continuándose nuestrá fuga), más de mill é. ciento é septenta, é assi paresçió por alarde; é de los indios nuestros amigos de Tascaltecle que decís dos mill, sin dubda fueron más de ocho mill.

Arc. Maravillome cómo despues que Cortés se acogéó, é los que escaparon, á la tierra de Tascaltccle, cómo no acabaron á él é á los cluripstianos, dexando allá muertos á los amigos; é aun assi diz que no les daban de comer sino por rescate los de Guaulipa, ques ya término de Tascaltccle, $y$ el rescate no le querian si 110 era oro.

C.s. Tenedlo, señor, por falso todo esso; porque eu casa de sus padres no pudieran liallar más buen acoggimiento los clıripstianos, é lodo quanio quisieron, é aun sin pedirlo, se les dió graçioso é de muy buena roluntad.

Alc. Para mucho lia seydo el marqués, é digno es de quanto tiene é de unucho más; é tengo láslima de rer lisiado un cavallero tan valeroso, é manco de dos dedos de la mano izquierda, como lo escriluí é saqué de su relaçion, é puse en el capítulo XV; pero las cosas de la gucrra assi son, é los honores é la palma de la victoria no se adquieren durmiendo.

C.ı. Sin dubda, señor, Cortés lıa seydo venturoso é sagaz capitan, é los prínçipes suelen haçer merçedes á quien los sirve, y es bien las hagan á todos los que en su serviçio real trabasan; pero algunos lie visto yo que trabaxan é sirven é nunca medran, é otros que no haçen tanto como aquellos son gratificarlos é aprovechados, pero assi fuessen todos remunerados como el marqués lo ha sido en lo de sus dedos, de que le aveys lástima. Tuvo Dios poco que laçer en sanarle; é salid, señor, desse cuyrlado: que assi co- 
mo los sacó de Castilla, quando passó la primera vezá estas partes, assi se los tiene agora en España, porque nunca fué manco dellos ni le faltan; é assi nunca ovo menester çirujano ni miraglo para guarescer desse trabaxo.

Alc. Señol Jolıan Cano, es rerdad aquella cruchlad que diçen quel marqués usó con Chulula, ques una cibdad por donde passó la primera vez, que fué á México?

C.. Muy grand verdad es; pero esso yo no lo ví, porque aun no era yo ydo á la tierra: pero súpelo despues de muchos que lo vieron é se hallaron en essa cruel haçaña.

Alc. Cómo oystes deçir que passó?

C.. Lo que oy por cosa muy notoria es, que en aquella cibdad piclió Hernando Cortés tres mill indios, para que llevassen el fardage, é se los dieron, é los lifco todos poner á cuchillo, sin que escapasse ninguno.

Alc. Racon tiene el Emperador, nuestro señor, de mandar quitar los indios á todos los chripstianos.

C.. Ilágase lo que Su Magestad mandare é fuesse servido, que esso es lo ques mejor; pero yo no querria que padesçiessen justos por pecadores. Quien haçe crueldades, páguclas; mas el que no comete delicto ¿́por qué le han de castiģar? Esto es matcria para más espaçio, é yo me tengo de emlsarcar esta noche y es ya quassi hora del Ave Maria. Mirad, señor alcayde, si hay en México en qué pueda yo emplearme en vuestro serviçio: que yo lo haré con entera roluntad é olpra. Y en lo que toca á la libertad de los indios, sin dubda á unos se les avia de rogar con ellos á que los toviessen é gohermassen, e los industrassen en las cosas de nuestra sancta fée cathólica, é á otros se debian guitar; pero pues aqui está el obispo de Chiapa, fray Bartolomé de las Casas, que ha seydo el movedor é inventor destas mudanças, é va carẹdo de frayles mançebos de su Órden, con él podeys, señor alcayde, desenvolver esta matcria de indios. É yo no me quiero más entremeter ni hablar en clla, aunque sabria deçir mi parte.

Alc. Sin dulsda, señor Johan Cano, Vuestra Nerçed habla como prudente; y estas cosas deben ser assi ordenadas de Dios, y es de pensar queste reverendo obispo de Cibdad Real en la provincia de Cliapa, como celoso del serviçio de Dios é de Su Magestad, sea movido ál cstas peregrinaçiones en que anda: é plega á Dios quél é sus frayles açierten á servirles. Pero él no está tan bien conmigo, como pensays: antes se ha quexado de mí, por lo que escribí çerca de aquellos labradores é nuevos cavalleros que quiso haģer, é con sendas cruçes, que querian paresçer á las de Calatrava seyendo labradores é de otras mezclas é género de gente baxa, quando fué á Cubagua é ál Cumaná; é lo dixo al señor obispo de Sanct Johan, don Rodrigo de Bastidas, para que me lo dixesse, é assi me lo dixo. É lo que yo respondí a su quexa, no to hiçe por satisfacer al obispo de Chiapa, sino á la auctoridad é bondad del señor obispo de Sanct Johan, é su sancta intençion: é fué que le supliqué que le dixesse, que en rerdad yo no ture cuenta ni respecto, quando aquello escribi, á le haçer pessar ni plaçer, sino á deçir lo que passó; é que vies. se un libro, ques la primera parte deslas Ilistorias de Indias, que se imprimió el año de mill é quinicntos é treynta y çinco, é allí estaba lo que escribí; y que holgaba porque estábamos en parte que todo lo que dixe é lo que dexé de deçir se probaria fáçilmente; é que supiesse que aquel libro estaba ya en lengua toscana é françesa é alemana é latina é griega é turca é aráliga aunque yo le escribí en castellana; y que pues él continuaba nuevas empressas, é yo no aria de 
çessar de escribir las materias de Indias en tanto que Sus Magestades desto fuessen servidos, quie yo tengo esperança en Dios que le dexarí mejor açertar en lo por venir que en lo passado, é assi adelanto le paresceria mejor mi pluma. Y como el señor obispo de Sanct Johan estan noble, é le consta la verdarl, é quár sin passion yo escribo, el obispo de Chiapa quedó satisfeclio: aunque yo no ando por satisfaçer ú su paladar ni otro, sino por cumplir con lo que debo, hablando con ros, señor, lo çierto. Y por lanto. quanto á la carga de los niuchos frayles, me paresçe en rerdad questas tierras manan ó que Hueven frayles; pero pues son sin canas todos é de treynta años abaxo, plega á Dios que todos açierten á servirle. Ya los ví entrar en esta ciludad de dos en dos hasta treynta dellos, con sendos bordones é sus sayas y escapularios é sombreros é sin capas, y el obispo detrás dellos. Ello parescia una devola farsa, é agora la comiençan: no sabemos en qué parará; el tiempo lo dirá, y este liaga Nuestro Señor al propóssilo de su sancto serviçio. Pero pues van háçia aquellos nuevos vulcanes, decidme, señor, qué cosa son, si los aveys visto, é qué cosa es otro que teneys allá en la Nueva España, que se dice Guaxoçingo.

Ca. El vulcan de Chatco ó Guaxoçiu- go todo es una cosa, é alimbraba de nuclie tres é quatro leguas é mảs, é de dia salia continuo humo, é á veçes llamas de frego: lo qual está en un escollo de la Sierra Nevada, en la qual nunca falla perpétua nieve, y está á nueve leguas de México. Pero este fuego é humo que he dicho turó hasta siete años, poco más ó unenos, despues que Hernando Cortés passó á aquellas parıes, é ya no sale fuego alguno de allí; pero ha quedado mucho açufre é muy buenoque se ha sacado para lraçer pólvora, é lıay quanto quisieren sacar dello. Pero en Guatimala hay dos vulcanes ó montes fogosos destos muy es. pantables, é eclan piedras muy grandíssimas fucra de sí, quemadas, é lançan aquellas bocas mucho humo, y es cosa de muy horrible aspecto, cn espeçial como le vieron quando murió la pecadora de: doña Beatriz de la Cueva, muger dol adelantado don Pedro de Alvarado. P'leg:al á Nuestro Señor de quedar con Vuestra Merçed, señor alcayde, é dadme liçençia: que atiende la barca para yrme á la nao.

Alc. Señol Johan Cano, el Espíritu Sincto vaya con Vuestra Mlerçed, é os dé tan próspero viage é navegaçion que en pocos dias y en salvamento llegueys ć ruestra casa, é halleys á la señora doña Isabel é los hijos é hijas con la salıd, qro Vuestra Merçed ỳ ellos os desseays.

\section{CAPITULO I.V.}

Con que en poeas palabras el auctor dá eonclusion á esle libro XXXIII de la segunda parlc.

Y

o me hallo ya en España en este año de mill é quinientos é quarenta y oclıo años, é diré aqui solamente dos cosas para conclusion de arpueste libro liasta este pressente tiempo. La una es, que como todos los sabios mejor pueden advertir é sospechar lo que no vé el listoriador, forcado es que oscriba por diverssas inforTO.10 11!. maçiones; y en lo que toca á esta materia de la Nueva España, yo he dicho lo que supe de personas que son calificalas é de crédito; é tambien no he rexado de decir lo quel nesmo marqués don Hermando Cortés é sus cartas é relaciones dirigidas al Emperalor, nuestro señor, le iuformaron. Y sin rubda sus sorvicios fuc- 
ron gramdes. y el Eimperalor, mustrosnor. liberal é grato remumerador con él, pues le dió titulo de marpues eon estado é vassillos, é casa de seīor illustre é nuucha renta. Lo segumdo os. rumel illustre scinor don Antonio de Hendoça, visorey de la Nueva España, passó á gobermarla ol año de mill é quinientos é treỹnta y cinco años, de manera quo en el pressento laa treçe gue estál en csta ticrra. Sil prudencia ó rectitud 10 se juede deçir en poeas hojas, é por tanto es menester libro é lractato por si, el qual con el licmpose lirá é acommlará con el pressente; pero diré arfui solamente lo que no so pmerle newar, ni hay en Indias quien In ignore. Y es que aquella tierra se prodic- ra, i a lo menos esturiera rebclada ó en Lanta alteraçion como lo están ol ras provincias de Indias, í causa de las muevas orlonanças que allí fueron, lo fual se reruso con lis prudencia del visoley; e que como sintió la alteraçion del vulggo, obedesciendo al Emperador, nuestro scñor, é á Sus Mageslades, suspendió la erecucion de algunnas cosas de yue la repriblica se ạvariaba, é dió notiçia á Su Magestad, é proveyó de manera que todo sc quiteló é se remedio. É luro tanta fuerca su buen seso é natural, que se puedo afirmar rue dió de nuevo la tierra al Rey. pues que excusó las novedades que eslahan aparejadas. Esto requicre más larọan historia, é se rescrva para obro ticmpo.

\section{CAPITLLO LVI:}

En que se tracla la muerle del marqués del Valle, don Hernando Cortes.

B

Brevemente quicro contar el fin de don Hernando Cortés, marqués del Valle primero; y scrá en esto sumaria mi pluma. porque he visto algunos memoriales í acucrdos escriptos por algunos aficionalos suyos, á quicues se les encomendaria (pue escriliessen en su alabança, ó ellos por su comedimiento larian por complacer á sus subcessores, ó por qualquicr causa que á cllo les movicsse. Mi fin es otro. é deçir lo que compete á mi listoria é no más; pues que cu este libro XXXIli yo he escripto. lo quel letor pucde aver visto cerea de lo que al marqués é á la conquisla de Nueva España compete.

El marqués, despues que vino de las Indias, annque cansado de las fatigas i subcessos que por él passaron en la Nuera Espania, llegado á Castilla se fué á

* Aqui esta falto el MS. aulógrafo de Oviedo, suplicinclose este y el siguiente capilulo con la conpia del siglo XVl, que pose lo bibliutea Culombina la corte de Su Nagestad, é fué muy bicn rescebido é açotado del Empera‘lor, é continuó su corte, como scñor de. estado, é con muy buena casa é anctoridad. É con muclios gastos, é fué con Su Magrestad á la compressa de Argel, donde le cupo harta parte de aquel naufragio : demás del peligro é lrabaxo de su perso. na le costó muchos millares de dueados. é perclió mucha haçienda en alavios de. su casa é persona: é despues que Céssar se fué á Flandes, el marqués quedó en la corte dal Príncipe, nuestro señor, continuando el scrviçio de Su Alteça, con muchos gastos é bucna casa, é soliçitando sus pleytos é negocios: é cómo era ya viejo é cansado, temiendo los estios del invicrno en Madrid, ć por ceperar sus hijos, por quien avia cnviado para los casar en Fspaña con señores, con quien lo de esla 11." parle de la Iistoria general de Indias, copia que antes de aliora hemos citalo. 
fractaba, salió de la corte en el mes de septiembre de mill é quinientos é quarenla y scys años, é se fuć á Sevilla, donde alggunos meses esturo. I el año siguiente adolescrió de la enfermedad que murió en un luggar, á media legua de Sevilla, que se diçe Castilleja de la Guesta, é passó desta pressente vida á la eterna á los dos dias del mes de diçiembre de mill é quinientos é quarenta y siete años. É dexó por su albaçea prinçipal al illustríssimo seĩor don Johan Alonso de Guzman, duque de Merlina Sidonia: el qual, como tan grand scĩor é verdadero amigo, celebró sus obsequias é honras funcrales la semana antes de la Tatividad de Chripsto, Nuestro Redemptor, de aquel mes de diçiembre, en el monesterio de Sancl Françisco de Sevilla, é con tanta pompa é solempnidad como se pudiera lacer con un muy grand prínçipe. É se le hiço un mauscolo muy alto é de muchas gradas, y ençima un lecho muy alto, entoldato fodo aquel ámbito é la iglesia de paños negros, é con incontables laclás é çera ardiendo, é con muchas banderas é pendones de sus armas del marqués, é con lodas las çerimonias é offiçios divinos que se pueden é suelen haçer á un grand prínçipe un dia á vísperas é otro á misil, donde se le dixeron muchats, é se dieron nuchas limosnas á polıres. É concurrieron quantos seĩores é cavalleros é personas principales ovo en la cibdad, é con luto el duque é otros señores é cavalleros: y el marqués nuevo ó segrundo del Valte, su hijo, lo llevó è turo el illustríssimo duque á par de sí : y en fin, se higo en esto todo lo posible é sumptuosamente que se pudiera lager con el mayor grande de Castilla.

É murió como callhólico, resçchidos los sacramentos é fecho su testamento é dexando por su universal heredero é mayorazgo a su hijo legítimo don Mlartin Cortés, mançolo de hasta veynte años ó menos, buen cavallero, é só la tutela é favor del señor durque; é a lo que mues. trá ó se puede juzgar de su persona, se espera que será y es bien digno del estado en que subçede, é de otro que muy mayor fuesse. E con tauto se concluye este libro XXXIII.

Téngalo Dios en su gloria al marqués, que en la verdad digno es de mucha memoria: y él es el prinçipio é fundamento de su casa y estidlo, é por su persona é méritos grandes to ha adquirido, como la historia pressente, aunque sumariamente, lo ha contado.

\section{CAPITULO LVII.}

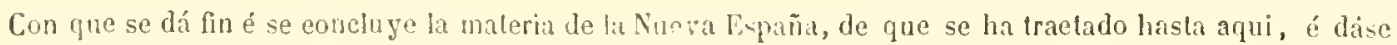
notiçia de una nao que vino en fin desle año de mill équinientos á q1arenla y ocho años á España, eargada de plata

$\mathbb{D}$ rias, que lıallándose en Sovilla rino une nao de la Nueva España cargala de plata, é ques raģon que se liaģa menıria desta nao, pucs ques al propóssito del marqués defuncto é del grand serviçio que licgo en confuristar lantos reynos é movincias para la corona real de Castilla. F. decirse há sumariamente, porefue es! its cosas é riquuegas de Indias no tienen nescessidad de fúlunlas ni adornamiento de palabras, sino llanamente, usando de la limpiega é facultad que pide la historia para que las cosas sean mejor entendidas é claras.

Subcedió que, lunes veynte é quatro de diçiembre del ano de mill é quinientos é quarenta y oclıo, víspera de la Nativi- 
dard de Chripsto, Nuestro Redemptor, llezó un barco á Sevilla, con cartas para los offiçiales de Su Magestad que residen en la casa real de la Contractaçion de las lndias, façiéndoles saber que estaba ya dentro del rio una nao venida de la Nue. va España, de que era macstre Françisco Santos é piloto Alfaro. E aquella partió de la Nueva España cargada de plata, é para la embarcar cclaban fuera el lastre de las piedras que tenia; é pusicron tantos quintales de plata en ella por offa ó carya que assi lo que vino para Su Mageslad, como para mercaderes é particulares personas, son más de sessenta mill marcos de plata: lo qual, el mesmo dia ya dicho lo dixeron é sertificaron al chro.

- Como vá advertido en la Vida y escritos de Ovicdo, no llegó á redactar esta $M V .{ }^{a}$ parte de la IIistoria de Indias, sorprendiendole la mucrte cuando comenzaba á hacer la edicion de la II. ${ }^{2}$, segun al linal del libro XX nolamos. En el mismo año de 1548, en que lacia Oviedo la adverlencia que dá molivo á la presente nota, preparaba tamben la segunda edicion de la I. ${ }^{a}$ parle, ya publicada en 1535 , y aumentada en más de un tercio, eomo declara el mismo autor y habrán tenido ocasion de ver los lectores entendidos en bibliografia, Las explicaciones que dá el primer cronista de Indias cn los úlli- nista destas materias el thessorero Fran. sisco Tello, y el contador Diego de Cárate, officiiles de Su Magestad é jueces en la dicha casa de la Contractaçion de Indias. É luego acudió á la dicha casa mucha gente é mercateres á resçeloir cartas que vinieron en la mesma nao. ì fué público é notorio que la plata questa nao truxo, vale sobre trege mill ducados de oro. Con lo qual se concluye el libro pressente; é lo que de aqui adelante subcediere en las cosas de la Nueva España, se porná en la quarta parte desta General y natural historia de Indias, que verná despues de la impression de aquestas partes que hasta el pressente están escriptas*.

mos capilulos del presente libro respecto de csta proyectada publicacion, son en nucstro juicio bastantes para convencer de que no tuvo parte directa en la impresion de 1547 , segun intentan sostener, sin alegar prueba alguna convincente, algunos eruditos. Oportuno creenos por tanto el reiterar cuanto dijimos en la nota 35 de la IV. "parte de la Vida del Alcaide de Santo Domingo, quien sin duda no debió ignorar la suerte de su obra, siendo evidente que el absoluto silencio que guarda sobre la edicion de 1547 quila á la misma la autoridad, que han pretendido darle cicrtos bibliófilos. 
Este es el libro déçimo quinto de la segmula parte, y es el trigéssimo quarto de la $N a$ tural y general historia de las Indias, islas y Tierra-Firme del mar Oçéano, é ceptro real de los Reyes é reyno de Castilla é de Leon: el qual tracta de la provinçia é gobernaçion llamada la Nueva Galiçia, é que los indios é naturales llaman Xalisco, en la parte oçidental de la Tierra-Firme.

\section{PROIIENIO.}

\section{C}

on grand dificultad se pueden ilustrar ó poner en perfiçion las cosas que son fechas por lombres sin expiriencia, ó que sin tener visto ó bien considerado é iprendido su offiçio se ponen á enseñar (qualquier artifiçio que sea) lo que no ha visto; pues eslá manifiesto que aun los que lo ven é son diestros en sus artes, cadá dia hallan que emendar ó acresçentac é corregir en sus proprias dottrinas (puliendo é afeytando sus mesmas pálabras é obras, dando é inventando nuevas reglas é dechado para quel mesmo arte mejor se entienda de los que vinieren subcediendo y exerçilando la mesma sçiençia), como cala dia lo vemos en estas nuestras cartas de navegar. que las pos- meras son las mejores é más gुicrlas, porque vienen corrigiendo las primeras. Y assi será lıasta llegar á la verdadera perfiçion que han de tener, porque conviene que passe algun tiempo de nesgessidad para entenderse la verdadera geographia deslas tierras é mares de nuestras Indias de la corona real de Castilla lan puntual é çertificada é particulariçadamente como es menester. Yo estoy maravillado cómo algunas personas se lán puesto ál escribil las cosas de acá dende líropa (cuyos nombres es mejor que se callen que no que se digan), pues lablan á liento en lo que no ven ni pueden entender sin su pres. sençia, é informados de quien no conossen, pues que aumque estando en esta 
licha conviene en le que hombre no vee (anpue cerca de arpil acacza, ó haya lo

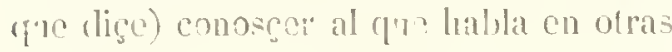
provincias, é saber qué persona es, p lnype sus palablas se açipten ó tomen por Jurlas ó reras. Y assi ho hallado muchos y lie oydo rosas, que amuque las escucho, ui las niego ni las aprucbo, puesto que en mis borradores para mi acuerklo las noto; pero no las escribo en limpin, sin que mis ujos me descagañen, si cs posible rerlas, ó que lualle contertes que me salisfirgan. I para laçermo diestro é detorminarme, antes que gaste el tiempo en acomula" renglones en esta materia, hago lo que laçian aquellos antiguos romanos, que enseñaban á sus galcotes ó remeros en tierra, pues que sentados en bancos puestoz rn el suclo los imponian é mostraban el officio, para que despues en el agua lo exerçitassen, con alguna parte de indusuria ya entendido. I assi querria yo queslas historias de nuestras Intlas, que reo escriptas deste España é otras partes, oviessen tomado sa prinçipio, viendo arpuestas, é que no fuesse todo de oydas. Y porque puse la comparacion en los romanos, dirć lo que hiçicron sin saluel ‘ué cosa cran aquellos narios, que llaman quinqueremi, en los quales sus oncmigos cartagrinenses eran expertos (é aun al pressente con quanto estál escripto hay pocos maestros cn Italia y España é Francia, é aun un toda la Europa, que los stipiessen haçer . I por sí ó por no, quicro decir lo que en este caso escrilió aquel curioso é gentil historial Leonardo Aretino en su tractado de la Guerra púnica ${ }^{",}$ el fual diege que teniendo guerra la república romana con la de Carlago, deliberaron de poner en Ponto çicnto é reynte naves (que de nucvo començaron á coleficar) é ordenaron que cient dellas fuessen quinque remi é las demás fuessen trirremi:

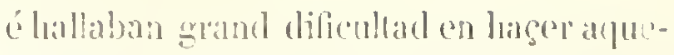
llat de los cinco remos, poryuce en Italia no avia macstro que oviesse ferlo bil género de maves. Pero lo que les a yuló á lats lacor fuć una, quel cónsul Appio Claudio les lomó á los cartagyinenses, quando passó á Meçina, en la qual mirando los malestros turicron dechado para harce tates naves; y en tanto que se haçian, la moltitud indolla aprendia, mirando cómo se a vian de excregitar. I para esto, puestos los bancos en cl arenal por órden, romo eslán en la nave los renadores sentados 'u aquacllos á la voz del cómitre que los regia ó mandaba redurian los lmaços á mover los yemos jor el arena. Í el mesno auctor dige que cada quinqueremi tenia trescricntos liombres al remo é çiento é vernte otros conubatientes é sobrestan. tes, é arueste numero se observaba por los romanos é.por los cartaginenses en tales navios. He querido deçir los cosas: la ‘una qué maneláa de navios era esta, é la otra la industria é pronçipio de mostrar. remando en el arena, cómo arian de bogar en el agua. I' assi á este propóssitn aplicando, digo questas materias de que fracto, se han de rer y exercitar por estas mares é arenales é tierras ásperas é llanas é de qualquicr género que sean, para agertar ál darlas a entender ál los que dende léxos las leycren ó escucharen. Y si go con mi rudo ingenio dende acá no lo açertare á haçer, á lo menos sibrá el letor que escribo deharo de aquella bandera inmóvil, ques persererando en estas partes, escriliendo las cosas dellas, para que se pueda sospechai que caso que no lo diga lau bicn quanto la materia meresce. ál lo menos mós ayna hallaré quicon nuc lo té á entendec en csta ticrra, que no apartado della en Milan ó en Siçilia, para que pueda fuanto all objeto llevar más reglada y çierta lil 
leçion quanto más reçino me liallo de aquellas regiones, de quien tracto. T porque dixe de susso bander immóvil, digo que segund el auctor alegado, teniendo guterra los galos contra los romanos, vićndlose en nesgessidad los ínsubros, detiberaron de venir á batalla eampal; é aplaşadal junta su gente. pusicron en el campo çinquenta mill lombres, é sacaron fuera del templo de Minerra cierta: banderas, las quales llamaban inmóriles, porque lícito no era huyr el que fuesse con aquelias banderas. Fassi yo no pucdo huyr de las Indias, porque soy ricjo é constituydo en eclad. "y cssa poca de substançia ó bienes de fortuna ó temporales que para mi substentaçion é de mi familia é casa plıgo á Dios darme, en eslas partes él ordenó que fuesse, con muchos trabaxos y en diverseas regiones é tiempos adquirido, para que aprendiesse é riesse la ealidad y el ser de lo quo diresse en estas historias: é no quiso que en España (juedasse, aunque me crić eu la casa real de Castiila, sino que llevándose Dios al sereníssimo príneipe do:1
Jolsan, mi señor, é filtándonne su real pressençia, de quicn esperalsa ser remınerado y heredado en mi propria patria, por mis servicios, fuesse peregrinando por el mundo é riniesse á frarar cn estas tierras tan extrañas ć desviadas de clonde nasçí é soy natural.

De todo sea Dios loado, porque con su favor miscrieordioso he podido vivir é ver y cscribir estos tractados; é assi espero en él que en lo que me queda d: la vida podré deegir más en su servicion é alabanega é contentamiento de los que: estas mis ocupaciones é libros passaren. En este, ques del numero XXNIV, se tractará de la gobernaçion é reyno llamado la Ninera Galiçia, aunque muy di. ferente é apartada de aquella que en Lispaña assi llamamos; puesto que en alguna manera no del todo descmejante, quanto á la aspereça de las sierras bravas é de las gentes belicosas naturales della: entre las quales el proprio nombre desta prorinçia es é se llama Xaliseo, como más larga ć particularmente la listolia lo mostrará en los capítulos sigruientes.

\section{CAPITULO I.}

Cómo fué pruveydo Nuño de Guzman por capilan general é gobernalor de la Nueva Esplaña, deude la qual fué á conquislar é poblar la provinęia de Xaliseo éotras con ella comarcanas, de las quales despmes lué gobernador, é aquello todo se llama ngora el lreyno de la Nucva Galicia; í tambien se dirán otras eosil; ancxas al discurso de la historia.

S scĩor, é por su Real Senado ó Consejo le Indias las diferencias que en la Nuera España andaban entre sus offiçales sobre la gobernaçion de la tierral, fuć provešso por gobernador é capitan general un cavallero de la eibdad de Guadalasara, llamado Nuño de Guzman : el qual ydo á aquellas partes el año de mill é quinienlos é veynte y seys, tomó el officio en Temistitan, é fué obedesciclo, é çessaron las contiendas y cscándalos fuc en aque- lla tierra avia entre los españoles é offçiales y el marqués del Valle Hernando Cortés: é dende á poco tiempo quedó tai mal yuisto cono los otros. É cómo Sus Hagestudes por los defettos de sus ministros supieron esto, acorlaron quel presidente desta Real Audiencia de Sancto Domingo, obispo desta cibdad, don Sebastian Ramirez de Fuenleal, fuesse á reformar todas aquellas faltas de los jueces passados é á poner los indios en libertad é la tierra en justicia. Él fué é hico lo que le pa- 
rescrió que convernia al serviggio de Dios ó de Sn Hagestad é á la conservacion é sustentaçion é conversion de los malurales; porque a la rerdat, labblando sin perjugio de malie, sn expiriençia ema muchla en las cosas de justiçia, é sus lelras é industria é buen natural bastantes para lo de acá. Fa assi por sus méritos é servicios, despues que á España volvió el Emperador, nuestro señor, teniéndose por muy servido dél, é por más se servir de tan luen cutendimiento, le mejoró en olispado é dignidades, é le dió la presidençia de la Chançilleria Real que reside en la villa de Valladolid, é le hiço merced de la cáthedra episeopal de la muy antigua é muy noble é muy leal cibdad de Leon é su dióçesis, ques una de las más principales iglesias de sus reynos, é despues le higo merged de la de Cuenca, ques de más renta. E dende aruesta cil)larl de Sancto Domingo passó á la Nineva España é aum gocando en ausença desta presidençia é sus salarios con los de acuIlá, en tanto que se proveyó de presidente para aqui. Pues como Nuño de Guzman tuesse arisado de su yda, fuésse por no le atender, temiendo que en su residençia le avian de fatigill los que dél estaban quexosos: y para esto acordó de luaçer nna entrada, só color de paçificar las provinçias que llaman Uliclichimecas é Jalisco ó Xálisco é yr en demanda de Culuacan. E puesto su camino en efutto, halló gente belicosa restida de cueros de venados muy bien adolyados, é gentiles archeros, é muy dispuestos ellos é sus mugeres, é de mayores estaturas é fuergas que los indios de Nueva España, é muy guerreros. É llevóse consigro quinientos houlres pocos menos de caballo, pero no todos cllos de su voluntad, sino eontra su grado los más, é algunos pressos, é otros cngañalos de sus palabras: lo qual no pudiera hager, si supieran que yla el perlado ya dicho ú ntro presidente á le qui- lare el cargo. É cómo llegó á la provineria de Alechuacan, el soinor della, llamadu Cagongi, que estalna de paz é scrvia á llernando Cortés, le resçilió muy birn á él é á los cluripstianos, é les livo dar todo lo nescessario de hastimentos: y en pago de su servicio le prendió, é fué fama que le sacó más de dic\% mill marcos de plata é mucho oro, é le tomó diezó doge mill indios que llevó consiģo: é porque no se purliesse quexar. le hiço quemar con olros indios principales, dando color á su injustiça como le paresçió. E jrosiguió su canino, é llegó á aquella ticra de Xalisco ó de la Nueva Galiçia, donde luvo continua guerra é le mataron muclıos españoles: é allí residiendo é continuando la gnerra, como diestro capitan é valiente soldado (porque su persona era (al), conquistó la provinçia de Xalisco ó otras comarcanas, que los naturales llaman Clıamola, é al prinçipal pucblo ó caJeģa diçen assimesmo Chamola ; é los españoles lo llamaban la Nueva Galiçia, no porque es menos ni más antigua que la que en Espana Galiçia se diçe, sino porque nuevamente la hallaron Ios cliripstianos , é les paresçió que por ser lierra muy áspera é montuosa se le debia dar tal nombre. El qual lo ovieron nuestros gallegos é su prinçipio, segund diçen, de los griegos que despues del fin de la guerral de Troya, Teucro, por la muerte de su hermano Ayax, venido en odio de Talamon su padre, no le resçibiendo en el reyno, fuésse ál Epiro y edeficó allí una sibdad, llamada Salamina por el antiģon nombe de su patria. Despues, sabiendo la muerte de su padre, volvió á la patria, lo qual le contradixo é vedó Euriģe, hijo de Ayax, é fuésse en España, é tomó aquel lugar é puerto donde al pressente es la nueva Carlago: édespues passó á Galiçia. é puso allí su silla, é dió nombre á aquella sente, é fueron llamados parte de aquellos do Caliçia amprithres, ate. Esio 
é otras cosas escribió Justino en la alureviaçion de Trogo Pompeyo '. Assi que este es el orígen de los gallegos conforme á este auctor; pero yo por más antiguo que lo ques dicho lo tengo, pues Justino confiessa que esse Teucro halló polslada aquella tierra: é caso quél los hiçiesse llamar gallegos é á la provinçia Galiçia, no la pobló él nuevamente, ni dexa de confessar, por lo ques dicho ser tan antigua ó más Galiçia que los troyanos. Estc cavalleı Nuño de Guzman, como diçen que en parte es gallego, procuró de renovar donde es dicho este nombre de
Galiçia; é fundó tres pueblos de clıripstianos en aquella tierra, donde les dió solares é sus caballerias, ó çierto térnino para en que viviessen é grangeassen sus haçiendas é agricoltura, porque es tierra muy fértil é de muchos mantenimientos é animales é aves, como en la Nıeva España: de la qual dista çiento é veynte leguas algo más, que hay dende. la grand cibdad de Temistitan liasta la cibdad de Compostela, quel dicho Nuño de Guzman fundó en la costa de la nar del Sur, y es la cabeça de la Nueva Galiçia.

\section{CAPITULO II.}

En que se traclan algunas particularidades de la Nueva Galiẹia é provinçias de Xalisco, é de su fertilidal, é de la provinçia de Culuacan, é olras cosas.

\section{A} dias los españoles llaman Nueva Galiçia, inclúyense en él muchas provingias; é las principales entre los naturales se llaman Xalisco, Culuacan é Chamola. É aqueste es más proprio nombre suyo, porque Chamola es un grand pucblo, que antes que los chripstianos fuessen á aquella tierra cra la caluecera de toda ella. En la qual, como de susso se dixo, la gente es belicosa: son grandes flecheros é monteros, al qual exercicio son muy dados los naturales dende antes que entren en la cdad adolescente. É su segunda grangeria é muy ordinaria es criar colmenas, é tiénenlas en las casas colgadas en el ayre; y en lugar de corchos (que no los tienen) para los vassos de las alyejas toman un troço de árbol é láicenlo vacuo, del tamaño é proporçion que en España lo haçen de la corteca del alcornoque; y en una casa diez y en otra veynte ó treynta, é más ó menos, tienen colgadas sus colmenas, é allí crian sus panales é miel muy exçclente, é tal que la de Cerrato ó de la Alcarria en Castilla, 0 la de Caspe en Aragon no le haçen ventaja en buen sabor é color y en todo lo que la buena miel se sucle usar. Las abejas son pequeñas é no mayores que moscas, é son muchas, é no pican ni haçen mal, porque son desarmadas. Para sacar la miel, de que usan comer y echar en sus manjares tienen una ó dos colmenas diputadas para gastar dellas ordinariamente (porque las demás cstán cntelas para el tracto é rescate de la miel é de la sera, ques mereaduria de que mucho se aprovechan, é lan por ella otras cosas, questos indios no alcançan). E meten por çierto agugero de la colmena, quitando un tapon, un palo liso que para aquello tienen fecho, é por allí destila é sale uno ó dos açumbres de miel ó lo que quicren sacar, sin desbaratar la colmena ni haçerle detrimento ni causar alteraçion á las abejas; é cómo 
son muchas las colınenas, assi es en grandissima cantidad la çera é muy buena.

El prinçipal pueblo ó ciblad de los chripstianos se llama Compostela, á imitaçion de la cilsdad de Sanctiago en España ó Galiçia, la qual cibdarl de Compostela fundó é polıló Nuño de Guzman, como se dixo en el capílulo preçedente, á la qual Sus Hagestades enviaron á le tomar residençia, é para esto fué el liçençiado de la Torre: é fué remiticlo á España, donde le envió presso para dar sus descargos y estar á derecho con sus érnulos, donde Nuño de Guzman piensa que le han de ser fechas merçedes por sus serviçios; é llegóa Castilla el año que pissó de mill é quinientos é treỹnta y nueve años. En la verdad, segund algunos diçen, él sirvió á Su Magestad muy bien en aquellas partes, é otros le juzgan por áspero gobernador. Yo no he visto alguno que, seyendo justiçia, sepa complaçer á todos; porque sies justo, diçen ques crudo é incomportable, é si manso é piadoso, diçen que no vale nada. El medio que la de tener el juez en la administraçion de los negoçios no plaçe sino á jocos. Y lay otra cosa peor: (que por la nayor parte los más de los que aćá vienen con ta. les cargos, tienen más fin á hacerer dineros que no á corregir delictos, puesto ques justo que el que trabaxa é sirve medre en su offiçio; mas laa de ser con las condiçiones que se deben procurar estos bicnes de fortuna, para que no hagan mal provecho á quien los adquiere. Digo que se busquen sin ofensa del prógimo ó daño de terçero, aunqne en este tiempo (y más en estas partes que en otras) la costunibre está en contrario. Pues sea el uso como lo quisiéredes: que no os juzgarán en la otra vida conforme á los estatutos o cautelas que acá se usan, sino á la ley divina, que no sufre engaño ni fraude.

\section{CAPITULO III.}

Hn el qual se traeta una relaçion quel historiador destas materias ovo despues de un hidalgo llamadn Françisco de Arzeo, é de olros que sc ballaron con Nuño de Guzman, quando fuć á eonquistar ć poblar la Nueva Galiçia; é euéntase más apuntada é particularmente que lo que está dieho en los capílulos preçedentes.

\section{$\mathrm{S}_{\mathrm{i}}$} xo en el prohemio deste libro XXXIY, vereys quánto aprovecha escribir estas cosas dende las Indias, é cómo el historiador seçiiano é lombardo dende España no pudieron entender ni inquirir estas materias tan çierta ni pumtualmente como el tiempo las dispone; y ammue el protonotario Pedro Mártir, que era de Milan, é fray Bernardo Gentil, que era seçiliano, é ambos fueron liistoriógraphos de Su Magestad, hablaron en cosas de Indias, digo que puesto que su latinidad é tractados no careşiessen de buen estilo, forçado es que se sospeche que les faltó çierta informaçion en muchas cosas de las que tocaron. I si dixeren que al Rey é á sn Consejo se sirvió assi, como essos doctos chronistas lo apuntaron, no todas veces sabe el Rey por tales cartas todo to que consuena con la verdad ni lo ques nesçessario para colmar la historia, ni los que lo escriben á Su Magestad no le dan tan por menudo essa relaçion, por no le - dar pessadumbre, é ann porque todos no lo saben haçer ni pueden comprender de una rez ni de pocos to que no ven (é digen informados de otros), ni tienen tanto cuyclado de la listoria como de la ganançia é otros interesses, en que más fundamcn- 
to lıaçen que en escribir regladamente, ni tan examinadas las cosas como el tiempo poco á poco nos lo enseña é dá á entender, que lo que ayer sentiamos ó supimos de una manera, lo hallamos mañana de ofra. Menester es vivir y escudriñar con atençion lo que se ha de escribir, para que la verdad quede como se debe entender. Y assi yo, despues de escripto lo ques dicho en los dos capítulos de sus. so, he visto é platicado con hombres de vista é buen entendimiento é meresçedores de crédito, en espeçial un hidalgo, llamado Françisco de Arzeo é otros, los quales diçen quel présidente Nuño de Guzman partió de la cibdad de Temistitan dia de los Reyes del año de mill é quinientos é treynta y tres años con çiento é çinquienta de caballo, é con quinientos caballos é con hasta dosçientos hombres de guerra ápié é de su guarda, españoles é muy bien aderesçados. Los capitanes que allí yban eran Chripstobal de Otañez, vizcayno, capitan de quarenta ginetes, cuyo alfercz era un Fulano de Cayas, natural de Ecija: otro capitan se llamaba Françisco Verdugo, natural de la villa de Cuéllar é veçino de la cilıdad de Temistitan, cuyo alferez fué este Françisco Arzeo, de quien de susso se hiço mençion: el capitan Samaniego, natural de Segovia, cuyo alferez era un lidalgo llamado Flores, natural de Salamanca : este capitan llevaba treynta lanças ginetas. El capitan Chripstóbal de Barrios, veçino de la cibdad de Temistitan, y su alferez Françisco Barron. Cada un capitan de los ques dicho llevaban sus banderas, muy bien armados todos é proveydos, como gente diestra é de guerra é sufiçientes para la empressa, é señalados con diferentes devisas.

Acompañaban la persona del general Nuño de Guzman quarenta sobresalientes, que cran relevałos de velar é de yr á entradas, y eran personas señaladas é veteranos mílites, é comian á su mesa, éá par de su persona estaban continuadamente. El alferez del guion, que andaba con el general, era un cavallero que se llamaba Pedro de Guzman, natural de Guadalaxara. El guion era de tela de plata, é bordada en él una imágen de Nuestra Señora, de tela de oro. É capitanes de á pié eran Proaño, natural de Córlova, con quarenta soldados bien en órden, é Diego Vazquez, natural de Guadalaxara, con otros tantos soldados. E...." era assimesmo capitan con otros quarenta hombres, é los restantes soldados de á pié yban con el capitan de la guardia; é por todos, como es dicho, yban hasta dosçientos soldados. É salieron este dia de México con el general hasta quinçe mill hombres amigos, de los naturales de la tierra é provinçia de Héxico, hombres de guerra, los quales no llevaban carga alguna de los chripstianos, mas de lo quellos para si mesmos avian menester. Era gente muy Iuçida é con muchas devisas de oro é plata en sus rodelas.

Sacó Nuño de Guzman consigo un grand scñor indio, llamado Caçouçi, señor le la provinçia de Mechuacan, ques quarenta leguas de México, al qual los chripstianos llaman Pero Pança. Este se ofresçió de guiarle é llevarle á tierras bien pobladas de gente é aluundante de bastimentos, quél deçia que era la tierra de donde avia proçedido el orígen de los mexicanos. Los indios desta provinçia de Hechuacan Ilámanse tarascos, y es la mejor gente que laay en la Nueva España de carga é de provecho, é aun de la más fiel. Vivia este Caçonçi en un pueblo que se llama Cinçonça, que quiere deçir en aquella lengua ciludad. Alli mandó el general que se hiçiesse alarde ó reseña de la gen- 
te que llevaba, é mandó proveer de todo lo nescessalio para su camino, é repossó en aquella pobacsion treyula ó quarenta dias. En todo aquel tiempo este Caçonçi liço dar á cada español dos gallinas, que son tamaũas ó mayores que los paros de Castilla, é media fanega de mahiz ordinariamente cada dia, é una india que le gruisasse de comer, é seys cargas de hierba para su caballo, é muchas fructas de diverssas maneras de las que en aquella tierra hay; é quando llegó el ticmpo de la partida, dió de sus indios diez mill para que llevassen las petacas de los cluripstianos. Es una petaca una manera de çesta muy bien fecha, é algunas forradas en cueros de venados, é con sus atapadores, que cabe tanto como media arca ó caxa de ropa ; é láçenlas del tamano que quieren. Demás destos indios ques dicho yban otros muchos, que llevaba el dicho Caçonçi para serviçio de su persona, é ylua siempre en una mula del general, al qual sirvió este Caçonçi é le dió doge mill pessos de oro, quél repartió entre los soldarlos. Y en la cibutal de Néxico les dió Yuño de Guzman muchos caballos é armas, que repartió entre los que mas nescessidad tenian; é cómo era presirlente de la Nueva España, quando liço csta jornada, quedaron los oydores de la Audiençia Real que allí residian en su lugar por grobernadores, que eran los liçençiados llatienço é Delgadillo é otros dos que se murieron.

Anduvo este exérecito por sus jornadas é tierra de paz suljeta á México ocho ó diez dias, é al cabo dellos llegaron á un rio que hasta estonçes no le avian visto los chripstianos, é porque fué dia de la Purificaçion púsosele al rio el mesmo nombre. É passaron de la otra parte, é assentaron allí su real é campo, y estovieron alli algunos dias, assi por repossar como por tentar la tierra é saber lo que en ella avia, porque alli ni dende adclante ni estaba hollado ni visto por los españoles.

\section{CAPITULO IV.}

Cómo el prinẹipal señor ques dicho, llamado Caẹonçi, avia fecho falsa relaçion al general Nuño de Guzman, é cómo despues dixo que no sabia la tierra *, le hiço un proçesso é lo mandó quemar: é cuéntanse otras cosas que passaron despues é los sacrificios de los que quemaban los indios en los hornos.

\section{D} ovo fecho assentar su exército de la otra parte é junto á la costa del rio de la Purificaçion, paresçiéndole bien la dispusiçion de la tierra, quiso saber é informarse muy bien della, é hiço haçer luego una iglesia de piedra, donde se çelebraron muchas misas é se predicó algunas veçes lá verdad evangélica; porque donde quiera que Ilegaba, haçia poner mucha diligençia en la conversion de los indios, y en los baptiçar é reduçir á la union de los fieles

- Aqui se leia en el códice autógrafo: "E se supo que avia muerto [el Caçonçi] tregnta f́ çinen mapañoles é fäeholos máscarasn. Al final del ep- clripstianos, aunque alli donde paró estaba la gente de la tierra alçada é huyda á los arcabucos é montes. I para recogerlos, si posiljle fuesse, hiçieron algunas entradas la tierra adentro, á unas partes é otras, de que ningun provecho, sino mucho cansançio se siguió; de fué nesçessario de se aprovechar, si pudiera, de la guia que hasta allá los llevó, que era aquel señor, llamado Pero Pança porque cra gruesso, que como dicho es, se deçia Caçonçi: al qual habló el general con

grafe suprimió tambien otra clàusula de menos importancia. 
sus nagualatos ó lenguas, é nunca se pudo dél sacar ni dixo sino que no sabia la tierra, ni la avia andado, é todo al revés de cómo hasta alli lo avia çertificado é dicho. Ovo tanto enojo desto el general, que le mandó cchar unos grillos, é le hiço tener á buen recabdo : é tornóle á interrogar diverssas veçes, é á preguntarle por las cosas é promesas quel mesmo caçique avia primero dicho é ofresçido; y por halagos que se le liçieron, ni por temores con que le amonestaron, no diso ni confessó cosa que fuesse al propóssito ni concertasse con lo que avie dicho primero. En fin, el general le hïco baçer su proçcsso é sentençiarlo á muerte é que muriesse quemado: el qual, quando se vidlo serea de su fin, dixo que por su mandado avian muerto sus súbditos é vassallos treynta é çinco españoles, é que los hallarian las manos é los rostros con sus cabellos é los piés, pucstos como máscaras, en una casa cinco leguas de su pueblo, donde los tenia escondidos en un monte. É quando se queria regoçijar, los haçia sacar el mesmo Caçonçi á los arejtos é fiestas; é que desta forma hallarian aquellos chripstianos en aquella casa ques dicho, é assimesmo hallarian mucha plata é oro é grand cantidad de ropa.

Preguntándole cómo avian muerto é quándo aquellos chripstianos, dixo que aquellos cran de los que yban desmandados dende Néxico, uno á uno, á buscar la vida (ó á topar más çicrto con su muer1c), é que cómo los veian solos, los mataban é haçian clellos aquella forma de espectáculos, por más se vengar de los españoles. Feclia esta confession, mandó el general á diez de cabalio que para esto escogió, que fuessen á aquella casa que Caconçi dixo, é supiessen si cra assi como deçia, é truxessen ante él lo que lallassen de aquellas cosas que en el tormento avia declarado Caçonçi. E en quince dias furron é volvieron, é tru- xeron todo lo quél dixo; é visto que cra assi, mandó luego el general luaçer um grand palenque ó estacado, donde se hiço justiçia del Caçonçi, y en un grand fuego fué quemarlo; é híçose saber á 10dos sus vassallos la causa de su muerte, é á lo que mostraron en lo exterior todos lo tovicron por lien, poreque los tractaba nıal, é deçian cllos que avia seydo muy bien fecho matarle. Y el general hirgo alçar por señor á un hijo de Caçonçi, llamado don Pedro, que se mostraba nury amigo de los chripstianos; mas despues que los españoles passaron adelante en prosecucion de su camino, se supo que avian ydo muchos indios de la provinçia de Hechuacan, incrédulos de la muerte de Caçonçi, á se informar de lo ques dicho; é cómo supieron la rerdad é justiçáa que dél se hiço, arrincaron el palo que avia quedado donde estuvo atado quemándose, ó ralyeron la seniça que hallaron; é todo se lo llevaron á su tierra.

Del rio ques diclıo de la Purificaçion, se partió este exérçito sin guia alguna, é siguicron por la costa de aquella ribera ocho dias, todo por despoblado, é andaban cada dia tres ó quatro leguas; y en fin deste tiempo llegaron á una grand provinçia, á vista deila; é aunque era de mañana repossaron allí basta otro dia siguiente, que al punto del alva, cada capitan puesta su gente en órden, movieron é fueron á un pucblo; é no liallaron gento en él, porque avian lurydo de temor. Aquella provinçia se llama Coyna; mas hallaron liarta comida.

Dende alli, repartida la gente del exérçito en sus capitanes, fueron en seguinuiento de los indios; é á dos ó tres legruas de allí laallaron muclıa gente de guerra, é pelcaron con los nuestros é hirieron algunos españoles é caballos, é al cálıo los indios fueron desharatados con mucho daño suyo, é sc enseñorearon los clripstianos de la lierra. E un notable é diabó- 
lico sacrificio se viclo en aquella provinçia, que por su novedal no se debe devar en silençio. Y es que en los puchlos que topaban, en los más dellos, hallaban unos hornos muy grandes, llenos de gente muerla é con muy grandes fuegos los hornos; é de aquellos cuerpos que allí se asaban ó coçian corria mucha manteca ó salrin ó sangre, porque poco antes que los chripstianos llegassen los avian echaılo é ofresçido en sacrifiçio á sus dioses, segund se supo de los indios que se tomaron en aquella entrada.

En todas las partes, donde este exérçito esturo algruma noche, quedaron fixadas cruçes, é se buscalıa el más alto árbol que se podia hallar para las poner. En conclusion, toda la provinçia Coyna fué sojuzgada, é quedó de paz en reynte dias que podia ser lo que en ella estorieron los españoles liaçiendo la guerra; y assi por temor del espada, como por halagos é Juena industria, quando convenia é los indios atendian, todo se paçificó: y muchos de los nalurales quedaron en sus casas é assientos, é muchos baxaron al infierno, que ni quisieron la paz, ni amn daban lugar á que se tractasse.

\section{CAPITULO V.}

rómo el general Nuño de Guzman conquistó la provinçia llsmada Cuysco, é la que se diçe Tomala, è olra que nombran Nuchisclan, é otras que se tlaman Maxalpa, Suchipila y Elteve, é olros pueblos; é otras cosas notables que convienen al discurso de la historia.

\section{D} cias fue se tractó en el precedente capílulo, sin perder tiempo acordó el general de se partir con su exérçitóá olra provincia que se llamaba Cuysco, que está ribera de un muy grande y hermoso rio; $y$ nandó que los chripstianos é indios amigos que yban con él, se hiçiessen dos partes, é los unos fuessen por la una costa del rio é los otros por la otra. É caminando desta manera, quando llegaron á estar dos tiros de ballesta de an pueblo prinçipal, toparon çicrtas canoas en el rio, llenas de gente de guerra, apartadas de las costas é puestas á la milad de la anchura del rio: é dende alli tiraban muchas flechas con sus arcos contra los chripstianos, é aun haçian algun daño. Siguióse que un capitan, llamado Françisco Verdugo, llevaba una ballesta en el arçon de su caballo, é apeóse é púsose junto á la costa é començó á tirar saetas á los de las canoas; é cómo la ballesta era reçia y él la sabia muy bien exerçitar, ningun liro faltaba ni dexó de herir alg̣un indio : por. que viéndole desviado de los chripstianos é solo, las canoas se le açercaron de tal manera, que una dellas andaba llena de sangre por los liros queste capilan haçia: é no haçian los indios sino echar sangre fuera de la canoa. I las mesmas sactas, con que estaban heridos los indios, ellos se las sacaban de sus carnes é las tornaban á tirar con sus arcos á los españoles con mucho ánimo; é cómo algunos indios estaban mal heridos de las sactas, no pudiendo más disimular la burla, caian de la canoa en el rio muertos. Y cómo se recreaçieron más ballesteros, y el daño que se haçia con las ballestas en los contrarios era mayor, se rindieron é vinieron á pedir paz, é se les olorgó. É assi nuestra gente llegó al pueblo quassi á medio dia, el qual estaba solo, é toda la gente dél sc aria alçado; é viendo esto los españoles, passaron adclante por la costa del mesmo rio, unos por la una parte é otros por la otra, é llegaron hasta estar enfrente de una isleta que se haçia en la mitad del rin. é alli costaha inda la gente del puehlo 
con sus hijos é mugreres é lıaçiendas, encastillados é fortalesçidos, hechas albarradas é defensas de madera, creyendo que allí no era bastante ningun exćrçito á los enojar, porque el rio ylua ian grande, que tenia bien que haçer en llegar una sacta dende ticrra adonde los indios estaban, assi de la una parte ó costa de la ribera como de la otra. Pero los espanoles no dexaban por este inconviniente, aunque era muy grande, de entrar por el rio á nado con sus caballos, é siguieron lıáçia aquel peñon ó isleta con tanta osadia, que era cosa mucho de ver; y en el instante los indios comeñçaron á gasta. innumerables flechas coutra los nuestros. Mas al cabo, viendo la constançia é atreviniento con que los chripstianos yban, desampararon la isleta los indios é fuéronse á nado, que no quedó en ella sino niños pequeños; mas como en ambas costas del rio a via gente clel exérçito chripstiano, tomáronse muchos prissioneros, que quassi no escapó ninguno de los contrarios; é fueron tantos que passaban de diez mill ánimas los que fueron captivos.

Á esta saçon llegó el general, que venia en la retroguarda é reçaga, al diclıo pueblo de Cuysco que estaba despoblado, é llegaron assimesmo los capitanes é gente de la avanguardia que volvia con la pressa é victoria ques dicho, de que ovo mucho plaçer el general. É para se informar de lo subgedido, mandó que llevassen á los señores prinçipales de aquel puebio, é dixéronle que uno, llamado Sacachimal é quedaba muy mal herido, que era el señor de la tierra, é que otro quas. si tan grana señor le avian muerto los chripstianos en el trançe ya dicho. É quiso el general que truxessen ante él aquel que estaba herido, é assi se hiço: el qual era honibre de grande estatura, de edad de hasta quarenta años, é traia una saeta hincada por los pechos liasta las plumas, é hablaba con tan buen alicnto é semblan- te, como si no estuviera herido, y estaba Lan apretada la saeta que no le salia gola de sangre: é despues que un buen espaçio estuvo hablando con el general é dando sus desculpas, óvole mançilla el general; é desseando su salud, si pudiera ser, mandóle curar á un liçençiado Muñoz. grand çirujano, que yba en el exérçito. É assi cómo le sacó la saela, cayó muerto, lo qual pessó al general é á todos los españoles, porque tenian creydo que si viviera aquel, aprovechára mucho su amistad á los chripstianos: y el general higo alçar por señor á un lijo del muerto, é quedó acpuella provinçia de paz, é poblada de los naturales della y en sus casas.

De aquel pueblo é provinçia de Cuysco passó el general á la provinçia que se diçe Tomala, que está çinco leguas adelante, la qual tomó : no tenia señor y era gobernada por una señora. Este señorio es de seys mill casas ó más, todas en un llano de tierra muy fértil é abundante de muchos bastimentos é fructas. $\hat{\mathrm{E}}$ antes que llegasse la avanguardia salió de las poblaçiones mucha gente, é dieron una grita tan alta é continuada, que paresçia que abrian el çielo, é de mucho terror y espanto á los que no han oydo aquello. Más cómo los españoles estabian ya diestros é sus orejas acostumbradas á esso, puestos en órden continuaron su passo á passo contra los indios, non obstante quellos se mostraban feroçes, é deçian que querian la guerra é no servir é obedesçer á los chripstianos: é hiçiéronse fuertes en un çerrillo poco trabaxoso de subir, raso é sin arboleda; y era grande el número de los indios que allí estaban en un bata. llon. É cómo llcgó el general, hiço yr al ellos las lenguas con algunos soldados de buena confiança, é mandóles deçir que quisiessen la paz é ser amigos, ofresçiéndoles todo buen tractamiento: á lo qual respondieron con mucha soberbia que no querian sino guerra, é començándola, sol- 
taban flechas contra los de la eubaxada. Estonces el general mandó yr un rapilan con gente por un ladlo del çerro é otro por otro, y él con el resto del exérçito por enmedio; é sulnóse el çerro á fuerega de armas sin mucho trabaxo y en poco espaçio de liempo, porque cómo los indios vieron çerea de sí los caballos, voírieron las espaldas por unos llanos adelante, y como fueron seguidos, mataron muchos dellos.

Deçia este alferez Françisco de Arzeo, que signiendo á su capitan Françisco Verduggo, vidlo que alançeó á un iudio: el qual, antes quel Verdugo llegasse, le tiró quatro flechas, é con la una le linió el caballo; é cómo el capitan era lrombre de buen ánimo, llegó a él é dióle de lançadas, é tales que por algumas partes de la persona traia el indio arrastrando las tripas. I cómo aquel indio debia de ser prinçipal, assi era valiente hombre é peleaba mejor que los otros; é traia unas fuionlas de oro al cuello, é otras en las munecas de los braços, y en las manos una macana, á manera de porra, llena de puntas de piedras pedernales, é de la manija de la macana pendia una correa atravessada é atada fuertemente al braço. É con esta macana, non obstante que esLaba muy herido, daba muy recios golpes en los braços al caluallo del capitan: el qual le avia dado una grand langada por las espaldas, que estaba el hierro de la lança entre los huessos interiores de] indio, tan asido que no podia sacar la lança, é fué nesçessario quel Françisco de Arzeo se apeasse de su caballo á sacarla de donde estaba; é lornó á calualgar é siguieron el dicho alcançe lasta que por delante no paresçió algun indio. E dieron. vuelta é llegaron al pueblo al liempo quel sol se ponia, é juntando alli el exérȩito, se curaron los heridos, que ovo harlos de

- Aqui has una laguna en el códicc aulógrafo, los clutipstianos é de sus calsallos flechalos, é repossaron allí é no les fallaron muchas lichres é grandes de las de Castilla (ó semejantes á ellas, salvo quel pelo es más escuro). Los indios de aquellas provinçias son caribes, que comen carne liumana todas las reçes que la pueden aver.

Passado el vençiniento ques dicho, vino la señora del pueblo de paz, é poblóse é paçilicóse la provinçia, aunque no de los muerlos, que fueron muchos: po:que aunque los españoles eran pocos (a) número, los amigos indios que consigo traian eran muclios, é quando la cosa ylua de vençida, estos eran los que haçian el daño muy cresçido é sin alğuna misericordia, sin perdonar á clico ni á grande, ni á muger lampoco, sin que se pudiesse estorbar hasta el fin del rençimiento.

Allí estuvo el exérçito nuestro más de treynta dias, descansando é lo!gando, é dende allí passaron á olra provinçiaque se diçe Nuchisclan; é llámase assi porque hay muchas tunas en ella, á la qual fructa en aquella tierra llaman en su lengua muchisclan. Hallaron la tierra alçada, é repossaron allí la Semana Sancta. Media legrua de allí estaba un peñon subjeto á un pueblo yermo, donde pararon por el tiempo sanclo, como es dicho, y estaba poblado de muchas casas, donde se puso una cruz muy alla. I cómo todos los soldados ó los más de los que allí andaban no eran unuy contemplativos, no dexaron por ser el liempo sancto de yr á entrar en otra provinçia que se llama Xalpa *, é á olra que se dice Suchipila, é á otra nombrada Elteve, é á otros pueblos, de donde llevaron al pucblo, en quel general avia quedado, muchas mugeres é niños; é rolvieron los indios amigos mexicanos é tarascos de Hechuacan cargados de mucha ropa é aves é plumages é oro é plata é con muchos bastimentos.

la cu al so ha llenado por el de la Bibliol. Crlombina. 
El Jueves Sancto, al ticmpo quel general estaha oyendo la passion, vinieron quatro indios de paz con unas orcjeras é unos braçaletes de oro que pressentaron al capitan general en señal de paz, é los dos traian consigo dos ydolos de aquellos quellos adoran; é como la misa é offiçio divino se acaló, el general, despues que ovo comido, hiço llamar aquellos indios por un naguatato ó intérpetre, é híçoles muchas pregrunias, entre las quales les hiço preguntar que para qué traian aquellos ydolos. Y ellos respondieron que no eran sino sus dioses, por quien cran gohernados, é que aruellos les criahan sus mahiçales é frésoles é axi é gallinas, é les daban los hijos é mugeres é la ropa y el sol y el ağua é todo quanto bien tenian; é les daban la vida é la muerte, quando les plaçia, é que como á tales dioses é seĩores suyos los adoraban é acataban é scrvian. El general les respondió é liço dar á entender por las lenguas que todo quanto deçian era falso é mentira, é fue no avia más de un solo Dios Todopoderoso que estaba en el çielo, é que saliessen de tan grand error, é que mirassen que todo quanto deçian era burla é que vivian engañados. I ellos replicaron que no conosçian otro Dios sino aquellos ydolos; y el gobernador les dixo que los queria quemar, como á cosa que no cra nada ni se podia defender, é los indios respondieron á esto que no ternia el fuego tal poder que pudiesse empescer ni tocar en sus dioses. Estonçes el golsernador mandó tracr leña, ć muy presto vinieron más de dosçientas carģas della; é fecho grand fuego, mandó echar los ydolos dentro en él, é cómo eran de mantas llenas de sangre de los diabólicos sacrifi- cios que usan de hombres lumanos con sus cuchillos te pefternales, que entre aquellas sangrientas mantas estahan, en poco espaçio de tiempo lo hiço el fueğo todo çeniça, de lo fual quedaron no poco espantados los indios, que avian traydo los ydolos é los tenian por dioses. Y ol golecrnador, viéndolos assi maravillados, les liço deçil que no se espantassen de averse quemado aquellos sus espetáculos é filsos dioses, porque no eran nadia ni tenian ninguma deidad ni fuerça; é que ereyessen en solo Dios verdadero, que crió el çielo é lá tierra, é que aquel es solo el que dá la vida é la muerte, y es poderoso en todo é por todo; é que luego hiçiessen llamar á torlos los señores de sus provinçias, é conosciessen á Dios, é fuessen amigos de los chripstianos, é no creyesssen ni ydolatrassen en aquellos desvarios, porque sus ánimas se salvassen. Acerca desta materia callólica les dixo muchas cosas provechosas é al propóssito de su salvaçion é remedio; lo qual todos quatro indios dixeron que lo avian bien entenflido, é muy contentos fuéronse los dos dellos á llamar sus señores, é quedaron los otros dos con el general. E quando llegó el Sábado Sanclo, víspera de Páscua, vinieron más de veynte mill ánimas de paz, é se baptiçaron todos, é resçibieron agua del Espírilu Sancto, lo qual no podia rer ningun cathólico sin lígrimas é alegre devoçion é mucho gogo. Y el general los envió á sus casas muy contentos, é quedaron de paz todos aquellos pueblos y en mucho sosiego debaxo de la handera é señorio de Castilla, como huenos vassallos de Su Magestad, y en la union é número de la repúlulica chripstiana. 


\section{ClPITHA II.}

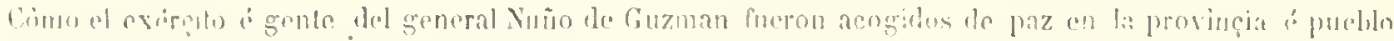

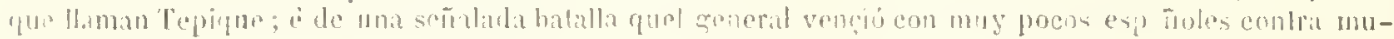
chos iudios en los eampos de lat provineia, que se rlige Centiquiparue.

屏 provincia llimada Tomala, é mandó á las wuias del cxército que lo llorassen á una provinçia que se nombra Tepique, de lis yual ya le avian dado noliçia; é lriço divilir torla su gente en dos partes, é que fursecn por diverssos caminos á salir á juntarse en el pucblo prinçipal, llamado assimesmo Tepique, que estalsa adelante de Ninchisclan quarenta leguas: é de los dos eaminos que tomaron, ol uno era muy bueno, y el otro muy áspero de sierras é despcñaderos. Por cl buen camino é poblado fué el golsernador con todo el fardage rle petacas é carruage é indios é caballos é pucreos é carneros é todo lo demás; é por el mal camino fueron cl capitan Cherino, vector de Su Magestad, y el capitan Françiseo Vterdugo, y en dicz y sicte dias no pudicron hallar cosa que de eontar sea, sino grandes é ásperas sicrras é despeñaderos: é parlesçicron mucha hambre é otras nesçessidades, y en fin destos diez y siete dias llegraron á in robledal, sin saber arlónde se cstaban. ó acordaron de dormir allí aquella noche. fun negro del veedor adclantóse dos le. śuas de allí á busear de comer, é virio ına granel provincia é una lagguna con muschas canoas, é dió luego la vuelta i dar mandado é aviso á los eapitanes ya dichos: é sabida esta nueva, cabalgaron treynta dle calsallo, aunque cra tarde, é ficon al puclslo, el qual cra el mesmo Tepigue, adonde avia el grobernador de y"í salir. Ellegado allí el Cherino con los lreynta dle calrallo, ya de noche, salió to1o el puchlo de paz é con mucha comillis raves é fructas; é liego por la mañana los que avian quedado en el robledal fueron al puoblo, (que estalı bien polılado de indios. Era gente de buena raçon: é allí malaron la lamulure de las sicrras quo avian passado, é preguntaron á los naturales si ienian nueva del general, é dixeron que no: y ellos quisieron saluer qué camino avian llevarlo aquellos clripstianos, é sabido, cspantáronse mucho, é no sin raçon, é con grrand sospiro dixeron que si cran páxaros ó ares que avian rolado. Hegund yo supe del Arzeo é otros que lo anduvieron, tenian bien de que maravillarse, segund el camino, que cra dificultoso y espantable para haçerle hombres á pié, quanio más á caballo. Derde á ocho dias despues llegró el gobernador con sil esérçito é todo lo rlemás, próspern é contento, porque aria liallado por cl otro camino muchos pucblos é muy granres é todos los dexaba de paz.

En aquel puchlo de Tepique estovicron los chripstianos más de treynta dias, reformándose é dándose buena vida, porque la tierra es aplaçible é fértil de todo, é hay mucha caça é monteria. I en esto tiempo ovieron noticia de una grand provinçia que se diçe Centiqnipaque, doçe leguas de Tepique : é los de aquel señorio enviaron á deçir á los españoles que no les passasse por pensamiento de yr á su provinçia, si no que les çertificaban que á todos les comerian eon axí, é que tenian puesias é aparejadas las ollas para cllo. El gobernador les envió î́ deçir que no se pusiessen en defensa é quisiessen paz. é buena amistad con él é su exército, é lc diessen mantenimientos, é viniessen á la olidiencia del muy poderoso Rey de 
Castilla, Nuestro Señor, si no fluel hartit un castigo en ellos yue nuncia se les olvidasse, é los pornia á cuchillo é los destruyria.

Ýdos los embavadores, mandó salir al capitan Clnipstólal de Barrios con treynlar de caballo, é que fuesse á ver é collsiderar la provinçia é dispusiçion de la licra; é vídose que era miy grande é muy poblada, é tenia á media legua é á ruarto de legua quarenia pucblos unos le ollos, é lan corcanos é allegiados do la mar del Sar, quel más léxos estaba d) s leguas della (que aunque comummena los espanoles la llaman del Strr, ya alí lit pueden decir ocçidental, porque la costa siempre se va volviento la via del Nor. t: é aquella mar es el mesmo Océano. l'ro dexemos esto, porque en su lugar se Iractará más puntualmente lo que hiriere al caso de la cosmographia.

El capitan ques dicho le suberedió mal en su vela, é volvió bien descalabrado él é los que con él fueron, é su alferez perlió la bandera, é se tomaron al pucblo de Tepique con vergienca é daño, non obstante que los indios amigos, que avian por olra parte entrado en aquelta provinsia, é arian ydo por mandado del general á ver la ticra, truxeron muchas cintas de oro é plata que robaron á muchos ruachachos é mugeres. Cómo el general vido el mal tractamiento de su capitan, mandó levantar el real é novió para aquella provinçia Centiquipaçue, é dende á quatro dias llegó á un poderoso rio tue estaba á dos leguas de la poblaçion principal, y en aquel rio aria serdo desbaratado cl capitan Barrios, é todo lo de atrás quedó de paz: digo dende Tepique llegó el exérçito á arfuel rio víspera de Pásqua de Espíritu Sancto, é durnicron allí aquella noche, laçiendo Luena guardia, como gente diestra en la guerra; no paresçia que por toda aquella tiorra oviesse persona.
Otro dia for la mañana, dia de Pásyua, oyó el gobernador misa, é assi por ser la fiesta solempne como por el ancto de possesion que en aquella tierra qui-n (omar por Su Nagestad, caljalgó en mu hermoso caballo á la estradiota, con un sayo de tela de plata bordado de oro, 6 la guamiçion del caballo de lo mesmo, é hien armado debaxo de su gentil atavio, porque llevaba su cota é cuera de anto. E de sus solpresalientes é de la compañia del capitan Chripstóbal de Oñate junto Lasta sessenta de caballo, é dexó buen lecaludo en la batalla principal y en la rotroguarda, é tomó la delantera, é passí u lio con los solbresalientes en númere de sus sessenta cavalleros por todos, i: como fué de lia otra parte, hico tocar sus tromprefas y echó mano á la cespadía, y encontinentr, llevéndola arrancada ó desnuda en su mano derecha, puso las pieruas á su cahallo, é començó á deçir á altas roçes quél tomaba la possesion real it rorporal é actualmente por el Rey poderoso don Cárlos, Nucstro Señor, como Rey de Castilla, é por la cattrólica é sereníssima Reyna doña Johana, su madre, $c$ sus subçessores en la corona é ceptro real de Castilla; é que si algun cavallero ó príncipe ó capitan alguno avia ú otra persona que se lo contradixesse, quél eslaba presto con su persona é con su exérçito, uno á uno é dos por dos ó más, de: lo defender con las armas é verdad é títulos de justiçia que Su Magestad tiens: en aquellas lierras é mares é reyuos. í usando é continuando la possesion real que dello todo tiene, é si nesçessario era tomándola de nuevo, liço sus auctos en el caso convinientes, é pidiólo por testinonio en nomlure de Su Magestad : é cóno su capilan, mandólo á un escribano é notario público que pressente cotaba ; é no paresçió persona alguna fue se lo contradixesse. É assí en paçifica possesion - a assentó por aucto, é usauto della, man- 
ló que de allí adelante aquella tierra é provincia, Ilamada Centiquijaque, que se Ilamase la Hayor España. É feclo esto, proçedió su camino adclante, é paresçiéronse todos los puchlos ques dicho é un llano, por donde yban caminando, de más de dos leguas, en el qual no avia árbol ilguno ni aun piedras, sino hicrba é pequeña, é la más cresçida seria liasta la rodilla, ques liarto cocta segund los herbagales grandes destas partes é lndias. í yendo en buena órden por su camino, avia entre aquella lierba doçe mill lıombres 6 más de guerra cchados en el suelo tendidos é puestos, por sus esquadrones, é todos cllos gente escogida y encubiertos de la mancra ques dicho; porque pensaban que si los chripstianos los viessen avian de huyr é rolverse, é por tomarlos á su plaçer, usaron deste ardid. Cómo los españoles llegaron serca dellos, levantáronse todos á un ticmpo con mucha grita, é arremeticron contra los nuestros con tan grand ímpetu é denuedo como lo pudieran mostrar los más animosos é diestros soldados que puede aver en el mundo. Estonces los españoles, aunque no llevahan armadas sino las calıcças é los pechos de los caluallos, porque no les dicron tiempo para cllo, arremeticron para los enemigos ustribo con estribo, é con la voz é apcllielo del גpóstol Sanctiago ; é rompiéronlos é hiçicron grand estrago en aquella gente búrhara, puesto que eran más de treynta esquadrones: y en cada esquadron aria hombres que mandaban á los otros de la muchedumlire, y essos particulares no traian armas sino unos hastones de quatro ó çinco palmos, con los quales dalian al indio que 10 pelcaba, como era el deber, osadamicnte.

Estos indios estarian del rio, donde el general avia dexado el restante del exérçito passando el fardage, legua y media grande, é la grita de los indios sc oý tan claro en el rio, como si estovieran un tiro de honda los unos de los otros.

Estaba un arealuteo ó boscage pequeno junto al rio, en que avia mucha genice de guerra escondida, atcudiendo para ditr en el fardage quando fuesse tiempo; $e$ quiso Dios que giertos indios de los amigros vicron los plumages que traian é dixéronlo á los españoles, é fucron sicrtos le á caballo lácia la çelada : é cómo loz enenigos vieron que cran sentidos, salicron todos fuera, como buenos guerreros, cclando muchas flechas iláçcia los chripstianos; é cómo el rio esladia cresçdo, no pudierou los nuestros ofenderlos, como quisieran, aunque fucron en su sesuimiento: y eclı́tronse los indios al agua, é paráronse de la otra parte del rio, é dende el otro cabo alçaloan la pienna é grilaban como por escarnio.

Acabado de passar todo el fardage, llegó el general con su gente, que volvia del alcançe de su victoria, que fué muy señalada é muy sangrienta, é renian todos muy mal heridos: pero no murió ninguno, é quedaron en el campo muertos más de çinco mill indios, aunque era gente muy ljien armada, segund su costumlre, é traian carcaxes de cucros muy bicu adolados, que parescian mantas, é las flechas tenian quatro dedos de luengo unos engrastes de oro á los tendales, por donde las tomaban para poncrlas en la cuer. da del areo. Todos los más de aquellos indlios traian gutaras, que son çapatos con una sola sucla, sin capelladas, é asidos con cuerdas de algodon dende los dedos á los tovillos por ençima del empeyne del pié.

Assi que, recogido el gencral con su exérçito, llegó á la polslaçion á lıora de rísperas, é no hallaron gente alguna, sino yermos ó solos los puchlos, é apossentáronse los nuestros donde mejor les paresçió; y el terçero dia adelante de la batalla salieron algmos de á caluallo á rer 
la matança, é no liallaron en todo el campo, donde ella fué, indio alģuno ni vivo ni muerto: que todos los arian recogido los naturales de la lierra. É dentro de qunce dias todos los de la comarca vinicron de paz é dieron la obidiençia, é descansaron los españoles bien treynta dias, lien proveydos de todo lo nesçessario, porque arquella provinȩia es la mayor de todas las de aquella tierra, y en muy hermoso as- sicnto de llanos émuy fértil region, é de muchas y hermosas pesquerias de ostias é lenguados é otros peseados. Hay muchas liebres de la manera de las de Castilla é muchos géneros de fructas, i muy abundante de maliz é legumbres, assi como frésoles de muclıas maneras; é finalmente es luena ticra é rica de oro é plata, por lo que se vido que los indios usaban é traian por arreo de sus personas.

\section{CAPITULO VII.}

Cómo el general Nuño de Guzman é su exérçito fueron i la abundantissima provinçia de Izlucian, e la l̆allaron despoblada é sin gente; é de un grand huraean que se pensaron perder eon lodo su exérçilo, é nurieron desta causa las tres partes de los indios amigos que en eompañia del exérçito chripstiano yluan; è fué nesẹessario de enviar por gente de españoles ci indios amigos para rehaęerse el campo, eomo se hiço, é otras cosas locantes à la historia.

V. torias do no dexar en olvido cosa notalo en bien ni en mal, aunque sea d́ alğunos lesaplaçible la lecion, si les tocare ó fuere en viluperio de sus amigos ó deludos; porque de otra manera no seria en lanto teniclo lo que redundare en loor é fama de los que lo merezcan. E assi noté desta relaçion é de los que lıe oydo lıablar en este viage del golsernador Nuño de Guzman, $\dot{e}$ a una voge, sin discrepancia dicen todos los que lo vieron quel maestre de campo Gonçalo Lopez, vecino do la cibdad de Sevilla, fué uno de los que "mejor" se señalaron ć más trabaxiron en esta jornada, é que su persona era de muclıo mérito é digno de señaladas merceles por lo que sirvió á Su Magestad é á su general, á su costa é con diez calsaIlos; y en fin salieron olros con haciendi sin averla trayulo, y él, lrayéndola é gyas. lándola y empoñándose por ayydar él otros, quedó con más de seys mill pessos de deluda.

E: dencle aquella provingia de Cenliquipaque passó el exérçito callólico à otra que se Ilama Iztuclau, rue estáu la una de la otra diez leguas. La de Izlu. clan está en la ribera de un poderoso rio, el qual es lan grande que los çinco meses del año no se radea; é llegaron á esta lierra los chripstianos y estovieron en ella quatro meses, hasta que passó el invierno é la grand furia de las aguas. Hallaron Loda la comarca alçada de miedo de los clıripslianos. Es grande aquel señorio, é más de quatro leguas el rio abaxo é rio arriba estí en ambas sus costas poblado de muy grandes casas que en aquella tierlaa hay, é de mucha caça; y en todo el tiempo ques dicho que los españoles alli estovieron, con más de sessenta puercos é muchos carneros é orejas, é muchas yeguis è caballos, é reynte mill ó más indios amigos é más de dosçientos españoles, nunca se salió á buscar comida para torlo esto de dos leguas arriba. Este rio tiene nuchas diverssidades de peseados, é nuy grandes algunos.

Siguióse que mediado septiemlıre, un dias por la mañana, sobrevino tan grand tormenta de agua, digo de viento, que rompia los árboles tan gruessos como tres cucrpos de caballos, é destos árboles en 
machar cantidad; é luró esta tempestat d.ulde las ocho de la mañana lıasta quel sol se ponia, é tan grande cómo fué el viento lamana fué el agua que llovió jumIamente: é á media nocle salió el rio de madie. de lal manera que qualio leguas x'u lorno parescia una mar ó un laggo de agual. Estaluan las casas, donde el general paralua é todo su real de los españoles, sobre la liarranca del rio, que fué más de seys braças lo que cresçió el rio para salir te la madre ó fuera de su curso acostumbrado, é llevóse assi las casas del apossento del grobernador como las demás en fodo el real: de manera que todos pensaI' n perescer, é aun assi subgediera, si no -P) sulvieran en los árboles que avian quelado destrocados de la tormenta del vien( ), y en ellos subieron vituallas de maliz Slo que cada uno podia para su sustenlaçion. Aquella cresçiente luró tres dias naturales, en el qual tiempo todos los calallos se andaban suclios para donde se querian yr nadando, é á partes atollando (2) apeando en busca de la lierba. Todos los ofros ganados que llevaban de racas c ovejas é puercos, peresçicron.

Passados tres dias, abaxó el aggua é su furia é tornó el rio á su lugar, é quedaron los campos en nuchas partes llenos de pescados é renados é liebres é conejus é raposas é olros animales ahogeados en todo lo que alcanḉ aquella cresçien10, que era mucho de ver é nueva á los yjos de los que la miraban: de los indios anigos, que eran reynte mill ó más, las tros partes dellos murieron con el trabaso ques dicho, é por la humedad de la lisra é por hambre é perderse todos los bastimentos. Y estando en esta nescessidad, que era una de las mayores que se preden pensar ó se han visto en estas partes, acordó el general que aquel Gonçalo Lopez, maestre de campo, de quieu so: hiço mençion de susso, como hombre şue era para mucho, volviesse dende aquella provingia de latuchan ál la de Hecluacan, que prochaba ya mós de cicut leguas de allí, (on vegute de calsallo, ál traer indios amigos parra continuar la cmpressa.

En rlos meses fué é tornó é truxo nucha cantidad deilos, é assimesmo alonnos repañoles bien aderescados par:a lis wuerra. Y entretanto quel mastre te campo fué á hacerp lo yues dicho, manclés a general al capitan Frangisco Verduger que fuesse á otra provinça gue se llami Clamedat diez é siete legruas adelante. é que demás de su gente llevasse ante sí fodos los indios amigos para que no se acabassen de morir. É luego el dicho capitan se partió para Chancda con los indios que avian quedado de México é dis Mechuacan, los quales yluan enfernos é maltractados: é lardaron en aquellas dicz é sicte leguas reynte dias, con muclio trabaxo, porque por donde yluan todo era ciénegas é moltilud de mosquitos ineomportables. E con mucha falta de comirla llegaron á aquella prorinçia de Chameda é lialláronla de paz, la qual si assi no estoviera é la hallaran de guerra, passaran mucho riesgro, segund yban los nuesLros, porque es mucha la polilaçion: é las casas de allí son de adobes é con terl’ados, en la ribera de un hermoso rio é quatro leguas de la mar del Sur. E assi cómo los espanoles llegaron, licićronles grandes apossentamientos fuera de su pueblo, é allí les daljan cada dia rreyntá gallinas de aquellas, que como se la dicho en otra parte, cada una es mayor é aun mejor que un paro de España: é dábanles treynta cargas de pescado fresco, ques cada carga de indio arroba é media de jesso; é mahiz les dalian quanto cra menester para todos. Alli andaluan los inclios vestidos de algodon é gutaras calçados: las indias traen sus naguas é camisas lasta los piés: no se cargan aquellos indios on las cepaldas, como los de la Nuera lis- 
paña, sino con balangas en un palo, como se dixo que lo acostumbran en la provinçia de Cueváo en Castilla del Oro, en los lrombros: é llevan la carga, ó par. te della mejor diciendo, una alrás é ofra adelante, en un palo ligero de sí mesmo, tan gruesso como la muñeca del hraco o más, remarticla la carga en dos partos, é cadir una alada quissi al caho de aquel baston, . cerca de las puntas dél, é cuelga una red con la milad del pescado de la una paricé ofra de la otra, y en el palo sus muescas, donde andan asidas aquellas redes.

Pues cómo el capitan Verdugo esturo bien apossentado, è viloque la provinçia cra grande é fértil, é qual gohernador se quedaba en la ofraque Ilaman Iztuclan por falla de tamemes, que assi llaman á los inrlios de carga, hiço llamar á los señores é pidióles mill indios para que fuessen á traer al general sus cargas é fardage del exérçito. dió ajuel pucblo dentro te seya dias los mill indios que le pidieron, é particron dende alli para Iztuclan; é llešarlus á dó el gobernador ustaba soscribiólos muy bien, é con ellos é con los demás que tenia fuésse adonde estaha el capitan Liancisco de Verdugo. E los naturales del parch!o de Chameda le hiçieron rand resçibimiento é demostraçion sle piaçerles con su persona, é con el amislad é nuevo conosçimiento con los chripsianos. Los indios que traian las cargas, cómo no sabian qué cosa era cargarse en las espaldas de las pelacas é pesso que, les echaron, llegaron á sus casas muy maliractados, è los más dellos corriendo sangre é desollados é llagados de las cargas; é desque se vieron en su puchlo, ano- chesçicron é no annanesçicron en él. é fuéronse lodos á un peñon é pesqueria, que tenian en la mar. E dende á quince dias despues desto llegó el maestre do campo Gonçalo Lopez, que venia de la cildad de Hechuacan con muchos amigos indios, é algunos cluipstianos vinicron bien aderesçalos assimesmo, é fruxeron muchos puerens é olras cosas de las de Castilla: con el qual socorro, asei el gobernador como los demás del exércilo, se holgaron mucho, porque allegó á muy buen liempo y era muy desseado. Luego se proveyó en enviar gente á buscar los indios que se avian alçado, é halláronlos en unos esteros è manglares, y en tal dispusiçion que la guerra en ellos iuró algunos pocos de dias, é hirieron algunos españoles; pero pagáronlo bien largamente con sus vidas los contrarios, $\dot{c}$ al fin quedaron con los demás conquistados é assentados en sus casas.

Antes que deste pueblo arrincassen todos los del exérçito, liçieron en diverssas jornadas muchas entradas, con compañia de mucha cantidad de los amigos. è corrieron más de çient leguas por la lierra adentro é çerca, é por la costa de la otra mar del Sur (aunque alli más la pueden deçir ocçidental é del Norte, porque cómo en otras partes está diclio, aquella costa se vuclve de la parte septentrional). É assi en todo aquello andal a este exército de los españoles é de Nuño de Guzman á diez é á doçe é á veynte leguas, é á menos en algunas partes, à visia de la otra mar, haçiendo la guerra é paçificando la tierra, é tambien alterándola, porque hallaban muclıos puclılos despoblados por su temor. 


\section{C.PITULO VIII.}

En que se tracta de la provinẹia é pueblo llamado Ciguatan, que los españoles llamaron Amaçonas, é cuéntanse otras parlieulares cosas en adornamiento é verdadera relaçion, ¿́ lo que atli passó.

$\mathbb{E}$ n el libro XIIT, capílulo $\mathrm{X}$, se dixo cómo los españolos lian liallado en muchas partes pueblos, donde las mugeres son revnas ó caçicas é scñoras absolutas, é no sus maridos, y en espeçial una llamaldi Orocomay, en cuyo puclolo é conrersion desta reyna no viven lombres, sino los quella envia á llamár para mandarles alguna cosa ó enviarlos á la guerra. Has lo que aqui se dirá es, é pienso yo é algunos afirman ques lo mesmo de que luvo notiçia Ilernando Cortés, marqués del Valle, por aviso de un capitan suyo é de los señores de la provinçia de Ciguatan, como más largamente lo dixe en el libro XXXH1, capítulo XXXVI; pero allí hablan en isla de mugeres, ć lo que agora diré es la Tierra-Firme é cerea de la otra mar. Y el nombre de lo uno é de lo otro es todo mo, ques Ciguatan, de que se pucde colegir que Ciguatan es grand provinçia é señorio. É tornando á nuestra lustoria de Nuño de Guzman, digo assi.

Andando la genle deste exérçito, como se dixo de susso, en sus entradis é guerra çerca de la costa de la otra mar, tuvieron nueva de una polslaçion de mugeres, é luego las pusieron nombre Amasonas. Ordo esto por los españoles, antiçipóse un capitan, llamalo Chripstóbal de Oñate, á suplicar al general Kuño de Guzman, que le hiçiesse merced de aquella cmpressa ć pacificacion de aquellas ama. çonas: y el general se lo conçedió, é fué con su capitania su viage en busca dellas; y en el camino fuć muy mal herido en un pueblo de indios que se llama Quínola, con el ayuda de otro pucblo queslá á una legua é se diçe Quilla. É informándome yo desto, pensé quel questa rolacion me daba, debia de ser amigo e deroto de aquel juego que se llama de la primera, y en efetto supe de aquel é de otros que aquellos dos puchlos tienen aquellos nombres que he dicho, Quinola é Quila: é quel capitan ques dicho é los más de su compañia fiıcron bien descalalıados en Quínola, á causa de lo qual aguardaron alli al ģobernador: é llegado, pidióle la empressa el capitan maestre de campo Gonçalo Lopez para y al pueblo de las mugeres ques dieho, é fuéle conçedido: el qual llegéó por sus jornadas ú çinco leguas del pueblo de Ciguatan, llatmado assi porque era todo de mugeres; é alcançólo ya çerea un mensajero del general, con el qual le envió á mandar que le atendiesse, porque queria ver qué cosa cran essas mugeres.

Otro dia siguiente, continuando su camino, estando á vista de la poblaçion, hallaron çrea della grand número del género femenino, en el camino puestas aquellas mugeres, esperando á los españoles, é restidas de camisas blancas hasta los. jiés, é plegadas por la garganta é muñecas. Allegándose el capitan Gonçalo Lopez é su gente con mucha órden láçia aquellas mugeres, para romper por ellas, Iomaron todas tanto temor de los caballos, que acordaron de veuir de paz; é llevaron á su pueblo á los españoles, é diéronles muy hien de comer é todo lo nescessario, de lo quellos tenian nescessidad.

Aquel pueblo es de hasta mil casas, é muy bien edeficado, é las calles en gentil conçierto, è assentado en lo mejor de la tierra é más fértil é aplaçible: é queriendo los españoles inquirir el modo de 
vivir dessas mugeres, súpose dellas mosmas que todos los mancebos de aquella comarca vienen á aquella polılaçion de las mugeres quatro meses del año á dormir con ellas, y ellas se casan con ellos de prestado por aquel tiempo, é no más, sin se ocupar ellos en más de las servir é eontentar en lo quellas les mandan que hagan de diar en el pueblo ó en el campo, y en qualquier género de servicio quellas los quieren ocupar de dia, é de noche dánles sus proprias personas é camas. Y en este tiempo cultivan é labran é siembran la tierra é los mahiçales é legumbres, é lo cogen é ponen dentro en las casas donde laan seydo hospedados: é eumplido aquel tiempo ques dicho, todos ellos se van é tornan á sus tierras donde son naturales; é si ellas quedan preñadas, despues que han parido, envian los hijos á los padres para que los crien é hagan dellos lo que les plığniesse, despues que han dos ó tres meses, ó antes; é si paren hijas, retiénenlas consigo é criáulas para la aumentaçion de la república é suya.

Vieron los españoles entre aquellas mugeres turquesas ó esmeraldas, é deçíanles que avia destas dos maneras de picdras presçiosas mucha cantidad é muy buena. Pero porque dixe de susso quel nombre, de que tuvo notiçia Cortés, de las amaçonas y este pueblo de mngeres se diçe Cignatan, inquiriendo yo con más personas la materia, supe questas mugeres, ques dicho que descubrió este exérçito de Nuño de Guzman, se llama Ciguralan, é queste vocablo quiere deçir pue- blo de mugeres. Pero despues en España liallé á Nuño de Girmmin en la corte de Su Mlagestad, año de mill é quinientos é quarenta y siele; é quíseme dél informar destas mugeres, é me dixo ques muy grand mentira degir que son amaçonas ni que viven sin hombres, porque él esturo allí, como es dicho, é que á la vuelta lis halló con sus maridos.

La comarca es muy gentil é de mucha fertilidad de mahiçales é frésoles é melones çetoris é algodonales; é lay mucha eaça de puercos, renados, liebres é conejos é otras salvaginas, é muchas fructas. É dende aqueste pueblo hasta la cibdad de Temistitan hay tresçientas leğuas; é á todo aquello puso nombre Niño de Guzman la Nueva Galiçiu; en el qual reyno é señorio fundó una cibdad, é nombróla Compostcla ; ć una villa pobló assimesmo, éllamóla Guadalaxara, y está en la provingia que ilaman Tomala; $y$ en la provincia de las no amaçonas ques dicho, otra villa que se diçe Sanct Mliguel: é assimesmo fundó otro pueblo, é llamóse la villa del Espíritu Sancto; é hiço una aldea ó lugar, que se llama la provinçia donde se hiço poblar Chameta.

En este viage y empressa sirvió muy bien á Su Magestad este cavallero Nuño de Guzman é los que con él se hallaron, aunque no faltaron quexosos dél para le remover é haçerle yr á España, como la historia lo ha contado; pero si en mi tiempo yo supiere más cosas del jaez desta listoria ó Nueva Galiçia, tambien lo escriliré yo ó lo remitiré al que continuare estas historias despues de mis dias. 


\section{CAPITULO IX.}

En que se traela de la nueva Audiençia que Su Çessárea Magestad proveyó para la gobernarion de Xalisco ó Nueva Galiçia.

E slando la Cessárea Magestad en Alemania, é su Consejo Real de Indias en la villa de Aranda de Duero, fueron proveydos oydores con grandes salarios para la Nueva Galicia, con que dellos se pudiesse apelar á la Chancilleria é Audiencia que reside en la Nueva España en la cihdad de lléxico, donde es visorey el ilustre señor don Antonio de Mendoça. É destos oydores los tres dellos se particron de Sevilla en el mes de mayo del año de mill é quinientos é quarenta y ocho, que fueron el liçençiado Lebron de
Quiñones, y el liçençado ó dotor Sepúlveda, y el liçenciado Contreras; é fucron át nuestra cibdad de Sancto Domingo de la Isla Española para proceder dende allí á México é yr adelante, y en Sancto Domingro murió el Sepúlveda, hombre noble é buen letrado. Dios le tenga en su glória, é á los demís dexe Dios açertar á lacer justiçia é lo que conviene á la conversion de aquellas gentes bárbaras: que segund sus persones, esperança se ticne que assi será al serviçio de Jesu Chripsto, Nucstro Redemptor. 
Este es el libro déçimo sexto de la segunda parte, y es el trigéssimo quinto de la General y natural historia de las Indias, islas y Tierra-Firme del mar Osćano de la corona real de Castilla é Reyes della : ol qual tracta de la gobernaçion del rio de Panueo é del rio Hermoso é sus provincias, que son dos rios grandes que juntos entran en la costa del Norte; é assimesno se traela del rio de las Palınas, que está más al Oriente subiendo por la dicha costa la vuelta de la provinçia que Ilaman La Florida; é tracta cómo se perdió el eapitan Pamphilo de Narvaez é su gente, que fuerou á poblar aquellas proviuçias é rios.

\section{PROILNIO.}

$\mathbf{E}$

el libro XXXIII se tracta cómo el capitan Ilernando Cortés hiço poblar el rio é provinçia de Panueo, é conquistó parte de arquella tierra. Tambien se dixo allí cómo yendo á ella por goberuador el adelantado de aqquella provinçia Françiseo de Garay, se perdió él é su armada , é la mayor parte de su grente murió, unos á manos de los indios é otros por diverssas maneras, y él en fin con ellos, éfué morir á Temistitan': despues de lo qual el eapitan Pampliilo de Narvaez (de quicn se tractó en el mesmo libro XXXIII, é se dixo que eon una armada le envió el adelantado Diego Velazquez dende Cuba á la
Nueva España , á quitar de allí el capitan Iternando Cortés, é fuć presso por él, é perdió un ojo, é lo tuvo algun tiempo detenido), passado esso, fué á España, é dende clla, eon licencia del Emperador, nuestro señor , é eomo eapilan general é gobernador suyo, fué á polblar con otra armada al rio que llaman de las Palmas, en cierta parte de la cosla del Norte, eomo adelante se diıŕ́.

Paresçe que les dá el tiempo su pago á los liombres que no se contentan con lo honesto, en especial aquellos á quien Díos les dá de comer é los pone en luen estado y edad para l'- 
possar é darle graçias, sin que la coldicia dehiesse alterarlos ni nover á luscar nuevos trabaxos. I lanto es mayor la culpa quanto más es grande la expiniencia de los lales, (que aviéndose visto polsres y erergitados en muchas desaventmas, salidos dellas é desacordados del bien yue Dios les hage en darles oportunidad jara sil reposso, no le toman: antes demás de desconosece á la homelad divina lo que por ellos lá fecho, olvidan la unuerte y el castiggo que lrás ella consiguen los ingratos, y alrévense ál degir: - Ya yo sé qué cosa son lados malos: para mí ninguna ocasion arrí que me espante ni lagga volver atrás: quien con poco se contenta, no puede ser mucho ni merescerlo». É assi á este propóssito hablando de papo, é oyéndose llamar ruestra Señoria é Magníficos, embelesados, levantados en el ayre, é trocando el sesso, escuchando lagoteros é hambrientos soldados, dan con el juiçio al través, é ofrescen sus personas á lo que no pueden bastar sus fuercas; é poniendo las ánimas en condi. cion, haçen unos fines que ningun cuerdo los puede aver envidia sino lástima.

Si Pampliilo de Narvaez no perdiera la memoria de cómo fué tractado en la Nueva España, é mirála quán al revés le salieron sus pensamientos, no luscéra otros torbellinos é fatigas, é contentárase con que seyendo un hidalgo que passó á cslas partes con una espada é una capa á buscar la vida, alcançó honra é muger virtuosa lijarlalgo, é le dió Dios hijos é lıasienda con que bastantemente pudiera passar, segund el sel' de su persona: que era virtuoso é hombre de gentil criança é de limpia sangre, é quando convino se avia mostrado en la miliçia no menos esforgado que diestro soldado é despues capitan. É él fué el que despues acabó de pacificar é conquistar la isla de Cuba, y en aquella vivia y estaba bien heredado é próspero; é aun duspues yıe salió de la prission é uñas de Cortés, latló á bu muger Maria de Valencuela, (pue avia algunos años que le atcudia en tan buena lanla é repulaçion, como purto costar Penélope: puesto que no texia é destexia, como apuella, por la dubla que tenia ó esperanga de la venida de su marido Llixes, estolra, certificada de la prission é trabaxos del suyo, grangeaba sulaçienda é la acrescontaloa é guardaba para le redimir é ayudar. É assi laalló, quando él vino á su casa, allende de hatlar la laçienda que dexó acrescentada, que le tenia trege o catorce mill pessos de oro de minas que la muger avia cogido con sus esclavos é indios, to qual el mesmo Pampliilo de Narvacz me certificó en Toledo el año de mill é quinientos é reynte y çinco, estando en aquella cibdad la Cessárea Nagestad. I pidiendo justiça y desafios contra Cortés, como en otra parte to he dicho, é aconsejándole yo, como amiggo, que se sosugasse ya en su casa é companiia de su nugerer é hijos, é diesse graçias á Dios, pues tenia en qué vivir é con qué passal este vado mundano é tan lleno de inconvinientes, como sus desseos guiahan á este mandar hijos agenos, deliérale de parescer que lo que yo degia no era tan á su propóssito como lo quél negocialja. É assi acabó como negrocios mal fundados é para su muerte é otros muchos solicilados, pues no le faltaba edad para luscar quictud: que tantos ó más años avia que yo, é su persona no me paresçia á mí que estaba poco gastada. Aunque é me dió las gracias por el consejo, ví que no le liacia buen estómago, é acordéme de lo que un labrator me pregruntó una vez, seyendo yo mangebo, que me dixo assi: "Aosadas, que essos que soys de palaçio no sabeys por qué le dan al asno la tergera rez con el palo?... Y Y yo le respondi que debia de ser porque aguijasse, y el villano replicó: "No es essa la cansa, simo porcue el asno no se acuerda 
de la primerar rez que le castigan ó dan con el palo, é porque la segunda no se cnmendó". To é otros que le escuchábamos, juzgábamosle por de buena raçon, aunque paresçiónos que sus palabras era hicn tenerlas en la memoria, pues que eran dignas de ser acogridas é que se entendian tan bien á los hombres como á los asnos, pues por tales se deben aver los que por unuchos acotes no se enmiendan. Yed si podria bastar á un hombre mo y otro y otro y más peligros para corregirse. Dexemos esto. El caso es que niuguno puede huyr de lo que estát de. Dios ordenado; más puesto quello es assi, quédale al hombre una eleçion libre para escoger lo que le conviene é saber conosger lo malo y elegir lo bueno 4 . Mas quando se escoge lo uno de aquesto, fixase una constançia ó tema en alğmas personas, é máxime en aquellas que se van trás sus desseos inútiles, que no les dexa disputar ni considerar ó atender á consultar con la raçon, para disçernir ni entender lo que deben seguir, é assi acude luego lo que cscribe Vitruvio, distinguiendo la cogitaçion, la qual diçe ques una cura llena de estudio é de industria é de viguilançia con voluptad de propóssito efetto ? É como he dicho esto que Vitruvio diçe para la eleçion ser conviniente, conviértenlo los imprudentes en uso de aquello que debrím excusar. Diçe el dotor Céssar Cessariano, comentador del auctor alegado, sobre el capílulo III, libro 1 de Vitruvio: "El bien obrar letifica, y el mal hace con dolor arrepenlir». Esto acaesçe á los que no lien pensadis é ponderadas primero sus empressas, se pierden con ellas, é lo ques peor, causan que otros muchos acaben mal. Deben los hombres para perpetuarse, no en esta mortal morada, sino en la que para sicnpre la de permanesçer, con-

1 Sciat reprobare malum, eligere bonum (Isaias, cap. 7).

2 Vitr. De Architecturá, lib. 1, cap. 2. formarse é fundarse en limpios desseos, que no discrepen del serviçio de Dios; y si los pone en estas partes ó Indias, miren que no sea lanto en buscar riqueças mal avidıs é bañadas en sangre lummana, como en convertir é procurar la salvafion destos tristes indios: que í la verdat soy de opinion que pocos capitanes de los que han passado ać́ han procurado esta perpetuidad que digo; y si ellos mojassen ó templassen el ardor de sus espadas cobdiçiosas en la çera é blandura de la misericordia y en la resina de la templanç, y piadosamente se oviessen con esta gente, acaescerles hía lo que al hierro ardiente le acaesce para su perpetuydad.

Diçe este famoso dotor é comentador, que de susso se dixo, que los clavos de hierro no pueden turar donde se clavan, porque se corrompen con el orin ó moho; mas si quando es caliente é bien ençendido, fuesse muerto en la çera é resina derritiéndola, se templa é assi se conserva perpétuamente; é diçe este dotor que lo ha probado ${ }^{3}$. Hallo yo que assi como nuestra fée cathólica se funda en un solo Dios é trino, que assi el buen chripstiano debe fundarse é acordarse siempre de tres cosas, que despues se incluyen assimesmo é resumen en una, é son temer é amar á Dios sobre todo, sin ofender al prógimo más que a sí mesmo, obedesçiendo servir al Rey é señor natural, velar é guardar la propria ánima, no pecando á sabiendas, porque guardando qualquiera destas cosas, se cumplen todas, y en faltando à una dellas, faltan d́ todas. No açertará alğuno á subir en lo alto con el pié derecho, si no sigue el número dispar en los escalones; y esta regla inesma se ha de guardar en la escala de la gloria: quiero deçir, que començando

3 Cesar Cesariano en el comento sobre el lib. I de Vilruvio De Architectura, etc., cap. b. 
el buen obrar con buena intençion é continućndolo assi, acaba el efelto en el mesmo sancto fin. Vitruvio amonesta que las gradas ó escalones se deben constituir de manera que siempre sean nones ó dispar, porque quando con el pié dereclıo se sube la grada primera, assi por el semejante en la última será el primero que se ponga '. Pero los escalones del capitan Pamphilo fueron pares é semejantes á sus cogitaçiones. Bien creo yo que su fin seria pensar que su camino resultaria en servicio de Dios; mas junto con esso era muy afiçionado á preceder á otros de más industria ó mejor fortuna, é assi siempre quando pensaha que yba adelante, se lallaba é halló más atrás. Deste liidaigo se lıará relaçion é de su desventurado fin é infeliçe armada en este libro XXXV, segund la notiçia que hasta el tiempo pres. sente se tiene de su viage: en el qual sub- çedieron cosas de mucho dolor é tristeça, é aun miraglos en essos pocos que escaparon ó quedaron con la vida, despues de haber padesçido innumerables naufragrios é peligros, como se puede colegir por la relaçion que át esta heal Audiençia, que reside en esta cildad de Sancto Domingo, enviaron tres lidalgos, llamados Álvar Nunez Cabega de Vaca, é Andrés Dorantes é Alonso del Castillo: los quales fueron con el mesmo Pampliilo de Narvaez, é cuentan por escripto lo que les acaesçió en su viage é por dónde anduvieron. É á la ruelta fueron á España á dar relaçion á Su Magestad vivi voce de las cosas que aqui se dirán, alargándome á su informaçion, é acortando algunas supérfluas palabras que duplicadamente diçen; é no faltaré de lo substançial é médula de lo que su carta contiene y diçe.

\section{CAPITULO I.}

De la relaçion que hięieron los que escaparon de la desventurada armada del eapitan Pamphilo de Narvaez, é lo que les acaesció en la costa é ticrras septentrionales*.

\begin{abstract}
$A$
lvar Nuñez Cabeça de Vaca, é Alonso del Castillo, é Andrés Dorantes solos, é un negro llamado Estéban, escaparon del armada toda del gobernador Pamphilo de Narvaez. Y este Cabeça de Vaca fué por thessorero é offiçial de Su Magestad: el qual diçe que dende Xagua, ques un puerto ó ancon en la isla de Cuba, á quinçe de hebrero de mill é quinientos é veynte y siete años, avia escripto á Su Mlagestad lo que hasta allí les avia acaesçido, é del perdimiento de dos navios con sessenta homlres é todo lo que en ellos yba. É perdida esta gente é navios, é más veyinte caballos que en ellos yban,

1 Vitr., lib. Ill, cap. 3.

* Del presente titulo suprimió Oviedo estas palabras: "Para venir á lo qual, se dirả primero lo que
\end{abstract}

acordaron de invernar allí en el puerto de Xagua, donde diçe este Cabeça de Vaca que estuvo dende seys dias de noviembre del año ya dicho, con quatro navios é toda la gente, hasta veynte é dos dias del mes de lıebrero del siguiente aũo de mill é quinientos é veynte é ocho años, que llegó allí el gobernador. El qual se embarcó para seguir su viage en quatro navios é un hergantin, con quatrocientos lombres é ochenta cahallos; é anduvieron por lá mar hasta los doce lias de abril, martes de la Semana Sancta, que llegaron á la Tierra-Firme, é la fueron costeando hasta el jueves sancto, é sur-

les intervino hasla que salieron los españoles é su gobernador Pamphilo del pueblo llamado Apaliche". 
gieron en la costa en una bahía que era baxa , é al cabo della vieron unos buhios. É otro dia, viernes sancto, salieron en tierra con toda la más gente que pudieron sacar en los bateles, é fueron á desembarcar junto á los buhios, en los quales no hallaron sente, porque los avian desamparado; y el uno dellos era tan grande, que cupieran en él trescientas personas, é los demás eran pequeños. Hallaron muchas redes para pescar, y entrellas se halló una sonaja de oro.

Otro dia siguiente hiço el gobernador alçar pendones por Su Magestad é tomó la possesion de la tierra, é liço juntar los officiales de. Su Magestad é á los frayles que allí yban é la gente que avia salido en tierra toda, é pressentó sus provissiones reales que llevaba, é fueron obedesçidas por todos, y el dicho gobernador, admitido por tal gobernador é capitan general; é los offiçiales pressentaron las suyas, é assimesmo fueron avidos por offiçiales de Su Magestad. É luego se dió órden cómo se desembarcó toda la gente é caballos, los quales yban muy fatigados, porque avia muclios dias que los avian embarcado, é aun se avian quassi perdido la mitad dellos en la mar.

Otro dia domingo, dia de Pásqua de Resureccion, vinicron los indios de aquel pueblo, é hablaron á los chripstianos sin ser entendidos; pero parescia que los amenaçaban é deçian que se saliessen de la tierra, é haçian ademanes é fieros: é fecho aquesto se fueron. El dia siguiente, por ver la tierra é tentar lo que era, envió el gobernador seyss de caballo é quarenta hombres á pié la via del Nordeste, hasta que llegaron aquel dia á una bahia que entra por la tierra, é de allí se tornaron á la gente, y el gobernador con ellos, porque fué uno de los seys de calallo.

Otro dia adelante envió el gobernador un bergantin que Ilevaban, para que fues- se costeando la via de la Florida é buscasse un puerto quel piloto Miruclo deçia que sabia, adonde llevar esta gente (el qual él cró, é no sabia adónde se estaba). Émandóle que assi buscando atravessasse á la isla de Cuba é fuesse á la villa é puerto de la Ilabana en busca de otro navio que esperaban de allí, en el qual venian quarenta hombres é doçe caballos; é que si lo hallassen, que ambos navios tomassen en la Habana todo el bastimento que pudiessen, é lo llevassen adonde los chripstianos y el gobernadorquedaban.

Fecho aquesto, partieron de allí los chripstianos, é fueron á dar en la bahia ques dicho que avian descubierto, é costcáronla; é avian andado quatro leguas dende donde partieron, é hallaron algunos indios, é tomaron tres dellos é mostráronles los españoles un poco de mahiz, preguntíndoles dónde lo avia. É aquellos indios los guiaron á un puelslo que estaba al cabo de aquella bahia, é mostráronles un poco de maliz que allí tenian sembrado, que fué lo primero que vieron en aquella tierra: é allí hallaron unas caxas de Castilla grandes, y en cada una dellas un liombre muerto, é cubiertos los cuerpos con unos cueros pintados; é paresçióles al comisario é frayles que aquellos eran ydólatras, é los hiço el gobernador quemar. Assimesmo se hallaron pedaços de çapatos é lienco, é de paño é hierro alguno; é preguntados los indios, dixeron por señas que lo avian lıallado en un navio que se ạvia perdido en aquella costa é bahia. É mostróles un poco de oro, é dixeron que en aquella tierra no lo avia, sino léxos de allí, en la provinçia que dicen Apalache, en la qual avia nucho oro en grand cantidad, seģund ellos daban á entender por sus señas : é todo quanto les mostraban á aquellos indios, que á ellos les paresçia que los chripstianos tenian en algo, deçian que de aquello avia muclio en Apalache. Con esta simple infor- 
maçion so partieron de allí, lleraudlo consigo aquellos indios; é diez ó dore leguas de allí hallaron hasta loce ó quinge casas, adonde aria mahiz, y estovicron dos dias sin que se viesse iudio alguno. É acordaron de se tornar adonde avian dexado al contador é la otra gente con los navios; é llegarlos, les liçieron relaçion de lo que avian hallado por la tierra, que no era más de lo questá dicho.

Otro dia, primero dia de mayo, el gobernador hico juntar los offiçales del hey é al comisario; é por aucto, ante un escribano, les dixo que tenia volmutad de entrar la tierra adentro, é que los navios se fuessen por la costa, é pidióles sobresto su parescer. Y el thessorero Cabeça de Vaca le dixo que le paresçia que no debia desamparar los navios, sin los dexar primero en puerto é poblado; é que fecho aquesto, podria el gobernador é los que mandasse entrar la tierra adentro, é ternian lugar é parte señalada adonde pudiessen volver á buscar la gente, quando conviniesse; é que por muchas causas le paresçia que no debia cntrar la tierra adentro, porque aquella tierra por donde avia entrado por la informaçion de los indios, demás de lo que los chripstianos avian visto, era tierra pobre é sin gente; é tambien porque esperaban el bergantin é navio ques dicho que atendian con bastimento de la Habana, y aun porque los pilotos no sabian ni alcancaban á entender en qué parte estaban; é por otras causas que al thessorero le parescian justas, dixo que aquello quel gobernador hacia no se delsia de hager.

El comisario dixo que su parescer era que entrassen la tierra adentro, yendo cerca de la costa hasta llegar al puerto que los pilotos decian que estaria quince leguas de allí, la via de Panuco, é que no podrian passar sin tocar en él, porque entraba la tierra adentro dose leguas, é que allí esperarian á los navios é los navios esperarian á ellos; é que no se debian tornar a embarcar, poreure seria tentar a Jios, pues ell su viage tantas fortmos 6 trabaxos avian padesçidlo lasta llegar allí.

El contador y el reedor se conformaron con el comisario, y el gohernalor determinó de lacerlo assi; pero al thessorero, vista su voluntad, le requirió muchas reges que no entrasse, por las causas que aviadicho é otras que acrescrentaba en sus requirimientos, ui desamparasse los navios é gente que en ellos quedaba, sin que primero quedassen en pucrto conosçilo é poblado, é que despues hiçiesse lo que le paresçiesse; é assi lo pidió por testimonio al escribano que estaba pressente. Mas el gobernador replicó que porque allí no avia puerto ni dispasiçion para poblar, por la esterilidad de la tierra, que mudaba aquel pueblo que avia assentado, é ylua en busca de puerto é tierra para po. blar, é dixo que assi lo pedia por testimonio. É luego mandó que toda la gente se apercibiesse para yr con él, é que los navios se provegessen de lo que avian menester ; é otro dia partieron de allí, llevando quarenta de caballo é dosçicntos é sessenta hombres á pié. É fueron con él los dichos officiales y el comisario é otros frayles, y entraron la tierra adentro é anduvieron quince dias con una libra de pan é media de locino de raçion, liasta que llegaron á un rio, que passaron á nado; é passado, salieron á ellos doscientos indios, con los quales pelearon, é prendieron cinco ó seys dellos: los quales los llevaron á sus casas, que eran çerca de allí. donde hallaron mucho maliz en el canpo, que estala ya para comer. É otro dia los officiales é los frayles rogaron al gobernador que enviasse á reconosger la mar é puerto, si lo avia; y él mandó al thessorero é Alonso del Castillo que fuessen con quarenta hombres, é assi fueron á pié, porque no podian llevar caballos, 
é andovicron por unos baxos de la costa de la mar, por ostiares, obra de dos leguas, é llegaron á dar por dó passalua el rio, que avian passado el dia antes dentro de tierra; é porque era hondo, no le pudieron passar é se tornaron al real.

El dia signiente mandó el ģobernador á un capitan que con seys de caballo é quarenta hombres á pié passasse el rio, por donde avian venido, é reconosçiesse aquel ancon é viesse si avia puerto, é assi lo hiço; é halló que cra haxo é no podian entraralí navios. É fecha la relaçion, se partieron de allí en demanda de aquella provinçia llamada Apalache, llevando consigo por guia los indios que avian tomado ; é andlovieron hasta otro dia despues de Sanct Johan de junio, que llegaron á Apalache, que era la cosa del mundo que más desseaban, assi por el largo canino, como por la mucha nescessidad de los bastimentos; porque aunque en algunas partes hallaban maliz por la tierra, muchas veces caminaban quatro ó çinco jornadas sin lo hallar, é demás desto por el mucho oro que deçian avia en aquella provincia. É quando llegaton al pueblo, acometieron los españoles con mucho denuedo para entrar en él; pero no hallaron quien se lo resistiesse, é tomaron las muggeres é los muchachos, é no aria lomlres, que todos estaban fuera. Avia en aquella poblacion quarenta casas pequeñas é muy abrigadas, por el mucho frio é tempestades que en aquella ticra hace. Ilallaron muchos cueros de venados é alģunas mantas de hilo hasto: avia grand cantidad de mahiçales en el campo é mucho maliz seco en el pucblo. La ticra, por donde passaron estos espanoles, es llana é arenales tiessos, é de muchos pinares, aunque ralos é apartados unos pinos de otros. Hay muchas lagunas é muy muchos venados por toda la tierra, por las mnchas arboledas é árboles caydos á causa de las grandes lorTONiO III. mentas é huracanes, que muy á menudo en aquella region ocurren, é assi vieron muchos árboles rajados de alto á baxo de los rayos que caen; y en todo el camino, despues que passaron el rio ques dicho, no hallaron gente que los osasse esperar.

A cabo de dos dias que estaban en $A$ palache, vinieron los indios de paçes, y el cagique con ellos, é pidieron sus murgeres é hijos é diéronselos todos. El golsernador turo consigo al caçique; pero otro dia adelante acometicron é llegaron á poner fuego á los bulnios donde los chripstianos estaban, é serian lasta dosçientos indios; mas cómo los españoles estalıan en veli, salieron presto é osadamente á ellos, é acogiérouse al monte é á las sierras é no pudieron tomar á ninguno: pero matáronles dos ó tres dellos. Luego otro dia vinieron otros doscientos indios por otra parte é de otros puelilos é gente, é salicron assimesmo á cllos los cluripstianos, ć assimesmo se acogieron ć huyeron, como los primeros. En este pucblo estovieron el golyernador é los españoles veynte é seys dias, en los quales hiçieron tres entridats la ticrra adentro, é todo lo que vieron della hallaron muy pobre é de poca gente, é de muy malos passos é lágunas, é boscages de árboles muy espessos; é preguntando al caçique é á otros iudios que de atrás traian (çerca de alli) por la ticra é pueblos dellos, dixeron que todo era de menos gente é comidia que aquella donde estaban, é que aquella era la más prinçipal cosa que en aruella tierra hay, é que adelante hay muchos despolblados é çiéneras é lagunas é muy grandes boseages. Preguntáronles si háçia la mar aria pueblos é gente: dixeron que á ocho jornarlas de allí avia un puelslo que se diçe $\Delta u i e$, que eran amigros suyos, é que tenian mucho maliz é fésoles, é que estaba cerca de la mar: é con esto que los discron, cé con aver vis. 
10 en las entradas que licieron que la tierra en que estaban no era tal como les avian dicho, é que era sin ninguna esperança de hallar anlelinte incjor cosa, é que allí donde cstaban les avian comensado á licrir la grente é haçerles guerra, é que les avian mnerto á nn caciqne de los que los frayles faian de la Nueva España, é les hirieron á otros compañeros, yendo á beber, y estaban metidos en las lagnnas y espesmra grande de aquellos hoscages, é dende alli llechaban á quantos allí yban, acordaron los españoles, en fin de los reynte é seys dias, de se partir para Autc.

¿Parésceos, letor, ques buen passatiempo el anestos pecadores chripstianos traian? Querria yo que me dixessen qué les predicaron essos frayles é Pamphilo de Narvacz á aquellos españoles que tan çiegos se fueron, dexando sus patrias trís falsas palabras (y por muclios que mneren nunca escarmientan). ¿Qnién los aria çertificado aver visto aquel oro, que buscalıan? ¿Qué pilotos llevaban tan expertos en la navegaçion, pues que ni conosçieron la tierra, ni supieron dar raçon de dónde estaban? ¿É qué guias é qué intérpetres llevaron? Oh tenterario desalino! ¿Quć mayor crímen priede cometer un candillo que conducir gente á tierra que ni él ni otro de su luneste haya estado cu dla? Bien creo yo que se acordó Pamphilo, é más de una vez, de aquel consejo que yo le daba en Toledo. En verdad que yo estoy muchas veges maravillado é aun enojado destos capilanes, viendo que por lina parte son astutos é mañosos é valientes varones, é por otra, aunque han visto muchas cabeças aggenas quelıradas, en quien podrian aver escarunentado, no temen ni escarmientan de peligro algyno. Y pluguiesse á Dios que los que assi padescen, con solas sus vi- das pargussen, sin que las ánimas resçibiessen detrimento! Pero yo duludo de la salvagion de las mús, porfur la dias que vivo en cotas ludias ! he visto que se lundan, por la mayor parto, cn esta maldila coluliçia, posponicudo todos los escrínpulos que á sus consciencias serian provechosos é dignos de açplar. Pues cómo en el prohemio le loé yo á Pamplito de diestro soldado é despues capitan, racon es quro dó cucuta de él de mí en este caso. Digo que yo he visto muy valicntes homlres con la lança ó esparla en la mano, que quitados de allí, son de ningun goljicrno, y salria nostrar algunos con el dedo. El pelear es lo de menos, porque rarissimos son los hombres de vergienca que no peleen, quando conviene á su honra; é más capilanes hay que sepan pelear é mandar á pocos que golsernar un exérçito; é más capitanes son los que lay para mandados que para saber mandar. Pamplilo, en tanto que le mandó á él Diego Velazquez, dentro en la isla de Cuba, supo servir é lacer lo que le mandaron. Ouando salió de allí é fué á la Nueva España, en el libro XXXllI se puede ver el recalulo que se dió, y en este XXXY lecrés cómo acabó su gobernaçion.

Passemos á lo demás: ques cosa que aunque no liene remedio ni enmienda, tiene alguna parte de aviso, ó le causará esta relacion, para los venideros capilanes é gobernadores é gobernados, si no se quisicren engañar ellos mesmos, çerrando los ojos al entendimiento; pues en este tractado hallarán de qué temer é de qué se deban reçelar los que nuevas empressas de aqnestas loman, pues cada dia veo que las procuran é traen hombres al carnero, sin saber dónde los llevan, ni ellos adónde se van ni á quién siguen. 


\section{CAPITUlo II.}

En el qual se traetan muchos trabaxos é nesçessidades, quel gobernador Pamphilo de Narvaez y eolas gentes padesẹieron; écúmo hị̣ieron cineo bareas pari yr á busear dónde pudiessen poblar; é eumo hirieron al gobernador de una pedrada; é eómo se vieron martas de muy finas çebellinas; é cómo se partio é desvió de la compañia el gobernador con su barea, í se perdieron las dos dellas é se ahogaron el veedor é otros; é cuéntanse otras cosas de nucha lástima.

D. ha dicho cómo esta gente se determinó de partirse para Aute, é assi lo pusieron en obra; é dende que salicron de Apalaehe, andovicron ocho ó nueve dias hasta que llegaron en Aute. Y en los malos passos é lagunas que liallaron, los indios dieron eon ellos é les lirieron çineo ó seys españoles é algumos calarllos, é les mataron un español. Llegados en Aute, hallaron quemadas todas las easas, ć muelıos maliçales que estaban ya para eomer, lambien los avian quemado. É dende á dos dias el gobernador mandó al thessorero Caheśa de Taea é á Andrés Dorantes é á Alonso del Castillo, que eon nueve de caballo é çinqüenta hombres.á pić fuessen en busca de la mar, y él quedó eon la otra gente alli, porrue mueha parte de los chripstianos cstaban enfermos, é eada dia adolesçian más. É assi particron estos hidalgos eon la compañia ques dicho, é llevaron consigo al eomisario.

Bien es de creer queste padre reverendo ya se contentara eon la gelda, que dexó en España poĩ venir á busear á estas partes estos gremiales ó mitras, que les haçen perder el tiempo é las vidas á algunos dellos: é aun los que han servido á Jios, olvidan despues fue se encasquetan essas dignidalus, que los menos dellos consigruen; y pluguiusse á Dios que no se aventriassen en ello las ánimas, non olstante que los que se mucven sin essos interesses ó amljiẹion ó desseo de prelacias, sino solamente por más servir á Dios en la eonversion destos indios, honesto é meritorio é sancto desseo us, y estos tales son los que acá haçen frueto; pero los demás remédielos Dios.

Aquel dia que de allí partieron llegaron á unos baxos de la mar, adonde estovieron aquella noelıe; é otro dia de mañana enviaron veynte liombres á reeonosçer la costa, é dixeron que no la avian podido ver, porque estaba léxos, é eon esto se volvieron al real, donde hallaron al gobernador, y el eontador y el reedor caydos malos, é otros muchos: é despues que alli repossaron un dia, se partieron otro adelante para aquel lugar do avian descubierto ó hallado la mar, llevando consigo todo el mahiz que pudieron, é llegaron con mucho trabaxo, porque no podian valerse eon los dolientes, que erún muelros. Ea alli estovieron dos dias buscando é pensando qué manera ternian para salvar las vidas é salir de aquella tierra, pues pensar de laçer navios en que fuesscn, paresciales eosa imposible, por-que no tenian clavaçon ni estopa, ui per, ni otras cosas que para ello eran nescessarias : é eómo ya la nesçessidad los tenia en aquel extremo, deshicieron los estriloz de los caballos é los frenos y espuelas para hacer lerramientas, é hicieron unos ciñulos de palo, é con eueros de: venados hicicron mos fuelles, é de las cosas ques dicho hiçieron licramientas. Éporrpue la gente estaba flaca è ng podian trabaxar, matahan de terçer it tereger diar m eilballo, que repartian é eomian los que trabaxiban é los dolientes: ¿ assi. 
for comer de aquella carme, trabavaban otros. I en quatro ó cinco culrablis que liçicron los de caballo é la gente más reçia en Aute, truxeron murlio malız, que hasto para comer en tanto que allí estovieron, 6 amm para llevar; é assi començaron á haçer hareas á quatro dias andados dol mes de argosto, é las calafitcaron con chapas de palmitos, é dellos hiçicron cucrlis, é las brearon con brea que hisieron de pinos, que hay muchos; é de lis camisis hiçieron velas, é de los cneros de las piernas de los caballos hiçicron rolas para llevar agna. En tanto que las barcas se harian, les mataron los indios diez chripstianos que andahan pescando pol' aquellos baxos de la costa á vista del real, sin loz poder socorrer, passados de parte á parte con las Rechas.

In inde donde dexaron las naos hasta donde se hiçieron estas bareas, y en todo lo que andovieron estos chripstianos, avrá hasta dosçientas ochenta leguas, poco másó menos (al parescer de los más que lo andovieron) y en toda aquella tierra no vieron sicra ni tuvicron notiçia de. Ila. La gente es muy grande, de buenos gestos é gentil dispusiçion, é son todos flecheros é muy grandes punteros, é los arcos de diez é dore palmos luengos, é ran gruessos quassi como la muñeca del braço (en las manijas é çerea dellas) é muy recíssimos é de linda madera: y es cosa para espantar é no crecdera, sin to ver, lo que passan las flechas.

Acabáronse çinco barcas í reynte dias del mes de septiembre, las quales cran de veynte é dos cobulos de luengo: é miriéronseles allí (quarenta liombres, pocos más ó menos, de dolençias. Destas barcas tomó cl gobernador una para sí é para quareula é ocho liomlres, é dió otra al contador é á los frayles con quarenta e sicle hombres, ć al thessorero é al veedor olra con quarenta é ocho liombres; é al capilan Tellez é á Peñalosa é Alonso del Castillo é Andrís Dorantes dió lis otras dos, y en cadil una dellas yban otros quarenta é ocho hombres. Acabados de comor los caballos, se embarcaron á reynte é dos dias del mes de septiemhre: é cómo las barcas cran peepueñas, con los hastimentos é ropas é amos yban muy carcradas, é no llevahan finera del agua más de un xome; é assi andovieron sicte dias por apuellos haxos, hasla que esta infeliçe gente llegó á una isleta pequeña que está ceréa de la Tierra-Firme, y on ella hallaron nnos ranchos, é tomraron allí cinco canoas. E aquel dia salicron á la costa, que hasta estonces no la arian rislo; é allí pararon las larcas, é con las canoas echaron falcas, é cresçicron é suljicron dos palmos más las barcas (fuera sobrel agua) é siguieron su riage. Fecho aquesto, entrando en muchos ancones que por la costa topaban, y en los haxos que hallaban. siempre la tierra les salia adclanto, yendo assi naregando $\sin$ saber adónde yban.

Una noche les salió una canoa á cllos é los fué siguiendo un rato, é volvieron a clla por le hablar, é no quiso atender; é como son navios muy ligeros, fuéronse los de la canoa, é los chripstianos siguieron su camino primero. Otro dia por la mañana les tomó una formenta, é surgicron en una isla, é no laallaron agua en clla, de la qual tonian falta grande; é alli estovieron tres dias, é cómo avia çiuco que no bebian, bebicron algunos ağa salada é mucha, é muriéronse por cllo rinco ó sers hombres de súluito. É visto que la sed cra incomportable, é aunque li tormenta no cra amansada, acordaron de yr háçia aquella parte donde avian risto yr la canoa que se ha dicho, eneomendándose á Dios é poniéndose en notorio peligro de la muerte: é atravesaron, é al tiempo quel sol se ponia, Ilogaron á una punta que liaçia allí abrigo é mınos mar, é salieron allí á ellos umas 
canoas é los liablatron, é fueron siguiéndolos bien una legua hasta donde tenian sus casas á la lengua ó costa del agrua, é delante dellas tenian muchos cántaros é olles llenas de agra, é mucho pesuado. lí assi como el gobernator saltó en lierra, salió á él el cagípie, é lo llevó á su casa, é le ofresçó el pescalo é agura que allí tenia, en recompensa de lo qual los clupipstianos le dieron quientas é eascabe. les é del mahiz que llevalan en las barcas. E afuella mesma noche, estando el cacique con el gobernador. dieron muchos indios sobre los clupipstianos, 6 mataron tres hombres que estaban celiados en la costa enfermos, é descalabraron al gohernador de una pedradí. E los que atlí se hallaron con él prentieron al caçque: el qual se les soltó é les dexó en las manos una manta que tenia cobijada de martas egebellinas é muy buenas, que segund dice el thessorero Cábeca de Vaca eran exçelentes, las mejores quél avia visto, é-aum lodos los otros españoles deçian lo mesmo, é olian á almizque, é ofras mantas lomaron de martas, pero no eran tales. E por estar el gobcrnador herido y cnfurmo, le metieron en las barcas con todos los dolientes é flacos que avia; é los indios les acometicron aquella noche tres veces, é al fin los deraron á los chuipstianos: é fueron muchos de los indios bien acuchillados, é de los españoles muchos heridos aquella noche. É alli estovieron dos dias despues, en los yaales no pudieron rer indio algumo.

De allí se particron en sus bareas, é dende á tres ó quatro dias llegarou á cutrar por unos esteros, é toparon una canoa con unos indios, é pidiéronles agral é diéronles una vassija en que la truxessen, é fucron con clloz dos chrijsatianos, é los indios que por relenes avian quedado en las hareas, quisióronse celiar al aģua é prendiéronlos. É otro dia de mairana romencaron á venir canoas, é los chripstianos salicron de los esteros a la mal", y en poco más tiempo de una hora estaban ya reyule canoas é lres ó quatro scriores principales indios ch cllas, é fralian cubicrats unas mantas de aquellas mur finas marlas cebellinas é los cabellos largos é sucltos: é pidieron los indios (que cruian los chripstianos, é los chripstianos les pedian los dos españoles. é los indios replicaron yue fucssen con ellos á sus casas, é no lo quisieron hager, porque la tierra era muy anegarla é de muchos esterns. É como no les quisicron dar los indios, pues no tornaban los elıripstianos, començaron los indios á lirar raras é algumas flechas: é assi passaron con cllos una refiega hasta que los dexaron. É se fucron adelante los nuestros é andovicron otros dos dias, al cabo de los quales la barca en que yba el lliessorero llegó á una punta que haçia la costa, é detrás della avia un rio que venia de avenida, muy crescido é grande; é un poco más atrás la barea del gohernactor é las otras surgicron en unas islas que estaban alli ferea: y el thessorero fuć á ellos é les dixo como aria descubiento aquel rio. É porque allí no avian hallado leña para losLilr mahiz é aria dos dias que lo comian crudlo, acortaron de se yr á neter en aquel rio, del qual en la mar se cogrió ağua dulçe: é yendo ȩerea dél, en el embocamiento la corriente grande dél no les dexaba toma: la lierra, é trabaxando por la tomar, saltó el viento en el Norte, é con él é con la mucha corriente los netió más en la mar. É navegaron aquchla noclıe é otro dial siguiente liasta lá noche, que se hallaron en tres bracas de liondo, é por aver visto adpuella tarele muchas alumadas por la costi, no osaluan salir cn lierra de noche: é surgieron, é como la corriente fué mucha é no tenian anclas, sino unas botalis de piedra, las comientes los sacaron ál la mar aquella noche, é yuinulo començó á scr de dia, no vieron la 
tierra ni ninguna barca vido á otra. Éas. si el thessorero Ilvar Nuñe Calbeca de Vaca, ques el que rsto cuentil, siẹuió su viage; é á hora de medio dia vido dos bareas dellas, é llegado í la primera, conoscrió que era la del golicmalor, é ovicron habla, y el gobernador le pidió al thessorero su paresçer açerca de lo que se debia hager : el qual le dixo que recogiesse la otra barea que paresçia, é que todas tres juntas yrian donde mandasse, y él respondió que queria tomar la tierra á fuerega de remos, é que assi lo liçiesse el thessorero con su barca. Fissi le fué siguiendo obra de legua y media, é cómo la gente ylua flaca é cansada, é avia tres dias que no comian sino maliz crudo, é un puño dello por raçion, no pudieron tener con la del golernador, que andaba más y era más ligera, é yba menos embaraçada. I el thessorero rogó al gobernador que le hiçiesse dar un cabo á subarea, y él dixo que no lo podia haçer: que hiçicsse lo que pulliesse, que no era liempo de aguardar á nadic, sino que cada uno procurasse de escapar la vida. No lo dixo assi aquel memorable conde de Niebla, don Enrique de Guzman, que por recoger á olros, recoggiéndolos en su barea, se linclió de tantos quél y cllos se ahogaron en Gibraltar "; pero el thessorero é los que yban con él no le pedian á Narraez que los tomasse en su barca, sino que les diesse un cabo de una cuerda para que su barca ayudasse á andar á la otra: que ya que se le diera, estaba en su mano soltarle quando quisicra, conviniéndole.

Tornando á la listoria, oyda la impiadosa respuesta del gobernador Pamphilo, cl thessorero le siguió un rato hasta que se perdió de vista; y estonçes el thessorero arribú solıre la otra barca que yba melida en la mar, la qual aguardó, ỹ era la que llevalua Peñalosa y el capilan Tellez. E assi juntas eslas dos barcas, navegaron Ires loras hasta la noche, é con la romel lambre que llevaban, é con averse mojarlo la noche antes con las olas de la mar, yba toda la gente cayda, é no aria çinco hombres diestros. É assi passaron afuclla noclie, é al quarto del alba el maestre de la barea del thessorero echó la sonda, é lialló siete braças de fondo; é porque la reventaçon era muy grande de las hondas, se tovieron á la mar lıasta que amanesçió, é se hallaron á una legua de tierra, é pusieron la proa en ella, é plugo á Dios que salieron en salro. E luego el lhessorero envió un hombre ál unos árboles que se parescian, para que dende ençima dellos viesse la tierra, é volvió é dixo que estaban en isla. É luego volvió á atalayar si veria algun camino ó vela, é tornó en la tarle é dixo que avia hallado é traia un poco de pez, é tras él renian tres indios, é tras aquellos otros dosçicntos todos flecheros; é tenian las orejas horadadas é por ellas metidos unos cañutos de cañas. Y el lhessorero y el veedor salieron á cllos é los llamaron, y ellos vinieron, é les dieron los eluripstianos de los rescates que llevaban, é cada uno de los indios dió una flecha en señal de amistad, é dixeron por señas que otro dia, en saliendo el sol, les tracrian de comer á los chripstianos. É assi lo hiçicron; porque luego otro dia por la mañana volvicron é truxeron pescado é unas rayces de las quellos comian, é ofro dia siguiente hiçieron lo mesmo: é allí se proveyeron de ağua é se embarcaI'on para seguir su camino. E para echar la barea al ågua, se desnudaron, é yendo assi metiéndola ál la mar, les dió un golpe de asua por la proa é mojó la una banda por donủe yluan remando, é con el agua y el frio soltaron los remos, é atraressó- 
se la barca: é dióles luego una ola otro golpe de mar é trastormóla, y el veedor é otros dos se asieron á ella, é los tomó debaxo é los anegó, é los demás escaparon encueros, sin salvar cosa alguna do quanto llevaban. I estovieron aquel dia en la costa con muy grandíssimo frio hasta la tarde, que tornaron los indios á verlos, é cómo los hallaron assi, començaron á llorar con los chripstianos, como quien se dolia de su trabaxo; é assi cl thessorero les rogó que los llevassen á sus casas (y ellos lo hiçicron) á dó esto- vieron aquella noche: é otro dia de nañana les dixeron los indios que avia otros como los chripstianos cerca de allí, por lo qual el thessorero envió dos hombres a saber quién eran, é laallaron que era Alonso del Castillo é Andrés Dorantes é toda la gente que cn su larca yban: la qual assimesmo avia dado al través en la mesma isla á çinco de noviembre, é la del thessorero avia salido otro dia adelante á la costa. Los quales particron con el thessorero é su compania de la ropa é comida, que cra bien poca.

\section{CAPITULO III.}

En que se traetan otros nuevos trabaxos de aquesta gente, é eómo se perdió el capilan Pamphilo de Narvaez, é cómo estos pecadores españoles vinieron á lanta nesçessidad que entrellos ovo de eomida que los unos fueron manjar de los otros; é otras desaventuras se euentan nunea oydas ni padesçidas, ni tan largas é continuas como aquesta gente turo, con que los más ó quassi todos se acabaron.

\section{Q} uando el thessorero Cabeça de Vaca é los de su barca se juntaron con los de la otra que tambien avia dado al través, segund se dixo en el capútulo precedente, acordaron de adobar su barca é yese en ella, é puesto en obra, lo mejor que pudieron la adobaron y echaron al agua; pero no se pudieron sostener en ella de broma é otras faltas, é assi ovielon de dar en ella al través, é acordaron de invernar en aquella isla por no poder haçer otra cosa. Y enviaron á un hidalgo llamado Figucroa, é con él otros trez chripstianos é á un indio, para que se fuessen á Panuco (creyendo que estaban çerca de Panuco) é que diessen aviso de dónde é cómo quedaban essotros; pero á cabo de cinco ó seys dias se les comencó á morir la gente, é fuć tanta la hambre, que se comieron çinco hombres unnos á otros. Dió assimesmo una dolençia de estómago en los naturales de la tierra, que se murieron la mitad dellos, é viendo esto los indios, tenian pensado de matar essos pocos cliripstianos que quedaban viyos, é deçian quellos les avian llevado aquel mal é pestilençia á la tierra. E quiso Dios que un prinçipal dellos dixo que no se avia de haçer assi, ni debian creel que aquellos chripstianos les avian traydo tal enfermedad, pues vian quellos tambien se avian muerto é no quedaban sino muy pocos, é que si los clıripstianos ovieran llerado aquel mal, que no se avian de morir. Assi por esto que dixo aquel prinçipal dexaron de matar á los chripstianos.

Segund ellos estaban, más crucldad fué para los españoles dexarlos vivos é no matarlos, que no conserrarlos con essa piedad en tanta penitençia é hambre é supliçio, pues que se estaban dos ó tres dias sin comer bocado. É á causa de es. tar todos enfermos é morirse como se morian los naturales, acordaron de se passar á la Tierra-Firme á unos anegadiços é paludes á comer ostiones, los quales comen tres ó quatro meses del año los inclios, sin conıer otra cosa alguna; é padesçen mucha lambre, é grandíssimo tra- 
haxo en se defender, de lia é de noche, de los mosquilos, que hay lantos ques cosa incomportable sufrirlos, é no liencn leña ni arya, sino salobre: ć otros puatro meses del año comen lichlas del campo é farçamoras; é dos meses olros clutuan mnas layges, é comen unas aratias muy grandes é lagartijis é culebras é ratones (pueslo cque algunas refes lienen renados 6́ olros dos meses comen pescado) que matan en canoas, ć ol ras rayges conten que son como turmas de licra, que sacan del agua. Aquella gente es muy bien dispuesta, é las mugeres son de grandiseimo trabaxo. Á Alonso del Castillo é Andrés Dorantes, los indios los passaron consigo á la Tierra-Firme á comer de aquellos ostiones, adonde estovicron has. ta en fin del mes de marego, año de mill b́ quinientos é veynte y nucve, que se volvicron á la mesma isla: é recogicroa los chripstianos que hallaron viros, que ya no eran más de calorçe. é devaron allí dos. porque estaban flaquíssimos é sin ninguna fuerga. I el flressorero Calbega de Vaca eslaba en la otra parte de la licrra, muy doliente é sin ceperança de vivir, y ellos passaron al ancon é se rinicron al luengo de la costa: y el thessorero se quedó allí dó cslaba çinco años é medio, cavando dende la mañana lıasta la noche, sacando rayses con una coa ó pato que usan los indios para aquello, debaxo de tierra é dehaxo del aggua, é trayendo cada dia una carga ó los de leña á cueslas sobre la carne é carona della, sin tener ropa alguna, sino como salvage ó indio. í assi los servia á los indios en el exergicio ya dicho, y cn las otras cosas que le mandaban, é de lievarles la casa ó su halo á cuestas, porque de tres á quatro dias se mudan, porque es assi sn costumbre, é no lienen assiento proprio por la micha liambre que lienen por toda aquella licra, buscando rayses; é no comen poco ni mucho de maliz. ni lo alcançu, ni se sicmlı̈i cosa ilggunir desla vida. La lierra es mury sana é templala, salvo quando vienta el Yorte por invicmo, que am los poscados se hiclan, dentro de la mar, de frio.

Andrés Dorantes dixo que vido nevar é apedrear juntamente en un dia, é ques tan gramde la hamlıre que allí se padesge quanto se pucde encarescer, é que adelante la hallaron mayor. É dige questa gente siente más el morir que todas las quél avia visto, é que assi los lloraban á los defunctos con mucho dolor é atcngion.

Visto el trabaxo ser 'tan grande y exScsivo, comencó cste cavallero á contractar cntrellos, é át tracrles de otras partes lo quellos no alcançaban é avian menester; y cntendiendo en esto, entró algunas vecos la tierra adentro, é fuć por el lıengo de la costa quarenta lognas adelante; é passó tres reges que fué un ancon, el qual dice que cree, que por las scũas dél, es el que Haman del Espírilu Sancto. E dos veces rolvió aquellas quarenla leguas por traer un ehripstiano que avia quelado vivo de los dos que avian dexado Castillo y Dorantes allí mury lacos, quando so particron de la isla, quel otro ya era muerto; ć lo sacaron la postrera vez, é lo trixo dessotra parte del dicho ancon del Espírilu Sancto diez leguas adelante á otros indios, que tenian gnerra con los que avian passado del Espírilu Sancto: los quales les dixeron sus nonubres é que arian muerto otros tres 6 qualro chripslianos, é que los demás se avian muerto alli ferca de hambre é de frio todos, é que los que cran viros eslaban muy maltraclados. E dixéronles muchas malas unevis junto con estoá estos dos chripstianos (digo á este Doranles é al compaìero que avia cobrado) é les ponian flechas en el coraçon, é los amenagaban que los arian de malar, é de miedo desto el otro chripstiano se tornó atrás, é dexó al Dorantes, que no le purdo dotener. É dende 
a dos ó tres dias que allí quecló, se partió de allí escondidamente, é topó con dos indios que lo llevaron adonde estaban Dorantes é Alonso del Castillo.

Llegado, pues, Andrés Jorantes adon. de estaban estos dos clripstianos é los que más se dirán, ağguardó alli á un indio suyo; é primero dia de abril se particron de allí cl dicho Indrés Dorantes é Alonso del Castillo é Diegzo Dorantes é Pedro Valdivieso; y el Asturiano clérigo é un negro estaban en una isla, atrús de donde perdicron las barcas, adonde se avian passado por la mucha hambre que alli tenian, é los indios los tornaron á passar el ancon otra vez, en una canoa, adonde avian perdido las harcas, é estalhan cssos pocos chripstianos que avian escapado de la hambre é frio del invierno; é alli tomaron olros seýs. Issi que eran ya doce chripstianos por todos. E quedíronse en la isla dos (que por llaquega no los pudicron llevar, é Calsegai de Vica é olro chripstiano que estahan més adentro, yue no los pudicron aver para lraclos; é los indios los fueron ál passar otro ancon por ricrtits cosas que les dieron. É de alli anduvieron dos legruas hasta un rio grinde, que començaba á crescer por avenidas é lluvias, é alli hiçieron balsas, en que passaron con unuclio trabaso, porque avia entrellos pocos nadadores: è dende allí fucron tres leguas lasta otro rio que veuia muy poderoso é arenido, é con tanta furia que salia el agua dulçe muy grand rato en la mar. E alli se hiçieron assinesmo unas balsas, ć le passaron eu ellas; é la primera passó bien, porque se ayuda. han, é la segunda ios sácó á la mar, porque cómo venían llacos é cansados del trabaxoso invierno passado é del camino, é no comian otra cosa sino una lierba que llaman pertrera (que avia mucha por lia costa) de la qual en España liageu vidro, é unos cangrejos yue crian en curvas en la costa, é no tienen quassi olra coTONO III. sa sino la cáscara, no tuvicron fuerga los que en aquella balsal yhan para salir en salvo; é alli se ahogaron dos liombres, otros dos salicron á nado, é la balsa salió con la corriente á la mar más de una legria, con un hombre asido á ella: é cómo se vido fuera de la corriente, se subió ençima é liiço vela de su propria persona, y el viento era de la mar é lo tornó á eclatr en tierra, y escapó.

No quedaloan ya sino diez de los doce ques dicho que avian salido, é allí hallaron otro chripstiano, que tambien se fue con ellos; é desque ovieron andado tres ó quatro leguas, toparon otro rio, é allí hallaron otra barca de las çinco suyas, que conoscieron ser la en que yba el contador Alonso Enriquez y el comisario; pero no supieron qué se avia hecho la gente della. É anduvieron otras ginco ó seys leguas hasta olro rio grande, en que estaban dos ranclos de indios, los quales luyeron; é de la otra parte del rio passaron iudios á los chripstianos é los conoscieron, porque por alli avian visto ya á los de la barca del gobernador é de la harca de Alonso Emriquez; é asegurándose, passérronlos en una canoa el rio. Lleváronlos á sus casas, en las quales ninguna cosa tenian que comer; pero dièronles un poco de pescado, con que passaron essa noche.

El dia siguiente se particron de allí, é al quarto dia llegaron á un ancon, aviéndoseles muerto en el camino dos liombres de hambre e de cansados: por manera que ya no quedaban sino nueve personas. Este ancon era anclio, é tenia quassi mna legua de través, é hage una punta Jácria la parte de Panuco, que sale á la mar quassi un quarto de legua, con unos mogotes de arena blanca é graudes, que de ragon se deben de parescer dende lexos en la mar, é por eslo sospecharon que debe ser el rio del Espírilu Sincto. E alli se vicron muy fatigados, por no poder hat- 
Hall mancra para passar; pero en fin laillaron una canoa duclobala, é arlerescáronlir la mejor (jure pudiuron, y en dos diis que eatovicron allí passaron ol anron, é luéroinse su camino muy fatigatos the la lambline, é los más ýram limchados de las lierluas que connian; é llegraron con mucho trablaso hasta un ancon pequeño, que restabil doge loggads adelante. Este

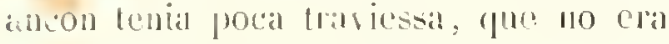
siruo como un rio en la anchura, é alli fallaron al dia que llegarron; é otro clia signiente vieron de la otra parte un indio, pero annque le llamaron, no quiso vinir, é se fué : é volvió á la tarde é truxo consigo un chripstiano, que se llamaba Figueroa, y era mo de los quatro que avian enviado el invicrno passado á ver si podian aportar á tierra de clripstianos, como ya quela dicho. É luego passaron ol indio y el chripstiano donde los mueve estaban: é allí les dixo cómo los otros tres compañeros se avian muerto, los dos de lambre, y el otro avian matiulo los indios; é les dico cómo avia topado con un chripstiano que llamaban Esquivel, que solo avia escapado de las dos hareas del śobernador é de Alonso Enriquez, comiendo carne de los que se morian, é yue todos los demás eran muertos de lambre, é algunos dellos comiéndose unos á otros; é que la larca de Alonso Enriyuez avia dado al través donde estos otros'ú avian hallado, como queda dicho. É que viniéndose la costa addelante, topó el gobernador con ellos, que aun renia en su barca por la mar ; é cómo los vido, determinó de echar toda sugente en tierra para que se fuessen junto con la costa, porque la barea fuesse más ligera, é porque ellos yban farligados de la mar é no lievaban cosa alguna que comer, é quél se aria cluedarlo en la barca á vista deilos, para quanclo oviesse algun ancon ó rio passarlos á todos en la barea : é (que assi llegaron al ancon ques dicho que croian r fues el del Espíritu Sancto; é allí el gobernalor passó la grente todia de la otra pirte del ancon, y olse puedón on la barar. que no quiso saltar en licrial, 6 quedalon solamente con él un piloto que se liamalsa Snton Perez, é un prage suyo que se decria Campo: é que assi cómo anocliessió. vino un Norte muy recio que los levo á la mar. que nunca más se supo rlallos; ć quel goberinador ylo muy flaco Y enfermoé ileno de lepra, é los yue con (i) yban no estabin muy reçios, por lo qual es de creer que la mar los comió; que toda la gente que allí avian quedado se aviau entrado por ciertos paludes é anegialicos que allí avia, é por la tierra adentro, cómo gente sin remedio, donde torlos muricron afuel invierno passado de liambre é de frio, é comiéndose algunos dellos á los otros, cémo es dicho. É no les supo aleçir otra cosa sino quel Esquivel andaba por alli, que lo tenian unos indios, é que podria ser que presto lo viessen: pero dende ahí á un mes, poco mís ó menos, se supo que los indios con quien estaba, le avian muerto porque se avia ydo dellos, é que salieron trás él é que lo mataron.

Alli estovicron con este chripstiano un rato, oyendole estas malas nuevas ques diclıo: é porque el indio con quien él venia no le queria dexar, fuéle forģado á yrse con él; é porque essotros no sabian nadar, no pudieron yr con ellos sino dos clrripstianos, de los quales el uno era un clérigo que se llamaba Asturiano. y el otro era un mançebo nadador, porque ninguno otro sabia nadar de los que quedalan. Y estos dos fueron con intençion de traer algun pescado que les dixeron (que tenian, é que tormarian á passarlos el ancon; é cómo los indios los vieron allá en sus casas, no quisieron volver con cillos ni dexarlos tormar: antes mudaron sus casas en sus canoas é llevíronse los otros dos clripstianos consigo, diçiéndo- 
les que luego volverian, é que vhan çerca de alli por" ma gicrla hoja quellos acostumbran coşer, de que haçen çierto brevage, el qual beben caliente fuanto lo pueden sufrir. Y el uno de los dos chripstianos se tornó otro dia de mañana á deçirles esto, é á les tracr á essotros sicte chripstianos un poeo de pescarlo que le avian dado: y estovieron alli arfuel dia por la metcha nescessidarl que tenian.

Oro dia signiente vieron por la mañana dos indios, de la otra parte, que eran de III rancho é veníanse á poner alli á courer çrçamoras, que las aria en algumas partes de aquella costa, "é andaban á ellas una temporada, en tanto que les turin, que les saben muy lien, é les son baslimento que los sostiene quando las hay. E llamáronlos, é passaron donde esins chripstianos estaban, como á gente que los tenian en poco, é ann les fomaron parte de lo que tenian, quassi por fuerça; é rogáronles que los passassen, é assi lo hiçieron en una canoa, é los lleraron á sus casas, que estaban alli junto. é aquella noche les diernn un poco de pescarlo. É otro dia fucron á pescar é Iornaron de noche con pescado, é les dieron una parte dello; é luego otro dia signiente se mularon é los llevaron consigo, de manera que nunca más pudiepon ver á los otros dos clutipstianos, que los indios avian llevado.

¡Inmenso Dios, qué Irabasos tan exçesivos para lan corta vidla como la rlel lımbre! iQué formentos lan inauditos para un cuerpo humano! ;Quć Lambres lan intolerables para una pereona tan Haca! ¿Qué desaventuras tan extremalas para carne tan sensilule! ;Qné muerles tan desesperadas para un entendimiento tan ratsonable! ¿Con qué pagaron los cipitanos é ministros destos viages, que lan enganados é burlados Ilevaron á tantos tristes á morir de lales muertes? P’uédese responder que ellos los pagaron con sus mismas coblicgits, que dieron crédito a sus palabras.

Ya sabemos que Pamplilo de Narvarez numca esturo en aquella ticra, arlomle pensó llevir estal gente, pensando ser senor é gobernador, é parésçeme que á solo no suj) goberuar. ¿l'uede ser ma yor liviandad que escuchar é segurir tales adarlides? Y vod qué tan uliestros cran sus pilotos, yue tampoco supieron lónde y han ni dónde estaban, quamdo á auquella tiepra passaron!... É assi acabaron los lonto Jres de la mar como los de la licra con malas murtes, sin ententerse los mone ni los olros.

Morir en uma balalla muchos, ó ancgarse en un viage, porpue se perdió la nao, por liempo ó por otro caso fortuito donde muchos perescicon, ó con ma pestilençia lerrible é presta, todas estats cosas son do mucho teror y ligurosas i infeliçes á los que las parlescon; mas amu en aquestos males hay algma parte de lien, porefue el que muere en la hatalla ¿ va ála guerra, si es cluripstiano va confessitlo é dexa fucho su fostamento é ordenada su ámima é continúa la gucra. sirviendo á su prínçipe: é aqueste lal puede morir en estado é eamino de sal. vaçion, pues ques mandado de su rey ó señor, á quien ni prede ni debe faltar, sin caer en rergüuença ni incurrir en culpa de mal vassallo ó criado. El yue se anega, como es dicho, antes que prinçipic su navegaçion ni entre en la mar, sc conficssa ć comulga é ordena su ánima, como callólico, é despues sigue su cambino, si os mandado, por eumplir con lo que debe: é si es por su motivo, si es mercader, ó le conviene por olmas causas justas, que tienen diseulpa honesta, aunque la muerte se atrariesse, é tambien pol buscar de comer sin perjuiçio de teresero. Y si, crmo es dicho, la muerte fué pestilençial é arrebatala, tambion dá Dios en lal caso, por su clemençia, liempo para reparar sus 
ámmas á los que assi mucren. Mas arquestos sin ventura, que con tantos é tan diverssos géneros de muertes palescieron, ¿qué se les puede igmalar con tracrlos su mala dicha é pecados á comerse unos á otros é é morirse raljiando de lambre é de sed, é de otras enfermedales é tralaxos, munca por lombres parlescirlos ni tan continuos?

Yo os digo, cavallero pohre, ó hiclalgo nesçessitado, ó artesano de mal reposiso, ó villano mal consejado. que rosotros é todos ios que destas calidides os laallastes en esta armadal, fue tenés jusla paga de vuestro mal acuerdo. Porque al polire cavallero fuera más seguro estado el fue se tenia, sirviendo á otros mayores: y al cscullero exerçitándoso de manera que si no le pudieri baztar su laçienda, bastara él á clla; y al arlesano no (lesamparar su officio, ni al villano su arado; porfuc en el carall y en las otras liblores y agricoltura, que dexó por venir á las Indias, avia más seguridad y quictud para el cuerpo é prira el ámima, que no escoger una liviandad lam notoria é peligrosa como hiçistes en seguir á Pamplito de Narracz. De Cula supicril él muy bien deçiros lo que lay en ella é dónde anduro; pero adonde os llevó, él no lo sabial, ni fué adonde pensalua yr : é ya que fucra tampoco lo avia visto, ni salbia lo que era aquello que luscalba, sino que quiso dexar su reposso por mandir. I si á sí solo lesasosegara, no fuera tan eresçido el daño; pero de su invençion é mal consejo os cupo tanta parte como á él, pues ni él eseapó de la muer. te, ni dexó de dírosla á todos.
Ilacedme ayora saber, los que avegy loydo, si oystes ni supistes ofral grente tan desdichada ni tan trabaxada ni lan mal aconsejada. Buscad essa peregrinadion de Ulices, ó essia navegacion de Jasson, ó los trabaxos de llércoles, que todo rsso es ficçiones é metíphoris, que entendidas como se deben entender, ni liallareys de qué os maravillar, ni son companacion igual con los trabaxos destos pecadores que tan infeliçe camino é lin licieron. E qualquiera de todos cstos padesçió más que los tres cappitanes (pues dicho, aunque con cllos pongays á Perseo con su Mednsa, si por estos passos andurieran questos anduricron.

¡Olı malclito oro! jolt thessoros é ganancias de tanto peligro! jolı martas çeJellinas! Bicn creo yo que si al prescio questos ovicron aquella manla (que la dicho la historia que se le quedó á Narvaez á vucltas de aquella pedirada) se alcanrassen estos enforros coliclianos que los invicrnos usan los príncipes é señores prinçipales en Europa, que las tendrian en más; pero ussas cómpuranse con lineros, y cstotras con sangre é con las vidas. ć aun no las pudieron sacar ni traer de entre arjucllas gentes salvages.

Tornemos á la historia, que no aremos llegado al cabo, amque de la gente de Narvaez ya no nos quedan sino tan pocos hombres de todos quantos llevó, como se lia dicho de susso, é como lo oyrés en el capítulo siguiente, progediendo en la mesma relaçion de arpuel cavallero Álvar Nuñez Calseça de Vaca é sus consortes. 


\section{CAPITULO IV.}

Fn el qual se cuenlan olros trahaxos é eauliverio que padencieron estus hidalgos Alvar Nuñez Cabera de

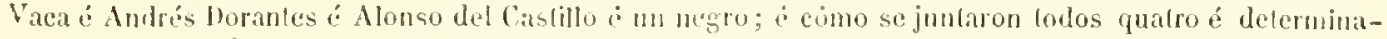
ron de morir ó sélir de entre arpuetla mala generap̧ion de indios i buscal lierra de chripstianos, é lo que les subcedio, procurando de seguir su buen desseo.

C Aomo un capilan ú hombre de repulaçion ó persona de las que destas partes é Indias van á España (y en especial los que van á pedir trobernaciones é nuevas conquistas, é saben mediananente menear la lengua para allegar gente) se pone á derramar palaliras entre los que no lo entienden. todos los tales yue le recuchan piensan que todo (puanto acá layy, sin que quede isla ni paluo ni rincon de la Tierra-F̈irme é de las Juclias, lo sube é to ha risto y andado y lo liene muy bien entendido (é aun no dexan essos lales predicatores de laiblar en todo), ó aquellos indoltos oyentes se les figura y creen que las Indias serán como un reyno de Portugal ó de Nivarra, ó á lo menos ma cosa recogida é breve terreno, donde todos los que acá estám saben los mos de los otros é se pueden comunicar con la façilidarl que dende Córdova á Cirauada ó Sevilla, ó quando más lexos dende Castilla á Vizeara. Y de atpui resultan unos sobrescriptos de carlas que por acé vienen de las ignorantes madres ó mugeres que Juscan y escriben á sus hijos é maridos, é otros á sus parrientes, é diçen assi: "i mii desseado hijo Pero liodriguez, en las Indias"; ques como si dixesse: "I mi liijo Mahoma, en Ífriea, ó á Johán Marlinez, en Europa;" ó lo mesmo que si dixera en el olio mundo. Porepue todos los que algo sienten del assiento del mundo i su greographia no dexan de sospechar que esto de acú sea lan grande como las dos partes que diggo del mundo y el $A$ sia con cllas, é otro nuevo mundo, como algunos lo nombrall, Orbe Novo: y yo le
Ilamo, como he dicho otras veges cu eslas listorias, una milid del mesmo mundo en que Ĺfrica, Europa ni Asia no participan. Assi quiero deçil que tan á esenras vicnen muchos á estas Indias como los solbrescriplos que he dicho, sin entender ni salber á dónde van: y destos tales lopó Narvacz é hallan otros capilanes quantos quieren, ó á lo menos más de los que han menester, porpue la poloreca de los unos, é la coldedicia de los otros, é lá locura de los más no les dexa entender lo que haren ni á quién siguen. Verdad es que á vucllas dessos vienen algunos (jue nicjor fundan sus jropóssitos é camino, porque son mindalos del Prínçipe ó por otras causás más allegadas á raçon y oxcusables. Pero porrue seria posible que tambion fuesse engañado el Prinçipe como el polse compraticio, he miralo en una cosal, que no es pitra que niuguno la olvide; y es que quassi nunca Sus Magestades ponen su liacicuda é dincro en estos nucvos desculbrimientos, exrepto papel é palaluras buenas, é diggen á estos capitanes: "Si hiciéredes lo que deçís, haremos csto ó aquello, ó hagérscos lan mergedlesn. É dánle tilulo de adelantado ó gobernador, con licengial e porleres que vaya adonde sc ofrescice pror una capitulaçion, en furgia de lat ignnorançia de los gue lo lan de seguir con sus personis ó bicnes, al sabor de sus falsos blasones. É despachado de la cónte, viénese á SeviIlia con menos dineros de los que querria; y en tanto que un alambor por una parte é un frayle ó dos é algunos clérigos, que luegro se le allegan sú color de la conver- 
sion de los indios, por otras vias andan lrastornando sessos é prometiendo la riqueça de aquellos que ninguna cosa saben, entiende cl capitan en tomar camlios y en comprar navios cansados y ricjos, que quando ací llegan, ó vienen á Dios misericordia y á poder de duplicadas bombas, ó tales que no son para rolver ni pueden llevar á Castilla nueva ni racon de la carga que truxeron. E por otra parte un mançebo que haçen su secrelario (y que nunca supo (qué cosa es scereto) con otros sálrapas ó lagoteros de aquellos quel capitan ré que mejor lo salsrán urdir, entienden en lablar á los pobres companicros é atracrlos á dos cosas: la una que presten al capilan dineros sobre las esperanças ranas que les prometen, é sobre un conosgrimiento, que piensa el que lo resçibe ques una cédula de cambio: y assi esse pobre compañero dá essos pocos de dineros que le quedan, é si se dilata el armadijo, vende la capa y el sayo, é quédase en jubon como Gaillote, porque le paresce que denás de venir á tierra caliente llegará bien vestido con el favor que espera y que le han ofrescido. La otra cosa es que de diez en diez é más ó menos compañeros los haçen obligar é mancomunarse para pagar á çierto tiempo cada diez ó doçe ducados ó pessos de oro del flete donde van y de la comida, que no les dan sino tal ques qual pueden deçir los que á Fispaña vuclven destos assi engañados (que son los menos) porque como el viag̣e es largo é la vida corta, é las ocasiones para perderla innumerables, fodos los mús que acá vienen es de assiento é para no tornal á su ticra, y muy al reves de lo que en España se les figmó, como agora lo oyreys, é como lo arés oydo si arés leydo estas historias dende su principio, y como leerés un lo que está por deçir, si hasta el cabo en fin te mis lractalos quisiéredes ser informado para retestro aviso é para avisar á otros. Viligo assi:

Apucllos indios en cuya comprinia estaluan essos pocos de chripslianos (pue! capítulo de susso ha dicho, se cansaron di: les dar de comer (como acaesce en carla parte que los convidados se delienen mís que su huésped querria, y en espeçial alonde ni son desseados ni dan provecho); é por esto echaron los çinco dellos que se fuessen á otros indios, que degian que estiblan en otro ancon adelante seys leguas. Hassi lo hicieron, y estovieron en él mucho tiempo los tres que fueron al ancon, Alonso del Castillo, é Pedro de Valdivicso, primo de Andrés Dorantes, é oho que se deçia Diegro de Huelra : é los dos se fueron más baxo á la costa, é allí se murieron de hambre, porque el borantes diçe que los laalló despues nuertos, andando buscando su remedio, y el otro chripstiano primo suyo, que se deçia Diego Dorantes. E allí se quedaron en aguel rancho estos dos lidalg̣os é un negro, que les paresció que luastaba para lo que los inclios los querian, que era patra que les acarreassen á cuestas leña é agra é servirse dellos, como de esclaros. É dende á tres ó quatro dias los echaron assimosmo á estotros donde anduvieron perdirlos algunos dias é sin esperanca de remedio: é andando assi por apuellas ciénegas é desnudos en carnes, porque otros indios antes les avian despojado é de noche se arian ýdo con la ropa, fopran con los chripstianos muerlos, que eran de los cinco que avian echado los indios ú de-pedido, como es dielıo. É de allí fucron é Ioparon otros indios, é queduse con ellos el Andrés Dorantes, esu primo se fué adelante hasta el ancon, donde avian parado los ofros tres: é alli lo fué á rer el uno delíos, que era ol Valdivicso, que e-laba de la otra parte, é le dixo cómo arian passado por alli los onros dos chripstianos nadadores 
que los avian decado, é assimesno lo: avian despojado é dexídoles en carnes é dádoles muchos palos é descalabrádoles. porque no quisieron quedar con cllos; ó assi se fueron desnudos é maltractados, aviendo fecho juramento de no parar, anuque supieran morir, hasta lierra do dhripstianos. E diçe este Indrés Dorantes quél vido en aquel rancho la ropa de uno dellos, que cra del clérigo é con ella un Breviario é un Diornal; é luego este se torno, é dende á dos dias lo mataron porque queria luyr é dende á poco mataron al otro, que se deçia Diego de Huelva, porque se passó de ima possada á otra. É allí los tomaron por esclavos, sirviéndose dellos mís cruelmente que un unoro lo pudiera haçer, porque allende le andar en carnes vivas é de todo punto desnudos é descalços por aquella costa (que quemalsa en verano como fuego) no era otro su officio sino traer cargas de leña é de agua y todo lo demás que avian menester los inclios á rayz de las carnes, e arrastrando las canoas por aquellos anegados con aquellas calores.

Esta gente no come en todo el año sino pescarlo é poco, é con esto tienen mucha menos hambre que los de la ticra adentro (con quien despues estovieron) que, como otras cosas, esto les falla muchas veces, é por esta causa se mudan lan á menudo, porque si assi no lo hiciessen, no ternian qué comer. É demás desta penuria es otra muy grande la del agua dulçe (re la fual es muy falta aqueIla tierra), porque como andan entre anegadiços é agua saladla, el agua que tienen para beber es muy poca é mala, é léxos. E esto todo era para más fatiga de los chripstianos, assi en parlescer la mesma sed, como en les traer á cuestas el ageıa para los indios sus amos é aun para sus veçiurs; porque todos los mandiaban, e á torlos temian, é todos les tractalian unal de ohra é de palalıas. É los mucla- chos les polaton las barbas cada dia por sı passatiempo, y en viéndolos descuy dados les daha qualquier muchacho su repelon, é les tomaloa la mayor lisa é placer del mundo; é los rascuñaban de. mancra que muclias veces les haçian sangre; porque traen tales uñas, que aquellas son sus prinçipales armas ó cuchillos ordinarios para entre sí, si no es con quicn tienen guerra. E luasianles tantas é tales vexaçiones los muchachos, que en topándolos fucra de las casas, lnego eran con ellos con piedras é con quan. to se les ofresçia é hallal)an más á la ma no: de forma que para los rapaçes era un juego ó nueva caça é regoçijo, é como eran hidalgos é hrombres de bien é nuevos en lal vida, era menester que su paçiençia fuesse mucha é iơual á su trabaxo é penas en que los tenian, para sufrir tantos é tan incomportables tormen10s. E assi testificó este Dorantes que cree que Dios les daba esfuerço para ser pacientes en descuento de sus pecados é porque más meresçiessen; ć aunque quisicran no sufrir tales futigas, no podian haçer ofra cosa (exçepto desesperándosc), porque estaban gercados de agua. que todo aquello por donde andaban era isletas; ć si en su mano fucra, por mejor ovicran la muerte por el campo soIos é como lımbres sin ventura, pidienclo á Dios misericordia de sus culpas, é no vivir entre tan malvada é bestial gente. Entre la qual estoricron catorçe meses dende el mes de mayo liasta que en el año siguiente vino ofro mes de mayo, é llegó el mes de mayo adelante (del año de mill é quinientos é treynta); porque mediado el mes de agosto, estando ol Andrós Dorantes en la parte que le paresció más aparejada para sc porler yr, él se encomendó á Dios é se fué en milarl del dia por medio de todos los indios, que no quiso Dios que mirassen en él: é a quel dia passó una ağgua grande, é ancli- 
vo todo lo que pudo con muclio niedo, é olro dia dió en muos indios, que to res. çibieron de luena gana, poreque ya tenian notiçia que los clupipstianos servian hien; é Cistillo y el megro se queditron estonges, porque no pudieron yrze con el é dende á tres meses el negro se fuć tras él, é se foparon, aunque nunca estovieron juntos. Cástillo se quedó, y estuyo otro año y medio más entre aquella mala gente, lasta que halló ajrarejo para se ye trás de Dorantes: é quando llegó, no halló sino al negroo, porque no pudiendo sufrir aquellos indios por ser lan malos, como es dicho, se fuć cl Dorantes á olros más de veynte legrnas atrás, que estaban en un rio cerca del ancon del Bspiritu Sancto, que ga está dicho, que cran aquellos indios los que avian muer10 á bequivel, que era el chripstiano que se avia escapado solo de la gente de las dos larcas del golernador é de Alonso Furipuez. Esegund le discron los anesmos indios, que lo arian mucrto poreque avia soñado una nuzrer no sé qué desitino, porque los de aquella parte creen ensucnos ć matan sus proprios lijos por snctios: e dixo este lridalgo Dorantes quél vido en espaçio de quatro años mataly y enterrar vivos once ó doge niños: y estos son los muchachos, que hembras por maravilla dexan ninguna. Esta gente un tione otra ydolatria ni la creen simo este erron ques dichn. Curea de allí avian otros indios muerto á Ibieģo Dorantes. su primo, á calso de dos años que los servia y estaba entre ellos: de manera que ninguma seguridarl de la vida tenia més un dia que olro. Assi que, de torlos estos chripslianos ya no quedaban vivos sino oste Andrés Dorantes, é llonso del Castillo. y el negro, y el Cabega de Vaca, del qual estotros no sabian.

Entre aquesta gente ques dicho esturo Andrés Dorantes diez meses solo, padessiendo mucha hambre é continuo traba- xo, 6 con trmor que le avian de matar algm dia, pues via pue sus proprios hijos sin piedial ni misericondia los nualalan por un sneino do desvario, í que assi arian mucto á Esepuivel por lo mesmo. É assi no topaba indio por dó iba ó por donde estaba lrabaxando, carando layges, que no pensilsse que lo venia á matar por algm sneño, é lasta que lo reia passar adelante, no tenia seguridarl: quanto mís que los indios por la mayor parte, on topando al polne Dorantes, so lo moatraban nuy feroges, c alemnas vecos (cian murlas) venian eorricndo ál él (é á los otros donde estalian, é poníanles una fleclia í los pechos flochirlo el arco lista la oroja, é despues réanse é decíanles: ¿Oristes miedo?

Estos indios comen rayces, que sacan debaxo de tierra la mayor parte del invierno: $e$ son muy pocass é sacarlas con mucho trabaso, é la mayor parte del año passan grandíssima lambre é lodos los dias de la vida lan de llabaxar en ello ć dende la mañana lasta la noche. Assinesmo romen culebras é laqurutijas, ratones. quillos. cigrarras, ranas é bolas quantas sibandijas ellos pueden arer; é tambien algmas veges matan renados, é ponen fuego í ha lierra é savanas para los matar. Matan ratones, de gue lany mueha ranlidiul por entre apucllos rins; pero todo es poco, porpue como andán por apue rin tolo el inviorno de arriba alasoé de abayo arrila. que nmea paran de huscar de comel, espantan la caga ć todo lo acaban. Ilgunas veges comen pescalo que matan en aquel rio: pero poco, sino quando arione. ques en el mes de aluril: ć algimos años cresere dos veces, é la segunda es por mayo y estonces matan mucha cantidad de peseado é muy bueno, y escalan muchn dello; pero piérdescles lo más, porpue no tienen sal ni la alcancan para lo poner en cobro é que se pudiesse sostener para adclante. 
Hay en las costas de aruel rio muchas nueces, las quales comen en su liempo, porpue dan alli el fructo los nogales un aīo sí é otro no, é algunas veces passa IIII añn ó dos que no dan fructo; pero quando las hay, aquellas nueces son muchas é muy golosos los indios dellas, que de veynte é treynta leguas toda la comarca al rededor de alli van á comerlas : é passan sraud nesçessidad, porque como es mucha la gente que viene por esta fructa, en un dia espantan la carga é la matan toda, é no comen en todo un mes que turan las nueges otra cosa. Estas nueces son menudas muchio más que las de lispaña, é trabaxoso de sacar lo que de adentro se come dellas.

Esta gente, despues que viene el verano, en fin de mayo comen algun pescado, si les la quedado de lo que escalau de los rios avenidos; é comiençan á caminar para comor las tumas, ques una fructa que en aquella ticra lıay en abmndançia, é van más de quarenta leguas adelaute láçia Panuco á comerlas: las quales tienen en tanto, que no las dexan por cosa del mundo. Y aqueste es el mejor manjar quellos tienen en lodo el año, el qual les lura mes y medio ó dos meses, caminando é comiendo esta fructa, é natan algunos venados alguna vez, é aun acaesce á poca gente malar dosçientos ó lrescientos venados. E diçe este hidalgo Audrés Dorantes que en ocho dias vido que sessenta indios mataron tantos como el número que lıa diclıo, é que tambien acaesce matar quinientos; é otras muclıas veges ó las más no matan ninguno; y es desta manera. Que como ellos caminan por la costa, comen los de la tierra en ala, é como torlo el año está arpuello fodo despolslado é sin gente, lıay muclios, é trícnlos antecogidos al agrua, é tráienlos allí todo el dia hasta que se ahogan, y el tiempo é la marea los cela despues á la costa muretos, porque quando el iento To110 III. no es de la mar no los corren, é si los corren, luego se vuelven, porfue el venato no va sino contra el viento. Esto acaesce una vez ó dos, é assi las nás veçes no matan caça, é si la milan, es poca, si no es acaso, como he diclıo. Y assi con este exerçiçio passan adelante su camino hasta que se apartan del agua salada é se entran la tierra adentro, comiendo sus tunas, las quales comiençan á comer é madurar por aggosto, é túrales çinquïenta ó sessenta dias. Y este es el mejor tiempo del año para aquella gente, porque aunque no comen olra cosa sino tunas é algynos caracoles que rebuscan, de que se hartan de dia é de noche, eslán contentos en essa saçon, y en todo el otro tiempo del año se finan de hambre.

Alí en aquellas tunas se tornaron á juntar Castillo y el negro" é Andrés Dorantes, é se conçertaron para se yr: é como los indios nunca sosegaban ni estaban juntos, luego se yluan cada uno por su parte, é assi de nesçessidad estos pecadores de chripstianos se apartaban con sus amos. De forma (jue no podian efettuar su conçierto é voluntad (á lo menos por estonges) é cada uno se fué por su parte con sus señores á comer aquellas nucces, que avia muchas aquel año; pero llegados allí, vino Cabega de Vaca á se juntar con essotros, que avia çinco años que lo avian dexado atrís, donde se perdieron las barcas, que nunca más lo avian visto: é alli se conçertaron despues que Cabeça de Vaca llegó, porque como es diclo estaban apartados é no se podian comunicar sino en el tiempo de las tunas, aviendo que comer en el campo; y estonces, estando muchas veçes á punto para se yr, no parescia sino que sus pecados se lo estorbalıan, apartándolos á cada uno por su parte. Passados ya seys años, é venia en el séptimo año el tiempo de aquella fructa de las tunas, aunque cada tno destos chripstianos estaban aparta$7 i$ 
dos por sí, cada rual dellos ascondiclatmente se fucron é aportaron la tierra adentro á gicilar parte donde solian comor las lunis: é los indios no yluan allí estonces porque no las avial. Y al Dorantes fué cl primero que allí llegó, é acaso halló una gente de indios que aquel nresmo dia avian alli venido, los puales eran grandes enemigos de los otros con quienes avian estos chripstianos estado, é rescibiéronle muy lien: é á catho de tres ó quatro dias que allí cstaba . llegó el negro que ylua en su mastro, é Monso del Cirslillo, que estaban juntos, é alli se concertaron de buscar à Cabega de Vaea, que los esperalua adelante. E vieron unos lumnos bicu léxos, é acordaron que Dorantes y el negro fuessen á aquel humo, é quel Cirstillo quedasse allí para asegourar los indios é que no ereyessen que se yban: é dixéronles que yluan por otro compañero siryo, que creian que estaba en aquellos humos, para lo tracr allía su compañia, é que se quedasse Castillo hasla que volviossen. Y ellos liolgaron dello, é assi fueron é tovieron bien que andar hista la noche, que toparon con III indio que los llevó adonde Ciabeça de Vaca catabit, al qual dixeron como venian á buscarle; é plugo á Dios que los indios se mudaron otro dia ése pusicron más çerca de donde el Castillo avia quedado, é allí se tormaron á juntar, y encomendíndose lodos tres á Nuestro Scĩor, ovieron por mejor laçe! aquello que cran ols ligados como cluripstianos (é como liidalgos, (que cada uno dellos lo ena) que no vivir en vida tan salvagge é lan aparlada del serviçio de Dios é de toda burena racon. E con csta bucna roluntad como hombres de luena casta determinados, salieron; é assi Jhesu Chripsto los guió é obró de su infinita misericortia con ellos, é abriéndoles los caminos sin avellos en la ticra, é los coragones de los hom- lires tan salrages é indómitos, movió 1)ios á humillárseles á obedescerlos, co-

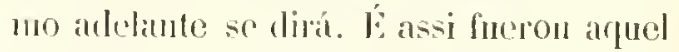
dia sin ser sentidos ni subiendo cllos adconde se yban, sino confiados en la clemençia divina, é buseando de arpuellas lunas que avia en la lierra, aunque ya crá el ticmpo que se acabaluan, porque cra por otubre: é plugro á la Madre de Dios que arguel dia á puesta del sol toparon con indios, puales ellos desscahan, que eran muy mansos é tenian algruna noticia de chripstianos, auncue poca, porque no sabian cómo los olros los traclaball mal (que fué harto bien para estos pecadores). É cóno cra ya principio del invierno, é yluan sin cneros para cubrirse, é las lumas se acabahan en los campos con que avian de caminar, lovieron nescessidad de parar allí aquel airo para aver algunos cueros con que se culsrir, gue les decian que los hallarian adclante: é pues estaban en camino é donde tenian mejor aparejo para quel siguiente año, venidas las tunas, pudiessen proseguir su propóssito, sosegraron por estonçes dende primero de olubre hasta el mes de agosto del año venidero. Pero en aquel tiempo que con estos indios estovieron, sufrieron mucha hambre, é no menos, antes mayor que en el tiempo passado de los siete años; $y$ era la cansa questos indios no estaban çerea del agua, donde pudiessen matar algrun pescallo è assi no comian allí sino rayçes: é tienen alli mayor trabaxo que todos los demás que aleançan alguna pesqueria. É assi cn todo el año no se veian lartos, é andan alli los muchachos tan flacos é lunchados (que paresçian sapos; pero á lo menos cutre aquestos indios fueron hien tractados essos chripstianos, é dexálanlos vivir en su libertad é haçer todo lo que querian. 


\section{CAPITULO V.}

En el qual se tracla la continuapion del camiuo questos tres chripslianos y el negro haçian, buscando cóno saldrian á lierra de eloripstianos; é cómo hiejeron mirgglos, sanando i nuclıos indios enfermos eon soliamente los santiguar; é euéntanse cosas notables é nescessarias al diseurso de la libioria.

l. slegado el mes de agosto, ya estos tres hidlalgos tenian allegados algunos cueros dé renados, é quando vieron tiempo aparcjado, huyeron con el tiento é secreto qque les convino de la parte é indios ques dicho de susso. É aquel mesmo dia que se partieron, andovieron siete leguras hasta topar con otros índios que cran amigos de los que dexal)an atrás, é allí los resçibieron bien é les dieron de lo rue tenian. É otro dia se mudaron é se vinicron assi adelante á se juntar con otros indios, é los llevaron consigo, é ylan á comer los unos é los otros unos granillos que estonçes madturaban; é hay por allí muy grandes montes de arloledas que llevaban essa fructa. É alli se juntaron con los otros, é los chripstianos se prassaron á ellos, porque era gente de nuís ací adelante é más á propóssito de su camino é intento: é detuviéronse por allí oclıo dias con aquellos, que no comian otril cosa sino unas liojas de tunas cogidas, porque estalsan esperaudo aquellos grranillos, que aun no estaban maduros. E a allí les dieron estos chripstianos parte de los cueros de venados que llevalan á trueco de dos perros para comer, porque estaban tan flacos, que no se atrevian andar una legrua; é comidos los perros, se despidieron de los indios é se fueron.

Á estos indios postreros les pessó mucho porque se yban, pero no se lo estorharon: é arpuel dia andovieron sinco ó seys leguas sin lallar cosa qué comer ni topar indio que los encaminasse; 6 llegaron aquella noche á un monte, donde durmieron, y enteraron muchas liojas de tunas, que otro dia por la mañana co- mieron (porque enterradas de un dia para otro estím menos ásperas é aptas para se coser mejor é de mejor digistion). É siguicron su camino lasta medio dia, que llegaron á dos ó tres ranchos, donde avia algunos indios, que les diseron que no tenian qué comer, pero que fuessen adelante, é que seyendo de noche, Ilegarian á unas casas donde les darian de comer: é assi passillou de alli, é llegaron allá é lıallaron qurarenta ó çinquienta ranchos. l' atlí fué donde primero començaron á temer é reverençiar á estos pocos cluripstianos é á tenerlos en muclıo, é allegálanse á ellos é fregálanon é fregálanse á sí mesnos, é deçian por señas á los dhripstianos que los fregassen é frotassen é los curassen: é truxéronles algumos dolientes para que los curassen, é los chripstianos to hacian assi, annque cstaban más acostumbrados á trabaxos que á laeger miraglos. Pero en virtud de Dios confiados, santiguándolos é soplíndolos (de la manera que lo haçen en Castilla aquellos (fue llaman saludadores), é los indios en el momento sentian mcjoria eu sus enfermedades, é díbanles de lo que tenian de conıer, é no olra cosa que eran aquellas hojas de tunas enterradas é algrmas tunas de la mesma manera, anm(que estaban verdes. Ý estovieron allí con aquellos indios quinçe dias por descansar algro, que estillan tan flacos, que no se atrevian á caminar; é coniendo de aquellas lıojas é algunas tunas que començaban á nodurar, se redriçicron é convalusçieron, colrando alguna más fuerça, é tornaron algo más en sí: é los indios lo haçian muy bien, é les daban de lorlo 
quanto teniau de muy buena voluntad, la quil nunea avian liallato latsta estouces en ningunos indios de torlos los que avian visto c trictallo, simo malslad è crucldades, como está dicho.

Dende allí lueron á otros indios dos legnas aldelante, é les dieron muchas cosas porque los curassen, é les luçieron mucha fiesta, é dićronles muy hien de comer tunas é carne, é ylan á caçar solamente para los clupipstianos: é alli se esforçaron alỵo más, é lúrcolo Dios tam bien, que to que no pensaban andar aunque la virla les turara oclio años, seaund los incomodos ó inconvinientes de tan largo camino, lo andurieron en diez uncses: que fué una cosa de muy grand miraglo, é que ninguno lo podia crecr como ello fué sino los que lo viessen. Y cstando alli, vinieron unas mugeres, que Yhan de allá adelante, á llevarles cosas; é desque de allí se parlieron los chripstianos, pessóles mucho á estos indios, é fuéronse trás cllos, rogándoles que se rolviessen, é que otro dia se yrian con aquellas mugeres ques dicho. E como no to quisieron hacer, se tornaron muy tristes: ¿ las mugreres se fueron trás los chripstianos (porque no se perdiessen), é fuéronse por el camino (que ya ellos avian dexado, é ylan perdidos), é pluğo á llos que á calo de dos ó tres leguas se vinieron á juntar á par de un agua ó rio pequeño: y cllas yhan tan mucrtas é causadas, como si cn ello les fucran las vidas. É dende alli se fucron con ellos, é andovieron aquel dia ocho ó nueve leguas grandes, sin déxar de caminar lodo el dia quanto pudieron: é antes quel sol se pusiesse llegaron á un rio, que á su parescer era más anclıo que Guadalquivir en Sevilla, é passáronlo todo á la rodilla é al muslo, é obra de dos lanças en luengo á los pechos, pero sin peligro. Pero prosiguiendo su viage llegaron en anochesçiendo á un puchlo de hasta cimut ranchos ó más de mucha gente, donid: los salieron á rescelbir con mucha grita é voges, é con unos calaharos grandes llenos de pedreguelas, con que cllos hagen sus areytos é músicas. É aunque creian que aquellos cliripstianos tenian virlud mucha para sanar los (nformos, cra mucho el mierlo es turbaçion que traian por llegar á fretar los clripstianos; pero non obslante su temor, no dexaban de allegar con mucho honor é devocion, como quien tocasse un cuerpo sancto. E assi aquellos iuclios, unos antes que otros, é nmelıos por ençima de los otros, se anticipalıan de manera que no se daban lugrar (á vucha de su temor) é con tanta priessa, que les ovieran de sacar los ojos con los dedos; é assi los llevaron á vuela pié hasta sus casas, donde les dieron de lo que tenian, é les truxeron luego dolientes para que los curassen, é dieron á un indio que yba con los chripstianos muchas llechas é cosas, porque los avia llevado é gruiado por allí. É el dia siguiente los llevaron lassta legua y media de allí á otro pucblo de otros septenta ú ochenta ranchos, que comian lunas en mucha alumndançia, é allí los resçibieron de la mesma manera que en el pueblo primero, é les dieron veynte y ocho panes de harina, ques una cosa que allí comen apuella gente, é la llaman mesquite, é les dieron otras cosas, é les liçieron mucha fiesta de bayles è areytos, segund su costumbre.

Alli se començó uma nueva forma de caminar en su viagre: y era que cómo venia muclua gente con estos clrripstianos a los acompañar, é á larerles alli todos los que venian á se fregar é curar con ellos, como sanctos, los (lespojaban (essos que de nuevo venian á los otros) é les tomaban lo que tenian, ć aun yban por las casas é robaban quanto hallaban; é paresçia que los dueños despojados holgaban lello. pensando que aquella mucra sanc- 
tidad era assi ordenada en el riclo, de donte pensaban cllos questos cluipstianos venian. Alli repossaron arguel dia y el sigrniente, é dende alli los llevaron olras seys leguas adelante á otros tantos lauichos: é ybau con ellos muchos hombres é mugeres con intençion de rolar lo que pudiessen, é assi lo hiçieron; por que llegados al pueblo, fueron los chripstianos rescebidos como en los lugares que avian passado, é aun mojor, tanto que les nolestaba la mollitud de la gente que sobrellos cargaba para que los freçassen é samassen las enfermedides (como de hecho los sanaban): é los.indios que con los rhripstianos avian yolo, robaban á los (juc assi sanaban é á los demás, de forma (jue no les dexaban cosa desta vidia; y estos robadores les haçian entender que assi lo qucrian.

En estos indios avia muchos çiegos, é muchos tucrtos de nubes en grand cantidad, y es gente muy lien dispuesta é de buenos gestos los hombres é las mugreres; mas allí curaron toulos los çiegos é tuertos é otras muchas cnfermedades, é á lo menos si los cluripstianos no los sanaban á tedos, los indios creian que los podian sanar. Cerca de allí estaban las sicrras, é se paresçia ma cordillera dellas que atravessaba la ticra derechamente al Nọ̣te; é de alli los llevaron á estos chripstianos otras çinco leguas adelante, hasta un rio que estaha al pié de la punta, donde començaba li dicha sicrra. E alli avia quarenta ó çinquicnta lanchos, á los quales roharon como á los otros, y ellos dicron á los chripstianos esso poco que les avia quedado, é arpuclla noche toda les licieron grandes arcytos é fieslas, é assimesmo los chripstianos los curaron, como lo acostumbraban. É lucogo aquella nocle enviaron a llamar gente ala vo hácia la mar, y el dia signiente vinicron muchos hombres é mugeres á ver estos chripstianos é sus miraglos, é á tracrles cosas que les dieron: é aquestos trabaxaron mucho por los llevar Láçia la mal, poryue allí se pensahan desquitar é salisfiece de lo que les avian á cllos tomado; é deçian que avia mucha grente, é que les darian á los chripstianos muchas cosas. Pero ellos no (puisicron yr sino arrila la ticra adentro, porque estaban escarmentarlos de la gente de la costa, é tambien porque sicmpre les avian dicho que no salian á la mar á la puesta del sol, é lasta alli avian miedo de dar en clla, quando no se calassen: é pior estas causas se querian subir més arrilı, é los indios se lo estorhaban mucho, diciendo que no avia gente ni comida sino muy léxos de allí; é cómo los indios vieron que no los podian mudar de su propóssito, enviaron indios á buscar ggente; é otro dia siguiente se partierón los chripstianos, é fueron con cllos mucha grente, cn que avia muchas mugeres, que les llevaban agua para el camino, que cra filto della é hat. cia muy mand calor, é tambien les lleval)an cosas de comer é otras cosas que les a vian dado: é aviendo andado dos leguas, toparon los indios que avian yelo á buscar gente, ć dixcron cómo no la avian hallado muy léxos de allí, de yue todos quedaron tristes é rogaron mucho á los chripstianos (jue se fuessen con ellos por donde los querian llevar. É cómo no lo pulieron acabar con cllos, se despielieron Ilorando, é se volvieron, dexíndoles allí las cargas: las quales tomaron á cueslas los cluipstianos é se fueron por aquel rio arrilua todo lo restante de aguel dia, liasta la noche que toparon mos indios que los llevaron á ocho ó diez ranchos que estaban metidos en un boscage ó arcalluco: é hallaron los indios llorando de devocion, é los resciljieron cómo se ha dicho yue en ofras partes se avia fecho, é les dieron de comer de lo que tenian. E. ofro dia de mañana vinieron los indios que los avian dexado á los chripstianos 
en su rastro (que tovieron nuevas cómo los otros ques dicho estahan alli) é reníanlos á robar, para se esquitar ó salisfacer de lo que otros avian tomado á ellos, é assi les tomaron fuanto pudieron, aunque todo era poco, é dixéroules á los otros la manera pue con los chripstianos avian de tener. E otro dia los llevaron de alli é duruieron aquella noche en el camino; y el dia siguiente llegaron á muchos ranchos, donde se les liço el rescilimiento acostumbrado, y cllos se esquitaron de lo que les avian tomado, é aun llevaron mucho más, quanto pudicron llevar á cuestas. É desta manera fueron por la halda de la sierra ochenta leguas, poeo más ó menos, entrándose por la tierra adentro derecho al Norte; é allí toparon al pié de la sierra quatro ranchos de otra nascion é lengua, que deçian que cran de más allá la tierra adentro, é que yban de camino para su tierra. Aquestos dicron á los chripslianos un cascabel de laton é çiertas manlas de algodon, é decian que aquello venia de háçia el Norte, atravessando la lierra háçia la mar del Sur: é otro dia se metieron por la sierra háça el Huesle ó Ponicnte, é lleváronlos á unos ranchos eabe un hermoso rio, adonde les dieron mucha margarila é alcohol; é dixéronles aquellos que los que les avian dado el cascabel tenian mucho de aquello é no se lo avian dado. De lo qual se colige que de alonde aquello se traia, puesto que no fuesse oro, avia assiento é fundian (aunque por raçon delia ser en la mar (lel Sur): é quando llegaron adonde les dieron aquel caseabel, arrian andado ciento é cinquicnta leguas, poco más ó menos, dende donde eomencaron á eaminar. É dende estos ranchos adonde esto les dicron, llevaron á los elrripstianos á cinco manadás ó congregaciones de ranchos, que en todo el eamino nunca los dexaron más de dos mill ánimas: é malábanles por el camino muclas lic- bres é venados, é toda firanla carea mataban, se lo lraian é daban, sin que osassen loeal para sí nu solo raton : ć los enusanos é los grrillos fuc las nugerescilosinnos se labliban, se los traian á los cluipstianos é se los diban, sin que osassen lomar para sí cosa alguma, murićndose de lıanlore, sin que los chripstianos no se lo diessen é santiguassen princro, porepue ereian que lnego seavian de morir", si ol'a cosa liciessen. E los chripstianos mindíbanles que no enterrassen la cagir; pero primero, despues que la cacalıan, ponianscla delante toda, é tomaban los chripstianos la que querian della é santigub́luanles la demáts ; é con cslárórlen vinieron todo el eamino lasta salir cn tierra de cluipstianos.

En aquellos lanchos que llegaron eran mucha gente é bien dispuesla; é dićronles allí muelı eantidad de piñones tan buenos é mejores que los de Castilli, porque tienen la cáseara de mancra que la comen con lo demís: las piñas dellos son muy chicpuitas, é los áljoles llenos por aquellas sierras en cantidad. E de allí los llevaron adclante muchos dias, é de aqueste arte eaminaron sin topar ohä gente alguna: é cómo vieron que no la lallaban, enviaron por todas partes á buscarla, é hiçieron venir ranclios de más de quince ó veynte leguas á esperarlos al camino; é assi los llevaron. É dende alli se tomó ofra nueva órden de caminar, é fué que cómo los que llevaban á eslos elripstianos robaban quanto avia é laallaban en los ranchos, dende nuevamente cutraban, ya no tomaban nada, sino como earla uno de los ehripstianos hacian su buhio por sí, é allí lo lenian puesto en órden é allegado lodo lo que lenian, para que los chripstianos hiciessen dello su voluntad; é ninguno osaba tomar dello cosa alguna de arjuellas. É los chripstianos lo tomaban todo, ó lo que les parescia dello; é dexaban despojados á los huéspedes, 
para que toviessen nescessidad de llevarlos adclante para se esquitar de la mesma forma. Eaquestos los llevaron adelante por unas sicras desesperadas más de otras çinquenta legrrus, con mucha hambre por el mal aparejo de la tierra, que no avia tunas ni otra cosa ; é quassi al cabo de la jornada les començaron á adolesçer, é tenian muy grand trabaxo con ellos en los santiguar é soplarlos, porque quassi no quedó nadie que no adolesçiesse: é assi los llevaron á más de cient ranchos que ostahan en un llano esperándolos, que los avian de léxos hecho venir allí, é avia uuclıa gente por todo aquello. E todos aruellos, los unos é los otros, les dieron piñones en cantidad, é los resçibicron de la mesma manera que los passados, é dálanles quanto tenian, sin les quedar cosa desta vida para sí. É otro dia los llevaron adelante é algumas cosas que les avian quedado y eran vicjas, las dexaban por aquel campo, que no podian acabar con cllos que las llevassen, é las petacas de que liaçian sus caxas, tambien las dexaban. É aquestos les dixeron que no avia gente sino nuty léxos de alli, é yue aquellos eran sus enemigos : é los chripstianos les dixeron que enviassen algun indio que les dixessen cómo yban (porque assi lo acostumbrilsan en todo el camino, quando yban á algrunos ranclios nuevos, que primero yluan quatro indios, uno $\mathrm{cu}$ nombre de cada uno destos chripstianos, para que les aderesçassen casas, é que $l_{0}$ que les avian de dar estoviesse junto é á punto). É assi estos indios acordaron de enviar dos mugeres, ma que tenian captiva de aquellos de donde venian, é otra que fué con clla: que hombre no lo osaron enviar por la guerra que lenian, é tambien porque no se entendian. E assi se fueron los chripstianos con todil la gente trás aquellas dos mugreres, nudándose cada dia, á esperar la respuesta que traerian en çierta parte: é assi cómo co- mençaron á caminar, la gente començó á adolescer, en tanta mancra (jue los chripstianos avian muclia lástima dellos, porque aquesta cra la mejor gente que avian topado. E avian concertado que esperassen las mugeres é la respuesta que traerian; é assi pararon tres dias, que no quisicron llevar á los chripstianos por otra parte por la guerra que tenian. Estonges Andrés Dorantes dixo á un indio suyo que les dixesse que por aquello que querian haçer se avian de morir; é fué tanto el espanto que tomaron, y el miedo que se les acresçentó sobrel que se tenian ellos, que otro dia de mañana fueron á caça, é á medio dia vinieron malos, é cada dia caian más, y en dos dias sc murieron muchos é adolesçieron más de tresçientas personas. É colsraron "tanto temor, creyendo que los chripstianos lo causaban de cnojados, que no los osaban mirar a la cara ni alçar los ojos del suclo, estando delante dellos. É fuć cosa maravillosa de ver que en quinçe dias no más que entre aquellos indios estovieron, nunca vieron á ningruno dellos reyr ni llorar ni laçer otra mudanca, aunque á algunos se les morian los padres, é á algunos sus mugeres é sus hijos, é á otras sus maridos; é assi lo disimulaban é comportaban con igual semblante como si ningun pessar por ellos passara. Cosa más maravillosa: que á los niños de tela ni á los muchachos de más edad numea los vieron llorar ni reyr en todo el tiempo questos chripstianos estovieron con ellos, como si fucran vicjos de cient años. Esta gente no osaha comer ni beher ni haçer cosa desta vida, sin pedir liçencia át los chripstianos, pensando que teniau poder para matarlos ó darles la vida, é que por esso se morian, porcpue los chripstianos estaban enojados. F́ á calo de dos ó tres dias que alli estovieron, vinieron las mugeres é truxcron muy ruynes nuevas, diçiendo que la gente que avian yolo á buscar erau 
ydos á las racas, é que por lodo arpucllo no alvial gente. Visto asto, los imlios dixerou quellos estahan malos todos, cómo los chripstiauos lo vian, á que cram de muy léxos; é que los clupipstianos se fuessen á las vacás, que era arrilua loúçia el Norte, é que lallarian gente; é quellos se querian quedar é yrse í otra parte, porque tenian muy grand hambre: que las tunas eran acabadas. E los chripstianos les disieron que no, si no que por alli los aviau de llevar, que era láçia el Hueste ó Poniente, porque aquel era su derecho camino; é que los dolientes se quedassen, é veynte ó treyula dellos que estaban buenos fuessen con ellos, é que uno de los chripstianos yria con aquellas indias á luscar la gente é traclla al cani110: é parescrió que los indios se avian holgato de oyr esto.

Otro dia siguiente partieron de alli, é caminaron tres dias uno en pós de otro, é Lambien pantió Alonso dal Castillo, que se lálló mís dispuesto, é fué con el negro é las indias: las quales lo llevaron á un rio, domde liallimon groute é casals é assicnto, é algrmos fésoles é calal agras que comian, aunque muy poco. I calıo de los tres dias rolvió Castillo á los clnipestianos, y el negro se quedó para traer la gente al camino.

Mas porque de susso se hico mencion de vaeas, no enticnda el letor fue son de las nnertras, sino de aquellas que los españoles llaman vacas en algumas partes de la Tierra-Firme é algunos impropriamente las diçen dantas, porque los cucros dellas son tanto ó más reçios quel de los húfinos. Los indios en la provincial de Cuevir. en la grohernaçion de Castilla del Oro, Iliman á tal animal heori, como se dixo en la primera parte destas historias, en el libro XII é capítulo XI.

\section{CAPITULO VI.}

En el qual se da fin á la relaẹion deslos hidalgos Alvar Nuñez Cabeça de Vacit, Andrós Dorantes o Alonso Iel Castillo; a se euenta el discurso de su peregrinaęion é trabaxoso canino, é olras cosas que por ellos passaron hasta llegar á un pueblo de ehripstianos en la gobernacion de la Nueva Galiẹa.

O tro dia siguiente, despues que Alonso del Castillo tornó adonde le atendian sus compañeros el tluessorero ilvar Nuñez Cabega de V́aca é Andrés Dorantes, se particron é fueron á toparse con la gente quel negro traia; é alli les dieron quanto traian, que eran algumas mantas de cueros de vacas ó dautas (de las que se diso de susso) é cueros de venados, é sus arcos é llechas, é muchos calabacos é algunos fésoles : é todo lo dicron los chripstianos á aquellos indios que los avian traido lıasta alli, é se volvieron contentos: é con estotros, aunque los despojaron, se partirron, é continuaron sn camino liasta sus casas, que estaban çiu- co ó seys leguas de alli en aquel rio, donde sembraban; pero por la mucha gente (fue avia, é la poca lierra é muy ápera, cra poco lo yue cogian; é por aquel rio arriba los llevaron á́ quatro manarlas de pucblos que avia. Tenian poco de comer, y csso cran fésoles é calalıaģas é poquito malliz, é no tenian cllos en qué guisarlo; pero hacianlo macamorras ( pue son como puches ó polcadas) en unos calabacos graudes, de afjucsta manera. Ilaçian fuegro y echalıan en él muchas piedras guijenias é limpias á calintar, y echaban agua en cl calabaco é al!í echaban las piedras, é cómo venian ardiendo, harcian lıcevir el ayua. é allí celtalan la harina de 
los fésoles, y echahan más piedras cnçima, hasla que eslaba buena la maçamorra, é assi la comian.

Allí les dixeron que adclante no avia más harina ui fésoles, ni cosa cle comer, hasta treynta ó quarenta jornadas más adclante, que cra yendo de la parte donde se pone el sol hasta el Norte, de donde aquellos indios avian avido ó traido aquella simiente; é que todos los indios que hasta allí avia, tcnian mucha lambre, ć que avian de yr por aquel rio arriba lá́cia cl Norte otras nueve ó dicz jornadas, sin cosa de comer, hasla atravessar el rio que de allí avian de atravessar, todo lo demás avian de yr al Iluesle ó Poniente hasta donde avia mahiz, é mucho, é que tambien lo avia háçia la mano derccha al Norte, é más abaxo por toda aquella tierra debia ser á la cosliı, segund despues paresçió; pero que cra muy más léxos, é que estotro era lo más çcrcano, ć que elan todos amigos lasta allá é de una lengua. Estos indios daban ya mucha canlidad de mantas de vacas, é deçian quellos las malaban en verano çerea de alli, é que avia muchas. É assi fucron por este rio arriba las nucve jornadas, cada dia caminando hasla la noche, con grandissima hambre: é siempre á la noche dormian en casas é con gente que les daban muchas manlas de vacas é otras cosas, que lrocaran cllos de buena gana por roscas de Uirera, porque no les daban de comer, ó no to tenian, sino una cosa que aquellos indios llaman masarrones, que cogian de unos árboles, que cran muy mala cosa, é aun no para bestias, $\sin 0$ para aquellas que lo muelen con unas piedras: en fin es lodo palillos, é assi se come. Comian los chripstianos algunos pedaçillos de grorduras de venados que traian á cuestas; é laaliaban en el camino poca gente, é deçianles rue eran ydos á comer las vacas, tres jormadas de alli on mos llanos entre las sierras que deTol10 III. çian venian de arriba háçia la mar, o quellos se ylan tambicn allá. É assi andovicron por aquel rio arriba quinçe jornadas, sin descansar, por la inuclıa liambre que avia: é dende allí atravessaron al Hucsle ó Poniente, é fucron más de otras veynte hasta el maliz por gente algro hambrienta, pero no tanto, porque comian unos polvos de hierbas, é malaban mucha caça de liebre, que sicmpre los chripstianos la llevaloan solırada. En este camino descansaban alģunas veçes, como lo solian laçer; é llegados á las primcras casas, donde avia mahiz, que scria más de dosçienlas leguas de Culuacan (donde estaba poblando Nuño de Guz. man, é avia una villa, é los indios de paz) alli les dieron mucla cantidad de mahiz é harina loslada é fésoles é calabaças é otras semillas, ć de las otras cosas que les solian dar. É tenian estos indios algunas casas pequeñas de tierra, fochas de lapias con sus terrados, las más de petacas (petaca, quiere deçir sesla): assi que scrian como emplentas, 6 cosil texida de hojas de palmas ó bexucos, ú otra trabaçon semejante.

Desta manera fueron más de ochenta leguas, é de ires á tres dias é de dos á dos dias Ilegaban á pucblos, é descansaban un dia ó dos en calla pucblo. É dende alli les començaron á dar muchas mantas de algodon, é bucnas, é lodo lo que tonian, que ninguna cosa les quedaba, é alyumas turyucsas assimesmo: lo qual todo, assi como se lo daban á los chrijslianos, lo tornaban á dar cllos. E avia tantos dolientes que los afligian é cansaban con las curas dellos, porque eran mucha gente é á lodes los avian de fregar é saludar; y el que no quedaba saludado, pensaba que se avia de morir: é venian de dicz é doce leguas á la redonla á les tracr cnfermos, é venian con cllos (digo con los clripstianos do quice que ylan) nuill ó mill é quinicntas perso- 
nas, é algunas veges passaban de tres mill, hasta que salierou á lo llino, cerea 1. la costa; é (fuando allí llegaron, avia acho meses que no salian do las sierras.

A todas aquellas gentes amonestiban é imponian estos cluripstianos en que 10riessen inclinaçion al çiclo, é que ì él alÇassen los ojos; é puestas las manos juntas, hincíndlose de rodillas, yuando toviessen alğma nesçessidad, se encomendassen á Dios Todoporleroso. I assi ellos lo haçian, é creian questos chripstianos venian del çiclo, é holgaban muclıo quando les contaban algunas cosas de allá; pero no se lo sabian dar á entender como quisicran, por falta de lengua, porque si esta tovicran, scgund la fée é afiçion con que escuchaban é seguian á los cluripstianos, é segund las pocas yrronias é ydolatrias que afuellas gentes tenian, decian estos cluripstianos que escaparon, que sin dubda creian que fueran huenos chripstianos.

Esta gente les tenia tanto amor, que quando se parlieron yban llorando é los que los llevaban adelante; é algunas mugeres que estaban preñadas é otras reçien paridas renian con los niños en lıraços á se despedir de los chripstianos, dando á los niños tres ó quatro granos de mahiz en las manos, porque los tomassen los chripstianos é les diessen liçençia, paresciéndoles que si aquellos tomaban de los niños que nunca avian de adolescer ni estar malos. P'ues passadas las sicrras ques dicho, ilegaron estos quatro chripstianos lque son los tres españoles ques dicho y el neggro, que era chripstiano, llamado Estéban a tres puchlos que estaban juntos é pequeños, en que avia hasta veynte casas en ellos, las quales eran como las passadas é junlas (que no estaba aqui una é otra acullá, como en la ticra de paz que despues vicron). E alli vino gente de la costa á los chripstianos, que scrian de dogé quinçe leguas de allí, seg̣und por señas lo daluan á entender; é á este puehlo, ómejor diçiendo pueblos juntos, nombraron los cluipstianos la lilla de los Corarones, porepue les dieron allí más de seyscrientos coraģones le venados escalados é secos. Toda esta gente, dende las primeras casas del mahiz, andan los hombres muy deshonestos, sin se colbrir cosa alguna de sus personas; é las mugeres muy lıonestas, con unas sayás de cueros de renados las ta los piés, é con falda que detrás les arrastra alouna cosa, é abiertas por delante liasta el suelo y enlaçadas con unas correas. lit tracn debaxo, por donde están abiertas, una mantilla de algoolon é otra encima, é unas gorogucras de alggodon, que les cubren todos los pechos.

Decíanles aquellos indios yue por tola aquella costa del Sur hácia el Norte ('jue mejor se puede é debe llamar, no (lel Sur sino septentrional) avia mucha sente é mucha comicla é mucho algodon, é las casas grandes; é que tenian muchas piedras turquesas, quellos las traian de allá por rescate, é no les supieron dar racon de oro alguno ni tovicron nucra de minas. E assi creyeron estos chripstianos, por lo que alli les dixeron, é por lo que antes que entrassen en las sierras vicron, que aquel cascabel é mantas que les dieron de algodon (como lo la contado la listoria) venian de arriba de la otra mar b costa ques dicho, é assi les dixeron que está polilada de mucha gente é comida. É tambien les paresció que aquellos terradillos é andar las mugeres en hábito tan lionesto, lo aprendian é tomaban deIla; porque dende allí luácia acá adelantc, bien trescientas leguas, hasta $\mathrm{mm}$ rio que desculbrió Nuño de Guzman, avia aquel trage é casas, é de allí para acá adclante no, sino las casas de petacas é de paja, é las mugeres con unas mantillas lrasta el medio, é algunas más honestas hasta la rodilla. Despues de aqueste 
pueblo fueron treyna leguas liasta este rio ya dicho, haciéndoseles los resçibimientos que se han dicho é acompañando á los chripstianos: é allí les llovió quinçe dias é les fué forçado parar, y cra por navidad; é tovieron allí siempre mucha gente consigo, que nunea los dexaban, annque eran de bien léxos.

Allí vido Castillo á un indio una hevilleta de çinto ó talavarte é un clavo de herrar colgado del pescueço como por joyel, é tomósele; é preguntáronle los chripstianos que qué cosas eran arquellas, é respondió que otros hombres, como aquellos chripstianos, avian liegado alli con caluallos é lanças y espadas; é señalaban cómo los alançeaban ć los mataban á los indios. É cierto ellos los tovieron por chripstianos, porque antes que allí llegassen estos tres españoles é el negro, les avian enseñado cómo eslaba alli un indio que avia venido de allá de háçia los de las barcas é los avia de lievar á ellos, é deçíanlo muchás reces. É cómo no los cntendian, estaban espantados, é segund despues paresçió, por to que en Culuacan les dixeron despues los españoles, aquel indio era de dos ó tres que los de Nuno de Guzman avian dexado, quando alli llegaron, enfermos é cansados.

Dende allí començaron á caminar con muy grand desseo é alegria de la nueva yue tenian estos pocos chripstianos de los españoles de adelante, é los indios nunca otra cosa haçian sino hablarles en cllo, como en cosa con que les lascian plaçer, tanto que aunque to querian disimular no podian, é lemian que á la frontera de los chripstianos les avian de hager alguna burla. É dende donde les llovió hasta los chripstianos avia çient leguas ó más; i dende el pueblo de Coracones liasta ali siempre fueron costcando, diezú doçe leguas metidos en tierra: y en aquellas cicnt leguas en algunas partes avia de comer y en otras mucha hambre, que no comian sino cortecas de árboles é otras rayces, é malas venturas, á causa de to qual estaban tan flacos é sarnosos que era láslima verlos. Écausábalo que deçian que avian entrarlo por allí los chripstianos tres veges, é les avian llerado la gente é destruydo los puelsos; y estaban tan temoriçalos é medrosos que no osaban parescer en ninguna parte, sino arjui uno é acullá ofro, como gente arentada por los montes debaxo de una esterilla, sin reposo ni osar sembrar. Mas con todo su temor, todos se juntaban para rescebir eslos pocos clnipstianos, porque los icnian por cosa sancta é divina, ó por lıombres venidos del cielo, por los llevar adelante. É atun essa esterilla que tenian (é acostumbra cada uno tener arrollada sobre sus liombros ó só el sobaco, porque es su cama solsre que duermen) la traian para se la dill; é fué assi, que donde pensaluan resçelir más daño, allí los tenian en más é resçebian más lıonra: ques més de maravillar. É assi fueron hasta un puclslo que estaba en una sierra, encima de un risco muy alto é fragoso, por miedo de los chripstianos; y está este pueblo quarenta leguas de Culuacan, donde estaban los españoles; é allí los resçibieron con muclio plaçer, é se juntó muclıa gente de muchas partes que los yloan á ver. É otro dia luego siguiente enviaron sus mensajeros adelante á otros pueblos que estahan tres dias de camino de allí, para que les liçiessen las casas ó ranchos é se junlassen para los resçebir; ć quando fueron, no hallaron los españoles allí, que andaban liaciendo esclavos, y estovicron una noche sobrellos mirándolos; é otro dia huscaron gente por aquellos montes al redelor, é cómo no la hallaron, que avian ydo muy léxos, se fornaron é les diseron lo que avian visto, tan turbados que quassi no podian hablar. F́ toda ba gente assimesmo se furlió é ovieron muy grand miedo, é muchos se despidicron é se tor- 
naron; ć á los que quedaron dixéronles estos clripstianos afortunados que no oviessen temor, quellos harian á los cluripslianos, de quien temian, que se tornassen á su assiento é no les liçiessen mal, é que fuessen sus amigos: lo qual holgaron de oýr, é respondicron que assi lo hiçiessen, porque no osahan sembrar ni estar en sus casas por amor dellos, é que se morian de lambre. É assi asegurados, se fueron con los tres chripstianos, é entrellos venian indios de más de ochenta leguas atrás, que deçian que nunca los avian de lexar. E assi prosiguieron su camino, é quando llegaron al pueblo, no hallaron los cluripstianos; pero hallaron sus ranchos, é avia dos dias que avian ydo de allí, é determinaron de yr trás cllos y cuvíronles á deçir que los esperassen ó quellos volviessen á estos otros. Y el Cabeça de Vaca tomó el trabaro de yr trís ellos, é llevó consigo al negrro é á una doçena de indios : é los que quedaban, que eran los otros dos chripslianos, enviaron á buscar la gente que estaba huyda por los montesé arcabucosó boscages; é otro dia siguiente vinieron más de tresçientas ánimas hombresé mugeres, é dixeron que otro dia vendrian más, que estaban huydos más léxos: é assi sacaron mís que estaban apartados é se juntaron más de quatroçientas personas de aquellos auscntados, sin los otros indios que con los chripstianos se venian.

El thessorero Cabega de Vaca anduvo todo aquel dia hasta la noche en rastro de los chripstianos, y el siguiente dia allegó á dó estaban alojados é assentados en salto cerca de un rio, sin saber adónde avian de yr, porque avia quince dias que no haçian un esclavo ni porlian ver un indio. E llegado donde los cluripstianos estaban, que serian laasta reynte de caballo, quedaron admirados y espantados de ver al Caloça de Vaca, é mucho más de oyrle, é arer passado por tantas tierras é direrssas grentes é lenguas; é dieron muclıas graçias á Dios, Nuestro Señor, por tan nuevo é grandíssimo misterio. É assi estos otros les piclieron por testimonio de la manera que venian é traian aquella gente de paz é de buena voluntad que los seguian; y ellos se lo dieron por fée é testimonio, el qual se envió á Sus Magestades, dando loores á Jhesu Clurips10. Nuestro Redemptor, que fué servido de guardar estos pocos chripstianos de tan innumerables trabaxos, para que viniessen á dar cuenta al Emperador Rer, nuestro señor, del subçesso de aquella desdichada armada, é de la calidad de la ticra questos vieron. Y estovieron allí un dia con ellos.

É porque essa gente de españoles avia çiertos dias que no podian aver un indio ni persona, é tenian neşessidad de bastimento para los caballos, rogaron á estotros peregrinos que enviassen á llamar gente de la que estaba por los montes escondida de temor. É hiçiéronles sus mensajeros, como lo acostumbraban haçer por todo el camino, é luego vinicron al otro dia lıasta seyş̧ientas ánimas hombres é mugeres, é algunas con sus niños en los braços de teta, é con ollas de malıiz embarradas las bocas, que de temor de los chripstianos las tenian escondidas por los montes.

¿Parésçeos, letor chripstiano, ques contemplativo este passo y exerçiçio diferente de los españoles que estaban en aquella ticrra, é de los quatro peregrinos, que los unos andalsan haçiendo esclavos é á saltear, como de susso es dicho, é los otros venian sanando enfermos é haciendo miraglos?.. De que podeys colegir quánta parte destos trabaxos consiste en la buena ó mala intençion é obras de los mesmos chripstianos, é por el número de los muertos é de los vivos podeys congecturar to que os paresçicre. Pues no los tengays á todos los que por ací andan 
é han andado por españoles, aunque la mayor parte dellos lo son, sino de direrssas nasçiones, que llamándlose chripstianos, acú lan passado en lusca deste o.'o, é algुumos lo hallan por su mal, é otros nunca lo topan, sino la muerte é angustias tales como las que podeys aver entendido de aquesta leçion.

Tornemos á la historia é relaçion destos hidalgos, que diģe que despues de recogida aquella gente que andaba alçada, por mandado de aquellos pocos cliripstianos, dixeron á estos peregrinos acpel que yba por capilan de los españoles que toparon, que los hahlasse é dixesse que hiçiessen sus assientos en sus pucblos é liçiessen sus sementeras como solian, é que los clıripstianos no les lırian mal ni enojo alg̣uno, ni querian sino que quando los chripstianos passassen pol sus casas, les diessen de comer á ellos é á sus caballos. Y esto se les dió á entender, é les dieron liçençia que se fuessen seguros á sus pueblos: los quales no se querian yr ni apartar de los chripstianos, diciendo que no los avian servido bien ni acompañado, como se debiera de haçer. En fin, Cabeça de Vaca é sus compañeros les dixeron que se fuessen en buen hora, porque cllos yban donde estaba el señor de los chripstianos, é quellos le hablarian para que mandasse que no los persiguiessen ni enojassen. É assi se fueron los indios en paz, é aquestos chripstianos se fucron con tres de caballo que los acompañaron hasta la villa de Culuacan, que fué poblada en la costa de la nar del Sur, al Poniente, por Nuño de Guzman, que seria bien treynta y çinco leguas ó nús de allí. Y el caudillo ó capitan de la gente de aquellos españoles se fueron hácia las sierras á lacer esclavos.

Llegados pues estos chripstianos, oclıo leguas antes de la villa, á un valle pohlado de paz, salió á cllos el alcalde mayor de la villa, llamado Melchior Diaz, é los resçibió mny lien, é dando graças á Dios por las maravillas que con estos hidalgos avia obrado. É porque tenian çer. ca de allí muchos pueblos levantados é la gente dellos no se avia ydo á la sierra, enviaron dos ó tres indios de los que po. co avia que avian hecho esclavos, é con una seña que les dieron estos peregrinos chripstianos enviaron á llamar todos los indios que estaban alçados, é mandáronles deçir que viniessen seguros é que ningun mal les seria fecho. E los mensajeros fucron con aquella seña, que era un calabaco que solian traer cada uno en las manos, é tardaron allí çinco ó seys dias, é á cabo dessos vinieron é truxeron tres señores ó caçiques prinçipales é quince 0 diez y seys indios otros de los levantados: los quales truxeron á ofrescer quientas é turquesas é muy lindos plumajes á los tres chripstianos peregrinos delante del dicho Nelchior Diaz, alcalde mayor. El qual les hiço hablar, dándoles á entender cómo estos chripstianos veniau del çielo, é habian andado por muchas partes, diciéndoles que toviessen inclinaçion al çielo, é que allá está el scĩor de todo lo criado, é que á los buenos daba gloria, quando él queria que muriessen en aquesta vida, é á los que no le querian bien é no le creian é servian, como á su solo Dios Todopoderoso, les daba pena de fuego para siempre janrás. É que aquellos pocos chripstianos avian allí venido, para deçir á los otros que no hiçiessen mal ni enojassen ni matassen á los indios, con tanto que se assentassen en sus puelılos é creyessen en Dios, é hiçiessen iglesias donde él fuesse servido, é pusiessen cruçes en los pucblos é las truxessen consigo: é que quando algunos chripstianos fuessen por su tierra; que los saliessen á resçebir con una cruz, á la qual todos se humillarian, é desta manera no los harian mal é los ternian por hermanos; y ellos to entendieron muy bien, é dixeron que 
assi lo larian, é se fueron. E luego començaron á baxal de las sierras á poblar, é liçicron igglesias, é pusieron sus eruçes, como les fué mandaulo. É assi fué por todo arfuello que estabia poblado de paz por nucstros chripstianos.

Plega ál Nuestro Redemplor questas srentes salvages, en rida é rentura de la Cessílrea Catlólica Magestad, vengan en conosçimiento é serviçio de Dios, y ell obidiencia de la corona real de Castilla, como buenos é fieles rassallos de Su Magestad, á quien estos tres hidalgos ya dichos, Álvar Nuñez Cabegáa de Taca, é InArés Dorantes é Alonso del Castillo, hiaciendo relaçion de lo que la historia ha dicho, to escribieron, sertificando que por loda la ticra, donde andovicron, no vicron ydolatria, ni sacrificar hombres, ni saber qué cosa es, hasla que llegaron á la cibdad de Compostela, que edeficó é pobló en aquellas partes el gobernador Nuño de Guzman.

Esta relaçion sacó el chronista de la carla, questos lidalgos enriaron á la Real Audiençia, que reside en esta cibdad de Sancto Domingo desta Isla Espaĩola, dende el puerto de la Habana, donde tocaron el año passado de mill é quinientos é treynta y nucro años, yendo de camino para Castilla á dar relaçion de lo ques diclıo al Emperador Rey, nuestro scñor, é á su Real Conscjo de ludias.

É assi que, cste fuć el subçesso del capitan Pampluilo de Narvacz é de su armala, al qual é los demás haya Dios perdonado por su infinita misericordia, tomando en descuento de sus culpas sus trabaxos é muertes tan desapiadadas. É assi se debe creer que la bondad divina remedió sus ámimas, pues que cran chripstianos, é su desseo seria el que era ragon que toviessen de ampliar la república cluripstiana é servir á su Prínçipe, é remediar su pobreça ó nesçessidad cada uno en su calidad honesta, ó justamente para que meresciessen en la úllima hora de su vida aquel sospiro que el profeta Ezechiel diçe: "En qualqquiera hora quel pecador sospirare é llamare, será perdonado ${ }^{4}$. \

Lo que subcedicre en estas provinçias donde fué Pampliilo de Narvaez á polslar, ó mejor diçiendo á perderse, si en mi liempo fuere, acomularse há en prosecuçion de la historia, ó escribirlo há quien me sulsgedicre en la continuaçion desta General historia destas Indias.

\section{CAPITULO VII.}

En quel auctor destas historias cuenta algunas cosas que en la relacion sussodicha no cuentan, las qualcs despues en España, año de mill é quinientos é quarenta y siete años, en la cúrte del Prínęipe don Felipe, nuestro señor, cn Madrid, te contó é dixo el mesmo Alvar Kuñez Cabcęa de Vaca : Las quales cosas son del mesno jaez é propria historia é licra, donde se perdiú el dicho Pamplito de Narvaez é su gente.

To odo esto ques dicho en esla relaçion lo aria fecho imprimir este carallero é anda de molde, é yo le rogué que me lo mostrasse ; é despues de arerme intormalo dél, é ser personal que delo dársole crédito, assi por su expiriençia como

1 Quia nolo mortem morientis, dicit Dominus beus: reverhinini el vivite. (Ezech., cap. XVII, porque todo se tiene pol çicrto, diré lo que en este capítulo hiciere al caso lorevemente, pues que no se debe preterir ni olvidar, á ruelta de lantos trabaxos, lo que adelante podria en parte aprovechar, é al pressente salisfacer á la histo- 
ria. Pero en alguna manera yo tengo por buena la relacion de los tres é por más clara que estotra quel uno solo haçe é hiro imprimir, puesto que, como digo, yo tomo della é del mesmo auctor Calıeça de Vaca lo que en este capítulo él añade, é ques bien dicho é nesçessario, non embargante que, como gente tan trabaxarla, no relatan ni aum tenian forma de alcancar á saber en qué grados ni altura andovieron perdidos, viendo lo que hasta aqui es dicho: de lo qual no me maravillo, pues quel mesmo piloto que los llevó, Ilamado Viruclo, no los supo gruiar al puerto questa armada fué á buscar é no supo decir adónde los puso ni dónde estaban; é como el principio fué errado, tampoco se arcertó el medio, y el fin le hiçieron tal como es dicho. Ni quiero consentir al Cabeca de Vaca el nombre que en su impression dá á aquella isla, que llama de Mal Hado, pues en la primera relaçion no le pusieron nombre, ni ćl se le puede dar: antes en aquella isla fueron bien tractados los chripstianos, como él mesmo lo confiessa en la una é otra relaçion; é si la mar ó fortuna les quitaron las dos barcas, no ovieron mejor dicha las restantes ni tal donde aportaron.

Diçen ambas relaçiones que los frayles avian hecho quemar los cuerpos que hallaron muertos metidos en las caxas de Castilla, diçiendo que eran ydólatras; é fuera mejor haçer que se enterrassen, pues las mesmas caxas ó otros indiçios les daba ocasion que se pensasse que eran chripstianos; ́c assi se diçe en la segunda relacion que de indios supicron despues que aquellos defunctos eran cliripstianos.

Diçe más Cabeça de Vaca: que á los diez y sicte de junio de mill é quinientos é veynte y siete años partió el gobernador Pamplito de Narvaez con su armada del puerto de Sanct Lúcar de Barrameda para yre á polslar en la costa del Norte de la Tierra-Firme, á las provinçias questán dende el rio de las Palmas liasta el cabo de la Florida, con cinco navios, en que yluan seysçientos honbres, pocos más ó menos, en la qual armada yloan por officiales de Su Magestad estos: Illvar Nunez Cabeça de Taca por thessorero é alguaçil mayor, Alonso Enriquez por contador, Alonso de Solís por factor é vecrlor, fray Johan Guticrez, de la Orden de Sanct Françisco, por comisario, con otros quatro frayles de la mesma Orden. Y en quarenta y çinco dias llegaron á la Isla Española, donde se proveyeron de caballos ć otras cosas, é aun se les quedaron luasta çiento é quarenta personas; y essos fueron los inejor librados, porque en un Iıuracan ó tormenta que los tomó adelante en la isla de Cuba en el puerto de la villa de la Trinidad, se les perdieron dos navios con hasta sessenta hombres é rejnte caluallos. $\dot{\mathbf{E}}$ invernaron los que quedaron en aquella isla, é á los quatro de Noviemlıre del mesmo año llegó allí el gohernador con los quatro navios, con que avia ydo á Sanctiago, ques el prinçipal preblo de aquella isla; é mandó que se fuessen todos doçe leguas de alli al puerto de la Xagua, dende el qual despues, con los quatro navios é un bergantin, se partió con quatroçientos lombres é ochenta caballos, de los (quales los treynta y ocho perdieron en su camino ; é desembarcaron en Tierra-Firme quarenta y dos bien flacos é fatigados.

Diçe más Cabeça de Vaca: que en çierto rio se ahogó Jolıan Velazquez de Cuéllar é su caballo, el qual caballo lo comieron los españoles, porque les faltaban otros manjares.

Diçe más en esta su relaçion impressa, quando habla en la provinçia de $A$ palaclıe é sus confines: que lıallaron grandes árboles é montes, nogales, laureles é árboles de liquidámbar, sedros, sabinas, 
ençinas, pinos, robles, palmitos baxos, como los del Andaluçia, malicgales, casas desparçidas, como en los Xelves, venados, é un animal que trac los hijos en la bolsa; é destos más lie visto yo, y en la primera parte destas historias, en el libro Xll, capítulo XXYll, se diçe qué animales son estos, queste cavallero quiere deçir son los que en la lengua de Cueva se llaman churchas. Dice assimesmo que hay muchas ares assi como ánsares, ánades, patos reales, dorales, garcotas, perdiçes, palomas, alcones, ncblies, gavilanes, esmerejones, papagayos de diverssas maneras. Es la gente bien dispuesta é fleclıeros en las más partes. Nombra çinco chripstianos, que de lambre se comieron unos á otros, é llamábanse Sierra, Diego Lopez, Corral, Palaçios, Gonçalo Ruiz.

Diçe Cabega de Vaca que çierta gente, por donde andorieron de hombres bien dispuestos, traen la una teta horadada de una parte á otra, é algomos ambas, é por el agugero atraressada una caña tan gruessa como dos dedos é tan luenga como dos palmos y medio: é assimesno traen louradado el labio de la boca inferior, é por el agugero puesta en él una caña delgada.

Diçe que entierran los hombres que se mueren, é á los que dellos son médicos los queman por los lionrar, y en tanto que arden baylan los otros indios, e toman los huessos quemados ć lá́çenlos polvos, é por fiesta los beben los parientes de los tales físicos. Essos son de mucha auctoridad é pueden tener dos 6 tres mugeres, é los otros liombres sendas los que se casan. Todo apucl año la caça que matan é pescado, lo dam á la muger sin osar comer ni faltar cosa alguna, é la muger lo dá todo ello á sus padres: en el qual tiempo de aquel año ni los suegros entran cu casa dol yerno ni el yerno en casa de los suegros, ni tan- poco los cuñados, ni se lablan; é si acaso se topan, se desvian un tiro de ballesta uno de otro, las cabecas baxas mirando en ticra, y clla (digo la reçien casada) pucde ver é hablar á todos. Quando se muere alguno, en tres meses siguientes no buscan de comer, aunque mueran de lamIre: é sus casas son de esteras é solyre conclas de ostiones. Curan los médicos á soplos, é sajan al paçiente en cl lugar do siente el dolor, é cluppan alredudor, é tambien le dan cauterios de fuego, é á los unos é otros soplan, porque assi dicen que cchan el mal fuera; y en pago de su trabaxo, dan al médico quanto tienen.

En la isla, que Cabeça de Vaca llama de Mal Hado, diçe que hay dos linages, los unos se diçen capoques, y cl otro han é tienen por costumbre, quando se ven antes que se hablen, estar media lıora llorando; é despues el ques visitado, se le. vanta primero ć dá al otro quanto tiene, y el otro lo resçilue é dende á poco se vá con ello, é á reces sin le lıablar.

Y en otra parte diçe en su segunda relaçion quel gobernador, donde aportó despues en su barea revocó el poder que avia dado á su teniente Pantoja, el qual á los pocos que quedaban los tractalıa mal; é que se revolvió con él otro liidalgo llamado Sotomayor, é con un palo lo mató; é que los que se morian, los comian los que quedahan vivos, fechos tasajos; é quel postrero de aquellos que murieron fue el Sotomayor, al qual hico tasajos un Esquivel, con los quales se sostuvo algunos dias, é que despues á este lo malaron indlios. El qual Esquivel es el que dixo cómo el gobernador le avia llevado la mar en su barca con un pag̣e é otro lınlre, é lo contó á un Figucroa. É la muerte del Esquivel fuć por un sueño de una india, porque alli creen en sus sueños, éa reces matan á sus proprios hiijos por sus sneños. é a las hijas liagen comer á perros muchos dellos, assi como nascrno 
porque diçen que no las luan de casar con parientes ni darlas á sus enemigos para que multipliquen: é las que toman por mugeres eómpranlas, é dan por ellas un arco é dos flechas é una red de lıasta una braçada luenga é otro tanto ancla.

Comen arañas, hueros de hormigas, gusanos é lagartijas, culebras, víboras, e comen tierra é madera y estiércol de venado, é todo lo que pueden aver. Son grandes ladrones é mienten muclio. Corren dende la mañana lasta la noche $\sin$ descansar, é assi cansan los ganados é los toman vivos. Ilay sodomitas entrellos, é algunos tan abominables que tienen ot ro hombre por muger públicamente; é los tales paçientes afeminados no entienden en cosa alguma de los hombres, sino en torlos los exerçiçios que se ocupan las mugeres.

Diçe essa segunda relaçion que hay vacas en algunas partes tamañas como las de España, é los cuernos pequeños, como moriscas, y el pelo muy largo ; é unas son pardas é otras negras, é de buena carne é gordas; é de las pieles de los beçerros laçen mantas para se cubrir, é de los enéros de las vacas mayores haçen çapatos é rodelas. Estas vacas vienen de háçia cl Septentrion, é se extienden más de quatroçientas leguas hasta la costa de la Florida, é llegan á ella.

Dende aquella isla de Mal IIado adelante, en mucha parte de lo questos que escaparon andovieron, diçe Cabeça de Vaca, que despues que la muger se empreña, no duerme con cl marido hası dos años cumplidos que han criado los hijos, los quales maman liasta que han doçe aũos, que sepan buscar de comer : é preguntando la causa, diçen sus padres que se lıace por la muclıa hambre de aquella ticrra, porque de hambre no se mueran, ni queden flacos é sin fuerças.

bexaban las mugeres por pequeña ó ninguna causa, é cásanse con otros. EsTUNO III. to haçen los mançebos é sin hijos; pero los que tienen hijos, no los dexan, é perseveran en su compañia.

Si riñen los naturales, dánse de palos, $i$ no han de entrar por ningun caso arco ni fleclıa en la rençilla; é los que los han de despartir, han de ser las mugeres é no los liombres en ninģuna manera.

Quando las mugreres están con su costumbre, no buscan de comer sino para si solas, porque ninguna persona come de lo quellas traen en el tiempo que están assi. É allí es donde un hombre se casa con otro, y el paçiente anda como muger é sirve en todo lo que la mugger ha de servir á su marido.

Mezquizquez es una fructa como garrobas, de que haçen çierto manjar mezclado con tierra, y ella por sí es amarga é la tierra la haçe dulçe é buena de comer desta manera. IJaçen un hoyo en tierra, y cchada la fructa en aquel hoyo, allí la muelen á pison, é molida, de la tierra que se le pega del hoyo mezclada, añaden fructa, é májanla más, é despues sécanla é pónenla en una vassija á manera de espuerta, é cubren toda la pasta de aggua que le echan; é despues el que la majó, pruébala, é si le paresçe que no está dulçe, añaden tierra é párase mejor. Ė fecho esto, siéntanse á la redonda deste manjar los que lo han de comer, é cada qual mete la mano é saca lo que puede, é come de las pepitas é cáscaras é agua. Haçen otros polagres en dos ó tres moleduras de la mesma fructa.

En un grand pueblo hallaron estos chripstianos que todos los naturales de aquel pueblo eran tuertos de nubes, ó ciegos de todo punto.

Diçe essa postrera relaçion que los indios, en ciertas partes, les dieron á estos cluripstianos, Cabcça de Vaea é sus compañeros, unos talegruillos de plata; y es crror del impressor, pues que avia de 
deçir taleğuillos de margarita, é no de platia.

llay pinos chicos é muchos piñones, ¿ las piñas como luevos, é los piñones mejores que los de España, porque ticnen las cáscaras muy delgadas; é quanlo estín verdes, los muelen é haçen dellos pellas, é assi las comen; é si están secos, los muelen con las cáscaras é los comen hechos polvos. Hay por allí muchas lichres, que matan á palos con garlotes, juntámdose muchos caçadlores; é lay inuchos venados, que matan con flechas.

Diçe esta última relaçion que hallaron Cabeça de Vaca é sus compañeros una gente, que la terçera parte del año no comen sino unos polvos de paja.

En otra parte diçe que á Dorantes le dieron esmeraldas, fechas puntas de flechas; é preguntándoles que de dónde les llevaban essas esmeraldas, respondieron los indios que se las traian de unas muy altas sierras que están háçia el Norte, é las trocaban á trueco de penachos é plumas de papagayos.

Diçe que luay Ires maneras de venados, é que la una dellas son tamaños como novillos de Castilla.

Haçe memoria de la hierba que algunos flecheros de aquellas partes tienen, de unos árboles del tamaño de mançanos, que no es menester más de coger la fructa é untar la flecha con ella, é que si no liene fructa quiebran una rama, é con una leche que tienen haçe lo mesmo; é que lıy muchos destos árboles que son tan ponçoñosos, que si majan las hojas dél é las lavan en alguna agua allegada, todos los venados, é qualesquiera otros animales, que della beban, revientan luego.
En esto destos mançanillos, esta relaçion labla de oydas; é yo he visto muclıos é innumerables dellos, y en otra parte destas listorias se escribe por mi más largamente lo que toca á esta hierla de los flecheros.

Diçe esta relaçion postrera de Cabeça de Vaca, que por toda aquella tierra donde alcançan sierra; vicron grandes muestras de oro é alcohol, lierro, cobre ć ot ros metales. Yo quisicra esto más claro, é más larga claridad en ello. En la relacion primera que la Audiençia Real me dió, ques la que se contiene hasta en fin del capítulo preçedente, diçe que vino de Cuba, del puerto de la Habana, y en estotra, de que tracta este capítulo, diçe que tocó Cabeça de Vaca en la IIahana, é que llegó á Lisbona á nueve de agosto de mill é quinientos é treynta é sicte años. Pero porque estos tres hidalgos me paresce que hombres que escapassen con las vidas no los lıa avido en Indias más trahaxados, y es raçon que particular mençion se laga de la calidad de sus personas, digo quel uno es este auctor de la segunda relaçion, llamado Álvar Nuñez Cabeca de Vaca, lijo de Françisco de Vera é nicto de Pedro de Vera, el que fué capitan prinçipal quando se conquistó Canaria, é su madre se llama doña Teresa Cabeça de Vaca, natural de Xerez de la Frontera. El segundo es Alonso del Castillo Maldonado, natural de Salamanca, liijo del dofor Castillo é de doña Aldonça Maldonado. El terçero es Andrés Dorantes, lijo de Pablo Dorantes, natural de Béjar é veçino de Gibraleon. El quarto se llama Estebanico, de color negro, aláralee, natural de Açamor, en África. 
Aqueste es el libro déçimo séptimo de la segunda parte, y es el trigéssinio sexto de la General y natural historia de las Indias, islas y Tierra-Firme del mar Oçéano de la corona é çeptro real de Castilla é de los Reyes della: el qual tracta de la gobernaçion de la provinçia llamada La Florida, ques en la Tierra-Firme á la parte del Norte, y está Norte Sur con la isla de Cuba é puerto della, que llaman la Mlatançi.

\section{PROHEMIO.}

\section{S} sas, que los soldados sean galardonados segund lo meresçiessen sus obras '; é sentençia es de Dios, é su sagrada Iglesia inanda que creamos que los que bien obraren, yrán á la vida elerna, é los que mal obraren, al fuego eterno ${ }^{2}$. Esto es la fée cathślica, y el que fiel é firmemente no to creyere, no puede ser salvo. É assi es cosa justa que aunque estos capitanes, de quien en los libros preçedentes se ha tractado, hayan seydo infelices en sus cmpressas, acabándose sus dias en ellas con muertes é trabaxos de tauta lástima,

1 Ienofonte, lib. HI.

Et qui bona egerunt, ibunt in vilam elernam: que sospechemos que no avrá Dios permitido que sus fatigas se hayan perdido, no consiguiendo la paga exterior quel grand rey Ciro, como justo capitan, daba á sus soldados, ó que los señores del mundo pueden dar á quien los sirve, que son remuneraçiones transitorias. Mas avráles dado la gloria que Sancto Athanasio diçe en su Cathólico Símbolo; porque no solamente por ensanchar la religion chripstiana gastaron su haçienda é bienes temporales, mas pusieron sus personas á todo quanto peligro se pueden poner ó determinar los buenos mílites ó un vale-

qui verò mala, in ignem efernum (S. Alhanasio, De symbolo calholico). 
roso é noble capitan, é con la bandera de Cluripsto é con liçençia é volıntad de su Prínçipe, fuerou á morir, dexando su reposso é quielud, é tomando tan notorios y excesivos trabaxos como hallaron y en que acabaron sus offiçios, como caraIleros de Jhesu Chripsto. Y porque trás la trabaxosa armada ć infeliçe evento del capitan Pamplilo de Narvaez (de quien en el libro preçedente se tractó) se dirá en el pressente la mucrte é fin de Johan Ponçe de Leon, adelantado de Bimini; no se la de entender que sus Irabaxos fucron despues de los de Narvacz, sino primero, como el letor lo podrá adrertir en su leçion, si en ello quisiere mirar, por los tiempos en que lo uno é lo otro acacsçió. Mas aunque fué mucho antes la muerte de Johan Ponçe, pónese aqui despues del dicho capitan Narvaez por la conlinuaçion de la costa é geographia ó assiento de la Tierra-Firme, que traygo dende el estrecho famoso que descubrió el capitan Fernando de Magallanes en el otro hemispherio ó polo antárlico, é voy descubriendo hasta llegar á los Bacallaos é lierra que llaman del Labrador, como lo prometí en el prohemio ó introduçion del libro XX desta General historia de Indias, ques el primero desta segunda parte dellas. É lo que hasta el pressente liempo se sabe desta tierra é gobernaçion de la provincia de la Florida, es muy poco en comparaçion de lo que se espera saber adelante, despues que la tierra se pueble é sea mejor entendida que hasta agora. É porque para reçitar los serviçios é méritos del adelantado Johan Ponçe de Leon, si se oviessen de deçir dende su prinçipio, seria nesçessario tornar á escribir é repetir parte de lo questá dicho, si el letor quisicre mejor entenderlo, lea el libro XVI de la primera parte, dende el capítulo 11 adelante, é allí hallará cómo dende la isla do Sanct Jolıan, donde este capitan tenia su assiento, descubrió á la parte del Norte las islas de Bimini, la. prinçipal de las quales eslá en reynte y sicte grados desta parte de la línia equinoçial, veynte leguas al Oriente del Leste al IIueste con la Florida, ques en Tierra-Firme, que fué assimesmo kesculbierta por el dicho Johan Ponçe. Y en el libro XVI de la primera parte destas historias, en el caprítulo XI, yo escrilsí cómo desculrrió assimesmo la isla llanada Balıamá. Queda agora de deçir algunas particularidades desta tierra Florida, cuyo assiento puntualmente é su cosla ya se dixo en el libro XXI , capítulo IX en esta scgunda parte, é no hay nesçessidad de cansar al quo lee, pues allí lo hallará. Tambien se dirá su desastrado fin de una flecha ó sacta, de la qual fructa cn aquella tierra hallaron este capitan é su gente más que no del oro que buscaban los que le siguieron, quél no lo aria menester, porque tenia assaz bienes temporales en que pudiera vivir, si no toviera lan avivalo el desseo de la conversion de aquellas gentes, ó de acresçentar su estado é persona en estas temporalidades, que son tan deleznables é de tan inconstante pressa como las anguillas, é aun más presto se descabullen de las manos de los hombres. Lo qual no harian, si tomassen un puño de lierra para retenellas, á lo menos para usarlas, acordándose de aquellas palabras que diçe el saçerdole á los fieles, poniéndoles aquella cruz de çeniça el primero dia de quaresma, para acoldarles que son ceniça ó tierra ', é que en ella nos aremos de resolver, jara que todo lo del suelo se teng̣a por lo ques, é la memoria esté fixa en lo que ha de permanesçer é nunca acabarse. I desta manera lo que turaren estas cosas de lierra, usarse hian como conviniesse al ánima é 
al cuerpo, é no serian causa quella con él muricsse, ni que por lo menos se olvidasse lo ques más, é una gloria tan infinita. Donde plega á Dios que á todos los que resçibieren su baptismo é nombre clıripstiano haga dignosque la goçen; pues que los compró Nuestro Redemptor con su propria é presçiosa sangre é muerte, en la qual caben los méritos que á los pecadores faltan para conseguir la divina misericordia; é con essa mesma sangre é passion de quien la vertió son todos capaçes de aquellas çelestiales sillas, donde plega á Jhesu Chripsto questos milites, que en estas partes laan piregonado su féc, estén colocados, é que ell ellas se les hayan convertido aquellos thessoros que acá abaxo buscaban, que no es de creer que moririan tan desacordados que los desseen viviendo, sino para servir á Dios con ellos. El uno reparando su propria nesçessidad, y el otro por criar sus hijos é sostener la carga matrimonial, y el otro por haçer limosnas con to que adquiriesse, y el otro para visitar la casa sancti de Hierusalem é otras callólicas é sanctas peregrinaçiones. É assi con diverssos é buenos propóssitos pueden aver bien acabado quanto á Dios, aunque á los lionbres les parezea otra cosa; porque en la verdad estas cosas del ánima ninguno puede justamente juzgarlas, sino quien las crió. Los hombres juzguen á sí mesmos y enmiéndense, pues tan poco es el tiempo que nos puede acompañar en esta vida, é tan perpétuo é infinito el que la de turar la otra en bien ó en mal, segund la auctoridad que del Sancto Athanasio se alegó de susso.

\section{CAPITULO I.}

En el qual se tracta del armada quel adelantado Jolan Ponçe de Leon hiço, con que fué á poblar é conquistar en la Tierra-Firme, á la parte del Norte, la provinẹia que llaman Lá Florida, quél avia anles descubierlo, é cómo le desbarataron los indios é le hirieron de una flecha, de que vino á morir á la isla de Cuba, alias Fernandina; è assimesmo se traclan olras parlicularidades dessa tierra.

C Aomo se dixo en el libro XVI de la primera parte destas liistorias, Johan Ponçe de Leon avia conquistado é paçificado la isla de Boriquen, que agora se llama de Sanct Jolıan, y en aquella isla por su industria é grangerias vino á ser muy rico hombre, é á tener muclio ganado de vacas é ovejas é puercos é yeguas, é cogió mucho oro de minas, é allegó tantos bienes, que pudiera muy bien passar esta vida (é aun ayudar á otros en sus miscrias). É cómo era hidalgo é lımbre de gentiles é altos pensamientos, paresçióle que quitándole el cargo de la gobernacion de la isla de Sanct Jolıan (como se lo quitaron por la diligençia é saggaçidad de sus émulos) quél no podia estar ni vivir contento donde otros le mandassen; é assi por esto como por cmplear bien el tiempo, é pensando que con él é sus dineros (que tenia hartos) podria, sirvicndo á Dios é al licy con ellos, doblar é liacerlos muclıos más, é acresçentar su persona en títulos de honor y estado: é para este efetto, ó mejor diçicndo para aquel que su ventura le tenia guardado, despues que descubrió á Bimini é le dió cl Rey tílulo de adelantado por lo que avia gastado é servido en sus armadas é buscando aquella fucute de Bimini, que los indios avian dado á entender que laçia renovar é retoñescer é refrescar la edad é fuerças del que bebia ó se lavaba en aquella fuente, cómo todo aquello paró en la vanidad que delia de parar una cosa tan fabulosa é mendace, é vido que 
avia sesdo burlado é mal informado, no cansado por gastos ni tralıaxos, rolvió a amar con más acuerdo y expensas, é provesó é puso en órden çiertos navios para entrar por la Tierra-Firme en la banla del Yorte, en aquella costa é punta que entra en la mar çient leguas de longitud é çinqiienta de latitud, poco más ó menos. E paresçióle que demás de lo que se podia alcangar é saber de las islas que por allí hay, que tambien en la Tierrafirme se podrian saluer otros secretos é rosas importantes, é convertir aquellas fentes á Dios con utilidad grande de su persona en particular é generalmente para todos los que con él yban, que eran losçientos hombres é çinquienta caballos ('n los navios, ques dicho. É hasta poner in efelto essa armada, dispendió mucho: ¿ passó á aquella tierra por el mes de . . * del año de mill é quinientos é vernte años: é como buen poblador, llevó yeguas é terneras é puereos é ovejas é cabras é todas las maneras de animales ‘lomésticos é útiles al serviçio de los hombres; é tambien para la agricoltura é lahor del campo fué proveydo de todas siunientes, eomo si el negoçio de su poblaçion no estoviera en múls de llegar é cultivar la tierra é apaçentar sus ganados. Pero el temple de la region era muy diferente é desconviniente á lo quél llevaba imaginado, é los naturales de la tierra gente muy áspera é muy salvage é belicosa é feroz é indómita é no acostumbrala á quietud ni á dexar su libertad tan fáçilmente en discreçion ó voluntad extrangera de otros liombres, ni en eleçion de aquellos frayles é elérigos de que ylua acompanado para el exerciçio del culto divino é serviçio de la igglesia, aunque predicassen quanto quisiessen, ni pudieran ser entendidos con la brevedad que

- Hay un claro en el cúdice aulógrafo, que no os posible ahora llenar sin exposicion, pues que en ol canitulo XI del libro XVI, en que habla oviedo se les figuralıa á ellos é al que allá los llevó, si Dios de poder absoluto no los hiçiera ser entendidos de aquellas grentes barbaríssimas é salvages ydólatras é colmadas de delictos é viçios. Quiero deçir, que aunque, eomo en la verdad todo lo que paresce dificultoso es fáçil de obrar á Dios, quando le plaçe, es bien que pensemos que no somos merescedores de essa façilidad, ni tan á pié enjuto se 10men essas truchas: é quiere que primero se reformen las personas de los pescadores, para que cayşan en conosçimiento de la verdad los que los han de escuchar é seguir. Non obstante que con este capitan yluan personas religiosas é de buena dotrina; pero pues todo se erró, é se perdió el armada y el capitan y el tiempo é haçienda juntamente y en breves dias, de pensar es que no era Dios servido ni el liempo llegado de la conversion de aquella tierra é provinçia á nuestra sancla fée eathóliea, pues permite quel diablo aun los tenga engañados é por suyos á aquellos indios, é que se aumente la poblaçion infernal eon sus ánimas.

Esta armada llegó á aquella tierra el año que está dicho; é luego el adelantado Johan Ponçe, cómo se desembarcó, dió, como hombre proveydo, órden en que la gente de su armada descausasse; é quando le paresçió, movió con su grente y entró por la tierra y en una guaçábara ó batalla que oro con los indios, cómo él ега animoso eapitan, é se halló de los primeros, é no tan diestro en aquella tierra como en las islas, eargaron tantos é tales de losenemigos, que no bastó su gente é su esfuerco á los resistir. $Y$ en fin le desbarataron é mataron parte de los chripstianos, é murieron más que doblados de los indios, y él salió herido de un flecha-

de la expedicion de Pimini, tampoco designa el mes en que turo principio esta enpresa. 
co malamente; ć acordó de se yr á la isla de Cuba para se curar, si pudiesse, é con más gente é pujança volver á essa conquista. É assi se embarcó é llegó á la isla al puerto de la Habana, donde desjues de aliegado, vivió poco; pero murió como cathólico é rescebidos los sacramentos, é lambien muricron otros que yban heridos, é otros de enfermedades. Pero porque este gobernador vido poco de aquella tierra, é despues andando el tiempo, passó á ella otro adelantado, que fué Hernando de Solo, é con más gente é poder, é no con mejor ni tal ventura, pues allá quedó muerto, é se supo niucho más de aquella tierra de la Florida, él que se quisiere informar della, si es- tos mis libros ha leydo á reo, ya fo avrá visto en la primera parte desta Generab historia de Indias: é si no la traydo continuada su leçion, ocurra al lilsro XV'II de la primera parte, dende el capítulo XXI hasta el fin del capítulo XXX, í verá una lecion notable de la ferocidad de aquella gente septentrional, é nuchas particularidades é cosas nuevas de oyr. Tambien se dixo en el libro XXXII, en la conquista de la Nueva España, que una caravela de las deste adelantado Johan Ponçe de Leon, aportó á la Nueva España, é aquella llevó poca gente de los que escaparon del otro peligro de la Florida.

\section{CAPITULO II.}

En el qual se traeta de ẹicrto animal ó vaeas montesas, que hay en la Tierra-Firme á las espaldas dr la provinçia de la Florida é parte septentrional de la mar del Norte.

M Tierra-Firme, á la parte del Norte é mares más puestas al Septentrion, han visto muchas vacas é toros, los quales en sí son comunmente mayores reses que nuestras vacas de España. Tienen los pescueços muy llenos de lana, é la cabeça traen algo más baxa que las vacas de España: é dende las corvas ál medias piernas aljaxo hasta las uñas están assimesmo con mucha lana, é lo demás de su cuerpo es raso é las colas largas, de la manera que acá las tienen las vacas, é los cuernos puntiagudos y cl uno contra el otro, co- mo sc verá en la figura pressente. Los machos tienen una corcoba alta sobre los hombros, é las hembras no la tienen, é la lana de lo restante del cuerpoes como merina, espessa; é no anda ni se muere portante ni de andadura ó passcando, sino a par, como acá haria un caballo maniatado; pero son sueltos é muy salvages é innumerables. La carne dellos es bucna y cl cuero muy reçio, é lodos cllos son de color leonado escuro. Estos animales hay en mucha parte de la TierraFirme al Septentrion. E porque el letor mejor lo entienda se pone aqui su figura '. 
Aqueste es el libro déçimo octaro de la scgunda parte, y es el trigéssimo séptimo de la Valural y general Historia de las Indias, islas y Tierrra-Firme del mar Océano de la corona é çeptro real de Castilla é de Leon: el qual tracta de la gobernaçion de la provinça llamada Chicora (é mús propriamente dicha Gualdape) en la Tierra-Firme, á la parte del Norte, que fué á poblar el liçençiado Lúcas Vazquez de Ayllon, veçino desta cibdad de Sancto Domingo de la Isla Española, oydor de Su Magestad en el Audiençia é Chançilleria Real que aqui reside, cavallero de la Órden militar del $\Lambda$ póstol Sanctiago.

\section{PROIIEMIO.}

E que ha de mandar soldados, soldado debe ser primero. Dexemos estar aparte los prinçipes é reyes, que nasçieron señores, porque aquessos son fuera desta regla: é aun los tales, usando las armas, las entienden mejor (puesto que dende que nasçen siempre hallan çerca de sí quien esto é otra qualquiera sçiençia con verdadera expiriençia les pueda enseñar). Pero los otros varones es menester que sean exerçitados, como disçípulos, antes que prediquen ó usen como maestros.

Yo creo bien quel liçençiado Lúcas Vazquez de Ayllon supiera ser alcalde é haçer justiçia, deçidiendo un letigio que ante él se tractara, porque para esse efetto aprendio dercchos; pero nunca se vis- tió coraça ni çiñó espada para ganar sueldo con ella, ni defender su capa, ni adquirir la agena por milite. Aunque en la verdad era de buena casta de hijosdalgo, porque yo conosçí á su padre, Jolıan de Ayllon, más ha de çinquienta años, en tal possesion, veçino é regidor ó jurado cn la cibdad de Toledo; é conozco hien lıa quarenta é más años otro su hijo, hermano del mesno liçençiado, cavallero de la Orden militar del Apóstol Sanctiago, Hamado Perálrarez de Ayllon, al qual ví en Italia, militando en serviçio del duque de Valentinoes, don Céssar de Borja , é muy bien estimado entre los cavalleros de su exérçilo. Y ví queste mesmo Perálvarez de Ayllon se halló en la defensa del castillo ó fortaleça de Salsas, año de mill 
é quinientos y tres, con el capitan don Sancho de Castilla, alcayde de la dicha Salsas, é con otros cavalleros é hidalgos que la defendieron valerosamente al exérçito é casa de Françia, aunque la echalon por tierra yuassi por la grand artilleria con que la batieron, é aun tenia ya mucha parte á fuerça de picos para la poner en quientos; pero quedaron los cercados invençilles, hasta que en persolia el Rey Cathólico don Fernando la socorrió. E aquel dia que los françeses alçaron su campo, é con daño suyo se fueron, entró el exérçito del Rey Cathólico quemando é tomando castillos é villas por Françia (assi como fueron Cijar é Fitot é ha Palma, é despues Leocata).

Aquel mesmo dia ví quel Rey armó cavalleros por su mano tres hijos del duque de Alva, don Fadrique de Toledo, que fueron don Garçia de Toledo, primogénito del dicho duque (el qual don Garçia fué padre del duque de Alva que hoy es don Fernando Ślvarez de Toledo); y el segundo que armó cavallero fué don Pedro de Toledo, marqués de Villafranca, hermano del dicho don Garçia; é í don Fernando de Toledo, comendador mayor que fué despues de Alcántaca, hijo menor del dicho duque don Fadrique. $\mathrm{Y}$ el quarto fué un hidalgo leonés, llamado Martin de Robles, que se halló dentro en la defensa de Salsas: el quinto fué Pedro de Losada, acemilero mayor del Rey, que tambien estuvo dentro de Salsás; y el sexto que alnó cavallero fué este Perálvarez de $\Delta y-$ llon, al qual, dende á pocos dias, le dió el Rey el hábito de Sanctiago é le hiço otras merçedes. Este bien sé yo que s:rpiera mandar soldados, porque fué soldado y exerçitado en la militar disçipliIla; pero el liçençialo Ayllon, su lıermano, no se tenia otro crédito en cosas de guerra sino que era nohle persollat en conversaçion.

En esta isla turo cargo de justiçia, é despues fuć oydor en el Audiençia Rual que aqui reside, donde higo bien su offiçio, é assi se pensaba que hicjiera el du capitan é grobernador, porque demás de ser de buena casta, avia mucho tiempo que residia en esta isla. Pero el que tomó á la postre con su armada, nunca le avia hecho: créese que si hallara la tierra adonde fué de paz, que la gobernara bien. Pero quisiera yo, pues tomaba las armas, que aviéndolas usado, pudiera deçii lo que dixo Narco al pucblo romano en aquella oraçion, que consta por el Yugurtino tractado de Salustio, por estas palabras: "Aquello quessos suelen oyr é leer. yo lo he visto, é parte por mí mesmo he fecho: é aquello quessos en los lilıros, yo en la milicia to he aprendidon. 1

Assi que quiero deçir, quel liçençiado Ayllon, no por hombre de guerra, pero por virtuoso cavallero é persona de buen entendimiento, era tenido. Exerçitados han de ser los que exérçitos han de mandar, muy bien diçe el mesmo auctor: "Fáçil es todo prinçipio de guerra, mas nuty difigil el fin; porque el començar es liçito a qualquiera por desútil que sea; mas el fenescer es solamente concedido á los vencedores". ${ }^{2}$

Como quier quello sea, no desmeresçe su buen desseo del liçençiado, porque su fin créese que era de cathólico, é que desseaba servir á Dios é al Rey, acrescentando el número de los chripstianos é aumentando señorios á la Céssarea Milgestad é corona de Castilla; é tambien á rueltas desso poner su persona en inás estado, puesto quel que tenia aqui era mus preheminente é tan prinçipal, como es dicho. É si fuera desto ques dicho, le nuovió alguna ambiçion ó colsdiça, lıondhe 
rra, é su persona é bienes lo pagraron, é ron él otros muchos por le creer, y él jorque creyó á un medio traydor, criado sirgo y esclavo, é natural de aquella tierra, que lleró por guia: el qual, por tornar á su patria, le dió á entender lo que no pudo hacer verdad.

El año de mill é quinientos é veynte y tres yo fuí á España, é yendo dende Sevilla á la corte passé por Nuestra Señora de Guadalupe, donde hallé al liçençiado Ayllon que venia para esta su empressa, despachado é favoresçido, é con el hábito de Sanctiago quel Emperador poco antes le avia dado; é cómo éramos amigos, comunicóme su viage, é çierto me pessó oyrle deçir adónde yba : é díxome la confianca grande que tenia de aquel esclavo, é que le avia fecho chripstiano, é que era muy buena persona é de muy gentil juiçio. Llevaba yo estonçes una perla grande que tuve, de la qual se hiço mencion en el libro XIX, capítulo Vill de la primera parte, que pessaba reynte é seys quilates y era perfetta é redonda, é quise que la viesse, porque él me deçia que aquel indio le decia que las aria exçelentes é grandes en su tierra: é dixo el licençiado que era muy peqqueña á respecto de las que le prometia aquel su adalid, é tanto más se me repressentó é tuve por çierto su engaño; é cré que aquel indio mentia en quanto le aria diclıo, é quel desseo de volrer á su patria le haçia deçir todo aqquello, de que conosçia quel liçenciado se holgaba, é que como astuto acomulaba novelas que no se le debian creer; é assi se lo dixe al liçençiado. Él me respondió quel indio era ya muy ladimo é muy buen chripstiano, é tenia tan. to amor al liçençiarlo como si fuera su hijo, é quél le tractaba como si le engenIrara; ć assi á este propóssito me le loó lanto, que conosçi que le creia como si fuera evangelista: pero lo que sacó de su crédito la historia lo dirá.

Parésceme ál mí que todos los cautelosos tienen por dechado aquel ardid que Inilual usó con los romanos (quando les dió aquella derrota é vençimiento memorable de li balalla de Canas) ques procurar yuel viento dé al enemigo en la cara, para que con dificultad se defienda le las armas del adverssario, é dando al vencedor en las espaldas, más sin empacho consiga su victoria. É assi este enemigo familiar dalsa con el viento de la esperança en los ojos al liçençiado, su amo, é le çegó de tal manera que le destruyó.

Diçe Luçio Frontino que Anibal, çerca de Canas, aviendo considerado quel viento volturno (id est Susueste) por un cierto rio, fuera de la natura de todos los rios, la mañana temprano ultra modo soplaba, de manera que los monteçillos del arena é del polvo levantaba, é que de tal forma ordenó sus esquadras, que toda la fuerça del viento daba en las espaldas á los suyos y en los ojos y en la cara á los romanos: por la qual cosa, sumamente á sus enemigos contraria é adverssa, consiguió aquella memorable victoria ".

Assi á nuestro propóssito quadra lo que está dicho, para quel prudente siempre esté en vela con los hombres sospechosos. ¿Qué se puede fiar de un esclaro, sino esperar dél que, quando no os catáredes, avés de hallaros sin él?

En una oraçion que al pueblo romano hiço Cayo Ilemio, diçe ques mayor vergíienca perder la ganada libertad, que aver seydo siempre subjeto ${ }^{2}$.

Claro está yuel escla vo no meresçe ser crey do, porque el dolor intrínseco que en su ánimo padtesce, viéndose presso, le cstimula é acuerda que procure ser exento. F. aun de aqui se colige la justa intençion 
de la ley, que dispensa que los contractos que olorgan los que están pressos, no los obligan á guardarlos, ni deben aver efetto. No sé yo cómo el liçençiado, seyendo tan buen jurista, ignoró aquesto, dando crédito á su prissionero ó esclavo, pues como captivo tenia liçencia de mentir ó deçir torlo aquello que le paresçiesse que era abrirle el camino para tornar á su tierra, á su muger é hijos, si los tenia, ó á holgarse con sus padres é amigos en su patria, cobrando su libertad é restaurando su persona sin captiverio. Y essa fée de baptismo que acá le prestaron, si en él imprimiera, no hiçiera lo que hiço. Ello está bien entendido y el tiempo lo mostró con la obra y efetto en que paró el armada é los pecadores que en ella se hallaron, de los quales, como de testigos de vista, yo fú informado de lo que aqui se dirá, en especial de tres roligiosos de la Orden de los Predicadores, fray Antonio Montesino, fray Antonio de Cervantes é fray Pedro de Estrada, é de Françisco Gomez, que fuć capitan é alcalde ó teniente del dicho liçençiado, é de Pedro de Quexo, que fué por piloto mayor, é de Johan Rodriguez Mlalaver, é de otras personas fidedignas que escaparon é volvieron á esta cibdad de Sancto Domingo; é al pressente algunos dellos están vivos é viven aqui, que merescen crédito.

\section{capítulo I.}

En que se tracta el subçesso de la mal eneaminada empressa de la gobernaẹion é armada del liçençiado Lúeas Vazquez de Ayllon, que fué à la Tierra-Firme á la parte que nos es opuesta í la parte del Norte, dende la villa del Puerto de Plata desta lsla Española; é eóno é dónde murió el lic̣ençiado é la mayor parte de la gente que llevó.

E n la prefacion de susso se dixo cómo el año de mill é quinientos é reynte $y$ tres vino despachado é proveydo el licençiado Lúcas Vazquez de Ayllon para yr por capitan general é gobernador de Su Nagestad á cierta provinçia de la Tierra-Firme, que está de la otra parte de la isla Fernandina, álias Cuba : el qual, cómo aqui á Sancto Domingo llegó, venido de España, residió en su officio de oydor desta Real Audiença é Clancilleria que aqui hay; é tambien entendia en se aderescar é proveer para las cosas de su armada é haçer su viage. É tardó tanto en esto, que le enviaron á mandar los señores del Consejo Real de Indias que pusiesse en efetto su cmupressa, conforme á lo que tenia capitulado, si no gue proveerian en el negocio para que fuesse otro capitan á lo hacer, é le exchurian de la negoçiacion ó cargo que se le avia dado, paraque aquella tierra se poblasse: y por esto él se determinó de se dar más priessa en su partida, la qual fué dende el Puerto de Plata, que en esta isla está á la parte de la banda del Norte: de donde salió mediado el mes de julio del año de mill é quinientos é veynte y seys años con una nao grande, que era la capitana, é otra que llaman la Bretona, é otra na nombrada Sancta Cathalina, é otra que se dice la Chorruca, é un bergantin é un patáx ó gaharra. Assi que, eran seys velas por todas, en que fueron quinientos hombres, é los más dellos isleños é diestros en estas partes, é ochenta ó noventa caballos muy buenos, é bien proveydo de todos los laastimentos é cosas que para la jornada le paresçió que era nesçessario.

De la manera ques dicho fué su viage derecho á se desembarcar en un rio que le Ilaman rio Jordan, que está más al 
Griente de la provinçia de la Florida, en lit mosma costa de la Tierra-Firme, cienlo é rinqiienta leguas, poco más ó menos: la boca del qual rio está en treynta é lres grados é dos terços desta parte de Ia línia equinoçial, á la banda de nuestro polo ático.

Aquella tierra quel liçençiado $A$ yllon é su armada fucron á buscar, la llama el chronista Pedro Mártir en su tractado Chicora, porque aquel indio falso adalid quel liçcnçiado llevó, é otras lenguas de aquella tierra la nombraban assi; pero dende á muy pocos dias se huyeron la tierra adentro, é dexaron en blanco al liçençiado é á los demás que de sus palabras fiaban: y en toda la costa, ni en lo que dentro de la tierra vieron los españoles, ni se pudo ver ni aver notiçia de provinçia ni puerto, ni rio ni poblaçion que tal nombre loviesse: ni vieron tierra ni provincia que se llamasse de los nombres que se contenian en la capitulaçion quel liçençiado tuvo con Su Magestad Cessárea, que yo he visto, que son los quel dicho indio le dehiera avisar. É diçe la liçençia real que le dá facultad para que pueda yr ol dicho liçençiado, ó enviar á prosegguir (1) descubrimiento de la tierra é provinçias é islas de Duahe, Chicora, Yta, Tanrac, Anica, Tivecocayo, Xapira, Guacaya, Xoxi, Sona, Pasqui, Aranui, Xamunanuc, Huaque, Tamaca, Yenyohol, Pahoc, Yamiscalon, Orixa, Inisiguanin $y$ Noxa: que en cada nombre destos pensó el liçenciado que llevaba un thessoro, é como he dicho ninguna tierra se supo de tales títulos. Pero parésceme que hastaba d the adelantado que por la capitulaçion roal se le prometió destas tierras é provinçias é islas, é de todo lo que por su industria fuesse descubierto; é otras merçedes se le prometicron por la dicha capitulaçion, fecha en Vtalladolid á veynte ¿ seys de junio de mill é quinientos é veynte y tres anos. Assi que, este fué el rucaludo queste cavallero sacó de la confiança de su indio Françisco de Clicora. Pero el prinçipio de la perdiçion é desrentura de aquesta armada, fué que al entrar, que la dicha nao capitana entraba en el rio Jordan, se perdió con todos los bastimentos (puesto que se salvó la gente), é los otros navios que erau menores entraron sin peligro.

Despues que estovieron allí algunos dias, descontentos de la tierra é ydas las lenguas ó guias que llevaron, acordaron de yrse á pohlar la costa adelante háçia la costa ocçidental, é fueron ál un grand rio quarenta ó quarenta é cinco leguas (le allí, pocas más ó menos) que se dice Gualdape : é allí assentaron su campo ó real en la costa dél, é començaron á lincer casas, porque no las avia, sino alqunas caserias léxos unas de otras, é la licrra toda muy llana é de muchas çiénegas, pero el rio muy poderoso é de muchos é buenos pescados; é á la entrada dél era baxo si con la cresçiente no entrahan los navios. É cómo les faltaban mantenimientos y en la tierra no los hallaban, élos frios eran muy grandes, porque aquclla tierra, donde pararon, está en treynta é tres grados para arriba, y era raso, adolesçió mucha gente é muriéronse muchos; y el liçençiado luego cayó malo é lambien se lo llevó Dios. El qual murió como cathólico, resçebidos los sacramentos, é arrepentido de sus culpas é de sus pensamientos é armada: é passó de aquesta vida dia de Sanct Lúcas, á diez é ocho dias de otulıe de aquel año de mill é quinientos é reynte y seys. É dexó ordenado que fuesse gobernador en su lugar, en tanto que Sus Magestades proveyessen to que fuesse su serviçio, un sobrino suyo, thessorero de la isla de Sanct Johan, que se deçia Johan Ramirez, é que estaba ausente en essa saçon en la dicha isla de Sanct Jolın; y en tanto quedaba por su capitan é teniente aquel Françisco Gomez. 
de quien se hiço mencion de susso en el prohemio. Pero cntre essos soldatos é gcnte que quedó no faltaron un par de hombres desconcertados amotinadores, que pusieron en trabaxo á todos: dc los quales el prinçipal fué un Ginés Donçel, veçino desta cibdad é natural de la villa de Gibraltar, que se juntó con otro de tan mal sesso como ćl, quc se deçia Pedro de Baçan, como más largamente se clirá en el siguiente capítulo.

\section{CAPITULO II.}

En que se tracta de la lirania é molin de Ginés Donęel é Pedro de Baçan, é cómo fuẻ prcsso esle Gines Donçel é se hiço justiçia del Pedro de Baçan. É tambien cuenta la historia cómo trayendo el cuerpo del liçençiado Ayllon muerto á esta Isla, lo echaron cn la mar* .

G to al licenciado $A$ ylfon, como hombre sin consejo é que confiaba de su habilidad ć sagaçidad quc podria scr capitan de los que querlaban, só color que como ostahan rlescontentos de la tierra él decia que los llevaria della, é dando otras falsas colores á su desatino, prendió al tenicnte é á los alcaldes, é púsolos en grand nesçcssidlad; é truxo á su opinion í un Perlro de Baçan, que no tenia más sosiego quél, é á otros desconçcrtarlos é aparejados á haçer su voluntad ć lo que le paresçiesse. En esta sacon los indios mataron algunos españoles desmandados: los quales son muy grandes flecheros, pero no tienen hierba, sino muy reçios arcos que haçen de castaños (que hay muclos la tierra adentro), é traen sus carcajes de cueros de adives é otros animalcs: é la gente natural de aquella ticrra son bien dispuestas personas, ć más altos que los indios destas nuestras islas comunmente.

No porlicndo comportar algunos hombres re bien la tirania ć sobcrbia del dicho Ginés Donçel é de su parçialidar, juntáronse algunos, y en espeçial dos hidilgos, llamados Oliveros é Monesterio, ć con otros que se allegaron á su parescer

\footnotetext{
- De cste cpigrafe suprimió Oviedo algunas drúusulas insignilicantes para la inteligencia de la
}

acordaron de hablarle al Ginćs para que soltassc los que tenia pressos, dándolc á entender que caia en mal caso, é que era muy mal fechı. Á lo qual él replicó lo que le paresçió, culpándolos é diçicndo que los pressos sc querian yr ć dexarlos perdirlos á los demás en la tierra, é llevarse los navios, é atribuíanles otras culpas que no tenian. Desta habla é amonestaçion le quedó al Ginés Donçel una perpétua enemistad con Oliveros, porque era hombre de hecho, y el que rodeaba de deshaçer é no consentir la tirania rlel Ginés; é comencó á tractar con el Baçan cómo le matassen á él é al Nonesterio. É una noche que avian de poner en cfetto su mala intençion, siguróse que unos negros pegaron fuego á la casa del Ginés por su proprio scsso rlessos esclavos; y estaban allí los pressos, ć ardiendo el fucgo, acudicron todos á lo matar: é assi ovo lugar de salir los pressos de donde estaban detenidos. En esse mesmo tiempo el Baçan fué á matar al dicho Monesterio, que estaba en su posada; y el otro, cono era liombre de buen ánimo, salió á él é començóle á maltractar, porque el Baçan yba armarlo. Y tambien en esse tiempo é saçon cl Oliveros buscaba at Ginés Donçel (el qual armarlo se avia

liistoria, por lo cual no juzgamos necesario reproducillas. 
escondido debaxo de una barbacoa ó lecho) é queríalo prender : é cómo se oian las roges é combate que entre el Bagan é Nonesterio avia, acudió ál cllas el Oliveros , é llegado dixo al Baçan que se diesse á prission, y úl respondióle con muchas cuclilladas que le tiró, y el Oliveros entró con él, é de un revés que le dió en una pierna dió con él en licrra, é allí le dieron otras heridas, è quedó presso. F́ acudieron luego donde el fuego andaba, y el Ginés estaba todavia escondido: é finalmente se dió á prission, é fué puesta la justiçia é los alcaldes en libertad, é fué mandado arrastrar é degollar el dicho Baçan, é assi se puso por olıra, aunque él cstaba tal, que sin esso no podia escipar de las heridas.

Prosso el Ginćs é otros algunos de su confederacion, acordaron estos que quedaban de se venir á estas islas, ć pusiéronlo en efetto: é metieron el cuerpo del liçençiado en la gabarra ó patáx, para lo traer á esta cibdad de Sancto Domingo, donde tenia su casa é assiento, ó al puerto de Plata, donde tenia la mitad de un injenio poderoso y era bien heredado para lo traer dende allí á esta cibdad; pero porque tovieron mala navegacion, al cabo dieron con él en la grand sepoltura desta mar oceana, donde están ó fueron eclados otros capi. tanes é gobernadores (ó los eclıó su ven.
Iura antes é despues que al liçençiado). Asssi que en esto paró su vaobernaçion.

Todos los que quediaron se vinieron á estas islas Española é Sanct Johan: pero fucron los menos de los fucste camino higieron, porque de gunientos que se embarcaron en puerto de Plata no se escaparon çiento é çincjienta lombres con las vidas, é los más dellos de enfermedades é de hanubre.

Desla manera, letor mio é señor prudente, que aveys aqui oydo en este libro é otros destas historias, se busca el oro cn cstas partes, é topan más ayna con lloro é muerte de los cuerpos y en aventura mucha é peligro de las ánimas.

Vengamos agora á labblar en las cosas particulares de aquella tierra é rio de Gualdape, de la qual ninguna mençion ni pintura haçe la carta de navegar; pero no hay duda en to dicho por los muchos tesligos que, por su mal, lo vieron y escotaron en ella sus trabaxos é vidas; é al pressente lıay algunos en esta cibdad é isla que lo testifican. E con todo quanto padescrieron loan algunos la forma de la region que vieron, é diçen que llevándo. se la forma que se requiere para poblar en tal parte, é assaz bastimentos hasta calar y entender la tierra, no podria dexar de ser buena cosa, por ser cl temple della más al propóssito de españoles, é por lo que se dirál adelante.

\section{CAPITULO $11 \%$.}

En que se tractan algunas partieularidades de la provinçia de Gualdape en la tierra del Norte, donde murió el liẹençiado Lúcas Vazquez de Ayllon.

L te tio de Sancta Plena abaxo al Ocde el rio de Sancta Elena abaso al Occirlente, es toda tierra llana. Las poblaçiones no las vieron estos españoles que fueron con el liçençiado Ayllon, sino algunas casas ó buhios á manera de caserios, !esos unos de olros: y en algunas islctas de la costa perucũas lay çiertas mezquitas ó templos de aquella gente ydúlatra, é muchos huessos do defunctos, apartados los de los muchachos é niños de los mayores. Y cstos son como hossarios ó carneros de la gente comun, porque los de los liombres prinçipales están 
por sí en capilla ó templo separado de lá otrá commidad, é lambien en isletas. É aquellas casas ó templos tienen paredes de cal é canto (la qual cal haçen de conchas de ostiones de la mar) y estas son de hasta un estado y medio de alto, é lo demís de esse estado y medio arriba es de madera de pinos, que hay muchos. IIay algunas casas prinçipales por aquella costa, que debe entre aquella gente ser avida cada mua dellas por un pueblo, porque son muy grandes, é son fechas de pinos muy altos é muy gentiles; y en lo alto déxanles sus ramas é hojas, é despues que haçen una hikera ó rengle de pinos por pared é otra del otro cabo, quedando enmedio el anchura de quince ó treynta piés de una rengle á otra, é de luengo bien tresçientos ó más piés, por lo alto juntan las ramas, é assi no hay nescessidad de texado ni cubierta, non obstante que con esteras muy lien puestas cubren todo lo alto, entretexilas en los vácuos ó lumbres de entre los pinos dichos, é por de dentro hay otros pinos atravessados con la haz de los primeros, que duplican el grosor de la pared. De forma que la lapia queda gruessa é fucrte, porque están juntos los maderos: y cu cada casa destas tales pueden muy bien estar ó caber dosçientos lımbres, é vivit en ellas, como lo haçen los indios, dexándoles su puerta donde conviene.

Los animales que hay, á lo menos de los que se turo notiçia, son tigres, dantas ó beoris, çiervos, concjos, adives, que son como çorras, é muchos dellos son muy pintados é grilan toda la noche sin cessar, de quando en quando toda ella, hasta que comiença ál esclarescer el dia siguiente; gatillos, monillos pardillos con solos dos dientes altos, con que horadau las nueçes é se comen lo de dentro, ques malo de despegar de la nuez.

Las aves que láy son inmumerables grtulas. é naturales de la mesua tierra, cuervos, tordos, gorriones como los de Castilla, perdiçes como las de Castilla, tórtolas, ámsares loravas, ánadesé otras aves.

Los árboles, de que los testigros ques dicho me informaron que hay en aquella tierra, son pinos é muchos robles de los que dan agallas, ençinas de bellotas, parras de uvas montesinas, castaños (pero la fructa es pequeña), mimbres, cañas de las de España hnecas, noggales, çarçamoras, las quales, passas fechas, las guardan los indios para comerlas en el invierno. Hay morales é servos é laureles: hay mucho çumaque é buenos palmitos de los baxos de España é muy buenos.

De las hierbas hay açederas é çerrajas.

En lo de los pescados hay mucho que deçir; é la pesqueria del rio Gualdape es cosa mucho de maravillar por su grand abundançia de pescados é muy buenos, segrund afirman los religiosos nombrados é otras personas, que diçen que vieron que en un lançe de un chinchorro se sacaron solore seysçientas moxarras, é comió toda la gente dellas, é aun les sobró mu cho pescado. Pero de una moxarra en espeçial diçen que tenia sicte palmos de luengo é tres ó más de ancho, de que comieron á la mesa el liçençiado Ayllon é diez ó dloçe personas, é no la pudieron acabar, y es muy exçelente pescado. Lenguados muchos, é algunos de dos palmos é dos é medio é tres de luengo muy singulares: açedias muchas; liças muchas é muy grandes é luuenas, é otros muchos pescados de los que por acá hay, assi como guavinas, róbalos, dahaos é otros, é de cada género destos é otros en mucha albundancia. Pero con todo esto se murieron hartos hombres de ham. hre por falta de pan é por no poder con sus enfermedades pescar ni valerse mos á otros.

Era tanto el frio, que como se embarcaron enfeımos é inal proveydos, se murieron de frio en la caravela nombrada 
Sancla Cathalina siete hombres que se helaron; y en la nao Choruca acaesció una cosa de las que son raras veces ó nunca vistas, y fué que uno de aquellos pecadores, queriéndose descalçar las calcas, se le despegó toda la carne de las piernas ambas dende las rodillas abaxo, é le quedaron los huessos limpios, y essa noche se murió.

El caso es que resumiendo el general perdimiento desta gente, escaparon de quinientos hombres que en esta armada fueron, no más de çiento é çinquienta. ;Oh capitanes, que predicays destas ticrras que vays á poblar ó á saltear é destruyr, pregonando conversion é baptismo é destruyendo la tierra en que entrays é á los naturales della, é matando á los chripstianos que con rosotros llevays embelesados é atronados de vucstras promesas, fritas en el asarten de los desventurados tristes que os escuchan é creen, sin sabler dónde ys, sin ninguna certinidad ni expiriencia de las provinças, donde los llevays á padescer lantas é tan nuevis inaneras de muertes! Dios os lo perdone! Que muchas reces me acuerdo de un cavallero, que lo llevaban á degollar con tres ó quatro criados suyos partiçipantes en el delicto, éaquellos yban delante dél; y el que yba más cerca del señor . cómo dieron el pregon reçitando la muerte que se les mandaba clar, volvió la cabeca é dixo á si amo: "jOh señor, que por vos me llevan aqui á morì! " Y enojado el cavallero del poco ánimo de su criado, respondió é dixo: "Bien reys que no me quedo yo en la possadan. Assi que, estos que padescen, bien ven que se acuerda Dios de los medir á la igguala, é á las veçes Iraçen peor fiı que aquellos engañalos de sus sermones. l)ios los tenga á todos en via de silvaģion. Y ros, letor, si aveys de venir á Indias, no os pesse de leer estos mis libros, é plega á Jhesu Chripsto que sea con más ventura que han tenido los más de los que acé ham venido.

La mayor parte deste daño consiste en que estos capitanes no saben dónde van, ni se proveen apropóssito de lo que conviene, sino de lo que les paresçe á ellos. $Y$ es imposible açertarse unas cosas é negocios que son tan grandes en sí, en es. pegial en aquellas partes septentrionales, donde la gente es más feroz é la tierra muy fria, é serian menester otros aparejos é conçicrto quel ques apropóssito destotras partes australes. Pero con la expiriençia de los errores se acostumbran corregir las cosas vonideras con regla é remedio para todo; y assi placerá á Nues. tro Señor que de aqui adelante haya tal correccion y aviso, que todo sulsceda en aumentacion de la república chripstiana, y en aerescentamiento é prosperidad de la silla é ceptro real de Castilla.

Con todas las culpas que pongo á los capilanes é á sus sermones, quicro acordar á los soldados que la guerra es de calidad que solo el nombre le basta para que aquel que entra en ella entienda que lo primero que ha de ofresger á la milicia es la vida, é que en los exérçitos pocos nasgen, é que la mayor parte de los que perseveran, se mueren ó los matan. E pues esto es lo más cicrto, proponga el cathólico soldado de hager de tal manera su officio, que su ámima no se pierda ni la dé á su capitan ni á su Rey, sino á Dios, cuya es. 


\section{CAPITULO IV.}

De olras partieularidades de peseados, que se vieron por nuestros españoles en aquella tierra, donde murió el liçençiado Ay̆llon, cotras eosas que eompelen à la hisloria.

$\mathrm{C}$ omo el subçesso de la gobernaçion del liçençiado Ayllon paró en lo que la historia ha dicho, y en aquella ningun español quedó vivo, los que escaparon, despues que volvieron á estas islas, cada uno tiró por su parte; pero no faltan de todo punto algunas personas que testiftcan lo ques dicho, é aun añaden que en el rio de Gualdape se tomaron en una canal sobre septeçientos lenguados perfettos, y algunos dellos mucho mayores que los de España. É muchos otros pescados se tomaron en reçes, assi como albures, vagres, çentollas, besuguillos de palmo é de xeme de luengo. Pero entre lo ques dicho è muchas corbinas, é galludillos, é tollos, é caçones muy grandes é chicos, é arañas buenas, ovo dos pescados de que yo me maravillé quanto más apartados eran de lo que tengo dicho: uno fué un caçon tan grande, que mandó la justiçia que no comiessen dél, porque no hiçiesse daño; mas cómo la nesçessidad era de más fuerça que los alcaldes, constriñó á quatro ó çinco hombres á que comiessen del caçon, é híçoles mal provecho, porque se les cayeron é pelaron las barbas é cabcllos é çejas, sin que en essas ni en otra parte de sus personas les quedasse pelo alguno. El otro es çierto pescado de mar que tiene concha como tortuga, pero es delgada como la del cangrrejo é neggra, é tiene muchos piés de cada banda ó costado, é abierto hállanle muchos huevos no mayores que lentejas: estando crudo este pescado, él é los huevos hieden mucho á marisco; y estando coçido, huele muy bien y es buen manjar é de buena digestion.

Assi lo que se dixo en los capítulos precedentes como en este, lo testifican los padres que tengo alegados é otras personas de crédito. $Y$ esto baste quanto á este breve libro del número XXXVII hasta quel tiempo nos avise de otras cosas, que en él se acresçienten. 
Aqueste es el libro déçimo nono de la segunda parte, y es el trigéssimo octavo de la Natural y general historia de que aqui se tracta, el qual, aunque no compete á las Indias, es al propóssito de la continuaçion de la tierra septentrional, que hasta en fin del libro preçedente se ha continuado, pues se continúa la lierra, é se cree ques toda una, segund adelante se dirá.

\section{PROHEMIO.}

Este último libro desta segunda parte lie querido poner aqui para confundir las opiniones de los antiguos cosmógraphos y escriptores, que tovieron que la tierra questá debaxo de los polos es inhabili. ble; y por lo que vemos é se sabe agora le muchos de la mar que lo han andado, é poi lo que un moderno é docto varon nos enseña con sus letras y expiriençia é pintura, se vé lo contrario. $\mathrm{Y}$ porque yo hasta en fin del libro antes deste he tray. lo continuada la grand costa de la Tierra-Firme dende el Estrecho de Magallanes liáçia la tierra del Labrador, que está al Norte ó parte septentrional, é aquella donde yo acalué me dá á entender que se junta con Europa, diré lo que desta materia he entendido, lo qual para mi es co- sa muy nueva, é assi creo que lo será á otros muchos, que mejor tienen entendida la geographia é assiento del universo, alegando é probando con quien lo diçe, ques Olao Gotho, natural de aquellas partes y provinçia de donde salieron aquellos famosos godos, que tanta parte del mundo conquistaron, y entre los otros reynos se hicicron señores de España: en la qual hasta el pressente tiempo tura en la casa real de Castilla la subçession gótica é señorio de aquellos godos, pues que la Cessírea Magestad é sus predeçessores penden de aquella prosípia, y perma. nesçe y turará muchos siglos en sus sul). cessores y desçendientes, ál gloria y servicio de Dios, y para aumento y favor de la chripstiana religion, como to remos 
efelluar en virlud y prudencia de nuestros Prínçipes passados y pressentes. Y lo mesmo harán sus herederos por la dis. pensaçion y clemençia divina, que siempre se la mostrado y muestra serles favorable méritanente, porque sus desseos y sus obras son una mesma cosa, y cssa es ensanchar la fée y faroresçer los vicarios de Dios y la lglesia Apostólica de Roma, é destruyr los infieles é castigar los heréticos é ydblatras. I assi como lo laçen, assi los esfuerça y favoresçe Dios, y contínumente aumenta é prospera su real çeptro é alta estirpe.

SUMARIA RELACุiON DE LA PARTE SEPTENTHONAL, EY LA QUAL EL CHRONISTA DESTAS IHSTORIAS DÁ Á ENTEXDER LO QLE DESTAS MATERIAS NLEVAMENTE IIA SABIDO; É DICE ASSI:

\section{H} exçelente pintura que se puede ver ni arbitrar ni pensar, cono quiera quel artífiçe é pintor della es el mesmo Dios, é rlél solo permitida, é solo él bastante para lal obra. Cosa es que á los ojos harta é satisfaçe, sin les dar pessadumbre ni eansançio, $\sin$ acabar de deleytar el entendimiento lumano, al qual recrea é agrada en tanta manera, que nunca le liene sin goçosa admiraçion, dando graçias al señor de tan copiosa é alta sahiduria. Esto movió al famoso poeta nuestro Johan de Mena, quando dixo en el prinçpio de aquella su obra, que enderescó al ilustre marqués de Santillana, don Ínigo Lopez de Mendoça :

\section{Despues quel pintor del mundo} Paró nuestra vida ufana, elc.

Que sea Dios pintor del mundo é componedor é criador de las diverssas coJores é matiçes de la moltitud de sus obras é de lodo lo que contiene é de que nuestra vista puede ser capaz, nos lo inuestra, é la Sagrada Eseriplura ad plenum enseña: In principio creavil Deus colum el terram, etc. Y esse mesmo dixo: Fial lux, é fué hecha. Dividió las tinieblas, é dixo: Fial firmamentum in medio aquarum, et dividal aquas ab aquis, elc., é assi se cumplió. Assimesmo dixo: "Júntense las aguas que están debaxo del çielo en un lugarn, é assi se hiço, é llamóse aquello mar. "Produzca la tierra hierbas é hagan simiente, é los árboles lıgan mançanas é fructo, segund sus géneros ", é assi se efelluó como lo mandó. Crió el sol é la luna é luminarias, dividiendo la luz de las tinieblas: crió los animales é aves sobre la tierra: crió las lyallenas grandes é animales de agua produçidas en sus espeçies; é quiso que la. lierra produresse lodas las demás diforençias de animales en su género y espeçic: liço el hombre á su propria imágen a semejança, é bendíxole con su muger ".

Ved, letor, si es hermosa pintura aquesta que aveys oydo, é cómo nimguna otra se le iguala. Mirad la órden del çielo, sus estrellas é planelas é cursos, é las otras innumerables cosas que en la eomposiçion del universo hay que ver é contemplar; ćtodas é cada una dellas os manifestarán lo que delsemos a tan sapientíssimo pintor é tan inmenso é solserano Dios é Señor; pues como diçe el poeta alegado, Ian ufana paró nuestra vida. É mirad en quán grande eslado é ser nos constituyó, que por su propria é su- 
ma liberalidad todo to dió al lombre, que quanto mayores son las merçedes tanto es más justa la puniçion del ingrrato desconosçido. que olvida su Dios é Señor é tantos benefiçios (é aquellos multiplicados con aquella infinita misericordia, con (fue nos redimió la passion de Clurip̧sto con su sangre, comprando con su propria vida las nuestras, yne estaban perdidas por la culpa del hombe). No plega prues á Nuestro Señor que se pierda tanto bien por nuestro descuydo é maliçia, ni que en vano lava padesçido nuestro Redemptor para mi ni para otro chripstiano al wa110, pues todos fuimos el contrapesso de tal presçio é la balança, por quien se puso cn la cruz el Señor del mundo é de todo lo que en él hay é arrá. En crya confiança quicro en este íltimo capítulo lractar de cosas que confunden é reprueluan é muestran ser rana y erónea la opinion de todos los auctores passados, que torieron que la tórricla çona é lo que está debaxo de los polos, es deshabitado é inculto. Y en verdad, aunque como naturales quisiessen escudriñar ć conformarse en lal error, no podian dexar de ignorarlo, pues ignoraban quel Maestro que supo hacer el çielo é la tierra é todo lo demús sabria é podria proveer en esso que le paresçia dificultoso: quanto más que no como experimentadores, como nuestros españoles, buscando el mundo, sino cono especuladores, estándose quedos, hablaban á su benepláçito. Muchıo me satisfaçe el diclıo de aquella vicja de Tales Milesio, que queriendo él mirar y entender las estrellas é cosas del çiclo, no viendo un hoyo que tenial cabe sí en que eayó, ć llamando en su ayuda á la vicja que le servia, para que le diesse la mano al salir del hoyo, le dixo ella: "¿Por qué racon, oh Tales, quicres comprender é

1 Qua ralione ;oln Thales! quxe in cœlis surt comprensurum le arbitriris, quan ea qux sunt ante arbitrar las cosas questán en el giclo, pues no ves las que tienes delante de los ojos? " Por çierto, non obstante, que lo questa rieja quiso sinificar es que no nos extendamos á unás de lo que nos es posible. Mucho es to que debenos á los que nos dan notiçia de lo que no avemos visto ni sabemos, como yo agora debo á un varon notable é docto de acjuel ilusIríssimo senado de la Señoria de Venecia. Ilamado el sectetario Micer Johan Baptista hamussio, que de oyr él que soy inclinado á estas materias, de que tracto, sin conoscerme, me la querido por amigo, é me ha con letras comunicado una nueva geograplia, que con auctoridad apostólica del Summo Pontifiçe é de la Señoria ya dicha se ha imprimido en aquella ínclita cibdad por industria é letras del docto varon Olao Gotho: al qual favoresçe la auctoridad del reverendíssimo arçobispo, el señor Johan Magno Gotho, arçolispo Lpsalense de Sueçia, primado é legado apostólico, natural de aquellas partes de Gothia. É cerca de la descripçion septentrional en nueve tablas ó pliegos de carta mayor pintado et in scriptis, con una relacion del mesmo anctor Olao Gotho, se me truxo el año passado de mill é quinientos é quarenta años. Y porque soy amigo de que á cada uno se conserve su crédito, é que no se le usurpe su trabaxo, ni se le dexe de loar su luena olma, pues ques ol auctor della quien lie dicho, diré delta poco, cn especial do la isla llamada lslandia é de la ticrra fueste cosmógrapho pone más septentrional. Porque quanto á la iórrida cona, ya qucla probado en el libro XXI, en cl capítulo V, ques liabitada, é nuestros españoles lo han experimentado é lo ren cada dia cul estas nuestras Indias (en la Tierra-Firme dellas); quanto a los polos digo que entre las otras cosas

occulos, videre non vales? (Diogenes Laerciu, De vita et moribus philusophorum.) 
quel magnífico secretario ya dicho ine lia escripto, una me ticne admirado; y es que la ticrra del Labrador, de quien se tractó en el libro precedente, sigue la via septentrional, y vuclve despues continuada al Oriente, é se junta y es ma mesma tierra con la Europa, é dexa mediterráneas á la dicha Islandia y Eseocia é Inglaterra é otras muchas é notables islas.

É porque este auctor se refiere (digo el Olao Gotho) á dar más particular informaçion destas cosas en cicrto tractado que escribe, é diçe que assimesmo eseribe otro el mesmo perlado Upsatense, que presto saldrán á luz, quando las bayamos risto, oyremos lo que dexa de deçir en lo que hasta aqui he visto pintado é brevemente escripto, pues se remite á lo que escrilıen ambos con más acuerdo é cumplida relaçion. Pero considerando é midicndo yo la primera destas sus nueve tablas ó partes (si to he sabido haçer) me paresce que la isla de Islandiá la pone dende septenta é seys grados desta parte de la equinoçial hasta ochenta é nueve. Assi que, seria la parte más septentrional della, solamente un grado de aquesta parte del polo ártico: cuya grandeça diçe que solsrepuja las dos Secilias. $\mathrm{Y}$ pone la isla Ilamada Magnete debaxo del polo é dále treynta millas de amplilud; é diçe que de la otra parte desta isla la brújula ó aguja de navegar pierde su fuerga. Por manera que assi dessa noredad de las agujas como del nombre de la isla, se puede sospechar que alli es el origen de la piedra yman, é que lıáçia Septentrion (digo de allí adelante) no tiene fuerça, é que dende allí lıáçia Mediodia reyna; porque este nombre es lo mesmo que pierlra yman, é desla isla de racon avia de tomar este nombre. Pero dire I'hinio ques nombrarla Magnes del nombre del que la halló, é que segund
Nieandro, fué hallada en la India, ete. ${ }^{*}$ Puesto quel mesmo Plinio diçe que en otras partes lo hay; pero yo estoy un poco entretenido, como he dicho, con el nombre de la isla Magnete, é con perder la piedra y'man ó magnete su fucrça, passando el polo.

No quiero detenerme en más de lo que toca á la isla que dixe de Islandia, porque la pone este auctor çerea de la costa que hasta aqui en la parte septentrional he seguido, por no distraerme de mi propóssito y de la grand costa que he continuado. Has para recreaçion del letor, digo que he visto en esta nueva pintura (que aqueste godo describe, é pone en la primera tabla ó parte) que en essa isla de Islandia hay tres exçelsos montes, en que está la sumidad ó cumbres más allas é superiores dellos cubiertas de perpétua nieve, é al pié de cada uno un horrendo abismo de perpétuo fuego, semejante al de la siçiliana Ethma ó Hongiluel con su holror cepantoso, ó como aquella caverna de Vuleano (que mejor pudiera llamar monte, porque yo le he visto y estado en él). Uno de los quales montes diçe que vulgarmente se llama IIcclafiel, y el otro Cruçis, y el terçero IIclgafiel, que quiere deçir Monte Sancto. Entre aquestos montes lay picdras altas, puestas por memoria de los fechos de los passados varones, en las quales se ven escriptas sus memorias antiguas.

La iglesia episcopal se llama Scalhondense.

Hay en la dicha isla quatro fuentes por contraria natura distintas, porque la una es maravillosamente caliente, é la otra fria, é la tergera es buena para beber é quitar la secl lumana, é la quarta es mortifera.

Cocea de aquestas fuentes los habitadores de alfuella ticrra sacan tan grand 
copia de asulre que lo venden por vilis. simo presçio, é dan mill libras dello por la déçima parte de un florin. P'one cl anctor alegado dos estupendos espectículos centre el fuego, el qual no pudiendo consumar la estopa, continuamente consume al agua, y entre un çierto caosó sima la horrenda profundidarl de la qual no se puede comprender con la vista, más difiçilmente se comprende con una cuerda (nviada abaxo con una pessa) espectículos de muertos; y diçe que muchas reçes acaesçe que los hombres que se han ahogarlo en la mar, aparescen íl los suyos el mesmo dia, no de otra manera que si vivos fuessen. É quando se les diçe que entren en casa, responden sospirando que han de yr al monte Ecla. Diçe más: que in aquella isla hay osos, raposas, licbres, halcones é cuerros blanquíssimns por todas las partes della. Dice que hay cierto hiclo ó parte congelada on aquella costa de mar, que se oyen salir della miserables gemidos é llantos de humana roz, que hage fée que allí son atormenladas las ánimas de los hombres, segund este auctor dige: de lo qual yo me remito á lo que la lgglesia Cathólica de Roma mandare que se crea.

No muy léxos de lo que está dicho pone é pinta unas piedras con veliemençia de exhalaçion, traydas por el ayre, como si volassen, no las tocando alguno.

En otra parte muestra tanta moltitud de pescado en montones tan grandes como 'asas poderosas que tienen para los venler, porque las gentes de aquella tierra quassi torlos comen pescarlo, porque siembran poco trigo é assi cogen poco; pero diçen que si más abundantemente sembrassen, alundarian de pan, el qual compran traydo de otras partes. É diçe que cree ques aquella generasçion en esto de la agricoltura tan peresosa, por la inmensa moltitul del pescado, en cambio del qual abundan de todas las otras cosas. llay un altíssimo monte que llaman Sancto, é una abadia llamada Elgafiel, la graud renta de la qual es todo butiro 6 manteca, la abmulancia de la qual manteca abundantemente por toda aquella patria se alministra.

La igglesia catlredral se llama lloldense.

Hay muclıs é grandes hatos de ganados; y es tanta la fertilidad de los pastos, que si los bueyes no son quitados de donde pascen, revientan de gordos.

Hay por aquellos mares grandíssimas ballenas, á semejança de grandes montos. que frastornan é ancgan las naves, si con el sonido de las trompetas é con el estrépito de vassos redondos vaçins cchados en la mar no son espanladas é detenidas; ́ los marineros no expertos tienen muchas veçes peligro, atacindo las íncoras á qualque parte de la ballena. pensando que se anclan ó amarran en alguna isla.

Hay por aquella mar mucha guerra entre los navios de los mercaderes por entrar é tomar puerto primero é a su propóssito. É los señores de aquella tierra no son acostumbrados á juzgar aquellas cosas que acaesgen en abierta é larga mar.

Pone este auctor dos escudos de armas m aquesta su tabla primera: el uno es de goles, vel sanguino, con un leon de oro rampante é coronado de una corona real, y en las manos una hacha de armas blanca vel argéntea, é sobrel escudo una real corona de oro. El otro cscudo assimesmo es el campo dél sanguino vel de goles, é un pescado de alto albaxo, cándirlo vel argénteo, escondida la cabeça ó cubierta debaso de una corona de oro. Este escudo tiene un coronel de oro sin flores, y es las armas proprias de la isla de Islandia, la qual obedesce al rey de Noruega, cuyas son las armas del primero escudo.

Á par de aquellos escudos está pintado un cavallero, que por fuerça de vion. 
to él y cl caballo caen á tierra, sinificando la mucha potençia del viento en aquella parte; y el viento que señala assi furioso, es Norte.

Pone assimesmo una mury grande iglesia edeficada con luessos de pescados é ballenas marinas.

Pone muchas cavernas ó cuevas, que usan los habiladores contra el frio, como aquellos que en Ífrica se esconden por el semejante en espeluncas contra la calor del sol, debaxo de tierra.

Pone çicrtos cavalleros armados, é dice que entrellos muchas veçes intervicnen crudíssimas gucrras, é alğunas dellas por ligeras causas.

Pinta un citarista ó músico, sentado á par de la costa de la mar, tañendo una vihuela de arco, al son de la qual vienen muchos pescarlos por el agua, é aves, por dó se prucba que en los confines de la tierra la música se estima é presçia mucho, pues que alguna vez aplica á sí los peçes é las aves.

Diçe que en el mar, helado por oclıo meses, en aquel tiempo los osos se meten debaxo del hielo á tomar é matar pescado, lo qual no podria acaesçer si allí en las cavernas del agua no oviesse grand moltitud de pescado.

Pinta un enano en la parte ó ticrra llamada Gruntlandia, combatiendo con otro hombre de grande estatura, sinificando que allí hay lombres pequeñissimos de cuerpo, pero perlinaçes é de grandíssimos ánimos.

Esta tierra Gruntlandia es fuera de la dicha isla, y está quatro grados adelante ó de la otra parte del polo ártico, la qual quieren deçir que se vá á juntar con la tierra del Labrador é de los Bacallaos, segund diçen los pilotos de aquellas partes. Y el reverendíssimo arçobispo Ipsalense confirma averlo assi oydo deçir, é quessa ticra de Gruntlandia vá despues enarcándose, subiendo ála parte oriental, é se junta con la Europa. Este nombre Gruntlandia quiere deçir arenosa tierra; y en la parte que la isla de Islandia mira á Grumtlandia está un monte altíssimo, que se llama Huitsark, que quiere decir monte blanco; en el qual pone este auctor un relox en lo alto con letras de plomo, por el qual se gobicrman los que andan por aquella mar, é se guardan de los escollos é baxos de Gruntlandia, ques mar peligroso muclio.

Assi que, todo lo ques dicho pinta é describe muy bien este docto varon Olao Gotho en su primera tabla ó parte de las nueve desta su gcographia, con polido y elegante estilo; y cn las otras ocho tablas pone otras muchas é maravillosas cosas, que yo remito á su tractado.

Pusc aquesta aqui por haçer solamente mençion de la tierra de la isla Magnete, que está debaxo del polo en noventa grados, é de la ticrra de Gruntlandia, que está de la otra parte del polo ártico quatro grados, como es dicho; é porque los auctores alegados to haçen una mesma costa continuada con la tierra del Labrador, é que se junta adelante al Oriente con la Europa é con su tierra mesma die Godos, de donde son naturales este arçobispo y el Olao Gotlı. Por manera que si aquesta ticrra toda es comunicada é una, como se debe creer por lo questos auctores diçen, á los quales me remito dende la ticrra del Labrador adelante; é por lo que yo tengo diclıo y escripto dende el Estreclıo de Magallanes lasta la tierra del Labrador, todo el mundo podenos deçir ques una mesma tierra é costa, sin la dividir la mar; pues que las tres partes Asia, Europa, Africa, una mesma tierri son todas tres, é la division dellas que los antiguos Ies dan en dos rios la ponen, que son el Thanais, entre la Europa e $\Lambda$ sia, y el Nilo entre $\Lambda$ sia é Ífrica. Pero estos rios no parten la tierra, quicro decir no la cortan, pues nasçen en elia; pe- 
ro los nascimientos del uno é del otro son incógnitos. Quanto al Thanais diçe Tholo. neo, quel Thanais es oculto su nasçimien10 '; é assimesmo solorel nascimiento del Nilo, despues que Diodoro ha escripto diverssas opiniones, tambien le dexa incierto é oculto su prinçipio ${ }^{2}$.

Concluyo, en que hasta nuestro ticmpo no está escripto por auctor alguno (le lengua hebráica, caldea, egipcia, greca ni latina, ni de otro género ni lenguage alguno, ni he ogdo cosa de tanta admiraçion como esta á todos los que leen, si esta geographia septentrional que de susso se ha tocado, los auctores ya dichos ú olros que merezcan crédito se afirman en ella. Y podremos estonces, dexando aparte las islas muy senialadas y descriptas de muchos auctores y conosçidas, y las que no sabemos, porfiar é aver por cierto que toda la tierra firme restante en el universo no son las tres partes que nombran Asia, África, Europa, sino inna sola parte entera é sin dividirse de la mar, é de aquessa la mitad ó más de la corona é ceptro real de Castilla é de Leon.

Plega á Jhesu Chripsto que assimesmo sea una sola la religion é fée é creençia de todos los hombres debaxo del gremio é obidiençia de la Iglesia Apostólica de

1 Tholom., lib. II, cap. I.
Roma é del Summo Ponlifice é vicario é subcessol del Apóstol Sanct Pedro é debaxo de la monarequia del Emperador Rey don Cárlos, nuestro señor, en cuya ven. tura é méritos lo veamos presto cfeltuado! É con esto se concluye el libro XXXYIII desta Natural y general historia destas Indias, islas y Tierra-Firme del mar Oséano.

Passemos á lo demís de la terçera parte, donde continuarć los libros que della se siguen liasta su definiçion, cuya memoria me dá mucha pena é dolor, porque tengo de relatar y deçir los tristes y desventurados fines é muertes do muchos y diverssos capitanes é personas señaladas que en estas partes han perdi. do las vidas; porque para mi condicion es grave y desaplaçible cosa pensar que mi pluma ha de seguir una forma de historia ó imitaçion tragédica; y en espeçial tocando á tantos de nuestros naturales españoles, á vuelta de los quales por mis pecados se me ahogó un solo hijo que me quedaba, del qual yo pensaba en mi postrimeria aver mejor goço. Plega al que assi le plugo que su ánima é de todos los demás estén en gloria, donde es. tá la perfetta y perpétua vida, en la vis. ta de aquel eterno Dios, que vive é rey. na per omnia sacula sœculorum. Amen.

2 Diodoro Sículo, lib. I.

FIN DL LA SEGUNDA PARTE. 


\section{INDICE GENERAL.}

Tabla del segundo volúmen de los nueve libros de la segunda parte de la Nalural y general historia de Indias, en que sumariamente se haçe memoria de lo que tracta cada liliro destos.

rägs.

LIBRO I, que es $\mathrm{X}$ de la II. ${ }^{a}$ parte y XXIX de la General historia de las Indias, que tracta de la provinẹia y gobernaçion de Castilla del Oro, que comunmente se suelc llamar

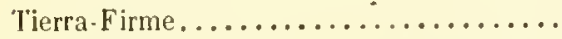

LIBRO II, que es XI dc la II. ${ }^{a}$ parte y XXX. de la General historia, que tracta de la gobernaçion de Cartago é sus anexos....... LIBRO IIl, que es XII de la II. ${ }^{a}$ parte y XXXI de la General historia, que tracta de las provinẹias é gobernaçiones del Cabo de Higueras é Puerlo de Honduras é de Yucatan: é despues torna á dexar á Yueatan é se junta con Gualimala, é por tanto este libro es más anexo é dedieado á la gobernaẹion de Honduras..................

LIBRO IV, que es XIHI de la II. parte y XXXII de la General historia, que tracta de la provinçia é gobernaęion de Yucatan.... LIRRO V, que es XIV de la $11 .{ }^{a}$ parte $\mathrm{y}$ XXXIII de la General historia, que Iracta re la provinẹia é gobernaçion é conquista \& poblaçion de la Nueva España, рог el eapilan Gonçalo Fernandez de Oviedo y Valdés, capilan de la fortaleça de Saneto Ilomingo y coronista del Emperador y Rey, nuestro señor.....................

J.IBRO II, que es XV de la II. ${ }^{\text {a }}$ parte y XXXlV de la General historia, que traeta de la provinẹia è gobernaçion llamada la Nirva Galiçia, é que los indios é nalurales llaman Xalisco, en la parte oẹidentalde la Tierra-Firme..................

I.IRRO VIl, que es XVI de la II. ${ }^{\text {a parle y }}$ XXXV de la General historia, que tracta de la gobernaçion del rio de Panueo é del
Pags.

rio Hermoso é sus provinçias, que son dos rios grandes que juntos entran en la cosla del Norte; é assimesmo se traela del rio de las Palmas, que está más al Oricnte subiendo por la dicha costa la vuelta de la provinẹia que llaman La Florida; é traeta cúmo se perdió el capitan Pamphilo de Narvaez é su genle, que fueron á poblar aquellas provinçias é rios.............. LIBPO VIII, que es XVIl de la II. ${ }^{\text {parle }} \mathrm{y}$ XXXVI de la General historia, que tracta de la gobernaçion de la provinẹia llamada La Florida, ques en la Ticra-Firme á la parte de Norte, y está Norte Sur con la isla de Cuba é puerlo della, que llaman la Ma-

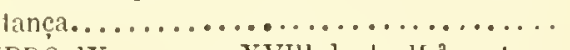

LIBRO IX, que es XVIIl de la $1 r^{\mathrm{a}}{ }^{\text {parte }} \mathrm{y}$ XXXVII de la General historia, que tracta de la gobernaçion de la provinçia llamada Chicora (é más propriamenle dicha Gualdape) en la Tierra-Firme, á la parte del Norte, que fué á poblar el liçenẹado Lúcas Vazquez de Aylion, vecino desta cibdad de Sanclo Domingo de Ia Isla Española, nydor de Su Mageslad en el Audiençia é Chancilleria Peal que aqui reside, cavallern de la Orden militar del Apóstol Sanctiago. LIBPO $\mathrm{X}$, que es XIX de la II. ${ }^{a}$ parle $\mathrm{y}$ XXXVIII de la General historia, el qual, aunque no compete á las Indias, es al propóssito de la continuaçion de la tierra septentrional, que hasta el fin del libro precedente se ha contisuado, pues se continúa la lierra, é se eree ques loda una, segund adelante se dira................. 63

Tabla particular con cada uno de los libros susodichos.

LIPRO XXIX. Prohemio............. Caritulo r. Cómo fué provehido Pedrarias I) avila de la gobernarion de Castilla del Oro, que tenia Taseo Niunce de Balloa, y otras cosas que convienen di la lịstoria....... TOMO III.
1 Capltilo II. De lo que subçedió á Vaseo Nuĩez de Balboa despues que se galıó el Datrien, y cómo descubrió el rio grande de Sanet fohan, que entra en el golpho de Ĺrabi, golras cosas nescessarias al proecsso 
de la listoria..........................

('vitulo 11. Como Vasco Nuñez de Bathou descubrió la mar del Sur y fué el primero lıombre que la enseîó á los clıripstianos, y le los eaçiqnes que hiço de paz, é otras cosas conęernientes á la historia..........

Capitulo iv. De la segunda possesion quel capitan Vaseo Nuñez de Balboa tomó de la mirr del Sur, é quáles chripstianos fueron los primeros que con él navegaron en ella, * de las primeras perlas que vieron de aquella mar, é otras cosas notables é nesçcssarias al discurso de la historia...........

Capituto $v$ Cómo el gobernador Vasco Nuìez de Balboa tornó al Darien clesde la mar del Sur, y cómo en çiertas provinçias hiço los eaçiques de paz...............

C.pitulo v1. Del viage del gobernador Pedrarias bávila á la Tierra-Firme, llamada Castilla del Oro, en la qual eslaba por capitan Vasco Nuñez de Balboa...........

C.ipitulo vir. Cómo estando con el armada en el puerlo de Sancta Marta el general PeUrarias Dávila, salto la segunda vez en tierra con gente, y entró la tierra adentro hasta tres leguas, é fueron pressos é muerlos algunos indios é indias; é de lo que subçedió en aquel puerto, é qué se conlenia en el requirimiento que se mandó hacer á los indios antes de romper guerra con cllos; otras cosas que convienen al discurso de la listoria........................

Capitulo vill. Cómo el gobernador Pedrarias Dávila llegó á la cibdad de Sancta $\mathrm{Na}$ ria del Anligua del Darien, donde estaba por gobernador el capilan Vasco Nuñez de lialboa, é lonó la possesion del offiçio, é se entendió en la residençia de Vasco Nuİez, é fué eluviado el teniente Johan de Ayora é otros capitanes con gente á poblar a la olra costa de la mar del Sur........

Capitulo $1 x$. Cómo el teniente Johan de Azora é otros capitanes fueron enviados con gente à poblar la costa de la mar del Sur; y cómo el Rey Cathólico le envió é hico merced à Vasco Nuñez del lílulo de adelantado de la mar del Sur y de la gobernaçion de las provinẹias de Coyba é Panama: $\therefore$ cómo Pedrarias tuvo forma que no usasse de tales mercedes; é de las parles quel gobernador é offiẹiales llevaron de las entradas, que fué una de las prinçipales causas de acabarse, $\dot{o}$ al menos disminuyrse los indios é asolarse la tierra, ete........

Capitulo x. En que se relatan algunas entradas que diversos eapilanes hicicron, por mandado del gobernador Pedrarias Dávila,

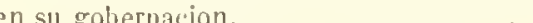

6 Capitulo xi. Cómo el vecdor Goncalo Fernandez de Oviedo fué á lispaña á buscar el remedio de la Tierra-Firme, ó desde á pocos dias que llegó á Castilla llevó llios al licy Cathólico á su gloria; é cúmo continuó su camino é fué à Flandes á dar nolicia a Rey don Cárlos, nuestro señor; é cómo fué proveydo por gobernador de Tierra-Firme Lope de Sosa, un cavallero de Córdova, $\dot{e}$

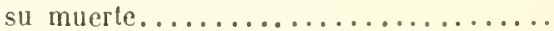

Capitulo xil, De la mucrte del adelantado Vasco Nuñez de Balboa, é Andrés de Valderrábano, é Fernando de Argiiello, é Luys Botello, é Fernan Muĩoz, que fueron en una hora degollados en la villa de Acla, en

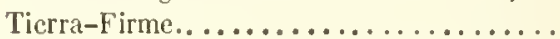

Capitulo xill. Cómo el licenciado Gaspar de Espinosa, alcalde mayor de Pedrarias, fué por su tenienle general por la mar del Sur con los navios que avia hecho el adelantado Vasco Nuñez de Balboa, é de lo que hiço en el viage, é otras cosas antes desto, en que este liçenẹiado se avia hallado....

Capitulo xiv. Cómo el capitan Gil Gonçalez de Avila fué á la Tierra-Firme con el piloto Andrẻs Niño, para yr desde Panamá á descubrir por la mar del Sur, por inandado del Çéssar ; é cómo el auctor destas historias volvió á Castilla del Oro, é de la forma que tuvo Pedrarias para despoblar el $\mathrm{Da}$ lien .........................

Capitulo xv. Cómo el coronista quedó por capitan é teniente de gobernador en el Darien; cómo los indios del caçique de Bea mataron al capitan Marlin de Mursa é á otros chripstianos: é cómo por aviso é industria del dicho capilan, auclor deslas historias, se paçificaron muchos caçiques é indios caribes é flccheros de la costa, ¿ se melicron en el Darien muchos pessos de oro por rescates..................

Capitulo xv. Cómo el auctor hiço jusliçia de los caẹiques de Corobari é Guaturo, que se avian rebelado del serviẹio de Sus Magestades, é cómo enviỏ presso á España al bachiller Diego de Corral, é otras cosas, que competen á la historia..............

Capitulo xviı. De la forma de la residencia de Pedrarias Dávila é su alcalde mayor el liçenciado Espinosa; é cómo no cansados los enemigos de faligar al auclor de aquestas historias, acordaron de le matar á trayçion, é fué muy mal herido...........

Capitulo xim. Del pregon que se diu en Acla para la residençia del gobernador Pcdrarias é sus officiales; é cómo se fixú aquel pregon en un poste de la plaça, é lo rasgó un caballo que fué del adelantado Vasco Nu- 
nez de Balboa; é cómo el juez de residencia la tomó al auclor destas historías, é condenó al que lo avia acuchillado á que fuesse ahoreado, y en otras penas............. Capitulo xix. Cómo fué presso el traydor de Simon Bernal é se hiço justiçia dél.....

Capitulo xx. Cómo el auctor se parlió de Acla, fingiendo que se yba á Panamí, donde el gobernador estaba, á se quexar dẻl, é se fue a España á pedir justiçia eontra $\mathrm{Pe}-$ drarias; é cómo el Emperador, nuestro sen̄or, le mandó oyl, é fuć proveydo por nupvo gobernador para Castilla del Oro Pedro de los Rios, un eavallero de Córdova; é utras particularidades se tractan convinienles à la historia....................

Capirclo xxi, Que tracta de algunas cosas notables que passaron en la Tierra-Firme entre el gobernador Pedrarias Dávila y el capitan Gil Gonęalez Dávila ć olros capilanes, en tanto que yo estuve en España negoçiando la yda del nucvo gohernador Pedro de los Rios, para que Pedrarias fuesse removido, é la relaçion de lo que descubriỏ el capitan Gil Gonçalez en la mar é costa austral de la Tierra-Firme, é porque es larga la narraçion de lo uno é de lo otro, yrá este capitulo diviso en ocho párrafos......

Capitulo xxil. De la tolal despoblaçion de la cibdad del Darien, é de las diferençias que tuvieron el obispo, fray Viçente I'edraça, y el liçençiado Salaya, alcalde mayor con Pedrarias; é del orígen é prínçipio del rlescubrimiento del Perú por los capitanes Françisco Piçarro é Iliego de Almagro, á su costa, y en compañia del maestrescuela Fernando de Luque; é de lo que acaesçić al sobernador Pedro de los Rios en la isla Dominica, quando yba á tomar la gobernacion de Castilla del Oro; é otras cosas....

C.rpitulo xim. Cómo el nuevo gobernador Pedro de los Rios, envió çicrta gente à pacificar el caçique Trota; é cómo fueron vencidos é desbaratados los chripstianos; é cóno vino nueva que Pedrarias avia degollado en Nicaragua á su tenjente Françiseo Hernandez; é cómo vino el capitan Diego de Almagro á Panamá, é truxo notiçia del descubrimicnto jel Perú; é por qué via el capitan Diego de Almagro, é por qué prescio echó fucra de su compañia en las cosàs $\therefore$ intercsses del Perú á Pedrarias Dávila...

Capitclo xxiv. De la residençia que lico Pedrarias ante el licençiado Johan de Salmeron, alcalde mayor de Pedro de los Rios, nuevo gobernador de Castilla del Oro; $\mathfrak{i}$ cómo Pedrarias y el auctor destas listorias se conçertaron, é con qué condięion........
Capitulo xxv. Que tracta de la grobernacion de Pedro de los Rios en Castilla del Oro, : de otros gobernadores é jueçes que le subçedieron liasta el año de mill é quinicntos $\dot{e}$ quarenta y un años................

Capirulo xxvi. De las costumbres é maneras de vivir viçiosas de los indios de la provincia de Cueva é de sus ydolatrias; éotras cosas particulares de la gobernaçion de Castilla del Oro é de sus provinçias..........

Capjerco xxvit. El qual tracta de los pueblos prinçipales de los clıripstianos en esta gobernaçion de Castilla del Oro, é de las casas é moradas de los indios, é de sus matrimonios é algunas de sus çerimonias é cos-

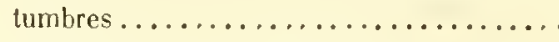

Caprtulo xxvil. De otras muchas particularidades de los indios de la gobernaçion de Castilla del Oro en la provinçia de la lengua de Cueva é otras partes...............

Capitulo xxix. De algunas parlicularidades de Castilla del Oro é sus provinçias, allende de las que se han dicho en los capítulos pre-

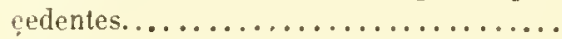

Capitulo xxx. De las minas del oro é perlas é riqueças de la provinçia de Cueva é Castilla del Oro, é del viage de la Espeẹieria desde Panamá á las islas de Maluco, é de la Puente admirablc, é otras cosas que pertenęsçen á la consecuençia historial........

Capitulo xxxi. En el qual se tracta de las obsequias é çerimonias de los indios, quando se muere algun señor ques tiva ó queví ó saco, é es principal, en la provinçia de Cueva é en algunas partes de la gobernaçion de Castilla del Oro..............

Capitrlo xxxı. De algunas particularidades de los indios de Cucva, é tambien se hace mençion de algunas cosas è general de aquella provinçia, que se añaden é ponen, a cresçentando el género dellas en los libros de la primera parte de aquestas historias. .

Capitula xxxil. En que sumariamente se tracla del subçesso é fin que hicieron los capitanes particulares, que ha avido en la gobernaçion de Castilla del Oro en tiempo del gobernador Pedrarias Iávila, $e ́$ antes é despues dél hasta el ticmpo pressente....

Capitulo xxxiv. En quel historiador culpa y desculpa á los gobernadores é offiçiales, y en deseargo de los eapitanes, y en reproche de los soldados é de los indios é naturales de la gobernacion de Castilla del Oro.

I.IBRO XXX. Prolıemio..............

Capitulo 1. Cómo Diego Gntierrez, grobernador de la provinçia de Carlago é sus anexos, fué bien resçebido é obedescidlo de los eaciques $\dot{e}$ indios de la tierra : é otras parti. 
cularidades al diseurso de la historia eonvinientes.....................

C.sptulo 11. Del subçesso del gobernador liego Gulierrez, é de su cobdicia c mal evento, é eómo le mataron los indios á élé á quantos españoles consigo tenia, exçepto sietc hombres.................

Cipitulo in. En que se haẹe relapion del mal subçeso del armada quel almirante envió á poblar st ducado de Veragua.......

LIBRO XXXI. Prohemio.............. Capituzo 1. En que se iracta del descubrimiento del Cabo de Higueras é puerto de llonduras, é de los eapilanes é gobernadores que allí ha avido, é otras cosas concerernientes á la historia...............

Cartuzo 11. De lo que subçooió al gobernador Diego Lopez de Salçedo, pocos dias antes que de Leon de Nicaragua se particsse para yr á Honduras, en la venida del capitan Diego Albitez, é el conçierlo que se dió entrellos, é la muerte de Diego Lopez, despues en su gobernacion, é las contiendas y escándalos que por su muerle ovo sobre quién avia de gobernar, é olras cosas quc son anexas al discurso de la historia......

Cispitulo m. De la eleçion de los nuevos gobernadores puestos por la república de la villa de Truxillo, que fueron el contador Andrés de Çereçeda é Vasco de Herrera, é cómo despues estovieron desconformes, é eómo los indios mataron á algunos chripstianos é se rebelaron en parte de la lierra, é cúmo el Diego Mlendez de Hinestrosa mató alevosamente a Vasco de Herrera, é los escándalos é forma que en ello se tuvo....

Cispitulo iv. De lo que Diego Mendez de Hinestrosa hięo con el favor de sus secaçes, despues que ovo muerto á Vaseo de Herrera ; é cómo, conlinuando sus desalinos, prendió despues al gobernador Andrés de Cereçeda; é cómo despues el Ceręeda le préndió al Diego Mendez é le hiço haçer quarlos, é se dió fin á su lirania........

Capıtulo v. Cómo el gobernador Andrẻs de Çereçeda, despues de la prission é casligo del tirano Diego Mendez de Hinestrosa, é castigados los que mataron á Vasco de Herrera, perdonó á los demás; é cómo Diegro Diaz de Herrera tenia amotinada la genle para yrse de la tierra; é cóno, viniendo por gobernador Diego Albilez, dió al través en la costa, $\dot{c}$ assi se ahogaron veynte $\mathrm{y}$ cinco hombres é çinco mugeres, é salió el grobernador á nado, é desde á nueve dias que fué resçebido por gobernador murió, é lexó por gobernador al mesmo Andrés de

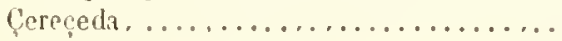

Capitulo vi, Cúmo Andrés de Çercçeda quedó por gobernador despues de la muerle del gobemador Diego Albilez, é de algunas cosas que subçedieron despues, é lo quel Çereçeda eseribió á esla Audiençia Real, que reside en csta cibdad de Sancto Domingo, del estado de aquella tierra é gobernaçion de Honduras hasta el año de mill é quinientos é treynta y tres, tnediado el mes de junio....................

Capitulo vil. Cómo el gobernador Andrés dc Cereęeda fué á poblar el valle de Naco, é cómo estando la tierra perdida enviaron á pedir socorro al adelantado don Pedro de Alvarado, gobernador de Gualimala, é fué en persona á paeificar la tierra é pobló la villa de Sanct Pedro, é despues fué á España, é cómo Sus Magestades mandaron juntar esta gobernaçion de Honduras con la de Yucatan, que estaba á cargo del adelintado don Franẹisco Montejo, é otras cosas.........

Capitulo vim. De la fertilidad de la tierra é provinçia de Honduras ė de aquella gobernaçion, é de algunas particularidades della é de los indios nalurales de alli.........

Capitulo ix. Cómo las provinçias de Yucatan é de llonduras se juntaron por mandado de Céssar é de su Real Consejo de Indias, é se dió eargo dellas al adelantado don Franęisco de Montejo, que primero era gobernador de Yucatan..............

C.apitulo x. En el qual se tracla de ęicrlo trueco é conviniencia entre los adelantarlos don Pedro de Alvarado é don Françisco de Montejo, por donde csla gobernaçion de Higueras é Honduras se tornó á dividir é se apartó de la de Yucatan, é se juntó con la de Gualimala....................

Capitrlo $\mathrm{x}$. De otras cosas é particularidades de la gobernaęion de Honduras, é de las minas ricas de oro é plata, que en aquella tierra hay...................

LIBRO XXXII. Prohemio.............. 201 Capitulo 1. En que sumariamente se tracta lo que haçe al propóssito de la hístoria é gobernaçion é descubrimiento de Yucatan hastael aĩo de mill é quinientos é quarenta

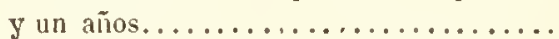

Capitulo II. El qual tracta del discurso desta historia de Yucatan é de muchas particularidades é nuevos é maravillosos nolables que á csla historia competen: é hácese relaçion de los caños, que se hallaron en la mar, de agua dulçe, é olras cosas muy dinas de oyr......................

Capitulo ill. De lo que subẹdió al adelanlado don Françisco de Montejo, desde que salió con los españoles, que le quedaban 
del pueblo de Conil, é de la república é jusliçia del pueblo llamado Cachir, é de los árboles del ençienso é su contractaçion, é de la grandissima poblacion llamada Chuaca, $\therefore$ de otras cusas que subredieron en aquella conquista......................

Ciprtulo iv. Del subçesso del adelantado don Francisco de Montejo, despues que estoro en Tavasco, é cómo fué en demanda de la cribdad de Acalan, é de las vistas de entre él y el capitan don Johan Enriquez de Guzman, é de una nueva invençion é nunca antes oyda ni vista, que los españoles inventaron para llevar sus caballos en canoas, é cuéntanse otras cosas conçernienles al discurso de la historia............ Capitulo v. De la cxtraña é nueva puente que los indios llamaban de Malinehe, que hiço el marqués don Hernando Cortés, por la qual passó con más de quinẹe mill hombres é muchos caballos; é de la que despues hiço haẹer quassi por el mesmo lugar cl capitan Alonso Dávila, por donde avia de passar con los caballos é gente, que con él yba en demanda de la cibdad de Acalan; è de olros muchos trabaxos é trançés por que passaron hasla que llegaron à Champuton..........................

Capitulo vi. Cómo cl adelantado don Francisco de Montejo fué á poblar al pueblo de Lảęro, que los indios llaman Campeche, é fundó una villa que se llamó Salamanca; é del mal subçesso de los españoles en esta jornada, $\dot{c}$ de muchos trançesque se siguieron en ella..................

Capitulo vil. En que se tracta cómo el teıriente Alonso Dávila é sus compañeros ovieron otro recuentro é batalla con los indios del pueblo de Cochua, que avian muerto los chripstianos que llevaban el pressente del oro al adelantado; é cómo los españoles fueron maltractados en este fecho de armas, é otras particularidades notables que passaron estos militantes é traba$x$ ados varones, hasta que tomaron el pueblo de Chitemal. ....................

Caritulo vill. Cómo el capitan Alonso Dávila é los españoles que con él estaban, desampararon é despoblaron aquella villa $\dot{e}$ assiento que avian fecho en Chitemal, é sc fueron en canoas duplieadas por poder llevar los caballos de la forma é usança nuevamente é por ellos inventada, é de los trabaxos extremados é trançes que les acaesçieron, con que se da fin á esta relacion del comendador don Alonso de Luxan.

LIBRO XXXill. Prohemio.............. Captclo 1. En que se tracta del prinçipio de la conquista de la Nueva España desde el tiempo del capitan Hernando Corlés, del rico pressente, que envió al Emperador Rey, nuestro señor; é eómo se apartó por esquirsitas formas de la obidiençia ć amistad del adelantado Diego Velazquez, su superior, por cuyo mandado avia ydo á aquella tierra : é deçirse han otras cosas, que conviene primeroque se declaren para la inteligencia del discurso de la historia........

Capitulo 11. Cómo el capitan Hernando Cortés delerminó de yr á Mćxico, é cómo primero dió al través con los navios, en que fué á la Nueva España, temiendo que la gente que dexaba en la villa de Veracruz, í olros, se le amotinarian; é cómo en el camino supo que çiertos navios del capitan Franẹiseo de Garay andaban en la costa, é del gentil ardid que tuvo para aver lenguat dellos; é cómo tomó siete hombres, é la informaçion que dellos tuvo; é cómo ovo noticia del rio de Panuco é del señor dél ; cómo su amistad con él fiço, ete........

Capitulo III. Cómo el capitan Hernando Collés prosiguió su camino para yr á ver á Monteçuma, señor de Mléxico, é del buen acogimiento que le fué hecho en las lierras de su señorio, é cómo se apartó deste eamino por consejo de los indios de Cempua!, sus amigos, para yr á ver é contraer amis. tad con Tascaltecle, é como en fin se hiço el amistad é confederacion con ellos...... Capitulo iv. De la embaxada quel principe Monteçuma envió al genera! Hernando Cortés, ofresçiéndose por vassallo é tributario del Emperador, con tanto que no fuesse $i$ su tierra; cémo los embaxadores procuraron desavenir al general eon los de la provinęia de Tascalteca ; é cómo los de la provinçia avisaron á Cortés de la gente, que tenia Monteçuma de guarniçion é de guerra, esperándole....................

Capitulo v. Cómo el capitan general Hernando Cortés se partió de Churultecal con delerminaçion de ver á Monteçuma é la grand cibdad de Temistilan; é lo que passó eon los embaxadores de Nonteçuma; é de lo que en este camino le intervino; é cómo se vido con Monteruma en aquella su grand eibdad; é de la traycion que contra los españoles se tractó pol un prinçipal señor, llamado Qualpopoca, vassallo de Mlontezuma, é otras cosas anexas al discurso de la his-

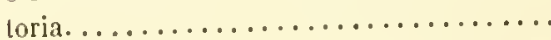

Caritulo vi. En el qual se tracta cómo el 278 capilan llernando Cortés prendió al grand prinçipe Monteçuma cautelosamente; é cómo fué hecha justiçia de Qualpopoca, se- 
ñor de Nintecal, é otros scinores principales que con él fueron quemalos, porque mataron sobre seguro çiertos ehripstianos......

C.npturo vin. En que la lisstoria traeta de las minas de oro de la Nueva lispaña, é de otras partieularidades de ȩiertas provinçias; $\therefore$ cómo el principe Tuehinteela vino á la obidienęia de Sus Magestades é á la amislad del capilan llernando Corlés, é dió lieenẹia que los chripstianos poblassen en su tierra........................

C.apitulo vill. Cómo fué presso el prinçipe Caeamaçin, señor de Aeuluaean, porque se rebeló despues de se aver ofresçido por vassallo del Rey, nuestro señor, é tambien se apartó de la anislad de Monteçuma, su señor, é fué puesto un hijo suyo del dieho Caeamaẹin por señor de su estado........

C.aritulo ix. En el qual se cuenla la relaçion quel grand prínẹipe Monteçuma dió de su origen á sus rassallos en una públiea audienẹia, en que les habló é mandó que obedesciessen é sirviessen al Emperador don Cảrlos, nuestro señor, eomo á Prey de Castilla é su natural señor, é despues dél perpétuamente à los Reyes de Castilla é de Leon, sus subcessores...............

Carituro $x$. En el qual se tracla eómo el eapitan Hernando Corlés persuadió ả Montcıuma que enviasse por sus tierras á pedir á los prinçipales señores é vassallos que sirviessen eon oro al Emperador Pey, nuestro señor, é lo hiçieron en eantidad de más de çiento é noventa y dos mill pessos, allende de olros çient mill pessos de valor é joyas; $\dot{f}$ de algunas partieularidades de la Nueva

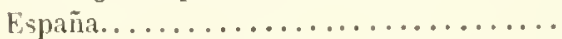

Capitulo $\mathrm{xl}$. En el qual se traeta de la ydoIr.tria é diabólicos saerifiẹos de los indios de la Nueva España, y en espeçial en la srand eibdad de Temistitan; é de otras partieularidades á la historia pressente permitidas, en eonlinuaçion de la relaeion quel capitan Hernando Cortés envió al Rey, nuestro señor...................

Capitulo xil. Cómo por mandado del adelintado Diego Velazquez fuć por eapitan é teniente suyo á la Nueva España el eapitan Pamphilo de Narvacz, eon revoeaçion de los poderes que dieho adelantado avia dado al eapitan hernando Cortés; é del reeuentro que entre estos dos eapitanes ovo; $\dot{c}$ eóuno fué presso Pamphilo de Narvacz, é que. dó Hernando Cortés muy más apoderado é absoluto capitan despues desta vieloria....

Caritulo xu. En que se traela como despues de presso el eapitan Pamphilo de Narvaez, supo Cortés que los de la eibdad de
Méxieo se avian alçado eontra los españoles que alli avian quedado cn guarda de Monteçuma, é del oro é joyas; é fué allí, despues de entrado, tovo mucha suerra eon los indios de la eibdad; é de la inuerte de Monteçuma: é euenta la historia algunas particularidades jotables en el easo.......

Capiulot xiv. En el qual se traeta eómo despues que Corlés é los españoles salieron de la eibdad de Temistitan, Ilegado á la cibdad de Tacuba, é prosigniendo en su fuga, é los indios en su aleançe, haçiendo todo el daño que podian, le mataron los hijos de Monteçunıa é á los otros pressos prinẹipales que los chripstianos tenian; é cómo se recogieron Cortés é su gente à la provinçia de Tasealtecle; é otras cosas dinas de la

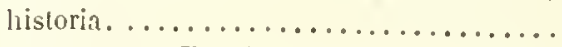

Capirulo xv. En el qual euenta la historia eómo los señores é prinçipales varones de la provineja de Tasealleea é de Guaxocingo vinieron á visitar al eapitan llernando Cortés é á los españoles, eondolićndose de lo que les avia aeaesçido eon los de Temistitan; é eỏmo se les ofrespieron para la venganca é eastigo de los eontrarios; ć eúmo eonquistó é ganó Hernando Cortés la provinçia de Tepeaca, ques gente de la liga é eonfederaçion de los de Culua ; é cuéntanse otras eosas notables.................

Capitulo xvi. Cómo el señor de la eibdad de Guaeachula envió sus mensajeros á Her nando Cortés, ofresciéndose al serviçio del Emperador ; é émo por su aviso é industria fuecon desbaratados más de treynta niill hombres de los de Culua, enemigos de los españoles; é eómo Heruando Cortés tomó \&́ pacificó la eibdad de Izcuean eon otras poblaciones, é vinieron a se eonfederar eon los ehripstianos mueho número de indios eontra los de Culua é Temistitan; é de la informacion que se ovo de un prisionero del estado de la grand eibdad; é del subcessor en el señorio de Monteçuma, llamado Guatimucin, señor de lzlapalapa, hermano de Montecuma, é otras partieularidades eon que se dará fin á la relacion de la earla que Hernando Corlés eseribió al Emperador, nuestro señor, desde la villa de Segura de la Frontera, en la Nueva España, á los treynta de otubre de mill $\dot{e}$ quinientos $\mathrm{y}$ veynte aĩos....................

Capitulo xull. Desde el qual traela la historia el subcesso de la eonquista de la Nueva España, é la recuperarion de la grand eibdad de Temistitan, é otras eosas anexas al verdarlero diseurso de la relaçion é terẹera carta que al Emperador Rey, nuestro se- 
īor, Cortés le envió, dándole cuenta é raçon de lo subçedido despues de todo lo ques dieho hasta fin del capítulo preçedente...

Capitulo xin. En que se tracla lo que Hernando Cortés dexó proveydo para la difiniçion de los bergantines, que se haçian para combatir por la laguna la grand cibdad de Temistitan; é como se partió contra ella é los de Culua; ć de la victoria que ovieron contra los de la cibdad de Izlapalapa, que lué un hecho muy notable, é glorioso prinęipio para esperar el fin victorioso que desla guerra adelante se consiguió.......

Capitulo xix. Cómo la cibdad de Otumba é otras quatro vinieron á la amistad de los chripstianos; è cómo hiçieron lo mesmo los de Chalco é otras provinçias, é cómo Hernando Cortés hiço traer á Tezcuco por tierra diez é ocho leguas los treçc bergantines o fustas, que avia mandado haçer para entrar por la laguna ả Temistitan, é otras cosas dignas de la historia.............

Capitulo xx. Cómo el capitan Hernando Cortés salió en campo muy poderosamente, a causa de la grand compañia de los amigos confederados, é dió sobre una poblaçion que se diçe Xaltoca, donde se hiço mucho daño en los enemigos, é lo mesmo hiço en la cibdad de Tacuba é otros pueblos..........................

Capitulo xxi. En el qual se tracta del socorro ¿ayuda que Hernando Cortés envió á los amigos confederados de la provinçia de $\mathrm{Ca}$ co; é cómo otros pueblos vinieron á la obidiençia de Sus Magestades; é cómo se tomó por mucha ventura la inexpugnable poblacion de Guamanaca, é vino á la obidiençia dc Sus Magestades el señor della; é cómo tomó é destruyó la cibdad de Suchimilco, ¿ otras cosas notables que Cortés é sus cortesanos míliles hiçicron, con mucha victoria é prósperos subçessos.............

Captelo xxil. En el qual se tracta de una carta que un hidalgo llamado Barrientos escribio al general Hernando Corlés desde la provinçia que llaman Chimanta; é de cómo se acabaron los bergantines é se echaron al agua para çercar á Temistitan; é cómo el gencral envió adclante çierlos capitanes é gente á poner guarniçiones çerca de la grand cibdad de Temistitan; $\dot{c}$ assimesmo se tractan otras cosas convinientes á la historia.........................

Capitulo xxin. Como el general Hernando Cortés entró en la laguna con los bergantines, é combatió é tomó el peñon de Iztapalapa; é cómo rompió é desbarató la flota de las canoas de los enemigos con mucha vic- toria ; é cómo fue çercada la grand cibdad de Temistitan, é fué conıbatida mucha parte della ć por muchas partes; é cómo lué en socorro de los españoles la gente de don Hernando, señor dc Thesayco, con más de çinqüenta mill hombres, con los quales eran ya más de çiento é treynta mill indios los amigos que en nuestro exérçito estaban en lavor é ayuda de los españoles contra Temistitan......................

Capitulo xxiv. En que se tracla cómo la segunda vez combatió el general Hernando Cortés é los españoles é confederados amigos suyos la grand cibdad de Temislitan, $\dot{e}$ se hiço mucha matança y estıago en los contrarlos, ė de algunos fechos notables que aquel dia é otros acaesẹieron. ............

Caprtulo xxv. En que se tracla de otros combates que Hernando Cortés é los espanoles é confederados indios, sus amigos, dieron á la cibdad de Temistilan; é de algunas cosas scñaladas que intervinieron en tanto que aquel ẹerco turó............

Caprtulo xxvı. Cómo otro dia el general Hernando Cortés tornó á entrar en la cibdad de Temistitan é ovo victoria; é cóno los enenigos desbarataron al capitan Alrarado; é cómo despues por vengar aquello, se acordó de combatir la cibdad por diverssas partes, é fué desbaratado el general Hernando Cortés é le hirieron á él en una pierna; é de otras cosas que acaesçieron en esta mala jornada. E tambion se tracta de otros trançes victoriosos y en favor de los chripstianos, en continuaçion del çerco de Temistitan.....................

Capitulo xxvi. Cómo los amigos confederados de Guarnaguacar vinieron á pedir socorro al general Hernando Cortés, é se 10 envió; é de la victoria quel capitan Andrés de Tapia é los españoles ovieron contra los indios de Marinalco; é de la victoria que contra los de Temistitan ovo un capitan, hombre prinçipal é señor de los de Tascaltcca, que se llamaba Chichimecatecle, el qual era uno de los amigos confedcrados de los chripstianos; é otras cosas que competen á la historia......................

Capitulo xxvill. En el qual la historia cuen. ta cómo se dieron á la cibdad de Temistilan çicrlos combates, é se le hiço mucho daño, ell que escolaron bicn los contrarios la victoria que avian avido, de que se tracló en el capilulo $\mathrm{XXV}$, è cuéntanse assimesno algunos trançes é cosas señaladas conçcrnientes a la listoria.................

Capitulo xxix. Cómo el gencral Hernando Corlés acordó de proseruir en los conıluates 
le la cibdad por su parte, é lo mesmo haçia el comendador Pedro de Alvarado por la suya $\dot{a}$ los otros capitanes; é eómo se ganó el mercado, plaça prinçipal de Temistitan; é eómo en otro dia, prosiguiéndose el combatimiento, se ganó otro barrio; é de otras cosas notables é convinientes al discurso de la historia.......................

Capitulo xxx. Enque se tracta eómo el general Hernando Corlés combatió la grand eibdad en la parte que estaban retraydos, é murieron en un dia más de quarenta mill personas de los enemigos; $\dot{e}$ cúmo otro dia siguiente mataron otros muchos, é fué tomada é ganada la eibdad de todo punto, é quedó Temistitan por de Sus Nagestades, é fué presso el señor della, llamado Guatinuçin, con otros eapitanes é prinçipales.....

Caprtulo xxxi. El qual tracta del valor del despojo que se ovo en la expugnacion é toma de la grand eibdad de Temistitan; é de cómo el señor de Ia zrand provinçia de Mechuacan envió por sus embaxadores á se ofresçer por vassallos del Rey de España, nuestro señor; é de la notiçia que ovo el general Hernando Cortés de la mar del Sur ó austral en la costa de la Nueva España meridional, é olras victorias é provinçias que se conquistarun por eapitanes de Hernando Cortés; é trảctanse assimesmo otras parlicularidades nolables................

Capitulo xxin, Cúno el general Hernando Cortés é los espaz̃oles acordaron de reedeficar la grand cibrad de Temistitan é haçer su assiento proprio é publaçion para los chripstianos en elia; é de cómo el señor de la provinçia de Coantepeque, cuyo señorio é jurisdiçion es á la mar del Sur; dio por sus embaxadores la ubidicnçia á Sus Magrstades; é de como Cluripstóbal de Tapia, reedor que fué de las fundiçiones del oro en esla Isla Española, fué por capitan é gobernador de la Nueva España é no fué resçebido ni admilido al vifięio. É tambien se tlaetan en este capilulo otras eosas que al estilo é continuacion de la historia son uesçessarius ......................

Captuco xxxm. Cómo el capilan general Hernando Corlés cuvió al comendidor Pedro de Alvarado á conquistar la provinẹiat de Teantepeque é la paçificó é llegó à la nar del Sur é tomó la possesion della por Suy Magestades, é de las grandes muestras de oro é perlas que hallo; é cómo el generat hiço harer navios en ta costa del Sur para deseobir por aquellas mares, con lo qual, con otras particularidades, se da tin å la relacion de la lercera carla, que escribiu
Hernando Cortés al Emperador de las cosas de la Nueva Esapina.................

Capitulo xxxiv. Continuandose la historia de la Nueva España, conforme á la quarta relacion que el gobernador Hernando Cortés envió al Emperador, nuestro señor, eon otras relaçiones que otros eapitanes parliculares le enviaron á Corlés despues de los subçessos que la historia ha eontado; é tráetase de otras provinçias que eonquistó é paçificó, é olras cosas notables........... Capitulo xxxv. En que se eontiene un capítulo á la letra, que el eapilan Hernando Cortés entre otras cosas eseribió al Emperador, nuestro señor, en esta su quarta relaçion, quejándose del obispo de Burgos, é otras cosas; é más adelante se tracta de la victoría que ovo contra los indios de la srand poblacion llamada Ayutuscolaclan; é de la eonquista de las lagunas de Panuco, é victoria que ovo con essos é otros pueblos, é otras cosas que convienen al discurso de la historia................

Caprtulo xxxvi. En el qual se tracla la paçificaçion de la provinçia de Coliman é de otras à ella cereanas, é de cierta relarion que le fue fecha al general de una isla poblada de mugeres, é de la yda del adelantado Françisco de Garay al rio ó provinçia de Panuco, é cómo tnurió despues en la grand eibdad de Temistitan, é olras eosas eonęernientes á la historia................

Capitulo xxxvil. El qual tracta cómo el general Hernando Cortés, eertificado de la rebelion de la provinçia é indios del rio $\mathrm{Pa}$ nuco, envió à socorrer á los vecinos de la villa de Santisteban del Puerto, é del señalado é grand castigo que se hiço en los prinẹipales indios rebelados en aquella provinçia é culpados en la muerle dcl adelantado Françisco de Garay...............

Capitulo xxxuill. Cómo el general Hernan. do Corlés tornó á continuar el propóssito que primero tuvo de enviar á poblar el puerto de Higueras é cabo de Honduras con el capitan Chripstóbal de Olit, segund se 10có en el eapilulo XXIV proveyó de navios é gente é todo lo nescessario: é cómo despachó assimesmo al eapitan Pedro de Alvarado por lierra con muy gentil gente de pié é de caballo á las cibdades de Iclaclan é Guatimala, como antes lo tenia propuesto................

C.spitzlo xxxix. En que se tracla cómo el gobernador Heruando Corlés envió al capilan Rodrigo Ranjel á conquistar las provincias de los capolecas é de los mixes, ques gente belicosa épuesta en lierra muy ás- 
pera é fragosa é tal que la gente de eaballo no puede servir ni aprovechar para la guerra de tales provincias é conquista....

Capitulo xl. En que el gobernador Hernando Cortés dá su desculpa en la dilacion de ciertos navios que hiço haçer en la costa de la mar del Sur; é assimesmo cuenta la historia la forma de la reedificaçion de la grand cibdad de Temistitan por la industria del dicho grobernador....................

Capitulo xul. En el qual se tracta cómo el general Hernando Cortés hiço haçer çiertas piecas de artilleria, é como buscando los materiales para ello, se hallaron minas de estaño é vena de hierro, é mucho salitre para haçer pólvora, é assimesmo açufre; é cómo envió una media culebrina de metal rico de uro é plata á Su Magestad Calhóliea, que escribió que le avia costado veynte y siete mill pessos de oro el metal é la hechura; é deçirsc han otras cosas que escribió en su relacion, con que se dará fin á ella, sin que se dexe eosa de lo substançial, puesto que se dirá con menos palabras....

Capjtulo XL11. En el qual se tracta una relaẹion quel capitan Alvarado envió al gobernador llernando Cortés desde la cibdad de Uclacan, á onçe dias de abril del año de mill é quiniontos ć veynte y quatro, la qual envió el gobernador al Çéssar juntamente con la otra, de que se ha tractado en los eapitulos precedentes.................

Capitulo xhlit. En que se tracta de otra relacion fecha por el mesmo capitan Pedro de Alvarado al gobernador Hernando Cortés desde la cibdad de Sanctiago de Guatimala, á ocho de julio de mill é quinientos é veynte y qualro años: la qual reliçion, por evitar prolixidad, se dirá conforme á lo substançial é sentençia de lo que contiene........

Capitulo xujv. Donde se tracta otra relaçion fecha por el capitan Diego de Godoy al gobernador Hernando Cortés, la qual, con las relaçiones que la historia la contado, envió al Emperador, nuestro señor; é deçirse ha lo substançial pol evitar prolixidad, sin que se dexe de expresar lodo lo ques notable é conviniente á la historia...............

Capitulo xlv. En el qual se tracta otra informaçion que de algunos cavalleros é milites que se hallaron en la conquista de la Nueva España se la sabido por la diligençia del chronista, en que muchas cosas hay eonformes con lo que queda dicho ; é tambien se dirán otras particularidades que no son de preterir ni se dexar de memorarlas, porque todas ellas son muy dignas de la pressente historia, é suyas........... TOMIO III.
Capitulo xuvi. En el qual se tracta de la mancra del estado é serviçio é sacrifiçios é ritos é ydolatria de Monteçuma, é de la forma de su easa, é de los animales é aves que tenia en sus palacios; é la forma con que se hiço scñor de México é Temistitan, é destruyó é mató con engaño en un convite una de dos parçialidades que allí avia: é dáse relacion de las nugeres é hijos que tenia; é otras cosas que conçiernen é son adherentes al discurso é verdad de la his-

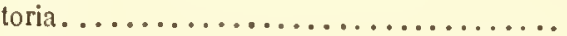

Capitulo xlvil. En que se tracta cómo Monteçuma dixo a Hernando Cortés que se fuesse él é los españoles de su tierra, prometiéndoles de les dar tanto oro que fuessen ricos, é de la prudente respuesta de Hernando Cortes: é cúmo llegó á la tierra Pamphilo de Narvaez, é fuć presso, é se tornó Cortés á México, de donde los indios lo echaron á él é á los españoles; é dc la muerte de Nonteçuma, é otras cosas convinjentes al discurso de la historia ó relaçion assaz diferente en algunas cosas á lo que se contó hasta el fin del capílulo XLlll.

Capitulo xlvil. En el qual se tracta cómo fué cobrada la grand cibdad de Temistitan, y el señor delia fuć presso; é otras particularidades. E dáse fin con este capítulo á esta relaçion que, como es dicho, fué sacada de muchas informaçiones de testigos que en aquella conquista se hallaron...........

Capitulo xlix. En el qual se contiene una relaçion de diverssas cosas de la Nueva Es. paña, quel chronista escribe por informaçion del reverendo padre vicario fray Diego de Loaysa, de la sagrada Órden de los Predicadores; é deçirsc há con más brevedad de la que este religioso le dió in scriptis,

480 firmado de su nombre..................
Capitulo L. En que el chronista escribe, mejor diçiendo, copia una breve relacion que le fué enviada desde la cibdad de Veneçia, adonde la avia enviado el señor visorey don Antonio de llendoça á su hermano el señor don Diego de Mendoça, embaxador de la Çessirea Magestad en la dicha Veneçia; é pónese á la letra el capítulo que en esto habla, é diçe despues el chronista su parescer en el mesmo caso.............

Capitulo li. En el qual se tracta una sumaria relaçion, en que se relata la forma que en la Nueva España tenian los indios en pagar los tribulos á Monteçuma é á sus señores, antes que allá fuessen los chripstianos, porque agora ya assi en lo que se dirá como en otras cosas, hay otras costumbres é novedades: é demás de lo que toca á los 
tribulos is agrieoltura, se diràn otras eosas cn que la historia hasta aqui no ha fecho mcnẹion, que son notables é dignas de se

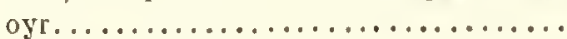

Cispitulo til. En que se tracta una çerta é notable relaeion quel visorey don Antonio de Mendoça por su carta mesiva escribio al historiador destas materias, en respuesta de otra quel auctor le avia eseripto para su informacion; é por ser nesçessaria é al propússito del discurso destas historias, se pone aqui a la letra..................

Capitulo zili. En que se contiene una carta quel historiador envio al visorey de la tiueva España, respondiendo à la letra del capitulo preçedente, en que se tocan algunas cosas eoncernientes à estas historias......

Cspitulo hiv. En el qual el auetor dá raẹon por que çessú su eamino è yda à España; é haçe relaçion de otras cosas a subçessos de la Nueva España, é diçe algunas particularidades que á su notieia lan venido, las qualcs son del jaez de las que la historia ha contado, é para màs verificaçion é verdad de algunos pasos que quedan eseriplos de otra forma, no le aviendo tan puntualmente informado, como agora se dirả. E cucntanse olras cosas del jaez destas materias, assi enmendando algunas cosas hasta aqui apuntadas, como declarando é perfięionando olras de que hay nesçessidad que Ios letores sean advertidos..............

Capitulo ly. Con que en pocas palabras el auctor dà conclusion a este libro XXXIll de la segunda parte...................

Capitulo lvi. En que se tracla de la muerte del marqués del Valle, don Hernando Cor-

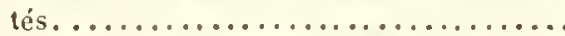

Capitulo Lvil. Conque se di fin é se eoncluye la materia de la Nueva España, de que se ha traclado hasta aqui, é dáse noticia de una nao que vino en fin deste año de mill è quinientos é quarenta y ocho años à Espaĩa, cargada de plata.......... LIBRO XXXIV. Prohemio............... Capitulo 1. Cômo fué proveydo Nuño de Guzman por eapitan general $\dot{e}$ gobernador de la Nueva España, dende la qual fué å conquistar é poblar la provinẹia de Xalisco è otras con clla comareanas, de las quales despues fué gobernador, é aquello todo se llama agora el reyno de la Nueva Galiçia; é tambien se dirản otras cosas anexas al discurso de la historia...............

Capituro II. En que se tractan algunas particularidades de la Nueva Galiçia é provinçias de Xaliseo, é de su fertilidad, é de la provinẹia de Culuacan, é otras cosas.....
Capitulo แl. En el qual se tracta una relaçion quel historiador destas materias ovo despues de un hidalgo llamado Franciseo de Arzeo, i de otros que se lıallaron con Nuño de Guzman, quando fué á eonquistar é poblar la Nueva Galiçia, é euéntase más apuntada é parlicularmente que lo que estå dicho en los capitulos preçedentes........

Caritulo iv. Cúmo el prinçipal señor ques dicho, llamado Caçonei, avia fecho falsa relaçion al general Nuño de Guzman, écómo despues dixo que no sabia la tierra, le hiço un proçesso é lo mandó quemar: ¿ cuéntanse otras cosas que passaron despues, é los saerificios é los que quemaban los indios en los hornos..............

541 Caritulo v. Como el general Nuño de Guzman eonquisto la provincia llamada Cuys. co, é la que se diçe Tomala, é otra que nombran Nuchiselan, é olras que se llaman Maxalpa, Suehipila y Elteve, ėotros pueblos; é olras cosas nolables que convienen al discurso de la historia.............

Capitulo vi. Cómo el exérçito $a$ gente del general Nuño de Guzman fueron acogidos de paz en la provinẹia é pueblo que llaman Te. pique; é de una señalada batalla quel gene. ral vençió eon muy poeos españoles contra muchos indios en los eampos da da provinçia, que se diçe Çentiquipaque..........

Capitulo vis. Cómo el general Nuño de Guz. man is su exérçito fureron ả la abundantissima provincia de Iztuclan, é la hallaron despoblada é sin gente; é de un grand huracan que se pensaron perder con todo su exėrẹito, é murieron desta eausa las tres parles de los indios amigos que en compañiz del exérçito ehripstiano yban; é fuẻ nesçessario de enviar por grente de españoles é indios amigos para rehaçerse el campo, como se hiço, é olras cosas tocantes á la historia...

Caritulo vin. En que se tracta de la provinçia é pueblo llamado Ciguatan, que los es pañoles llamaron Amaẹonas, é cuéntanse otras particulares cosas en adornamiento $\dot{e}$ verdadera relacion, é lo que alli passó....

Capitulo 1x. En que se tracta de la nueva Audienẹia que Su Cessárea Magestad proveyó para la gobernaçion de Xalisco ó Nue. va Galiçia.......................

LIBRO XXXV. Prohemio.............

Capitulo 1. De la relacion que hicieron los que eseaparon de la desventurada armada del capitan Pamphilo de Narvaez, é lo que les acaesçió en la eosta é tierras septentrio-

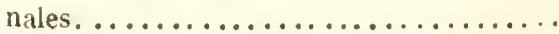

Capitulo Il. En el qual se tractan muchos trabaxos é nescessidades quel gohernado $r$ 
Pamphilo de Narvaez y eslas gentes padesçieron; ć cómo hiçieron çinco barcas para yr à buscar dỏnde pudiessen poblar; é cómo hirieron al gobernador de una pedrada; c cómo se vieron martas de muy finas cebellinas; é cómo se partió é Cesvió de la compañia el gobernador con su barea, é se perdieron las dos dellas é se alıogaron el veedor é otros; $\dot{c}$ cuentanse olras cosas de mucha lástima...................

Caritulo in. En que se tractan otros nuevos trabaxos de aquesla genle, ẻ cómo se perdió el capitan Pamphilo de Narracz, $\dot{e}$ eómo estos pecadores españoles vinieron á tanta nesçessidad que entrellos ovo de comida que los unos fueron manjar de los otros; é otras desavenluras se cuentan nunca oydas ni padesẹidas, ni lan largas e continuas como aquesta gente turo, con que los más ó quassi todos se acabaron.......

Capitulo iv. En el qual se cuentan otros trabaxos é cautiverio que padesçieron estos hidalgos Alvar Nuñez Cabeca de Vaca é Andrés Dorantes é Alonso del Castillo é un ncgro; é cómo se juntaron todos quatro é determinaron de morir ó salir de entre aquella mala generaçion de indios á buscar tierra de chripstianos, ė lo que les subçedió, procurando de seguir su buen desseo.

Capitulo v. En el qual se tracta la contiuuarion del camino questos tres chripslianos y el negro haçian, buscando cóno saldrian á lierra de chripslianos; ć cómo hiçieron miraglos, sanando a muelıos indios enfermos con solamente los santiguar; $\dot{e}$ cuẻntanse cosas notables é nesçcssarias al discurso de la historia................

Capitulo vi. En el qual se dá fin á la relaçion destos hidalgos Álvar Nuñez Cabeça de Vaca, Andrés Dorantes é Alonso del Castillo; é se cuenta el discurso de su peregrinaçion é trabaxoso camino, è olras cosas quc por cllos passaron liasta llegar á un pueblo de chripstianos en la gobernaçion de la Nueva Galiçia..............

Capitulo vir. En quel auctor destas hislorias cuenla alounas cosas que en la relacion sussodicha no cuentan, las quales despues en España, año de mill é quinientos é quarenta y sietc años, en la cúrte del Prínẹipe don Felipe, nuestro señor, en Madrid, le contó é dixo el mesıno Alvar Nuñez Cabeça de Vaca: las quales cosas son del mesmo jaez ė propria listoria é lierra, donde se perdio el dicho Pamphilo de Narvaez è su gente...................... 614

LIBRO XxxVl. Prohemio............ 619

Capitulo i. En el qual se tracta del armada quel adelanlado Johan Ponçe de Leon hico, con que fué à poblar é conquistar en la Tierra-Firme, i la parte del Norte, la provinçia que llaman La Florida, quél avia antcs descubierto, é cỏno le desbarataron los indios é le hirieron de una neeha, de que vino á morir á la isla de Cuba, alias Fernandiua; $\dot{e}$ assimesmo se tractan otras parlicularidades dessa tierra............

Caritulo 11. En el qual se tracta de cierto animal o vacas montesas, que hay en la Tierra-Firme à las espaldas de la provinçia de la Florida ú parte seplentrional de la mar del Norte........................

LIBRO XXXVII Prohemio..............

Capitulo i. En que se tracta el subçesso de la mal cncaminada empressa de la gobernaçion é armada del liçençiado Lúcas Vazquez de Ayllon, que fué it la Tierra-Firne á la parle que nos es opuesta á la parte del Norle, dende la villa del Puerto de Plata desta Isla Española; é cómo é dónde murió el liçençiado è la mayor parte de la gente que llevo.......................

Capitulo 11. En que se tracla de la lirania é molin de Ginés Donçel é Pedro de Baçan, è cómo fué presso este Gines Doncel ć se hiço justiçia del Pedro de Baçan. É tambien cuenla la historia como trayendo cl cuerpo del liçençiado Ayllon muerto à esta Isla, lo ceharou en la mar............

Capitulo 111. En que se tractan algunas parlieularidades de la provinçia de Gualdape en la tierra del Norle, donde mu rió el liçenẹiado Lueas Vazquez de Ayllon.....

Capitulo IV. De olras parlicularidades de peseados, que se vicron por muestros espanoles en aquella ticrra, donde inurio el licençiado Ayllon, $\dot{e}$ otras cosas que competen á la historia..................

LIBRO XXXVIll. Prohemio.............

Sumaria relaçion de la parte septentrional, en la qual el chronista destas historias dá á entender lo que destas matcrias nuevamen-

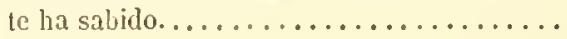




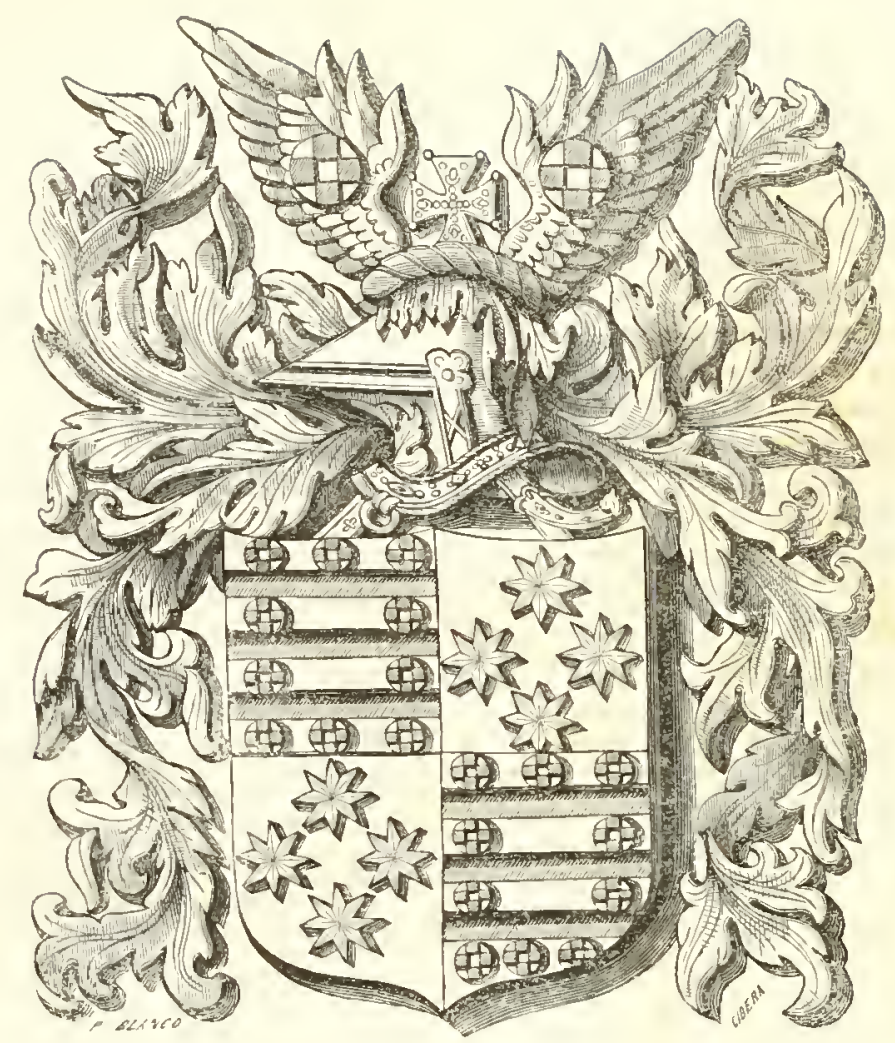




\section{ERRATAS QUE SE IIAN NOTADO.}

PÁGINA.

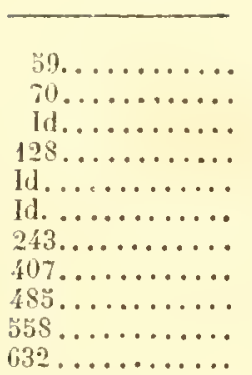

COLUMYA.

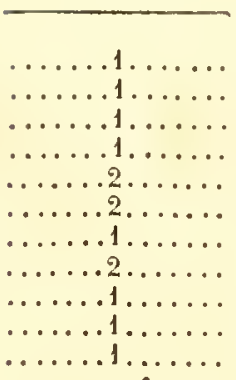

LINEA.

31.

$\ldots \ldots \ldots$

40.

$43 \ldots \ldots \ldots \ldots$

$38 \ldots \ldots \ldots \ldots$

19 .

35 .

2

24.

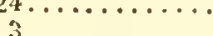

niltima..............

2.
DICE.

traxos.

teniene..

of ó rebelion.

ordenamente.

negligengia.

a los olras. a...........

ligar

éque......................

cibad...............

quinque remi........

Choruca.
LËASE.

trabaxos

teniente

to ó rebelion

ordenadamenle

negligencia

á las otras

Jlegar

cibdad

quinqueremi

Chorruca 



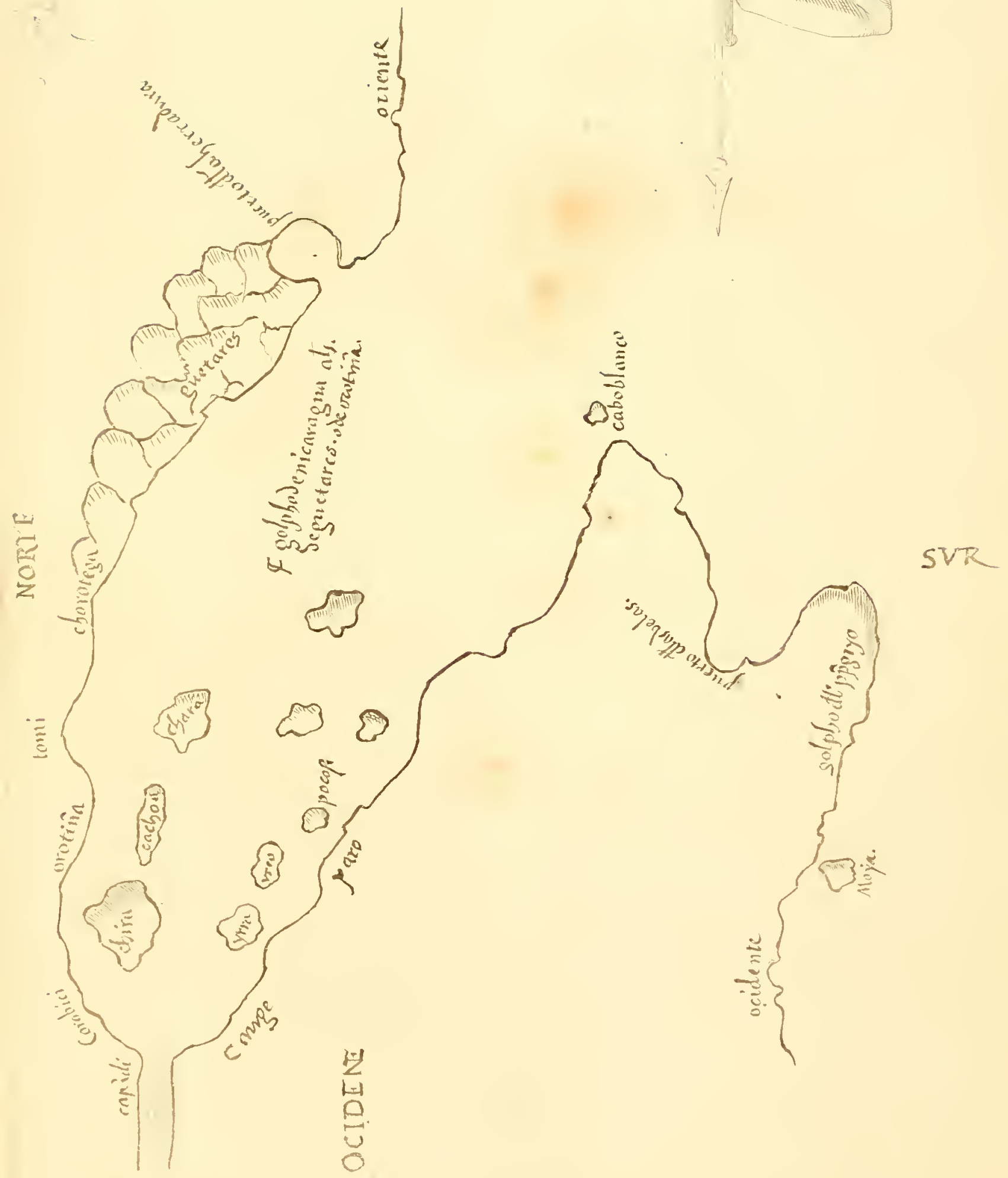





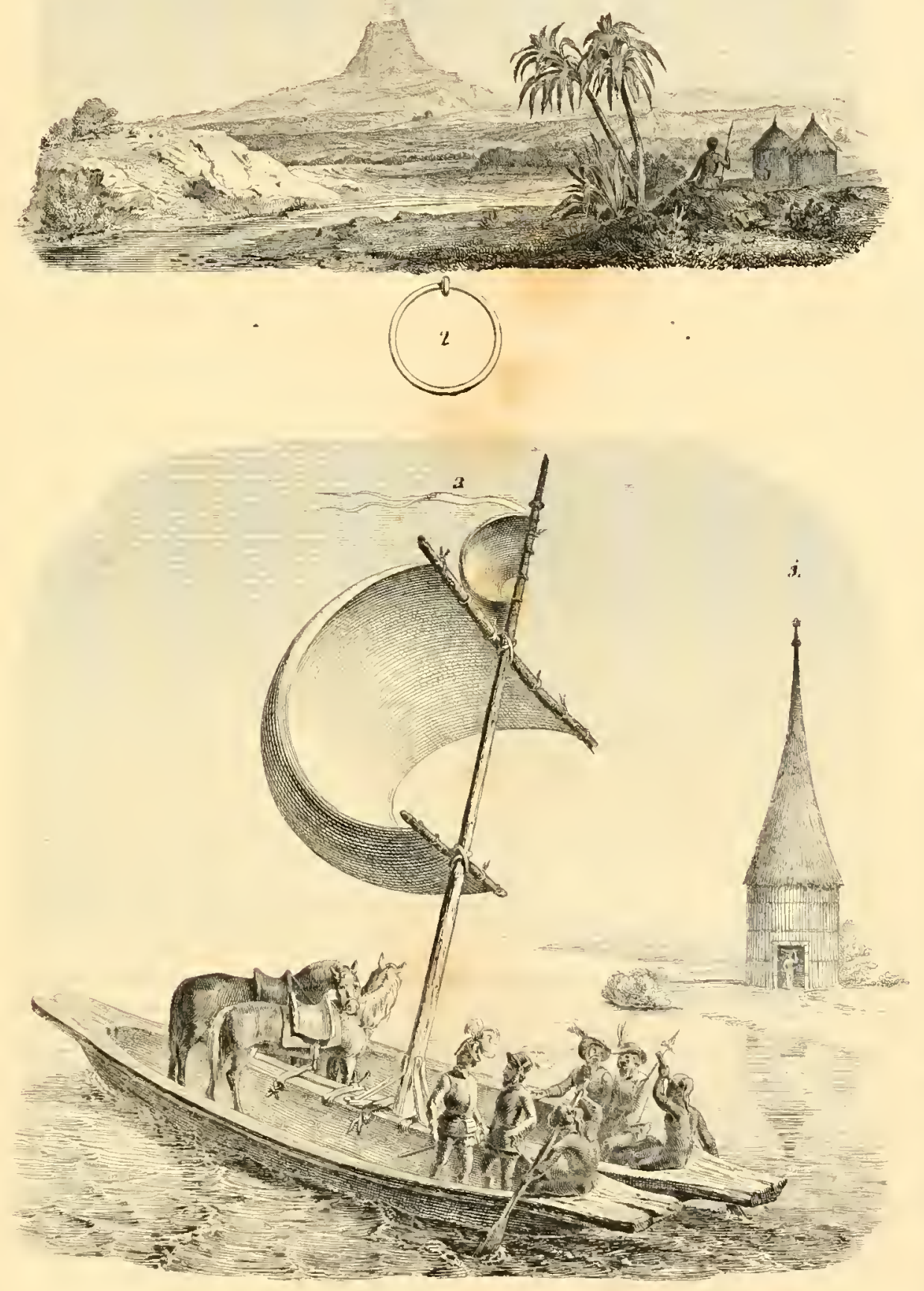









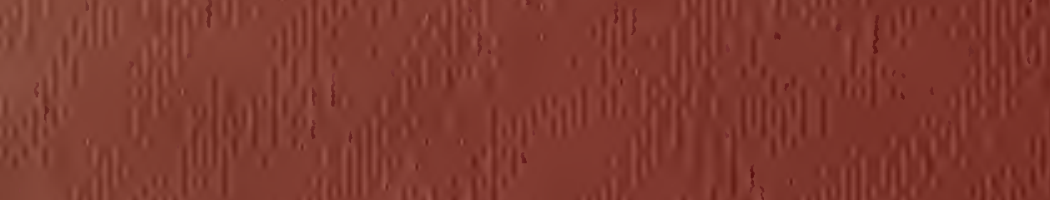
(1) , (1)

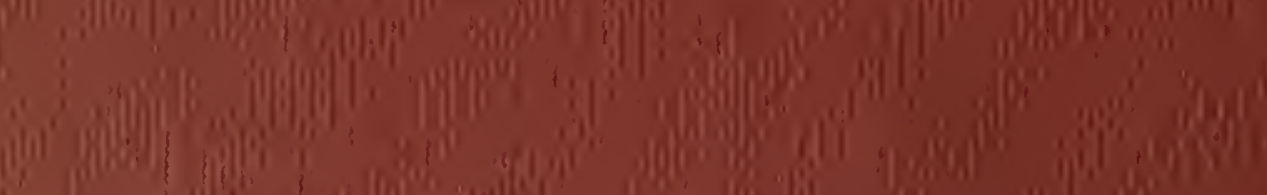
alin

i)

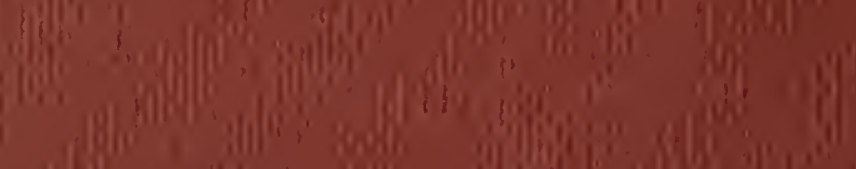

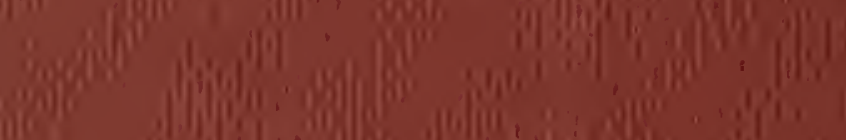

Yongen (1) i.

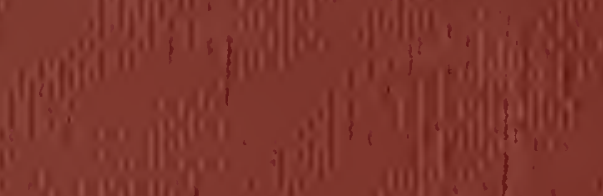
1.

$$
\text { 10 }
$$

